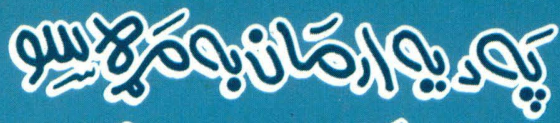

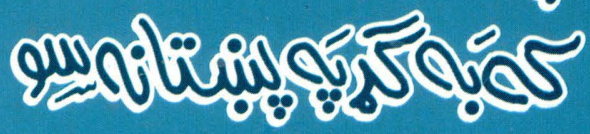
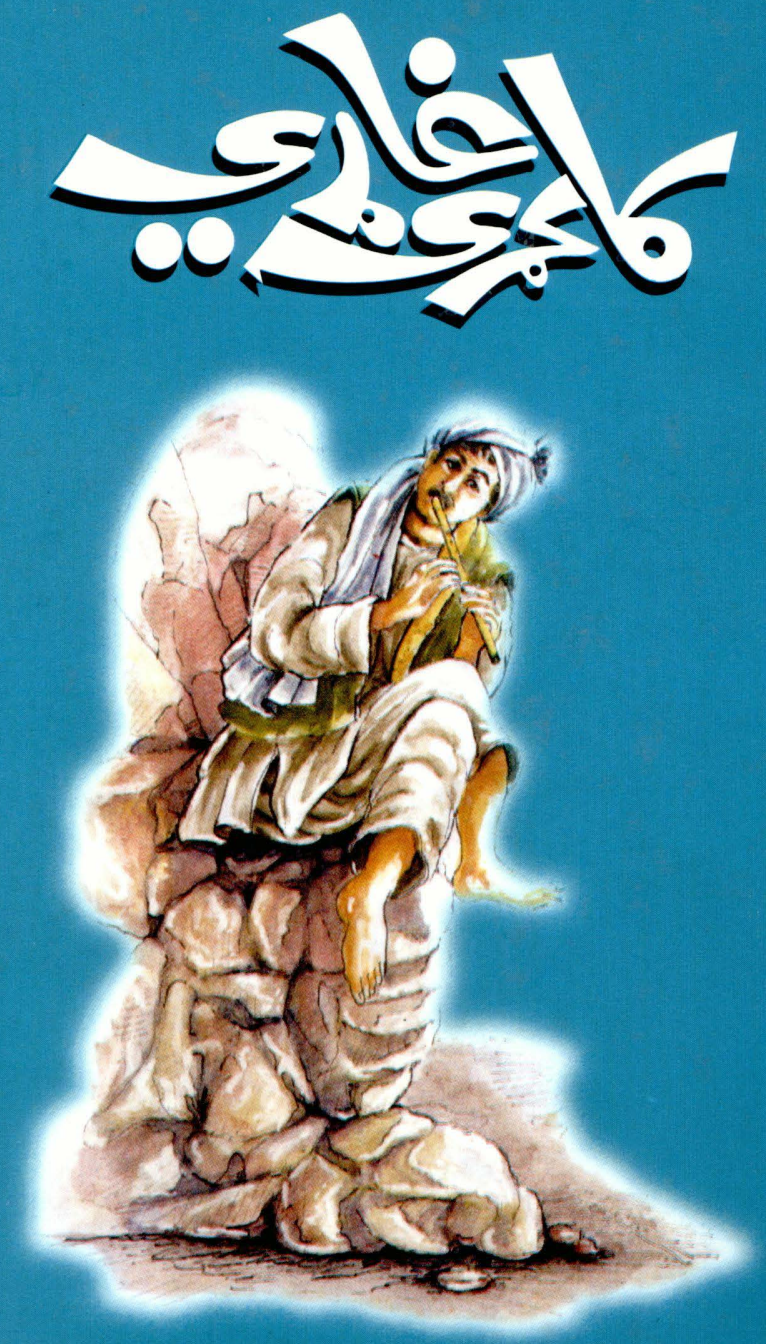

صعَّانوتريك 


\section{كاكرى غاري}

حميرنه او تولونه :

محمل صادق ذّر ك 


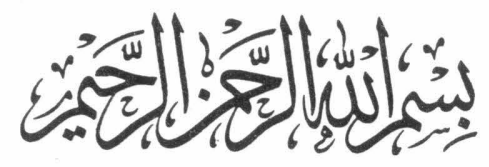

$$
\text { (حقوق يب دليكوال دي) }
$$

\section{كتاب بِّنَّنهنه :}

$* * * * * * * * * * * * * * * * * * * * * * * * * * * * * * * * * * *$

$$
\begin{aligned}
& \text { : : : : : }
\end{aligned}
$$

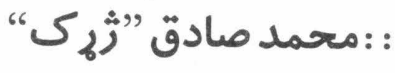

$$
\begin{aligned}
& \text { د كتاب نوم }
\end{aligned}
$$

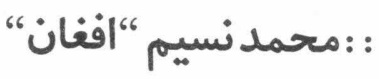

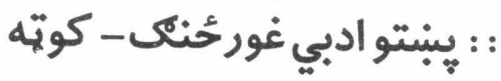

$$
\begin{aligned}
& \text { (YF) : : } \\
& \text { توكه : : : : : : : : : } \\
& \text { : : عبدالهادي تباند : : : : } \\
& \text { ثخيةنه او تولونه } \\
& \text { كميوز او هيزاين }
\end{aligned}
$$

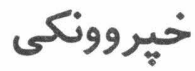

$$
\begin{aligned}
& \text { د خيروونو له } \\
& \text { الأنور: : }
\end{aligned}
$$

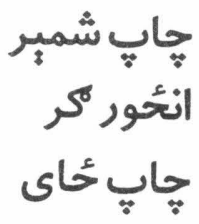




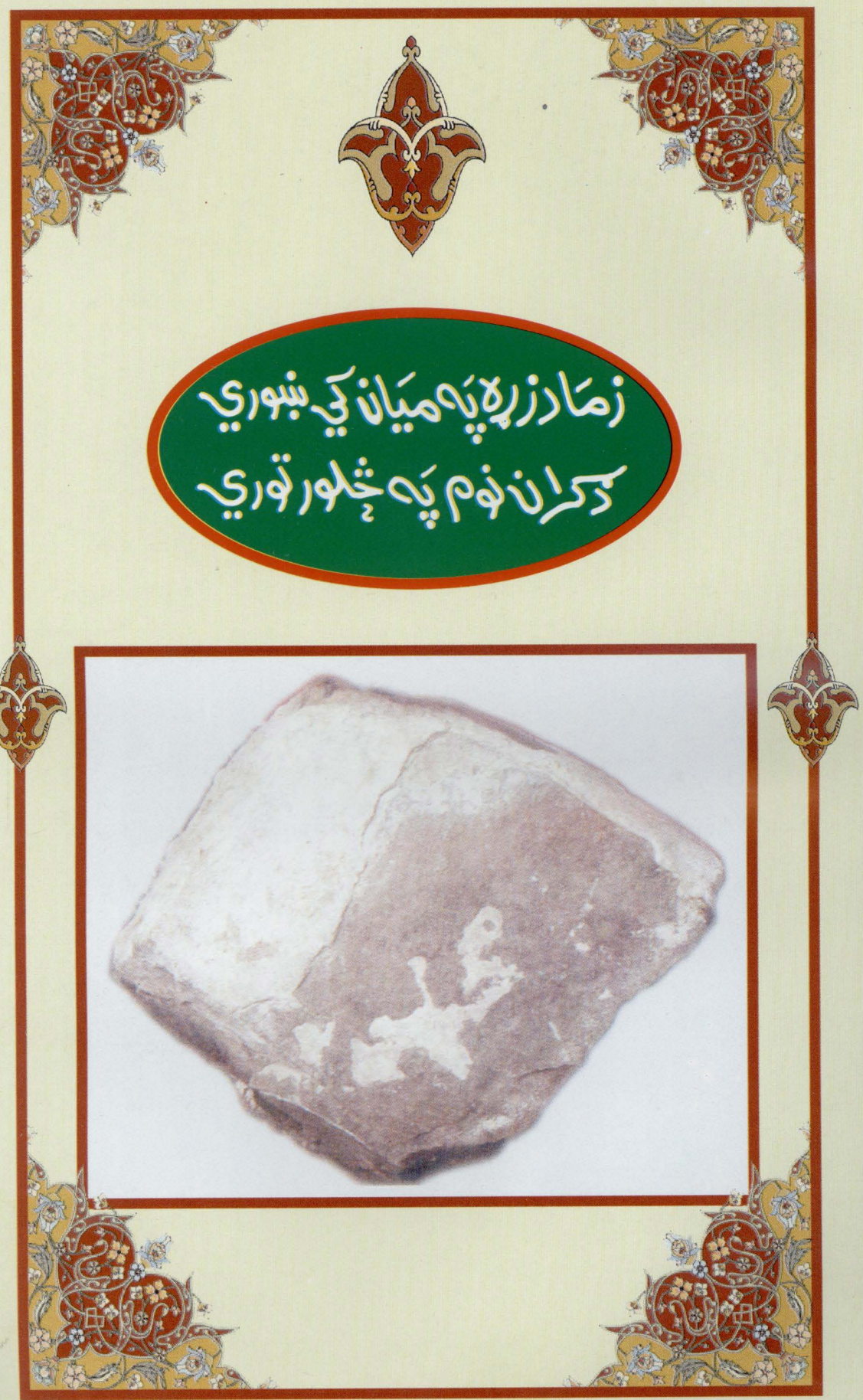




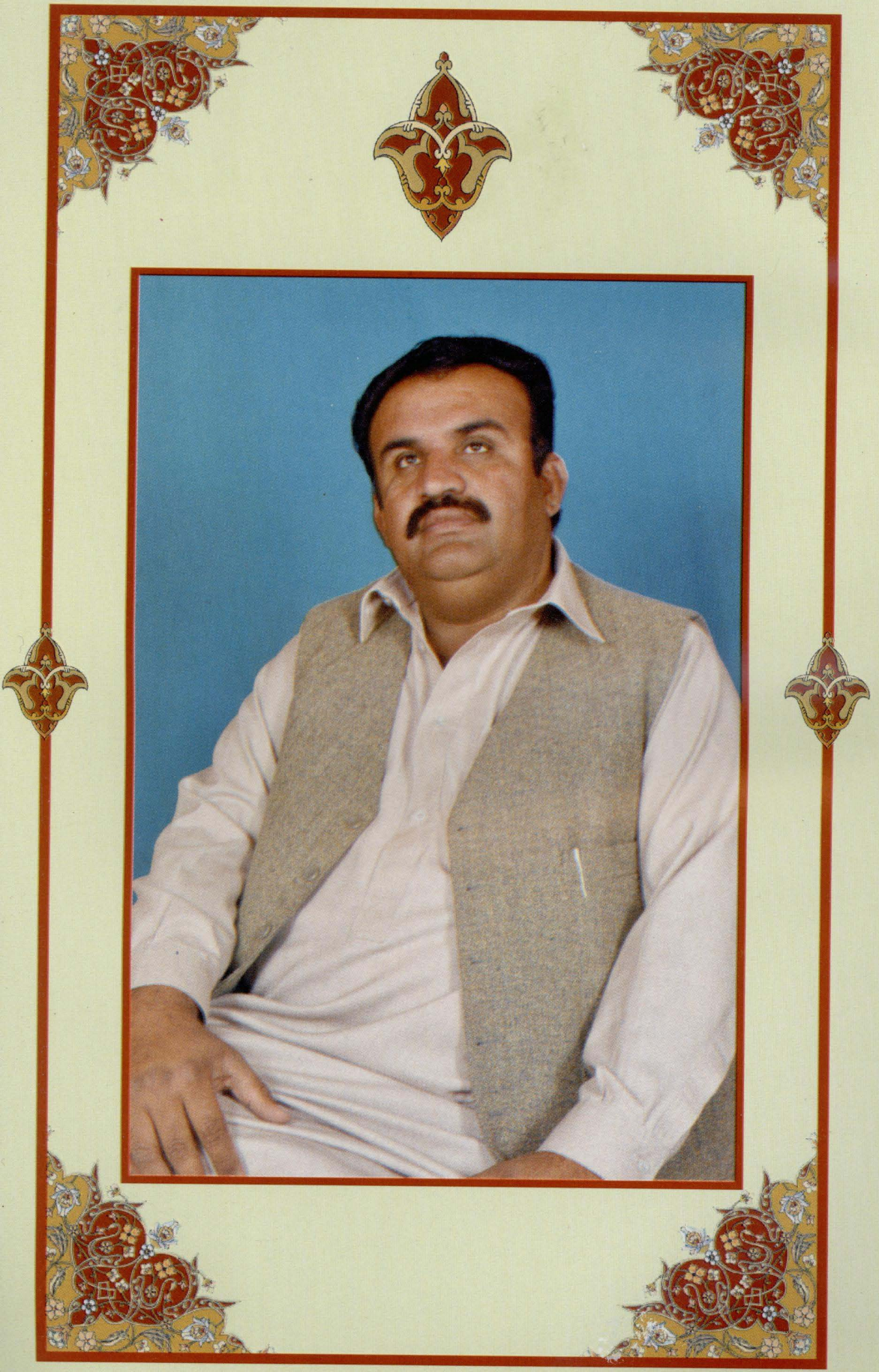




\section{توون}

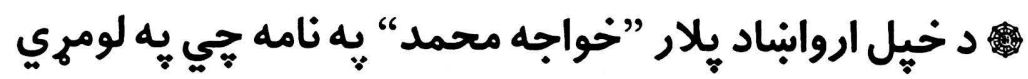

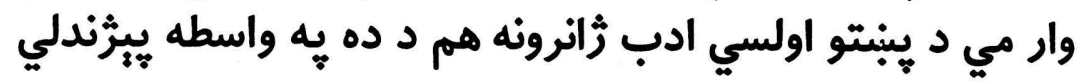
دي.

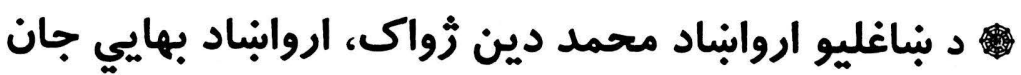

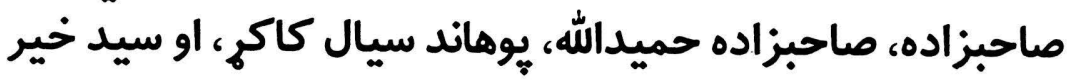

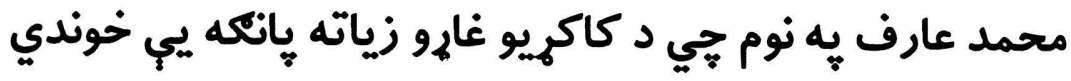

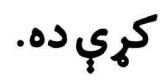

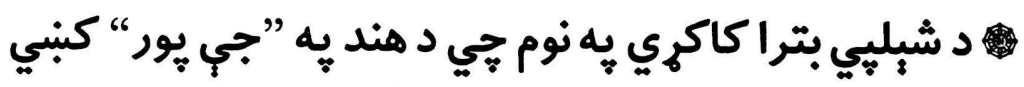

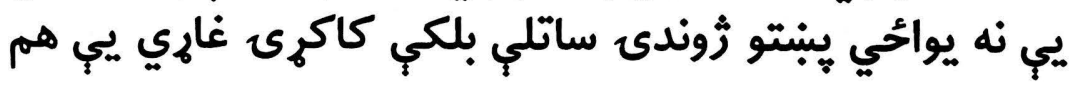
ورسرهزوندى ساتلي دي.

米米 


\section{مiّم}

له خيلو يارانو واصل واسطي، هاكتر نياقت تابان، محمد نعيم آزاد،

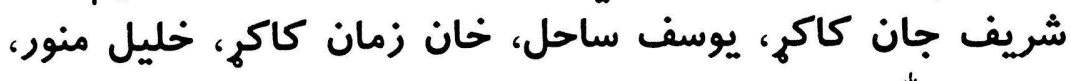

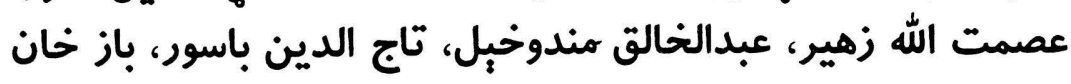

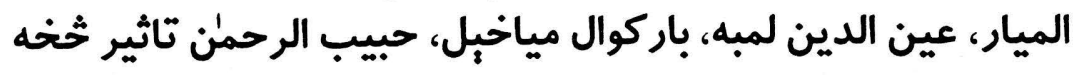

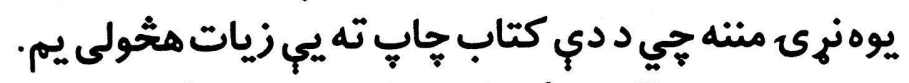

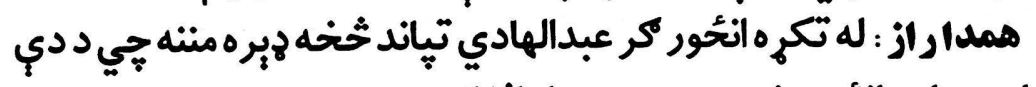

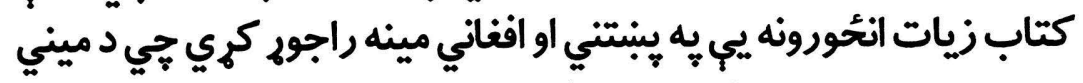

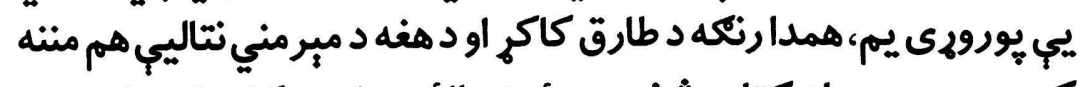

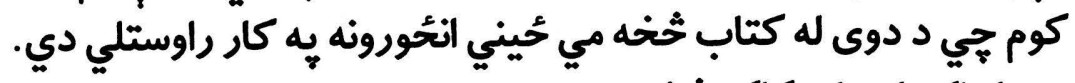

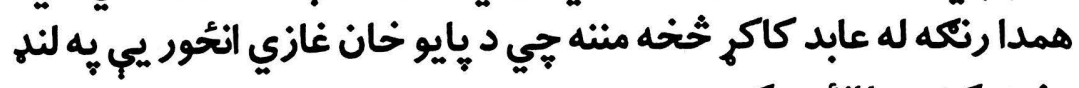
وخت كبني را انتحور كم.

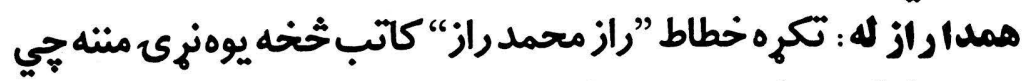

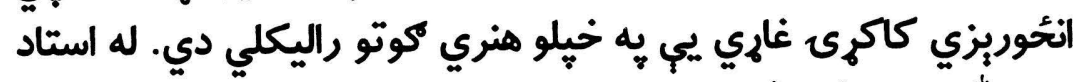

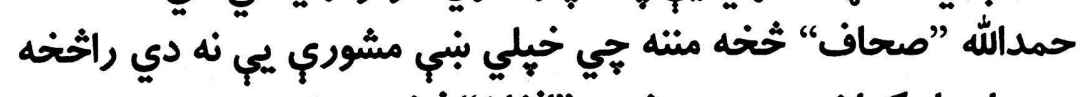

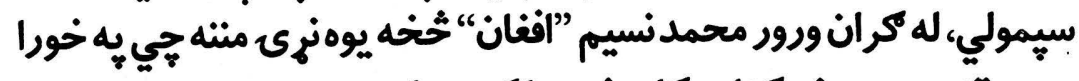

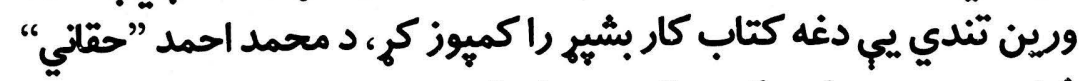

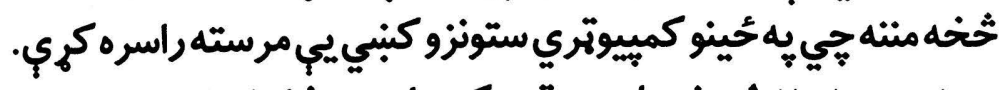

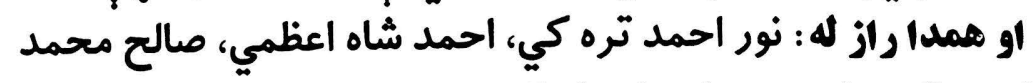

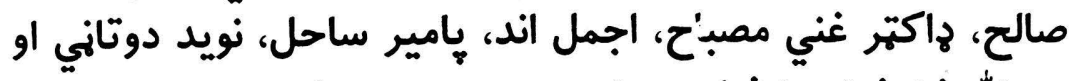

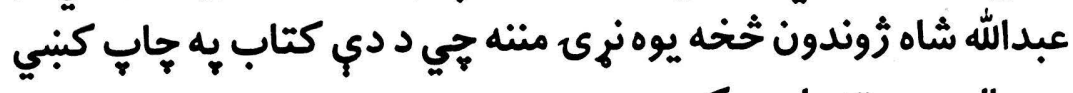
يي مالي مرسته راسره كري دهون. 


\section{د ثور حنتك يادنبت}

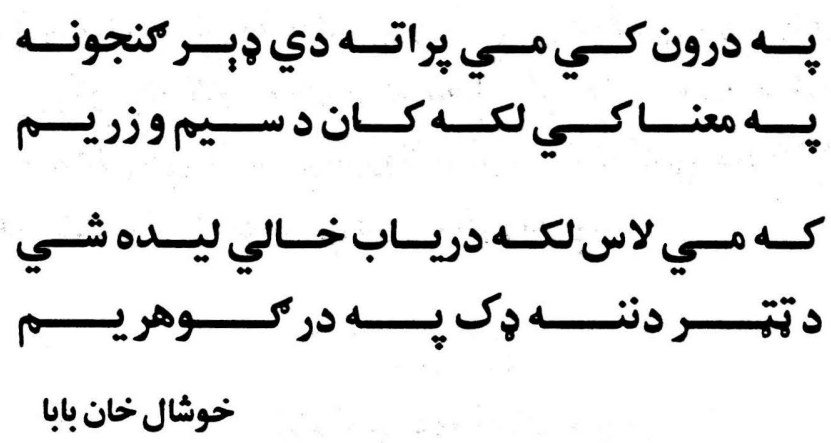

خر كنده او جوته ده، جي د هر غورحُنك بيلامه يا اساسي جوربنت او مانى هير يوه ارمان ودانيري، د زُبنيو غورحُنكونو يا ادبي تولنو ارمان

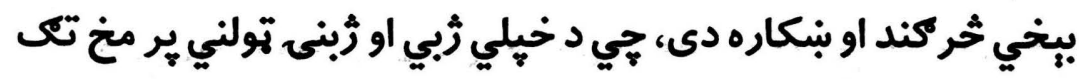
يب دزهره خبرهاو ارمانوي. يبنتو ادبي غورحَنك هم له دغه وياره بي برخي نه دى، جي و خيل

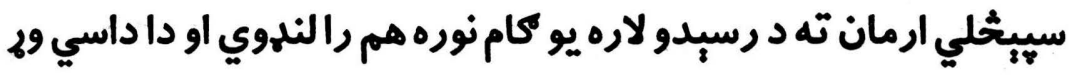
كام ياموي يا بولي يب جي د نظر د كاته يه هومره لاره ر النهوي، هغه يه دي جي د دي وه كتاب (كاكيرى غايري) منحُيانكه د تولني خبري رغوي، او د تولني د زيره د دي خبرو د درى كولو، راتولولو او ارزلو لهاره جي بياوري ليكوال : صادق ثرى كومي ستري كاللي او هاند او هخحي يبي

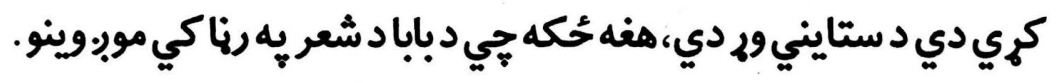




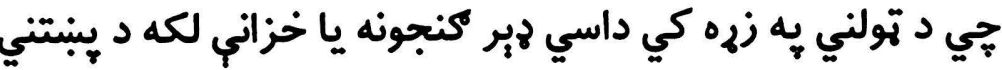

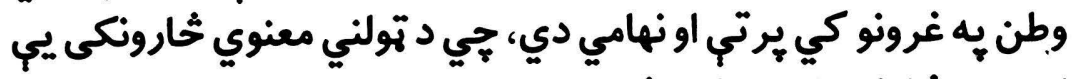

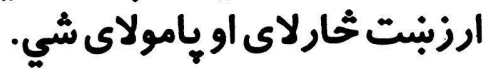

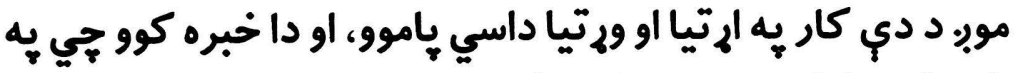

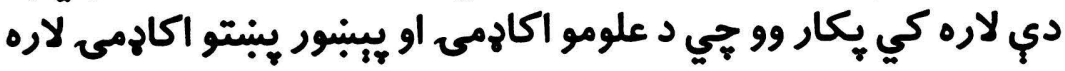

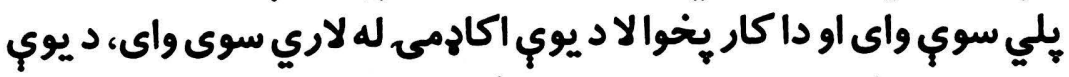

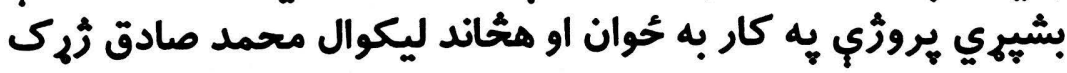

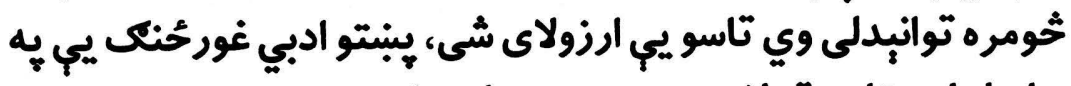

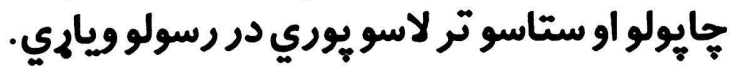

يه درونبتت

بِبتو ادبي غورحُنك كوته 


\section{ليكليك}

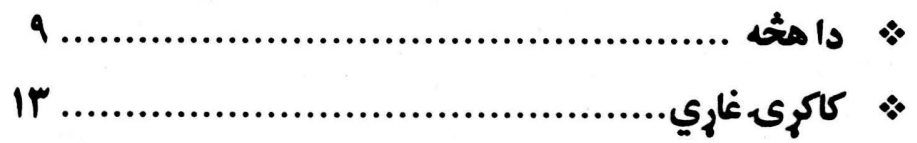

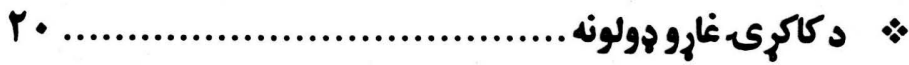

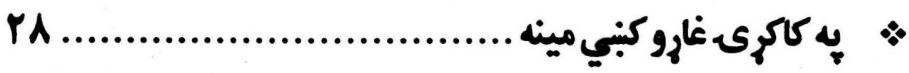

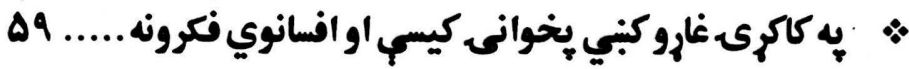

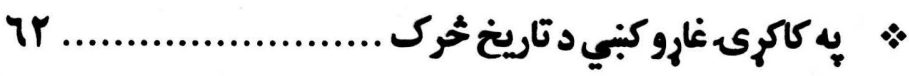

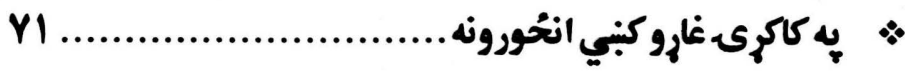

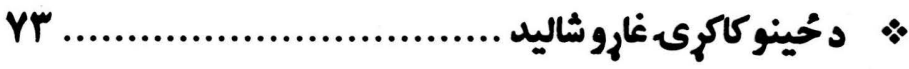

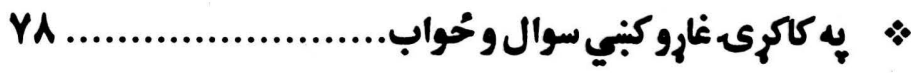

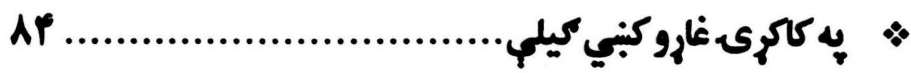

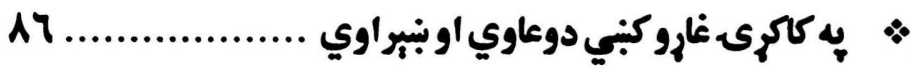

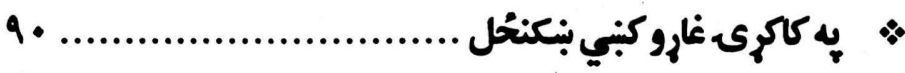

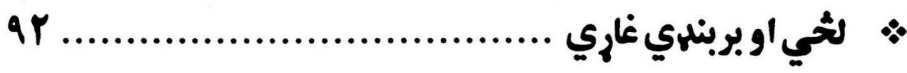

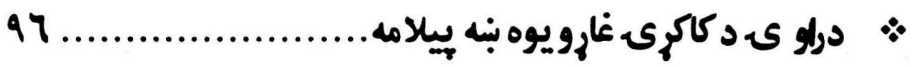

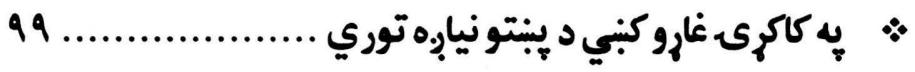

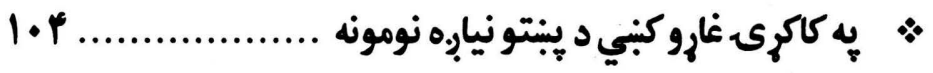

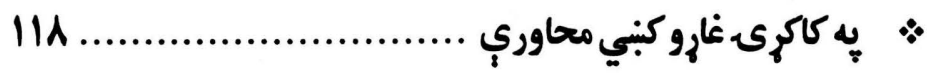


Irr

• به كاكرى غاروكبي متلونه

ira

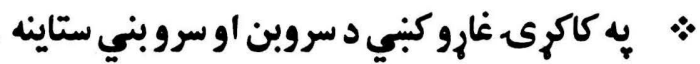
IrY

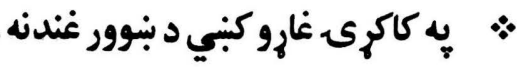
|ri

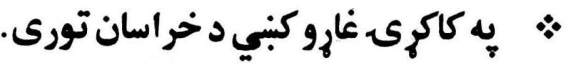
ira

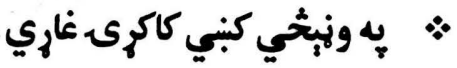
187

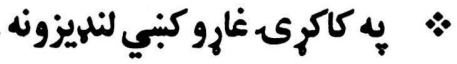
if 9

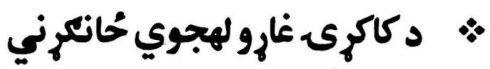
lor • $\Delta \cdot P$ هll

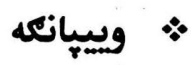
Drr

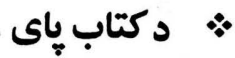

\& 


\section{: 10}

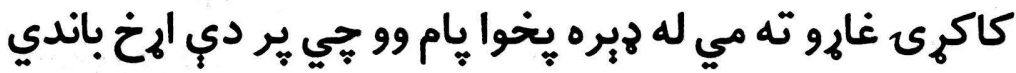

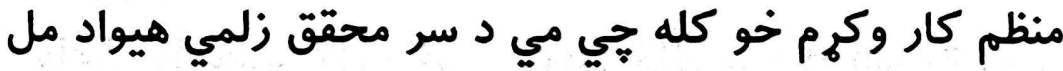
صاحب كتاب "يبنتو اولسي ادبيات، كنبي دا دا كربني ولوستي

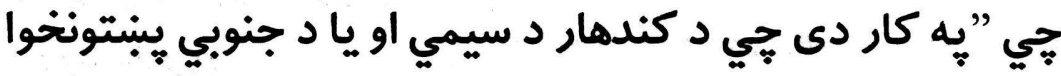

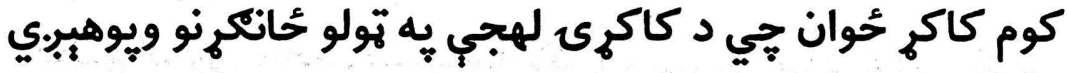

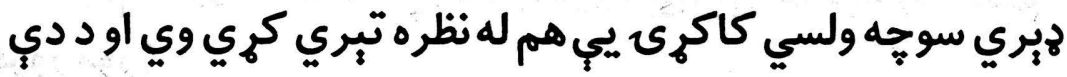

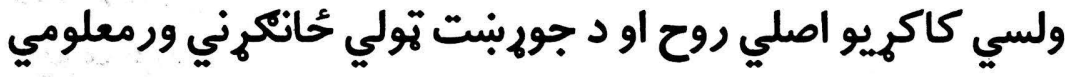
وي د دي سندرو تولي شوي متفرقي نموني او مجموعي له سرو سره يه

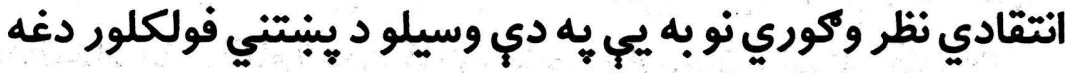

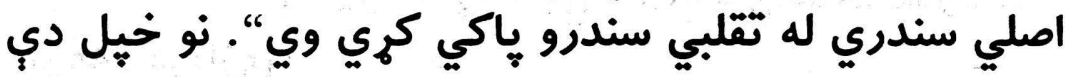

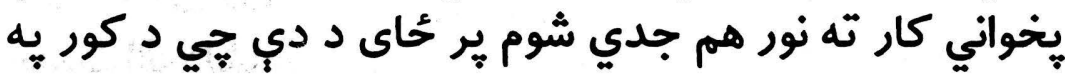

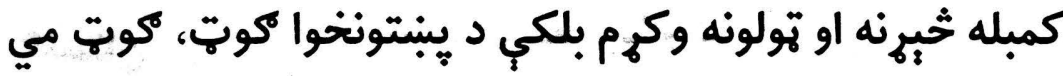

$$
\text { يسي كتلى دى. }
$$

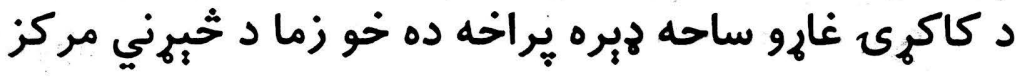

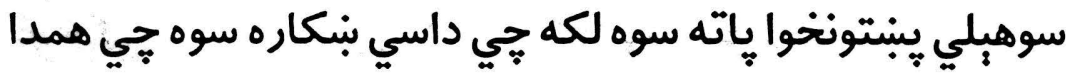

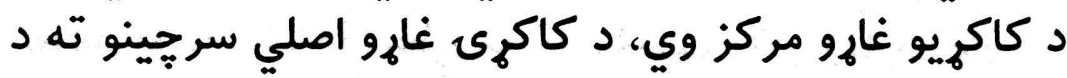

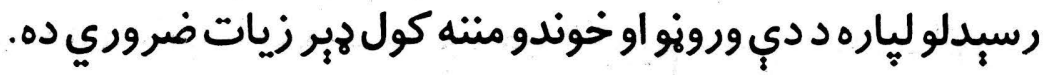


كاكرى غاري

كوته :

خليل منور ، لقمان كاكر ، سلطان عادل كاكر، عين الدين لمبه، حاجي فضل محمد نورزى، عصمت الله كبزيى.

$$
\begin{aligned}
& \text { ينين : بنين } \\
& \text { بازار كى: } \\
& \text { نعيم آزاد، نياز محمد مخمور. }
\end{aligned}
$$

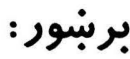

$$
\begin{aligned}
& \text { عبدالستار راهياب، } \\
& \text { خانوزى : }
\end{aligned}
$$

واصل واسطي، كل مكى، يروين كاكره، ذكاءالله يانيزى، عبدالرحيم سوزانه، زرغونه،

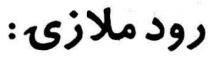

عظيم افروز، محمد نسيم سارنكزى، بي، بي سعديه (د عظيم

$$
\text { افروز مور)، }
$$

محمد شريف كاكر، عبدالغفور عيسى خدل، بسم الله خان، خدائيداد خان، نظام الدين كاكر، حاجي خان، هاشم استاد، قادر لالا،

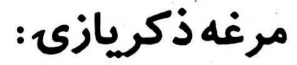
نعمت الله دلشاد، مركاد،

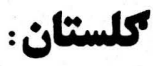

جيلاني حبيب زى، ناظر صادق، جاويد كاكر، يار محمد ينبتون، فوثمكح:

محمد يوسف ساحل، علي محمد ماستر، ذاكر زيارت وال،

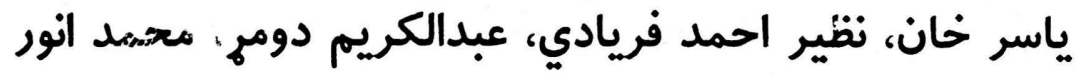


11 كاكرى غاري.

دومر، محمد شفيق دومر، نصيب الله، ولي محمد سارنكزى، عبدالرزاق بروانه، ولي سارنكزى، مئ، دومي،

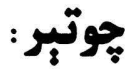

اروابناد شِّر جان بازيى، امان الله، ميراجان، حاجي محمد

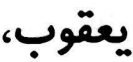

زور:

ظاهر تارن، نصر الدين دومر، سوراب خان دومر،

بجح

بصير خان، حبيب خان، قاسم خان، لال خان، نور محمد،

شبخون،

هندوباغ : ماحو،

حاجي نعمت الله جلالزى، اختر رسول، كليم الله، فتح خان

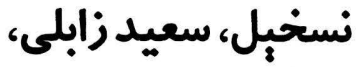
نيسح:

حيات الله، عبدالخالق، حاجي عظيم اكا، عبدالصادق، عبدالحى، احسان الله، رشيد خان، خيالي، عيدالئ،

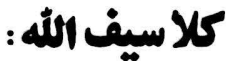

واجد تبرى، نصيب سنكريار، عبدالصمد جلالزى، نواز قايل،

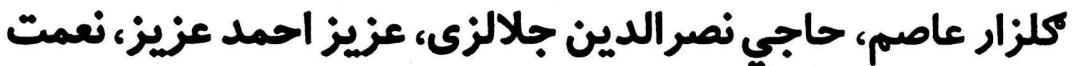

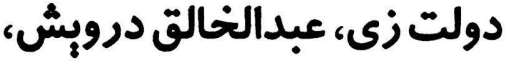
زُوب:

عبدالخالق مندوخبل، فبروز كبزيى، باز خان الميار، رمضان

$$
\begin{aligned}
& \text { شاه جرمى، }
\end{aligned}
$$

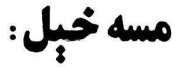

تاج الدين باسور ، نصر الله عرف تيكر، 
كاكرى غاري

بورى:

روزي شان جرمى، هاكتر عبدالرازق كاكر، تنوير احمد كاكر، عبدالله جرمى، عبدالستار جرمى شئ.

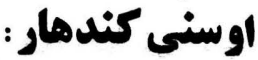

واصل حسن يار، هاكتر عبدالرازق يالوال، شهيد امان الله كاكر، محمد علي اندر، وني،

يه دي كتاب كنبي جي مي خخومره كار كرى دى دى د دي قضاوت

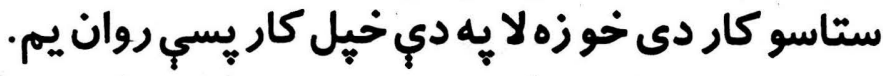

هيهدرنبّت:

محمد صادق ثزى : 


\section{كاكرى غاري}

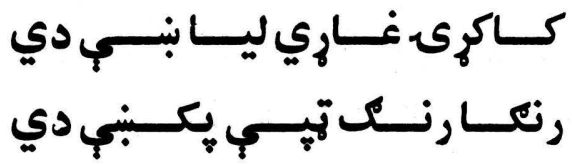

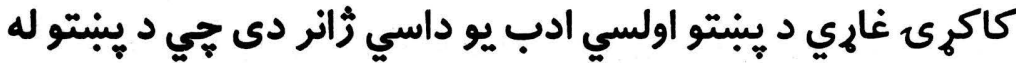

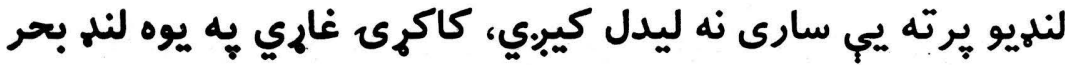

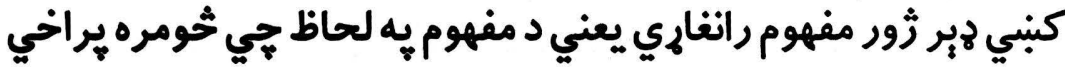

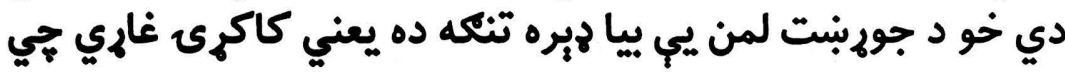

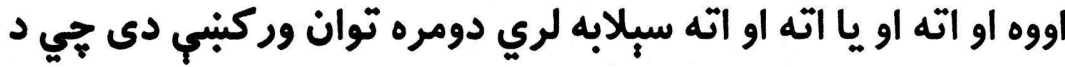

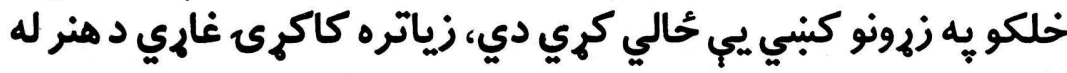

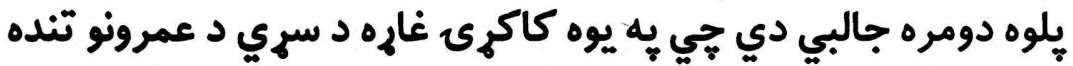

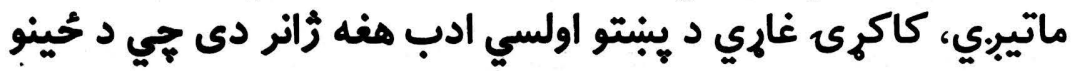

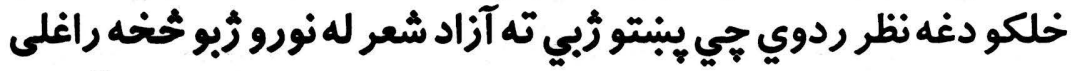

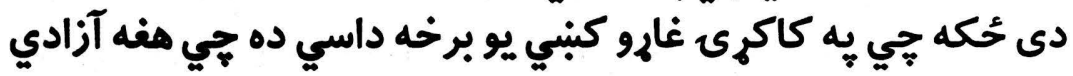

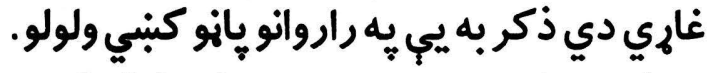

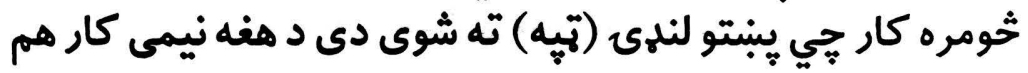

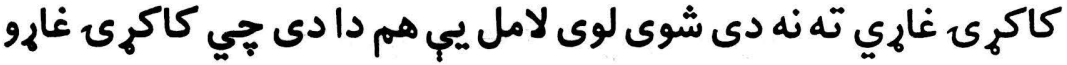

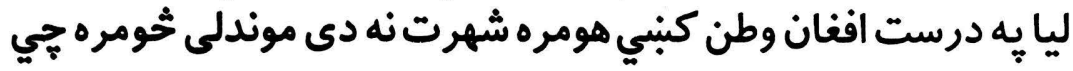

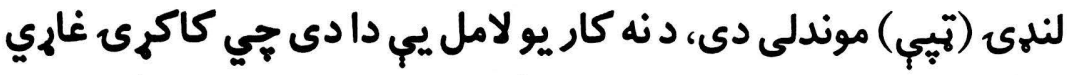

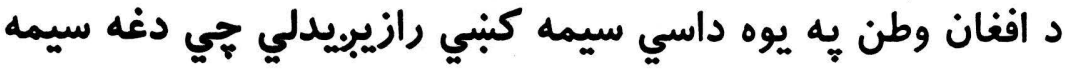


كاكرى غاري

"كاكر ستان او يبنين" (اوسنى سوهيلي يبنتونخوا) د هيورند د جبري

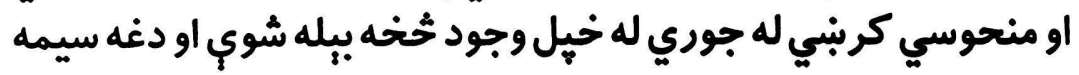

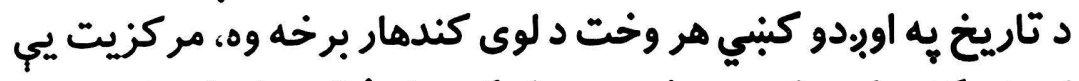

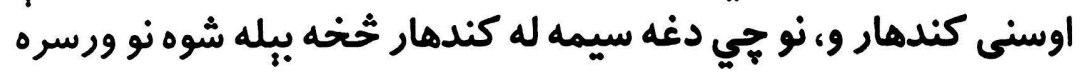

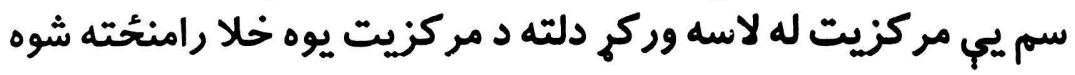

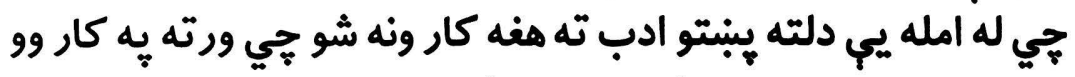

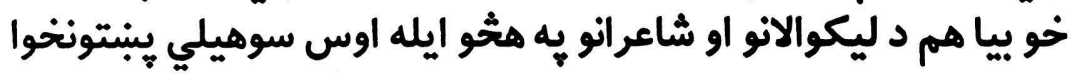

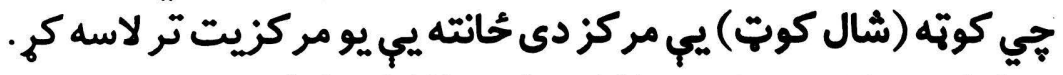

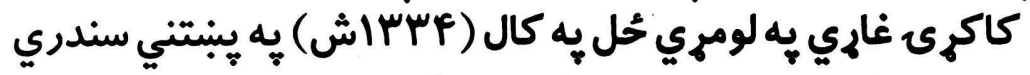

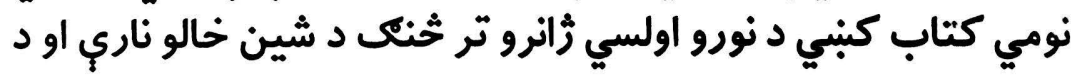

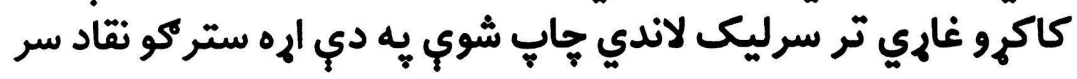

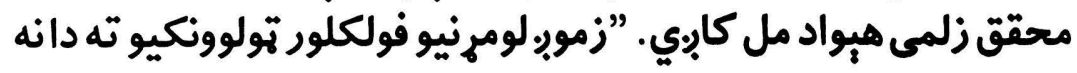

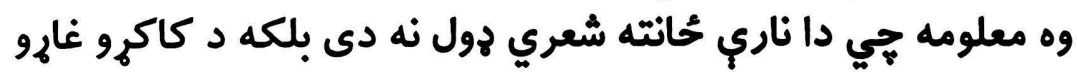

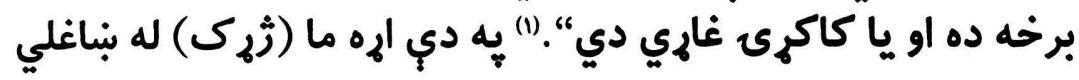

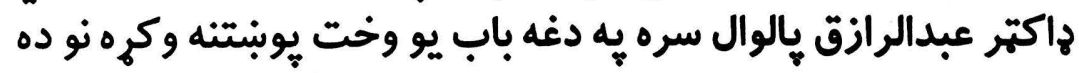

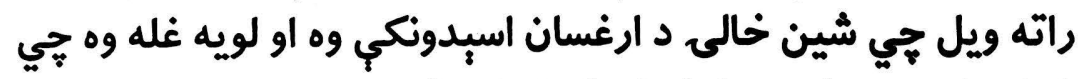

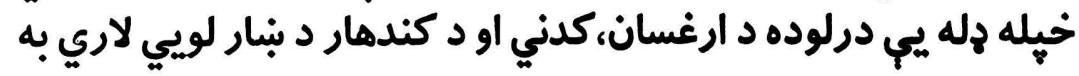

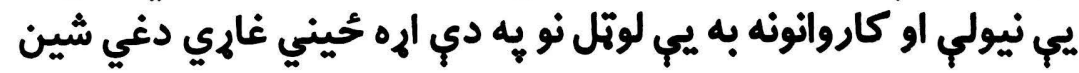

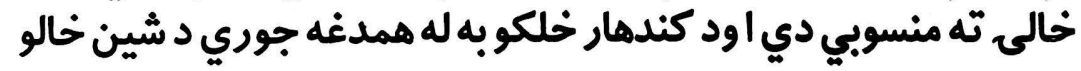

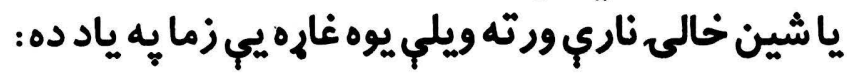

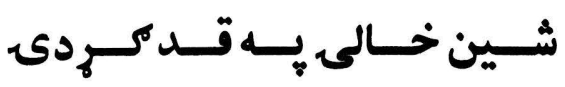

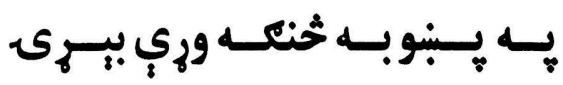

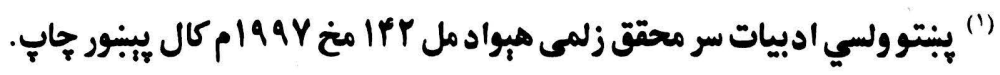


نو دا د شين خالى ناري نه بلكي كاكيرى غاري دي.

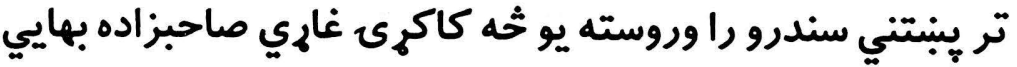

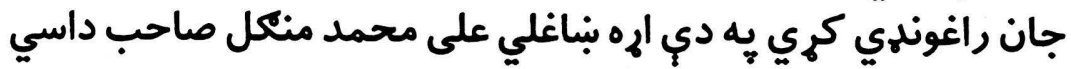

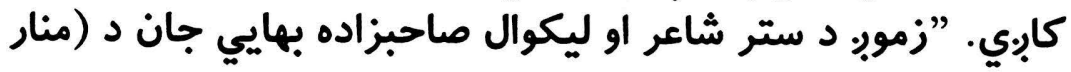

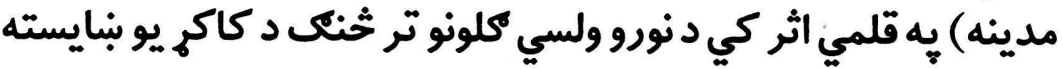

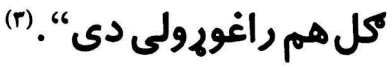

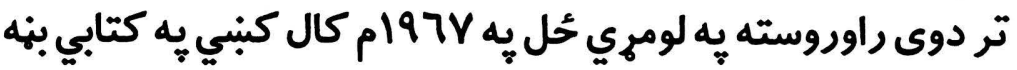

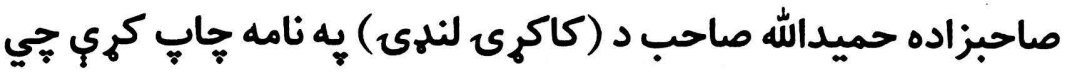

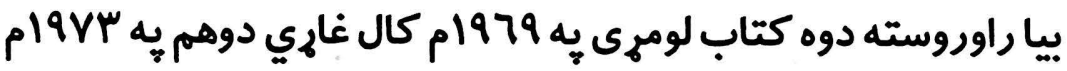

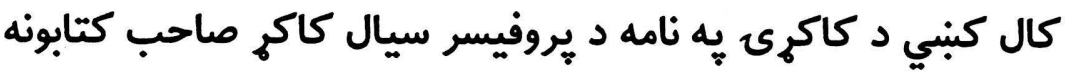

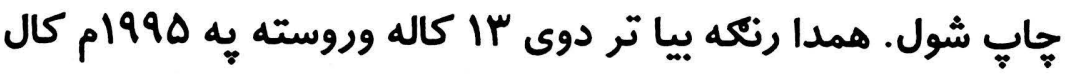

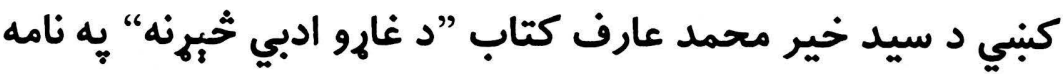

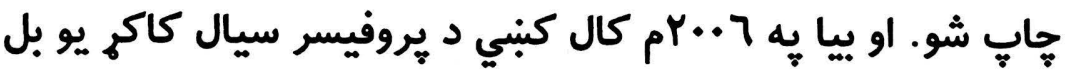

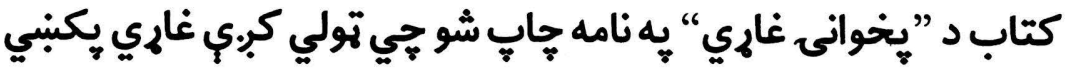
راغونلهي شوي دي، د دوى تولو مشرانو كار خيل كار ير خهيل، خيّل

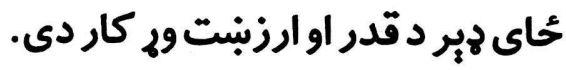
زه د فولكلور تولونكي د يوه شاكرد يه حيه حيث د مشر انو كار ته د دقدر

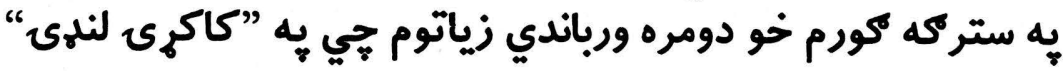

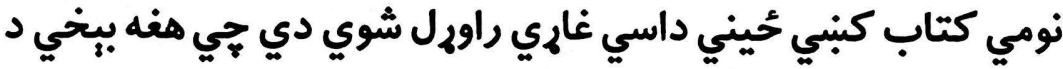

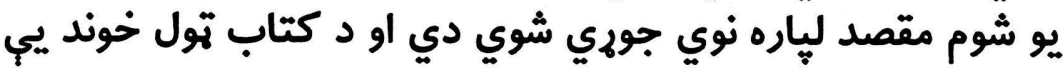

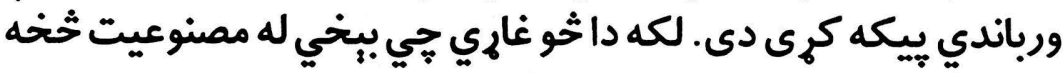

$$
\text { هي دوي: }
$$

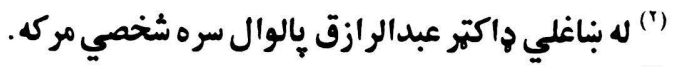

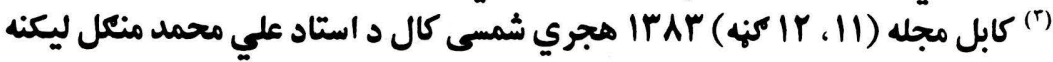


كاكرى غاري

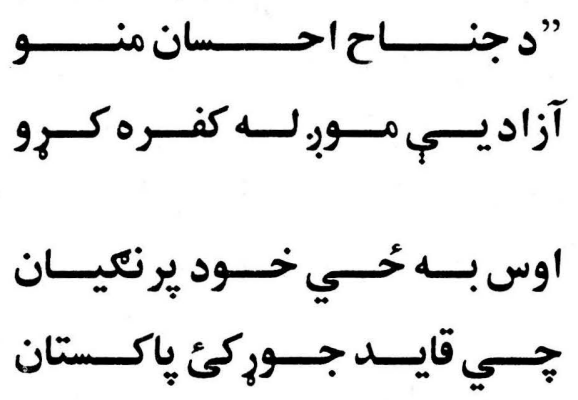

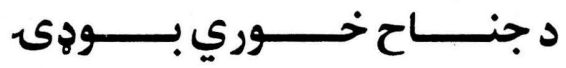

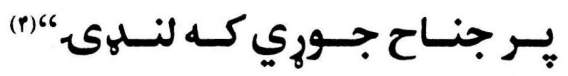

يه ”غاري"، نومي كتاب كنبي بيا داسي غاري راورل شوي دي جيد

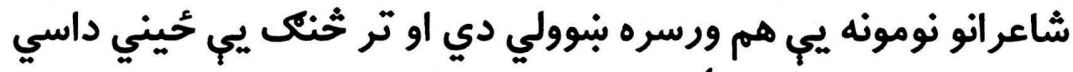

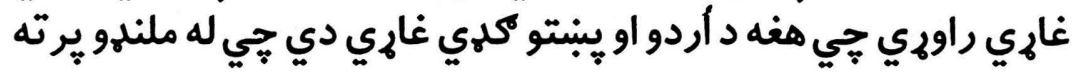

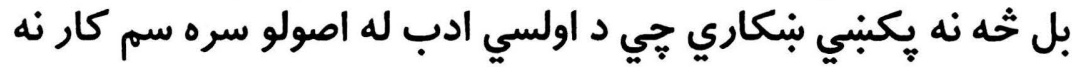
دى.

يه " بكاكرى" نومي كتاب كنبي هم دغسي تبروتني ليدل كيري

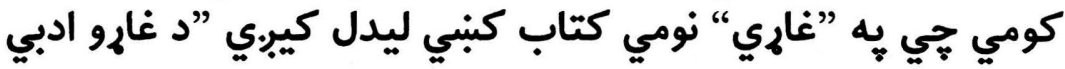

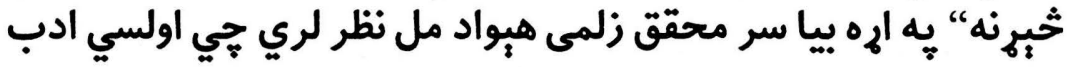

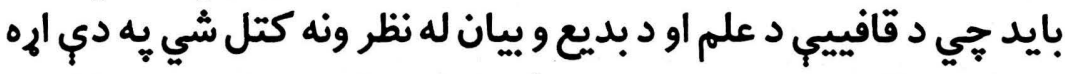

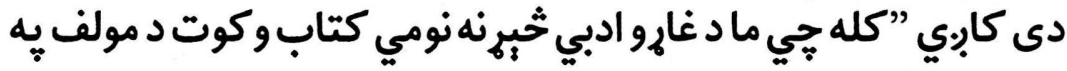

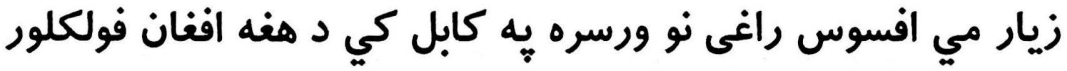

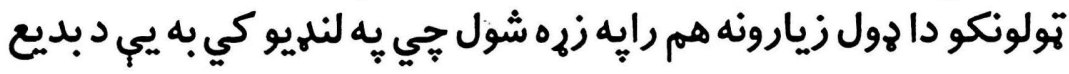

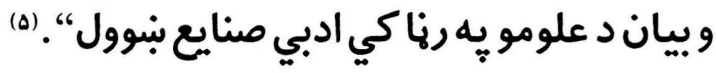

(")

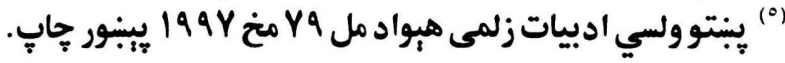


يخوانى غاري كتاب هُبر د ارزبنت ور كتاب دى خو متاسفانه خيل

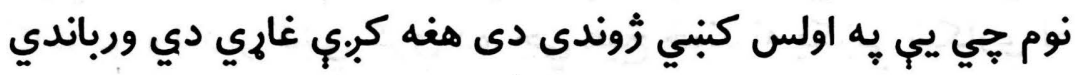

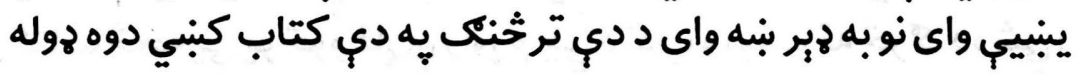

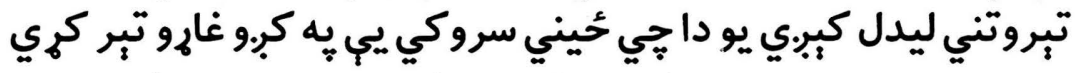

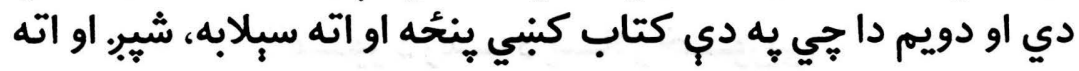

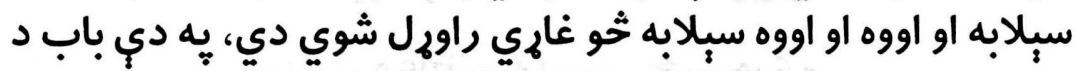

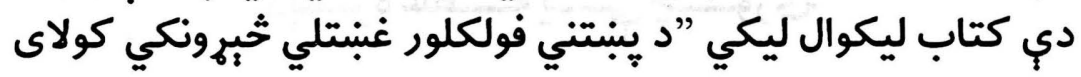

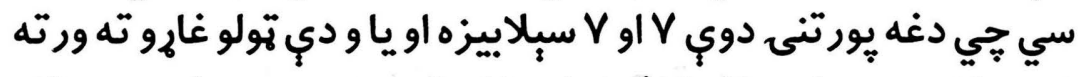

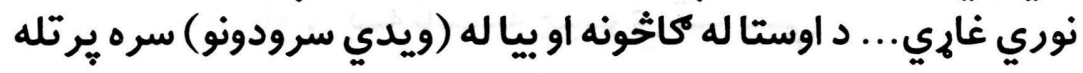

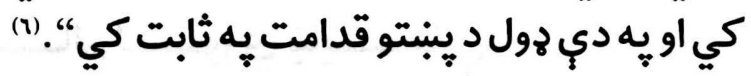

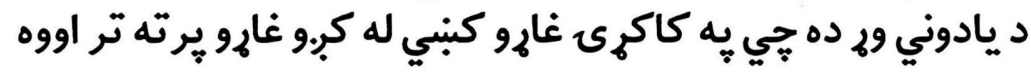

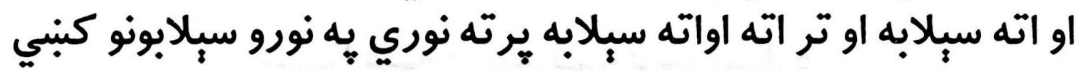

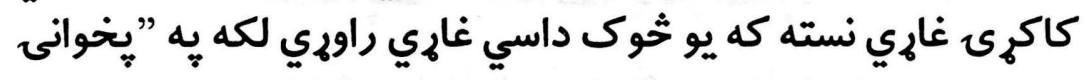

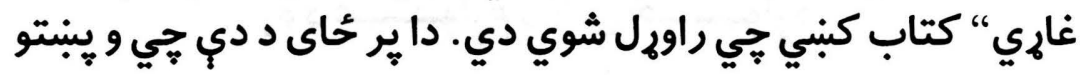

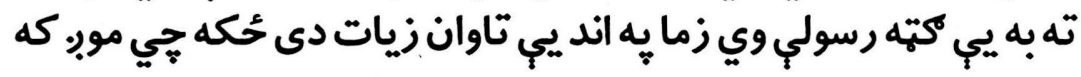

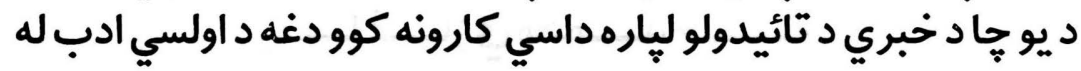

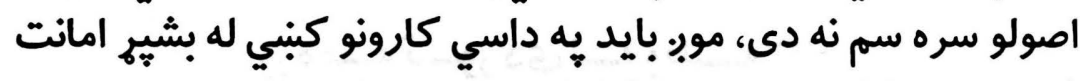

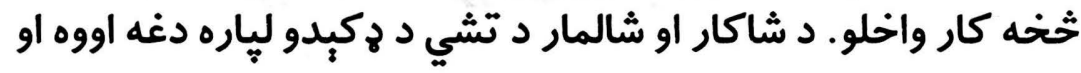

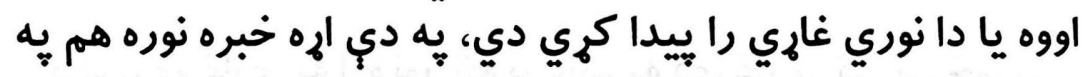

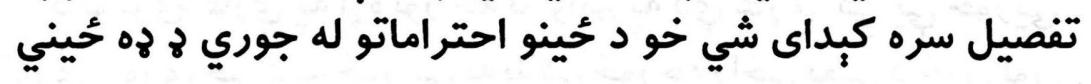
كوم.

له دي برته دري خلور كاله وراندي د غازي محمد حسين يو كتاب

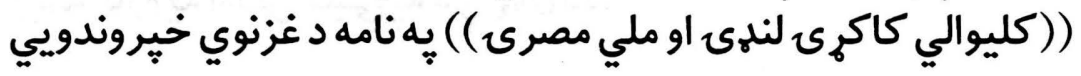

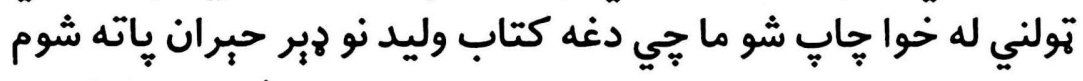

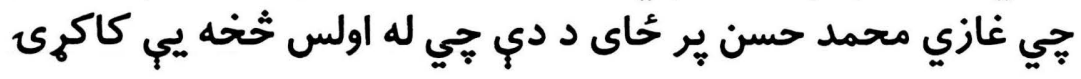

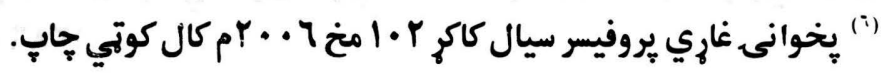


كاكرى غاري

غايدي او لنهى (تيب) راغونهي كري واى داسي يبكه شاعري يه

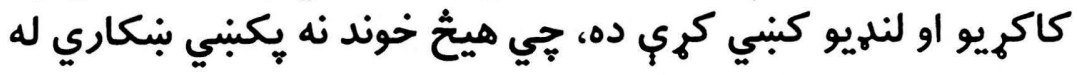

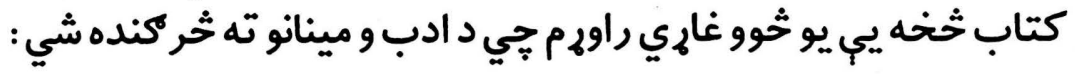
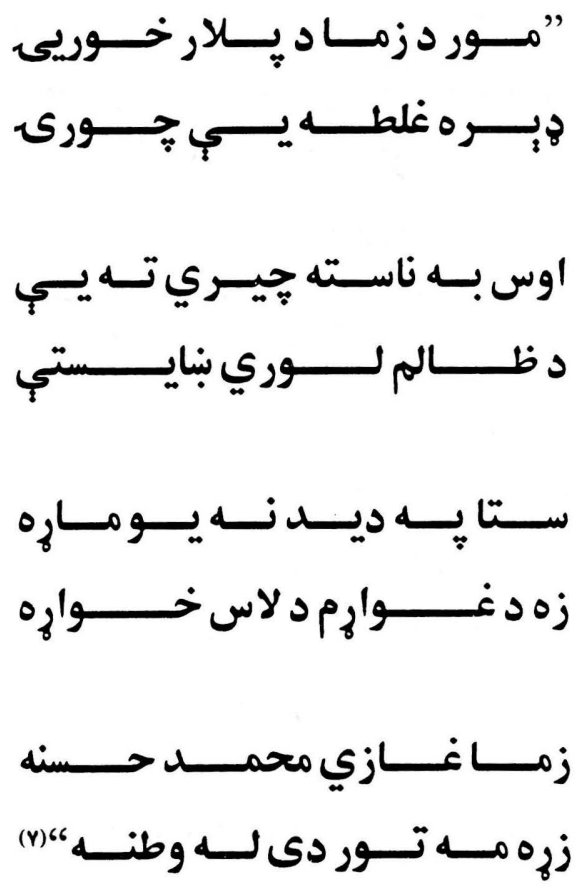

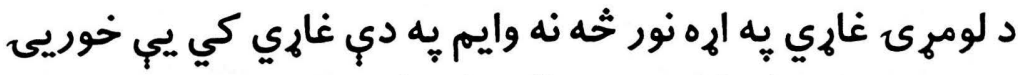

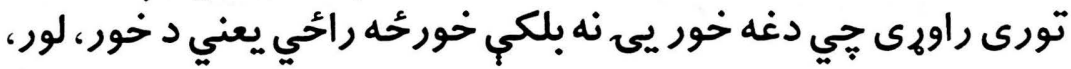

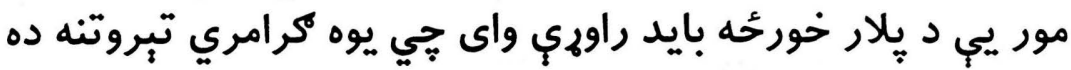

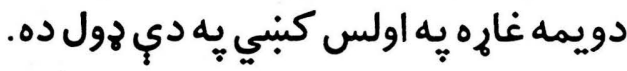

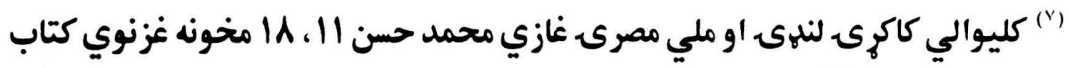

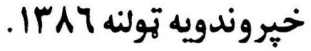


19 كاكرى غاري

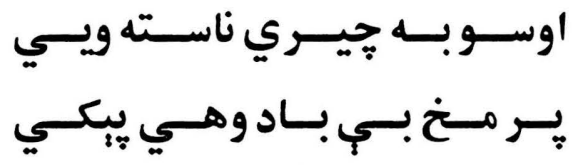

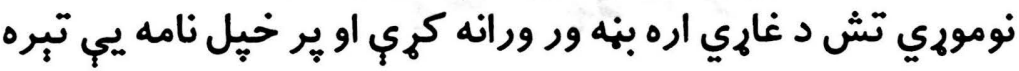

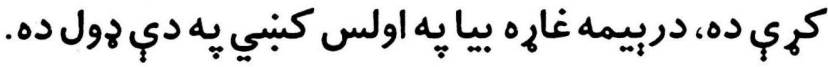

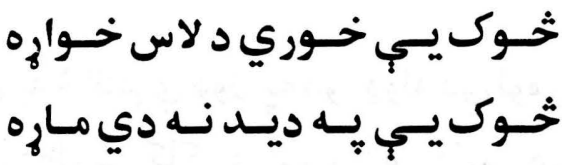

يا

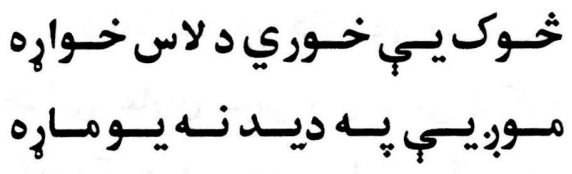

د نوموري د دي عمل يه باب قضاوت تاسو ته يريُردم.

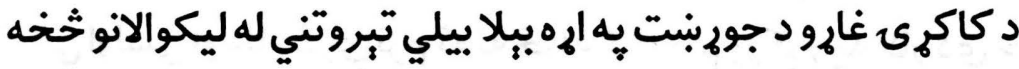

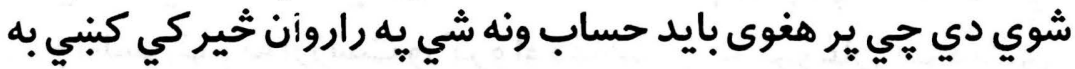

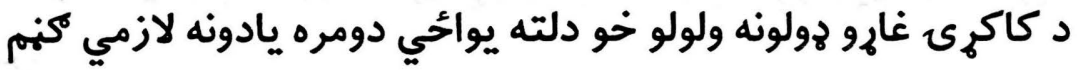

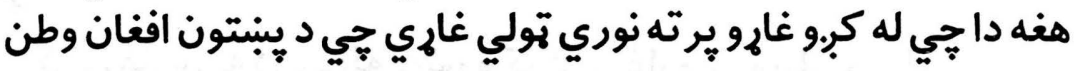

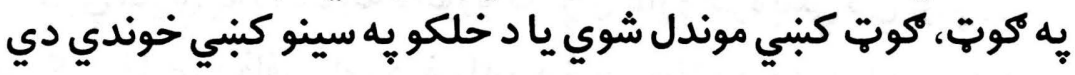

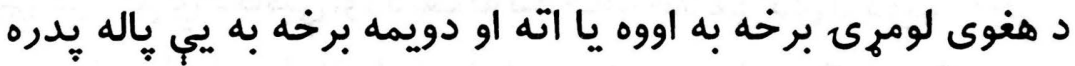

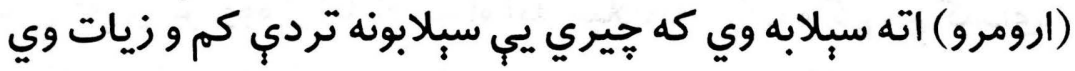

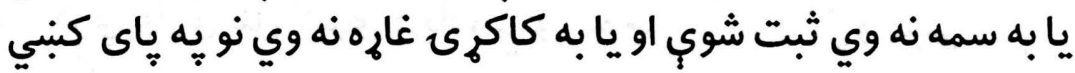

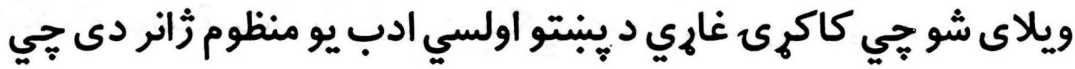

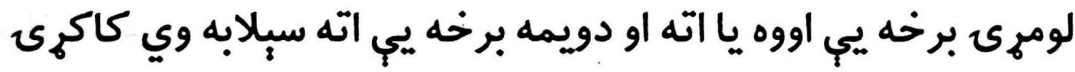
غاري بلل كيرب.ي. 
كاكرى غاري

\section{د كاكيرى فارو هولونه}

\section{(1) (1)ب غاري :}

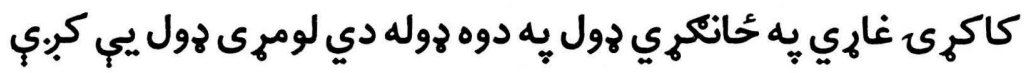

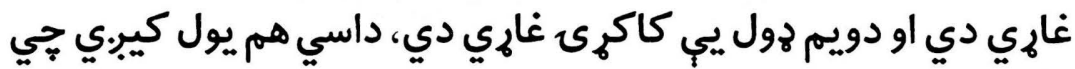

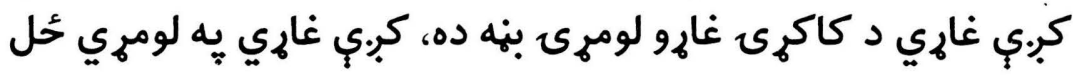

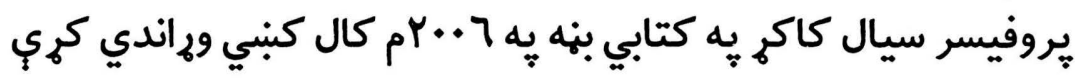

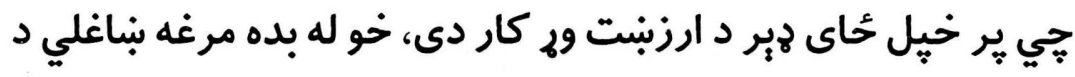

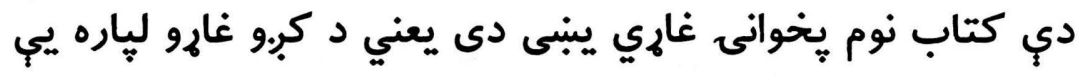

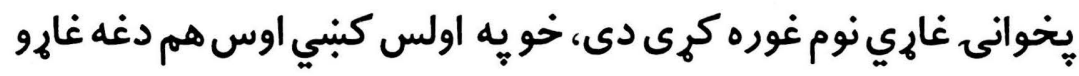

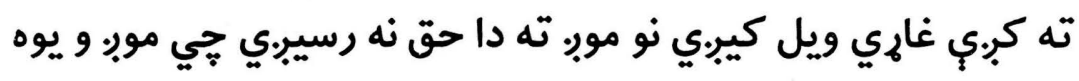

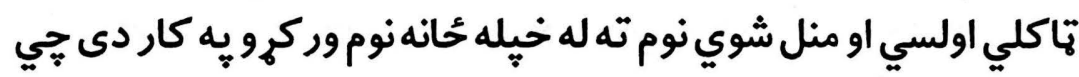

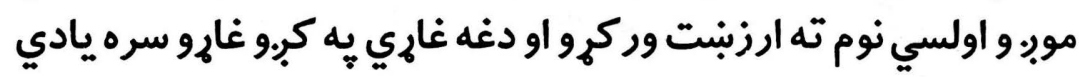
كرو.

كربي غاري يه دوه هوله له نورو كاكرى غارو سره بيلي دي لومرى دا جي كر.ر غاري د قافيب او رديف له بند ثخهه خلاصي دي او دويم داجي

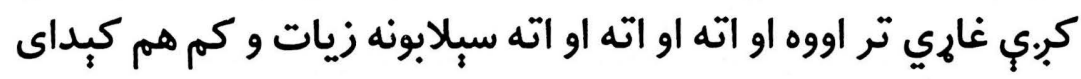

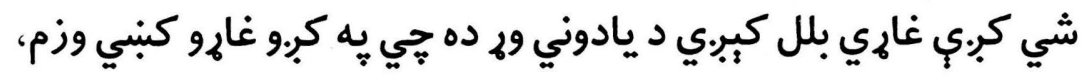

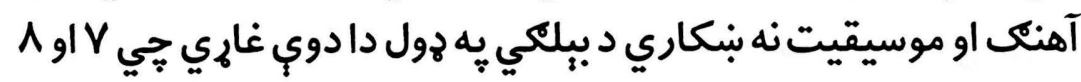

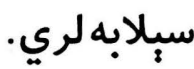


rI كاكرى غاري.

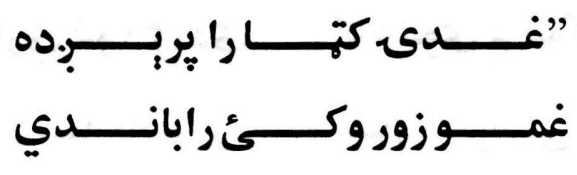

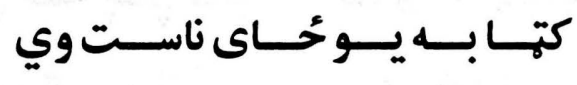

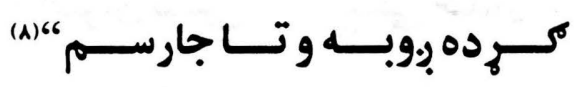

او دلته حُيني نور غاري راوهم جي موضوع بنه سيينه شي:

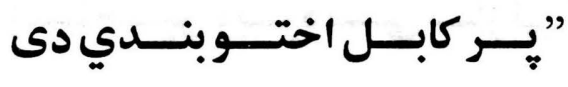

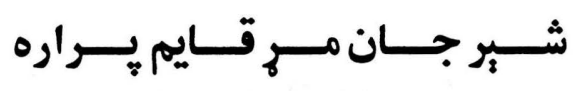

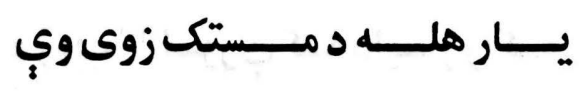

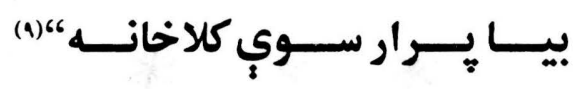

اوس به دلته حُيني كربي غاري راوهم جي زما د معلوماتو له مخي تر اوسه بل حُاى نه دي خهيري شُوي.

د غونسهى يـر سـر وليـار دى نـازك كـل دى د سـسيندي

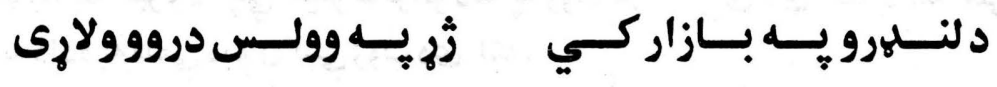

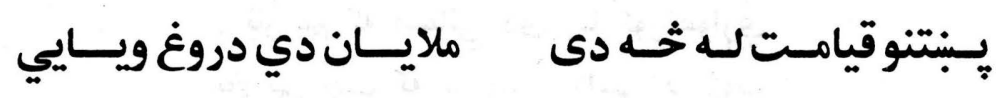

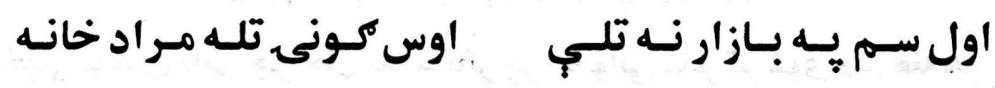

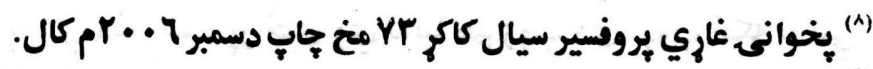

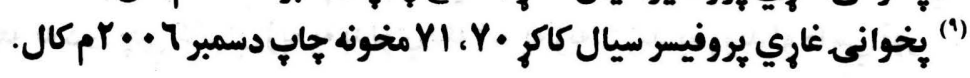




$$
\begin{aligned}
& \text { د ماجـت ليـاري نـودي دي مله لوى يرتوك تاوان دى }
\end{aligned}
$$

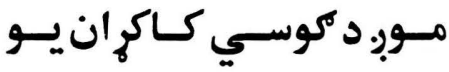

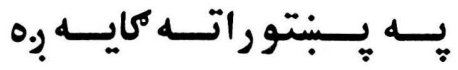

$$
\begin{aligned}
& \text { سـري نـارهوكـه خحي واورم }
\end{aligned}
$$

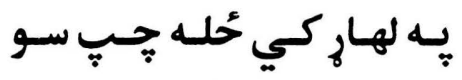

$$
\begin{aligned}
& \text { ينكي خداى نه دي راكئي }
\end{aligned}
$$

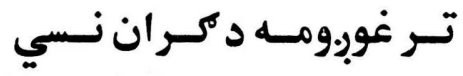

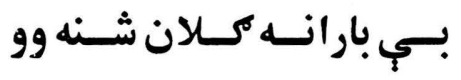

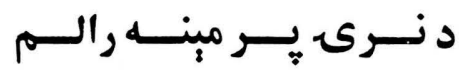

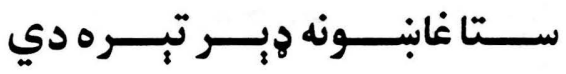

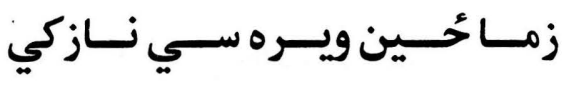

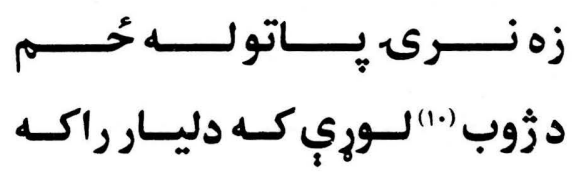

* * *

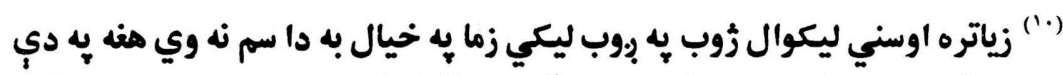

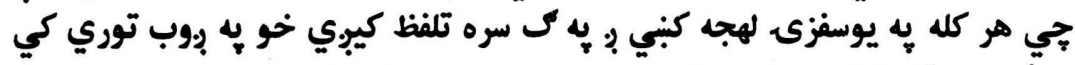

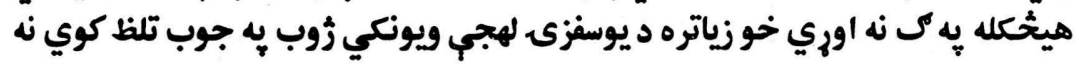

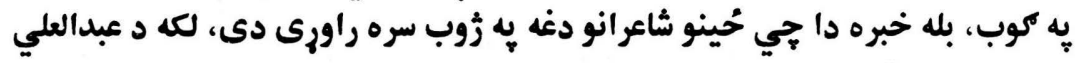

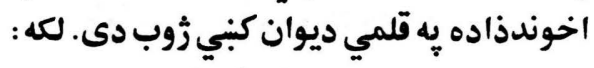

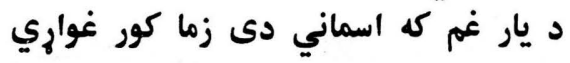

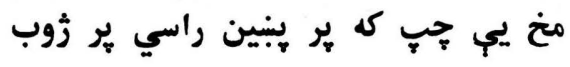

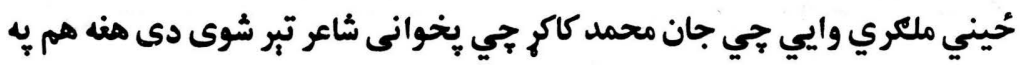

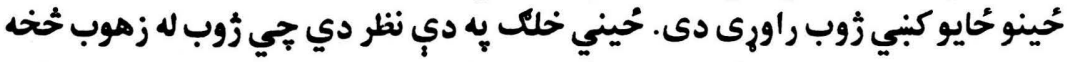

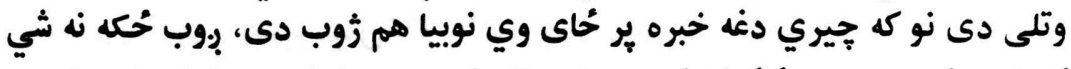

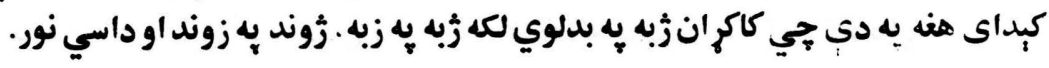




\section{: (Y) (Y)}

د يبنتو اولسي ادب دغه برخه لكه وراندي جي مي و ويل جي لومرى اتح

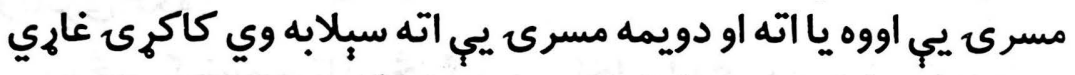

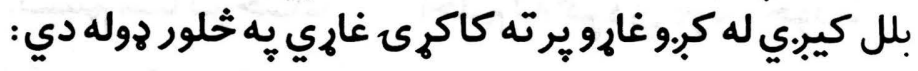

\section{1:آزادي غاري:}

r : هغه غاري جي قافيه او رديف دوارهلري

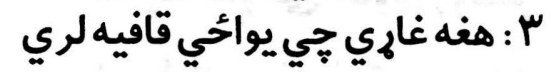
f : هغه غاري جي يواحي ري رديف لري. 


\section{: (1)}

آزادي غري هغه غاري دي جي د قافيب او رديف د بند خخهه آزادي

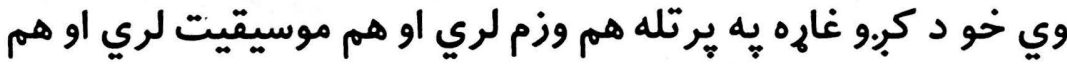

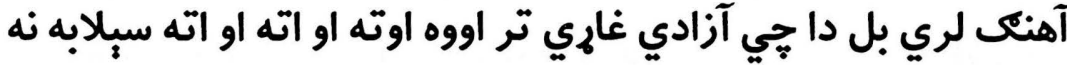
زياتربي، لكه:

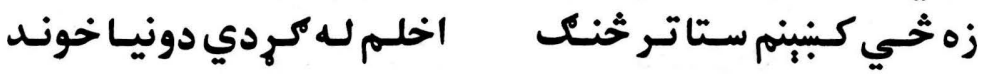

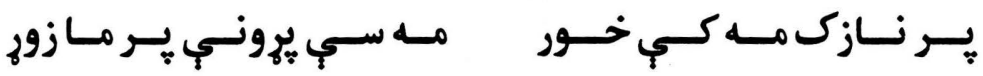

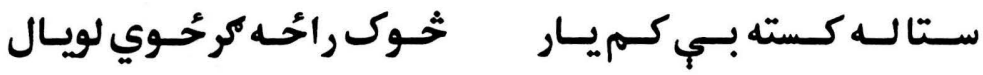

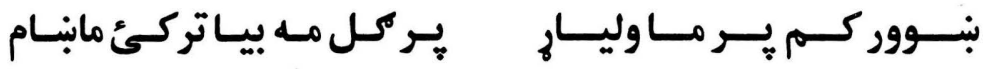

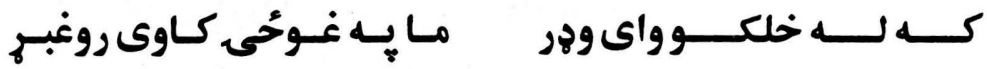

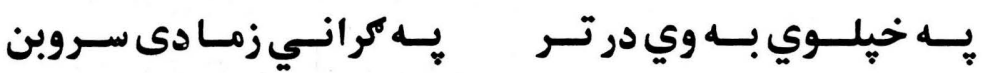

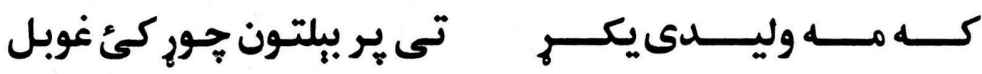

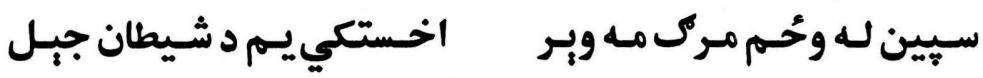

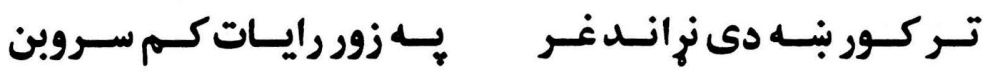

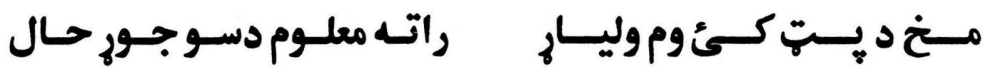

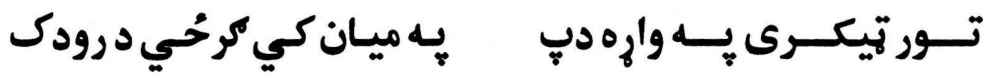

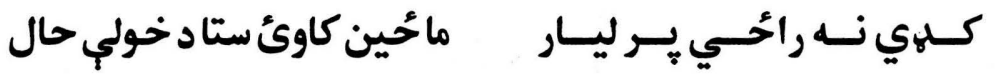

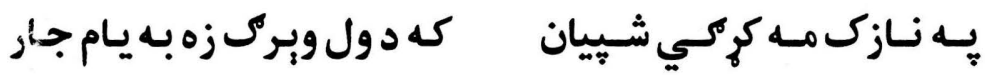

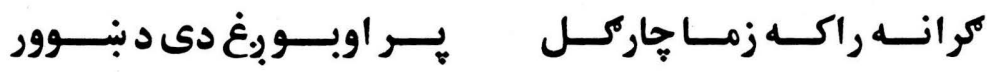

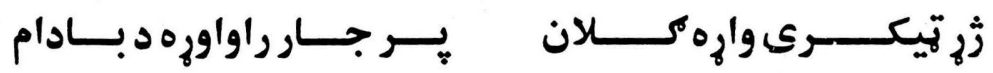




\section{(ץ) هغه غاري جي قافيه اور رديف دواره لري:}

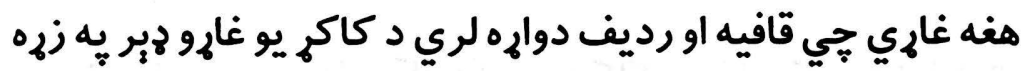

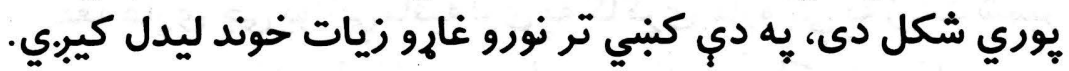
لكه:

\section{اوسب مــه خــوبر د لرمانــه سـو}

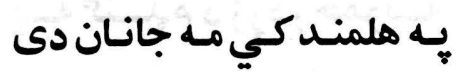
كر انه وخت تـره واى نـه سـم

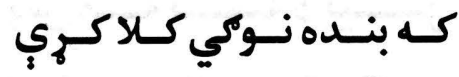
كرانـه اوس دمـزوشـيـي دي

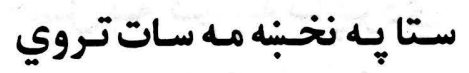
سهار كران حُي يه سيبدي كي ستاليـا زما ير ايمان شك دى بـوتى نـه سـوحي نـودي دي

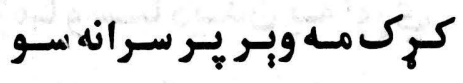
سـتا جاركـل ليونـوكـار دى خحي كران تلى زه بر سايه واى زهمها سكور سويد كوكل كي اوس بكساوه شـين خـالى سـوه

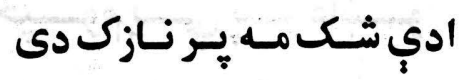

ومـهـ ليـــ يـهـــاى مـه نـهـ سـو

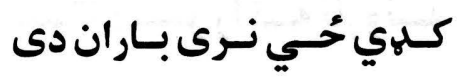

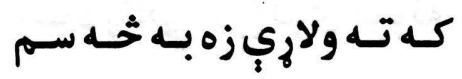

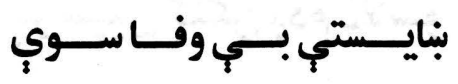
ستاغه ميـربـ زماغـه وزي دي زه خـــي راســم كلـى بـــروي يوه شِه ده خداى دي دوري

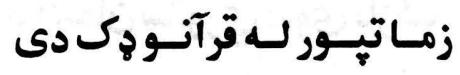

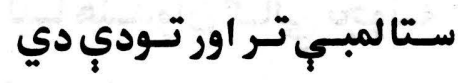
تــور تـوى دانـه، دانـهـ سـو

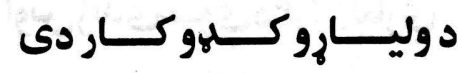

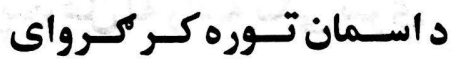

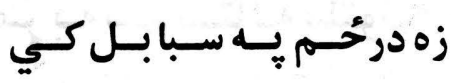
خوب مله ليد مانايب سيى سوه زمــاد غــاري اميـل ورك دى ليـ 
كاكرى غاري

\section{( ) هغه غاري جي يوائي قافيه لري}

هغه غاري جي يوائي قافيه لري يه كاكرى غارو كي يه زيات شمبر

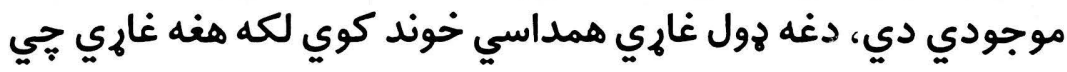
قافيه او رديف دوإه لري لكهي دودي دول

ســتا د ســـر راكـــهـ تارونـــه

رب د بركسي كي لوى غرونه

ير سيّين كنكن ب.دمم دلاسو

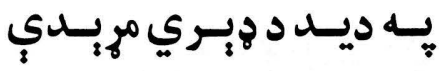

كــه د بــاور وي يــه يـاري

كنــدارى بــه سـي هلكــــ

د اسمان ستوري سوى نازك

ليـا هنــدوانكسالي نجونـــ

كه زونـدى رالي باسـوري

اوسزندىسويدوكرانلياري

ينه غل له راسه تتكي سري

مـر بـه سم سـتالـ بيلتونـه

تــوى راولـه شـــن خـالى

ليـري وطن لـه وري كرانـو

يب وزيقى تر شيدو سينيني

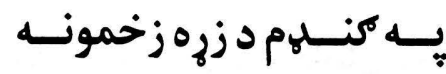

بــه ودر دي سـتـئ كورونــه

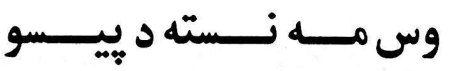

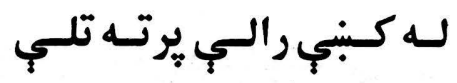

خيـل بـه كـم يـهـ تـا يـردي

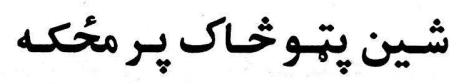

يه شِيه راسي يهـ روحُورك

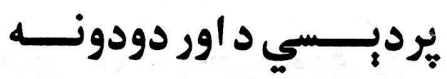

زمـاو سـتا ديـــن يـه اوري

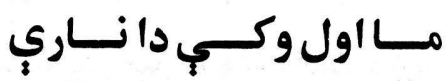

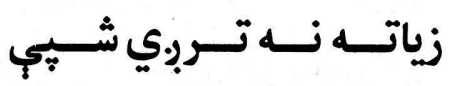

خـورب مـه سـي د سـر هلوونـه

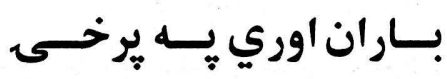

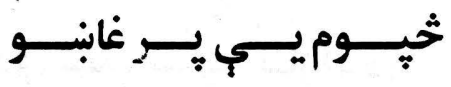

من: د ديتّ كه خلك د ويني 


\section{(F) (F) مغه غاري جي يوائحي رديف لري}

هغه غاري جي يواحي رديف لري د دغو شمبر هم بيخي زيات دي دي

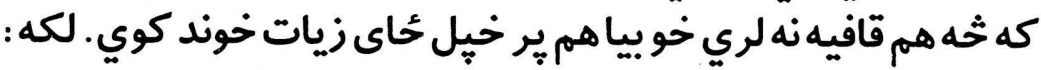

خداى

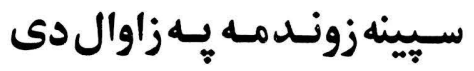

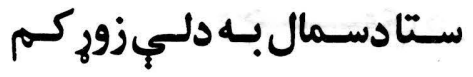

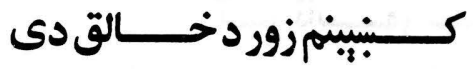
ياتـهـ سـوي بـهـ نزانسلدوردكي

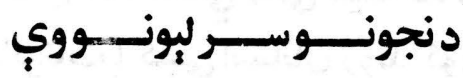
به لاس مه كوتكي

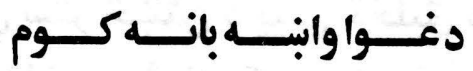

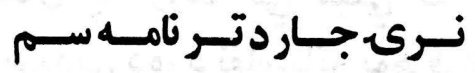

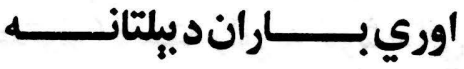
كـه كونسلوهـوم كـوميـيزيزه حوانـاندكـردكــ سـودايي

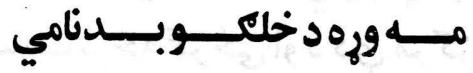

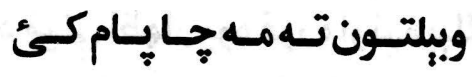
نسته تـور سـتركي_تهليـارزمـا
سر مه يـبنى ستا يِ غُبرِكي

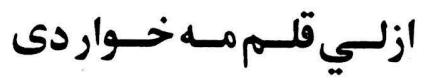
يواريجيخور مبيايبيتول كم ستا يه ستركوراته خوبٍ تصدى زمانصيب يه توروغروكي

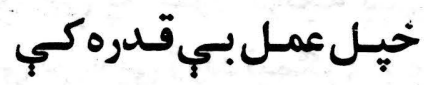
سر مه ثخوك ير يري

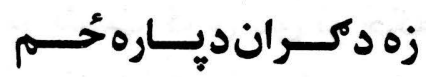
اولتــــى اوس اوبـهـ سـوم شين اسماانوورهيجيره

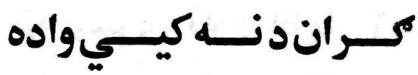

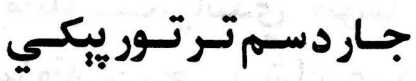
يـهـبلتــونكـهــانزنـي صبر بنه دىخي خداىراكئ خلــك وليـارديشــاوخوا 
كاكرى غاري

\section{يه كاكرى فارو كبني مينه}
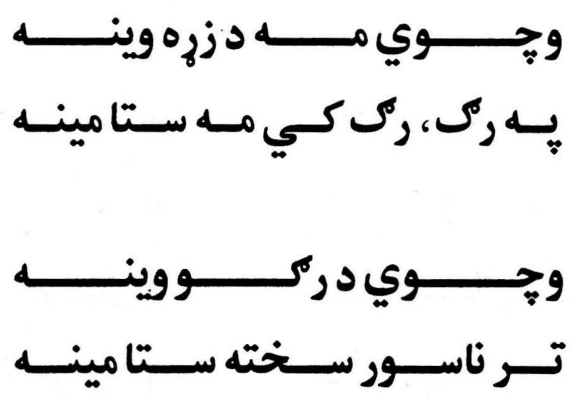

د زوند اساسي تككى مينه ده هر جيري جي به خيه ثلور كونجه بينى

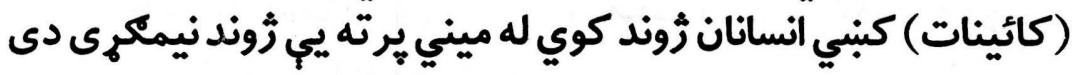

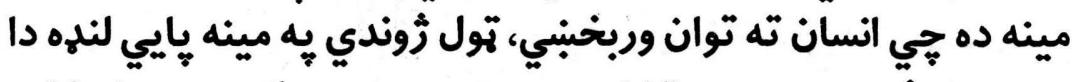

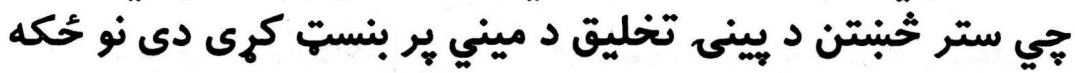

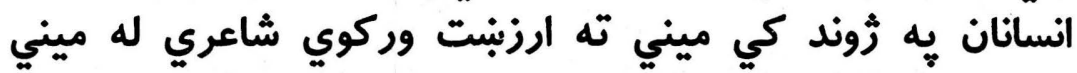

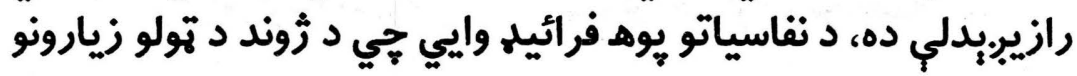

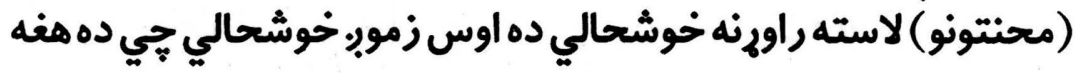

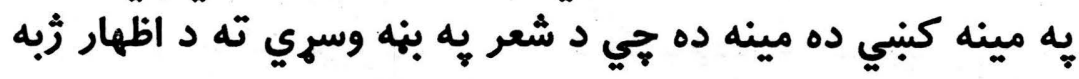

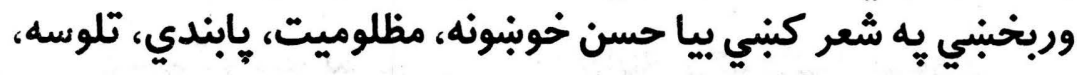

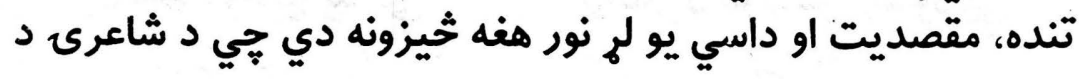
بنايست برخه كرحي او د دي مر كزه مئه مينه ده.

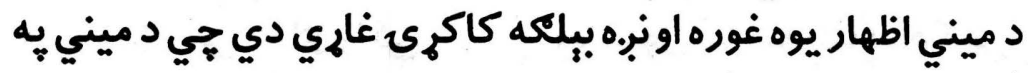

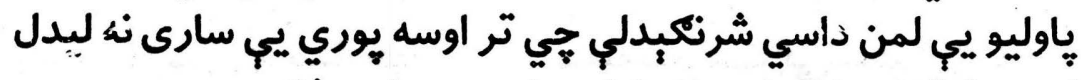

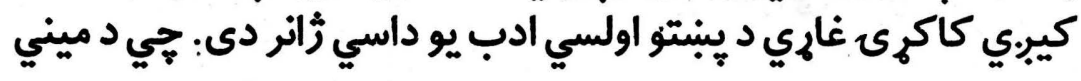


Yq كاكرى غاري.

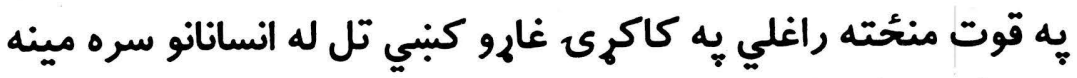

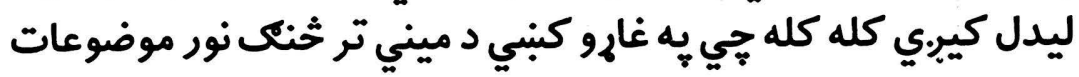

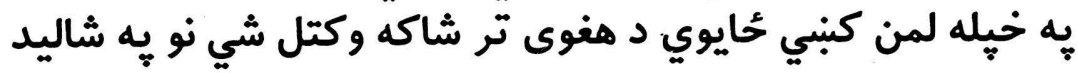

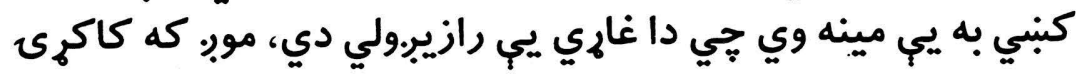

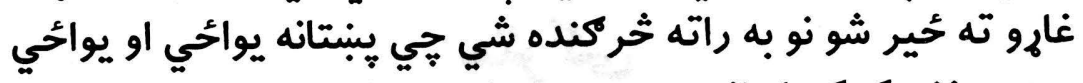

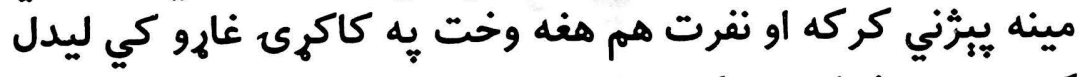

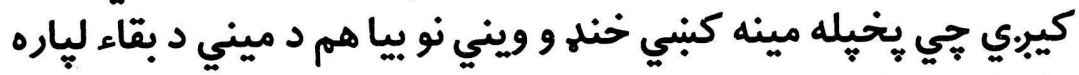

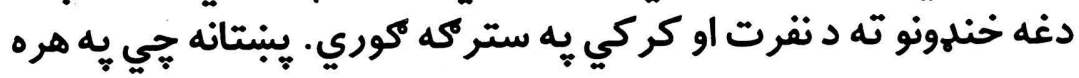

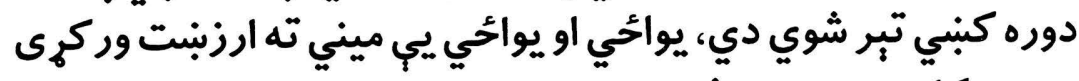

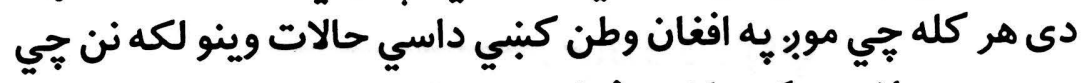

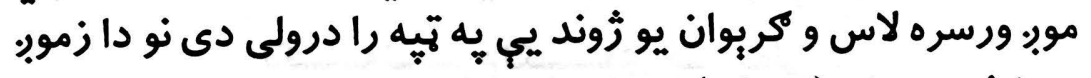

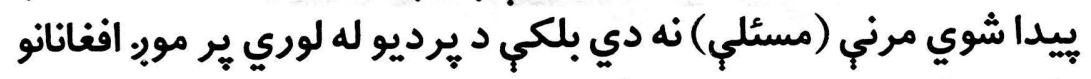

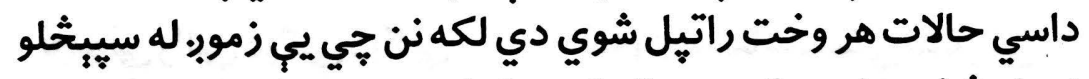

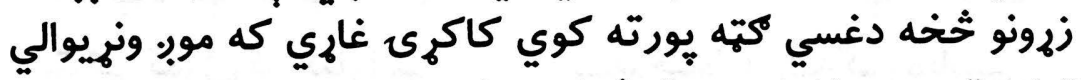

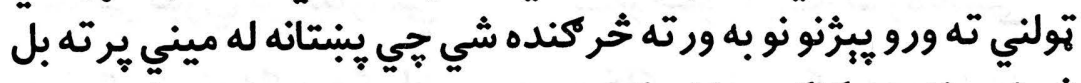

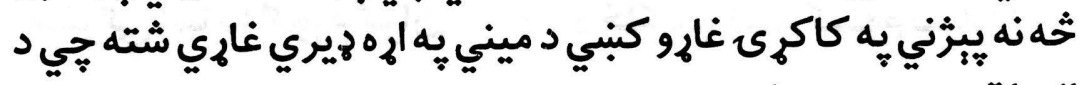

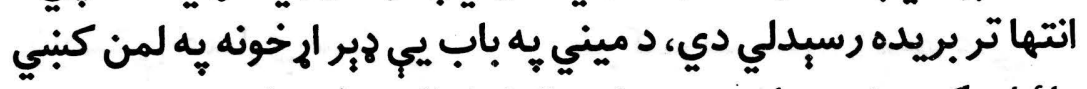

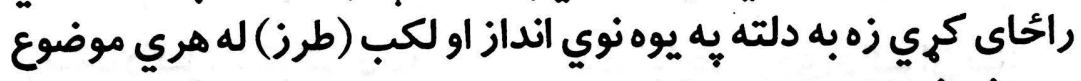

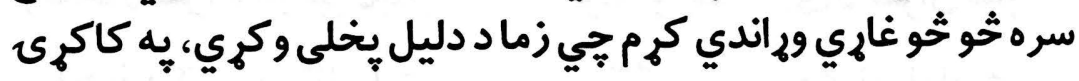

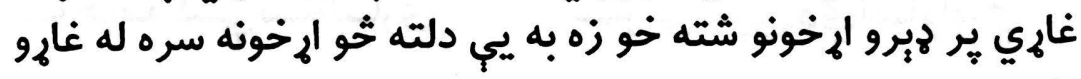
راونمان 


\section{ستر كي}

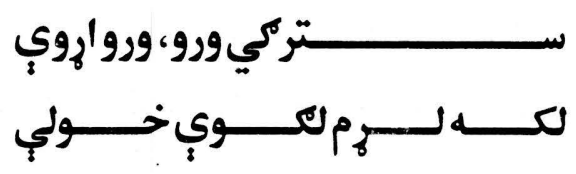

نـهـوي سـتابنايسستي سـتركي

نجـوني رالي دركي دركي

مـوبروخـوارانلـهــارهباسـي

ستركي توري كي بياراسي

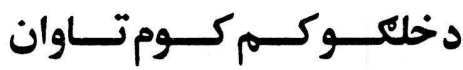

سـتركيزمإِـهــورمكران

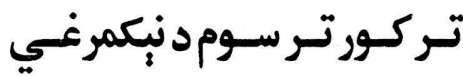

بايستسي خمـاري سـتركي

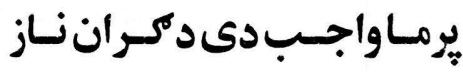

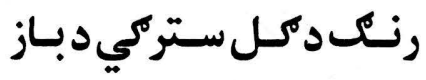

سـتركي سـيـي ديلمـاواوري

مـاخونسه كتــــــاليـاري

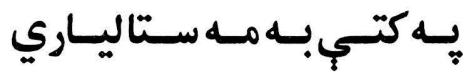

زمـادســــــــرويبـاري

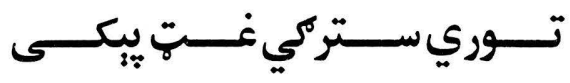

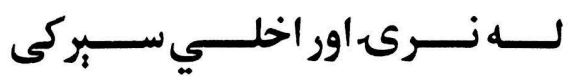




\section{زj}

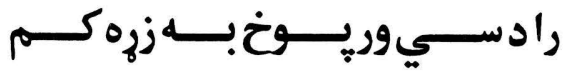

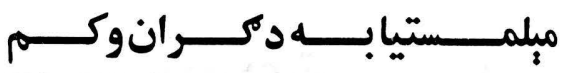

ســتادســـر راكـــــتارونـــــ

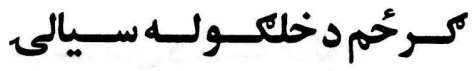

تـورياوبـهى دكسئزمـازيره

زرهمه سكور سويه كوكل كي

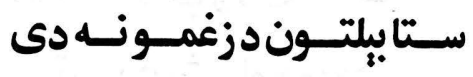

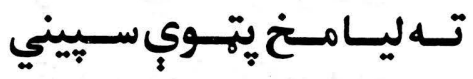

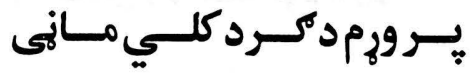

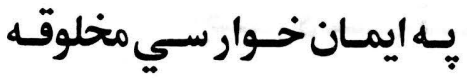

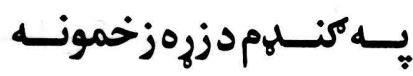

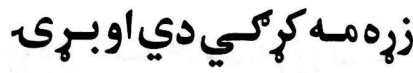

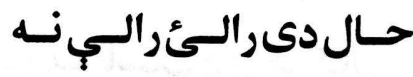

زهورئمريسه سـبابـلكيكي

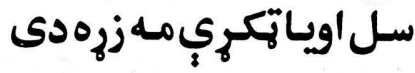

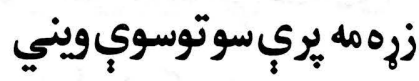

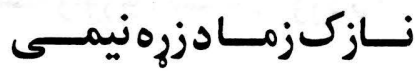

خوربمه سيدزركي خوكه

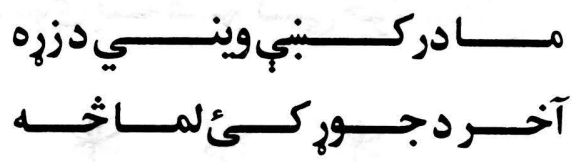

* * *s 


\section{Gutit}

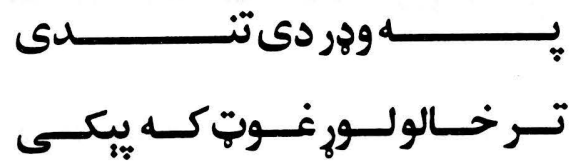

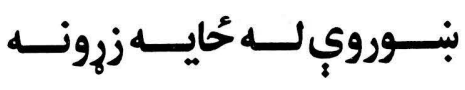

تـر سـر مـه ناسـت دى خركالى

يسواربسه خولـه وركـمبيـاتـى

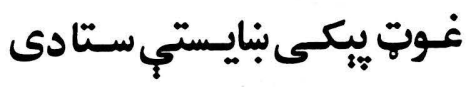

خولـــــــاوري كـــــه دروزهده

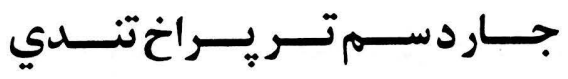

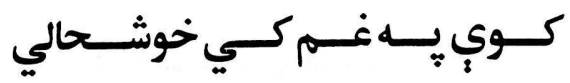

\& \& s 


\section{شونلبي}

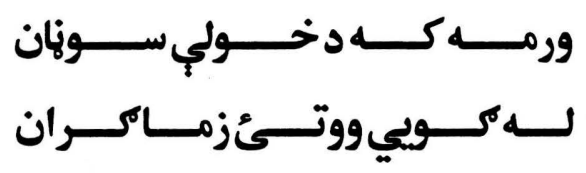

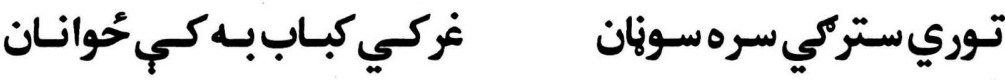

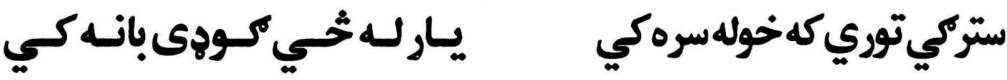

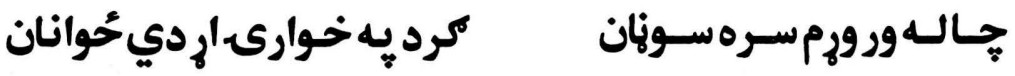

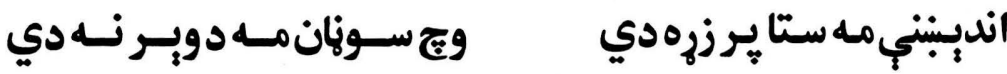

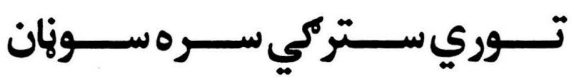

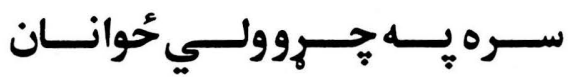

* \& s 


\section{خوله}

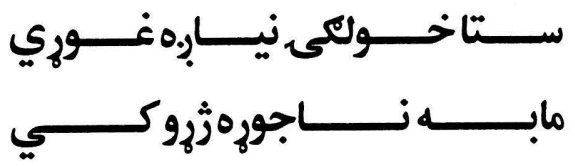

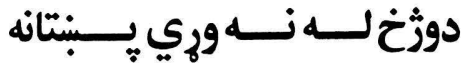

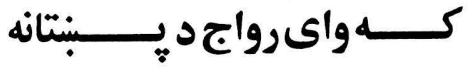

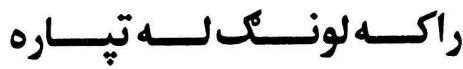

تـرواوره ســينه وهــتاخوله

زمـاخـولكى د سـيـين كـالي ده

وركى حـانكوى سـوه يـروياله

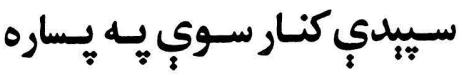

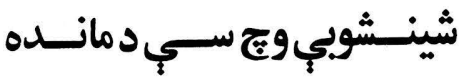

ماتــــه راكــه ســينينه خولــهـ

مـرك روا دى سـتا بـرخوله

زرهـمـهـ ايـبني سـتا يـر خوله

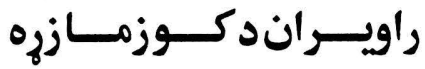

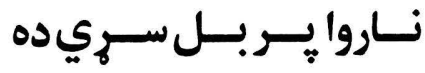

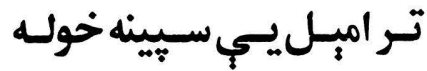

جـار دسـم تـر سـيـينه خولـه

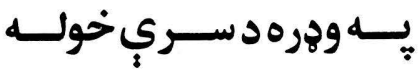

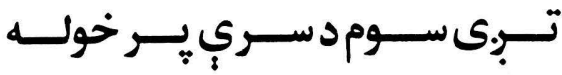

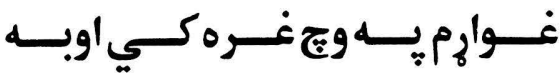

* s s 


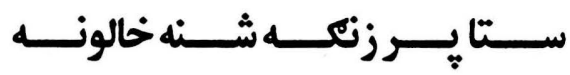

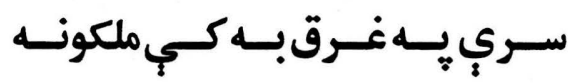

لــور دغـــرق كرمسه باســوري

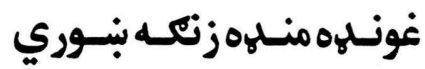

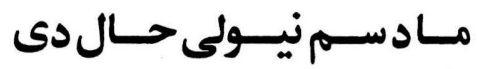

ستا ير غونلههزنكه خال دى

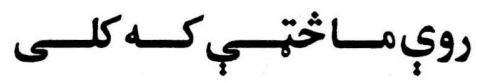

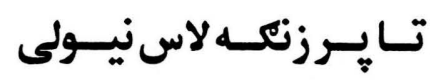

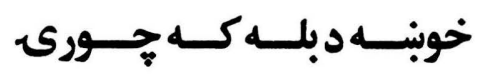

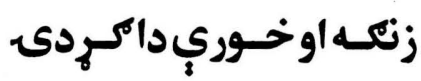

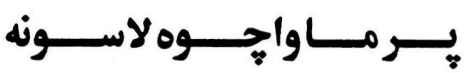

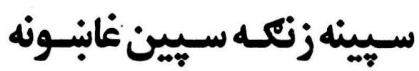

زماغــه اوس سـمه تكيــه ســوه

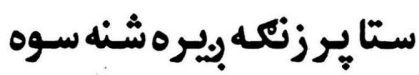

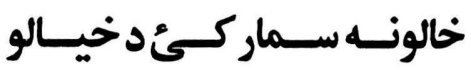

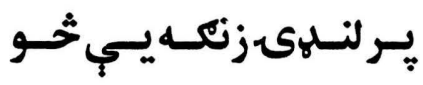

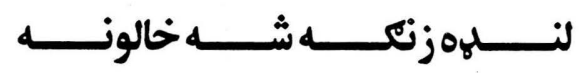

مونه 9

\& है है 


\section{فابنونه}

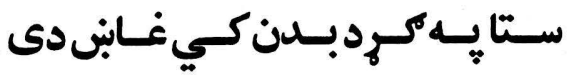

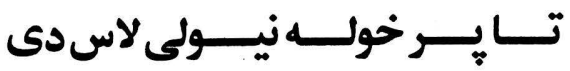

كه سيين غابندشين خالى دي

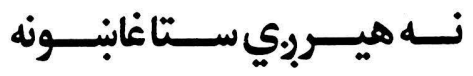

كـيجيرتـاسـوى بــاراندى

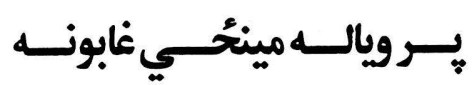

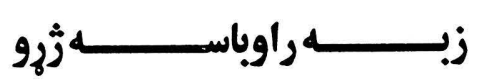

خي ساريب خابنه وي بنـاره

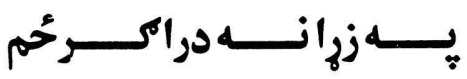

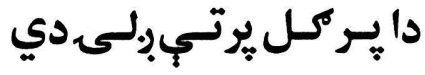

راته خانسـي هيـرينجونـه

سـتاد سـيـينوغابــوقامدى

ســينه خولــــآزاد غابنــونه

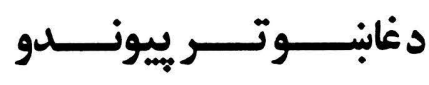

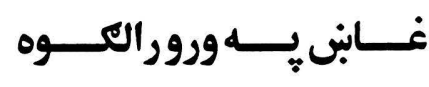

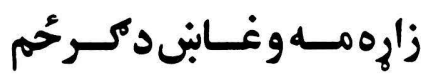

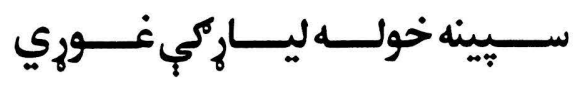

$$
\begin{aligned}
& \text { وورى ســورمل غــابنيــي جانـــي } \\
& \text { * s s }
\end{aligned}
$$




\section{كو كونه (بارخوكان)}

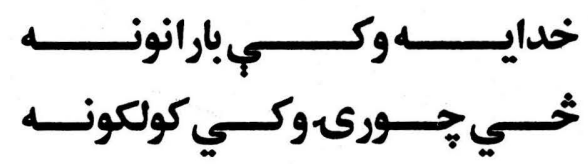

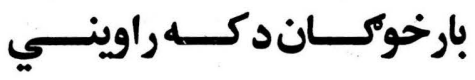

سـوركى نجــوني دبـوري دي

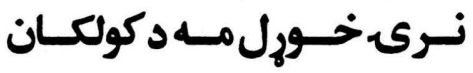

ســتاغابـــونه لكـــهـــتـي بارخوكسانيـيـانتكي دئي

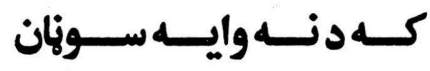

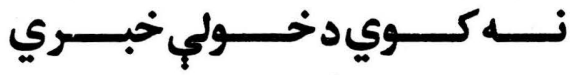

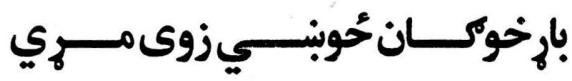

$$
\begin{aligned}
& \text { 米楼 }
\end{aligned}
$$




\section{๑}
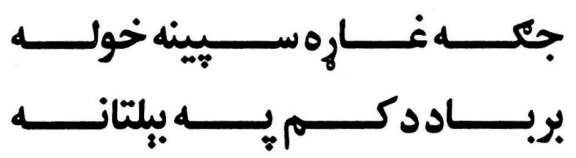

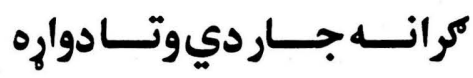

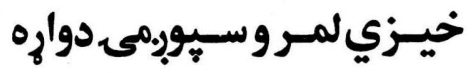

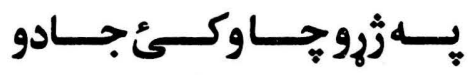

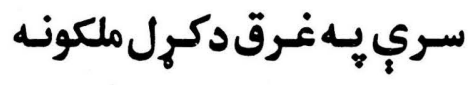

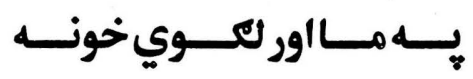

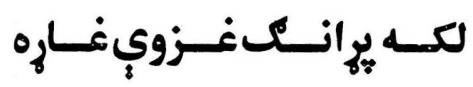

يـوجاركل دى بـل مـهناره

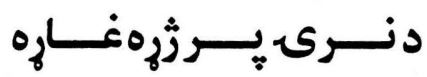

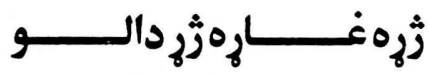

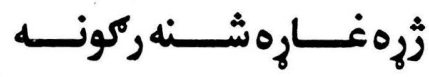

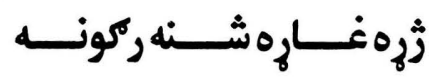

مـــاحِيكر دســـتركه ولاره

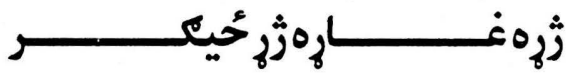

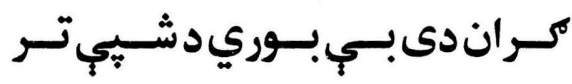

* s s 


\section{تهن:}

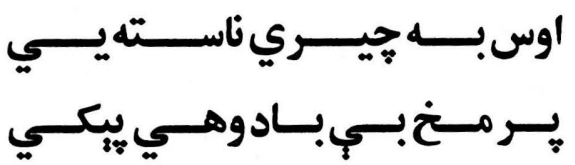

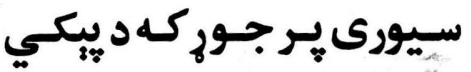

ســتاخالونــــ لمـــــــــي

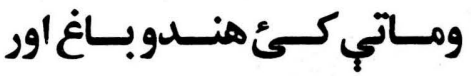

تــور بيكــى يــريسوهولـور

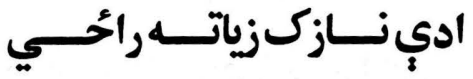

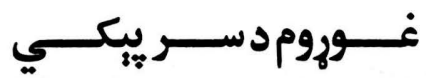

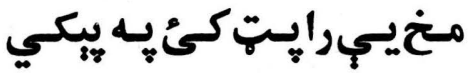

لـونىسـوهاوس مه خـوري

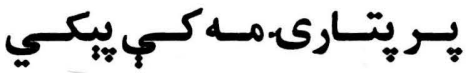

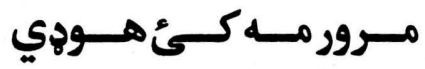

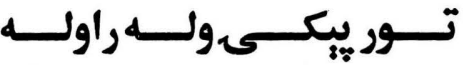

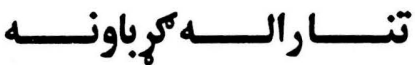

تـور يـكسى كـور ددئُجيـري

يـر دونيـابنايـستي هيـري

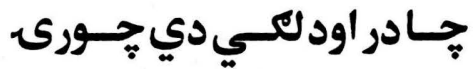

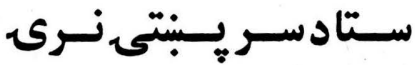

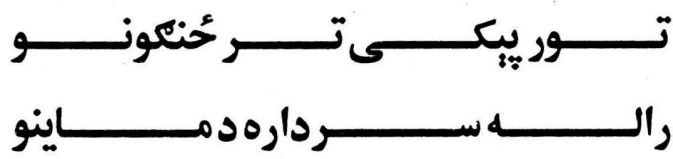

* * * 


\section{اورِدي}

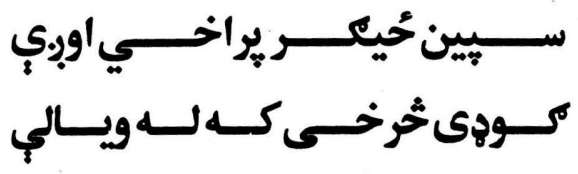

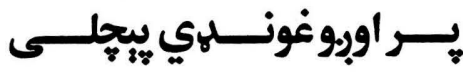

سـور تيكـى يـهـل يرلى

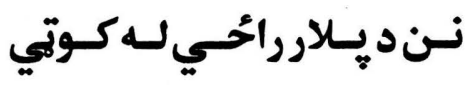

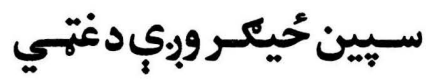

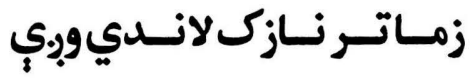

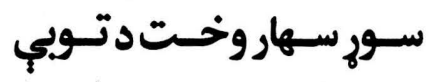

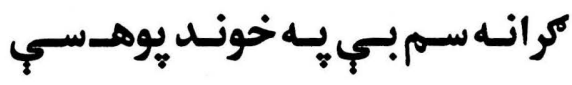

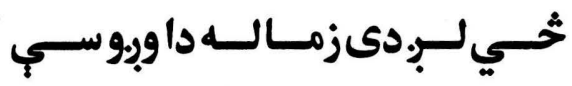

$$
\begin{aligned}
& \text { * s s }
\end{aligned}
$$




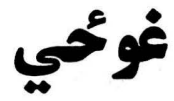

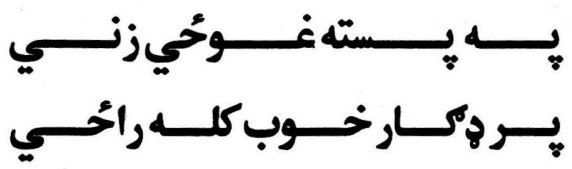

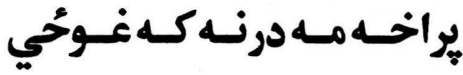

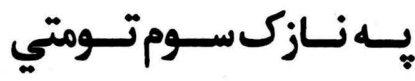

ادي همُحــوكي دكـــــــــم

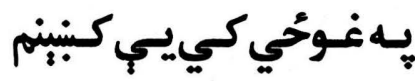

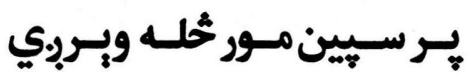

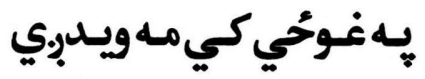

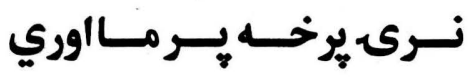

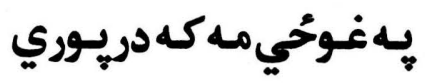

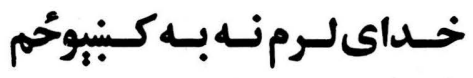
يـــهـــــوحي درنتـــوحُم كـردهوروبـنمن ده شـين خـالو

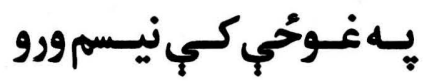

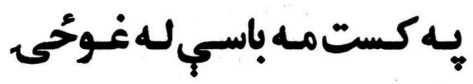

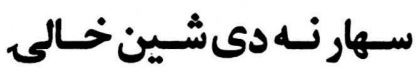

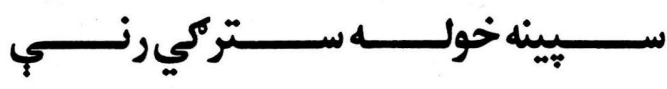

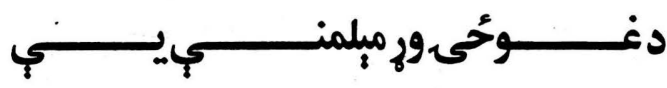

$$
\begin{aligned}
& \text { \& s \& }
\end{aligned}
$$




\section{تُ}

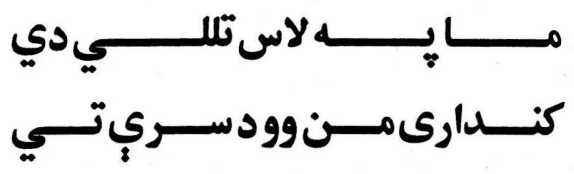

نو

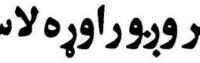

نـازكليـانــوركـوي مـانى

كـانى ليـاسـيـينوويـهـ مـاني

نازكىوياى يراخه كه غوحي

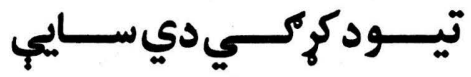

يـر مــرك خنــا مالـه راحــي

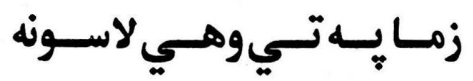

خـورومـه سـدثيـوسـرونه

مـإِهـ لاسكى روكى تهى

كرده شيه مه يروت يرتي

زهكـشنه دمسوريســــي

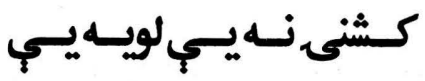

سـر مـهـيـبنى سـتا يـرتـي

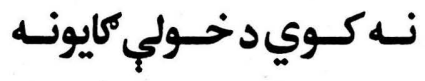

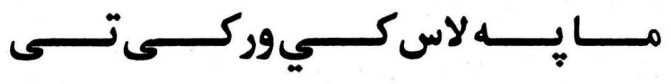

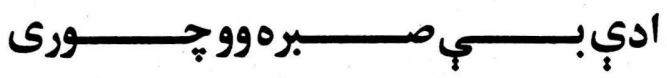

\& \& s 


\section{Xo}

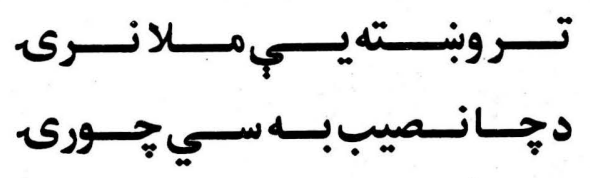

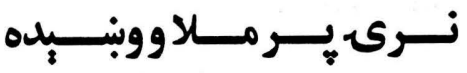

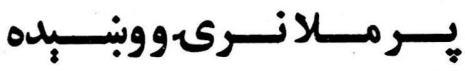

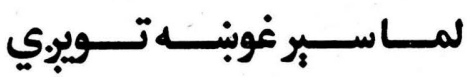

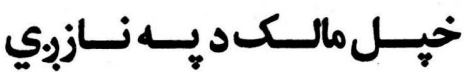

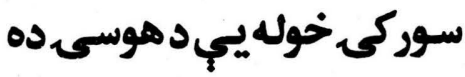

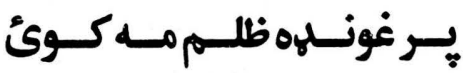

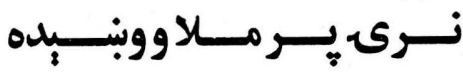

كوريبي لورلياريبينبـوه

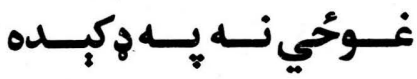

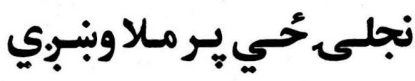

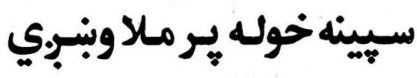

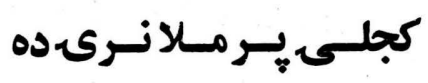

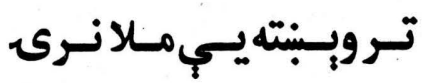

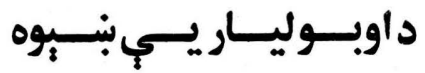

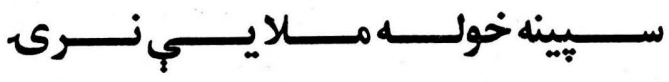

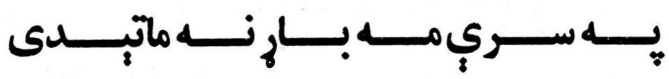

$$
\begin{aligned}
& \text { Es } E^{n} \quad E^{n}
\end{aligned}
$$




\section{لاسوثه}

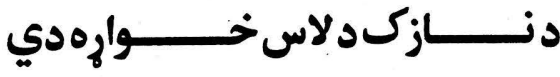

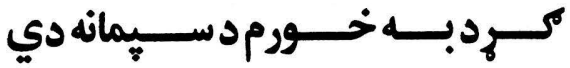

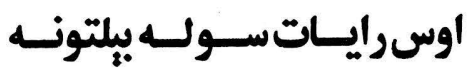

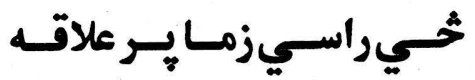

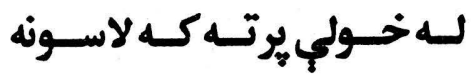

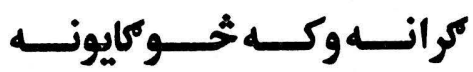

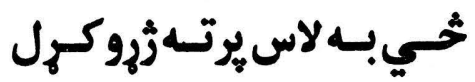

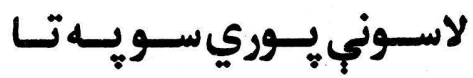

دنـازكـبنايـسته لاســونه

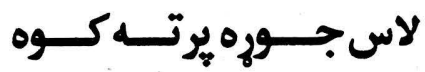

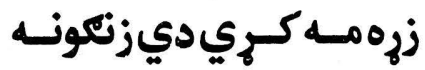
بايــــــه باســته لاســـونه

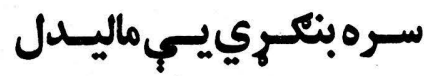

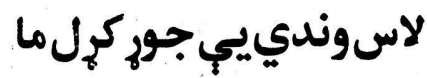

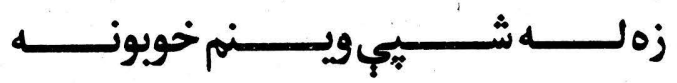

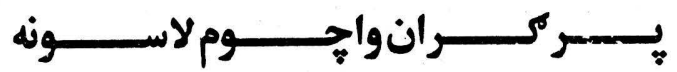

\& \& ets 


\section{كوثي}

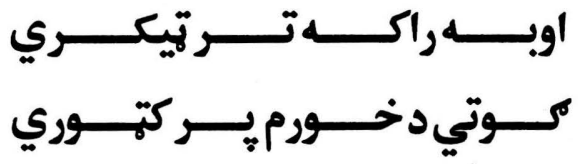

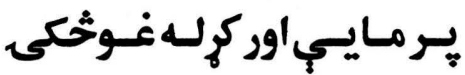

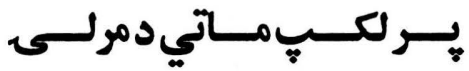

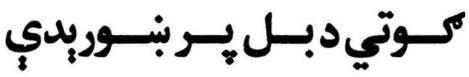

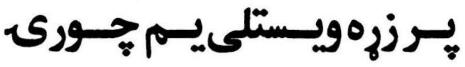

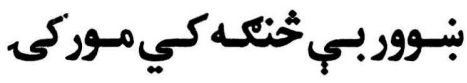

زركـربج جـوري كي كـوتمى

نجـوني نـوري يـهـواده سـوي
زمـادكــانكـوتينـــى

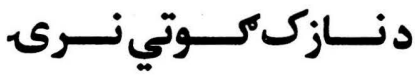

زوريسجيرواكـئسـتابـاجي

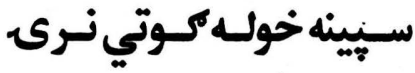

زمـادخـور كـوتينـــى

زمـاد سـرئكـوتي نـرى

كوتي زماخواري يهونسوي

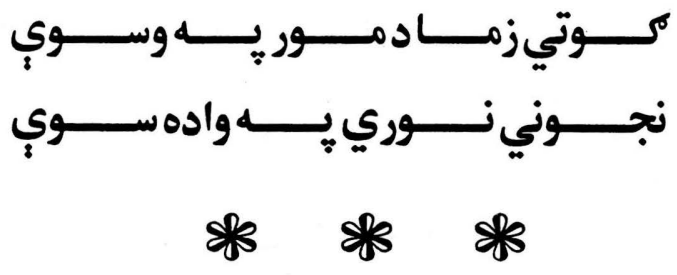




\section{مروندونه :}

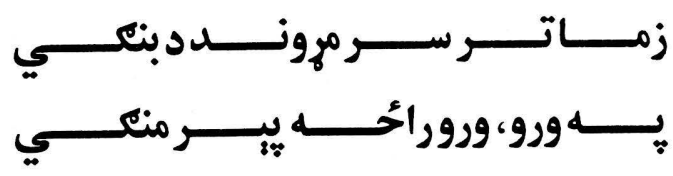

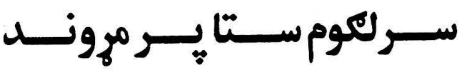

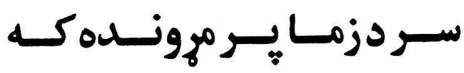

يـربالـبت خـوب كلـه راعَي

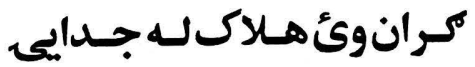

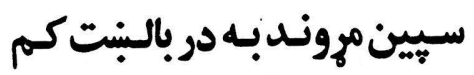

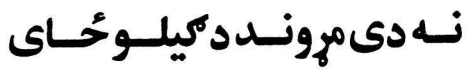

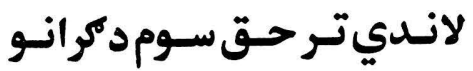

تركرانمـه لاندي مهوندكئ
خيـــــــه غوارمـهـ دزونــــ

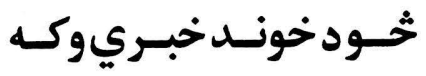

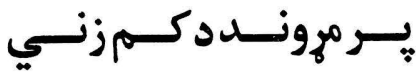

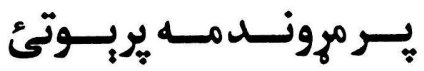

كه راحجي تلتك به كوبنت كم

راتـهلوكــه دخونـدكــاى

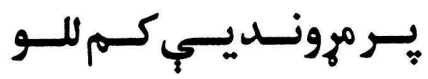

دعمــرو ارمـــان مـــهـ دى

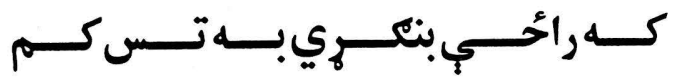

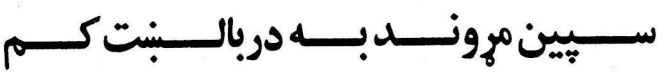

\& s s 


\section{ورنونه}

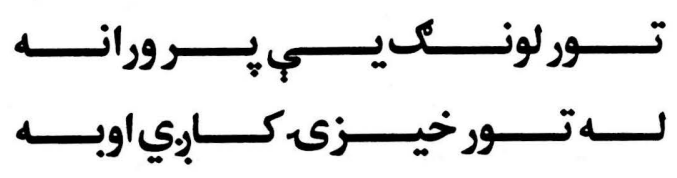

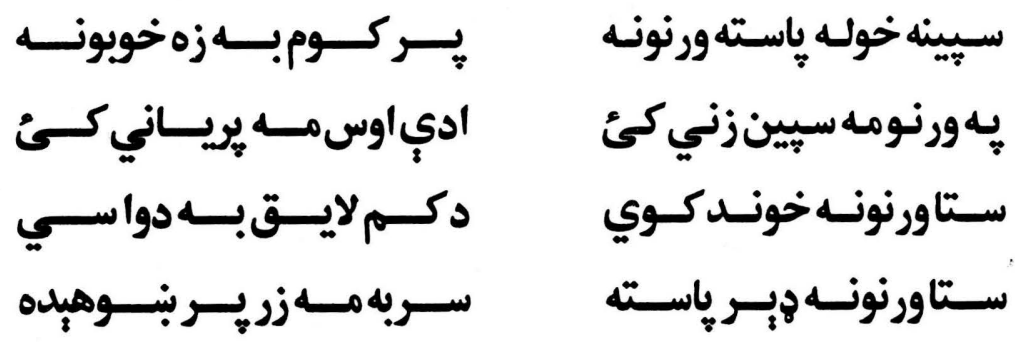

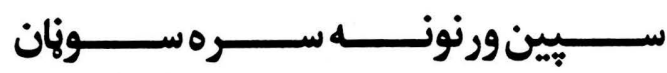

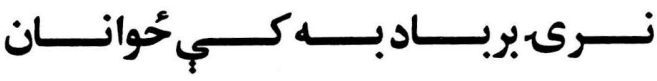

* \& *s 


\section{يل}
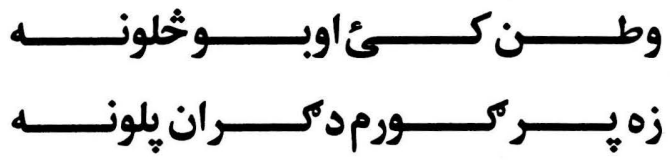

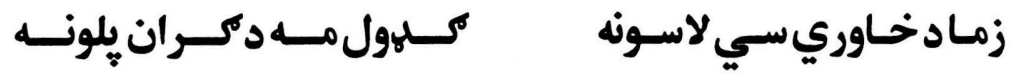

نـهراحِي

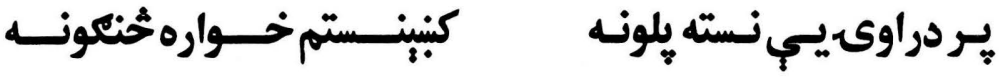

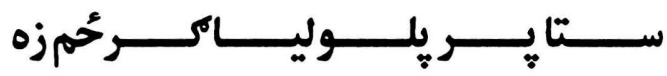

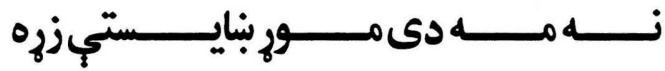

\& \&s 
Fq
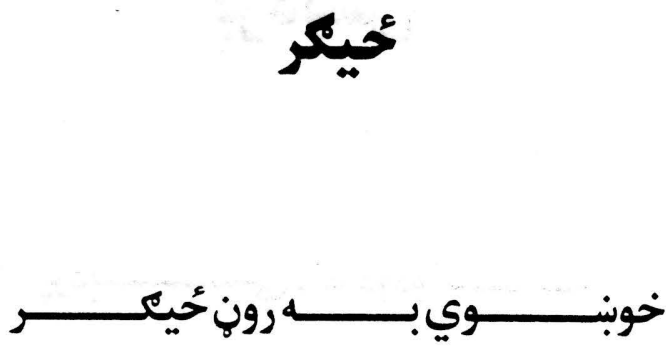

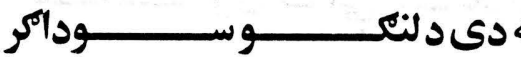

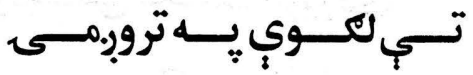

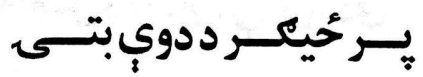

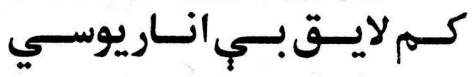

يـرحيكـــــ ددوي نركوسـي

بيادستا يِلار يري

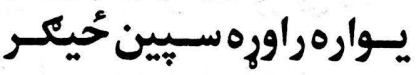

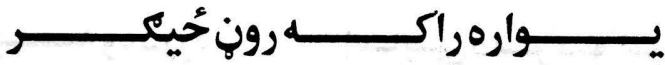

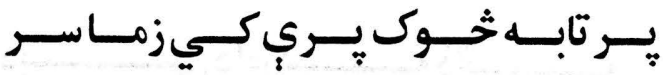

* * * 


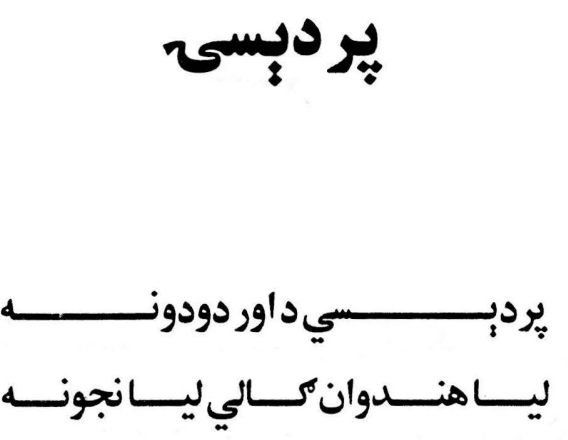

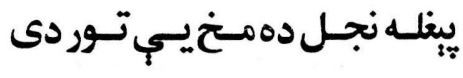

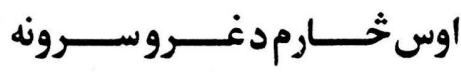

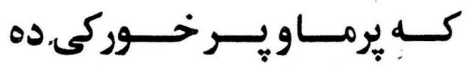

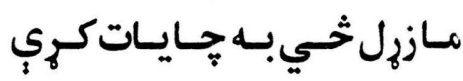

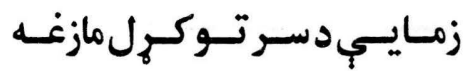

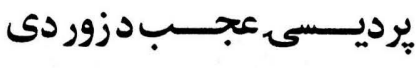

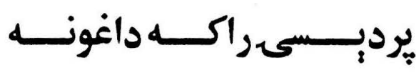

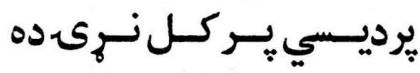

يرديـسـى ثـــــي آزادكــــي

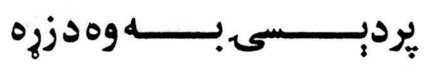

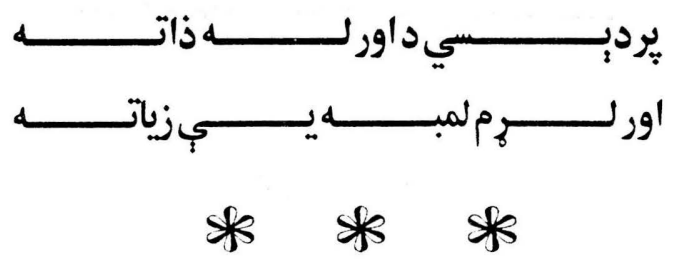




\section{خندا}

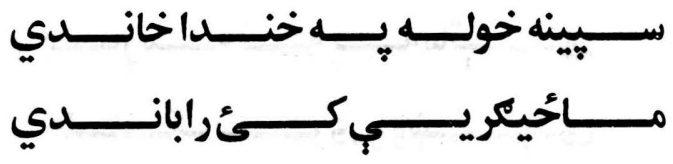

ورك

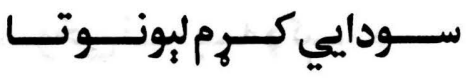

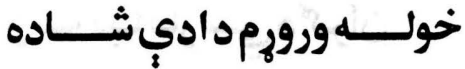

تـور مابنـام ثـي كَئرابانـدي

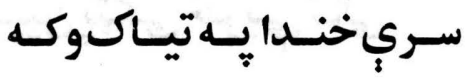

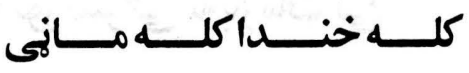

تـادخــداى كــي لمــاهــره
سـيـينه خولـه خنـدا دهبـره

سـيـينه خولسه خنـدا، خنـدا

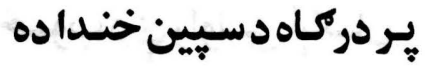
سينينه خوله دهراته خاندي

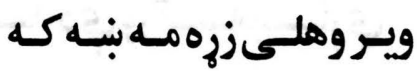
كراني سـتاعجـبكرانس سـينه خولـه خنـداد دِيـره

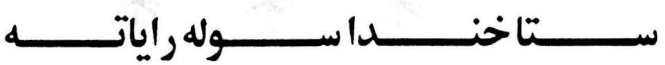

$* * *$ 


\section{بار}

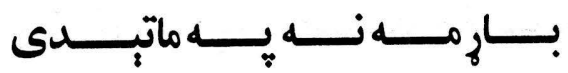

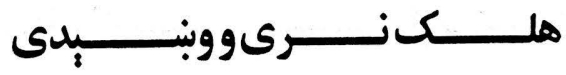

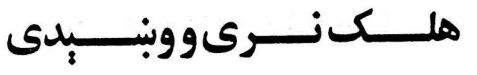

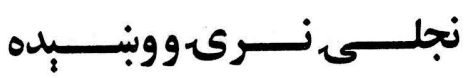

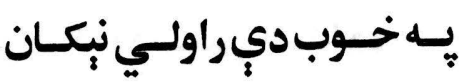

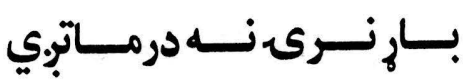

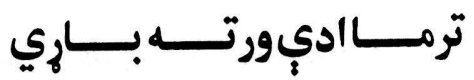

اوس جنـت غـوارمكي رواكـئ

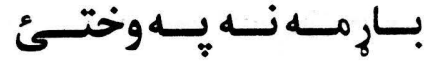

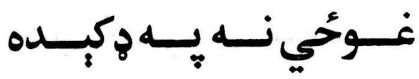

نـن مـه بيـابـار سي دكران

رانـزدي ســه سـهاركـبـي

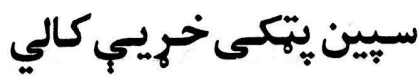

يه تور ستركي مل بار ماتكئ

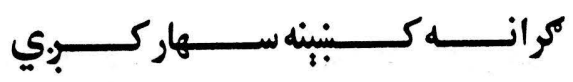

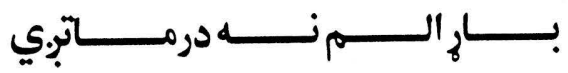

$$
\begin{aligned}
& \text { * \& * }
\end{aligned}
$$




\section{ח}

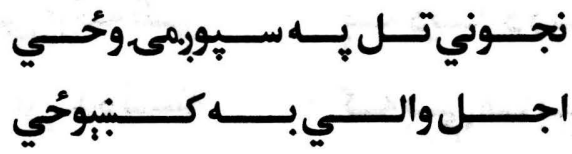

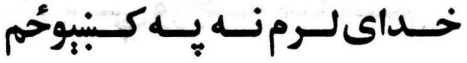

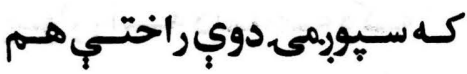

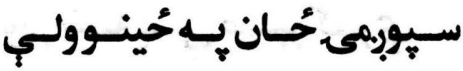

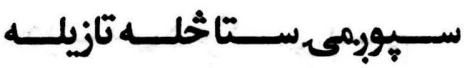

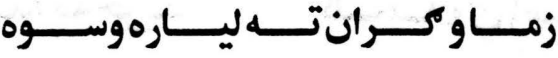

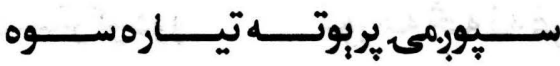

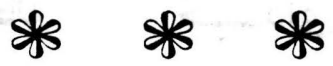

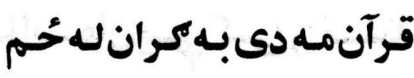

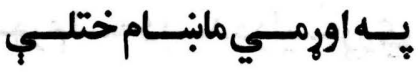
ناسـتهـيـم دوكـران بــهـ هيلـ 


\section{$\log _{0}$}

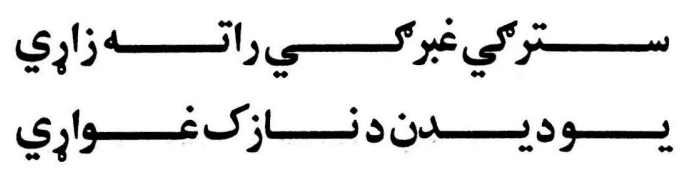

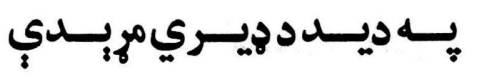

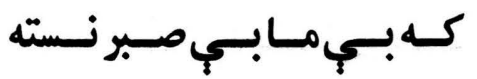

يسه ديـدزونـدى دجانـانيسم

تيـاسـمانيسـي كـــرواكـبنته

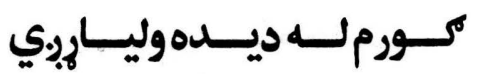

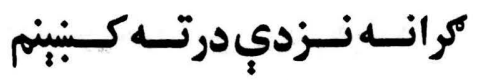

كلـهـبـهـويزمــاوسـتاديـــ

نـور مـه ثحـه نـه غوبــت له كر انـو

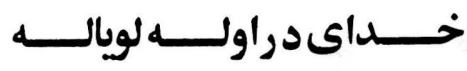

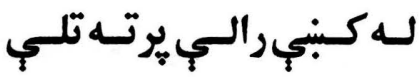

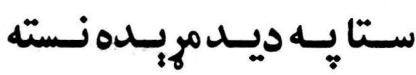

رادسـيـي ورجــاربسـهـ سـم

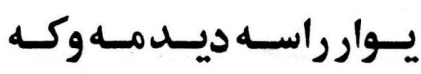

وهر بنـــهـيسـي صــبر كبـري

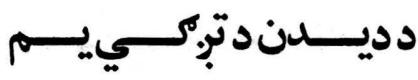

سيّينه خوله خندا بـه خريد ديـــيـيـي واى دستركودوو

ستا يه ديد بيس سوم.بي حاله

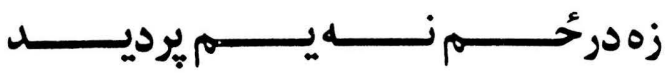

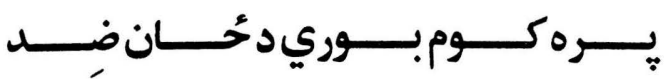

$$
\begin{aligned}
& \text { * * *s }
\end{aligned}
$$




\section{اوبهـي}

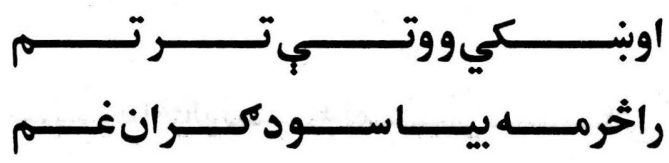

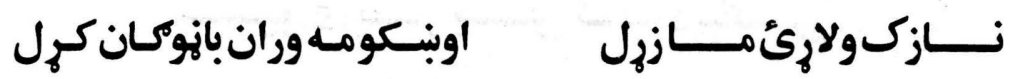

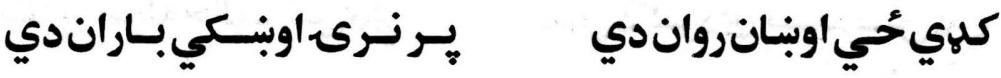

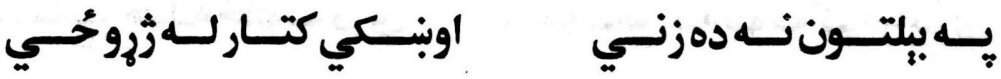

اوبنكب حُي يُ سينه خوله دوىيبي خوبنى خوري دواده

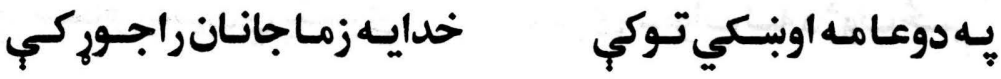

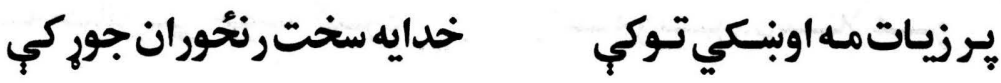

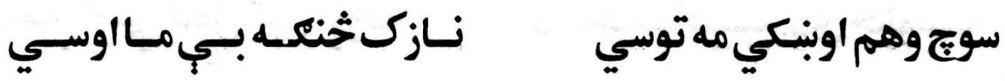
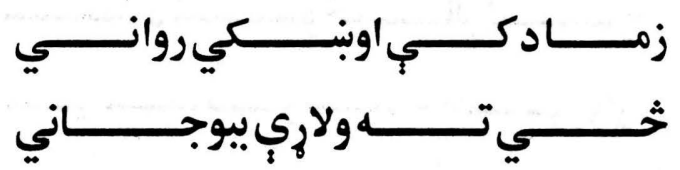

* * * 


\section{خالونه}

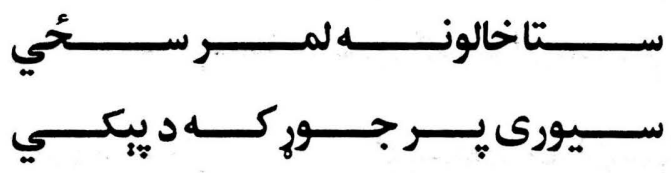

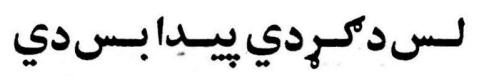

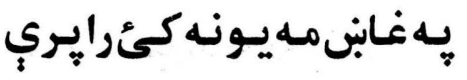

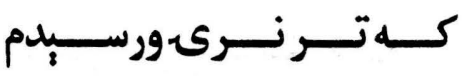

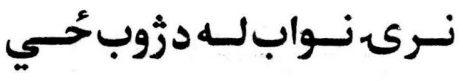

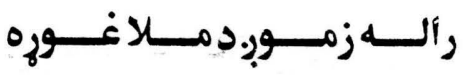

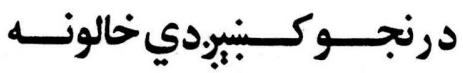

ستا ير خوله خالونه لسدي سـتا يـر خولـه خالونـهـ دري

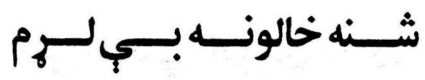

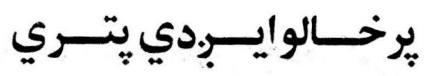

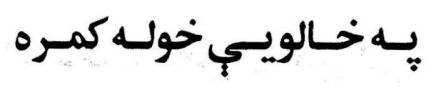
دلته راسي تهول كيززونه

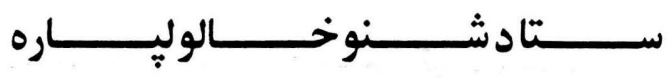

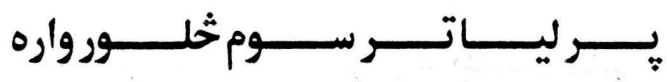
s * * 


\section{جار تكل}

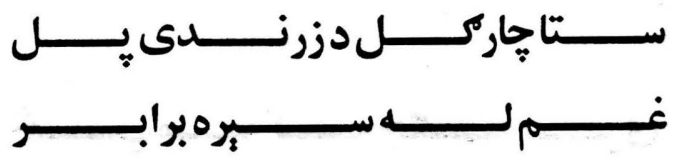

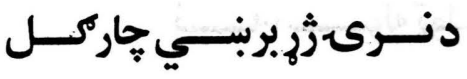

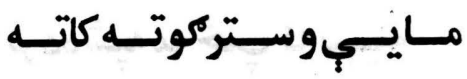

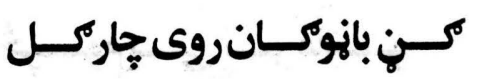

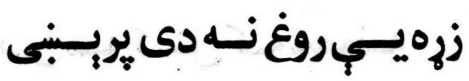

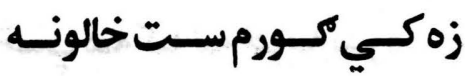

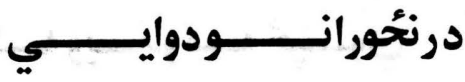

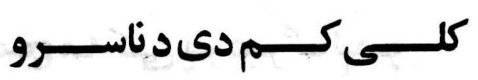

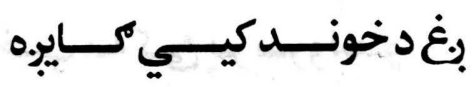

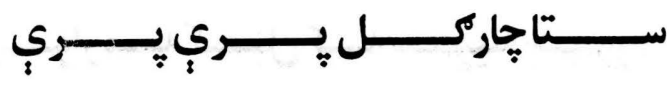

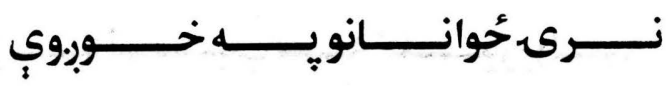

* * *

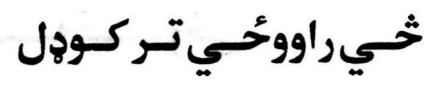

جاركل لور بيزوان يرخوله

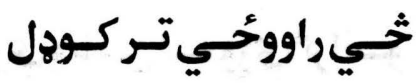
سبينه خوله جاركل يريبنى

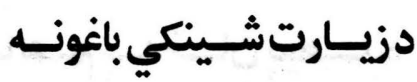
ستاجاركل شوكري سخوكري

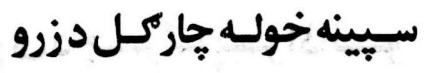
خــوكريـالى جاركـل يـزه 


\section{ثيول/مجول : كبنلول}

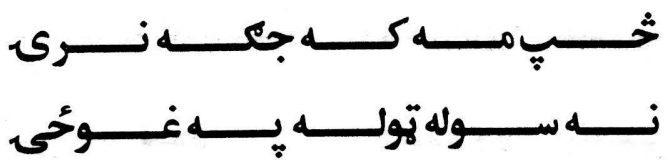

اوس مـــ رالـه تــــرخولـه وينــه

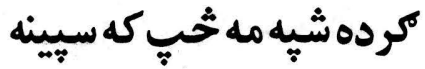

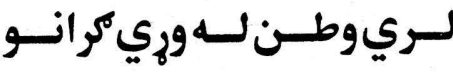

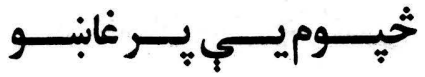

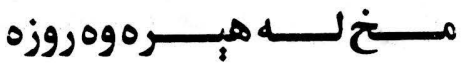

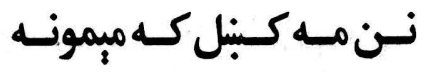

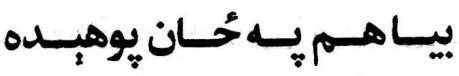

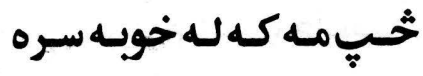

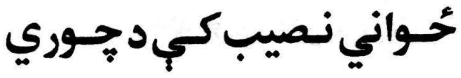

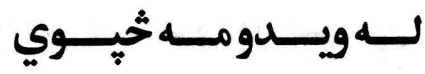

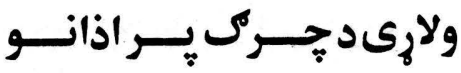

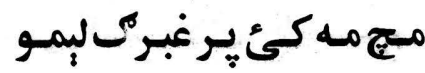

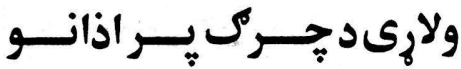

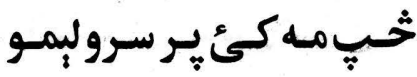

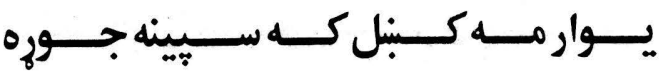

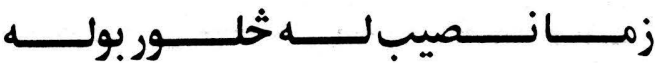

* * * 


\section{يه كاكرى غارو كنبي}

بخوانى كيسي، افساني او افسانوي فكرونه :

كاكرى غاري د بنبتو لرغوني اولسي هانكه ده جي له زركونو كلونو

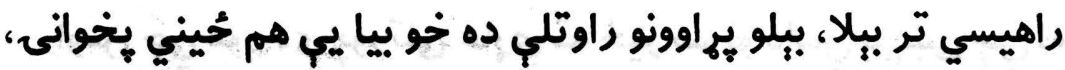
لرغوني كيسي، افساني او افسانوي فكرونه به خيله لمن كبني خوندي ساتلي دي، دغه موضوعات يب به يوه يا به بله بنه تر اوسه يوري مورب ته رارسبدلي دي د بنبنتو تانوبى د مذهبونو كُانكو كنل كير.ي نو كُكه ير ينبتي تولنه د هدبرو مذهبونو وح تر اوسه يوري يروت دي، يوه زمانه

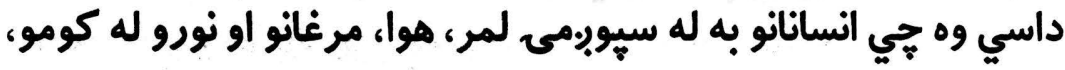
كومو ثيزونوخخهه به بي غونبني كولي ستوري، سيورنمى، لمر او اسمان يب داسي كنل لكه دغه جي د دوى به ثروند كبني دغسي كردارونه ولري لكه يو انسان هي يـي لري، لكه :

$$
\begin{aligned}
& \text { بــه اســمان كــي غـوروخي ســتوري }
\end{aligned}
$$

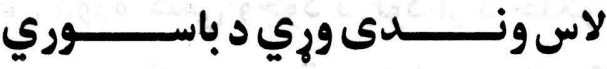

يهني دور كبني كه مور. دغه هول فكرونو ته كورونو انساني ذهنيب نه مني جي ستوري دغسي وكري او نه هغه وخت دغسي كيدل خو د هغه وخت خلكو دغسي فكر هم كاوه، 
كاكرى غاحي

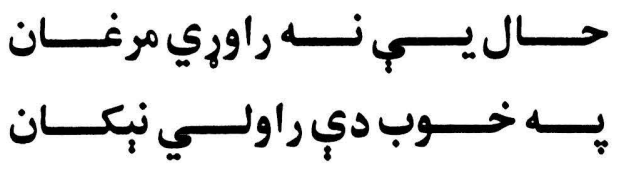

د دي كاكرى غاري يو نول حُواب داسي سته :

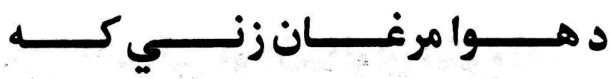

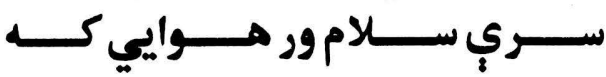

اوس جي موب. دي يورتنى غاري ته حُير سو نو داسي بريبني جي له

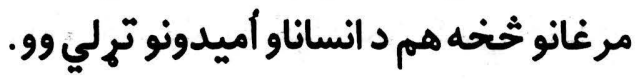
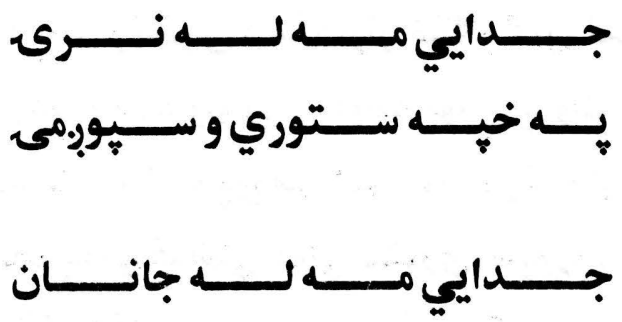

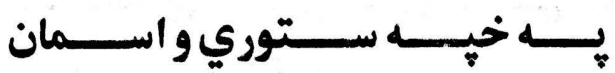

د ستورو، سيوبِمى او اسمان يه إحه دغه جول خيالونو او فكرونو يه ديه

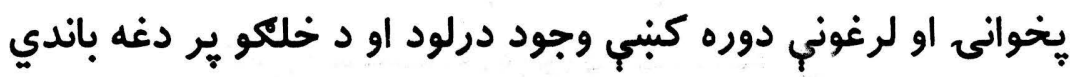

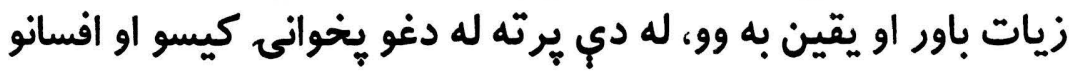

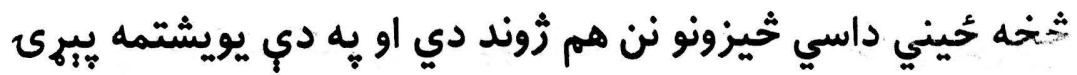

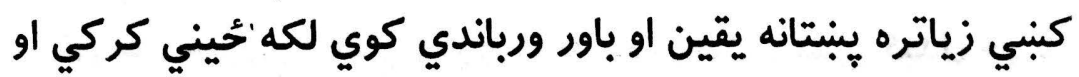
كر.ني جي دي لكه يه لاندي غارو كبني: 

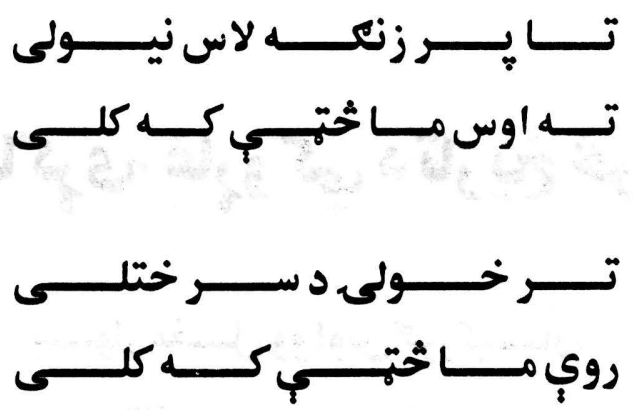

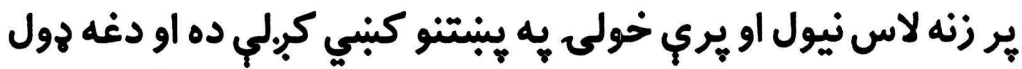

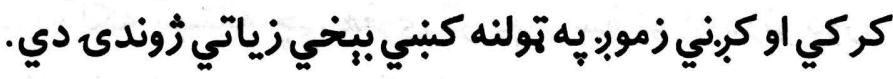

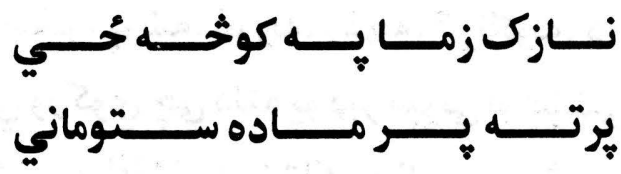

موبر اوس هم يه يُبنتني تولنه كبني وينو جي حُكه ستومانه يم يا

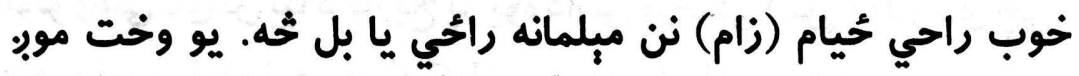

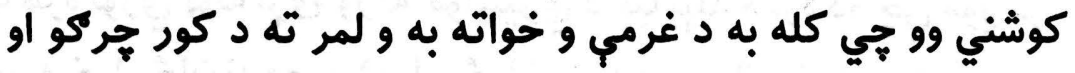

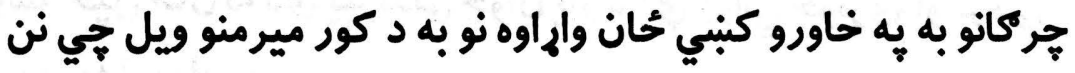

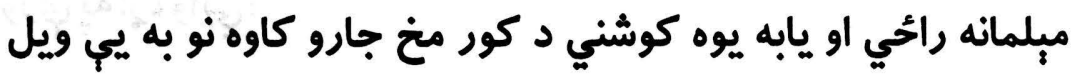

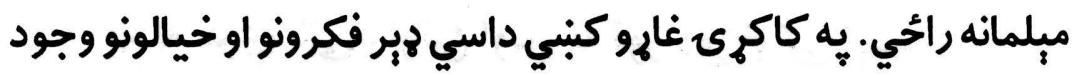
لري جي يخوا خو دغسي فكر او خيال كيداى شواى خو اوس به به ساينسي دور كبني ارزبنت نه لري. 


\section{يه كاكرى غإو كي دتاريخ ثرى}

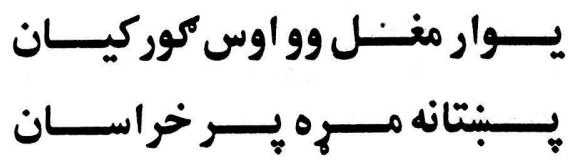

داسي قامونه لكه يبنتانه جي هغوى تر هُبرو سختو او درنو دورو

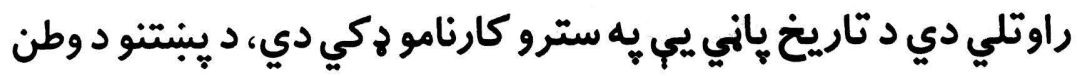

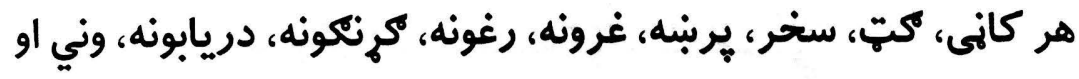

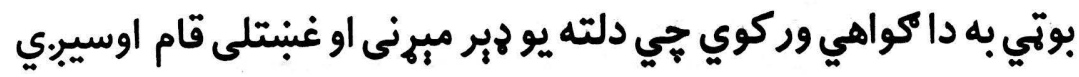

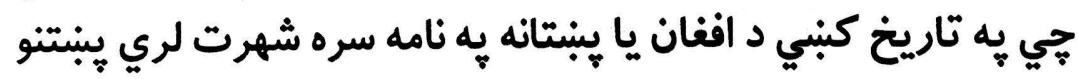

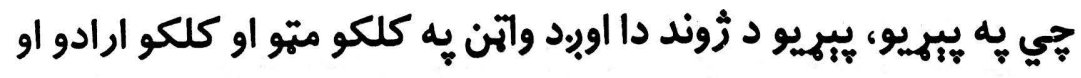

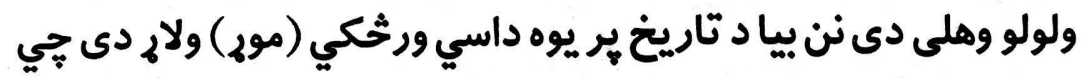

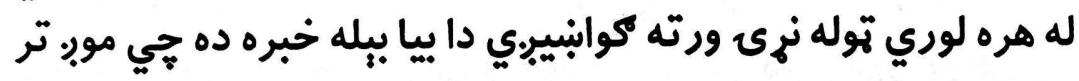

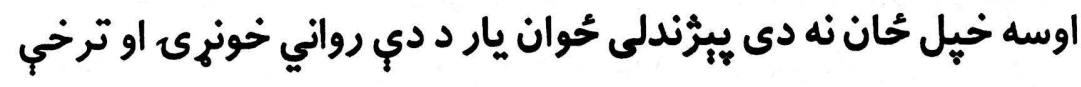
دوري يه أحه وايي:

يم له سري بتّى راوتَّ اوس يه تور دوزخ كي إبنم د لمبو له سرو وريو د زوندون تارونه وريبنم جي خوك ونه واهي دلته وجكالى دى زوند

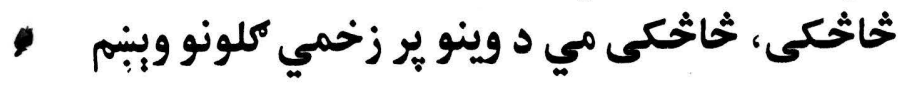


ר كاكرى غاري

موبر افغانانو نه يوائي دا جي به دي دوي روانه بِّبنه كبني داسي وهل

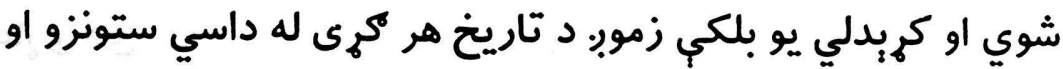

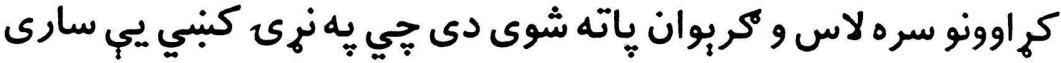

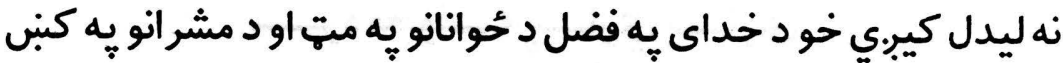

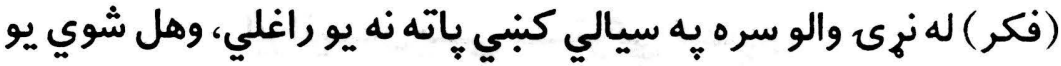

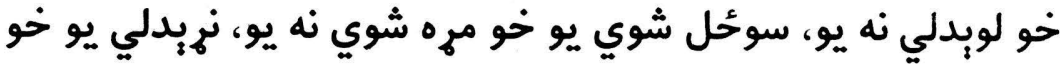

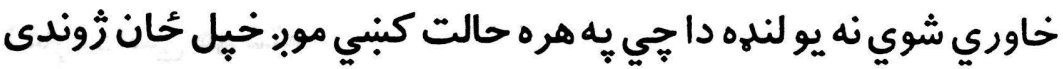

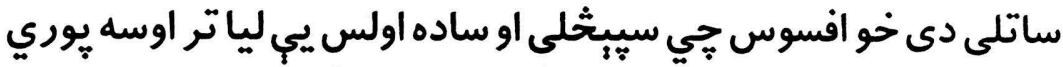

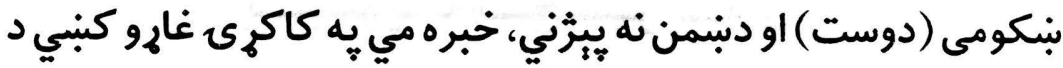
تاريخي ثرى كوله خونيت راخخه اوبد شو إنو

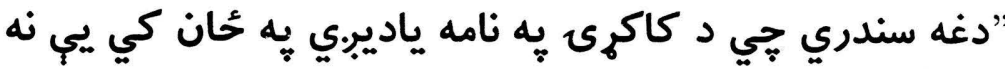

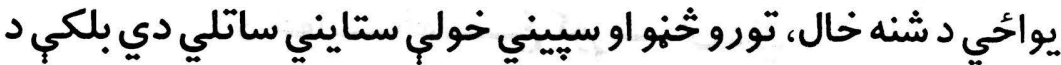

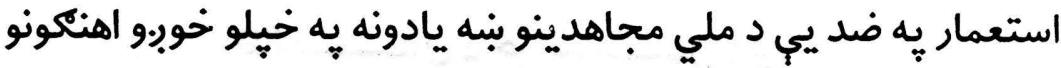

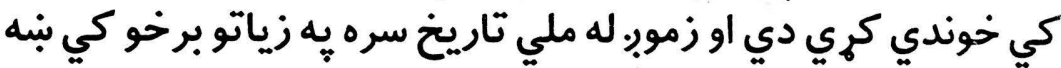

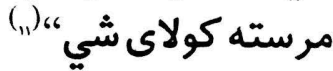

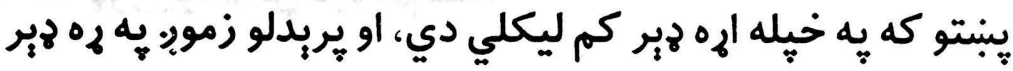

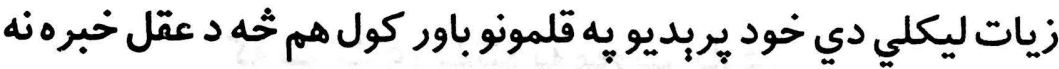

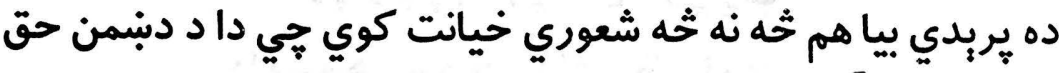

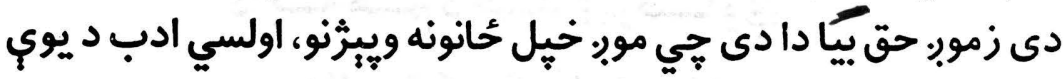
تولني هنداره كنّل كيبري نو كه له دغي هنداري خخخه موبر د زمان دوري او خاوري لري كرو يعني دغه ملي يانكه راخوندي كرو نو كواه جي تونول

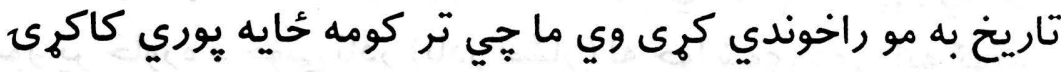
غاري راتولي كري يه اصطلاح يه اورو كنبي مالكه هم نه ده خو بيا هم 
كاكرى غاري

دومره خه يكبني موندلي دي جي خه نه ثخه حساب ير كيري كاكرى غاري دي.

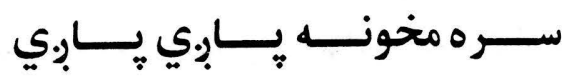

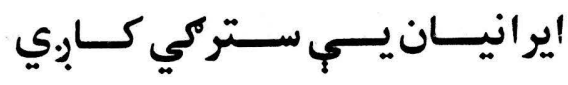

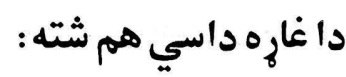

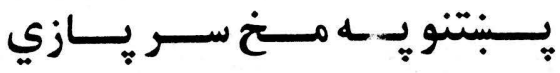

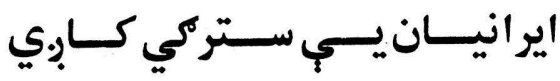

$$
\begin{aligned}
& \text { دحُوانــــانو مــــخ كورمـــــان دي }
\end{aligned}
$$

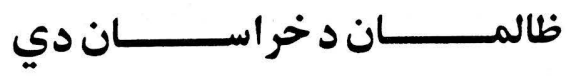

همدغه هول يوه د اتن ناره هم شته:

$$
\begin{aligned}
& \text { كه سر يإِبي ينبتنو يه منخ سر يِإِي }
\end{aligned}
$$

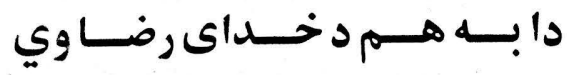

$$
\begin{aligned}
& \text { د سيدال ستركي نادر ايرانى كابري }
\end{aligned}
$$

يورتنى غارو ته كه موب. حُير شو نو د هوتكي دوري هغه يُبنبي جي

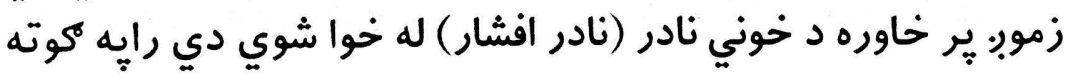

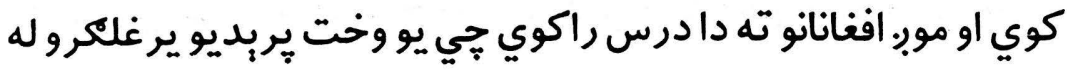

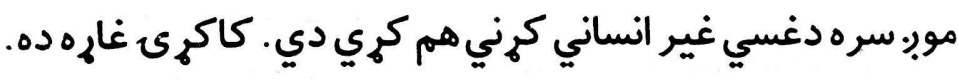


70

\section{د شــال كــوتَّ يـــــــلا يــوري

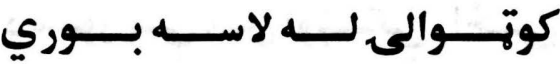

شال د يُبتنو لرغوني سيمه ده جي اوسنى كوته حُيني مر اد ده د شال كوت له جوري يب اوسنى كوتي ته شال كوت وايه شال يو نارئ نارينه نوم

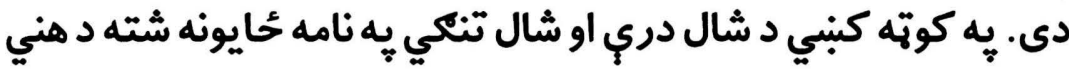

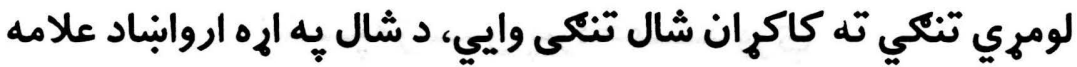

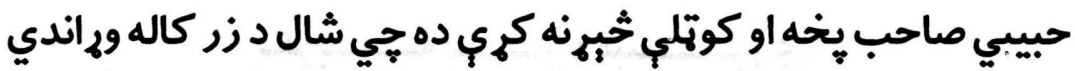

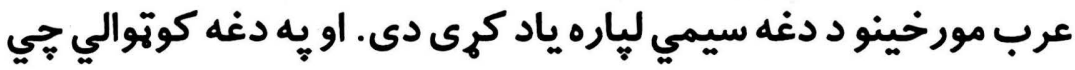

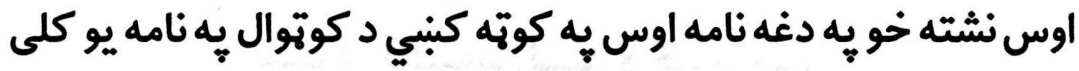

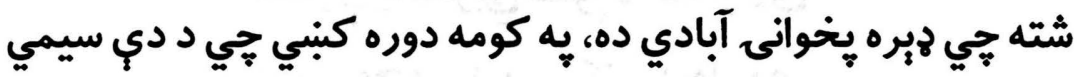

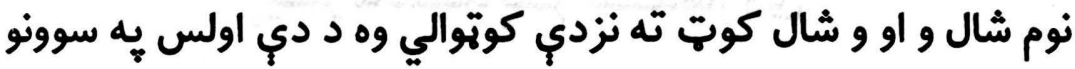

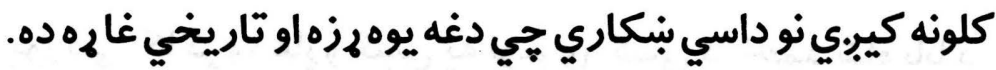
د يادوني وه ده جي د شال دري محٔكي د هني د خلكوي ديكو دي او د هني

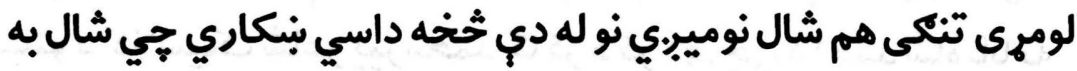

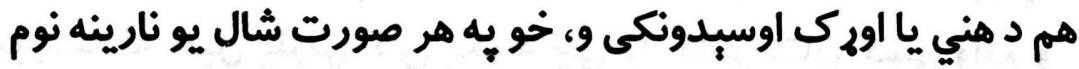
دى جي له كاكرو يرته يه نورو يُبتنو كبني اوس هم خال خال زوندى

يو ثو كاكرى غاري دي جي د احمد شاه بابا د دوري خر ك يبنكي ليدل كير.ب.

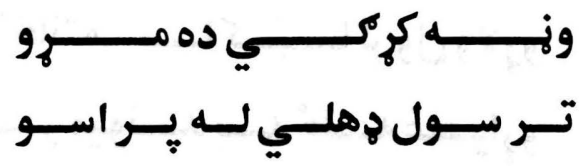


كاكرى غايدي
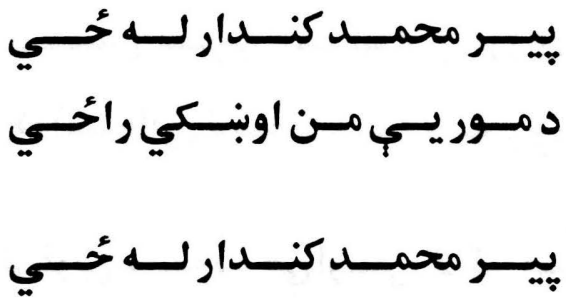

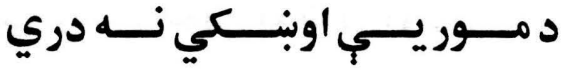

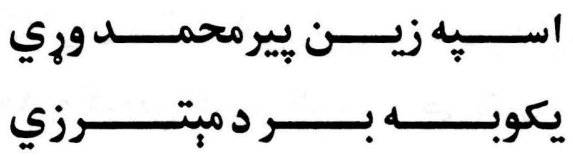

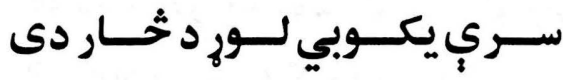

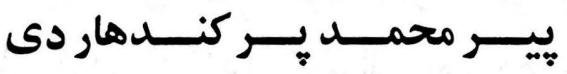

يه يورتنى كاكرى غارو كنبي يه لومرى كنبي د احمد شاه بابا د

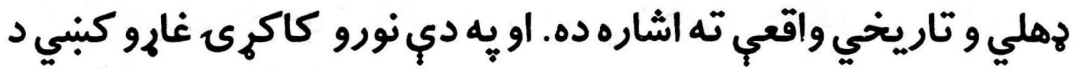

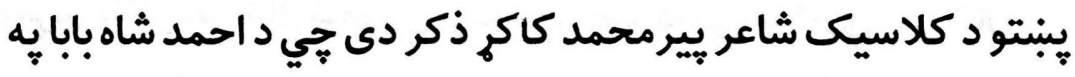
غوبنتنه له خيل يلرني كلي يكوبه جي هيه كاكرستان كنبي واقع و و

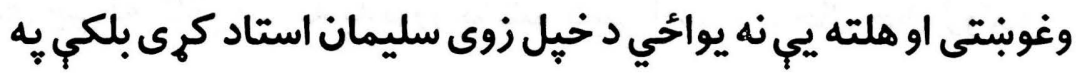

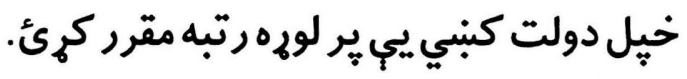

كاكرى غاري دي :

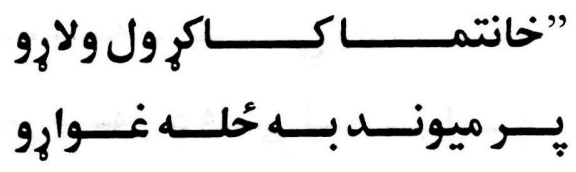



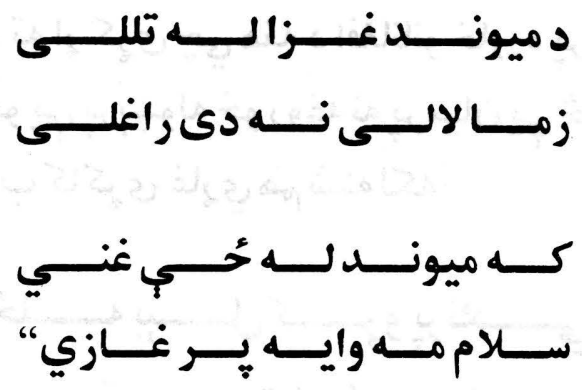

له يور تيو غارو خخه ثخر كنده ده جي د ميوند به به تاريخي غزا كبني

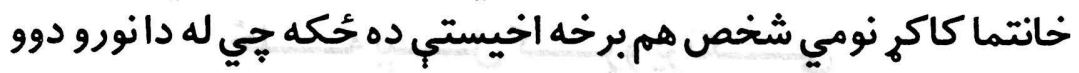

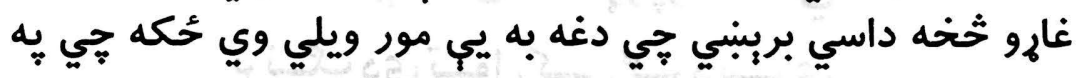

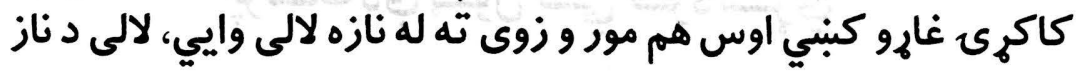

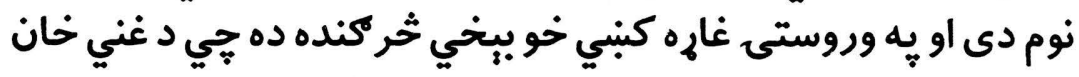

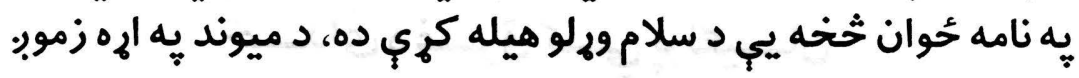

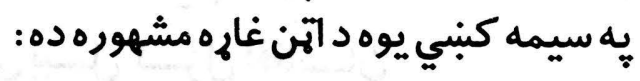

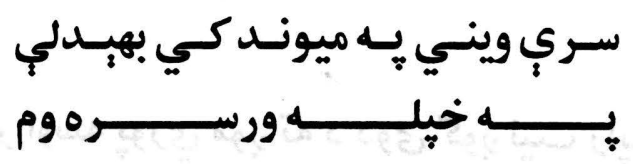

بايستب نجوني يه جنك كي جنكبدلي

له دي تاريخي واقعاتو يرته د كاكر ستان او يبنين د هغو غازيانو يه ذكر خو د كاكرى غارو لمن خكه ده جي له ير يرنكيانو سره يـي مبارزه

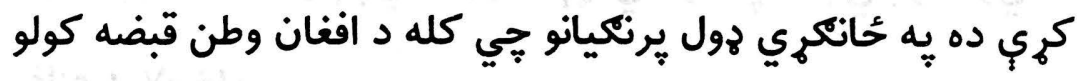

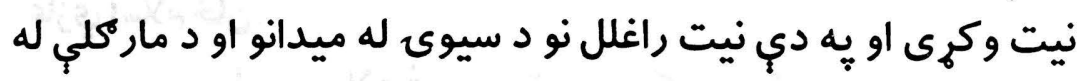

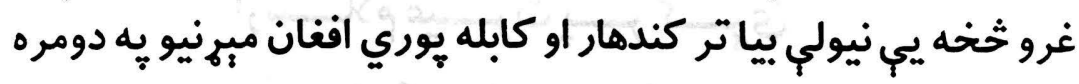

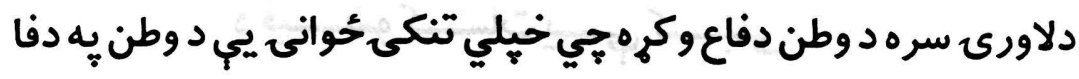

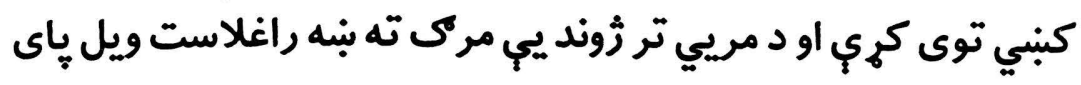


كاكرى غاري

يب يرنكى ودي ته الح كرى جي هغه د افغانانو خاوره هيرجب.دي، يرنكي د

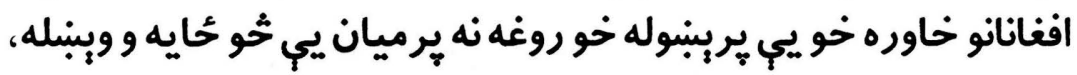

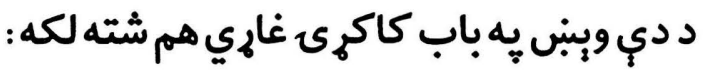
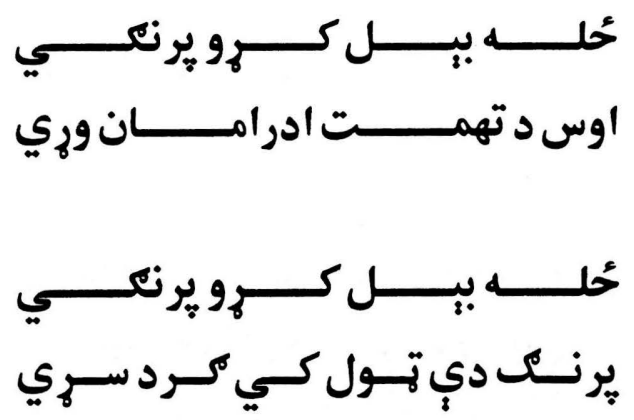

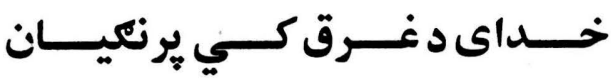

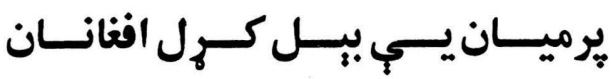

دغه ودبن تر اوسه يوري موبر ته د دوى كوب. نيت رايه كوته كوي

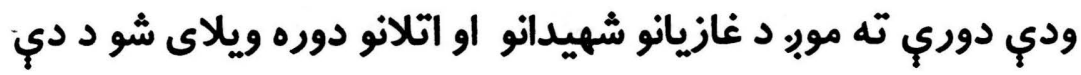

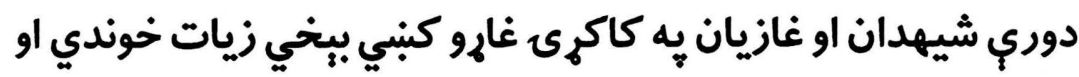

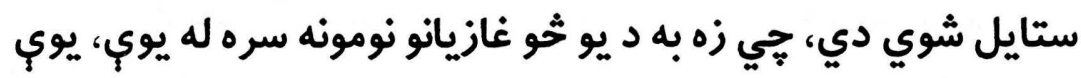

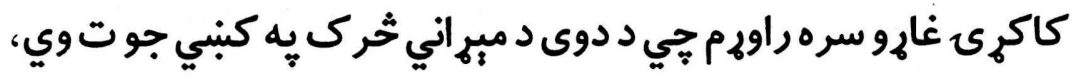

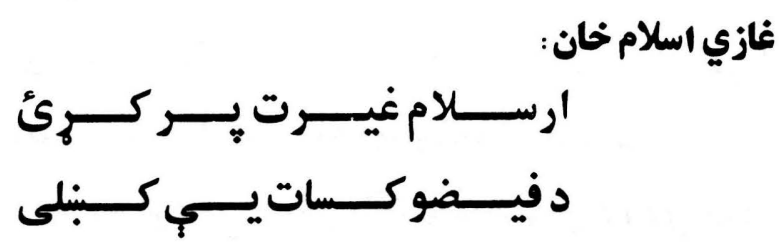


79 كاكرى غاري. ساون مسه خهل : كاري :

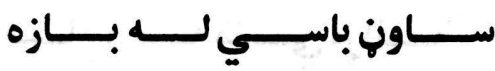

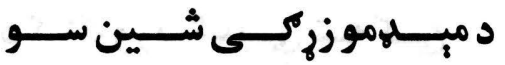

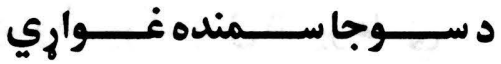

زٔزك ســوى د اسـمان ســتوري

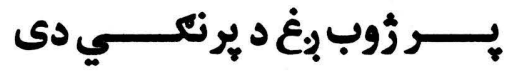

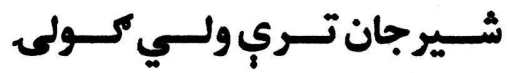

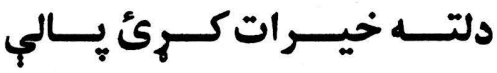

بخـت نـامي حُـان دكـئ غـازي

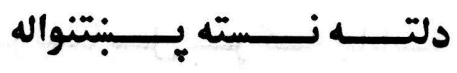
فيض محمد غازي :

فيض محمد بنـكاره بو بنبين سو شجاع غازي:

مـوريسي زاري وهي سـاندي

فازي زَرى خان :

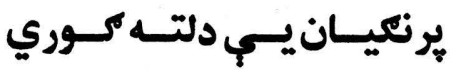
سر دار بثلك خان : - س

بنعـل مـر ظريسف تهيــي دى شير جان:

ميمــي بنـــــــــــــ بالدي شاه : د سـرك غناري بــه سـري بخت نامها : سـور د مركسئ سكهـزخمـي 
كاكرى غاري

جانان

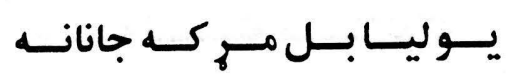

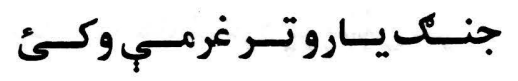

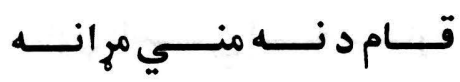

يار محمد صوبيدار :

دكسكو رنسك يسي بنسه كسئ

سردار شير :

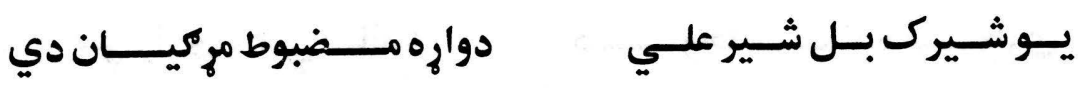

* * * 


\section{يه كاكرى غارو كبني انتورونه}

انتحور جورونه د فنكار كار دى يو هغه فنكار وي جي هغه رنك

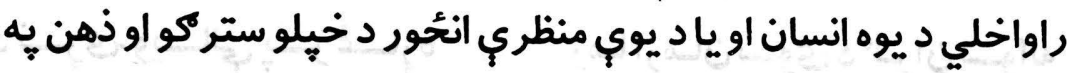

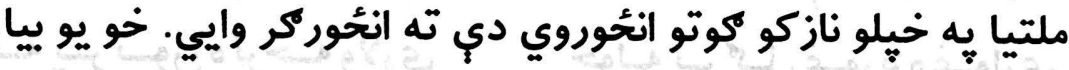

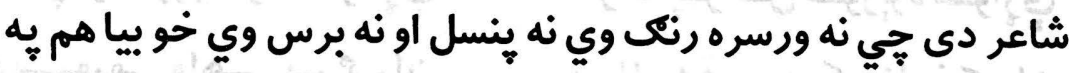

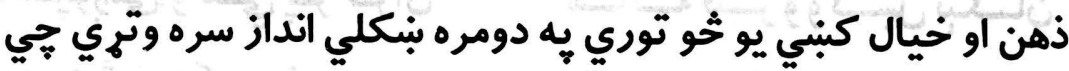

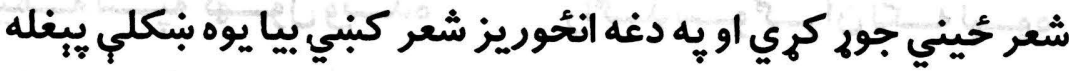

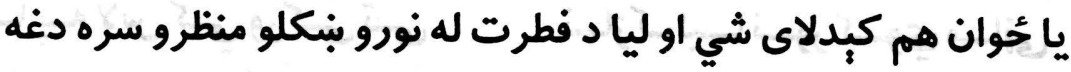

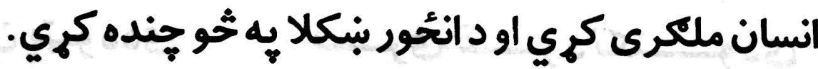

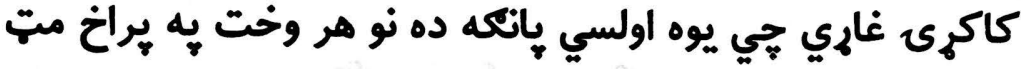

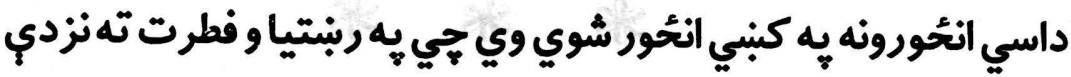
وي داسي هيري كاكر ىغاري سته جي انحُوريزي دي دئهي دلته به يهي

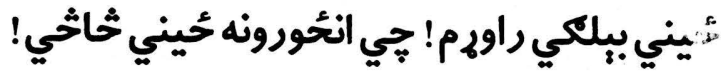

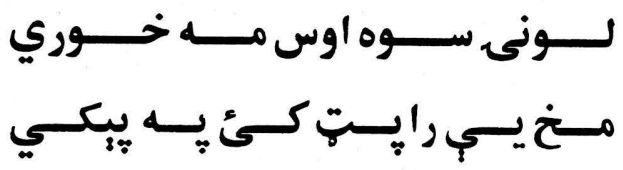

شينــشوبي وع ســـي دمانـــده

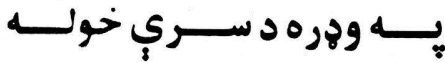

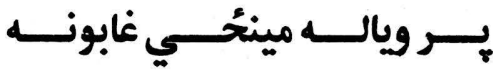

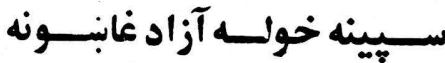


كاكرى غاري

سـيوري يــر جــور كـهـ د بيكسي

بــادامكسل وكــي بيــاتوسـي

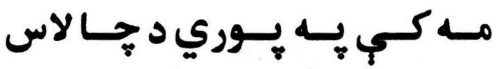

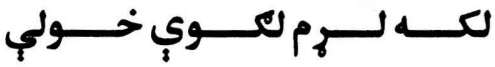

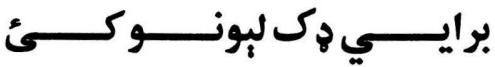

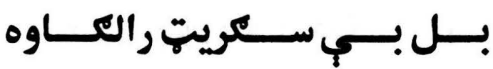

زمـا ارمـان سـوي د كـــان سـواله

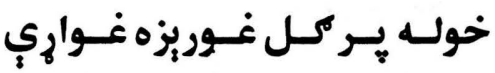

مـــــــــــر ووكــبل نبكـــان

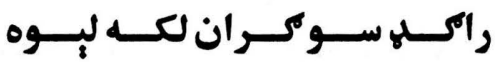

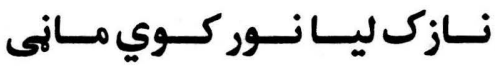

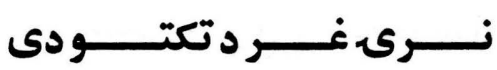

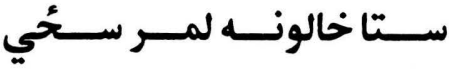

خـي مـهـ سـتا فكرونـه يوسـي

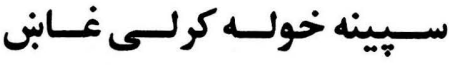

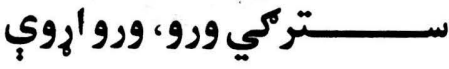

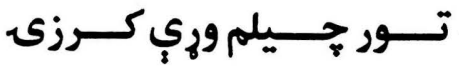

يــوبـي راكـــه سـينه خولـه

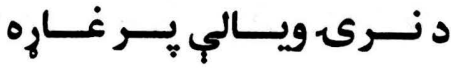

تــهـ يــــــــورره ترخــه ولاري

د سـيوبرجمى واهـي يـر كـران نيمـــهـ شـــيه كهــول ويســده

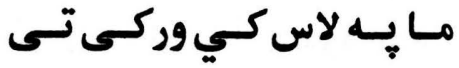
زمــاو سـتا ترميــان يتهو ددى

है? है? है? 


\section{دئينو كاني غاريو شاليد}

هره كاكرى غاره جي ويل شوي ده هغه به خهه نه خحه شاليد (يس

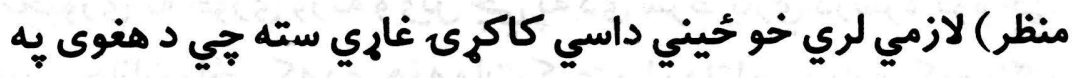

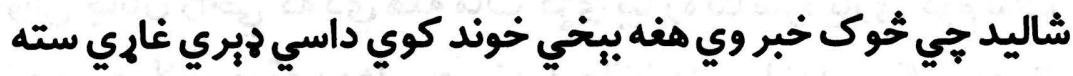
جي شاليد يب د اوسنيو خلكو نه دى ياد خو بيا حُيني داسي غاري هوي سته

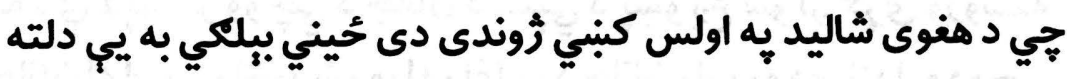
وراندي كرم.

ا : يو وخت يوه يبغله د خيلي بنكلا او بنايست له جوري د كلي له

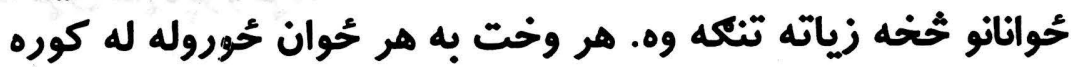

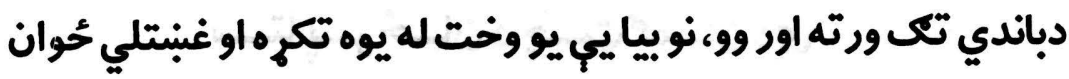

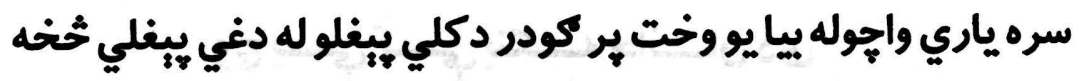

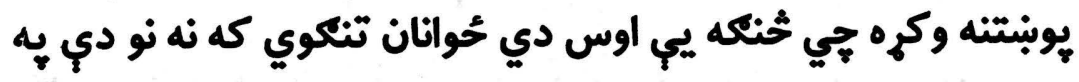

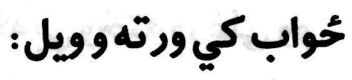

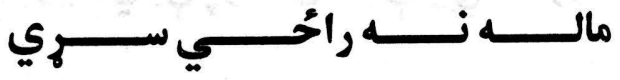

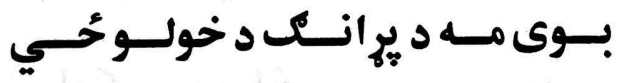

Y : يو وخت د يوي يُّلي د خهيل وخت يوه تكره مبارز جانان سره

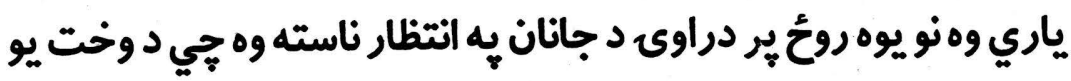


كاكرى غاري

VF

بل حُوان جي بنك نومبدى هغه تر جانان وراندي راغلى نو دي يـيغلي ته

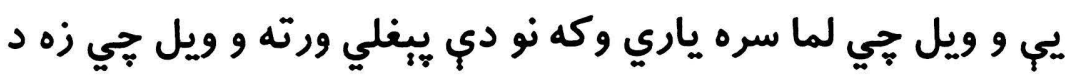

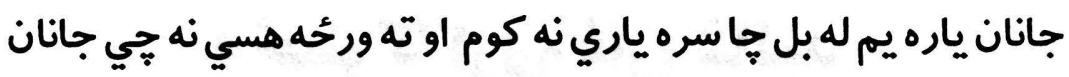

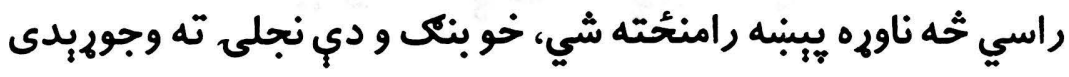

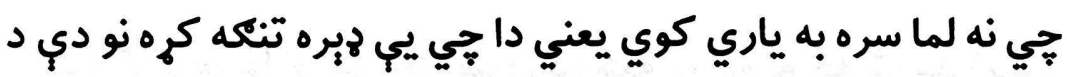

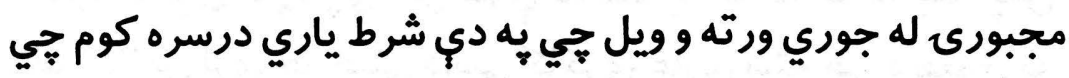

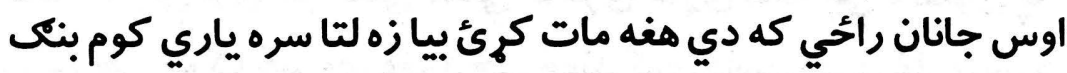

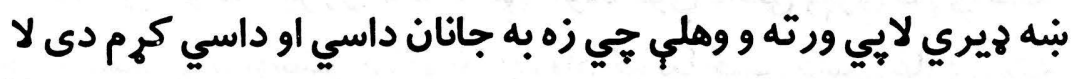

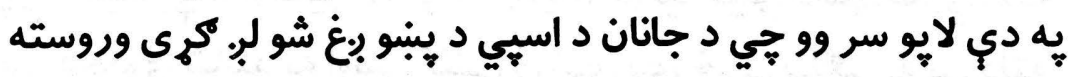

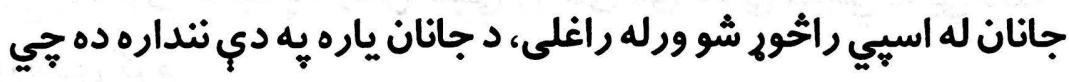

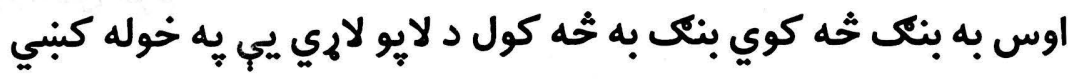

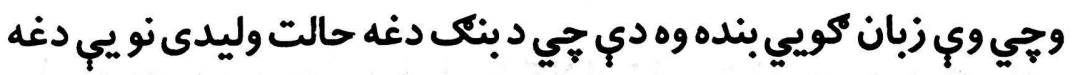
كاكرى غاره هير وكره:

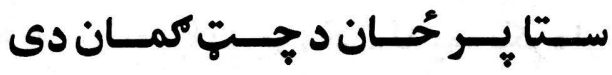

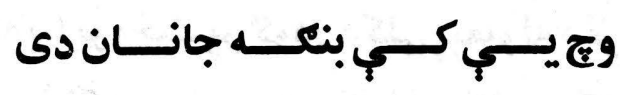

r : يو وخت يار محمدنومي سري خهلي ياري له بي وخته ورغلى وو

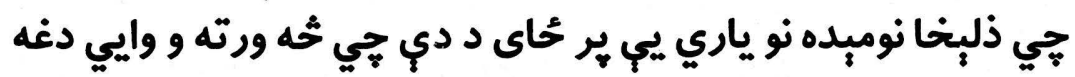
غاره هيب ير وكره.

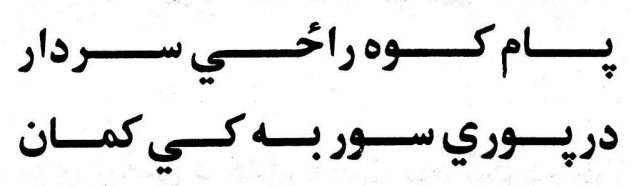




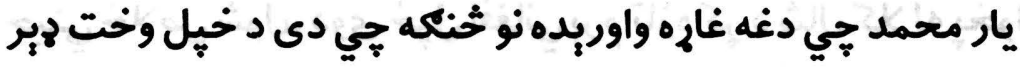

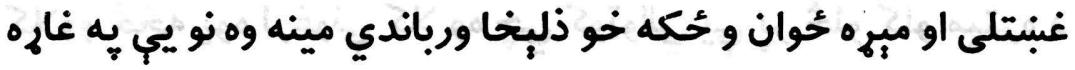

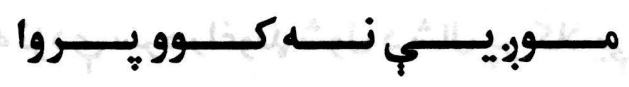

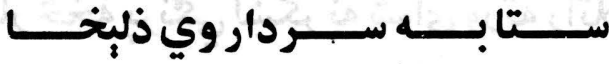

F : يو وخت د يبنتنو و نواب ته مريانو ليار نيولي وه او مريانو نواب

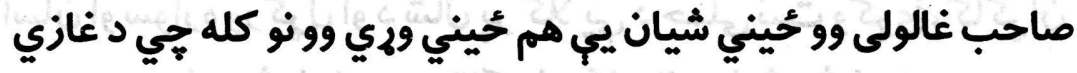

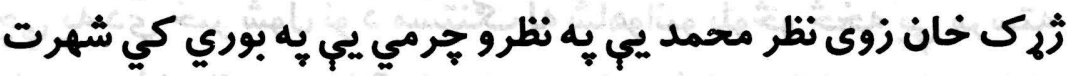

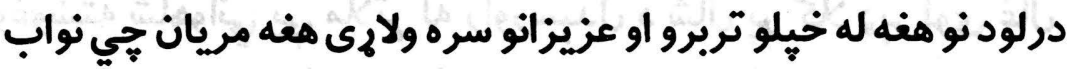

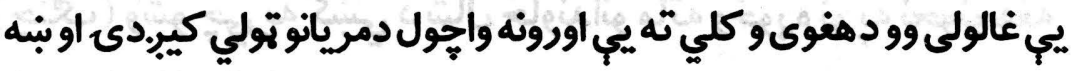

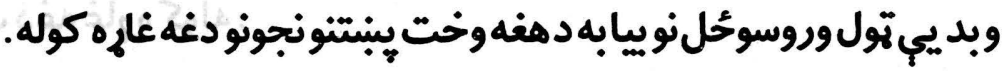

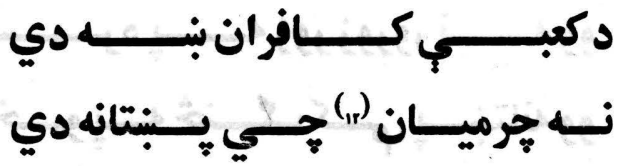

ه : كله جي يرنكيانو د سيوى له خوا ير يبنتونتوا وطن د يرغلنيت

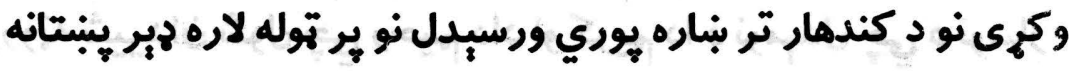
شهيدان شول دلته بيرته يه شال كوت (اوسنى كوته) كبني له كوتي

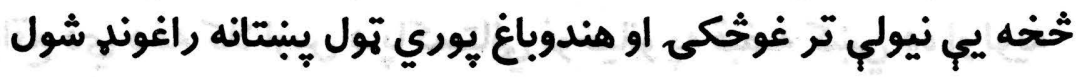

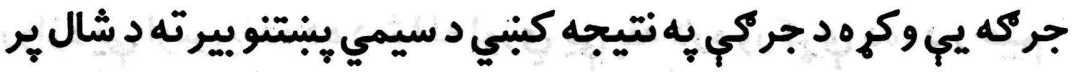

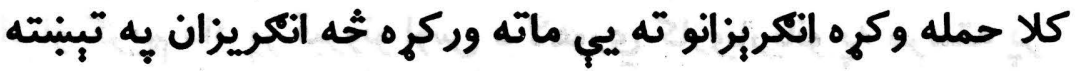


كاكرى غاري

حيني خلاص شول، دوى خيل افغاني برم تازه كر د شُال كلا له يخوانيو

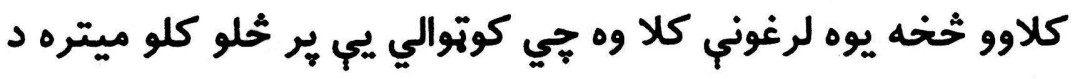

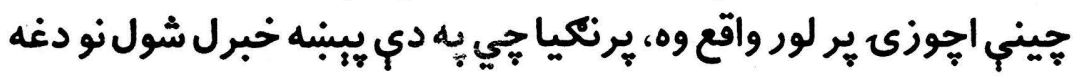

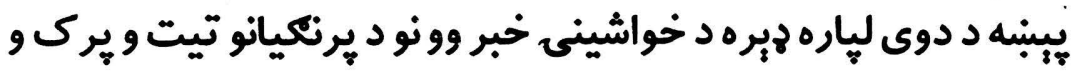

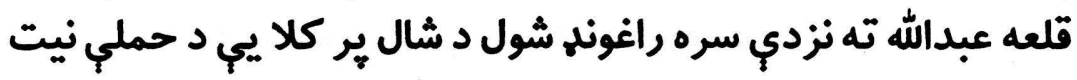

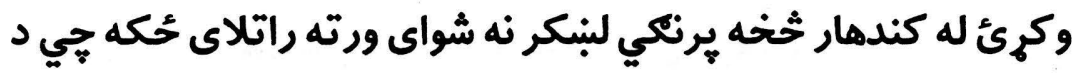
كندهار قوت يب كمزوره كيدى نو يرنكيانو سالو خان جي خيّل خيل لبنكر

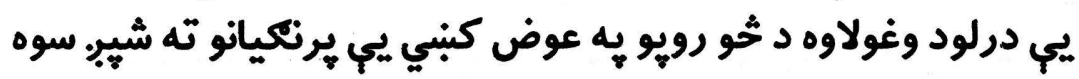

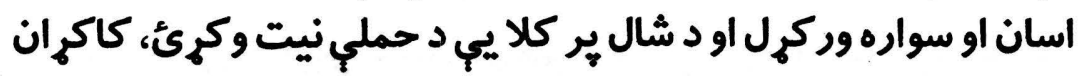

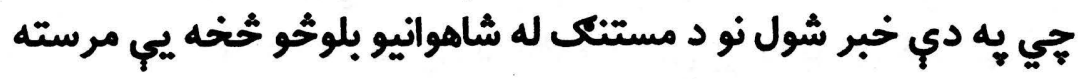

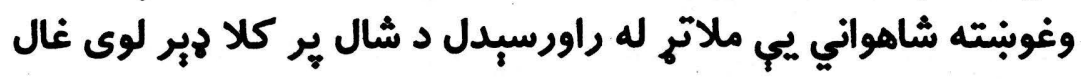

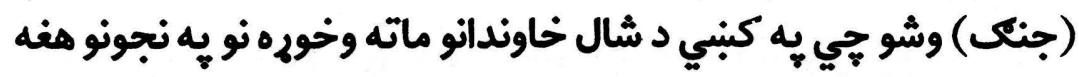
وخت دغه غاره كوله :

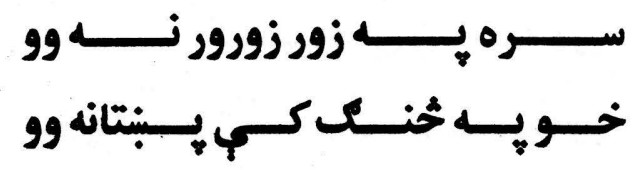

د يادوني وي ده جي يه دغه غال كبني د نورو شهيدانو تر شمنك دوه

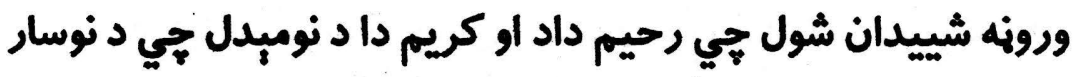

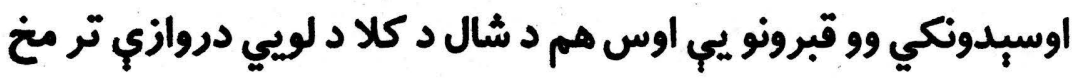

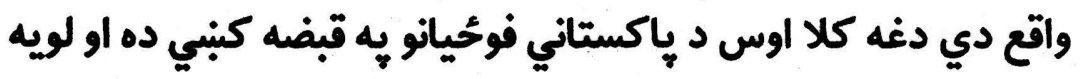

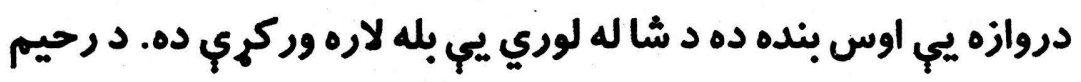

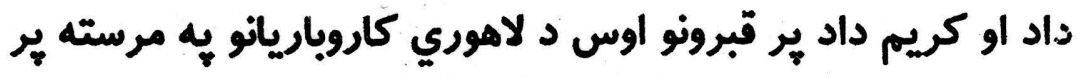
كتيبو يير خاكي او يير ضرورتي ليكلي يعني اصل نومونه يبي ور وران 
VY كاكرى غاري

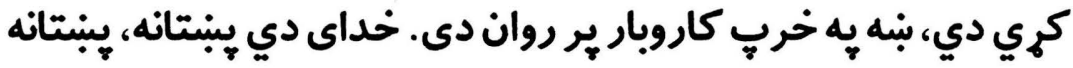
كري جي خيل افغاني غرور خلكو ته وبنيي او خيله تاريخي خاوري

$$
\text { بيرته د خيل وجود برخه كري. }
$$

7 : يو وخت يوه حوان له خيلي ياري خخه خوله غوبنتي وه دي انكار

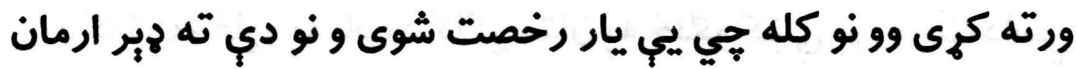

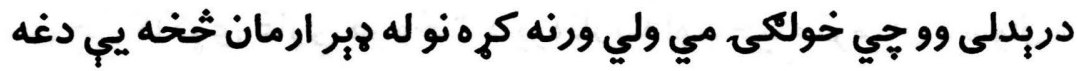

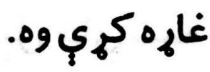

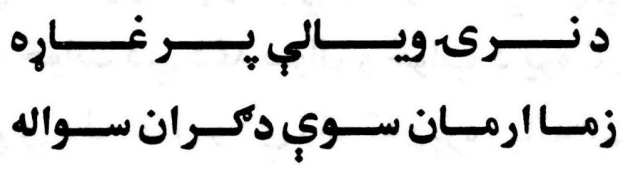

دي جي خنكه دغه غاره كري وه نو اتفاقاً يب خيل يلار ورباندي

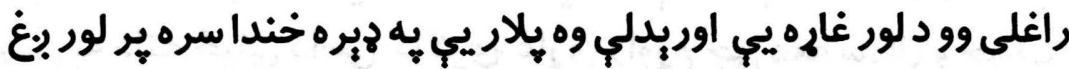
كر جي زويه ولي داسينه وايبي جي:

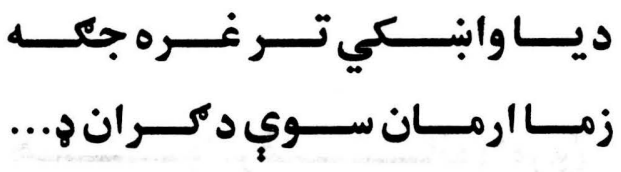

هيري كاكرى غاري شته جي هغه خيل شاليد لري خو د حُينو

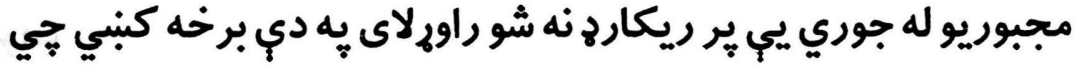
هم حيني كيسي دلته بيان شوي يه شاليد كبني مو نومونه او سيمي له

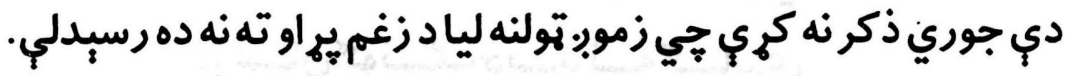
\& \& \& 
كاكرى غاري

\section{يه كاكرى غارو كبني سوالو حواب}

د كاكرى غارو يه باب د كاكر ستان يه خلكو كبني يو روايت داسي

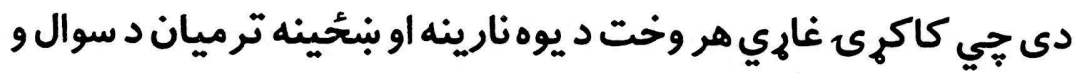

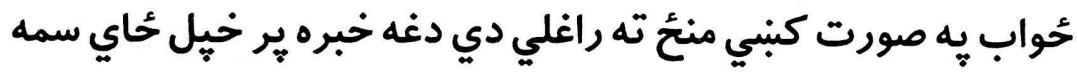

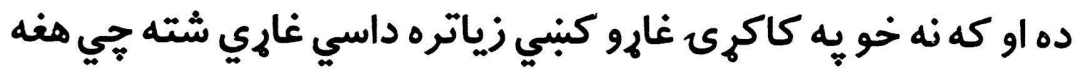
يو د بل سوال و حُواب دي دغه سوال و حُواب د ديوه نارينه او بنَحينه

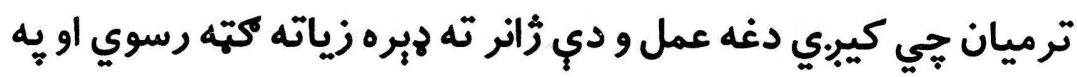

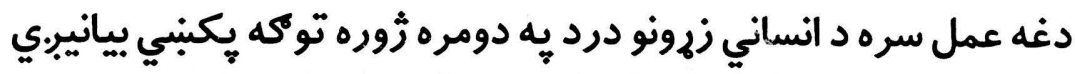

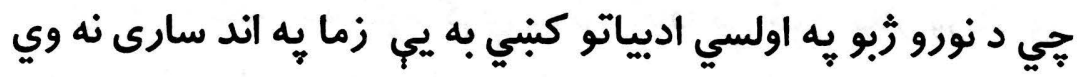
اوس به دلته حُيني داسي كاكيى غاري راوحم جي هغه سوال و حُواب
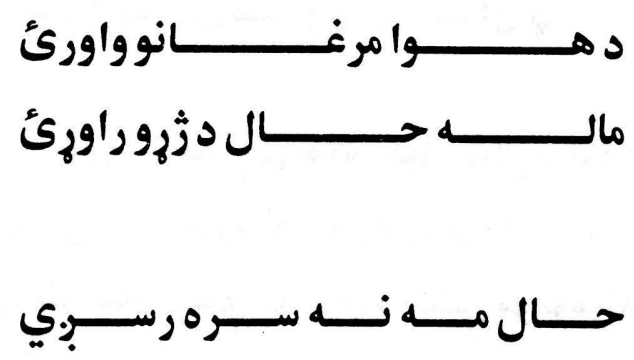

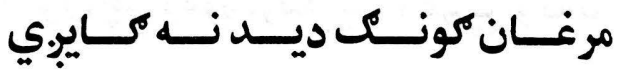

\&s is sts 


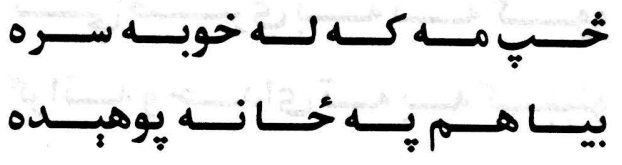

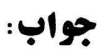

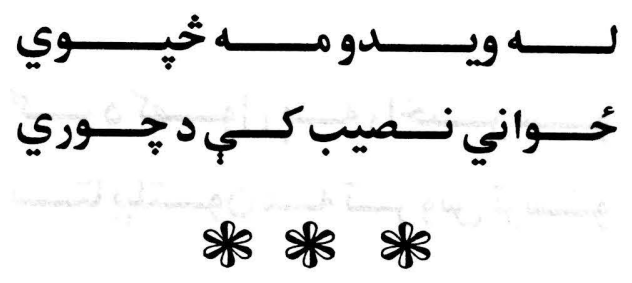

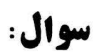

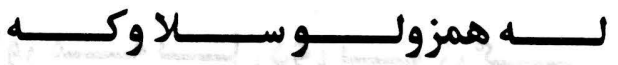

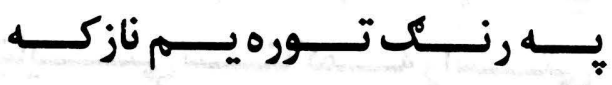

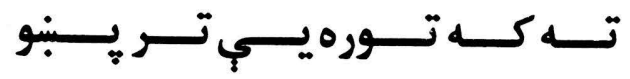

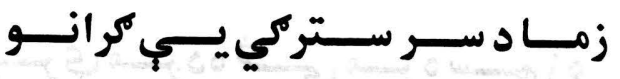

है? है? है?

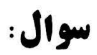

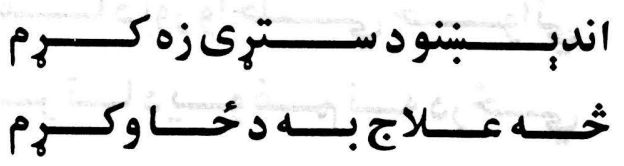



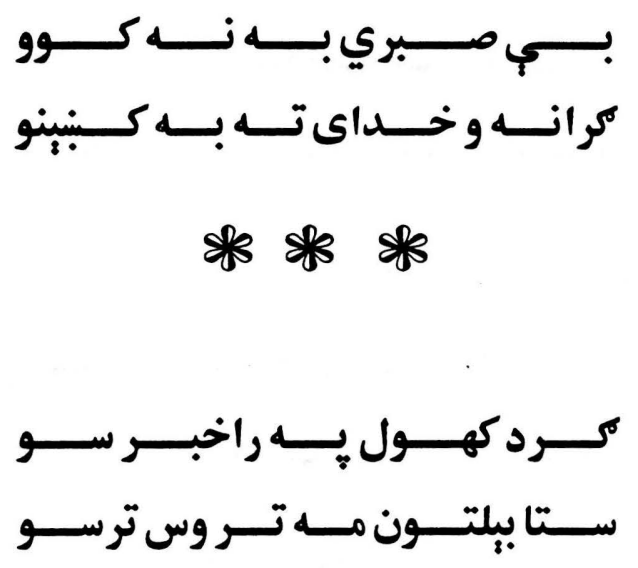

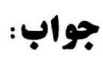

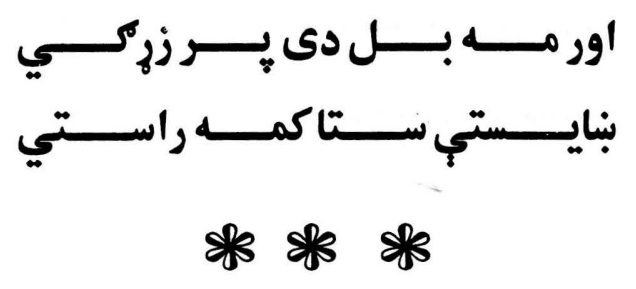

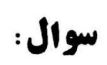

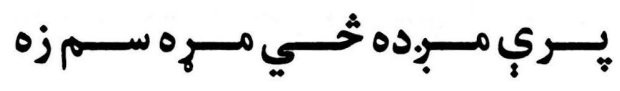

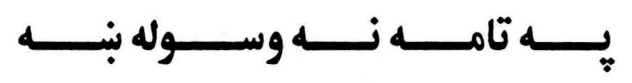

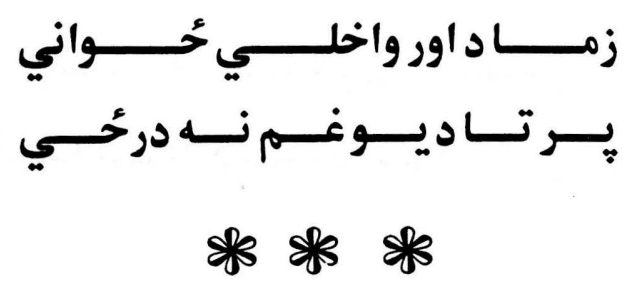




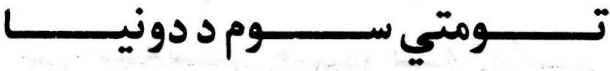

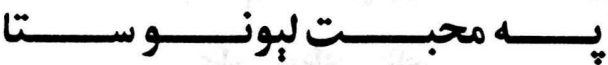

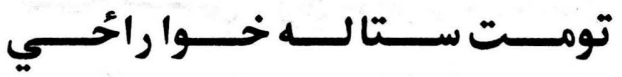

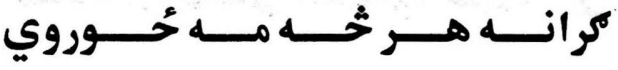

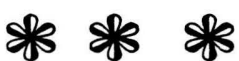
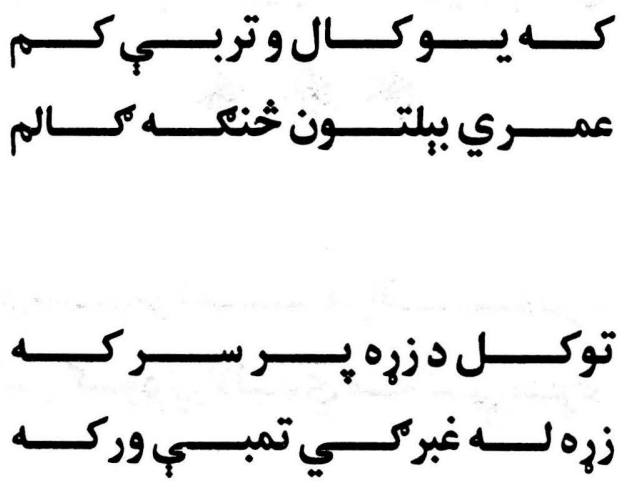

\&s \&

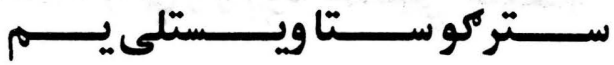

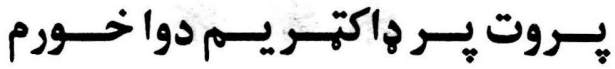




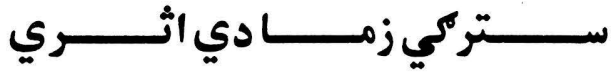

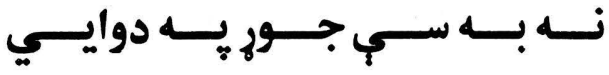 \\ * * * *}

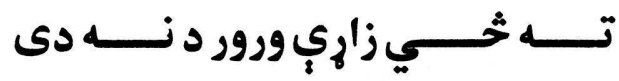

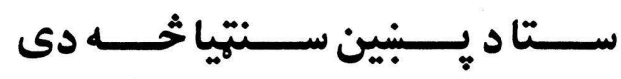

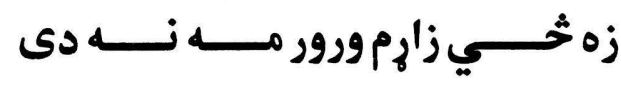

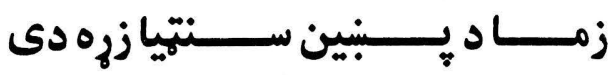

$$
\text { * * * * }
$$
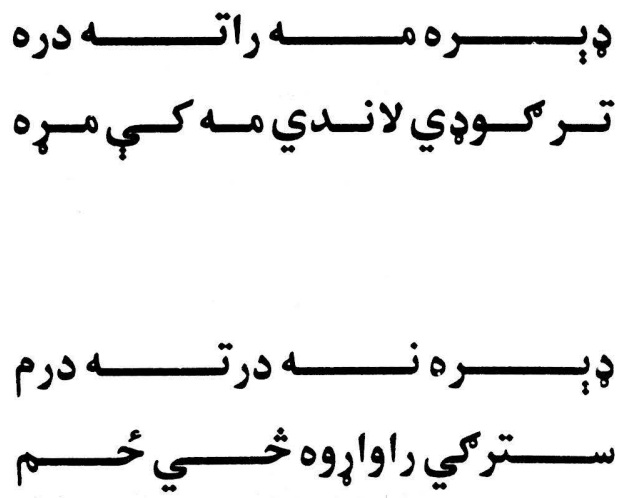

* * * 


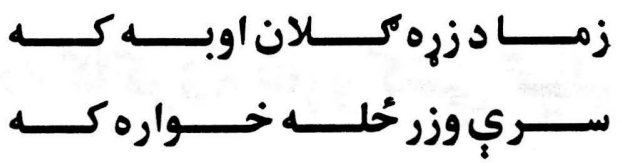

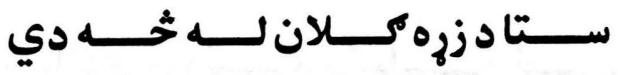

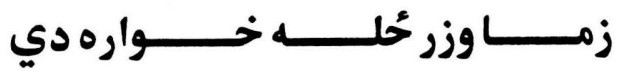

$$
\begin{aligned}
& \text { 数 数 }
\end{aligned}
$$
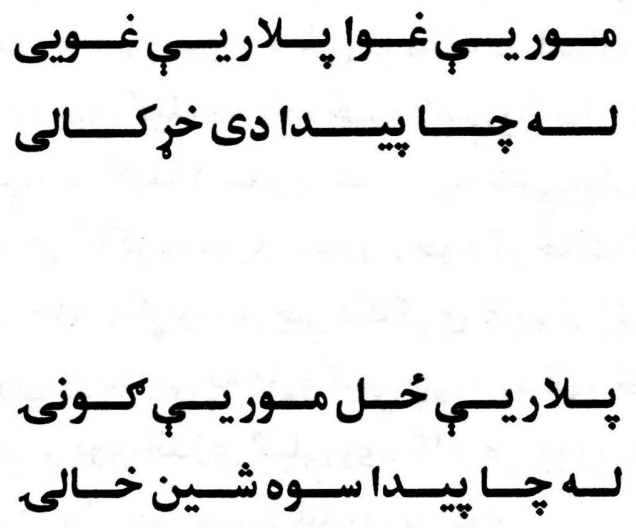

$$
\text { * * * }
$$




\section{يه كاكرى غارو كبني كيلجي}

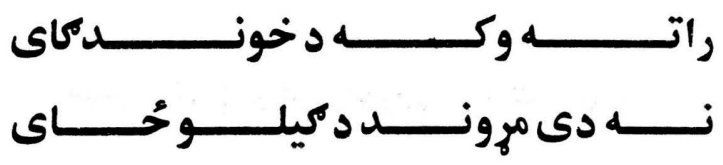

إنه توله نرى كبني به داسي تولنه نه وي جي يه هغه كنبي به يوه

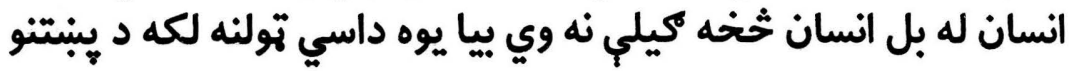

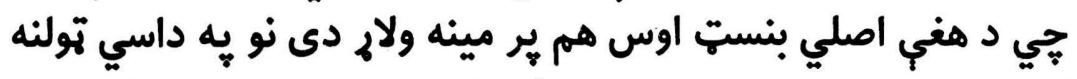

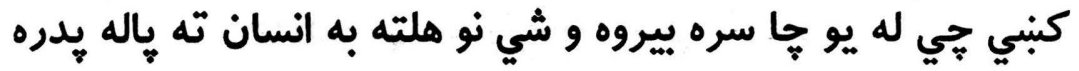

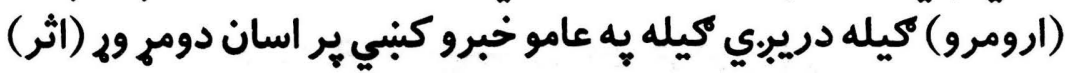

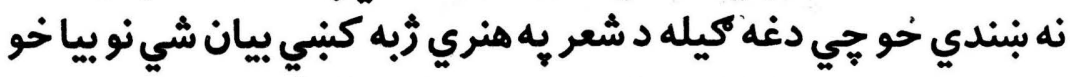

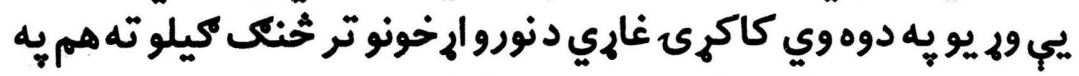

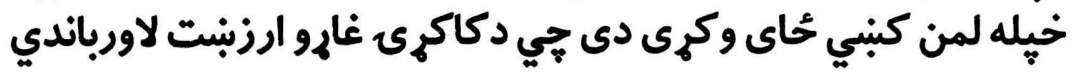

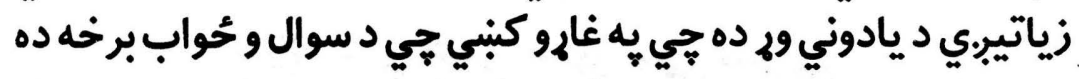

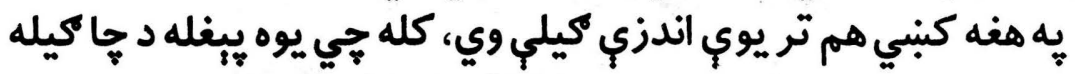
ور ير حُاى كوي نوبيا داسي ست (بلنه) ورته كوي:

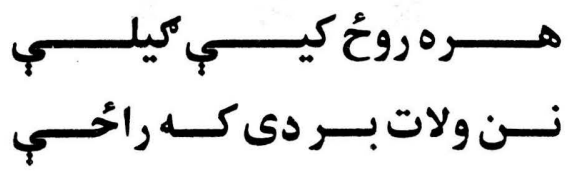

* * * 
AD كاكرى غاري.

اوس به دلته حُيني غائي راورم جي هغه له كيلو ثخخه ببخي خاكي دي، لكه:

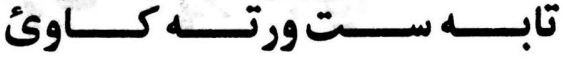

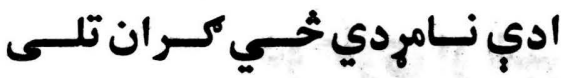

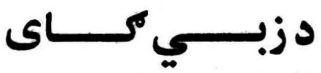

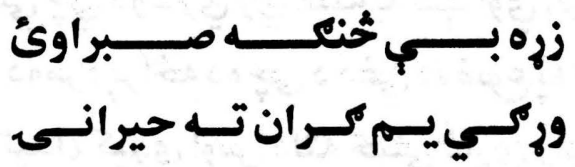
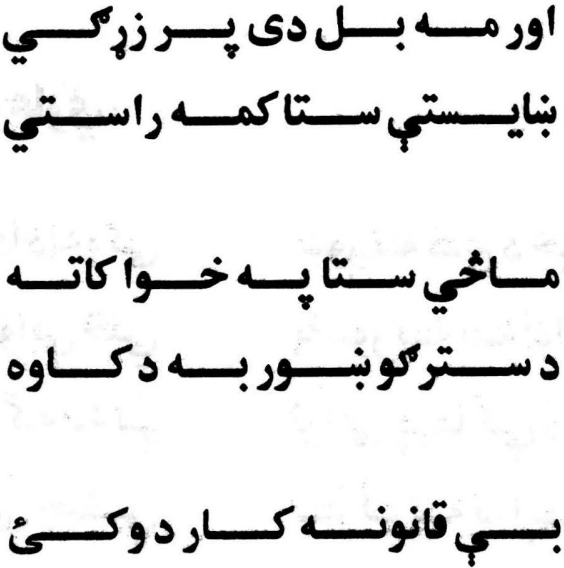

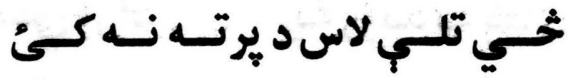

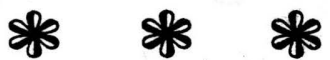


كاكرى غاري

\section{يه كاكرى غارو كبني}

\section{دوعاوي او بنّراوي}

كاكرى غاري دنورو إحخونو تر خنك دغه احخ هم يه خيله ويره لمن

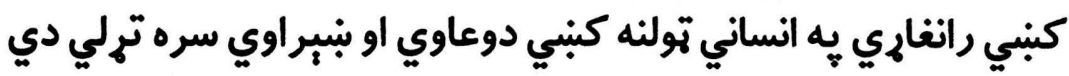

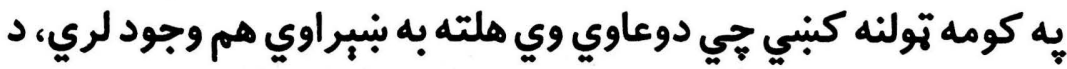

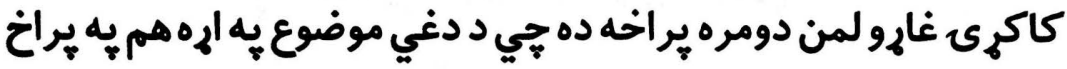
مت غاري بكبني ليدل كيري اوس دلته حُيني غاري راوحم جي يوائي دوعاوي يه كنبي وي.

يه غارو كبني دوعاوي:

مـوبر.بـه هـم د خيسـارهكي

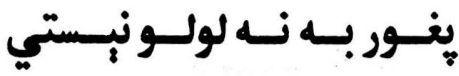

نيمس برماكي دكران خـوب.

نـازك يـهـ تـايوري راحُــي

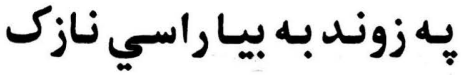

خداى د نازك نه كي نمستي

زوب دلـي راخراسـانكـي
خداى غني دىدادبهوكي

خداى غني دى وابي خلي

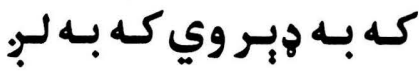

مــوري تــه سـي جنتـي

يسه مركسي د نه سي ورك

يه خوشحال مه زئكى وي

داخهمي وورهزراندكي 
نـــــيــارواولـي خدايسـ

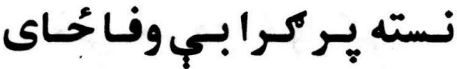

\section{زوب ورجار دى سرتر يايه}

حُوانيمركدئنكي

د دوعا به برتله يه كاكرى غاجو كبني بنّراوي بيخي زياتي ليدل

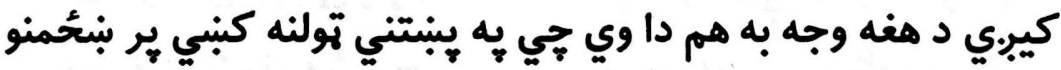

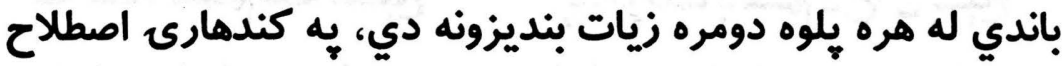

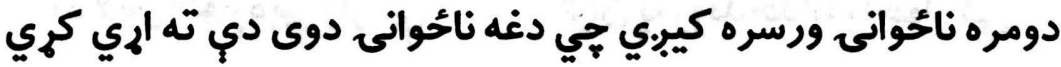

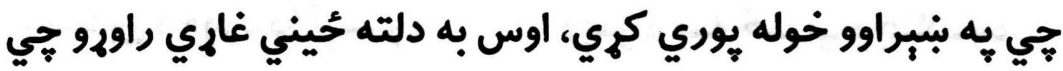

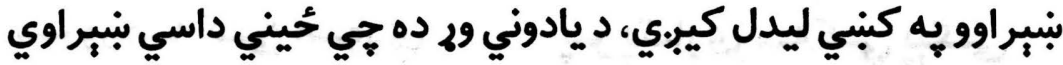

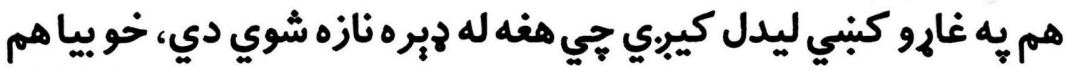
يهِ بْبر اوو كبنبي رائي.

به غارو كبني د ناز بنبراوي:

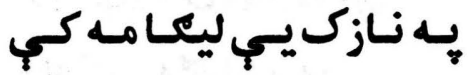

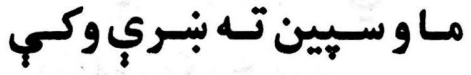

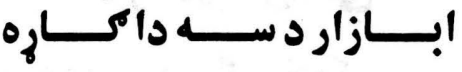

خـواره سـي برتهـ د يرجبـودم

كر انـه بـهـ برتـهـ دكـايوسـي

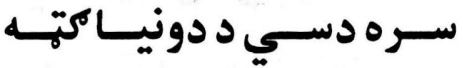

زمـا يرتـك د خـاوري واوري

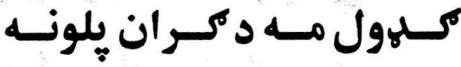

مالــه نــازه بنــــــوكـي

ومه كي لكيايمب مه كي

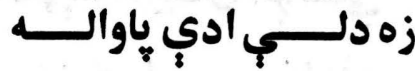

رانززدي ســه نـه د خــورم

مري د نه غوبني دي توسي

زه يـر زوب نـازك يركوتـهـ

زه خي حمم موركىبه زاري

زما د خاوري سي لاسونه 


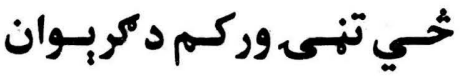

وج لركى سوم يِ دبوال كي

ستابـه لـور لـ زرار مهره سي

دكرانوختي له جـاغوارم

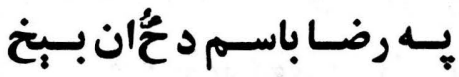

كرانيهزوندخدايهراخواركي

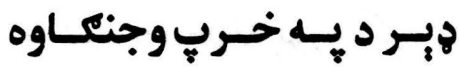

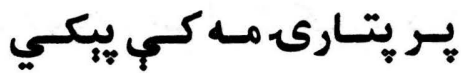

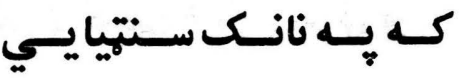

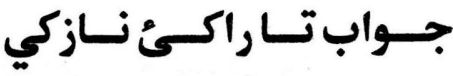

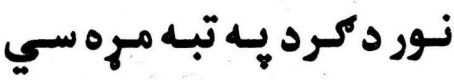

سـتاد دويــر قريبـان لـبر سـي

يه ايمان خـوار سي مخلوقه

كـه مـه روزي نـه دى نـازك

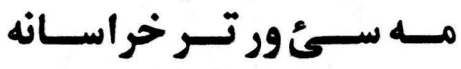

خـداى دوبغـل وكي بـــــاران

زمور. يه ميان جي دجاكارسي

دوجي درختي يه شان سي
صـبر وكـه اوخــــي حــان

نه راحي مولا دي خواركي

زماو ستا ياري د سره سي

حُسان دوخـورم ولهي زارم

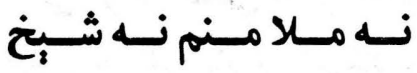

زماد لاس خوارهيج زاركي

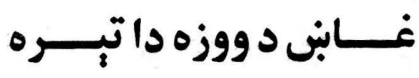

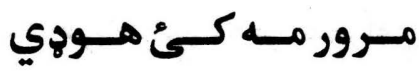

يه غارو كبني بنبّر اوي:

كونله سي يه كل تيكري

خوارهسيّه تهل تيكريكي

يه كاله كي مه كران بنه سي

زمادنته زره در خـوبر سي

خور.مه سي دزركي خُوكه

خداى دي كي له قامه ورى

كلهي مه وهـئ بي كرانه

زمــاو سـتا يـــر دبنــمنان

سوال كوم هغه دخوار سي

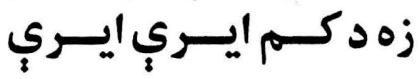


A9

دباندي سيّين نوند كئ باران

ادي روكي اوخري حُحان

كر انه خـوك بـه در رايات كي

خداىدسوريردىولاتكي

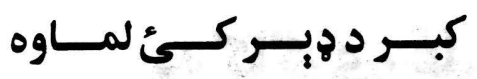

خـداى دكه يـر بـن واده

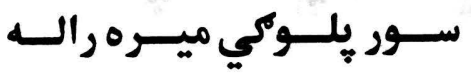

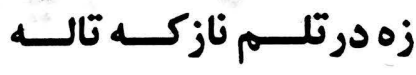

شينـشوبي وع سـي دمانـده

يـه وهره د ســري خولـه

*s 
كاكرى غاري

\section{به كاكرى غإو كبني بنكنئحل}

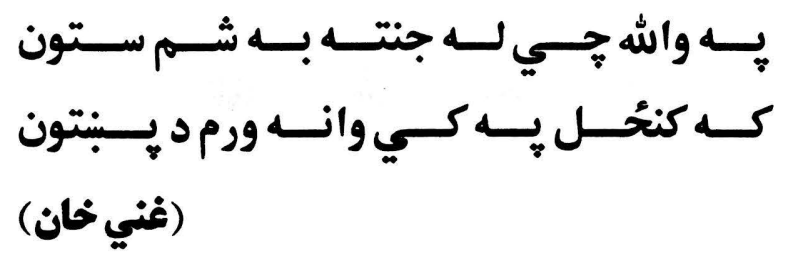

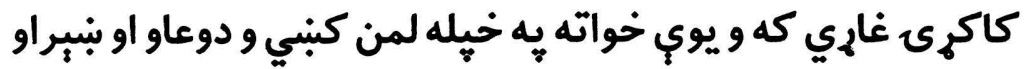

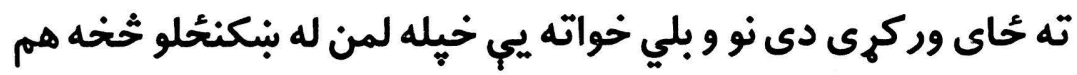

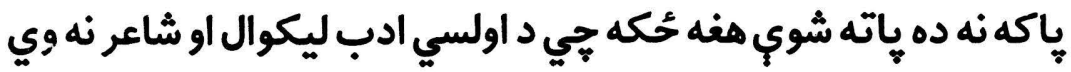

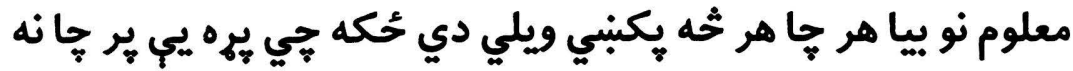

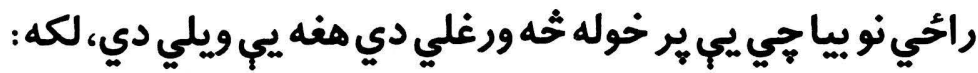

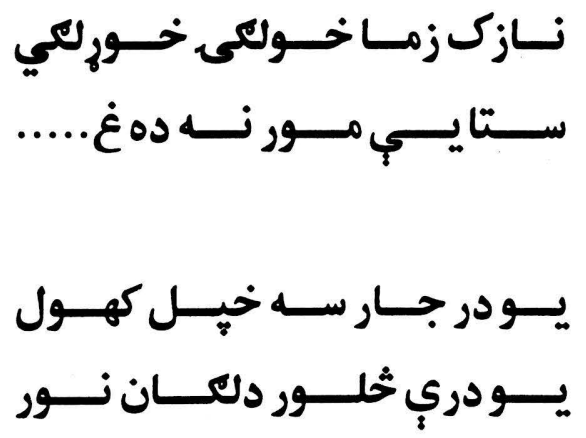



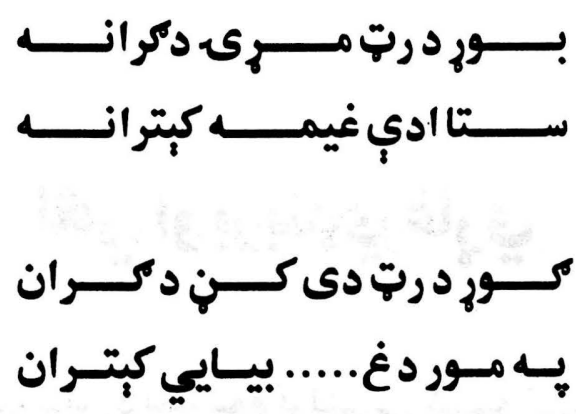

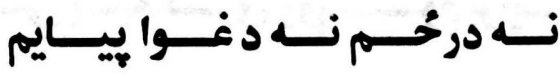

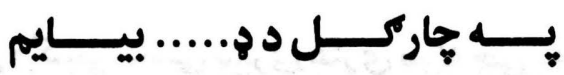

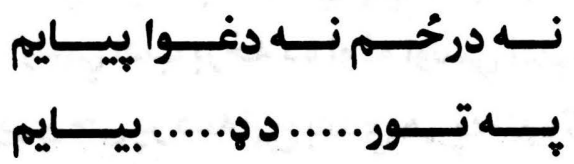

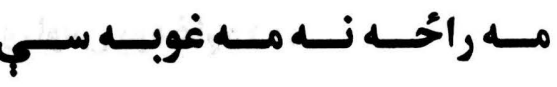

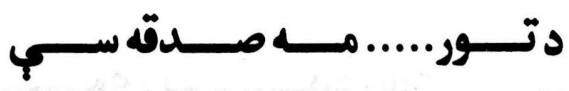
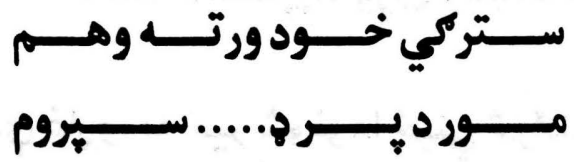

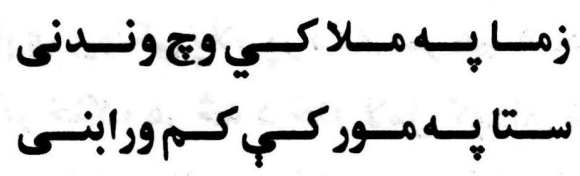
* * * 


\section{كلي او بربندي غاري}

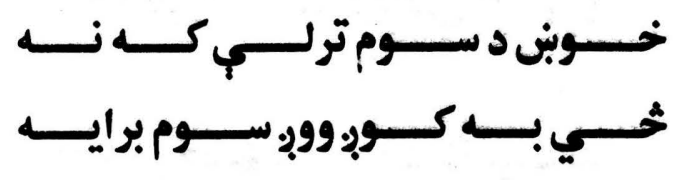

به كاكرى غارو كبني داسي جيري غاري سته جي به هغ هنه كبني لخي

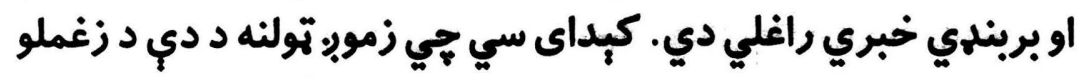

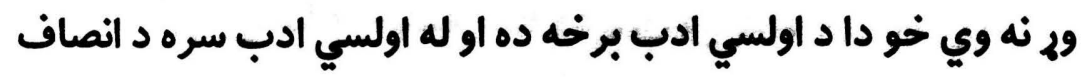

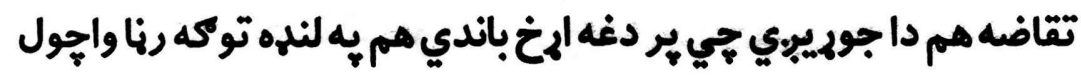
سي اوس كه يوي خواته به غارو كنبي لثخي و بربندي خبري راغلي دي د دي جير لاملونه دي اوس يوه غاره مدهـ
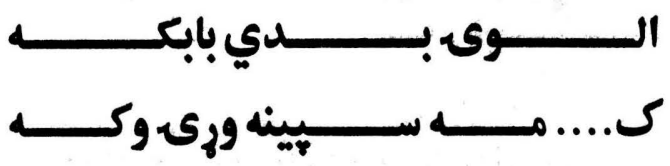

اوس كه موبر دي غاري ته حُير شو نو دا حُيني خحر كنديري جي يوه

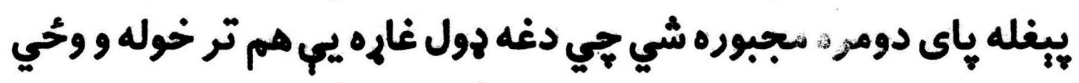

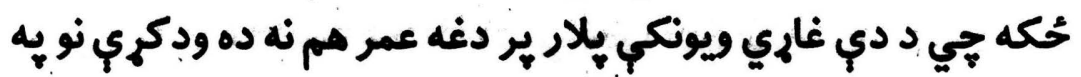

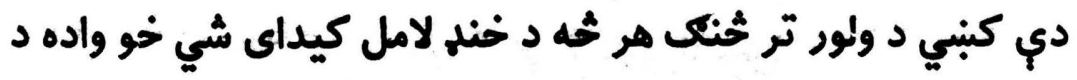

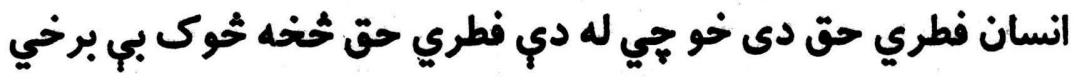
وي نوبيابه هاله يدره (ارومرو) وار تردي حمايه رسيري. 
9r كاكرى غاري. كله كله بيا غربت هم سرى له داسي حالاتو سره لاس و كريوان

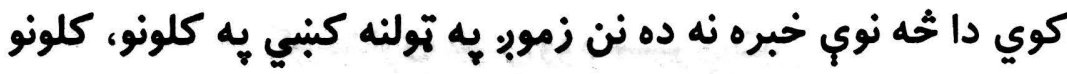

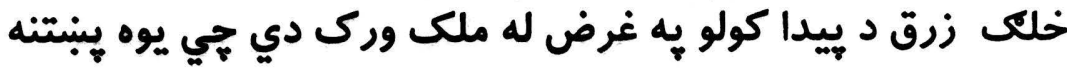
داسي غارهويلو ته إهـ شي.

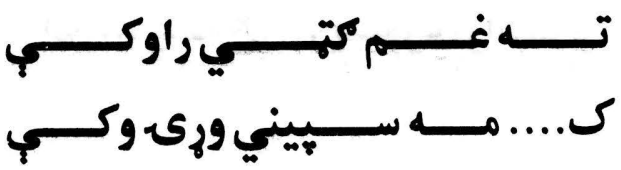

كاكرى غاري جي خومره هيه دي باب يه مخه راغلي ما خوندي كري

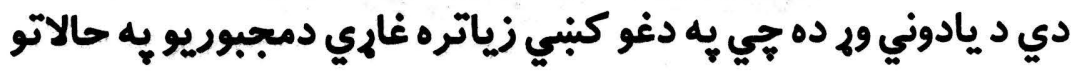

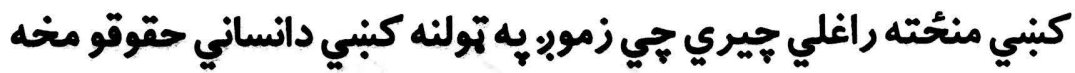

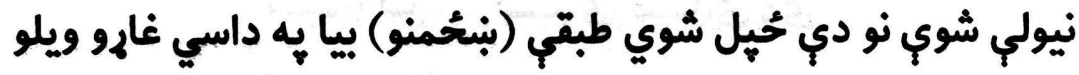

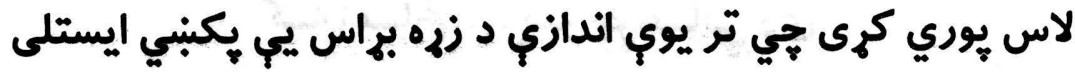

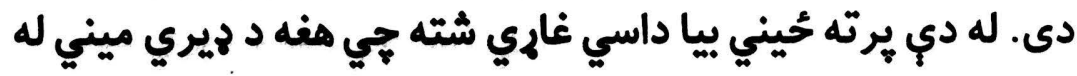

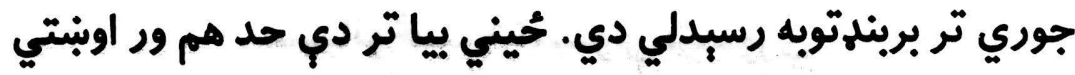

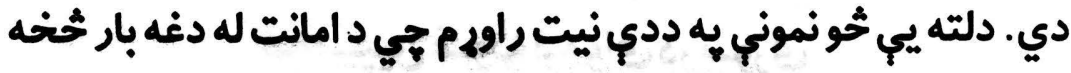

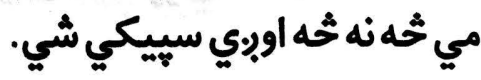

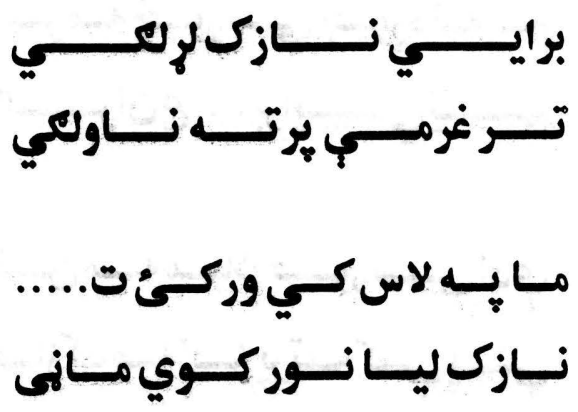


كاكرى غاري

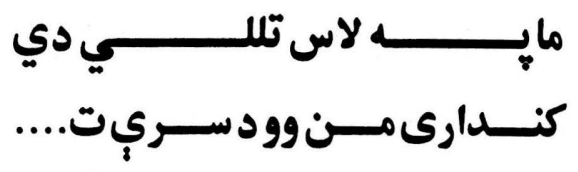

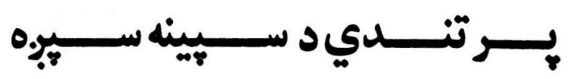

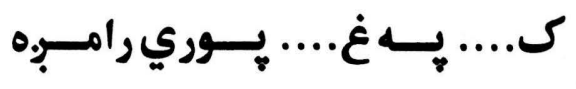

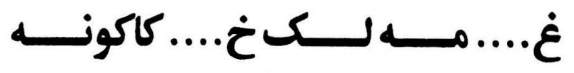

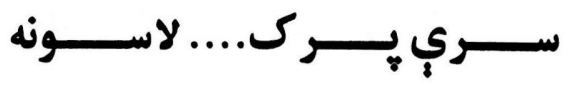

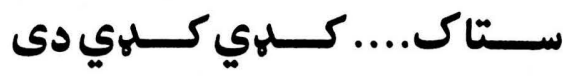

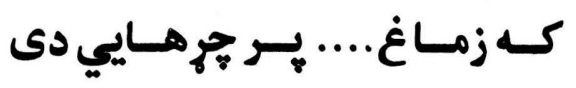

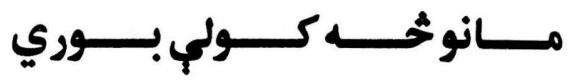

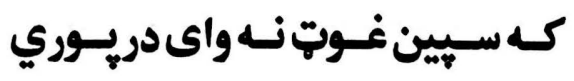

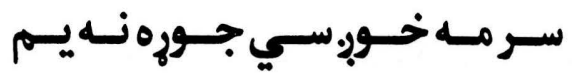

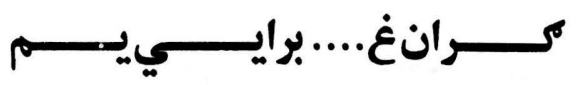

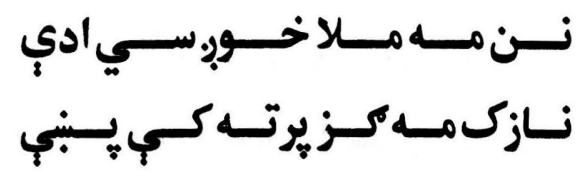




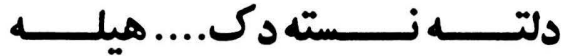

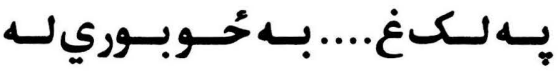

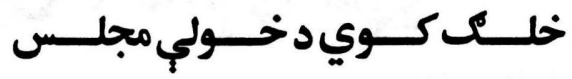

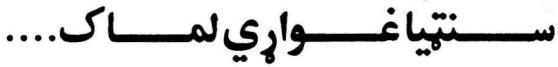

$$
\text { * * }
$$


يوه بنه يهيلمه

\section{دراوى دكاكرى غارو}

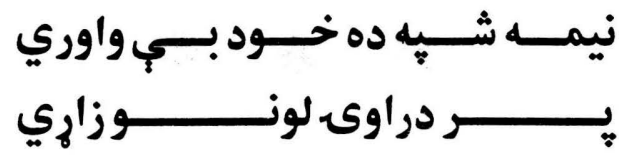

دراوى د يُبتو ثبي تورى دى جي يه كاكري كردود كنبي يه دوو معناوو كاريب.ي. ا : كله جي د دوو كورنيو تر ميان د واده نبته وتاكل شي نو ويل

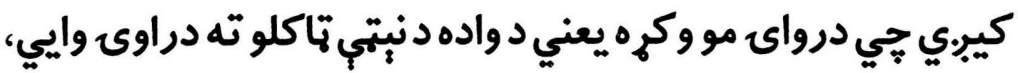

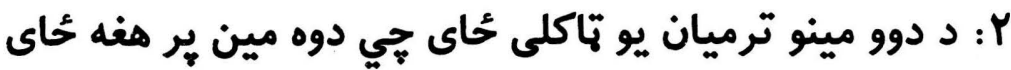
راغونديبري خيله دراوى سره كوي.

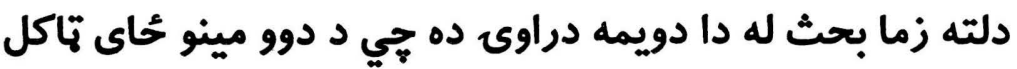

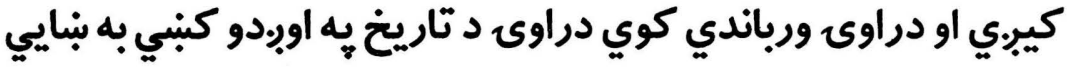

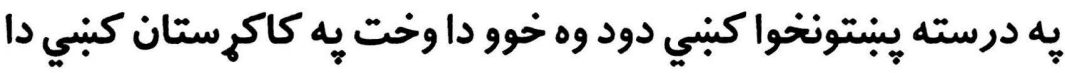

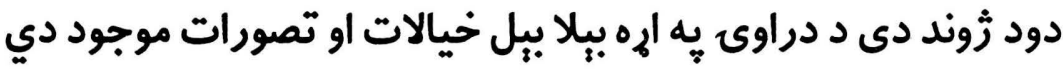
خو تر كومه حُايه جي ماته معلومه ده او يا مي له خلكو خدخه اودي اوريدلي دي او ياحقيقت لري هغه دا جي ير دراوى دوه مين راغونليبري تر هوبره

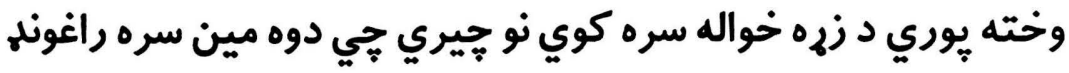
وي نو هلته به زياتره خبري اتري د كاكرى غاجو يه زبه سره كيدي نو 


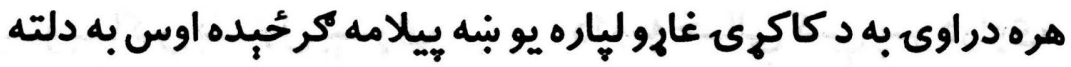
حَيني كاكي غاري راورم جي هغه يواحي د راوى به إهه دي يا بر دراوى منحُ تهه راغلي دي.

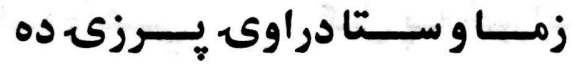

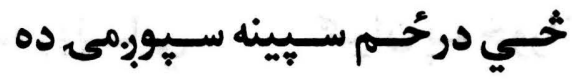

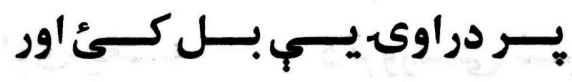

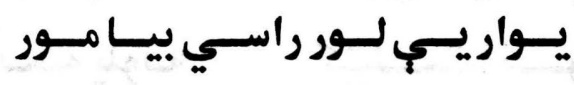

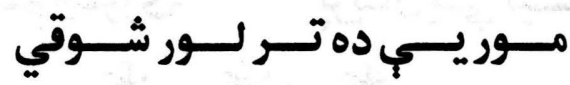

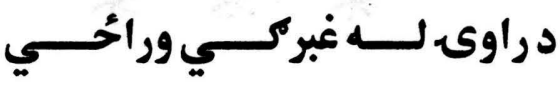

دجوسـو يووتـي وي تهـونجي

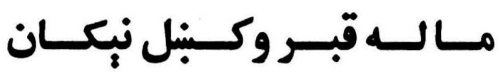

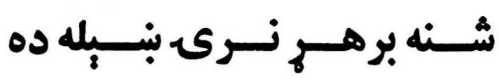

بانلى شـني سوكي دي ماخحس

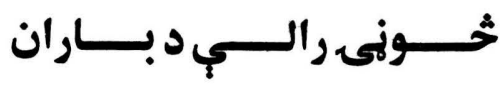

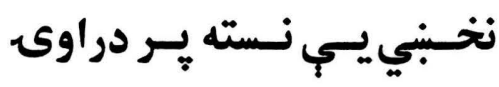

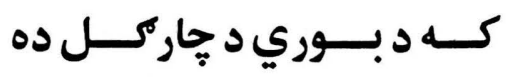

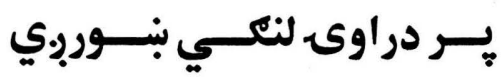

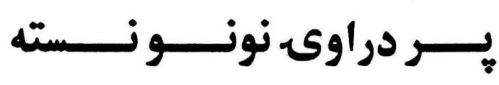

• •ـر دواوى رالسم د سـري د سـيورونم واهي هـ كـران زما و ستا دورواى بنـكاره ده كو انـله زمهـاو ســتا درواى

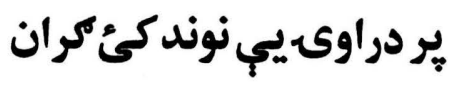
بـ وفي سـوه شــن خـالى : ده نجلـ ليـا هـم شــرمبري لمر خيه دى سيورومى نسته 
كاكرى غاري

دا مــه خــالي كـي :بـــ دراوى

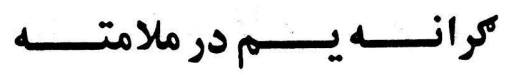

خــــكـى زر راورهم موقـــع ده

كـل يسه حُوزانـوكـي راحَـي

كـران يـه حُوزانسوكـي راحَي

ادي جنـــت وى د جارميــــان

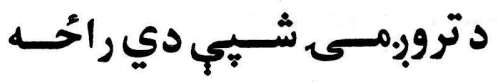

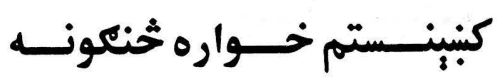

يريسان يسب نيسـي :ـــ دراوى * * *

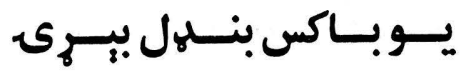

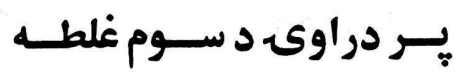

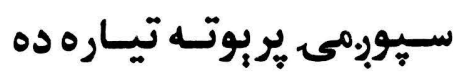

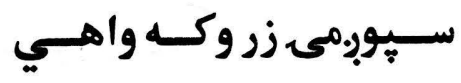

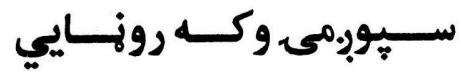

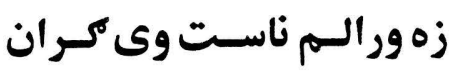

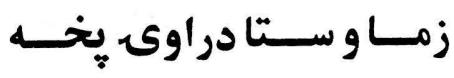
يـر دراوى يـي نسته يلونسه اوس بـه ثخنكسه كـم جحسورى 


\section{يه كاكرى غارو كبي نيإِه توري}

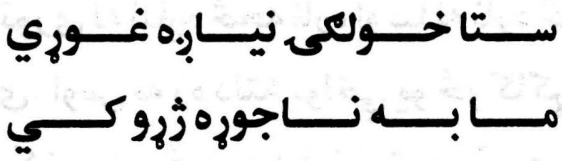

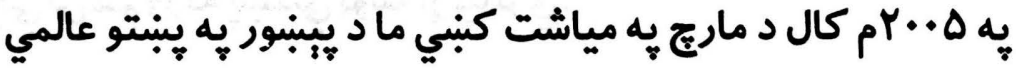

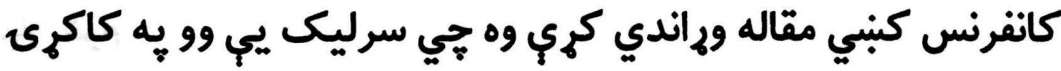

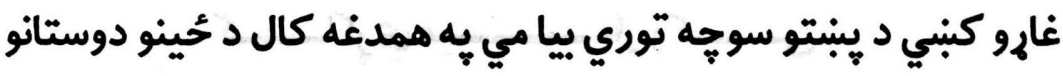

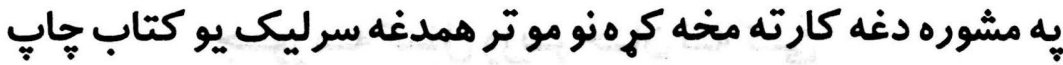
كر جي "سل" داسي توري يكنبي راغلي جي هغه ينبنتو سيندونو نه وه

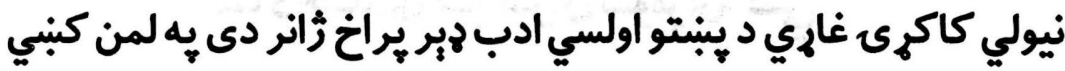

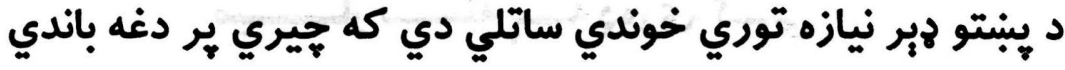

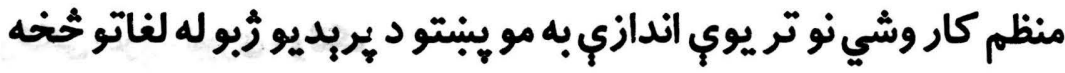

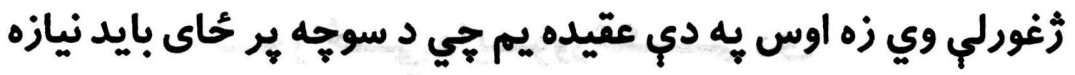

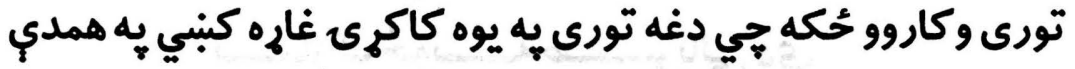

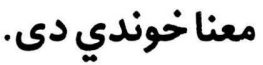

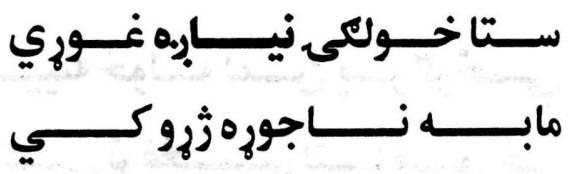

د توري او قلم خاوند د يبنتو ثبي بهلار ستر خوشحال خان ختجى هم يه خيل يو شعر كبني دغه توري داسي راوري دى. 
كاكرى غاري

$$
\begin{aligned}
& \text { " يه هره تنكه خوله كي بر ابر نه دي خـوابره } \\
& \text { يه يُحينوكي حلوا دي خوك نبات لري نار.ه،"(,) }
\end{aligned}
$$

د نيابهه او نابهه يواحي دومره تويير دى لكه يه ليار او لار كبني جي

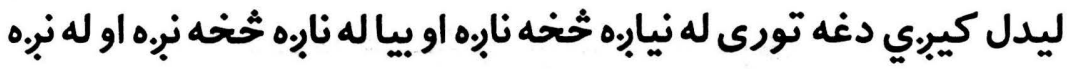

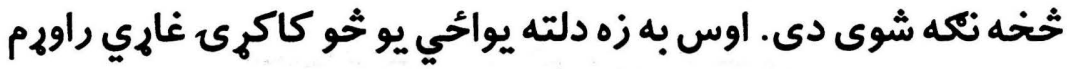

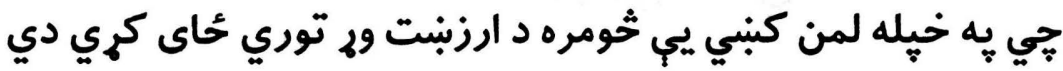

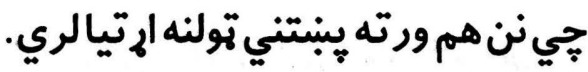

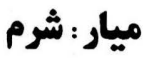

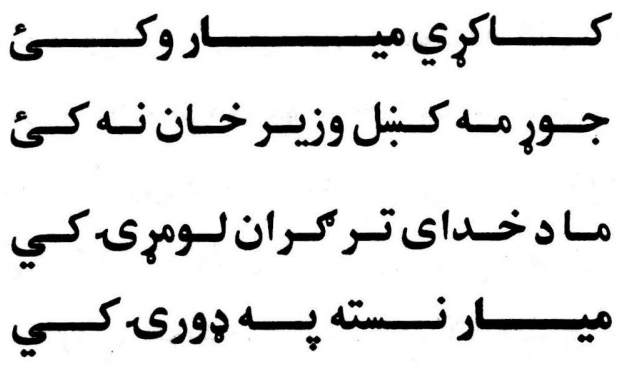

ورثكى : موز -لبوزى-ولنى

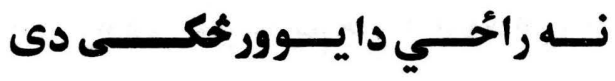

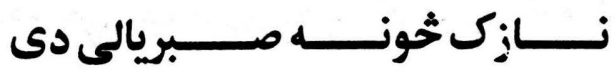

ترغئى - بثركى

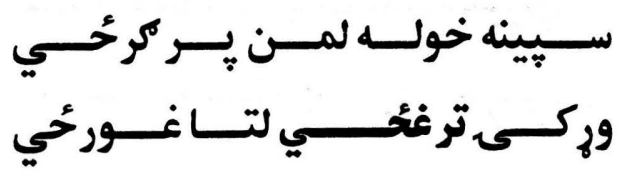

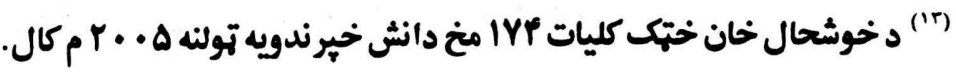




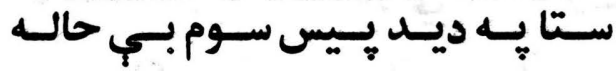

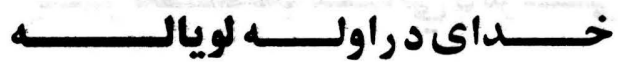

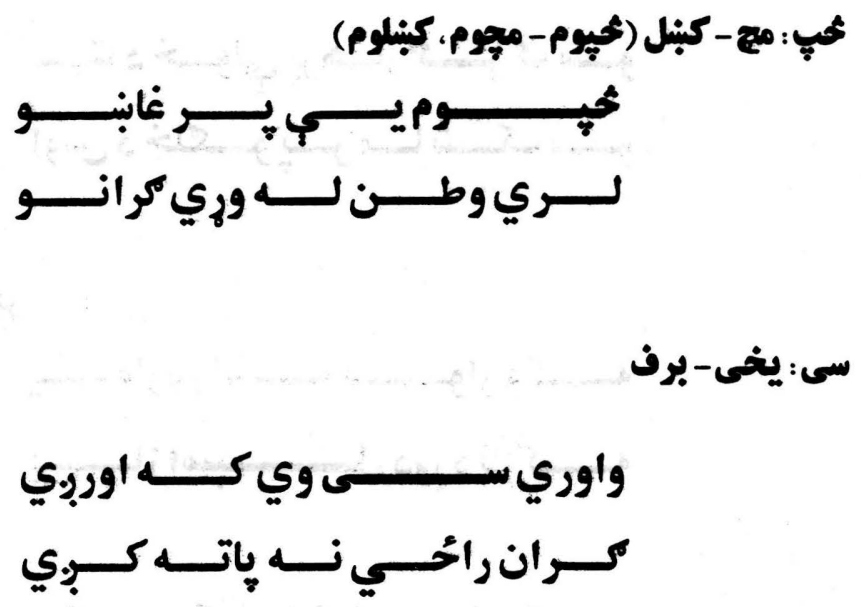

سوخ - قانع (سعُه مؤنث)

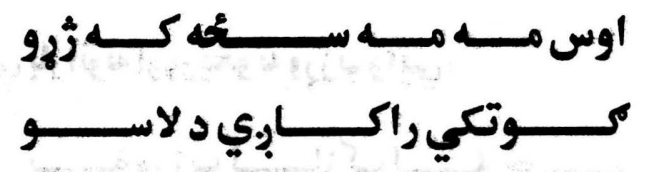

بنكومى : دوست

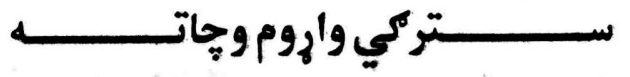

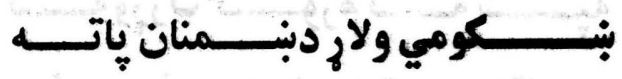




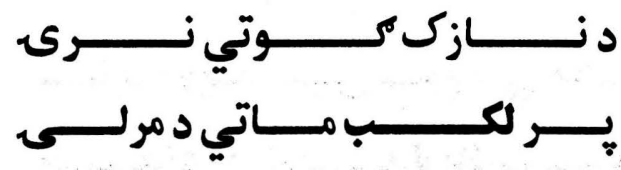

كزكى :خراب

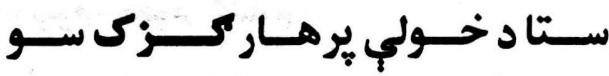

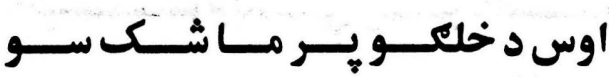

زامبـل : ستر بهج

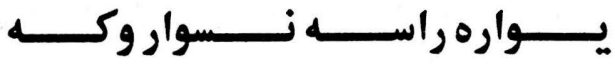

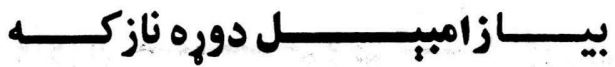

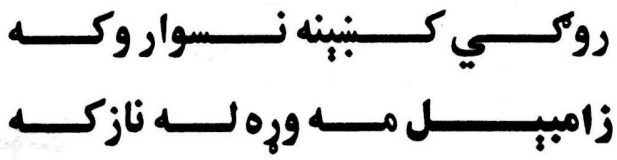

وززب : برله يسب بارانونه اووريغو تهوزبواييي:

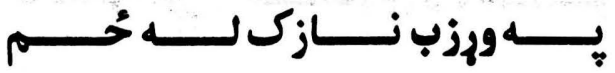

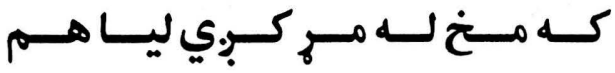

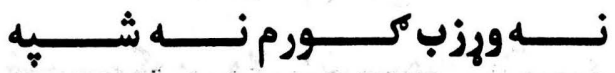

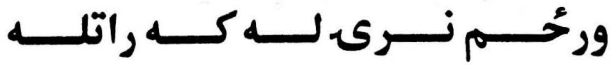


1.\%

كاكرى غاري

بي : عنر - يلمه

تـر مـاينومسـ حســان اسـترى كسئ

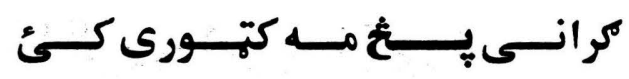

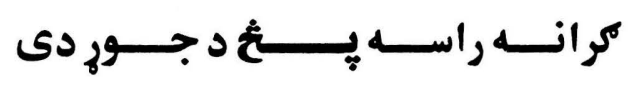

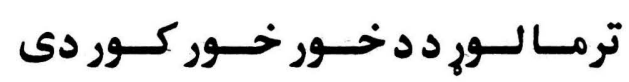

* * * 


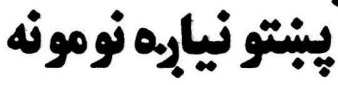

\section{يه كاكرى غارو كبني د}

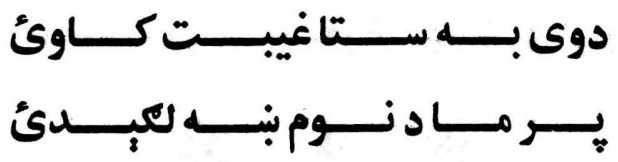

كاكرى غائي د يبنتّو اولسي ادب هُبره بلهايه او يراخه برخه ده زما

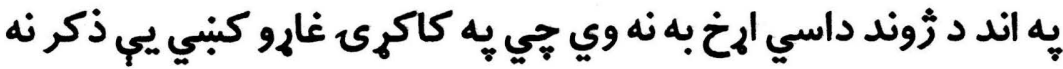

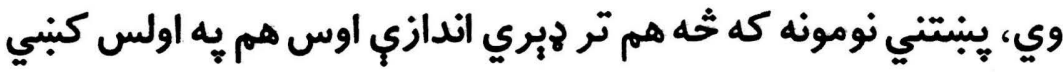

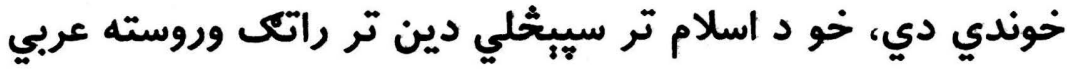

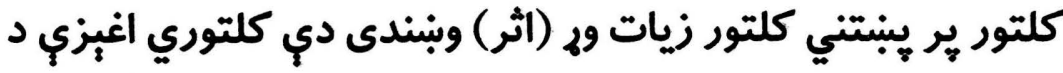

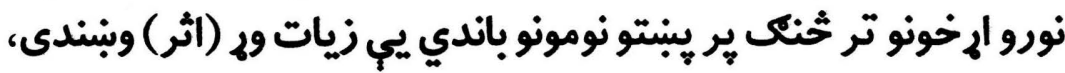

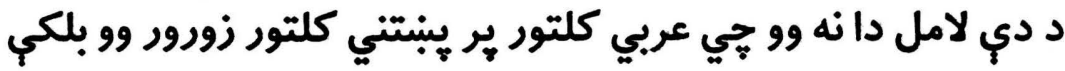

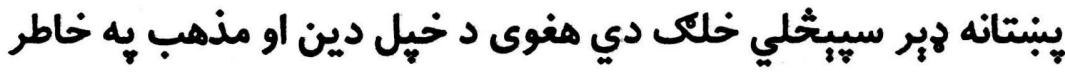

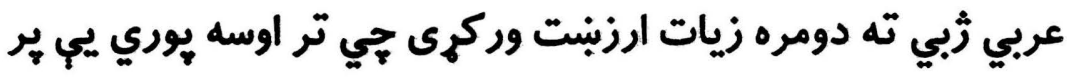

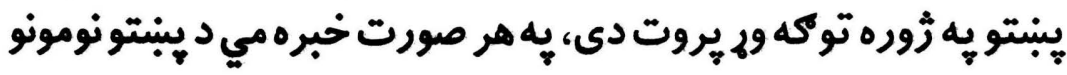

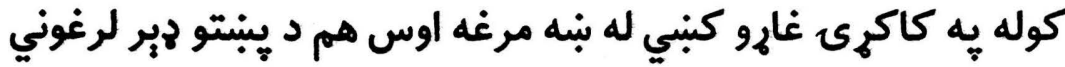
نومونه زوندي دي جي د يُبتني نومونو حُولى ورباندي ثخه نه ثريه هكيدلاى شي.

نو مونه : دنومونو تر تيب خخه يه دي جول دي،

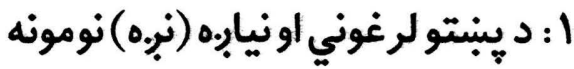




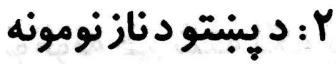

r : يه كاكرى غارو كبني ناخوبن (غندلي) نومونه

$$
\begin{aligned}
& \text { (1) د بينتو لرغوني اونياجبه (نب.ه) نومونه } \\
& \text { (Y) بنَحِينه نومونه }
\end{aligned}
$$

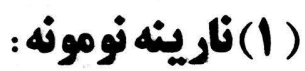

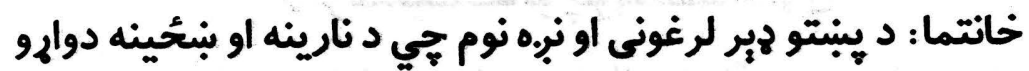
ليار بنول كير.ي او محاور تأد مغرور او مفروري لهياره كاريبري.

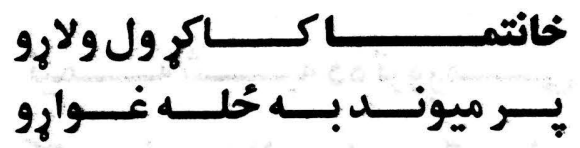

كنو : دنه نوم به بنبنو كي تر الوسه بوري رواج لري:

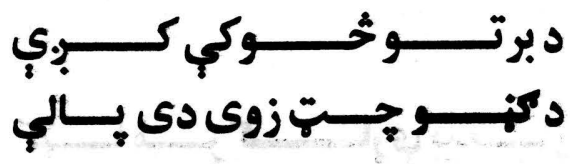

باله؟ :

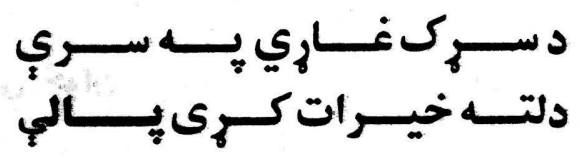

يالي د بنبتو بخوانى نوم دى دغه غاهـ و غازي بالي شاه ته

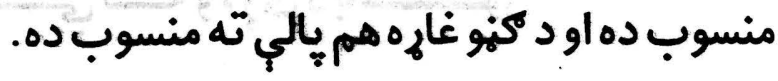


كاكرى غاري

يه دغه تر كيب كنبي د يبنتو نور نبره نومونه هم شته لكه بتتي،

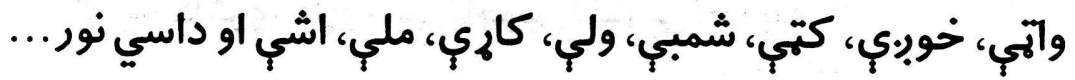

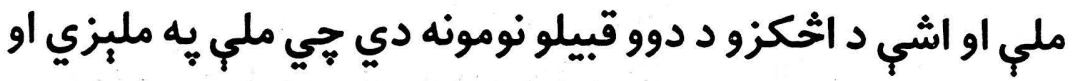
اشي يه اشبزي سره شهرت لري، يه اشي قبيله كبني مشهورو

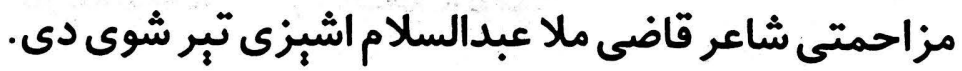

والتِي :

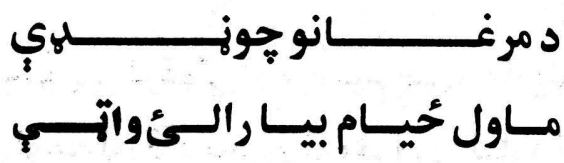

كت4:

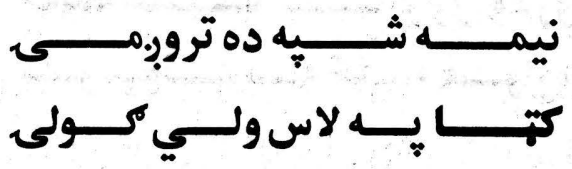

دغه فاره د يالب شاه و ورور كتّا ته منسوب ده،

كإُ

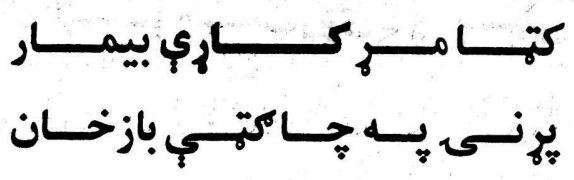

باسور : جِّ، غبنتلى، مُوان

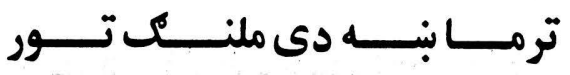

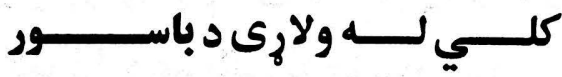




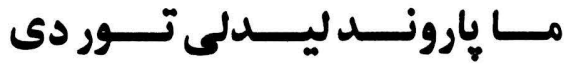

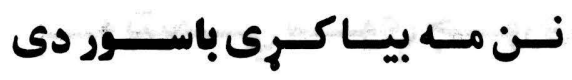

شال:

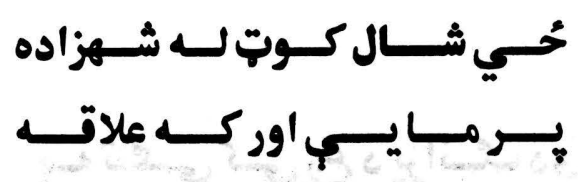

شال د بِبتتو لرغونى او نب.ه نوم دى د شال كلا هم و شال ته

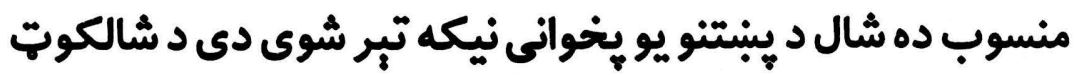
زوه نوم هم شال دى يه كوته كبني د شال دري او شال تنكي يه يه نامه سيمي شته يه سيمه كبني اوس هم د شال به نامه نومونه شته

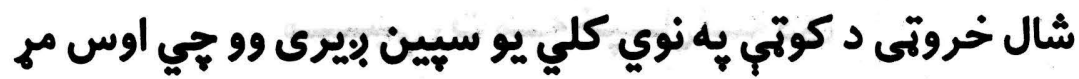

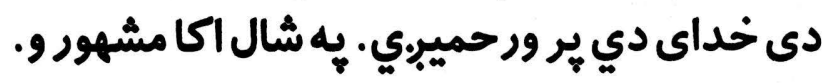
كجونى :كجن- نوار

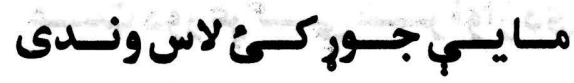

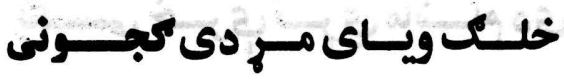

دغه غاره دمسه خيلو خيلو و كجوني ته منسوب ده. سمند:

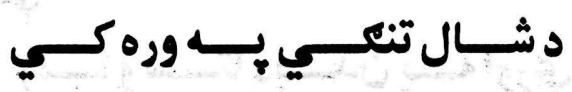

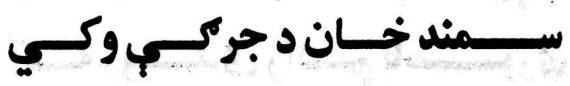


كاكرى غاري

- 1.1

:

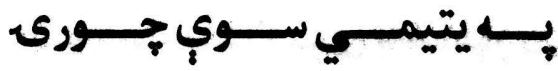

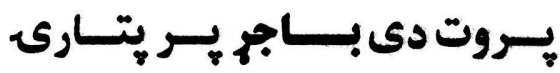

بايو :

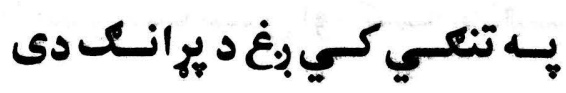

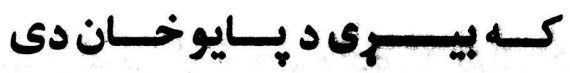

مبنهي:

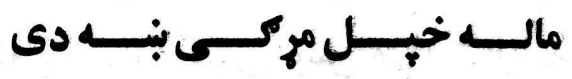

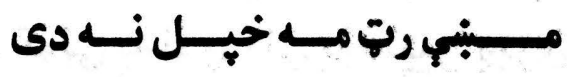

بكى:

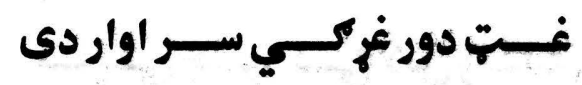

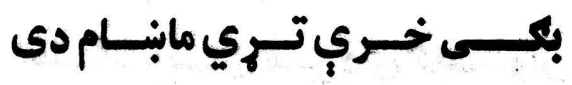

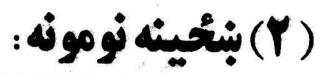

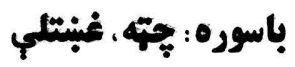

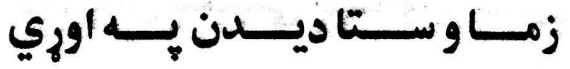

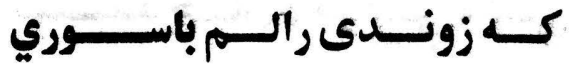



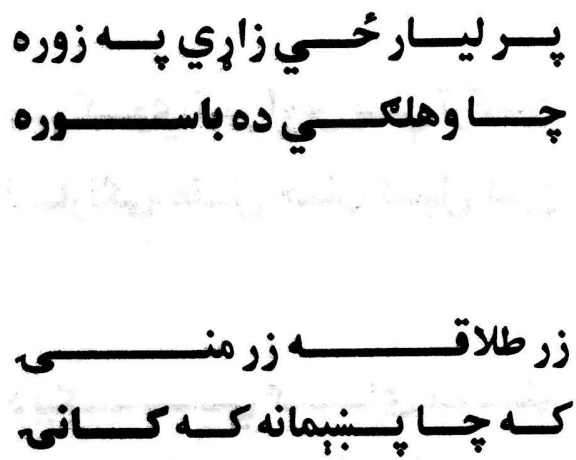

خانتما:

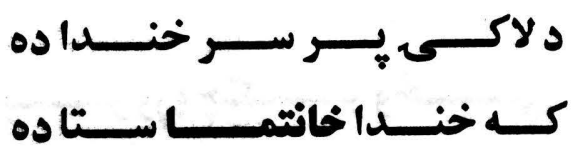

شكنه/ بنكه :

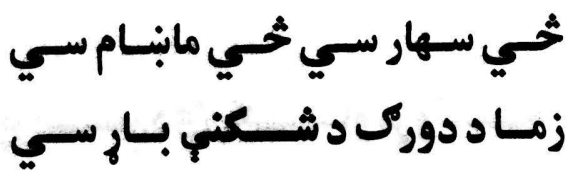

د جعفر قييلي زيوونوم شكون دى، مسه خيل اوس هم و جعفرو ته

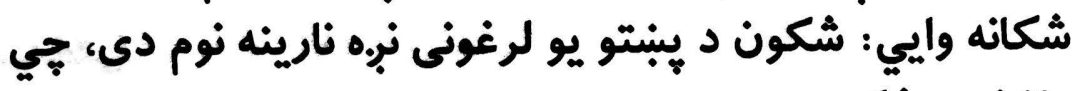
مؤنث تيب شكنه دهـ.

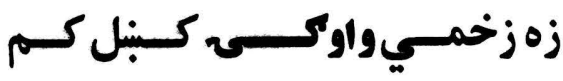

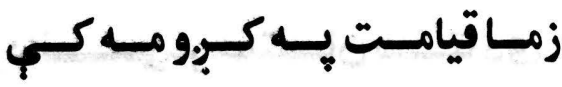

$$
\begin{aligned}
& \text { (كر.0 غاره) }
\end{aligned}
$$




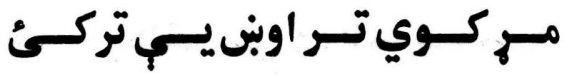

$$
\begin{aligned}
& \text { نسـارنكى عقـل خـان كـبل كسئ }
\end{aligned}
$$

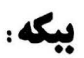
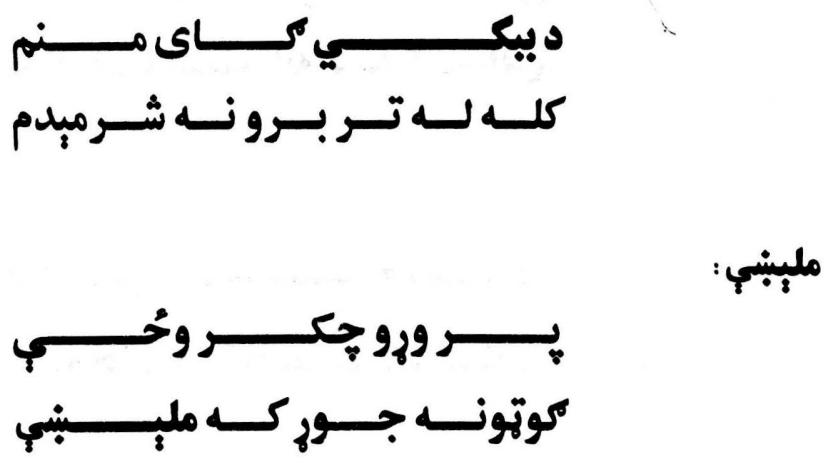

:

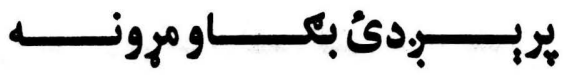

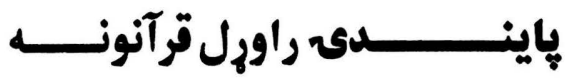

سيانثكحة:

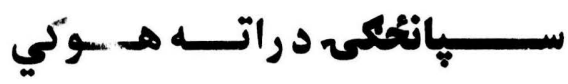

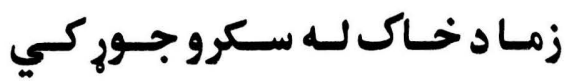

ودانـــــ رحمتـــان ســتادى

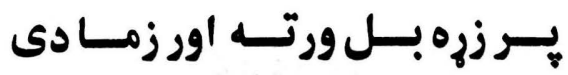


دحُحوانــــانوزره راســــور ســــوئ

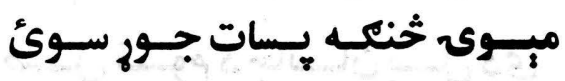

زرلبته :

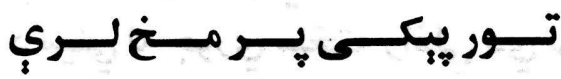

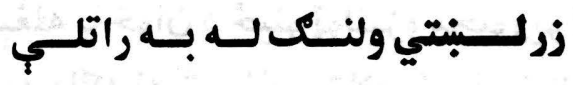

بارانى:

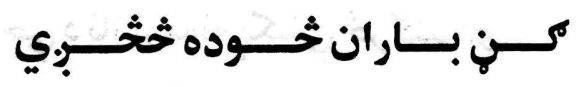

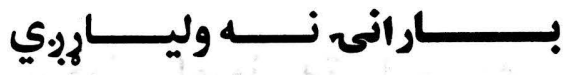

كلانه :

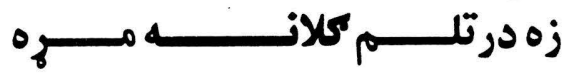

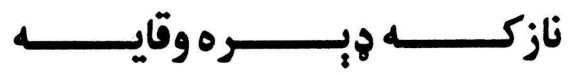

كل بغته :

تــاول نـــه بـــه ســي يــيس را

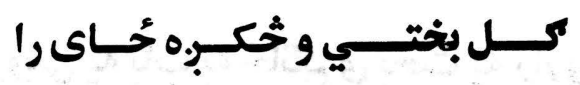

ميراجا:

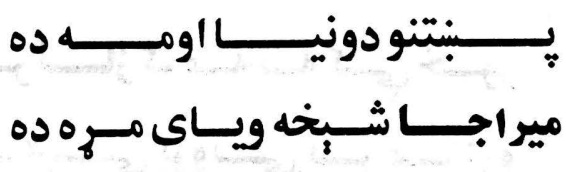


كاكرى غاري

\section{دناز نومونه}

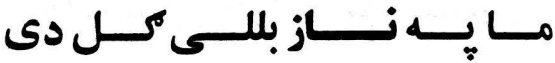 \\ اصــل نــــوم د جانـــان بـــل دى}

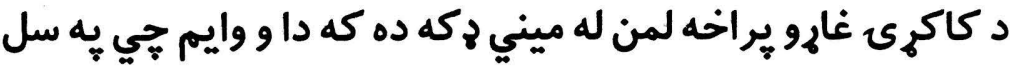

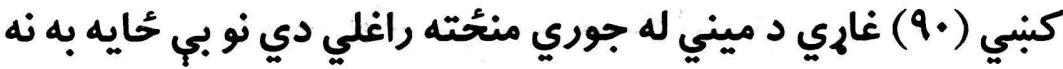

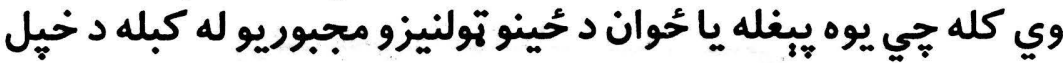

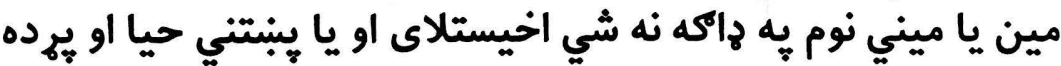

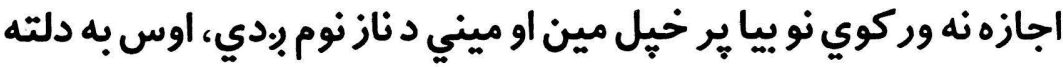

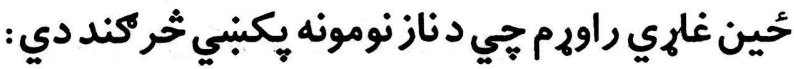
سروبن:

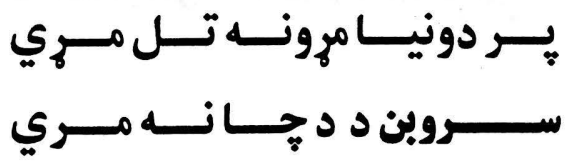

سروبنه :

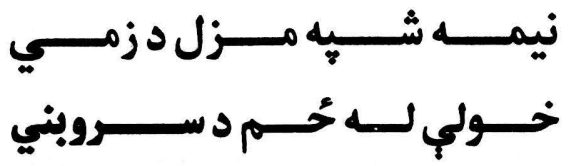

د سروبن او سروبني يه باب به حُانكرى بحث يه راروانو يانو كبني

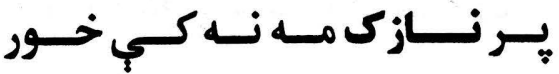

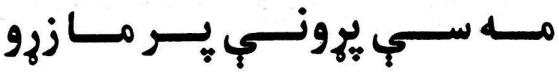




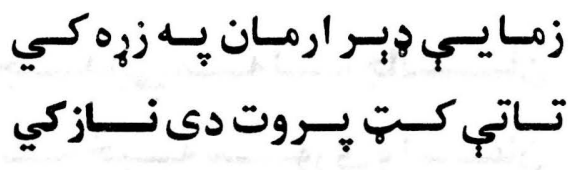

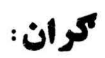

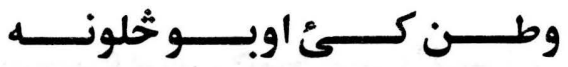

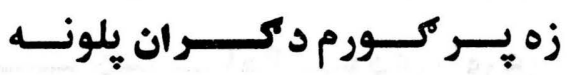

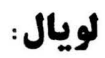

سـتا يـه ديــ يـيس سـوم بـي حالـه

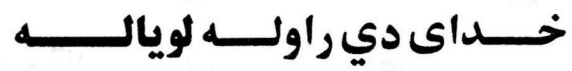

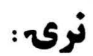

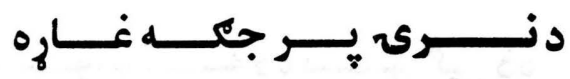

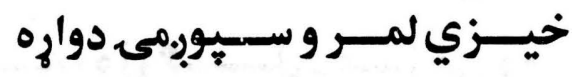

ليؤون :

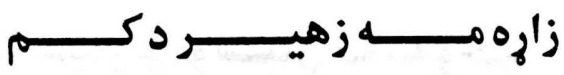

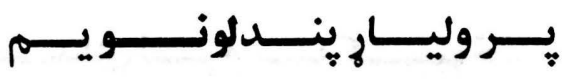

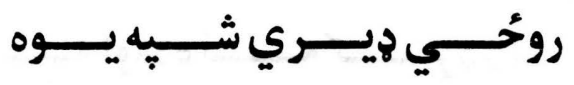

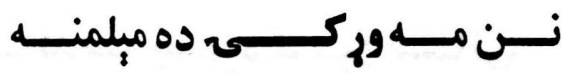




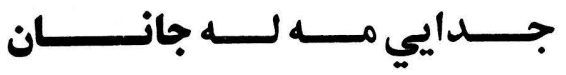

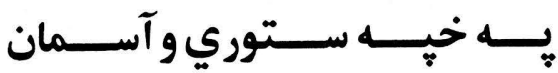

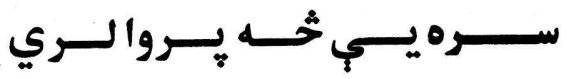

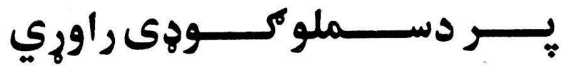

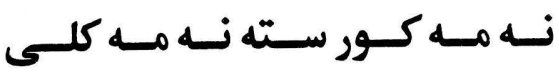

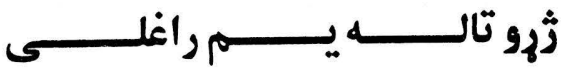

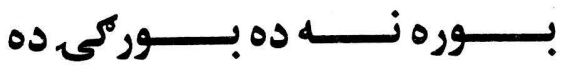

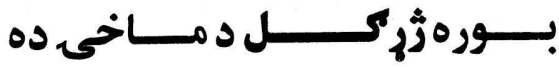

سيين:

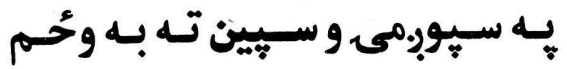

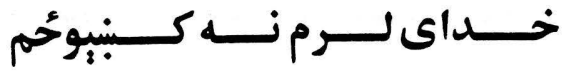

شين خالى :

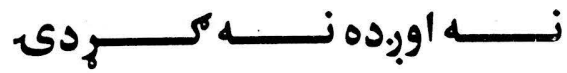

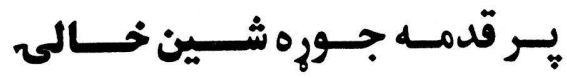


110

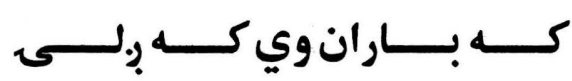

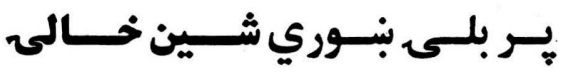

تورنى:

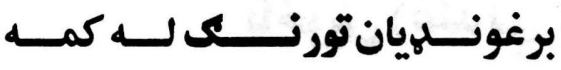

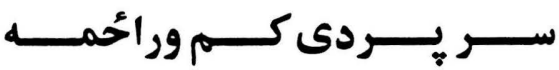

ككر :

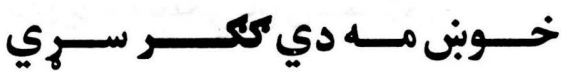

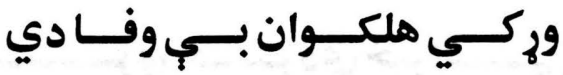

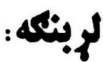

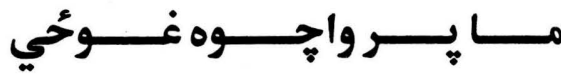

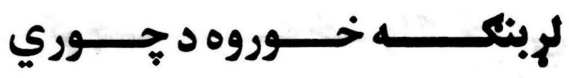

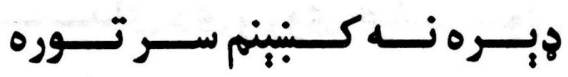

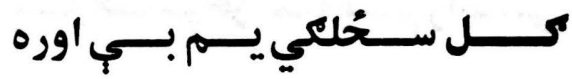

\& \& \& 


\section{بإكاكرى غاروكبني}

\section{ناخوبن (غندلي) نومونه}

يه كاكرى غارو كنبي كهو ويوي خواته دنازنومونه شته لهبله يلوهيياداسي

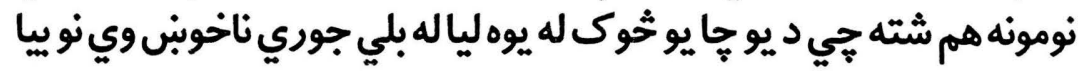

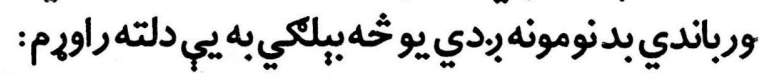
بنوور:
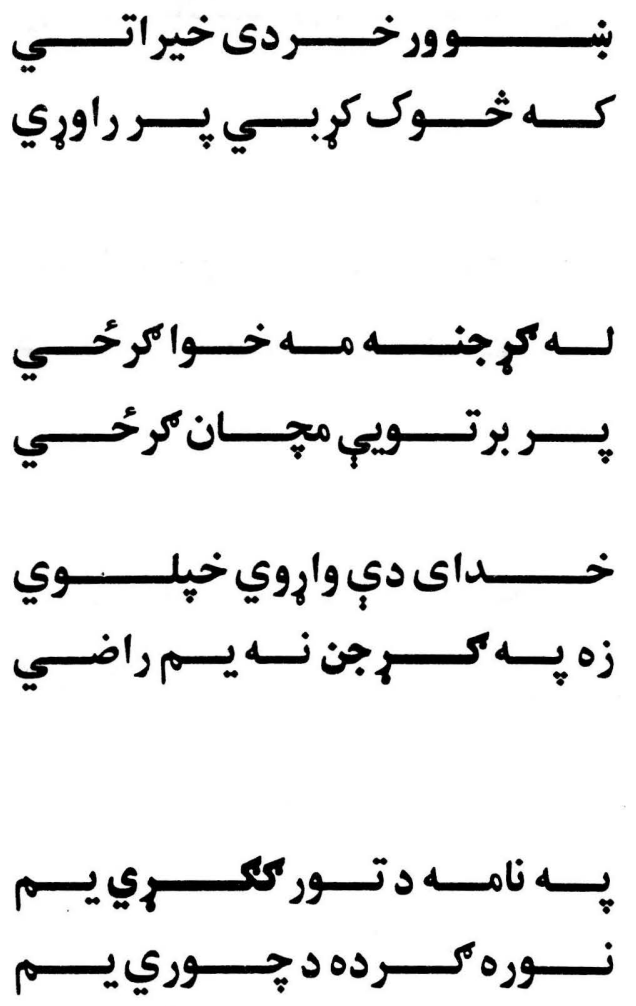


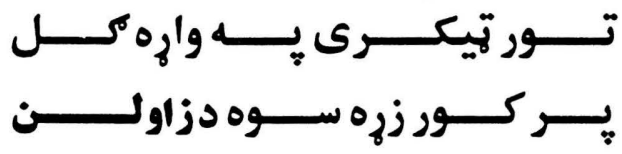

سنٌْن:

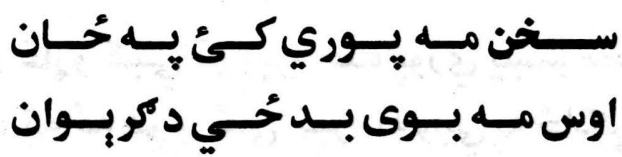

ही है। ही 


\section{به كاكرى غارو كبني محاوري}

يه كاكري غاجرو كبني تر هُبره حده يوري يبنتو محاوري هم ليدل

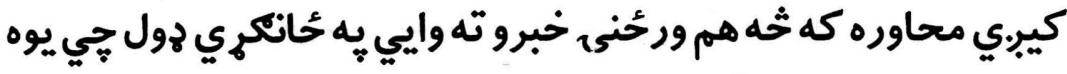

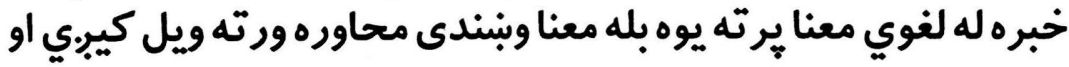

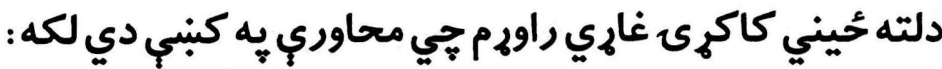

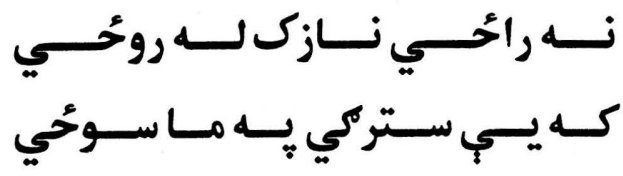

يه دي غاره كبني دوي محاوري راغلي دي:

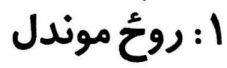

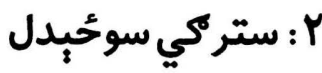

يه يورتنى كاكرى غاره كي يوه يُغله وايي جي نازى له دي جوري

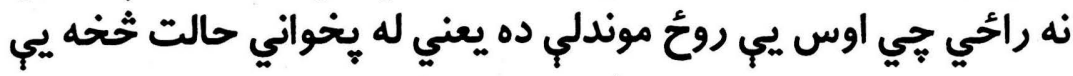

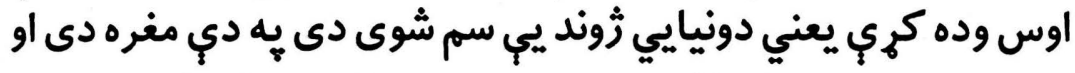

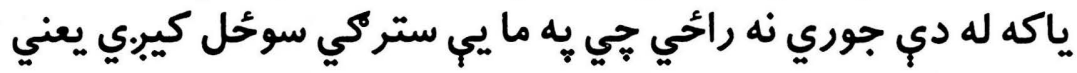

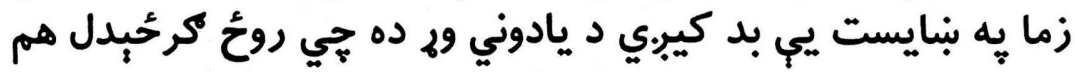
محاوره شته، 
119 كاكرى غاري.

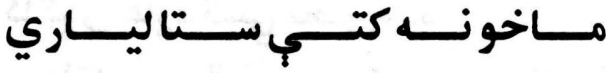

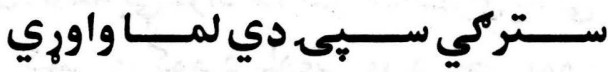

ا ، سبح ستركي : وري ستركي ، روكي (روي) ستركي.

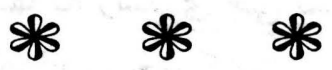

كاكرى غاره:

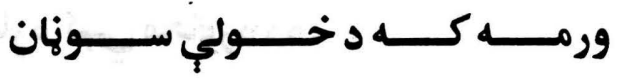

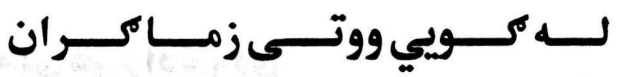

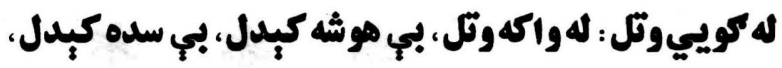
楼 米

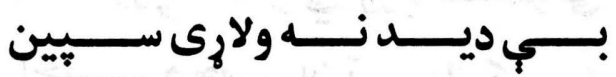

نــه خـــورم هودوى زهره مــه دى شـــين

شينزرى : زهير يا غمجنزه،

\& \&s \&

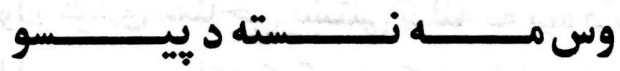

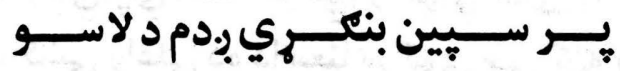

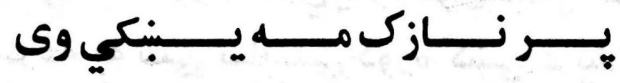

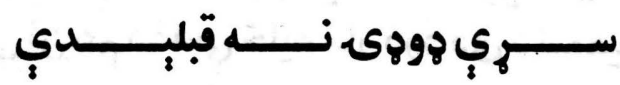

\& \& \& 
كاكرى غاري

$$
\text { يه لومرى كاكرى غاره كنبي محاوره دهه: }
$$

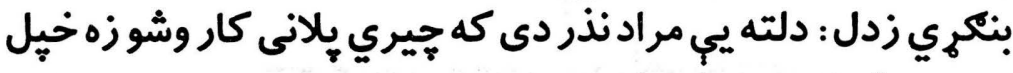

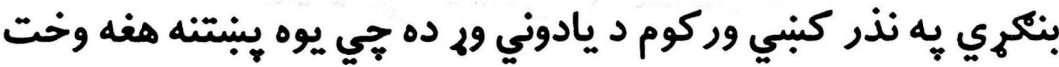

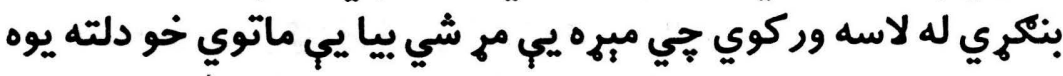

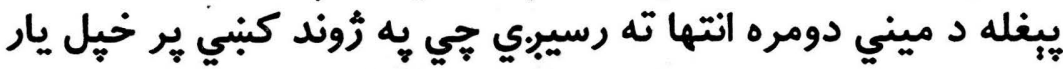
بنكري بـدي كه جيري خداى ور جور كرئ.

يه دويمه غاره كبني محاوره ده:

هوجى ب.د.دل : دلته يب هم مر اد نذر دى:

\& s s

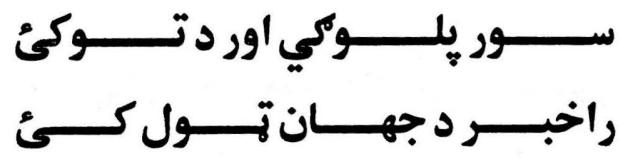

يه غاره كنبي محاوره دهه:

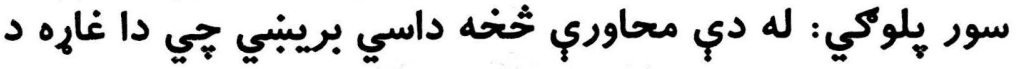

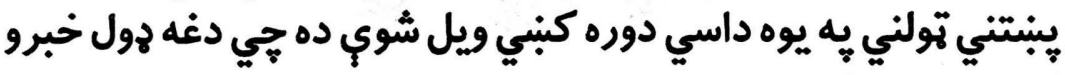

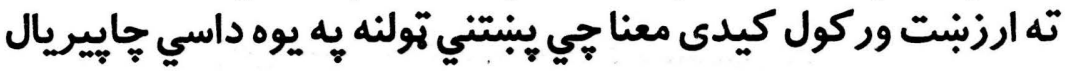

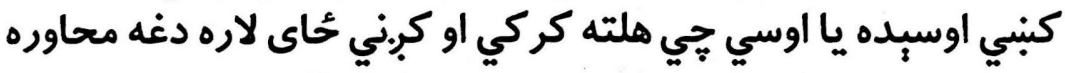

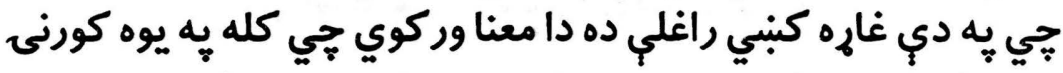

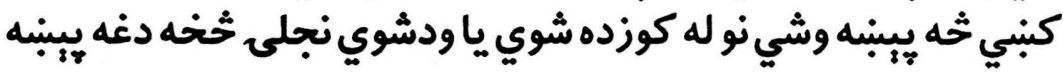

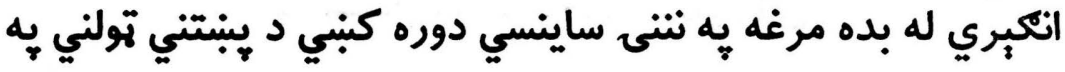

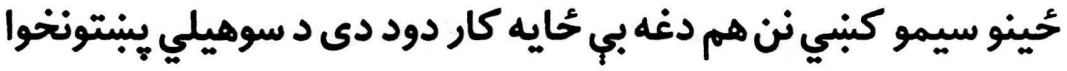
لوميرى ناول "وجه لبنته" هم دغه موضوع ينه ديه لمن كنبي رانغاري. 
$|r|$

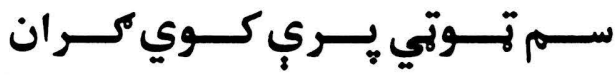

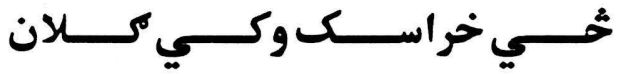

توتي بيري كول : به شرمي كول، بي حايه حركت كول : * *s

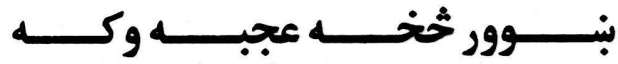

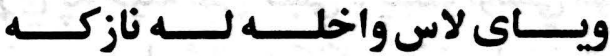

لاس اخيستل : مان محيني لولي كول، د بهز ارى ثركندونه :

* *s

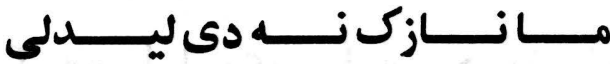

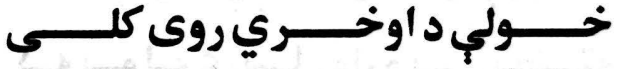

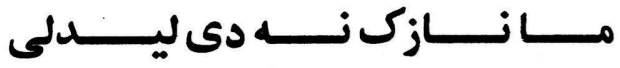

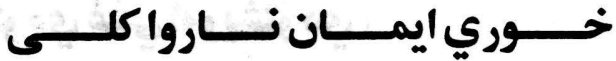

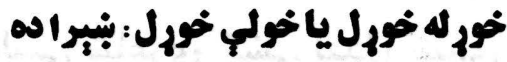

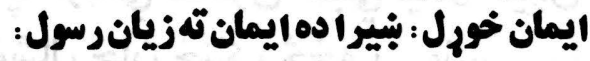

*s os

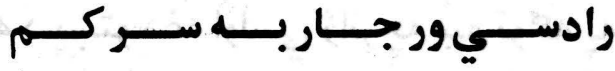

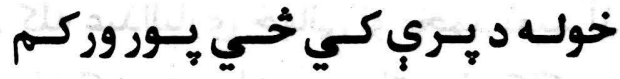

خوله بري كول : ير يوه بني بيوري.دل يعني يور تاكل.

* * *s 
كاكرى غاري

\section{يه كاكرى غارو كبني مثلونه}

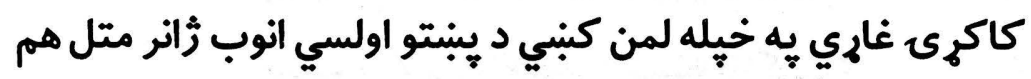

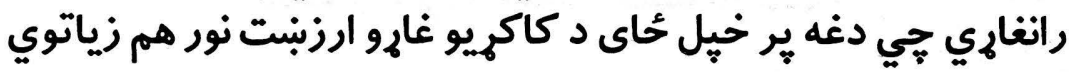

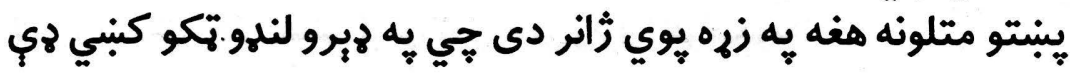
زور مفهوم رانغاري لكه دا دوه متلونه :

$$
\begin{aligned}
& \text { كسه سـلـلــري سـل ســره يوبنــته }
\end{aligned}
$$

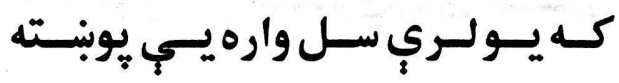

\section{(توري له كتو دي غشي له ويشتو دي)}

يبنتو متلونه يوائي دا جِي يه اولسي شاعرى كبني ليدل كيبري

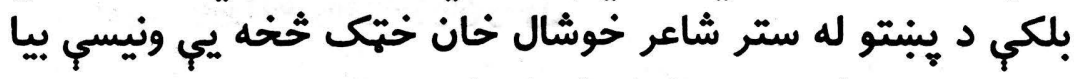

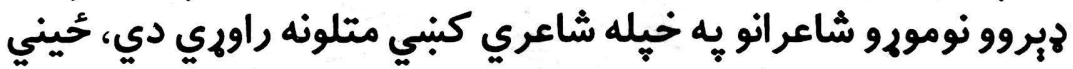

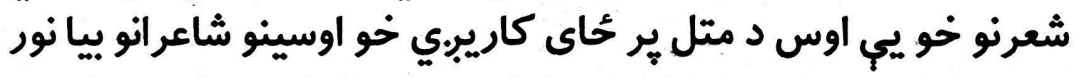

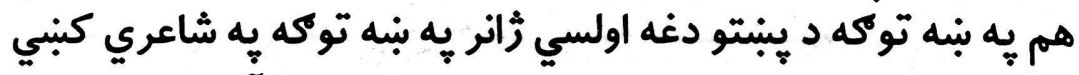

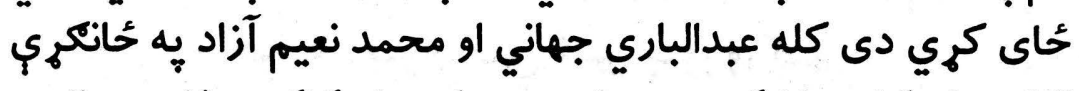

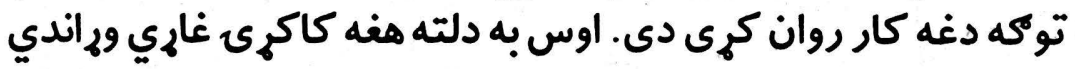

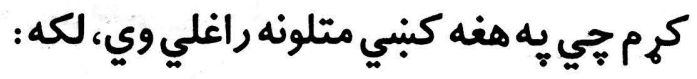




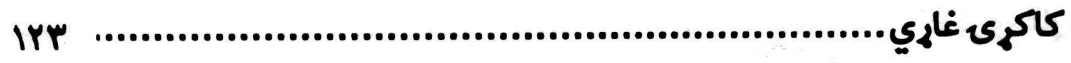

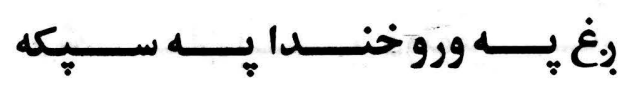

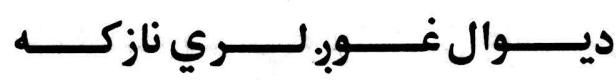

$$
\text { (ديوال هم غوبرونه لري) }
$$

* * *

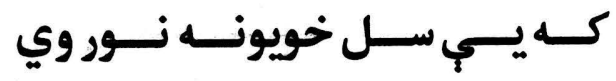

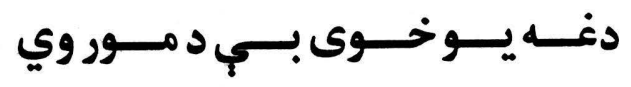

(دغه بشيره غاره د متل ير حُاى كاريبري)

* * * *

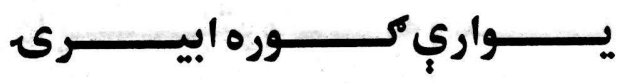

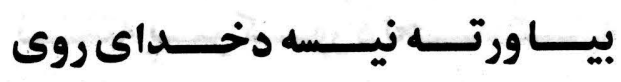

(دلته هم يه بشهره توكه غاحه د متل به توكه كاريبري)

*s *s

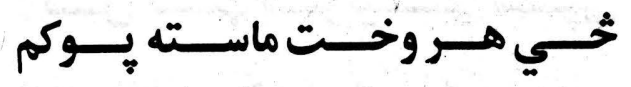

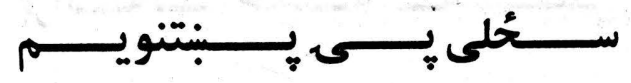

(شيدو سوخلى مستي يوكي)

* os 
كاكرى غاري

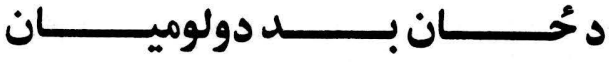

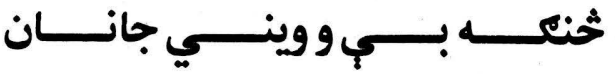

$$
\begin{aligned}
& \text { (خيل عمل د ولي ميـان - د بـل عمل د كلي ميـان) }
\end{aligned}
$$

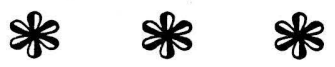

$$
\begin{aligned}
& \text { ي }
\end{aligned}
$$

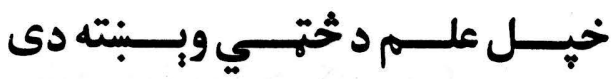

$$
\begin{aligned}
& \text { \& \& \& }
\end{aligned}
$$

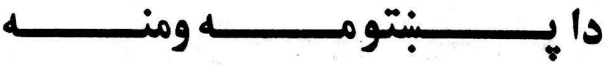

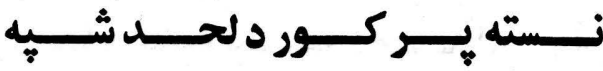

$$
\begin{aligned}
& \text { (دكور شيهنه ير كور كيري) } \\
& \text { है है? है? }
\end{aligned}
$$

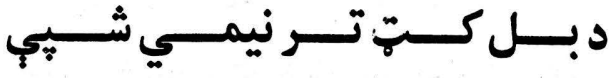

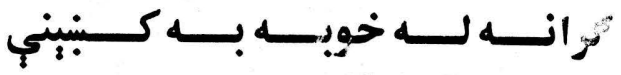

$$
\begin{aligned}
& \text { (د بل كت تر نيمو شيو دى) } \\
& \text { \& \&s }
\end{aligned}
$$




\section{כ س}

\section{يه كاكرى غازيو كبني}

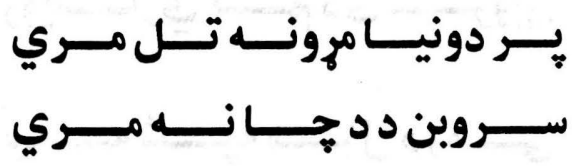

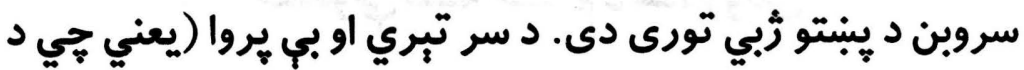

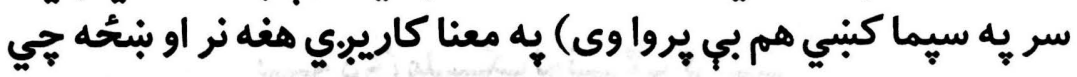
هغو ى له ننكيالتوب، غنبتلتوب، مير اني او نور بنه خويونو يونو خبنتن وي هغوى ته سروبن او سروبنه وائي، يه حُينو كايو كبني دغه نوم د هغه جا إلياره كاريب.ي جي هغه سر تبر وي. سروبن يا سروبنه هغه د ناز او له وياحه هكه نومونه دي جي د كاكرى غارو لمن ورباندي بنكلب ده يه كاكرى غارو كبني سروبن او سروبنه بيخي زياته خوندي ده، لكه :
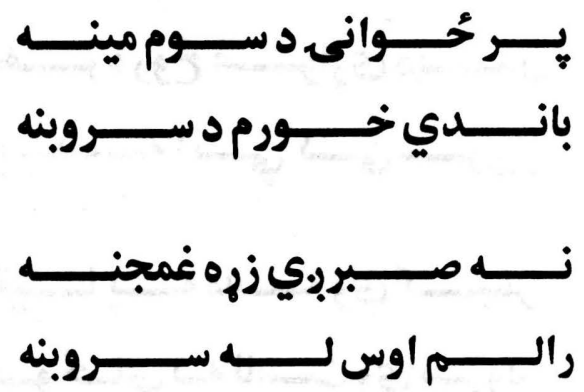

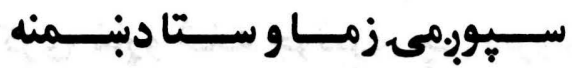

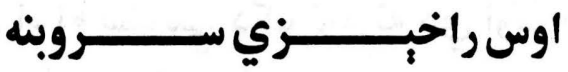


كاكرى غاري

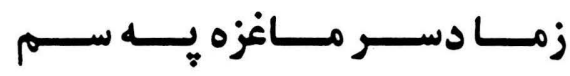

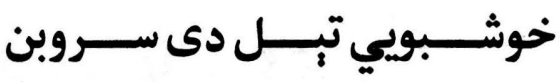

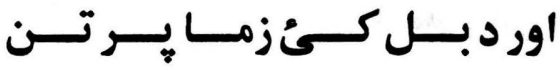

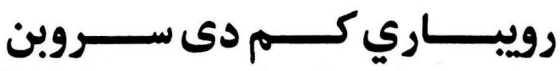

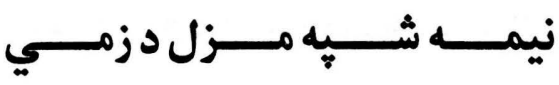

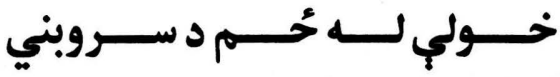

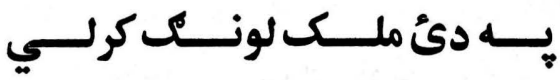

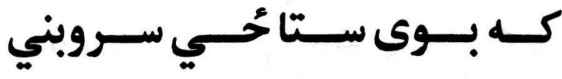

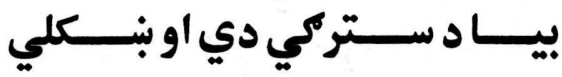

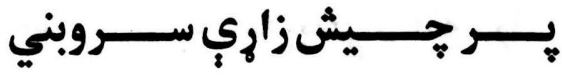

هـــــــــرورُخ غــــــواري ديــــــن

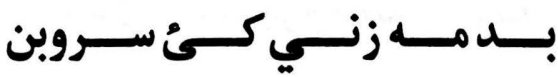

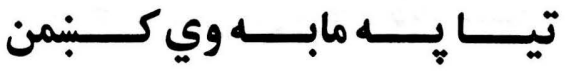

يسـوحـــاى بــه ناسـت وي ســروبن

له يورتنيو كاكرى غارو ثخهه جوتيربي جي سروبن او سروبنه د

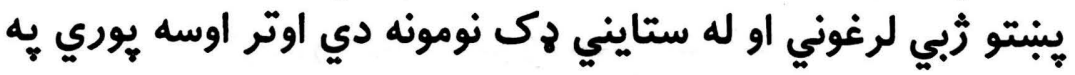

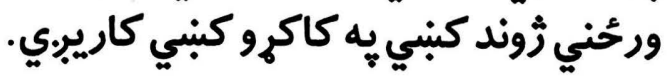


دَّبوور غندنه

\section{يه كاكرى فارو كبني}

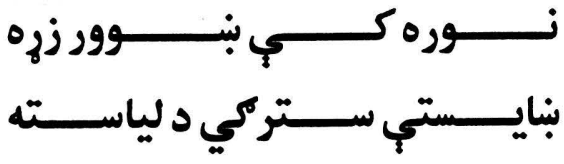

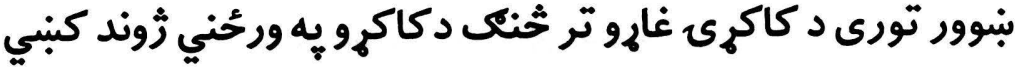

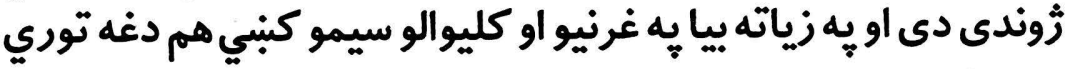

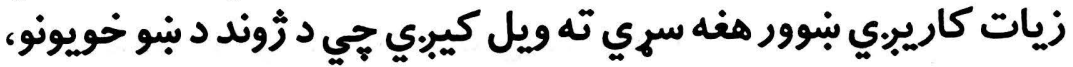

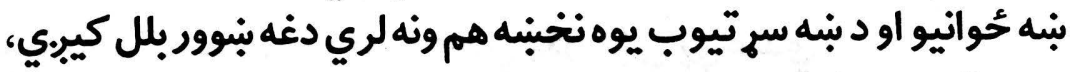

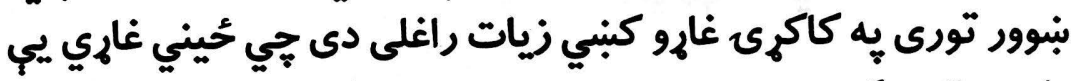

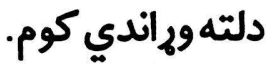

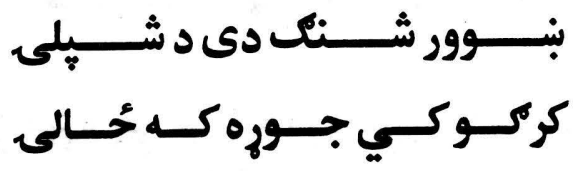

يه دي كاكرى غاره كبني يبي د بنوور تشبيه د شنك له وني سره

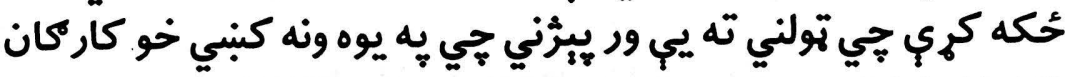

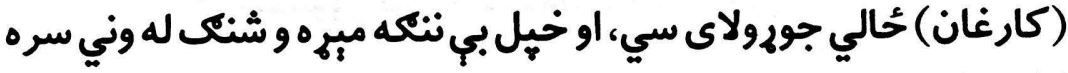

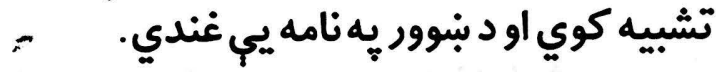

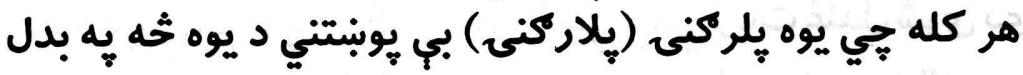

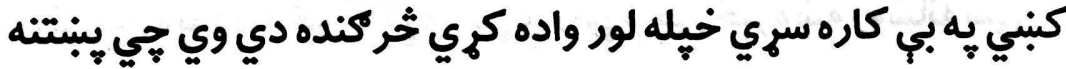


كاكرى غاري

IYA

يخله جي يه هر هول بي كاره او بي بنبي سري ته واده كري نو نو ينبتني

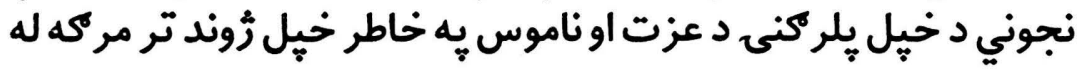

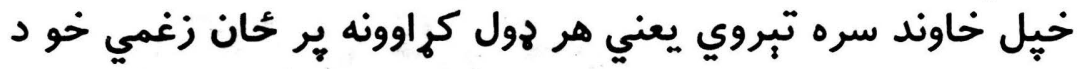

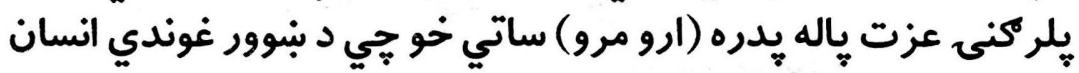

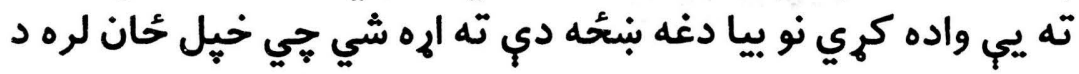

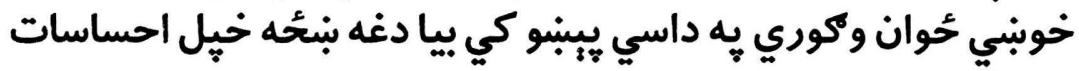

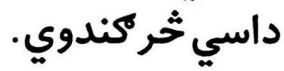

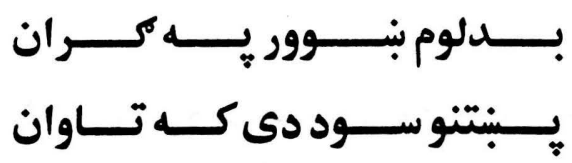

او كله بيا يبنتني د بنوور غوندي مبره خخخه دومره تنكي سي جي د

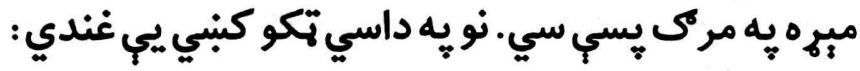

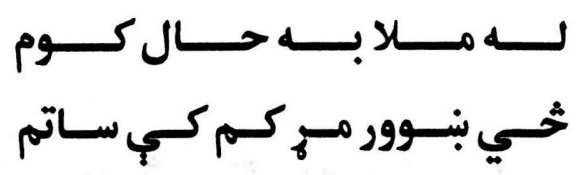

د بنوور غوندي مِهره جي بيا كله مره شي، نو دمبرمني يبي د خاورو

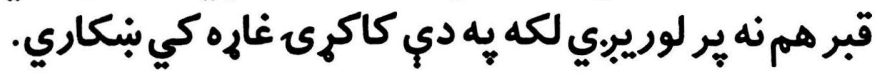

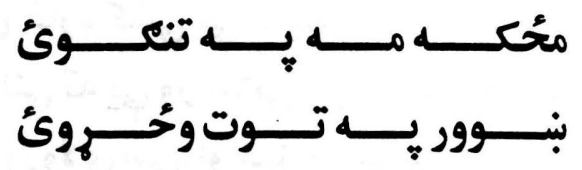

لنهه داجي بنوور يه كاكر يو غارو كبني بيني زيات غندل شُوى دى

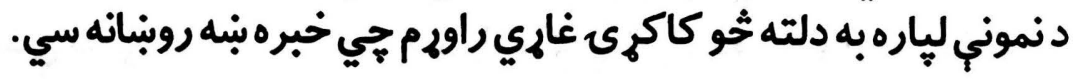




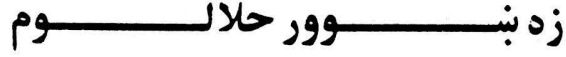

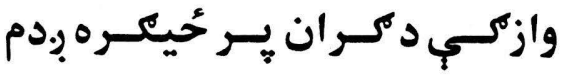

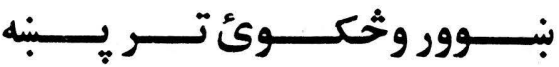

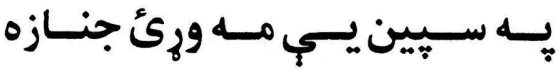

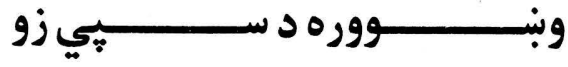

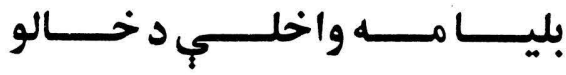

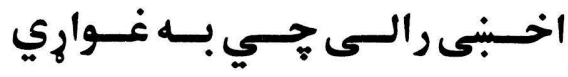

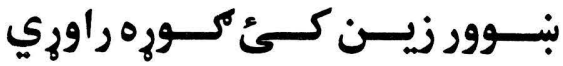

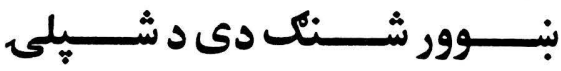

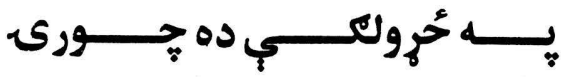

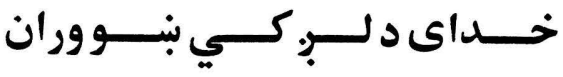

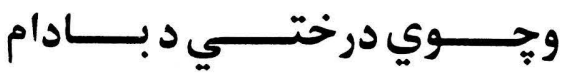

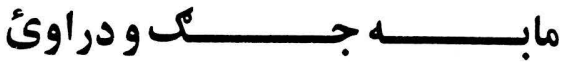

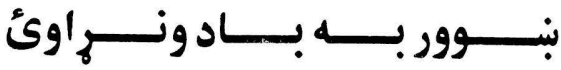


كاكرى غاري

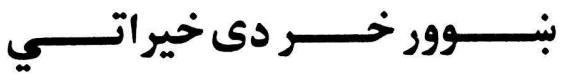

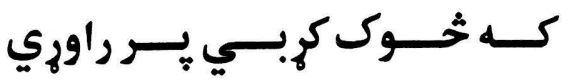

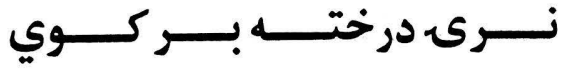

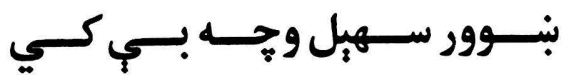

$$
\begin{aligned}
& \text { * \& }
\end{aligned}
$$




\section{ن خ مراسان ثورى}

\section{يه كاكرى فارو كبني}

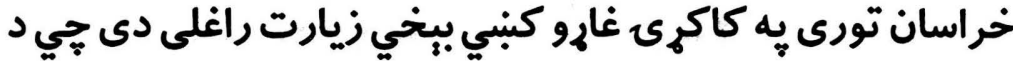

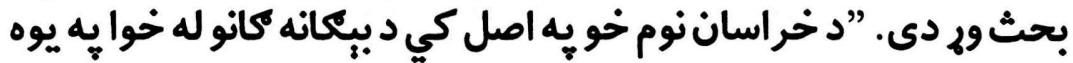

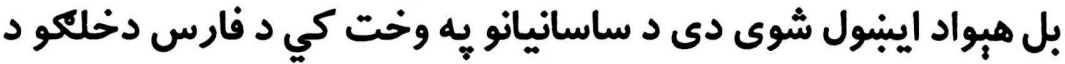

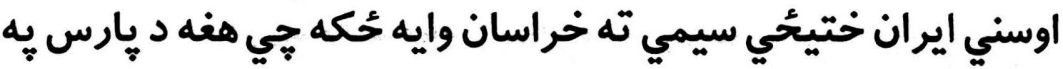

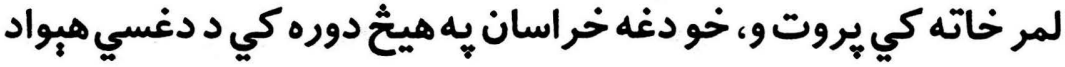

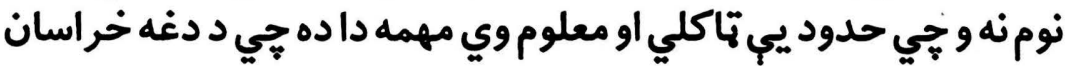

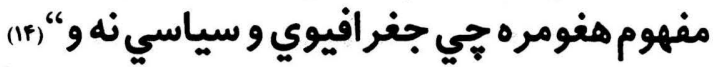

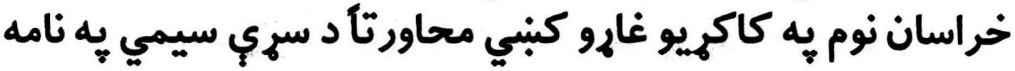

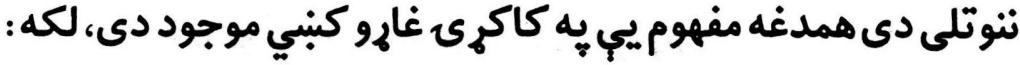

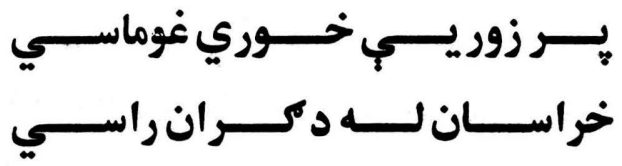

داغاره د غوخكى خلك داسي وايي:

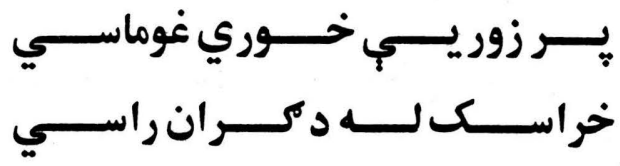

(1) زما غوره ليكني يوهاند هاكتر حسن كاكر 199 مخ د افغانستان د كلتوري ودي تولنه جاب • • ب ب مكال. 
كاكرى غاري

Irr

كاكران و كرمو سيمو ته زور (ثُور) وايي جي هيه يبنتو كبني دامان

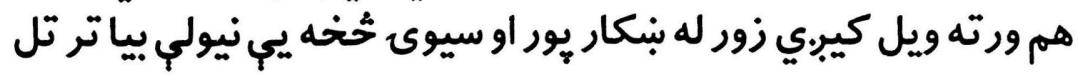

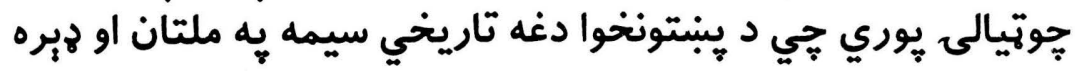

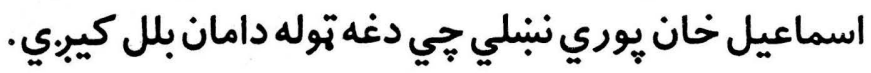

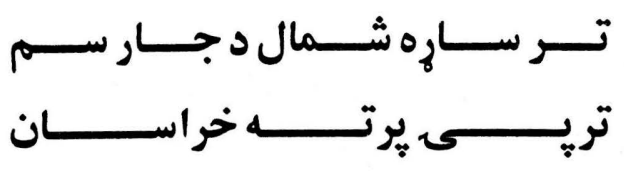

يعني تر سنحاوى ور لوهه سيمه جي يه يَ سره شهرت لري سره سيمه بلل كير.ي.

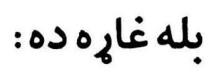

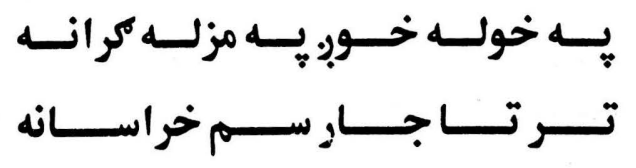

كله جي يبنتانه يونده به كرميو كبني د سري سيمو يه لور كهي

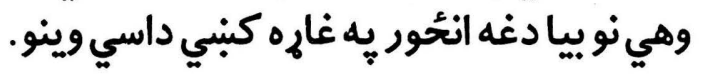

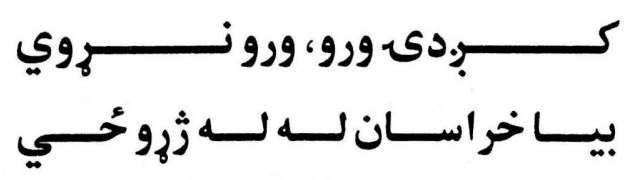

د زور (دامان) د كرمى حالت يو حُوان د كلهو د روانبدو يُ مهال يه غاره كنبي داسي انُّوري، 


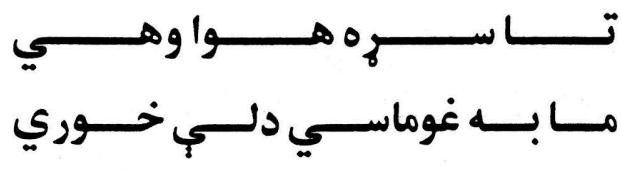

خيله مينه يبي بيا داسي مثبت حواب وركوي:

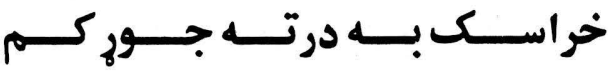

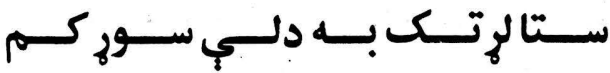

لرتك جي د له لي معنا وركوي خو دلته يه غاره كبني محاورتاً د

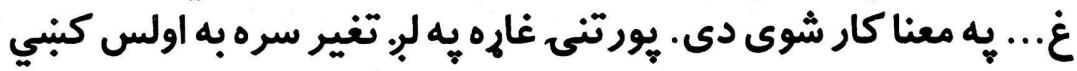

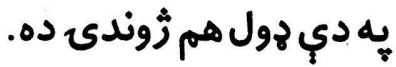

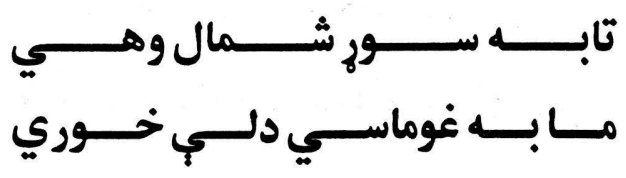

لكه وراندي جي مي و ويل جي كاكران و سري سيمي ته خراسان

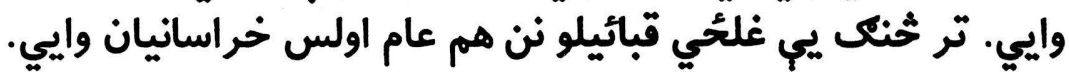

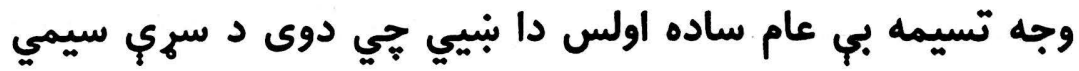

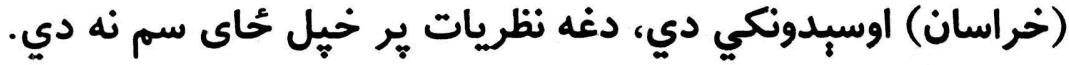

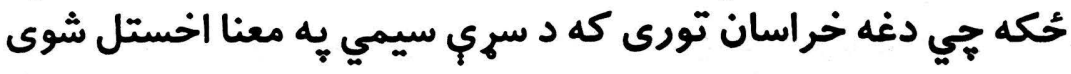

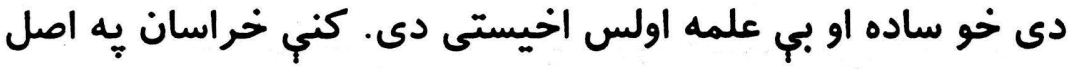

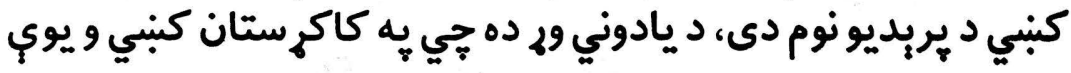

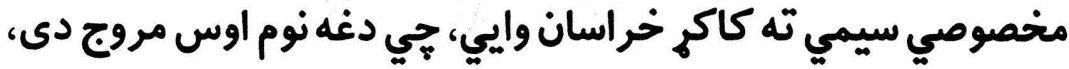

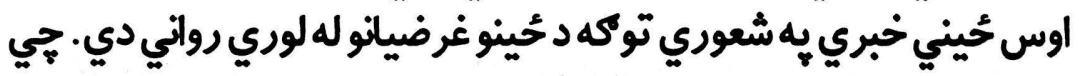

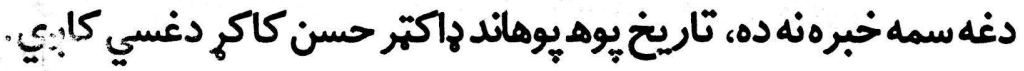


كاكرى غاري

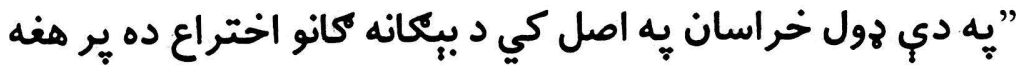

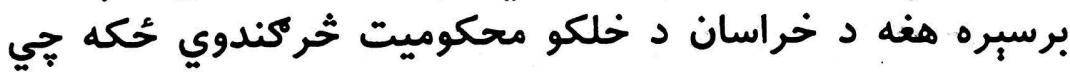

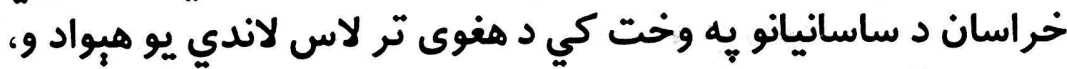

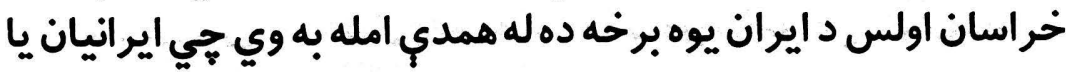

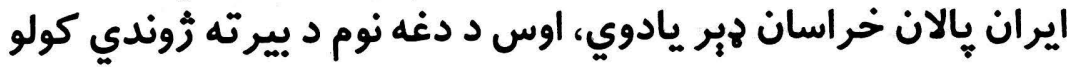

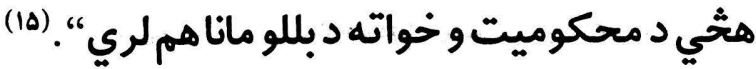

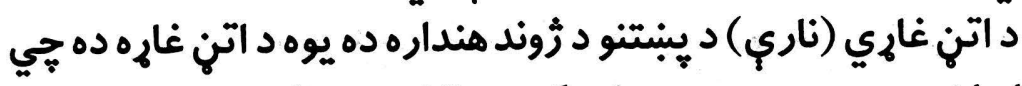

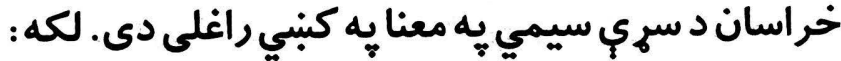

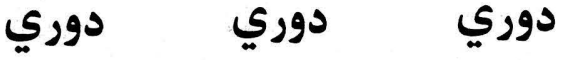

$$
\begin{aligned}
& \text { مـردك لكـهـ بـاران رابانـدي اوري }
\end{aligned}
$$

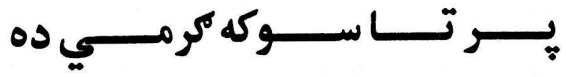

$$
\begin{aligned}
& \text { ير مور.ه خراسان دى واوري اوري }
\end{aligned}
$$

اوس به دلته حُيني كاكرى غاري راورم جي د سري سيمي پِه معنا خراسان توري يه كبني راغلى دى.

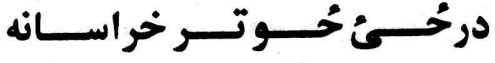

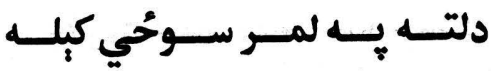

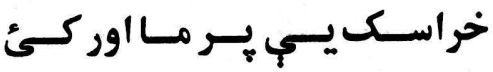

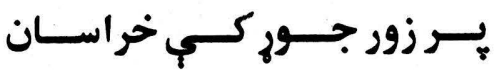

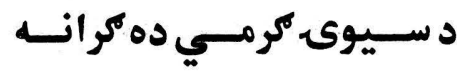

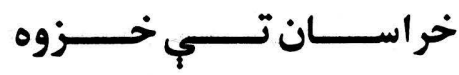
وركس راله غسميسي جـورئي

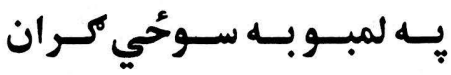

\section{* * *}

(10) زما غوره ليكني يوهاند حسن كاكي 199 مخ د افنانستان د كلتوري ودي تولنه جاب

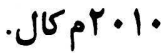




\section{كاكرى فاري}

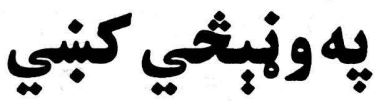

ماركنسترائن جوزف ايلفنبائن، علامه عبدالحى حبيبي، عمر كل

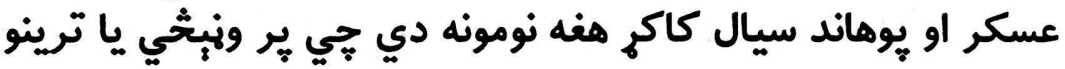

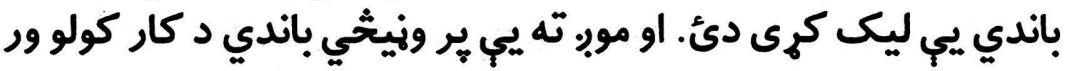

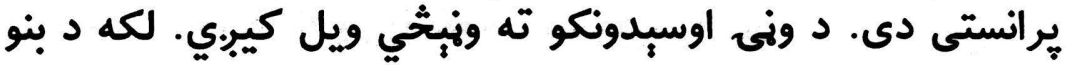

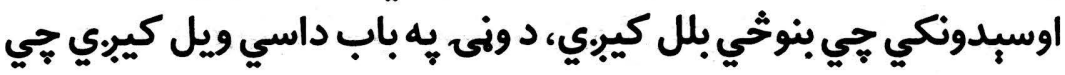

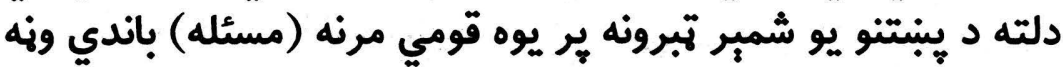

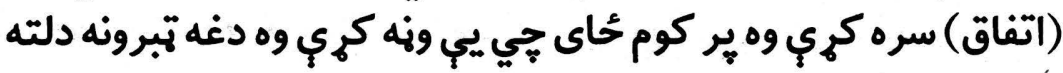

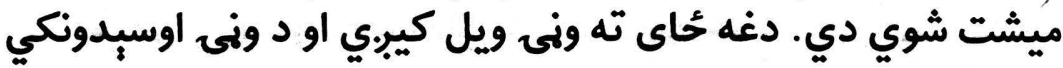

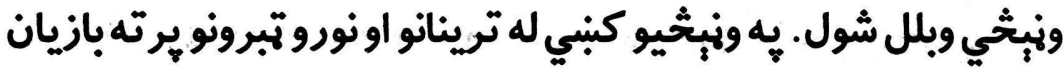

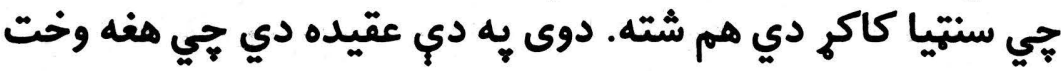

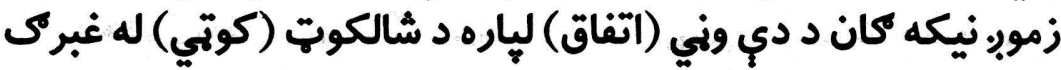

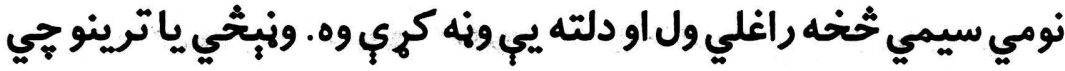

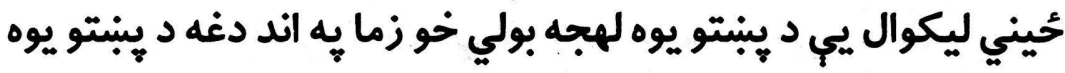

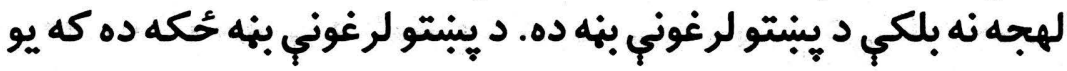

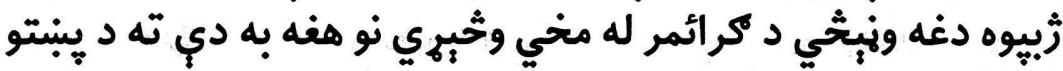

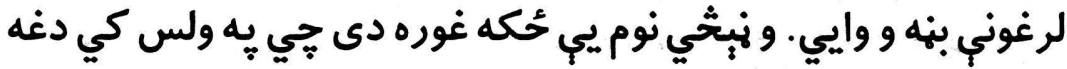

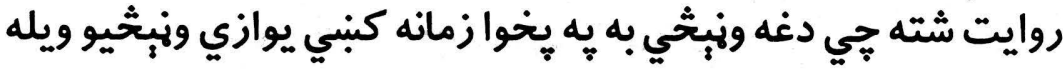

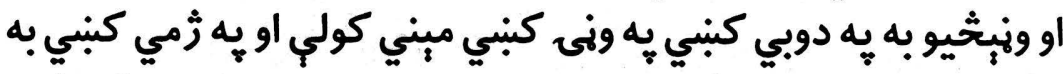

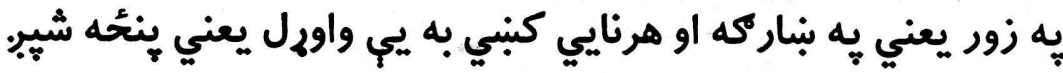

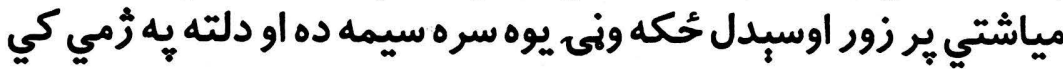


كاكرى غاري

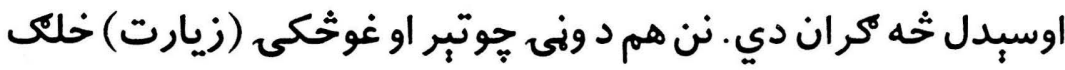

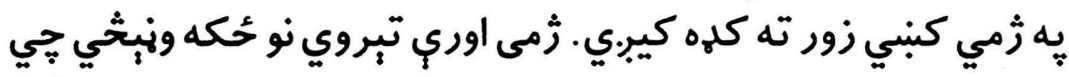

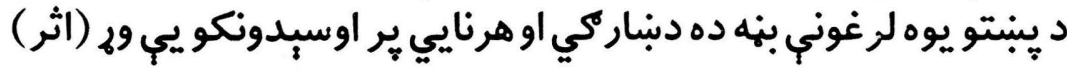

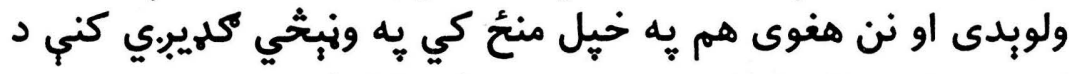

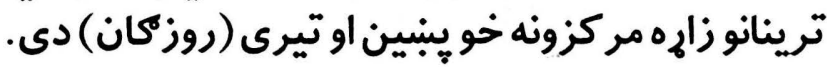

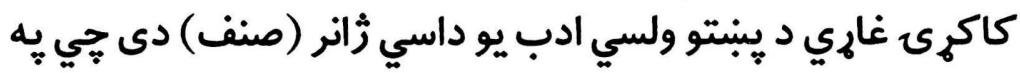

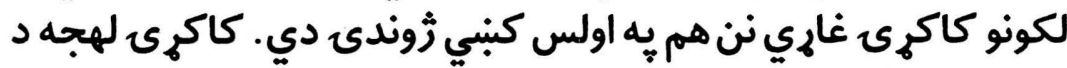

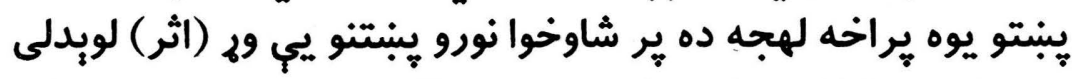

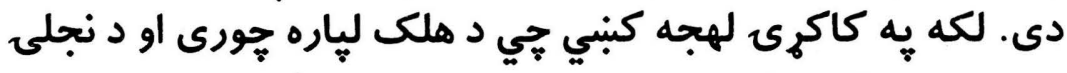

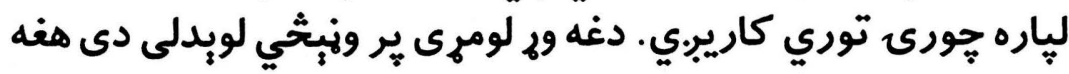

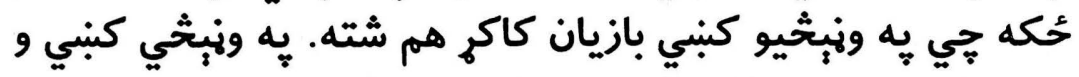

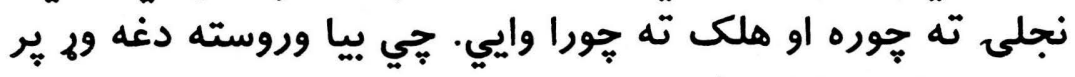

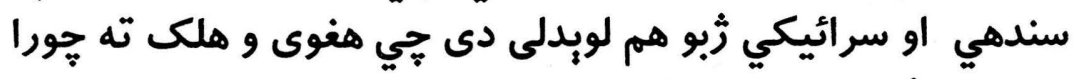

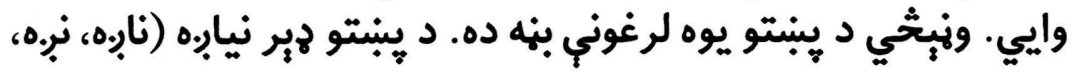

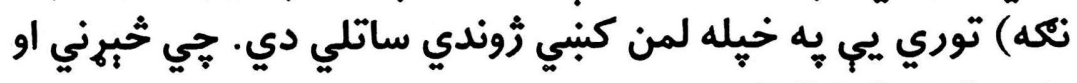
يلتني تهزياته إزتيالري. توري.

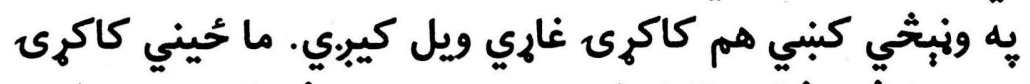

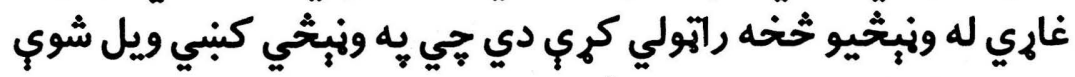

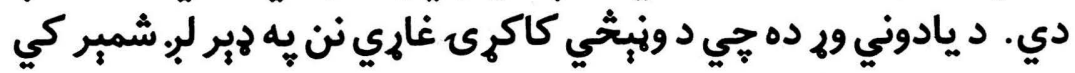

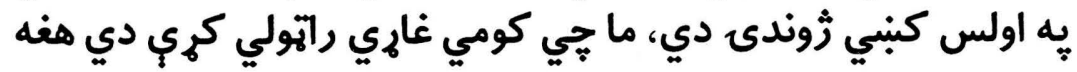
ستاسو و مخ ته بودم.

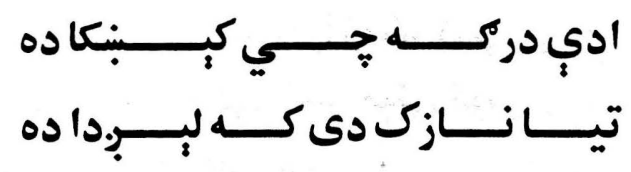



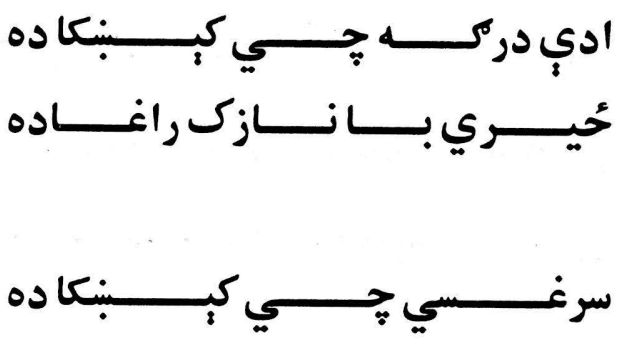

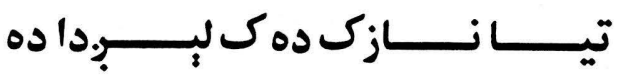

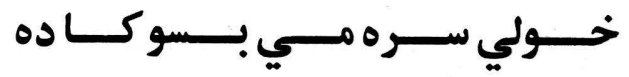

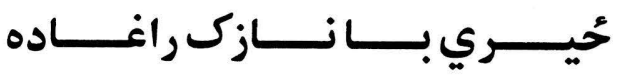

اوس يو داسي كاكرى غار • به لاس كني لرو لكه :

S من ثر ن

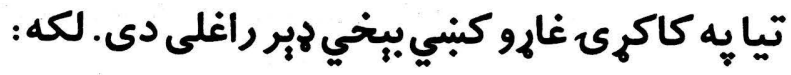
S ن

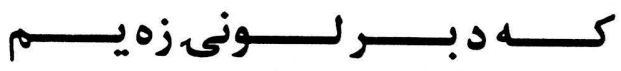

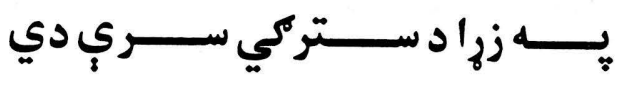

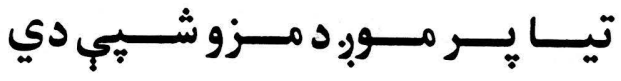


به ونتخِّي كبني يوه بله غاره ده لكه:

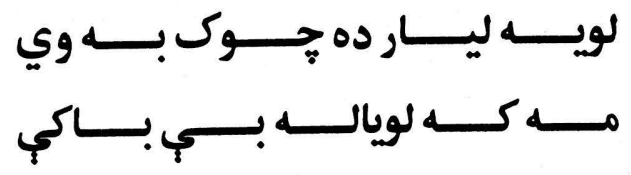

دغه هول كاكرى غاري سته لكه:

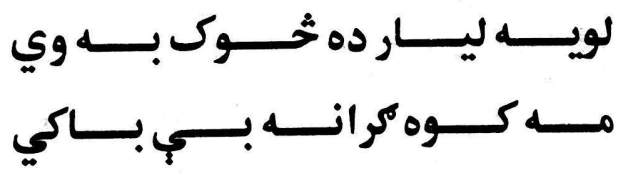

ي

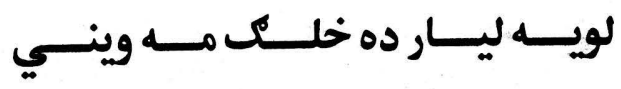

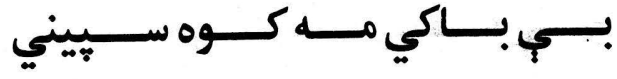

هم دا حول لويال تورى يه كاكرى غارو كبني جاير راغلى دى. لكه :

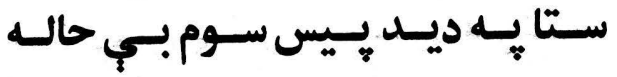

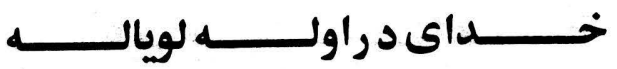

دونبخِي دري غاري دي لكه:

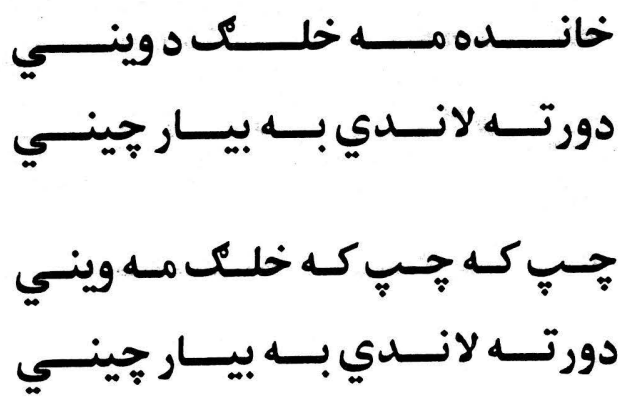




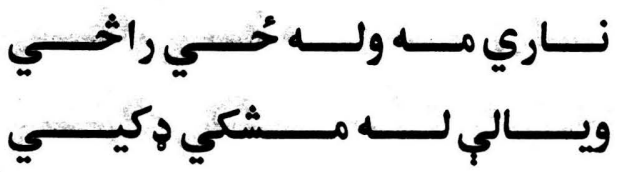

ثي يا كوهي ته يه ونبخغي كبني مشكي وايي اوجمع يبي مشكي دي. همدغه هول كاكرى غاحي شته جي دي غاجو ته ورته دي لكه:
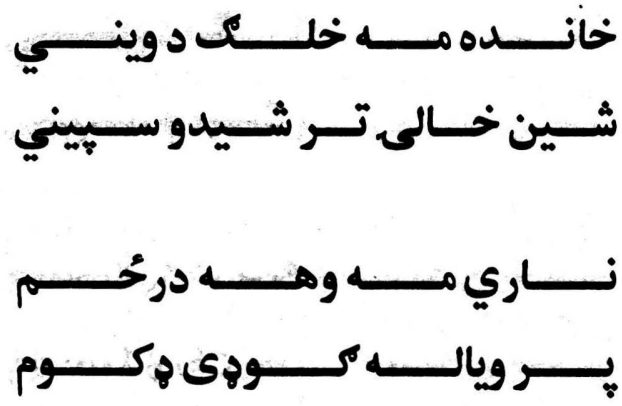

وياله يه كاكرى غارو كنبي ببني زيات كار شوى لكه :
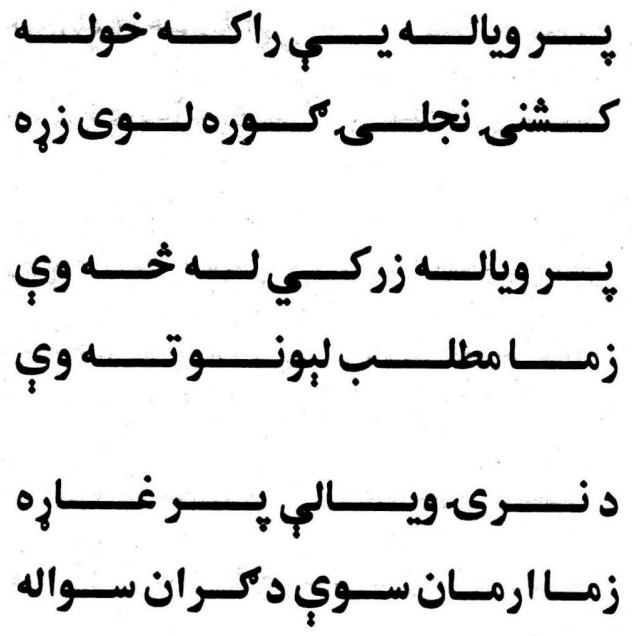
كاكرى غاري

يوه بله غاره ده :

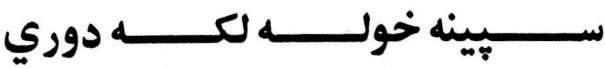

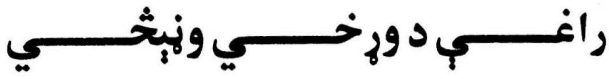

يه همدي خول كاكرى غاري يه اولس كنبي لرو لكه:

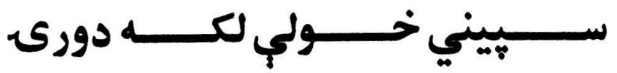

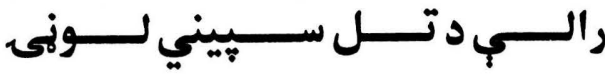

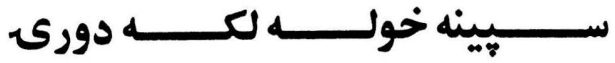

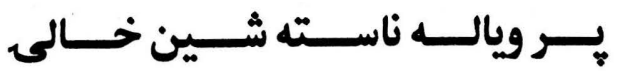

يه ونبحثي كبني غاره0ده :

تــــور تــــوى دانــــه، دانــــه كــــي

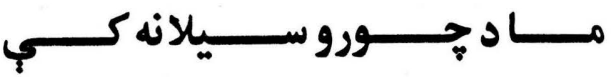

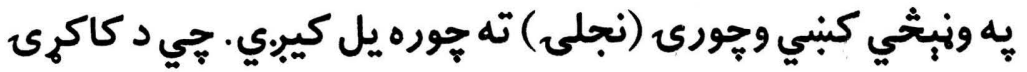

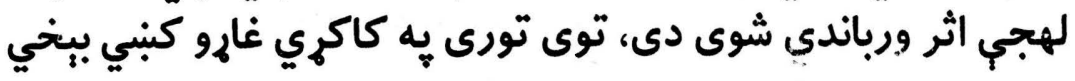
زيات راغلى دى نكه:

تــــوره تــــوى دانســه، دانـــه ســـو

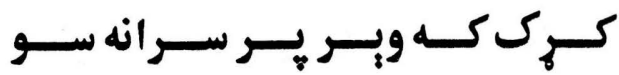


$|F|$

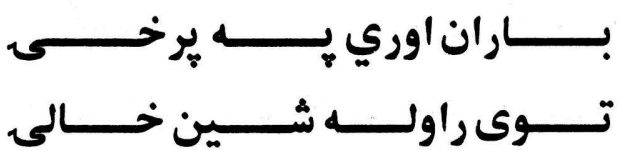

كاكرى غايجي.

هغه كاكرى غاري جي به ونبنخي كبني ويل شوي دي، بِه هغوى

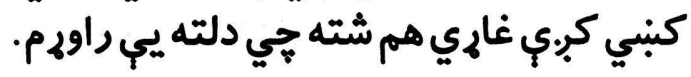

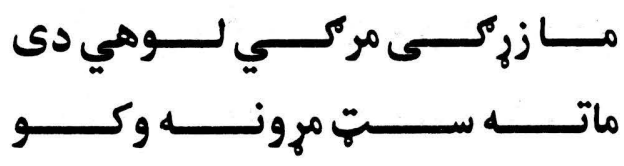

ست تورى يه كاكرى غارو كبني راغلى دى لكه :

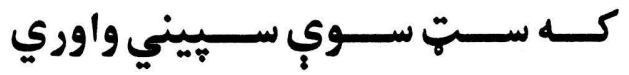

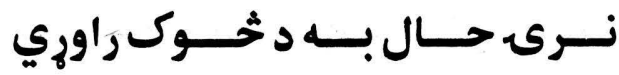

د ونجثي غاري دي :

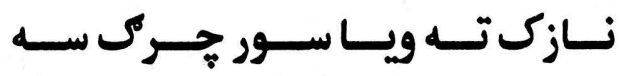

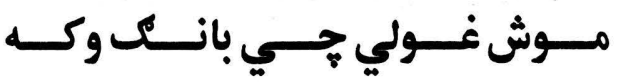

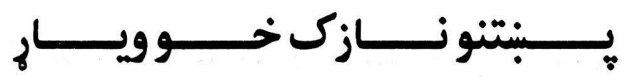

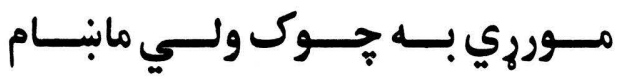

خو نوري ونبخي غاري دلته راورم جي د لوستونكو تنده هري ماته 

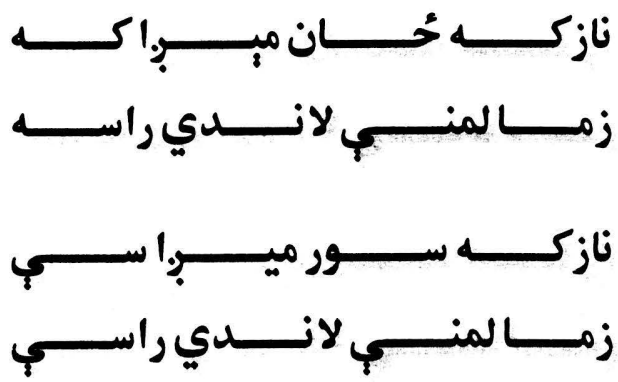

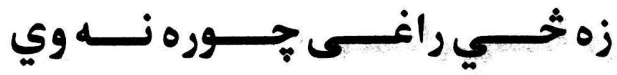

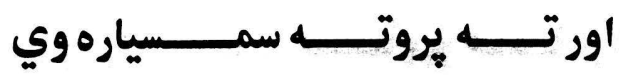

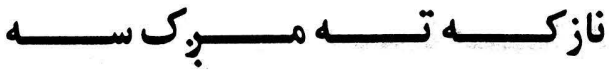

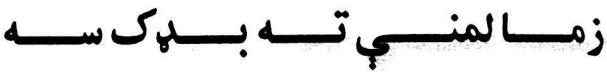

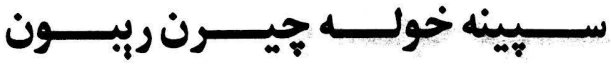

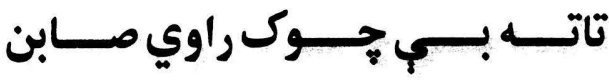

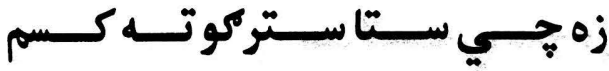
كـــــ دي كــــم كهــــل دي نــــم

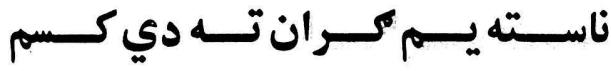

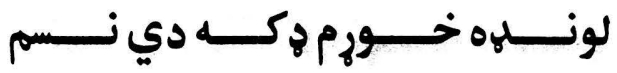

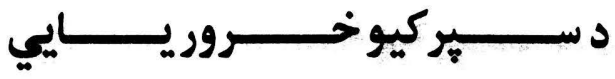

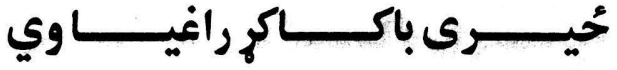




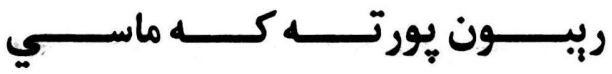

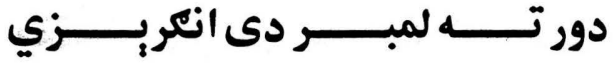

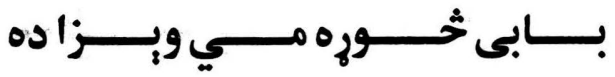

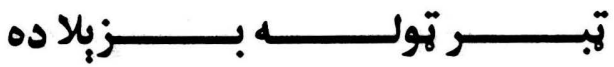

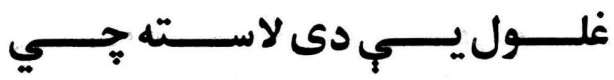

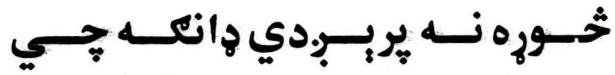

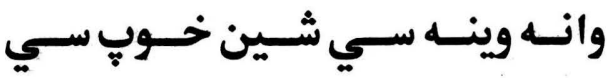

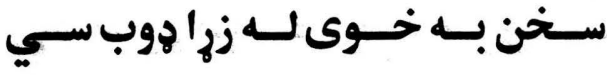

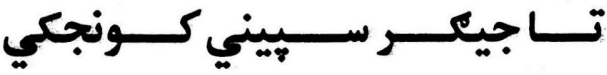

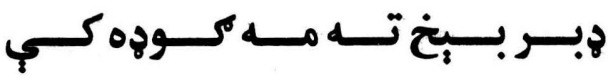

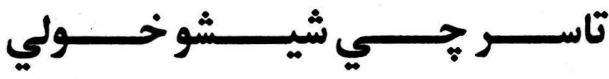

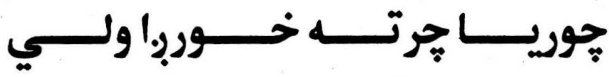

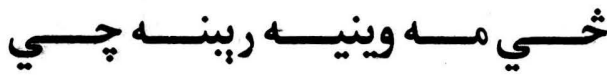

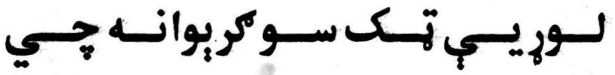



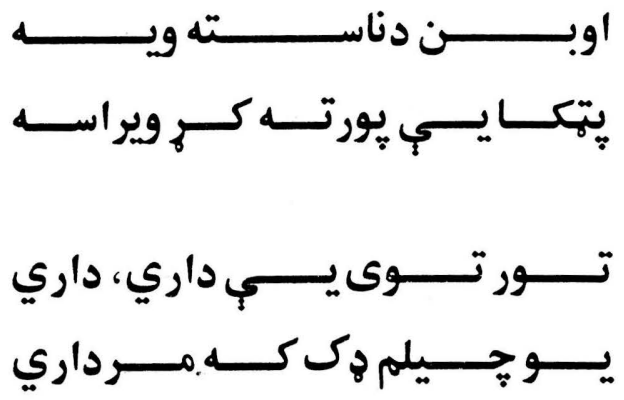

* * *

\begin{tabular}{|c|c|c|}
\hline عامه يِبْتو & ونجخي & نمبر \\
\hline مبر.ى & ميرب. & 1 \\
\hline راغلم & راغي & $r$ \\
\hline جورى،نجلى & جوره & $r$ \\
\hline هلته & اورته & $f$ \\
\hline موبرك & مر.ك، مه، ج.رى & $\Delta$ \\
\hline خيرن، مترن & جيرن & 7 \\
\hline كميس & ربيون & $V$ \\
\hline خوى & جوى & $\Lambda$ \\
\hline راوري & راوي & 9 \\
\hline كورم & كسم & 1. \\
\hline سترى، ستومان & كهل & 11 \\
\hline งร98 & لونهه & ir \\
\hline مره & 8 كه & ir \\
\hline برايي & حيري & If \\
\hline راغلى & راغيا & 10 \\
\hline "ِلار & بابى & 17 \\
\hline
\end{tabular}


IFD

\begin{tabular}{|c|c|}
\hline مرغى، جوغكه & خدوه \\
\hline ويشتلبي ياوزلي & ويزا \\
\hline مور & بزيلا \\
\hline بناخ & جانكي \\
\hline يريج.ده & وانه وينه \\
\hline بخيله & خوى \\
\hline حيكر، تتخر & جيكر \\
\hline داني & كونجكي \\
\hline عمي & شيشو \\
\hline & خولي \\
\hline خولكى، مجِه & خوربها \\
\hline وركوي & 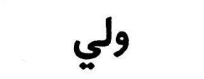 \\
\hline ونيوه & وينيه \\
\hline ريبون، كميس & رإبنه \\
\hline اوبه & اوبن \\
\hline وه & ويه \\
\hline تيكرى & يتكا \\
\hline وايي راعه، ويل راعَ & ويراسه \\
\hline يو، يو & داري، داري. \\
\hline
\end{tabular}

يادونه : يه ونُخي كنبي و يلار ته يِيار هم ويل كير.ي او ورور ته

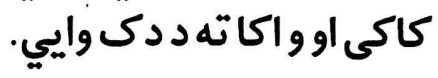

* * * 


\section{يه كاكرى غارو كبني لنلهيزونه}

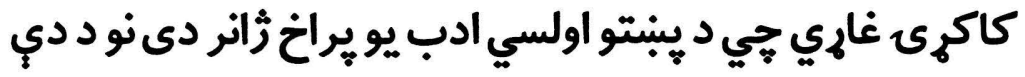

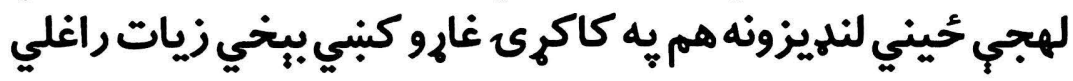

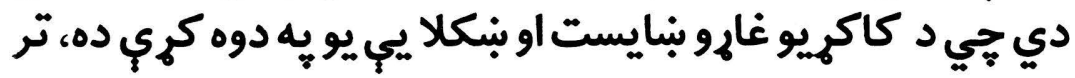

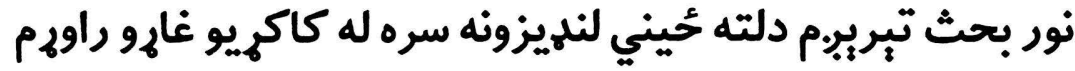

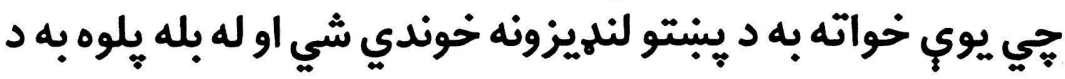
نورو لهجو لوستونكو ته اسانتيا رامنئ ته كري:

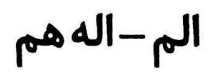

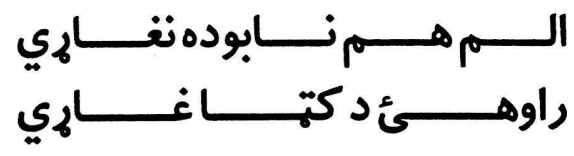

$$
\text { بيام-بياهم-به }
$$

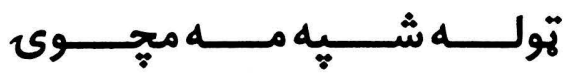

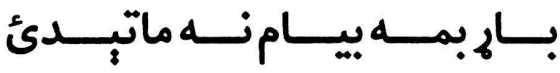

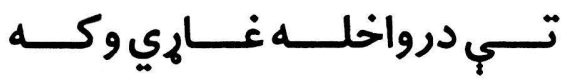

$$
\text { تي-تهيب }
$$

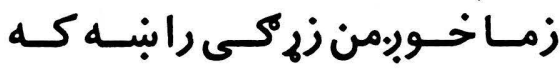




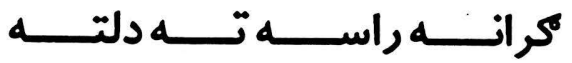

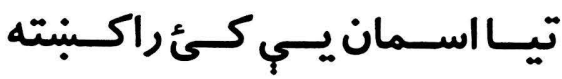

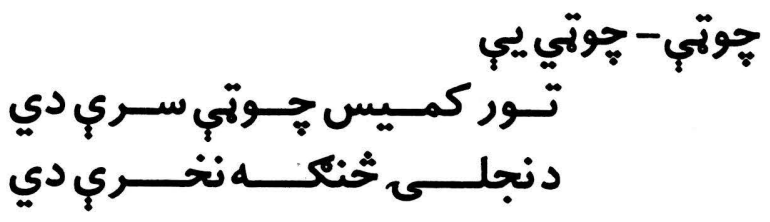

$$
\text { خوبِب - خوبنه مبي }
$$

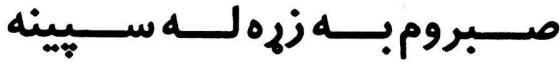

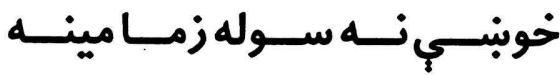

خلك ككه خاندي زونهي نبه دي

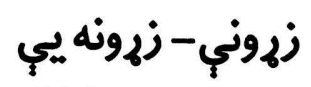

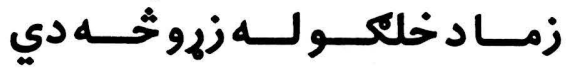

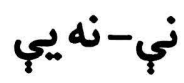

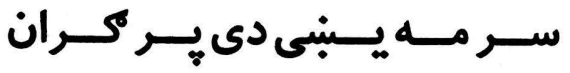

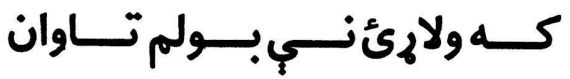

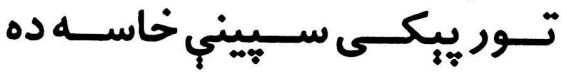

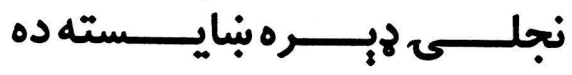


كاكرى غاري

$$
\text { كمي- كمه يبي }
$$

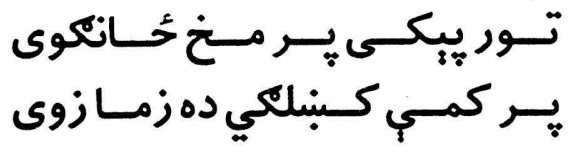

IFA

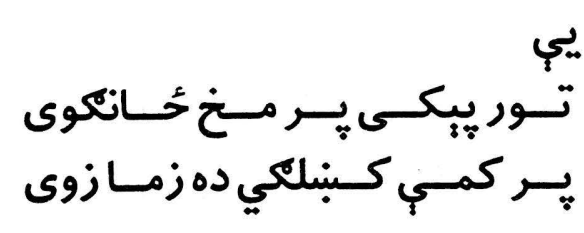

كي- كهيبي

كي خـوري سخت يـي يرهار دى

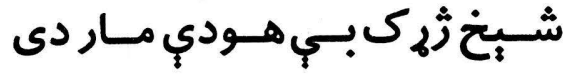

$$
\text { كلى - كرلى }
$$

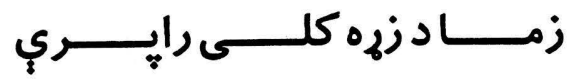

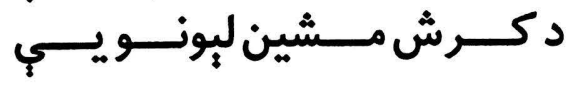

$$
\text { سار - سهار }
$$

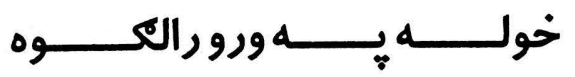

ثخي سـار يـي داغ نـهـ وي بنـــاره

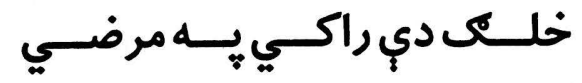

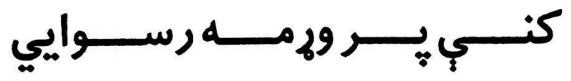

$$
\text { دي-ديبي }
$$

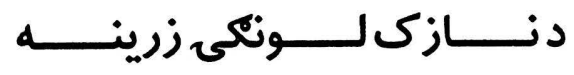

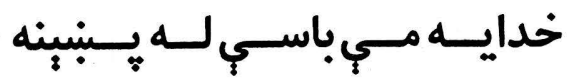




\section{دكاكرى غارو لهجوي حانكرني}

كاكرى لهجه د إبر كار تقاضه كوي البته زه دي كتاب ته

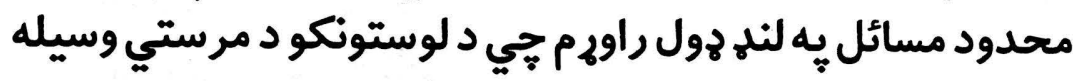

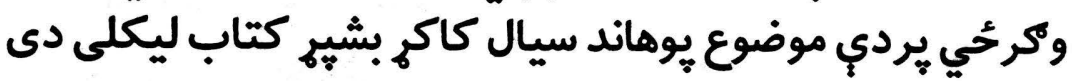

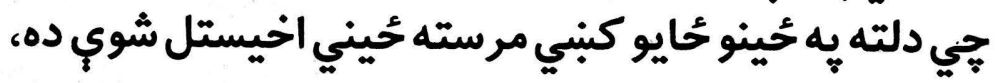

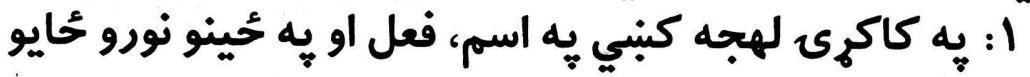
كبني مجهوله "ي، غورئي لكه:

$$
\text { ميّة }
$$

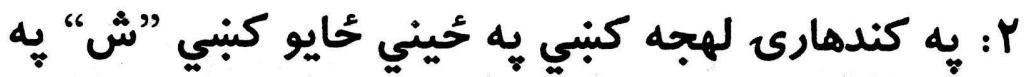
"س" بدلير.ي جي دغه حُانكرنه د كاكري لهجي هم دهي ده لكه :

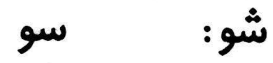

$$
\begin{aligned}
& \text { مياشت: مياست } \\
& \text { شيشتي: سيستي } \\
& \text { شخوند: سخيسند } \\
& \text { غوماشي: غوماسي }
\end{aligned}
$$


كاكرى غاري

10.

"ا: يه كاكرى لهجه كبني "كي" بنحُينه نخبنه ده د تورو يه ياى كبني جي مجهوله "ي"، راسي هلته بيا يه "كي" بدلير.ي لكه:

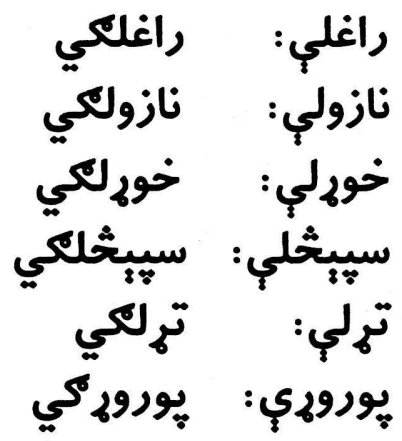

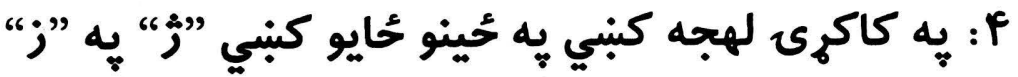
بدلبر.2 لكه :

ز ز ز زبه

ديادوني وه ده هي ذوبل تورى حيني كاكران يه يهوبل وايي. ه : يه كاكرى لهجه كبني جي "دي" يه جمله كبني راسي بيا "دي" يه "د" اوري لكه:

$$
\begin{aligned}
& \text { ســيـن "دي" راســي زمــإِـهـ كـار دى }
\end{aligned}
$$

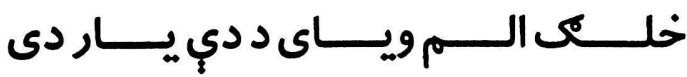


101

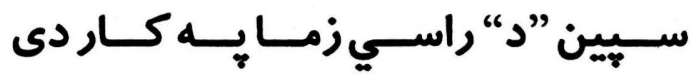

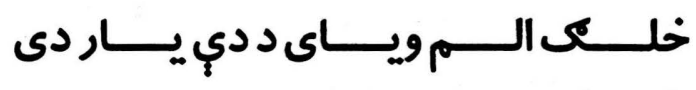

7 : يه كاكرى لهجه كبني "مي" يه "مه" اوري لكه:

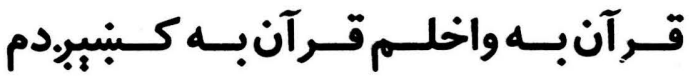

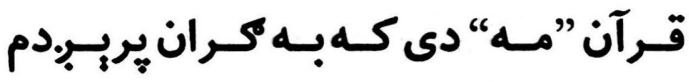

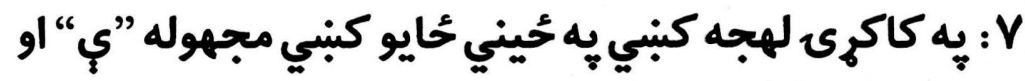
خر كنده "ي" به كي اوري لكه:

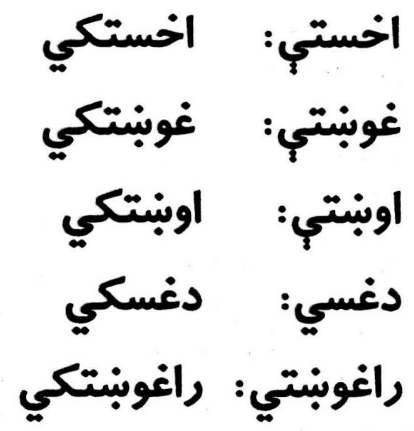

1: يه كاكرى لهجه كبني "جي" يه "خي" اوري زموب خينو

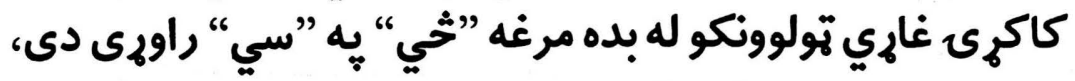

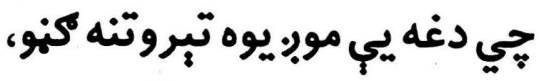
او د اختصار يه منظور نه سو كولاى جي يه يه دي إهوه له تهولو

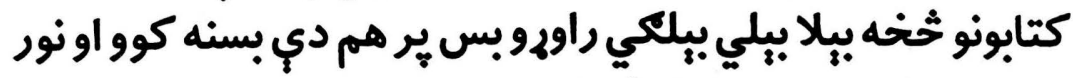

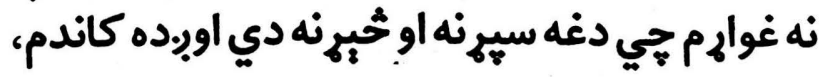


كاكرى غاري

lor

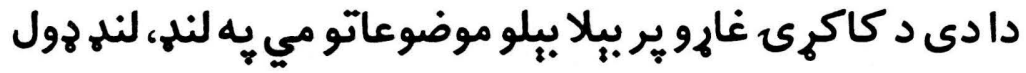

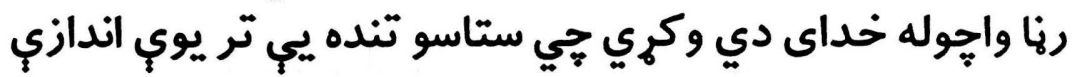

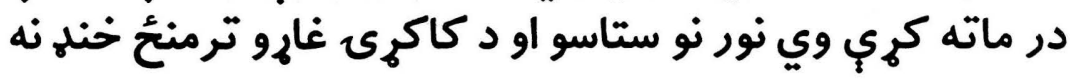

جوة_ير:م.

يه مينه

(محمدصادقثرى) 


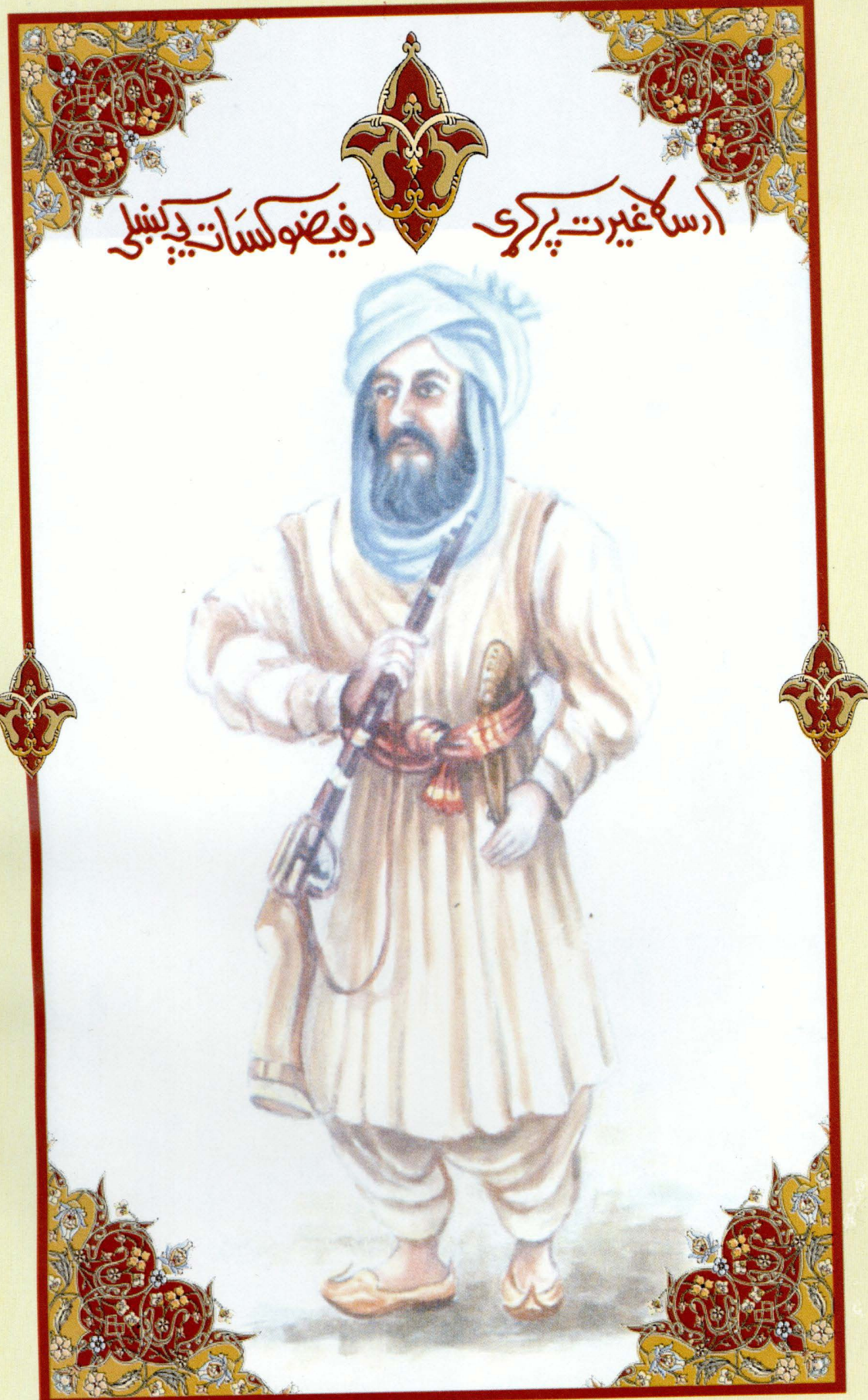




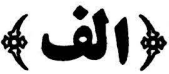

سور ساندي كل سوي د دامان هلكوان يجي كرد بولي ترورى

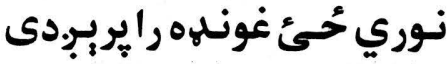

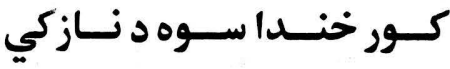

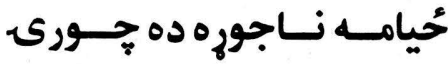

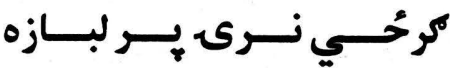

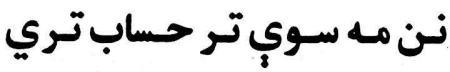

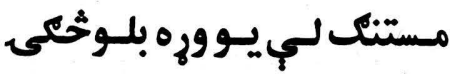

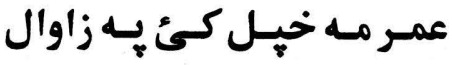

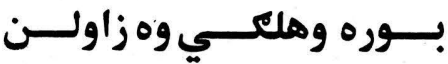

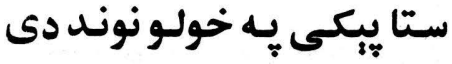

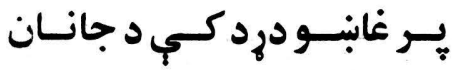

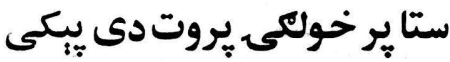

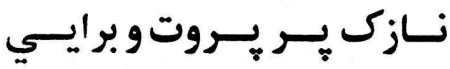

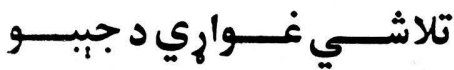

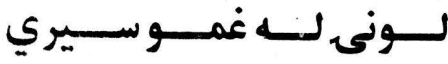

اوس دراســـ زمـــاجانــان اوس زره سـوه شـين خـالى

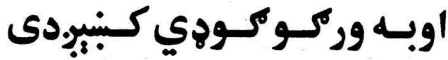
اوريجي بل كئ زما يه زرهذي كي

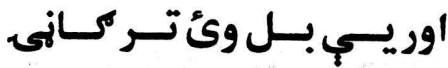

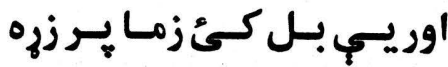

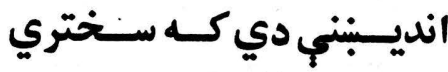

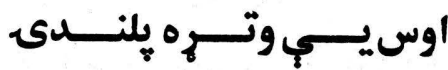

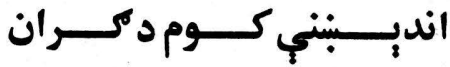

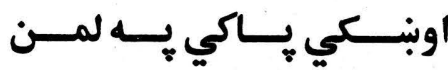
اوسدرحُه كورى د دروند ديى اوس مـه خــور سي بارخونـان

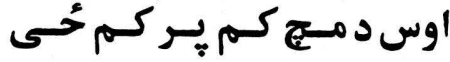
اوس مـه خورسـي دواره تـي

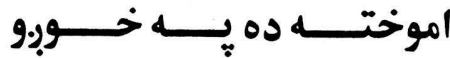
اوبـــكي مــــ تويــوه هيـــري 
كاكرى غاري

كـ زور سـوي كـإِي بـه توبــ زره كاغذذنه دى خحي خور كم

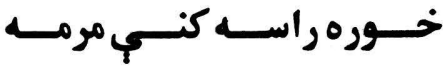

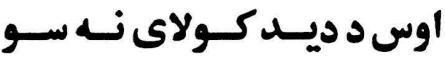

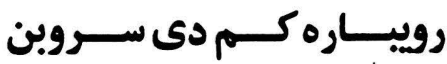

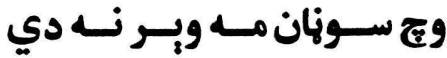

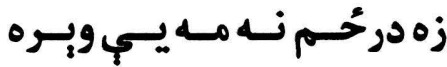
خلكيب خوبنى خـوري دواده

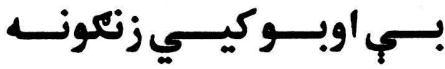

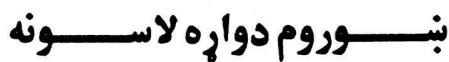

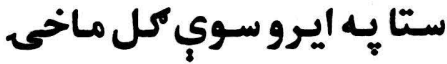

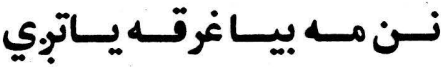

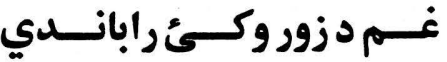

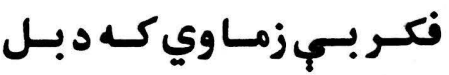

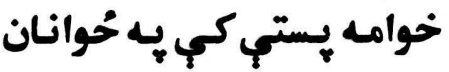

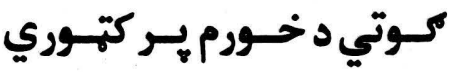

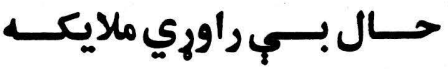
زماتر حُنك د د خـور كور دى دى

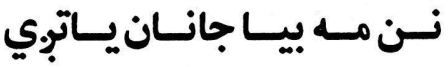
جُرمي د تينكي كه شني خري

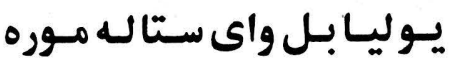

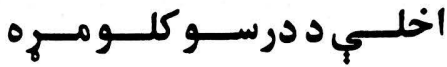

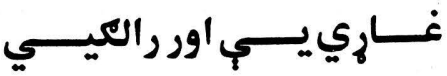

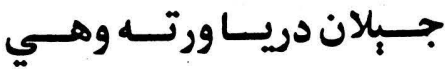

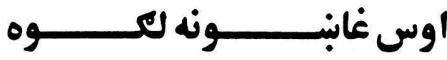

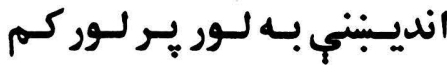

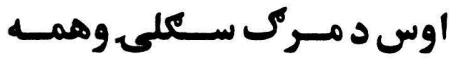

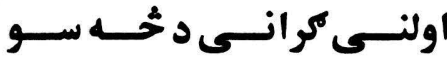

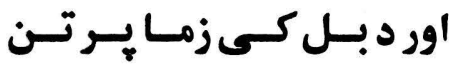

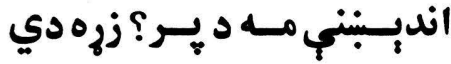

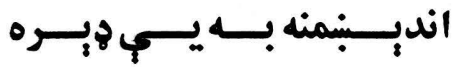
اوبتكي يجي حُي بو سينه خوله

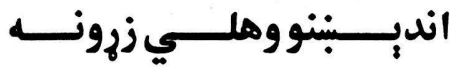

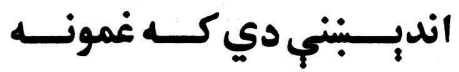

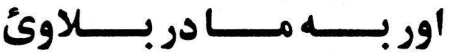

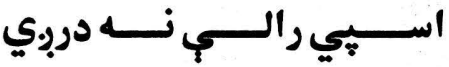
اوس سيرلى سوشني سوي سياندي

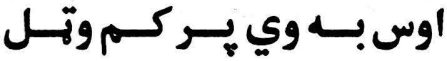

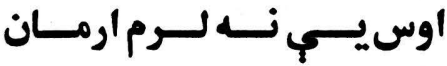

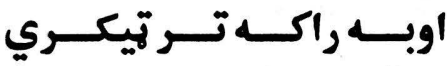

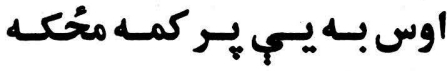

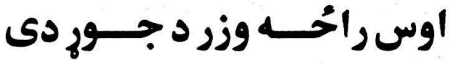

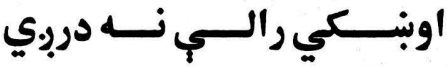

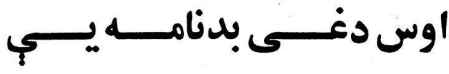
ارمــــان دى تكــــــــــــــوره

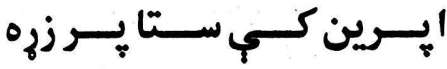

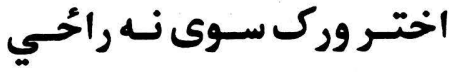

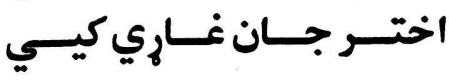




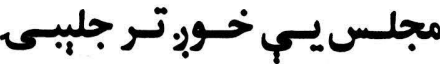
مـاكرانـ خــور دركيكي دهي

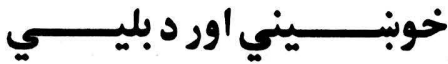

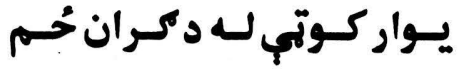
زمـاد خـواري هـر حـال زارئ

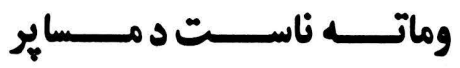

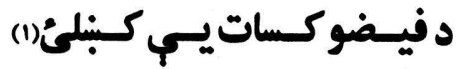

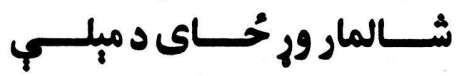
كــور تــه دو ولاره ســـ كرانـو خدايـــه لــ لاسـهـ د كيــل كـور لــه دولاره ســي كرانـو سـينه زونس مــه بـه زوال دئي تيـا يوليتعـل سـوي دو لاهـور تـاد ربخسواركي زمـاكرانــ

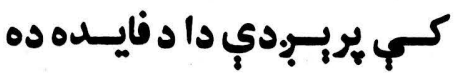

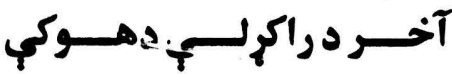

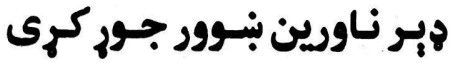
تـاجـورى والـي رايسادكـ

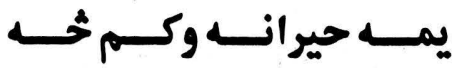
مـه سـي راسـيوى مبلـي لـ زمـايسي مـخ خحلـه راتـور كـئ

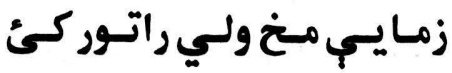

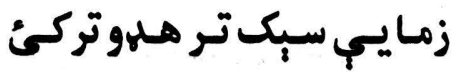

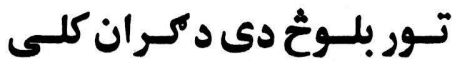

اخــبنى بنـــه دئ تـر خــوركى

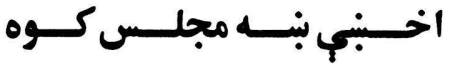

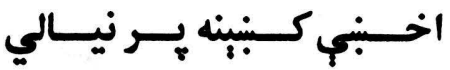

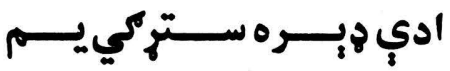

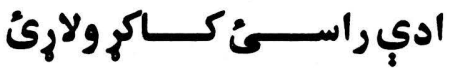

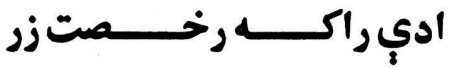

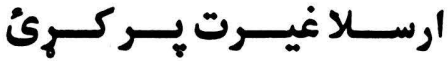

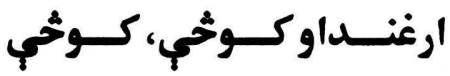

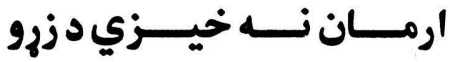

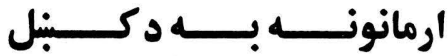

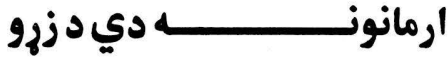

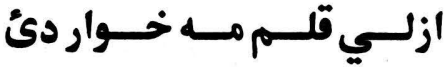
اسـكول يريـروده كـبنينه كـور

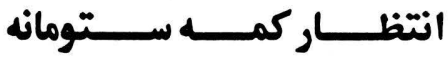

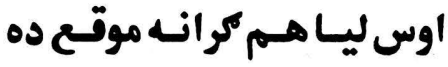

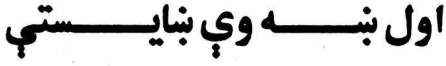

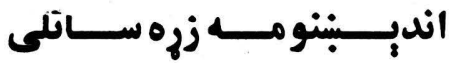

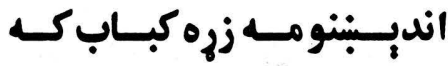

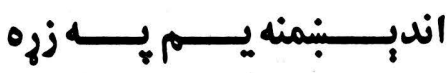

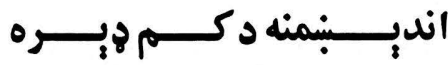

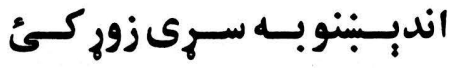

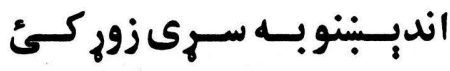

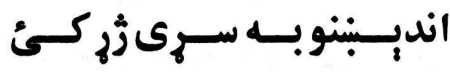

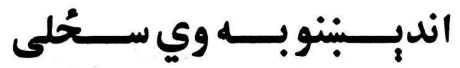


وابه وري حُحسان بـه زندى كمى

وس مه دوك يـر اسمان كـوره دكـران جـارت بـه مـهـ كـاوئ

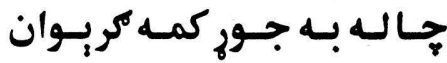
زره اخبار نه دى ثخي خور كم جمي

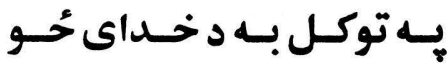
كه راحه بار سوئ دكران كور

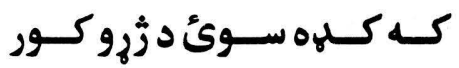

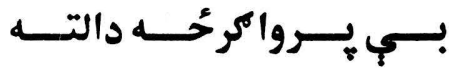

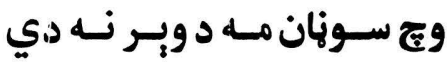

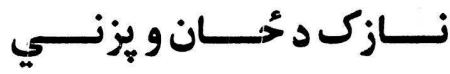

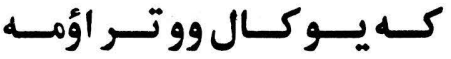
دكمــــزوري دي بــــــــاداره

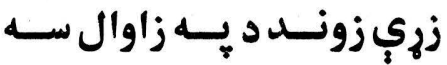

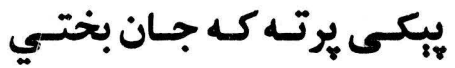

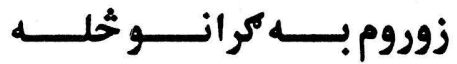

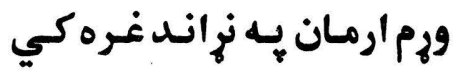

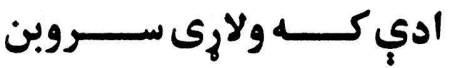

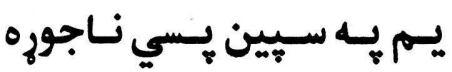
خلك وياى وركى له دونياحُحي

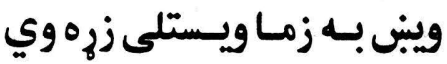
ير شين تيكري مـه يـاده سي

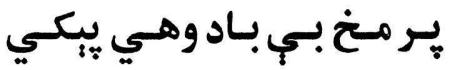

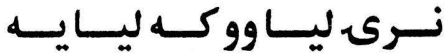

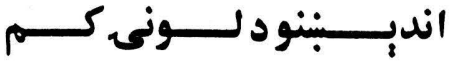

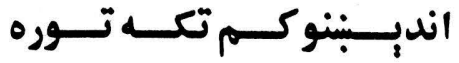

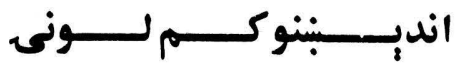

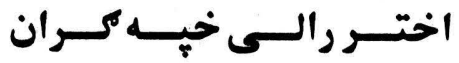

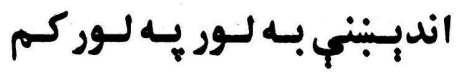

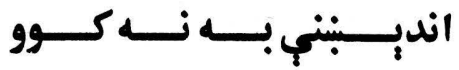

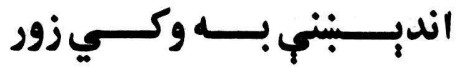

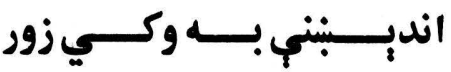
آسـمان لـور دى محُكـــــــتهـ

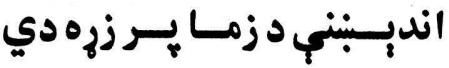

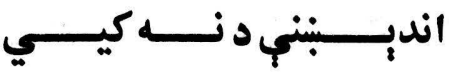

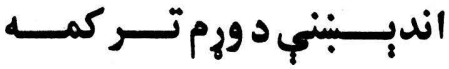

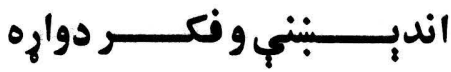

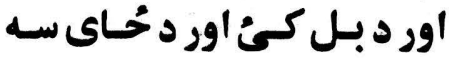
اوار ببنين دى توري درختي

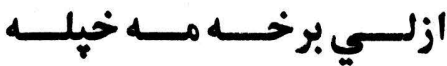

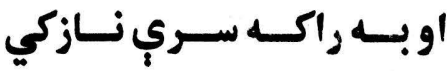

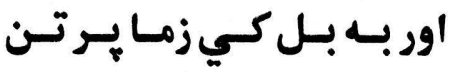

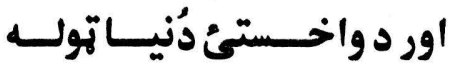

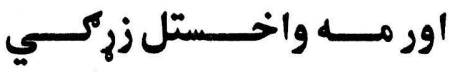
اوس بـه تـول خلكس ويده وي

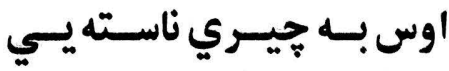

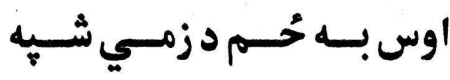

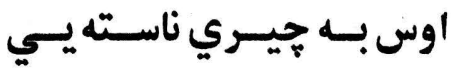




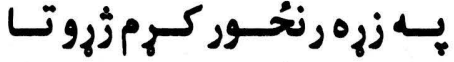

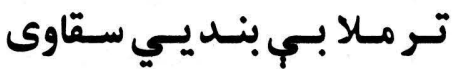
•ـر مـخ بـي بـاد وهـي هيكي

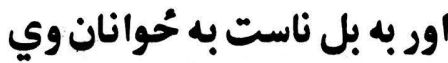

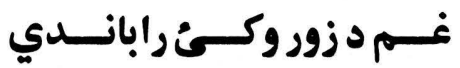
زخمـم جـور د مـور هـر زره سـي

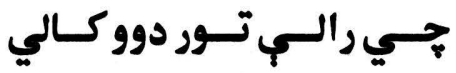

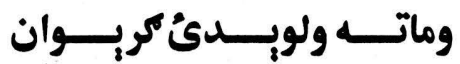

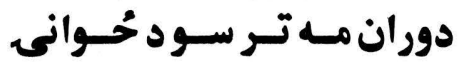
بِّزوندبه هبرينه بردم ستاخوله جـب لـ زئروكي خوله راوره

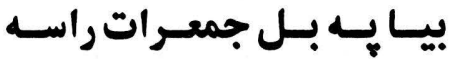

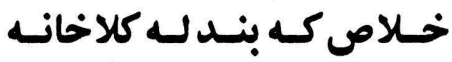

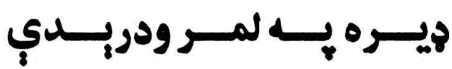

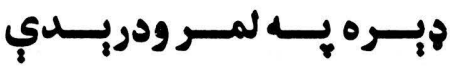

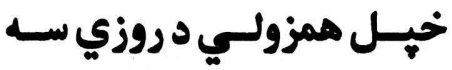

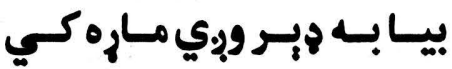

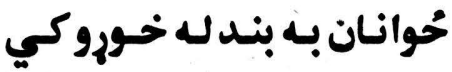

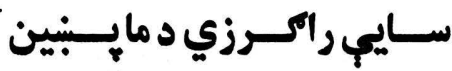

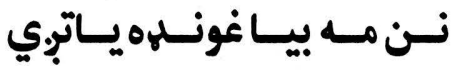
ير مايب ديد كرلى ستاكران

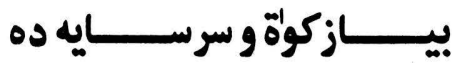
اوس به وى، وى نسته فايدي

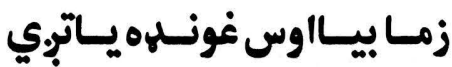

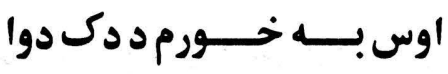

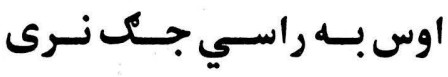

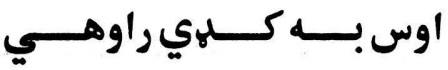

اوس بـه هر جيـيري مابنـام ووي اوسخ مونى كل سوي سياندي اوس خــوولاريخ رابـ نـه سي

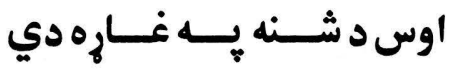

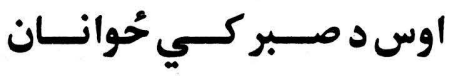

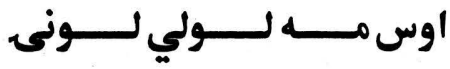

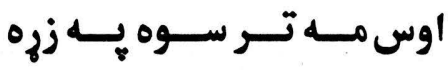

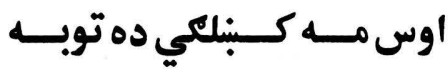

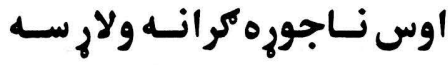

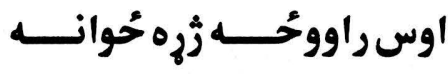

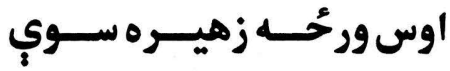

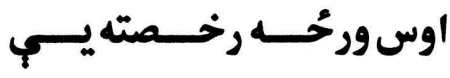

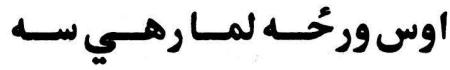
اوس وركسى اوخـي كسلانكي اوس وزكسى خــي لويسه سـي اوسيبي وخت دئر احُحي سيّن

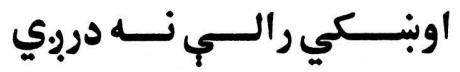

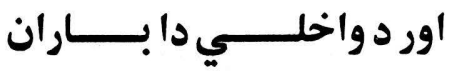

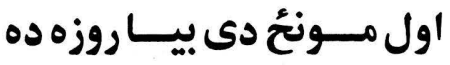

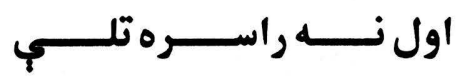
اى وخـت تـر بـه خُنكـهـ كبري 
نن مه هواسي د سري خـولب كـ سـتى خوبنـــ زمـا رضـاده

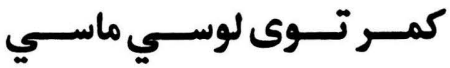

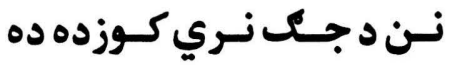

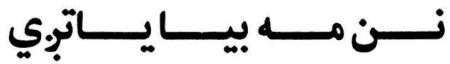

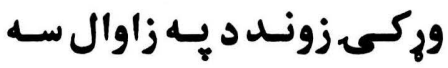

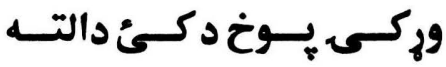

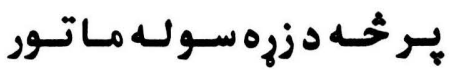

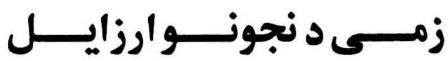
يريـانيـي نيسـي يـر دراوى

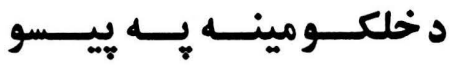

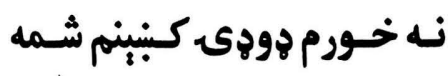

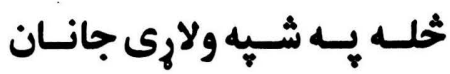

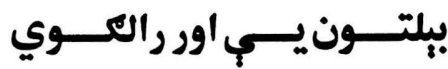
خـــداى د خواركـــ ناترسـي

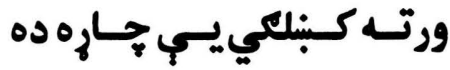

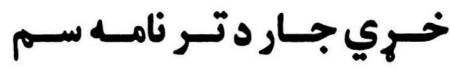

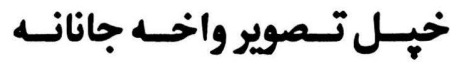

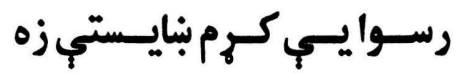

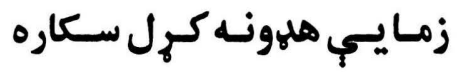

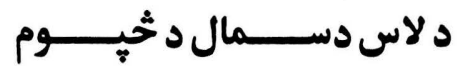

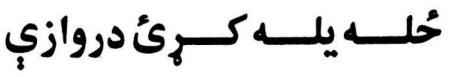
خـي مـه ديسد بـه مرينـه وكي كــ راحُحي سـوكي ليـانـهـ نـم

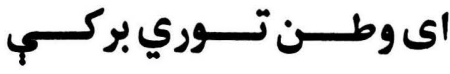

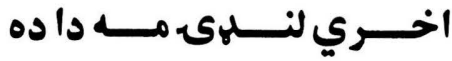

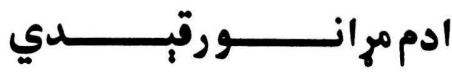
اسـمان اور مُحكــــــــوده ده

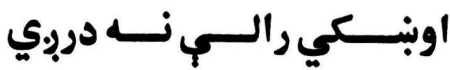

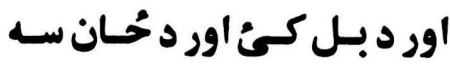

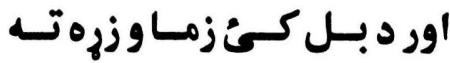
اخلم قر آن خُي يـي مه ورور

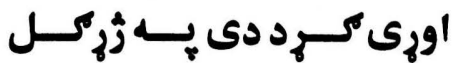

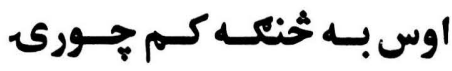
اخــلاص نـسته شــــن خــالو

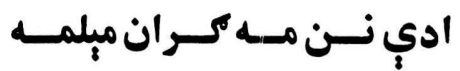

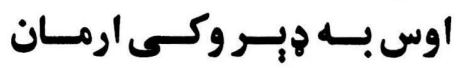

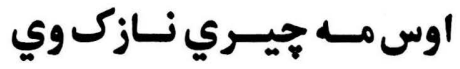
اوس مه خوبر دزري سر سي

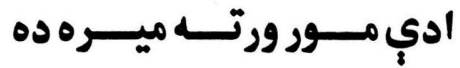
اول تـــــى اوس اوبــــ ســوم

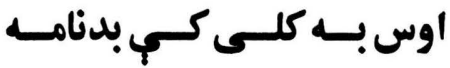

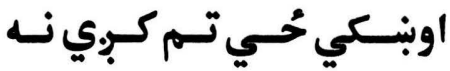

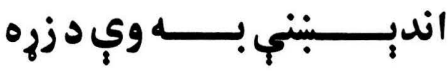

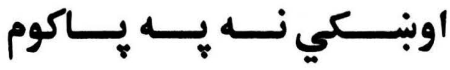
اوريسي اخلــي اوس جــامي

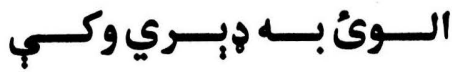
اور بلـبـ.بي ميـانيسي زهيسم 


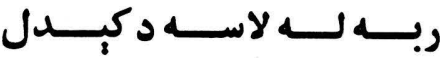

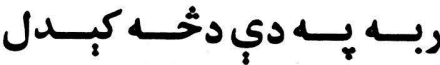

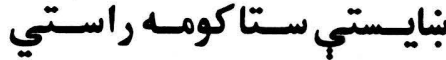

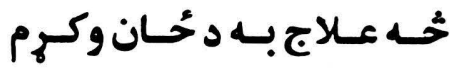

ديـلـ يـــه كلــو سـو د جانـان

سـتا بـه بـلتـون مــ كبـاب زوره

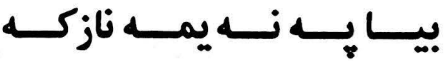

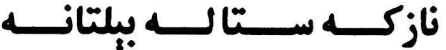

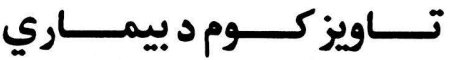

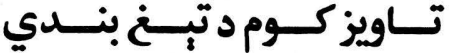

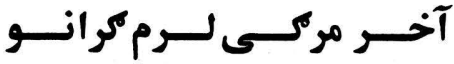

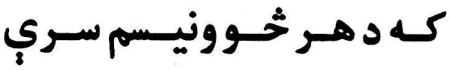

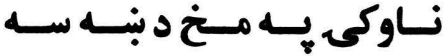
مـوركى سـتاغــم وي راسـره زموب. :به قسمت كي مزدوري

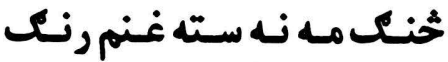

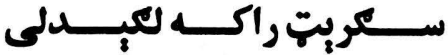
كرواخــب سوكي ليـانسه يسم

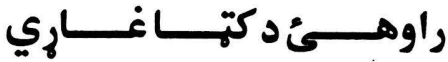
يـر ترآنـوبند سـوى خركالى

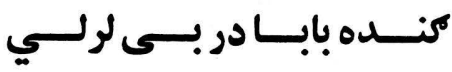

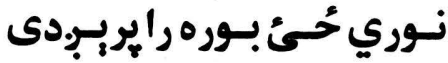
خطـادكـل خــوني حوانـان

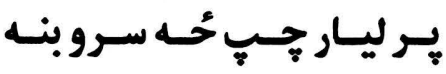

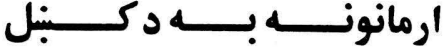

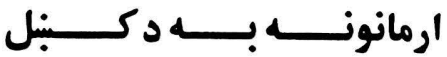

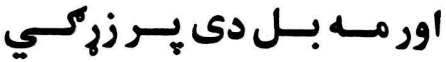

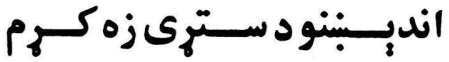

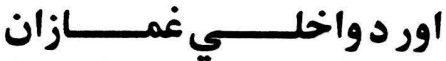

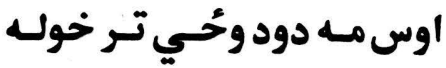

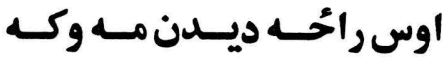

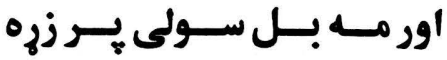

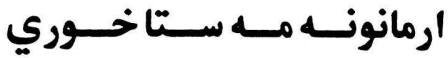

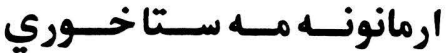

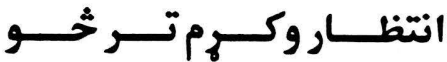

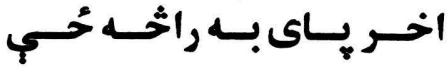

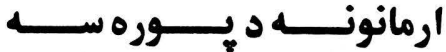
اوس كـه روحُوي اوكـه شـــه

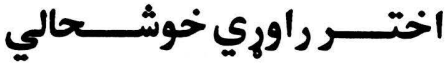
اور دو واخلــي ســور بلنــــ

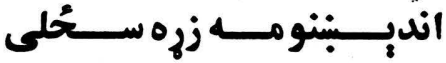

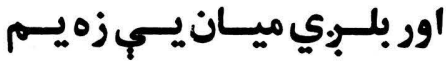

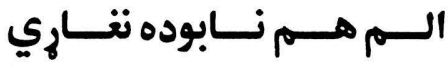

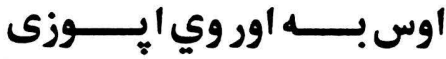

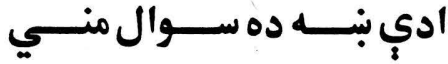

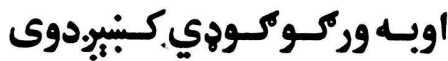

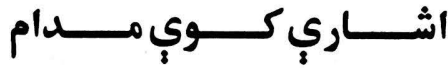

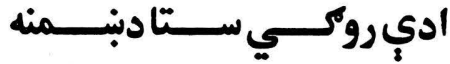


ثخسي راسـي تـاوارخطـاكسي

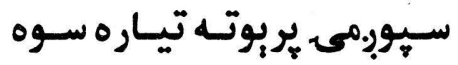

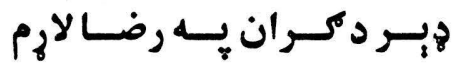

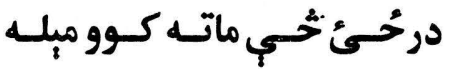
لوستي مي هم نه كو بيكي

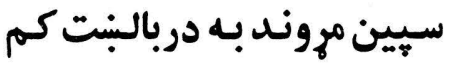

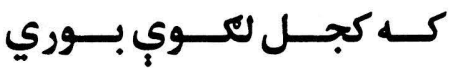

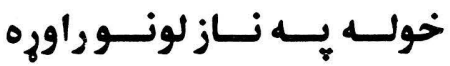

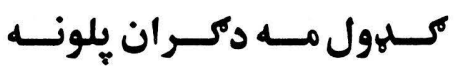
بـس راتـــرتركسـاريز ســوى

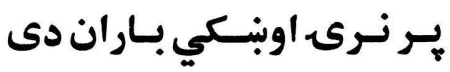

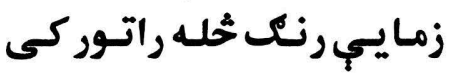

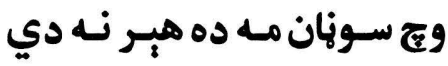

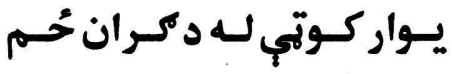
فكـربـي زمـاويكـه بيـابـل

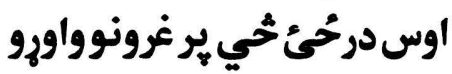

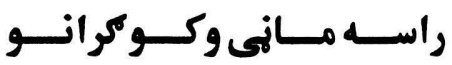

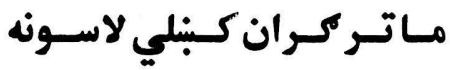
بـي مـدرى نـــه دي رايـاتي

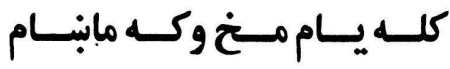

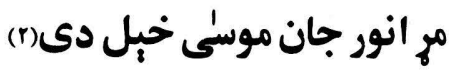

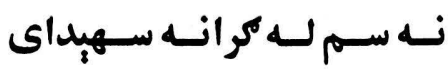

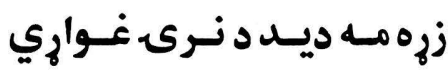

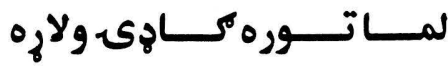

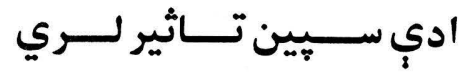

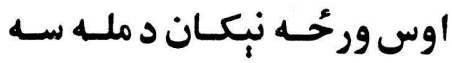

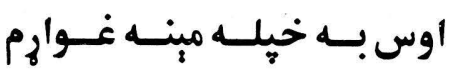

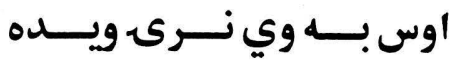

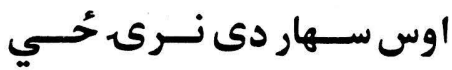

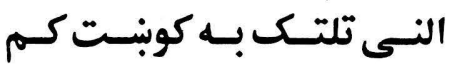

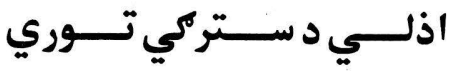

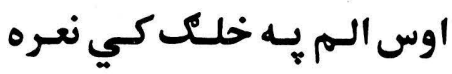
اوس مـه خـوبر سـي ميروندونس

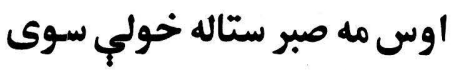

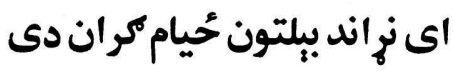

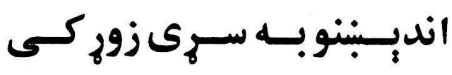

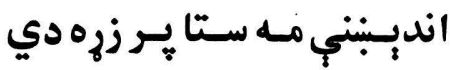

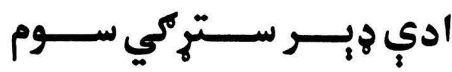

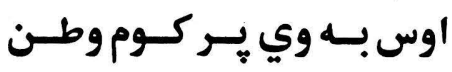

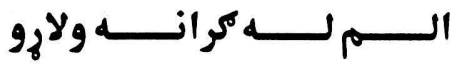

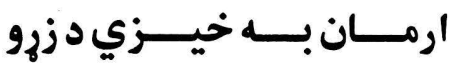

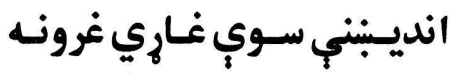
انديبني سوي د سبين زياتي

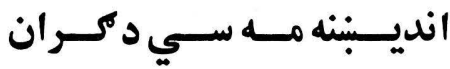

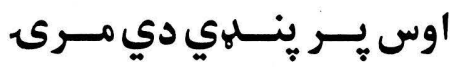

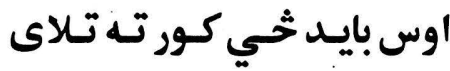
اوبــكي راليَ سـتركي زاري

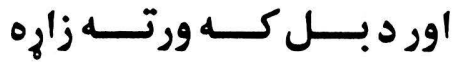


كر انسهـ مــخ بـــر بـــرووكسم به خوب راسه خحي حال دركم

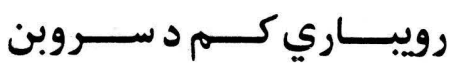

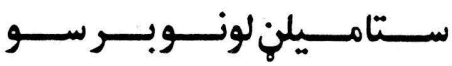
تـر تـالانـــي مـه جاركل دى

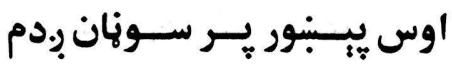
خــي سـوم يـهـ قـول د جانـان

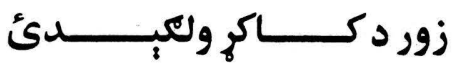

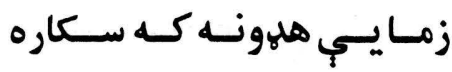

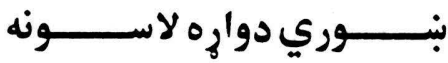

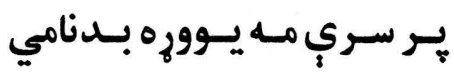

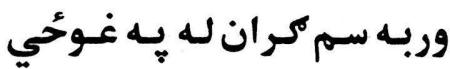

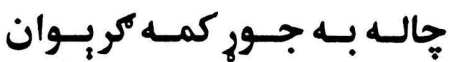

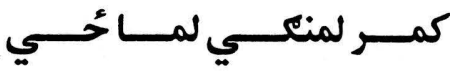

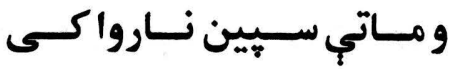
خدايه ماخلاص كي له يورو

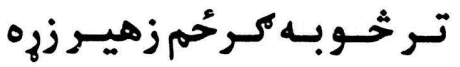
دباندي سيّين نوندكئ باران

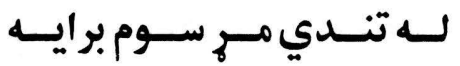
اوس د هلكوانــــو ادي ســـوي

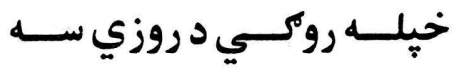

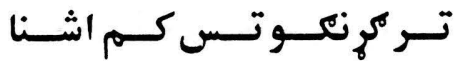

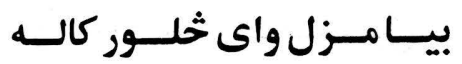
اوس بــهـ بيــــرقيــان بنــوري

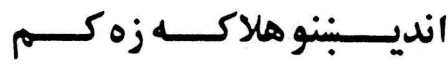

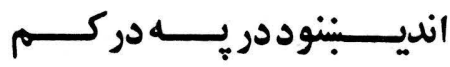

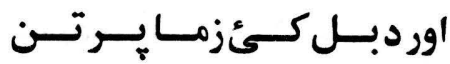

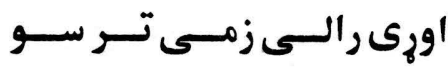

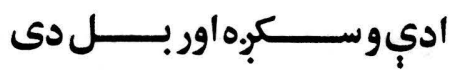

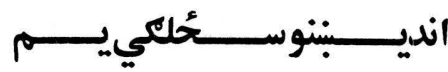

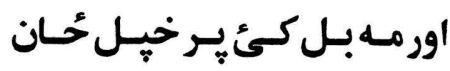

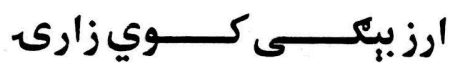

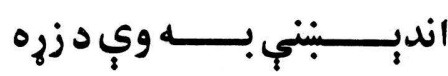

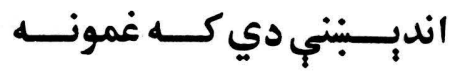

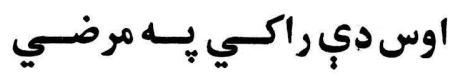

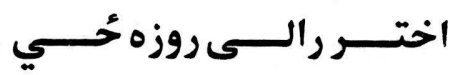

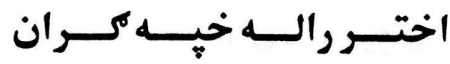

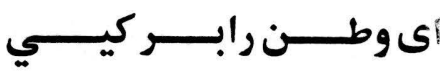

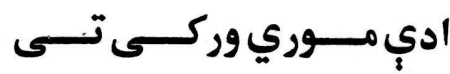

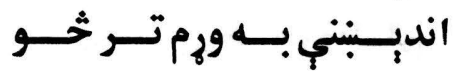

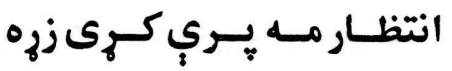
ادي روكــي وخـــوري حُّــان

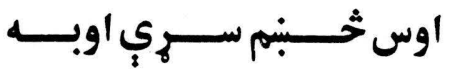

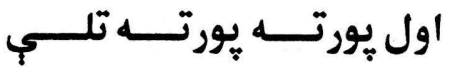

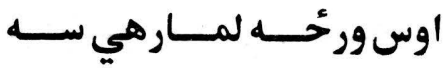

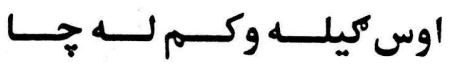

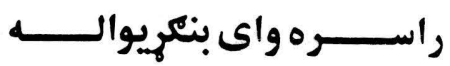
اخـلاص نسته سـتالـه لــوري 


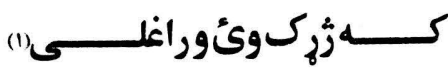

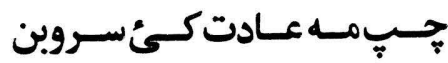

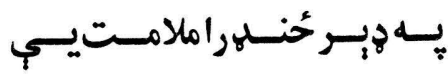

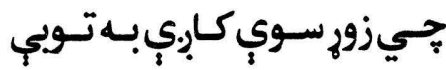

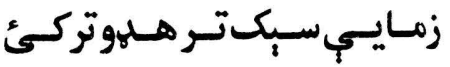

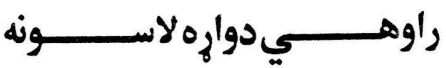

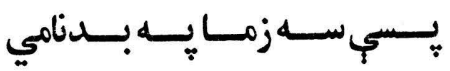

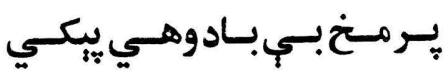

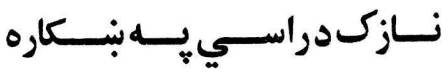

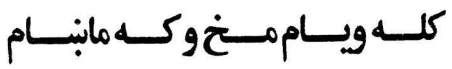

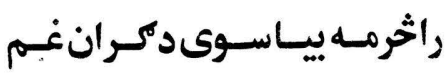

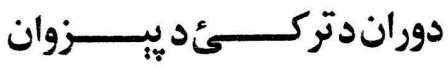

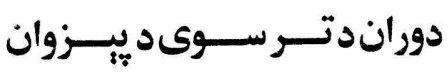

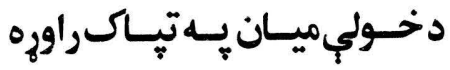

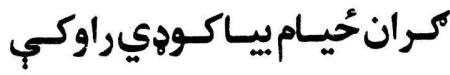

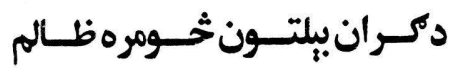

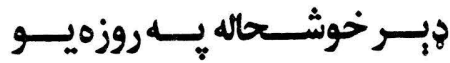

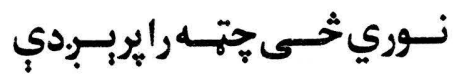

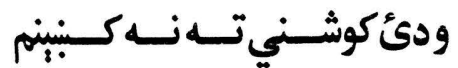

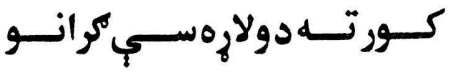

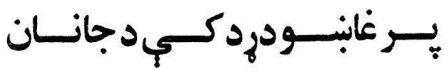

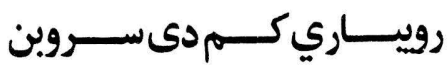

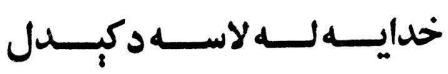

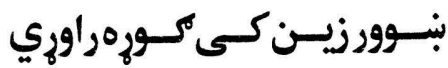

اوسبـــه ويتـــــر رودوتلــــى

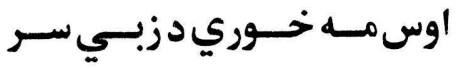

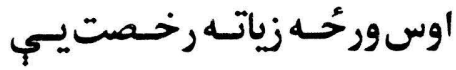

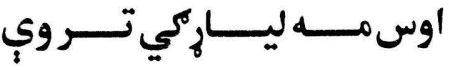

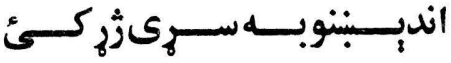

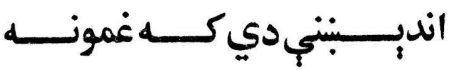

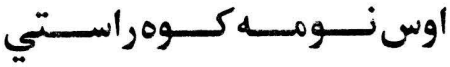

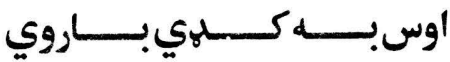

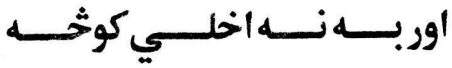

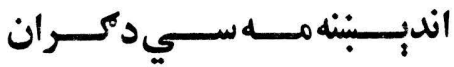

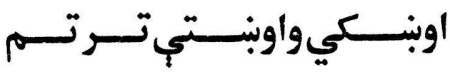

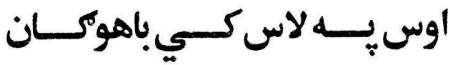

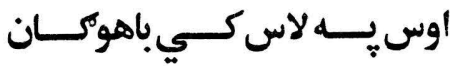

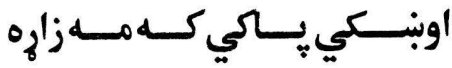

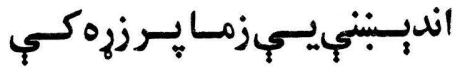

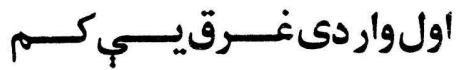

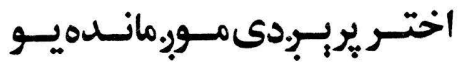

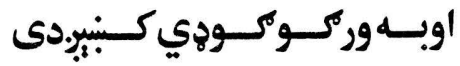

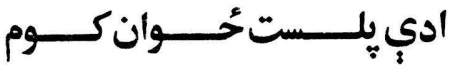

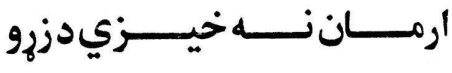

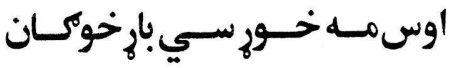

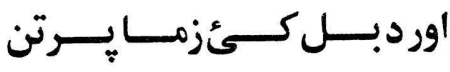

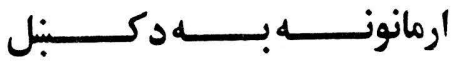
اخـبنى السى جــاىبــــــواري 


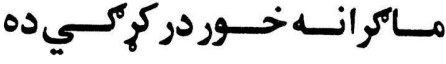

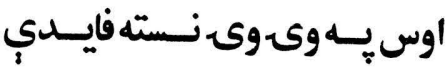

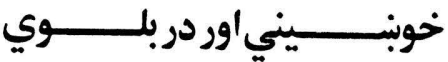

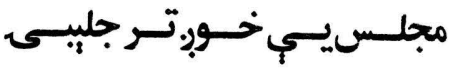
خـالق د نـن جـور كـي قيامست حـــي نـامردي دونيــامى لـه

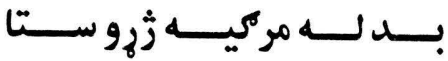
دكـران بلتحـون ثخـومره ظـالم

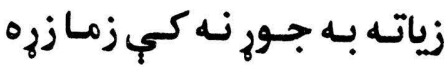
تـــــــوتي جــار سـم د لاسـو

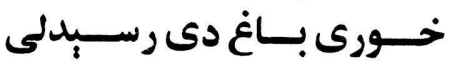
بـر مسخ بـي بـاد وهـي بـكسي

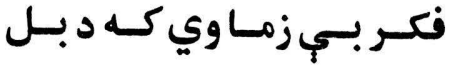
مــوري يسلم سـترى ســتومانه
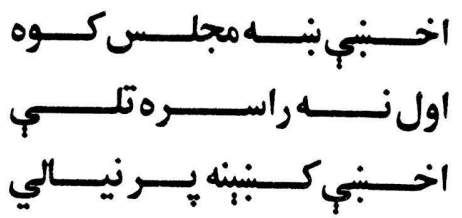

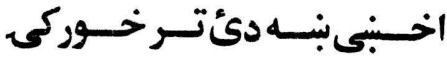
الـهم مـــرم ســتا بـــر محبـــت

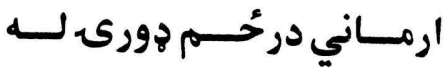

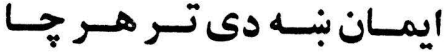

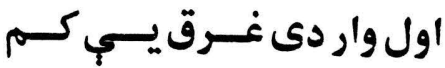

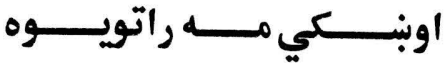

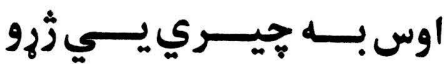
اوس ايسـي نـوى بــاغ نيــولى اوس بــه جيــــي ناسـتهـ يسي اوسبـه جيـري وي زمـاكسل اوس دسـتمي رالـم لــهــاره

然资 


\section{|ب}

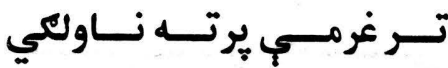

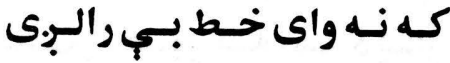
زماكرانسى بـه له جــاغـواري

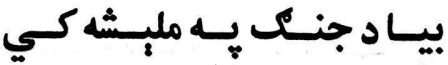

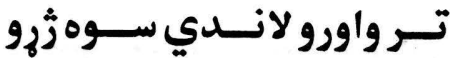

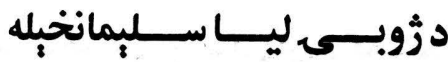

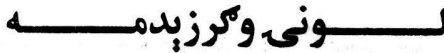

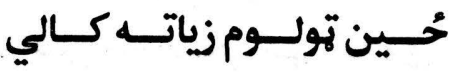

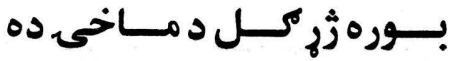

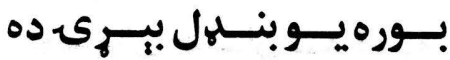

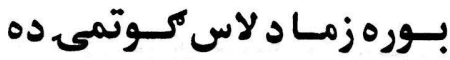

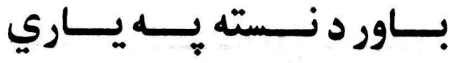

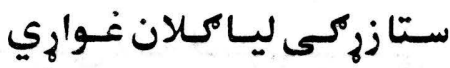

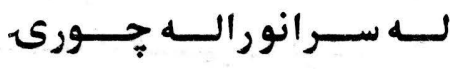

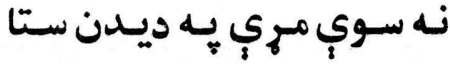

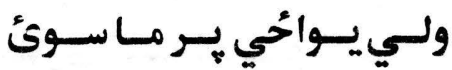

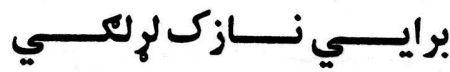

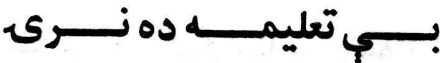

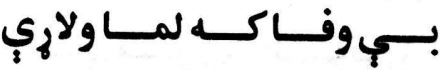

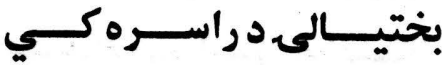

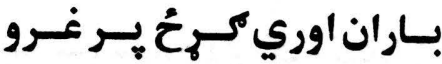

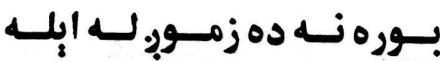

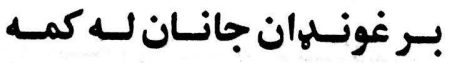

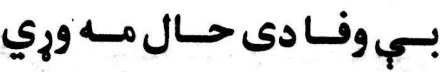

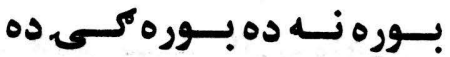

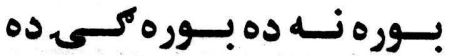

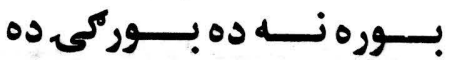

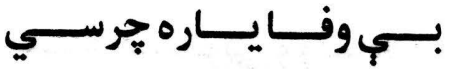

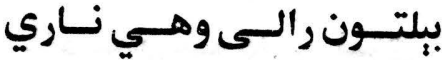

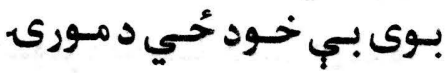

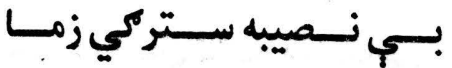
بلتـــون زمــاو ســتانيمسى 
مــاد مركسي خـــوب حُنكيسي

تـور تيكــى بنايستي سـتركي ستا به ليار كي زركي شنب سوي

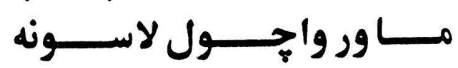

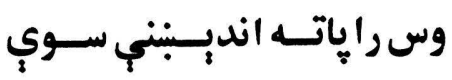

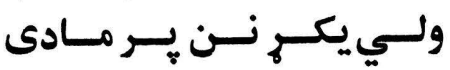

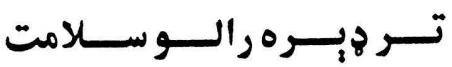
سـتا يـه ببلتــون سـوحي كـالي

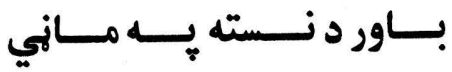
ليـايسي يـر غـحُ ليـا يـر ديـوال

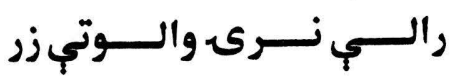

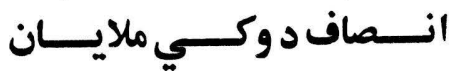

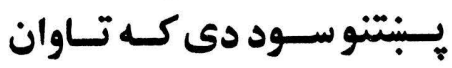

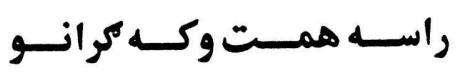

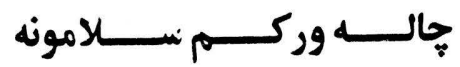

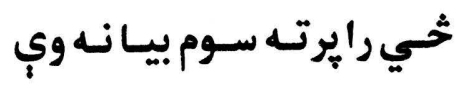

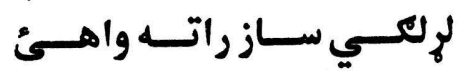

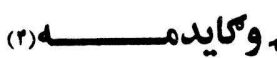
ونس

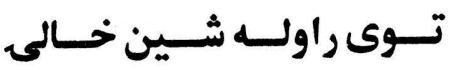
د ســـري لـستوني وونساوده

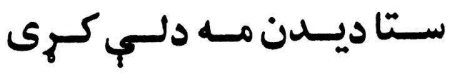

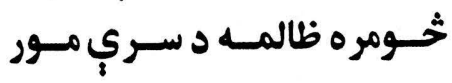

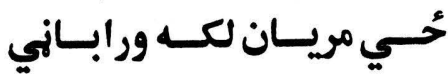

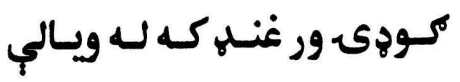

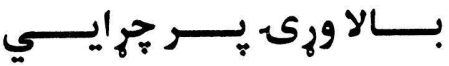
بانوكسان يـي دركي، دركي ببلتون رالى لياري دوي سوي

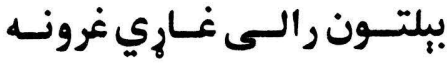
ببلتون رالى لاري دوي سوي

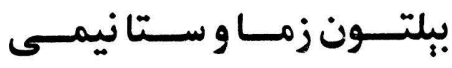

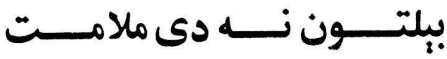

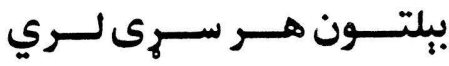

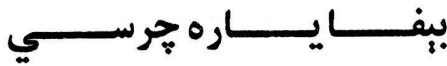

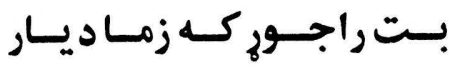
بخـت مـه لاندي سوتر تـر سخر

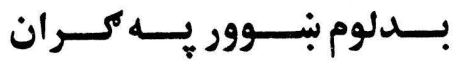

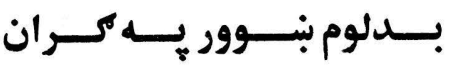

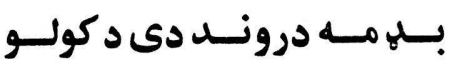

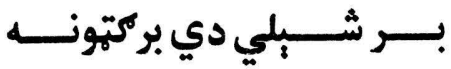

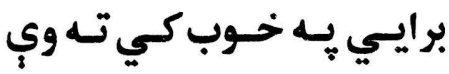

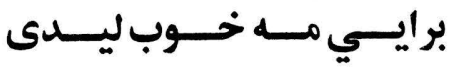

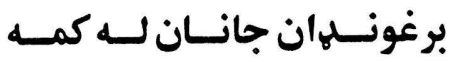

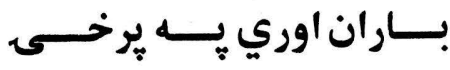

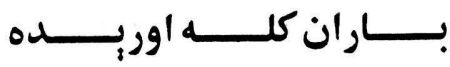

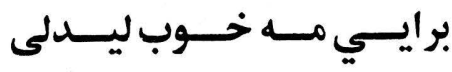

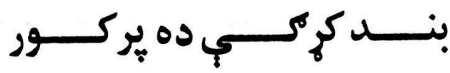
بنديب خلاص كئ ستا له غاري

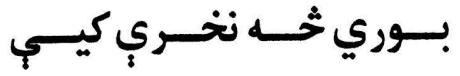




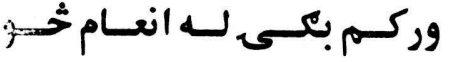
اوس مه خور. سي سونان دوارو

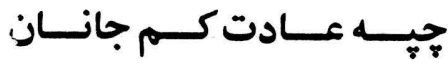

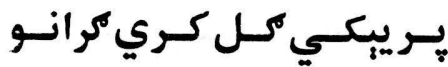

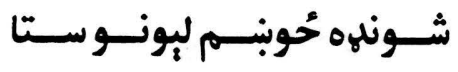

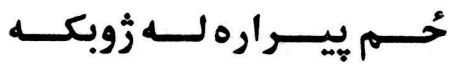
د خـولي خوند مه سهار تركئ بايسـتي سـتركي صسفا غــابن

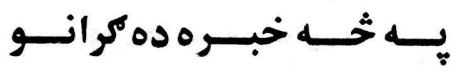
لـــر انــصاف د جانـان وكــي بـي بـروا ولاري سـي نجونس

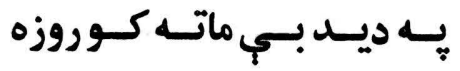
كـوره كسم كـل بسم روزي سي

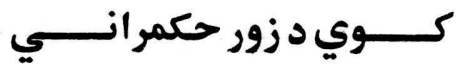
جـوري سـوى دزيرونسوازاري نـن يــر دراوى نـه وى

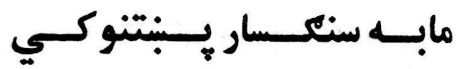

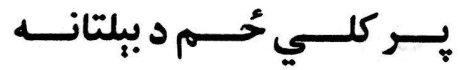
بـهـ كركي تانسه ده خــواري

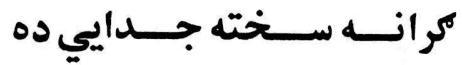

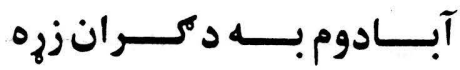
كـهـ بــه غــم تـلـ دكرانـووي آخري سوال مه دكران واوري كـوت يـه غنـاره كـه بيـا راسـه

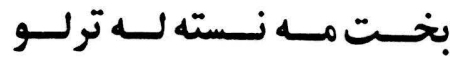

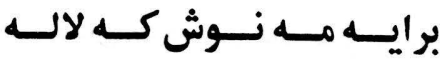

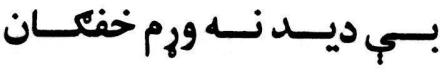

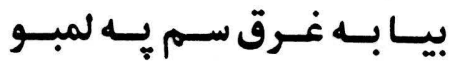

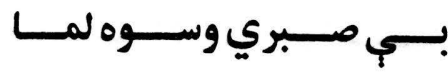

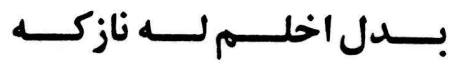

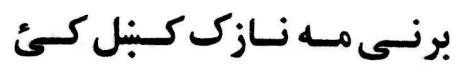

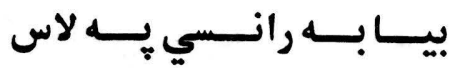

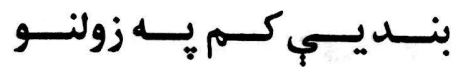

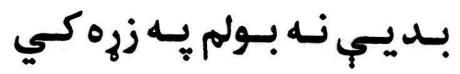

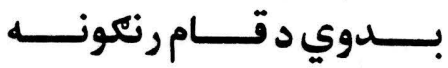

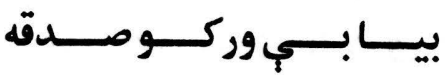
بيابه دا وخت د سـيركي سي

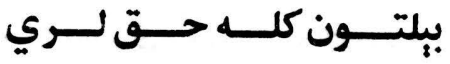

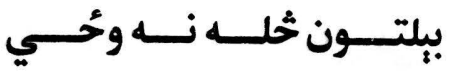

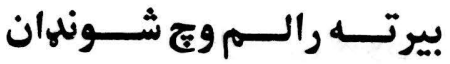

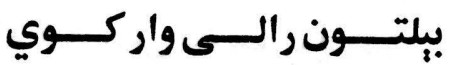
بخــت مــه سـوى لتـاكوزة

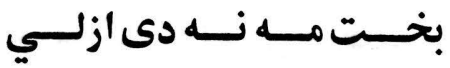

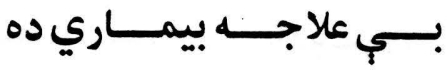

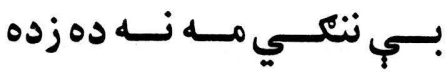

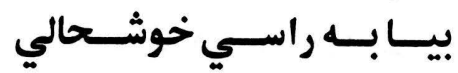

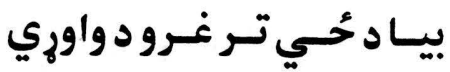
بـادكو لـربي كـور لـه ولارســ 


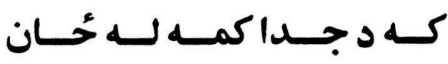

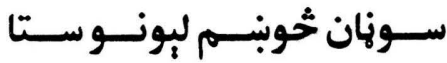
غمسى مسي يـو وري د جاركـل

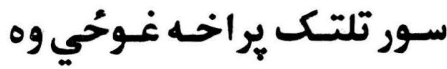

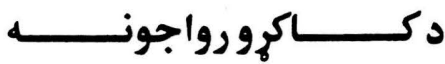

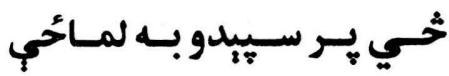

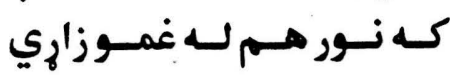

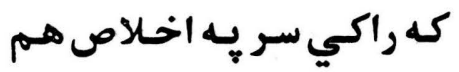
سـتا يـه بـلتــون سـوحي كـالي سري يه مر اد راسته غوحُحى له له

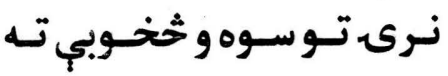

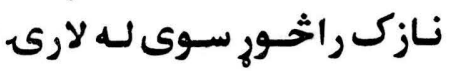

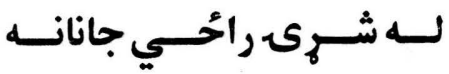

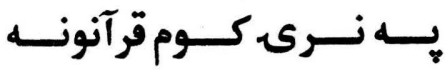
خيّل زوندون مه يه زاوال كى يَى

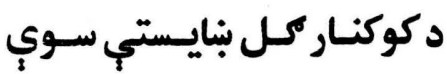
لالا كنجــوس نـهـ مـهـ يريـبردي

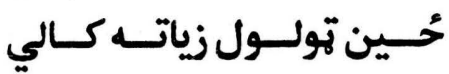
اوس مـه كاربي له سري هيلـ

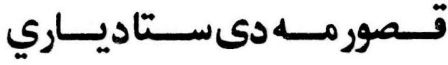

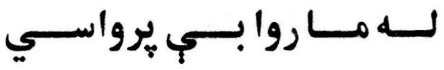
كه مه منظور نه كئ ستا خواست

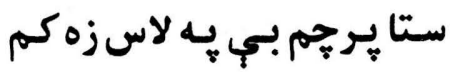
بيـابـه درمانـده سي هـئهورى

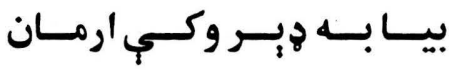

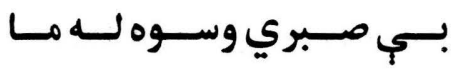

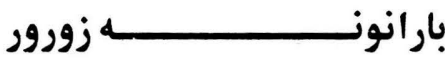

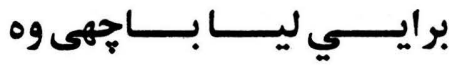

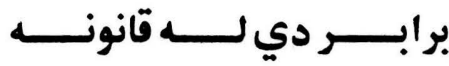
بيــابــه رانـهـ سـي دا شـيبي بلتـــون يـو دى زمـاـ غـاري

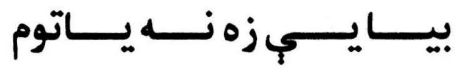

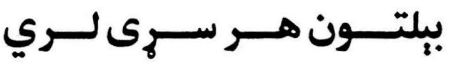
بس بسوليار دى حُحي دوكى لـ

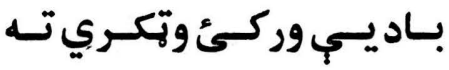

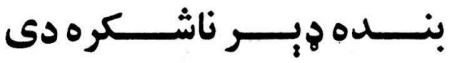

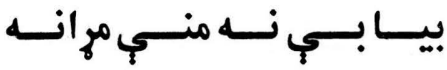

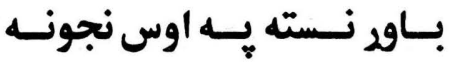

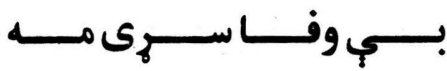

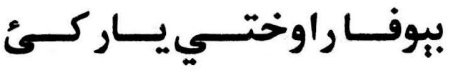
بابــــــــــه دى ســـوال منـــي بـي وفـادى حـال مـهـ وري

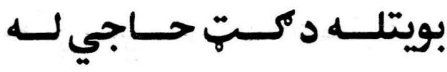

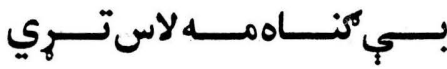

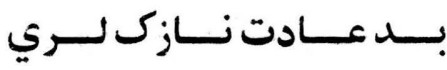

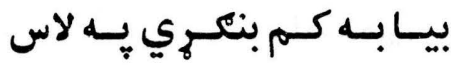
بنكـري راكسه مـات بـي نهـ كمم

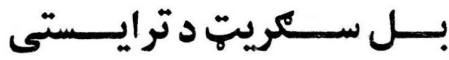


نه خورم هوودى زره مله دى شين

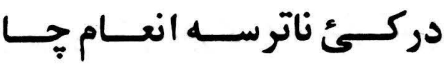

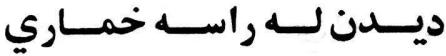
خي تلهي يرتهـ د لاس نه كئ

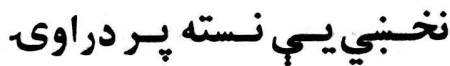

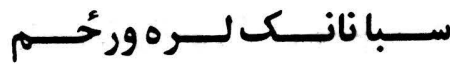

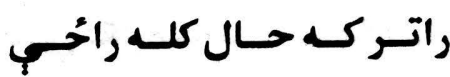
نـه سـوي مـري يــ ديـدار سـتا

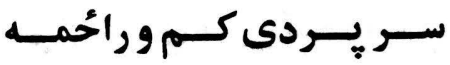

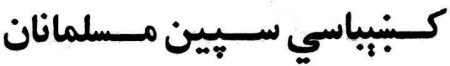

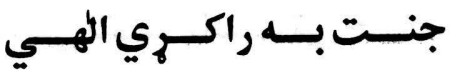

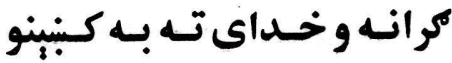

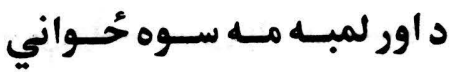

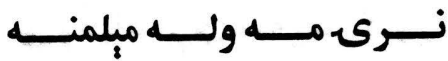
مـاد ببلتــون بـهـ اور سـوحُحي د زنـدكمى نـه سـته نـور خونس اوند

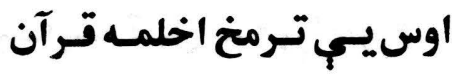

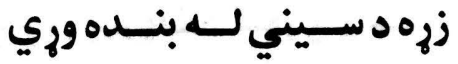

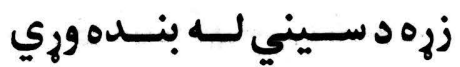
ستابـتــون كـران دى نـازكي

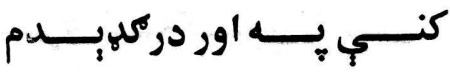
خداى د دبرباد كري غمازان

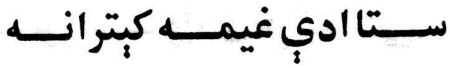

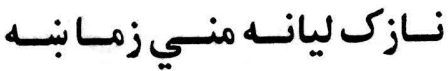

بــي ديدنـــهـ ولاري ســـينين

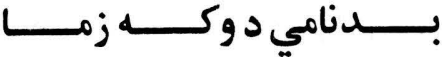

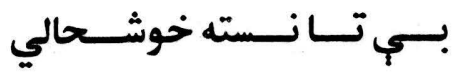

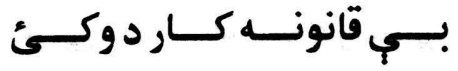
بــي وفـاسـوه شـين خــالى بذبخـي لانسـدي سـوم تـر غـم

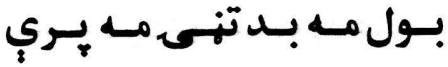

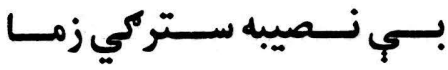

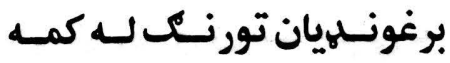

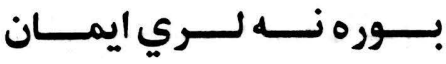

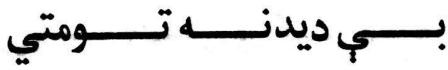

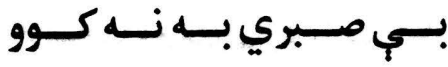

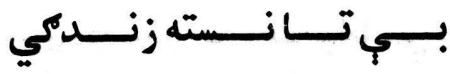

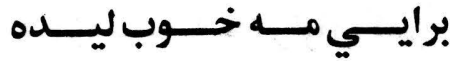

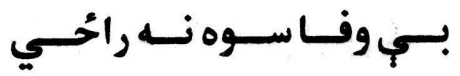

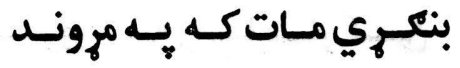

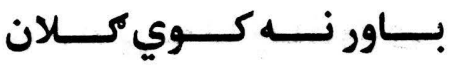
بيـايسـي كـــي ســرهــالي

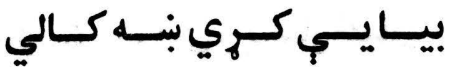
بربت مه ولوبدل يِ خوله كي

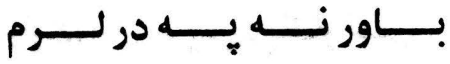

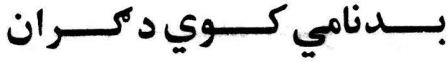

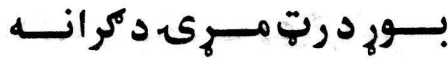
بـي قيمتـه مـه خـوري خولـ 
كاكرى غاري

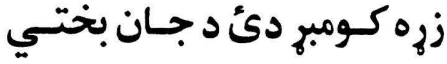
دحُان زوند مـه بـه زاوال كئ دئ

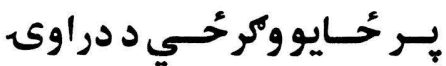

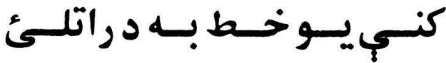

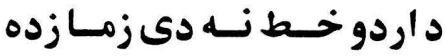

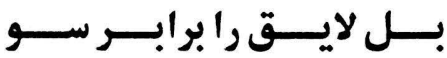

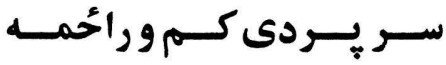
يسـر خــاك ورالــم د بـــاجه ما يبكى در ورى ستا خولي له

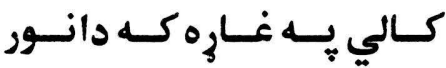
وجاتـــه حســال ور كــم دزئه

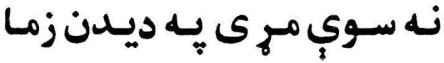

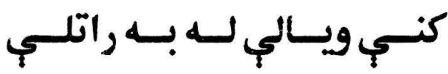
ياتـهـ زونـد مـهـ يـهـ زاوال كـئ زمـا يـر حُـاى كرحُحي اوس بلـه

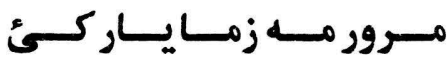

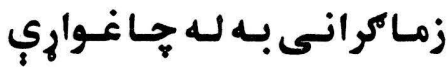

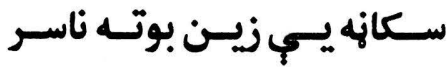

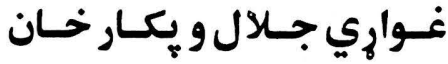

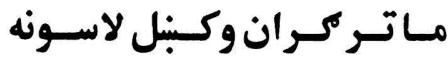

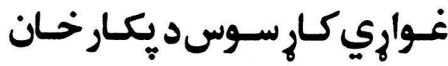

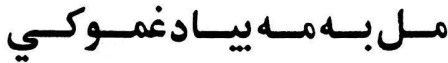

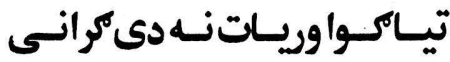

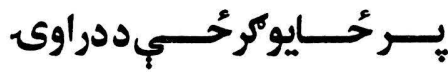

بهـار خــان كـــوي ســتـي بـي وفـا جـورى مـهـيـار كئ

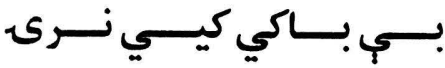

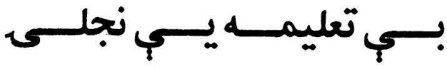

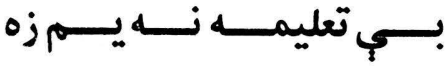

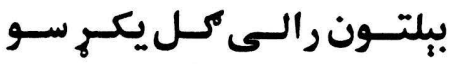

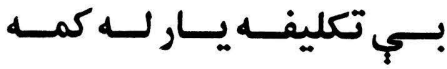

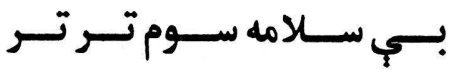
بـي صـبري مـهـ وكسه ديسـره

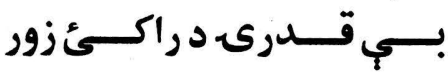

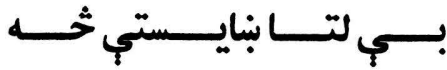
بــي نــصيبه ســـركي ســات

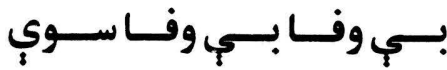

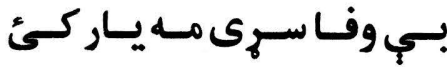

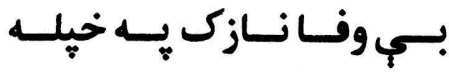

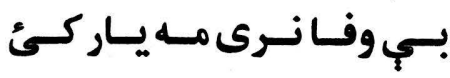

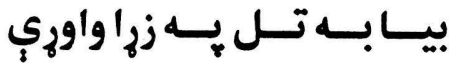
بيـرى يــروت دكــور يـر سـر

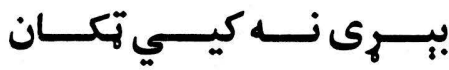

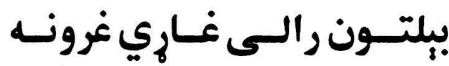

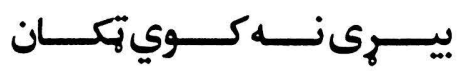

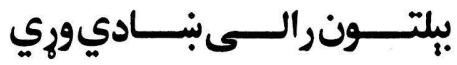

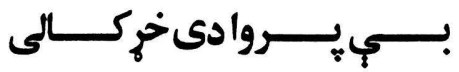

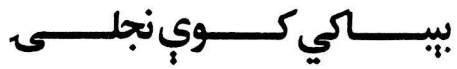




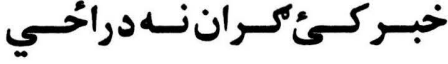

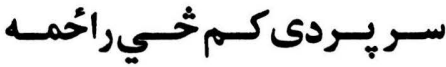

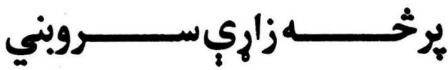

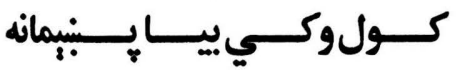

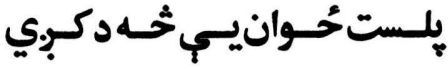

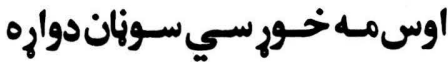

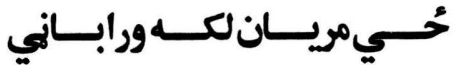

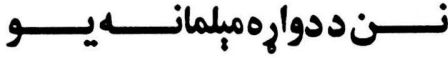
زوره هر هار نه دى خحي خلام كم نن مه خور سي سونان دواره د غـــو يـانْكي خـورم ناسـياله

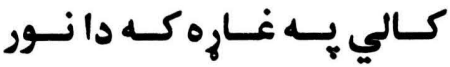

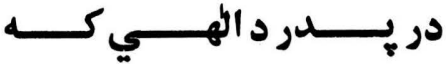
ثخي تلب لاس د يورته نه كئ اوس هب لارى كي خَي بنوده

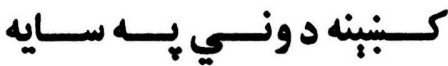

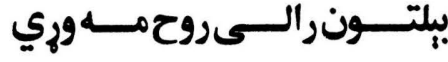

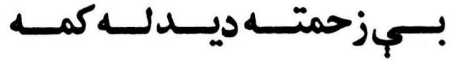
يــــادســتركي ديـاوبـــــــي

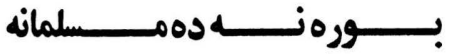

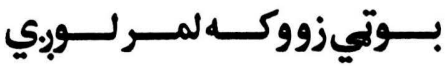

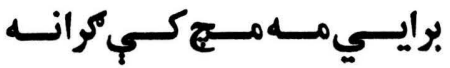
بنديجي خلاص كـ ستّاله نـاري

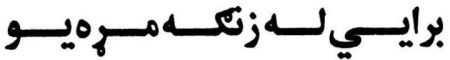
بــراي نـازك يـــ غــابن كـم

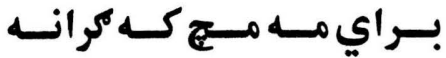
بـ قدرى د كـمبـي حاله

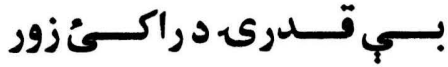

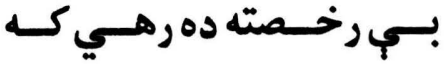

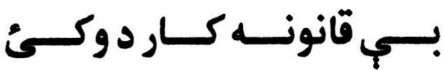

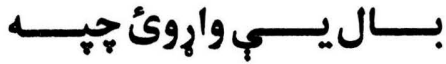

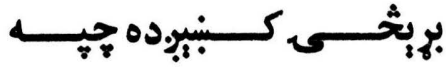
柴柴 


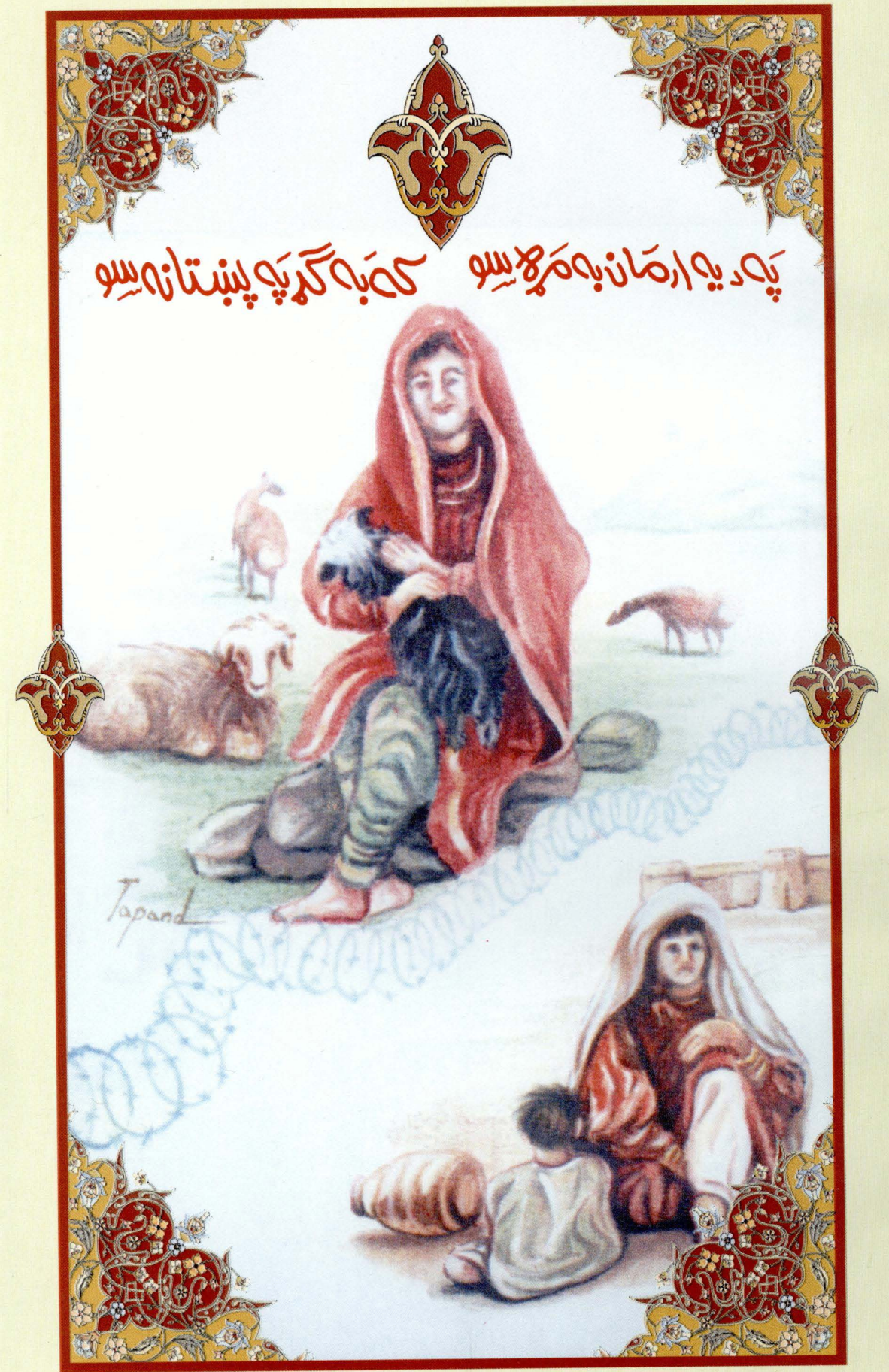




\section{番要}

نـن راته هيروت دى يـر بالبنت سـتاد نــــى بــزي جاركـل خــي راحُغلـي زمـا يـر لـوري

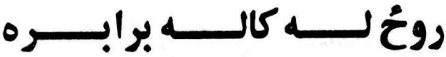
لنكون كران دى بيا به مره سي

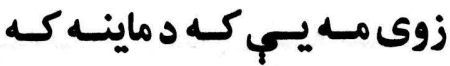

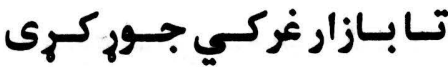

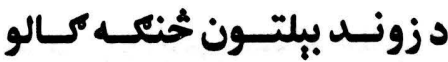

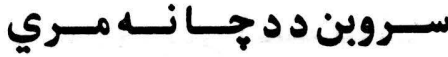

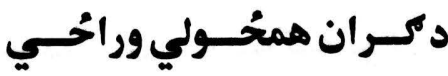

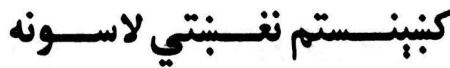

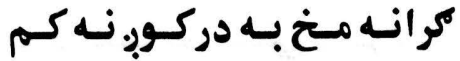
كشنى نجلس كسوره لـوى زره

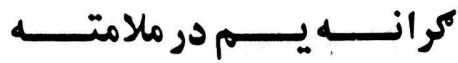

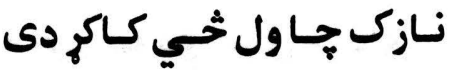

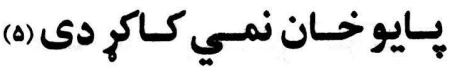

يـه خواستو مـه نـازك غوبنـت

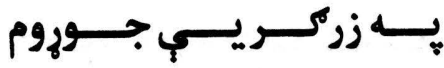

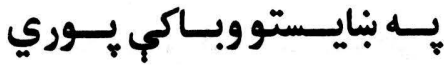

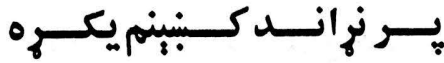
يـه حُحسوانى كي لنكـه مـه سي

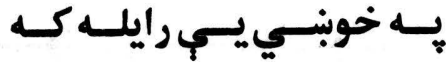

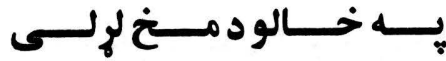

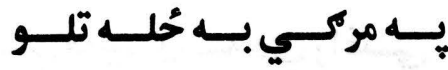
يــهـ مركسي مرونسه تـل مـري

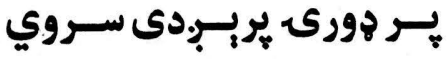

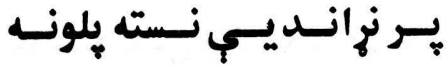

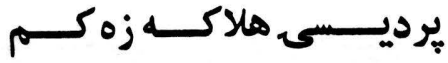

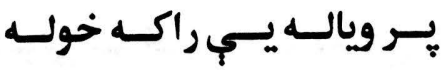

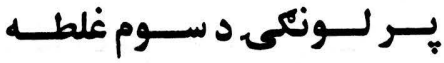

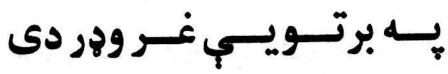

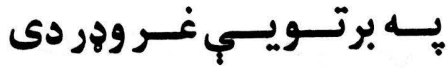


كاكرى غاري

ليـا هنـدوان كسالي ليـانجونــ

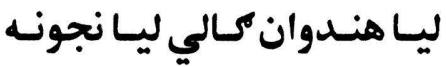
كـــور د تنـــك ســـــلباســنه غابن يب سيين بدن يبي تور دى

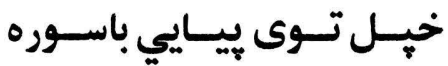

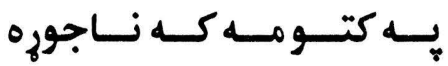

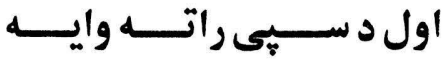

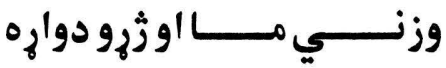
خداى به خير يبش كي نازكه

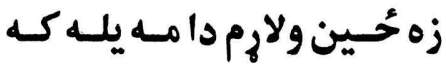

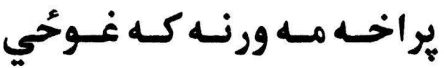
كـرده وريـبنبم ده شـين خـالو

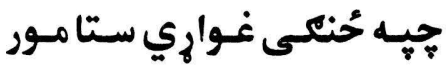

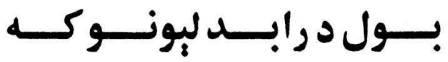

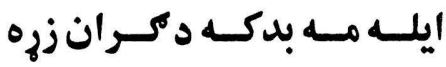
بــبـ قوليـان نـه دي راغلــي

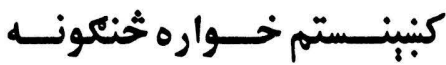

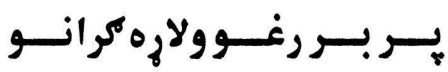

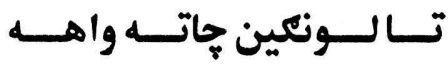
تـور يبكسى كـور ددى بجيـري خــولي لـه حُحسم د منــدوخبلي

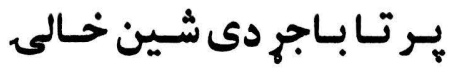

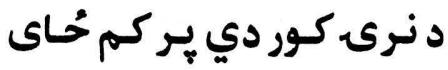
خدايسه زما جانان راجـوري

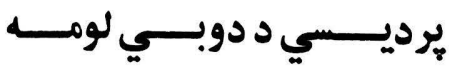

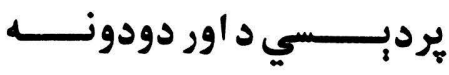

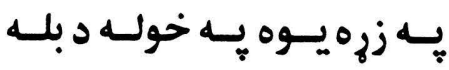

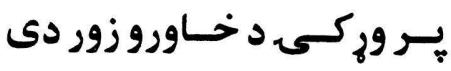

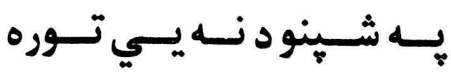

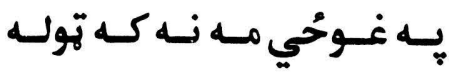

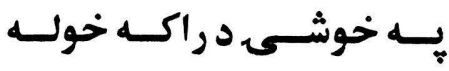

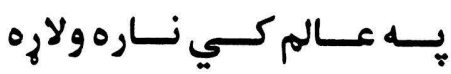

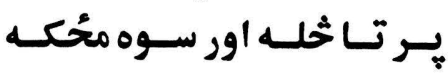

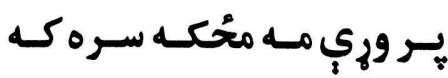

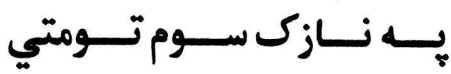

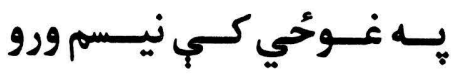

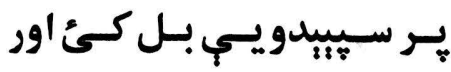

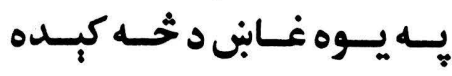

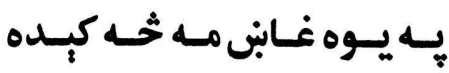
يـــر دراوى يـــي نـسته ثحلـي

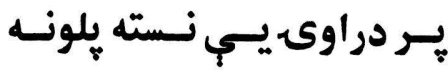

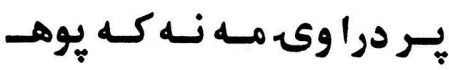

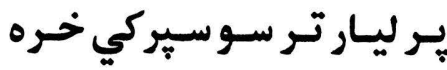

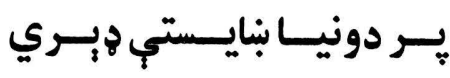

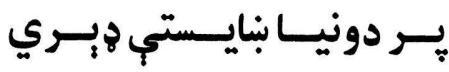

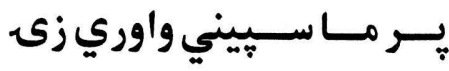

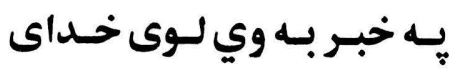
يــهـ دعـامـهـ اوبنــكي تـوكي 
ستى مـه كم كرى تـاوان دى

بـه ونـر غـم كـي مسه ويسردى بـهـ زونـد بـه بيـا راسـي نـازك بــهـ كرانــي زمهـادى ســروين

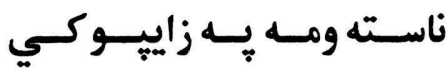
وركي اختـر لـه خوله درورم م

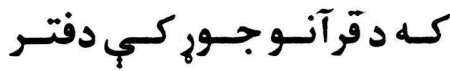

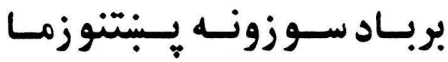

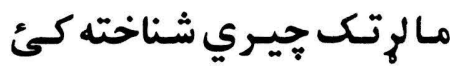

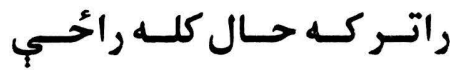
مـاول كَ اوس بــــره راحِي

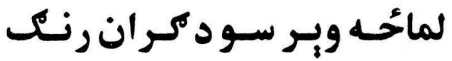

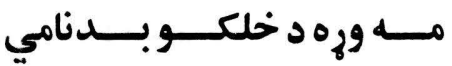

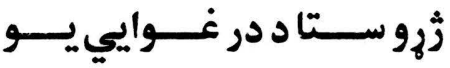

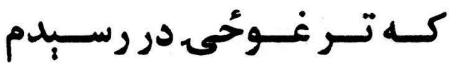
لبر. بريسان غـوحككي وه جحورى

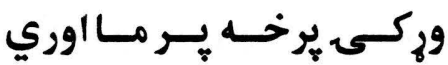
لاس ونـــي وري د باســوري لاس وندى وري د تور ستركي

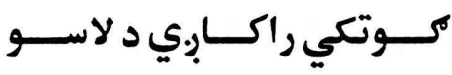

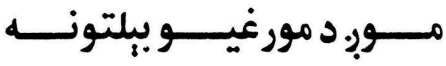

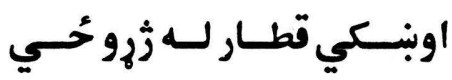

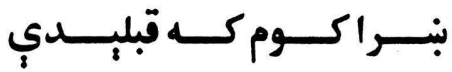

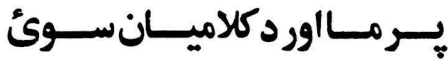

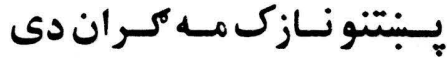

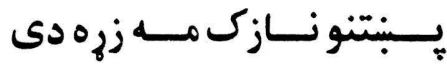
بـــه مركـــي د نسله ســي ورك

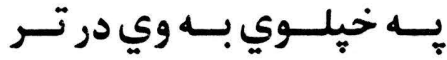
بام مهل وو د كر ان بـه بـبنو كي

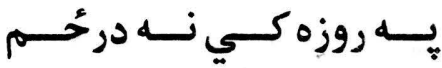
:

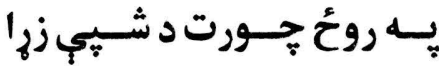

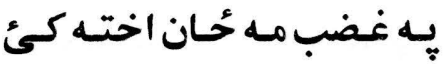

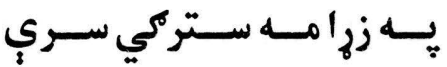

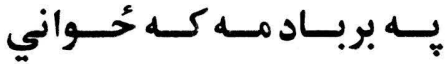

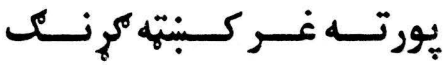

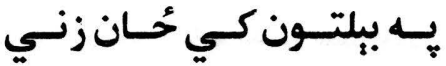
بردكــار درتــــه ير اتــــه يـــو

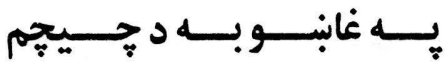

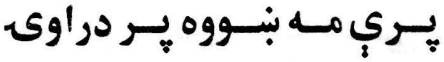

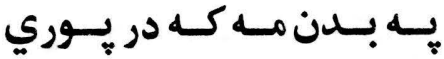
به آسمان كي غورزي ستوري به آسمان كي ستوري غورحي

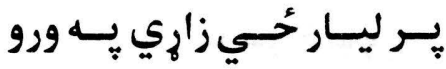

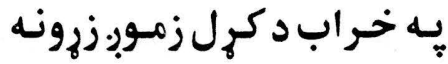

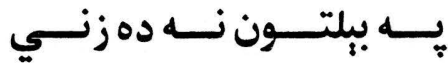

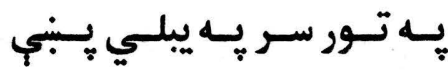

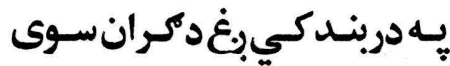




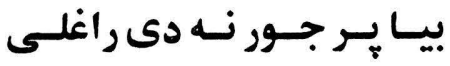

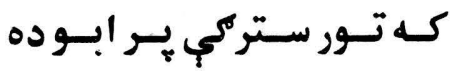

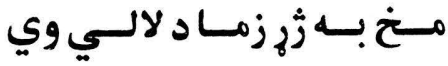

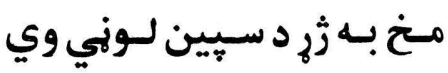

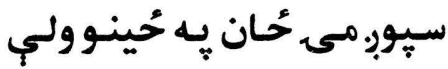

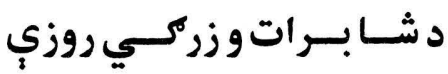

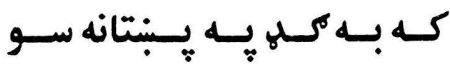

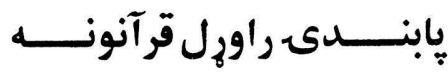
غم بـه دخود خور مـه بنايستي شـوكير كرم ديّر سـتابيلتانسه

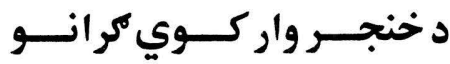

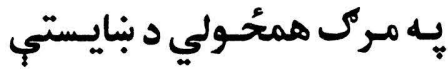

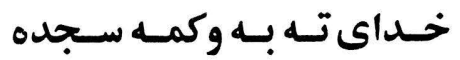

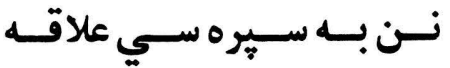

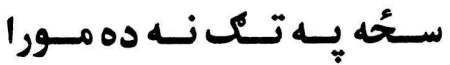

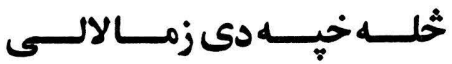

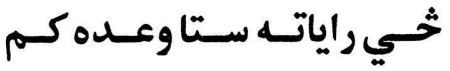

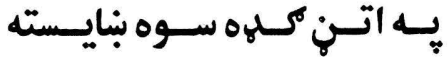

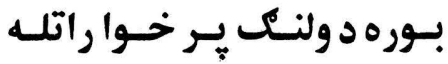

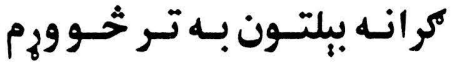
كلـى دي تــول سـي سـلامي نـرى بـاس كركسي دهيـاري

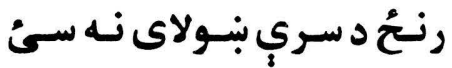

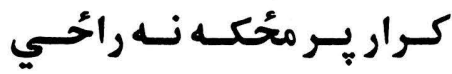

يري مه بنوى بي بنبي ملكرى

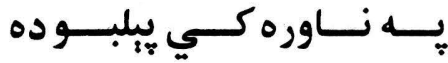

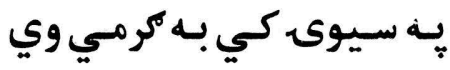
يـه سـيوى كي بـه كرمي ويس

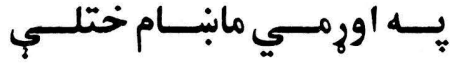

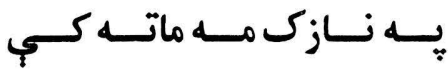

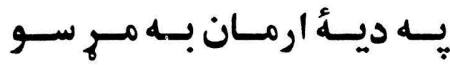

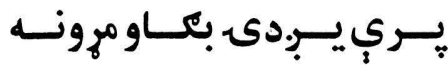

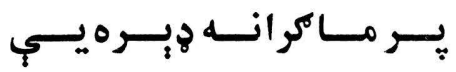

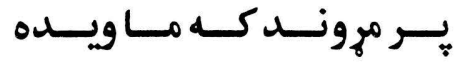

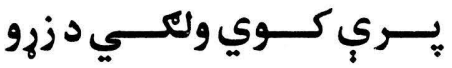

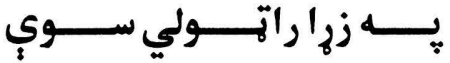

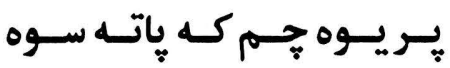

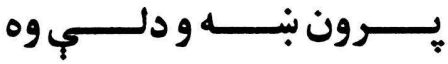

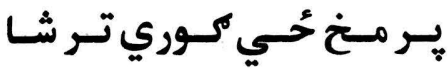

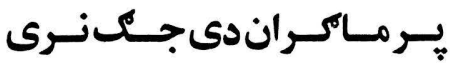

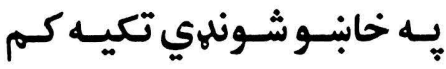

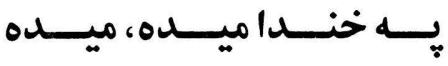

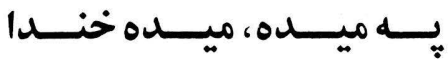

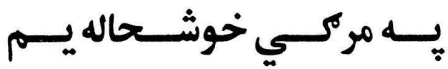

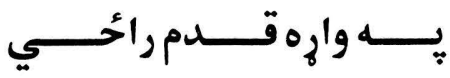

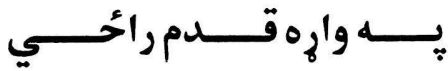

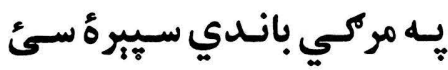

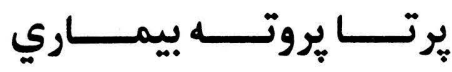




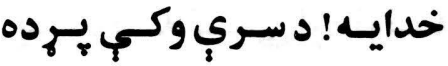

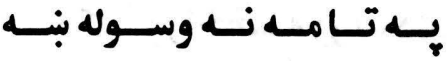

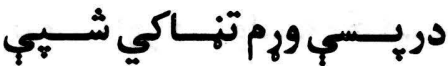
نــور ددرك نــــه دى معلــوم

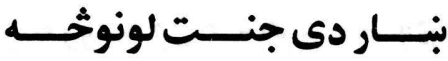

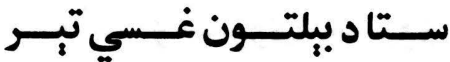

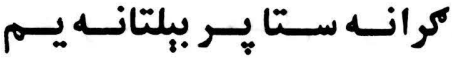

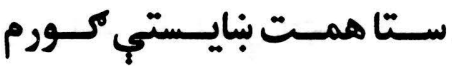

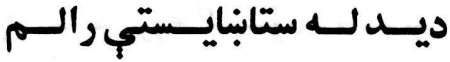
ديــنـن ديــار كـوي نبــــاروه

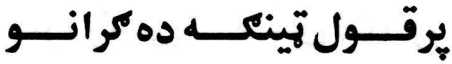
خــي مـهـ سـي لـه كرانـه صـبر

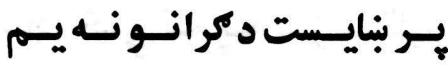
•به اخـلاص بـوره بنــاره سـي

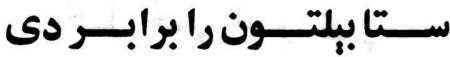

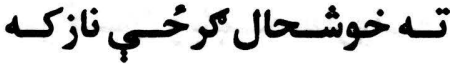
هيكي هجي خور كري هر تنلي

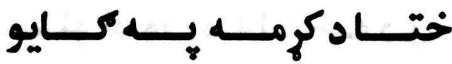
شــي نـزدي سـوي دونـازكي كهـول تهوله يـه مـا بوهـ تهـي تردي لياخدو سته خوشـحالي

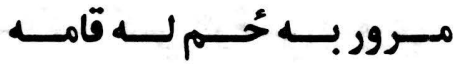
سـورسيجزمهاودكــرانزونــه

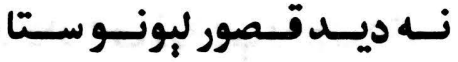

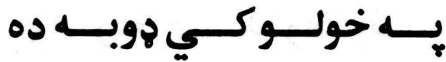

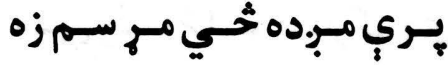

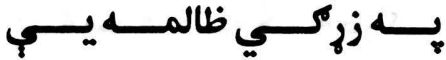

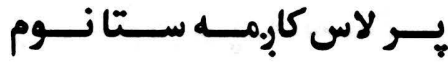
بـهـ كـي نهـ سـته زمـاشـناخته

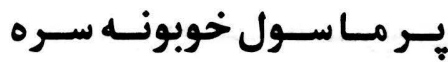

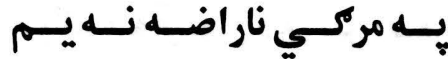
يـردى قام دى زهكي بنسورم يردى قام دى خـه كي غـوارم

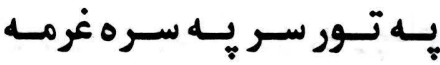

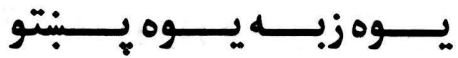

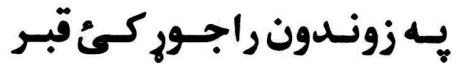

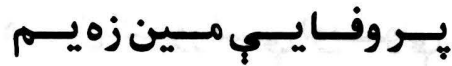

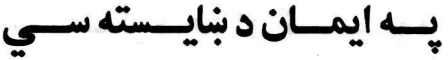

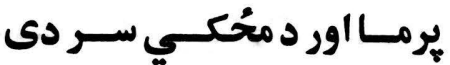

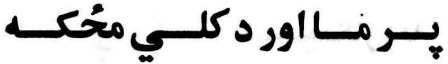

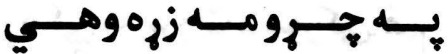

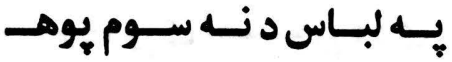

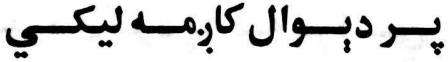
تـر بالبت مـه اوبنـكي توسي

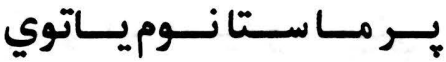

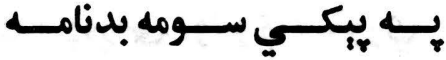

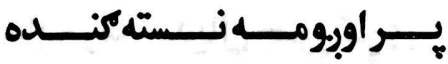

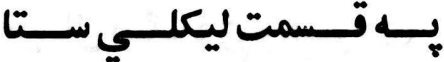




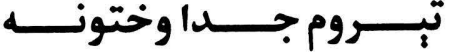

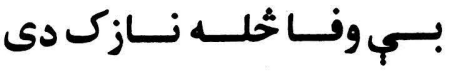

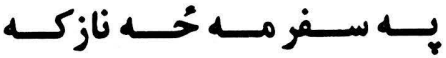

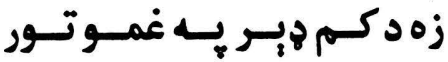

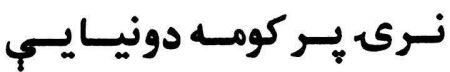

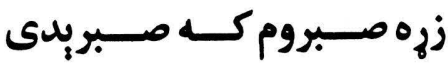

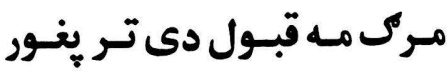

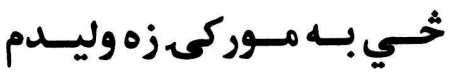

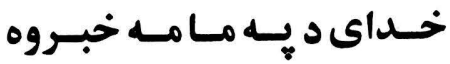

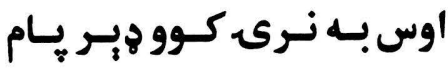

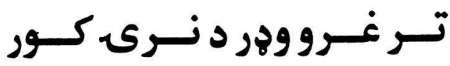

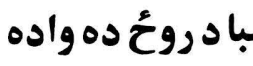

د بــلـ كـــور لـــي لويـــولي

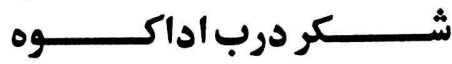

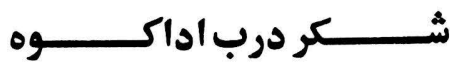

نــــاوكي وكــــه ســــــــارونه

زره كي مه يروت د موركى غم

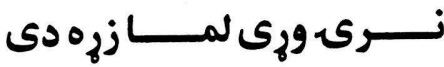

نور دي كرد يـه تبه مـه هـي

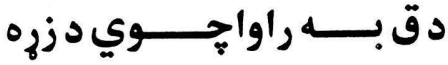

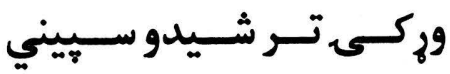

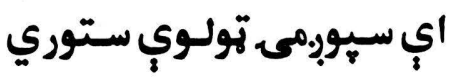

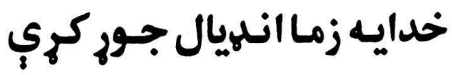

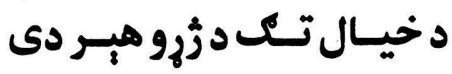

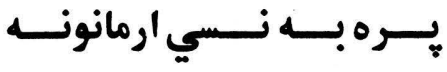

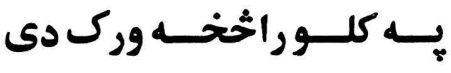

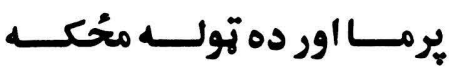

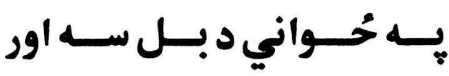

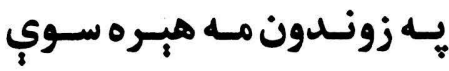

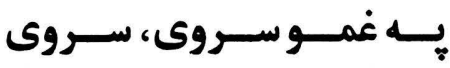

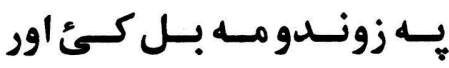

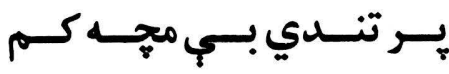

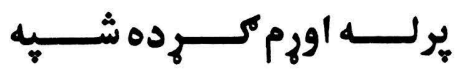

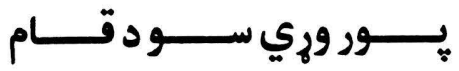

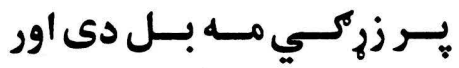

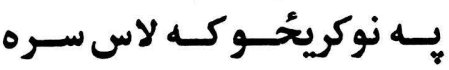

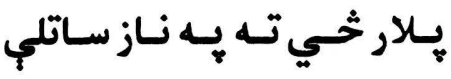

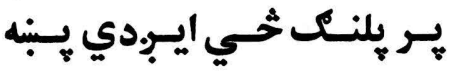

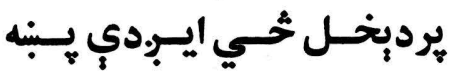

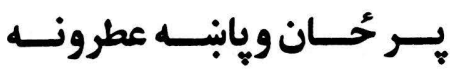

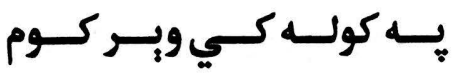

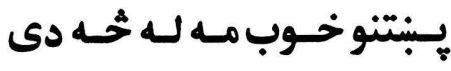
يـه كاله كي مي كران بنه سي

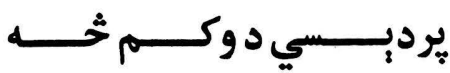

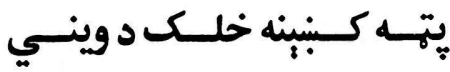

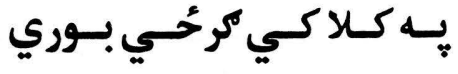
ير زيارت مه اوبنكي توى كري

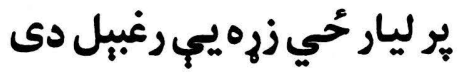


خــاى دوتـاكــــي لمــاويسر

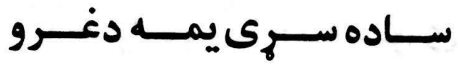

له موروه غواري د خحاى حـق

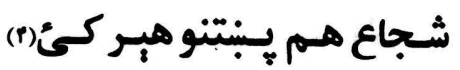
د شـجاع آس :به كي ورك سو بـا دمنح ثخله راغبـرك كـئ

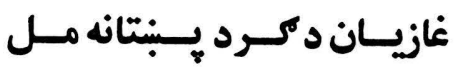

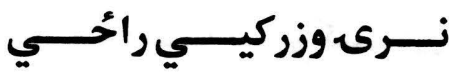

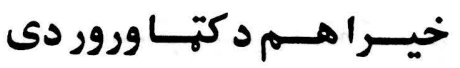

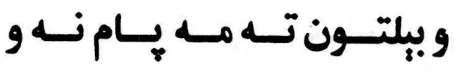

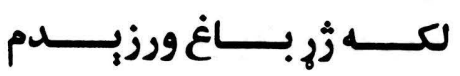
نن مه خيل بانوكان سره دي

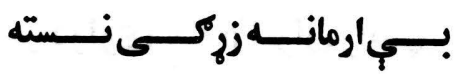
بهـ شابـه تور كورى راوري مـانـازك هـيـري شـناخته كـئ

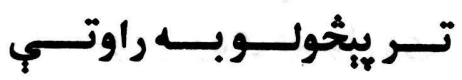
كر انسه غـم د بنـادى ورور دى

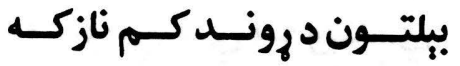
حُوان سرى دى منخي تور دى

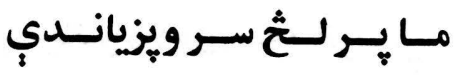
رنك يجي كل جانان يبي نوم دى سـا جاركل رالى د بـري لـه

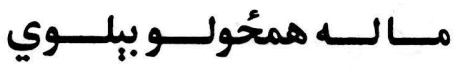
بـي ارمانسله زئكسى نـه سـته

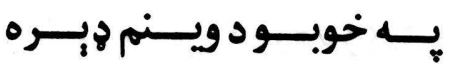

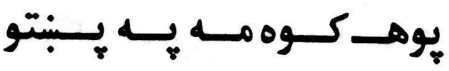

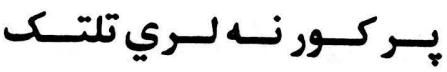

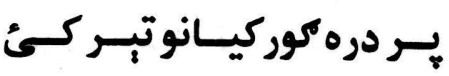

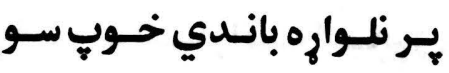

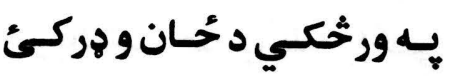

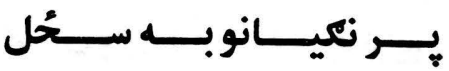

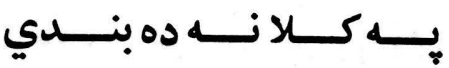

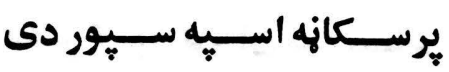

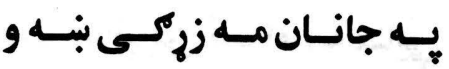

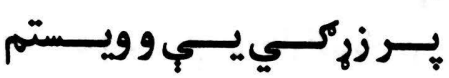

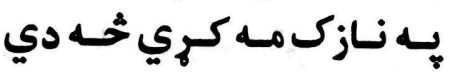

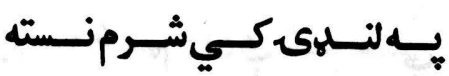
بنبي ورسوي كَئ ناوكي حَي

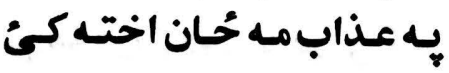

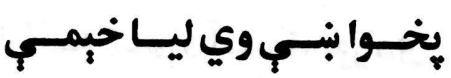
•ـهـ دونيـاكـي ظلـم زور دى

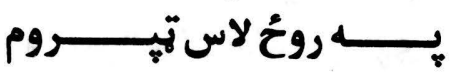

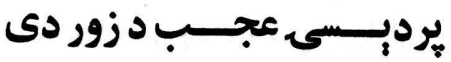
يــه هلكوانــوكــي راتلــــي : به هلكوانـوكــي معلـوم دى

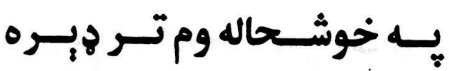

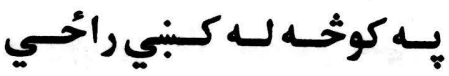

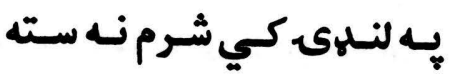


كشنى نجلمى كـوره لـوى زيره

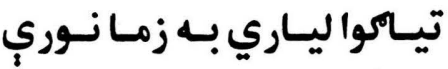
نرى نحيـام بيـاكركيـيـاري

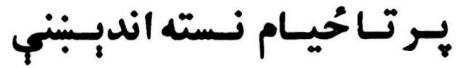

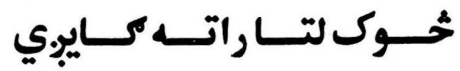

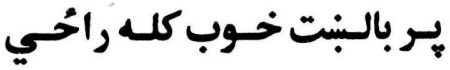
كران وى هـلاك لـ جـــايى

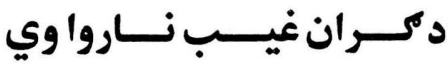

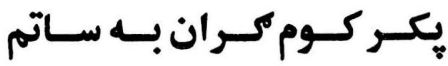
هُهـر مـانيجن حُحيـام لـه مـايجي

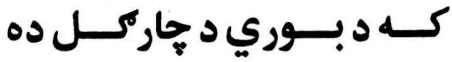

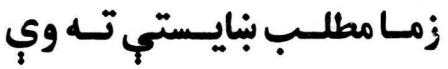

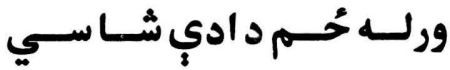
خالونــــــــمار كـــئ د خيــالو تى مه قرآن دى كه بهي وركم

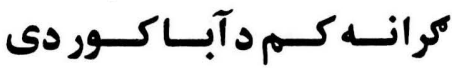

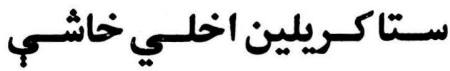

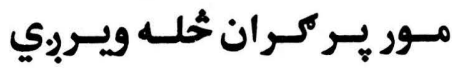

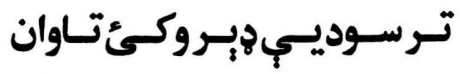
كـم لاحستق بــي انـاريوسـي جي ستر مـات سي د جـورى

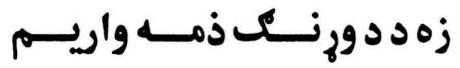

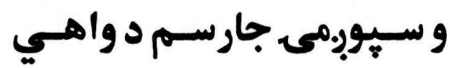

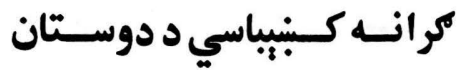

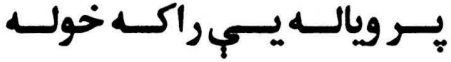

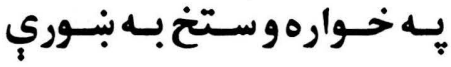

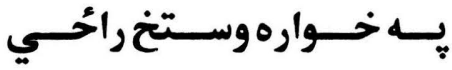

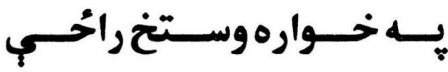

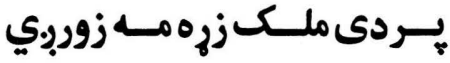

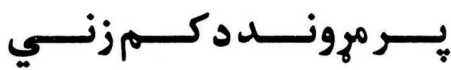

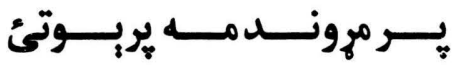

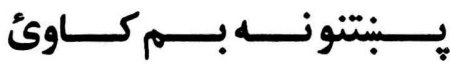

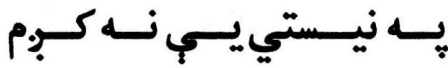

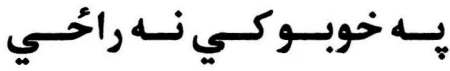
يرخيسزى ســايه د ســخرده

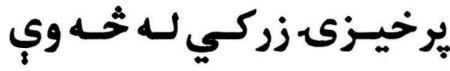
يـر ذراوى مـه دكـــان راسـي

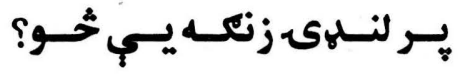
يـه غـوحُحي كي بـب لـر بـركم

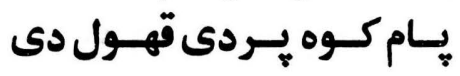
يـهـ غـوحَي كـي راسـه سـري

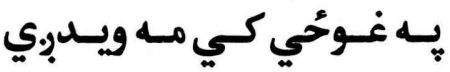

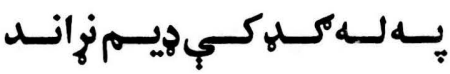
يرحيكــــ د دوي نـه نركوسي

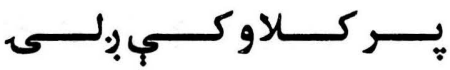

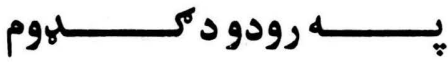

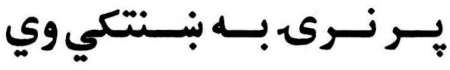

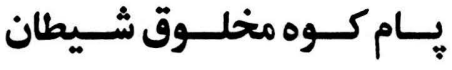


جكى دى دسره غوركئ سيركئ

ستاد راوى بوري بنـاره سي

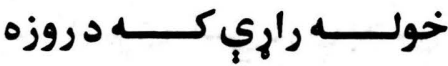

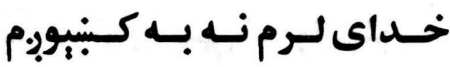

زووبنه

لاجه زوب

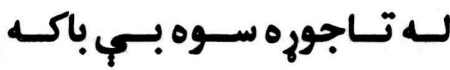

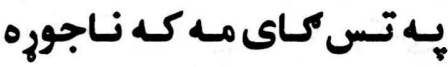

دغه جاول ثي ورور كران دى

نـازك بـه خـوب كـوي بــي مـا

يـر غابنـوز زمـاو دكـران جنـك

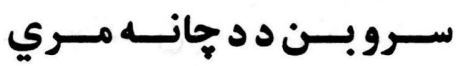

خوب كوم ستا يـه غوحُي كي

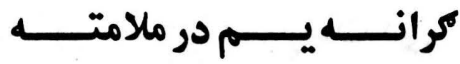

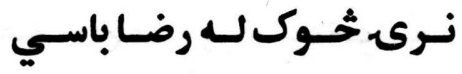

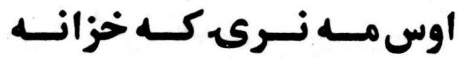

جي ستاكي نُحي سي د سبري

هـر نـرى ثمنكـــ مابنـام سـي

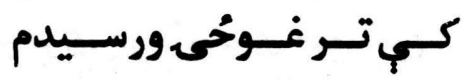

نن راته يروت دى يـر بالبّت

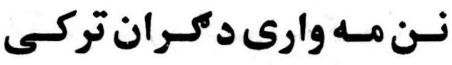

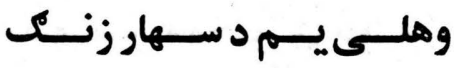

كـه لارى جـور بـه كي قيامست

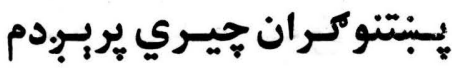

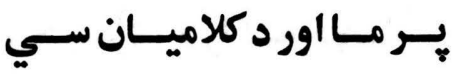

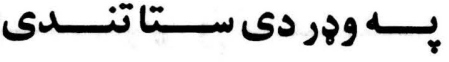

يسر مـادلتهـ مزكـه سـره سـي

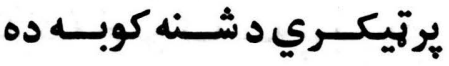

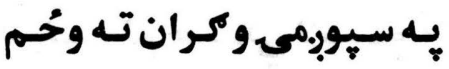

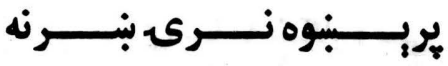

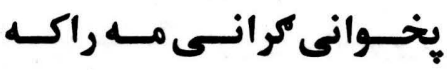

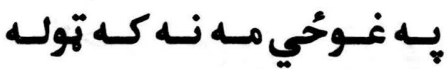

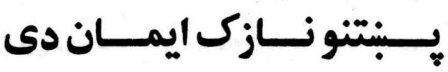

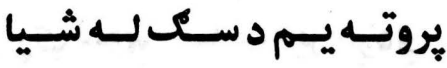

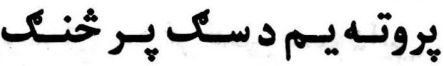

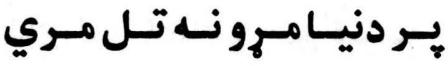
يتّ مه كه به تور تيكريسي

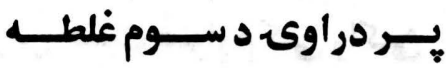
يـــر ورمسي مابـــام دراسـي

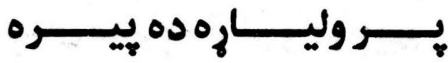

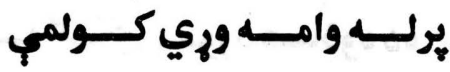
يــر مـايـو مـازيكر كـال سـي

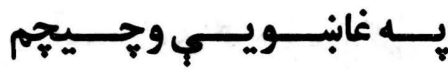
يسه سـوالومسه نـازك غوبنست

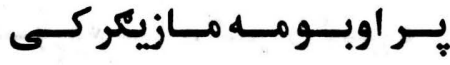

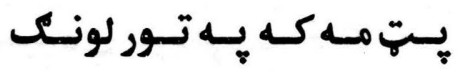

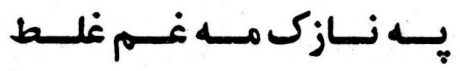

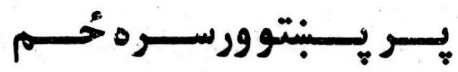
به كوثخه كي بوغ دكران سي 


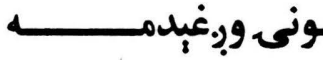

نــــى و رابـــانكي د جــــايب

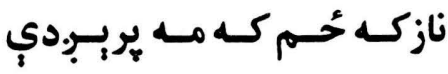

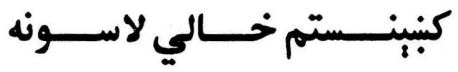
ك زوند وى بيا به بــكاره سي

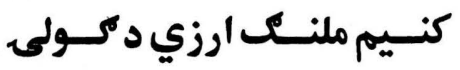

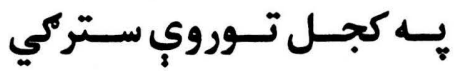

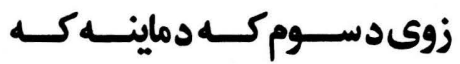
زازي لـونه نـه مـــ يريسبردي

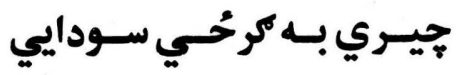
حُساى لـه راغلكسيـيـم كـبنينه

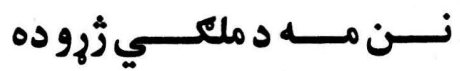
اوس جنـت غـوارم كي راكئ

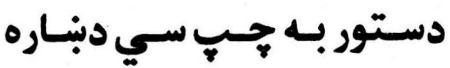

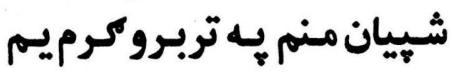

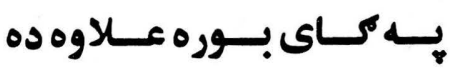

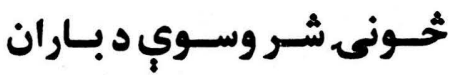

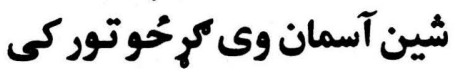
ستا بيلتون بنايستب كران دى سون

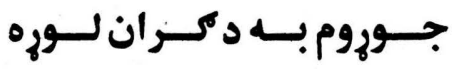

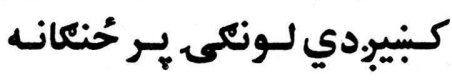

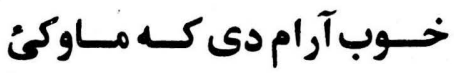

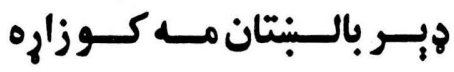

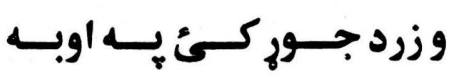

هـردى ملـك نــازك لـ كمــ

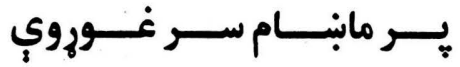
يسه كهــى كـي دري بجـي يـر دراوى يـيـي نـه ول يلونــ

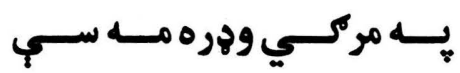

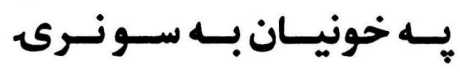
يـه غـوحي كـي راسـهـ روكي

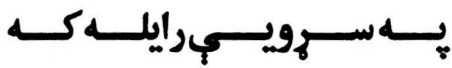

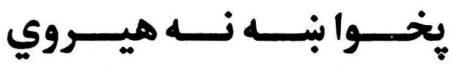

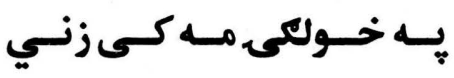

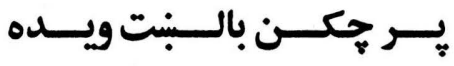

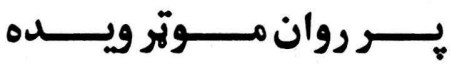
يهـ تور ستركي مه بارمات كمئ

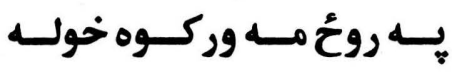

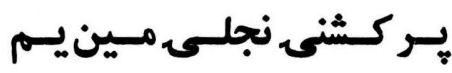

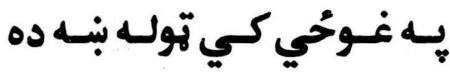
ير دراوى بـه نوندكي يكران ير نرى يج تيكرى خور كئ

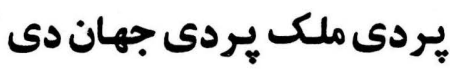

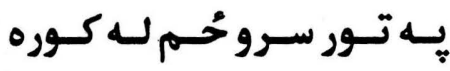
يـه تـور سـرمه وخـوري خوله بيـسلمى مه د سري خوله كئ

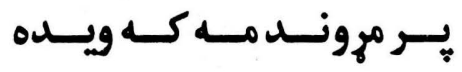

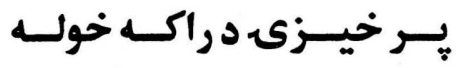




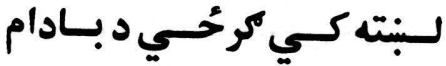
نـن مه خـوني دمكران بيار سي دخولب مه بوئ د سكريتّحي

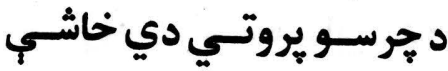

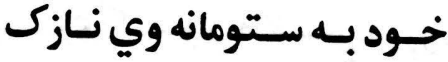

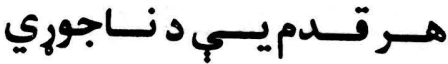

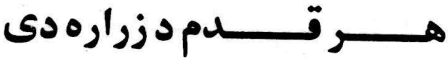

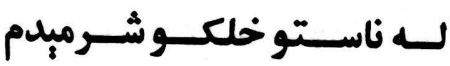
سـري دوردكـو يـهـ شـانيـي نـرى بنــد سـتالـه خـالو سـوم

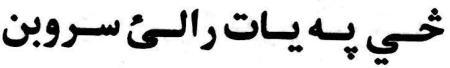

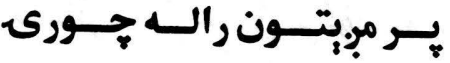

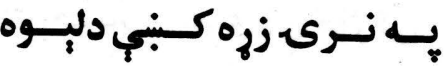

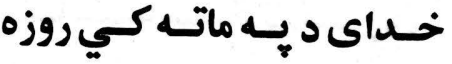

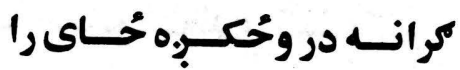

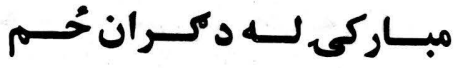
سـتاد نـرى سـونلهي جاركل ماته رايات سوى د سري خال

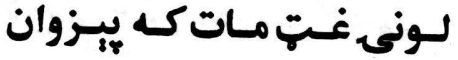
تر ماخداى بنه دى خُخب مل دى

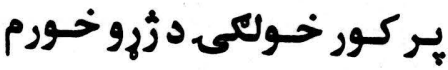

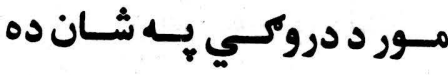

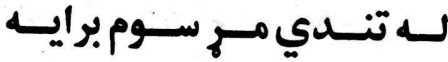
راحُـــه والــوتي تــور سـتركي

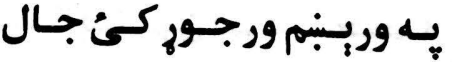
ير هر ترك نه زهره وليار سي

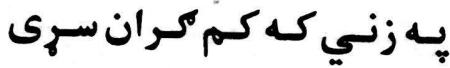

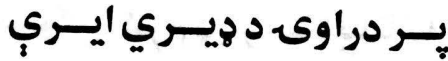

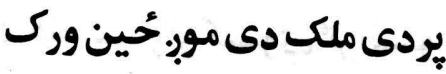

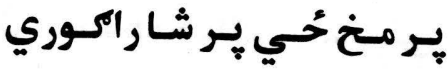

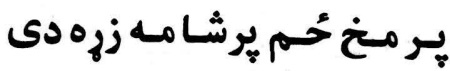

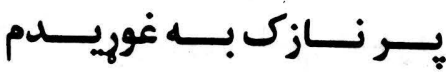

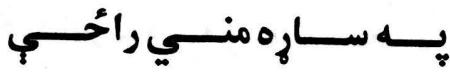
يـردي ملكس لـ بـه خحهـ يوسم يه حُنكون مه ثخرخ سوه ستن

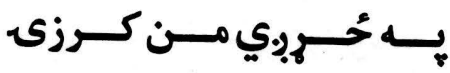

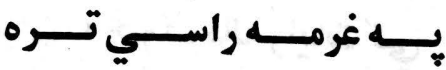

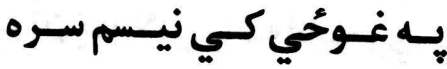

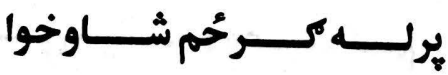
يــــلـوى عيـد خوشـحاله يـمر

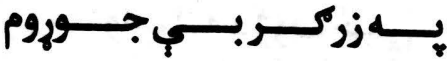

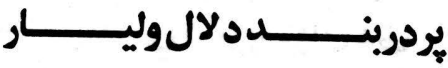

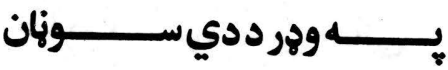

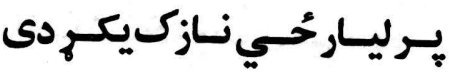

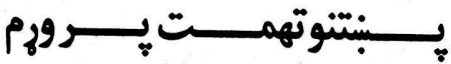

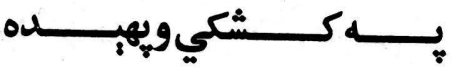

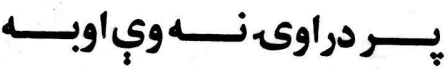

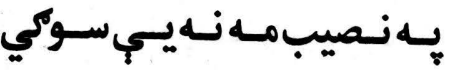




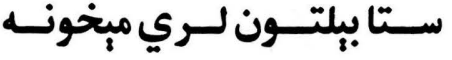

ير محُكه خوب هيري

غـم بـــ د خـود وريهـ بنايستي

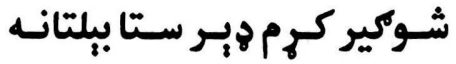

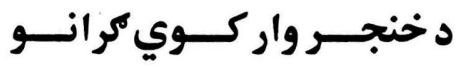

ير مرك همحُوكلكي د بنايستي

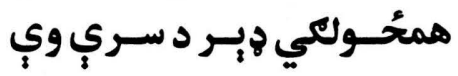
خدايـه مركـى راكـي جــــوره

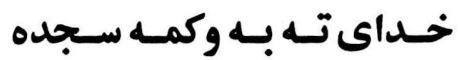

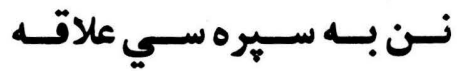

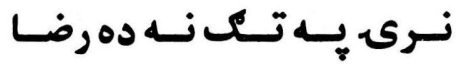

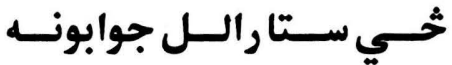
كران به خورك ماله رايات كي كـران يـهـ لاس راتـه كايســ بري

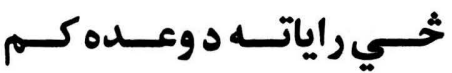

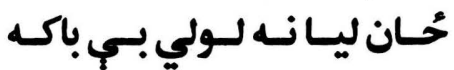

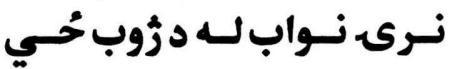

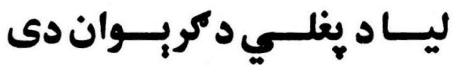
لله جـا يـيـدا سـوه شـين خـاله

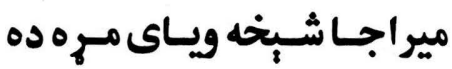

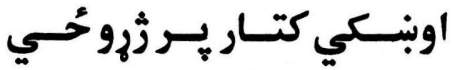
بغ ن دكران دى ورتلاى نه سم

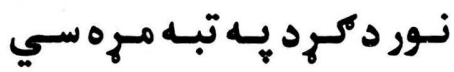

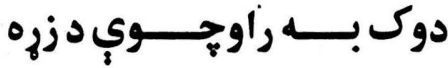

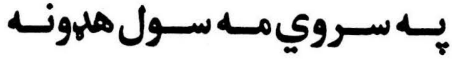

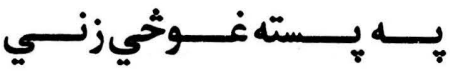

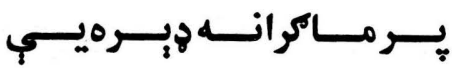

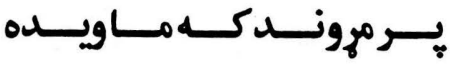

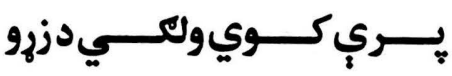

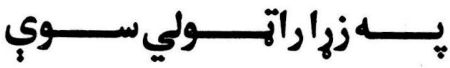

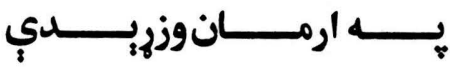

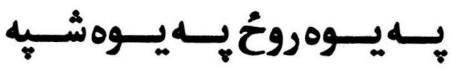

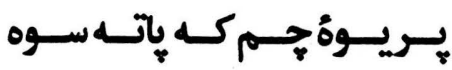

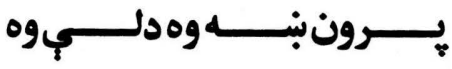

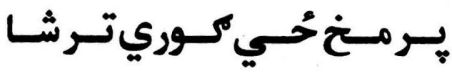

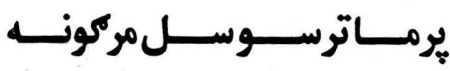
يردي خلكسديخداى يُخيخ

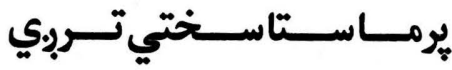

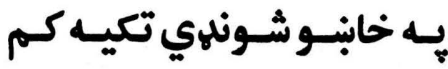
يـه غرمسه كي يسي خوله راكه

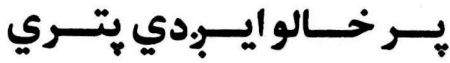
به دونيا كي خوند د قرآن دى

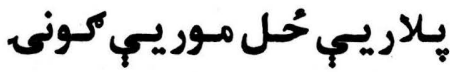

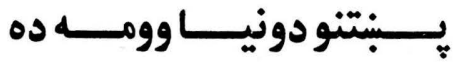

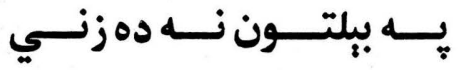
يـر كشني او بـر لـوى وره سـم بـهـ كلا كي مـه كران بنـه سي

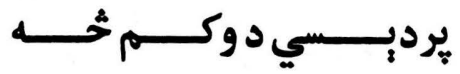


كه نـازك سـر غـواري ليـا هـم تنــى زمــاخـواري يـهـ وسـو

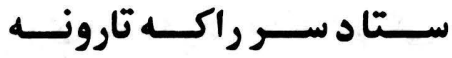
و بـلتــون تــه مـهـ بـام نـه وئ

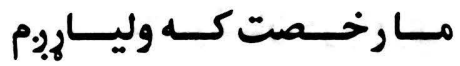
مـاززل ثخـي بـه جــايـاد كري

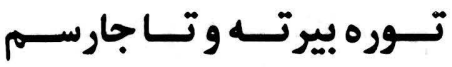
زمهـور. وزلـه د خـــاى وكـي

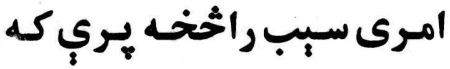
امرى سـب مه حُني يري كَئ

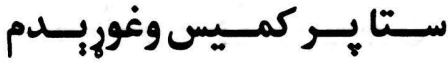
جــي سـتر مـاتكي د هـورى

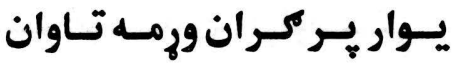
نن مه خيل بانهوكان سره دي تــود دى والــي مرغــي لمـــر كـوهى راواخلـه لـه بـاورى

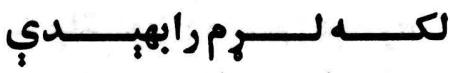

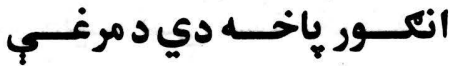

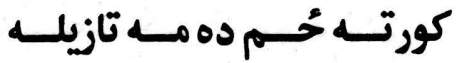
بانـلـي مــرم كـهـ د بــاور دى وركـى مسور نـه دهواوكـي

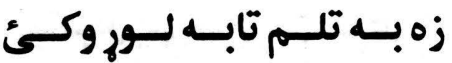

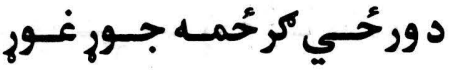
د شيب خوكس غواري صوفيان

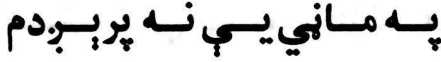

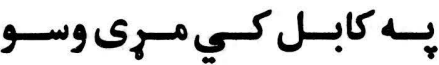

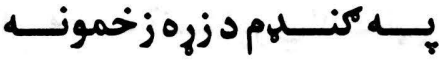

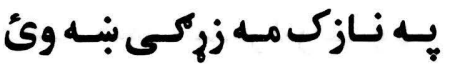

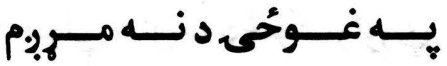

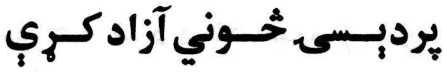

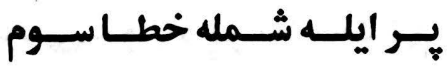

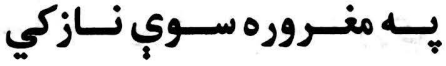
:هـ سـينه مـه لاس وراكسبي كـه بـه سـينه مـه لاس وركبن كَّ

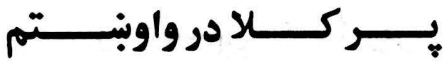

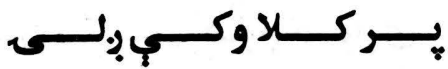

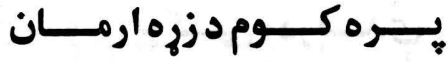

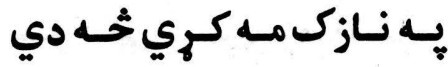

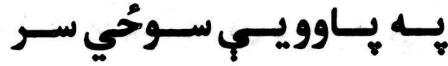

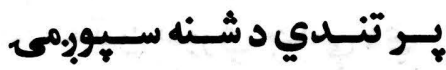

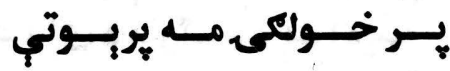

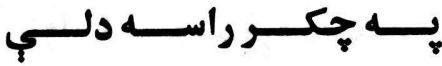

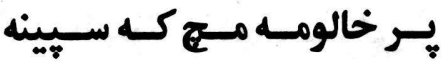
بـر خيـزى دنسازك يـل دى به كالبوت كي جـوره كركي

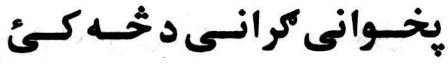

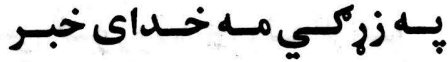

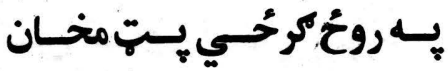




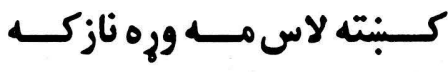

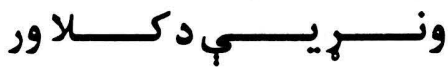

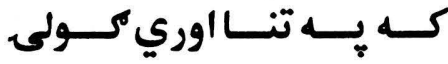

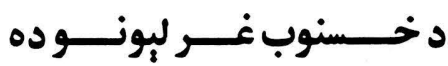

دخولب حال بـد دُحوك راوري

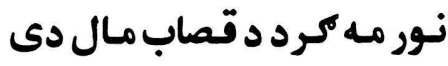

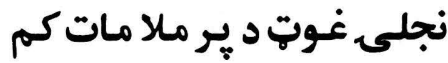

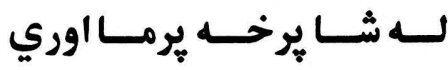

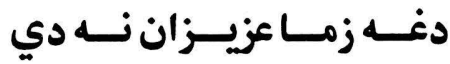

كـم لايستق بــي انــاريوسـيج

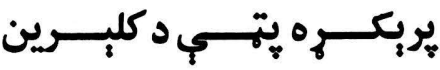

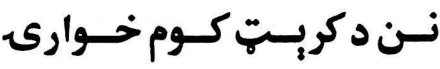

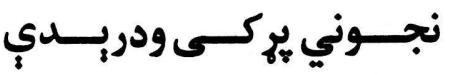

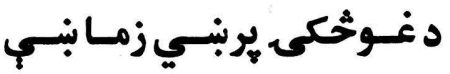

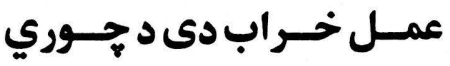

زماء يـهـ تـن يـوري جـامي دي

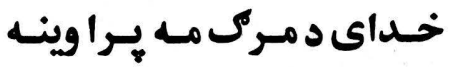

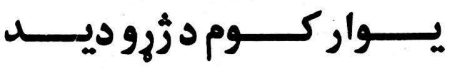

ماحُحسـ والــوتي تـــور سـترومي

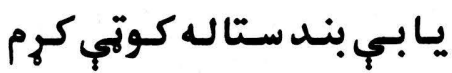

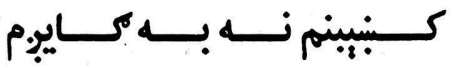

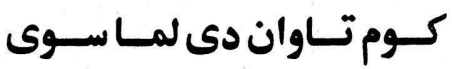

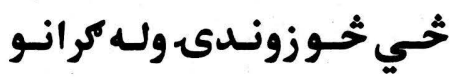

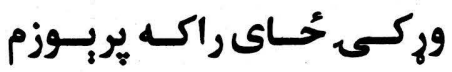

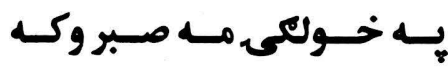

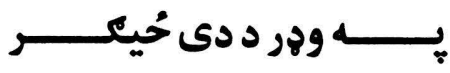

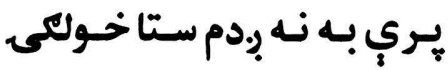

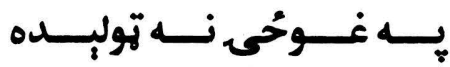

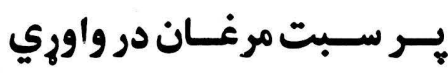

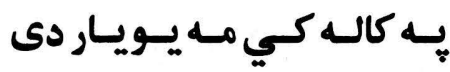

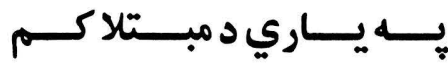

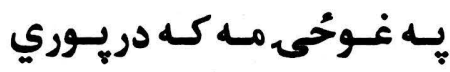

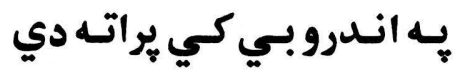
يـر حُحيكـر دي دوي نركوسي

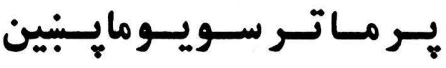

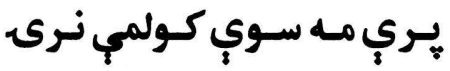

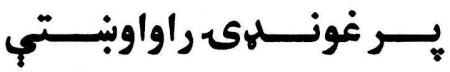
يـه كي كرحُي سينيني خهولي

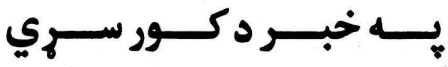
يخـوانى نجـوني يـابني دي

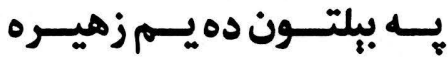
يـــر دنيــاكـي نـسته خريسـد يـه قسمت خـي نه وي سوكي

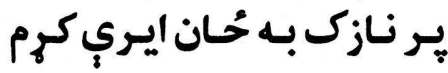

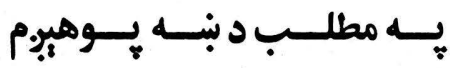
يـه تيكري يـي منخ بـتِ كرى

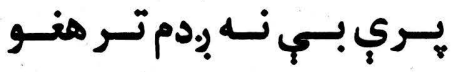

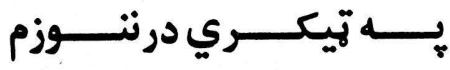




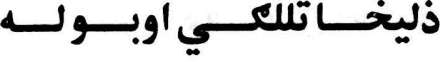

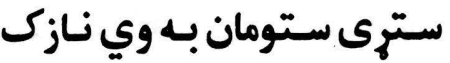
وركى د خـولي هـه خنـدا يـور

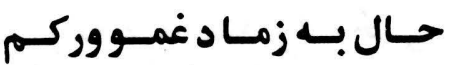
زه بــهـ سـتا دليـاري مـل سـم قيامـت ليـا هـم نـه دى معلـوم د خــداى بـه روى نـ تمكيده

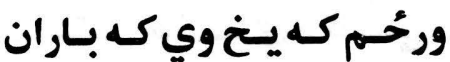
كه دول وإبرى زه بــيـام جـار

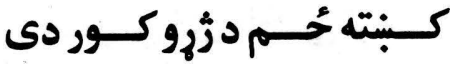

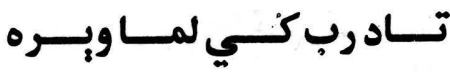

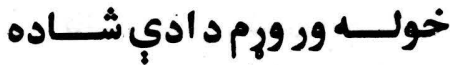
كه زوندوئ بيابه بنـاره سي اوس مـــ دبنـمن بــولي جانـان خولـ شـلومى دى د باسـوري

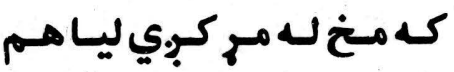

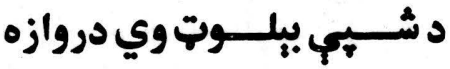

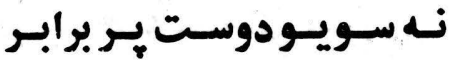
غوت يّكى بنايستي ستادى

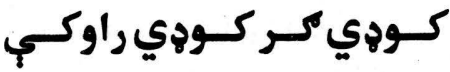

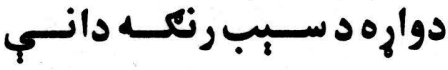
ننيجي خوريكي ده زما خوله

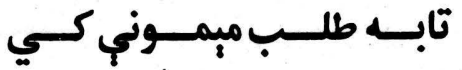

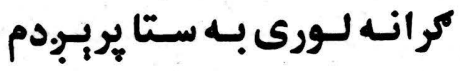

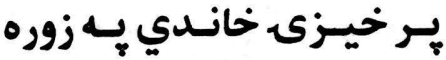

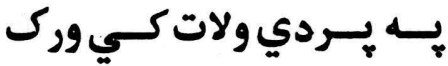

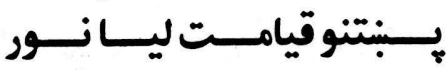

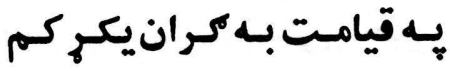

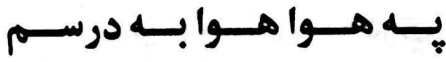

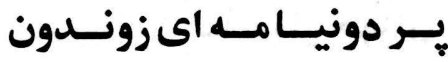

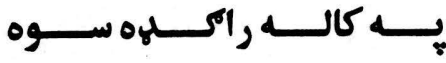

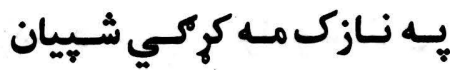

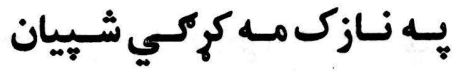

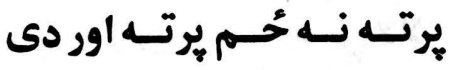

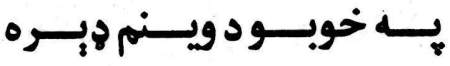
هودركساه د سـيـين خنــدا ده

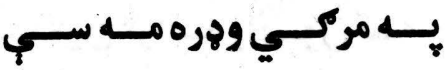

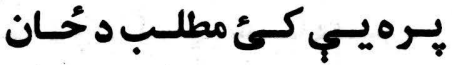

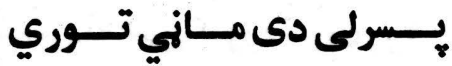

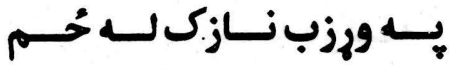

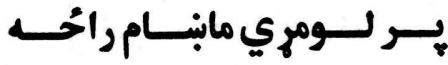

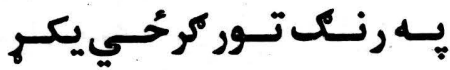

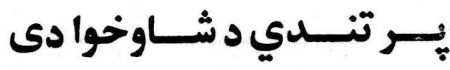

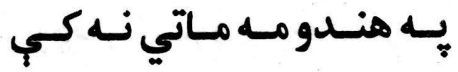

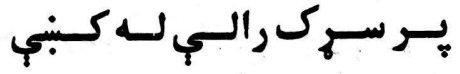

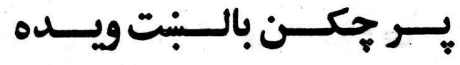
يــــلمى دى خلــك كـبني

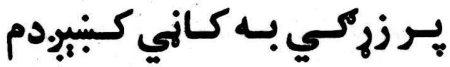


كاكرى غاجي

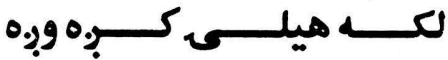
خلك وياى ير كران مه وره هيغور

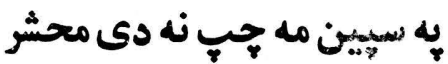
دمـوريـي مـن اوبــكي راحُبـي

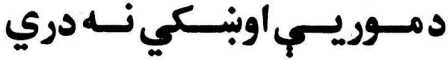
ستا د بيلتون شُنه سول حُوز ان

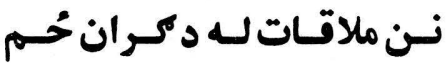

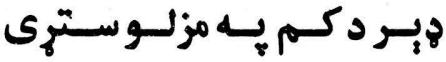
تـر داسـيـيـار بـي ده نبستي

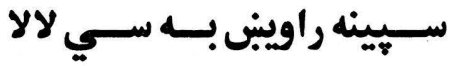

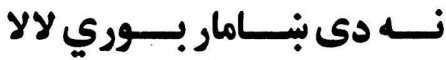

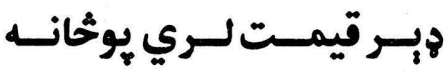

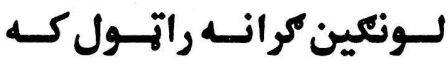

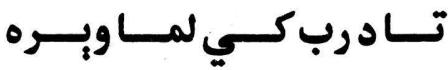
كشنم نجلم كـوره لـوى زره

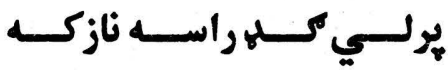
خلك ويايي شيخان دي لوانه كـران بـــ لاس راتـــــــيري

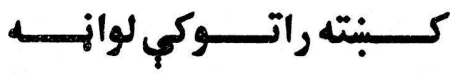
كـــوديكر كـــودي راوكـــي كــــــوى سـتا حُحسي سـروبني

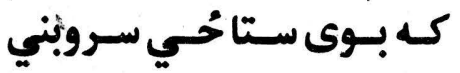
بسر مساكـ جن كسابريكساوين كـ جن حـق لـه سـبابيـايسم

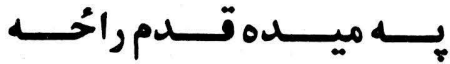

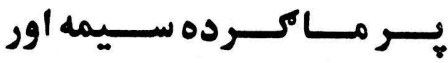

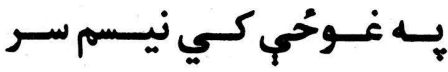

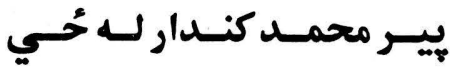

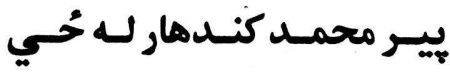

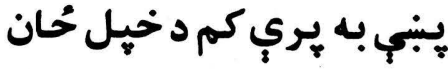

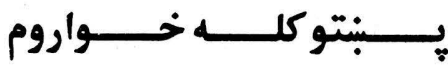

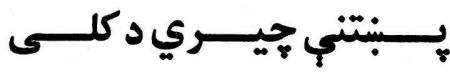

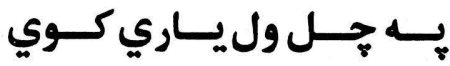
يــروت يــي دى ملخـى ترشت

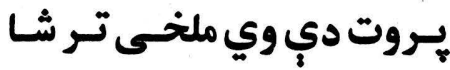

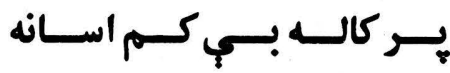
يه غوحُي كي مه حُاى جور كه

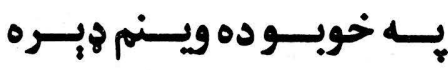

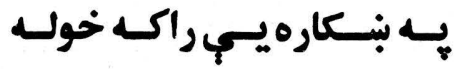

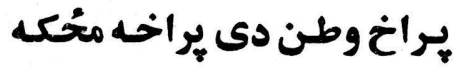

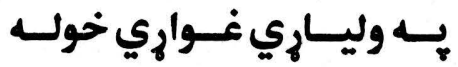

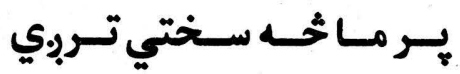

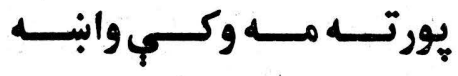
يــه هنـلدو مــه مـاتي نسه كـي

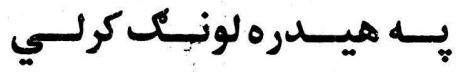

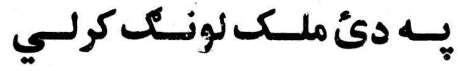

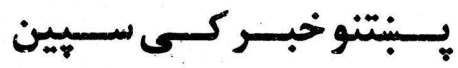

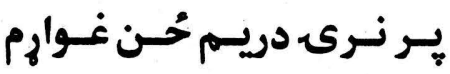




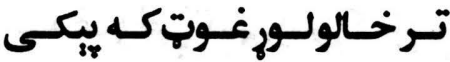

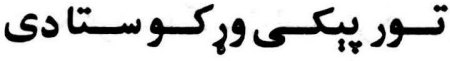

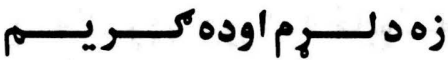

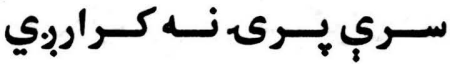

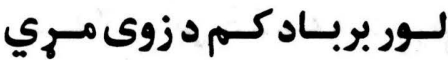
كل زما دوربين جحيخ لوكى لاسو

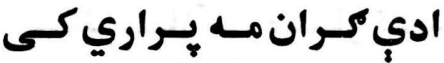

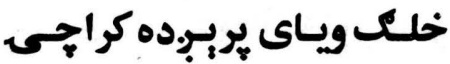

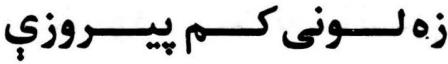

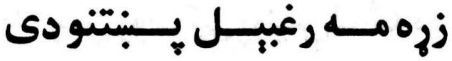
جانان نه راحُحي سيبدي سوي

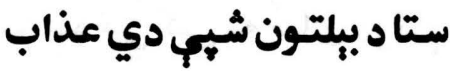

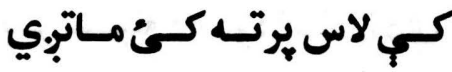
خيل مطلب بره كوي نجونه

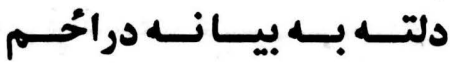

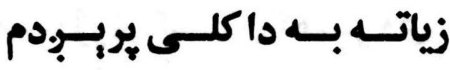

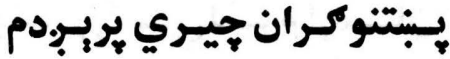
سـتركي دكـران لـه كيلـويسم ستابه خاوري خوري خالونه

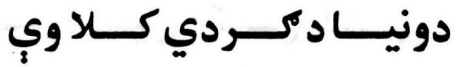

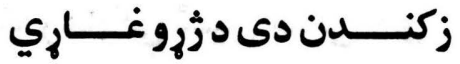

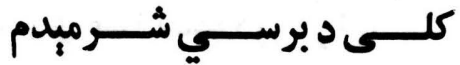

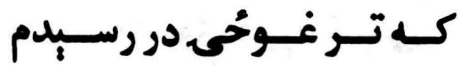

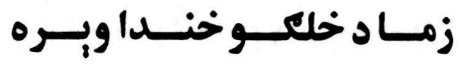

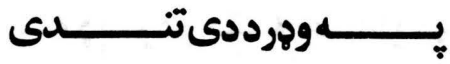

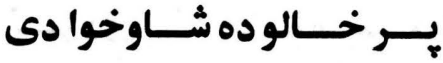

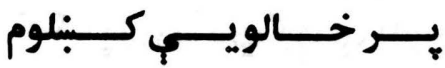

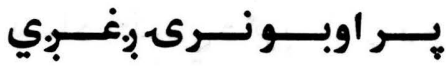

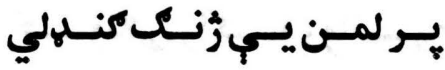

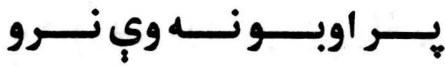

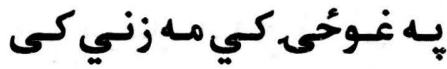

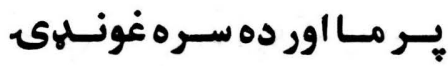

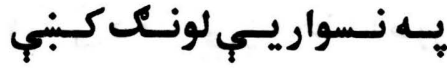

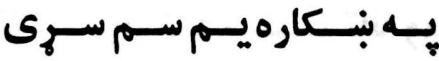
يـه زرا مه ستركي سري سوي

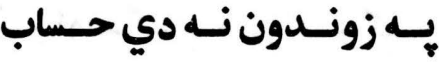

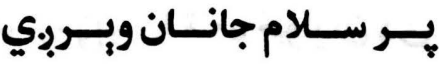

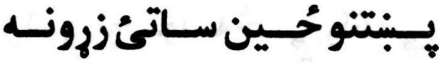

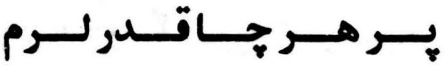

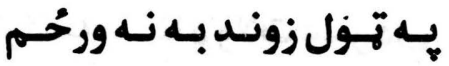

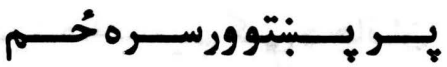

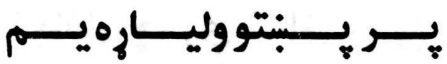

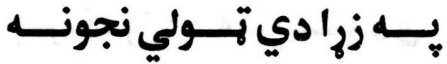

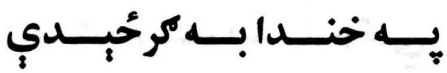
يـــه اسـمان كـي مرغـان زاري

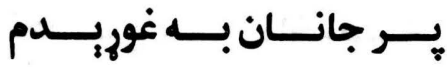

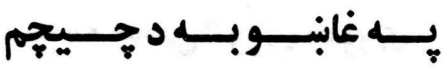

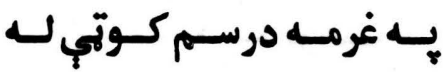




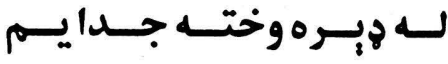

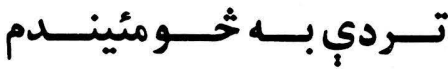
خلك يل زن دي كوري يلونه

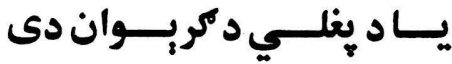

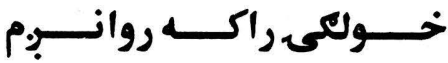
دخور يجي رود اوبنكي راحُي

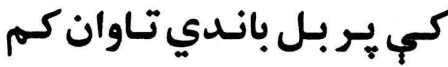

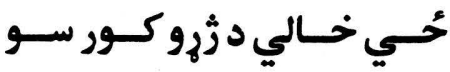
وركى د خـولي بـه خنـدا تـور

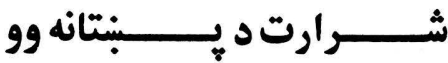

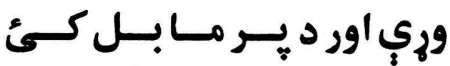

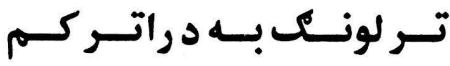

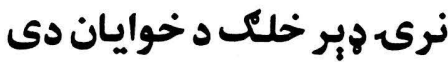

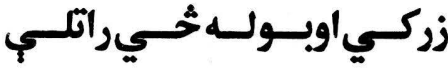

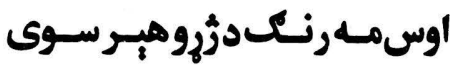

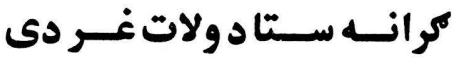
ديـدمـه نـصيب كـي د جانـان

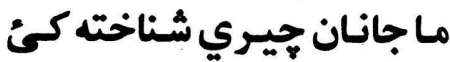

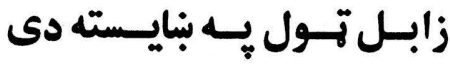
دوعـاكـوم سـتا بــــــارهكي كـه د ســروكلــوكيـلهى دي

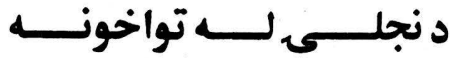
خلك مه جامي كوري جحورى

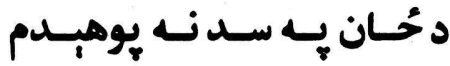

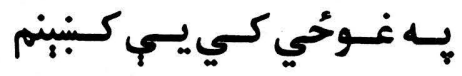

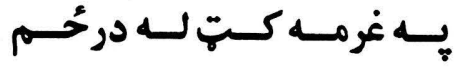

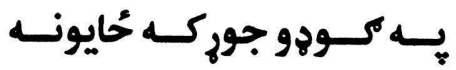
يه دونيا كي خوند د كران دى

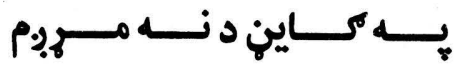
بيـــر محمــد كنــدار لـه وري

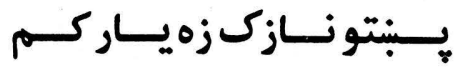

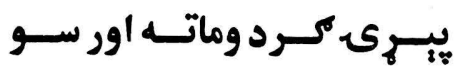

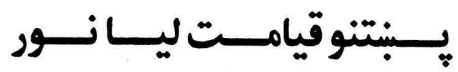
يه سيیينزوبكي يوليس بــهـ دبنــمن د حــال راتركئ

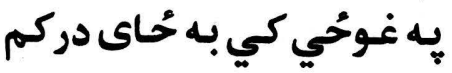

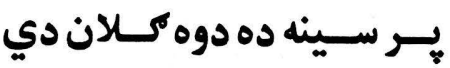

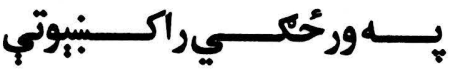

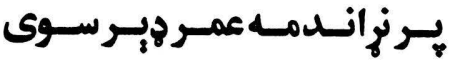

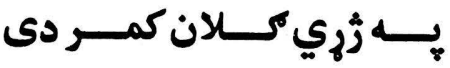

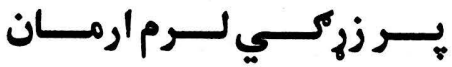

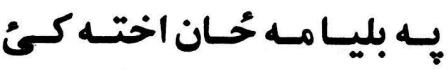

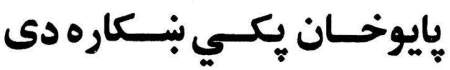

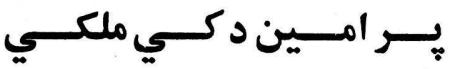

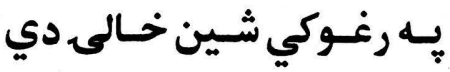

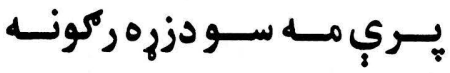

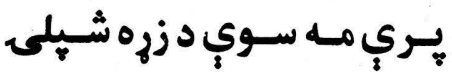

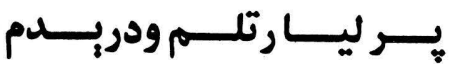




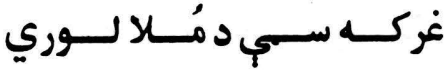

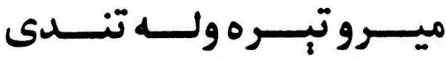

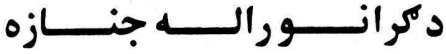

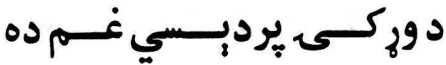

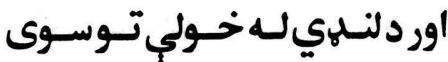

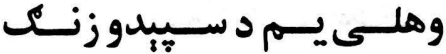

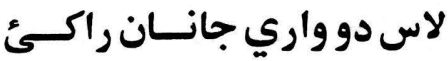

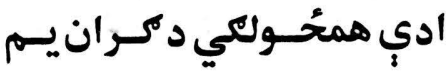

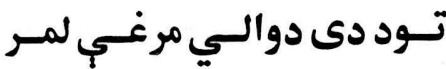

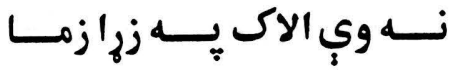

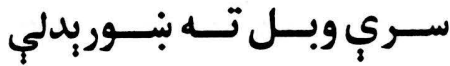

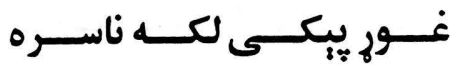

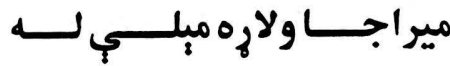
زه تـورك لـه حسم تيـارهكي

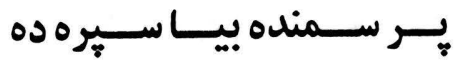

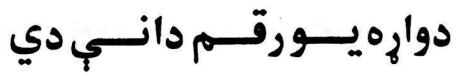

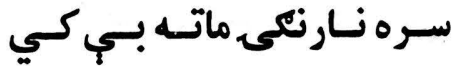

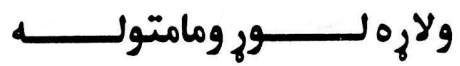
له تـودي رالم سـتا خـولي له جار سم د سبين تر هوبنياري سـترى سـتومان بـه وي نـازك بـوري بـاس كمكي دهيـاري سـتاد بنايسـتو سـتركو رانجــــ كرى هلك مه د خولي خواست
يسهـ تيكســـي دوركسي دوري

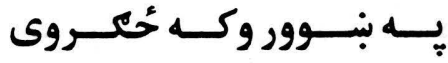
يــاريسي ناسـت وو يـهـ سـايه

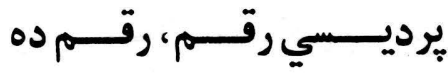

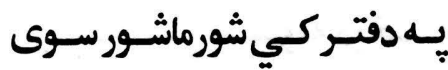

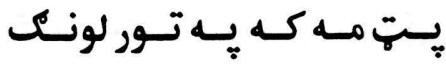
يـه غـوحي كـي مـه سـهاركئ

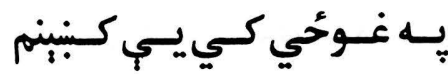

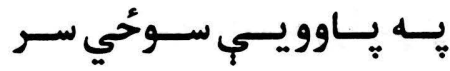

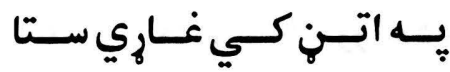

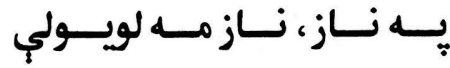

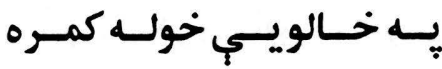

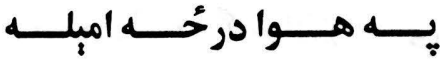
يـر سيوبريمى اوور خـوارهكي :مركم جيبري هبلمنسه ده يـــهـيكـري كـي آيُينـي دي

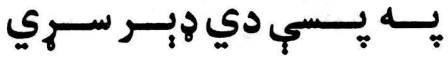
يــــــــواكويسي خولـه تــوره

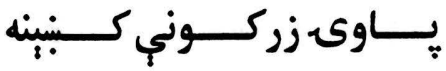

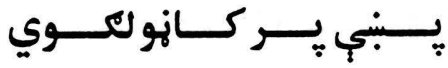

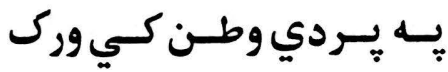

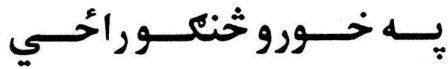

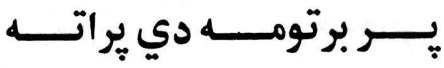

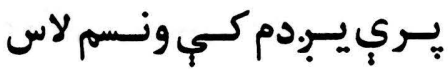




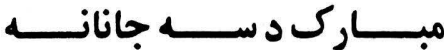

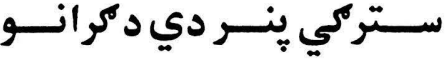

له كرمسى مـره سـوه بـي بخته يـــ دسـمال اوبــكي يــاكيي

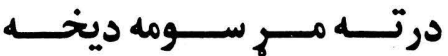

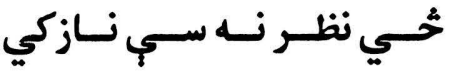

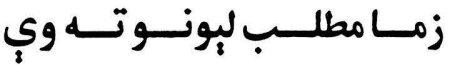

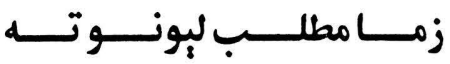

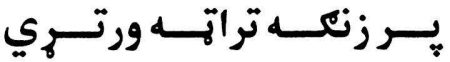

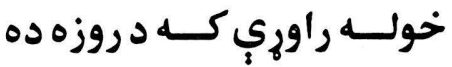

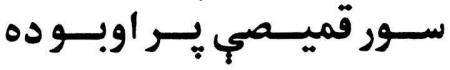
زرغون تيكرى غابن دزعفران

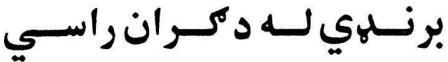
كـــان مـانهى كيـي ظـالم دى

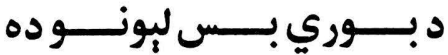

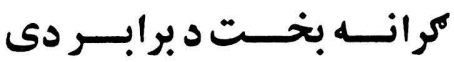
بـوره لمر ده ثخي بنـكاره سي جكــي نــرى بـــي بروايسي

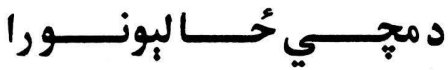

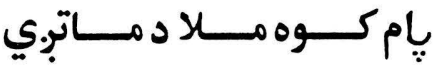
خولـــه راوري كــــه د روزه ده

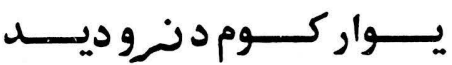
رنــرى اوس رالـه حُحــواني خوكلى يبي نور دلكاناخوري

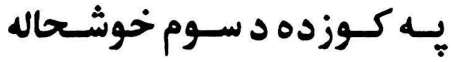

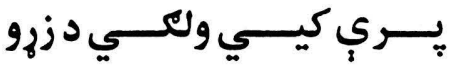

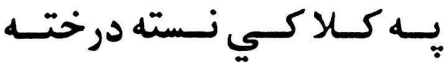
يسـه سـرو اوبنــكور راحسـهـ حُحي

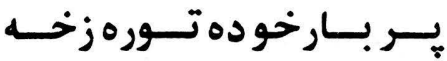
يبكسى يرتــه كـه لـه محُكسي يـر غونسهى زركي له ثخه وي

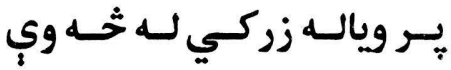
يسه حُحواني كي مسه ورور مـري

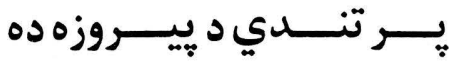

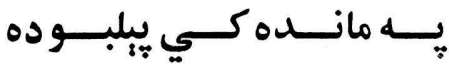
يســه بنايــسته دهـودر ميــان يــر كــودر مـهـ سـتركي باسـي

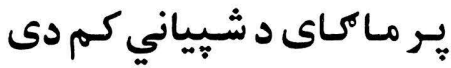

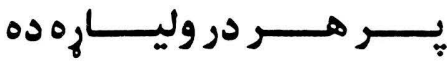

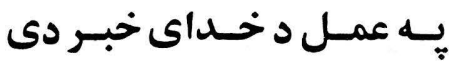

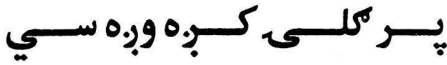

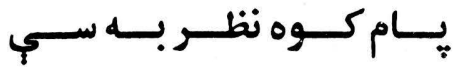

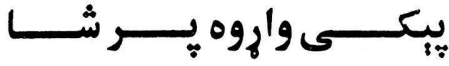

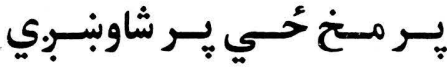

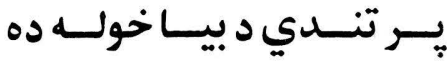
يـــه دنيــاكسي نـسته خريســ

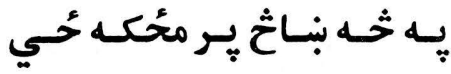

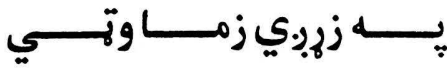


اوس جنـت غـوارم كـي راكـئ

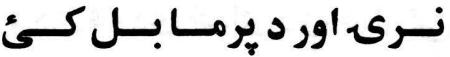
وجي كى درختي دو وبـالي شـين شـوبي وعَ سـي د مانـه

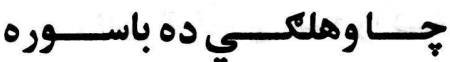

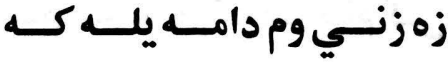

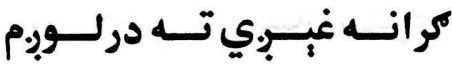
كهــــان خوابـلـى وليـا هـم

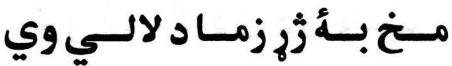

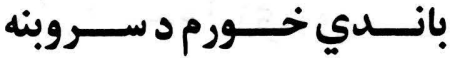
كوانـي .بورى بـه در ير.بـودم د خولي مها بوى د هرسو

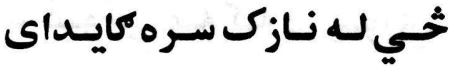

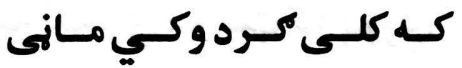
اوس ويـاى دى سـه لـه بالـبنته

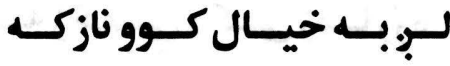
دوارهه تـــور كولــودانــي

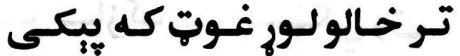
جتهـه حُحـي دزركـون بنــار لـه

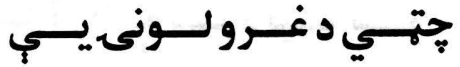
كودى ثرخ خـى كسه لـه ويسالي جار سم د سيسين تر هوبنـياري

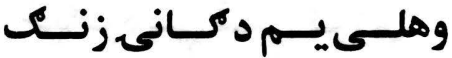

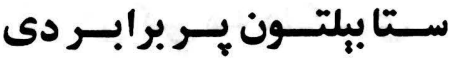

به تور ستركي مه بار مات كَّ

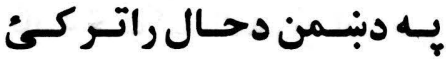

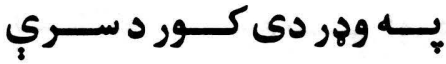

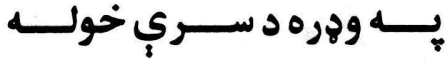

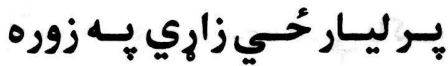

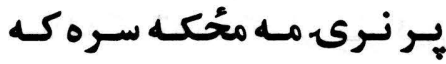

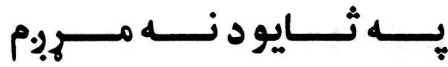

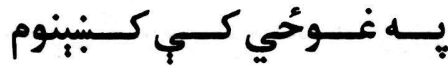
بـهـ نزانــــي بـه كرمسي وي

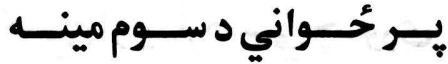

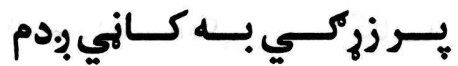

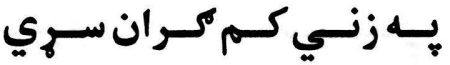

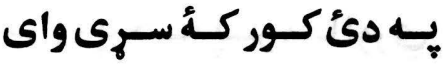

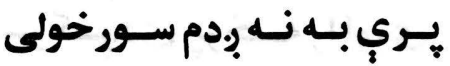

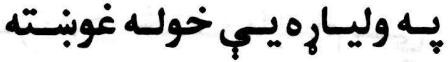

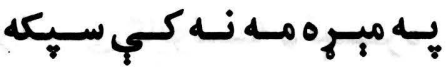

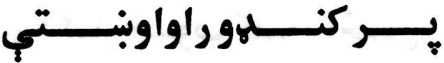

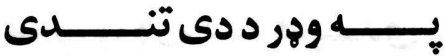

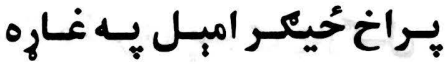

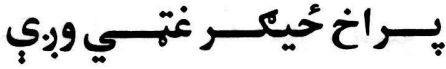

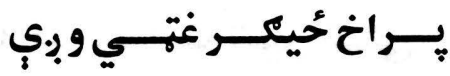

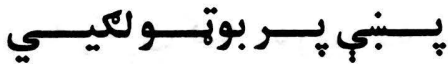

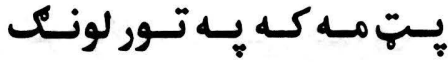
ير زركىي مـه لـوى كـومبر دى 


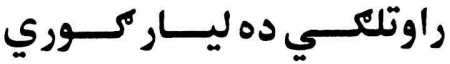
تابـه خــوك مالـه رايـات كـي

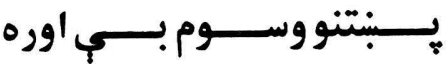

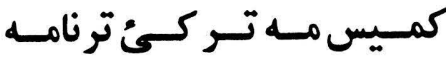

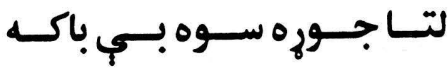

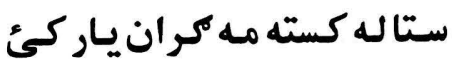

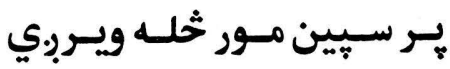

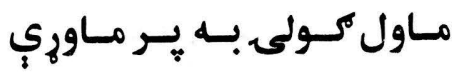

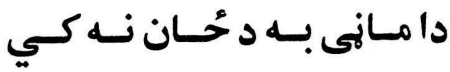

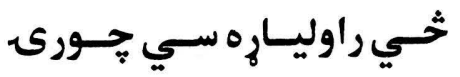

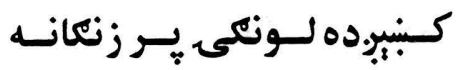

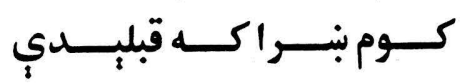

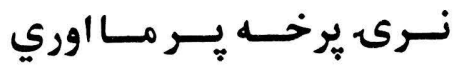

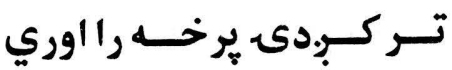

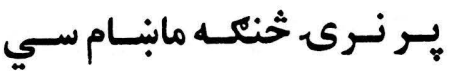

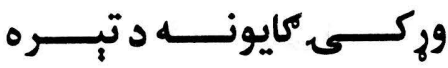

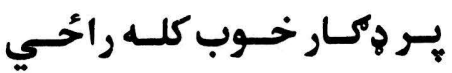

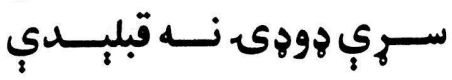

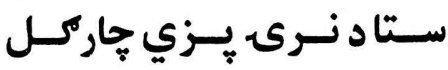

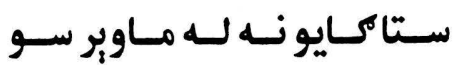

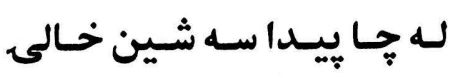

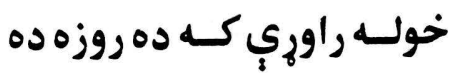
يـر كوم ولات بـه حُحي جـورى

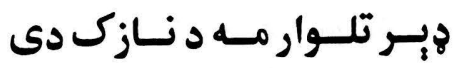

يسر لمسنـيسي كـرزى يــوري يردى قام دى خداى دئ خواركي يري مه ب.ددى د كر ان تر كوري

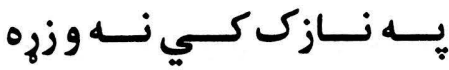

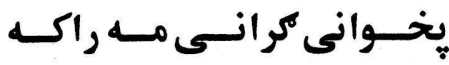

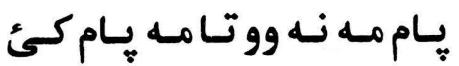

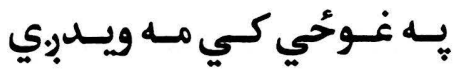

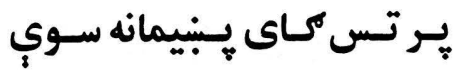

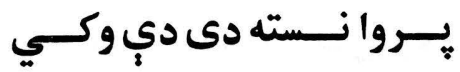

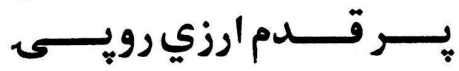

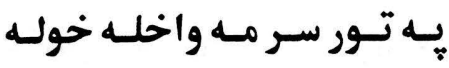

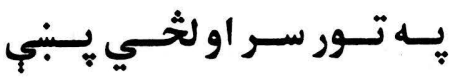

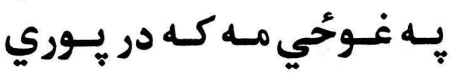

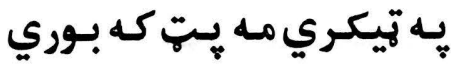

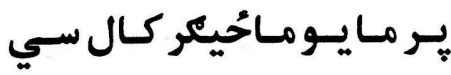

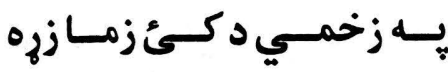

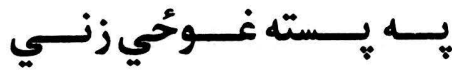

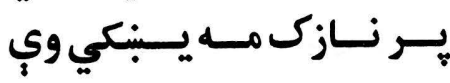

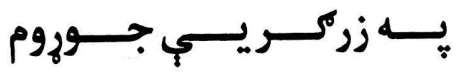

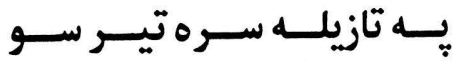
يـلاريسي حَل مـوريسي كـونى

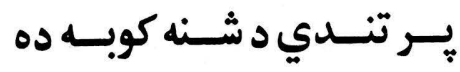

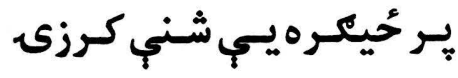

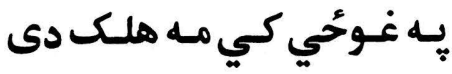


دجرسـوو بروتسي ويتهـتوتي

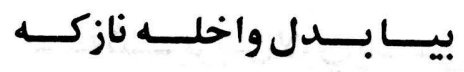

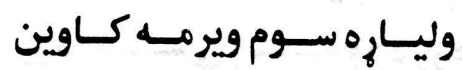

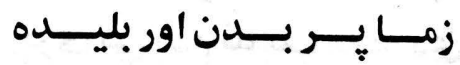

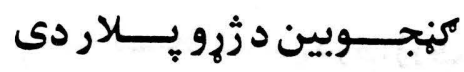

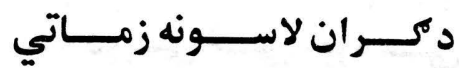

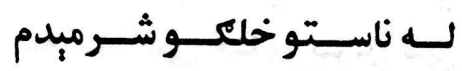

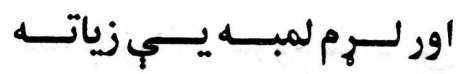

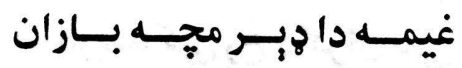
لر مــون د لــوى دى كجــــاوي ليـاخـوريسى ليـا بـي مامـاكم

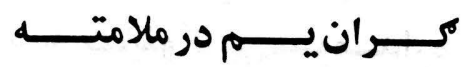

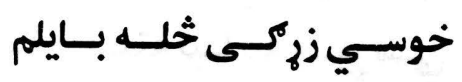
مــه سـي منــرور يـهـ حَّــواني

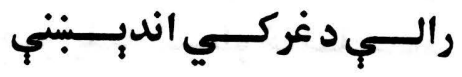
رخصت بـي كم يـه خوشحالي

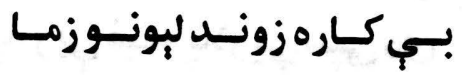

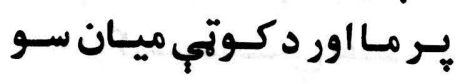

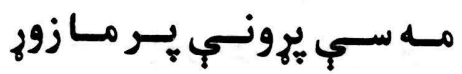

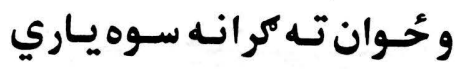

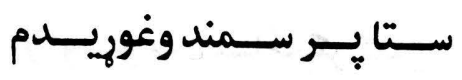

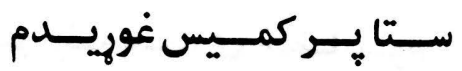
ولارى وبنـــــــار تــــــه ازاري

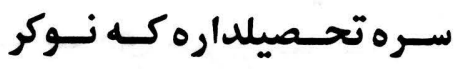

:ــــر دراوى رالــم د ســـري

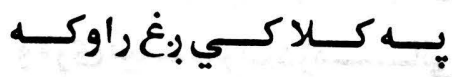

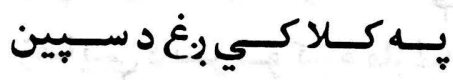

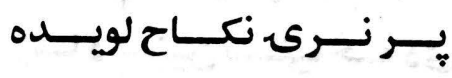

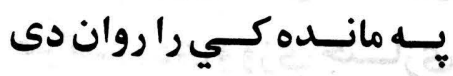

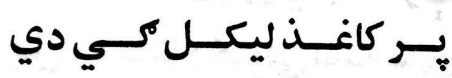

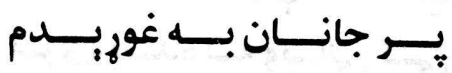

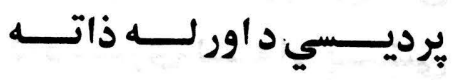

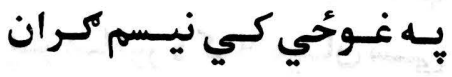

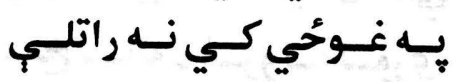

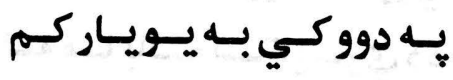

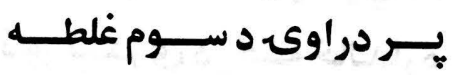

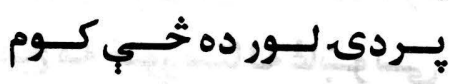

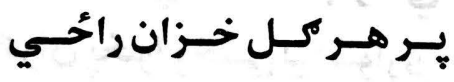

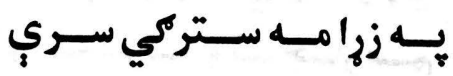
يردى زوى دى خـود بـه حُحي

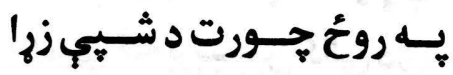

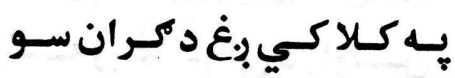

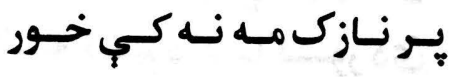

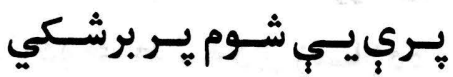

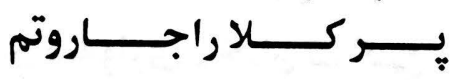

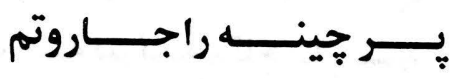

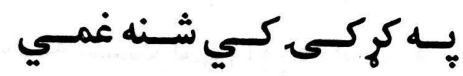

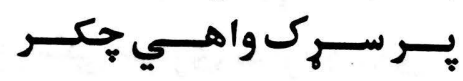


خونسد دمردي دنيـاكـار دى

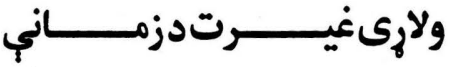

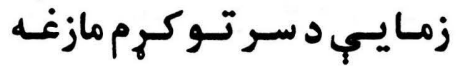

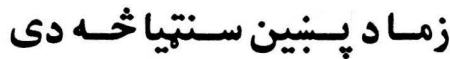

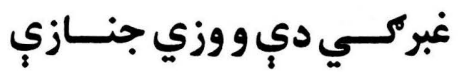

بـل مـه ستا دخـولب لمبـه سـي

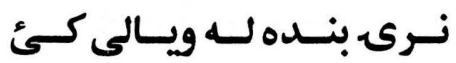

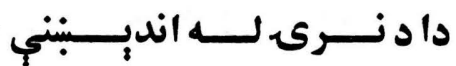
بــــــاور دكـلا ميــان سـي مــخ سـاته د غـــرولـهـ لــوري

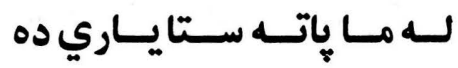
تـور تيكـرى درختـه خالداره

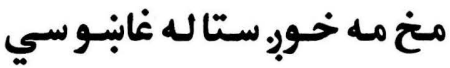
كران يخهوا وختي ليا غواري

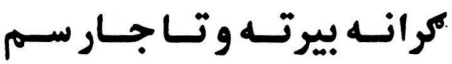

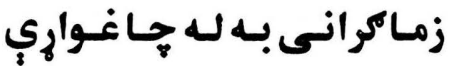
زوىيب ثحه بريبمين كالى دى

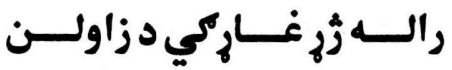
كلـــهـــــم د ابـــــــــور دئي داردوخسط نــه دى زمــازده نـن مـه وارى د دحسان تـر كـئ

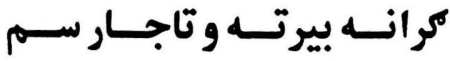

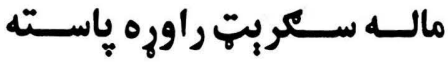
خوسكي خوارى مه بربادسوي

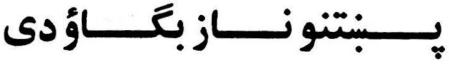

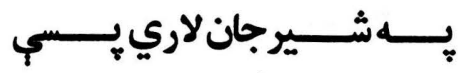

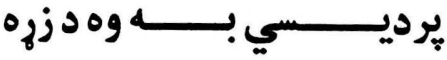
يري بي بـدم نصيب مه نه دئ

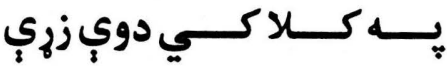

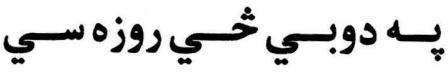

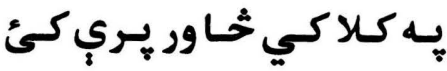

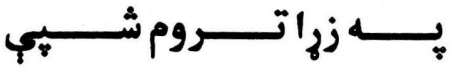
يـه دربند كي بِغ د دكران سي

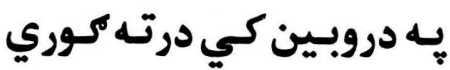

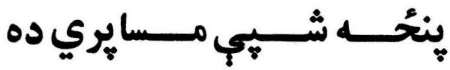

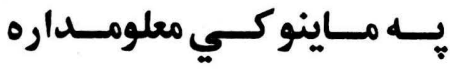
يـروا نـسته بيـابـه جــور سـي يحى مه توسوي لور مـه زاري

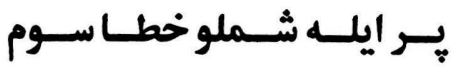

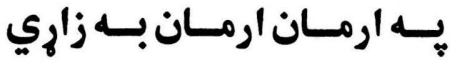
يلاريب غيمه يلاريب سيى دى يلى

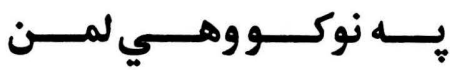

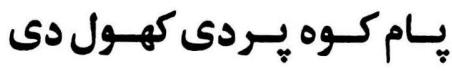

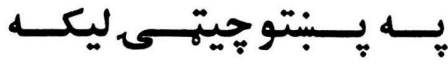

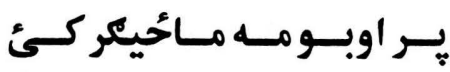

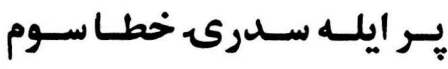

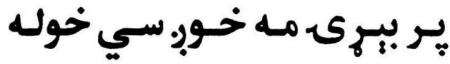

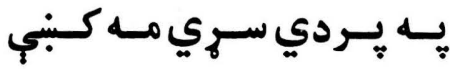




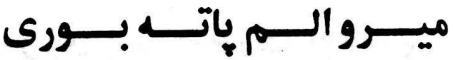

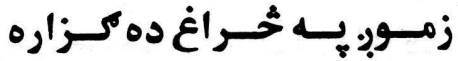
مـاول مركسى بـهـ يـر مـاوري

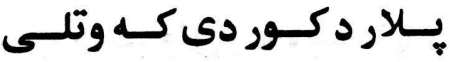

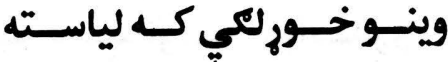

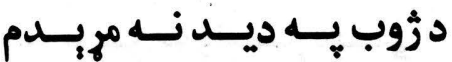
تر سوع م-خ كي مه لاس وركه

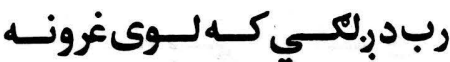
كــولي لانــدي د بــاجر كـــئ

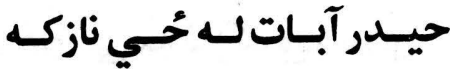
زياتـــه ســيزن ســو د زيــارت

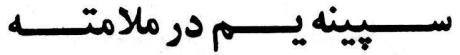

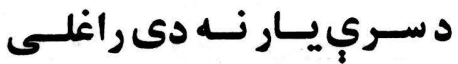
بوره لمـ ده ثخي بنـاره سي

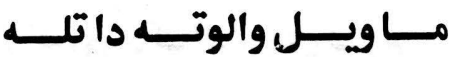
خــولب لـه حُـمـ د منــدوخيلي جـورى هـهـ كست ليـونى كمى

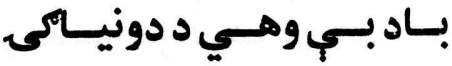

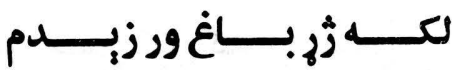

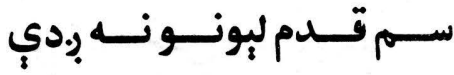

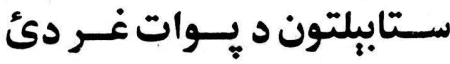

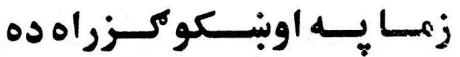

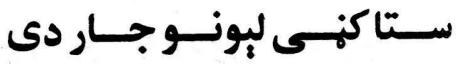
سين زيارت له دكران راسي

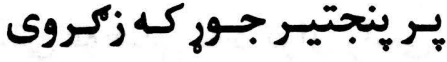

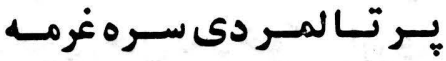

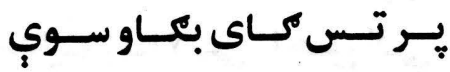

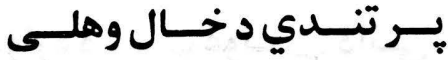

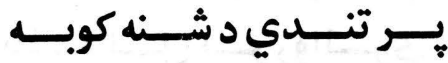
يـــــــــور خـــان راواوبنـــتم

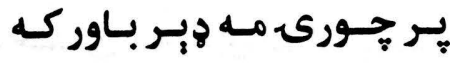

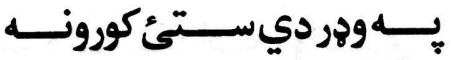

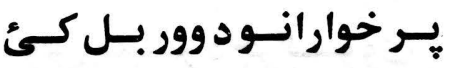

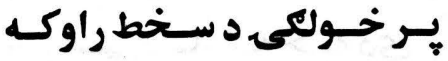

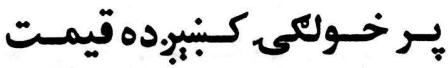

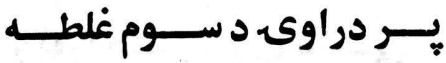

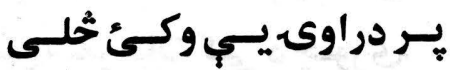

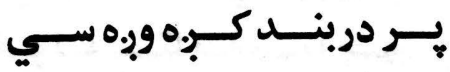

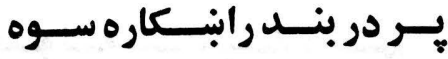

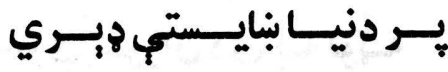

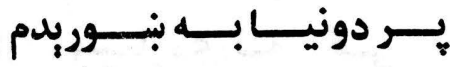

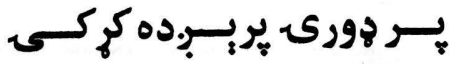

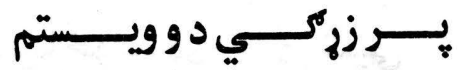
يسر زركسي داغونسه تسهـ بردي

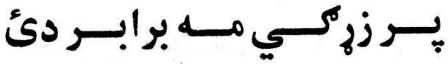

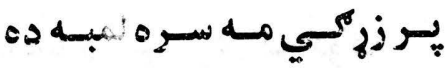
يـر زئكي مـه سـور بيوهـار دى زي

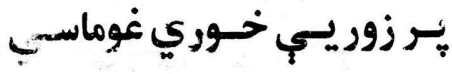


شنب غوخدكى له دمران راسي دخولي حال به دخوكى راوري

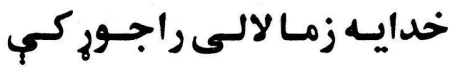
دواره د سـب غونسي ريدي دانسي

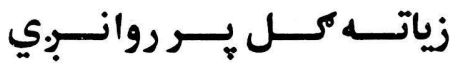

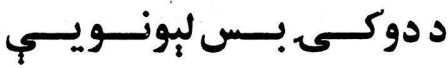
دخــاى يـهـ روى نـه كرزيـــه

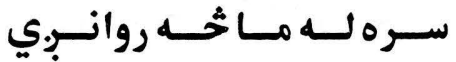
لـــونى ممبــــر د جرهــــو وئ ادي ركسي سـار لـه ثخــه دى

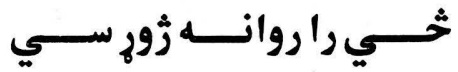

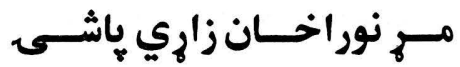
ثخي سـتر مـات كي د جـورى

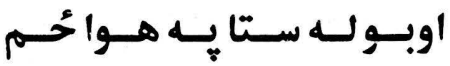

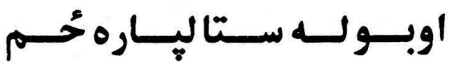

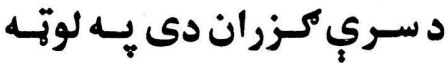

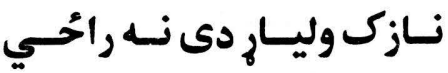

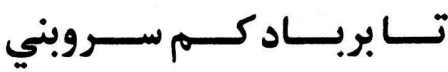
د دنيـا خوند دى خخلـور شـبي

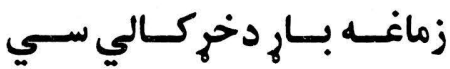
كسلهه سـوي خولـه درانـهـ كـ مات سه هنكـر يـري كه كوكه

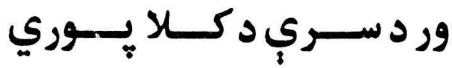
زمـازيركيسي كسئ نساجورة
يـر زوريسي خــوري غوماسـي

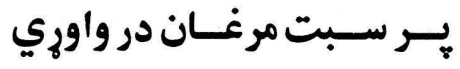
يـر زيـارت مـهـ اوبنـكي تـوكي

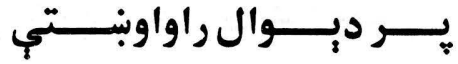

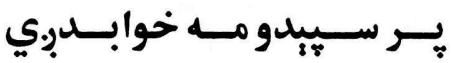

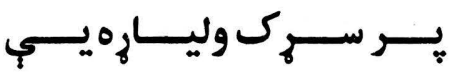

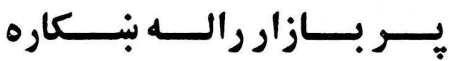

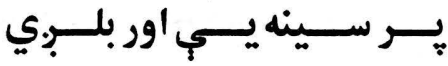

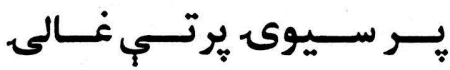

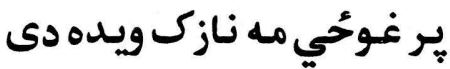

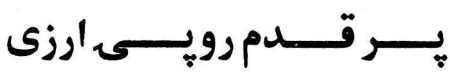

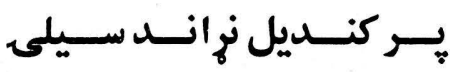

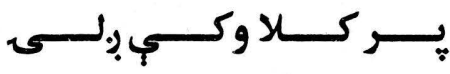

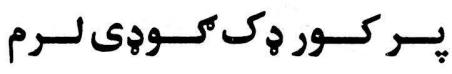

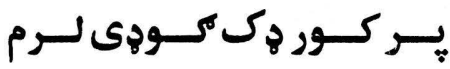

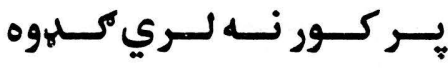
يـر كريسوان مـهـ اوبــكي حُحي

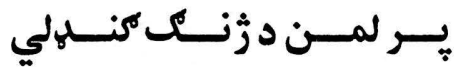

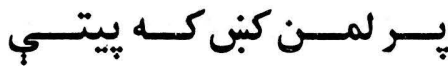

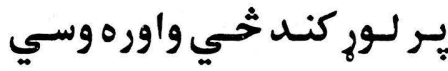

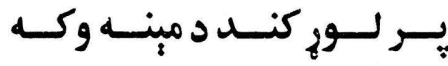

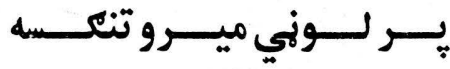
بر ليـار تر سوم دوري، دوري يـر ليـار حُحي خانـدي يـهـ زوره 
د خيـال تــ د ذأرو وبــــ دى تــــ اوس بغلــوزئ نبــي دي ستا دراوى سـيني بنساره ده نرى خـوك بـه د حسال راوري سات مه تر بـ خهل خله

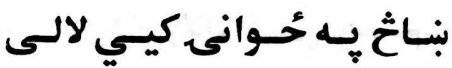

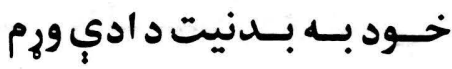
تر خداى ياك نو يو جاكرانيجي نـوري مــايني دكـي تـازوزي

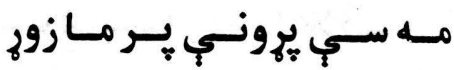
آسمان شين وى كئحو توركئ شـين آسمان وئ لمبو تور كئ

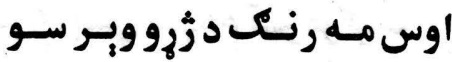

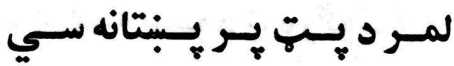

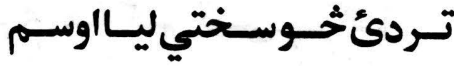
زياتسه كوانى نسه دى زمـا زده

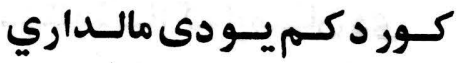

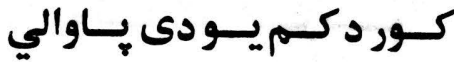
كرى هلك دى د خولي خواست حوان سرى دى مخغي تور دى بــر مسايستي زور كـى بنخـي

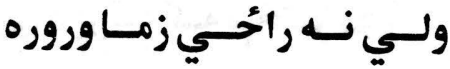

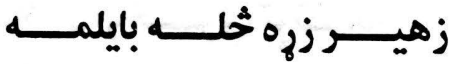

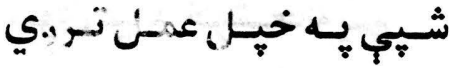

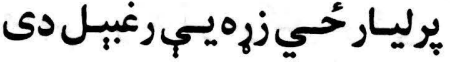
ير ليسار حُحي ملا يـب كر.ب دي

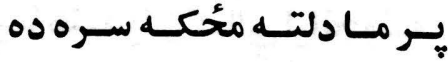
بــر مـاروالـي ســـيني واوري

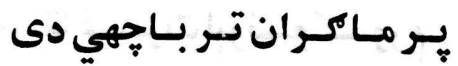

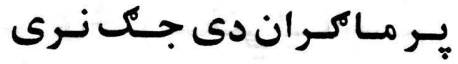

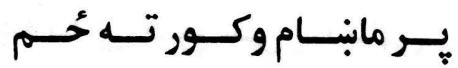

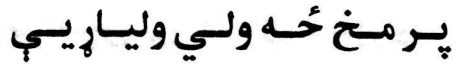
بـرنـازك مسه نسه كـي خـور

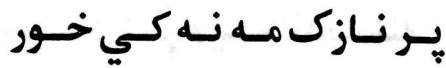
ير نرى يـي تيكرى خهور كئ ير نري يَي تيكرى خهور كئ

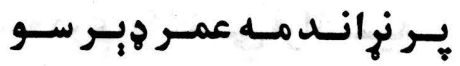
•ــر وركـي هلـك مـسه نسمي

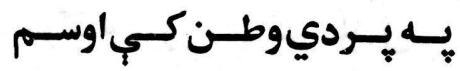

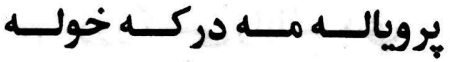
ير هـ دبنـت كردى وليـاري هر هـر دبــت كرودى وليـاري

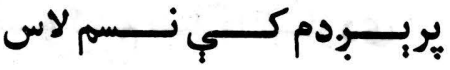

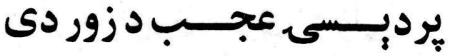

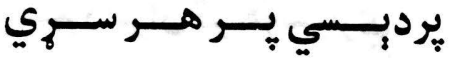
يرودجسي سـوه لـور لـه لـوره

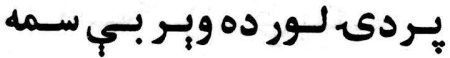

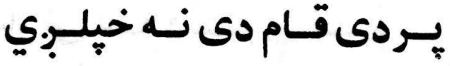


زمايـي زوندتر مرك بتر كئ

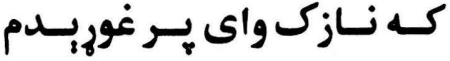

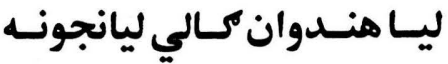

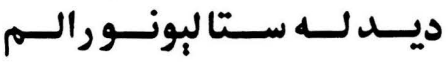

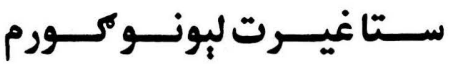

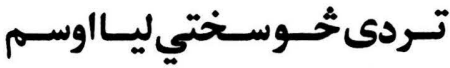

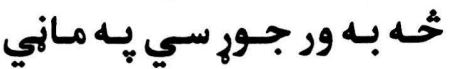

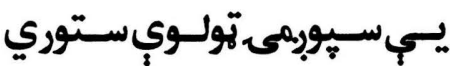

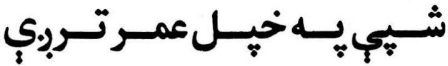

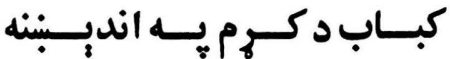
كـه سـوم تـر كرد بإكستان تر

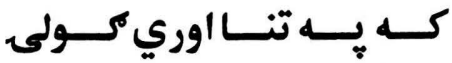

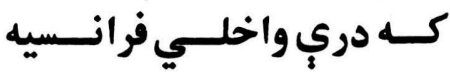

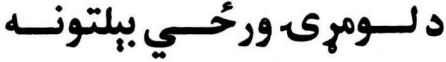

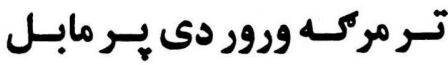

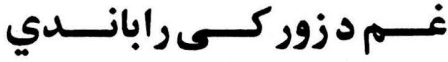
دادرواغ ديخحي ورور كراندى يرتسئ سـيورى يــر مـالمـر سـو

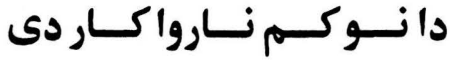
تاو د تر ماخيزي سري خـولي جـار سم دكران تر هوشياري

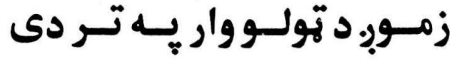

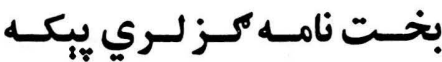
مبــاركى لــه د ســـري حُحسم

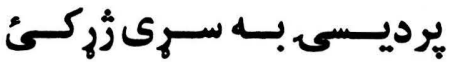

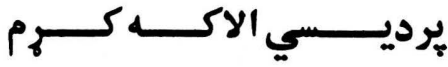

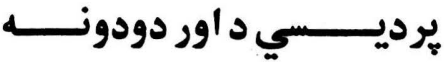
يردي خلك دي ثحه كي غوارم يردي خلك دي زه كي بنورم

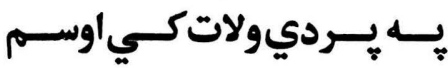

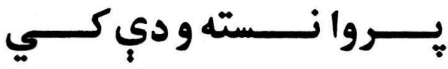

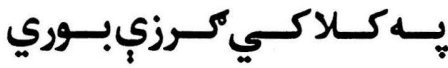

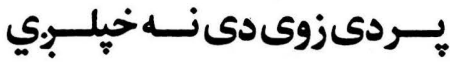

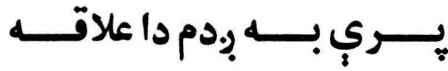

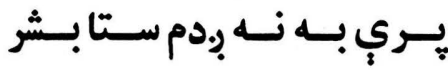
يـري بـه نـه بردم سـتا خــولكى

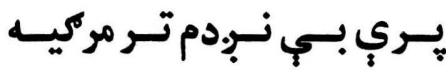

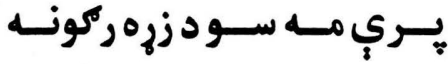

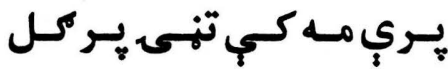
بسرلى سو شنب سوي سياندي

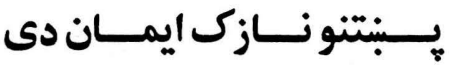

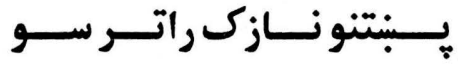

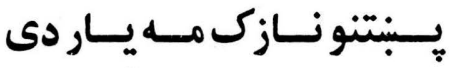

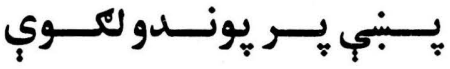

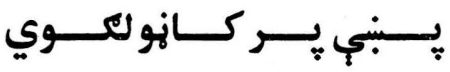

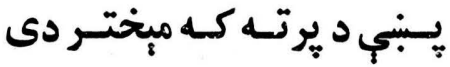

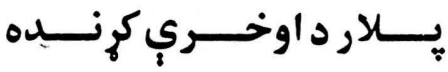
بــه لــوى عيــد خوشــاله يـم 


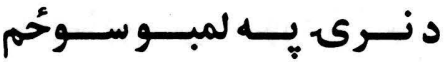
سـتا د سـر دبنــمنان وهــــ دي نـازك بسه خـوب كـوي بـي مـا

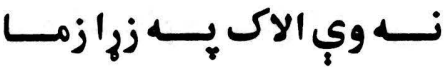
زمـوبر. بـه قـمت ده جــائي

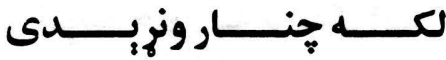
خـاى د مـرك مـه يـه راوينهـ •ـهـ روخ مـي ديــ كله كيـله

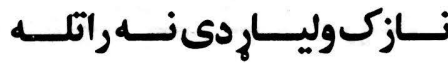
و سيّين ته وركئ د ثُوب ميان خـولب د خونس راكَّ ناسـري تـووت دى د نركي ادي كـور تـردئخــو سـختي ليـا اوسـم تـردي ثــو سـختي ليـا اوسـم سترى ستومانه به وي نسازك ستا جاركل راكس خــي يوسـم

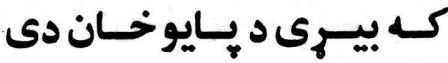
اوس جنـت غـوارم كَ راكئ

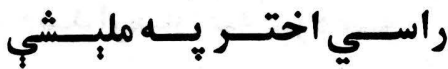

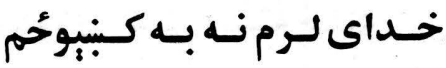

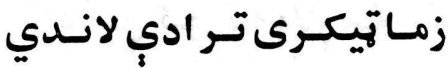

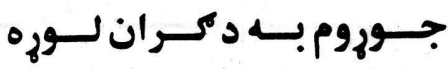

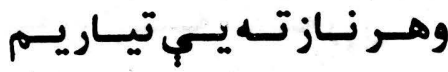

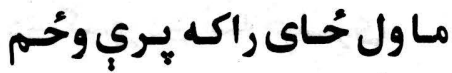

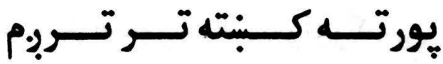
يرتـهـ كـوري نـور دوبـــ دي

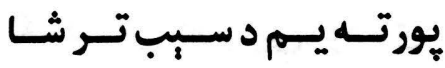

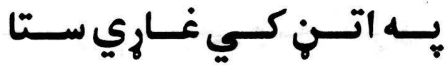

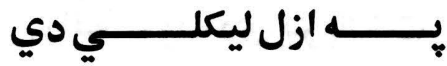
بـهـ بـازار كـي سـيـن راتلـى

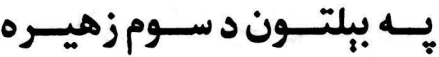

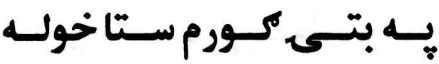

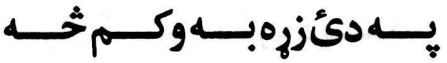
•بهـ بـوري كـي نسته سـيال

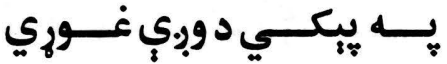

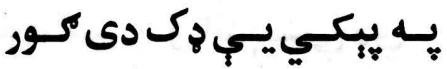
بــه بـردي وطسن كـي اوسـم

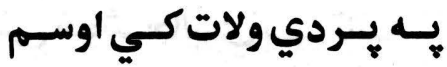

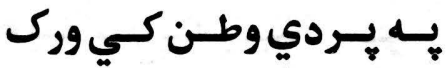

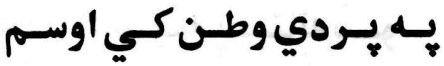
به تنكي كي بوغ د به انك دىى به تور ستركي مه بار مات كى

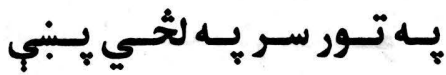

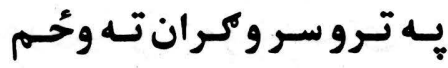
هــــــور سـر وحــم دبانـدي

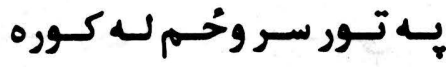
rـه تهمـت ديـار خوشـحال هيسم

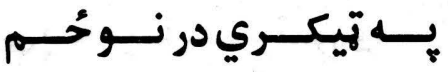


غونسله مــور نـــه دهرواوركسي

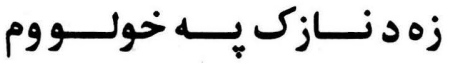

رنك يجي كل كلابِي نوم دى

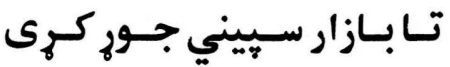

نـن راته يـروت دى يـر بالبنت

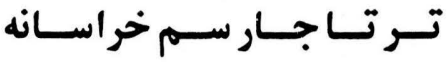

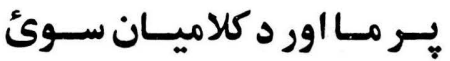

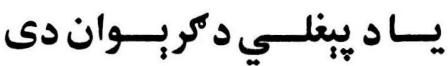

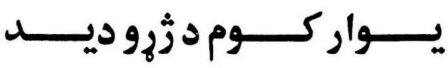

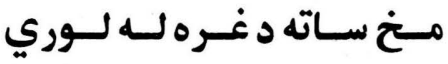

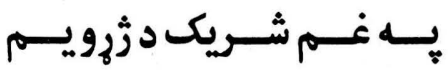

يــومركسى بــل انديـبنيني دي

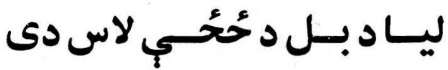

خـــي خوشـالإبري بــي تانسه

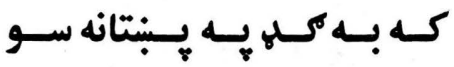

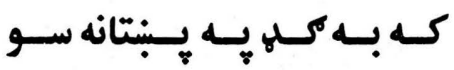

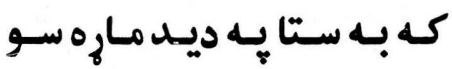

كـ بـي بيـا يـهـ ديـد مـاره سـو

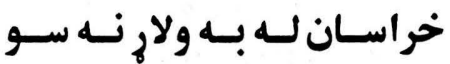

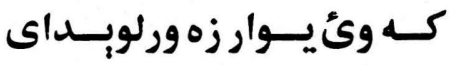

جي خوله خلاصه سوه بيا راسه

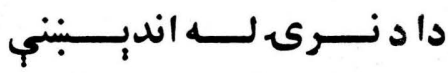

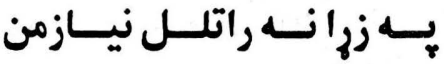

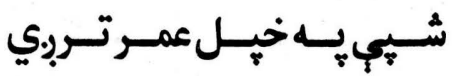

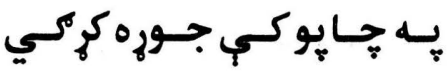

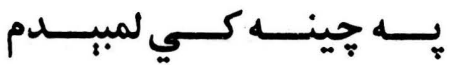

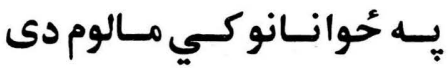

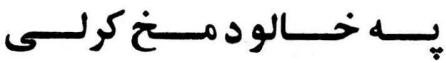

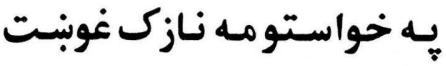

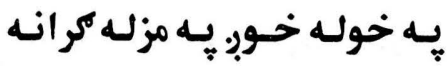
يه دربند كي ب.غ دكران سورئ يه دونياكي خوند د قرآن دى

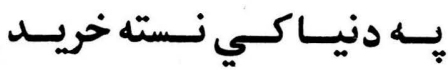
يـه دوربـين كـي درتهـ كـوري

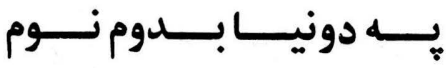
يه دونياكي خوارى دوي دي

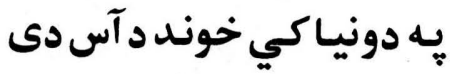

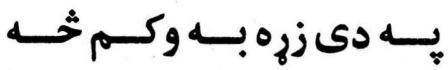

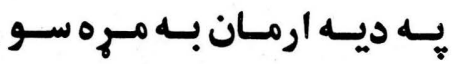

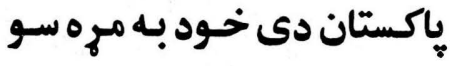

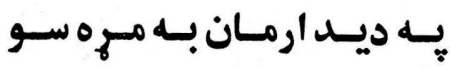

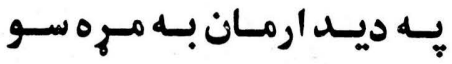

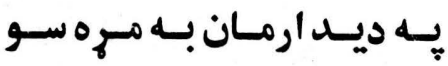

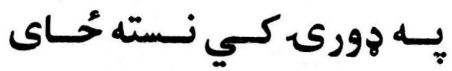
يسه روزه كسي كـور تـه ولار سـه

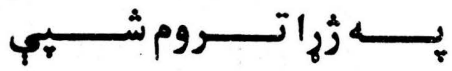
:

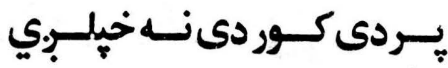




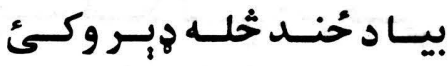

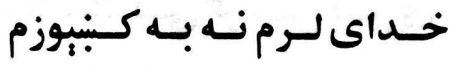

زور دجـــار منـزيـاد كـويري

كـل جــامي مـــ د بابـكـ دئ

بــه دسـمال اوبنـكي بـاكوي

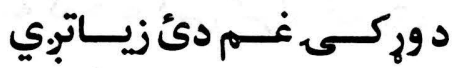

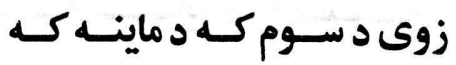

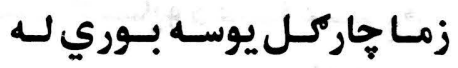

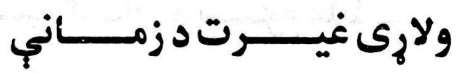

كران د سري غرمسي ليّوه دي

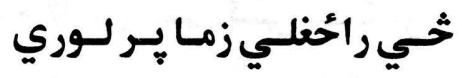

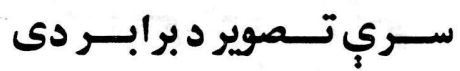

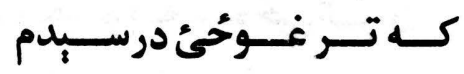

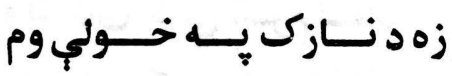

مـانـازك جيـري شـناخته كئ

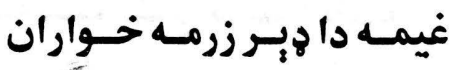

يه سيّين مه جهب نه دى محشُ

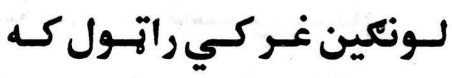

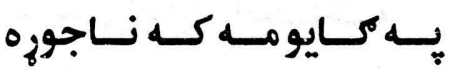

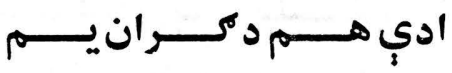

زمـاتــور سـتركى مـلا يـار دى

يـه ماجـت كي يـي مـور زاري

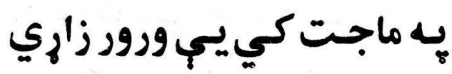

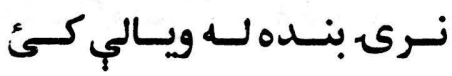

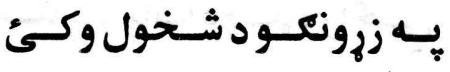

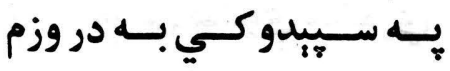

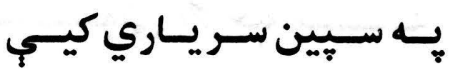

يه سخي تنكي كي خوبي دى

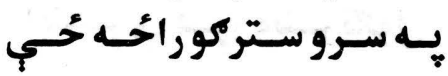
يه سره اور كي مه زره سوحي

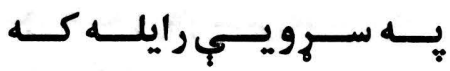

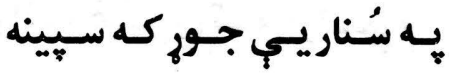

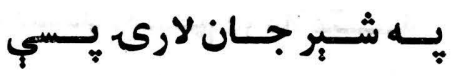

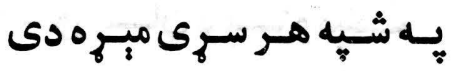

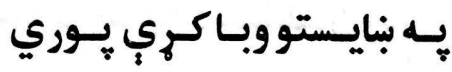

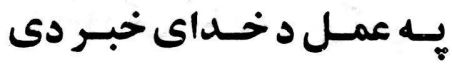

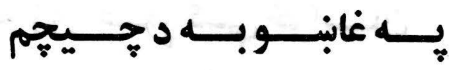

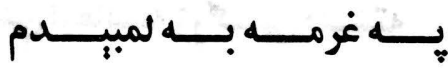
بـهـ غـضب مـه حُحسان اختـه كئ

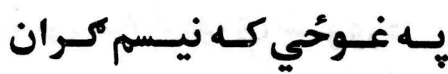
بــهـ غـوحُحي كـي نيـسم سـر يه غوحُي كي مه حُاى جوري كه

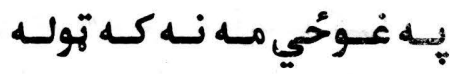
يسه غـوحي كـيسيس كـبنبنم

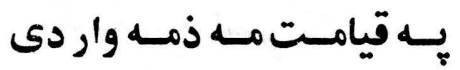

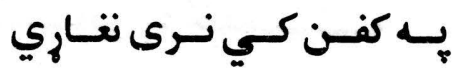

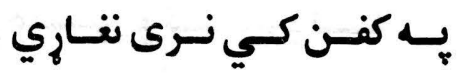

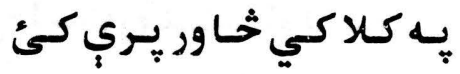


سـتا يــر باتـاغونسلهه راحسـي

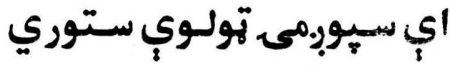

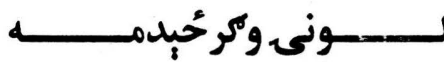
يــــــــاور د كلاميــان سـي

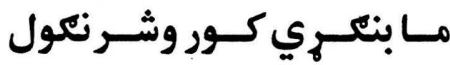

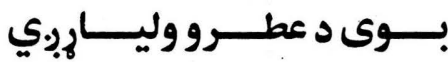

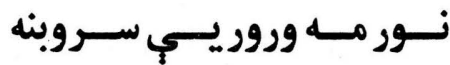

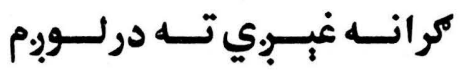

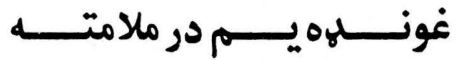

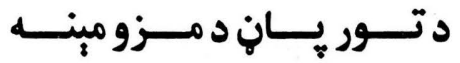

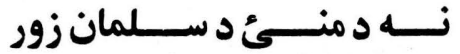
سـرهمـوركى نـه ده راوركسي

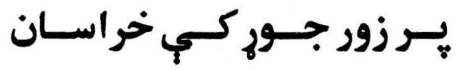

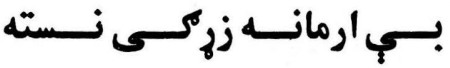
تـر سـوديسي هُيسر وكسئ تـاوان

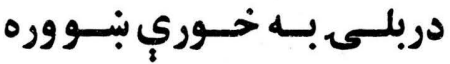

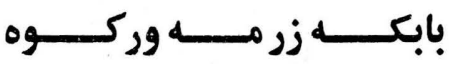

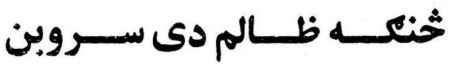

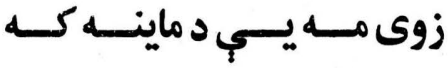

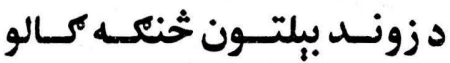

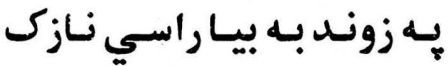

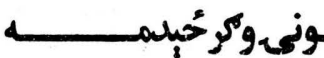

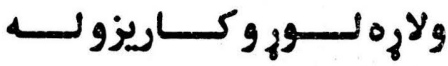

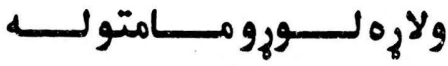

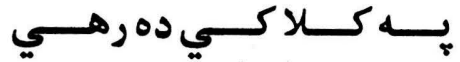
يسهـ كـلاكسي كرحسي بــوري

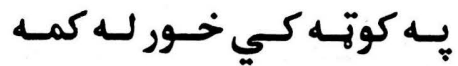
يـه كوخـه كي ب.غ دمكران سي

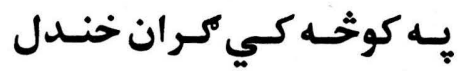

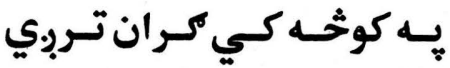

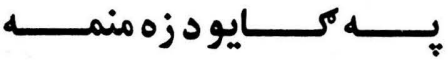

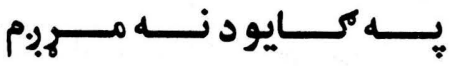

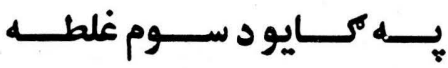
يـه كرد زوند مـه نه سوه وإبره

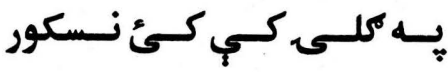

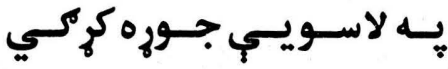

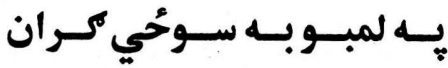

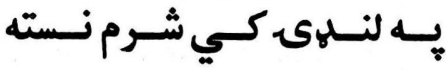

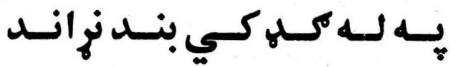

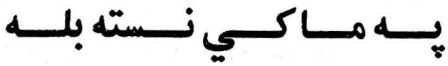

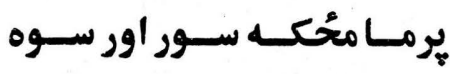

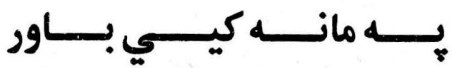

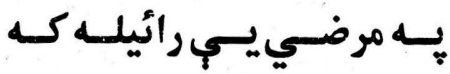

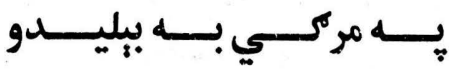

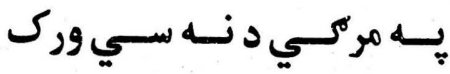

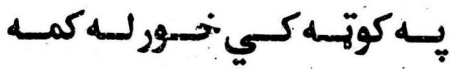
يـهـ مسواكويسي خولـه تــوره بـه مسـواكويسجي خولـه تـوره 
خـولي دوخهوري خُحي كايبري جـالـه يـهـ غـاره كم برويـبنمين

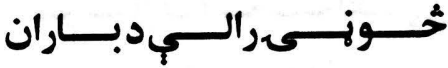
جورى بـاس كركي دهيـاري

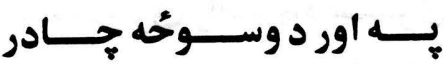
رب دربكسي كسي لـوى غرونس شـين شـوبي وج سي د مانـده

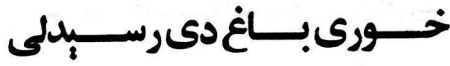
وس د ســـك يـــه هـلهو نـسته سـتركي وخــوري خخلـور بوســ تــور تيكـــى لنـلهوه جامـهـ ده

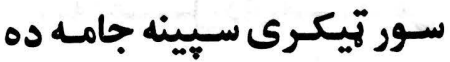

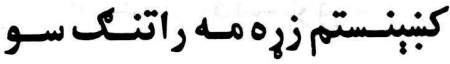
نسـواري تيكـرى يــر بانسـي

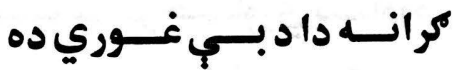

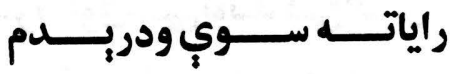

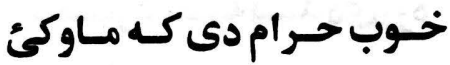
دوينـــوخونـــد دى د دورجى

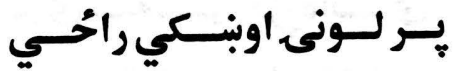
نـازك بــ خـوب كـوي بـي مـا مايـــهـ هوتــوكـي مايسـبنين

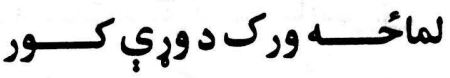

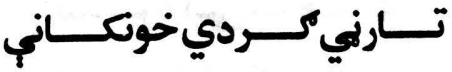

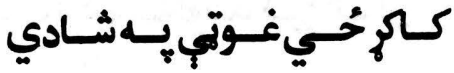

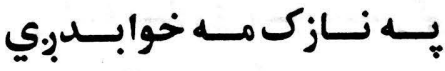

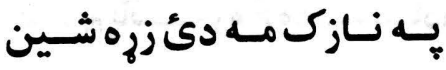

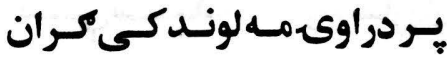

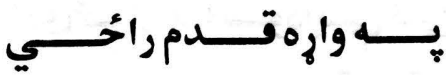

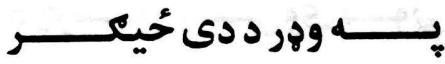

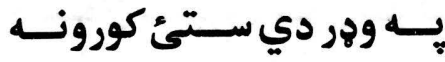

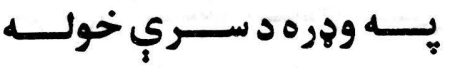

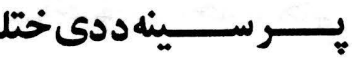

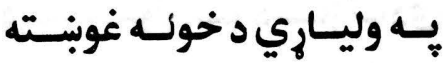

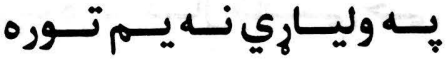

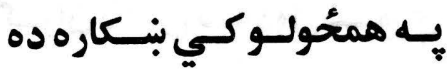

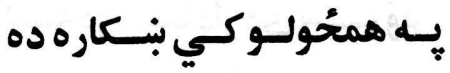

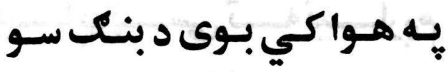

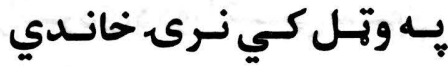

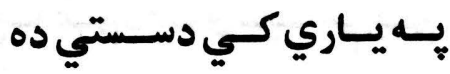

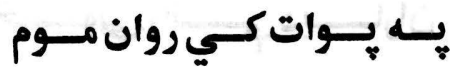
يــلمى مـه د سري خوله كئ

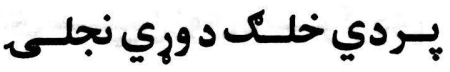

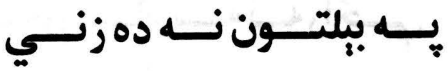

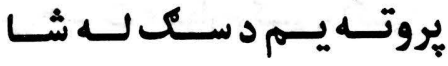

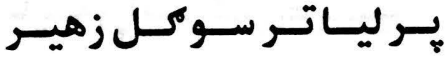

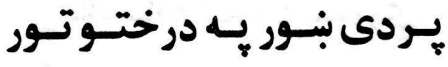

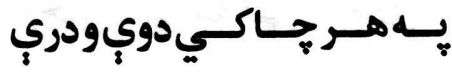

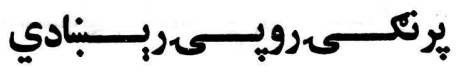




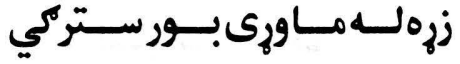

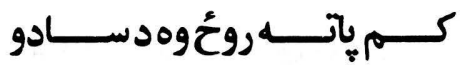

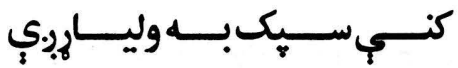

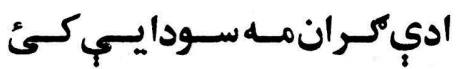

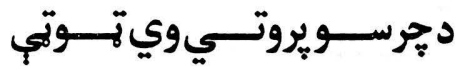
داسـمانسـتورىســوىنـازي

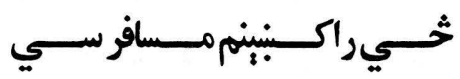

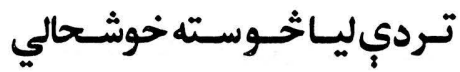

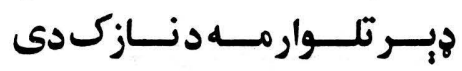

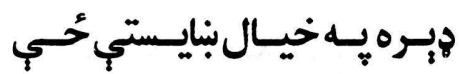

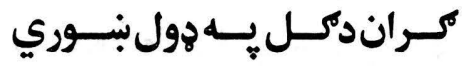

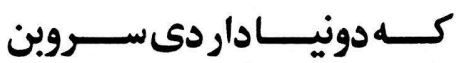

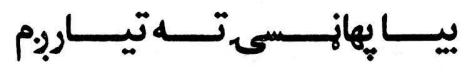

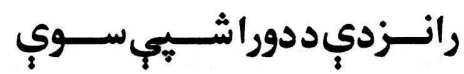

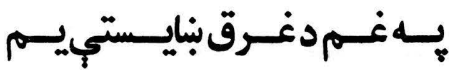

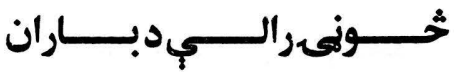
لـوى سـوى دبـلـملـكـ يـهـ أوبــــ

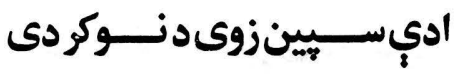

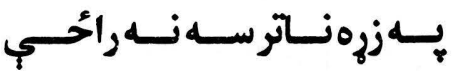
وس جنــتغــوارمكـيـئراكئ

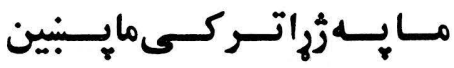

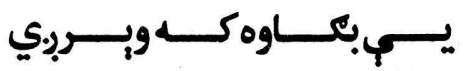

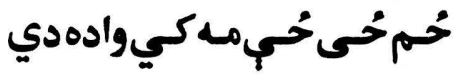

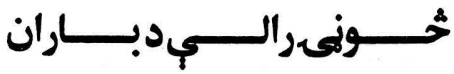

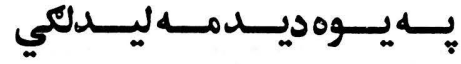

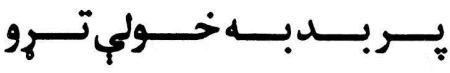

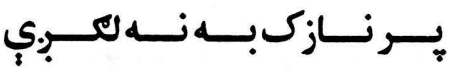

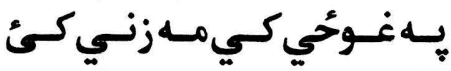

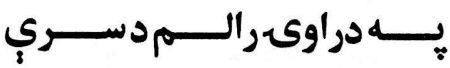

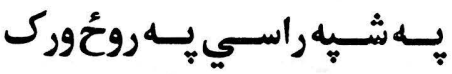

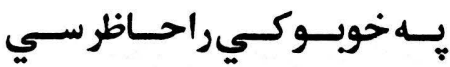

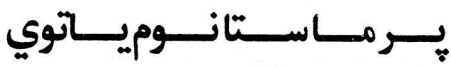

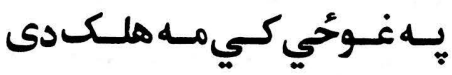

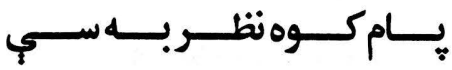

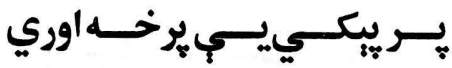

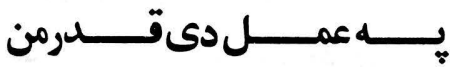

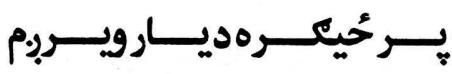

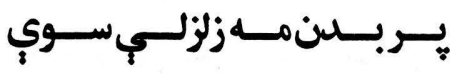

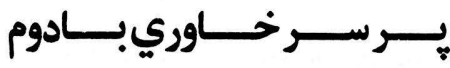

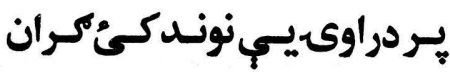

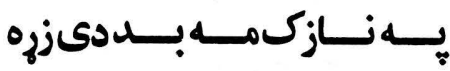

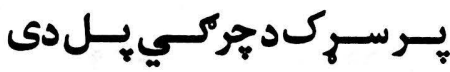

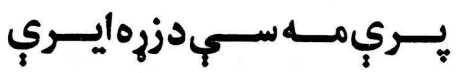

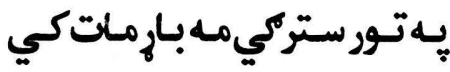

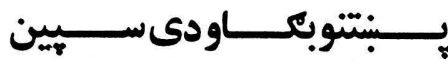

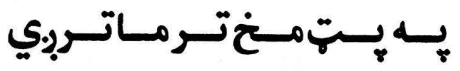

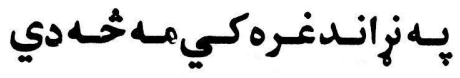

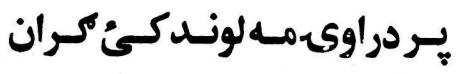




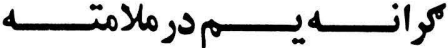

يـوواريسيـــــور راسـيـيـامــور

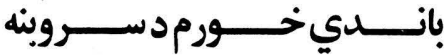

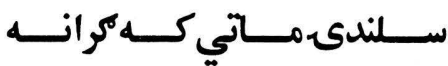

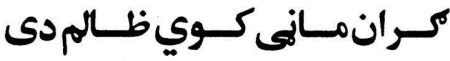

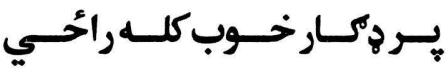

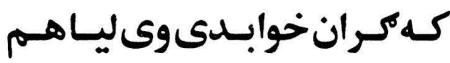

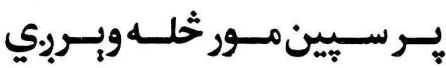

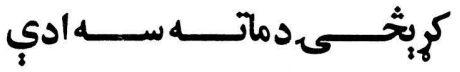
زمـاوستاليـاريـيـيـدويخحي

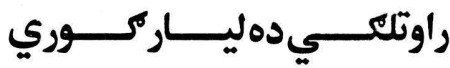

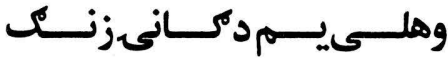

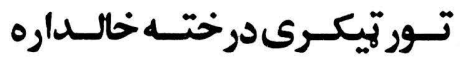

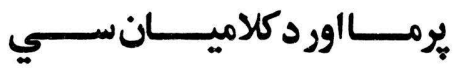
ادي ويـاى بروتـه ده زمـالـور خدايه سخت رنحُوارن جور كي كـــى جــــاد دونيــا وش دى

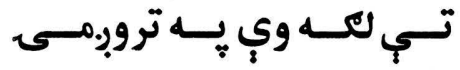
د دنيـا خونـد دى ثخلـور شـيـي زره لـه مـايــوور تـور سـتركي

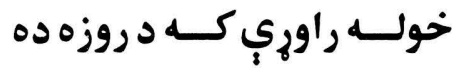

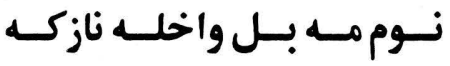

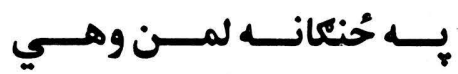

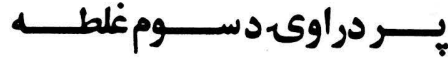

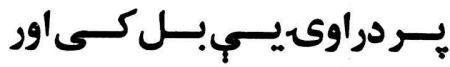

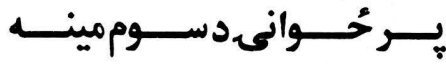

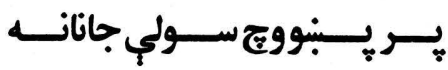

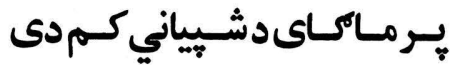

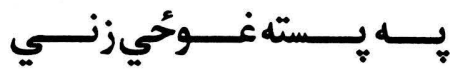

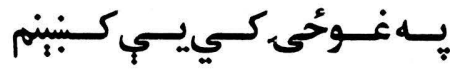

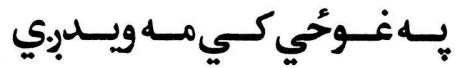

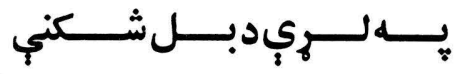

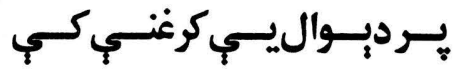

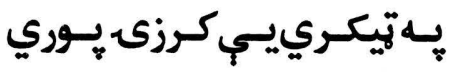

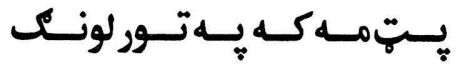

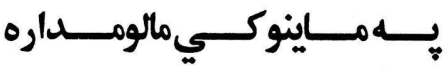

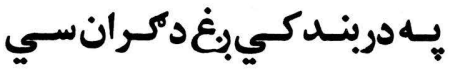
ير كتّ خـور كم تيكرى سيور يـر زيـارت مـه اوبــكي تـوكي

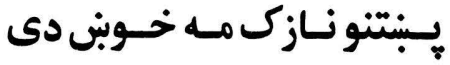

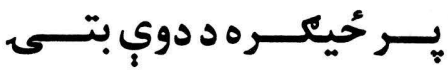

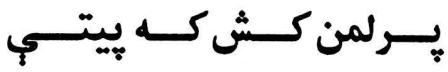

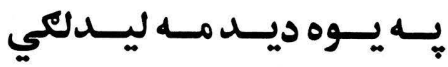

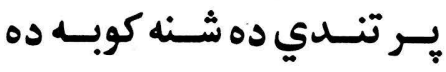

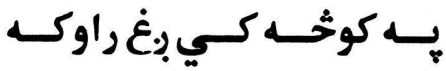

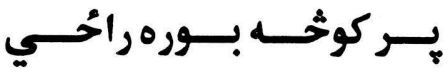




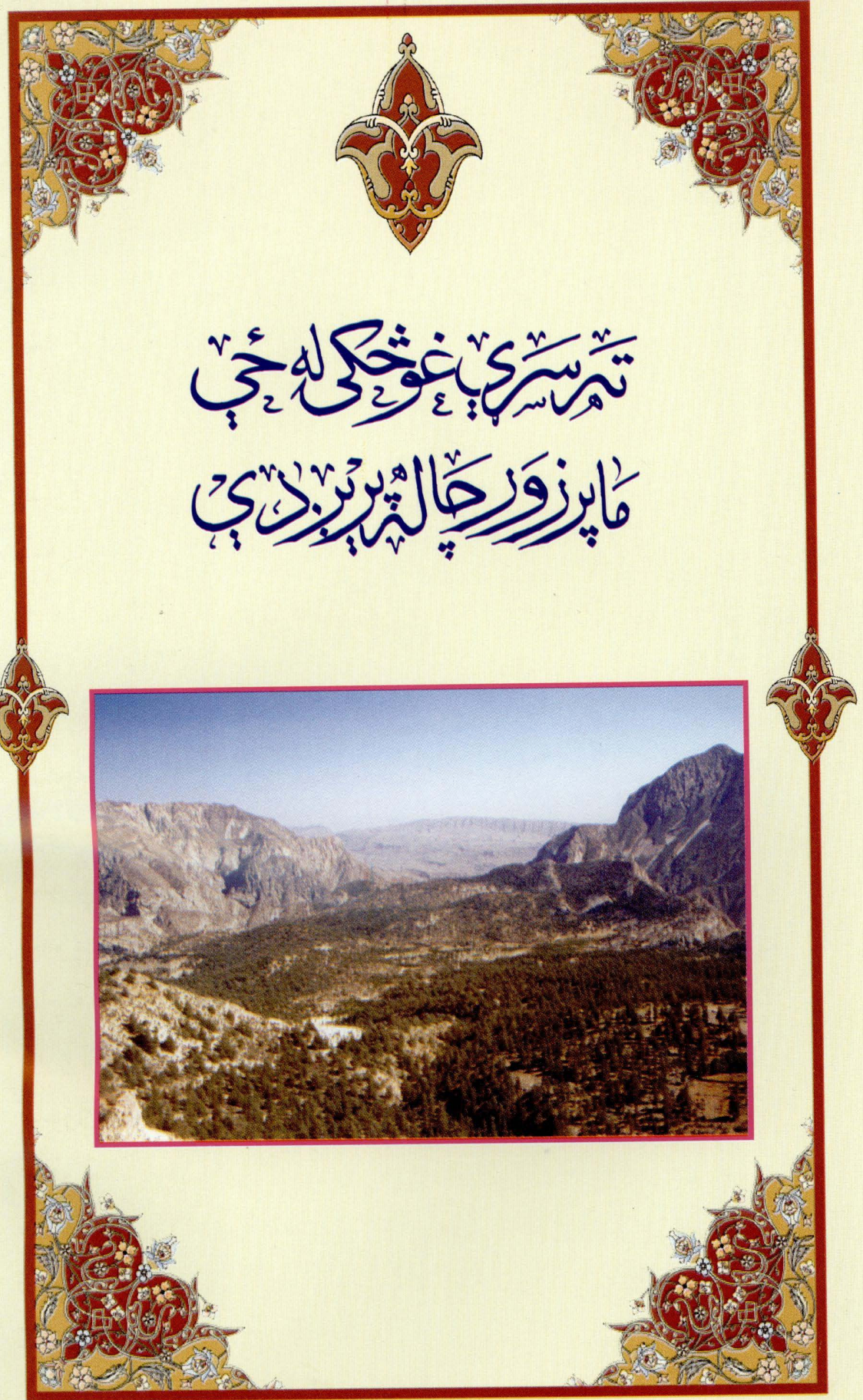




\section{斗委}

وليــــري دي بـــي اندإِــنـو

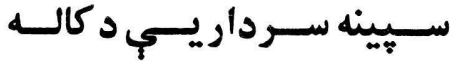

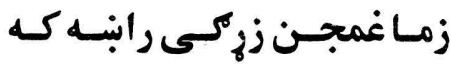

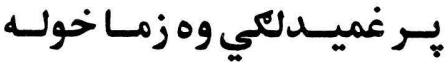
كه كرد ير ما خواري هويُوندي

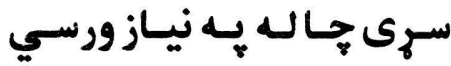

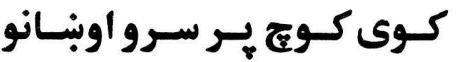

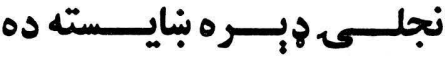
زمـابسي ديـــ هـر جنـازه سـي

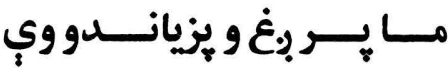

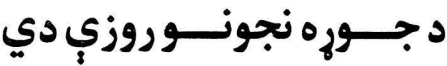

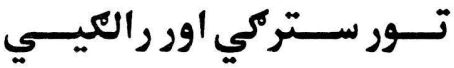
حُـــواني مــرك د كــم نـاداني مابس ير كت غوماسي خـوري

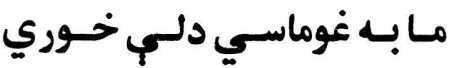
مــــــــوز زوماسـي خــوري

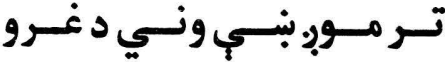

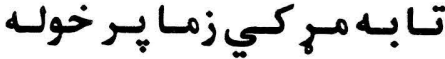

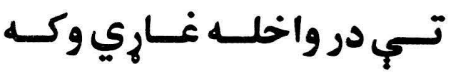

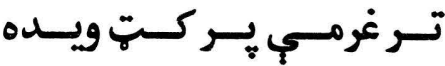
تــهـي حُحسي غــم راوبنسيجي

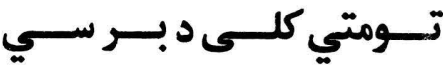

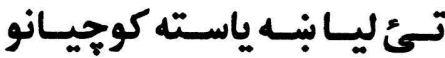

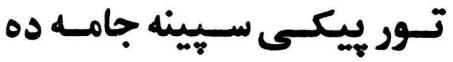
تـور يـكس نجلس د مـره سي تـا بـه غـرهكي ميـري بـوروي تورو كالي سيني يبي بنبي دي تـــوري ســتركي تـــور كـالي

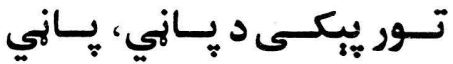

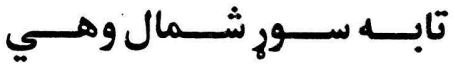

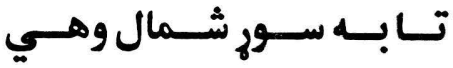

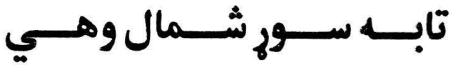


كاكرى غاري

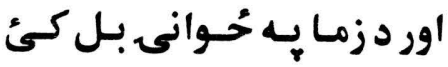

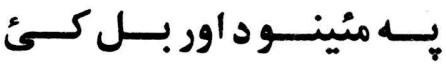

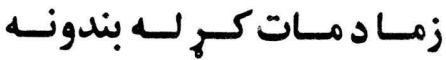

كور تهـ ولاره سه غم جـور دى

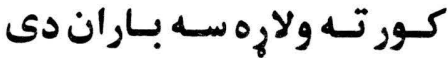

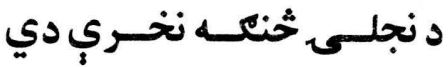

بـه يـبنوبـه خـود زولنـي ورئي

لـــونكين مـــه د جانـــان دى

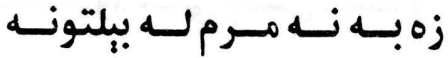

مـا بــه سـيـين ماتهـ كـي روزي

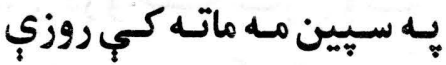

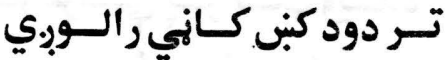

سـره بــ كـم غابنسي لـه راسـي

يسر سـر مـه شـال نـه درويـــئ

كران يـهـ بـاغوكي و د يـبنين

مـوب.بـه هـم درسـو خابنـوله

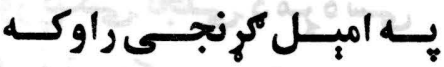

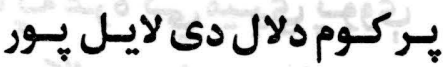

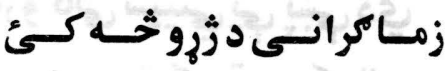

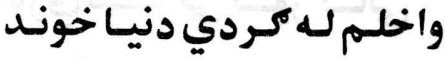

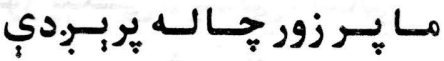

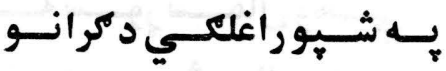

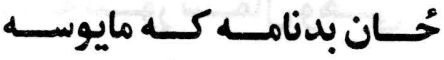

مطلــبـ مسه وئ ســتادكـايو

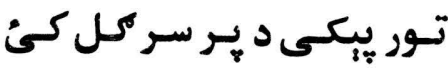

تـور بـكسى ثخى دو ول ول كـئ

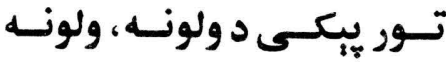

تـور يـكسى د يـر مـخ خـور دى

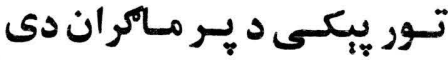

تـور قمـيص جـوتهي سـري دي

تـاخي سـيـيني خـولي خـوري

تـر جهان رابانسي

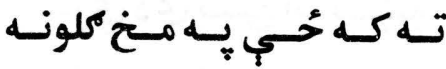

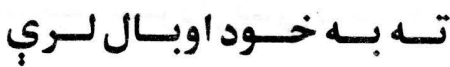

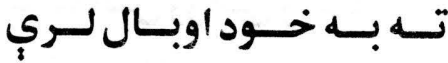

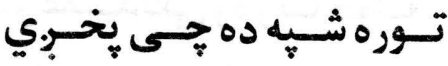

تكتــــو دى غابنـــي، غانبـــي

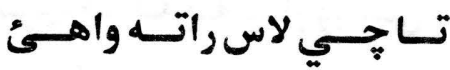

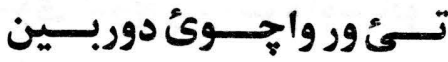

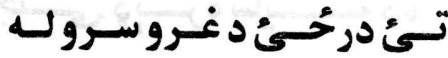

تـوره شـيه ده ليـار مـهـ وركـــ

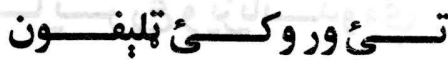

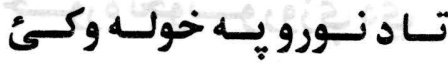
تـه جـي كسنبني زما يـر ثخنك

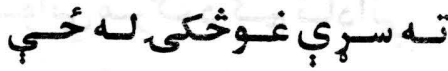
تسـوري ســتركي بــي رنجسـو

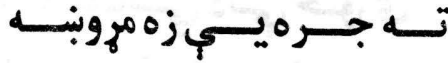

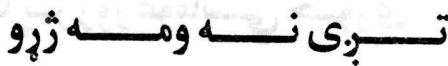




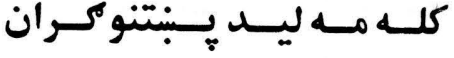

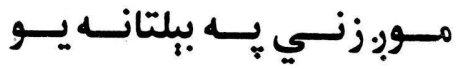
هوهي وخــورم دور وليـار سـم سـتا بـــه قرآنــو نـسته بــاور خوسي خوارى وي ثخي ماكنبي سـتا لـه مـاخــواري مـانه دى

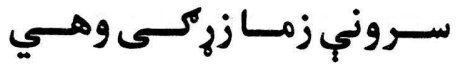

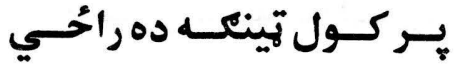
دوارهد تـــور كولـــودانـــي

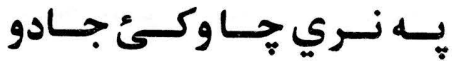

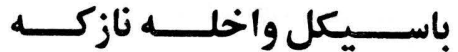
ادي نـامر دي خخي كر ان تلهُ

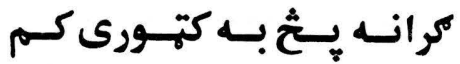

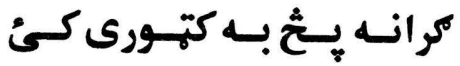
شـكـ د خلكــو لـه ززوو باسـي تـــــــــاد ناســته ده نبـــوهـ

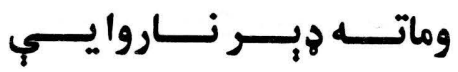

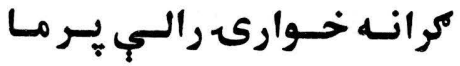

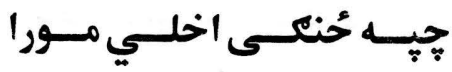

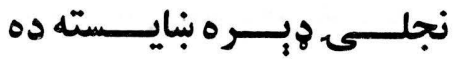

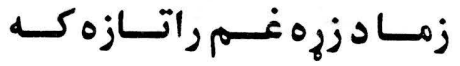
خلــك بـــي اوره ســوحوي سـيني واوري تـورو غـروكي كران به شين شوبو كي راخي

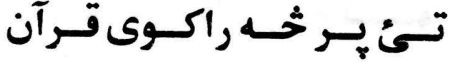

نزدي، نزدي ليا لري نبها يسو تــــــزي خـوني د جــار سـم

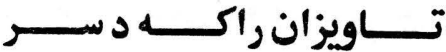

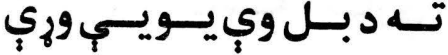

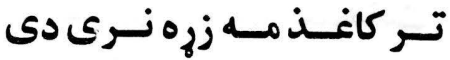

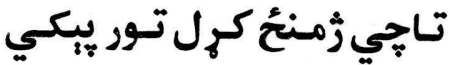

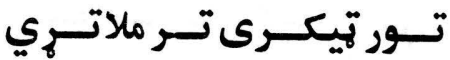

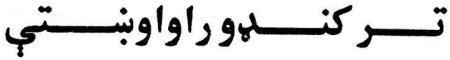

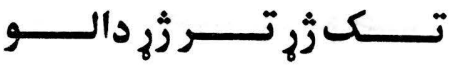

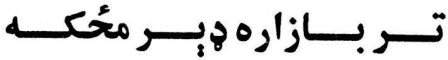

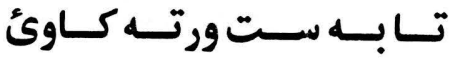
تـــ دوى بــ حُــان رومبـى كـم ترمـاينو بـه حُــان اسـترى كـئ تــــه سـوه بيرتسه بـه راسـي

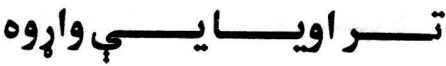

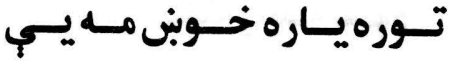

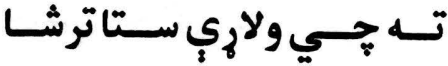
تــوري ســتركي نــــــــاكل

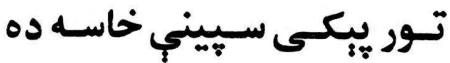

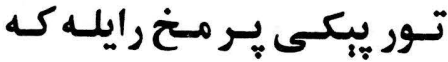

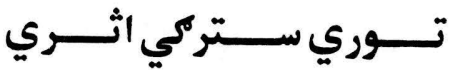
تـور لونك بـهـ دوكانوكي تروبومس ده سـيسي خـوري 


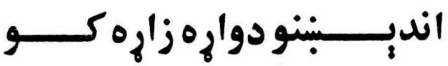

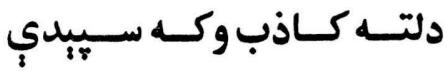
كــه جـــا ايمــان وي ســلامت كـه جــا ايمـان لـه دنيـا وراى

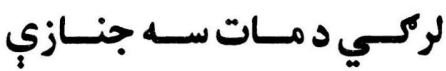

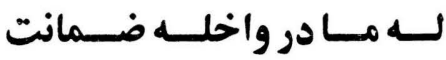

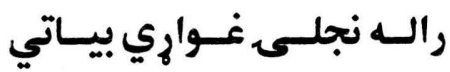
هـر تـور سـائيكل كله راحسي

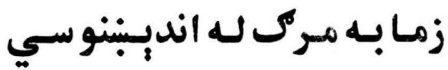

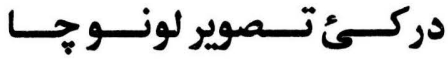

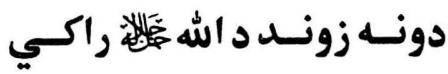

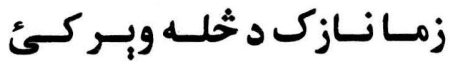
شين كل د هير خوب د كاوئ

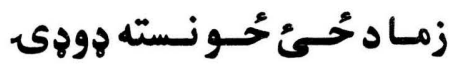

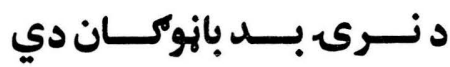

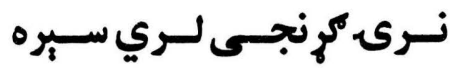

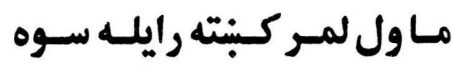
زوى بـب كم ثخي بـ رابنـوري

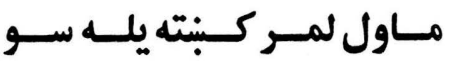

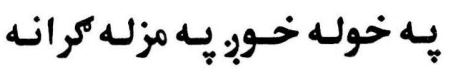
زمــالالـــ وتلـى حُـــوان دى

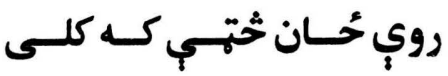

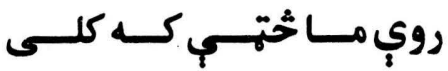

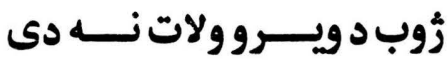

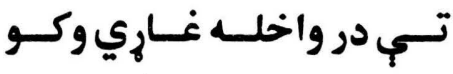
تــ جـي زمتالـه غـوحُق تلـي تــــر هورى نـــسته راحســت تـــر دورى نــــته بنــهـ حُحساى

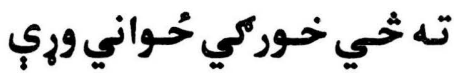

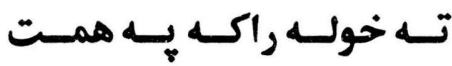

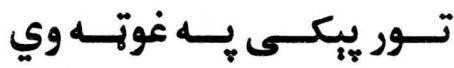

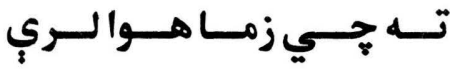

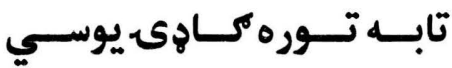

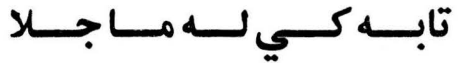
تـاد خـداى محتاجـه زمـاكي

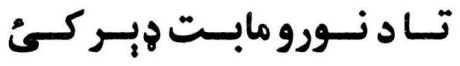

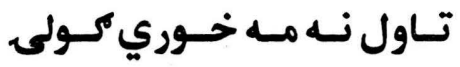

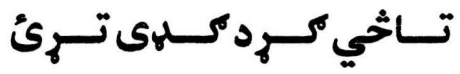

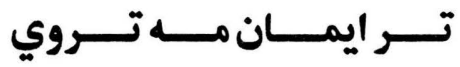

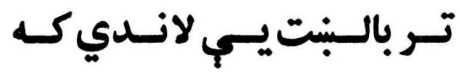

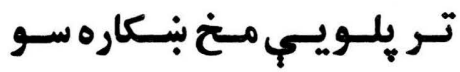

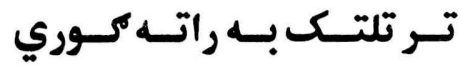
تر تيكري يسي منخ بنـاره سو

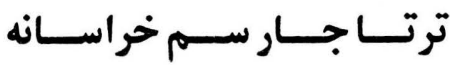

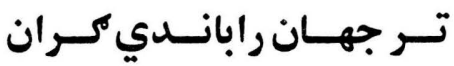

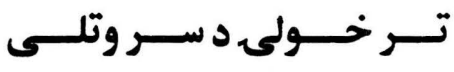

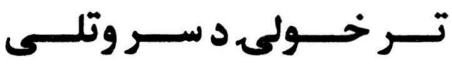

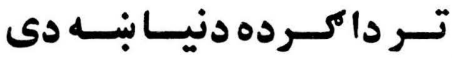


سـتركي كـوله د نـازك ووي

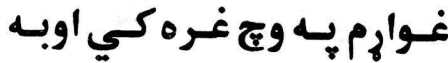

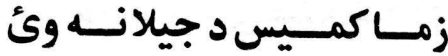

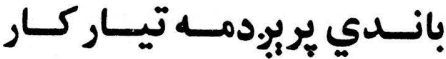
لس روبـس هوي.ودمسه تيـار كار تالـهـ مــاخـــــاروي مــانه دى

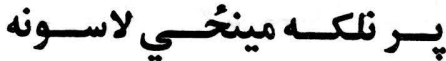
ذزرو اوس نـــو مــــساير ســـوم •ـاى مـه مـرك دى لـه برتتونـه

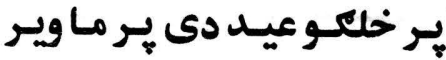
د مسور د هـمر نــه سـي دوزي

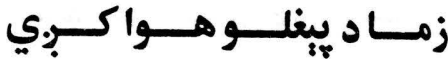

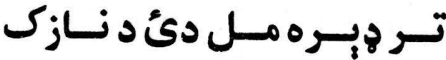
دزوه هـه مــراد ورحُحي نـازك وهـي بــ سـا د سينب زنك

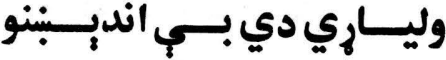
مـاخرخدمـول داسـي حُوانـان لـهـ مـاكـــانيـار مــوور ســو

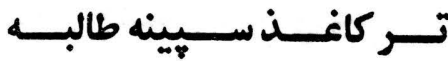
د مزكــي بنـــم ورتـــه مــالوم

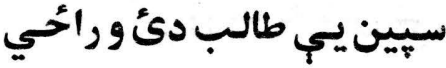

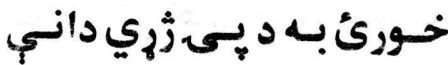

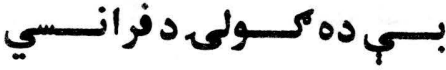

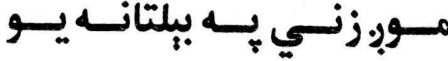

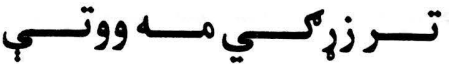
تـبرى سـوم د سـري :ــر خولسه

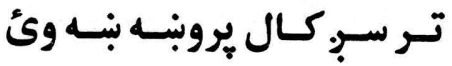

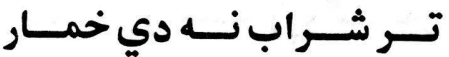
تـر غــوبونويسي سـر خريلسى

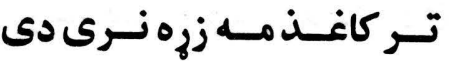

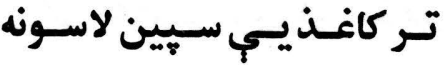

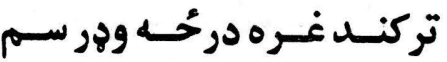

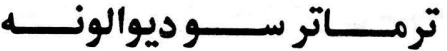

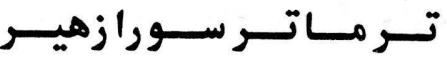

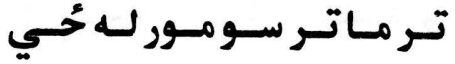

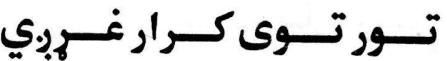
تــر مــانبــه دى تـور سـرك

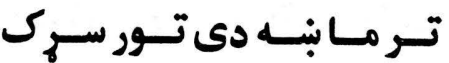
تــــــــانبـهـ دى تـور لونـك

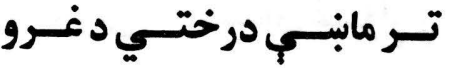

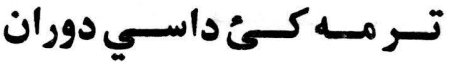
تـر مجنـون مــه حـال بتـر سـو تـر مسخ خولسه دركسم كـه زبـه

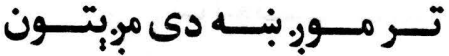

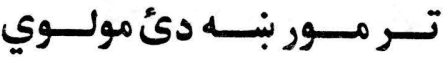

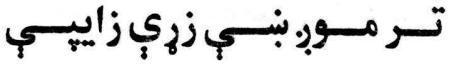

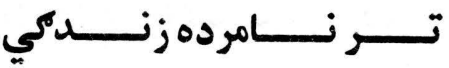

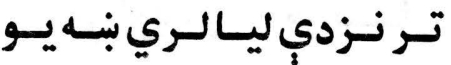




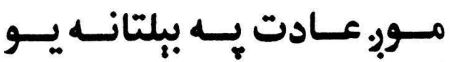

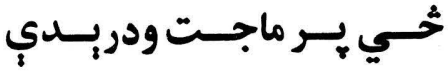

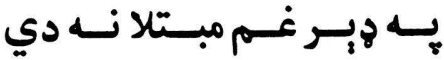

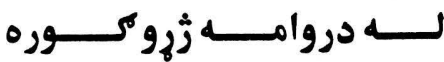

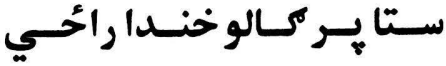

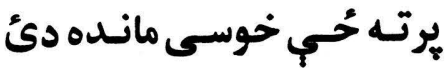

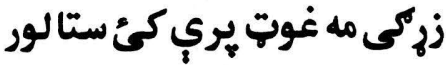
مطلــب مـــه وئ ســتا دكـايو

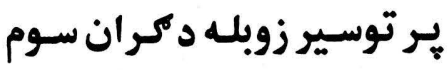

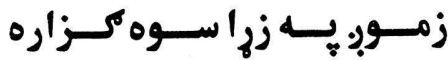

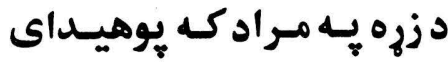

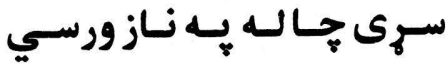
برتـور جمعسه خــان كـور واى

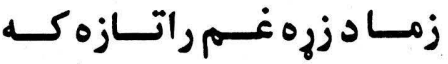
مـاخوبن كـــى مكتبــي دئ

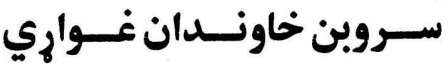

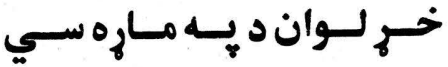

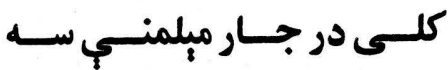

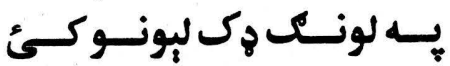

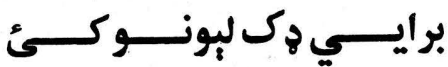
خونــــــي د نـازك ناستكي

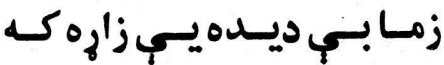
يروت هر هاكتر يم دوأ حسورم

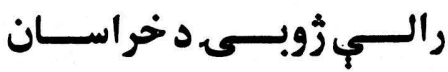

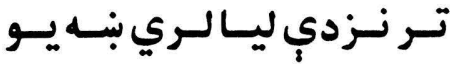

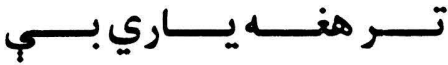
تـر هوبنــيار بـي عقله بنـه دي

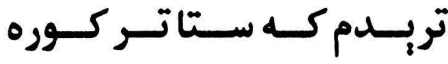

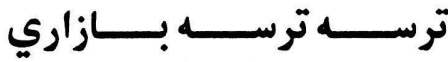

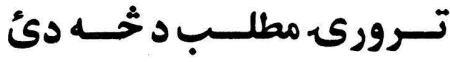

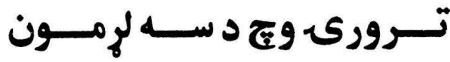

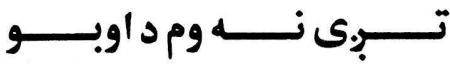

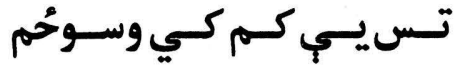

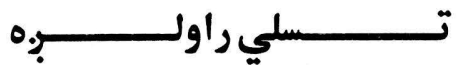
تـل بـه نـه واى دخــوبكـاى تـــومتي كلــــى دي بوسيــي

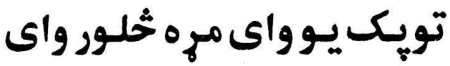

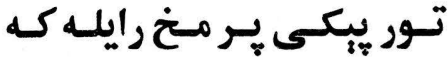
تـور يبكسى يسي يـر تندي دئ

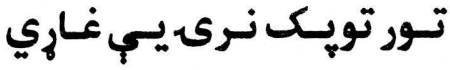
تـــور تــوى در رســي رســي

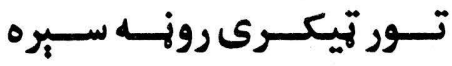

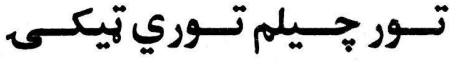

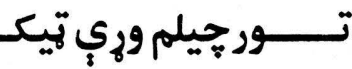
تور ستركي زرك يه لاس كي

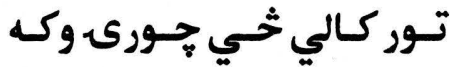

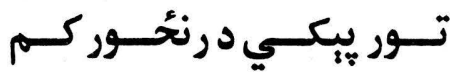

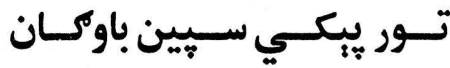




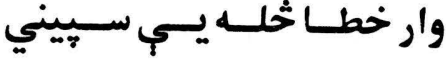

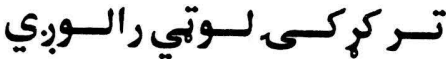

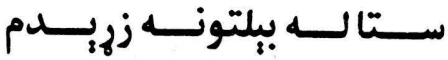

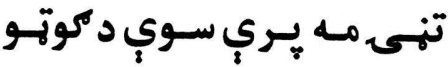
نـارنكى غونـلـي دانسه يـم حميـام نـازك باسـي لـه كوتجي خلـــ بـــي اوره ســوحوي

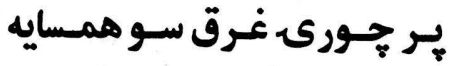
نــهـ زنــــان نـــه د هوروى دي

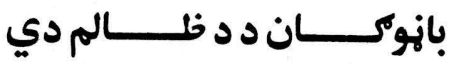
صـــادق ملــــــ دئ د نـــالى راكه د شبخ عبدالرحمال حال

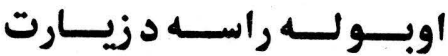

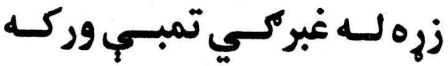

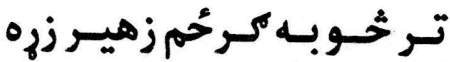

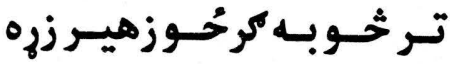

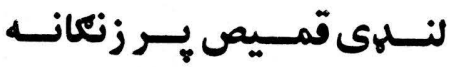
موروه محي نوم نه كي زماوير

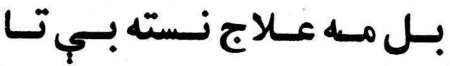
سـرى جــالـه يـه نيـاز ورسـي مخ به بت كم ثي كر ان ترسي كر انسه نـوري بـه شـناخته كي

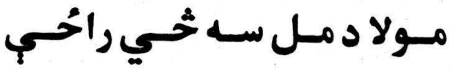
:به كنهو كي دسمال كنبر.ده
تـوره شـــه ده خـــوك د وينـي

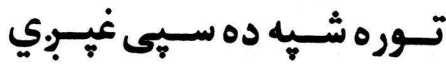

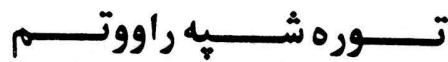

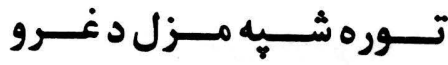

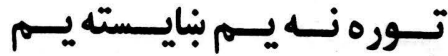

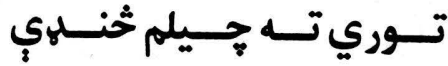

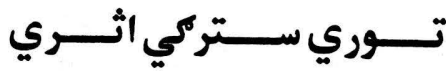

توري ستركي خوله يسب سره تـوري سـتركي دكـوله دي تــوري سـتركي ده د بسم دي تـوري سـتركي سـري ثَّهـ تبوري سـتركي سـور دسـمال

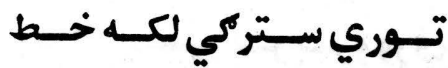
توكـل د خـــاى يـــر ســركه

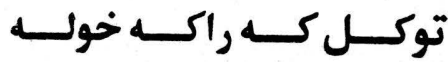

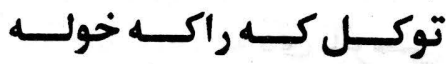

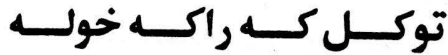

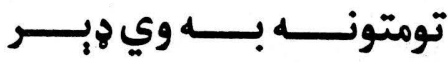

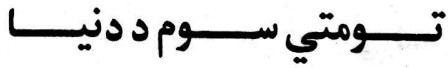

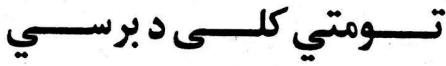
تــومتي كلـــى د بــــر ســي

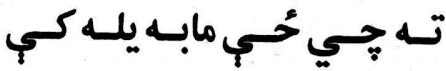

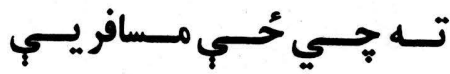

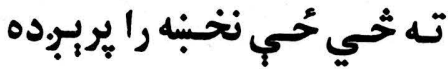


كاكرى غاري

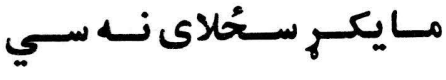

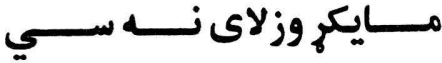

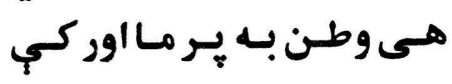

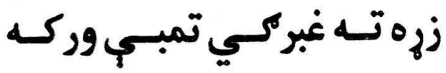

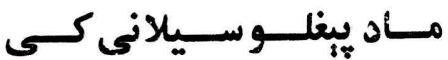

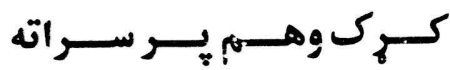

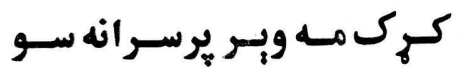

وركى حَانكوى سوه يـر وياله

مـابـه غوماسسى دلبي خـوري

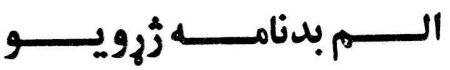

كر ان د كرد كلي شناخته دى

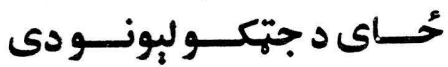

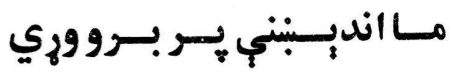

كه به خيل بنايست خبر سوي

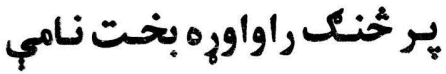

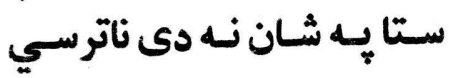

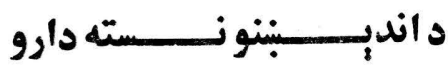

غركي كباب بــ كي حُوانـان

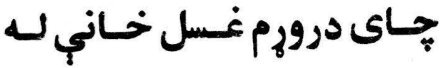

كس يـر بيلتـون سواسـت برابـر

تر غمم لاندي بـه زمازيرهـي

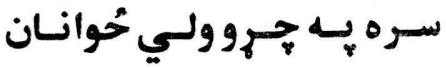

بلا دكودى جـورى حُحس كمئ

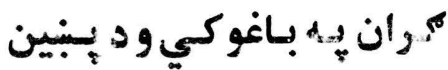

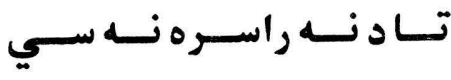

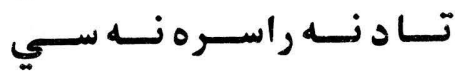

ته خحي حُحي ير زهه به زور كبي

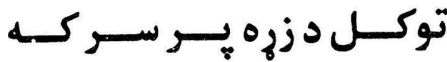

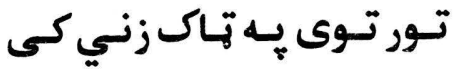

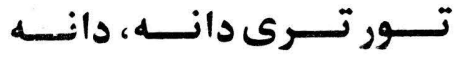

تـــور تــوى دانــه دانسـه ســو

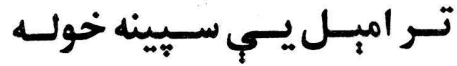

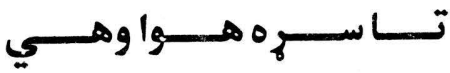

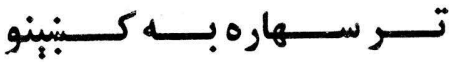

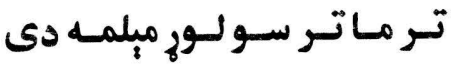

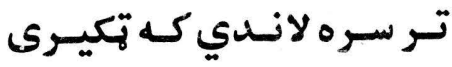

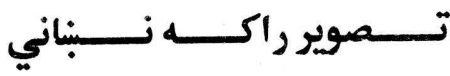

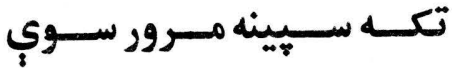

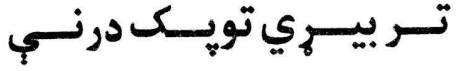

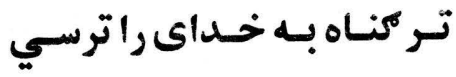

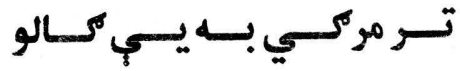

تــوري سـتركي سـره سـونان

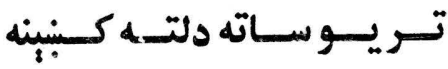

تسئيسي ولسئ خـاص يسر سـر

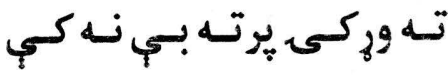

تــوري سـتركي ســره ســونان

تـاجي لـوى اودس بـهـوكى

تسئ ور واجـــــئ دوربــــين 
كه يـهـ جـال بنـده كى كرانـو تـس ودوو سـتركوتـه داسـتا زهيسي كرم هيتر يـ لمبـوتسور

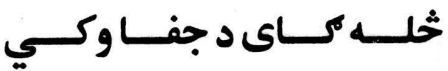

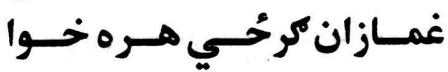

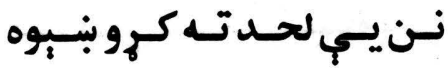

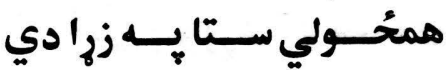

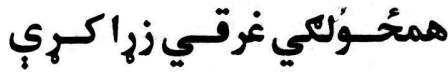
رايسـي د سـري بيلتــون دى

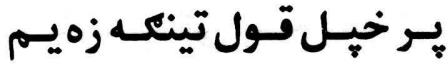

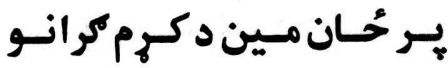

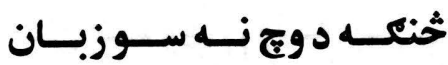

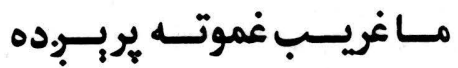
كراني زمساكسور دى كندواله خـوبن مه يجي تر بنسوحُوانانو كل لـوى سوبي مابـ تباه كي

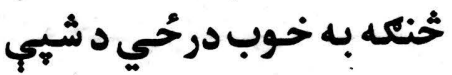
يـر ماسيـيـومـاحينكر كسال

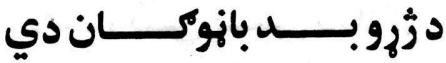
مسـدام دوينـي شـــين خـالى

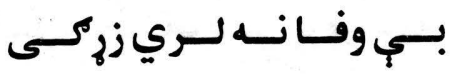
بور ستركي نه لري زرهان سوى لـون

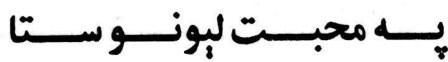

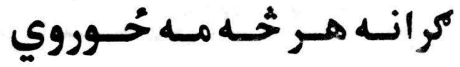

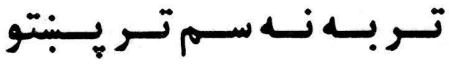

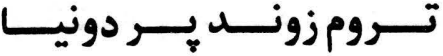

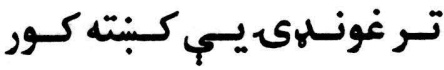
تل مه اوسي كران يه زيرهكي

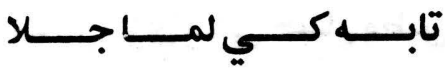

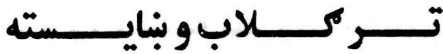

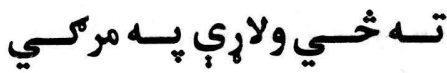

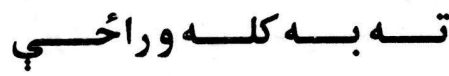

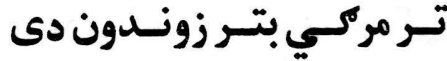

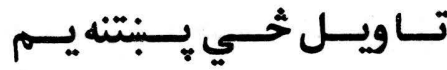

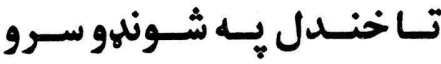
تـاخــي وركسئواكس دئحسان ته ير لاس نكريحُ كبنبِر.دده

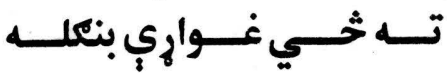

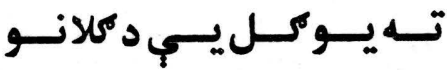

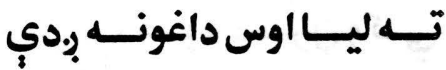

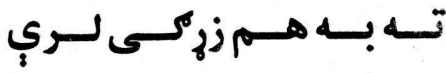

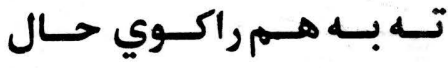

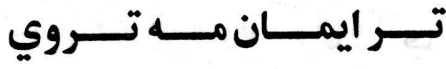

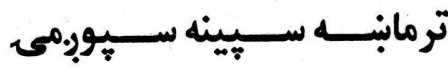
تـور كسالي تـوريسي تيكسيكرى

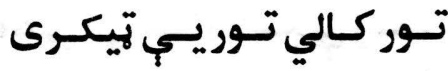

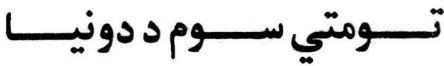
تومـت سـتالـه خــوارائحي 
كاكرىغاري

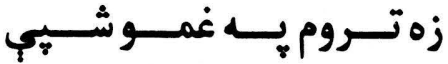

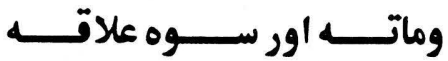

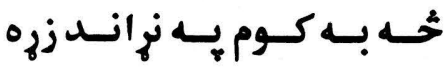

زمـا بـه قـسمت كـي اندهـنسنج

مـادر بـري يـبنى خيـل وطن

نـرى تينكسه بـر وعـدهـيـي

وماتـهـ زوزـل اور سـو جــورى

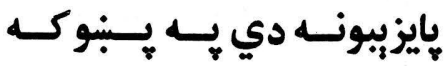
د كولب كاركران دى مـوركى

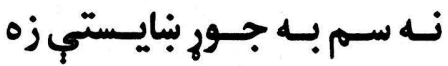

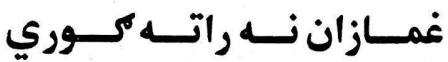

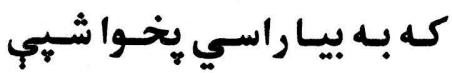

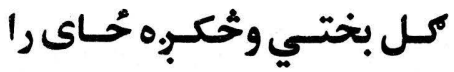

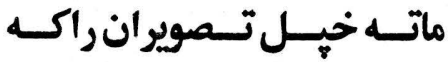
كلــــي لـــــــالوى د باســـور اوس بسه خــومرهمـزل ووكـي جـور سـي جنست ده علاقي رنكس د ورك د بـلتانــه سـي كـران بـه خــومرهمـزل وكـي رالـل دلـوى كالـهـ حُوانـان له تـور خيـزى كـاوي اوبسه وهـي بـ ستا دد سـنب زنك هـروت دى د بـوري هـرجبين كلــي لـه ولار ســي د باسـور

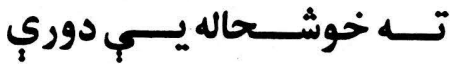

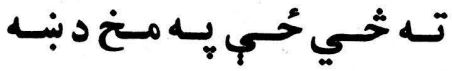

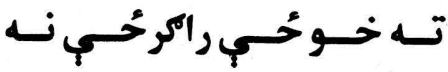

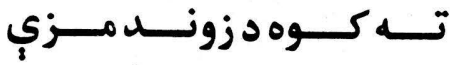
تــــــى يـــم ســــا د ديـــــن

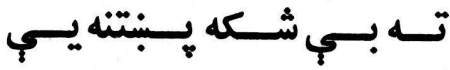
تسه خــي يسو وري تـر سـيوى تـه بـهـ غــاره هـار د سـرو كـه

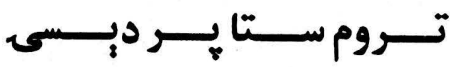

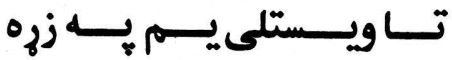
تـــ روحُ شـيه بنــه ده باسـوري تــل بــم وي ززونـــ ايـــــي

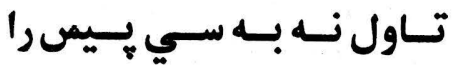

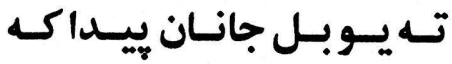

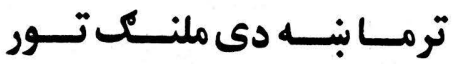

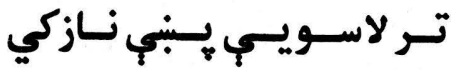

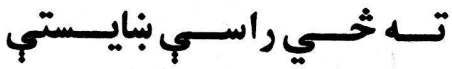

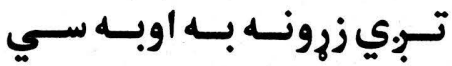

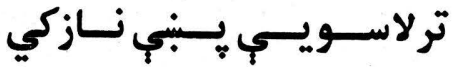

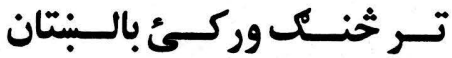

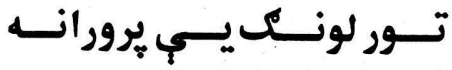

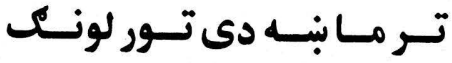

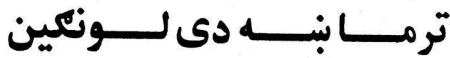

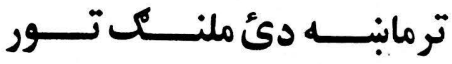


كــــــــــــــاس لاسبــــوراوئ

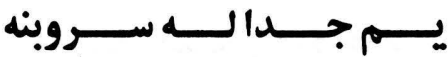

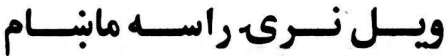

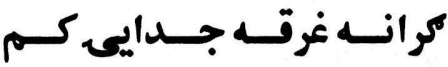

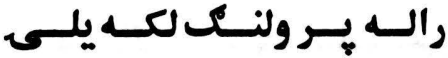

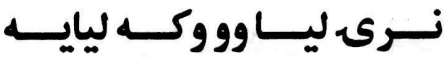

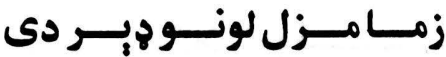
ادي ليــاورك دى خركــالى ادي ليـا ورك دى ثخلـور بـول

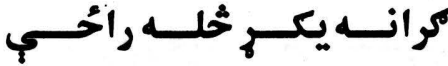
كه مه خندل هُبر دي حُحوانان

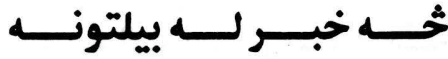

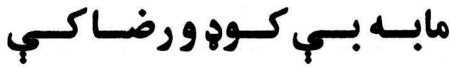

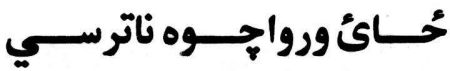

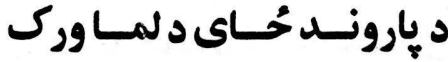

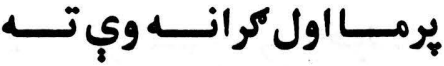

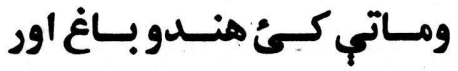
تر خداى لاندي مه ستا هيله

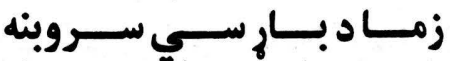

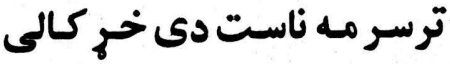

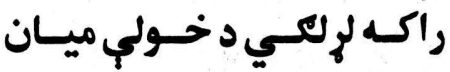

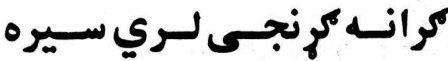

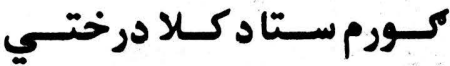
شـكـ دخلكـولــ زروباسـي

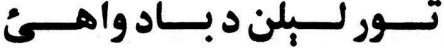
تر هى زوند به مرك سودمنه

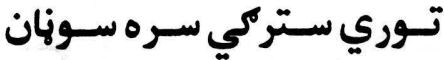

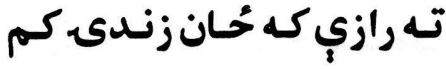

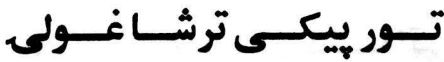

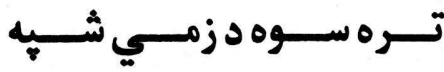

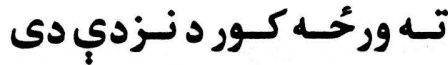

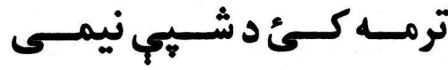

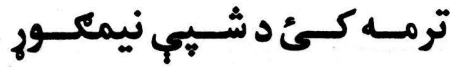

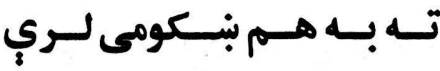

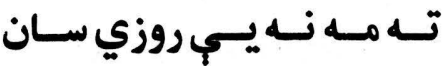

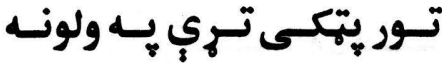

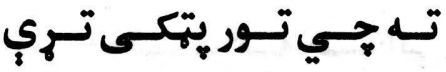

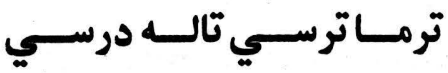

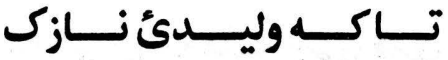
تـوري سـتركي كـورى خولـ

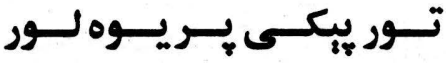

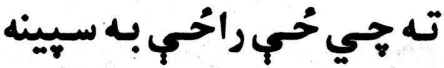

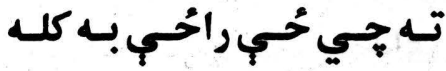

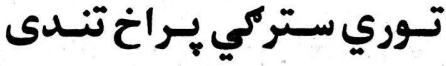

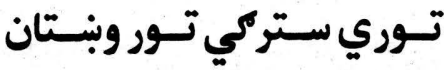

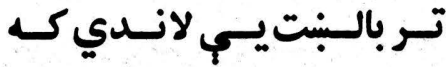

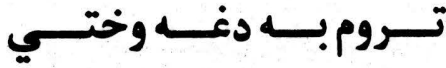

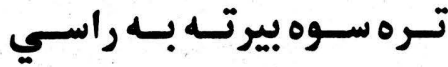


كاكرى غاري

rr.

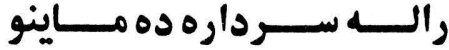

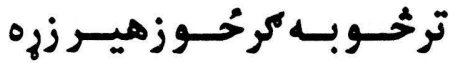

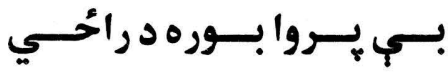

خوله بـر بالبنت واخله شـوقي

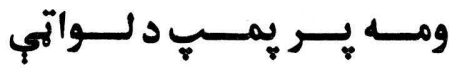

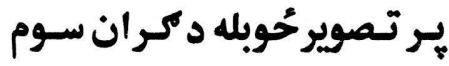

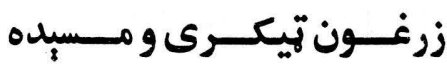

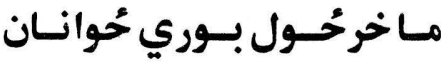

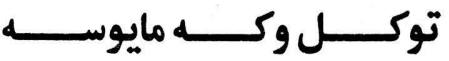

زالـى اسـلام د يـستخ خــولب

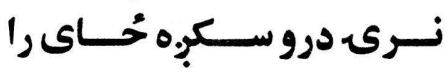

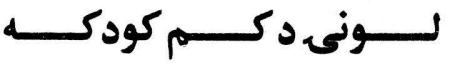

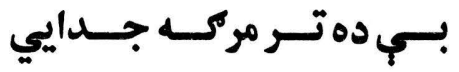

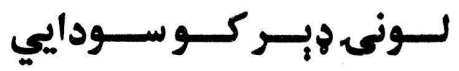

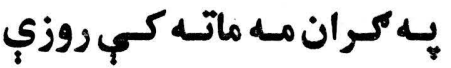

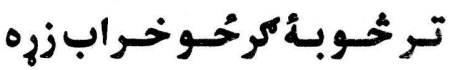

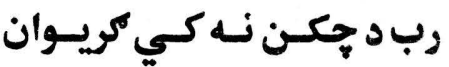

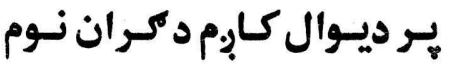

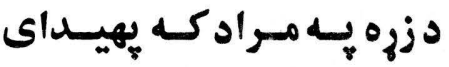

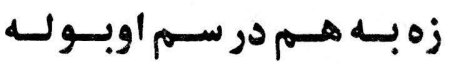

غواجم هبه وج غبرك كي اوبه

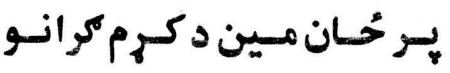

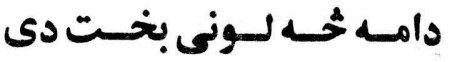

رايسـسي د سـري بإلتــون دى

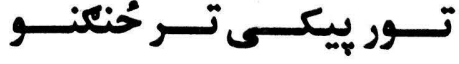

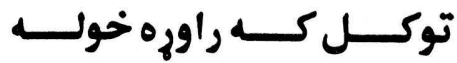

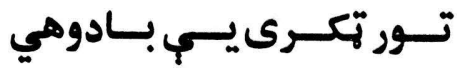

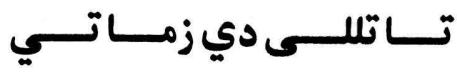

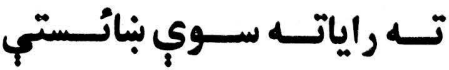

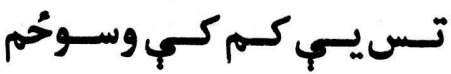
كوكلا راووتس

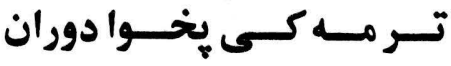

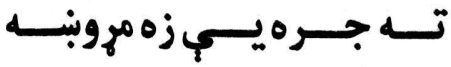

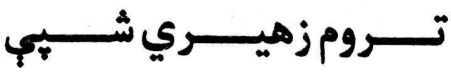

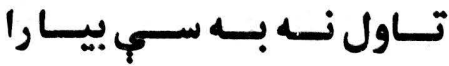

تـه بـه ثحسه سي زمـالـه حقـه

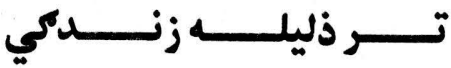

تــوري سـتركي غـوري نيكسي

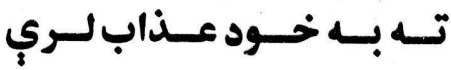

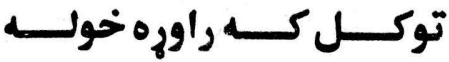

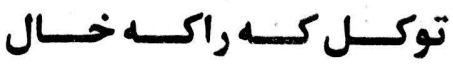
تـــور كــالي هيتكسـى ليلـــون

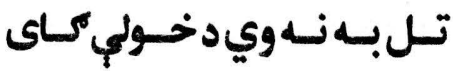

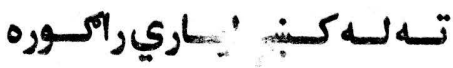

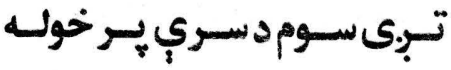

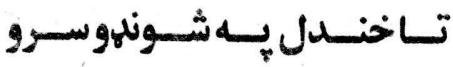

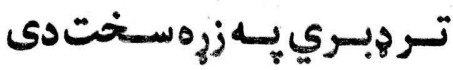

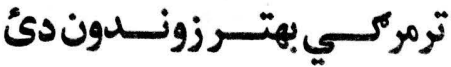




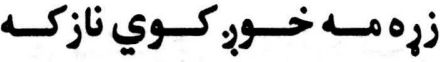

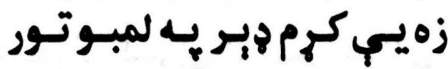

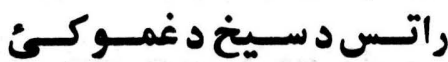

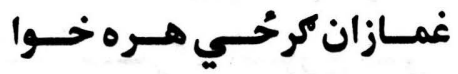
د نـــامردوكومــــان نـــور دى

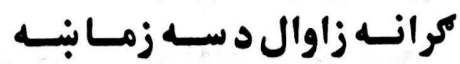

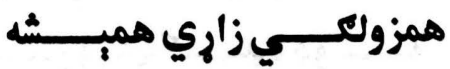
سـتا تعلــيم ثـــو دى نـازكي نــن د همزولكسوزئه

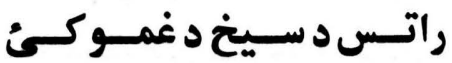

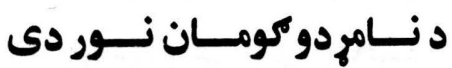
درواوى لـه نبركـي وراخــي

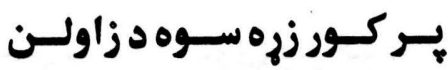

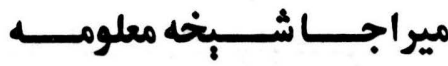

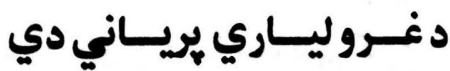

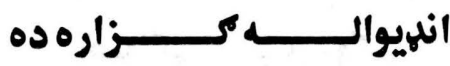

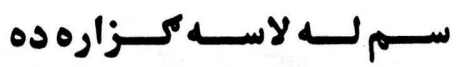

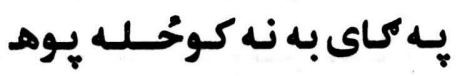
ك..... بــيني ورى وكى لــــمم تـاريخ ســـا ديــارىى

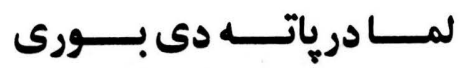

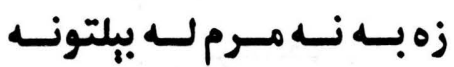

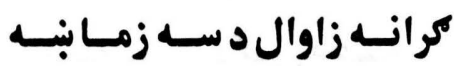

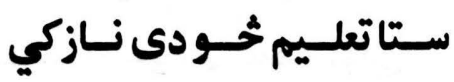

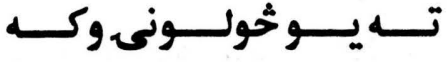

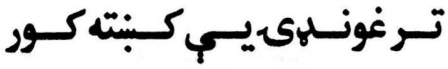

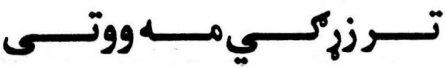

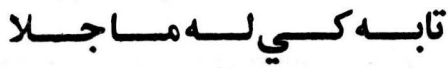

تـور يتّكى هلك مـه ورور دى

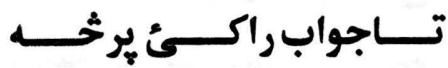

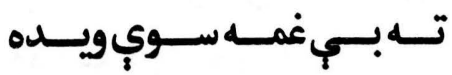
تـوري سـتركي يـري خمنكسي

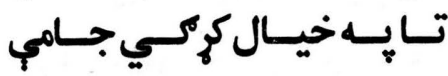

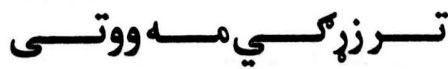
تـور بتجكى هلكس مـه ورور دى

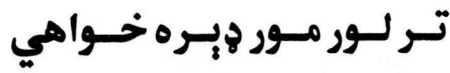

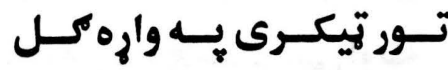
تـور تهيكــى هـر زى هاوونـه تسوره شـيه هلكسان كمـك دمي تر هاركل يسب كوتكي بنه ده

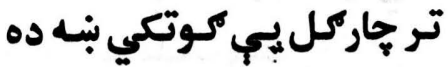

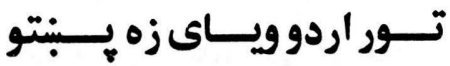

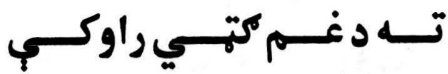

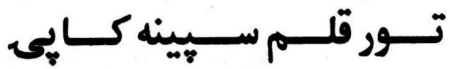

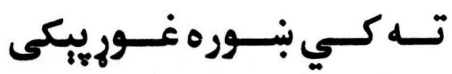

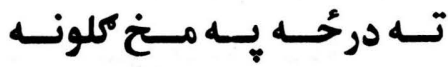

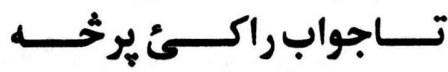
تـوري سـتركي هـري مُنكـي 
هــركسور زيره ســوه دزاولسن

اوس بـه هـر ملكس وسي بـاروان

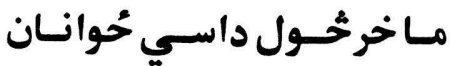
د بنـار نيمسى دى شـين خـالى

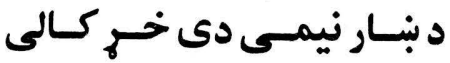

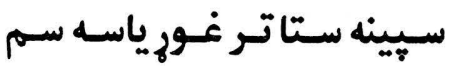

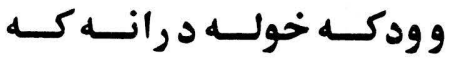

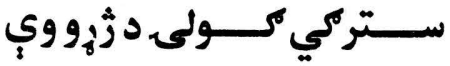

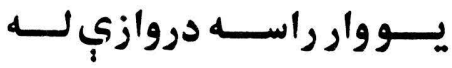

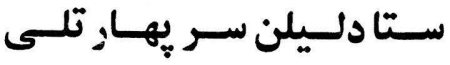

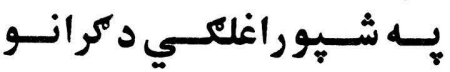
يـر تــور سـائيكل كلـه زاحسي

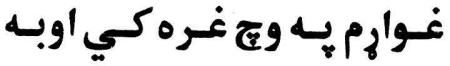

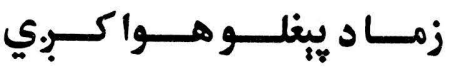

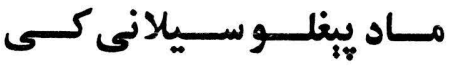
مـابِل باسـي لـه تـور سـتركي

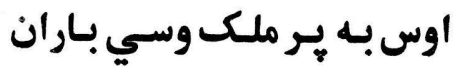

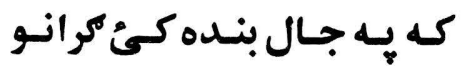
يـر كمي كبنلكي ده زمـازوى بروت دي يـر ستركو د جانان

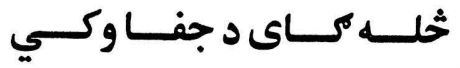
ومــاتي كـــ هنـــو بــاغ اور

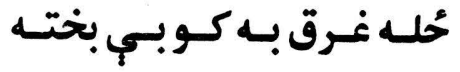

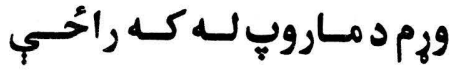

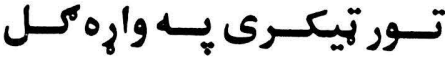

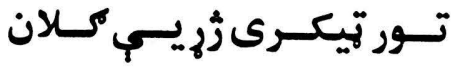

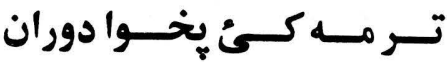

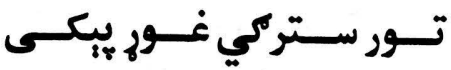

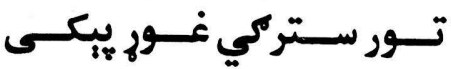

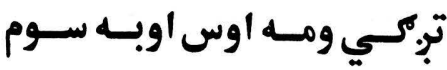

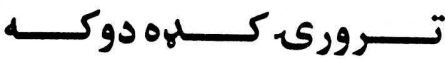

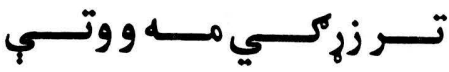

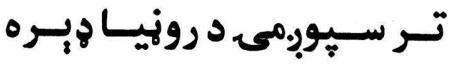

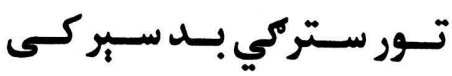

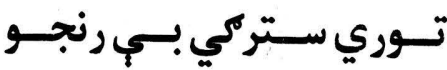

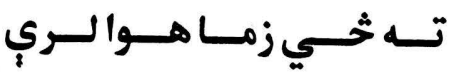

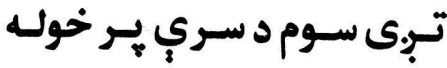

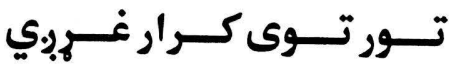

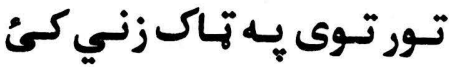
تـوري خــوكي ميـبـي روكي

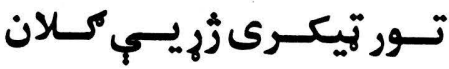

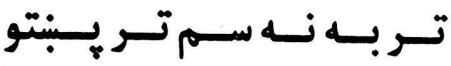

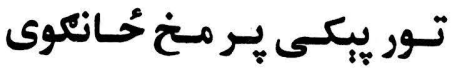
ترمهـا بــــه دي تـــور اوبـــــان تل مه اوسي كران به زرهـي

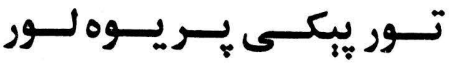

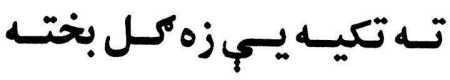

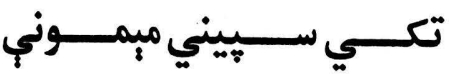




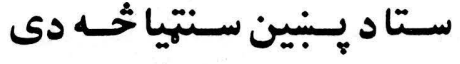

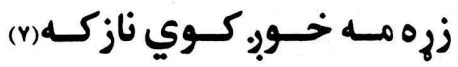

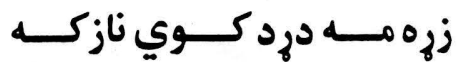

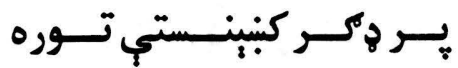
تر خداى لاندي مه ستا هيله يهلهيـان كي كرحي د رودى كـبنل مـه د عيـل بـه سـهار كـه تيـا بـه كنــيل كري كـلان شـنه بـــه زور رايـات كــم ســـووبن

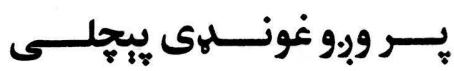

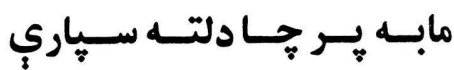

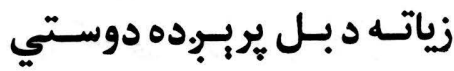
يه خداى كه لاس راكئ بل جا. •ــــر مـــاســور اور ولكيـــئ

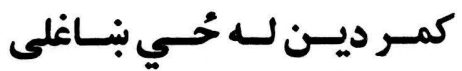

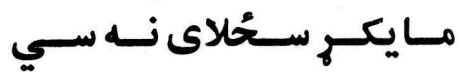

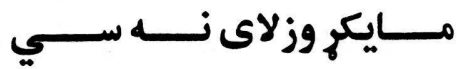
هـى وطـن بـه هـ مـاور كـي

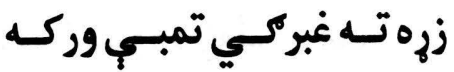
د بنـار نيمـى دى شـين خـالى

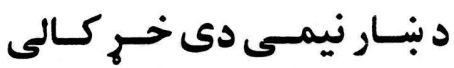

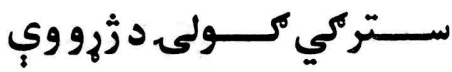

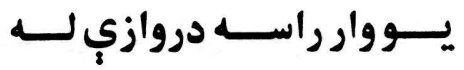

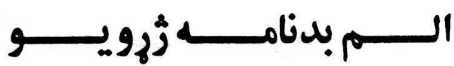

تـهـ خـــي زازي ورور د نـه دى

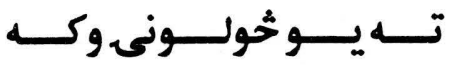

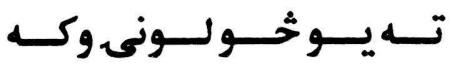

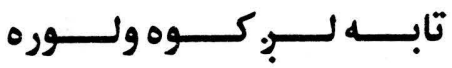

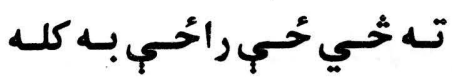

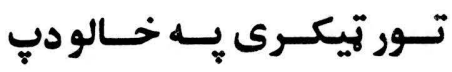

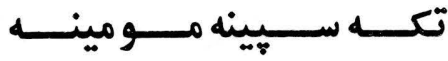
تـه خــي رالسي غـواري خولـ

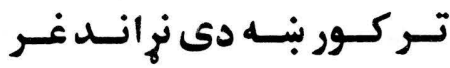

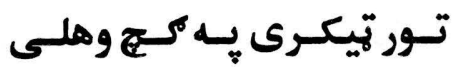

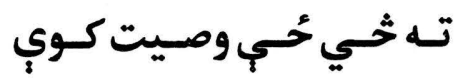

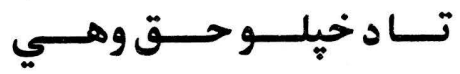

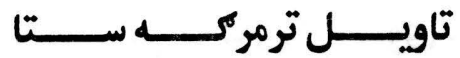

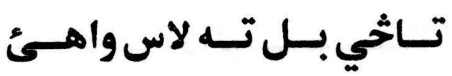

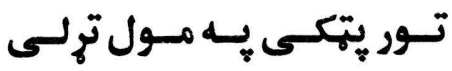

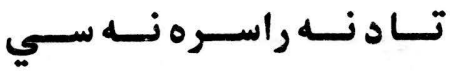
تــاد نـــه راســـره نـــه ســي ته خحي حَي ير زهوه به زور كي

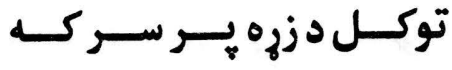

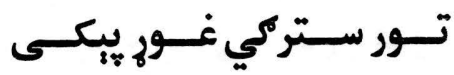

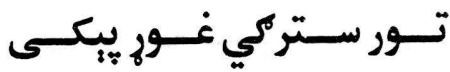

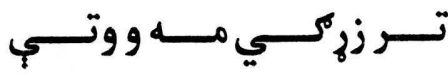

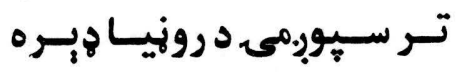

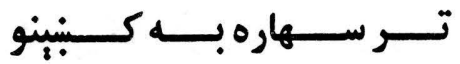




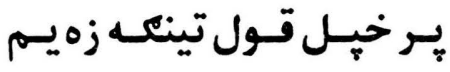

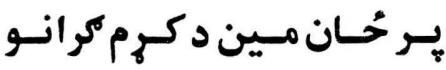

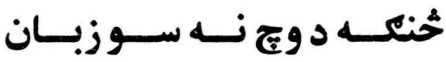

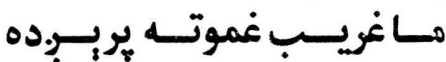

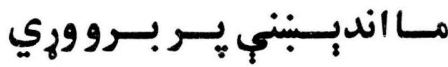
خـوبن مه يسي تر بنـو حُوانانو كـه لـوى سـوي مابـه تبـاه كي خنكه به خـوب درحُحي د شيبي

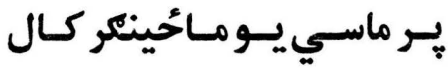

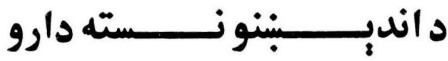
مــاميسي وينـي شـين خـالى

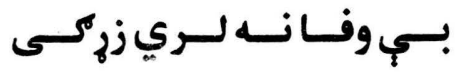
بور ستركي نه لري زيره سوى

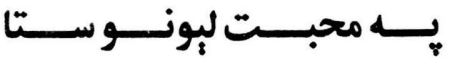

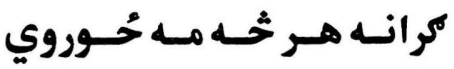

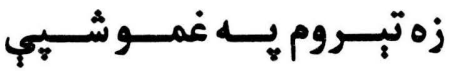

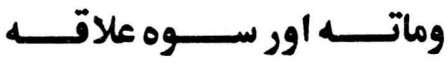

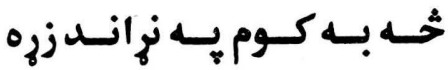
زمـا يـه قـسمت كي انديـبنيخ مـادر يـري يـبنى خيـل وطـن

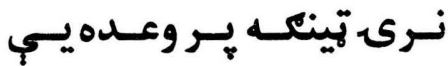

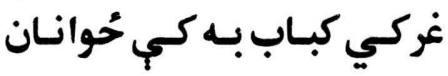

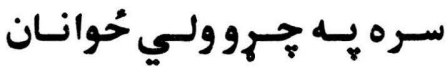
دكولي كار كران دى موركى

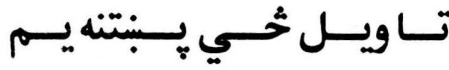

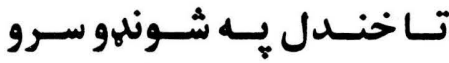
تـاخـــي وركسئ واك دحُّـان ته ير لاس نوكريحُي كنبّردده

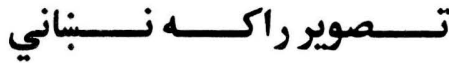

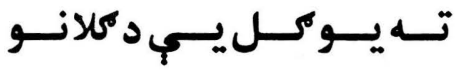

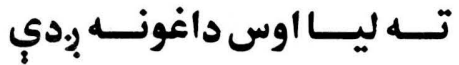

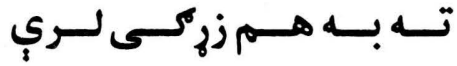
تــهـ بــه هـــم راكــوي حــال

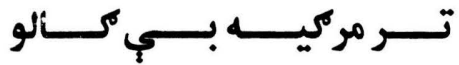

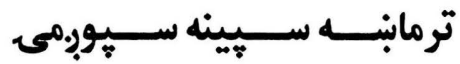

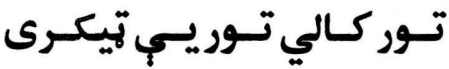

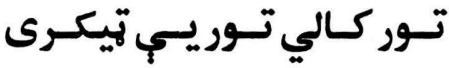

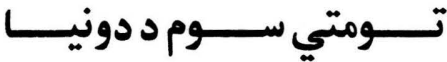

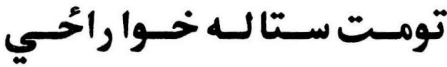

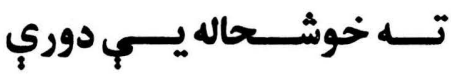

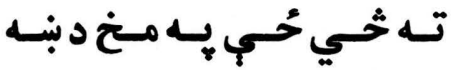

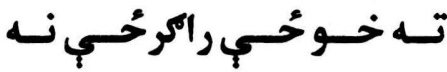

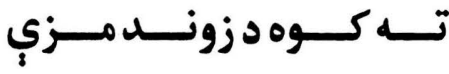

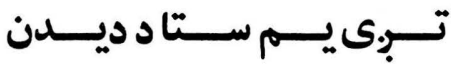

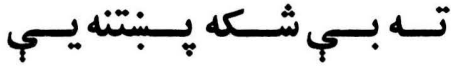
تــوري سـتركي ســره ســونان تــوري سـتركي ســره سـونان

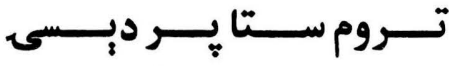




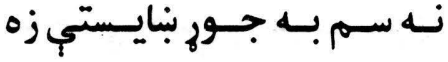
كر ان بـه بـاغوكي و د بــنين

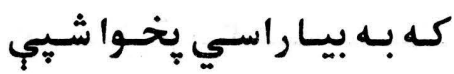

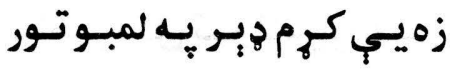

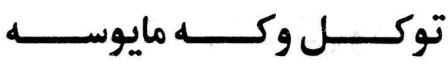

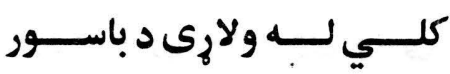

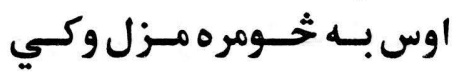
جـور سـي جنست لـه علاقـي رنـــ د ورك د بـلتانــه سـي كـران بـه خــومره مـزل وكي

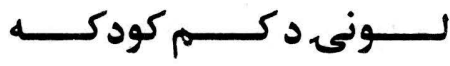

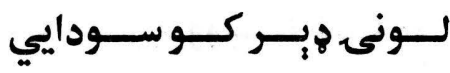
تبهـكـران مـه ماتـه كـي روزي

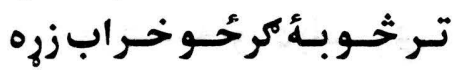
يـر ديـوال كـإِم دكـران نـوم

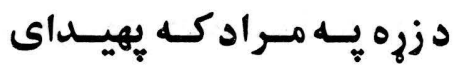

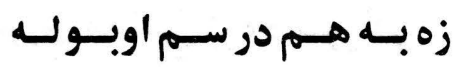

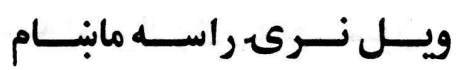
زهيـي كرم هوبـر بـه لمبـوتـور

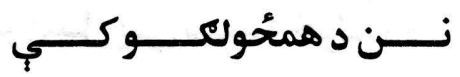

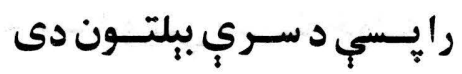

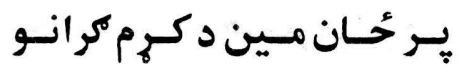

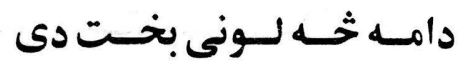

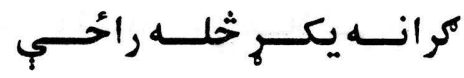

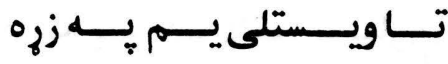

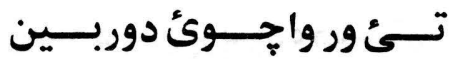

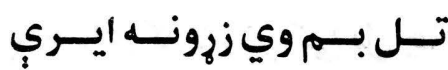

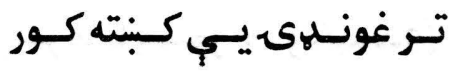

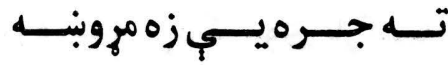

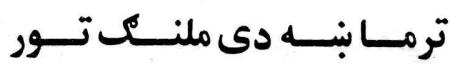

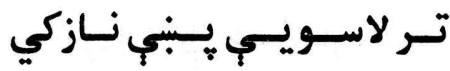

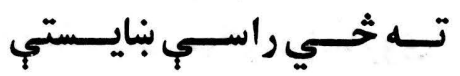
تـــوي زيرونــه بسـه اوبسـه سـي

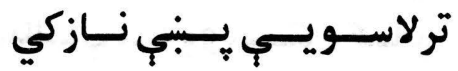

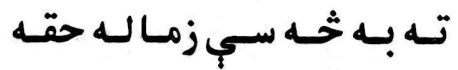
تـوري سـتركي غــور بيكسي

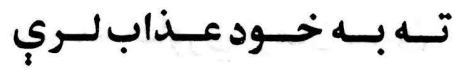

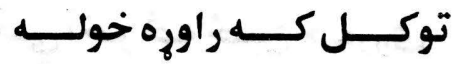

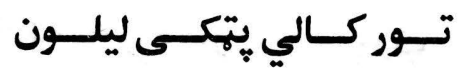

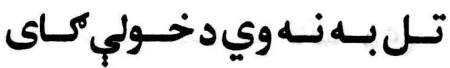

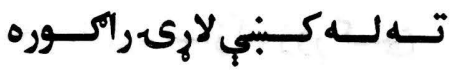
تسوري ســتركي سـره سـونان

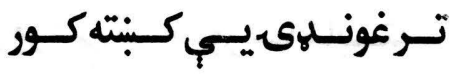

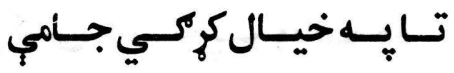

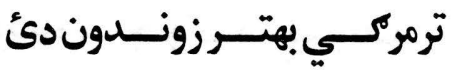

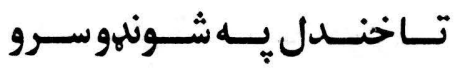

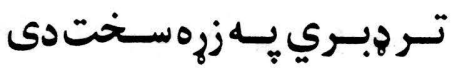
تـهله بـه هـم يـو دوستـ لـري 
كاكرى غاحي

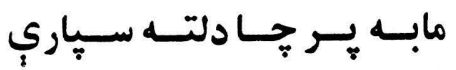

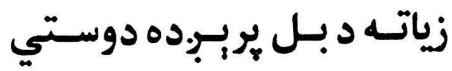
به خداى كه لاس راكئ بل جاء

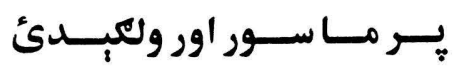

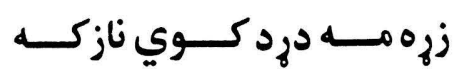

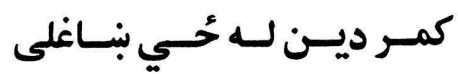

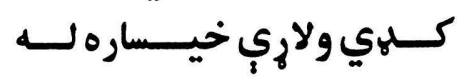
يـه بخـت د سـوكي د زمـازوى

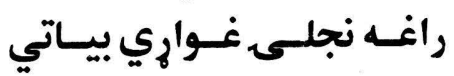

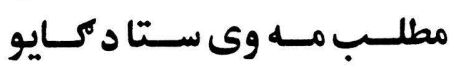

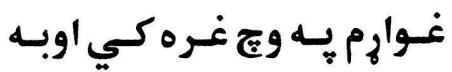

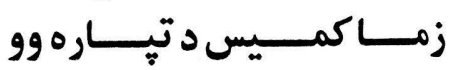
زياته مـه خـاوري ارمان سوئ

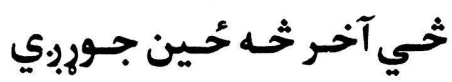

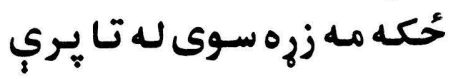

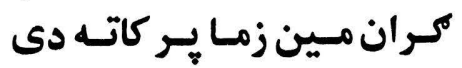

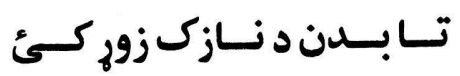
به منحُ كي جا راورئَ بيتتون وروريـي تـر خـور ليـابنايــته

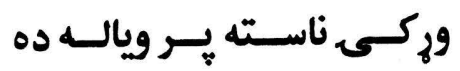
غونـلهه مـه جــوك كـه يـر ويالـ

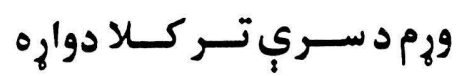
خدايه نصيب مه كي جـورى

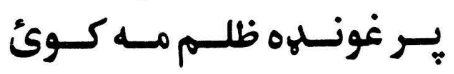

تــه خــي حُـي وصـيت كسوي

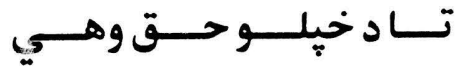

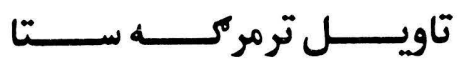

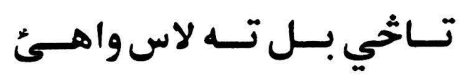

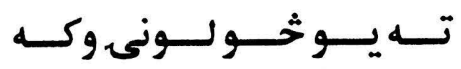

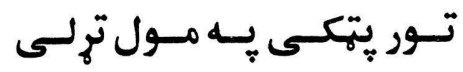

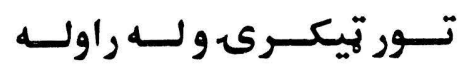

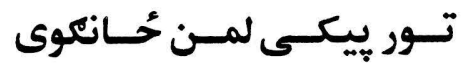

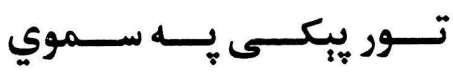

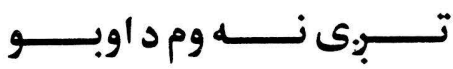

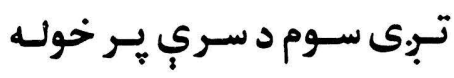

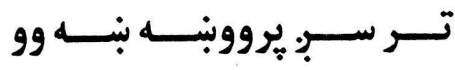

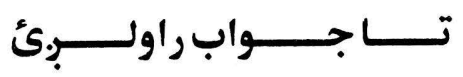
تـــــه ورحـــــــه اور د بلـــــــــي

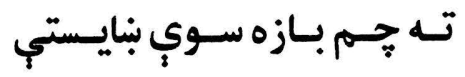

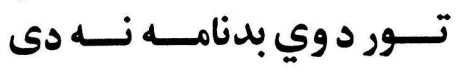
تـوري محككي زره د سـورئ

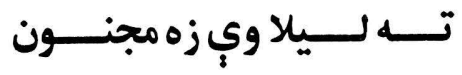

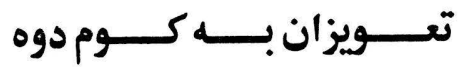
تـر امبـل يـي سـيـينه خوله ده

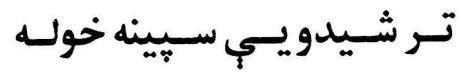

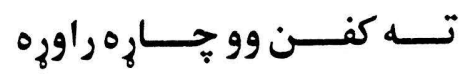

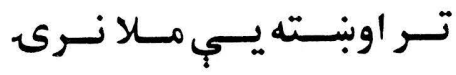

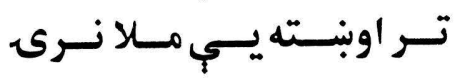




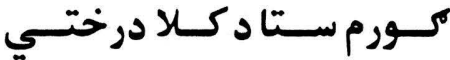

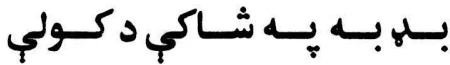
يـه لاستي زور كه د د بيلجي

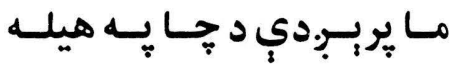

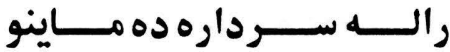

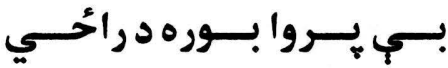

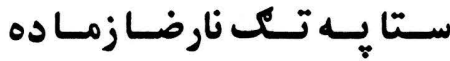
كه كرد بـر ما خواري بريُودي

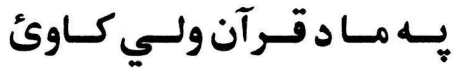

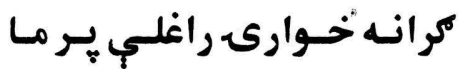

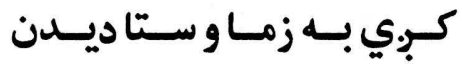
كر انــه تــل بــه دلـي نـهـيـم

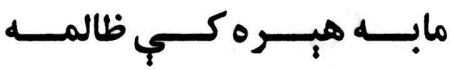

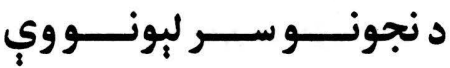

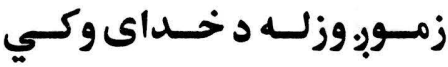

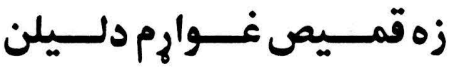

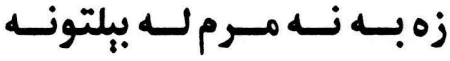

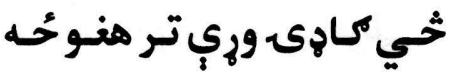
خــي تلـى يساك كـم د تـالى

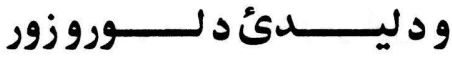

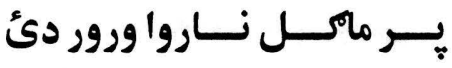

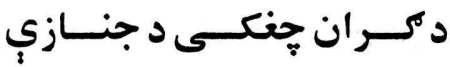

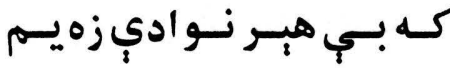

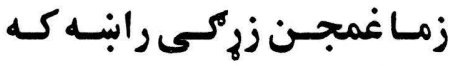

تــــروم بــــه دغـــــه وختـــــي

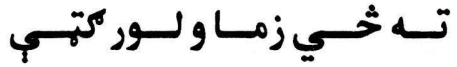

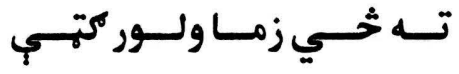
ته ثخي ولار سي كراجي لـ

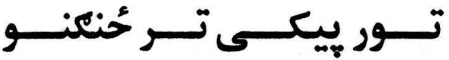

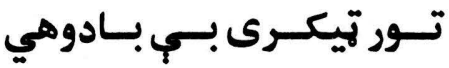

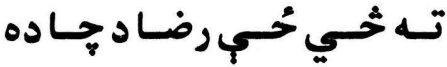

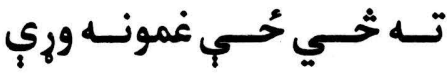

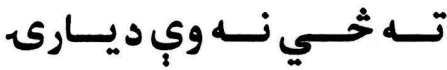

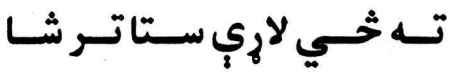

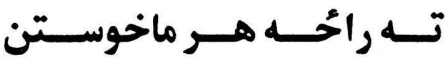

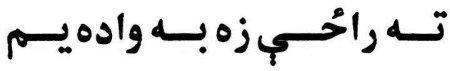
تـه ثخي حُحي راحسي بـه كلـ

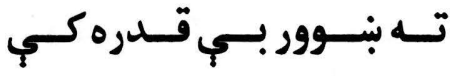

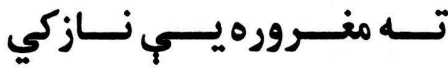

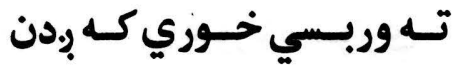

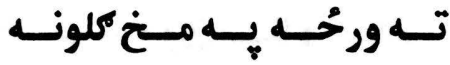

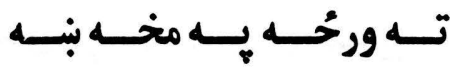

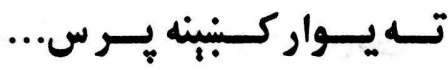

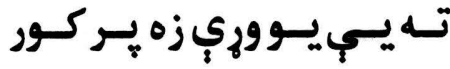
تهمت ويـايي م-خ يسي تور دى

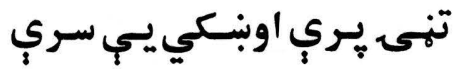

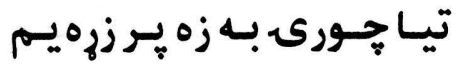

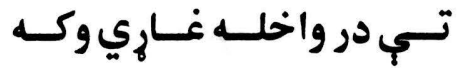


خواره سي تينك ونسه ياولي هُ دى غبركى به سيّين كالي

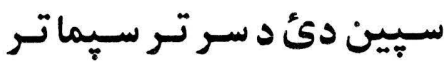

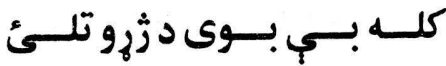
كـوى كــوع يـر سـرو أوبنـانو

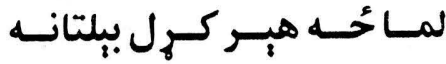
يـروت د غركي يـر ورانه دى

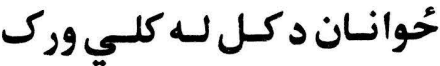

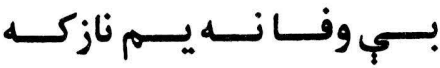

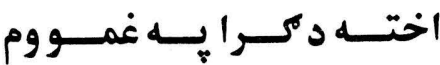
زمـاد بيـالـه خـــوروزار كـرل خـي سـر وتيـر ولار سي بنـوور تر سـردار زيـات بر بنسي شـوقي

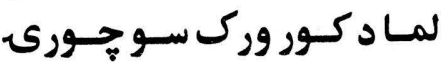

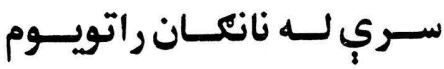
خولـه بـ كـل غـوربزه غـواري مطلــب مــه وئ ســتا د خـــالو

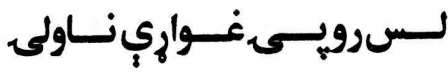

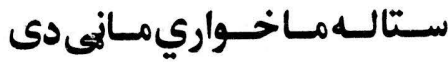
داوطـن بــهـ هـــــــاوركـي

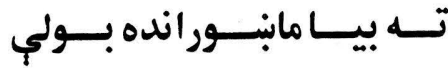

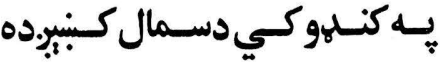

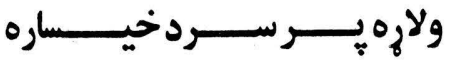
مــادسنكـــــار ليونــــوكـ

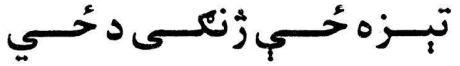

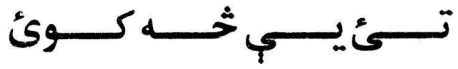

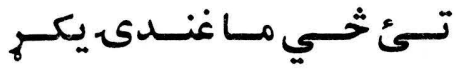

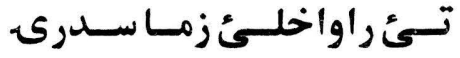
تــئ ليـا بـــه ياسـته كوجيـانو

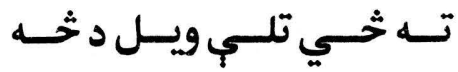

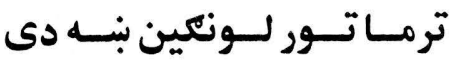

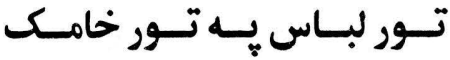

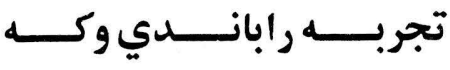

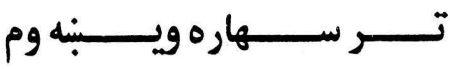
تـاخي سره اوبنـان كتـار كرل تسـسيسي كـئ ديـان يــر سـر توريجي كوت سيّين يجي كالي

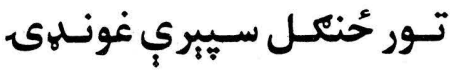

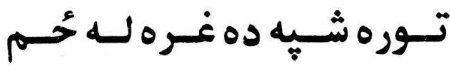

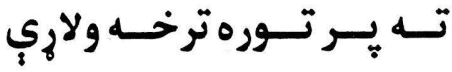

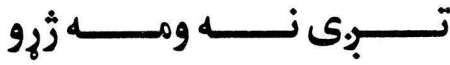

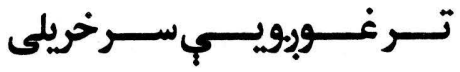

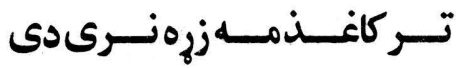
ته جي حُجي بر زيه به زور كي

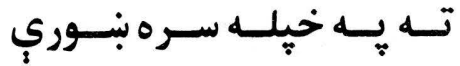

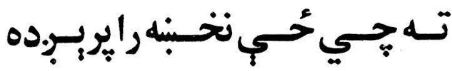

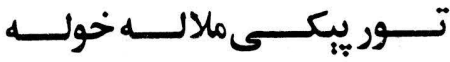

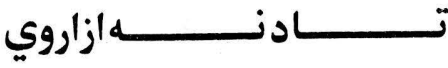




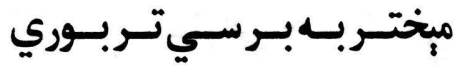

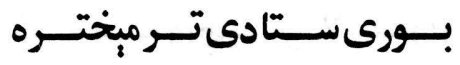

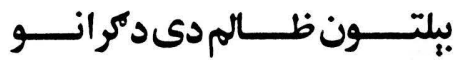

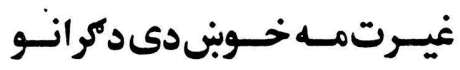

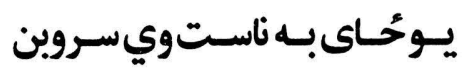

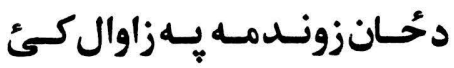

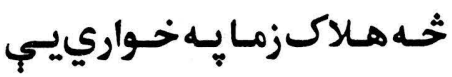

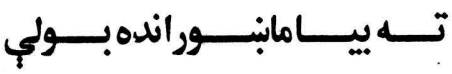

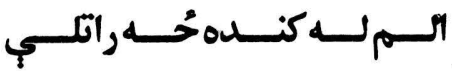

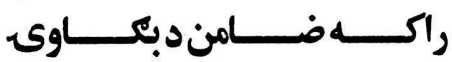

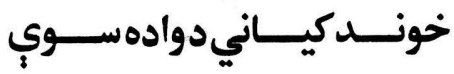

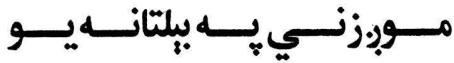

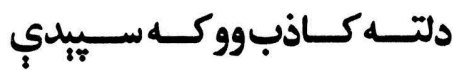

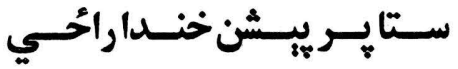

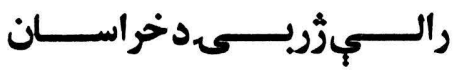

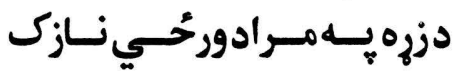

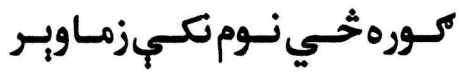

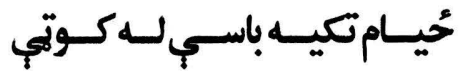
ثخي خـاىورجـوني بيكس

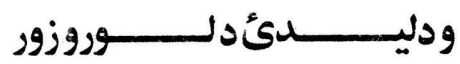

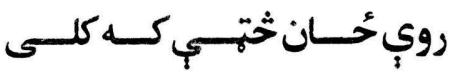

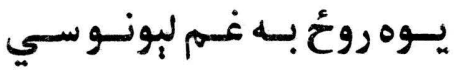

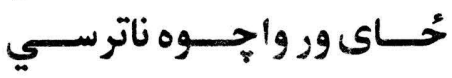

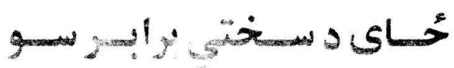

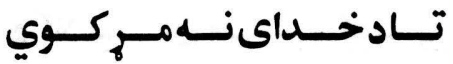

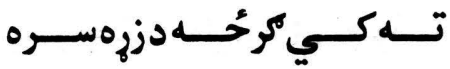

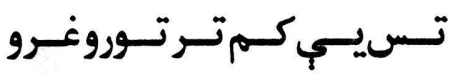

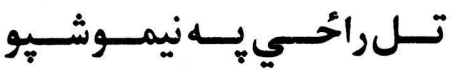

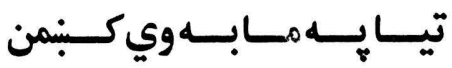

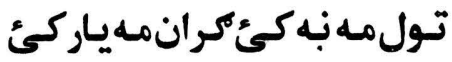

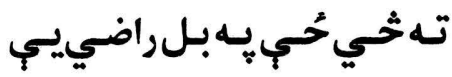

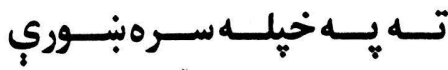

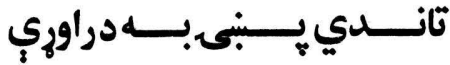

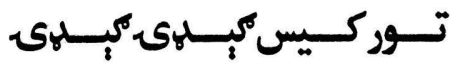

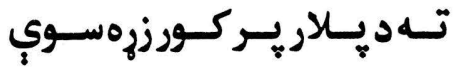

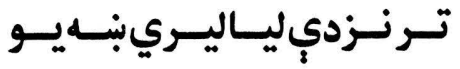

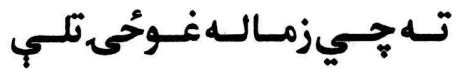

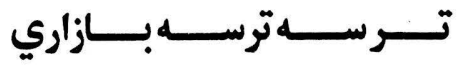

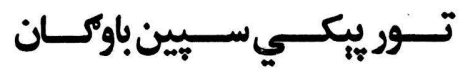

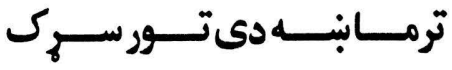

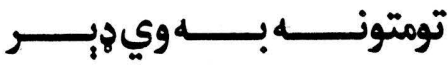

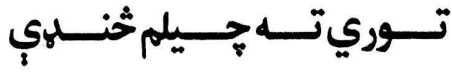

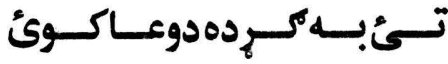

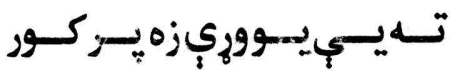

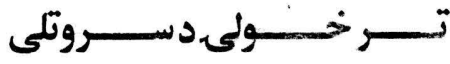
تـلـل بــه نـله وي خوشـــالي تــــ مــاتر ســي تالسه دوسـي

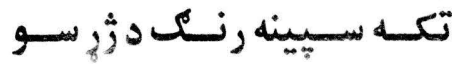


كاكرى غالهي

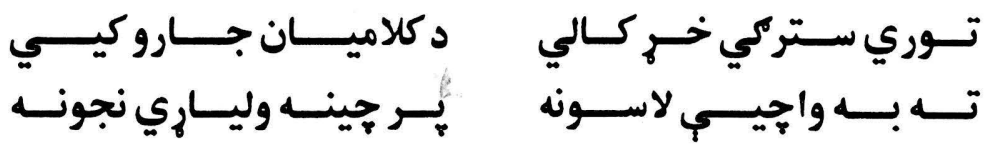

终牲 
$\stackrel{\sim}{N}$

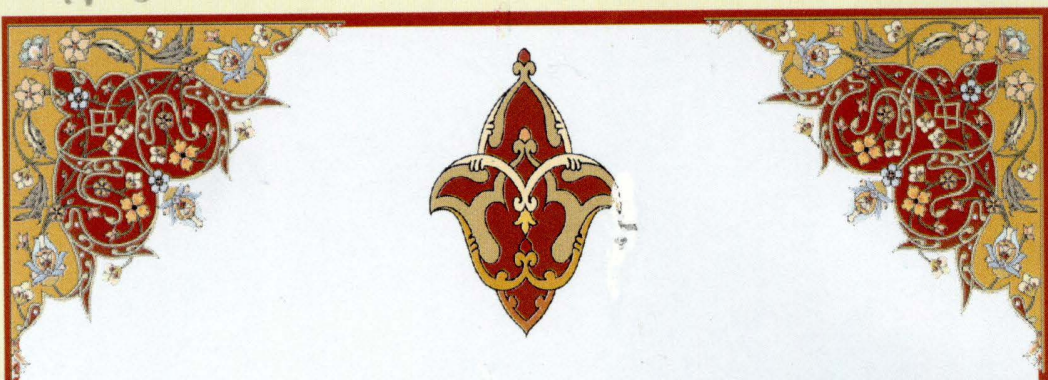

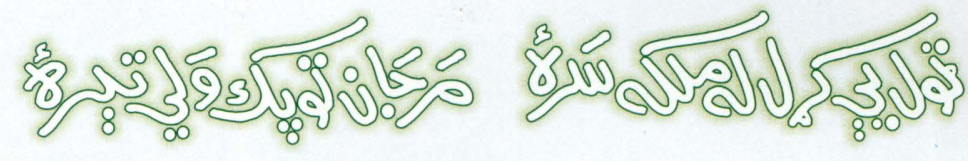
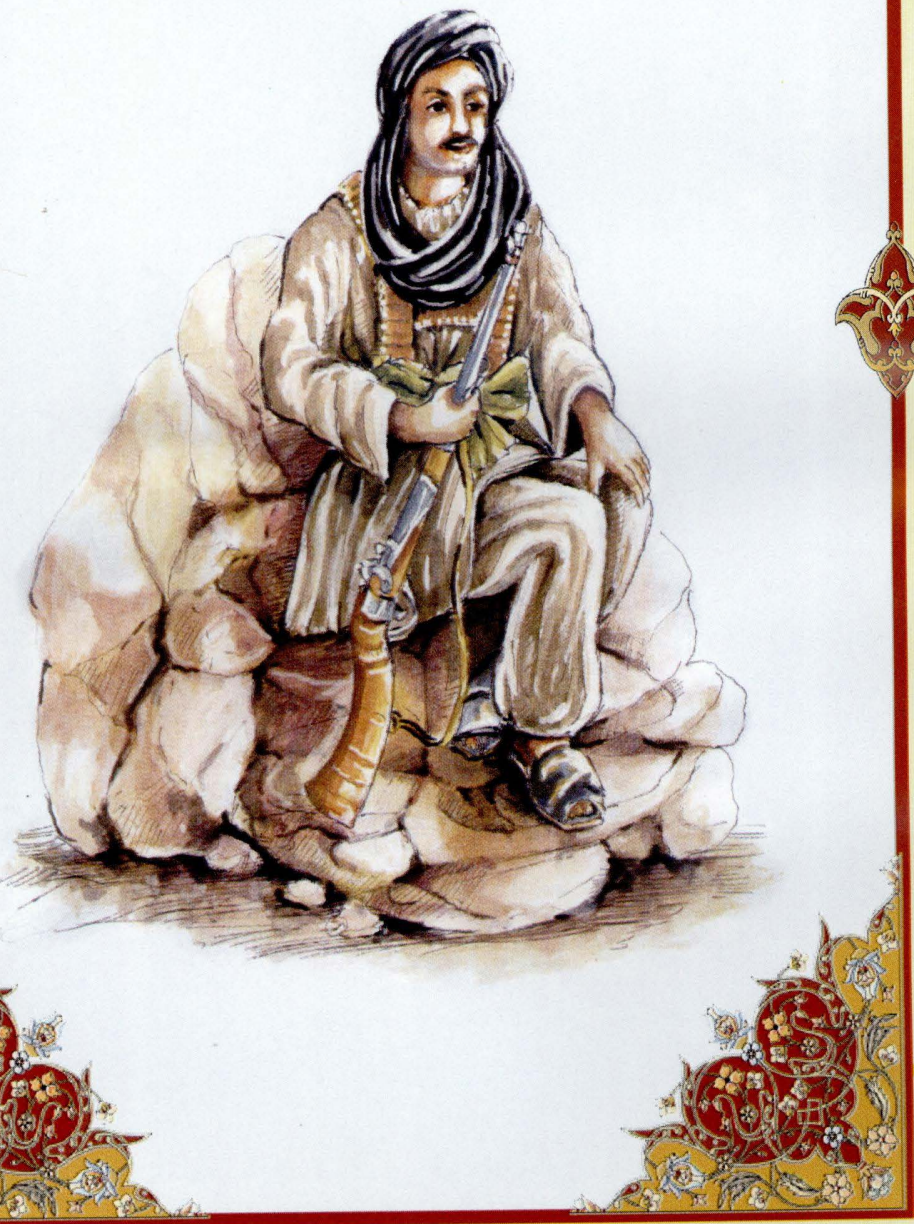


\section{(अ)}

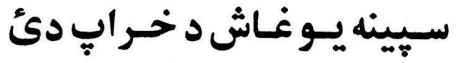

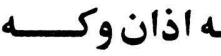

كور مـــه ليـــار د ر اتلـــو ســـا

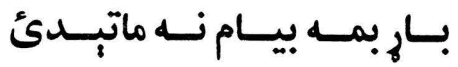
اور بـه بل كي زما بـه زيره كي سـتابسه ثخـوك راوري حالونه

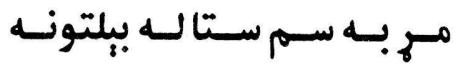

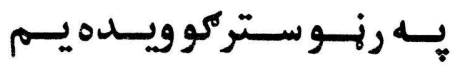

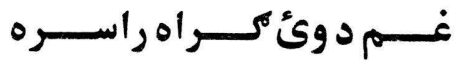
سـهار بـه :ـلـ درسـي بنايستتي

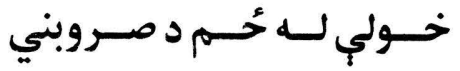
بــــاد خــال بــورهوراوكـي دواره لـه يــوي مسـوره بيــــا حـان د كئ خـلاص لـه بـلتانسه يــو ديــنـن د جانـان غـــوارم

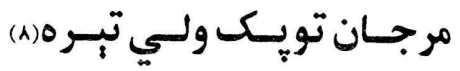

تهـول بــن دمكل كـلاب دى

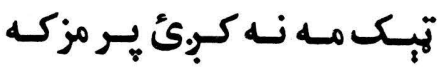

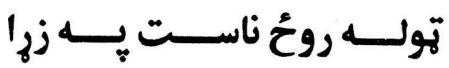

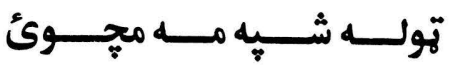
تيكـرى مـه نسه يـه خوله كي

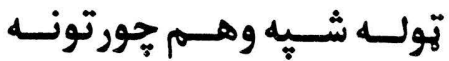

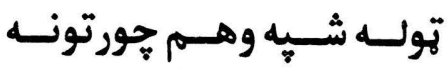

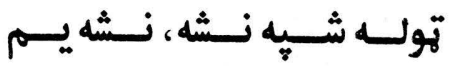

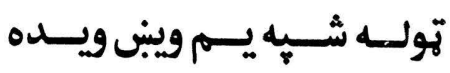

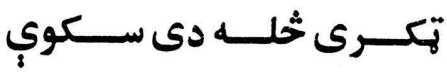
توبويسك نــوى شـيـي د زمسـي

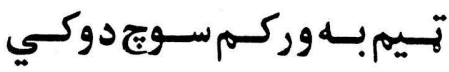

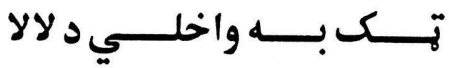

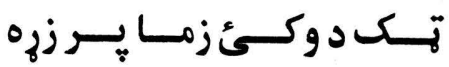

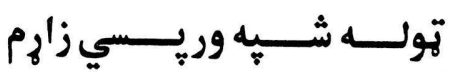
تهول تهي كى ليه مـرك ويده 
كاكرى غاري

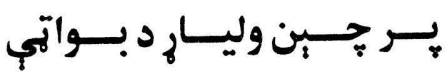

تيلـــي فــون راوكسـه ســـــي

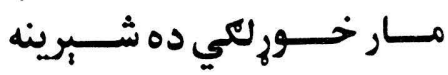

تهيلسي فـون رالسى لـه يـبنينه

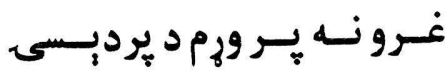

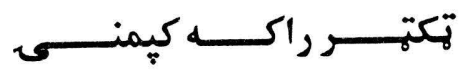

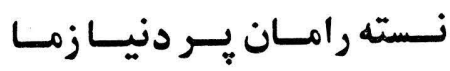

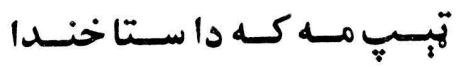

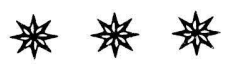



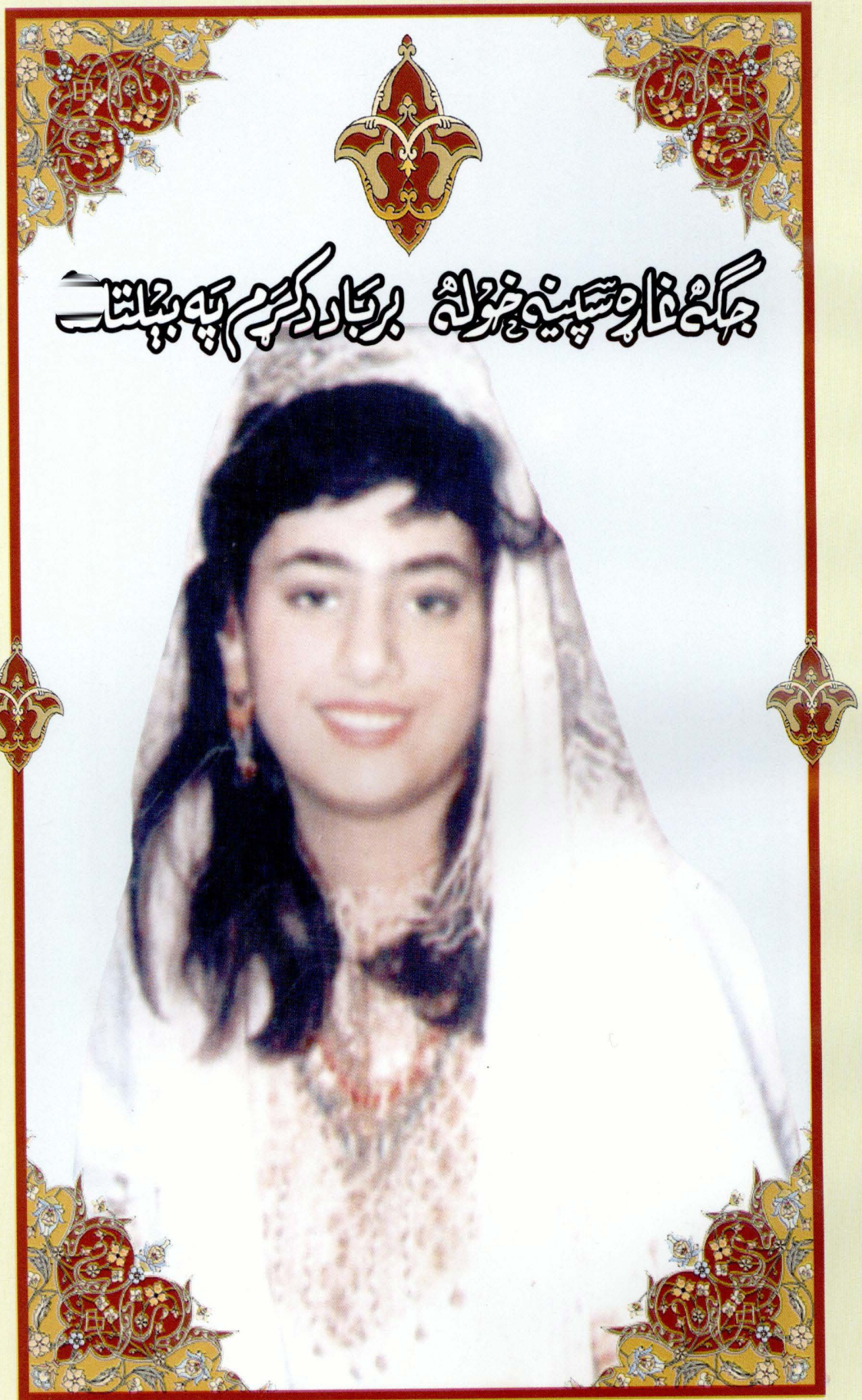


\section{(飞)}

خي ستا حُانكوى كي حُنكيدئ

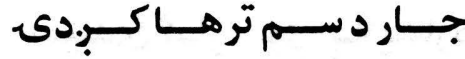

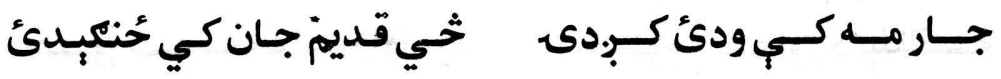

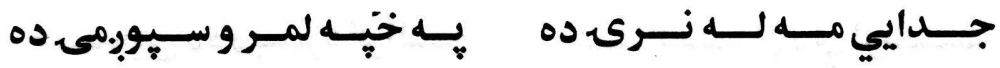

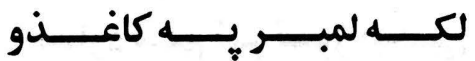

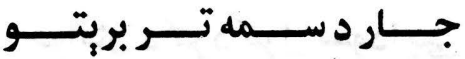

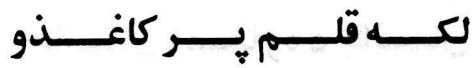

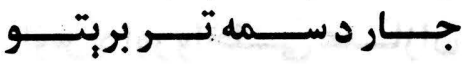

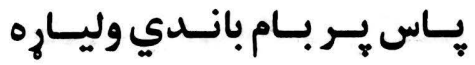

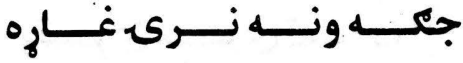
زمــاخــوريـواري رايريـبردى

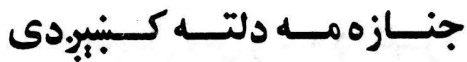

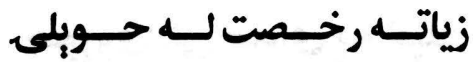

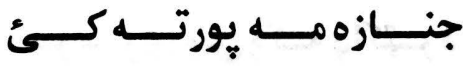

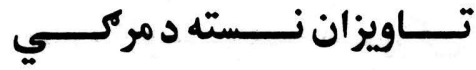

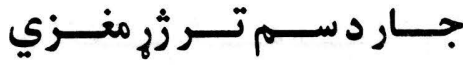

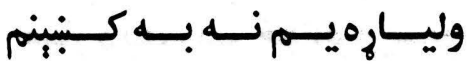

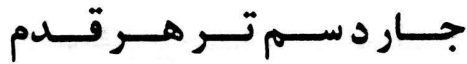

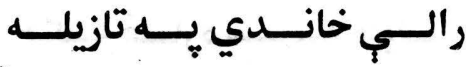

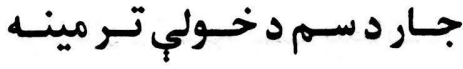

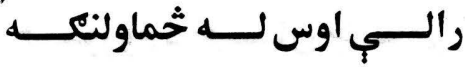

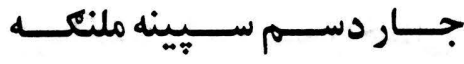
خـــي سـتا احسـوال مالـه راوري

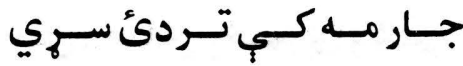

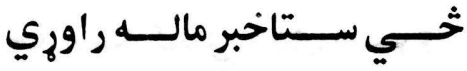

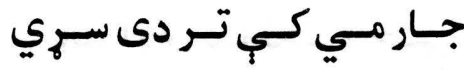
تــر تربــره هـيــر لــري كرانسى

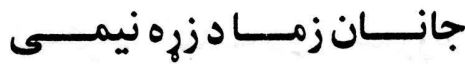

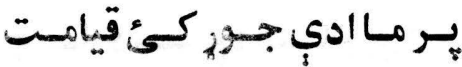

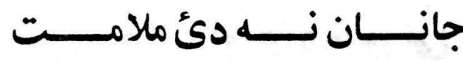


بنديـي كرد تسي كوكي دى

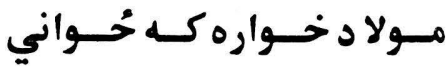
خـــي جمـادار سـي د كلــي

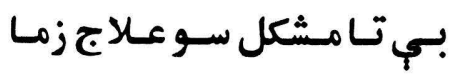

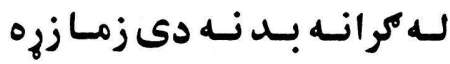

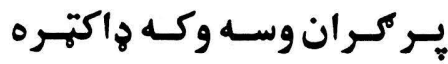
اوبــكو مـهـ جـوري كـي نـالى

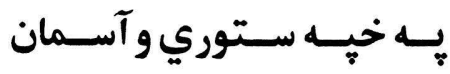
سيّدي كنـار سـوي يـه يـساره

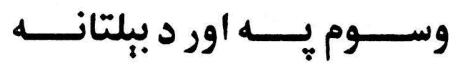

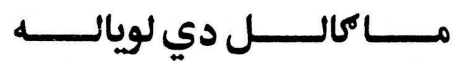
حُوانان دمكرد كرل سودا يسي

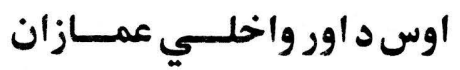

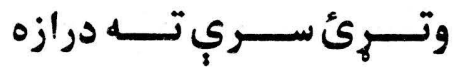
تــهـ خيـل وس وكـه هاكتهـره

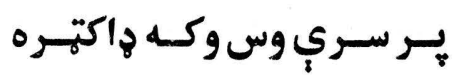

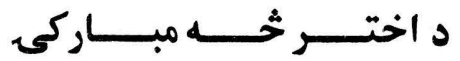

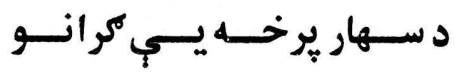

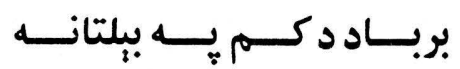

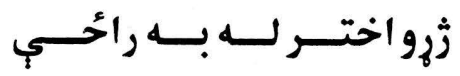

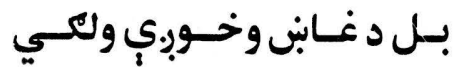

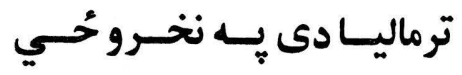

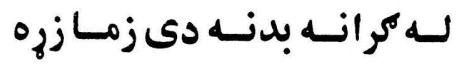
خي د حال راورئ د خـوركى
جنك كوي جانكل كي كنبي

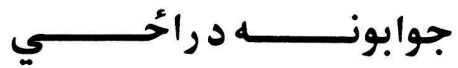

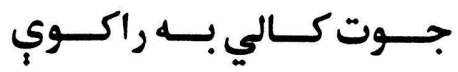

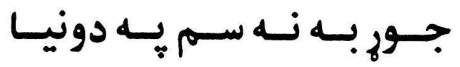

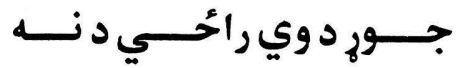
جـوروي بـي خــداى بخيلـه

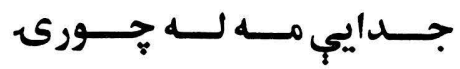

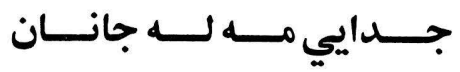

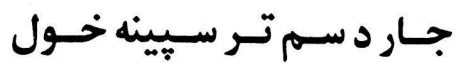

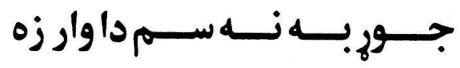

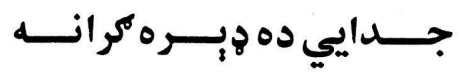

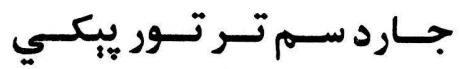

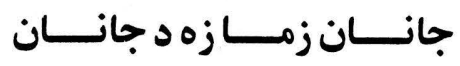

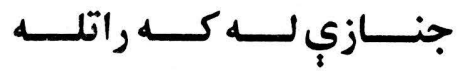
جـوروي يـب خـداى بـه خِّله جـوروي جيَ خداى يـه خيله

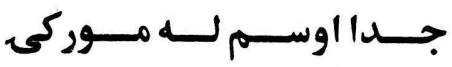

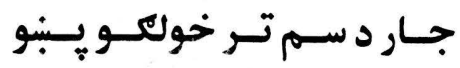

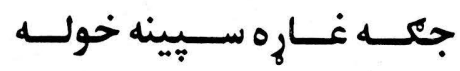

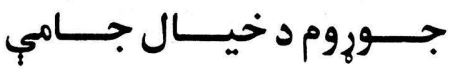
جــار د سـم د ســرو سـتركي

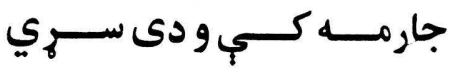

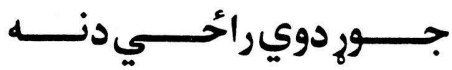

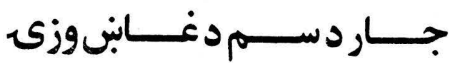


كه يج بـه غم كي خوشحالي

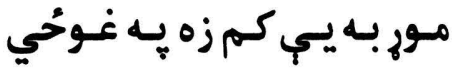

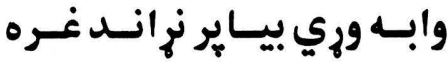

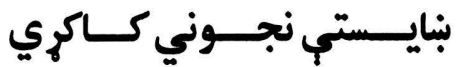

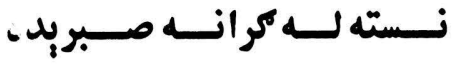

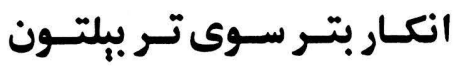
ستا دوستي مـه يـه كـار نه ده

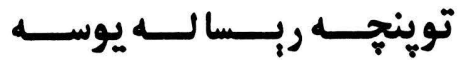
بــور كميـسـى لنــلهو غـــواري

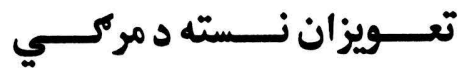

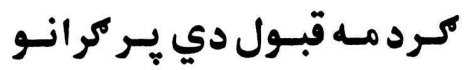

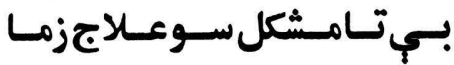

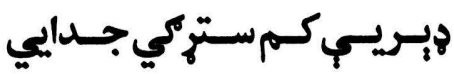

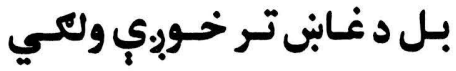

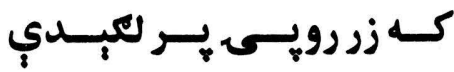
ايسم بـي كـوله ده شـين خـالو

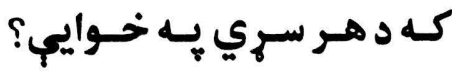
اسـيـي خــوك بــه در راباسـي تر جـرمن سخت دى كلاخـان

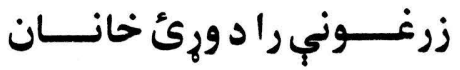

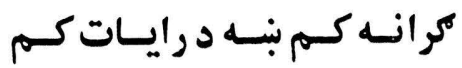

جـار د ســم تـــــــــراخ تنــدي جمعـرات دى سـيـين راحَّـي

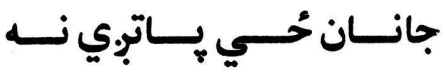
جكي درختي ستركي خري

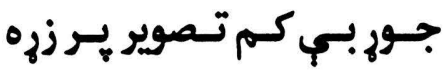
جـوريسي كـئ عجسب قـانون

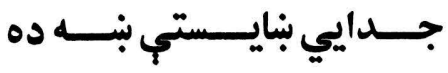

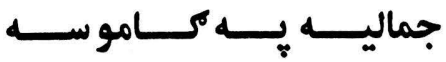

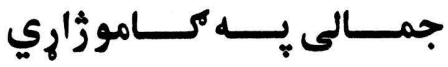

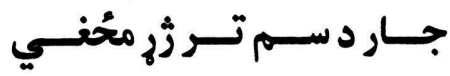

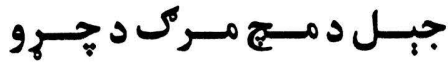

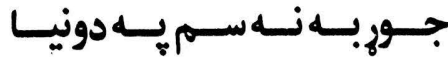

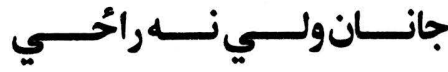
جـار د سـم تــ دواره سـتركي

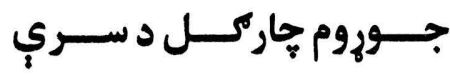

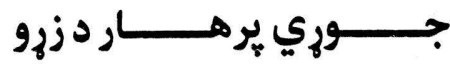

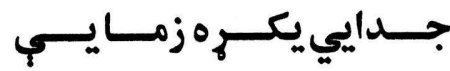
جمعرات دى كران به ولاهي سي جنكس كـوي يـر سبين ميـدان

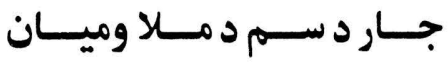
جــــورهوم نــــاجوره تــــاكم 


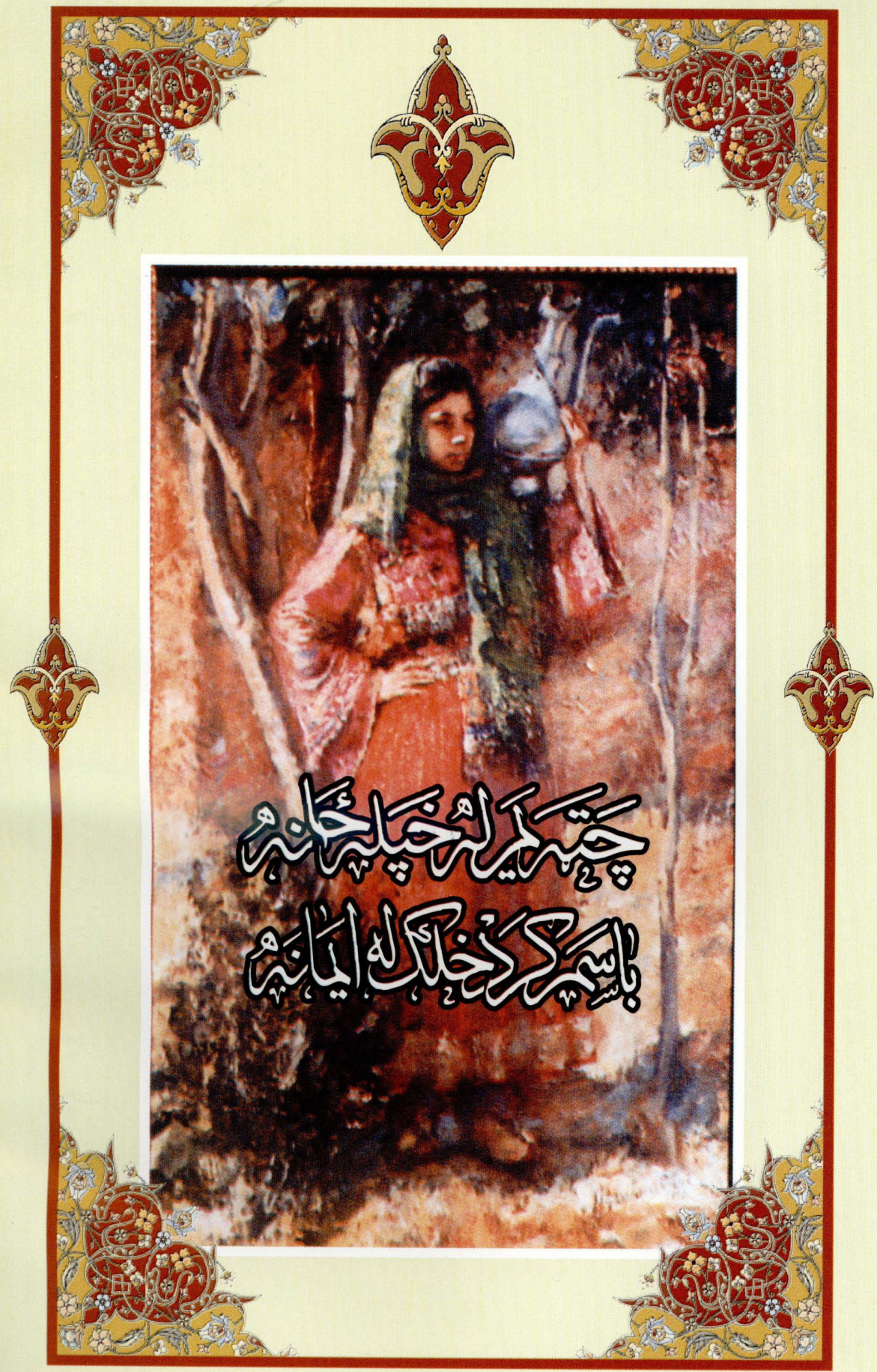




\section{(ङ)}

زركىى مـه مـات سـوله هـر جـا

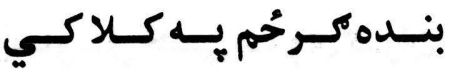

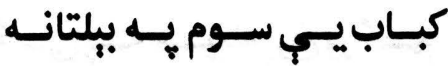

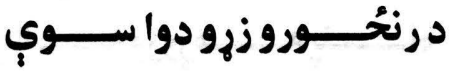

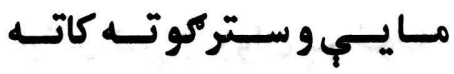
كي د يه خوارى ارح دي حُحوانان

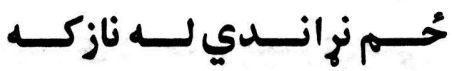

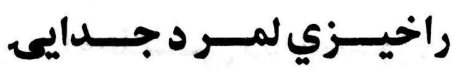
جــار دكـــران ودروازه ســـم سـك دوكيــ وكـي رابانـدي

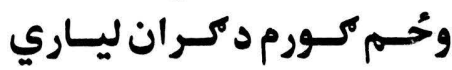

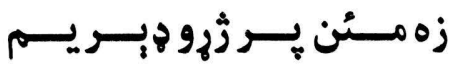
بـه خهوب كي هره روحُ راحُحي

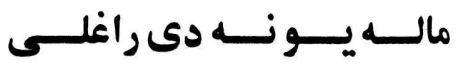

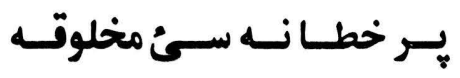

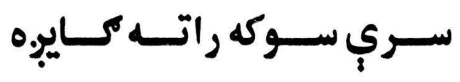

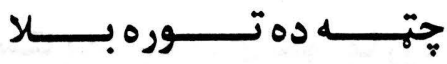
جرت مه هر وخت وي به تاكي

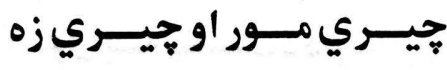
جيـري وي جيـري بيـانيدا سوي

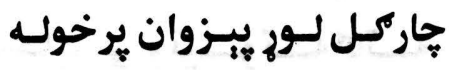

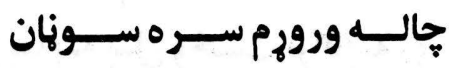

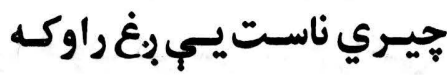

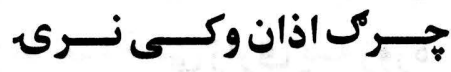
جـي راووحُحسم لـبر بـهـ بنـهـ سـم جي ده نسه يريسبردي دبانسي جـاى زه نـهـ كـوم ورينديـاري جــورت

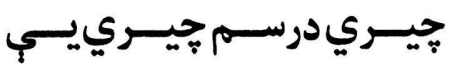

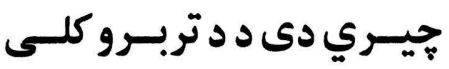

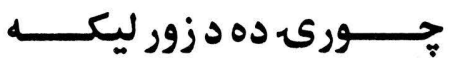

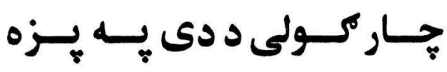


يوار خانان راوره خحي كبنل كم

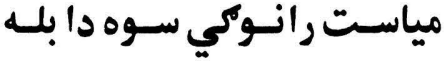
باسسم كـرد خلـكـ لـه ايمانسـ

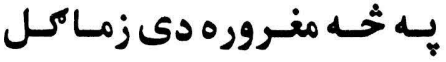

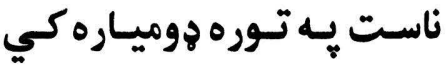

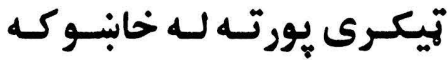

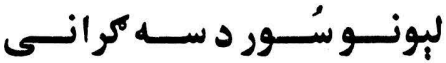

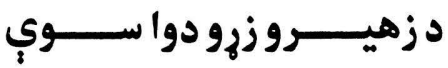

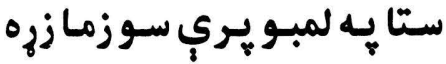

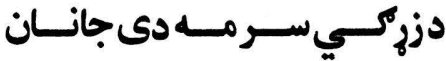

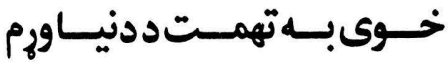

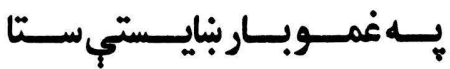

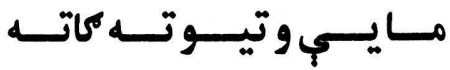

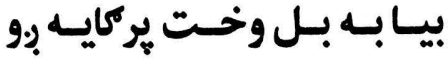
يه خـوبكي هر ، روحُ راحُحي

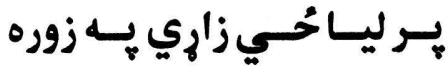

جركسه لـوى انعـام بـه دركسم جيـري ورك يسي سيّينه كلـ

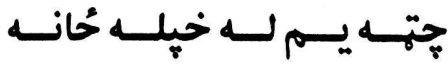

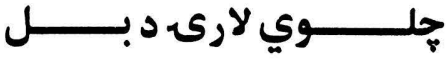
جيلم هـ نسوار يه خوله

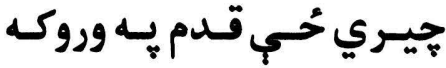

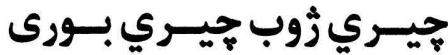
جيري جيري جيري بيدا سوي؟

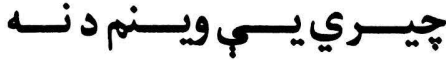

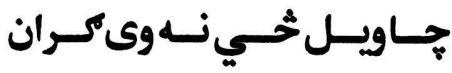

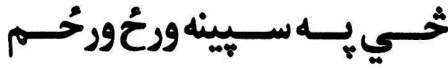

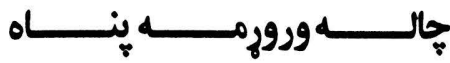
جاركـل لـو يخيزوان يـر خوله

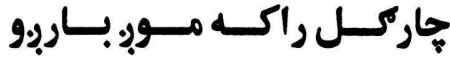

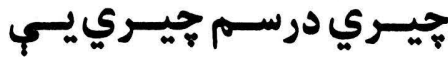

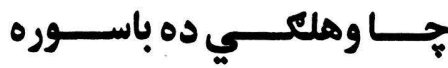

类类 
23891

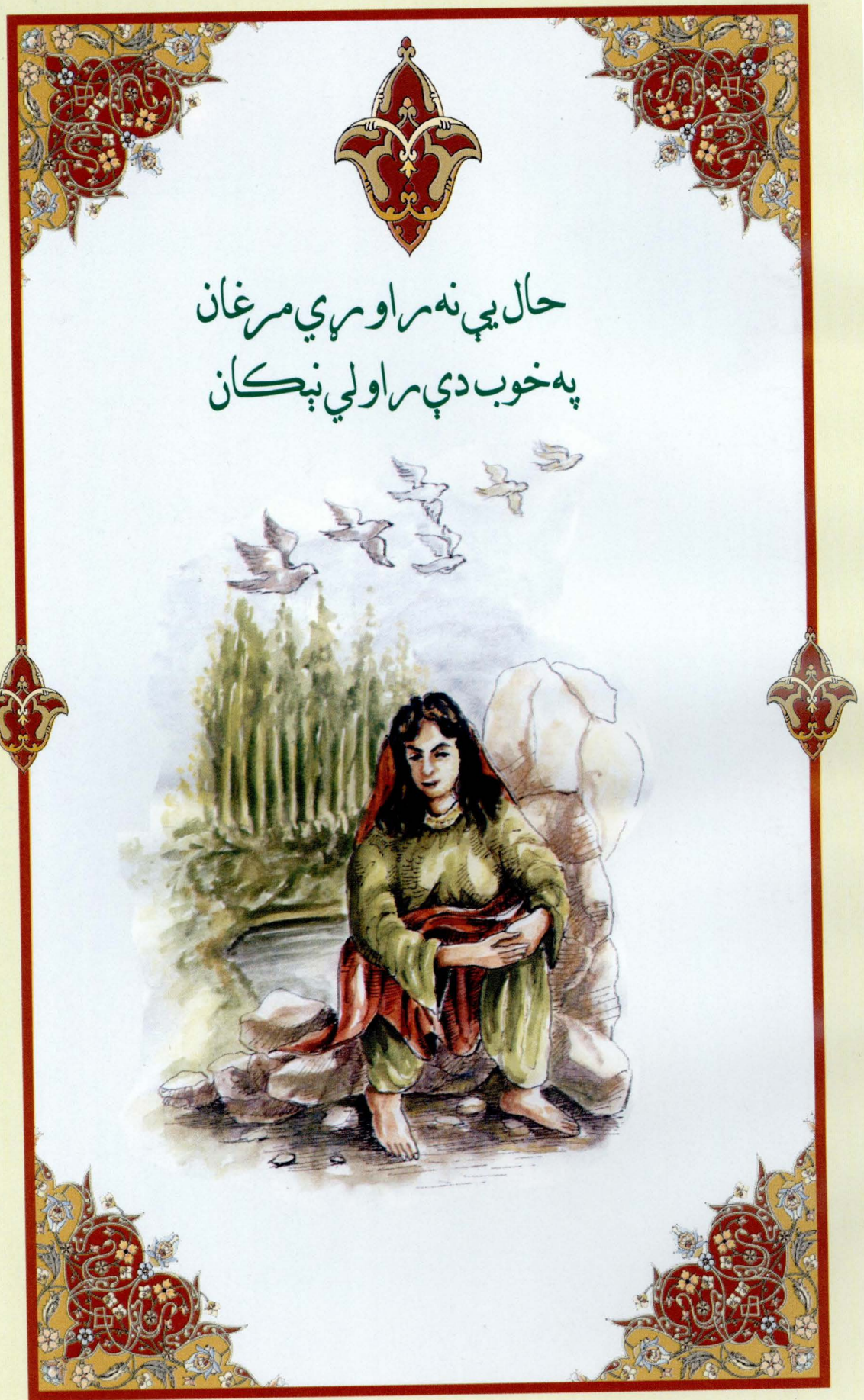




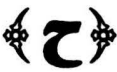

وارلـيس جـــور كـهـ شـمايلي

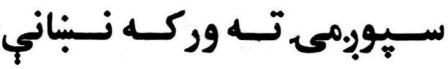

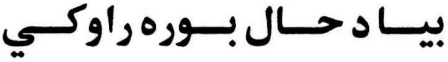

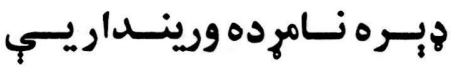

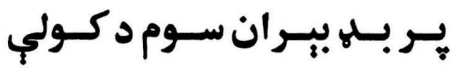

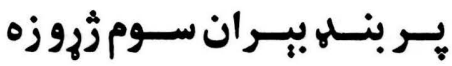

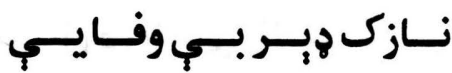
دكـــان بــي باكـــهـ دهيـاري

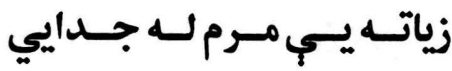

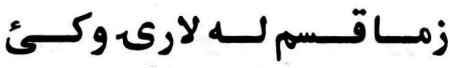

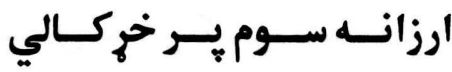
و يــنبو جــار ســم د راغلـــي

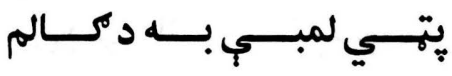
وركسى مـره مه كسه نـاجوره

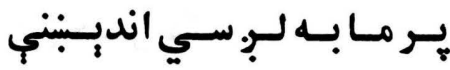
مرغان كونك دي نه ته كايري
حسال دنـــ راحسي لـهــــي

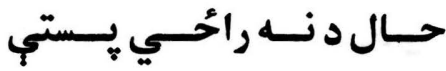
حسال بـه وركسم سـوع دوكي

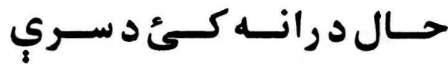

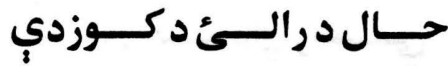

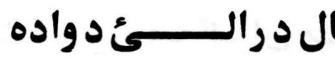
حسال مـه درسـي نـه راحُحي

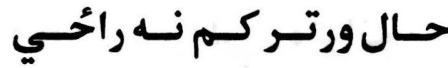

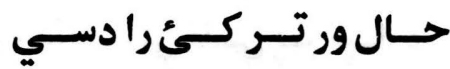
حال ور تركئ زرهيجي بنه كئ

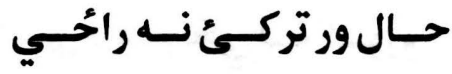
حسال يسي راورى سـتاد كلـي

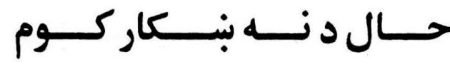

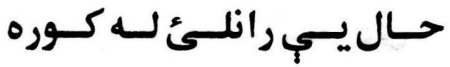

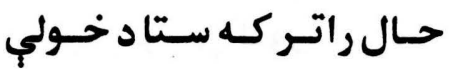
حسال مــه نـهـ ســره رسـبرِي 


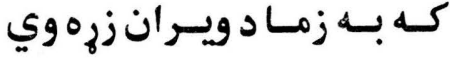

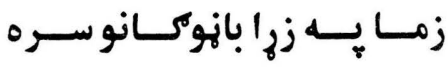

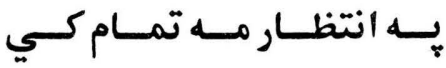

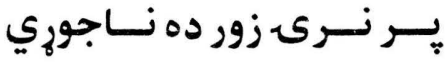

تمــامي ســوي د دنيــا شـيـي

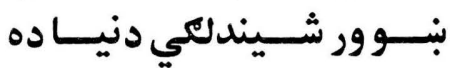

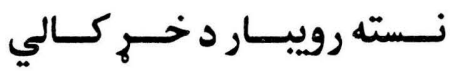

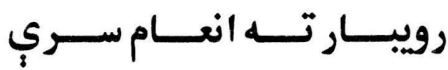

يـر بــوره حسق نسته زمـانــور

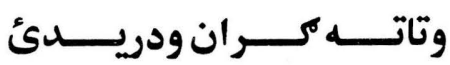

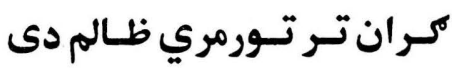

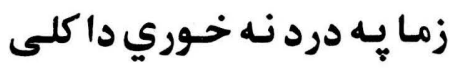

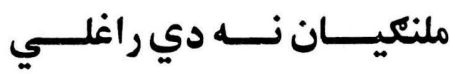

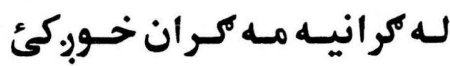

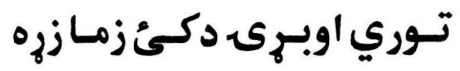

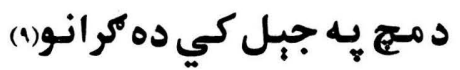

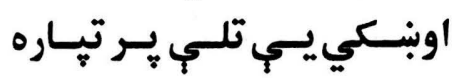

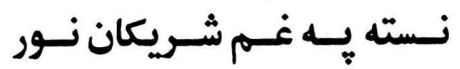
رالــي د غـــونحُي لـهـ كــورو

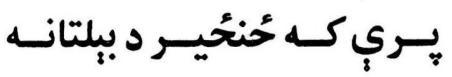

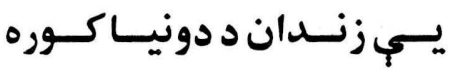

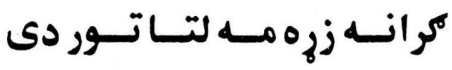

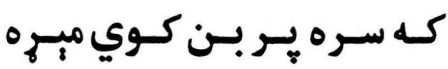

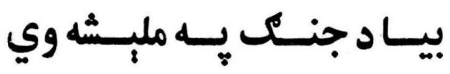

حـق بــهـ هيــر سـتا دمزلـه وي

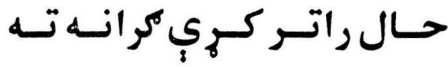

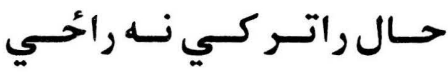
حلـقق يــي وع فريسـاد كــوي

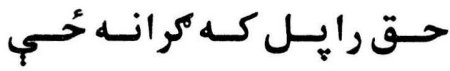

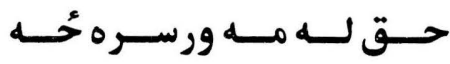
حسال بـي خــوك مالـه راوري حـال يـي راوري ستا د خـولي حال يسي راكئ يـه خيـل ورور

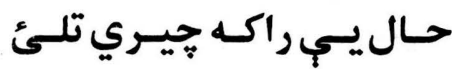
حاليسي رالئديديسي كمرى

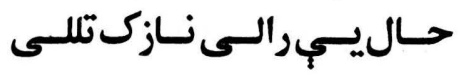

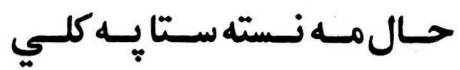

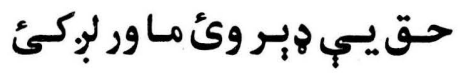

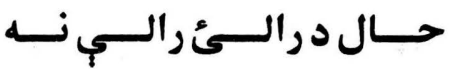
حسال بـي وري مرغـان دغــرو

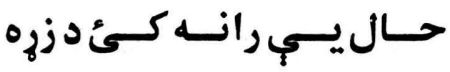

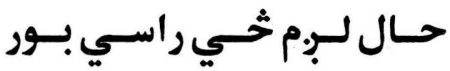

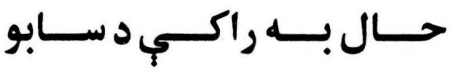

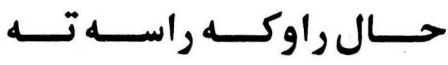
حـال يـي رالـى نـسته بــوره حال يي نسته غم يب جوري دى

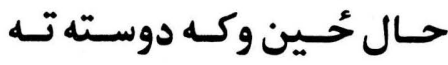

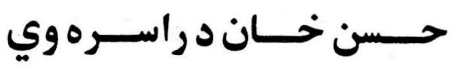




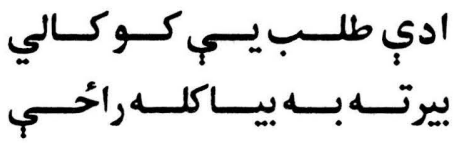

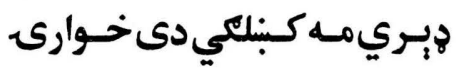

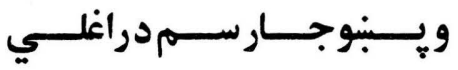

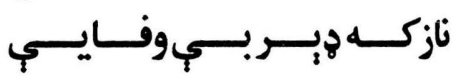

كران د بيرته بي كوز دوي سي

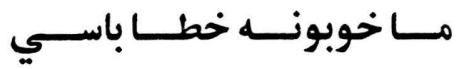

خوله وبنسم ونلهه بـي كار سي

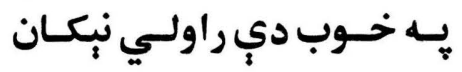

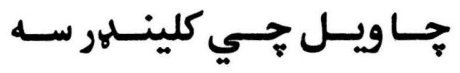

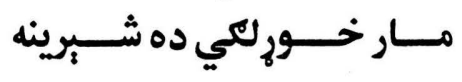

حـال يـي راكسه جيـري حُحي

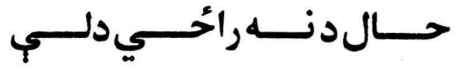

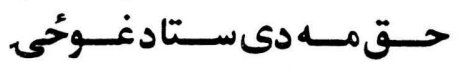

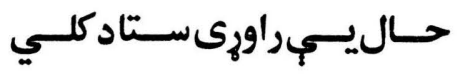

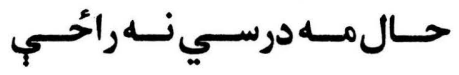

حـق د زماغــه بـــه بـسبي سـي حال ورتر كئ ثي كران راسي حال ور تر كئ ثخي كران راسي حـاليــي نـه راوري مرغــان

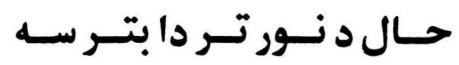
حـال يسي اوس رالئ لـه يـبنينه

然柴 


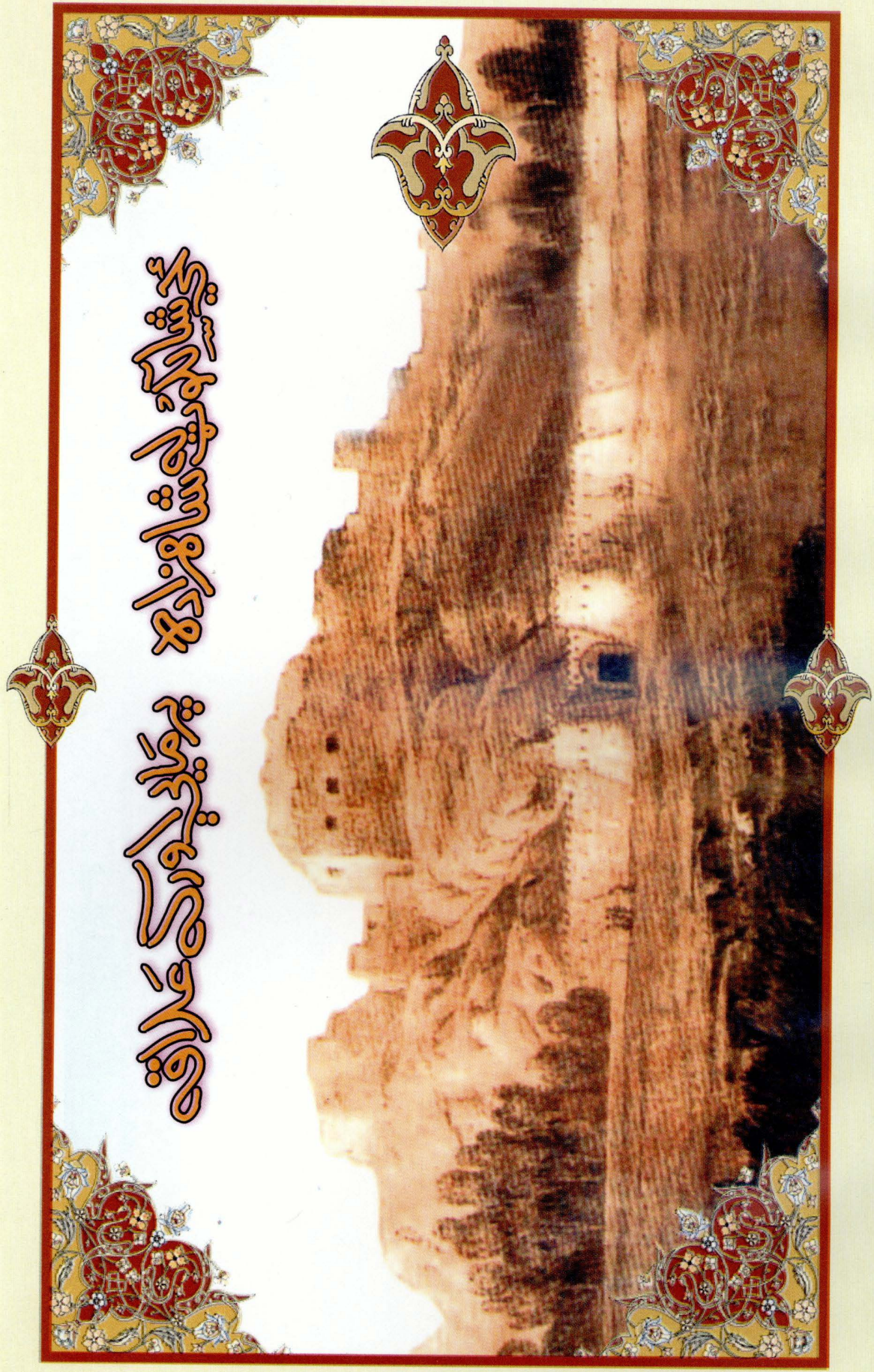


\&

نــــى دا سـتالـه برديـسى

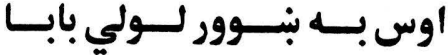

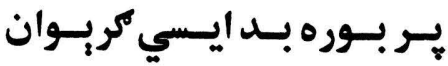
دحُان زوند مه بـه زاوال كئ

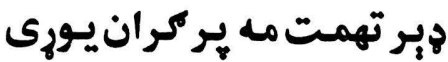
خداى بـ زوى در كي نازكي

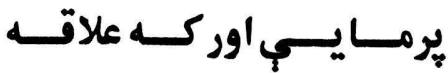

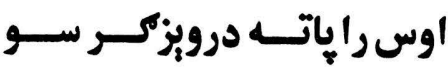

نازك يرديس دى كي كبنبني

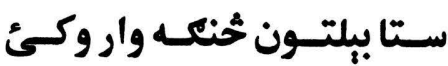

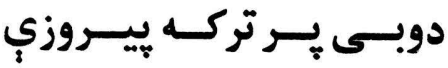

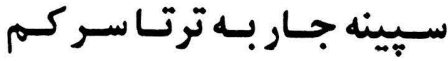

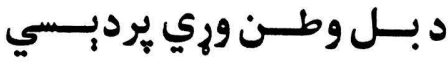

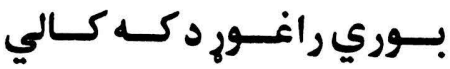

هيـــره كمزوركسي دزرهيسي ترمـاسـود مـن بـولي تإيسـين
حُــان بــــــــــوه روحُ زنـدى

حُــوى دكـران رالـوى كـى مـا

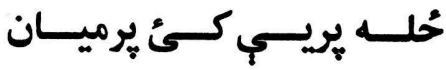
حُلـه خورمـهـ سـتادسـمال كـئ

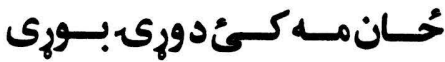
حُاى راجور كه به غوحُحي كي

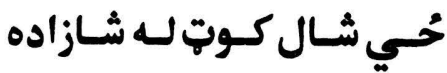

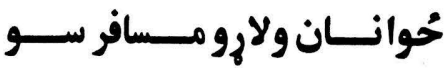

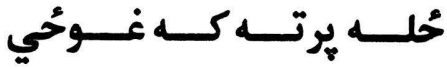

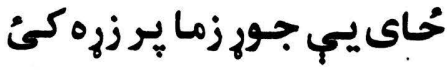

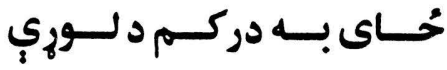
حُّاى راحُحي اختيـار بـه دركم

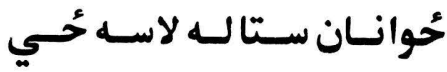

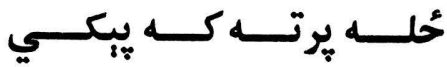
حُسـاى لـه راسـي كـي وهـي حُان تيار كي ولار سي سيّين 
كاكرى غاري

YFF

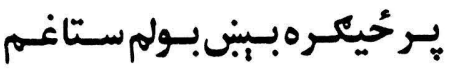

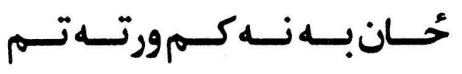

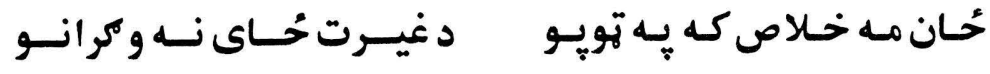

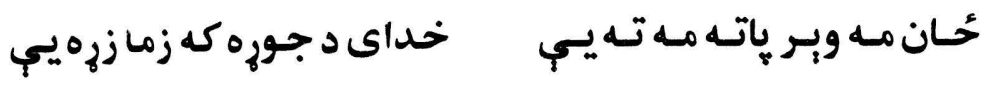

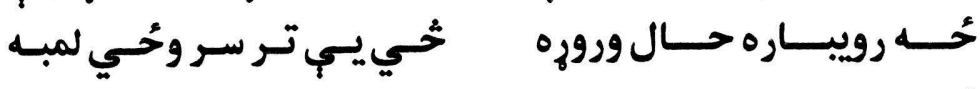

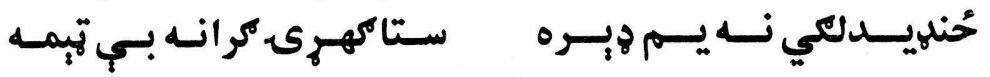

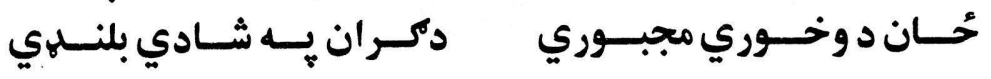

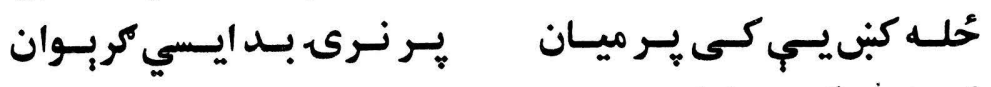

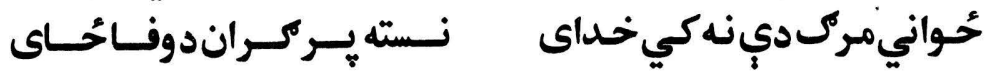

决决 


\section{$4 \dot{c}$}

يرمــــآخـــــر وي مــــاحيكر زمــاتكــاو د آسـمان سـتورى مندوخـوار ثخوك دي راوري

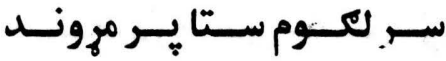
نسته تـور سـتركي تـه ليـار زمـا داور بـه ميـان كي ووز زمـازيره اوس بكـاوه شـين خـاله سـوه ثخي يـر كتّ راكي حُحسى ماله كوره ثي نوم نه كي زماوبر وركـي هلكسوانبـي وفـادي د غـابن مـه كـست نـه يركيــه

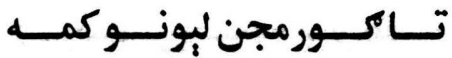

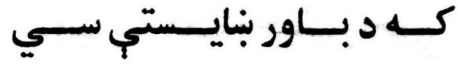
مـا انديـبنيني د جانـان خـوري

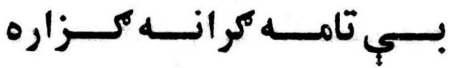
مـاتــر نـرى لـه مخـــــي

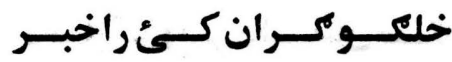

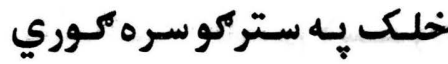
خولي كرد مركي خهوار كري

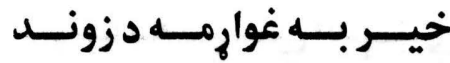

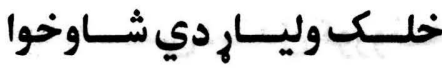

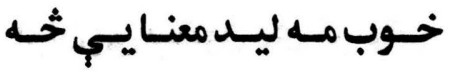
خوب مه ليد معنايي سبي سوه خونسلـ بـه دركسي هلتــه تالــ خلـكس بـه ويسايي تومست دونس خـــبن مــه دي كتسر سـرى

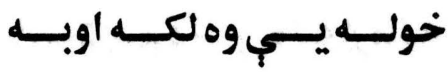

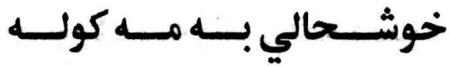

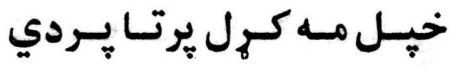
خلـك ويـده سي خـوبـكـي خواسـت د مـرك راتـــــــوه خواسـت كسوم د نيمسي شيـي 
مـا تــر مـوركى لـه مخــهـ كـي

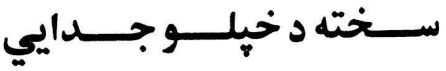

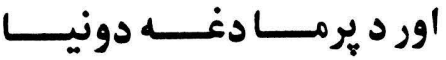
حُان به خلاص كري له ايمانه

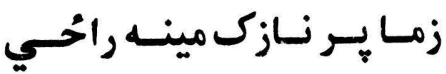

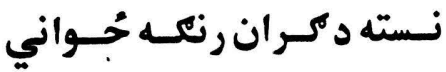
زمــــاو ســتاكنـــاه تـــويبري

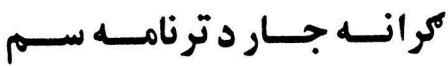

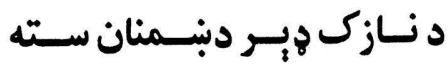

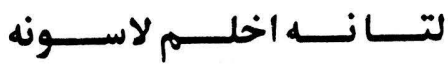
دوعـامـه كئهي دي د شـيبي يــر مـابـهـ لـبر سـي انديسبنهي

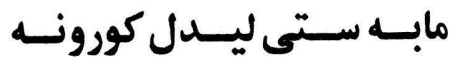
كرانيب بيلتون دى تر مركي

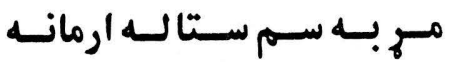

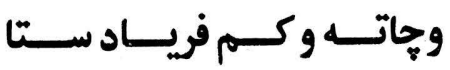

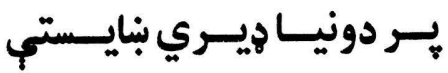

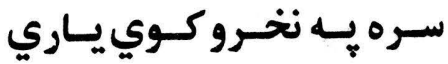

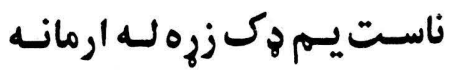

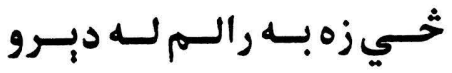
كـه مـهـ سـوه ماتــه يرديسـسي

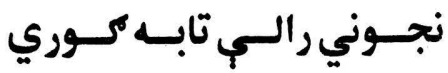

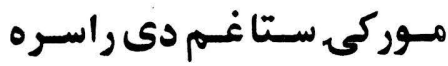
نازك سـوتر تـور غره لاندي
خواسـت كـوم د نيمـي شـيبي

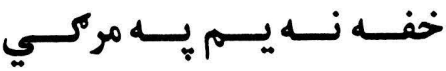
خدايســا ! جـــوره كـي لــيلا

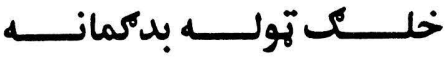

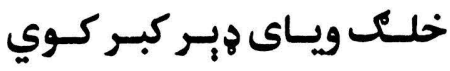

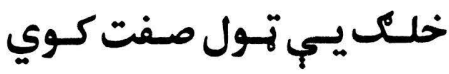
خلـك بنـه دي خحسي كايسه بـوي خوبن مه سوي ويلاى نه سم

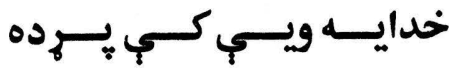

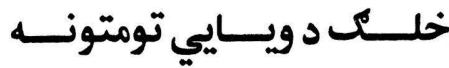
خدايـه مـهـ كــي ليـاري دوي

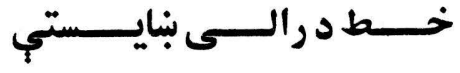

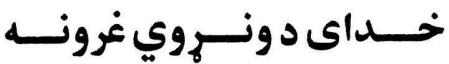

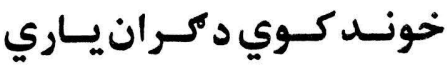

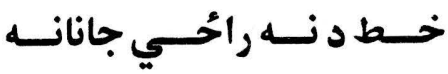

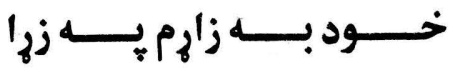
خوندكي نسته ستا دخـولبي

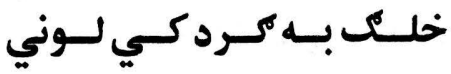

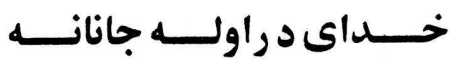

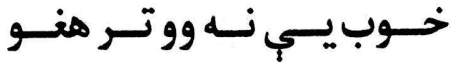

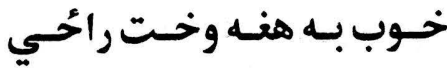
خوله د سره كه ستركي توري

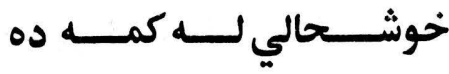
خـواره مـوريسي وهي ساندي 
هُي مـه لــلكي نسه واى سـره لـه تربسـرو قــى مالــه راحَّــي

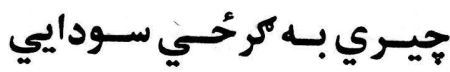

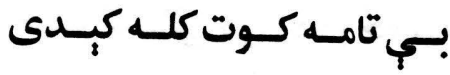
سـتابـه ونــر عمــر دوري سـي ستا مه تصوير كئ بوميان يري

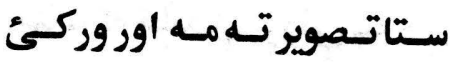

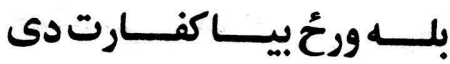

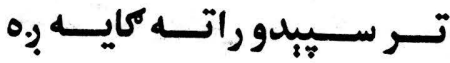

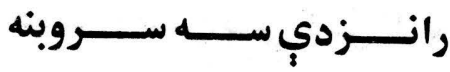

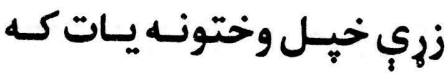
خونـل يــر زيـات وو د بــاوالو

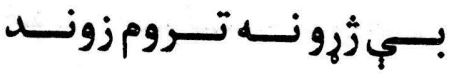
كـهـ مـهـ روزي نـهـ وي نـازك لاس بــه لاس كـي زُرو راكي

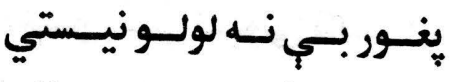

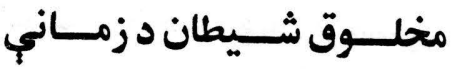
لـه مـوبر.خهـه نـوكي بر.بـاد دي مخــامخ تازـــه دار ناســت دى

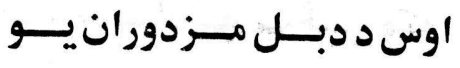
كـران بـه خـود راحِّي اوبولـ راسسي بسوره بـه نــوحي كـي

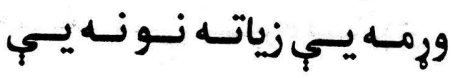

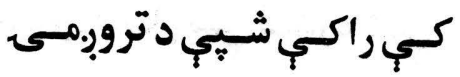

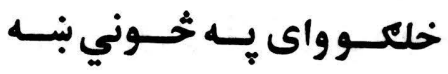
خونســــوي د بـلـل غـوحُّي خركـالي جيسبـ بــي خـالي

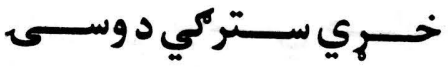
خاتولان به سري غونجيج سي

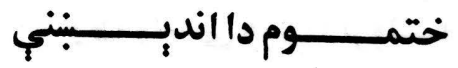
خيـل زئكى مهله در بــر كـئ

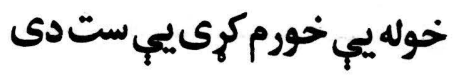
خولسه بسه دركسم مسه ويسلـوره خـوى بــه اخلـويسو لـه بلـه خـلداى تــه مــخ وماتـله شــاكه خوله مه نوش كه د حـاى والو خـداى د بنـــــي زمهـاقلمر خداى دي كي لـه قامهـ ورك خوبمهليفخداى خـاى غنـي دى وابكي خلـي

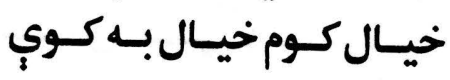

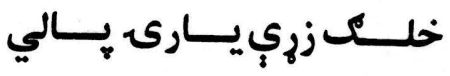
خانـه مـه بنــاره د عـابن دى

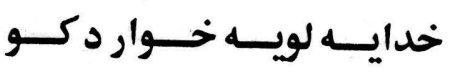

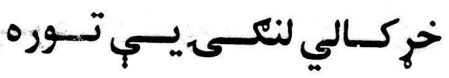
خـوب مـهليـل بـه ايسوزي كسي

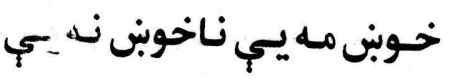

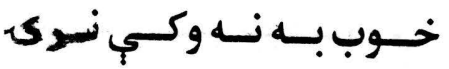


كي جن هوهى نه خوري مابنام

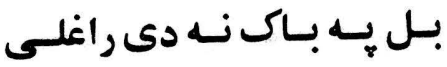

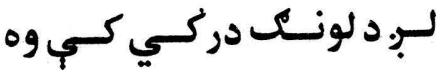
اوسيسـي مياسـتي حســـابمه

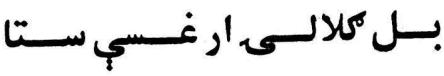

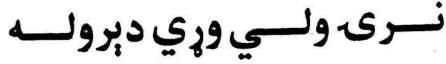

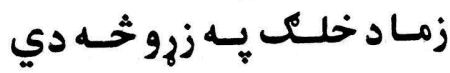

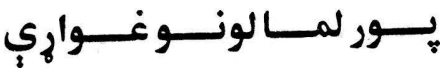

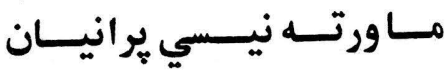
نه سوم يه كران يوري حُيام بنه

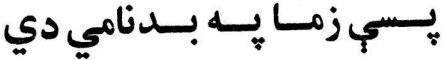
نه يب يه رؤح د حساب خلاص

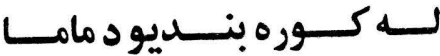

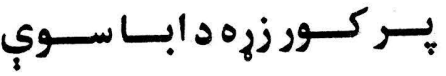
زماله غوحُح خخحه كران حُحي

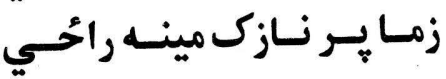

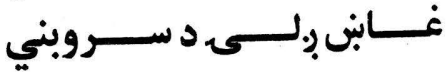
وج مجلـــس لونــــونـــــواري راخلاص كئ كران به ضمانت

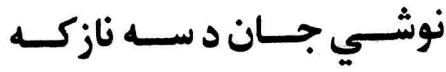

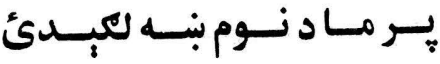

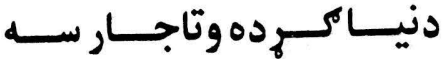

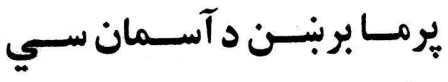

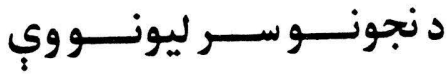

خــــــالى راتـر سـوى كـران

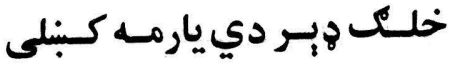

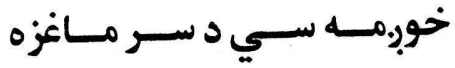

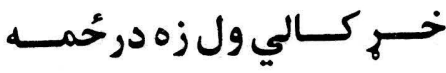

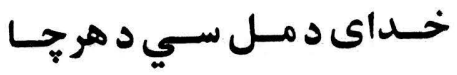

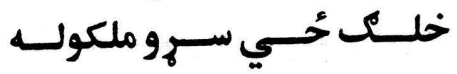
خلك كه خاندي زروني بنه دي خوله يسي راكه اوس يـر زازئي خلك كله ويايي تور دى كران

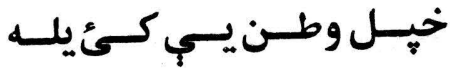
خيل مهل نه دي تـور مري دي

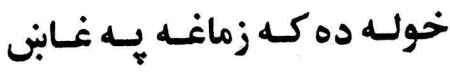
خونسـد مــو نسـسته نــن صـبـا خيـل عمـل بــي قـدرهـي خسـداى دي نــه سـهـار كــوي

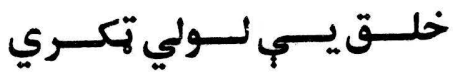
خولـهـ و وره ســونان بوبنــــي

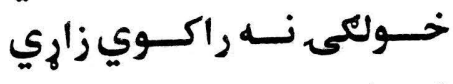

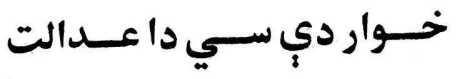
خوله مه ستا د غوري خحين وكه

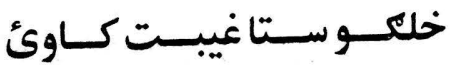

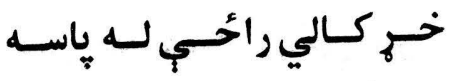

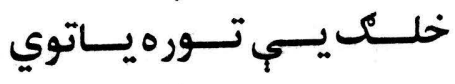
خيـل عمـل بــي قـدرهـي 


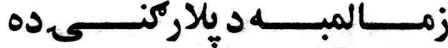

برمهـا غـــم بنايــستو ســتا دى

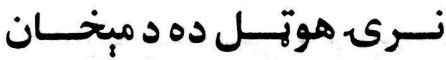

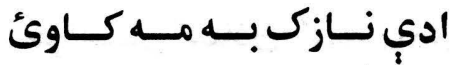
لارى نـازك كـاى مـهـ كـاوى

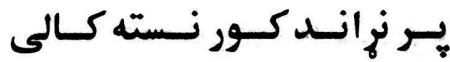
بانــي يريـــدم د دنيــاكسار و ورى سورمل غابن د جاندي

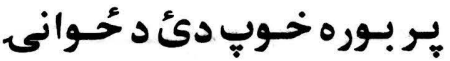
مـا انديسنبني دكر انـو خـوري

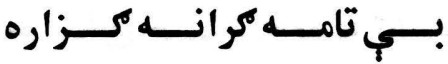

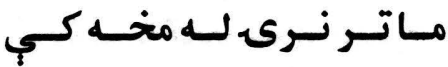
مـاتــر مسوركى لـه مخــه كـي

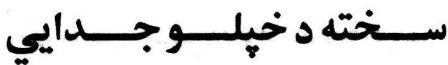
وكـرانتهـ زيرهوركم كـه سـر

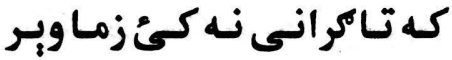

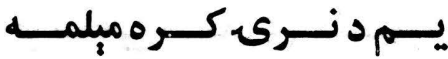
لـه خـوب يرتسه سـوه راحــي

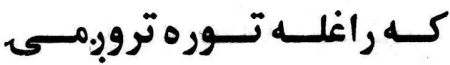

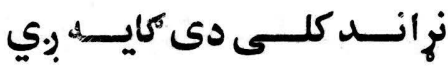
كر انــله كــه خــتم ســوه روزه خوب يجب ستا بـر حنكانه دى سـينه خـولكى بـهـ مـزو خـوره

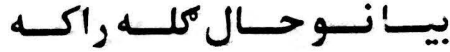

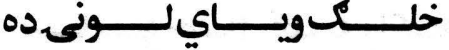

خلك حُحي نيـت يسي دورا دى

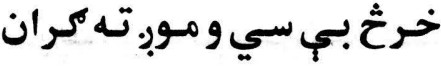

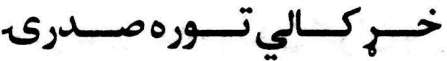

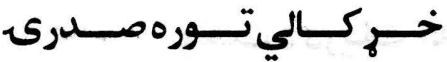

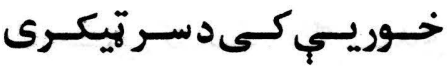

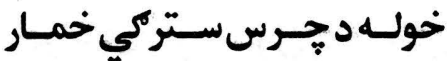

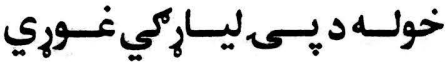

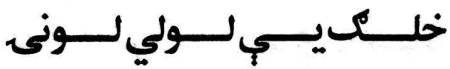
خلكسوبلهـسي خـوبـكـوي

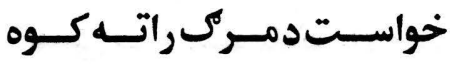

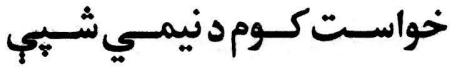

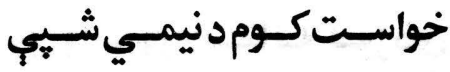

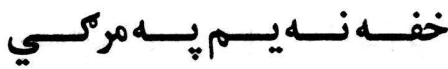

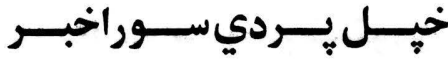

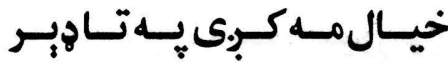

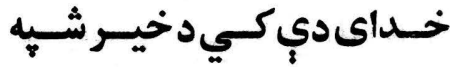

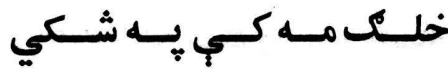

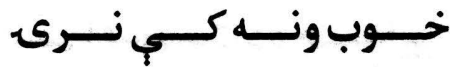

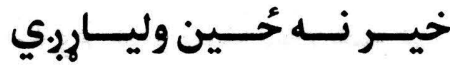
خولــهله بـــه دركـــم سرســـايه

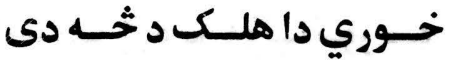

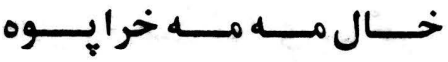
خولسه د غـو'رم سـوع توركسه 
كاكرى غاجي

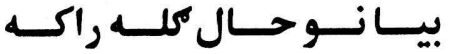

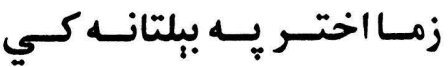

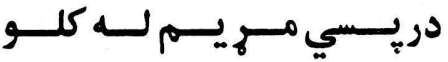

بي نرى مه زوندن كر ان ورئ زئي خيل وخـت د دريـات كه

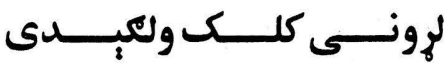

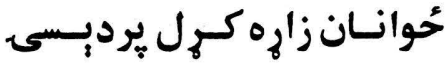

خـي راويسبنه سـوم بـلا نـهـ وي

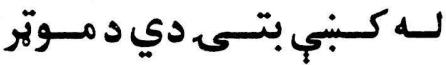

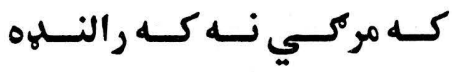

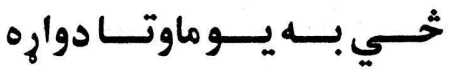

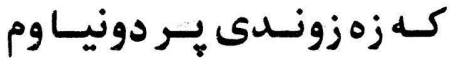

ول وابـه ورم سـتابلـ كــوزدي

جــواب اسـان دى د د داخــولي

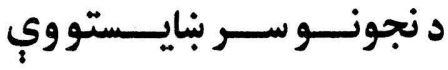

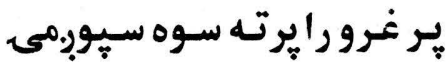

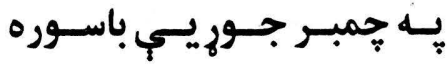

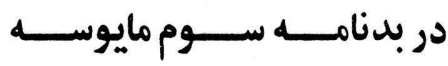

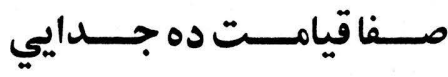

نـه وم خبــر سـتالـه دهـــــــي

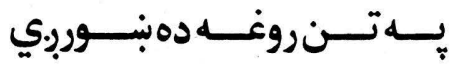

اوس مـه زره لـه دونيـاتـور سـو

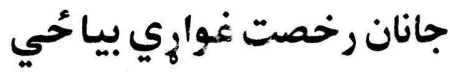

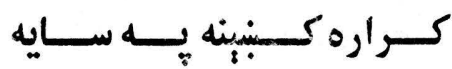

خولـه د غـــوارم سـوع بروكسـ خلك خوشتحاله ديـد بـ وكي

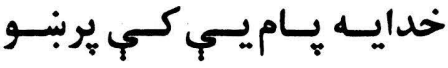
خر اســان كـلان، كـلان دئ خداى تـه مـخ كه و ماته شاكه خــوبر مـه سـي د سـر بنــيكرى خدايسه هيـــري كـي رويسـى

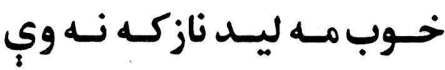

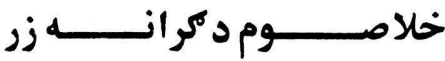

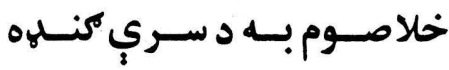

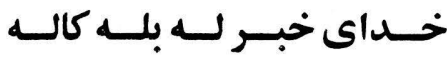

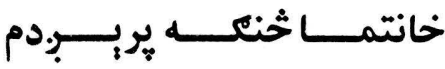
خــوب بــه نــه رازي د شــيـي

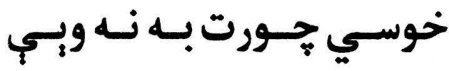

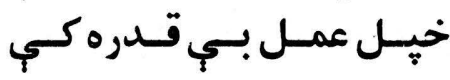
خلـك بـه شكـ واخلـي نـرى

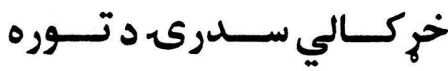

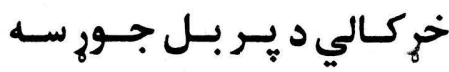

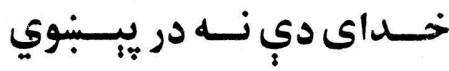
خيال مه وئ د مرك تر شيبي

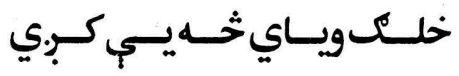

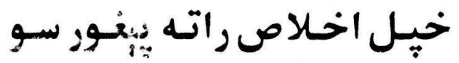
خــداى دي نــه سـ هار كـوي

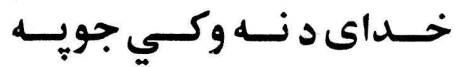




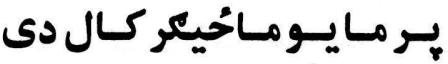

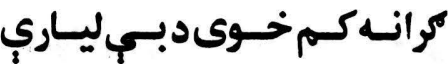

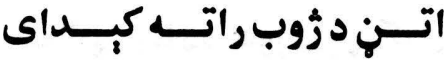
نـرى شــبخه ده قـرآن ويسيايي

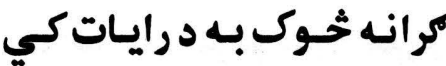
دمــخ يوست يـي دليـوه دى

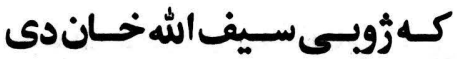

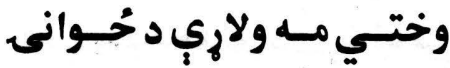
سـتا ببلتــون تهـ مـه حُحان وركئ د زره مـهـ خيـل نـه دى روزي

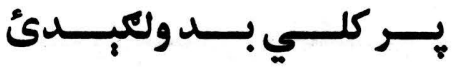
اوس بـه غـرق يـهـ غمـو مـاكي

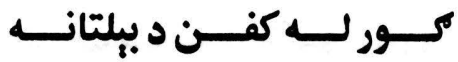
زياته ستا د بيلتون وخت دى

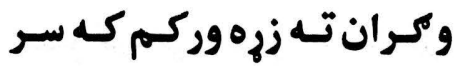

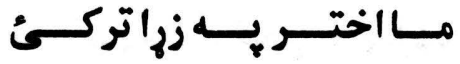

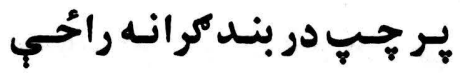

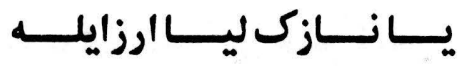
ديــن مسه سـتا نـه دى روزي

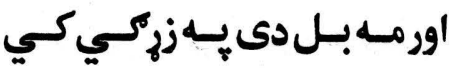

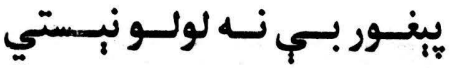

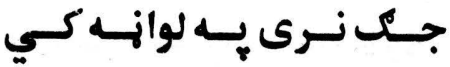

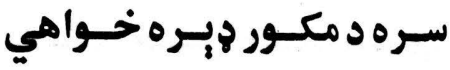

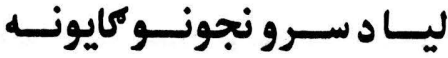

خداى خبر د زوو له حال دى

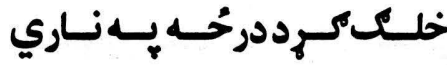

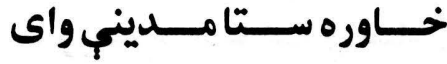
خلـــ ايلـه تومست يـر ويسايي خداى د سور يردى ولات كي خوبن مه دى ناخوبن مه نه دى

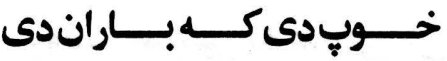

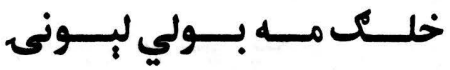
خيـل زيكى مـه دريـدر كـئ خــود بـه ورم د بــل خـــواري

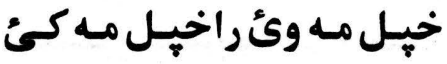

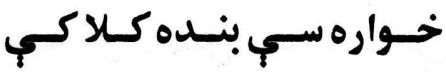

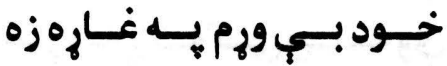
خلاصبه نسم تر جبل سخت دى

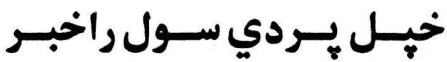

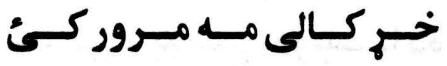

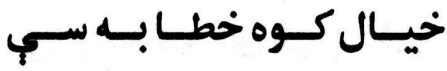
خــداى دي كـي يـر مـا نازيلــ

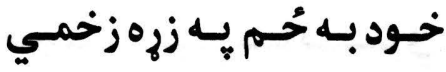

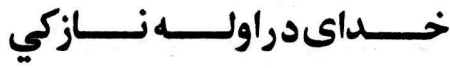
خـداى غنسي دى وابـي خلي خوبن مه دى هلك يِ زيره كي

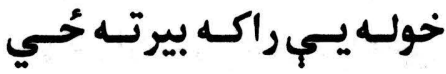

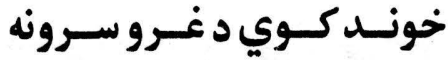




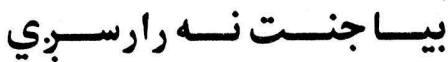

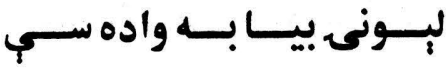

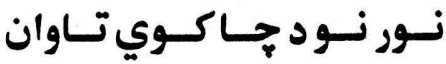

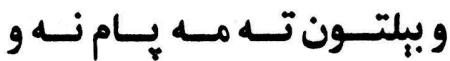

زمـور. تكسي د آسـمان سـتوري

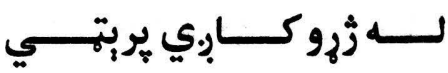

يروت د سبيني يه غوحُحي كي

نجلسى غبركسي ينجسي راكي ئهي

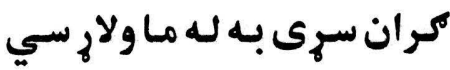

مـوبريجي يسه ديـد نسه يـو مـاره

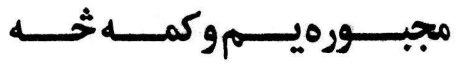

نـــه دى د بـــل بــــر كريــابي

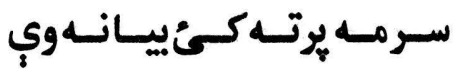

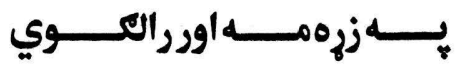

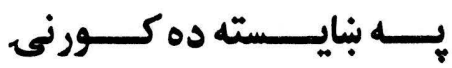

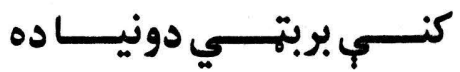

بي كر انه كم دى ثخي راحِي

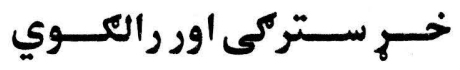

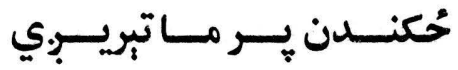

خداى د سهار جوركي قيامت

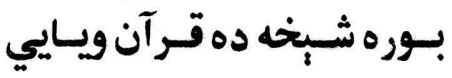

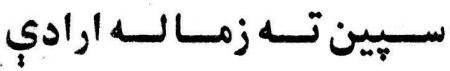

زهدمىران ليسار كـورم راحُي

سبين له بـه غبركي ترلهي
خوله بـه دركمى ثمـه مـه كبري

خـولكمق راكسه بنه مـه تـه سي خولكم زما ده خوري يبي كران

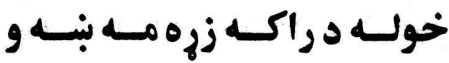
خلك بـه سـتركو سـرهكـوري

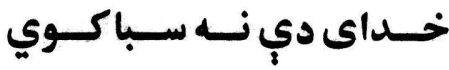
خـوب مـه ليـد بـه تنهايي كي خوبمهليدخداى ديخربتيّياكي خـوب د سُر سي بيسا به راسي خلك يب خوري د لاس خواره

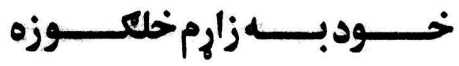

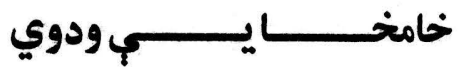

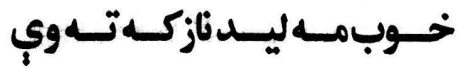

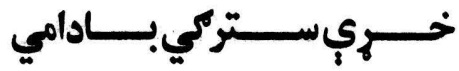

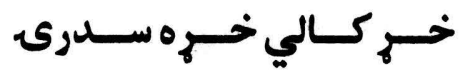
خوركى ستا د خوله خندا ده خــوب ظــالم دى تـــر مركـي

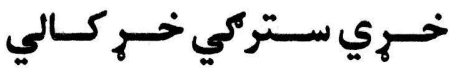
خــوروه راسـهـ سـامه خيـزي

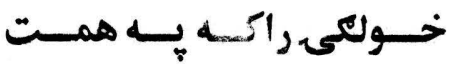
خلـك ايلـه تومست يـر ويسايي

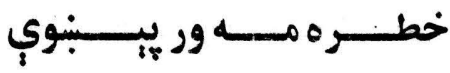

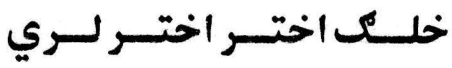

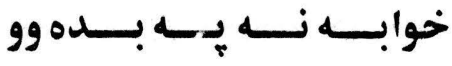




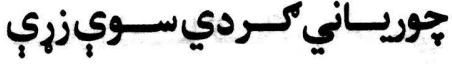

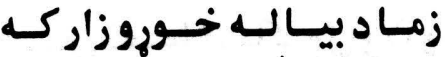
جي سره بيه غاره كي كوبروان كسبـتهويلتر غــواري كرانسو

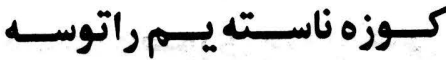

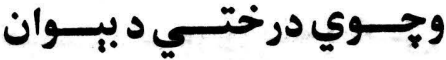

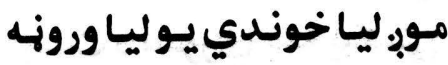

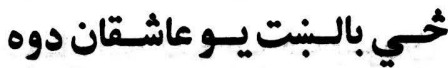

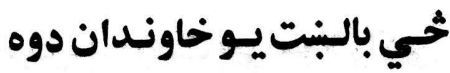

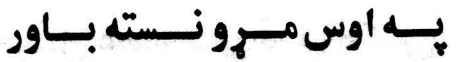

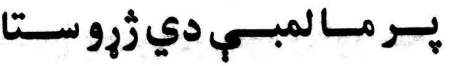

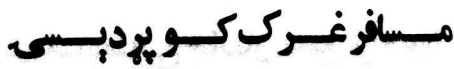
غسم بــردى بنــاركو جــور دى

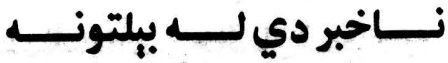
زرابــ در سـي شـين خـاله. مسور.بـه هـم د خيـسارهكي

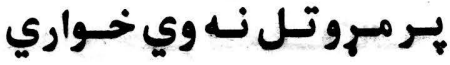

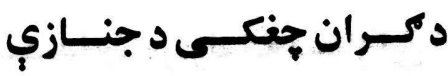

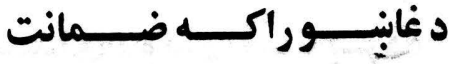

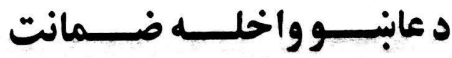
خــداي ذمــه وار دى د غابنــو بج جهورى خـوب كله راحُي بـي نـرى خـوب كلـ راخِي بـ سينه خسوب كله راحسي

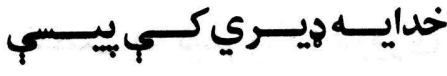

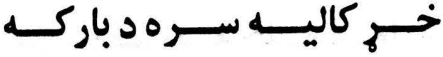
خــداى بـي كلـهـ كسي سـهار

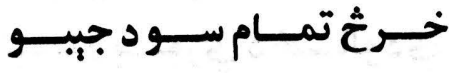

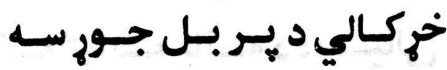

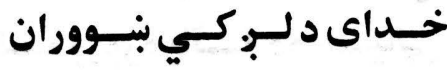

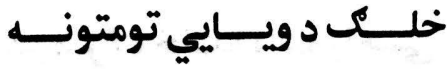

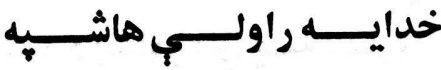

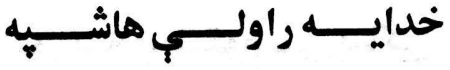

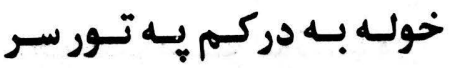

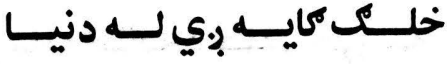

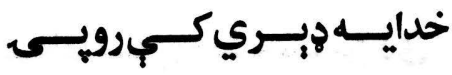
خراسك بنه دى باديب سوري دى خي خلك كه خاندي روغيب زيجرونه

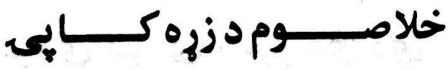
خداى غنـي دى داد بـ وكي خـداى غنـي دى وابـي خلي خونسلديكـر دي يـهـ بـسيجي

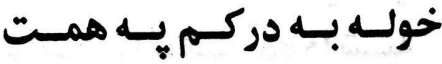

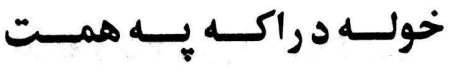

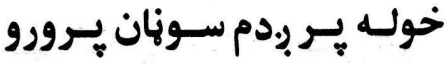

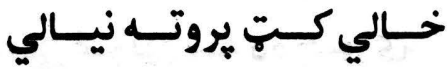

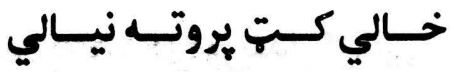

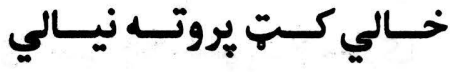


رخصت بـه نيـاز وركه تروري

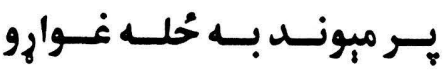

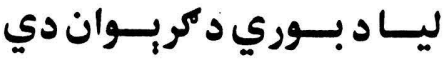

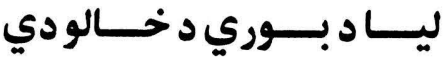

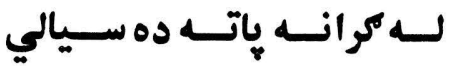
لـــه وروره ياتـــــ ده ســـالي يسر مـرك خنــدا مالـه راحسي

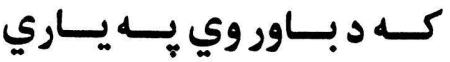
كــور تــه واسـتوم بـي بــاكي

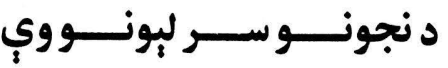

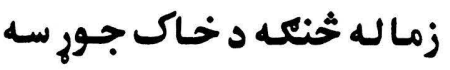

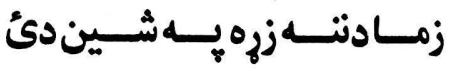
ولـور د زار سـه مـه يسب خـوره

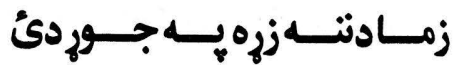

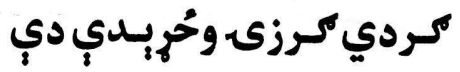

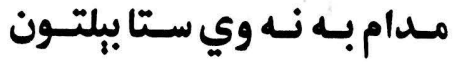

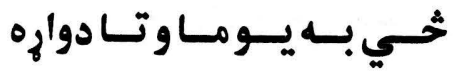

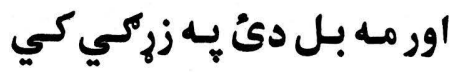

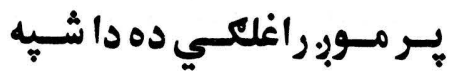

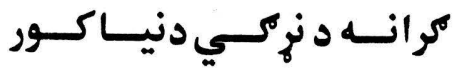
دغسى تنكسى بنـه ده جـورى

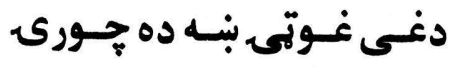
خود به وير كي وريندار كياني دئي يــي جخكــ د جنـازي

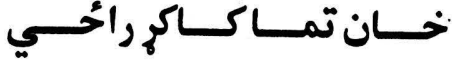

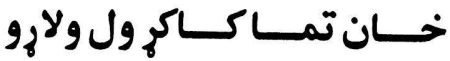

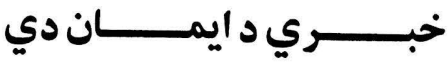

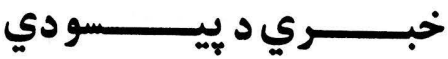
خيــت د بــوري يـــ يـيكسي

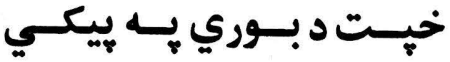

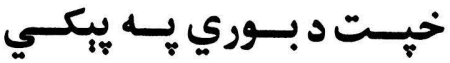

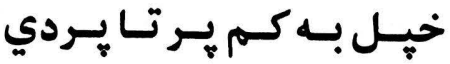
خيل يـر نيـت بـ مـولا راكي

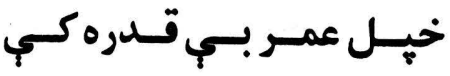

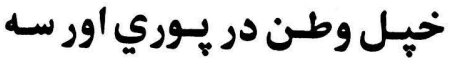

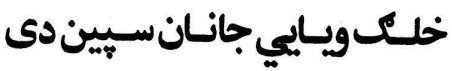

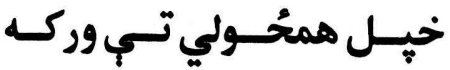
خلـــــوايسـي جانــانتـــور دى

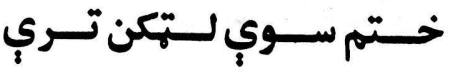

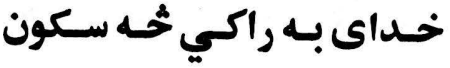

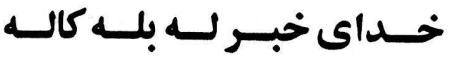

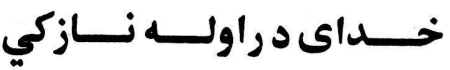

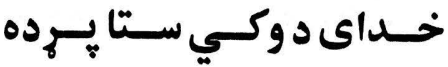
خـداى دي نه كي سـره جـوري

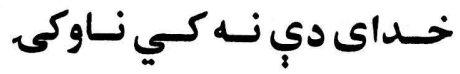
خـــاى دي نــه كـي نـاوكى

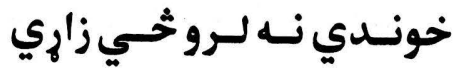

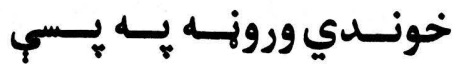


ليـابـم ديــ وسي ليا ناسـتكي خــــي همــش كـــوي ودونســ جوريـاني كـر دي سـوي زئري هلكوان به خوله غواري كوزدي

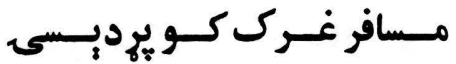

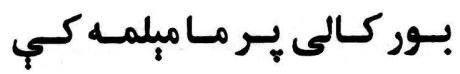
زه بـه تهمست ورم كـه بـلتـون

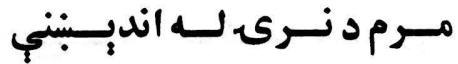

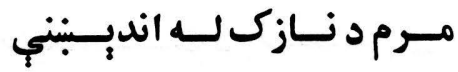

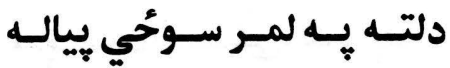

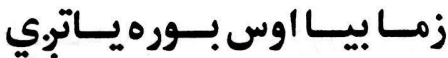

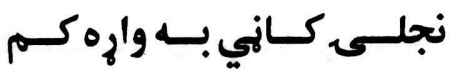

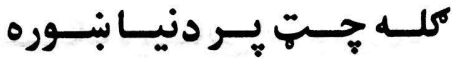

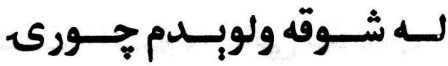
ناخحى نازكَحيام به حُواني

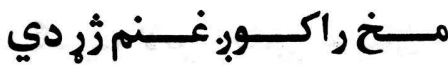
د سـيـين تك د منـلـوخي دى

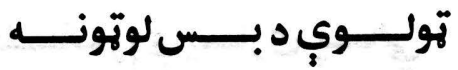

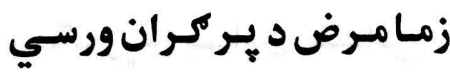
كسودوي بـلـ سـري راوكـئي

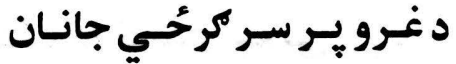
عجب سرى دى دمك اندوست خـهـ سـوى ويسالي لـه بـه راتلــئ

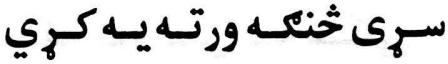

خدايسه تـري كسي دا مياستّي خدايسه ويـر كي زمـاتـر برونـه

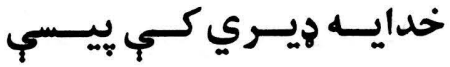

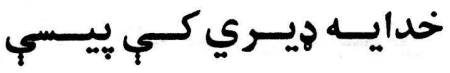

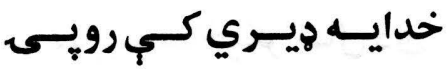

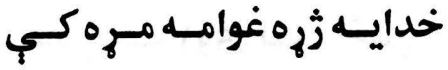
خدايـه سـور كي هـئزوندن

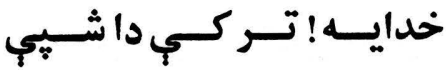

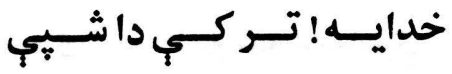

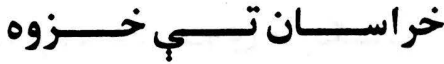

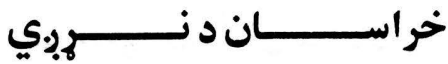

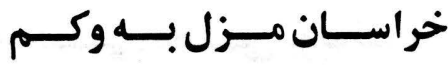
خـرخ بـه زه دركسم لـه كـوره

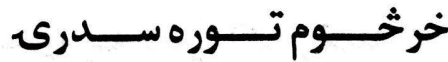

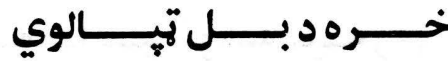

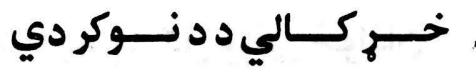
خـ كالي محبـت يـب هوير دى

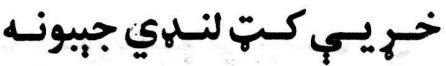

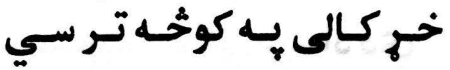

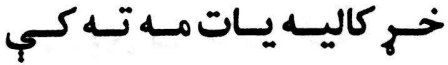

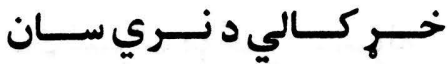
خـــ كـالى كايسـه ب.ني بوسـت خـــ كـالي كــوره لــونكى

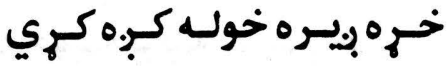


كاكرى غاجي

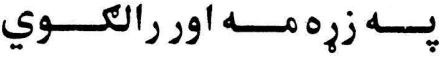

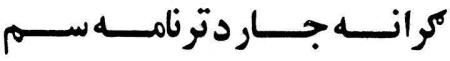
كر انــــه لمبــــي بــــهـ دمكــالم

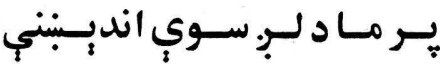

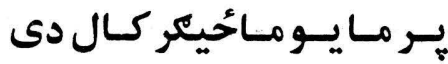

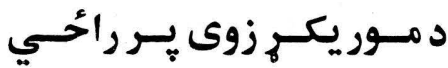

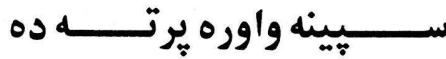
ير كرحي كران و شين خـالى

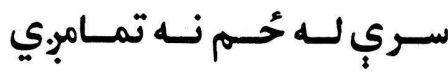
دواره واده ســوي خونكسـاني د غنسوخكى نــوكران مـهـه دي

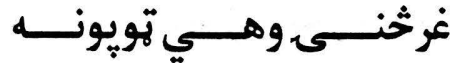

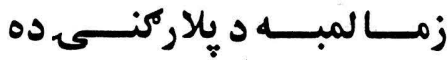
نـرى يـه لاس راكــ رخـصت

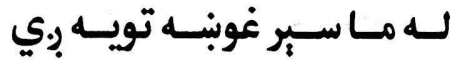
سره يِ جاركل وزني حُحوانان

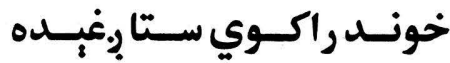
لــه مـــوبه نـــوكي بربـــاد دي

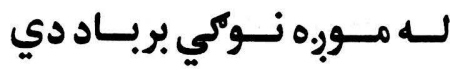

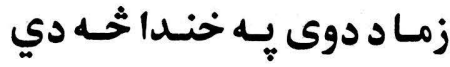

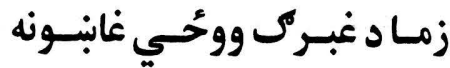

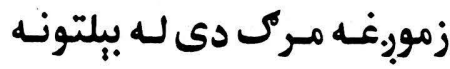
كر انـه كـم خـوى د بـي ليـاري

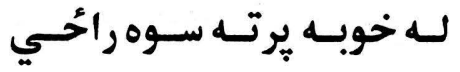

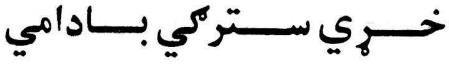

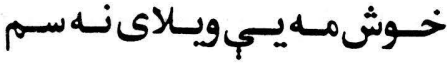

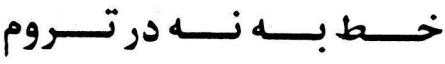

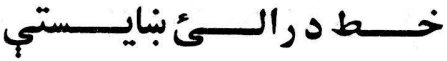
خطط راتـر كه خـه د حسال دى

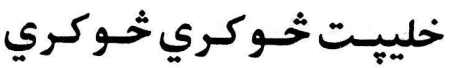

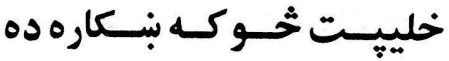

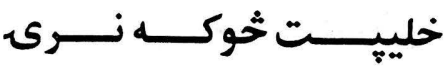

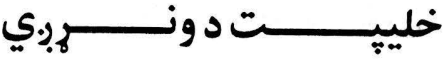

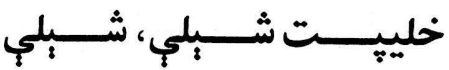

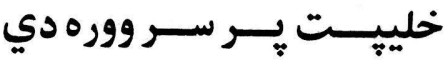

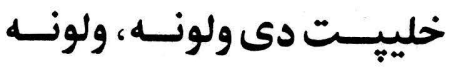

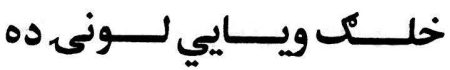

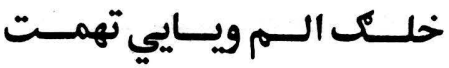
خلك بـه ويايي خحه يس كربي خلـك بــه لاس اخلـي بيهيـان

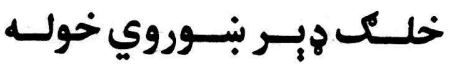

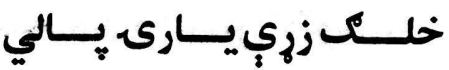

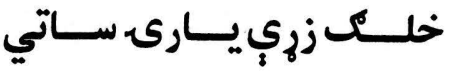
خلك كه خاندي زرونب بنه دي خلك كه خاندي بنه يب زيرونه خلك كه كرحي روغيب زيرونه

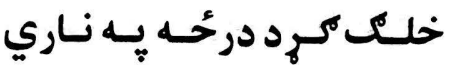

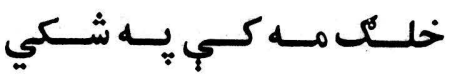


كر انــه اوس د مـزوز شـبِي دي

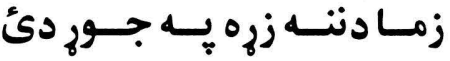

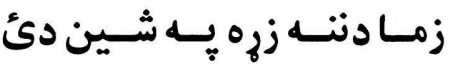

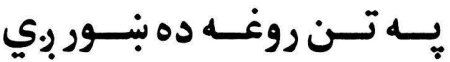
زمــاد ســتر كو بانوكــان دي

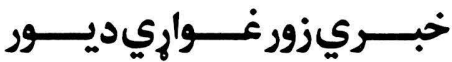

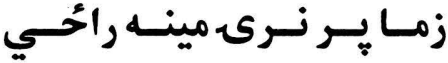

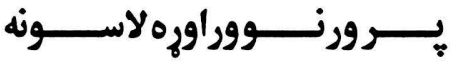
شبخحو سوسن كئ دزوب ميان يردى كبردى غواري لوى زيره

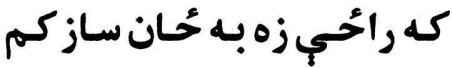

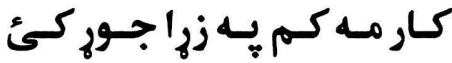

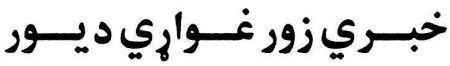

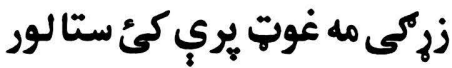

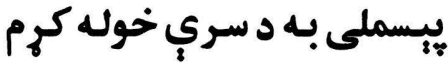
بي كو انه كم دى ثحي راحي

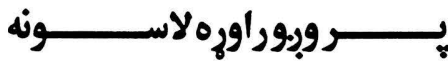

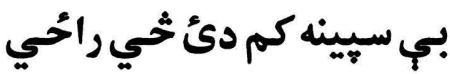
لاس راوزم بيـاخــلاص سـي راسـي بـوره بــهـ غـوحي كـي

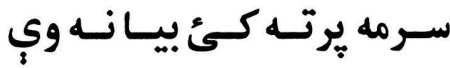
د جنك ميدان كي د دكران مله دوركـي وهيــر دبـــمنان سـوهوه

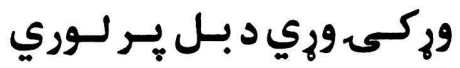

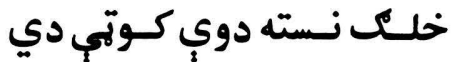
خلـك ويـايي جانـان تــور دئ خلك ويايي جانان سيين دئ

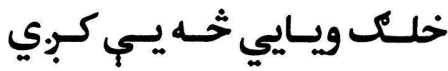
خلك ويايي ورونه كر ان دي

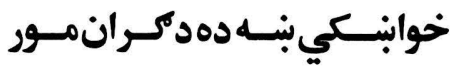

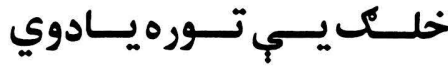

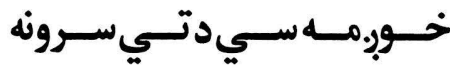
خلكــو وركـــئ لــوى انعــام

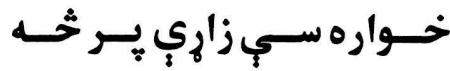

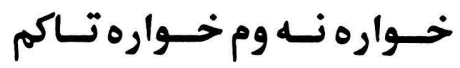
خواست مه وكئ سر مه تور كئ خوابنـكي بنـه ده دمكران مـور

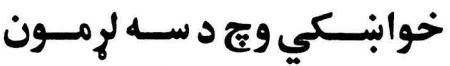

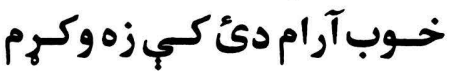

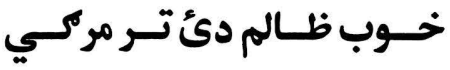

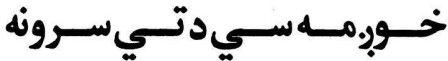

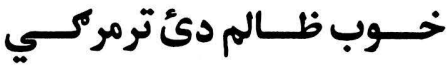
خوب مه ليد بور ستركي راسي

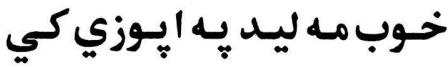
خــوب مـهـ ليــد نازكـهـ تــهـ وي خـوب مـه ليـدى د شيـي ويـه

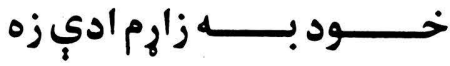
خـــود بـــــزازم ادي مــوري 


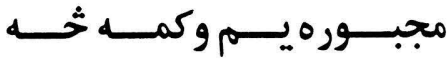

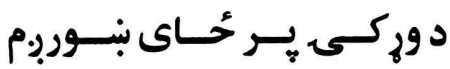
ول ثخي نازك ورور بـه راحي بـور هويـاى كـم دى خركسالى

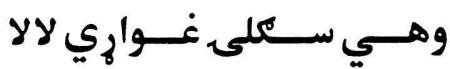

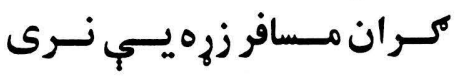

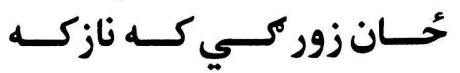

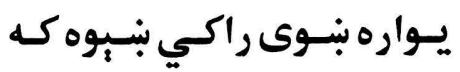

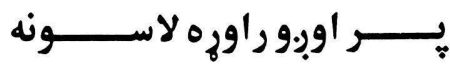

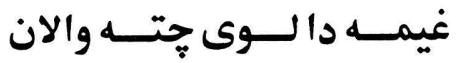

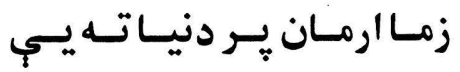

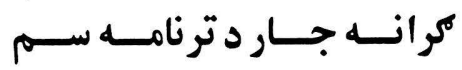
اوس ليا حُوان يم بيا به زرو سم ديم يّر ديـوال بـه درتهـ سـيور سـم

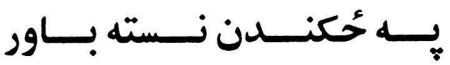
بانسـدي ير إسبر.دم د دنيــاكـار

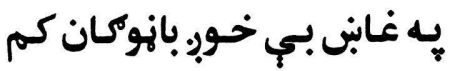

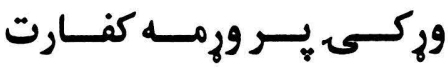

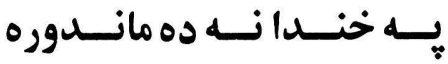

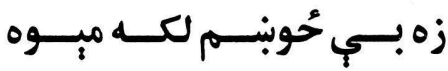

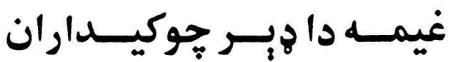
تـر داكر انسى نـه دى زمهـازده زياتـه كر انسى نـه دى زمـازده خي نامي كر جنيـي غـواري

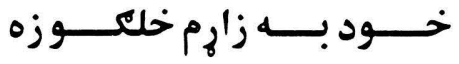

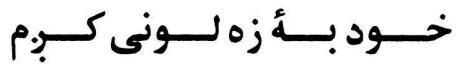

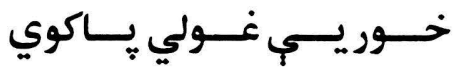
خــور يسي كـئ د سـر تيكـــى

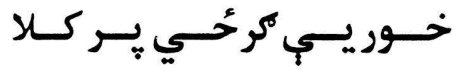

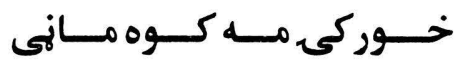

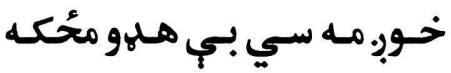

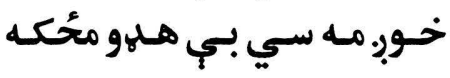
خــوبر مــه سـي د تــي سـرونه خــوش مـه دي وريكي هلكسان

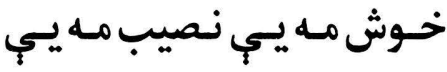
خـوش مـه يـي ويـلاى نـه سـم خولكيى راكه ثخي يه موري سم خوكلكى راكه ثخي يه مور سم

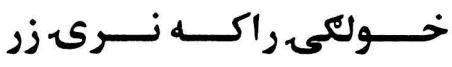
خوله بِه جرس ستركي خومار

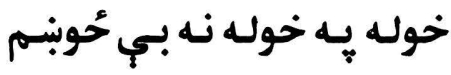

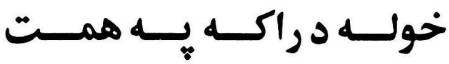

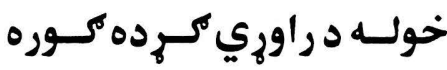

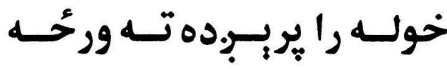
خوله كي راكس سـتا شـونهان

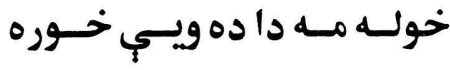
خولـه مـي دا دهويسي خــوره خوله مـه دى نـه ده لـ غـاري 
ثخي ساريجي داغ نه وي نبـاره

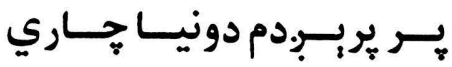
اوس مـه زره له دونيـاتـور سـو

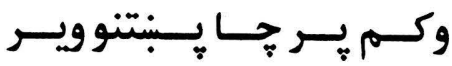

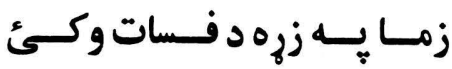
كران وليار زما ير دوستي دى

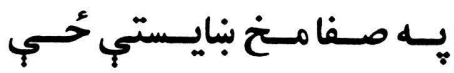
خلكسو نيــولكي دي مسورجي

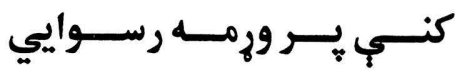

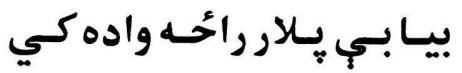
بـ ذَزو كـم دى خدي راحَّي

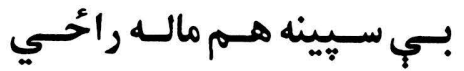
خي خـوك خبر نه كي كر انـو

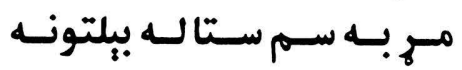
خــوكي لكــوكي دي جانـان

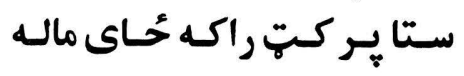

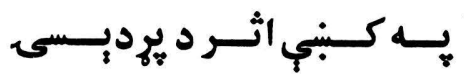

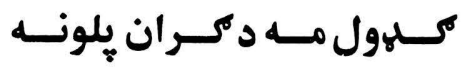
كرانـــهـ يلونــــه د نـــوين دي

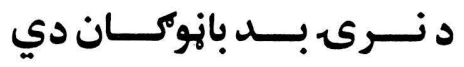
د اور بــهـ ميـان كـي وه برتــه خهي نامي خركاريسي غـواري بــاكــه مركـى رايسـي واى

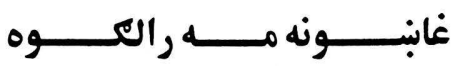

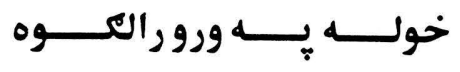
خوله ييج جرس ستركي خماري

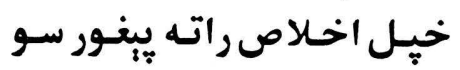
خيـل قسمت دى خيـل تقدير خيل د نه كئ خـوار د بنه كئ

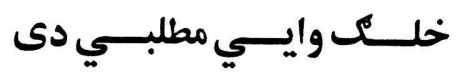

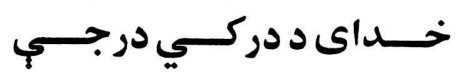
خيـــال كــوه كلــــه د شــيهي خلـسك دي راكـي بـهـ مرضسي

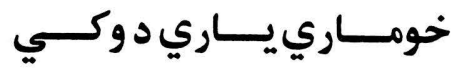
خـــوب بـــي دى تــــــــــــي

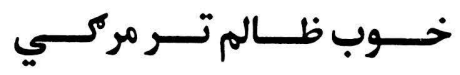

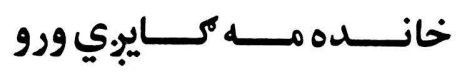
خــوبر مـهـ سـي د سـر هلهونــه خــوبر مـهـ سـي دواره كولكـان خونـلـ بـه هلتـه دركي كر انـه خونس كـوي د سـري لنـلهى

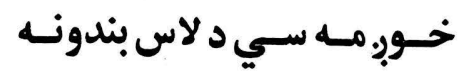
خلك هوبنيار ديكرديل زن خلكس يـب هبـر صـفت كـوي

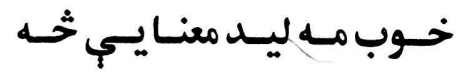
خوله مـه دى نـه ده لـه غـاري

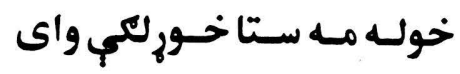
خولـه مـه سـتا ده وايسب خلـ 


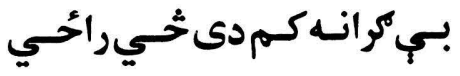

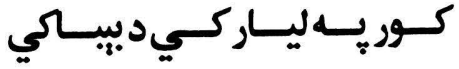

وروســــى ينــــور دى بكــــاوي

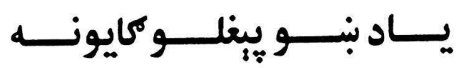

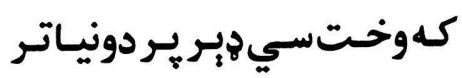

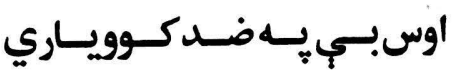

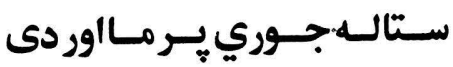

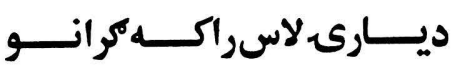

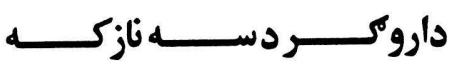

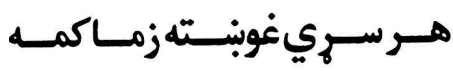

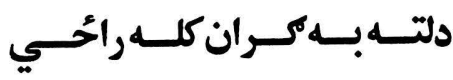

كسي اوسـبري سـيـين ورنونــه

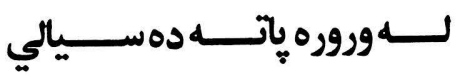

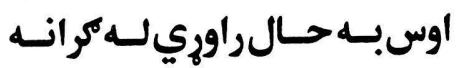

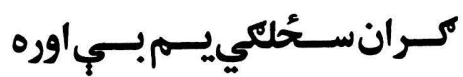

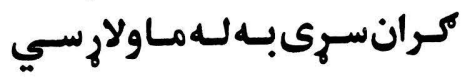

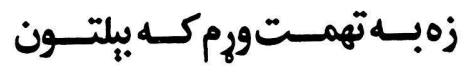

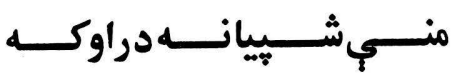

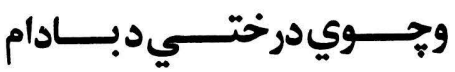

خـيسريورى وركي كولكونس

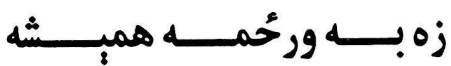

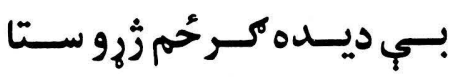

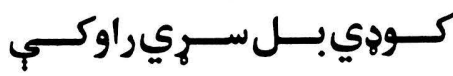

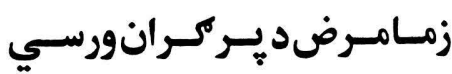

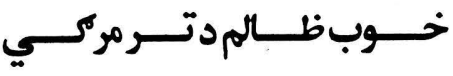

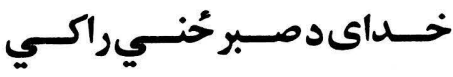

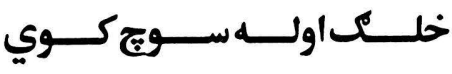

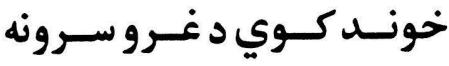

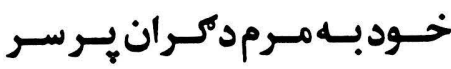

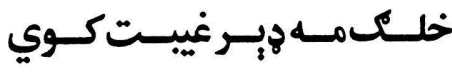

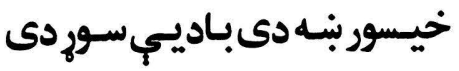

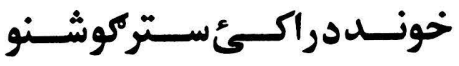

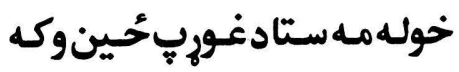

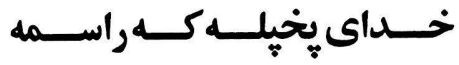

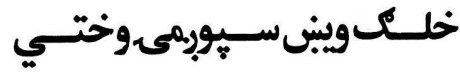

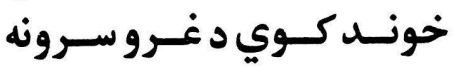

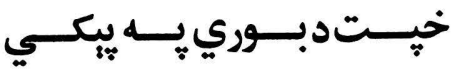

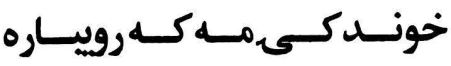

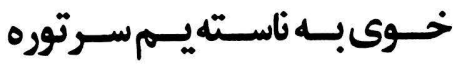
خـوبدسـور سي يـيـابـراسي

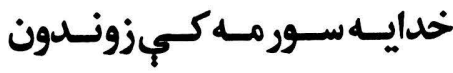

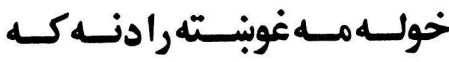

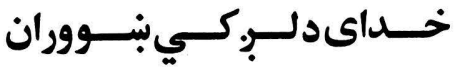

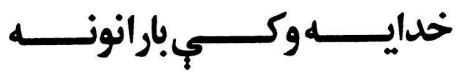

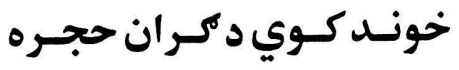

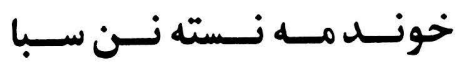

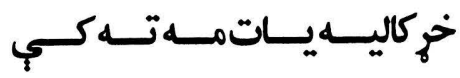

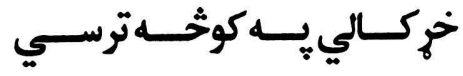


لـه كــور ه بنــد سـوم زيرو ســات

لـه كــوره بنــديــم نـــرو سـتـا

تر غـابن يسي ستركي بنايستي

تر غابنيب ورحككي بنايستي

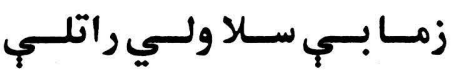

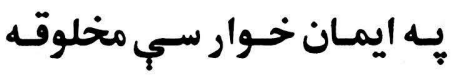

زمــاد سـر سـتركي ده كر انــو

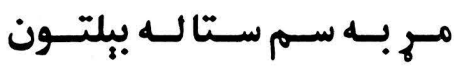

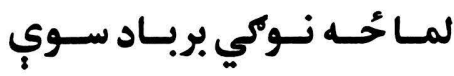

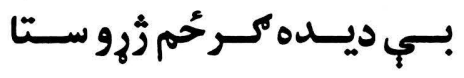

خونـــد مـــه نـــته نــن ســبا

خونــد مـــه نــــته نــنـ ســـبا خونـديـي واخستى له خـولب خونديسي واخستى لـه خـولي خلـك شــمن دي كـنـبـوزي

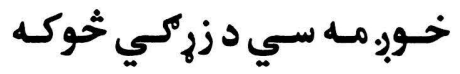
خلـك ويـاى تـوره ده تـر يـبنو

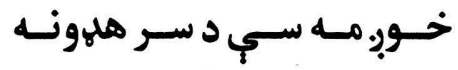

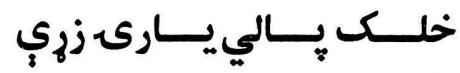
خونسـل مـــه نــسته نــن ســبا

然柴 


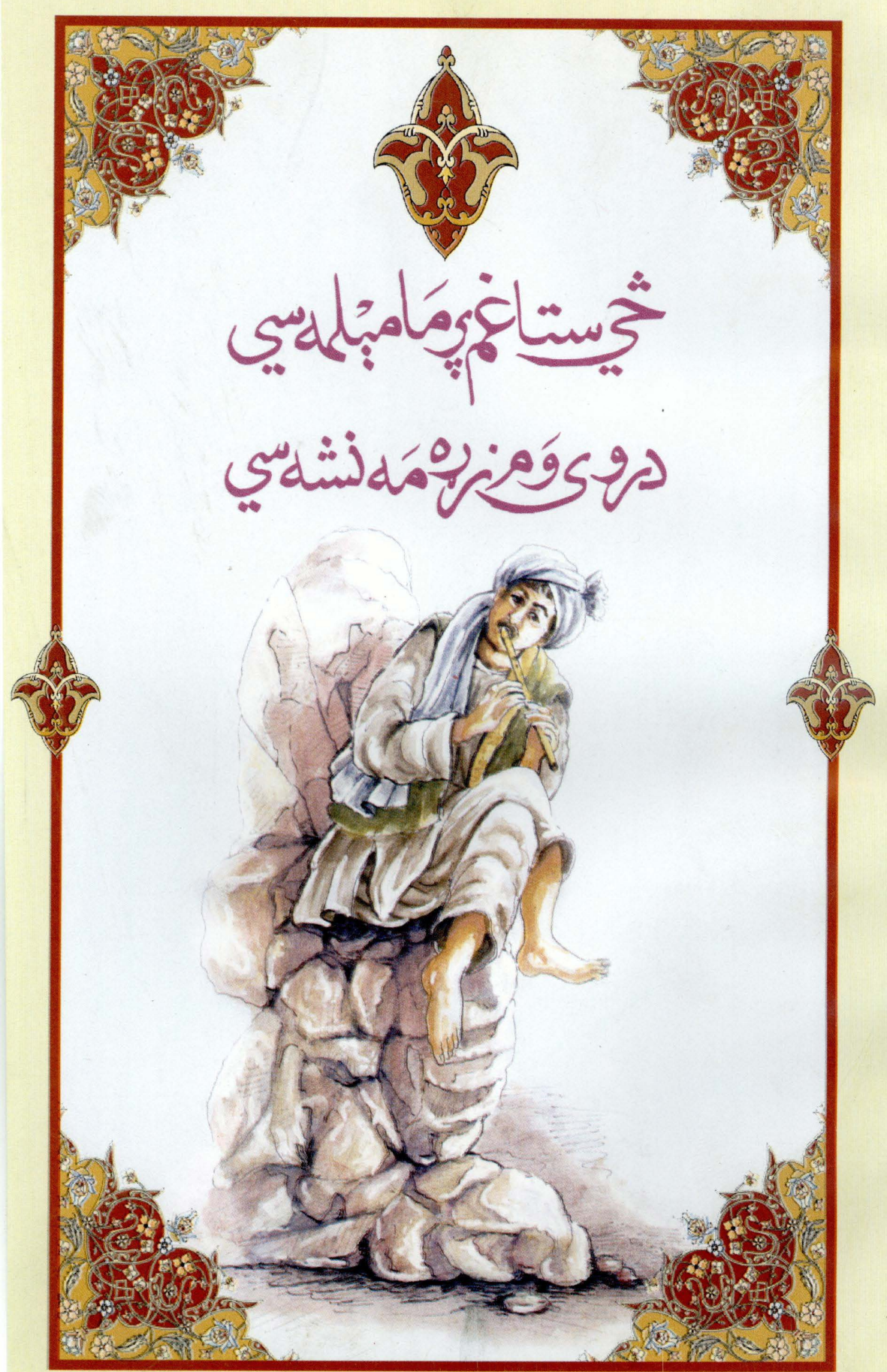




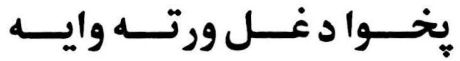

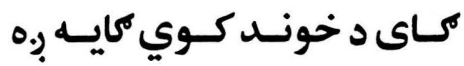

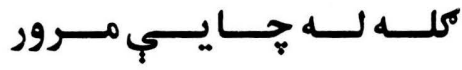

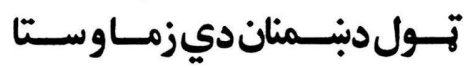
كـورهكى دى هـاكـور نـه دى

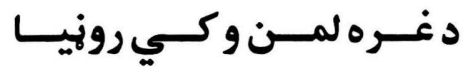
يـر تـن مـه اور واخلـي كــالى دي

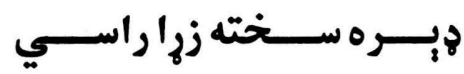

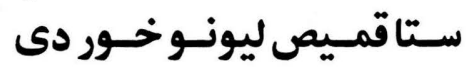

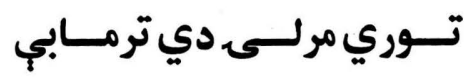

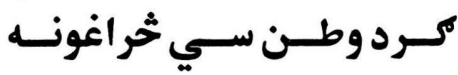

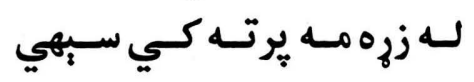
له خــولب مـه يرتسه سـي كـالي

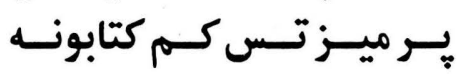

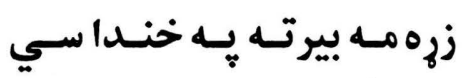

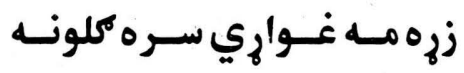

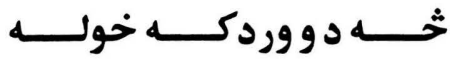

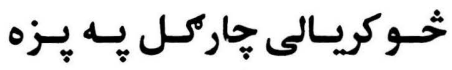

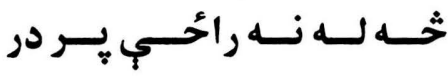

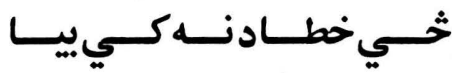
خي بابك يِ كور كي نه دى

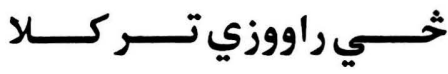
خــي رايـاد سـي سـتاكر انـى خـي مـه ياتـه سـتا خنــدا سـي

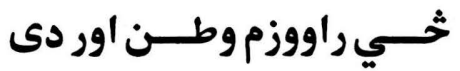

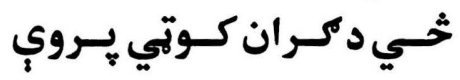

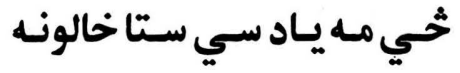
خــي بـــارهيـي سـي لنكي

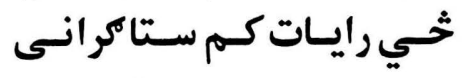

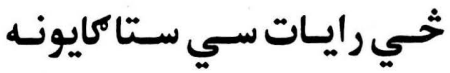

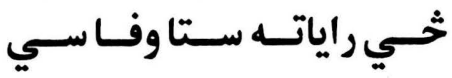
خـي رايـات سـي سـتا خالونس 
كاكرى غاجي

ير سخت خُاى بي جوابغواري

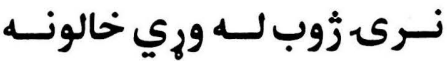

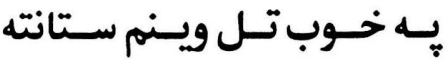

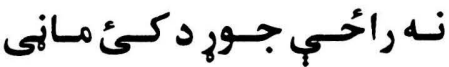

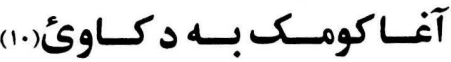

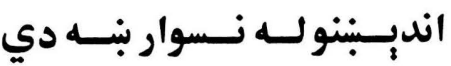
كر انـو زمـا يـه نـصيب نـهـ سـوه

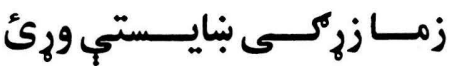

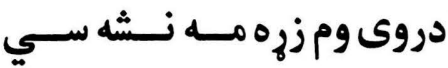

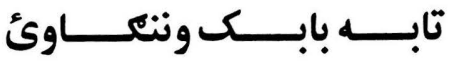
دجينـي يــر ليـاريسي كــوره اسكولي دئ بـاك يسي نسته جهـان تـول يـهـ غـر غـرهـي

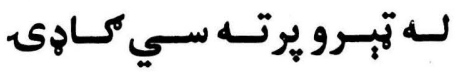

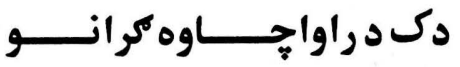
هـر مـاتنـور سـي د ثوب ميـان

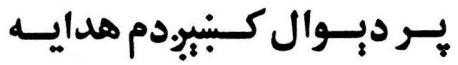
شيطان ويـاى يورتـه كـ كوتهـ

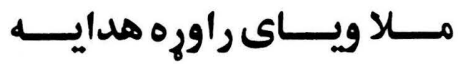
زما يـه لاس كي بتسى مـه سي

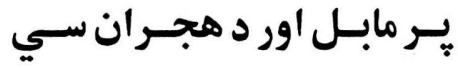

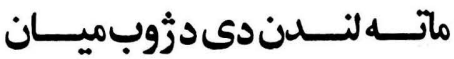

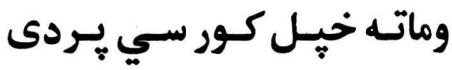

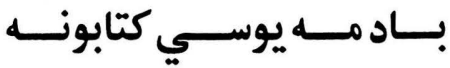

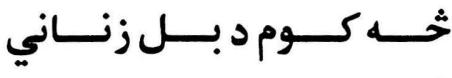

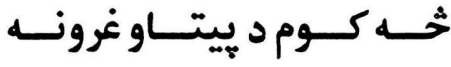

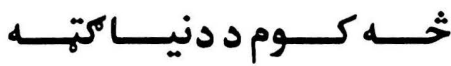

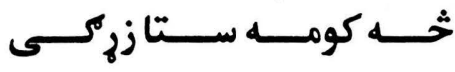
خُخي شـبر جان بهانـسى كـاوئ ثخب كـوم يـر خوله ترخهـ دي ثخـي كـوم يـهـ بــل واده سـوهي

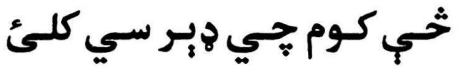
ثخي سـتا غـم يرمـا مبلمـه سـي

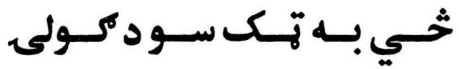
ثخي يـر سـريسي خـولى تـوره خـي يـر سـريسي خـولى نسته خي ير مـخ اوبنتان رايله كي

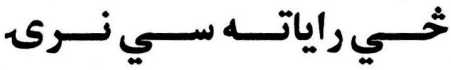

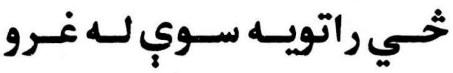

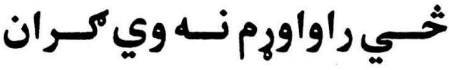

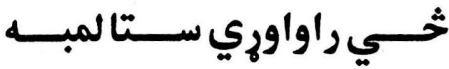

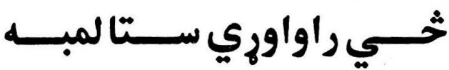

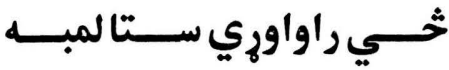
خي رايـات د سري كوته سي خـي رايـات زمـا جانـان سـي

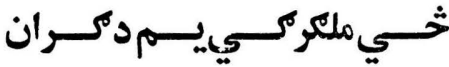
خــي رايـات سـي سـتاني انى

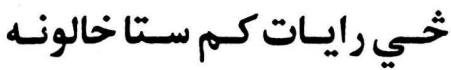




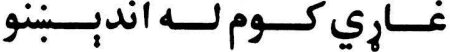

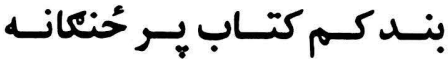

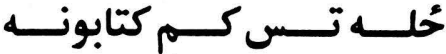
مـولادي سـتا بـه نسمسب كـي

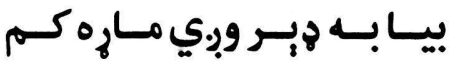
سـنك مــر مــر د ســي دا غـــر

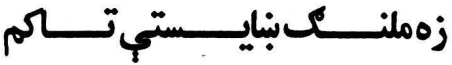
ســوكي نــاري لمـــا وســـي سـوكي نـاري راخدـه وسـي خوند مه ليا اوسه د سيني بنه

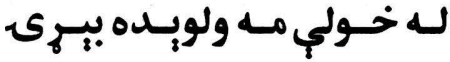

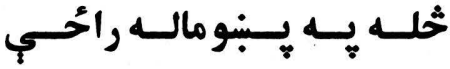

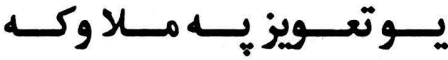

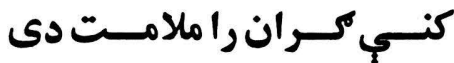

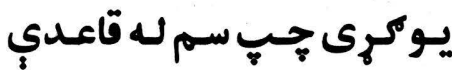
زوره مسه بيرتسه بـه خنـلـا سـي د زارو خونـــل مـــــ د هوهوى

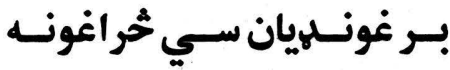

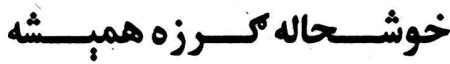
دا نور دي خاوري د بـنو سي كلى كم د منثـ و زعفر ان سي هلـك د تـور جـوري كـالي تيكـرى تس كـه تـر شـاكـوره تهـــى تس كـه دلي كـوره

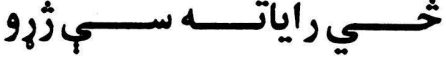

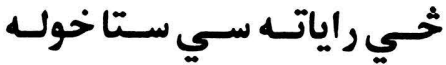

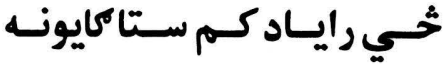
خحي زونـلـي انسانان خـوري ثخي زه خيل كشنيان ويله كم

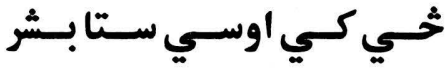

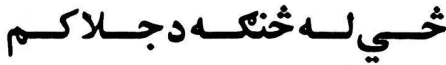
ثخي مه ستا لمبي بـ زوه سي ثخي مهل ستا لمبـي بـر زهره سي

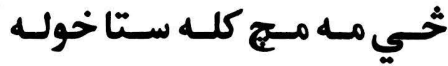

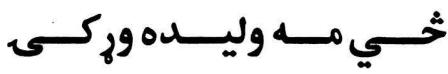

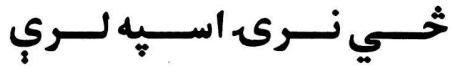

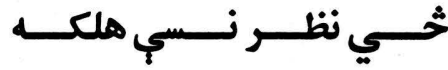
ثخيجي حال ويايم غيبت دى

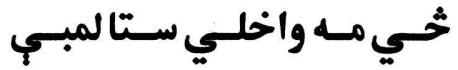

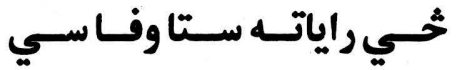

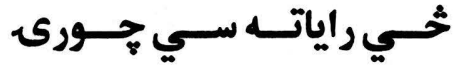

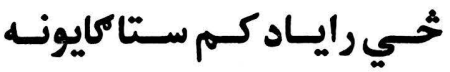

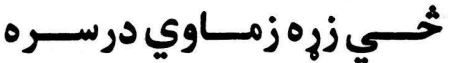

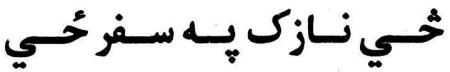
ثـــي نـازك كلـي لـه راسـي

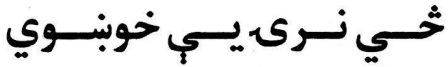

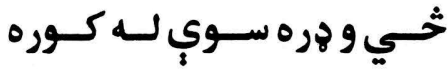

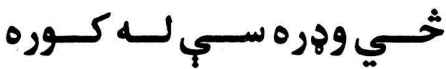


سـوحُي مـه سـتا بــه لمبــوزئه

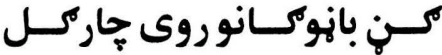
لــري وطــن لـهـ وري كر انــــ

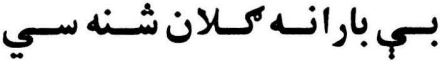

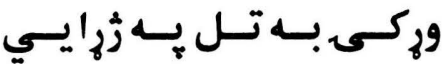
يريـانيسي نيسـي بـر دراوى

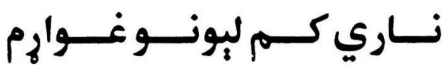

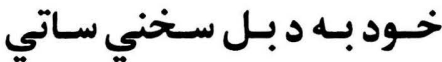
اوس بـه وى وى نسته فايدي

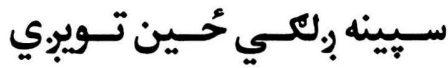
يه كور كي جور كمه شين وير

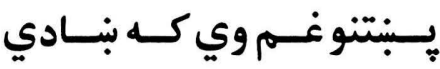

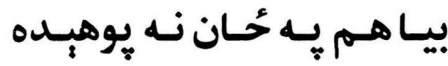
مـره خـور نـه سـته يـهـ ميـوي

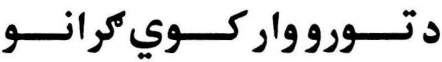

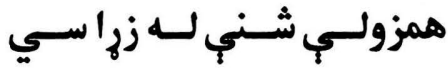
شـونلهي مـــ غبركسي وكنــئي خـي بـي نـرى يـر دونيـايسي

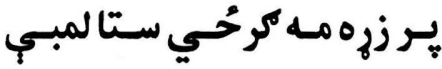

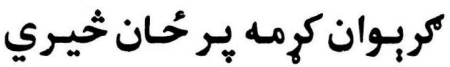

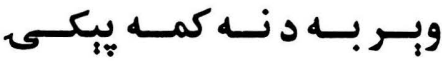

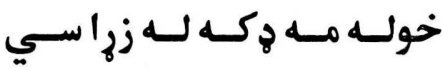

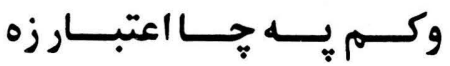

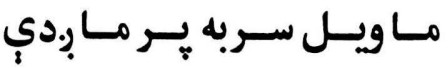

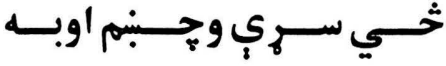

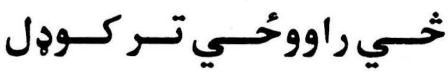

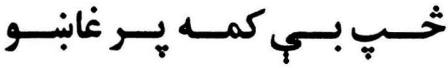

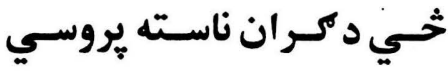

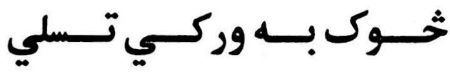

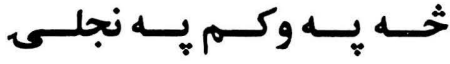

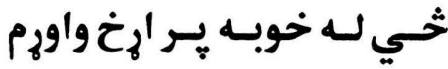

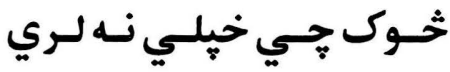

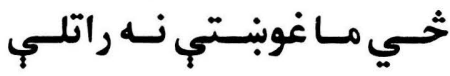

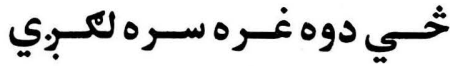

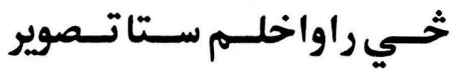

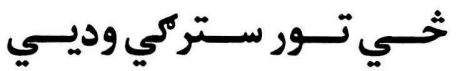

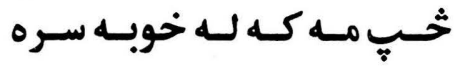

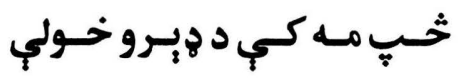

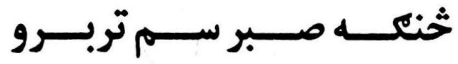

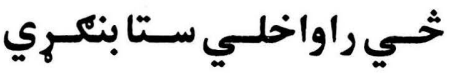
خــي مسي نـه واوري سـلكى

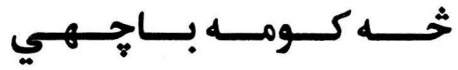

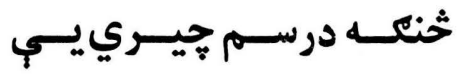

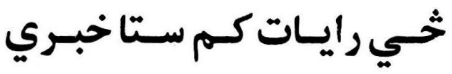

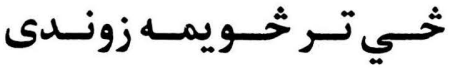
خـي سـتا جـورت لونـو راسي

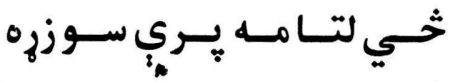

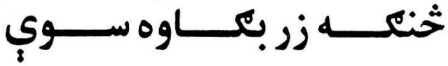




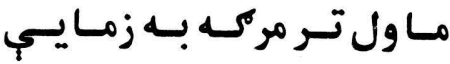

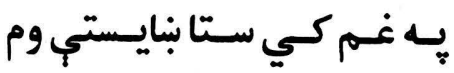

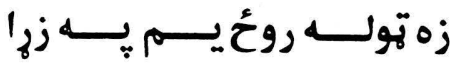

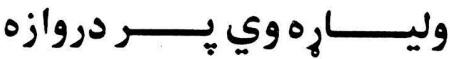

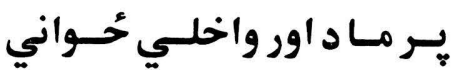

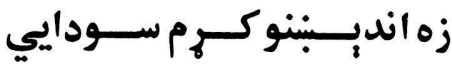

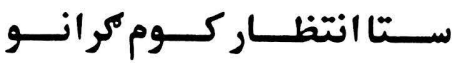

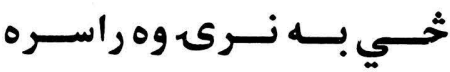
نــرى كــور بــي لتــا اور ســو

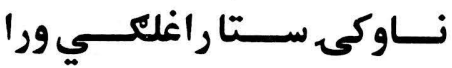

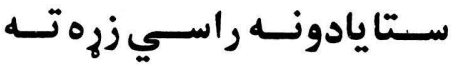
دكولب كار مه خـوري حُواني

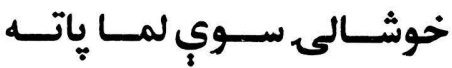
يه غروكي يتّ سولوكوركيان(11)

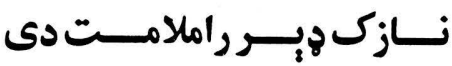

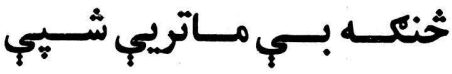

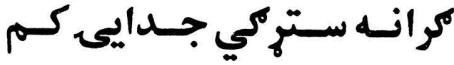

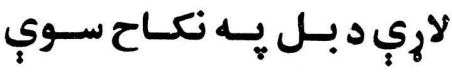

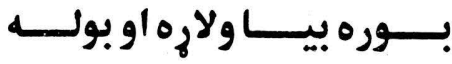

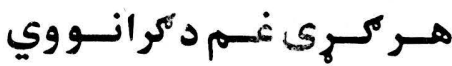

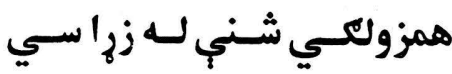
همزولكي تـوني سـوي خـازه

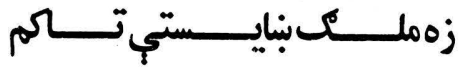

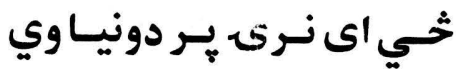

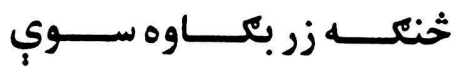

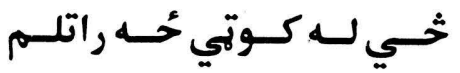

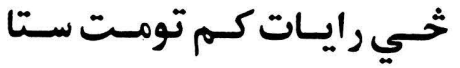

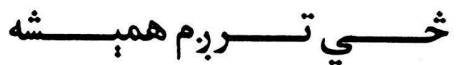

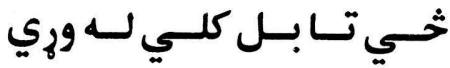

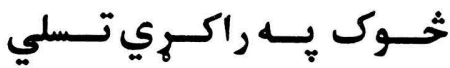

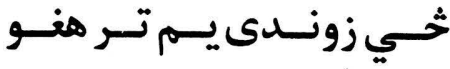

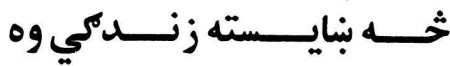

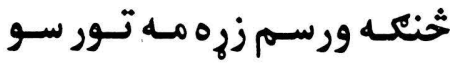

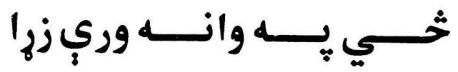

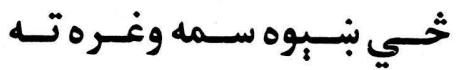

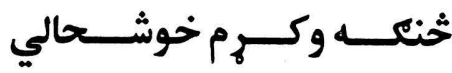

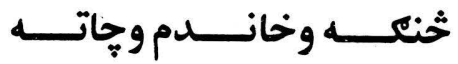

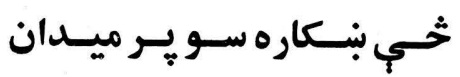
ثي يبي حال يايم غيبت دى

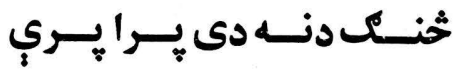

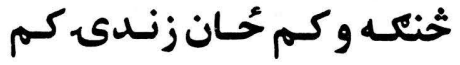

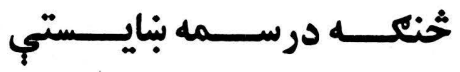

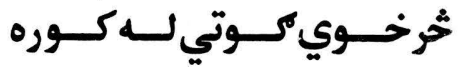

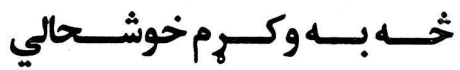

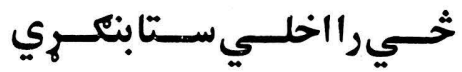

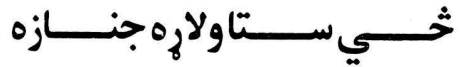

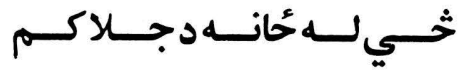

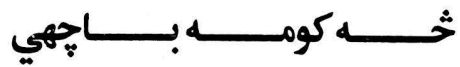


كاكرى غاري

برتـه مركى دى خــي راحسي

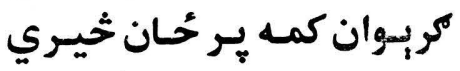

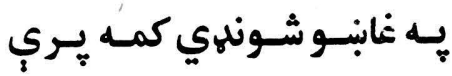

بـادام كـل وكـي بيـاتوسـي

ونسي كـل وكـي بيــاتوسـي

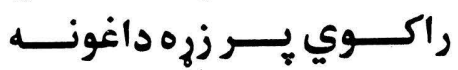

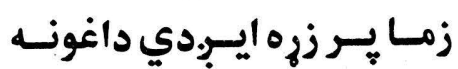

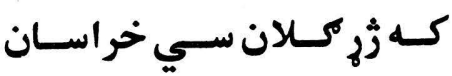

خداى خبر دى خي بيا راسي

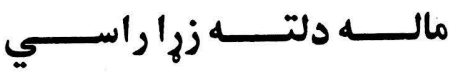

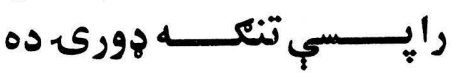

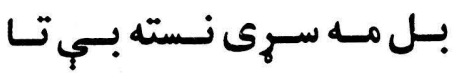

لـه نجلسى اور اخلسي سـبركى

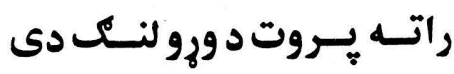

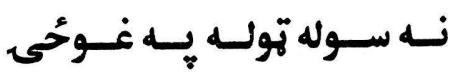

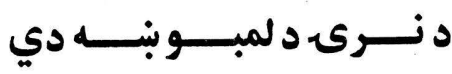

ولارى جينـار لـه د سـري كسور

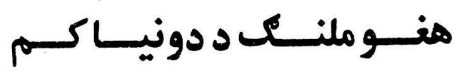

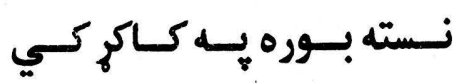

زمـاد درك د شـكني بـار سي

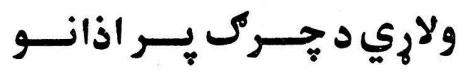

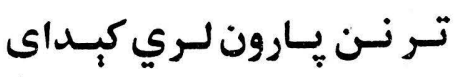

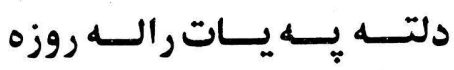

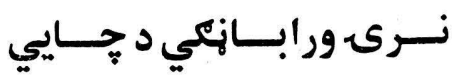

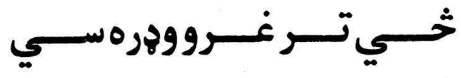

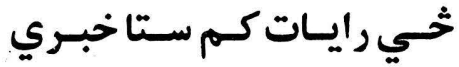
خــي رايـات كـم سـتاوعـدي

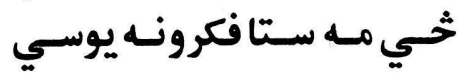

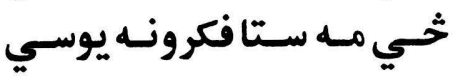

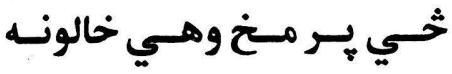

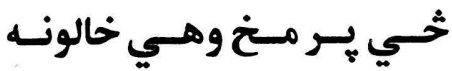
خـي كسوم خـي نسه وي مكران

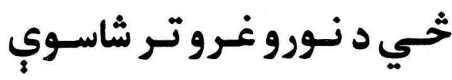

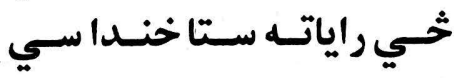

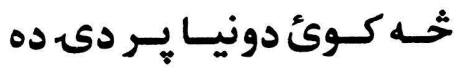

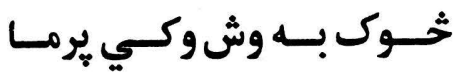
ثخي ير سركي سيّين تيكرى

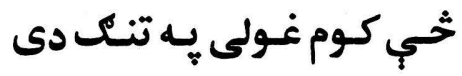

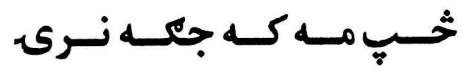

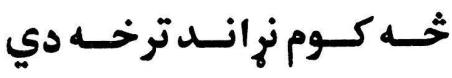

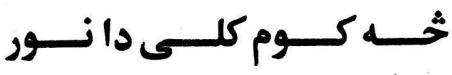

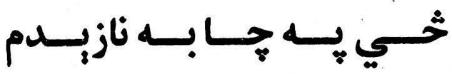

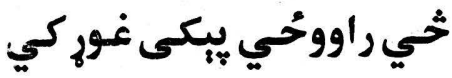
خي سهار سي خي مابنام سي

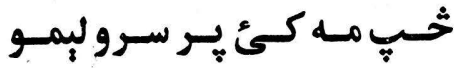

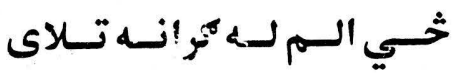

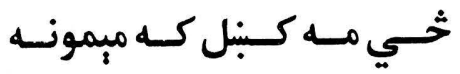

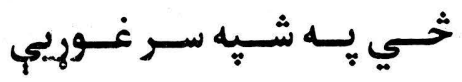




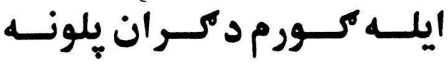

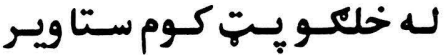

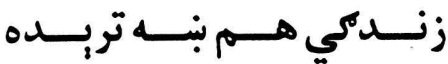

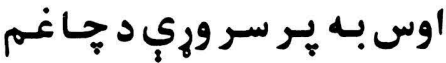

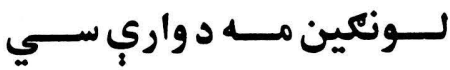

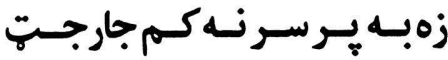

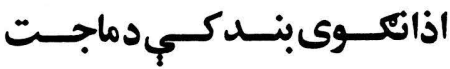
كـلـ دجنــت ســـي د بــاغجو

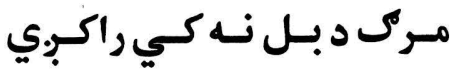

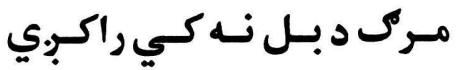
هنـوليـا هـم كـم تـر حُحسان تـر

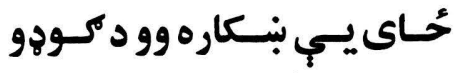

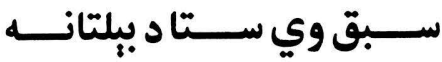

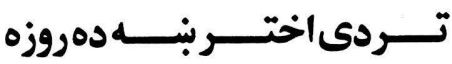

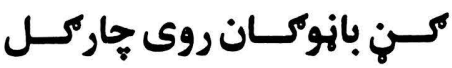

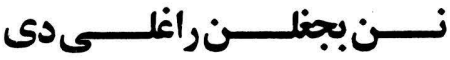

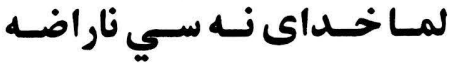

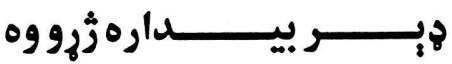
سـره راغلكسي ده خابنــولـه يـه نـه وو خوند د شـين خـالى

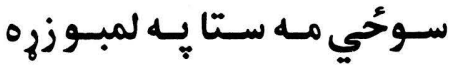

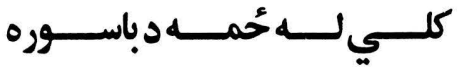
بريـانيـي نيسـي يـر دراوى د ســـركي كلـــى دي برســـي

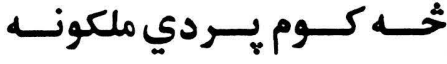

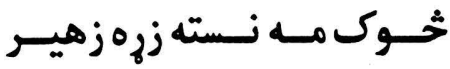

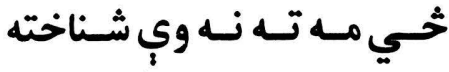

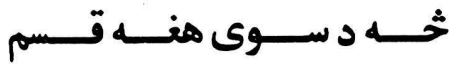
خي خي انلاسراوريدى يري

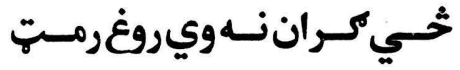

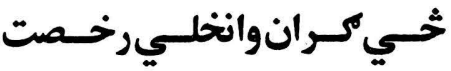

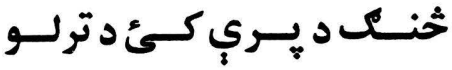

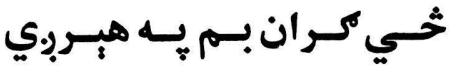

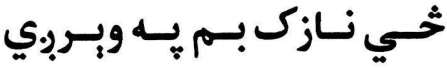

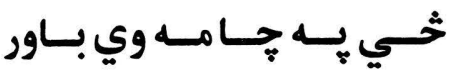

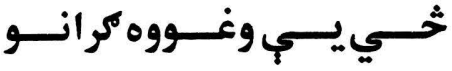

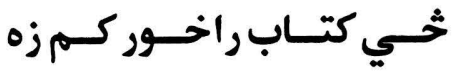

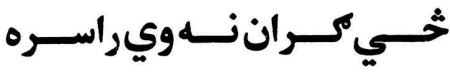

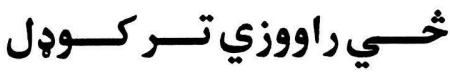

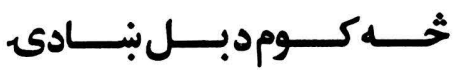

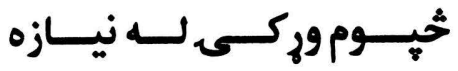

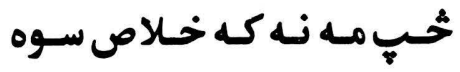

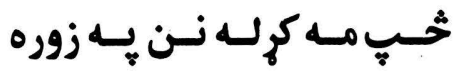

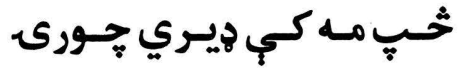

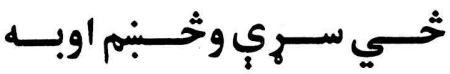

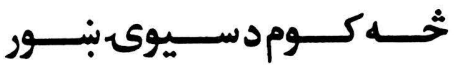

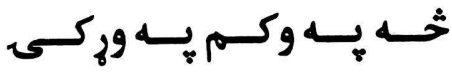
خي ته نه يمي خوك به ورسي 


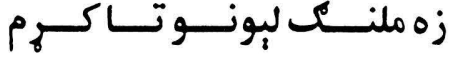

كران خوني دي باك يجي نسته

اخلي تور ستركى د زروز زنك

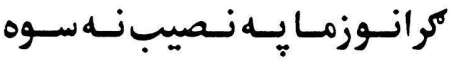

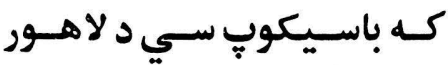
خوك ييج يه ديد نه دي ماره

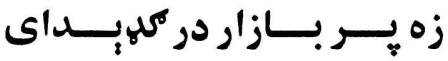

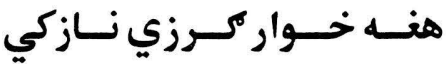

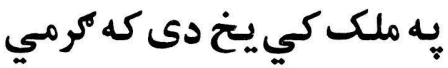

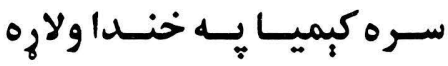

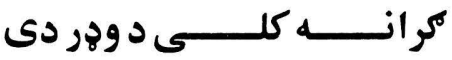
د نـــى ســور بربنــي جاركـل

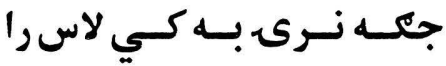

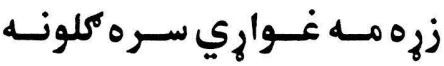

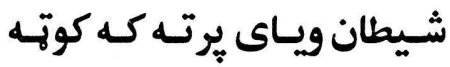

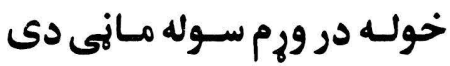

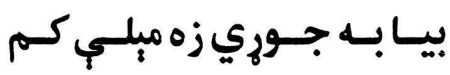
د غـــوخكى ديســ نــاروا دى د نازك خـوبن نه دى كريـوان

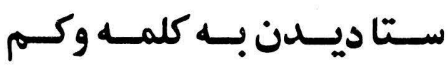

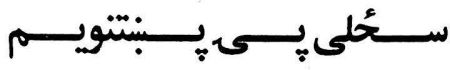

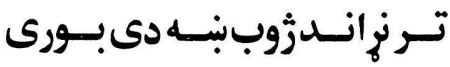

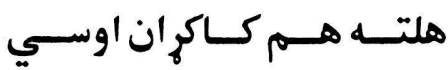

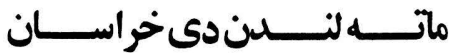

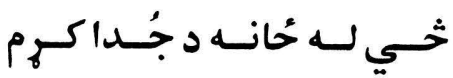
خـي يـر سريسي خـوله نسته خي خولى كبنبر.بدي ير خنك

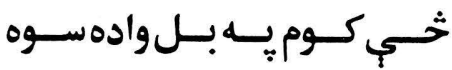

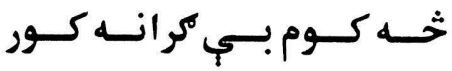
خوك يـي خوري د لاس خواره

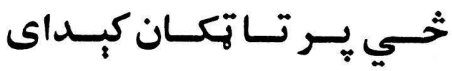

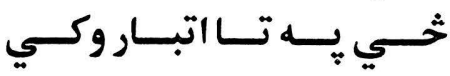

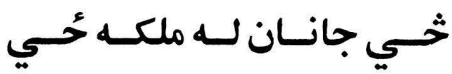

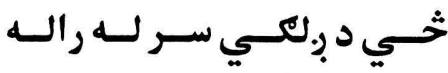
خــي راووزم تــوره تهـهـر دى

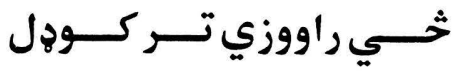

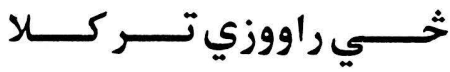
خـي رايـات سـي سـتا خالونـه

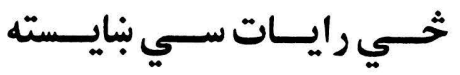
خيلهى كـإِه خـور تيكـى دىى خـي هلسك لـه تيـه يـري كـم خــي كسي نسه وي سـتا يبكسى

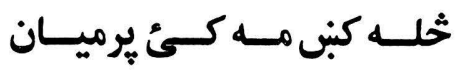

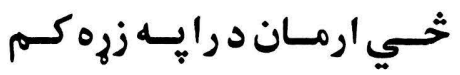

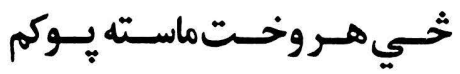

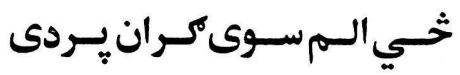
خـي د كسان بـر خــى توسـي

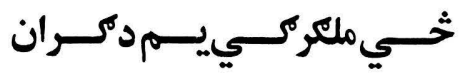




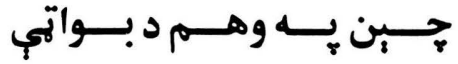

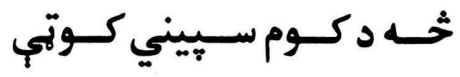
يرما يه زوند جور سي قيامت

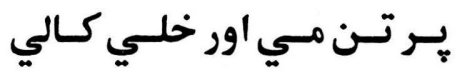
تنكه هورى جـوابيـي كران

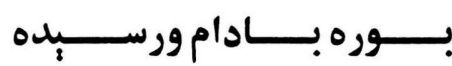

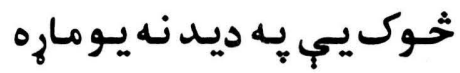

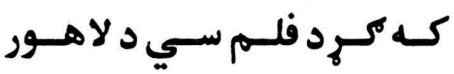

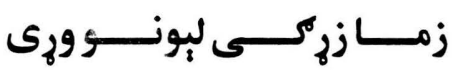

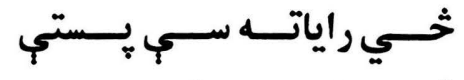
خـي دنسه ويسنم نـرى يستي يستي خـي رايـات سي سـتامتحبـت خي راياد كرم ستا خـوكري

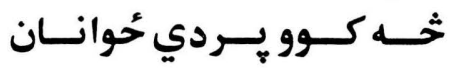

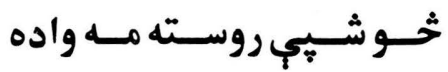
خوك يجي خوري د لاس خواره

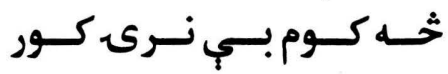

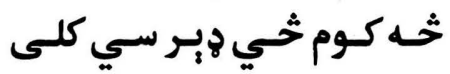

潾燐 


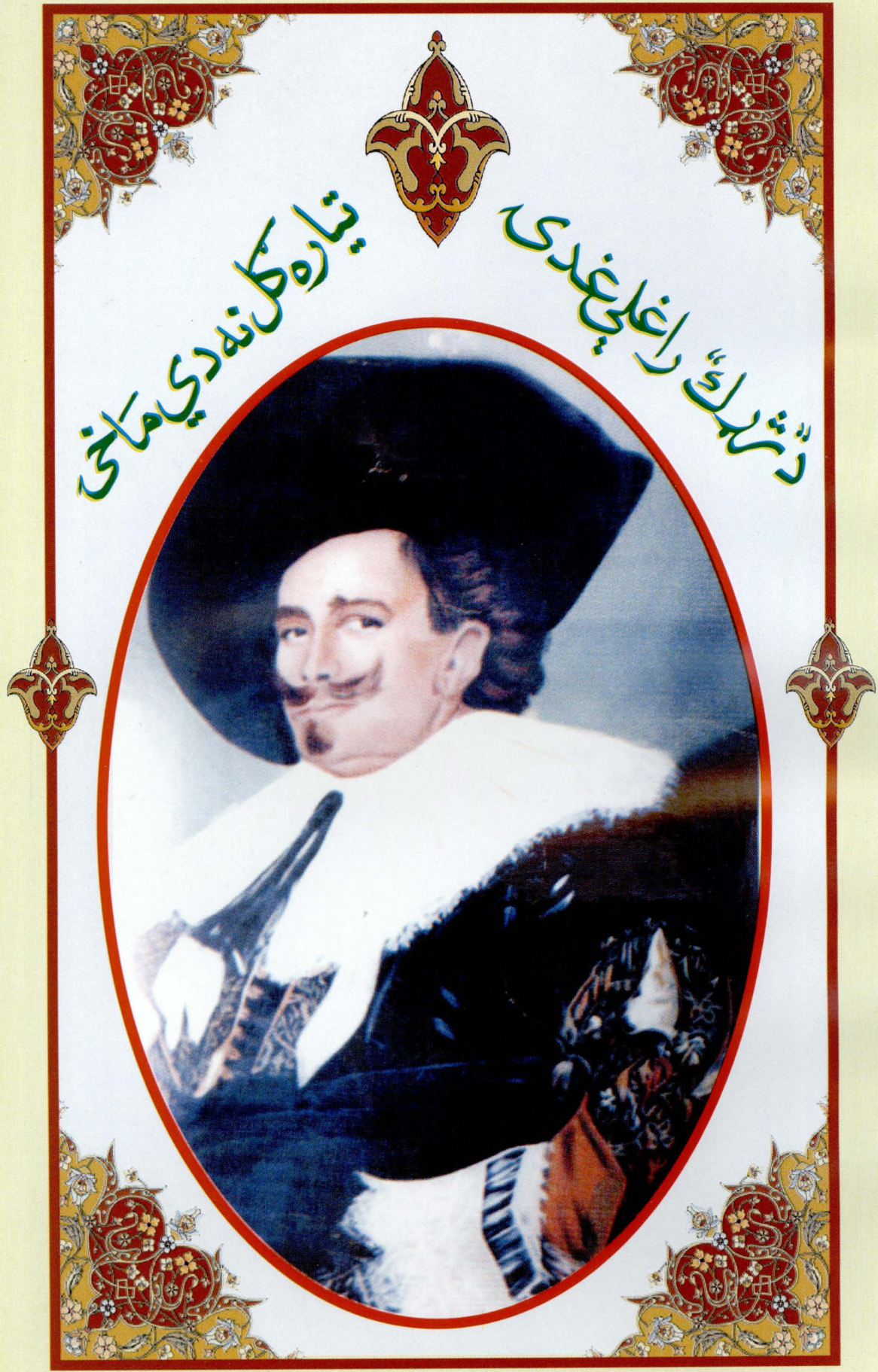


يـر مـا وبنـى سـوه شـــن خـالى زمـاتــور سـتركي مـلا يـار دى مئي

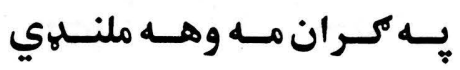

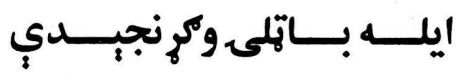

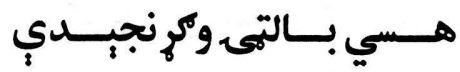

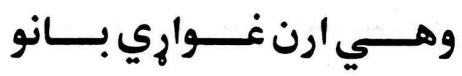

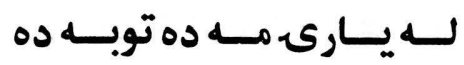
ثخـي زونــى تـابـهـ بـلـ وري

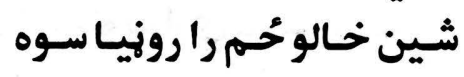

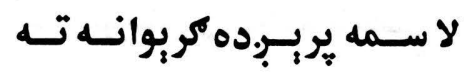
نـسته تـــور سـتركى شــــز اده نـرى حــق مـه دى دربانـدي

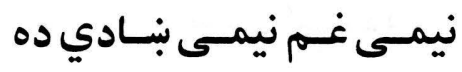

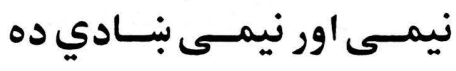

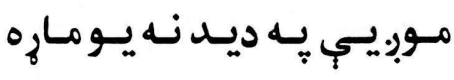

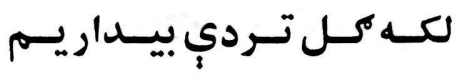

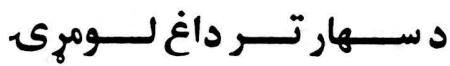

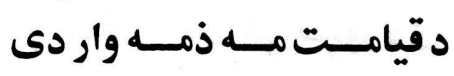

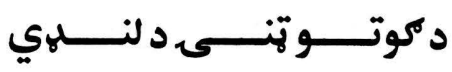
دلتــه نـــته ســينيني خـــولي

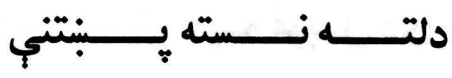

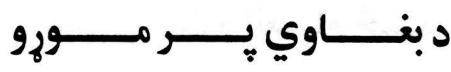
د تـــس كـــاى داى لمبــــه ده

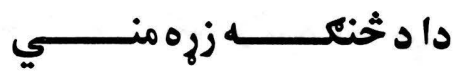

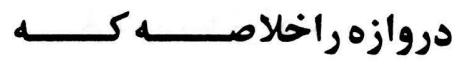

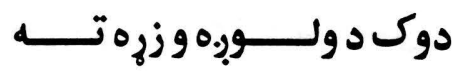

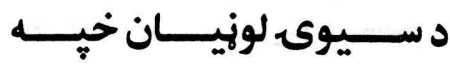

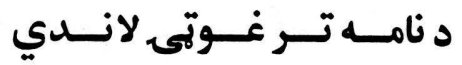

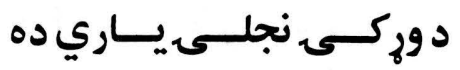

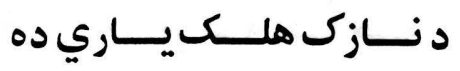
دوى ديب خـوري د لاس خـواره

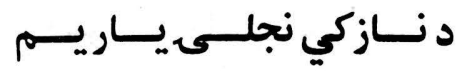


لالـك د غــره يـه سـيل حُحي دنــــى اوبنـــكوبــــاران دى دنــرى اوبنـــكوبـــاران دى

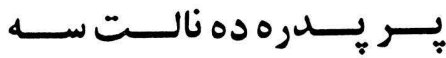

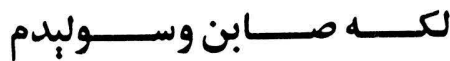
مــابج ديــد وكـــى بيــاولاره زما ارمان سوبو د كران سواله

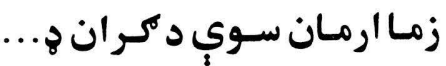

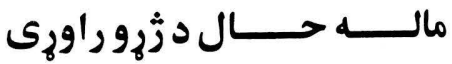
سور موتر جانان كي سيور دى سي

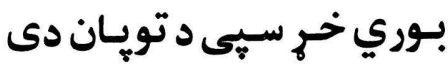

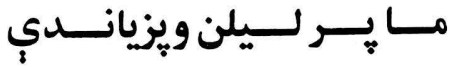
نــرى تــكـ د يـهـ غوبــل دى

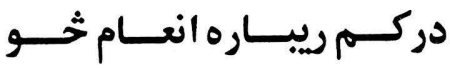

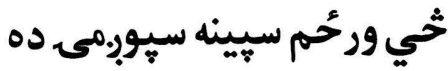

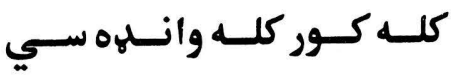

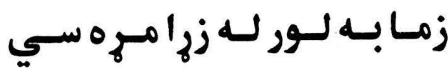

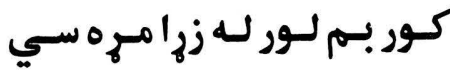

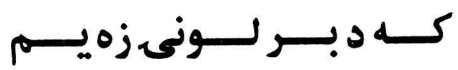
اوسيـيجي اورهبـابكـم كـ راحسب سـوكي ليـانـــيسم

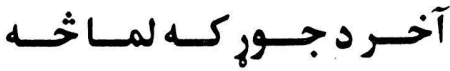

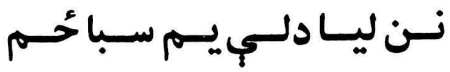

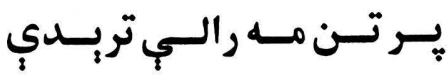

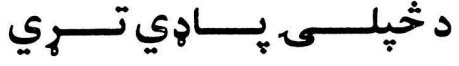

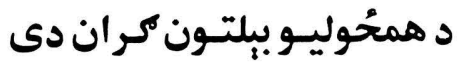

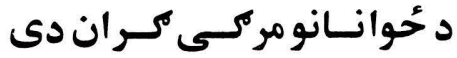

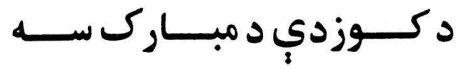

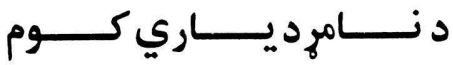

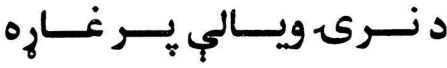

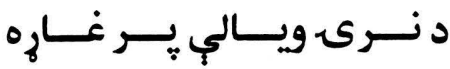

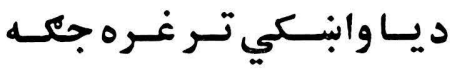

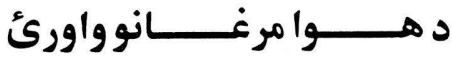
د جينـي يـر سـريسي كـور دى دي

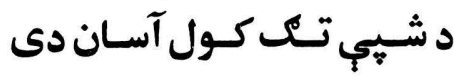

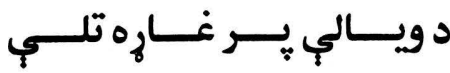
د تيـــــي بـر ميـان دمكل دى

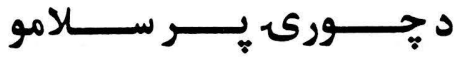

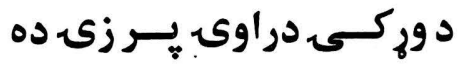

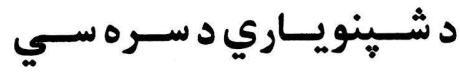

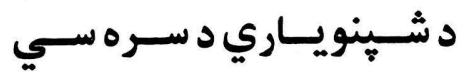

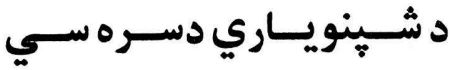

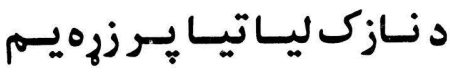

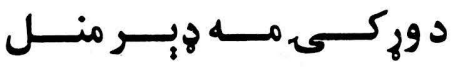
د سره اور بـه ميـان كي زهيسم

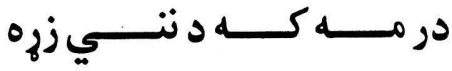

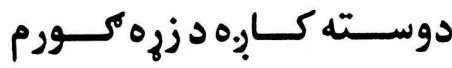

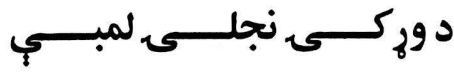


كه تُويـــ واى مـرك مـه كاوه

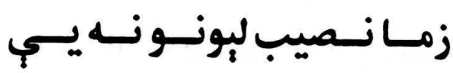

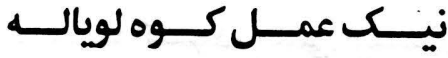

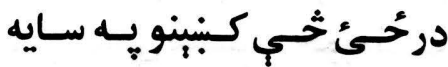

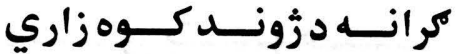

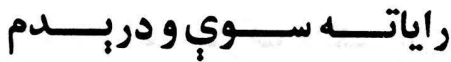
كـل بـهـتهاب كـوي كراسـونه

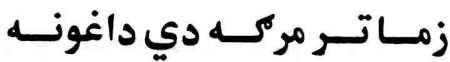

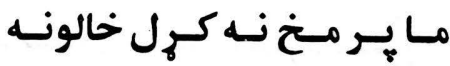

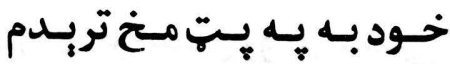
د سـيوى جميـل بـه مسه كالـه

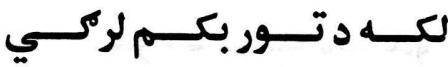

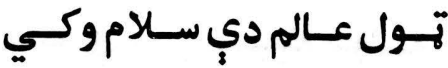

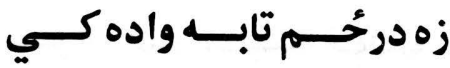
جـورى ثحـوى بسه دوادهكي

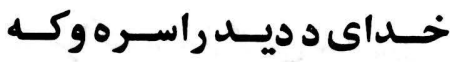

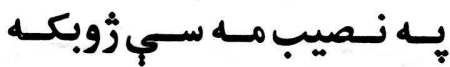
تهلبه د جــا بـه نسميب سـي

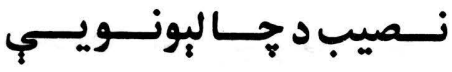

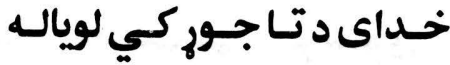
خداى خبر خّي بـه بيـا راسم

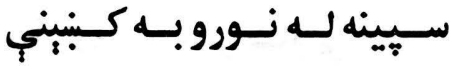

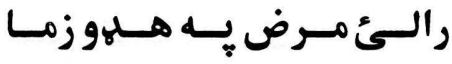
ستا بـكى بـه زر تار جـور دى

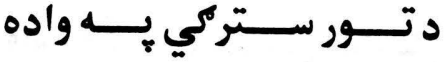

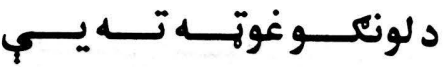

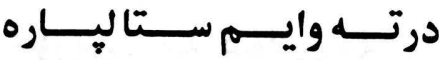

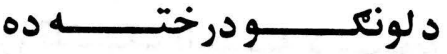

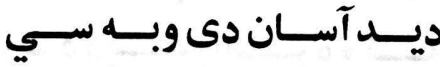

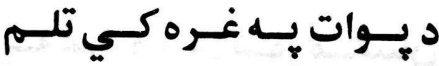

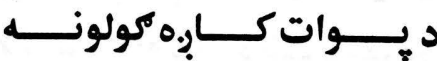

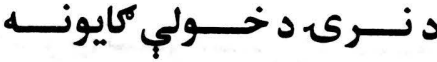

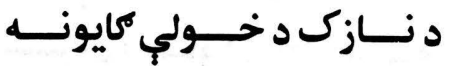
داســي ناســت وي لكـــــــم دوركــ نجلـــ :بــ خولــه

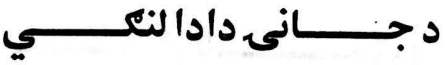
د نازك سكريت به خوله كي

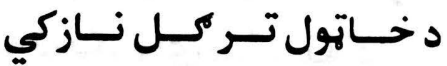

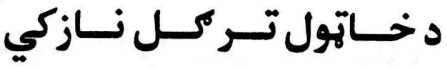

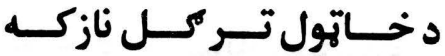

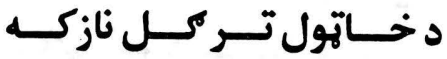

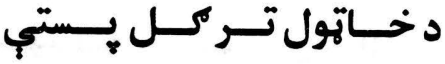

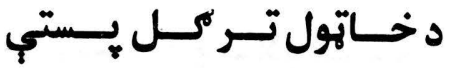

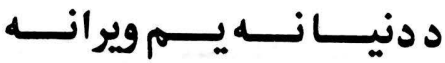

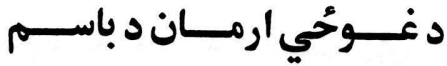

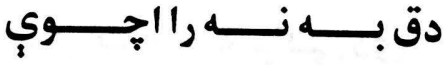

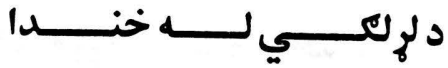
ديـ د خريــ بـلتـون د اور دى 


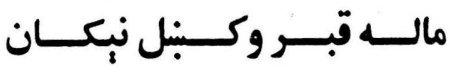

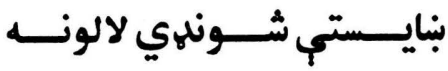

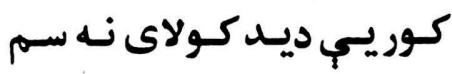

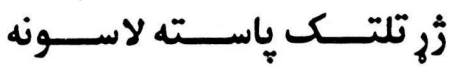

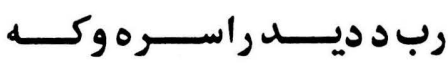
يسهـ غـارهو وري تـــور مـشينان لاســــــــهنه دوارهه بنـــــــــوروه

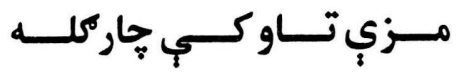

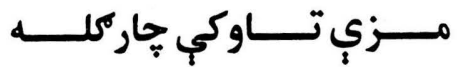
كه ولاري خـوب بـه نـه راحَي رب د مــرك مــهـ يـــه راوينـــ

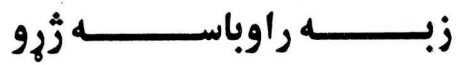
كه تويـك واى مـرك مـه كاوه كه تويكس واى مـرك مـه كاوه كه وس مـه واى مـرك مـه كاوه

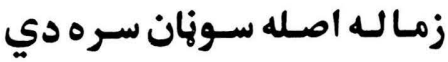

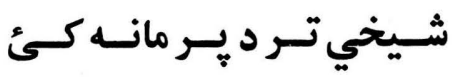

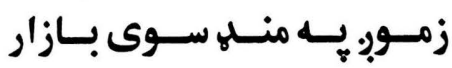

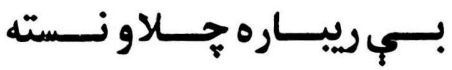

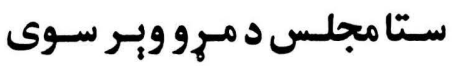

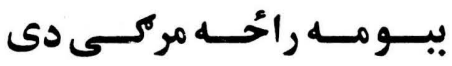

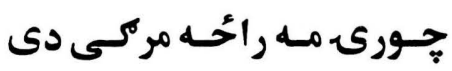

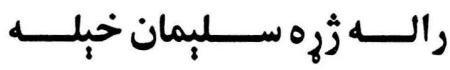

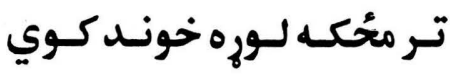

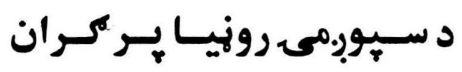

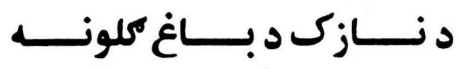

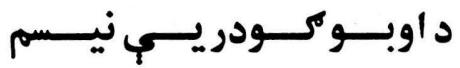

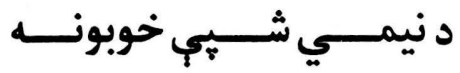

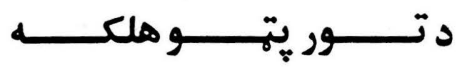

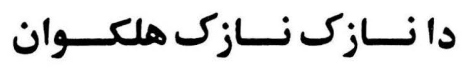

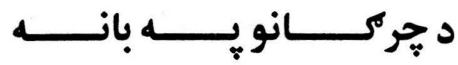

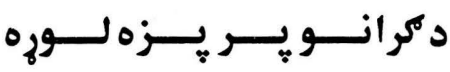

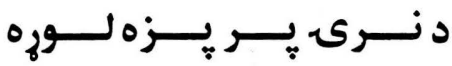

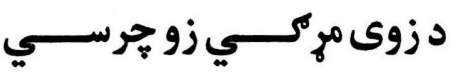

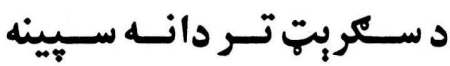

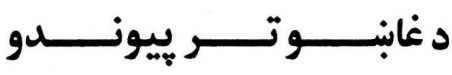

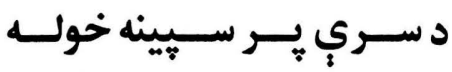

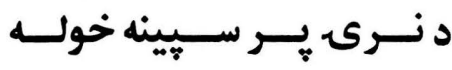

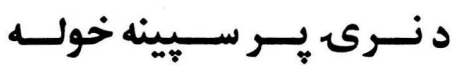
د نـسواك يـهـ لركـي نـهـ دي

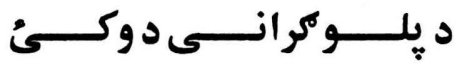

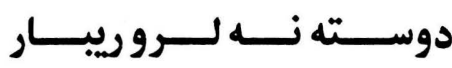
دوست مه سته ريبار مـه نسته

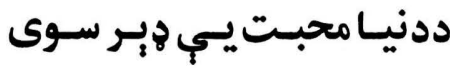

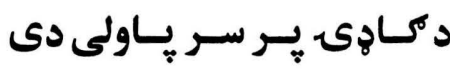

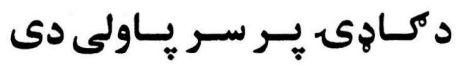

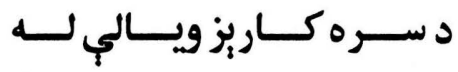

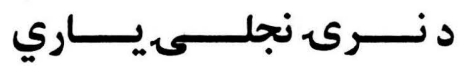


تركتّ يـر مُحكس خونس كوي

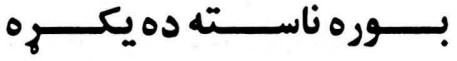

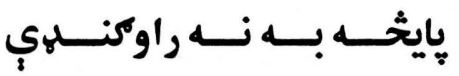

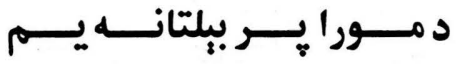

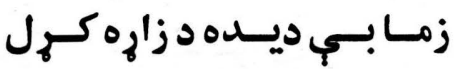
بـور سـتركي نـه وكسئ دوغبــ حُله تـار سـوي يـهـ مانــه كي

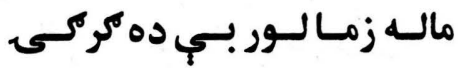
زه درتـلاى نـه سـم لـه كـوره لـري د ورور غونـــي كر انــى خحـه مـه غوبنــت سـتا لـه كر انيـه

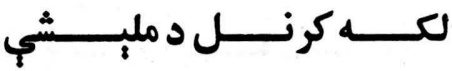

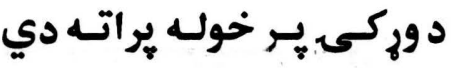

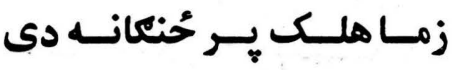

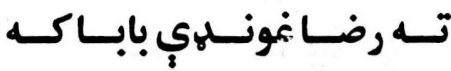

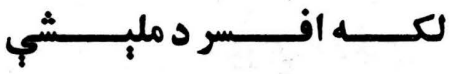
سري له سـيني يـبنى راورمـه نرى كل وه تـور سـاره سـوه

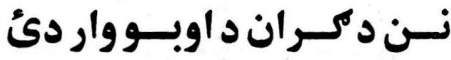
سـتا يــ تصوير كـور تهـ راحِم

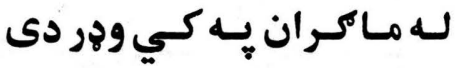

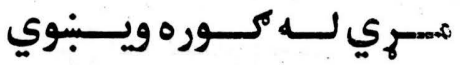

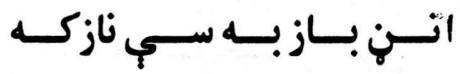

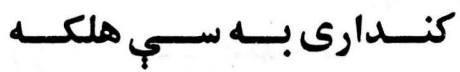

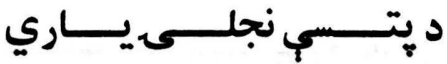

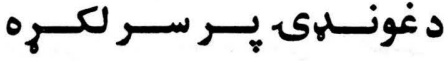

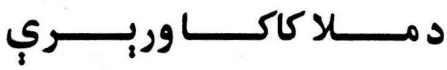

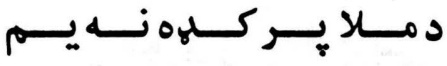

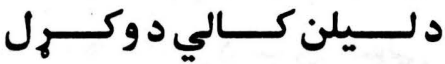

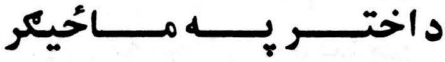

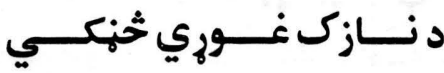

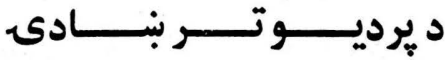

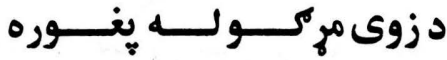

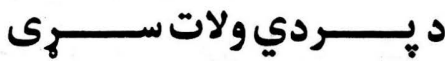

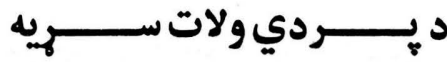

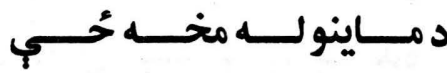

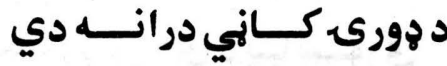

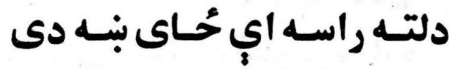

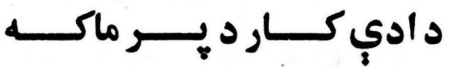

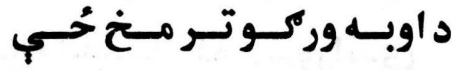

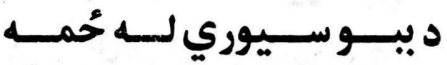
د بـلتـــون بـــه لمبــو وســوه

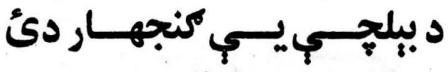

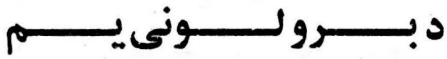

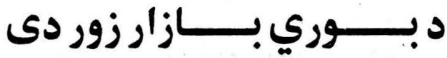

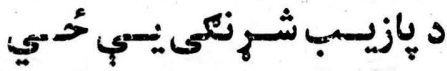

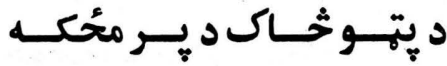

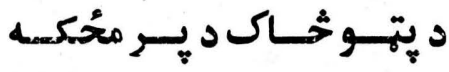




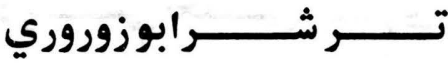

ادي رايـات مـهـ سـوىئر راحت

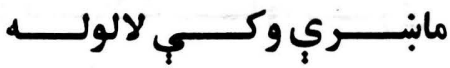
خلك بي خوري زما به قاتل سي نن مه هوا سي د سري خولي خولكى يه مردا راوره بياحُحي

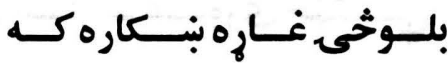

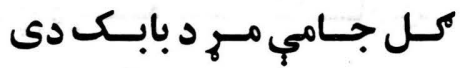
مـر دى شـــن كـل يـــ اودسـه

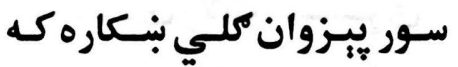

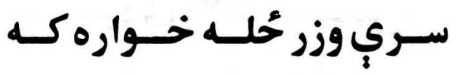

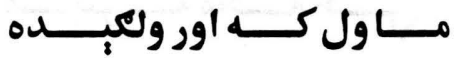

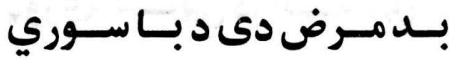

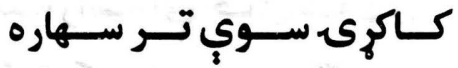

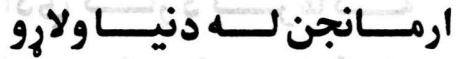
خوله مـ كبنل كه د بنـوراندي سري به كاى كي د تاسور دى

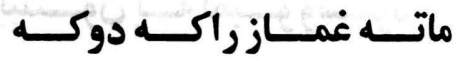

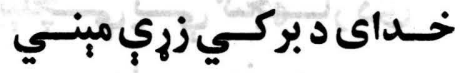
زمـابـــن تـر ســـه تــور سـو

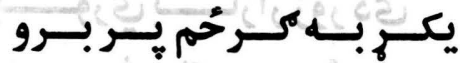
سـينتكى آس د غفـار خـان دى به خوشحاله يـاك رسـول كي

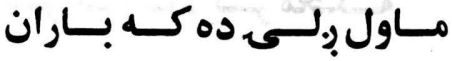

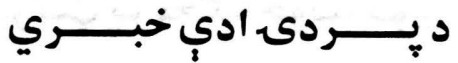

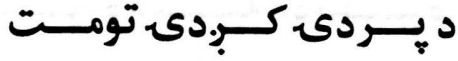

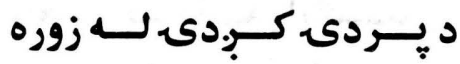

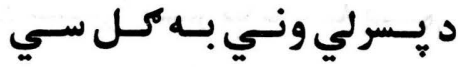
د ينجــــاب تـــــوري بركـــــي

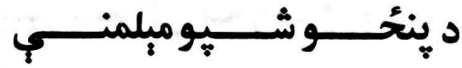

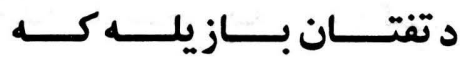
د تنكي بـه وره كي خـوب دى دي

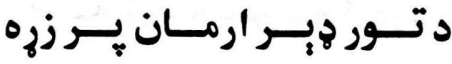

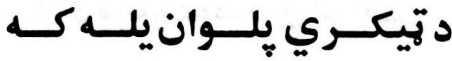

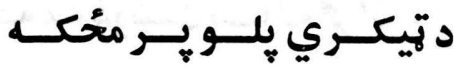

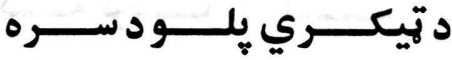

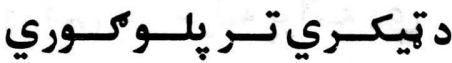

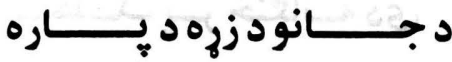

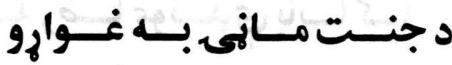
د جاركل تـر سـيوري لاندي د جاركسل غمسـى د سـور دى دي

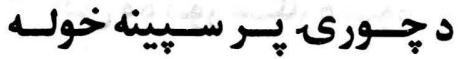
د جـــورى د راوى دهإيــري د جـورى تلتك ثخي خور سو

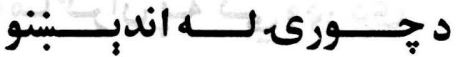

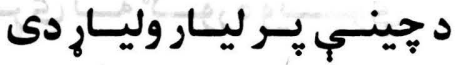

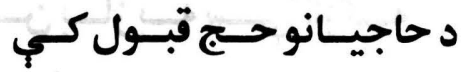

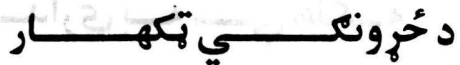


حُحي نرى سـتركي كَبْيكاري خي وركى ستركي كبنبكإي

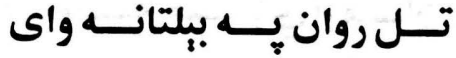

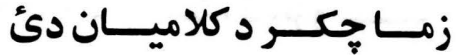
زمـــاجكــــر دكلانـــس دى

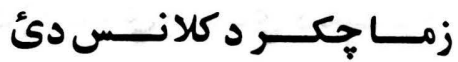

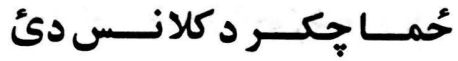
د مـــــووبنـــــي دروازي دي

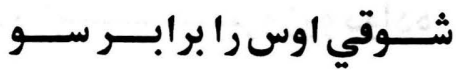
شـــنـي لارى دم ملِـــــي دي

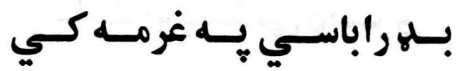
يـر نـرى حُــان خـاوري كـوم

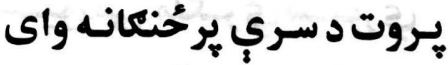
خوب د سري ير حُنكانه واى

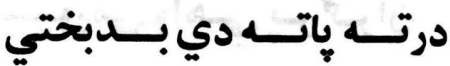
سـتار د خــداى نـهـــيــيم

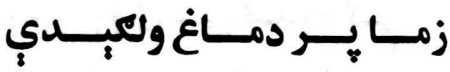

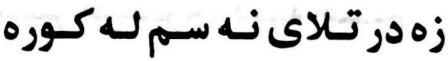
كه مـه رسك لله زٔرو كم سوى

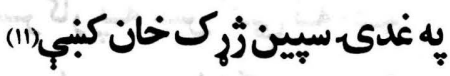
مائيكر كولي سـوي دروازي

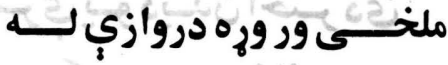

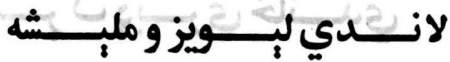
خلك خوشَحاله يـر ماغم دى

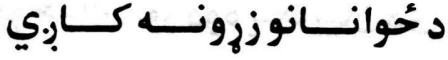

دحُوانـــانوزرونـــــــــابري

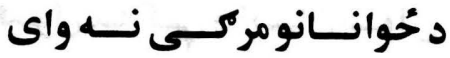

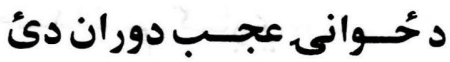
دحُــوانى غـهـ دئ حـوس دى

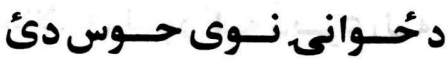

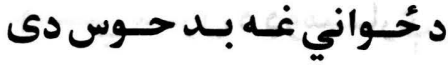
د زونـدون ليـاري اوبردي دي

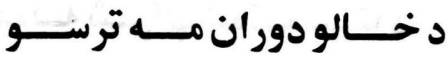
دخداى نور يِ وينوسري دي

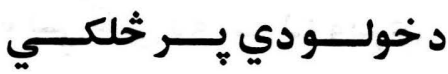

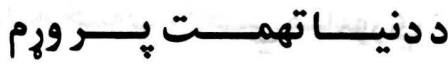

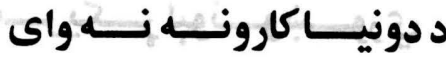

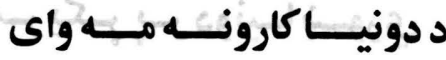
د دورى خـوارى دي سختي

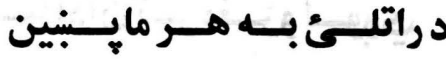

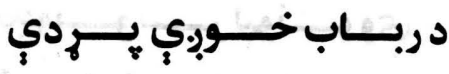

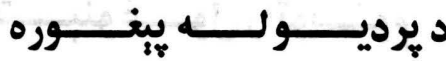

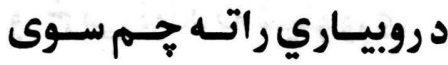

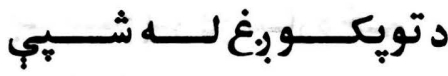

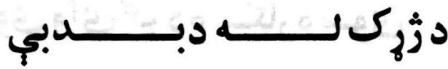

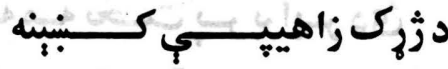

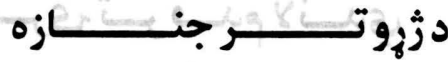

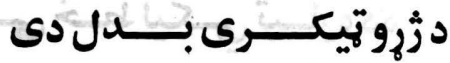


يوخداى نور دوه ينجاييان دي

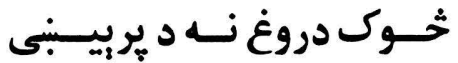

قبـول مـه كـي د ايمـان سـوال

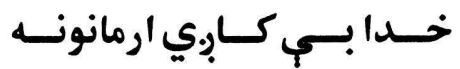

د يبتــ كيلسي دي زمــاسـي

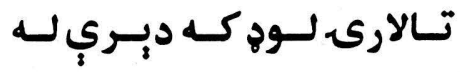

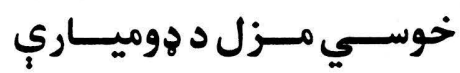

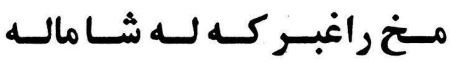

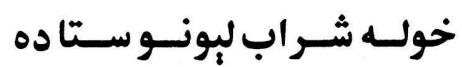

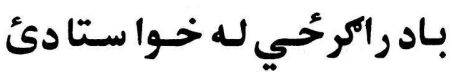

زهكي تلهى نـه سمر لـه وبـري

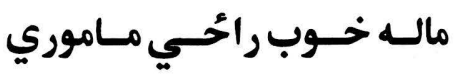

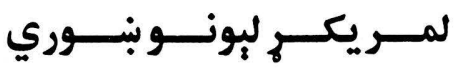

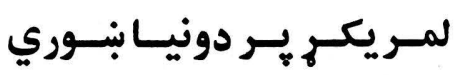

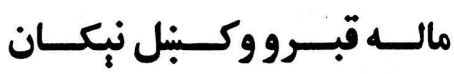

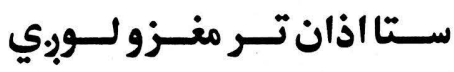

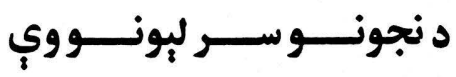

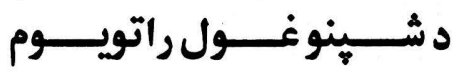

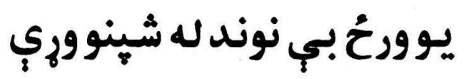

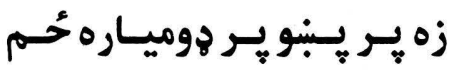
سوى واى كرده سـاره سوئ

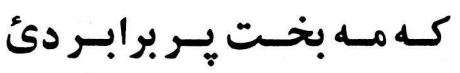

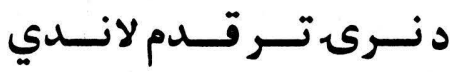
لالسى خـط ليكسي تيـاره ده

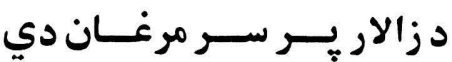

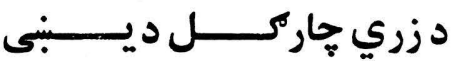

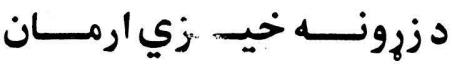

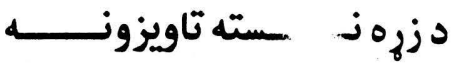

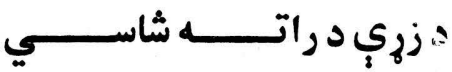

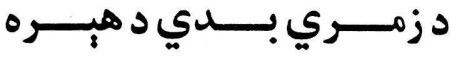

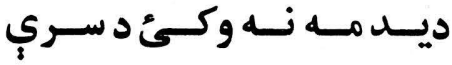

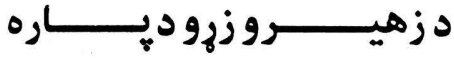

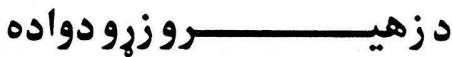

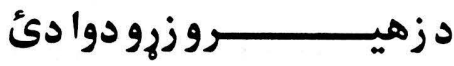

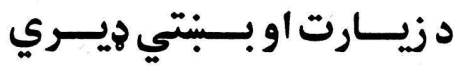

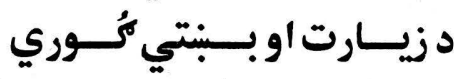

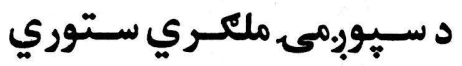

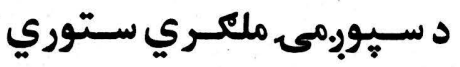

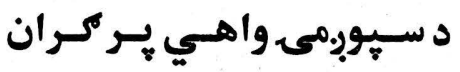

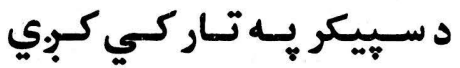

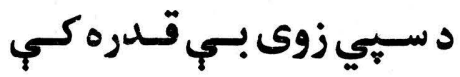

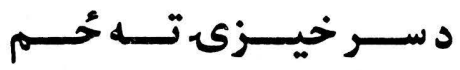

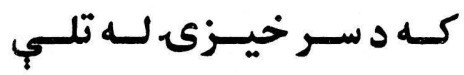

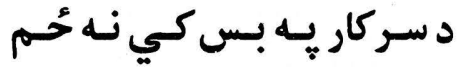
د سره اور بـه ميـان كي وسوئ

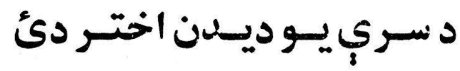

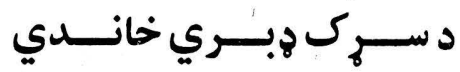

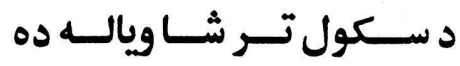


خـاى د مـرك مـه يـه راوينـه ستا ير حَكِ يروت واى نازك

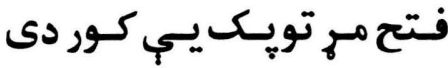
رخسصت مسـه سـمه كـه كر انسو

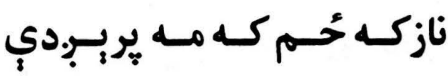

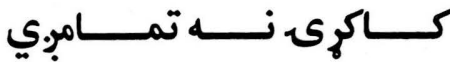

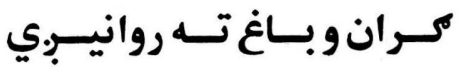

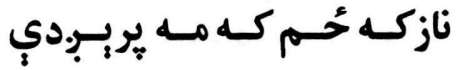

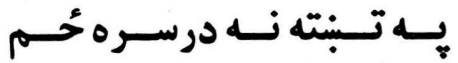

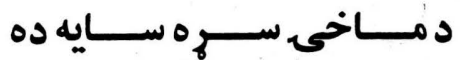
زمـوبر. لنـهى سـوي تـر مابــامه بيا سيّن موزتكي به لاس راكه خوسى مه يل كَئ د رود ميان

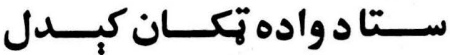
سـتركي يورتـه بـه نـاز تـه كـه تـب بــاران دي كـه سـاره دي خداى خبر دى خحي به بياراسم نــازيكىكـل دى د ســــــ

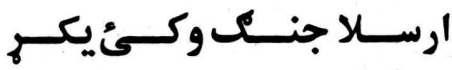

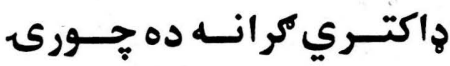

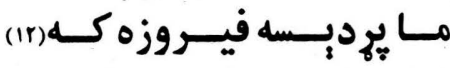
وزي مـه واى مرغـوني مـه واى هـ

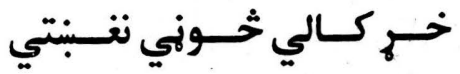

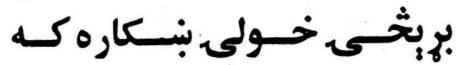

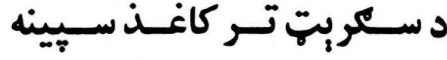

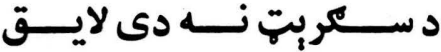
د ســنكر بــه سـر كـي اور دى

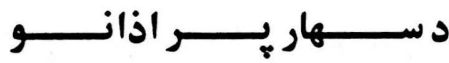

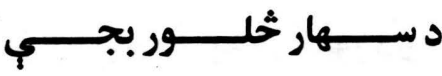

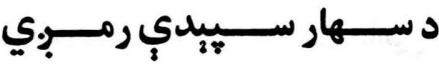

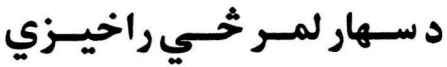

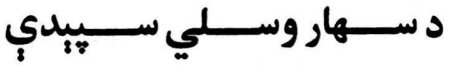

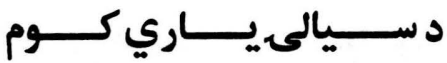

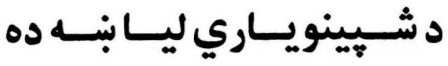

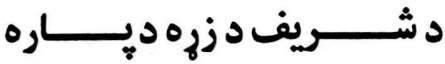

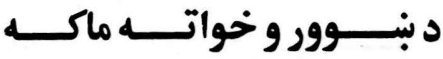

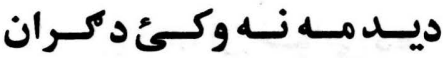

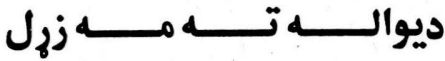

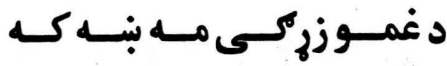
د غـومَكس يـر خـوا ووره دي

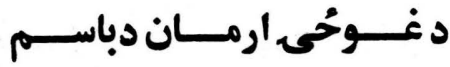

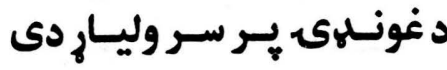

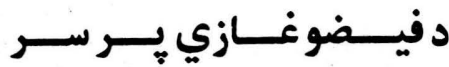

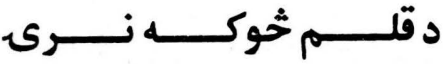

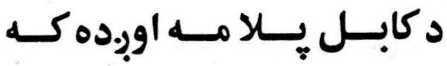
د كاسي بـ سر ميسته ته واى

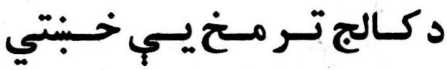

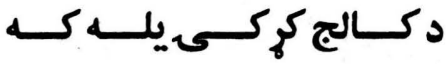


كاكرى غاري

يوهـ سـوم دكـران بــهـ اشــاره

يـــوار لاســـونه كـــــــــــاره

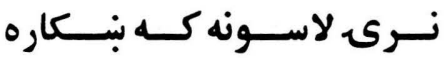

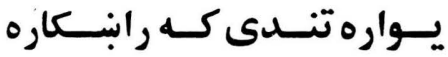

نـرى كــم دد ديـلار كــور دى

سكهان مردار كل بخت نـامي

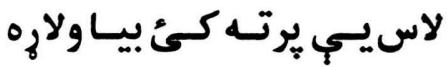

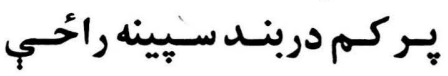

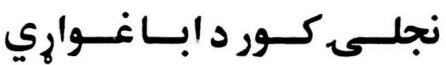

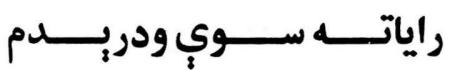

زوى مـه دى ثخي بـه رابنـوري

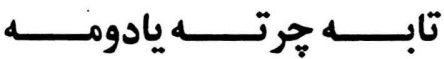

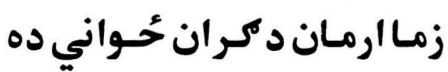

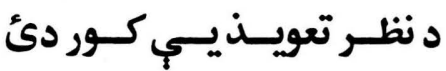

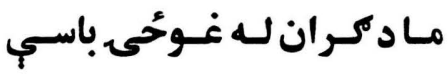

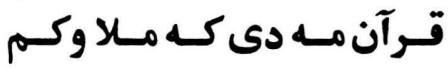

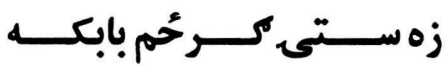

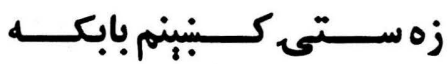

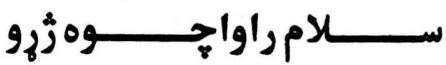

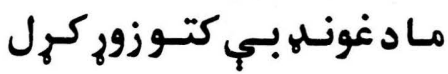

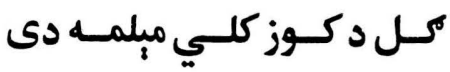

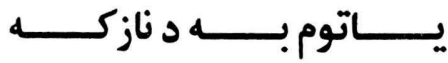

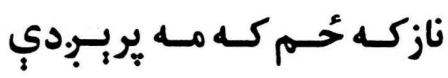

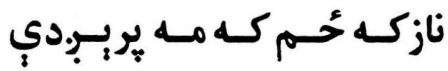

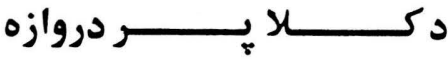

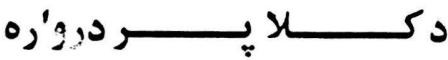

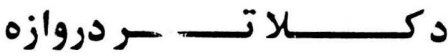

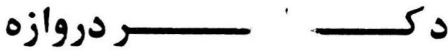

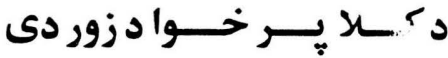

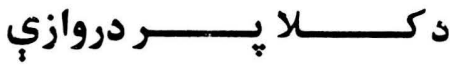

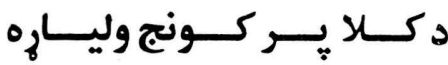

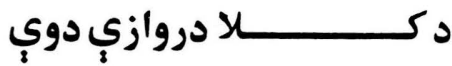

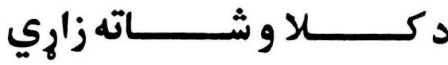

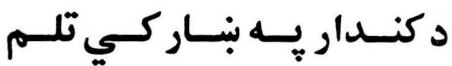

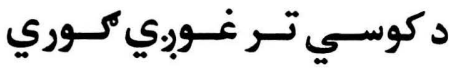

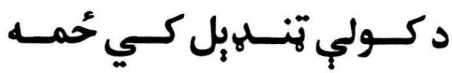

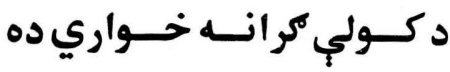
دكسادي يـه شـاكي سـيور دئ دكسانى جركسه مــردار سـي دكــونى كمــيس بــهـ وكــم

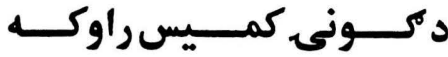

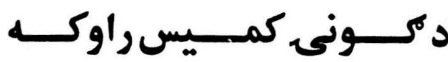

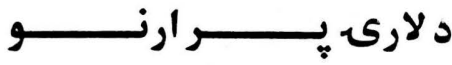

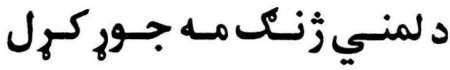
دلونكي ثخاك يبي بنـاره دي

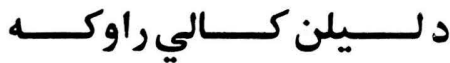

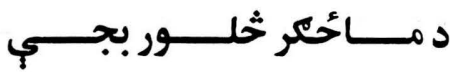

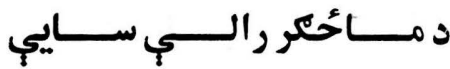




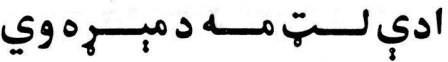

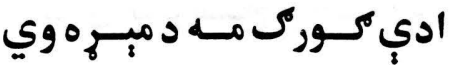

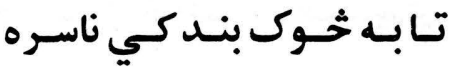

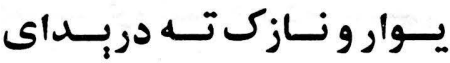

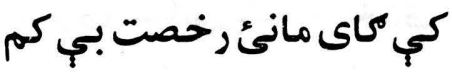

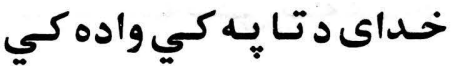

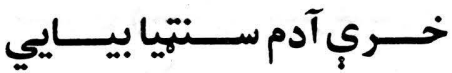

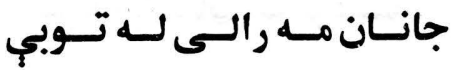

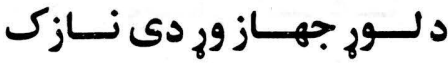
اوس بـه يـكى يـر اوبنان ورئ زمــالالــى نـــه دى راغلـــى

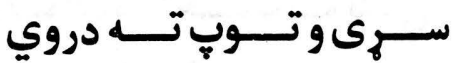
يـر خـولكى بـهـيـي مبلمهـ كمى

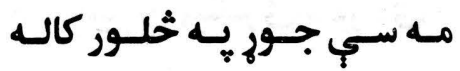

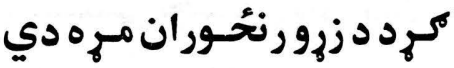
لنـــــى ويـــايم تـــــــــــهاره

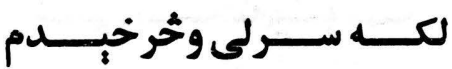
خـود بـي خـاوري كي يانونه دروي مـات سي تـه ليـازازي دروي مـات سي تـه ليـازاري

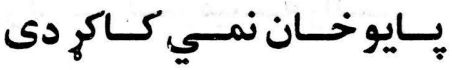

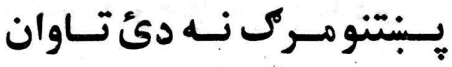

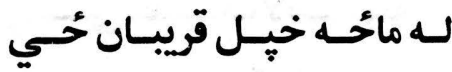
زمـايـي زونـدكئ يـــــاوال

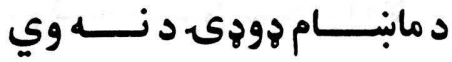

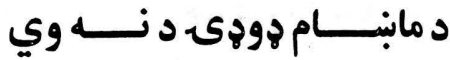

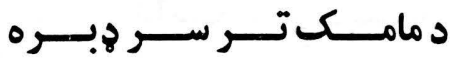

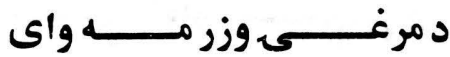

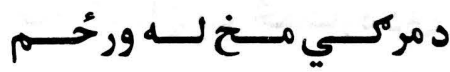

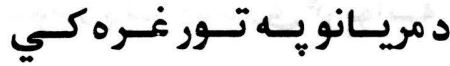

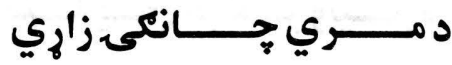
د مـــــوتر تـــــوري شيـــــــي

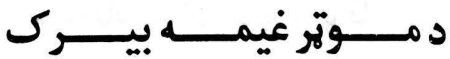

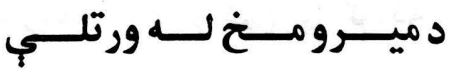

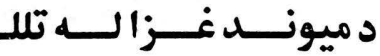

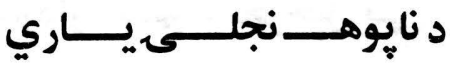

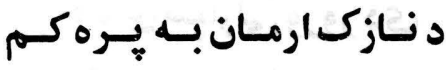

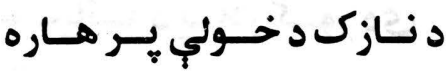
د تويسـكـ ويسـستلي بنـــهـ دي

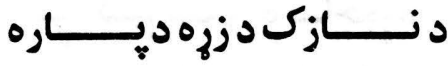

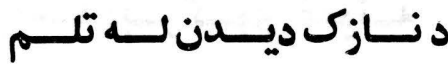
د نـــازك كونجـــك غابنــــونه

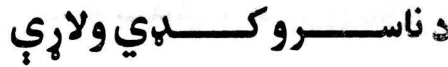

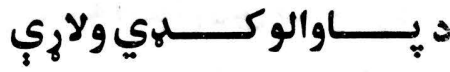

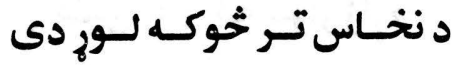

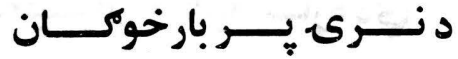

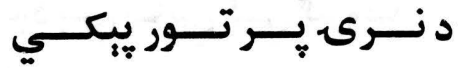

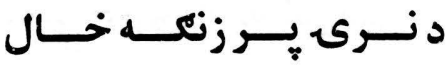




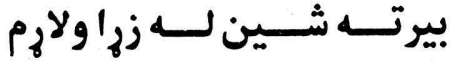

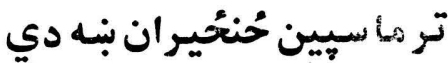

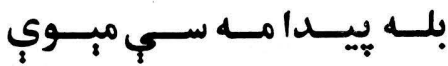

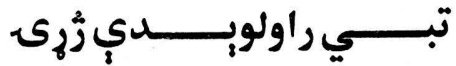

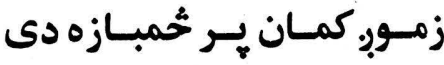

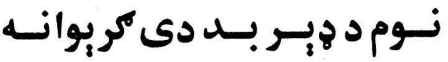

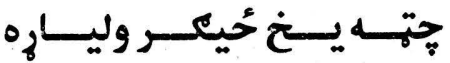

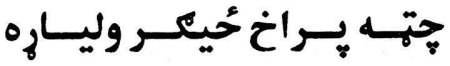

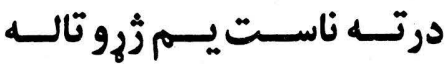

كال مل كرد دتر كئ بيجي كرانه

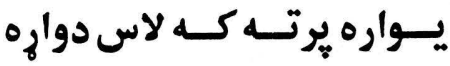

سـردار د نسيم سـنـخرخبل يسي لئي

ما ير خداى سيارلى ورور دى

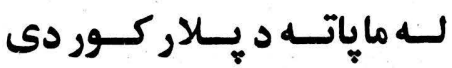

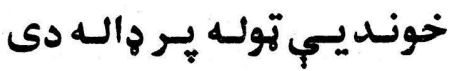

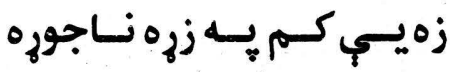

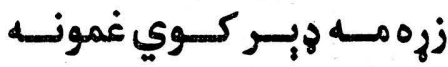

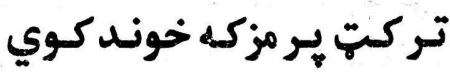

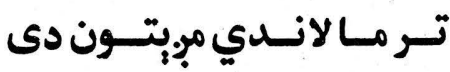

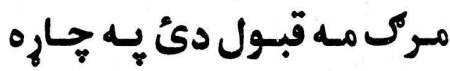

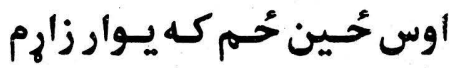

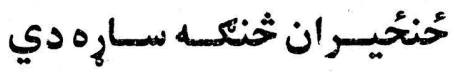

خـودبسي تشكيكي كي كيرونس

خلك بي خوري زما به قاتل سي كيروني

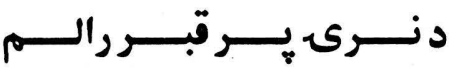

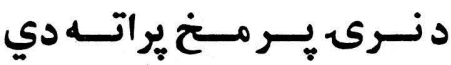

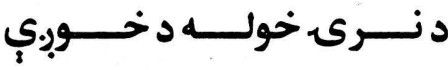

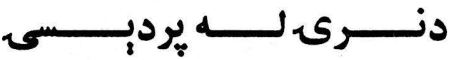

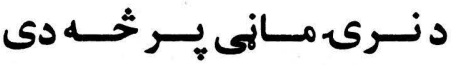

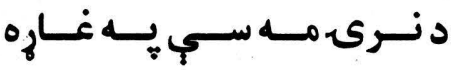

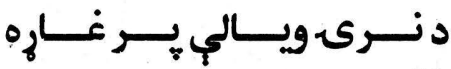

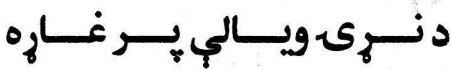

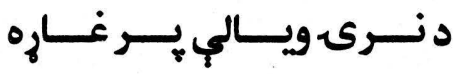

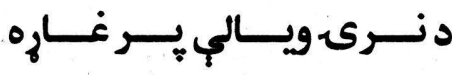

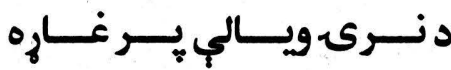

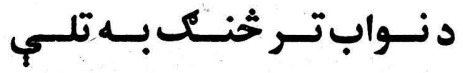

دوريندياري تيكرى تهور دى

دورينـدياري تيكـرى تـور دى

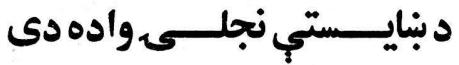

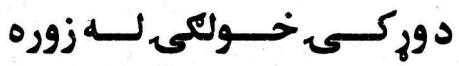

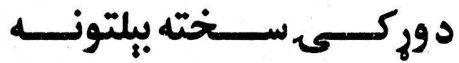

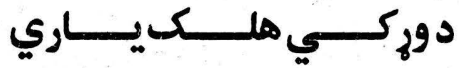

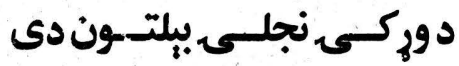

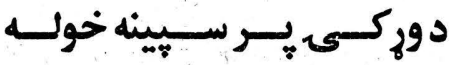

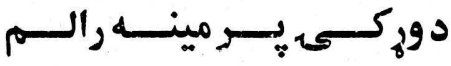

دوركسى يـر خولسه يراتسه دي

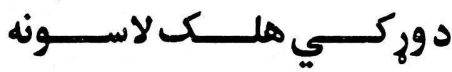

دوطـنميـوب بـهـــل سي سي 
YAD كاكرى غاري

حُم جورى له سود يج كار دى

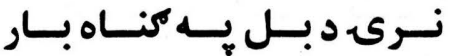

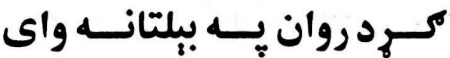
مالــــــه حــــــال د زّرو راورئ

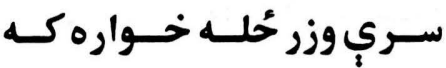
نــــى ســتاولـي انكــار دى كر كرحم جانـان تـه نـه يـهـ زاوال تــور ســتركي نــه دي قبلــوه ورور دي هم كنبر.بري خالونه خي به زنك واخلي له خولي زما

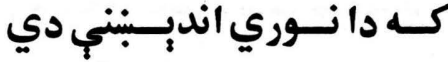
نــرى لـه مـا بـــر كومسهـ وري

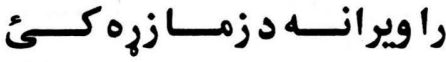
د غـاري هـار سـو د سـري غـم

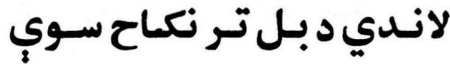
د بل بـ لاس كي دي زماتي ير ليار حُي له خندا شنه سي

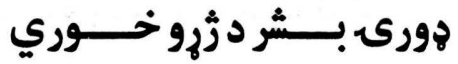

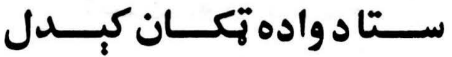
تبمـــور شــاه وركـــه تلاشــي

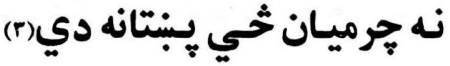

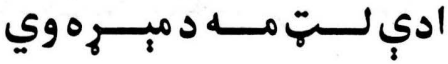

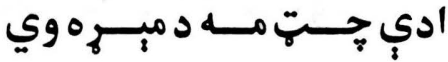

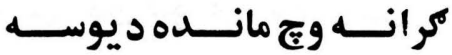

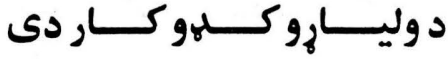

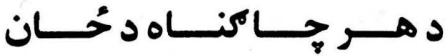

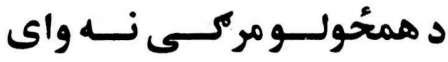

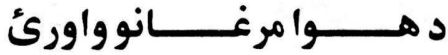

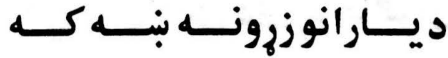
ديوه غابن مه درته سوال دى

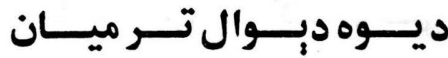
ديـوه غــابن سـوال مــه كـوه

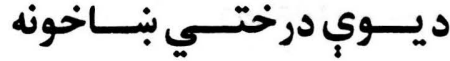
دابسـه ســي لــه كمــي خــــوا دا بـــر مــادكـــان لمبــي دي

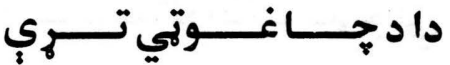

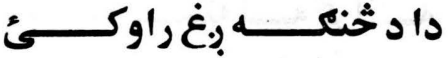

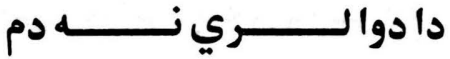
دادي خُنكــــه كــــم ترلــــي

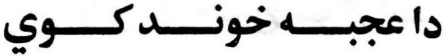
دا وركي هلكسان مـه بنـه سي

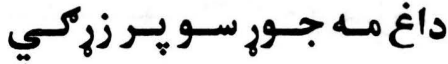

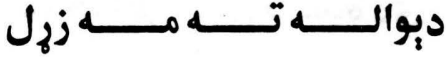
درتــه ناســت دي تــور مــري د كعبـــي كـــافران بنـــــــه دي د مابنــــــام هوودى د نـــــهـ وي د مانبــــــام هوودى د نــــــه وي

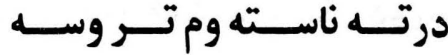




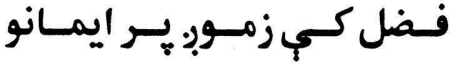

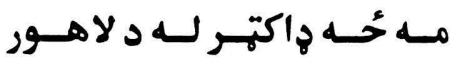
شين خالى نجونه يه كنبيج دي زوى د بل دى ير ماكر ان دى خي زوى د بل دى يـ ير ماكران يسهـ مــرك نرانــده لــور لاليي

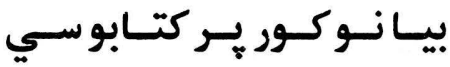

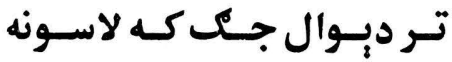

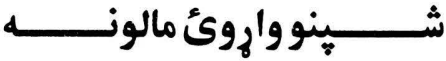

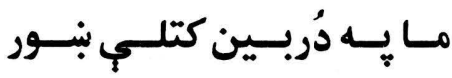

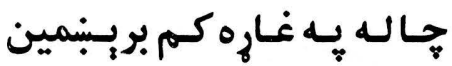

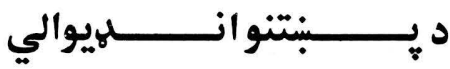

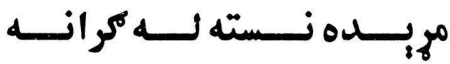

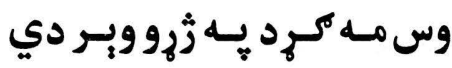
خوب د سري يُر حُنكانه واي

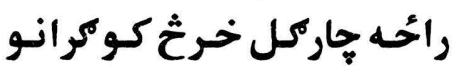

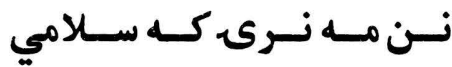

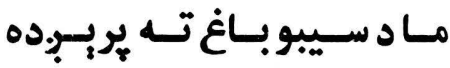

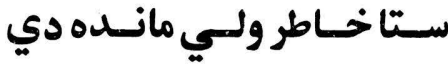
ستا نـوم كم خـاطر مانده دي

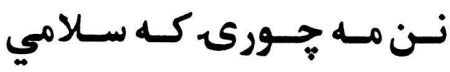

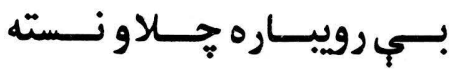

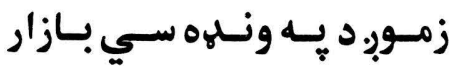
زوب د دوو جنتــــو ميـــان دى
درختـي وجـي سـوي د غــرو

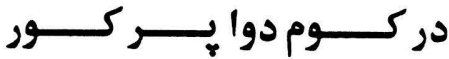

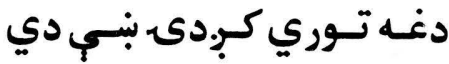

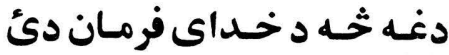
دغــه ثخــه د خـــداى فرمــان

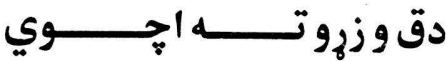
دلتــه راســي زرونــهـ يوســي

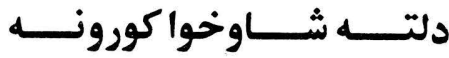

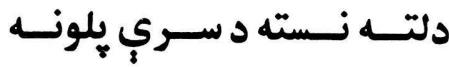

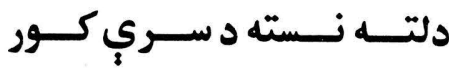

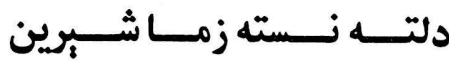

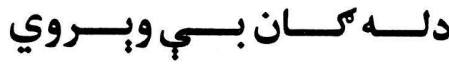

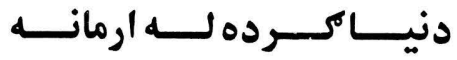

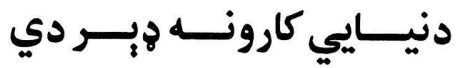

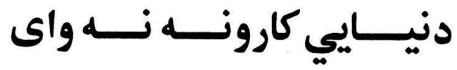

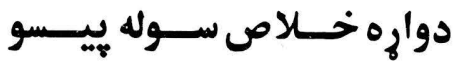

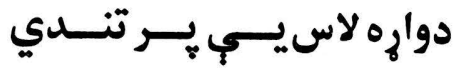

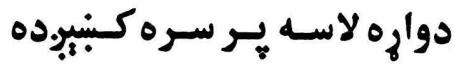

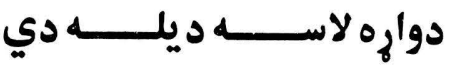
دواره لاســــــهـ ديلــــــــهـ دي

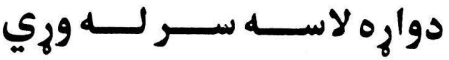
دوست مـه سته ريبار مـه نسته

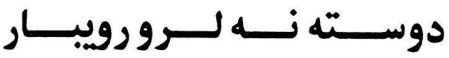
دوكسى دق بـوري زنـدان دى 
وركسى د سـخن بـهـ نكـاح وه

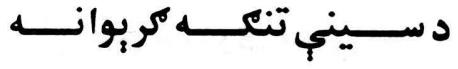

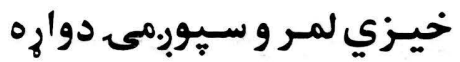

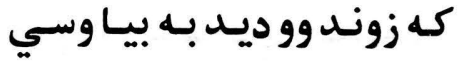
ســالــه ديــده مـــه روزه ده

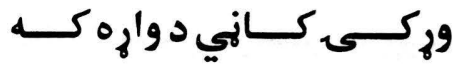
زمــــاد يــــوري انديـــبنه ده لـ كر انـه بــوى اخلــي كـالي خـوابره شيان مـ حُين خـواره

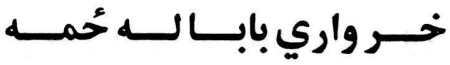

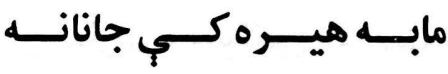

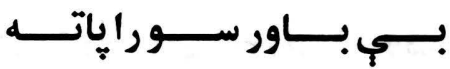

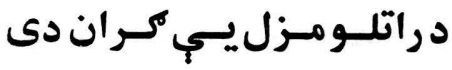

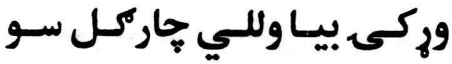
كران خــوك بـه د ديـار كـوري

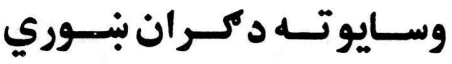

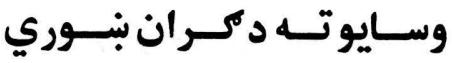
بيرتهـ سـتابي خنـدا ولار سـم

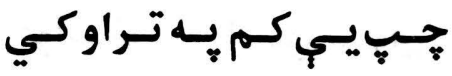

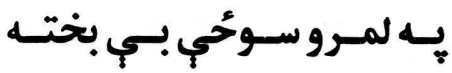

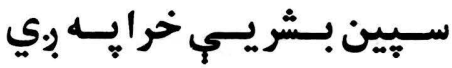

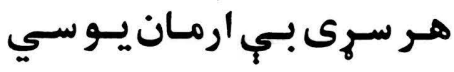

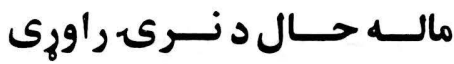
سـتا جاركـل لِونــوكـار دى

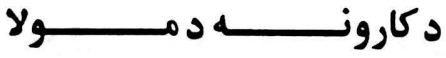

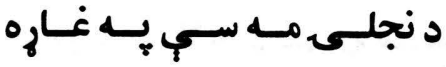

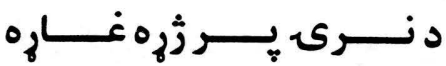

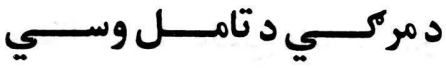

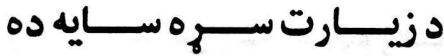

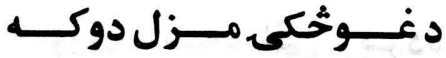

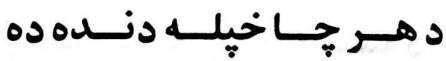

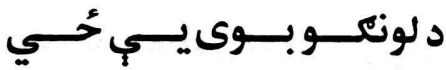

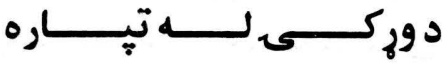

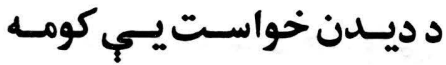

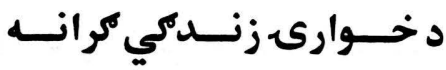

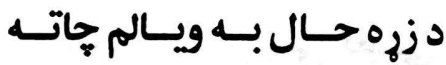

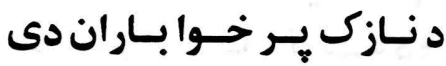
دخيـزي خومبـارى خـر سـو

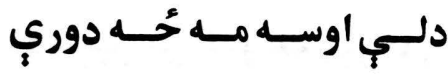

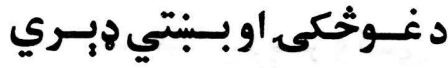

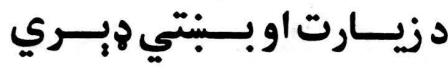
داثـــــم وار دى ثخـي راسـم دوركى خنــدا بـهـ كـور كي د ســيوى كرمــي ده ســـته

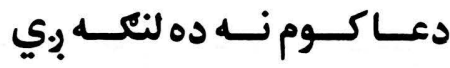
دنـابودي دمــخ تــور ســي

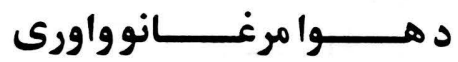

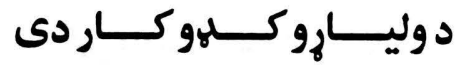


نــرى زركـوهزمـــــار دى كـور لـهـ تــلاى د نــــى نـسم خـي كرانتلهى زه برسايه واى

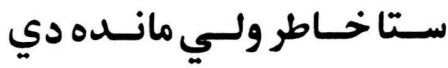

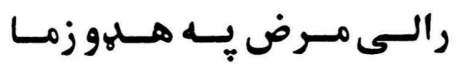
جــورى راسـه مـانهى بريـبر.ده زمــــاد بـــــوزي انديـــبنه ده اوس بـه شونحي له جـاغـواري

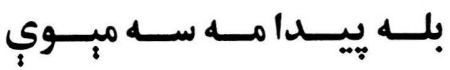

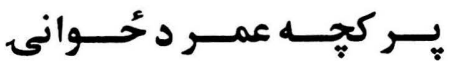

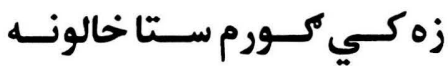

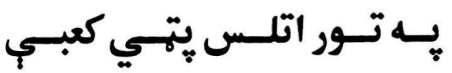

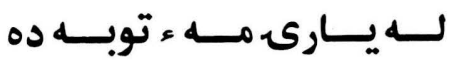
خدايـه ! مسي باسـي لـه يـبنينه ماد سبين بـي كتو هم زورج كل

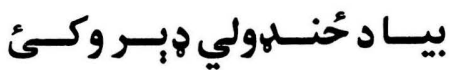

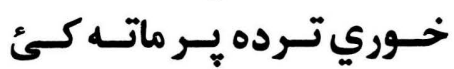

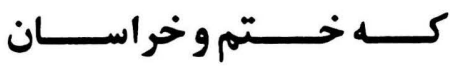
مبوى خنكه بِ يسات جوري سوى

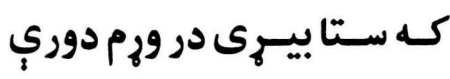
تـري سـوي سـتا يـهـ انديــنبنو ته مركي خُنسه حُحين يـو وري

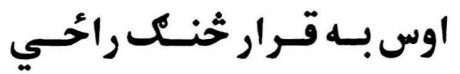

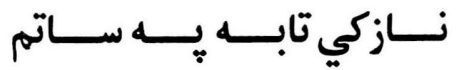

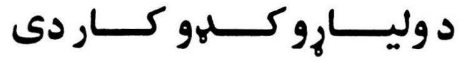
د اوبـــو لـــورى بــــي نـسم

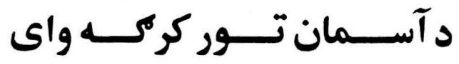

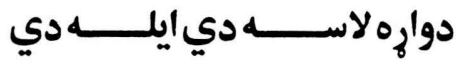
د ســـري بـــوري لـــه خنـــدا

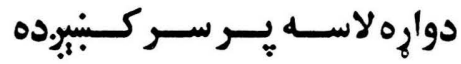

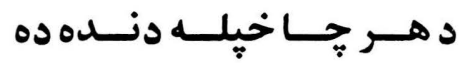

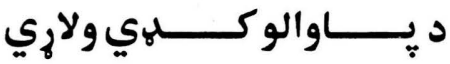

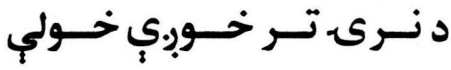

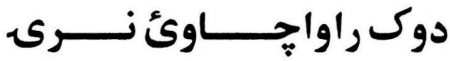

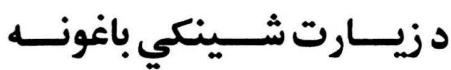

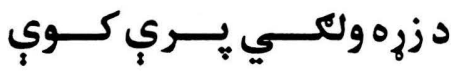
د تــس كـــاى د اى لمبـــه ده

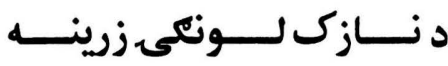

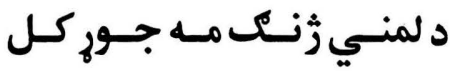

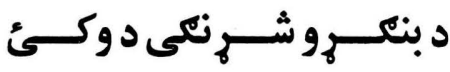

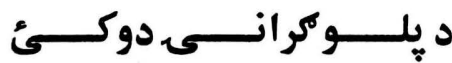

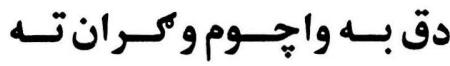

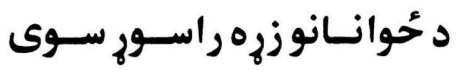

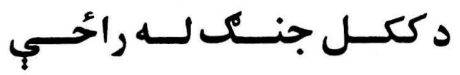

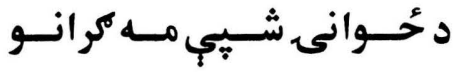

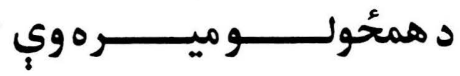

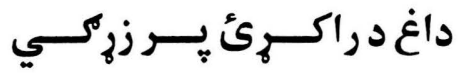

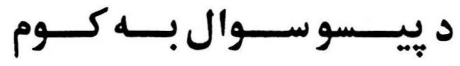




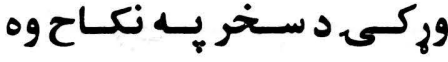

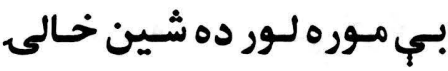
خيـزي لمـر و سـيوبر.مى دوارهـ

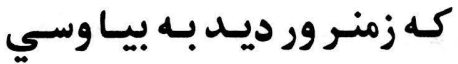
سـتالــه ديــده مـــه روزه ده

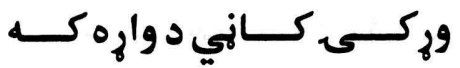
زمــــاد يــــوري انديــــنهنه ده لـه كر انـه بــوى اخلـي كـالي خـواجره شـيان مـه حــين خـواره

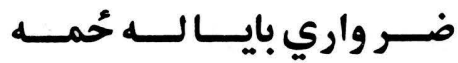

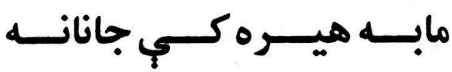

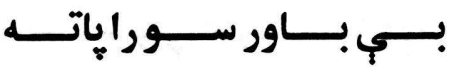

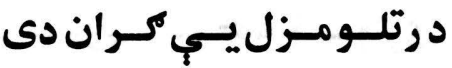

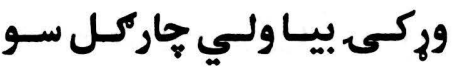
كران ثـوكـ بـه د ديـار كـوري

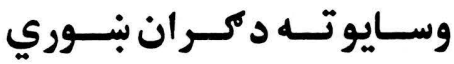

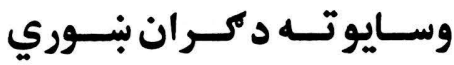
بيرته ستابي خنـدا ولار سـم

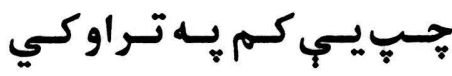

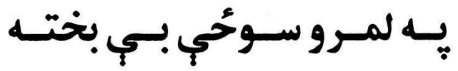
كر انـه ثــوك يـهـ دليـار كـوري هـر سـى بـي ارمـانيـو سـي

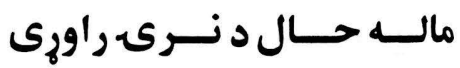
سـتا جاركـل لِونــوكـار دى

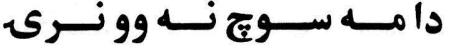

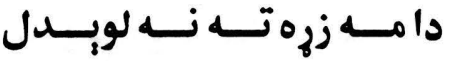

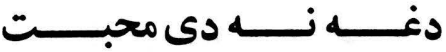

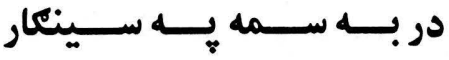

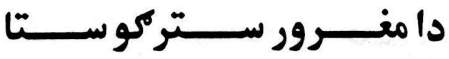

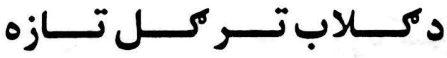

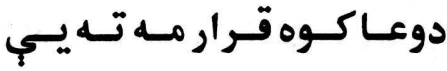

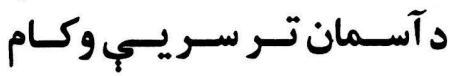

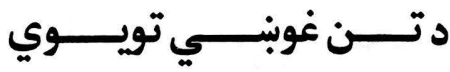
دزره ســــــتـي كــــــــــوري داسـي هيخـــوك نـــــــــوي

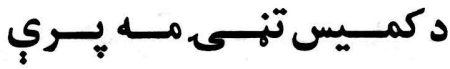

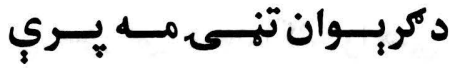

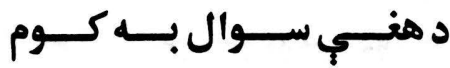

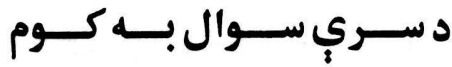

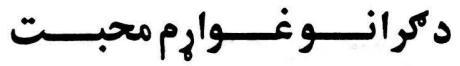

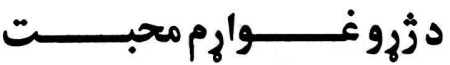

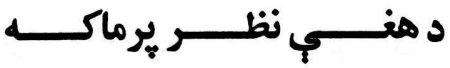
دبنـــــمنان د دي خوشيــــــــاله د سره اور يـه ميـان كي زهيم دقلــــم ســــــاهي تــــــيربـي

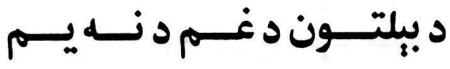
دايـوكال نه دى ثي تبرسي

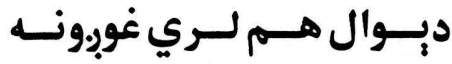


كاكرى غايجي

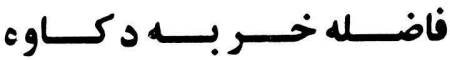

نـه يـي ويسنم تــوري سـتركي

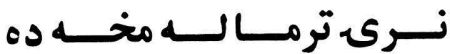

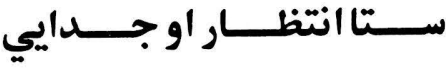

خــداى د يـــه مامـــه خبــروه

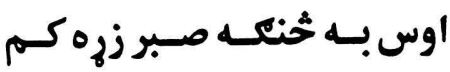

ماتـه سـتايـاد رايسهـ زيره سـي سـتا همحَــولكي مبلمنــي دي

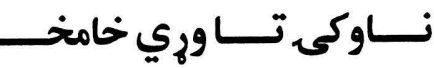

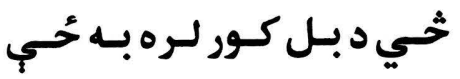

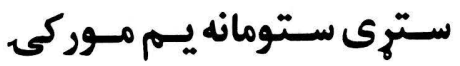

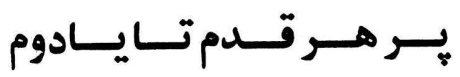
بي مـوركى خـوب كله راحِي

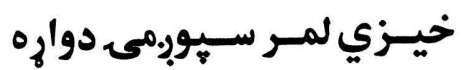

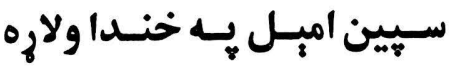

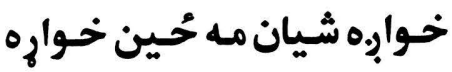
ثخي مـه ويسر نـه كـي مـستاني كرك وهي ناري شيرخى دى دروي مـات سي تـه ليـازاريخ سره بي خوري زما د قاتل سي

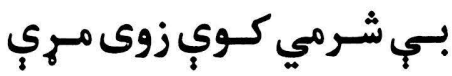
خود به شجاع مري بر سره خون

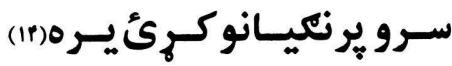

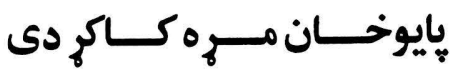

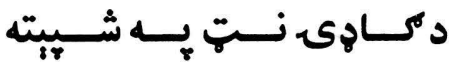

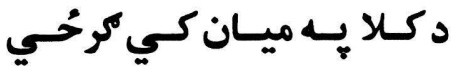

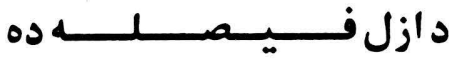

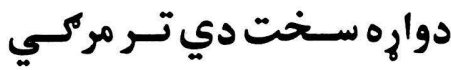

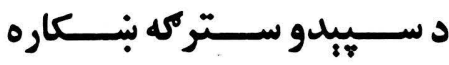

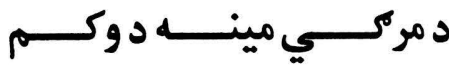
د شـيب تـول خلكس ويـده سي دواده شـــيجي د نـــزدي دي دوي

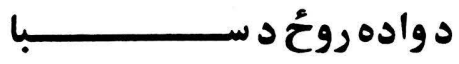

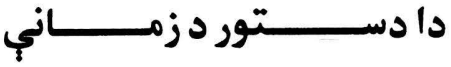

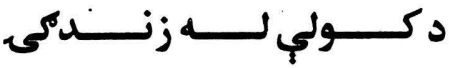

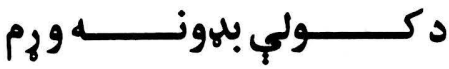

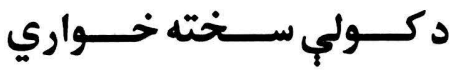

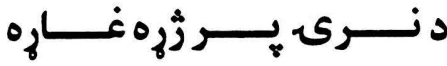

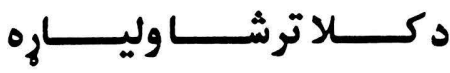

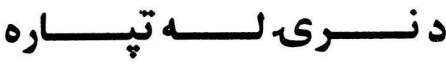

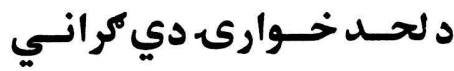

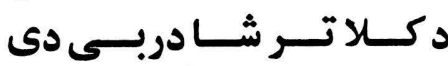

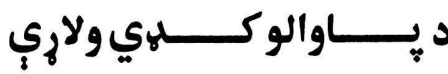

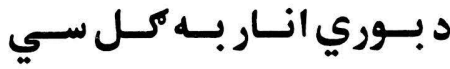

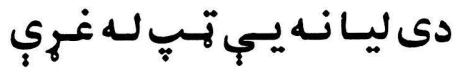

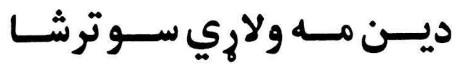

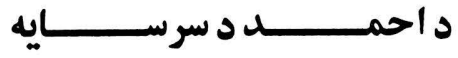

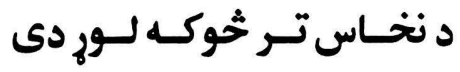


الهه نــور و صسورت خــان دي

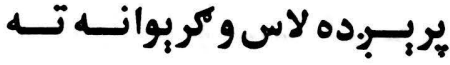

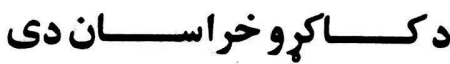
خَّي كـنبـإِي د لاس كـوتي به مياست كي يسو واره راحُّي

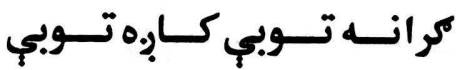
مـرك بـه راسـي تـه ليـازازي

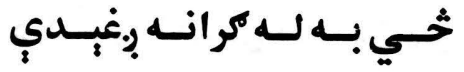

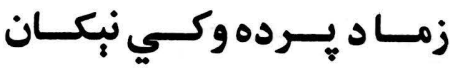

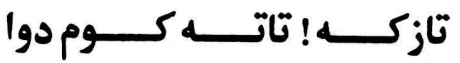

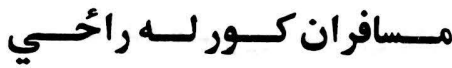

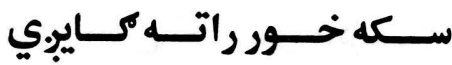
زمـا محبـت بــه د ارمـان سـي

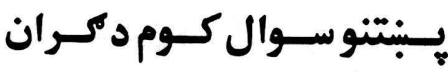

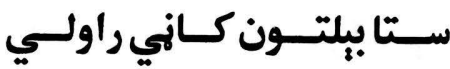
جنــــــارو صـوبيدار وكــ

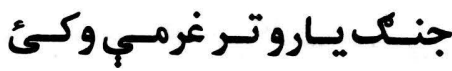
كهله دهـر سـري هـه خـوايتب

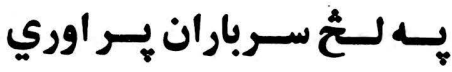
ورور وليــا لـستوني نتـنستي د نــــى اوبـــــو بــاران دى خـــاى د مـل ســـه هرورهوره

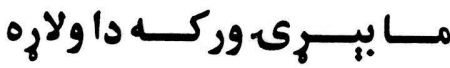

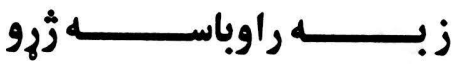

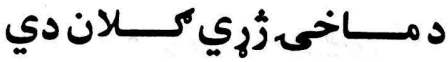

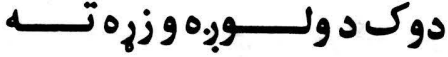
دمـــه وكــــه د غروميــان دى دكران ثخه ارمان بـه زهرهي

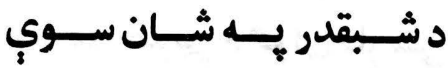

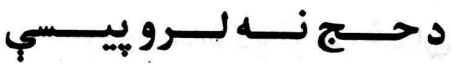

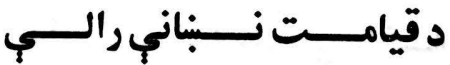

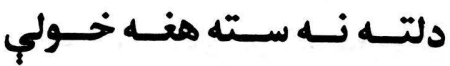

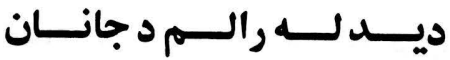

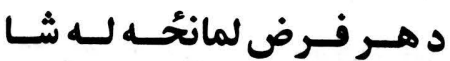

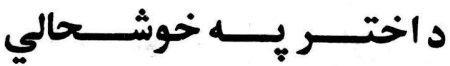

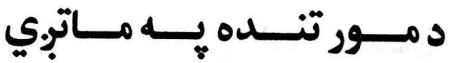
داءحــواني بــه دخــزان ســي

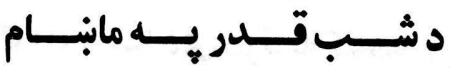

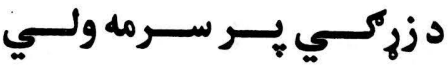

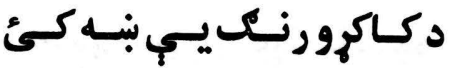

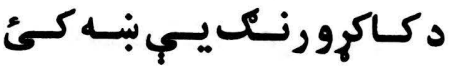

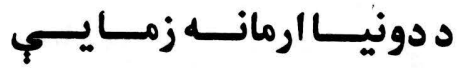
دكـالج بـه ميـان كي بنـوري دكـالج تـــر مــخ دي خــنتي

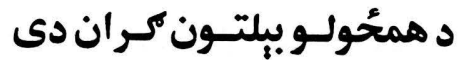

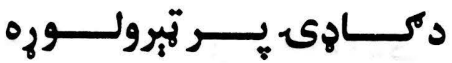

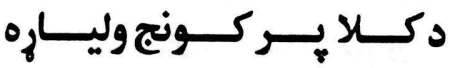

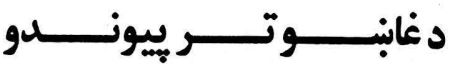


سر هـيوبر.مى خحلـوريسي خاله

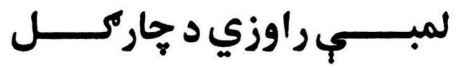
خوله مـه كبنل كه د بنـور اندي

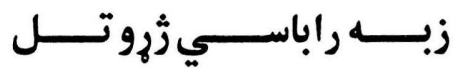
نـ مـه ثخـوني د كر ان بـار سي

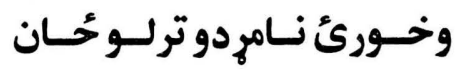

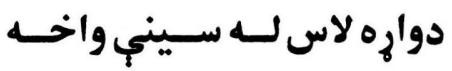

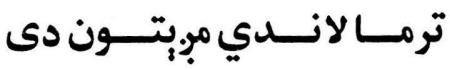

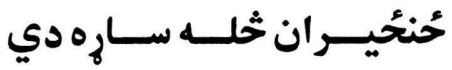

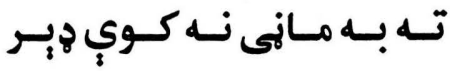

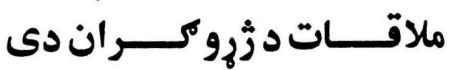

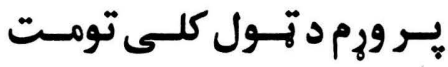

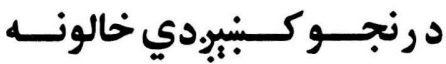

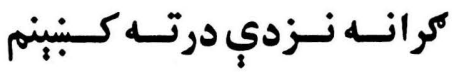

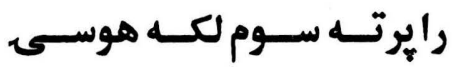

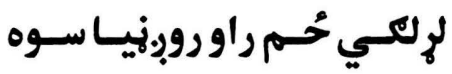

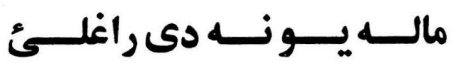

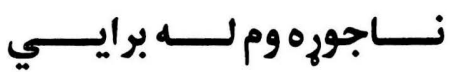

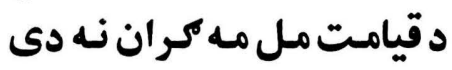
لمـــا روان ســـوى خركــالهـ اوس مه دوستان دبنمنان سوه

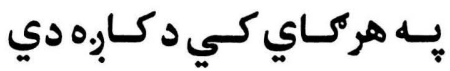

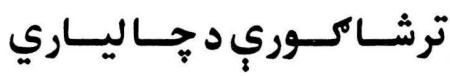

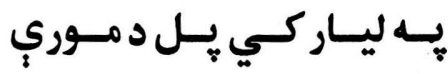

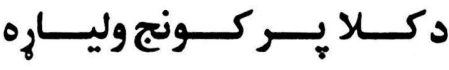
دحُوزانـــــوتــــــــــــــوهل

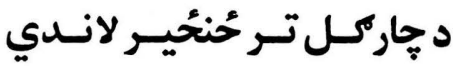

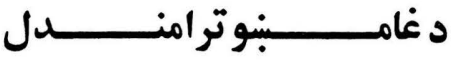
د شيب ديدد دخوبيب شاسي

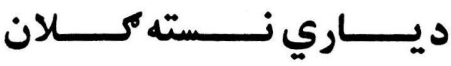

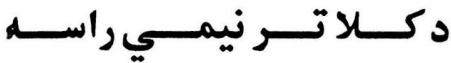
دكـشنى نجلســ بيلتــون دى دي

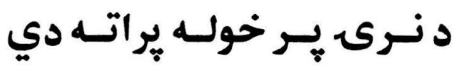

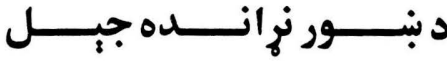

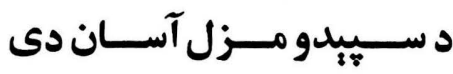

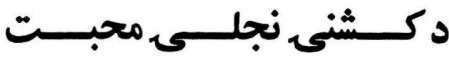
دلتـه راسي تــول كي زيرونس

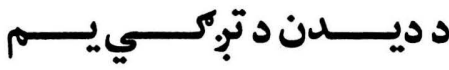

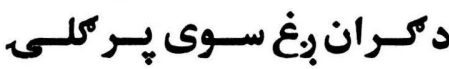

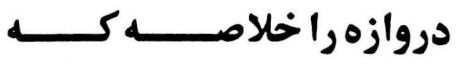

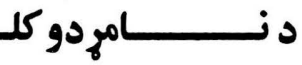

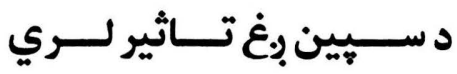

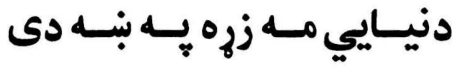

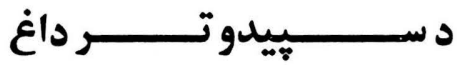

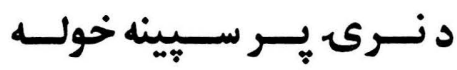
د تيـــــري يلــوان د شــنه دي

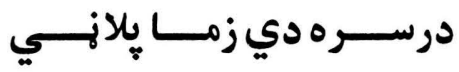

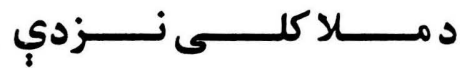


سـتاخــاطر خحلـــه مانـلـه دي بيا سيسن مو تخكي به لاس راكه

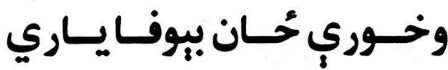

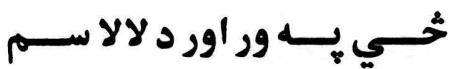
بـاد راوالـوت له خـوا سـتادى

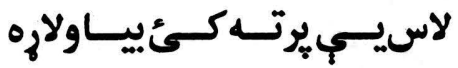

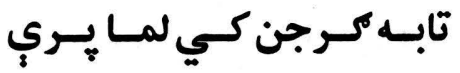

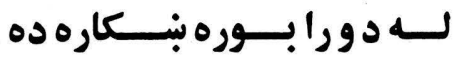

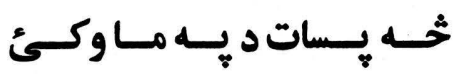
بيا به بـه خلك كى رسواسي ثخي بب عمل وي دخولي ميان كـور بــه درواغ كـوي يـاري

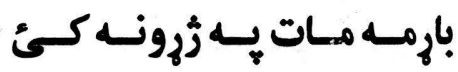
كنينــستم بـــري بـــــوان دى

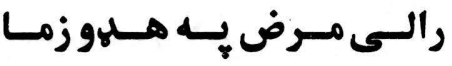
رانزدي بسه دكـران كـور سي

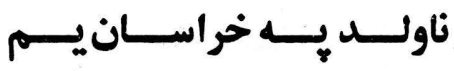
مـا بـه غابنسو كسنل كـه و ورى

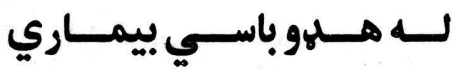

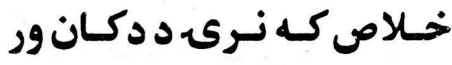

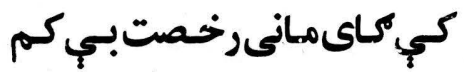
خوكى بـه مراد راكه بياحُب

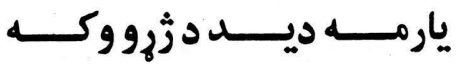
مز انه لـوى كـاى د تـاوان دى

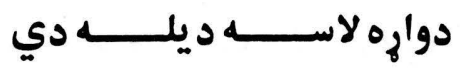

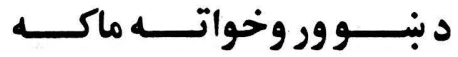

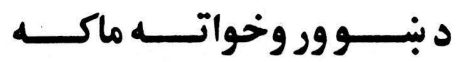

د غــوحُح ارمسـان بــي باسـم

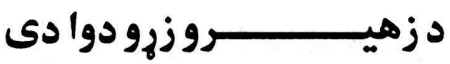

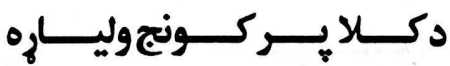

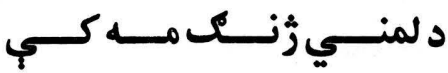

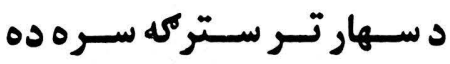

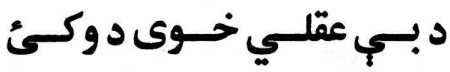

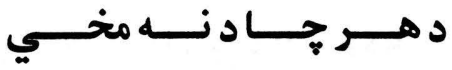
دلتـــــه نـــــــه دى انــــــان

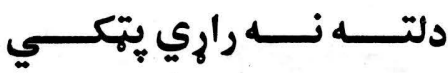

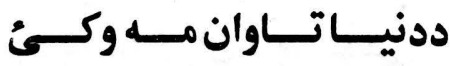
د نـازك اختيـار د دــان دى

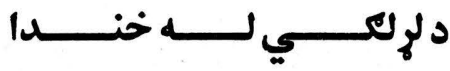
دازهيـر زيرونه بـه جـور سـي

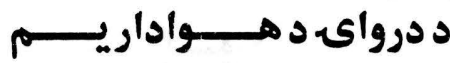

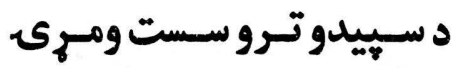

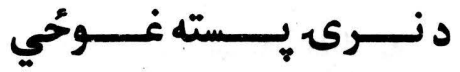

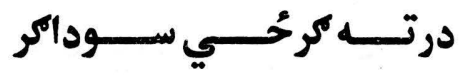

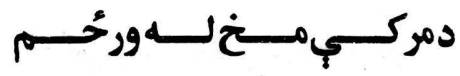

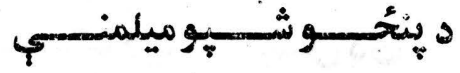

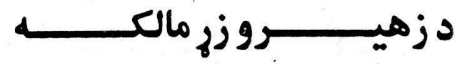

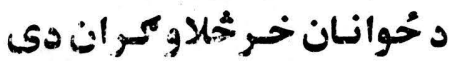


سـره ســونانْ يـهـ ختــدا ولاره

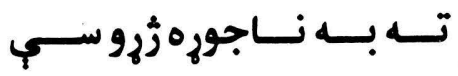

ثخـي درسـم كـور كـوي ديـاري

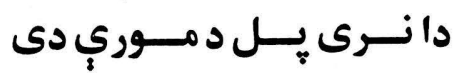

اوس مــه نــــى كــه سـلامي

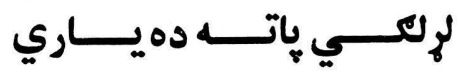

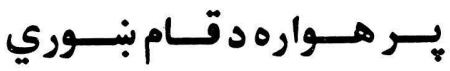
تر سـر رالاندي كـه سـتا لاس

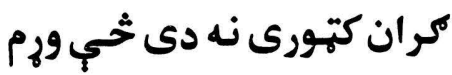

ديد ير حُاى راوره مابنام دى دي دي

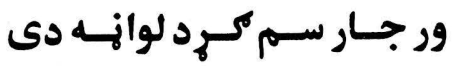

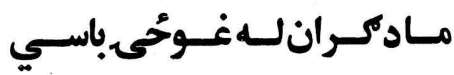

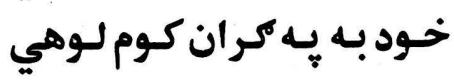

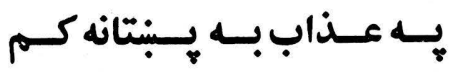

يـهـ خوله كي ورم د يرانسي

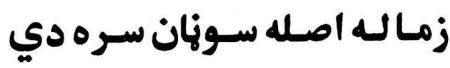

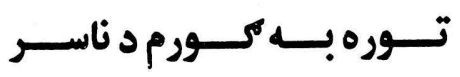

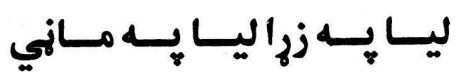

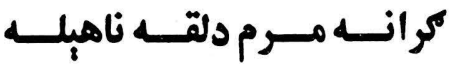

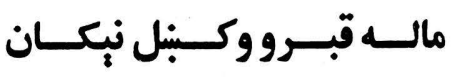

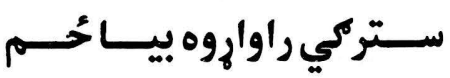

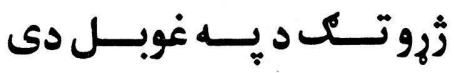

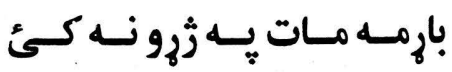

اوبسه خور مـه لـه ويسالي كـي

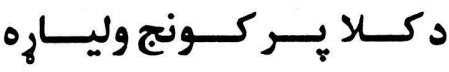

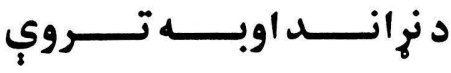

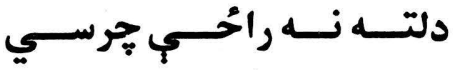

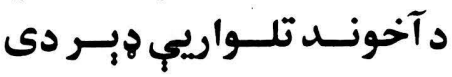

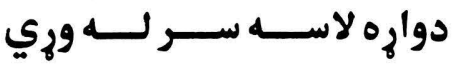

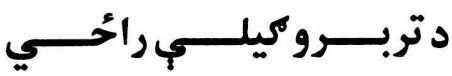

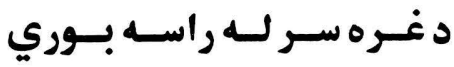

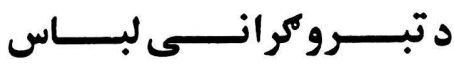

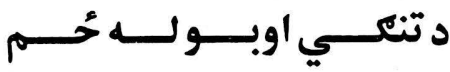

د نــابودي كـــور ويـــــان دى دي

د نــازك د ديـــاري ملــهـ دي

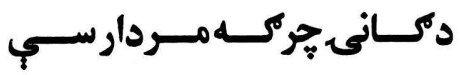

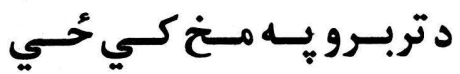

دايسوكسل دى تربسي نـهـم

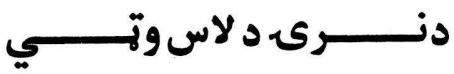

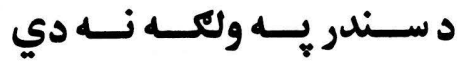

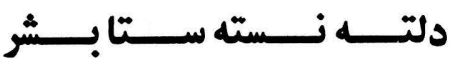

دا يــوكــال دى تربـــهـ سـي

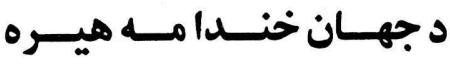

د سـيوريمى واهـي يـر كـران

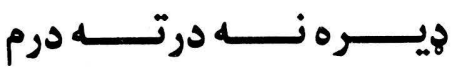

د تيكري يـر خحاك دمكل دى دون درن

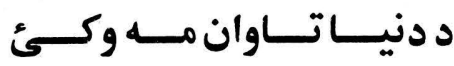

دخيـزى برخهـ مـه يـري كي 


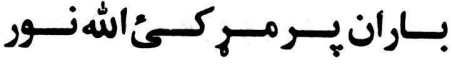

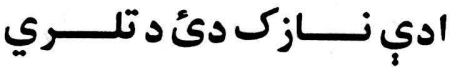

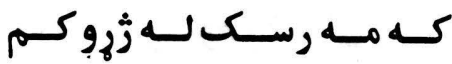

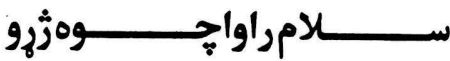

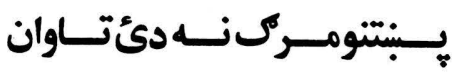

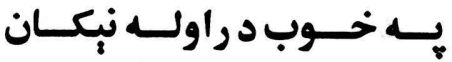

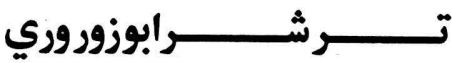
كـــد مـــرور ســــول يـــبتـانه

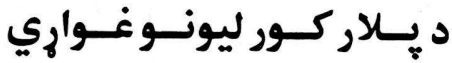

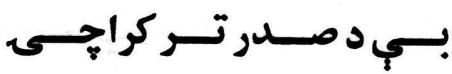
كـــران دى مــزل د دخراســان

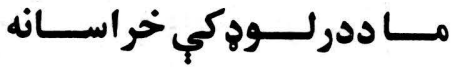
سـونانيـي كـل حُلـه رايـري

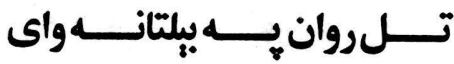

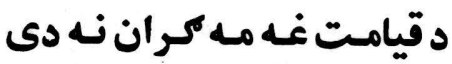
تـري سـوي سـتا يـــ انديــنينو نه سته كرانوخحي كي كبنبني

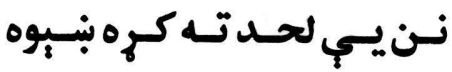

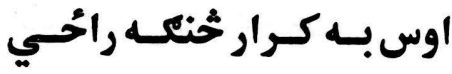

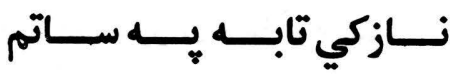

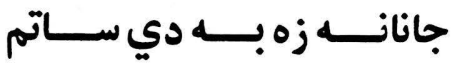

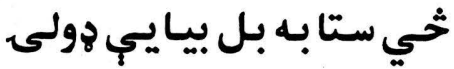

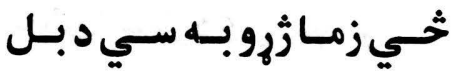

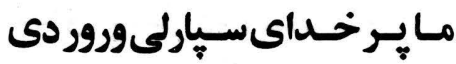

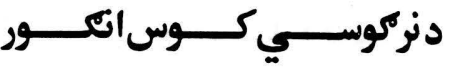

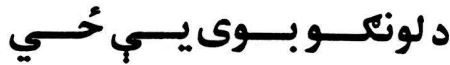

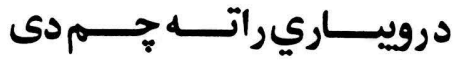

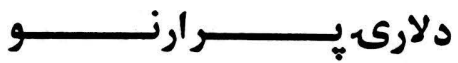

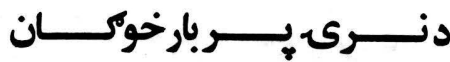

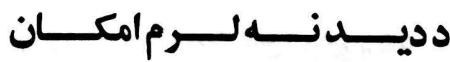

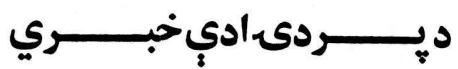

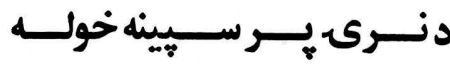

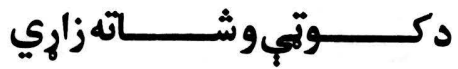

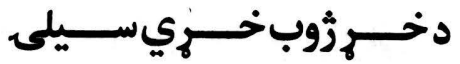

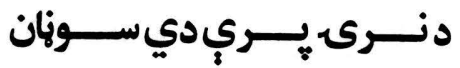

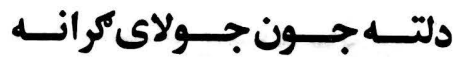

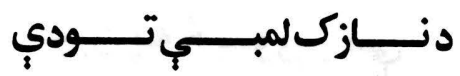

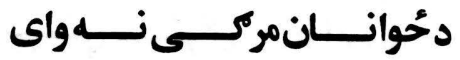

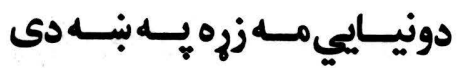

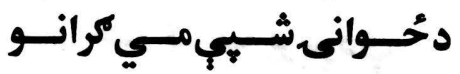

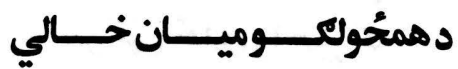

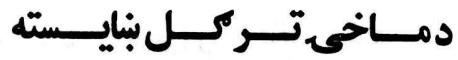

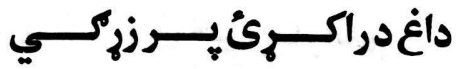

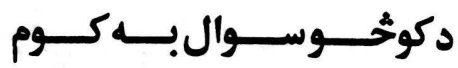

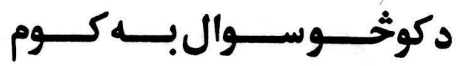

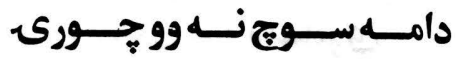

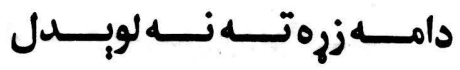

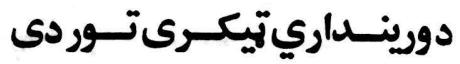




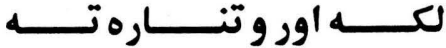

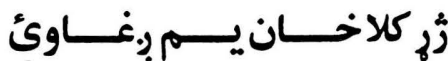

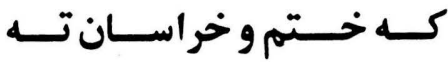

زوب دلــي راخراســانكـي

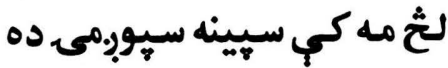

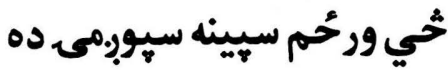

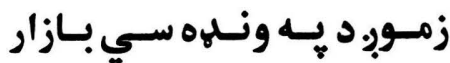

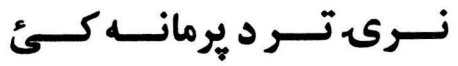

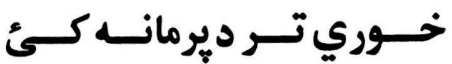

يـار ورحُم ثـي مسه آس راسي

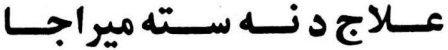

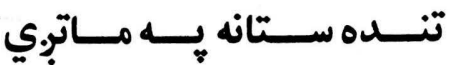

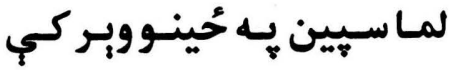

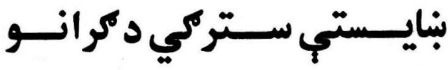

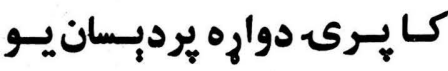

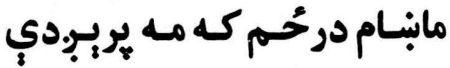

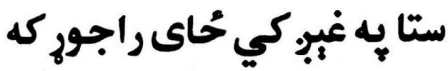

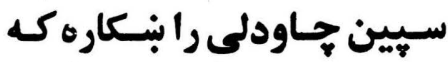
خداى خبر دى خهي بيار اسم

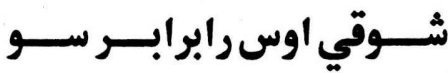

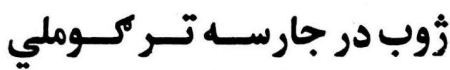

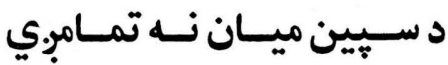

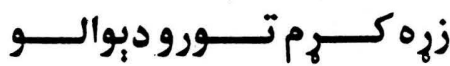

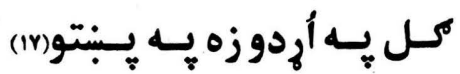

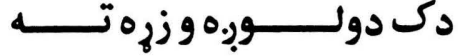

دوهرانـلـه ينحُحوسـت غـدى دورى

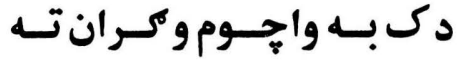
داخركسـي وورهزرانـدكـي

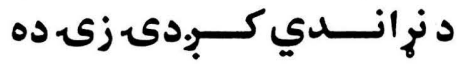

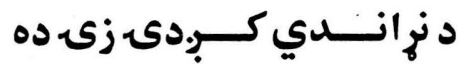

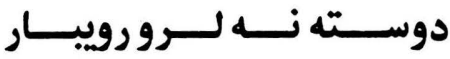

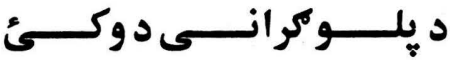

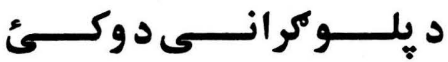

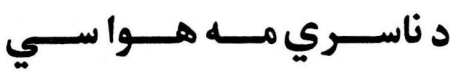

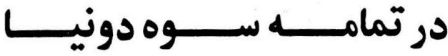
دلتــه هـــم حُوانــان اوسـبـري دحُوانـانومركسى دئسر كـي

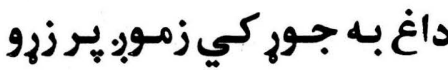

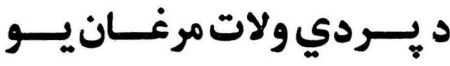

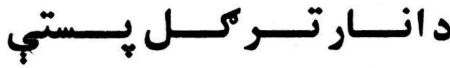

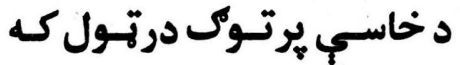

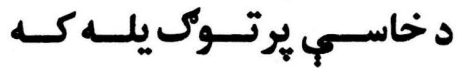
د خــــولكمـ ارمهــان د باســم

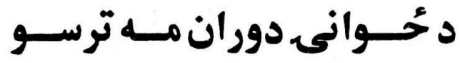
د مخخـول تـر خــوكي لـوري

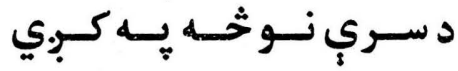

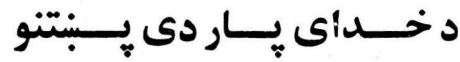
دخـــداى يـــار دى يـــنتبنو 


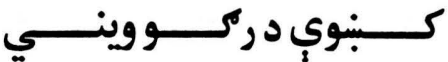

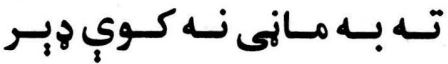

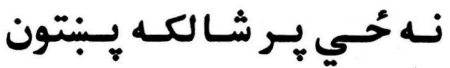

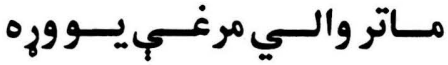
زمـاد خيـال كلـى .بـورى دى لـ

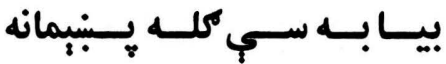
سـتا د ديـلـ مـه ارمـان وجــ وئ

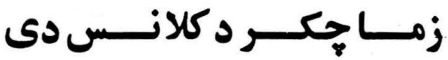

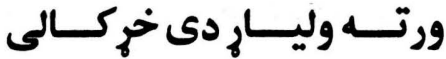
نــىى نـاري لـه اوبـوكـي

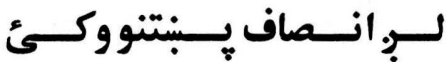

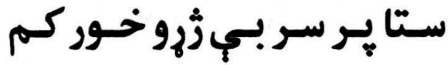

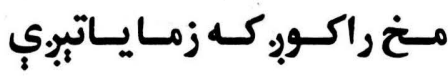

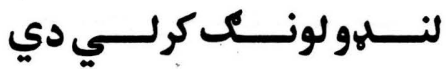

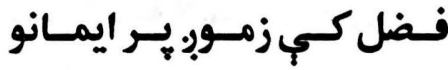

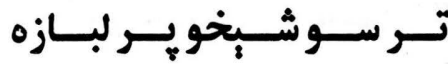

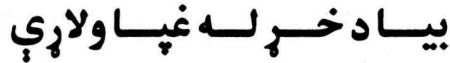

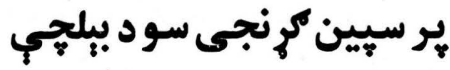
بـاد راكوخري له خـوا ستّادى بر تور ناست دى وري خوري به مايس وئر كئ د سرو بنسار خــوري لاسـونه كـــهــــــاره

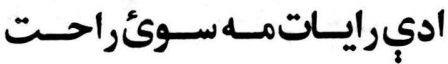
قبـول مــهكـي د ايمـان ســوال

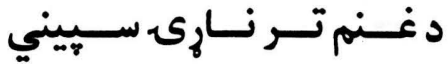

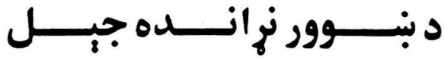
د بنايـــــه جانسـان بيلتــــون

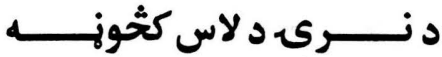

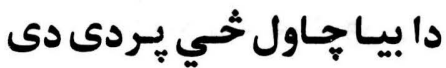

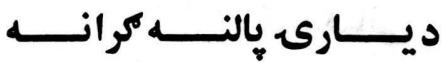

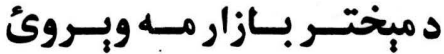

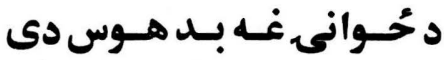

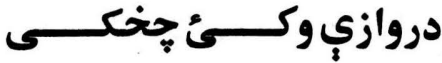
د زر تـار واكسي مسه وروكـي

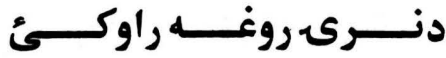
د بيـسو تيكـرى بـه جـور كـم

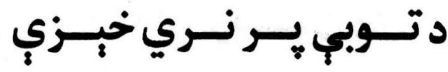

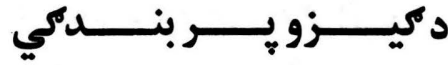
درختـي وجـي سـوي د غـرو

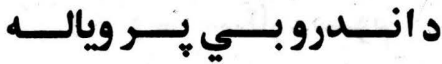

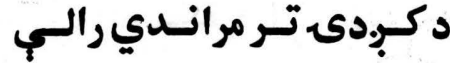

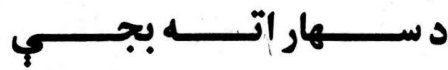

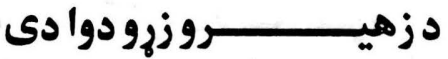

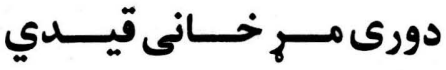

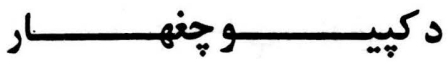

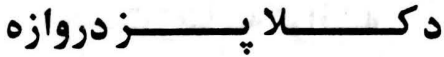

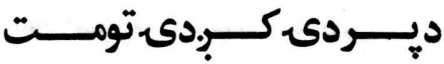

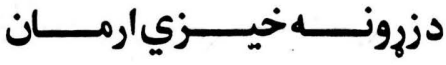


خداى خبر دى خمي بياراسم

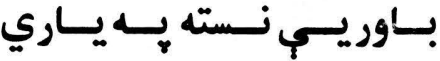

دحُنكـــل غـــوركي رانيـسـي

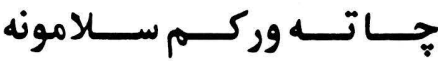

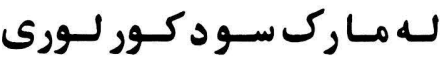
يـر خنــك راواوره خونكساني

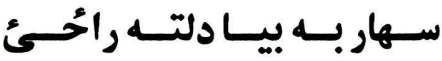

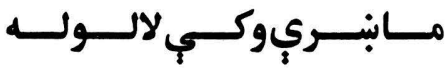
بــــه دسـمال راوره زمــايـاره كـنج لــ راتـويبي كـــ مـالتي

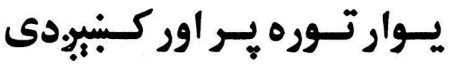

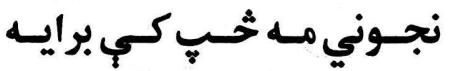

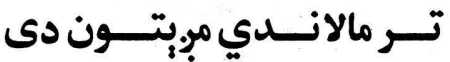

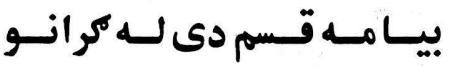

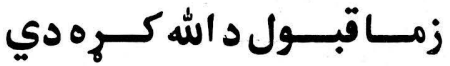
سـوكي وم توكله ســاره سـوم دنــــى اوبـــــوبــــاران دى

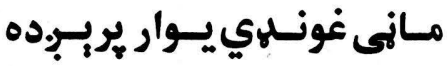

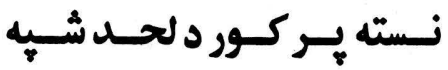

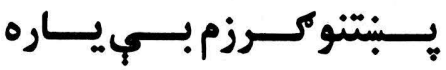

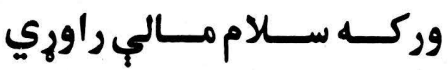

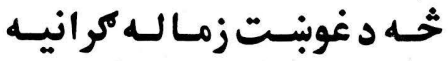
كر دبـه خـورم د سـيمانه دي بـهـ واكـد دبـليسي سـباحُحي

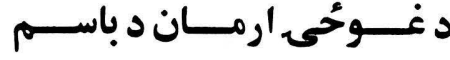

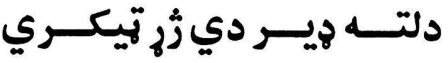

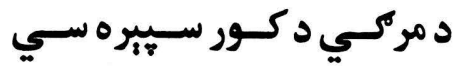

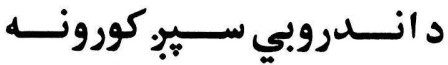

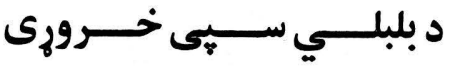

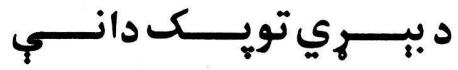

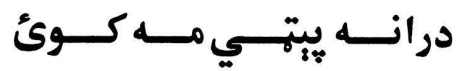

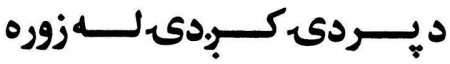

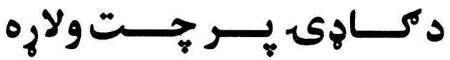

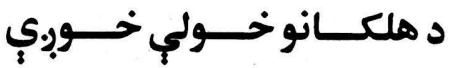

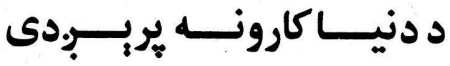

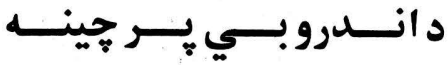
دوركسى نجلسى بـلتــون دى دي

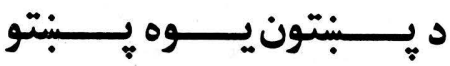

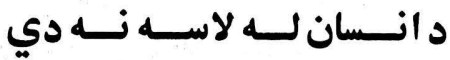

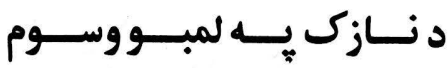

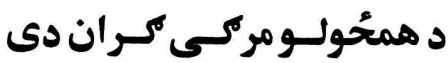

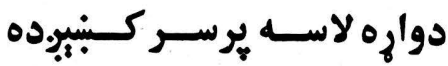

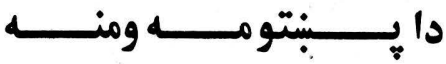

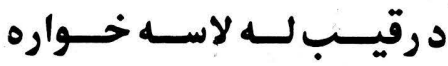

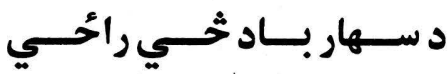

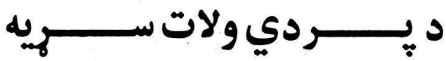
د نـــازك د لاس خــــواره دي

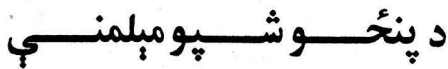




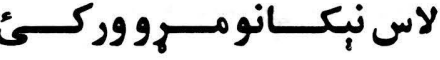

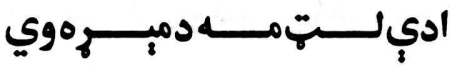

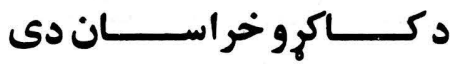

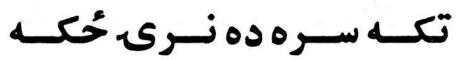

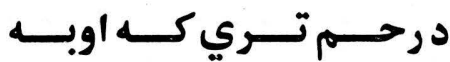
جهـــاز كــارى دى دواتهـــي

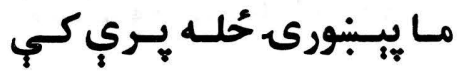

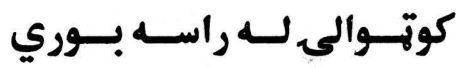
سـمندخـان د جركـي وكـي يويبي تويك دوي يسب زايّي بناخ لله سرو وينوزيندى دي

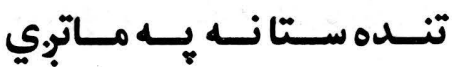
عجـب شـيان دي غبــر كوليـان

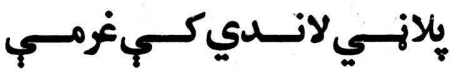

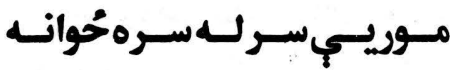

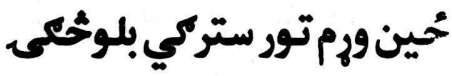

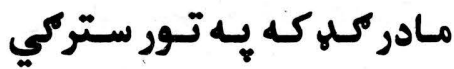

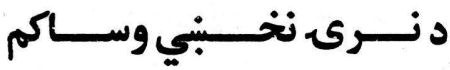

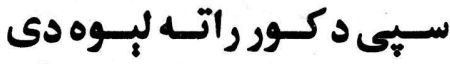

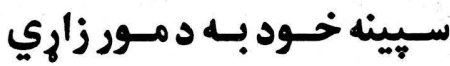
كـه مـه رسك لـه زٔروكم سـو تانـدكى مـره سـي بـر حُـواني حي وركى ستركي كبنيكاري تـر سـر رالانـدي كـه سـتا لاس
دوخلين بـه غره كي بندكئ

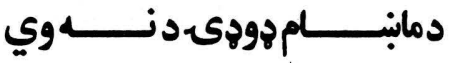
د سـر سـتركي د زره ميـان دى

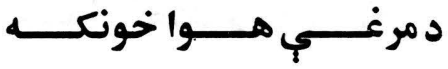

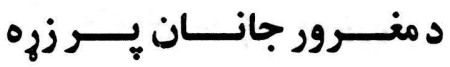

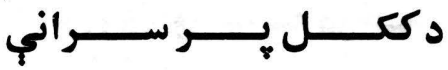

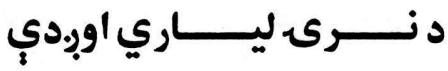
د شـال كـوتِّ يـــــلا يــوري

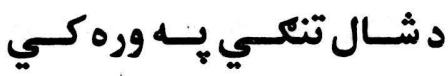

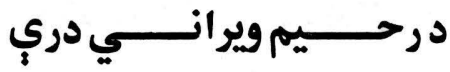

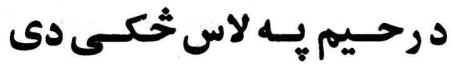

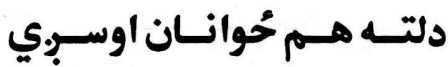

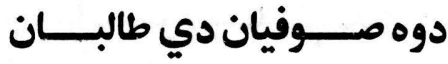

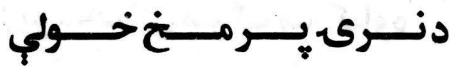

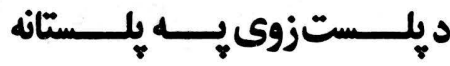

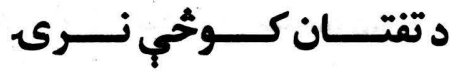

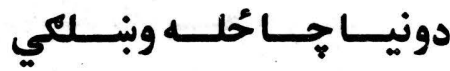

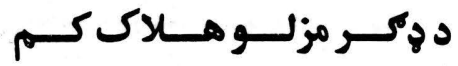

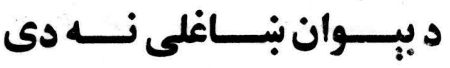
دخــــوانقى كــالي د نتـــاري

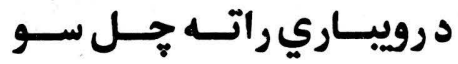

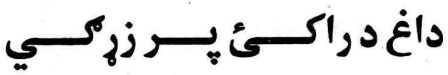

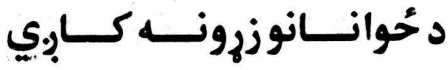

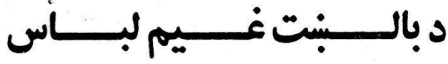


نــور جانــــ ناسـته ده بنــكاره

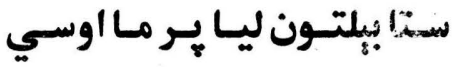

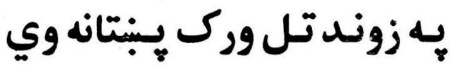
نــــته انـــصاف د دونيــاكى

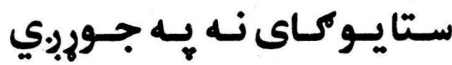

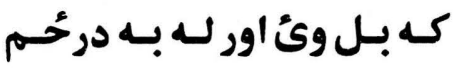

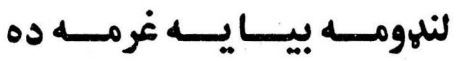
لنــلهو يــام كــوه مــاران دي

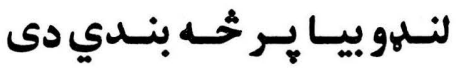

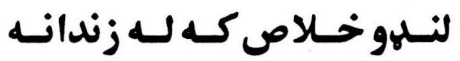

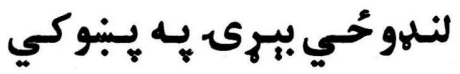

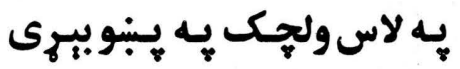

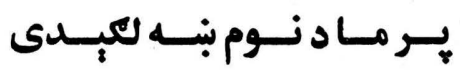
كه تويـك اي مـرك مـه كـاوه بيا سيـين متكي هيه لاس راكه

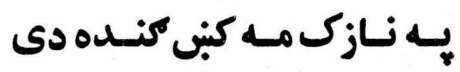

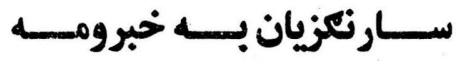

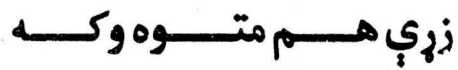

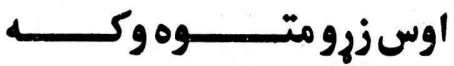

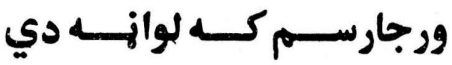

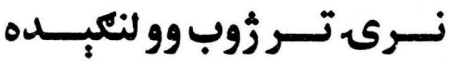

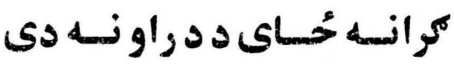

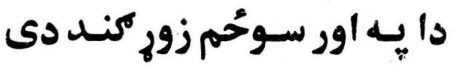
كزان دور بين سم كئ ماموري

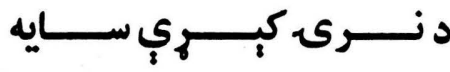
درختي كل وكي بيـاتوسي

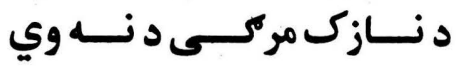

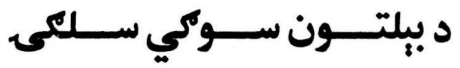

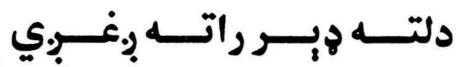

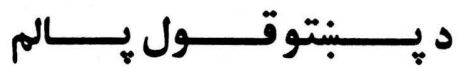

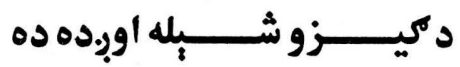

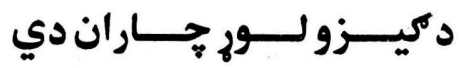

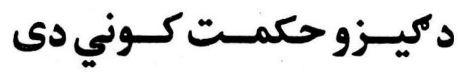

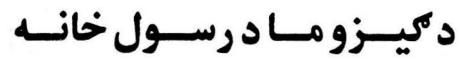

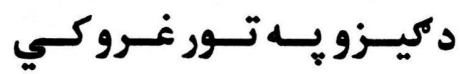

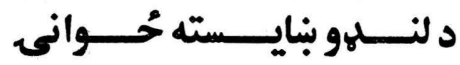
دوى بــه ســا غيبـت كــاوئ

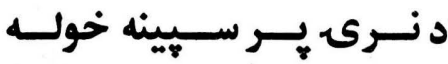

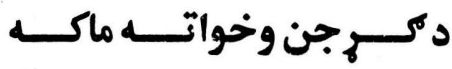
د خيّل حُان علاج مه زده دى

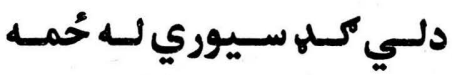

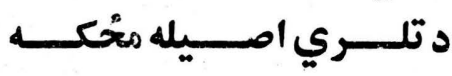

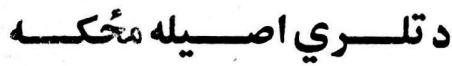

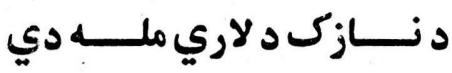

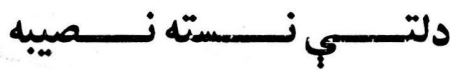

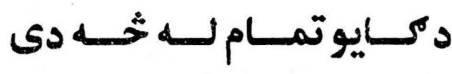

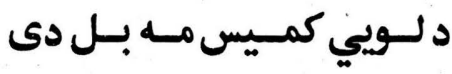
دكونسلهى ونسي يسه سيوري 


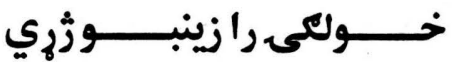
خـداى دمـرك مــه يـه راوينـه مـخ د يـتِ كـه خلـك دوينسي

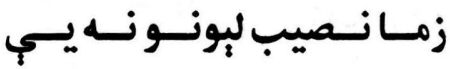
نـن مـه نيــت بيـاد جانـان دى

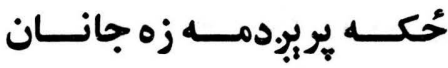
وخوري دمل غوندي حُواني

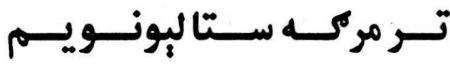

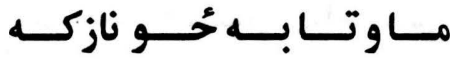
كـران د تربــرو كـوي سـيالي

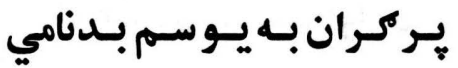
ثخي بـه وير د دونيـاحسال سي يــود دحــــواني بــــل دكــالي

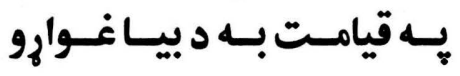

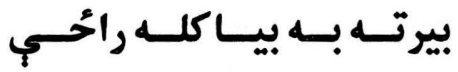

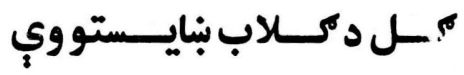
نـــى خــود بــه دمــور زاري و جمعب لمونحُ باندي هريجردم

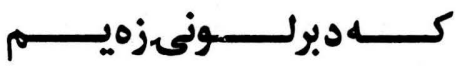

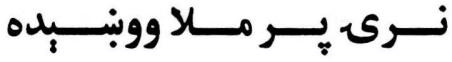

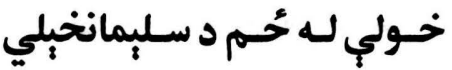

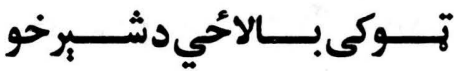

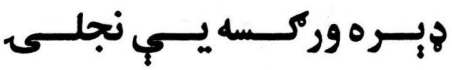
كــه ملخـــى در ورمبـهـ دوري

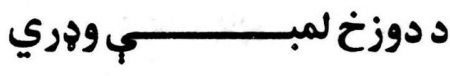

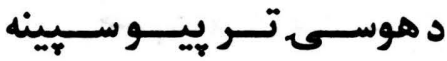

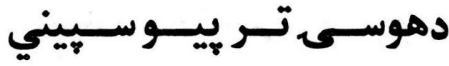

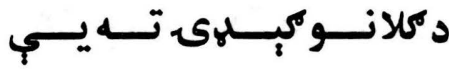
ديدبه وسي خداى مهرباندى دي دايمـــــان مـــــهـ دى تـــــاوان

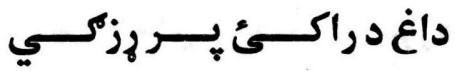

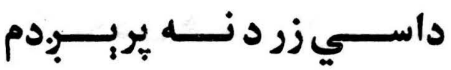

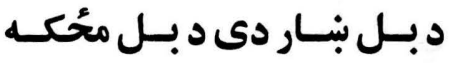
دنيــــرت شـــيجي تـــــروي

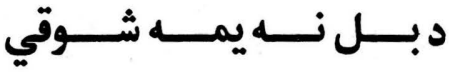

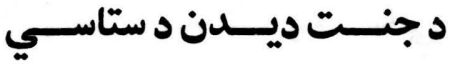

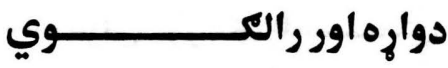

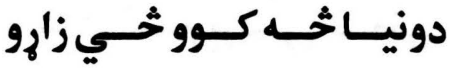
درتــه سـتركي سـوي تركيّي

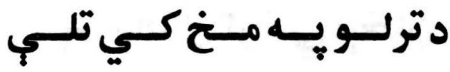
دحُــــوانى كــالي د نتـــاري

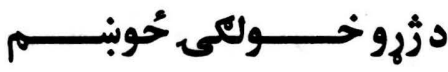

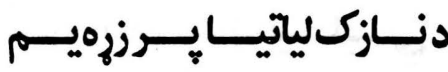

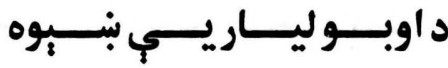
دي هر حُاى شين تيكرى هيري

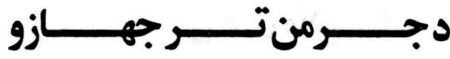

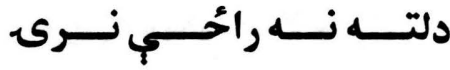

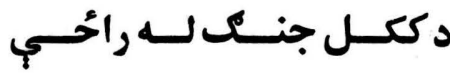


سـور تويـكـ هايوخحـان بنــوري

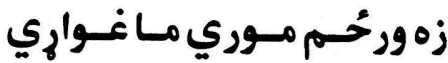

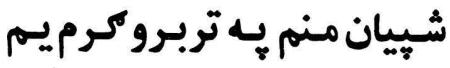

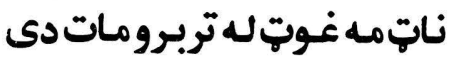

ونه

واروه لاسي

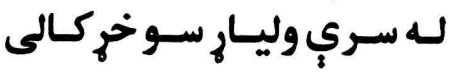

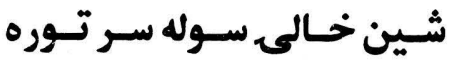

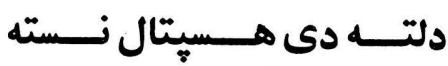

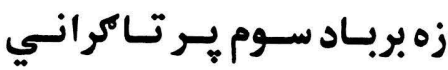

كمــيس د تـــور دى بنايسـتي بــي

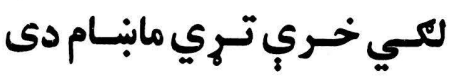

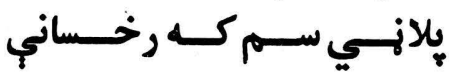

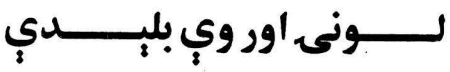

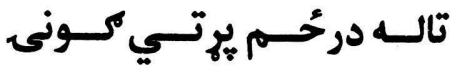

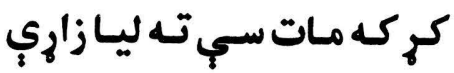

ستا يـر سايكل كرحُحي مبخدان

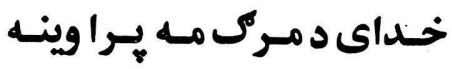

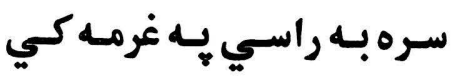

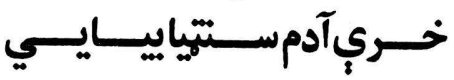

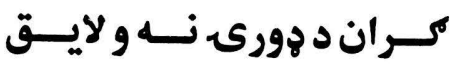

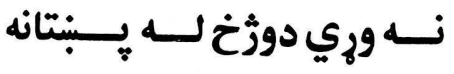

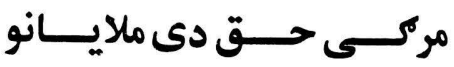

بيا سيّين موتكبي يه لاس راكد

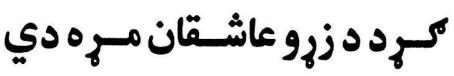

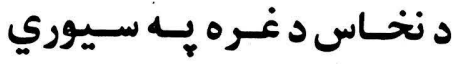

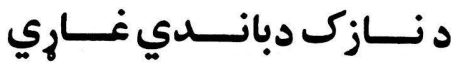

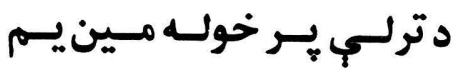

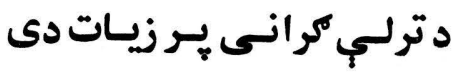

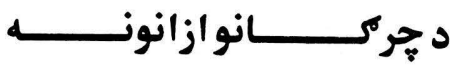

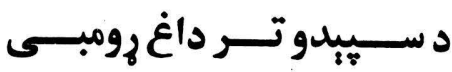

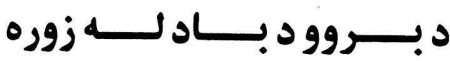

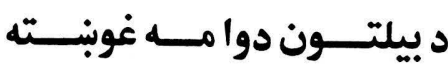

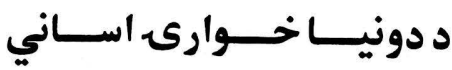

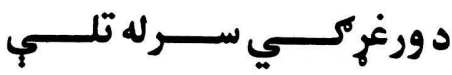

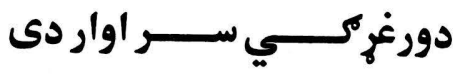

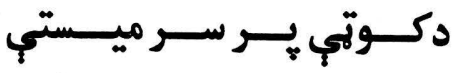

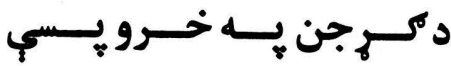

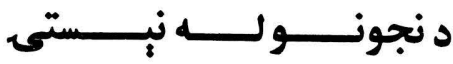

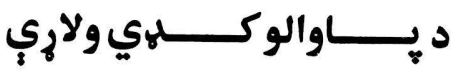

د نــــابودي يــــاى ويــــــان

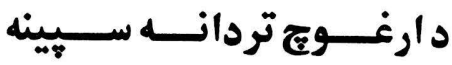

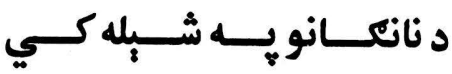

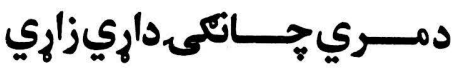

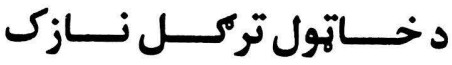

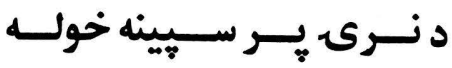

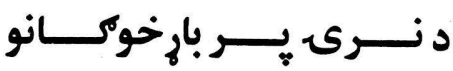

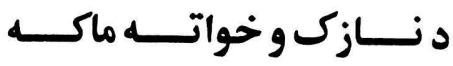

د تويــك ويسـستلي بـــــ دي 


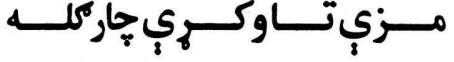

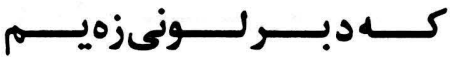

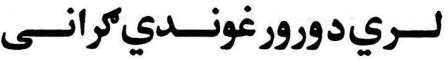
كـوريسي ديـدكـولاىنـهـــم

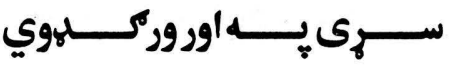

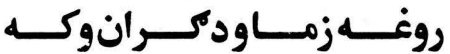

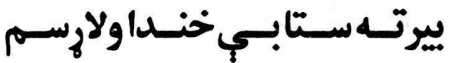

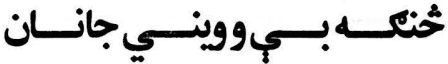

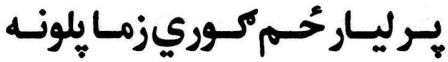

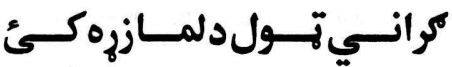

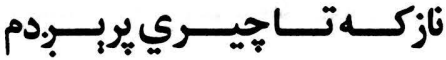

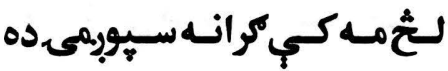

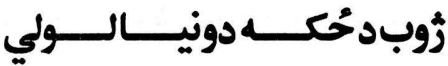

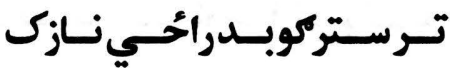
زمـادسـماليـوسـهليـاكـوتكي

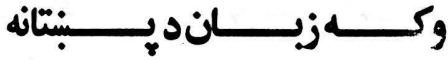

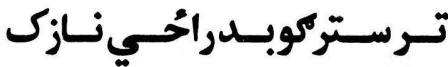

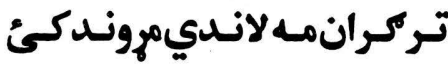

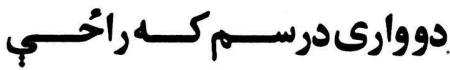

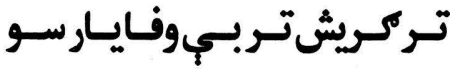

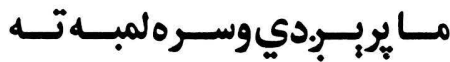

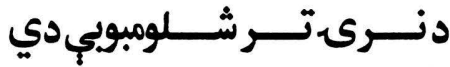

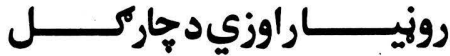

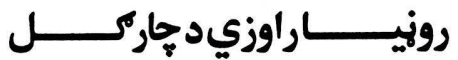

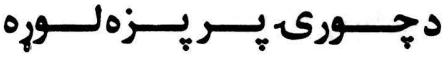

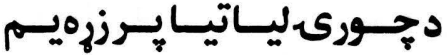

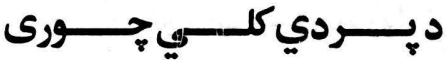

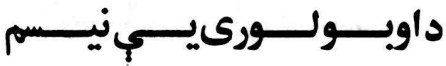

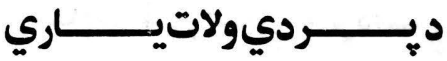

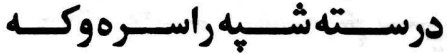

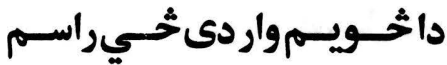

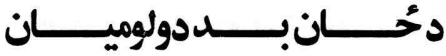

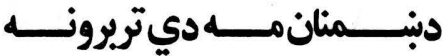

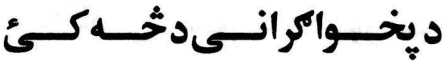

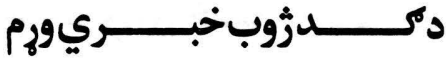

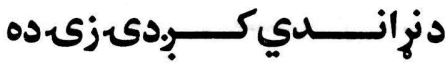

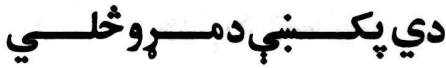

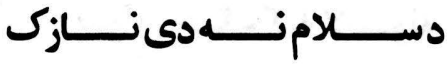

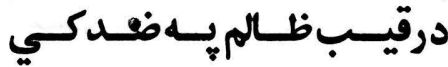

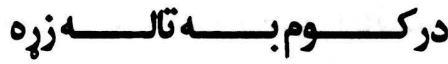

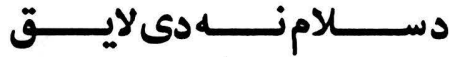

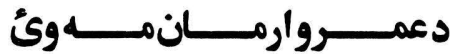

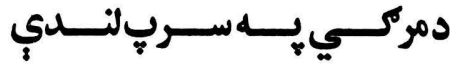

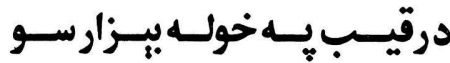

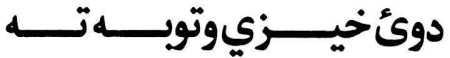

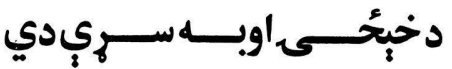

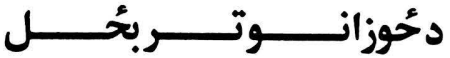

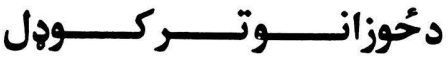


كاكرى غاري

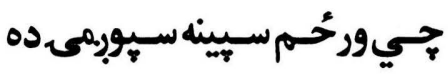

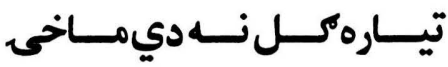

مـاحُيكر كولـبـســويْدروازي

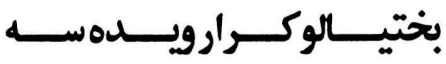

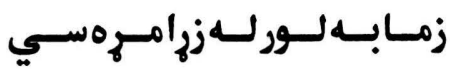

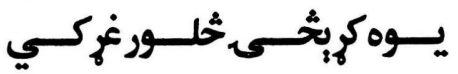

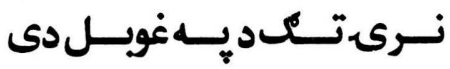

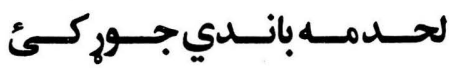

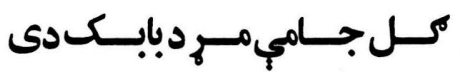

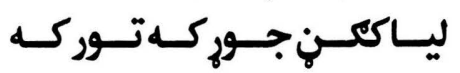

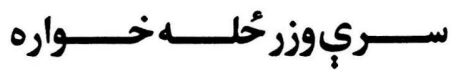

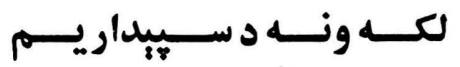

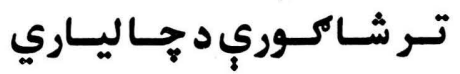
تــــــــــوال جــك كـه لاسـونه غضبكرد لـه نرى جـور دى

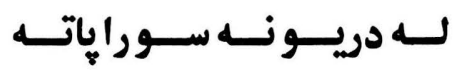

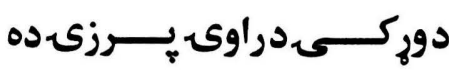

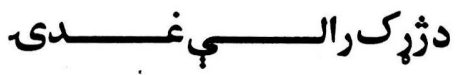

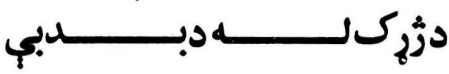

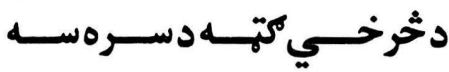

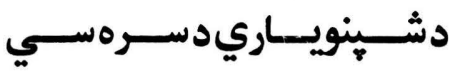

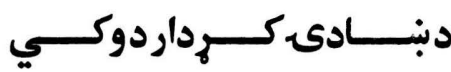

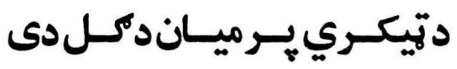

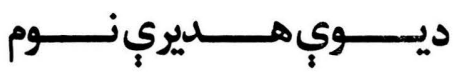

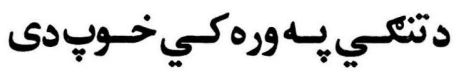

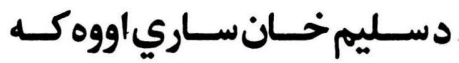

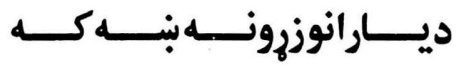

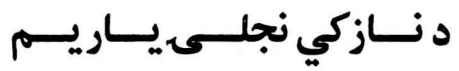

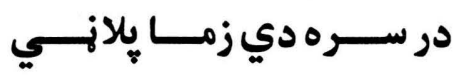

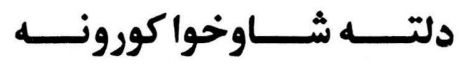
د مغنزي هـر خــوا يـي زور دى دي

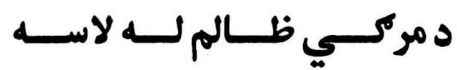
资次 


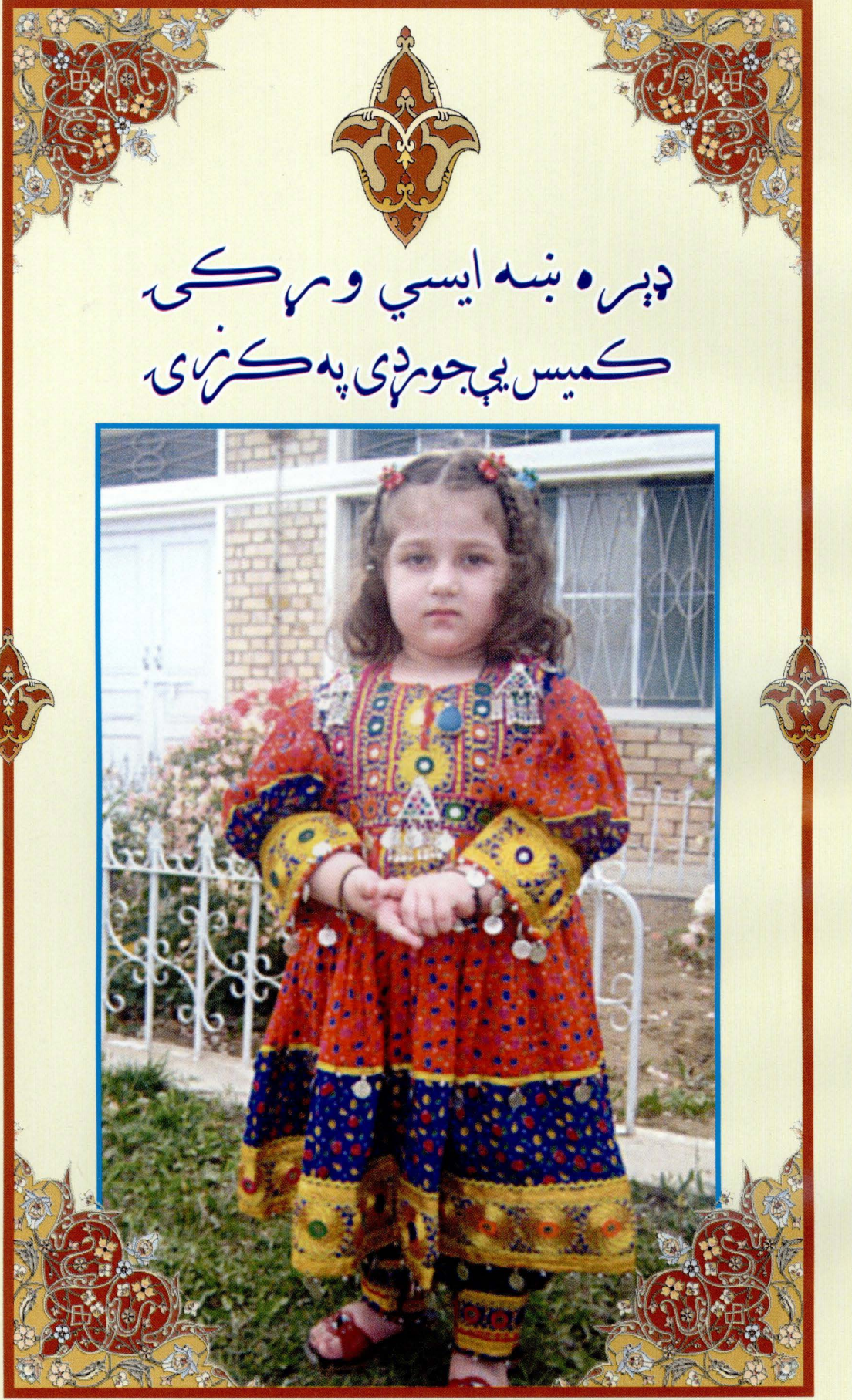




\section{8}

تولـه زونــد مـهـ يـهـ زاوال كـى

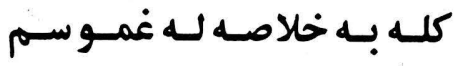

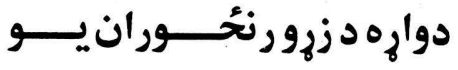

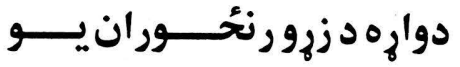

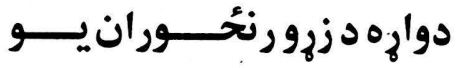
تر نصيب زيات غواري خواره

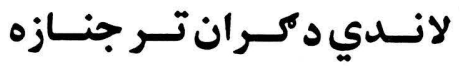
محبـت سـيال سـوى دكرانـو

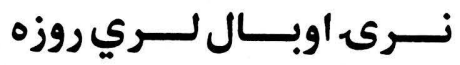
واخلـه رخسصت لـه يلاركنـى وري

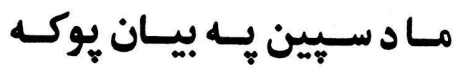

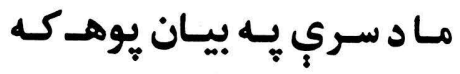

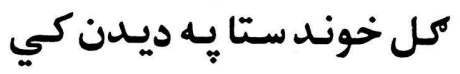

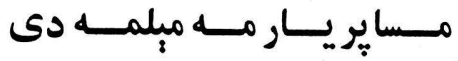
كـل سـحـلكي يـــم بـــي اوروه

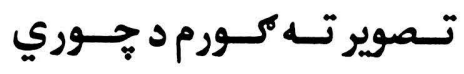

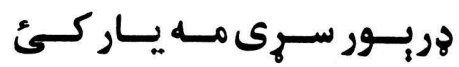

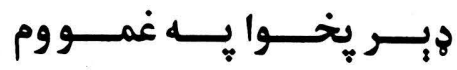

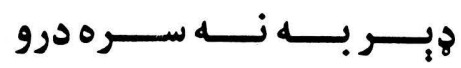

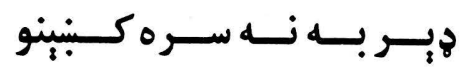

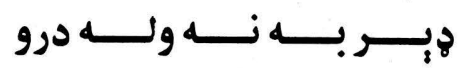

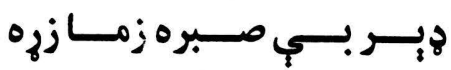

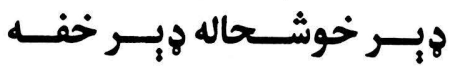

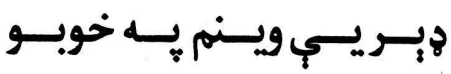

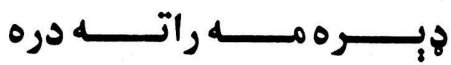

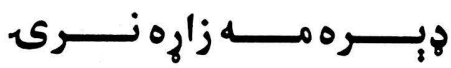

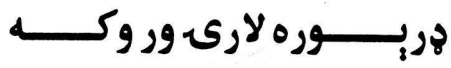

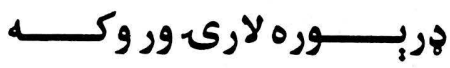
حُوانان ديبر دي يه وطن كي

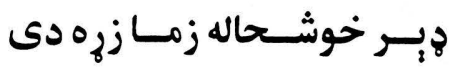

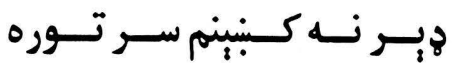

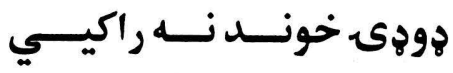


سبـي دي خـــروزي د بابسك

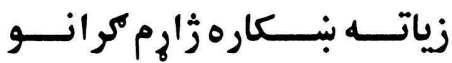

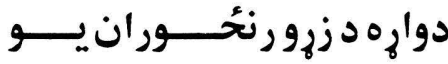
تر كـورى لاندي مـه كي مـره

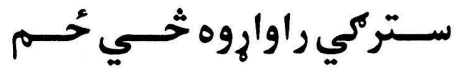

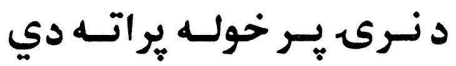
زما دكر ان يـر خوله ير اته دي

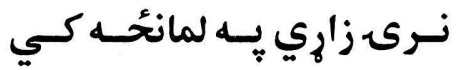

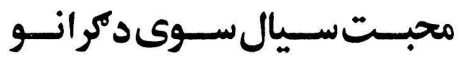

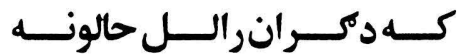
نـازك كــبــإبري زمـاكـوتي

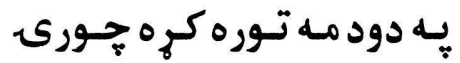
وركسى واخلـه د خــداى هيلـه كميسيب جور دى يه كرزى

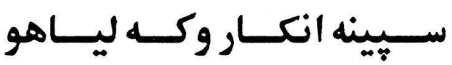

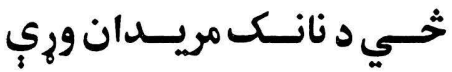

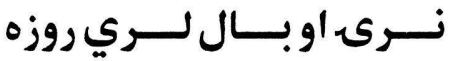

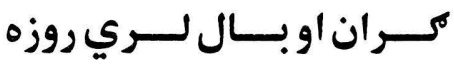

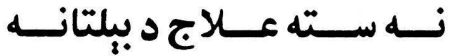
مـلاكــرزه يـــروا نــهـ ســته

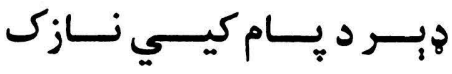

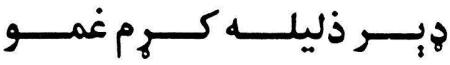

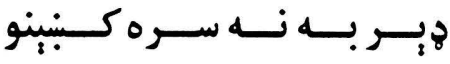

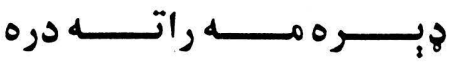

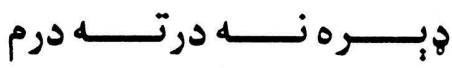

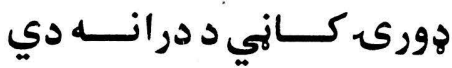

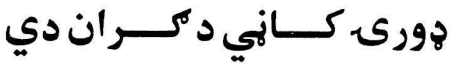

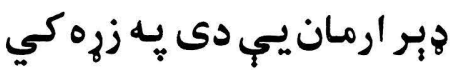

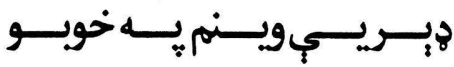

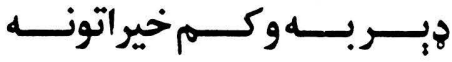

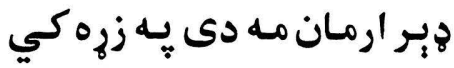

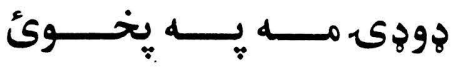

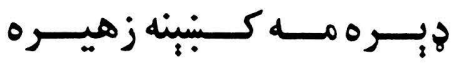

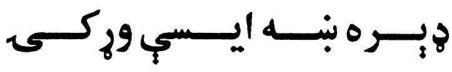

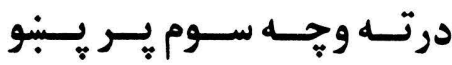

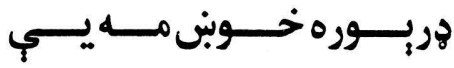

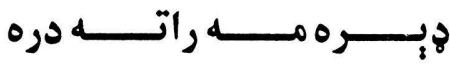

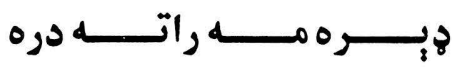

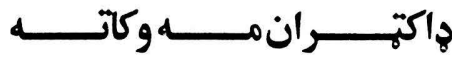

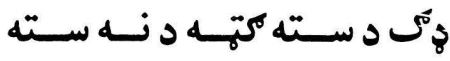
牲 牲 


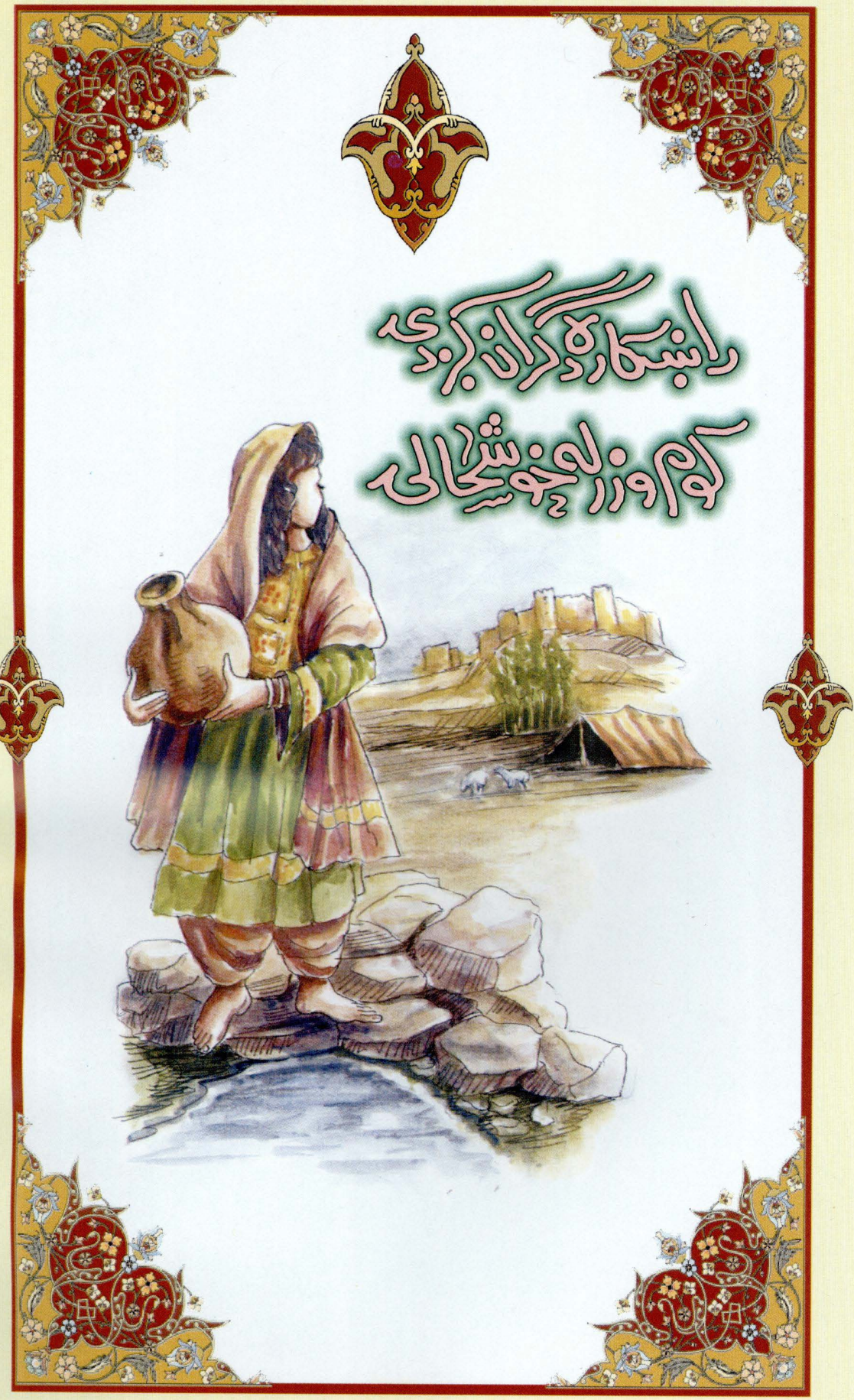




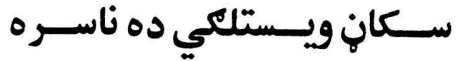
يــــملى مـه د سـري خوله كـه

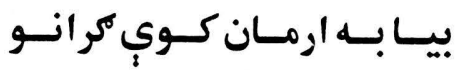

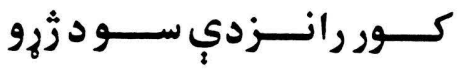
توت در خنهم كه خولجي راورىى

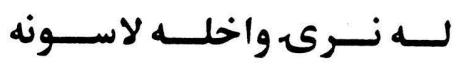

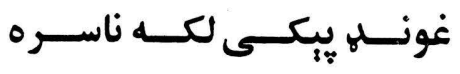

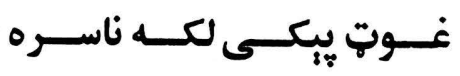
تر خنكس مه ناست دى ارزايل

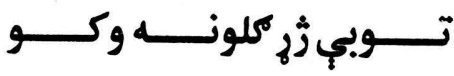

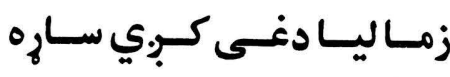

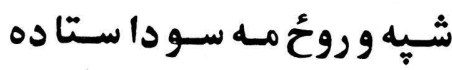

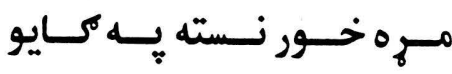

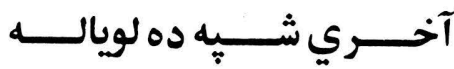

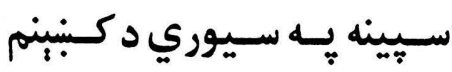
خي بـ زنك واخلي له زيره زما
رايسي وره د تــوى لـهـ سـره

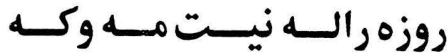
رخــصت راكـــه يــه لاســـو

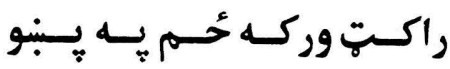

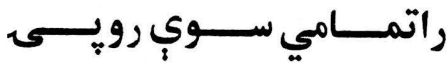

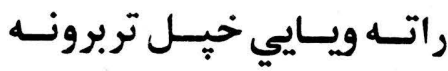

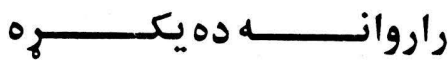

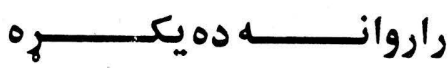

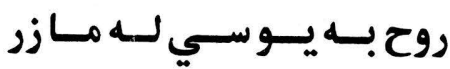

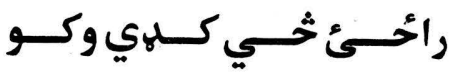

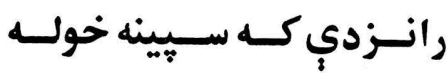

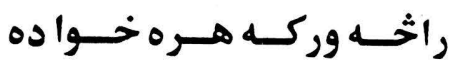

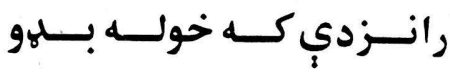

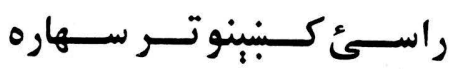

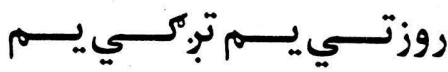

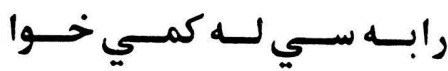




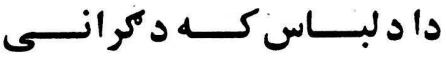

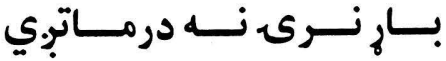

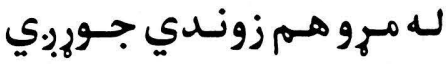

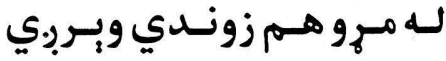

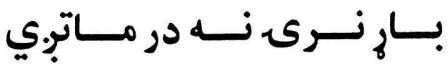

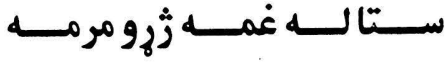

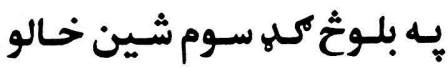

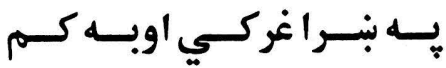

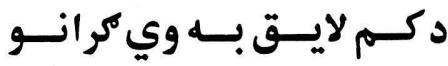

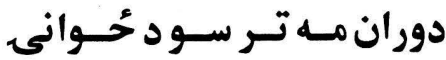

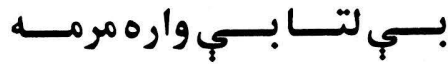
يـروت يـم د غـــــــي يركسالي

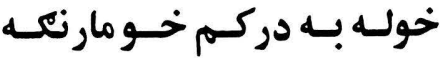

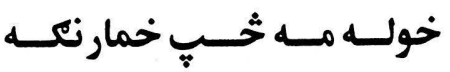

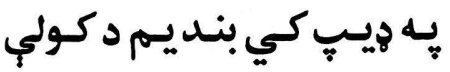

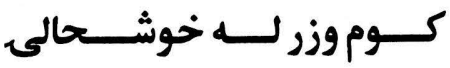

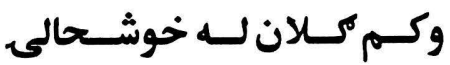
خوب مله دى وبر له خوشحالى وزكسى نجلسى كـوره لـوى زيره

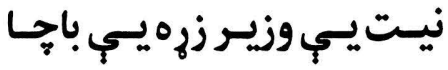
يه ميان كي كرزي بلوخ خان

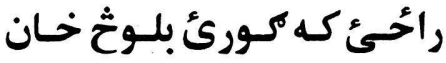

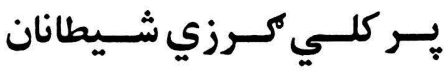
بيـامسكل دى كـه ديـد وسـو

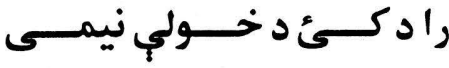

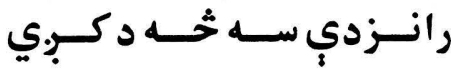

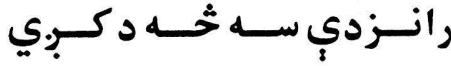

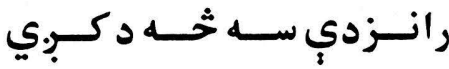

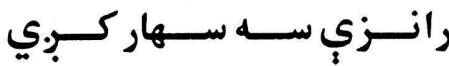

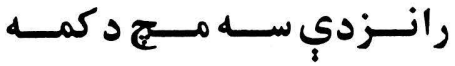

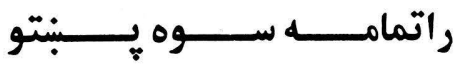

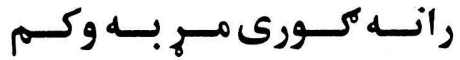

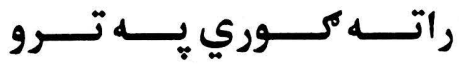

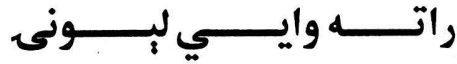

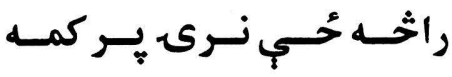

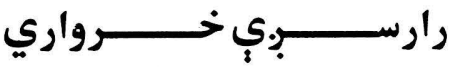

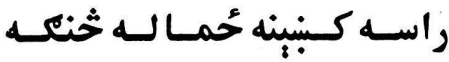

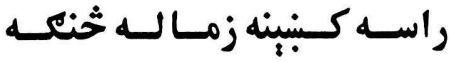

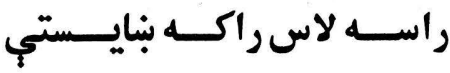

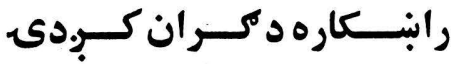

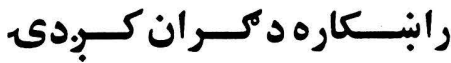

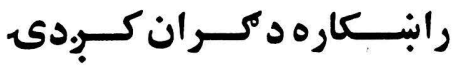

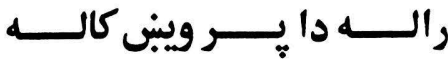

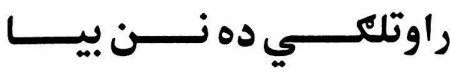

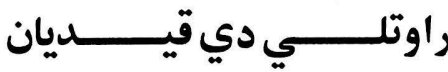

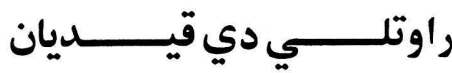

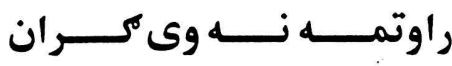
رخـصت راكس بــد مـه زيره سـو 


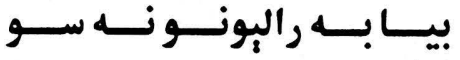
نهلهي تـر مركس لـه مـاخـلاص

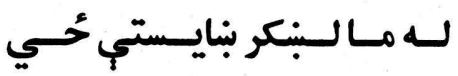
تـر شــوخو سـتركو د جــار سـم رابـسي مـرك غونـدي ظــالم

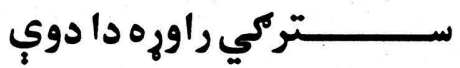

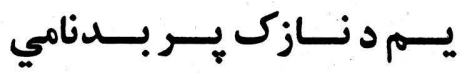

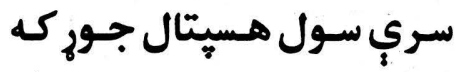

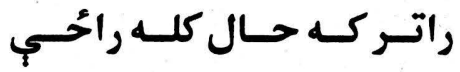

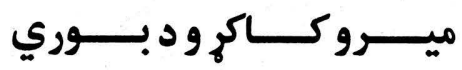
دزوى ميكي زوى سور اور دى

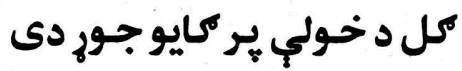
زيـارت كشمير دى كس راحِي

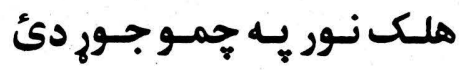

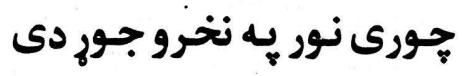

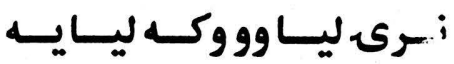
يرتابه خُوك يرئي كي زماسر

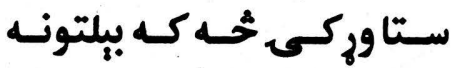

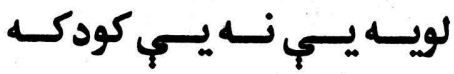
يـهـ تـابـوى دى دمكل بــوري

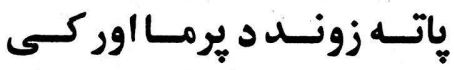

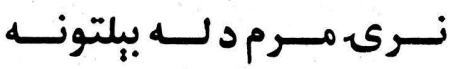

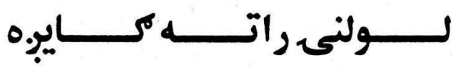
خــواره سـي بيرتـه د يريـبردم
رخـصت راكس بـد مـه زره سـو

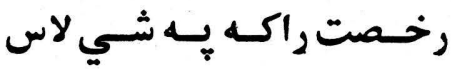

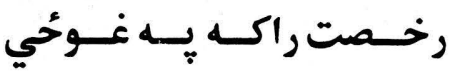

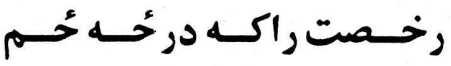
رخسـصت راكــه درئحسه حُحسم

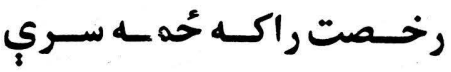

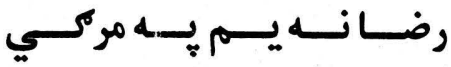

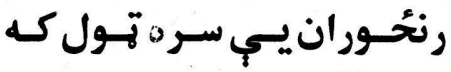

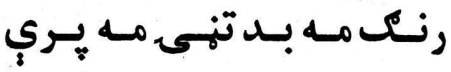

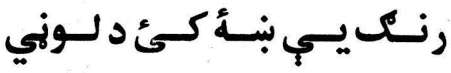
رنك يي مه كوره ثخي تور دى رنك ييج مه كوره ثخي تور دى

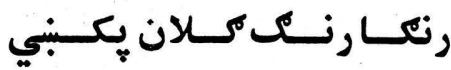
رنكي يجي مه كوره ثي تور دئ رنك يي مه كوره ثخي تور دى

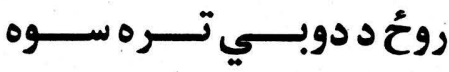

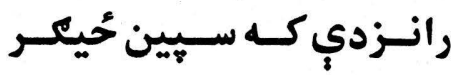

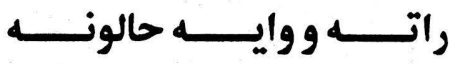

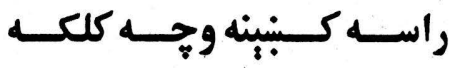

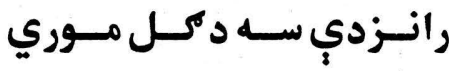

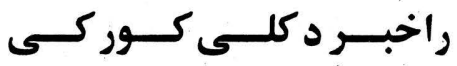

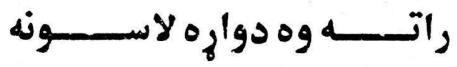

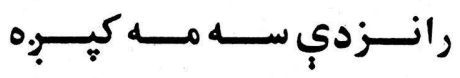

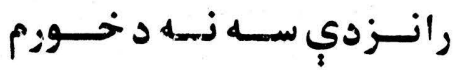


كر ان د خولي هر كايو جور دى

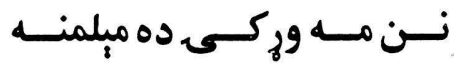

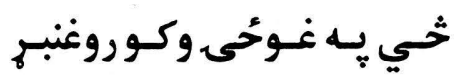

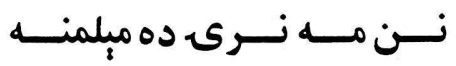

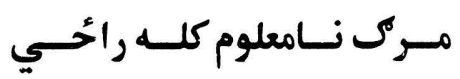

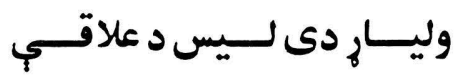

بيا مشكل دى خحي ديد وسي

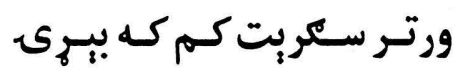

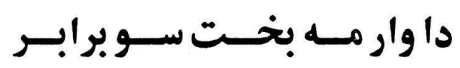

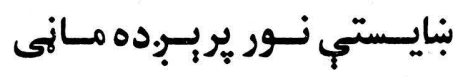
مـاول سـيورمى وختـي دوي

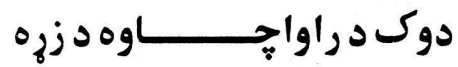

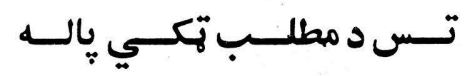
اوس بـي وهـي زمـا انديـنبني

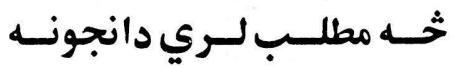

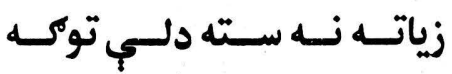

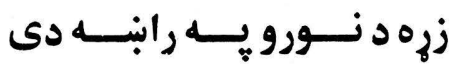

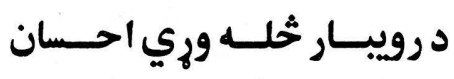

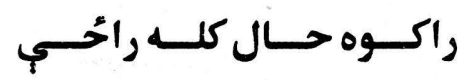

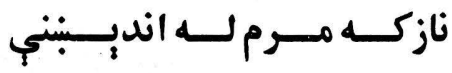
يه خيال كي ورك يم د جانان

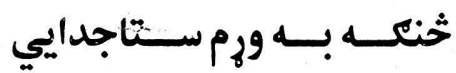
تــارن لــي يوسئ دكسوكى

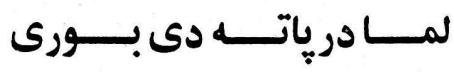

رنك يي مه كوره ثخي تور دى

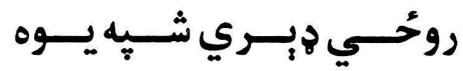

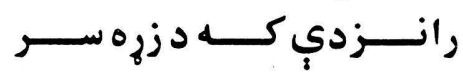

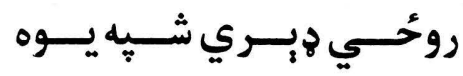

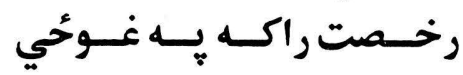

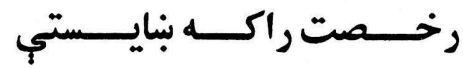
رخصت وركم بـد مـه زيره سي

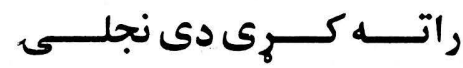

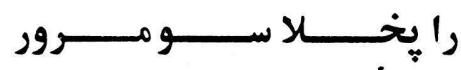

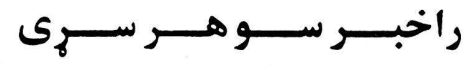
رابــــاره سـوي نجونـه دوري

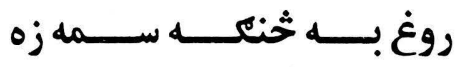

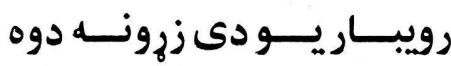

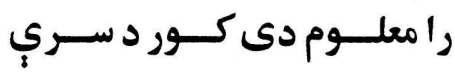

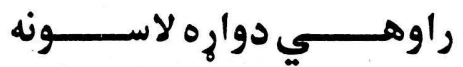

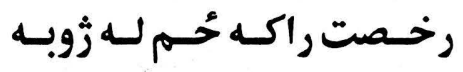

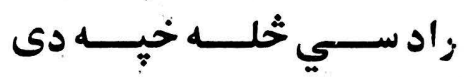

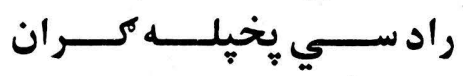

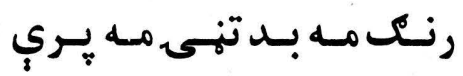

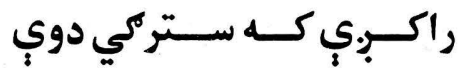

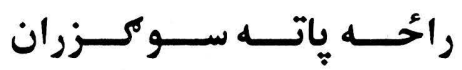

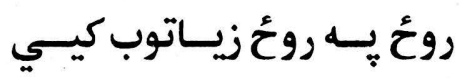

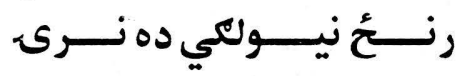

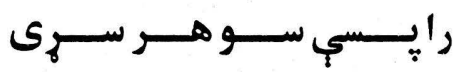




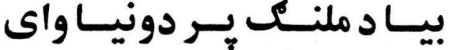

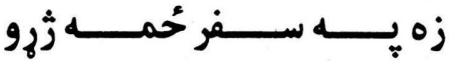

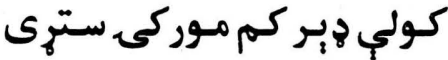

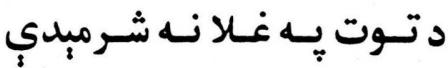

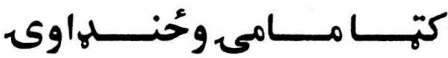
يبسلمى مه د سري خوله كئ

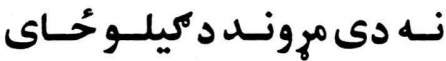
يـر مـاواجـب ديى دمكران نـاز

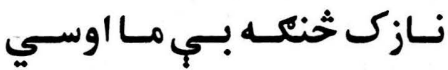

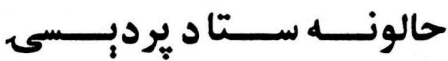

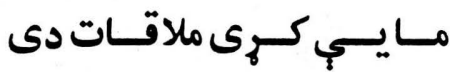

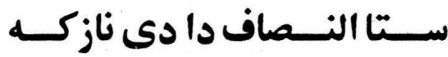

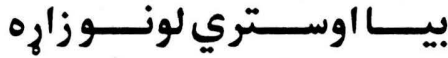

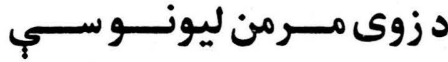
خيـل همزولي دمكران يـوكي سور جار كل يسي بـه ماينوكي

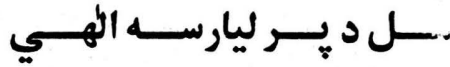

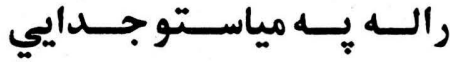
نرى نسواك مـه د خـولي كه قمـيس د كـران بـه خولـوتـور

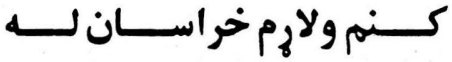

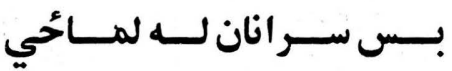

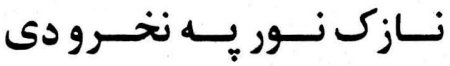
كران د خولي بير كايوجور دى
راســــره واى ســـتاكر انســى

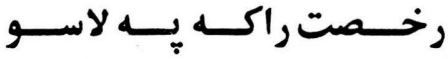

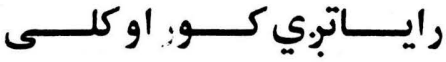

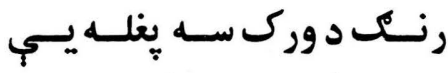

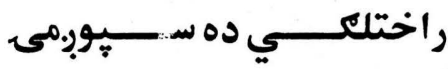

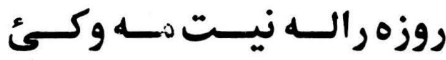

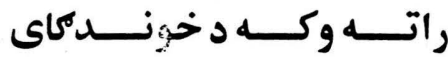

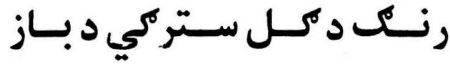
رى وهــم اونبـكي مــه توسـي

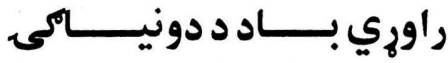
رنك ريب زيات تر كل كلاب دى

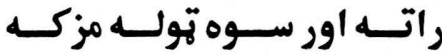

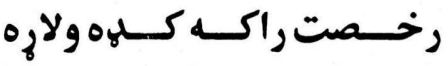
رابخــي كــه جـــاى د بـــري راتــهــــوري يـهـ مــاينوكـي راتـــه كـــوري يـــه كجوركـي

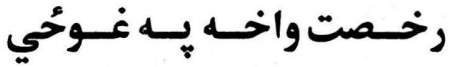
رخــصت اخــي نـازك حُــي

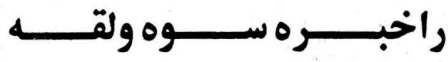

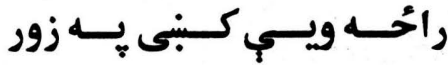

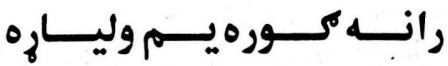

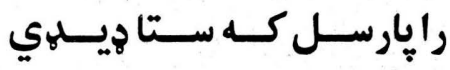
رنكسيب مه كورى خي تور دى رنكي مه كورئ خي تور دى 
نــــــــ دى دالان لونــــوتنــــــ

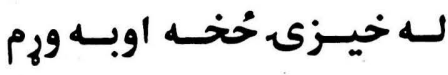

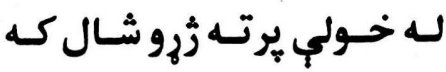

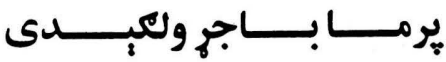

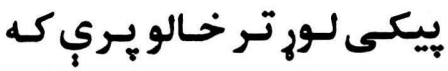

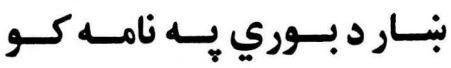

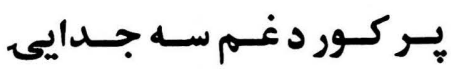

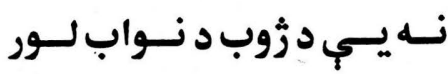

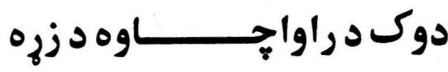

نــامردي مـرم لـــ يرديـسى

ارمــان مـــه دى ســتاغوحَى

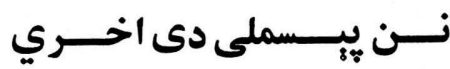

حُم كر اجسى لـه سـار وختسي

بيــــاو ســـتري لونــــــوزارهـ

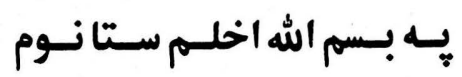

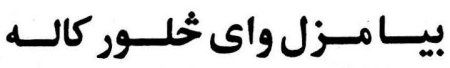

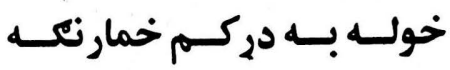
تـر واوره سـيـينه ده سـتا خولـه

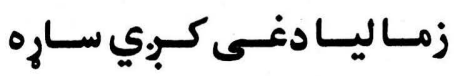
وروريسي وزيــ بـلاريسي باجـا

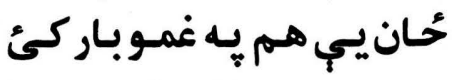
تيـاسـمانيـي كسئ راكسبته

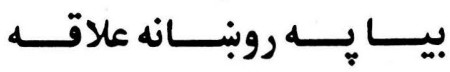
خوله ديري يُكي خي بور وركم

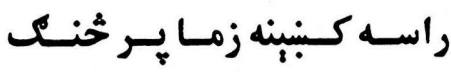

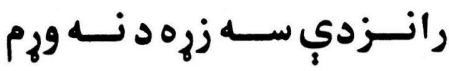

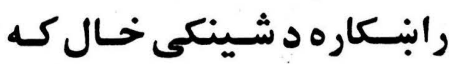

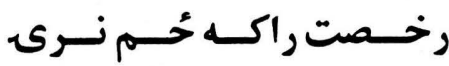

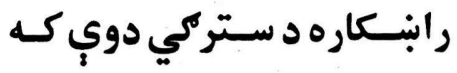

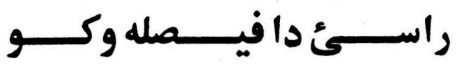

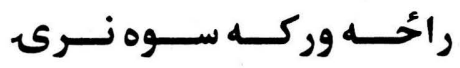

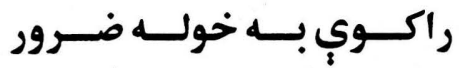

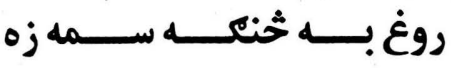

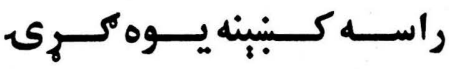

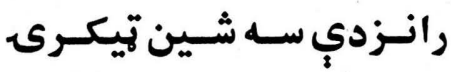
رخـصت غــواري زياتـهـ حُحسي

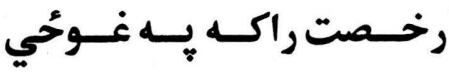
رخـصت راكـهـــاهى ولاره

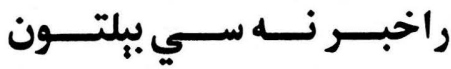

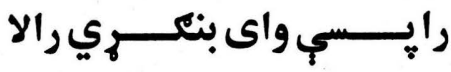

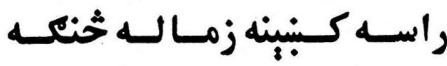

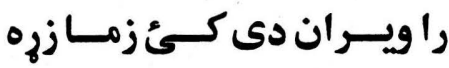

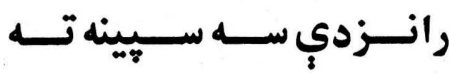

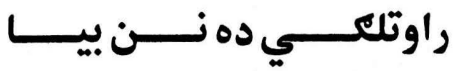

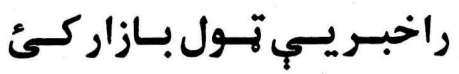

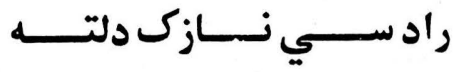

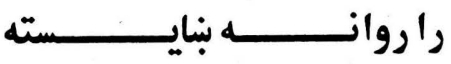
رادسـي ور جــار بـهـ سـر كـم 
بيـا سـهار كنبنـــاى نـهـ سـو

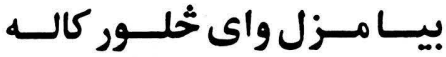

يـر مـاواجـبـ دى دكـر ان نـاز

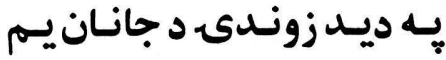

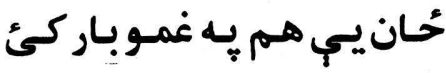

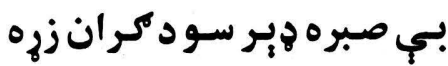

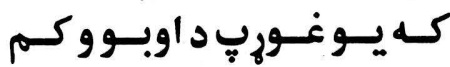

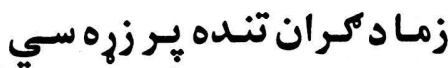

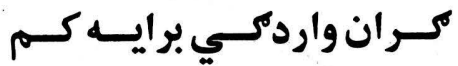
يـر مـاواجـب دى دمكران نيـاز

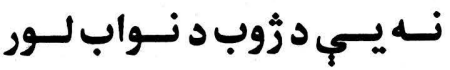

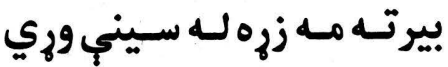

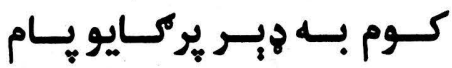
زره د غـرق لـه غمـوز زمـاكـئ سيور.مى ستار نكه حُان جوركي

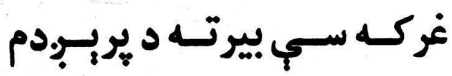

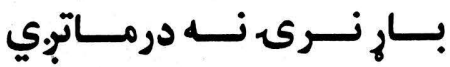

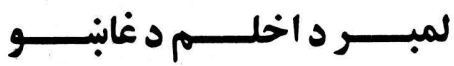

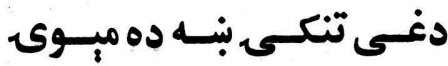

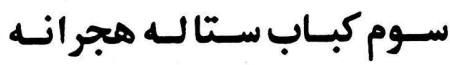

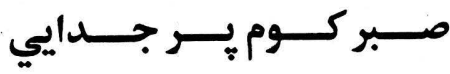
ير تابه خوك يري كي زما سر

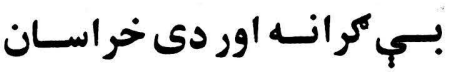

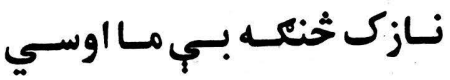

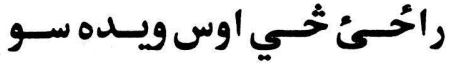

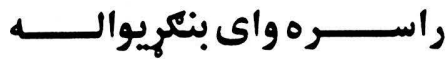

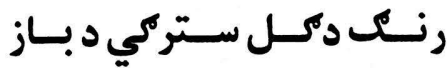

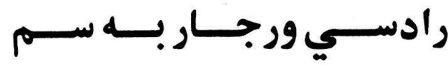

راخبـريسي تــول جهـان كـئ

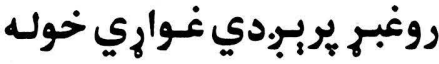

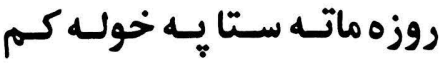

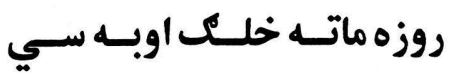

رالـى ويـبنه يـي يـــ شـيه كـم

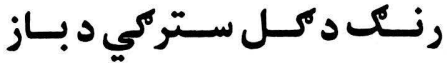

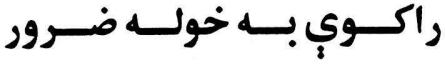

روحُ يـــه روحُ كرانسـى كـــوي

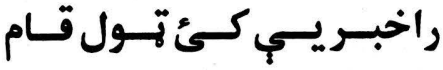

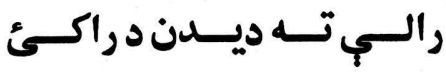

راختلكسي ده يـهـ شـبول كي

رانــزدي ســـه نـــه دخهــورم

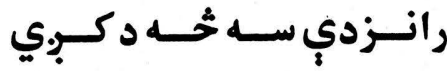

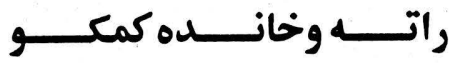

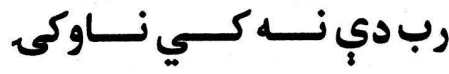

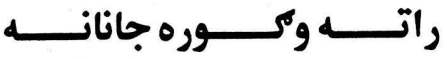

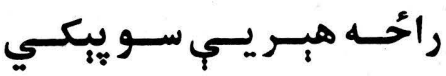

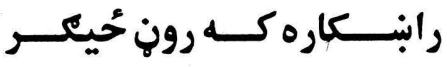

رامعلــوم يــي ســوئ ايمــان

رى وهــم اوبنـكي مـــ توسـي 
وزني مـه خلكـ ستا يـر يـاري

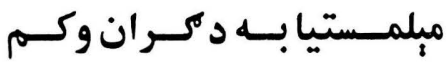
خـداى د تـاورك كي بيلتونه

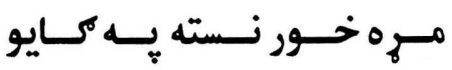

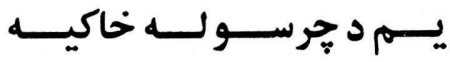

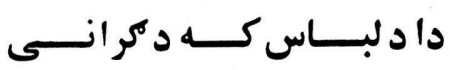
خلكـو برئبر.دى نـه سهم جانـان

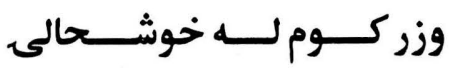

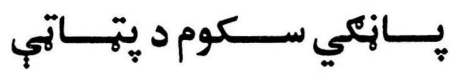
بيـا مـشكل دى خحي ديـد وسـو نه يـي تر مركه لـه مـاخـلاص

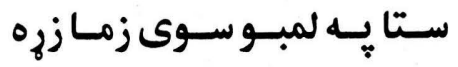

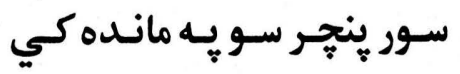

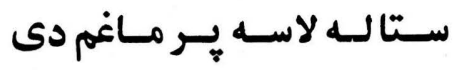

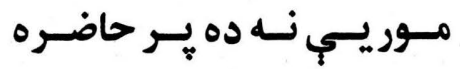
خلكـو يريـردى نـه سـم جانـان
راوزه لاس مــــــهـ راتــــــــي

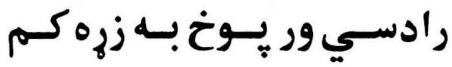

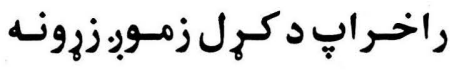

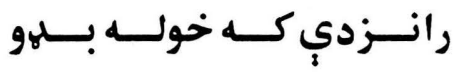

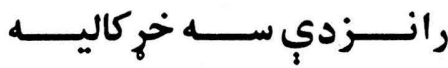

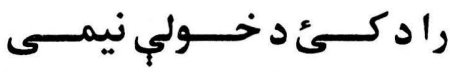

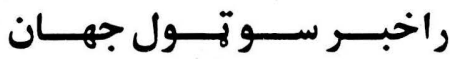

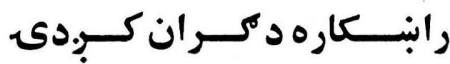

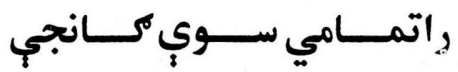
رخـصت راكـه بــد مـه زيره سـو

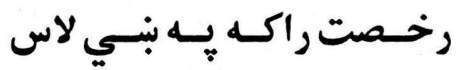

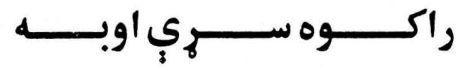
رسك مه نسته ستا يه خوله كي

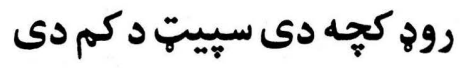

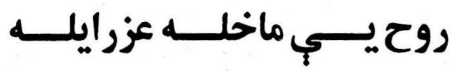

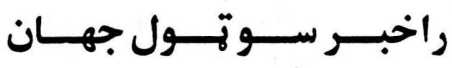




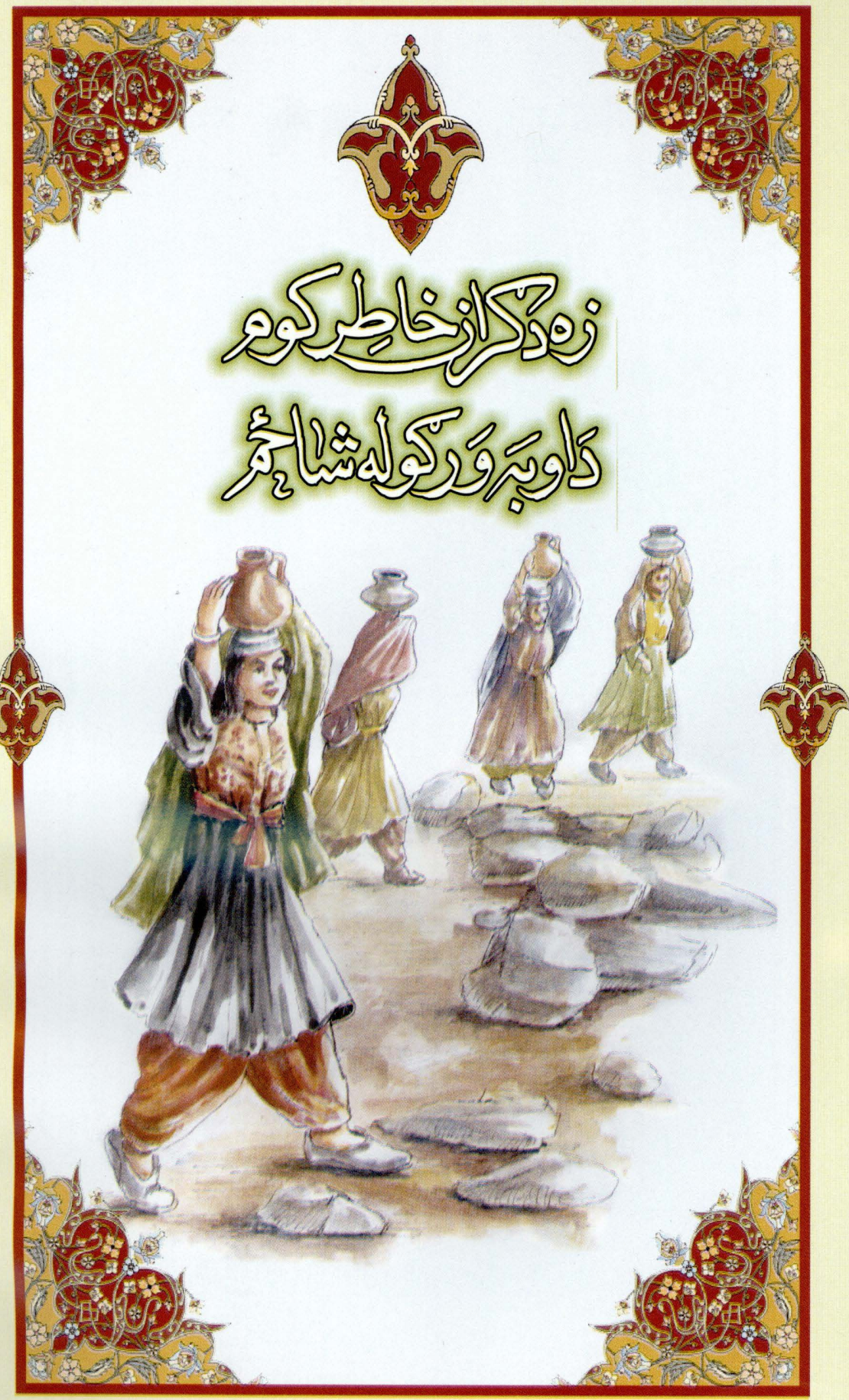




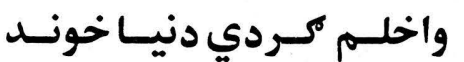
خوسكي بيسب هاكتران ووري بي باكه غـابن سوله تـاسيّين

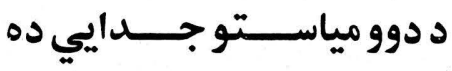

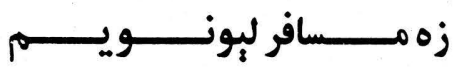

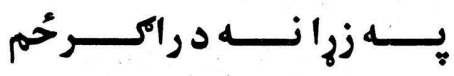
سوى واى كرد خوسكاره سوم دوجي درختي :يه شان سي وركــهـ سـي بــي وفيـايساري اوخــري حُحسان بــي وفـايـاري

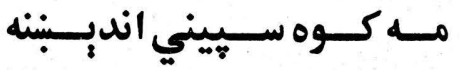
حال بي خُوك راله معلوم كي

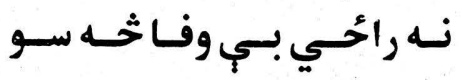
برتاكيّام دير كران دي كالي

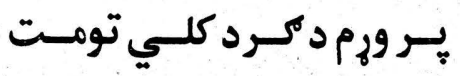

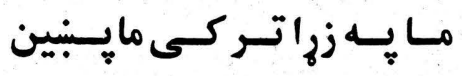

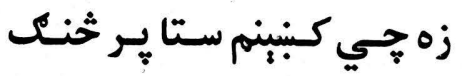

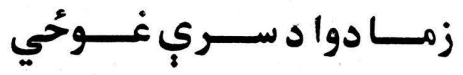

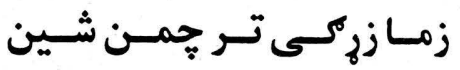

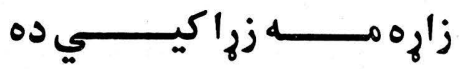

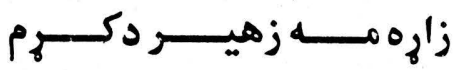

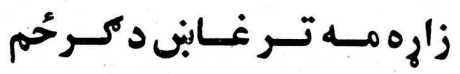
زه د ســري يــــ لمبـو وســوم

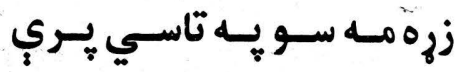

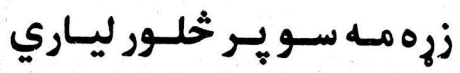

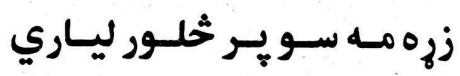

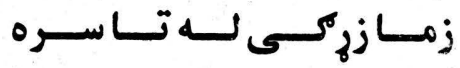
زه يه زوبك زمي سره يه بنبين زمــا بـ ســركو تــور اوبــهـ سـو

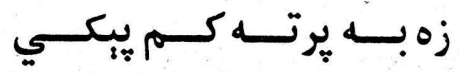

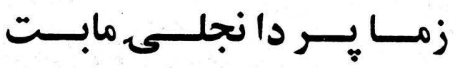

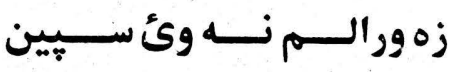




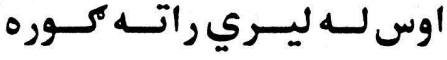

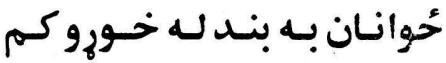

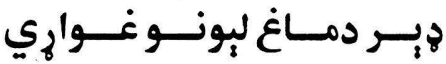

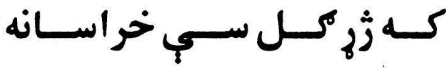
كـه جنــت سـي د يـلار كـوروه

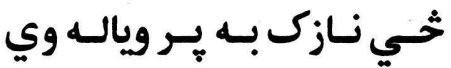

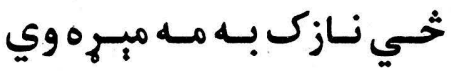

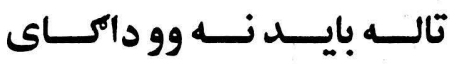

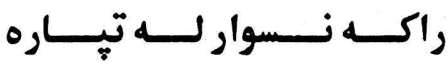

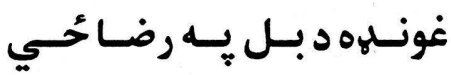

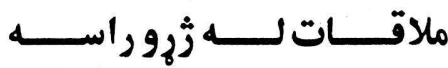
مثل ور ورئ دمكور خـولي لـ

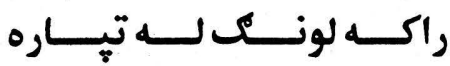

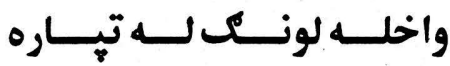

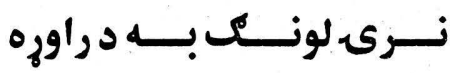
خبر خي سوم ستاله كوزدي

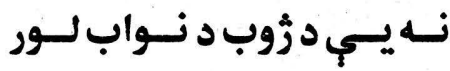
دوجي درختي بـه شان سي

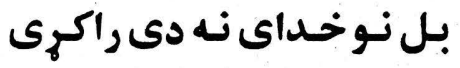
كـهـ شـيه و روحُ اوري بـــاران

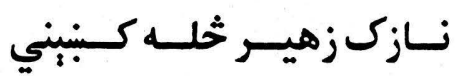

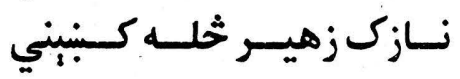

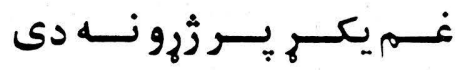
بسي اكسه جـــ دي د نـازى
زه زيـي بنـد كـم سـتالـه كـوره

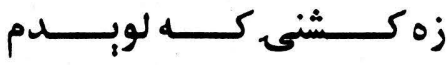

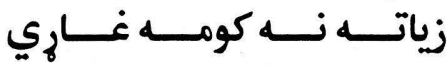

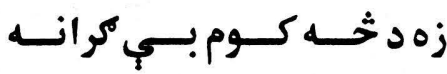

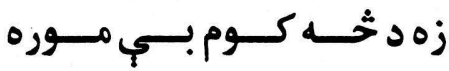

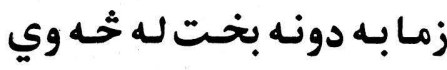

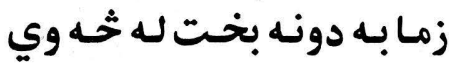

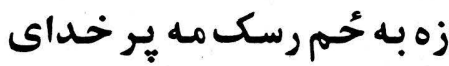

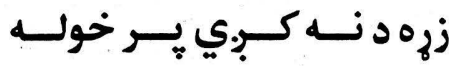

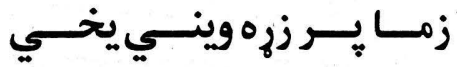

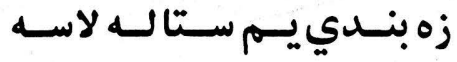

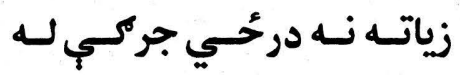

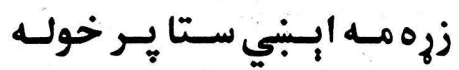

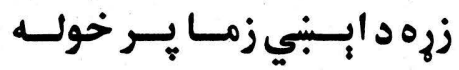

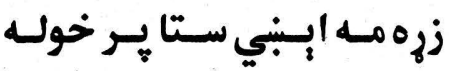

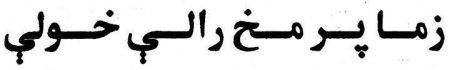

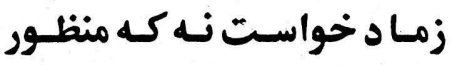

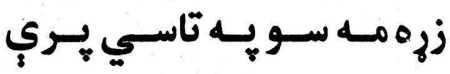

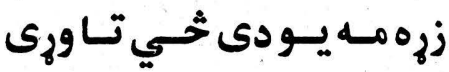

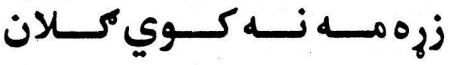

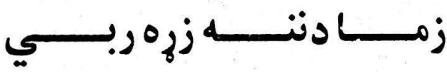

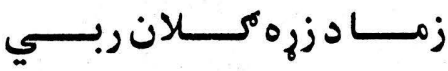

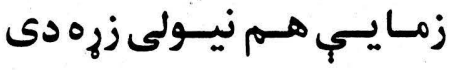

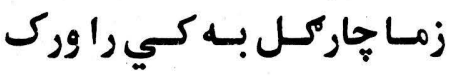


در خـور جكــن كـم كـه سـاده

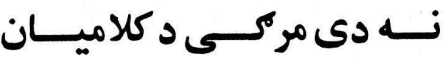

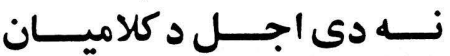
ســـوبـمى نــه وري ســلامونه

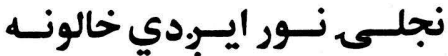
خلــــ خوشـــــاله دي كنـــــ

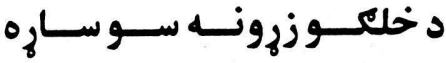

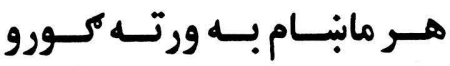

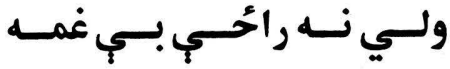

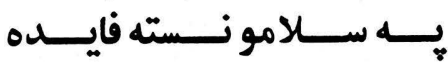

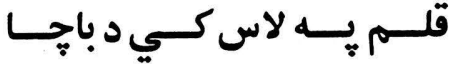

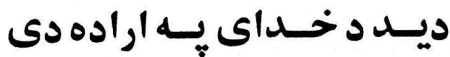

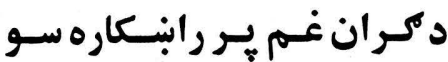

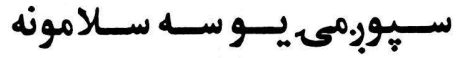

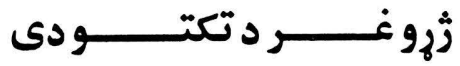

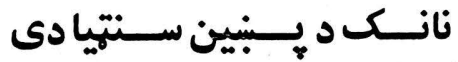
خـــي غلـط مــه نـه كـي بـوري كه تـور غـريجي شـنه وابنه سي

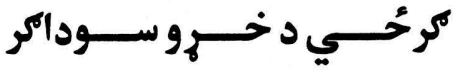

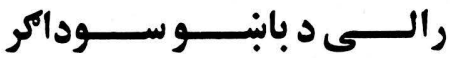

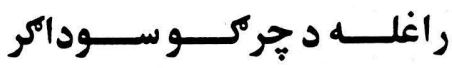

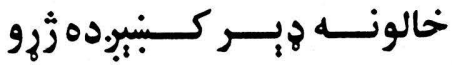
كــــان دكـن غـورزان كـوري

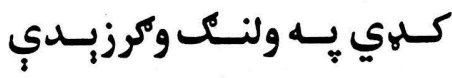

زمــا بــر سـر دي تيكــــي دوه

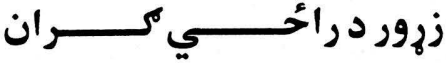

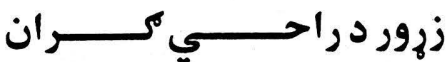

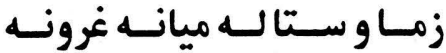

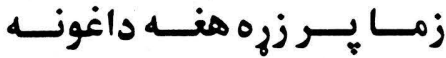

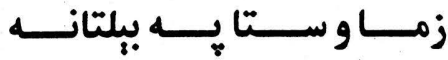

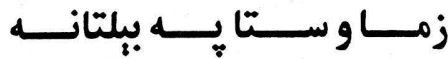

زمــاو سـتايـاري :ـــ سـتورو

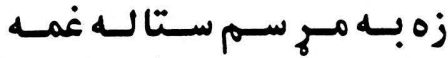

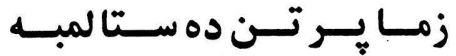

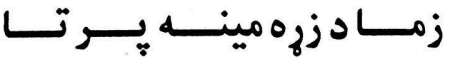

زه درحكـم نيــت مــه دغــه دى

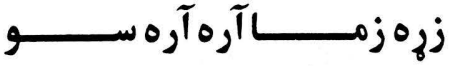

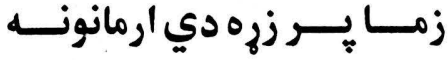

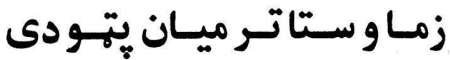

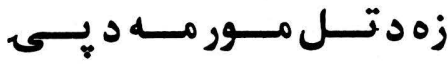
زمـورو د دوارو ســروى تـوري زما د كر ان لله جـوري بنه سي

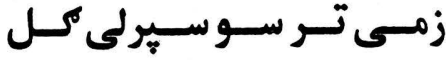
زمسـى تـــ سـو سـيركى كـل زمسـى تـــ سـو سـيرلى كـل

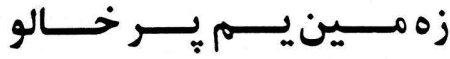
زمــور. د كلـي سـيـى خــــروي

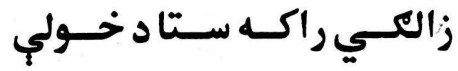


كاكرى غاري

ديــد دخــــاى يـــه ارادهدى دي

تــهـ ويـايــاروصــوبداريسـي

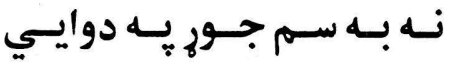
مـهـ سـي منــروره يـهـ حــــواني خلـك واى نـــوره ده نــاجوره

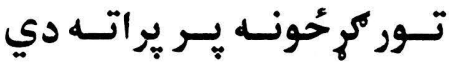

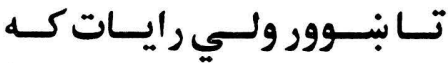

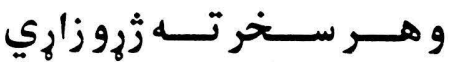

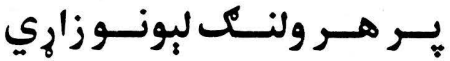

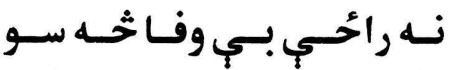
ســوحم يـــه دم لكـــه لالتهـين

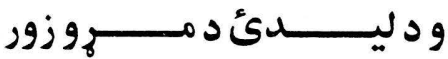
كـل بخــوا وختــي ليـانـواري كران يخـوا وختي ليـا غواري

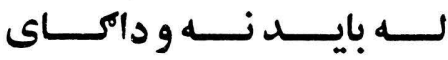
دجب دسمال نه دى خي ورجم

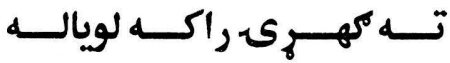

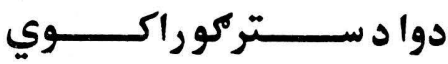

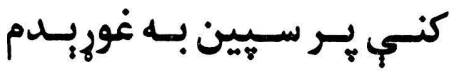

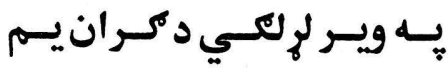
د خداى روى دى كه به زارئي

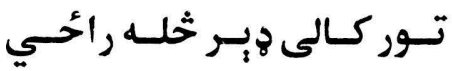
ور بي كم كه د دكان خوبن دي مجــــه دوروو واخلـــي جانــان
زم درحُهم نيــت مـه دنهـه دى

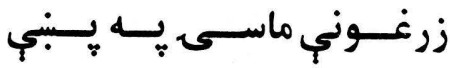

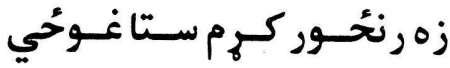

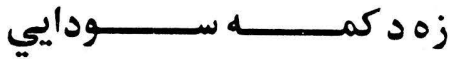

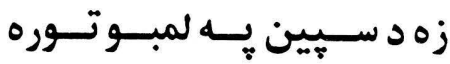

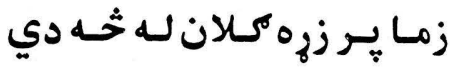

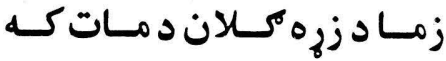
زمــاكر انسى لـهـ بلـه غـــواري

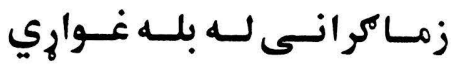
زمــاد سـتركو تــور اوبـهـ سـو

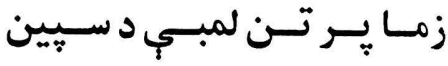

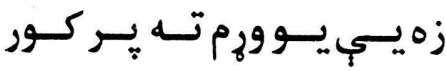

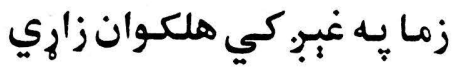

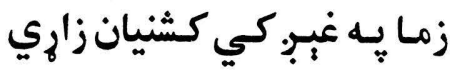
زمـايسي هـم روزي يـر خـداى

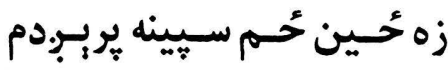

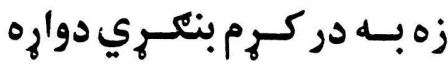

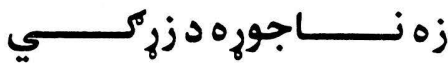

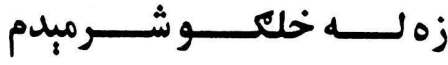

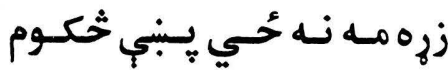

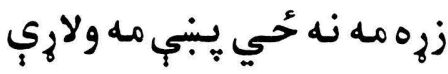

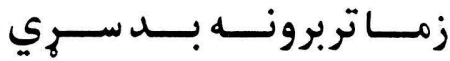
زمــاخالونــه لــنبتي، لـــنتي

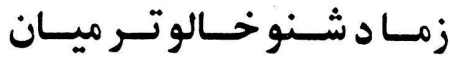


riq كاكرى غاحي

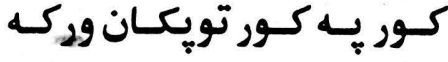

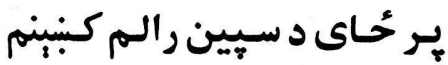

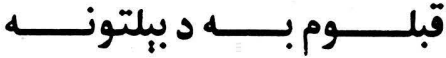

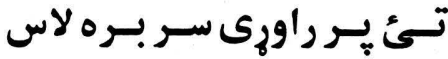

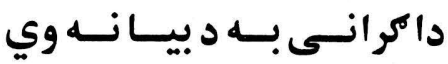

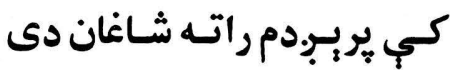

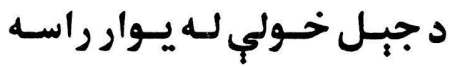

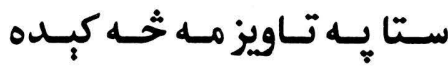
خولـه راوري كـه د سـيالي ده زما بهـ زوندكي به نوخحه وي

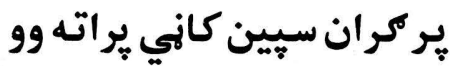
خوك بي راوري د غرو تهوكي خي خاندي يتّيب كي كرانو

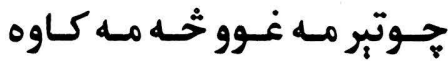

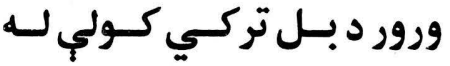

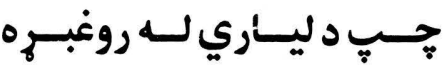
خــولب لـه بـل انسلهيوال كـوروه خـولي له بـل انهيوال غـواره ليـاري كـبري سـوي د جانـك

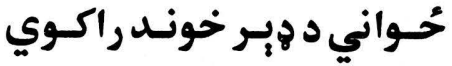
خــي سـتامسخ تـهـ مـه كتلـهـ ســـوربمى نــه وري ســامونه

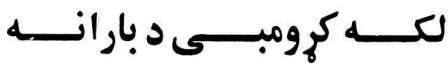

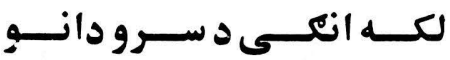

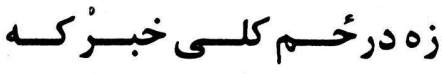

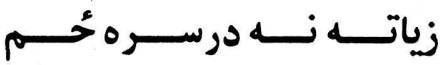

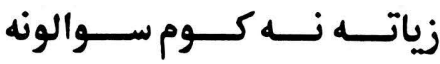

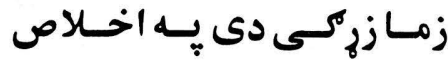

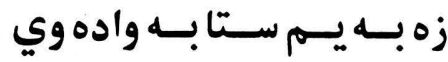

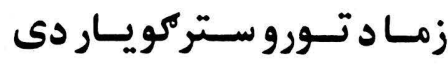

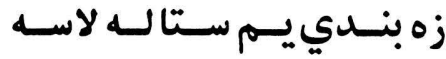

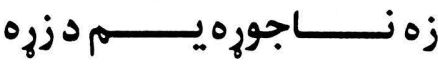

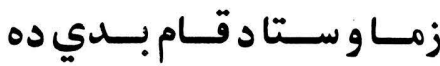
زه بــه ورسـم كـران بـهـ نـه وي

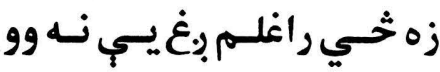

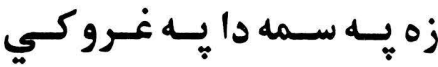

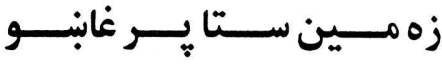

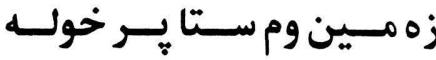

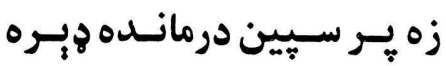

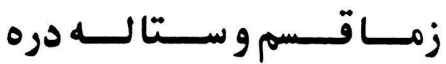

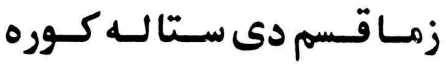

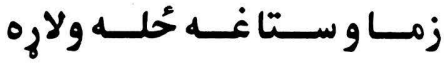

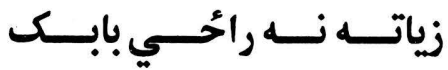
زه زد جــار ســم تــــــــــواني

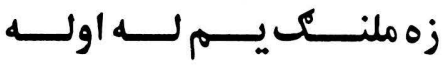
زه بــــهـه ور كـــــم ســــلامونه

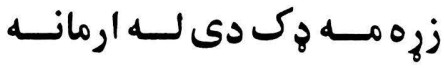
زره مــه هـ دى لـه ارمـانونو 


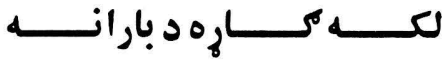

كــــــهـ و روحُ اوري بــاران

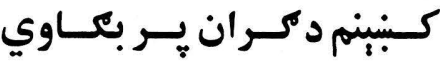

ير جورى بـ د سات تـبر تخروي

شـين تيكـــى درختـــ بالايسه

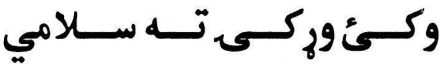

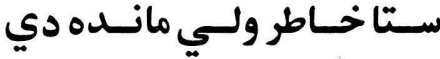

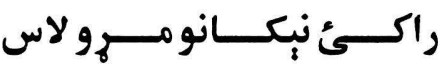

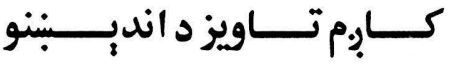

خي ستا ير مخخ اوبنكي راحُي كران خي حُي منخ د راكورب كي

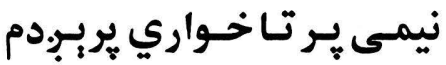

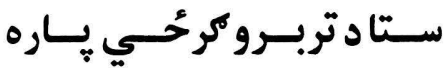

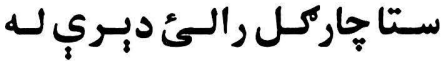

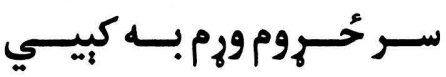
د خداى روى دى كه به زارئ خـــور بــــ لاس خخنهـــه راوري

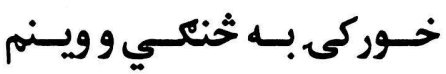

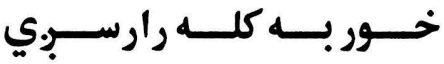

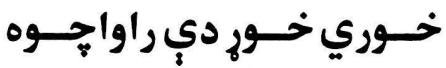

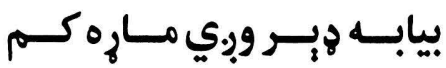

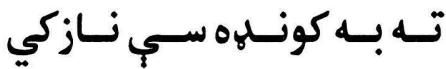

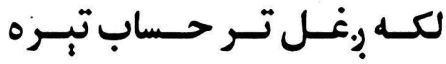
اوس دورم تـوري تيــاريلـ

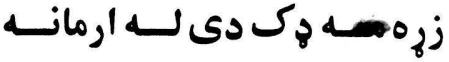

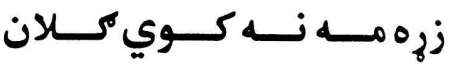

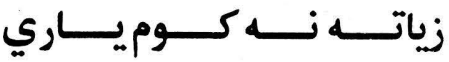
زمـاكر انسى بـه د خــود وإِر وي

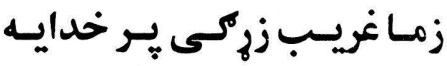

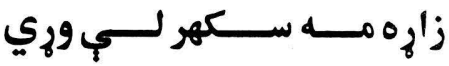

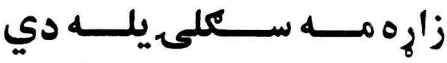

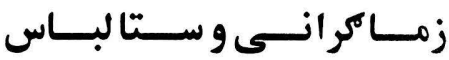

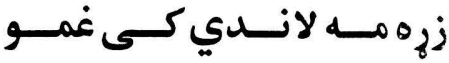

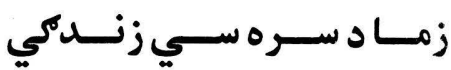

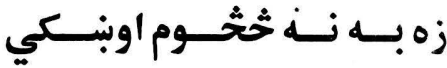

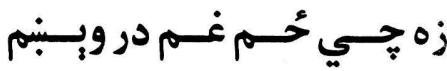

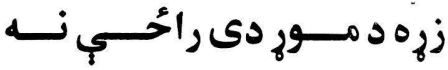

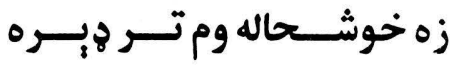

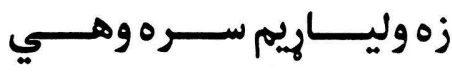
زرهم مله نه حُحي يبني مه ولاريخ

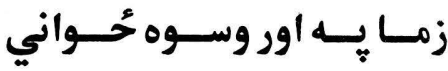

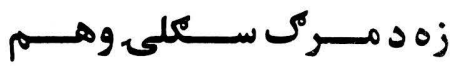

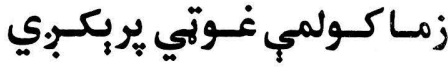

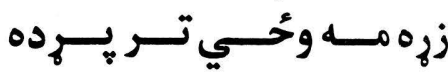
زه خي خيل كشنيان ويده كم

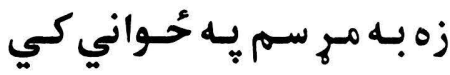

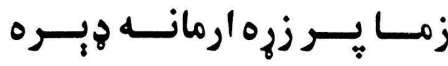

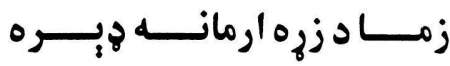




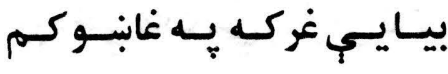

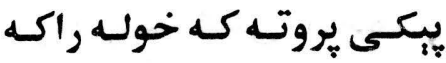

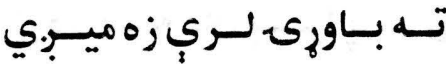

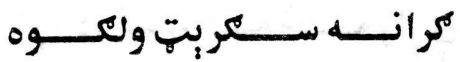

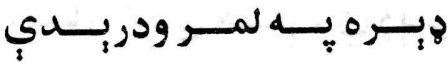

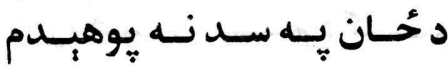

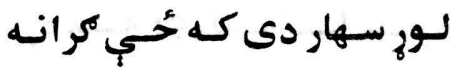

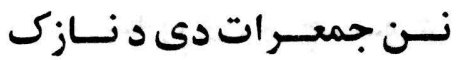

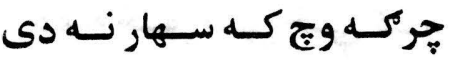

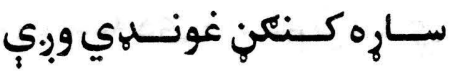

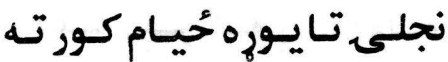
نـازكى مـه نونسئ كئ يـهـ بـاران خـي ســـ ولار سي تـر اووله

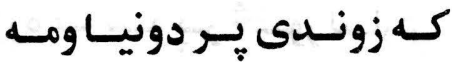

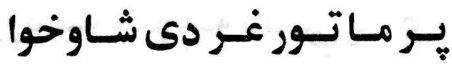

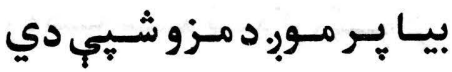
يسه اور هــم در كلديــداى سـم

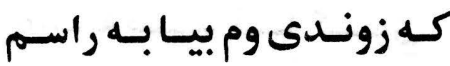

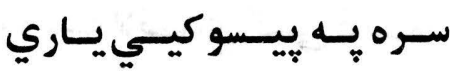
دمركسي روحُ نـــه ده بنـــكاره ملنـــ مــات د ســـ كجـكــول

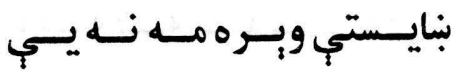

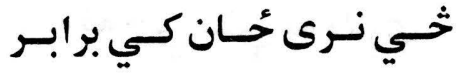

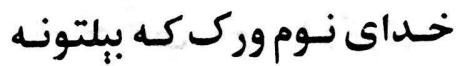

زهيــوه وم دوى يـــه دووكسم

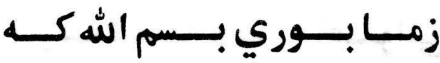

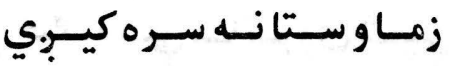

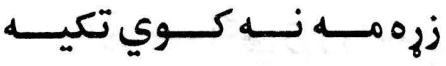

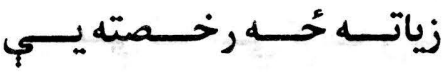

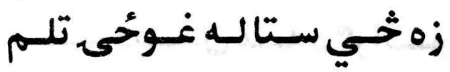

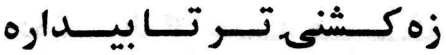

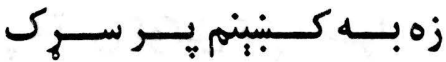
زما يه غبرب كي كران ويده دي

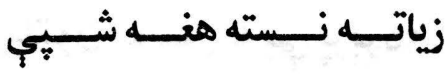
زمـا ائينه يـه ليـار كي يروته زه ويـــده وم اوخــــورم حئسـان

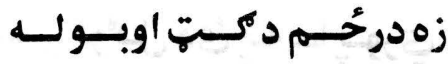

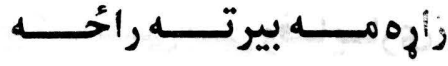

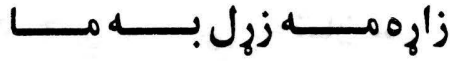
زارهمـهـ سـتركي د سـري دي

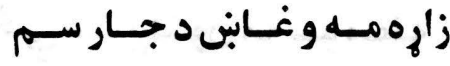

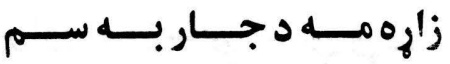

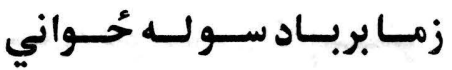

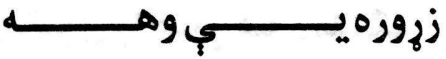

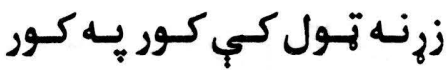

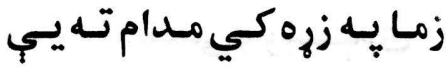

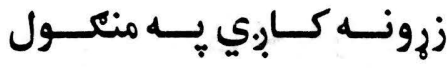

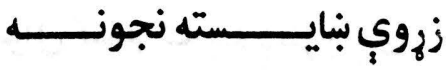


كــه هيــر وس بـــر دنيـاوكي

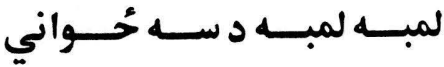

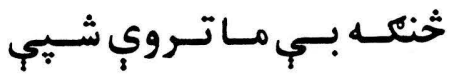

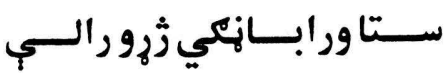

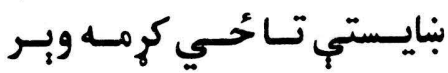

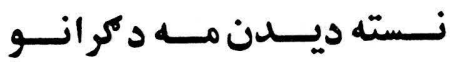

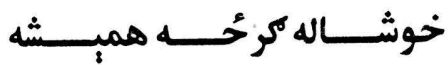
بـه تـس كوكـل كـإِم خــواري

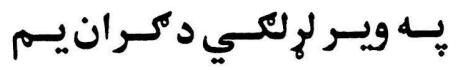
بيلتون يوليس نه يب بريبردي ثـي سـتابنـد سـول سـلامونه دكسور مركسي لسه بسي ورئسـ تسـس كوكل دئ بـهـ مـا يـوري

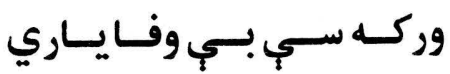
دوجي درختي يـه شان سي

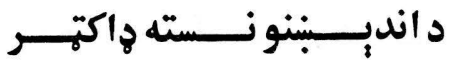
خي ستابِتــون مه سومبمله

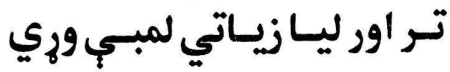

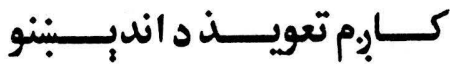
كجِكـول راجـور كـهـ دملنــك نن ير دراوى غوارم ستا خوله

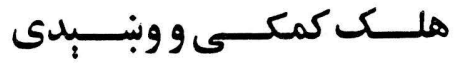
دخداى روى دئ كه به زاري

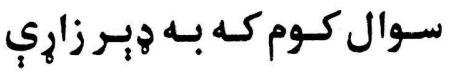

زره خي مات سي روغ بي نه كي

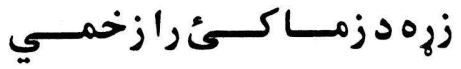

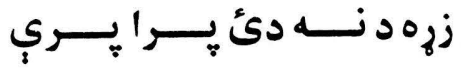

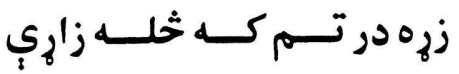

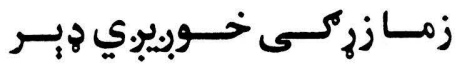

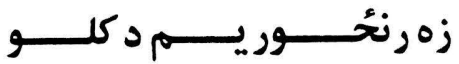

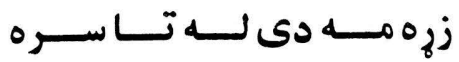

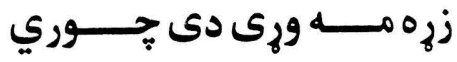

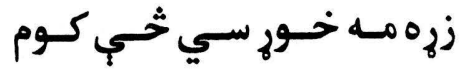

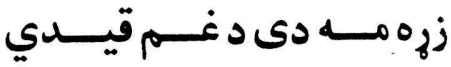

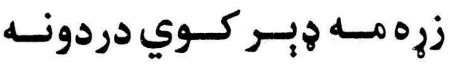

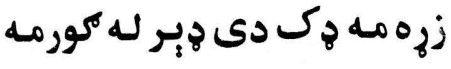

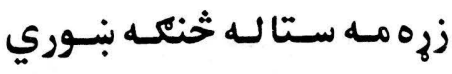

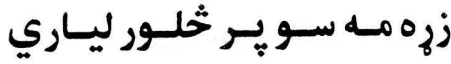

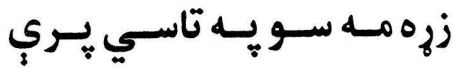

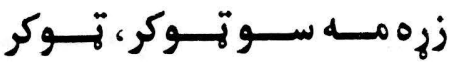

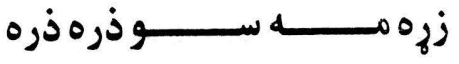

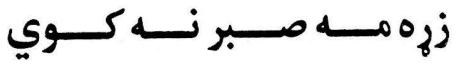

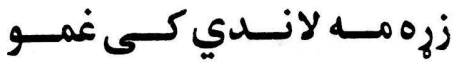
زرهم مـه لانسـي كـئ تـور زنـك

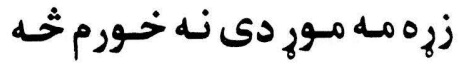

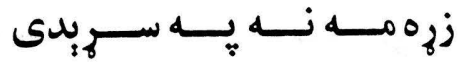
زرهم مه نه حُحي ينبي مه ولاري زره مله نه حُحي يبني مه ولاري 
يـوخــوشيب راكه ستاوالي

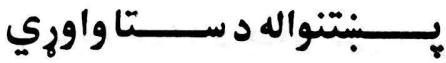

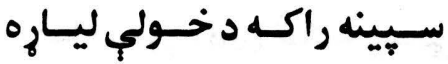

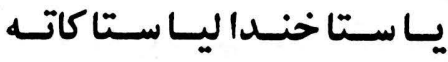

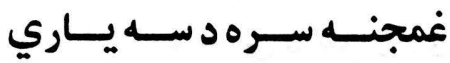

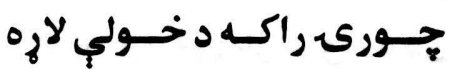

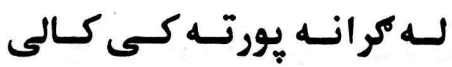
تــــ اور ليازيــاتيلمبــي وري دويسم خــداى نـه دى راكرى خــداى بــــ كلـه سـي مهربانـــ اخلـي رخـصت سـره لـه ترلـو

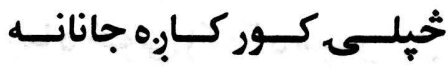
خداى د مردارهكي ستامور

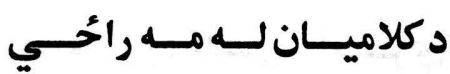

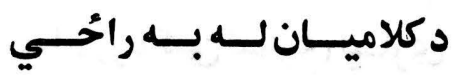
نــــته عــلاج ســتا د مــاني ثخي ستا ير منخ غوبني راحُي

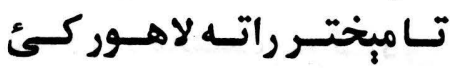

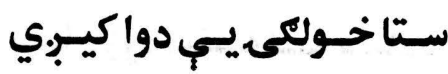

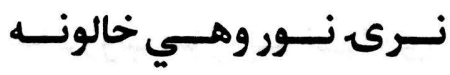

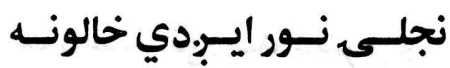

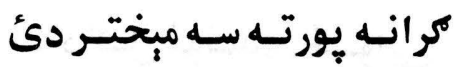

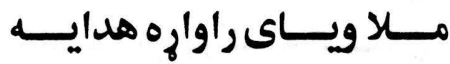

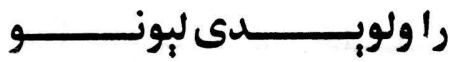

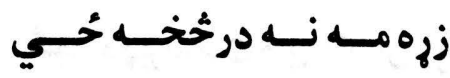

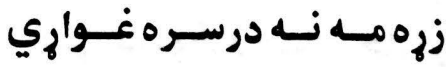

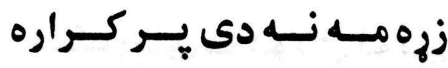

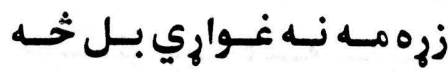

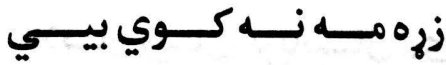

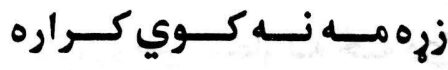

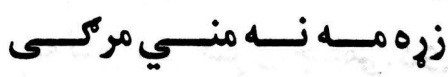

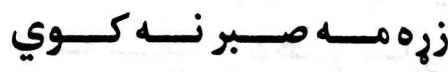

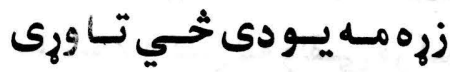

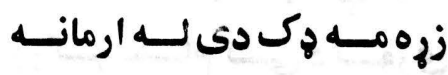

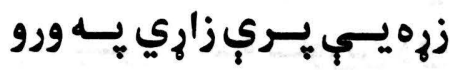

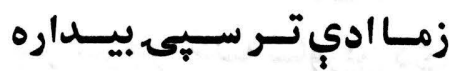

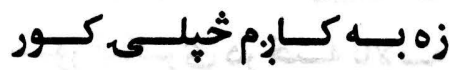

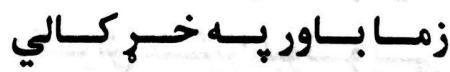

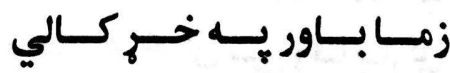

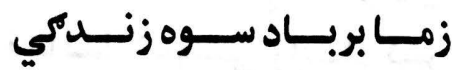

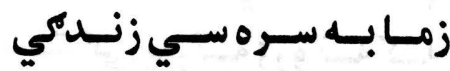

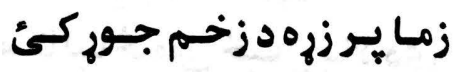

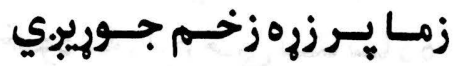

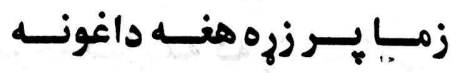

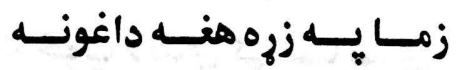

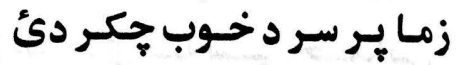

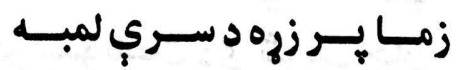

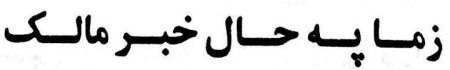


خومره هُبر سخت دى دمكرانزيره نه يب يه رؤح د حساب خلاص خلكس وياى ماكولاى نـه سي

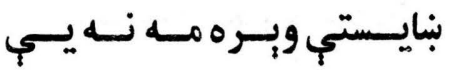
ملايسـان ويسـاى بريانيـان دي ادي روكي سـهار نـه خــه دئ يسه تـور سـر خـري جـامي دي

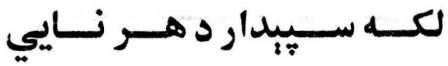
نـازك مـه كـئ لـه ولقي وركى

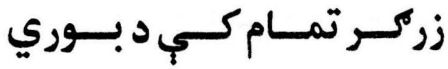

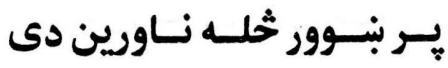

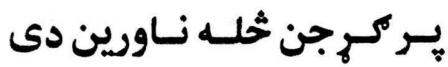
ســور تيكــى درختــه بالايسـ

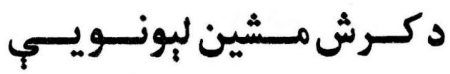
وخــوري حُحسان بــي وفـايـاري

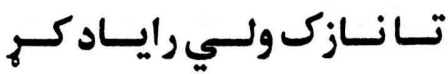

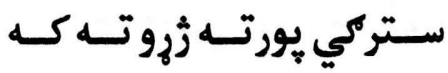
ستاليـاخــوني خيـال بـالا دى

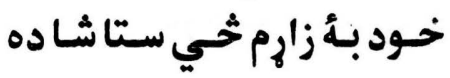
نرى كبنل مـه كه وار ستا دى كه خوبٍ لاندي كئ ستالورى

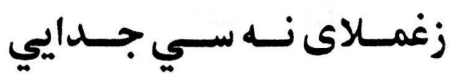
ير بيتو ناست دى شريف جان

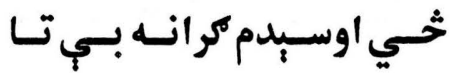

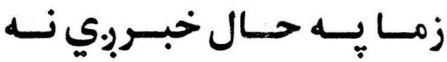
زما يـه خوله د جـك كسئ غـابن

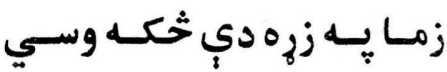
زما يسه زره ككي مـدام تـه يسي

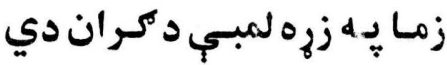
زما يه غبرِ كي نازك ويده دئ زمز يه يار كي نخبني دوي دي

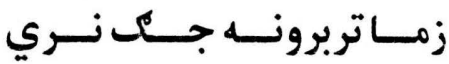

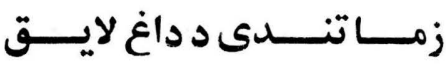

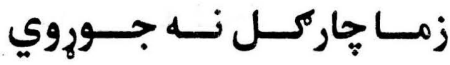

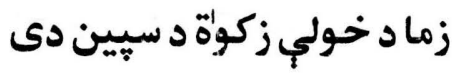

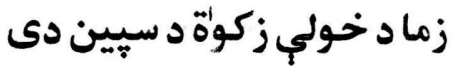
زما درسك زحين كم كئ خدايه!

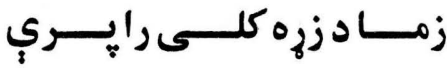

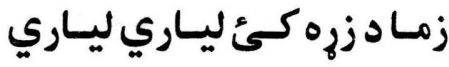

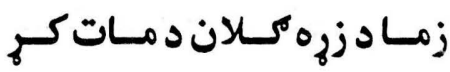

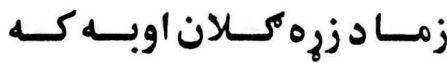

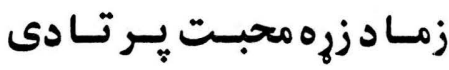

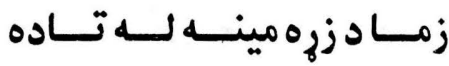

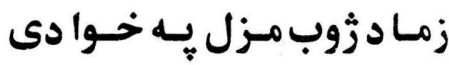

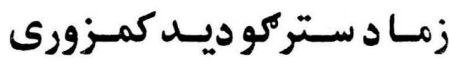

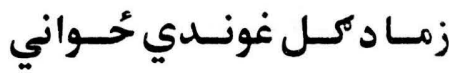

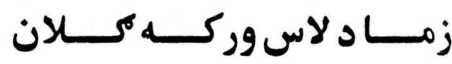

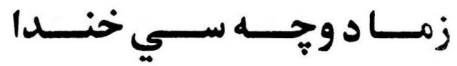




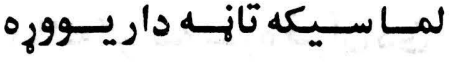

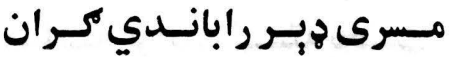
تسور سـتركي وابسه خلـي ازار

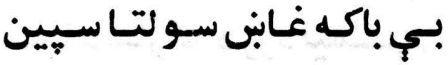

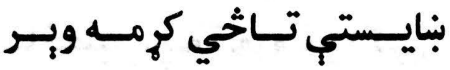

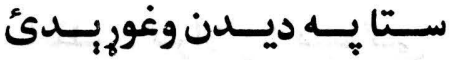

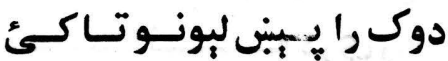
غـوتَ بـكَى بنايستَ سـتركي سـتركي كـولى د نجلـــ دي كـران بـه خــوى راحَـه كـايبري

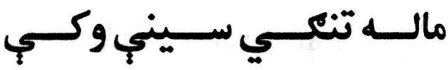
زمـا بـه وروريسج كيامسه كى جـورى بـل :ــ دونيـايـار كه كـه دواره غبركسي نـه راتلــي

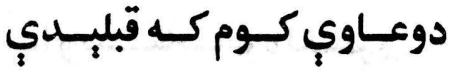
يه خهل تهّي به د سات تِّر وي تـور سـيـعل تـر بربنـاتيز دى ته •ـهـ مـوتر بسه د سـات تيـــ وي

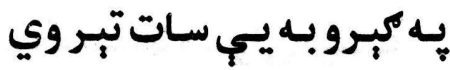
ستا انساف ثحوني زور راكئ سـتا انساف برخي زور راكئ دى لـه ميلـو نـه دى راخـلاص

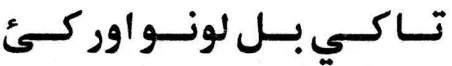

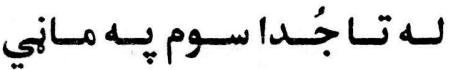

زمــــاد يســار د لاس كثخـــوره

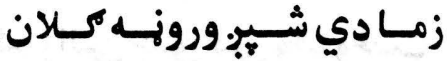

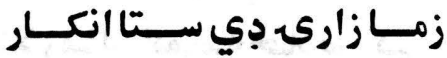

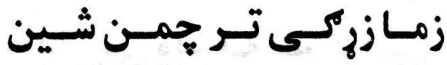

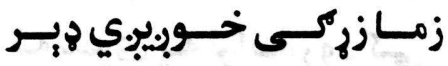

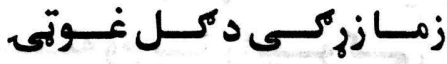

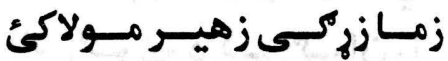

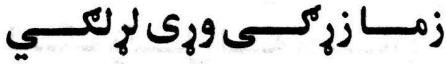

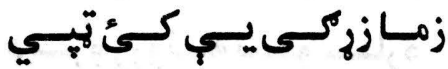
زمـاسـكس :ـهـ كور كي كري زمــانبـــرا د غــــو وابنــهـ كـي

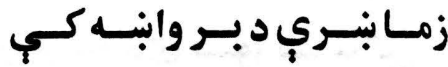
زمـاشـيرين زركى تر جـار كه

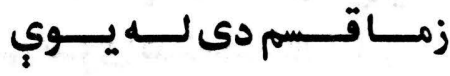
زمـاقسمت كـي نهلهي سري زمـاكر انسى بسه د خـود وير وي

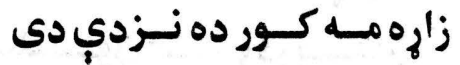
زماكو انس بسه د خـود ويـر وي زماكر انى به يج خود وير وي

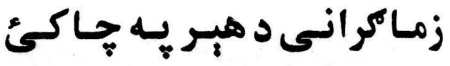

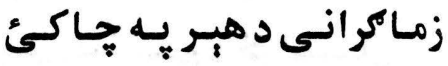

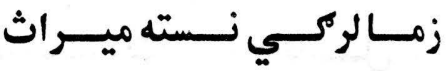

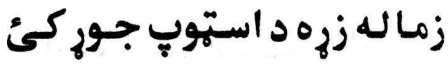

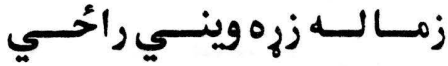


يـو د سـتركو يرهبز كر ان دئ كه رالهئ جـور بـي وفـاوخت

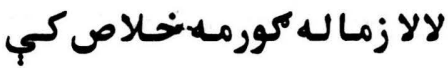
يـه بـل بـي وإبر نـه كـم كر انسى

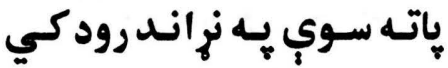

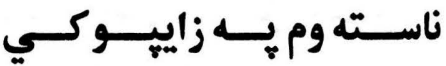
دلاسكـرى دكسي كـران را

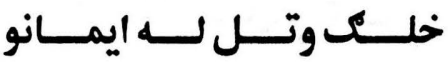

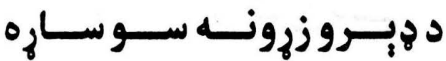

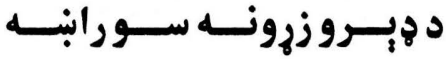

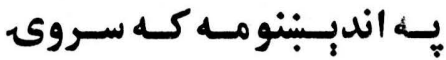
بارانونســـه دي بـــور ســتركي

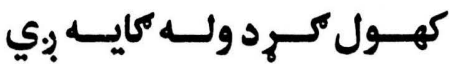
كي سرى سـته يـه كاله كي

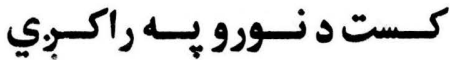

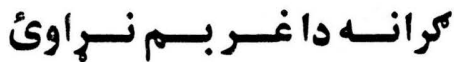

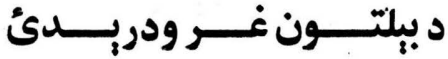

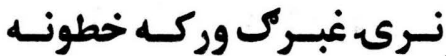

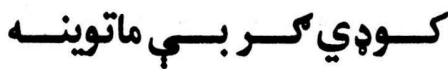

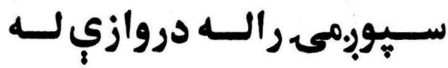
لالـــــــــــــــم د دخراســـــان

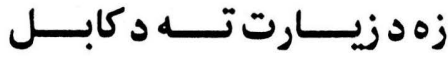

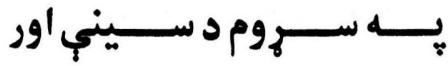

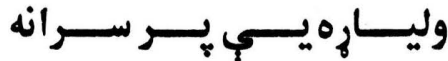

زمـالـه كر انسه سـره قـرآن دئ زمــالــه كر انــه نـسته بخـــت زما مركى يـه ديه مياست كي

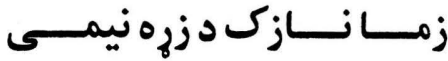
زمـانـصيب يـه تـورو غـروكي زمـا نظـر دكران يـه يـبنوكي

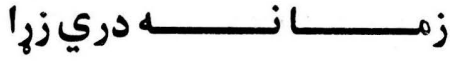

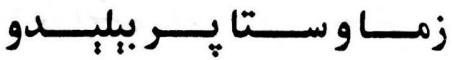

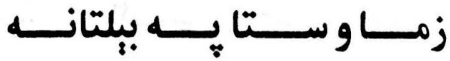

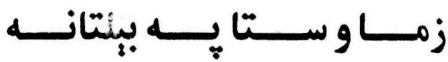

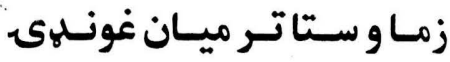

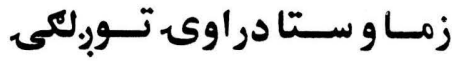
زمـاو سـتا روغـه حُيـام كبري

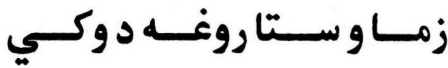

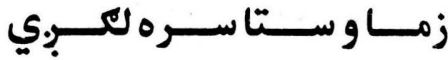

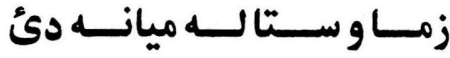

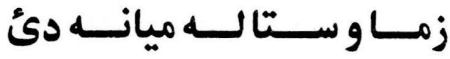

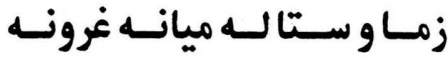

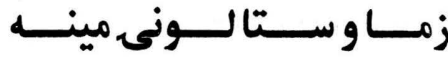

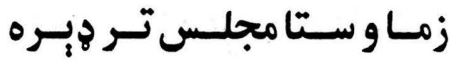

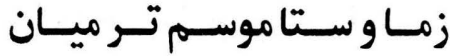

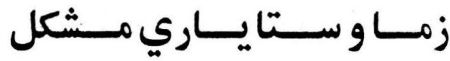

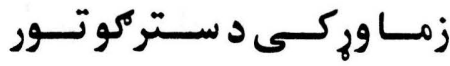

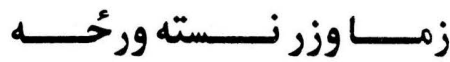


خلــ خوشــحاله دي كـه نـــ خومر هوبر سخت دى دكرانزه بنكـــي د مـات سـوله جــورى

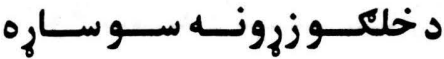

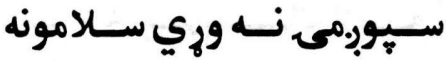
قبلـوهيــي د خــاى كـــه دي

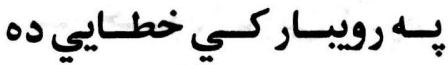
تــابيـانــور ايسـبني خالونــه وسبج ورور ولاري سي كولب له خلك وياى تكليف دى دورزي تـر تـابِي مست حُوانـان سـاتي

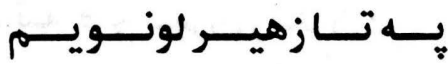

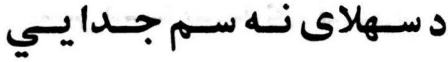
هلـك زركـون دى كـه لـونهى تر نصيب زيات غواري خواره

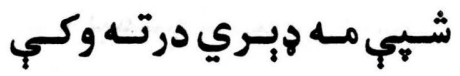

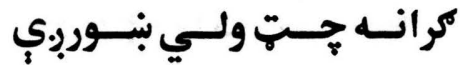

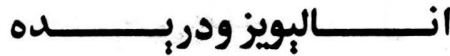

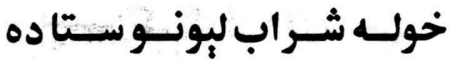
سـتاتيكـــى طالبـانكـوري ثخي غلـط مـه نـه كري بـوري

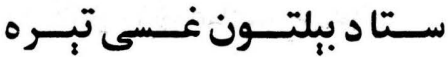
تـور تيكـرى مـه سـي :باللكي يتّ كر انى د يـر ما يـورى دى

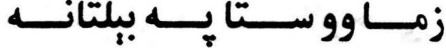

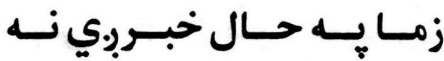

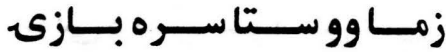

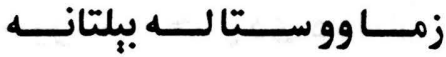

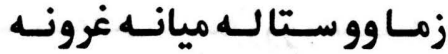

زمـاوووسـتالـه وسـه نسه دي

زمــا وو ســتايـاري سـهي ده

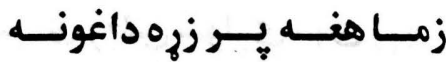

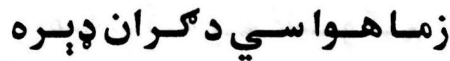
زمــا هواســي ســتاد ذخــولي

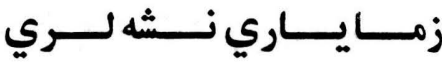
زمايسو سر دئ خحلاص به كرم زمــادكـل غونـلـي حــــواني

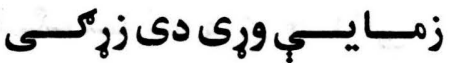

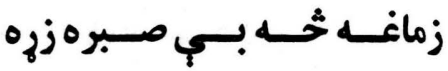

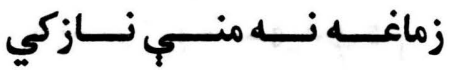

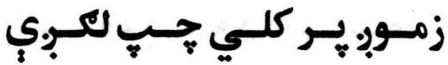

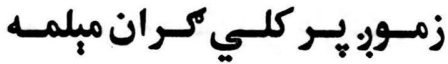
زمـوبر. بـه ديسن كـي نساروا ده زمـورِ حجـري لـه راسـه بـوري زمـورو دوارو سـدرى تـوري زمسـورو د شـيـي خوبونسه ســره

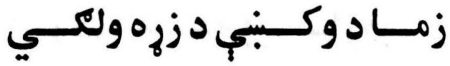
زمسوبر كلــى نــه دى هول دى نـ 


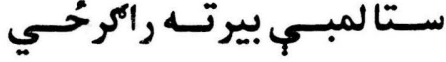
كسوتي د خــان يــــــــــوريدي

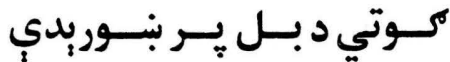
سـيـين مر مـه خبل دى د دامان

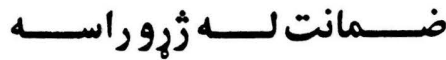
كران د مـخ بيرته راكوروكي

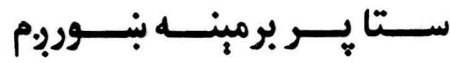
يردى وطن غـواري لـوى زيره

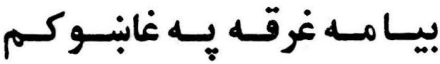
هـابـه هـم د دنيـاسـات وي سـره رخست غـواري وليـاره زوب د دوو جنتـــــوميـــان دى

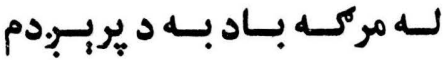
خلــك مــه نـله وري جـــايي

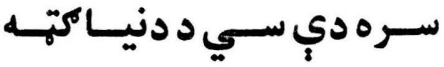

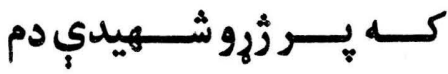

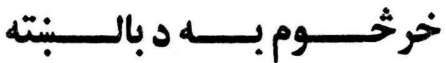
وختـت تـروم سـتا بـر هاركـل ثوك بهي الوري دخولب توكي ثوك بي واوري دخولي توكي

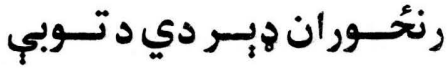

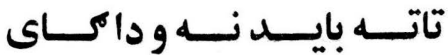

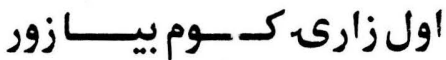

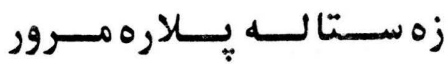

زمسى رالـى سـهـل غــورحي

زوريسـي راكــئ سـتابــاجي

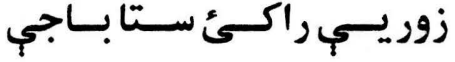

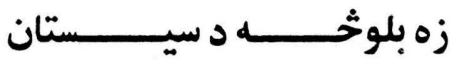

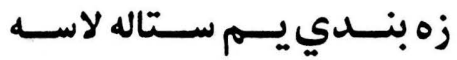
زه بـــه نــــه تويسـوم اوبنـــكي

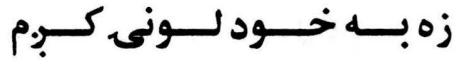

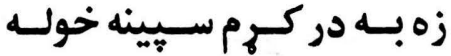

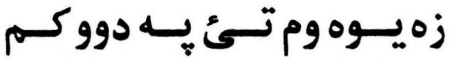
زه بـه راسهم كل بسه ناست وي ز0 بـه كـم كجكـول بـه غـاره زياتـه حُحم بـورى زنــان دى

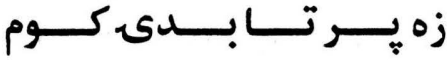

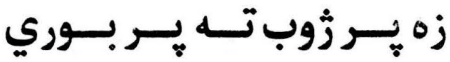

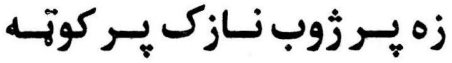

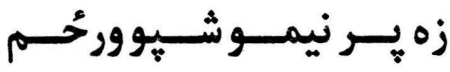

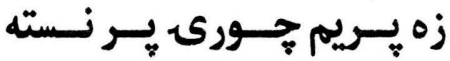

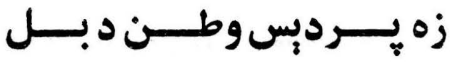
زه يه ينين كي كران به زوبكي زه يه ثل كي كر ان يه زوب كي

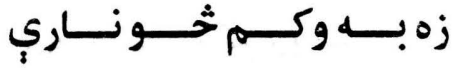
زه بــ حُحم دزق مـا بـر خــداى

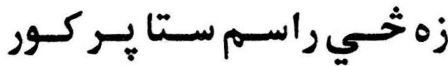

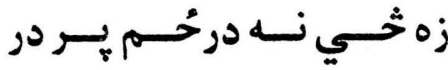


دنتــــه اور واخلــــي زمـــــزه

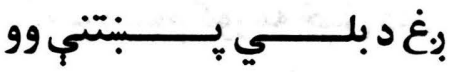

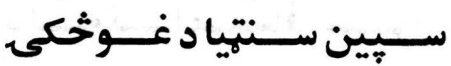
زركــل د كــان ســـتهيا دئ

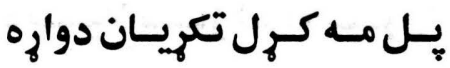

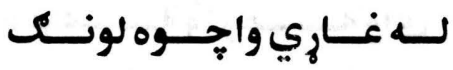

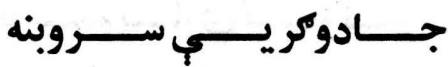

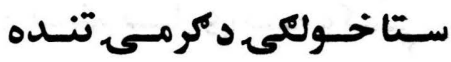

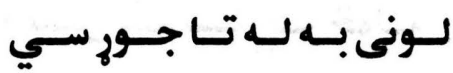
يـادومبــي د خــوليخ تــوكي

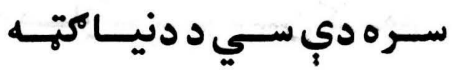

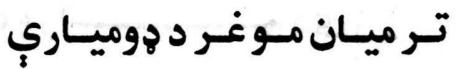

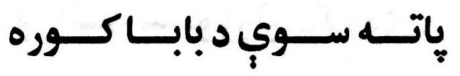
سـتاده نـوماتـهـ سي حــــواني

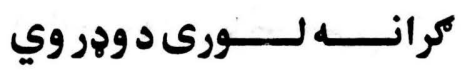

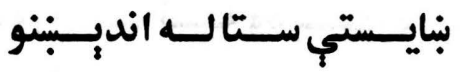

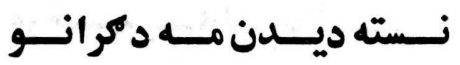

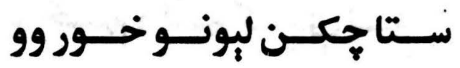

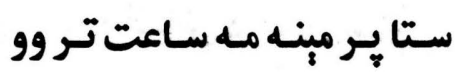

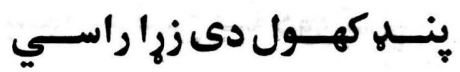

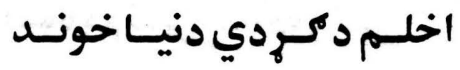
درباندي ورك به سي زما نوم

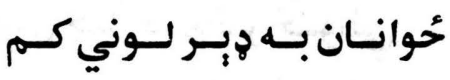

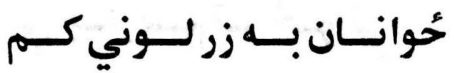

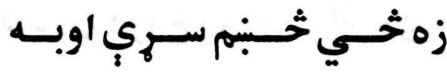

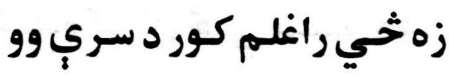

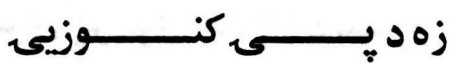

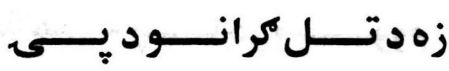

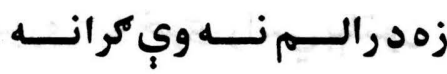

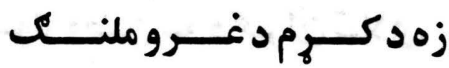

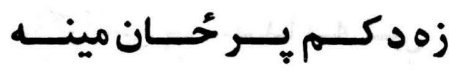

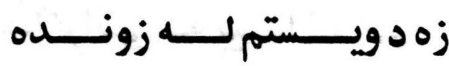

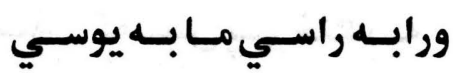
زه دلـي نـازك يـهـ زوبكـي

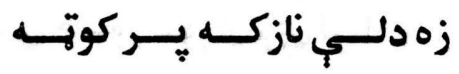

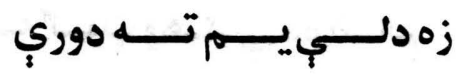

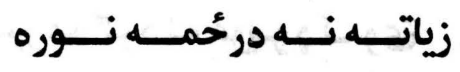

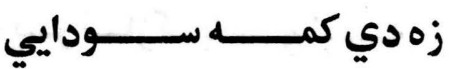

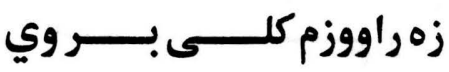

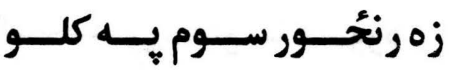

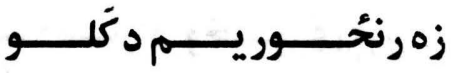
زه زخـي راغلـم حالـت نــور وو

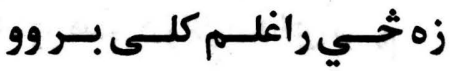

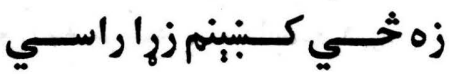
زه خـي كبنينم سـتا يـر خنـك

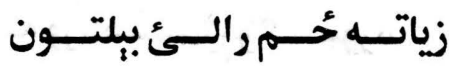

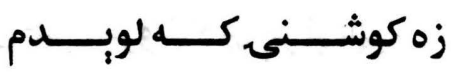

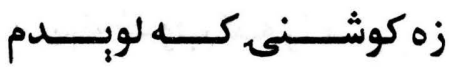


كــــان د روغ وي مـــافر دى

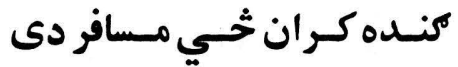
نرى بـر لوى خداى د سبِارم

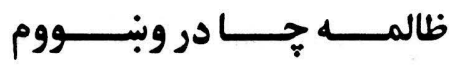
يوروخَ به خوى راسي ببلتون

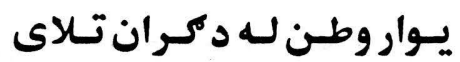

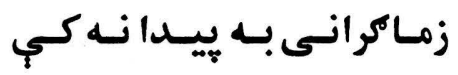

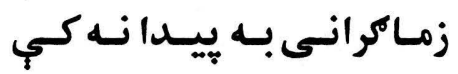

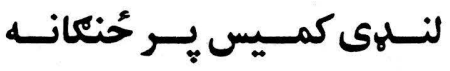

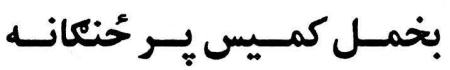
كسي خلــور نـوري وي ليـاهم

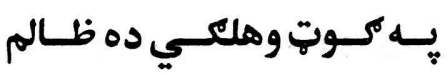
كور مه كرد لله غويـو ذهى ورئ

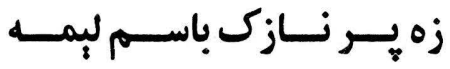

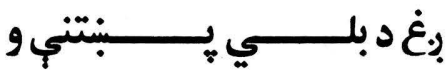

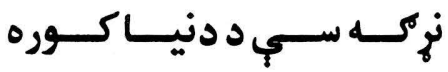

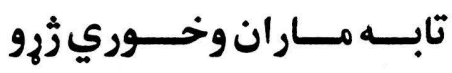

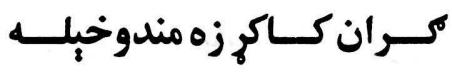

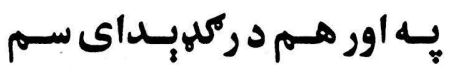

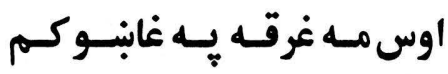

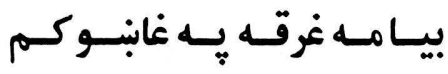

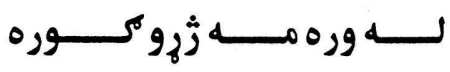
مين جان يروت دى ير نيالي

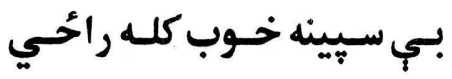

زه كه مره سوم كور مه خهبل دى هـ

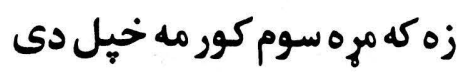

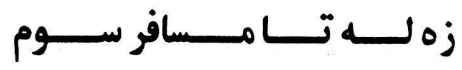

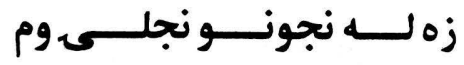

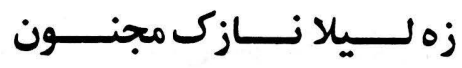

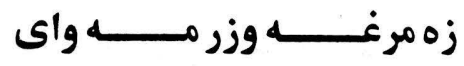

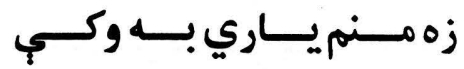

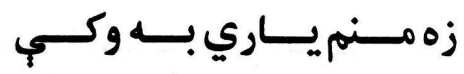

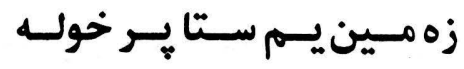

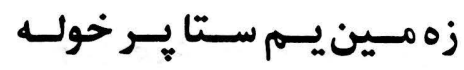

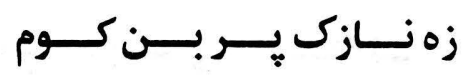

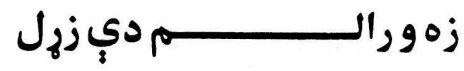
زهوروالــم بنـــو ورتيــك ووئ

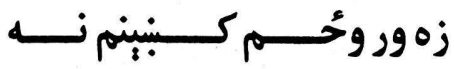

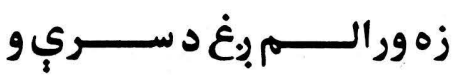
زهور رالــــم نـــــهـ وهبــــــوره

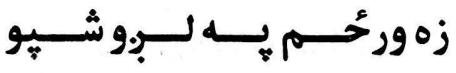

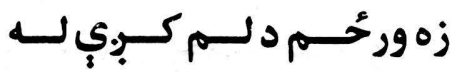

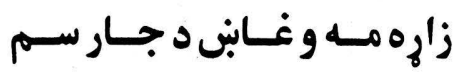

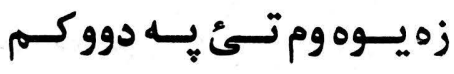

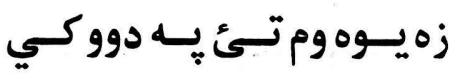
زه يـي بنـد كـم سـتا لـه كـوره

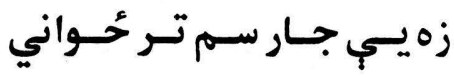

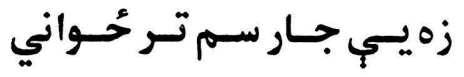




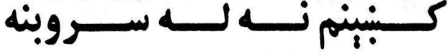

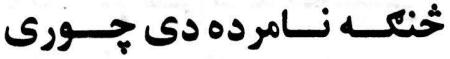

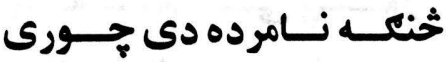

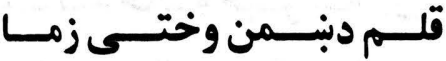

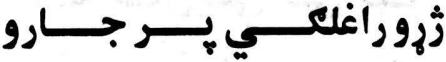

ثخي مـوريس خـوا بـه بله ووي

كـــــان هوايــــور واى د لارى

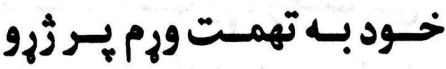

تـر.بـوره لازـدي سـه دسـتي

درثخهـه ورك نستي زمـانـوم

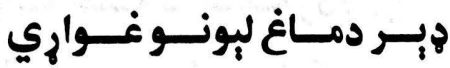

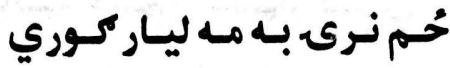

حُمم وركمى بـه مـه ليار كـوري

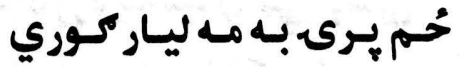

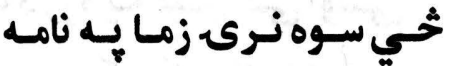

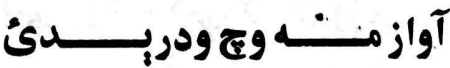

وخـت د سـيـين دكتـوتر سـو

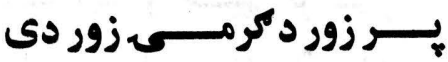

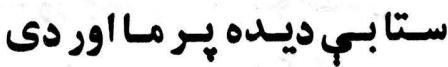

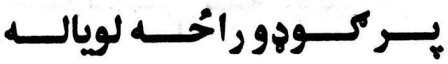

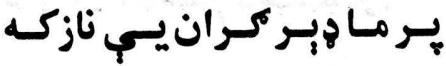

غسميكس يـر جــورى نـهـ دى

زالكي ولاري جخهاني سـوي

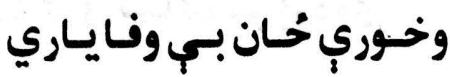

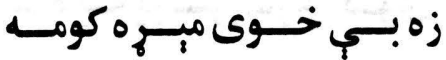

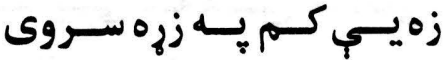

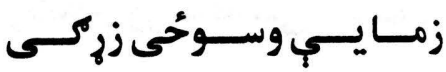

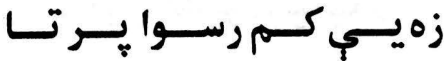

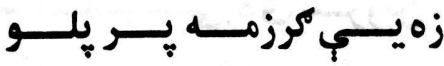

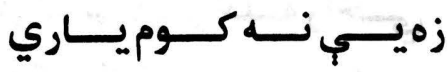

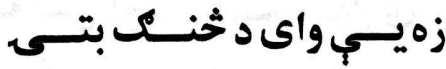

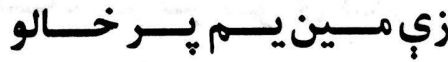

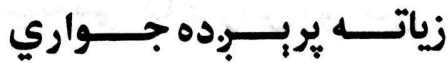

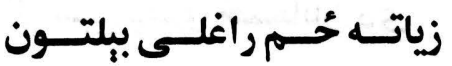

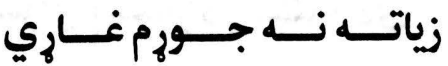

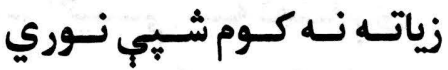

زياتــه نـهـ كـوم شـيهي نـوري

زياتـهله نـه كـوم شـيهي نـوري

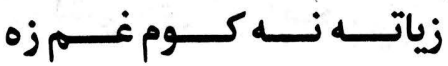

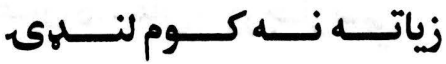

زياتـــه وولارى مـــاحِيكر ســـو

زيارت بنه دى باد يب سور دى

زيارت بنه دى باديب سور دى

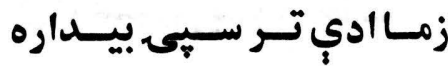

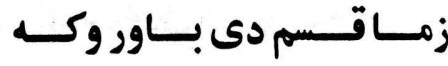

زمـايــي هـم نيسولى زمه دى

زما ارمان دكر ان خواري سوي

زمـاد زره كـئ ميـاري ليـاري 
سـرهـهـ بيـسويـاري كـوي

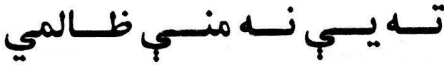
درباندي ورك به سي زما نوم كر انوياى زوند ير دونيابنه دى بيـالـه مرضـــ دى سـروبن

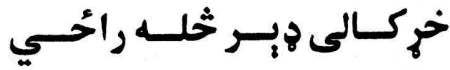

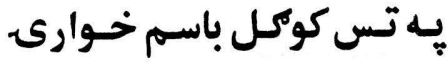

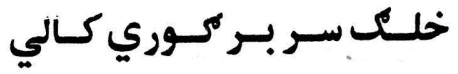
سياله يـي كهـ د واس زوركئ ستار شيخ وياى خسمانان دي

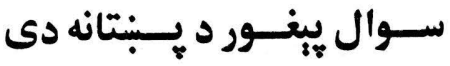

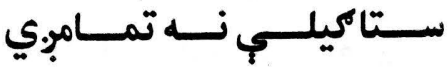
اوس د مــزيخ كـــوي كر انــــو كه بـي باكه يـه دي يوهـ سي كران كشنى دى كه رايوه سي زرغنون دسمال دورجـار سي دبـل هـر سـر د سـي ستـا شال يــر اوبـو ســ ســوم د بنــاخو

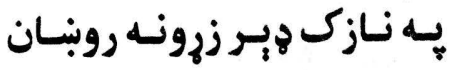

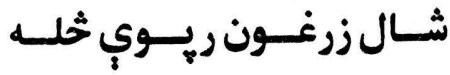
خــداى د و.غـــل وكـي بــاران

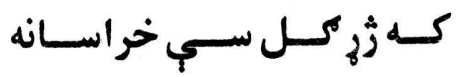
وركي يسم كـران تـه حير انسى خـوب. مسه كـي مسخ د اوبسه وئ
زمـــابربـــاد ســـوله حُحسـواني زهبـه مـ سـم سـتالـه مينـي

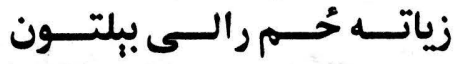
زمـالـه حالـه خبـر نـــه دى

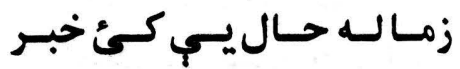

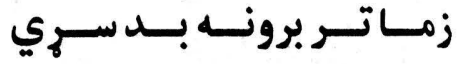

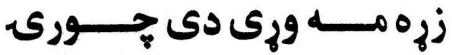

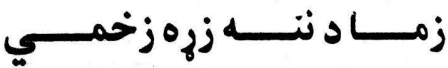

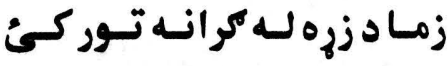
زما يــر زهره لمبسي دمكران دي

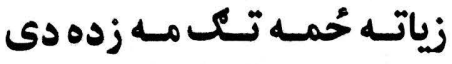

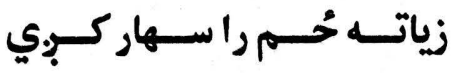

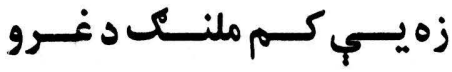
زماد زره يه ميـان كي اوسي زما د زره يه ميـان كي اوسي زه بـي وركـم كـي كــان وري

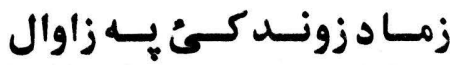

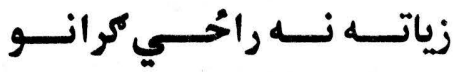

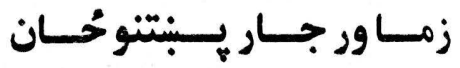

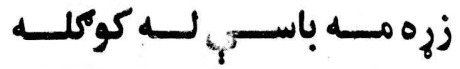

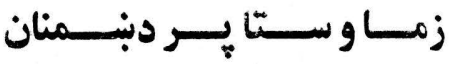
زه بــه نـهـ سـم در بسي كر انسه

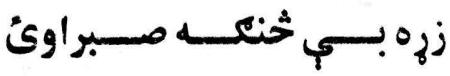

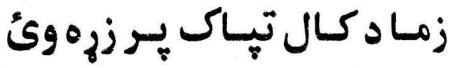


كرانـــــــار سـتاويساري يسم تيـا سـوم بيـا ورتــــــــوالكره كر ان يه زوند خدايه راخواركي

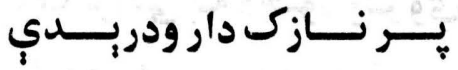

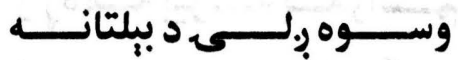

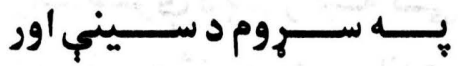

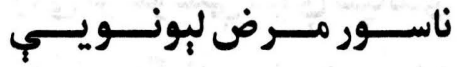
دوجي درختي ؛سه شان سي كـــــه انــــار د ســــرو دانـــــو

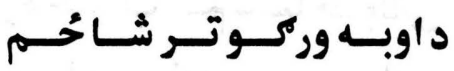

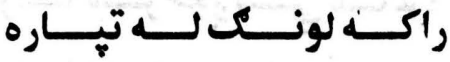
بس حُى حُى مه كي واده دي نجلمى تايو وره هُحيـام كور ته ير تاحُيام دوبر كران دى كالي

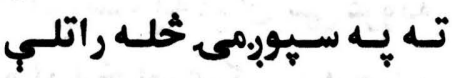

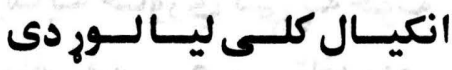
خوشـبـوي تبـل دى سـروبن

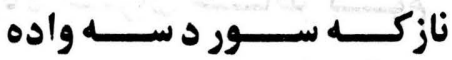
وازكي دكران يـر حُيكره ب.دم

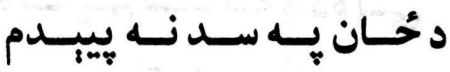
حُيامه زنك ولكي وي موخى

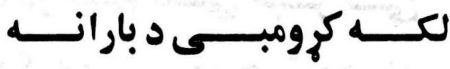

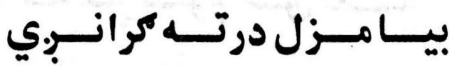

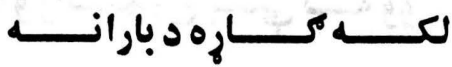

زرهم يـاءي كه يه ر اضي يسم

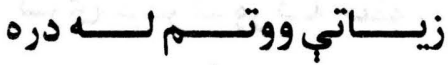
زمـادلاس خـوارهيس زار كيجي

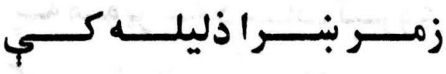

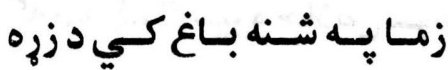

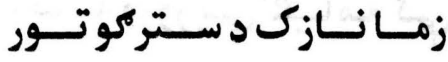

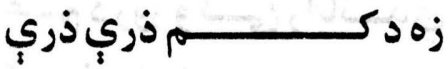

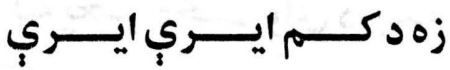

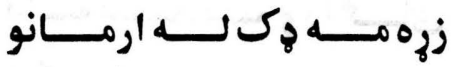

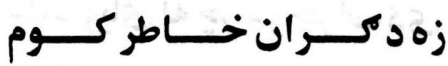

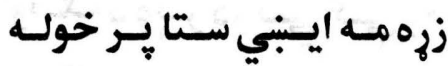

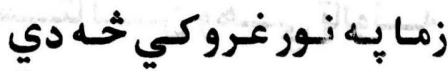

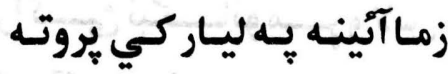

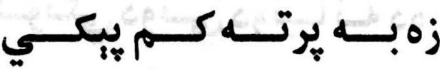

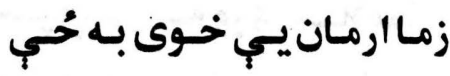

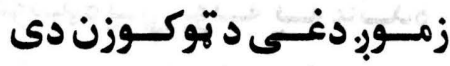

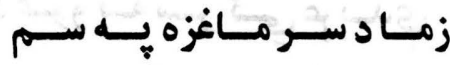

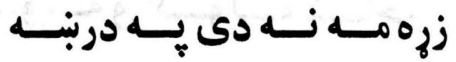

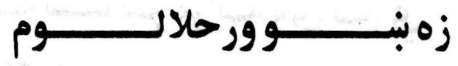

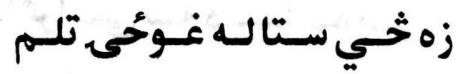

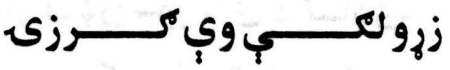

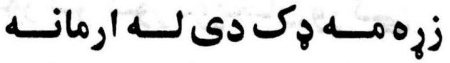

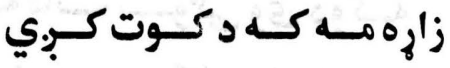

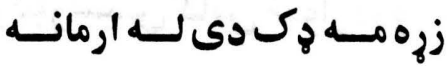




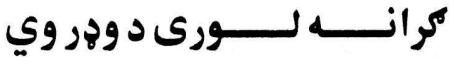

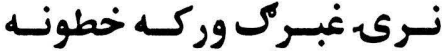

لالا زماله كور مـه خـلاص كي

يسه مــوتر بــه د ســات تـــروي

كه د مرك له سيرو خحلاص سوم

زما بـه وروريسي لكيـامـه كيجي

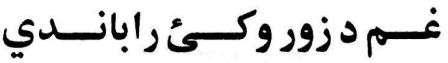

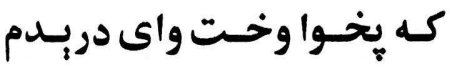

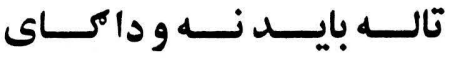

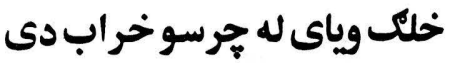

لونـكـ د هيــر دركسي كي وهي

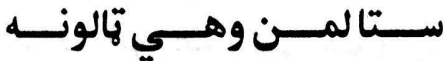

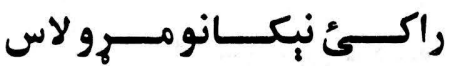

كـوتكي دونسي دونيـانـــ ده

سـبـوبمى نــهـ وري ســلامونه

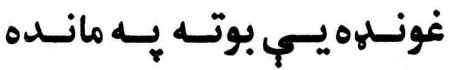

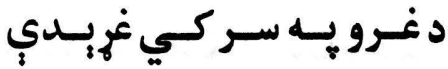

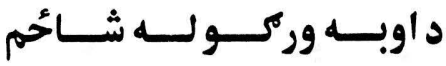

كسه سـتاتــر مركسه وي ويـاري

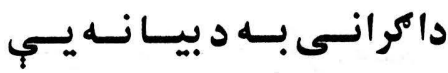

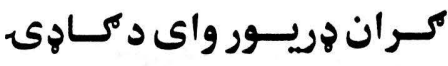

كـور يـر كـور تويكسان وركسئ

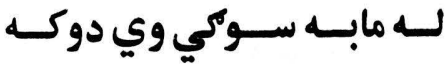

ير لور سيّين كاني خـواره وو

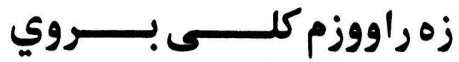

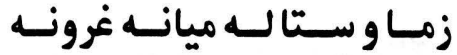

زما مركى بـه ديه مياست كمي

زمـاكر انـى بــه دخـود ويـر وي

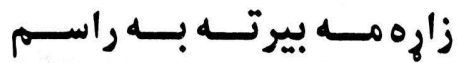

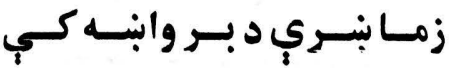

زمى تر سو شنب سوي سياندي

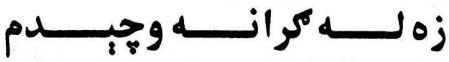

زه خي حُم رسك مه ير خداى

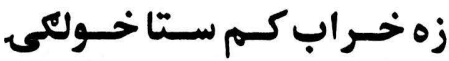

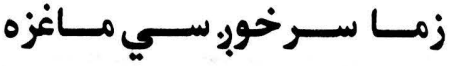

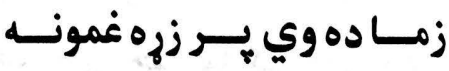

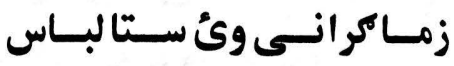

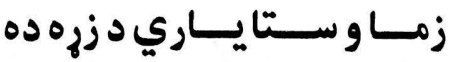

زما وو ستا يه ميان كي غرونه

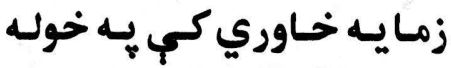

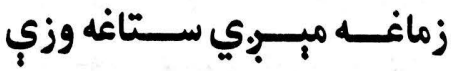

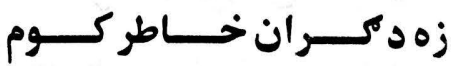

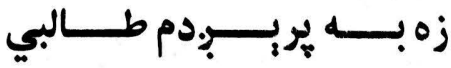

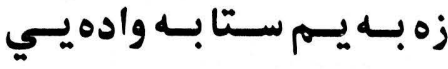

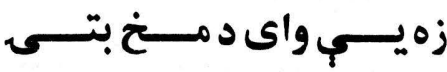

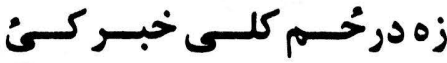

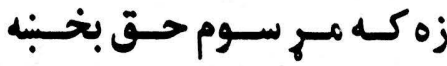

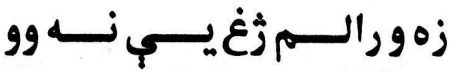




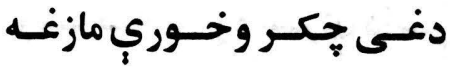

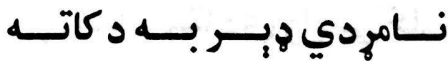
تبر خو سووخت د خوشحالي ستا تر خنك مه د دخور كور دى

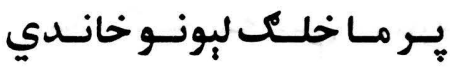

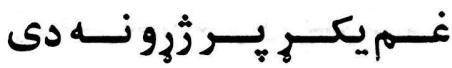

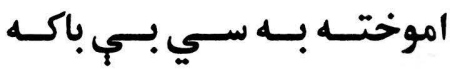

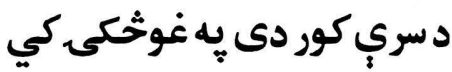

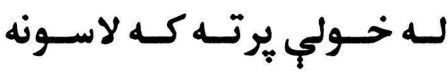

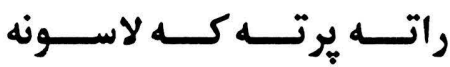

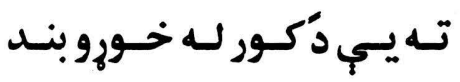

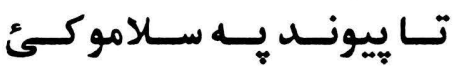

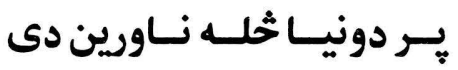
كه خوبٍ لاندي كئ ستا لورى

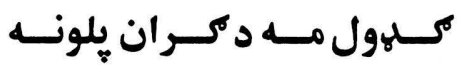

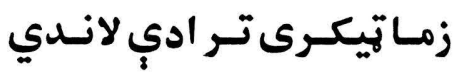
خـوك خبر نه دي بـي خدايس

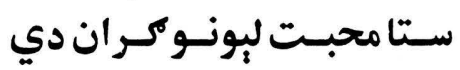

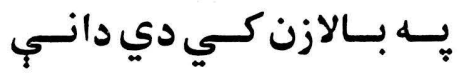
ستا يـه شـان نـه دى بسي بـاكي يـه اخـلاص مـه د دحسان مـل كـه

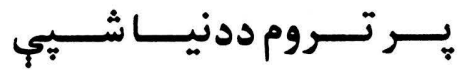

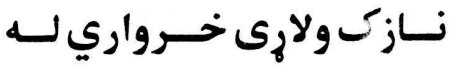

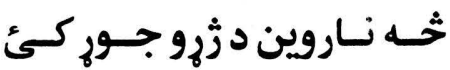

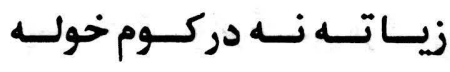

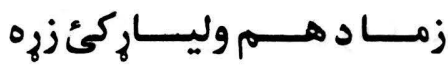

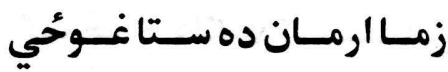

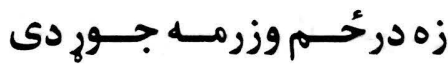

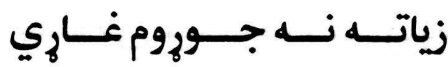

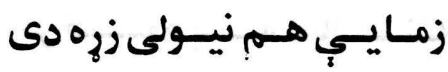

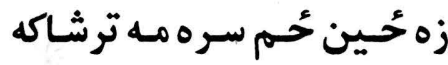

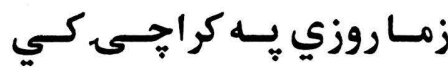

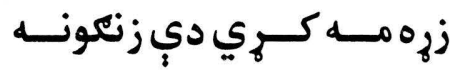

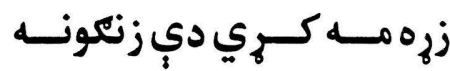

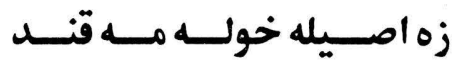

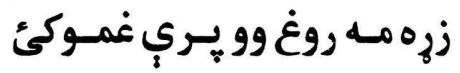

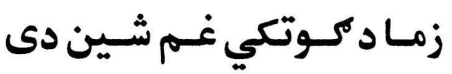

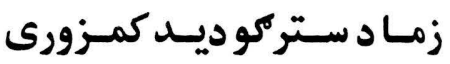

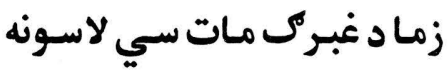

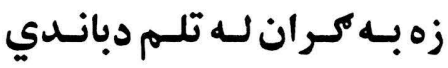

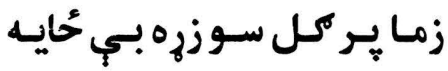

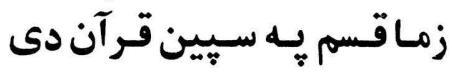

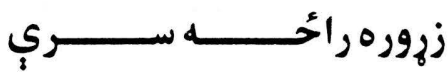

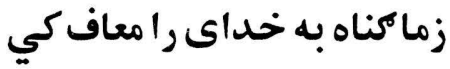

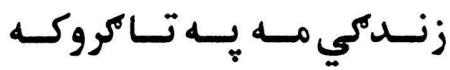

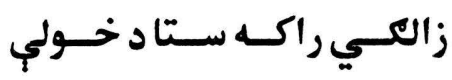

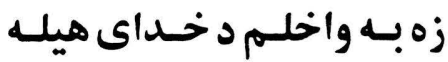
زمـاخوشـحاله زره د دتـور كـئ 
كاكرى غاري

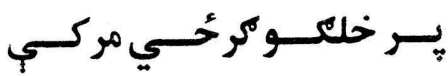

زياتسه كرانسى نسه دى زمـا زده

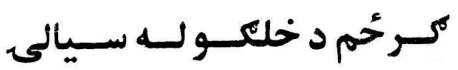

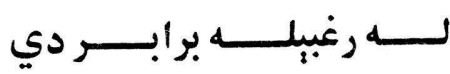

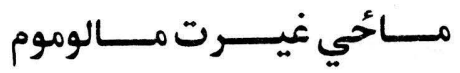

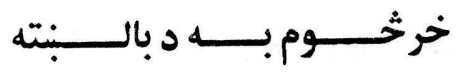

زمـــــــهـ غـاره سـري دانسي

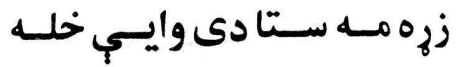

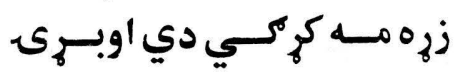

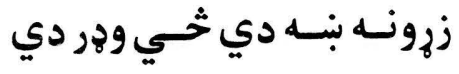

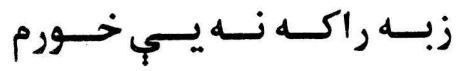

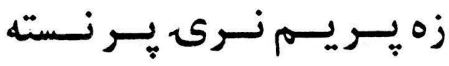

溇 


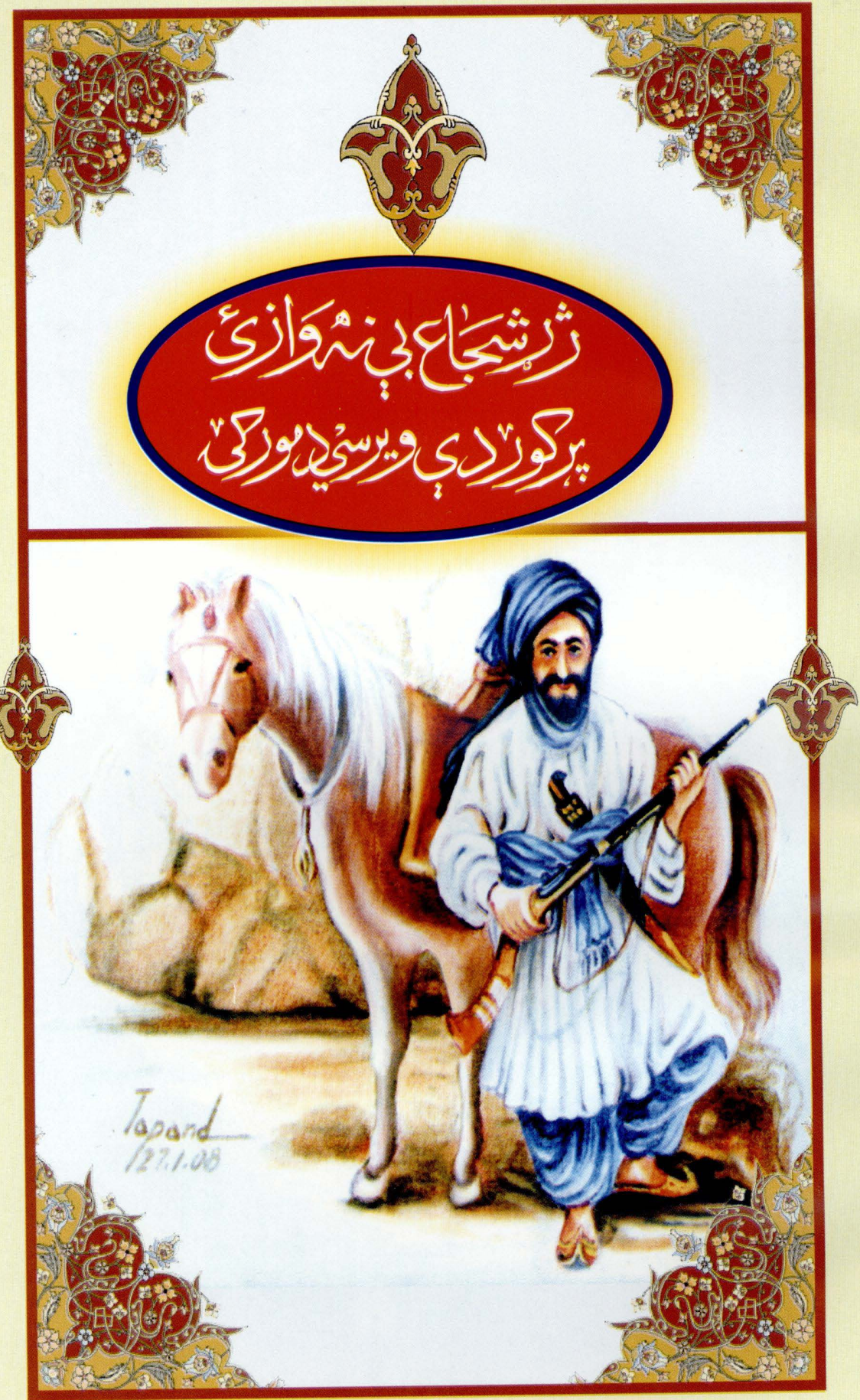




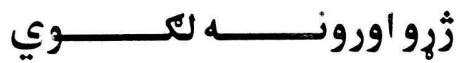

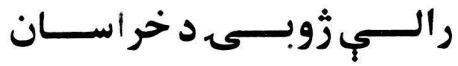

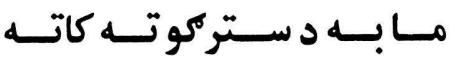

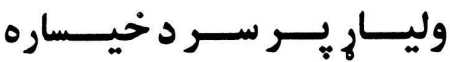

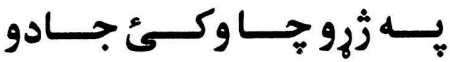

له يـبنيـي بـل باسي ماسى

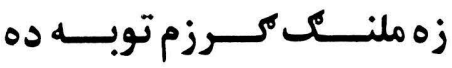

د هـــهو درد راوليــار ســــئ خداى د نوم ورك كه بيلتونه

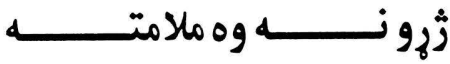

مرك يبي زور عواري مانهى دى

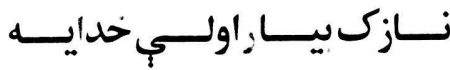

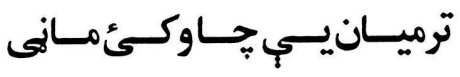

بـردى وطـن دى شـــن خـالو

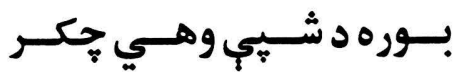

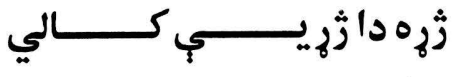

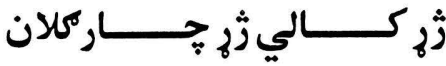

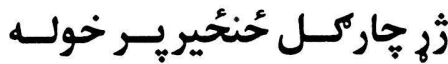

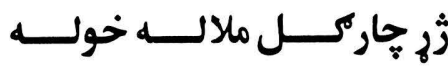

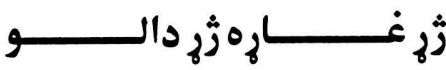

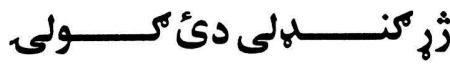

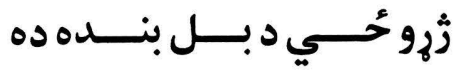

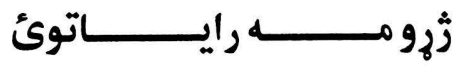

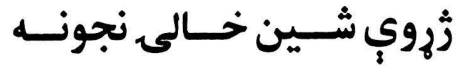

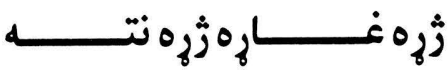

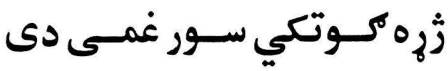

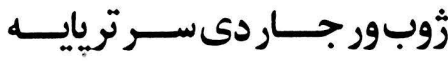

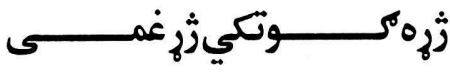

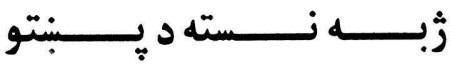

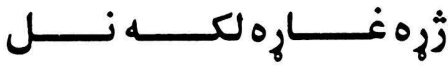


1290
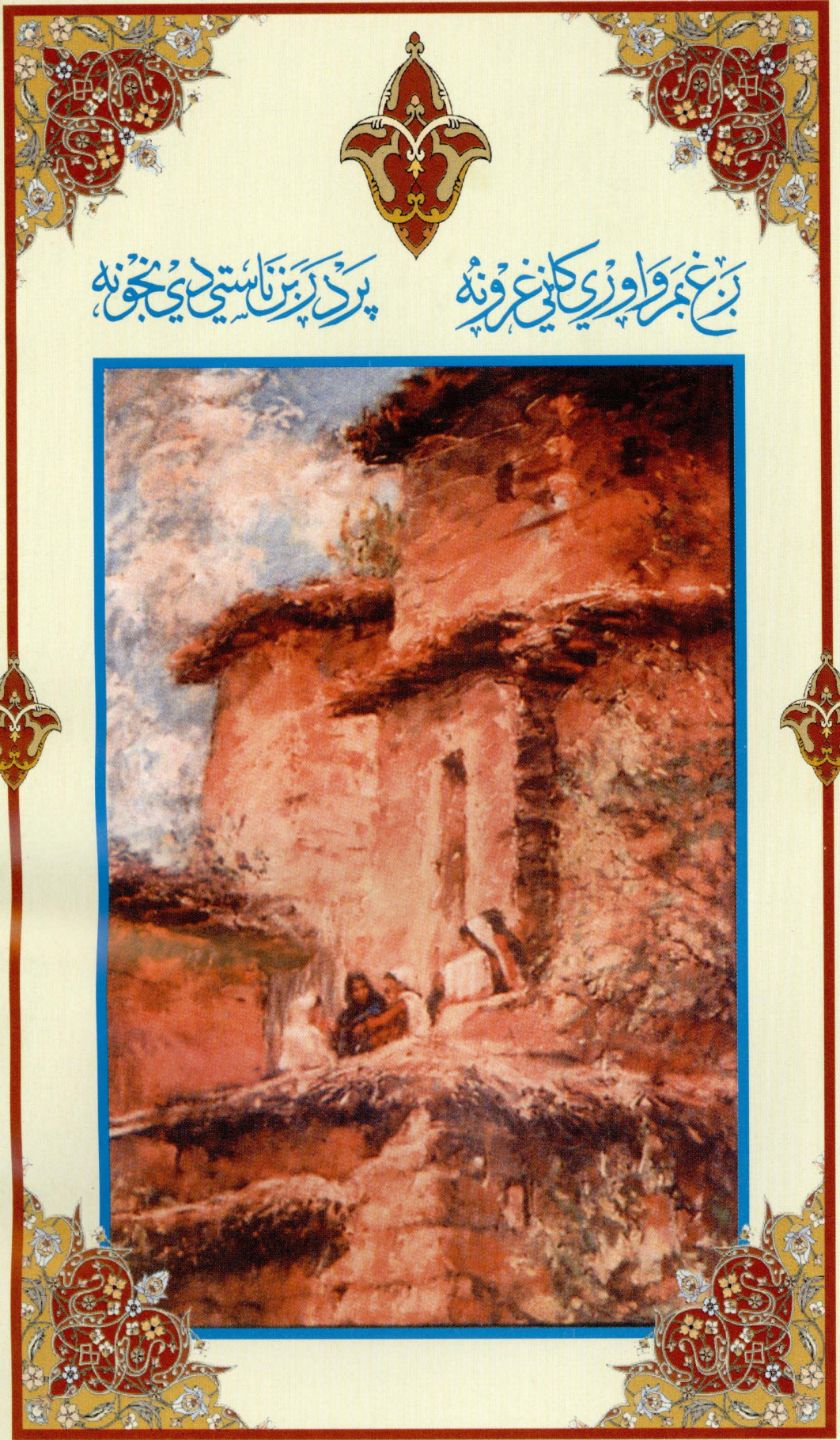


\section{(2)}

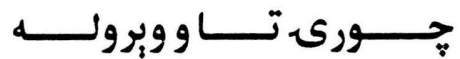

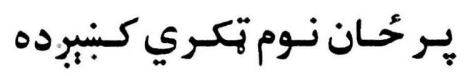

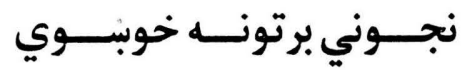

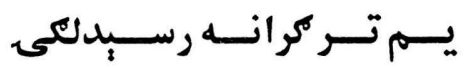

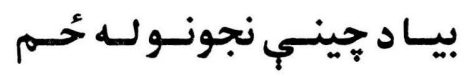

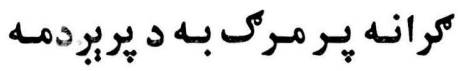

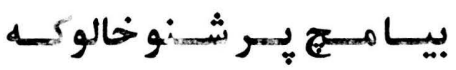

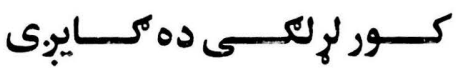
مـور دد كـران ده سـي كـايوبي

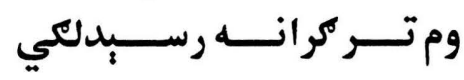
يـر دربنــد ناسـتي دي نجونـــ

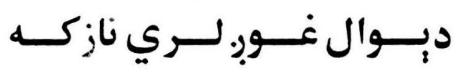

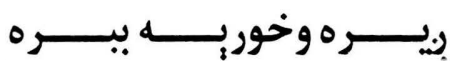

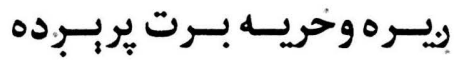

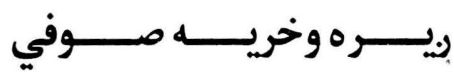

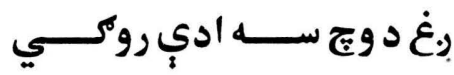

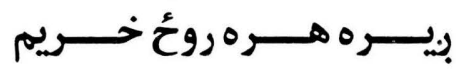

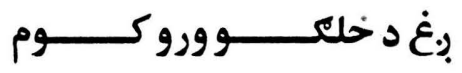

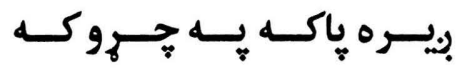

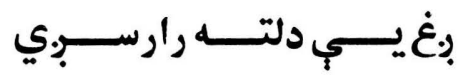

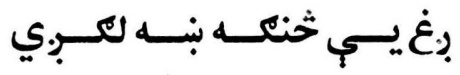

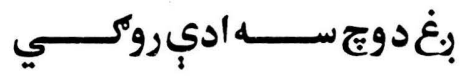

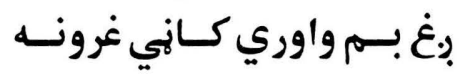

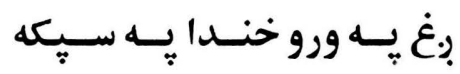

类潾 


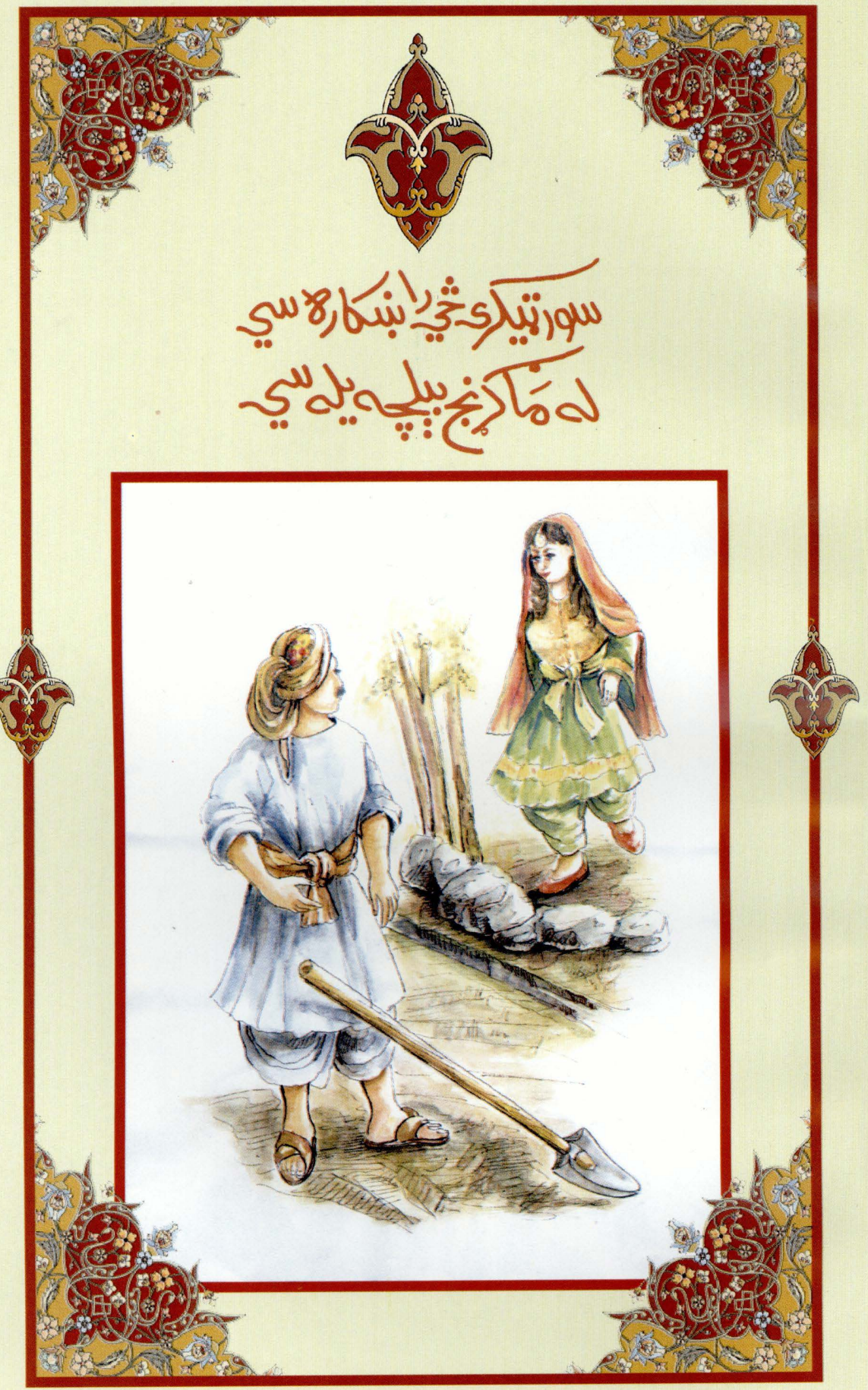




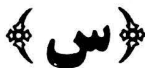

زمــوبر يــهـ ســلام دهــــاره

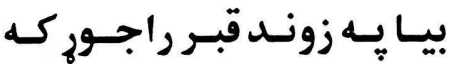

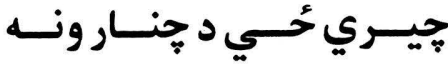

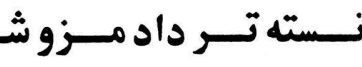

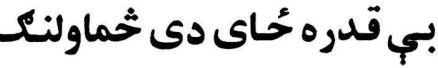
يسه بـس كسي ولاري د بربنــور

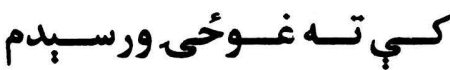

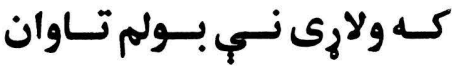

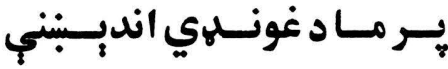
لـه مـوبر ولاري د خيـال شـيبي بــوره سيـستي بيلامسهـ كـي

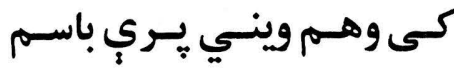
بـــونوبــه واخلـي لـه ويـالي

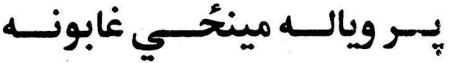

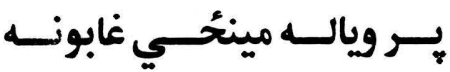

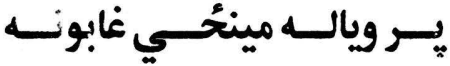

سينا

ستا بـه سيّينه خوله مـه مورة كه

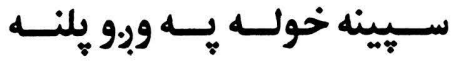

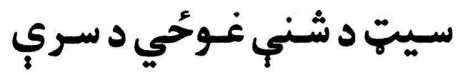
سـتا جاركـل بـهـ وكـي زنـك

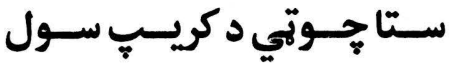

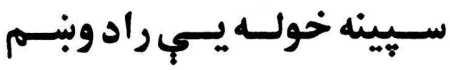

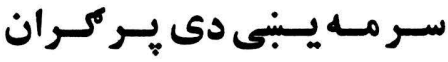
سبرلى كل دى سياندي شني

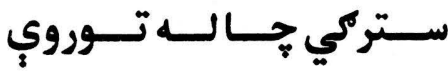
ستركي توريكي خوله سرهي

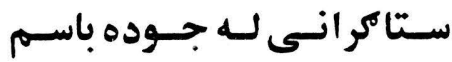

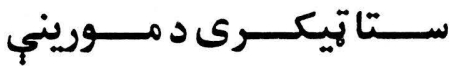

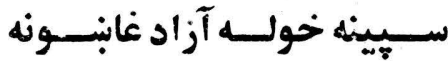
سـينينه خولـه ياسـته لاســونه

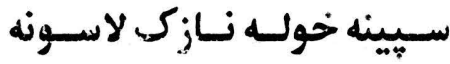


دى د بــلـل بايـــتـي كـــوري

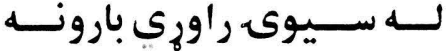

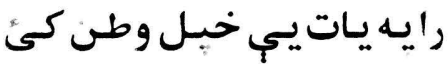

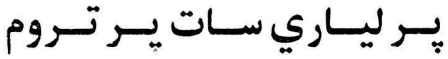

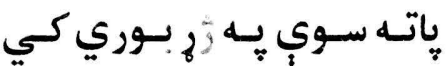

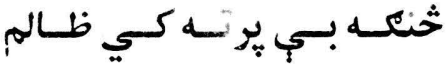

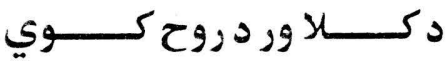
زمـاكهـول لـه سـري اوم دى وو:ى د زر غــاش د جانـــي

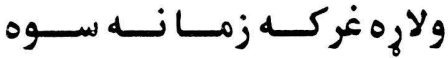

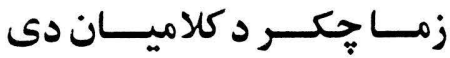

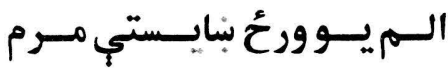

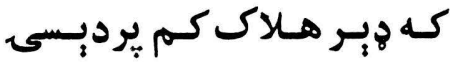

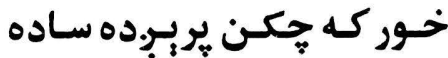
خـور كـه جـــن غيمــه سـاده تور ستركي سرت مه كيسلى

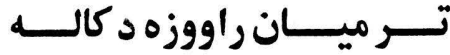

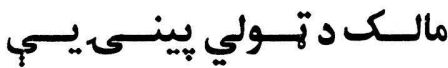
سـر ه دونـلهي بــه نامـه كـي

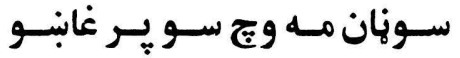

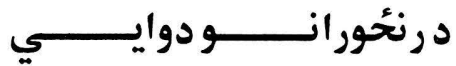
نـرى حُوانـان يـهـ يـري كـوي جـورى كباب د كىل حوانان ستا باسست د برداشت نه دى

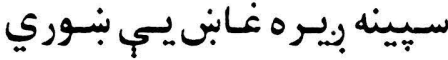

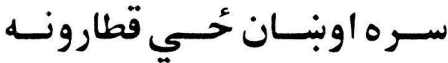

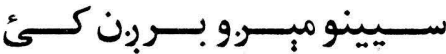

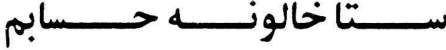

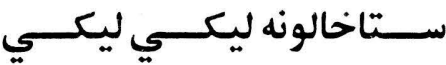

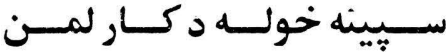

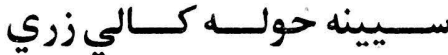
سرى نـه دى سور كى اور دى سيـينه خوله ليـاركي ميـسري

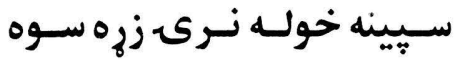
سيين كه حُي واك ئي دحان دى سـتا بــر خولـه مــرك قبلــوم

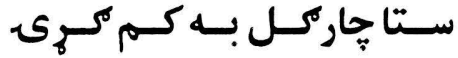
سـتا بــر سـر دي تيكــــي دوه سـتا يــر سـر دي تيـكـري دوه

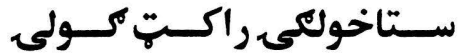

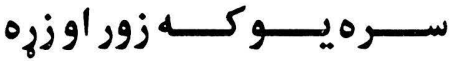

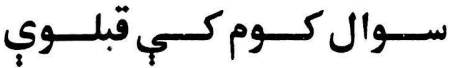
سـوال كـوم قبـوليسي تهـي كي

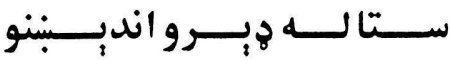
ستا جاركل خُو كري ثخو كري

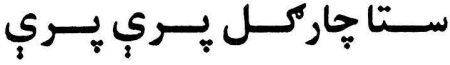

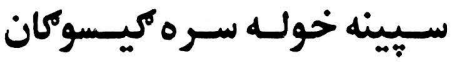

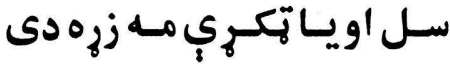


يــــ توبرومسى نيسـسي سـويان

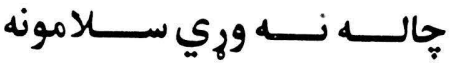

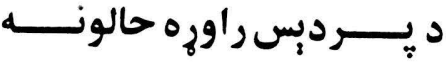

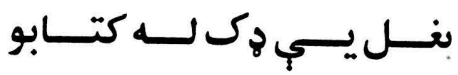

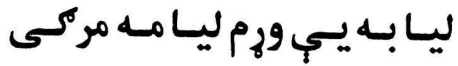

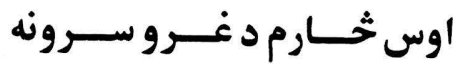
بيــامي دمــــ زولنــــي ورأى وج سـونان مـه د هيـر نـه دي

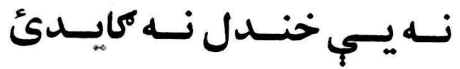
د خوارانـــو دزرو تـــواندى دي ير كم وتـل بـه خـوري دوهيى مــور بـي كـم تـاويز ور وكسي

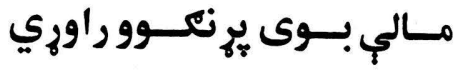

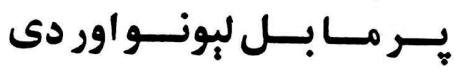

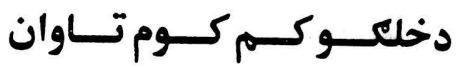
اوبـــولـــهـ راســـهـه د زيـــارت

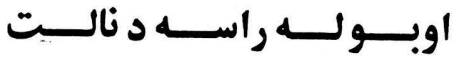

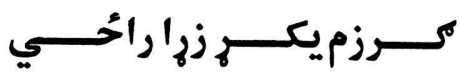

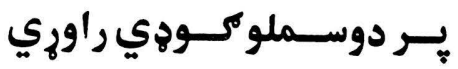
كلــى بــــ إسـسي بــي بــوري بـوري خوند كوي ستاتـوكي مابنــــام دوار دى د غنـــوحَح

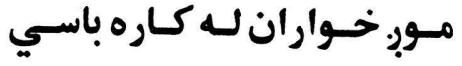
وجيـي كـي بنكـه جانـان دى
ســاو مــور تــــــــــم اريــان

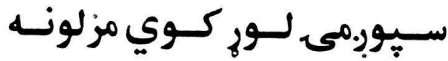

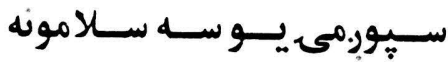

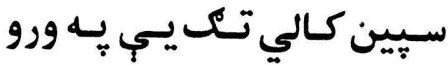

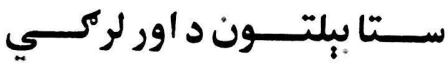

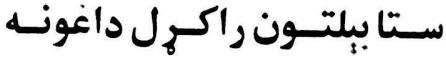

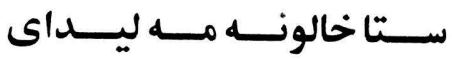

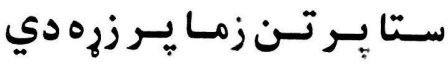

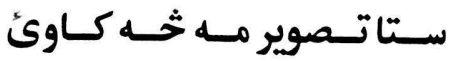
سيّن كالي تك يبي د خان دى

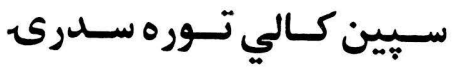
سور دسمال يسي ليكي ليكي

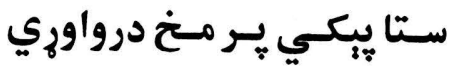

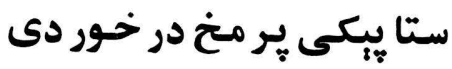

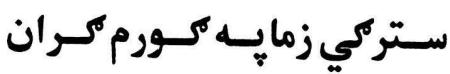
سـتركي تــوري كـهـ يـهـ خـــ سـتركي تـوري كـه يـهـ خـط

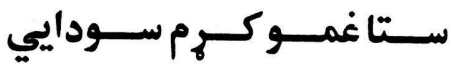

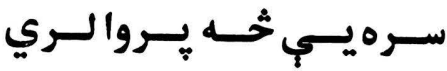
سبين تيكرى رويَ يه يوري

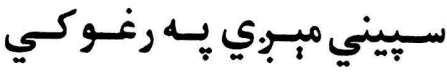

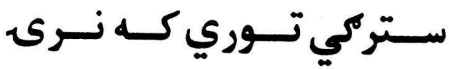
ستركي تـوري كي بيـار اسي

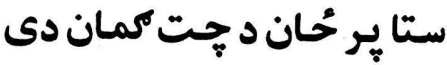




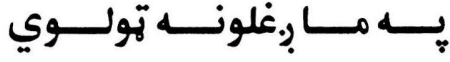

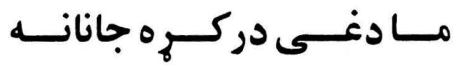

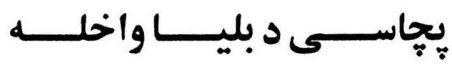

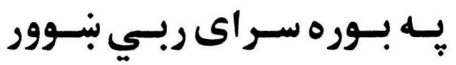

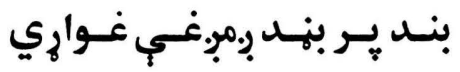

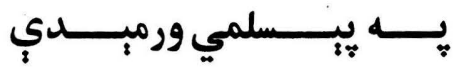

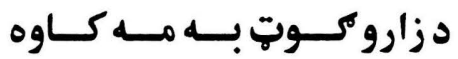
زرق د راواجــوي خــداى نـور كران يـه حُوزانـوكي روائسي زره كاغذ نه دى ثخب خـور كم

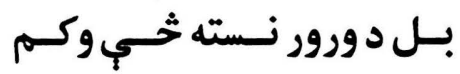
ما حُين بري كري د نياز غوتي يه لاس مله كوتكي د مكران دي زه بــي تيــور كـم دمكريــوان

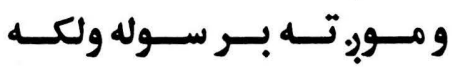

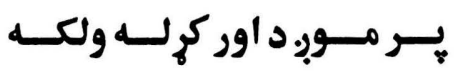
كـه ولارى هـم نـه دى تـاوان

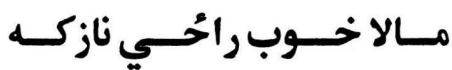

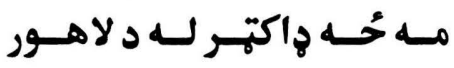
يـار لـه حُحي كـونى بانـهـ كي

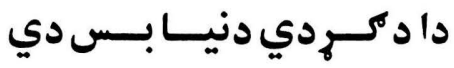

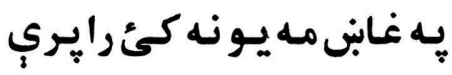

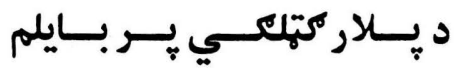

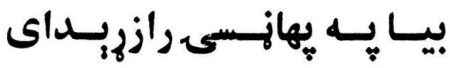

سـيـين دراسـي كسه راحسـي

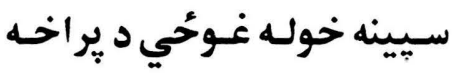

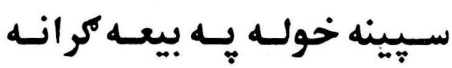

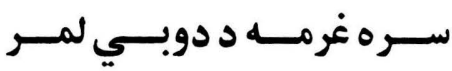

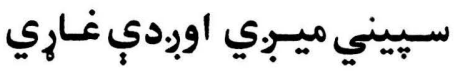

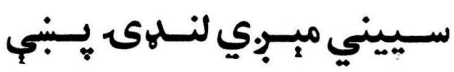

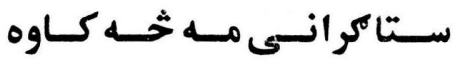

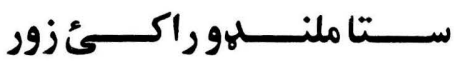

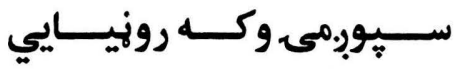

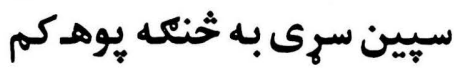

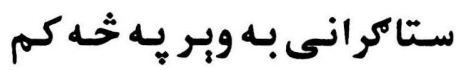
سـتاخولكى د لونسك بــــــي

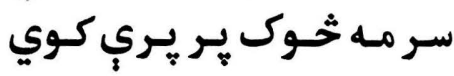

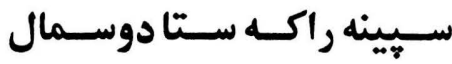

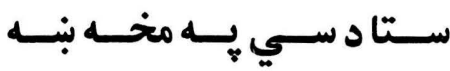

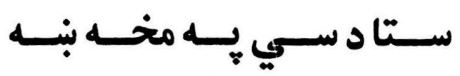

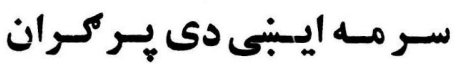

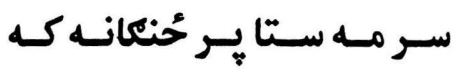

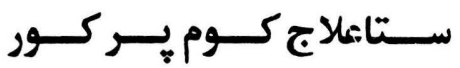
ستركي توري كي خوله سرهي ستا يـر خوله خالونسه لس دي سـتا يــر خولـه خالونـهـ دري

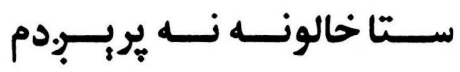

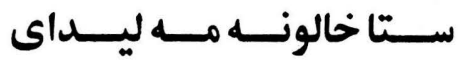


يروت يـر سول يـم دواخـورم

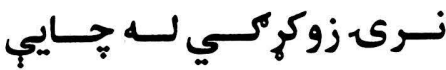
اوس مـه تكـاو اى بـ كيهي -تهو يسهـ بسس كسي ولارى د بــوري نرى حُلنـك غـواري ستا مـور

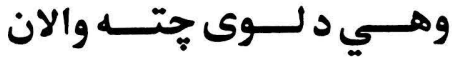

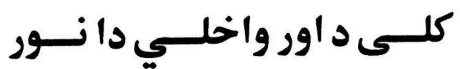
كور د لـ سـري نه سي خـالي يـر غـرو ختلكسي ده سـيوربمى

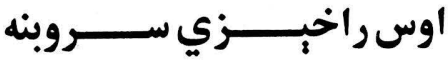

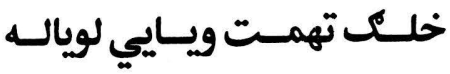

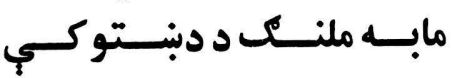

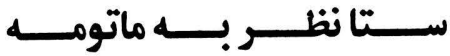

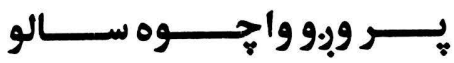

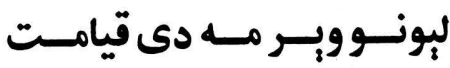

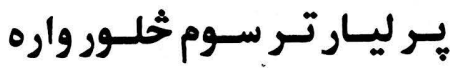

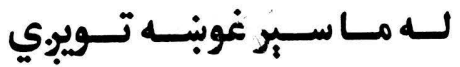

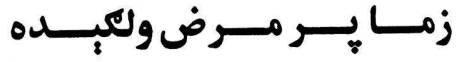

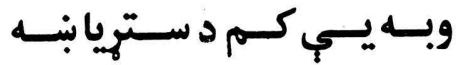

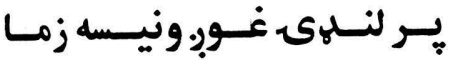
د نـــرو يـر سـر بنــوري جانـان

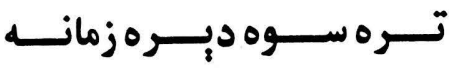

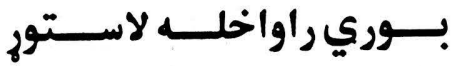
خي وهر سي بيايب تهول كد

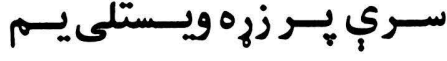

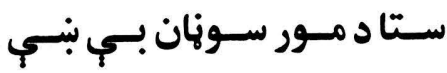

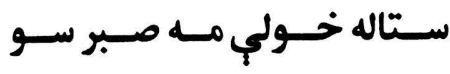

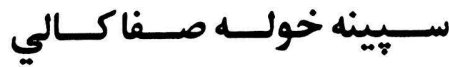

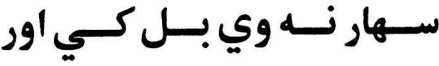

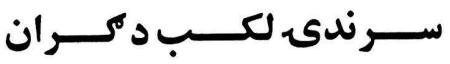
سورى تيكرى كهلانيبي تـور سـور تيكـرى كـلان بيـازي

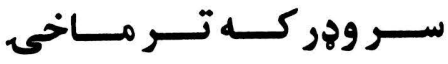

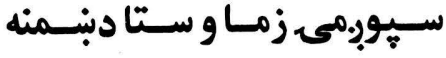

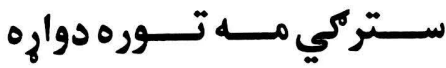
سـيـين كـالي ثـــي اغونــدي

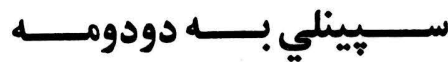

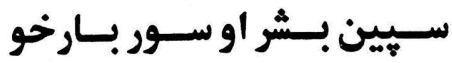
سـتا د سـيـيني خــولي مابـت ستا د سيـيني خـولي له ليـاره سـتا يـر سـر سـنخته بنــوروبي

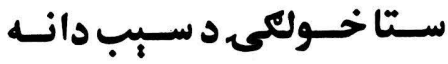

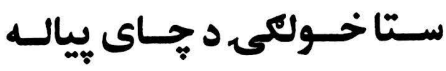

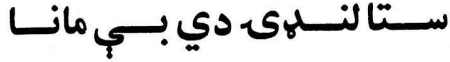
سيّين يرتوك خولي بِ كوتان

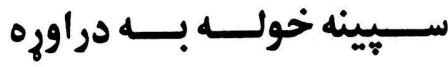

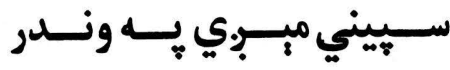

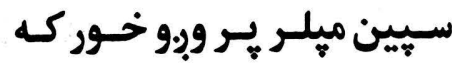


يه تكـ د زوى مري خي راحُبي اخستكي يـم د شـيطان جيـل تر خوبِ لاندي به زمازيرهي كي

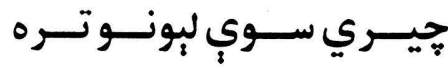

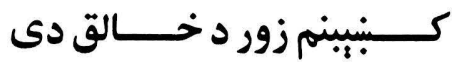

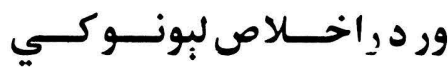

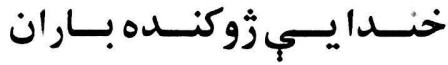
آخــريسي مــل سـوه بيمــاري

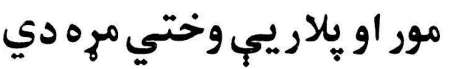

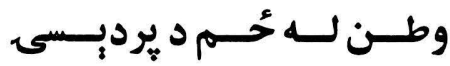

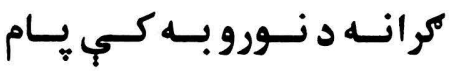

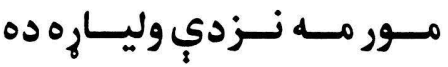

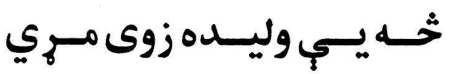

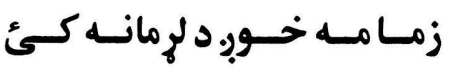
يـــ مـايجي تـري كـي خـوارى

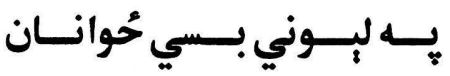

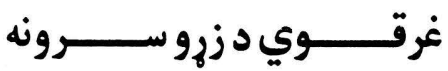

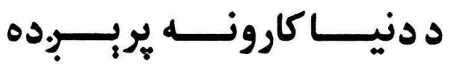

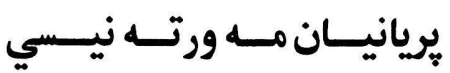

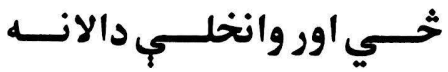

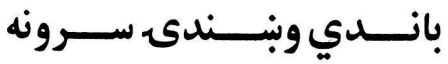

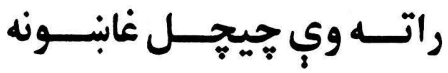
مطلب يبي نور دى د خورحي

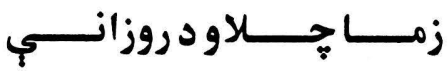

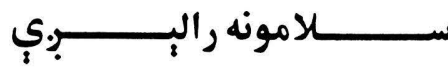

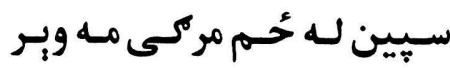

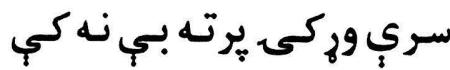

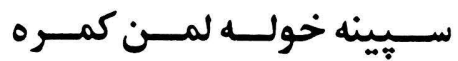
ستا ير سر د خـاورو خـوبي دى سي

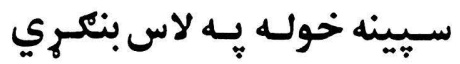

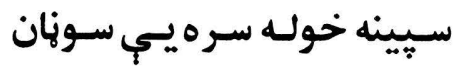

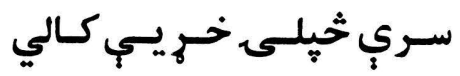
سـره سـونان يـي كاغـنـي دي

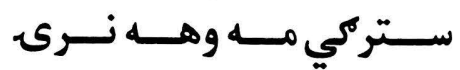

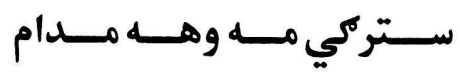

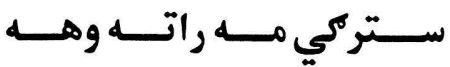
سـر تـور سـر بـهـ لـورهم حُخلـي

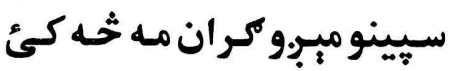

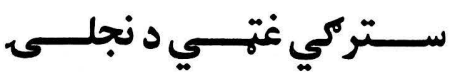
سـره كسالي سـيـين بـار خوكـان سـيـينه خولـه نــازك غانبــونه

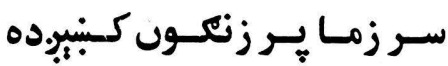
سـور كميسـي نجلهى ثخه سي

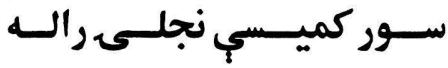

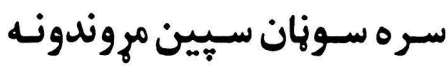
سبيني بـبنب سيّين مروندونه

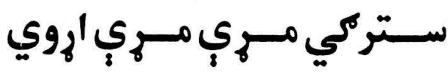

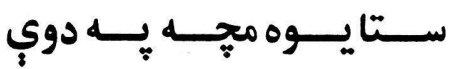


جـور سوى قيامت يـر كـواران

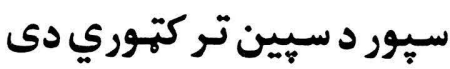

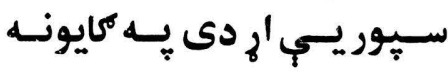

جي د سكاني له شـابل كري

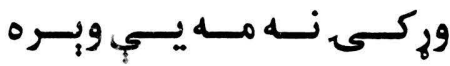

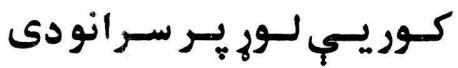

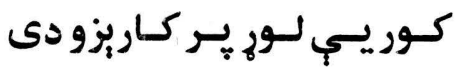

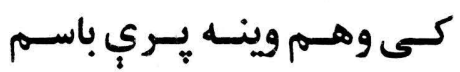

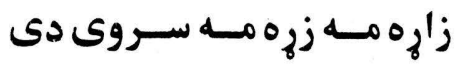

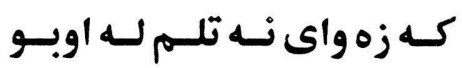

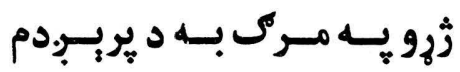

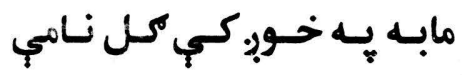

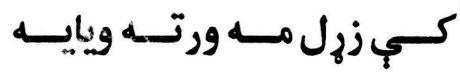

كندارلب يو وري سيني خولي

كر انـه بــهـ بـس كـي د بــوري

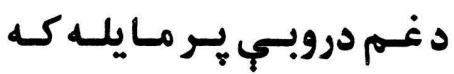

كـودى ثرخي كسه لله ويسالي

كـورى ثرخسى كـه لـه ويـالي

زمــامركسى نـسته بــي وراه

آخــــــي مسل سـوه بيمـاري

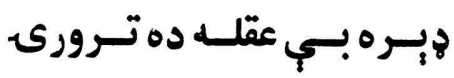

يـاس يـر هـكار اوسـي مـرادو

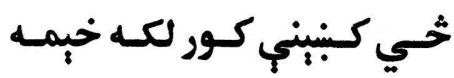

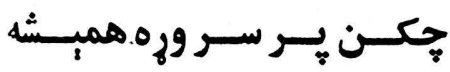

سكانيبي كور.سوى خوري سوى سكران

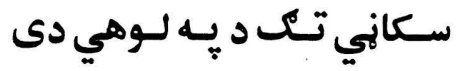
سكان وليسار كي نجي يسي ولونه ستركي وخـوري جـا نظر كي

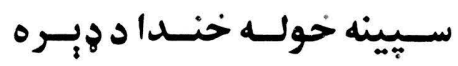

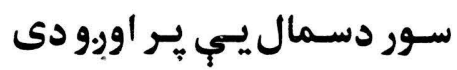

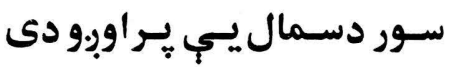

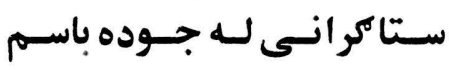
ستا يـر سر تيكـرى كـوى دى سي

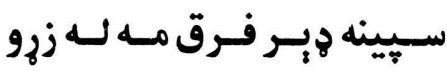

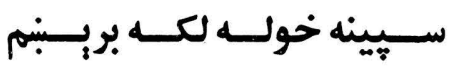

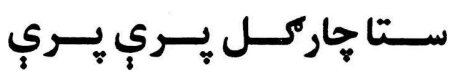

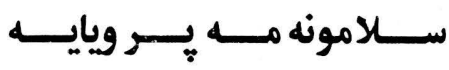

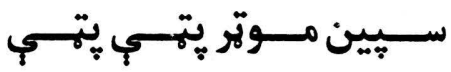

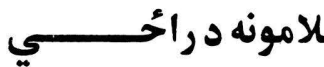

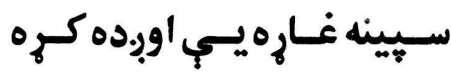

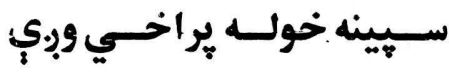

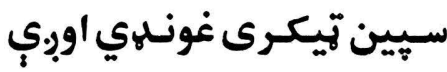

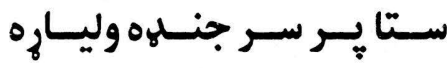

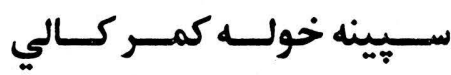

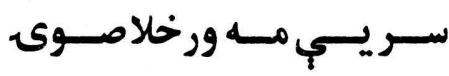

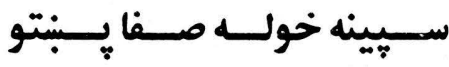

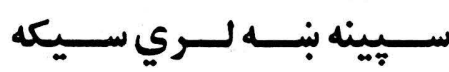

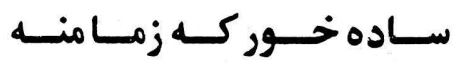




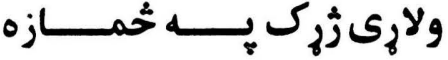

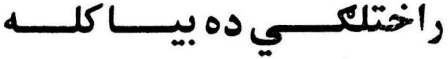

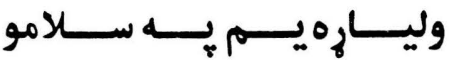

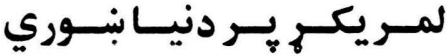

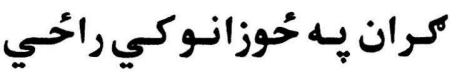

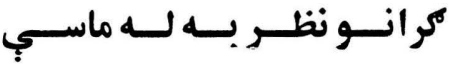

تربرو يـه لاس وركئ شَبر جان

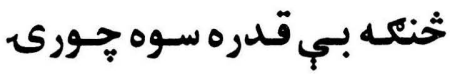

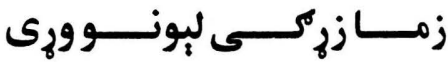

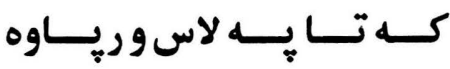

يسه شـيه كـي هـم رونيـاكـوي

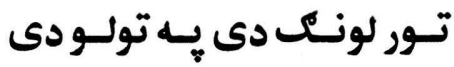

سـره بــة بـلـل واده يـيـداكسي

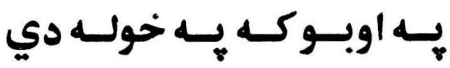

د سـري نــيم عمــر ورخــوري يـه دود بـي تـور كي دوكـولي لـه مـاويرسـول د قـرآن تـوري زمـامـرض د يــر كـران ورسي

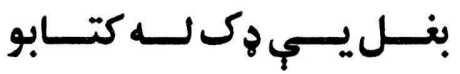

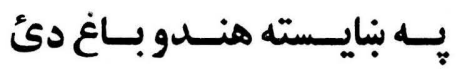

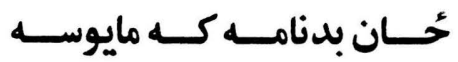

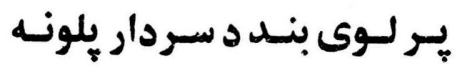

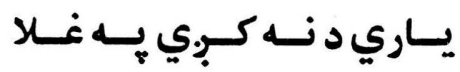
هــريسي مابست لـبريسي مـانى

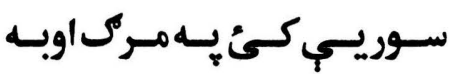

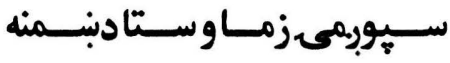

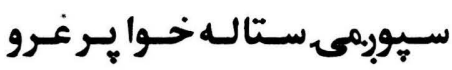
سبورِمح بنه دهمليبي ستوري

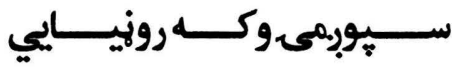

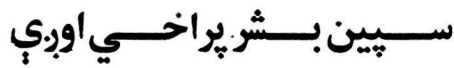

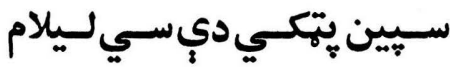

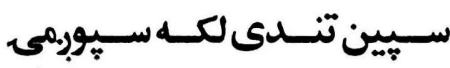

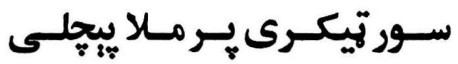

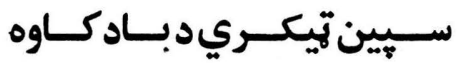

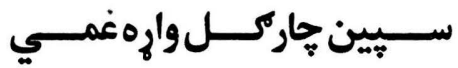

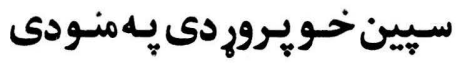

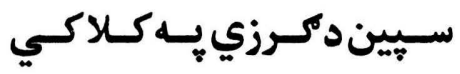

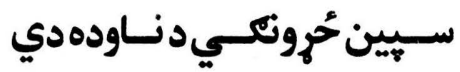

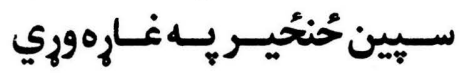

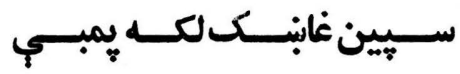

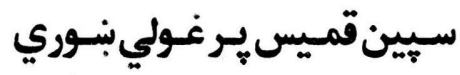

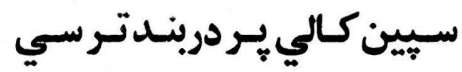

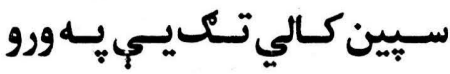

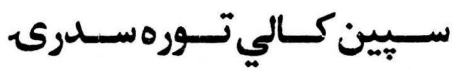

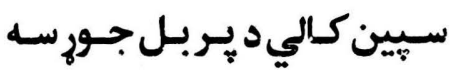

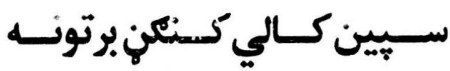

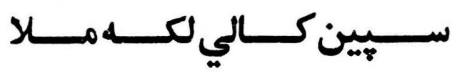
سيّين كميس جارجبت نيكـى 


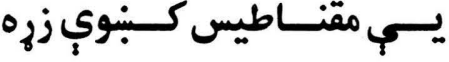

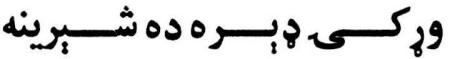

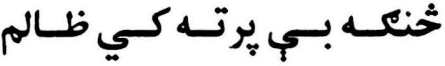
د سري ميل محككه دراوى ده يه

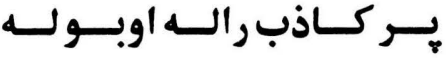

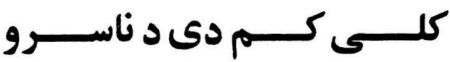
سـتاد راوى مــه نـه ده هيــره

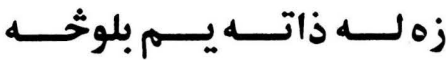

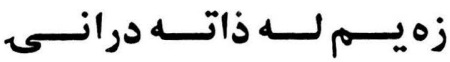

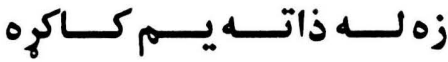

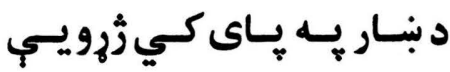

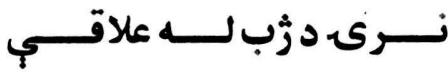

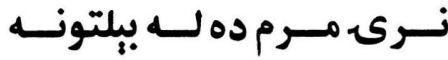

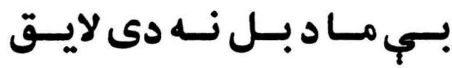
تـر مـرك يسي زور راكـئ مـاني

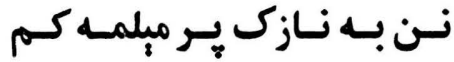

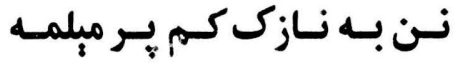
مـه كـي يـهـ يـوري د جـــالاس

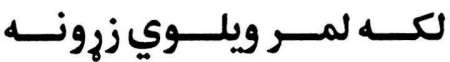

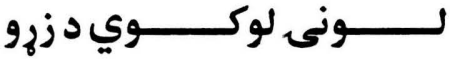

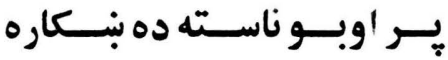
زه در الــــوحُمم بنــــــوراندي

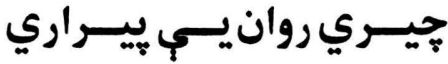

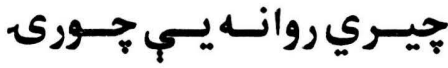

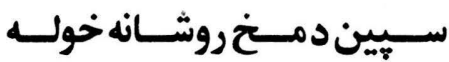

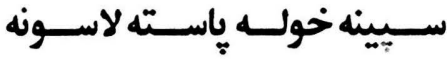

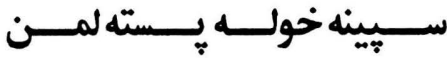

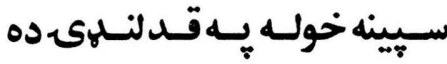

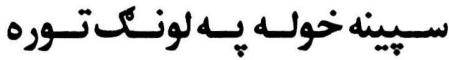

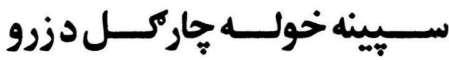

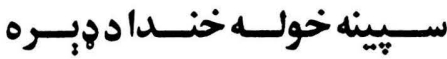

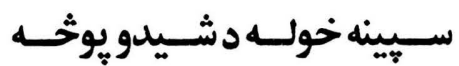

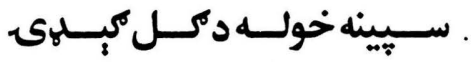

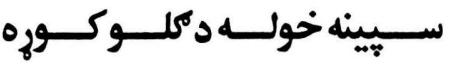

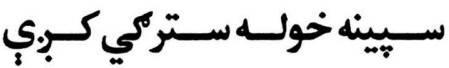

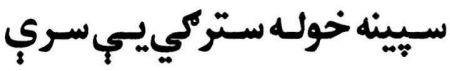

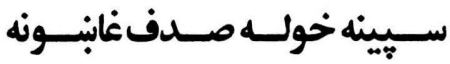

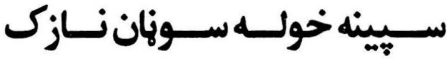

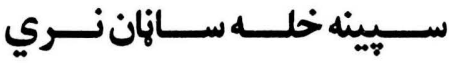

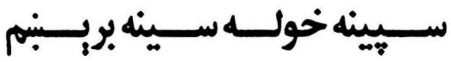

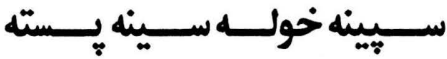

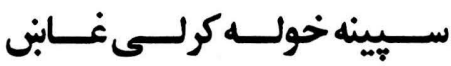

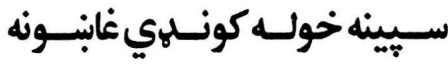

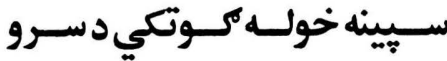

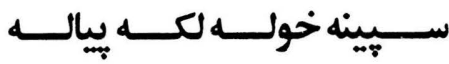

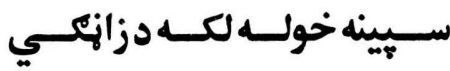

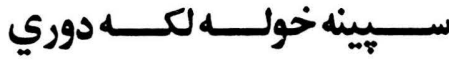

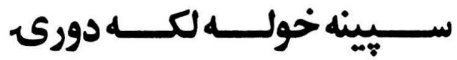




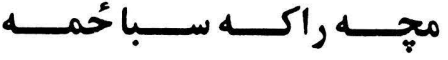

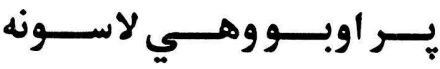

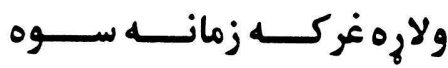

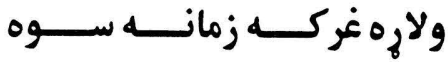
يسه تـن كهردى يـر مـخخ روزي

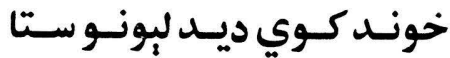

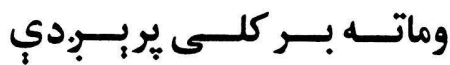

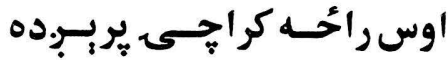

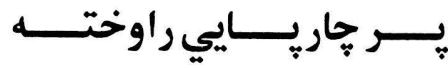

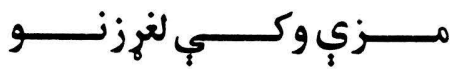
يه ملككي اوسي د كند كوت

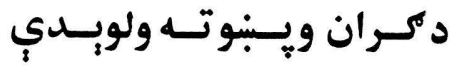

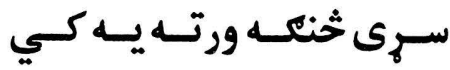

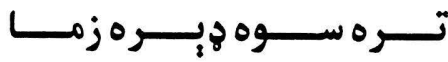

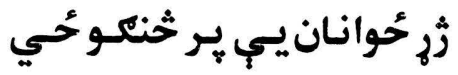

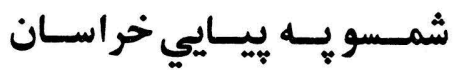

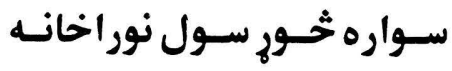

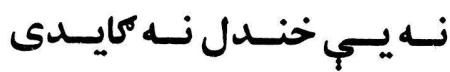

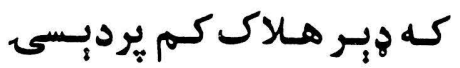

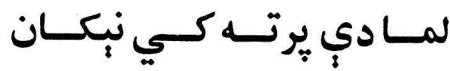

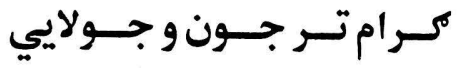

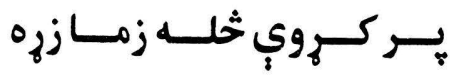

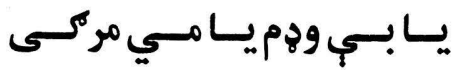

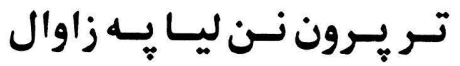

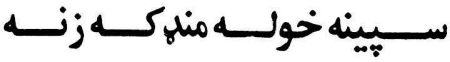

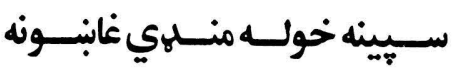

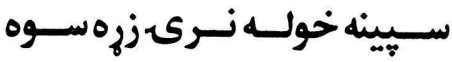

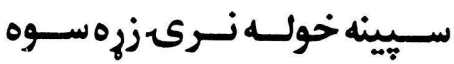

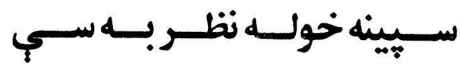

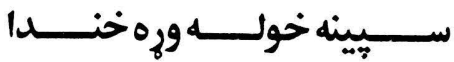

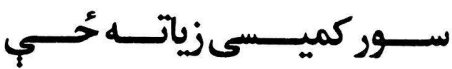

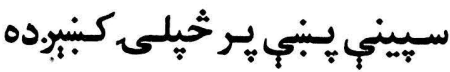

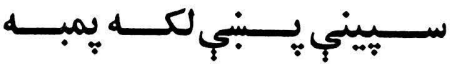

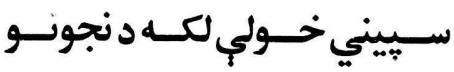
سبيني كالي دسنتروبِ

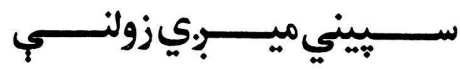

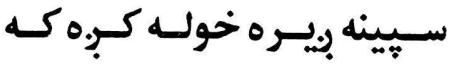

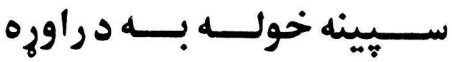

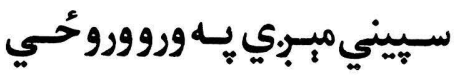

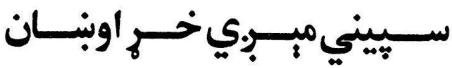

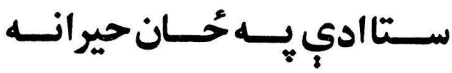

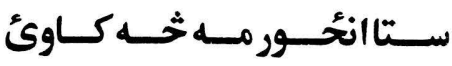

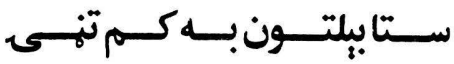

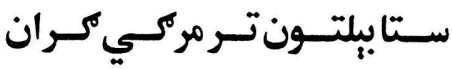

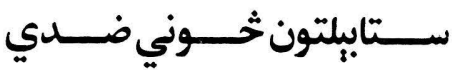
ســــتابلتــــــون داور ســـــــاره

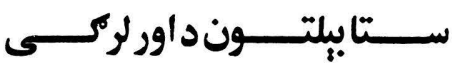

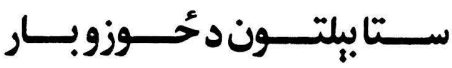


اوس خـــــــ د غـــــه ســــرونه د لاس كهـــى د مريــان وري د لاس كهـــى د مريــان وري بـاد بـرو دى بـوى بـي راوري

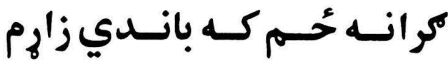

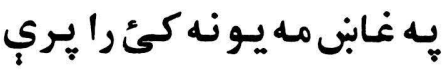

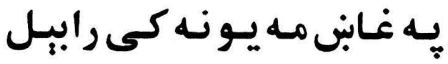

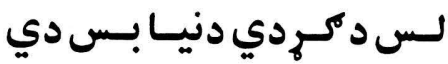

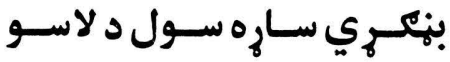

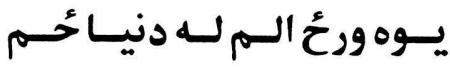
نـرى غبـرك بارخوكـان راوره

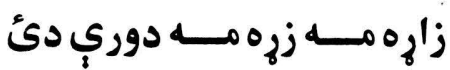

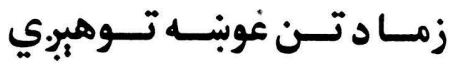

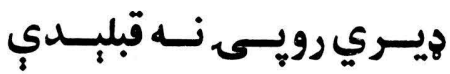

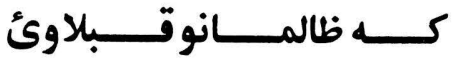
وج شـونلهان مـه د هيـر نـه دي

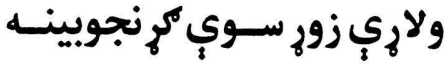

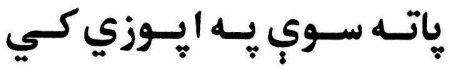

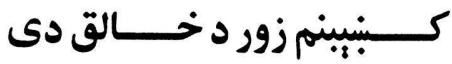

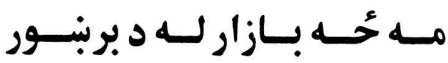
تـا يـر خولـه نيــولى لاس دى

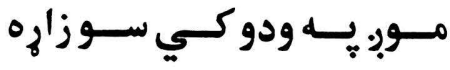

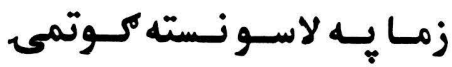

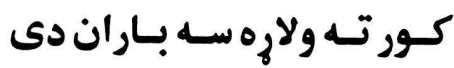

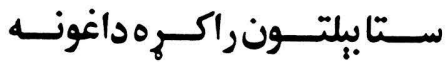

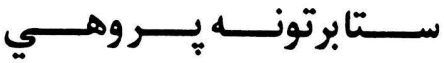

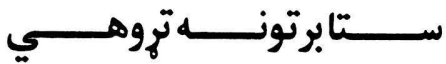

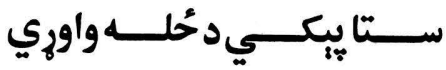

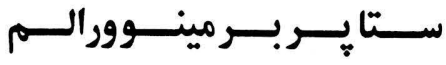

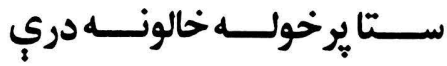

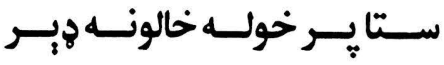

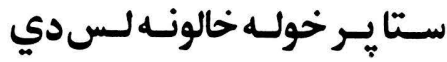

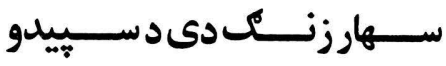

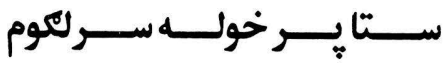

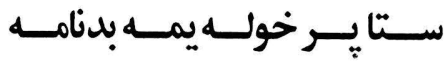
سـتا يــر ســرتيكرى كــوبي دئ

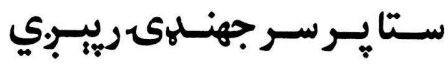

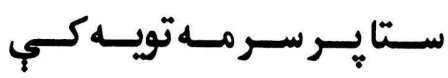

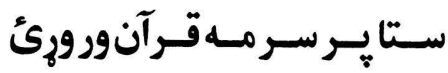

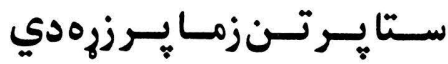

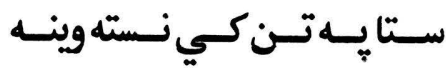

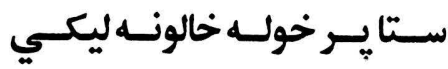

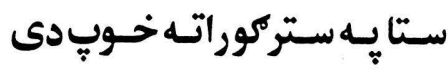

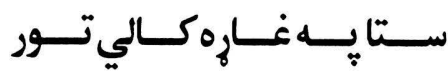

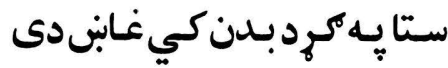

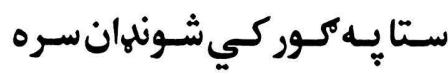

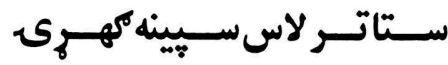

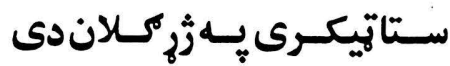


مابنـام بـي خـور كي يــ بنـوور راسـ ثحي سـيورى كـو مر انسو يه كور كي حُاى نسته ثخي ب.دم

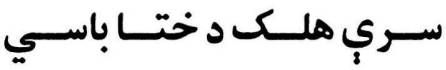

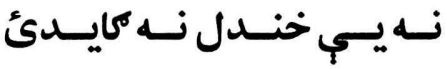
يسـه ليــاري ســات يـهـ تـــروم

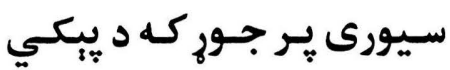

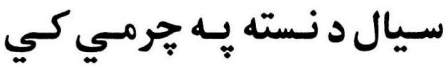

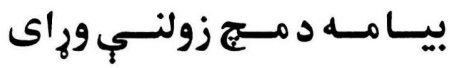

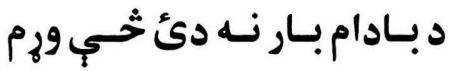

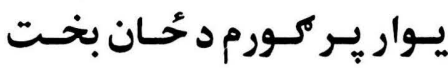

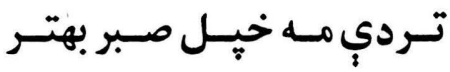

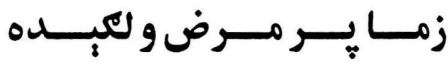

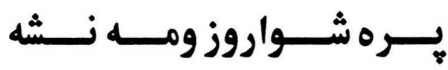

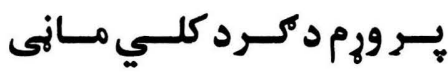
خـورمبـي نـرى يـر خراسـان

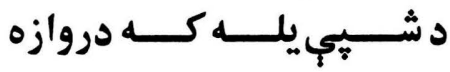
خي وي خورم نور سم سودايي خي لاس ور ورم تويسه بـي كم

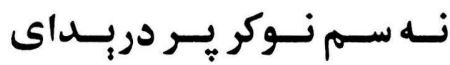

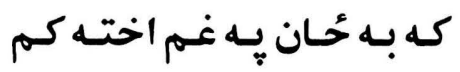

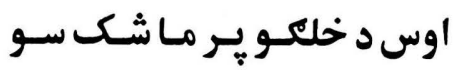

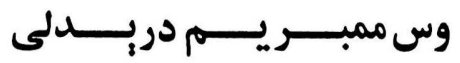
حيرانسه ورك يـهم ؛ــه سـوجو دوري

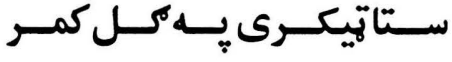

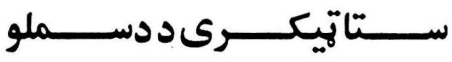

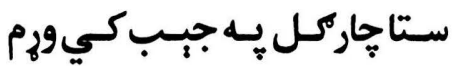

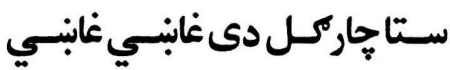

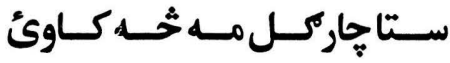

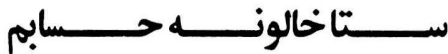

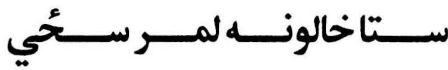

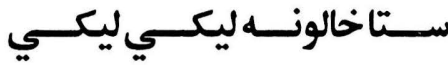

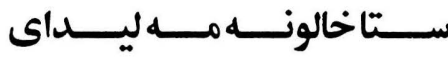

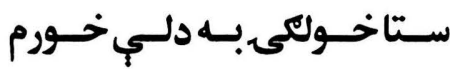

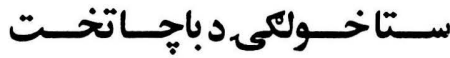

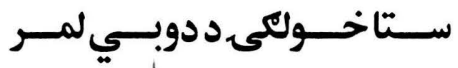

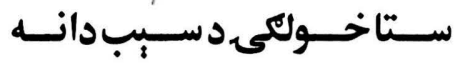

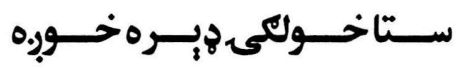

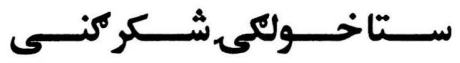

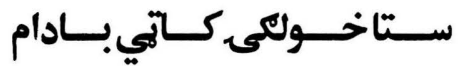

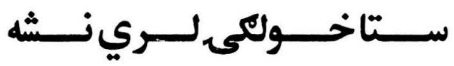

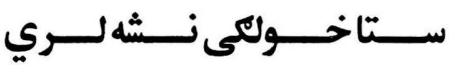

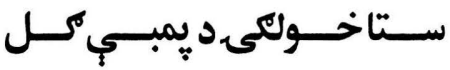

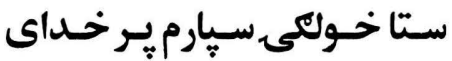

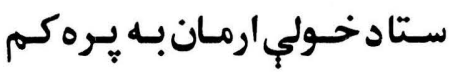

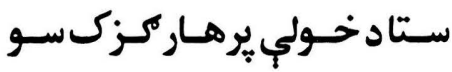

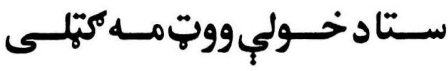

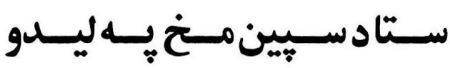




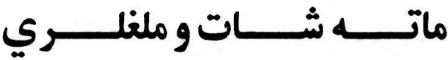

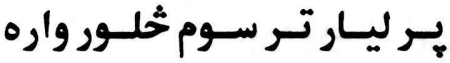

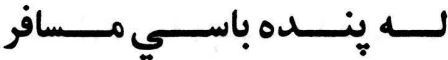

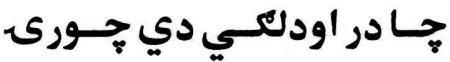

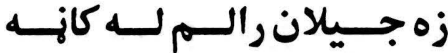

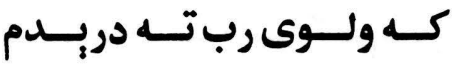

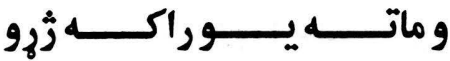

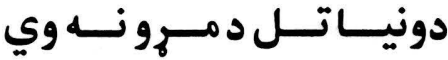

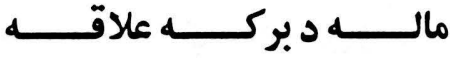

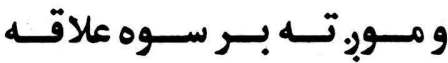
سـتاتلى مـادى كـال يــــــال

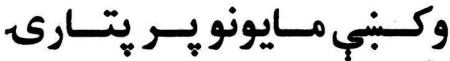

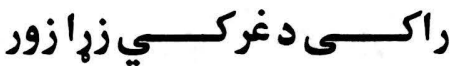

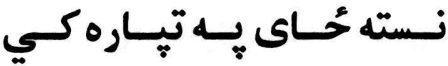
يه كونج كي كبّبرده سربايي

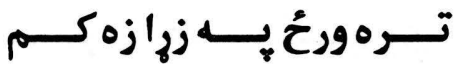

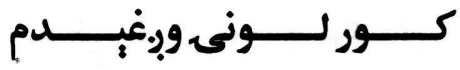
ورور د بـلـل نـسته ثــــي وكسم بـل دورور نسته ثــي يـار كمى

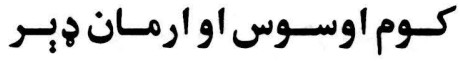

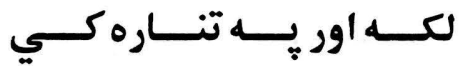

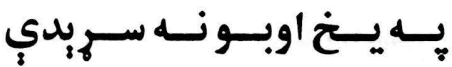

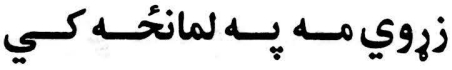

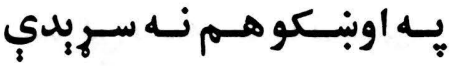

سـتادسـينيني خــولبي خبــري

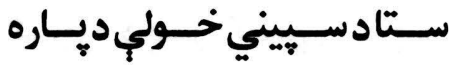

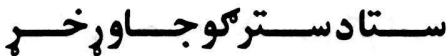

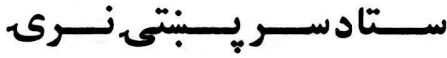

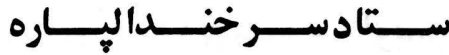

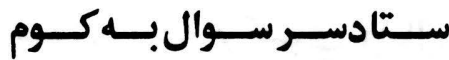

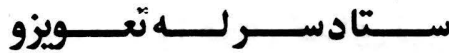

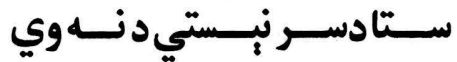

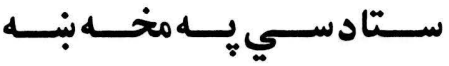

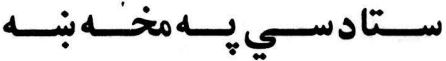

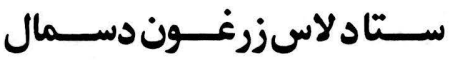

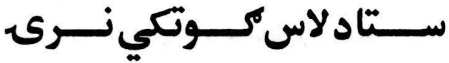

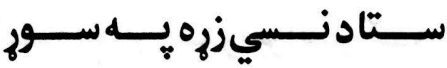

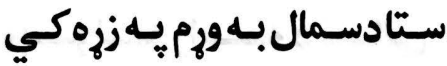

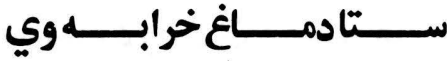

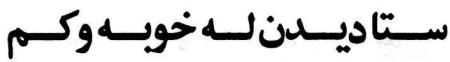

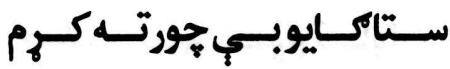

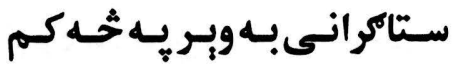

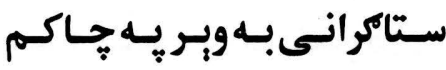

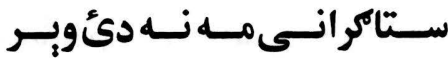

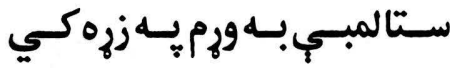

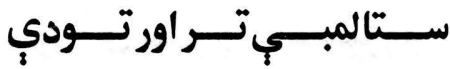

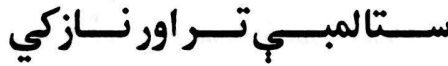

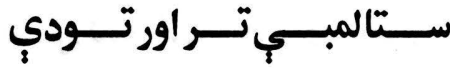




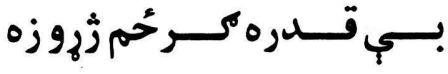

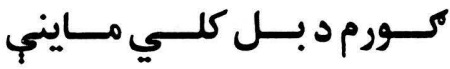

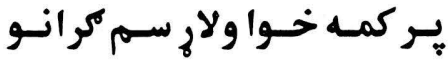

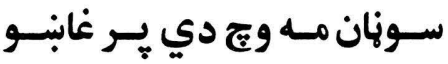

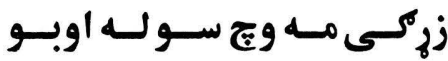
خــوك راحسه كرحسـوي لويـال رسك به راواجوي خداى نور

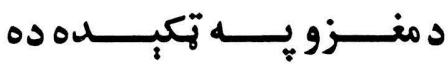

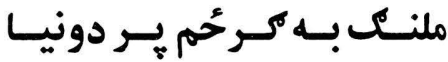

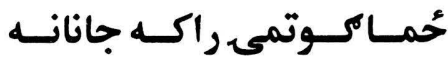

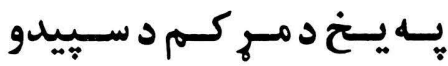

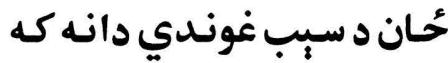

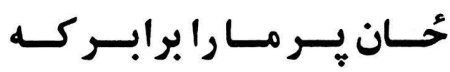

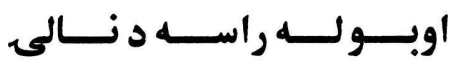

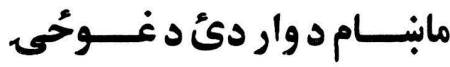

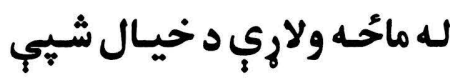
دخلكـــوكــم كـــوم تـــاوان

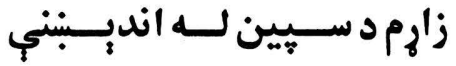

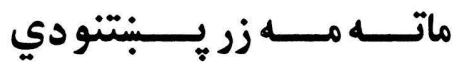
خلـك تهمست ويسايي جانانــ

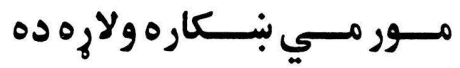

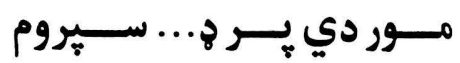

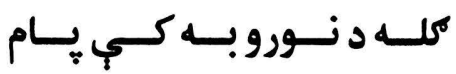

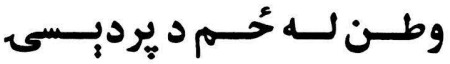

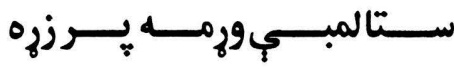

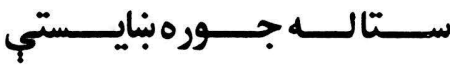

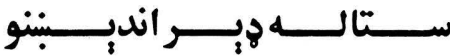

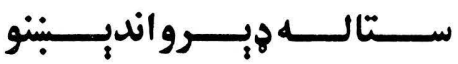

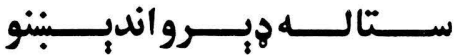

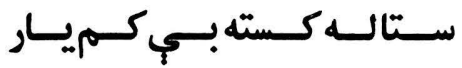

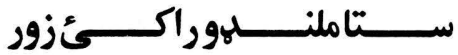

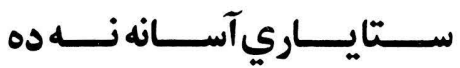

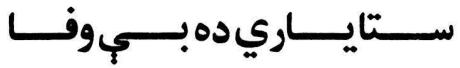

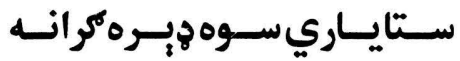

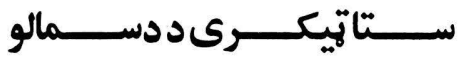
ستركي تـوري كه خوله سرهك

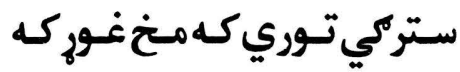

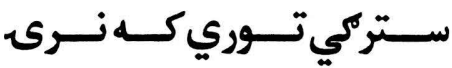

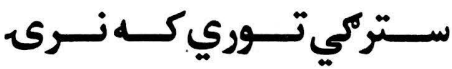

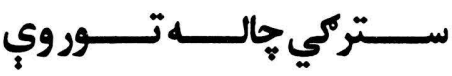

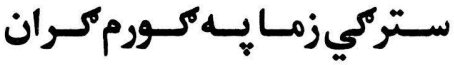

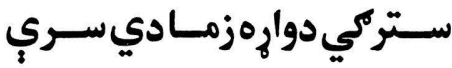

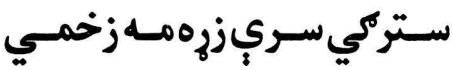

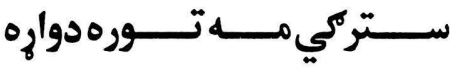

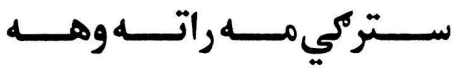

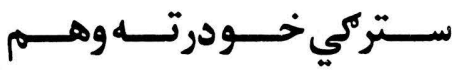

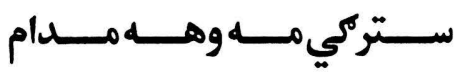

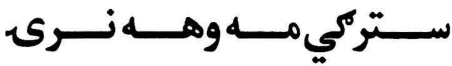




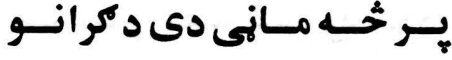
خـداى دوس جـورئه ميزانس

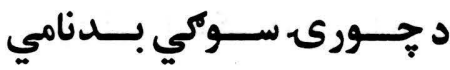

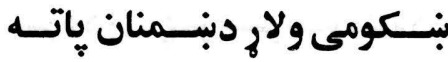

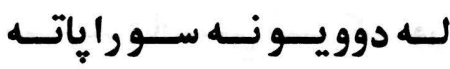

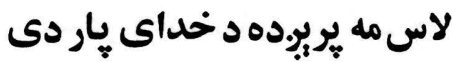
بيا به كران به خواستوغونوارئ

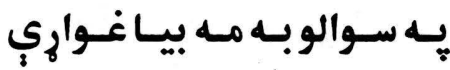

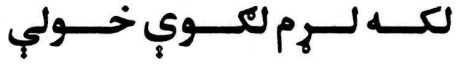

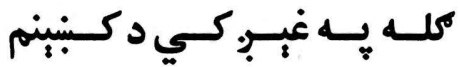

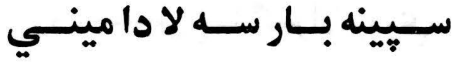
كر انــه بـار سـهـ لــه دا مينــي له غـرو را برتهـ سـوه سيوبر.مى زوليج زوى دزاري

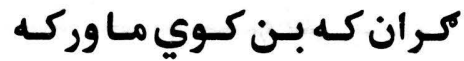

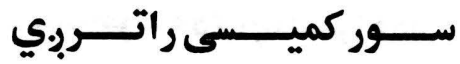

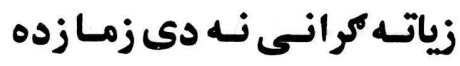
يه لاس مه كوتكي د سري دي

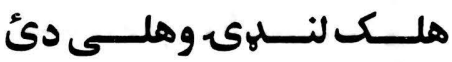
كه كار سي هم نه دى تاوان خداى د لوى خبر را يّبن كي

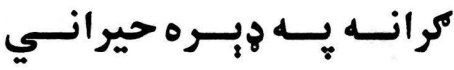

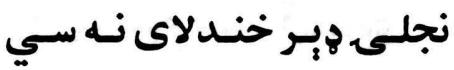

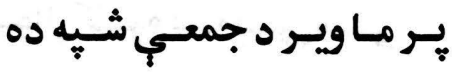

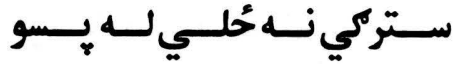

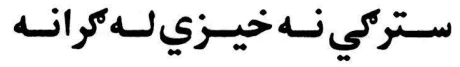

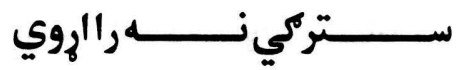

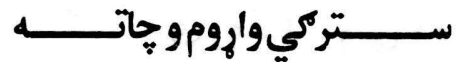

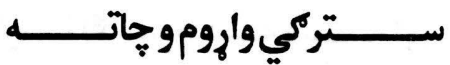

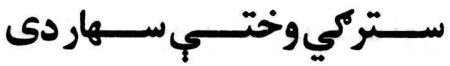

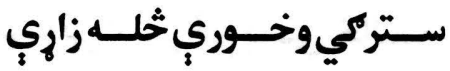

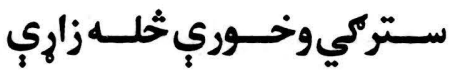
تـركي ووروراواروي

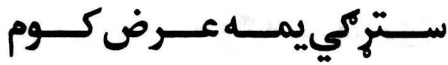

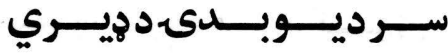

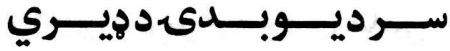

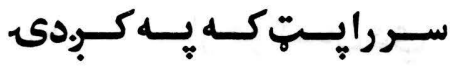

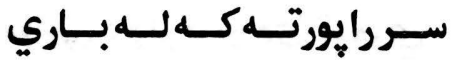

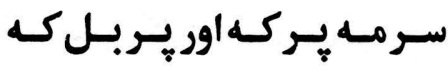

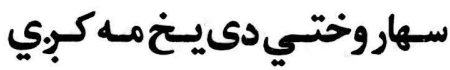

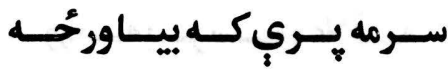

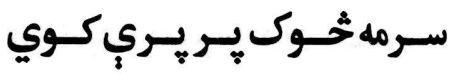

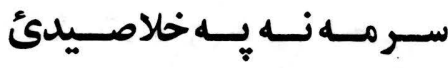

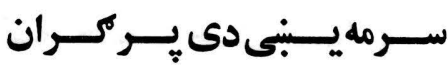

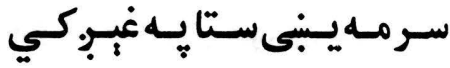

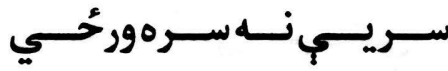
سور تيكرى يه خوله كينسي سـرهبـي غمـــــــور ويـدهده 


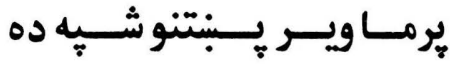

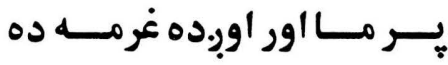

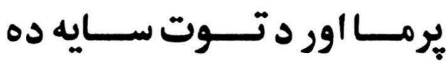
خلـكــــــاى روغــه لــونى ده

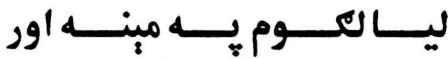

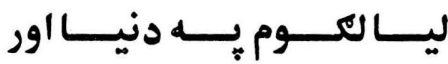

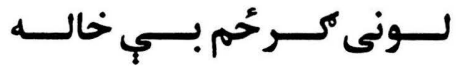
يـه غونسلهوه سـراى ربسي بنــوور

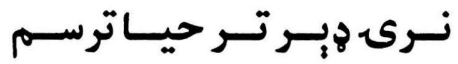
كوريجي بياير جركه سيور دئ

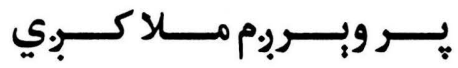
شلومبى د دير تريسو دى مامي

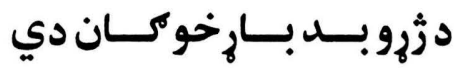
شلومبى د دهبر تريو دئ تروري

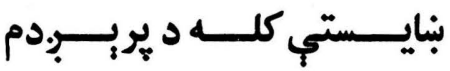

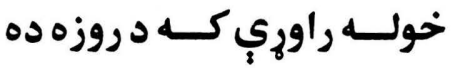

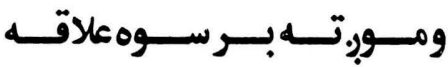
دكنــد يـــر ســرمه ده وانــلهوه

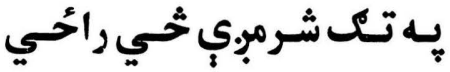
برتــور جمعـهـ خــان غــواري ير نازك خاوري موري سوري

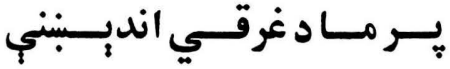
وركى د جــور يــر دنيـاكسي

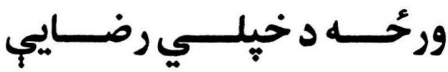

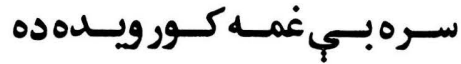
ســـرهـــرارهكـــور ويـــدهده ســــــــرارهكــورويـــدهده

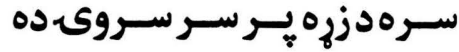

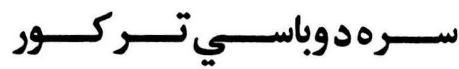

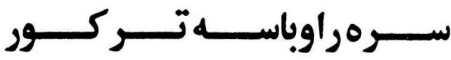

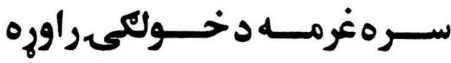

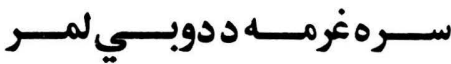

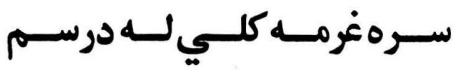
سـرهكالي تيكرىيـي تـور دئ

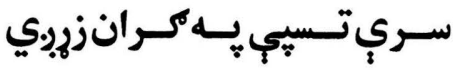

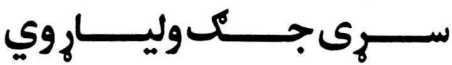

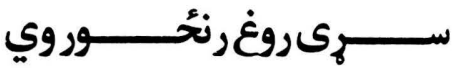

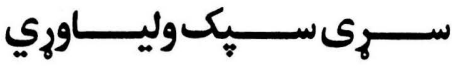

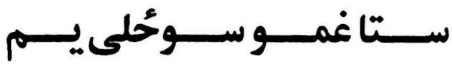

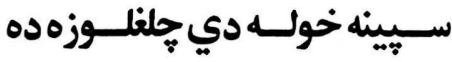

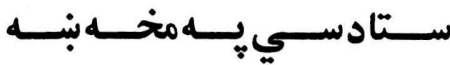

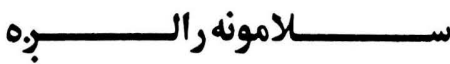

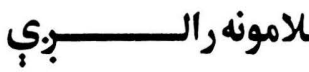

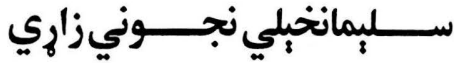
سوخي مونى سياندي شني سوي

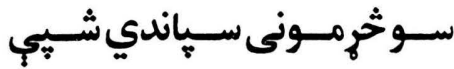

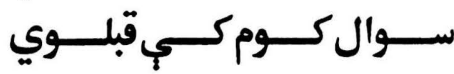
ســوالكــومنـــــــــــــــي 
يسـوار حُحسان كـهـ ترمــالانـــي

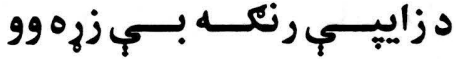

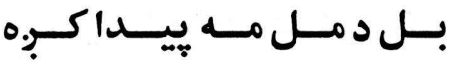

كرانـه اوس د مـزو شــبي دي

بـانوو سـتركي سـتومان دي

بـوتى نـه سـوحي نـودي دي

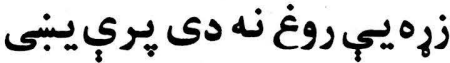

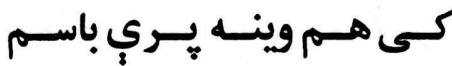

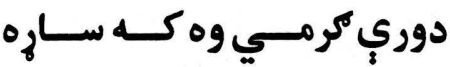

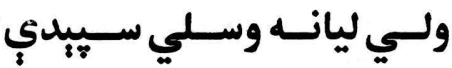

مور د اور بل كئ تور ستركي

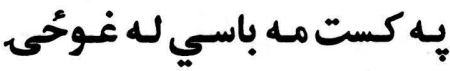

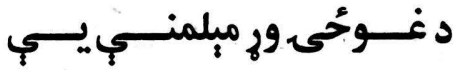

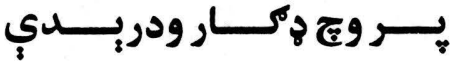

درخـرئى مــهـه سـتاكـاره

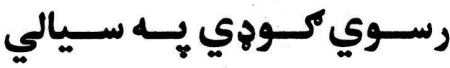

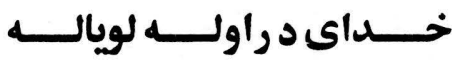

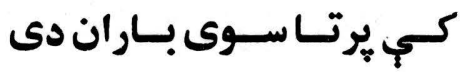

نـامرده يـي حُّم يسه مـات زيره

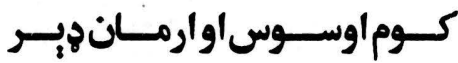

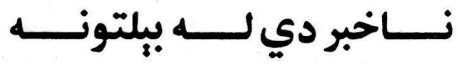

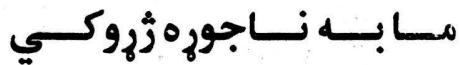

لمايسي ويرسو د خـولي خوند كـه مركى نـه سـوراورانسي
سبينه خوله يـستح غـولانحُحي

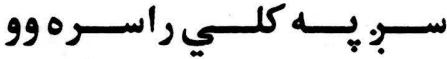

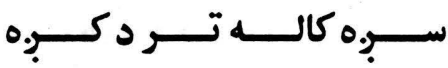

ستاغه مبربى زمـاغه وزي دي دي

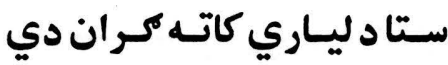

سـتالمبـي تــ اور تـودي دي

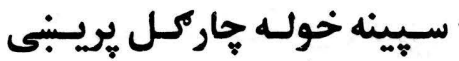
سـتاكرانسى لـه خيـال باسـم

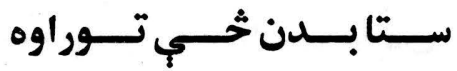
ستركي دوي خيزي كه دري سـتركي نـــه دي راختلكســـي ســهار نسهله دى شــين خــالى سـيـينه خولـه سـتركي رنسي

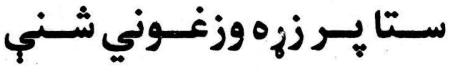

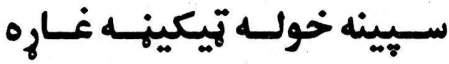

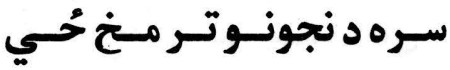

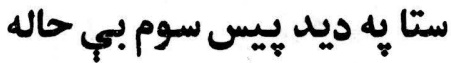

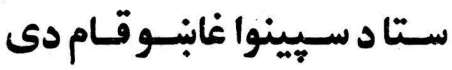

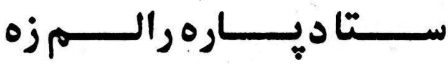

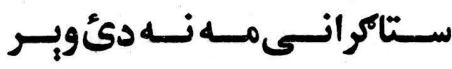
سـره يتكسي تــــي يسه ولونسه سـتا نخــولكى نيسـإبه نمستوري

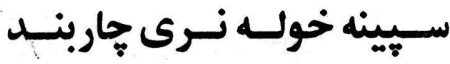

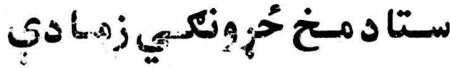




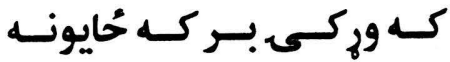
ثـي بـه لاس يورتس زروكى

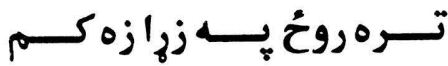

اخـستكي يـم د شـيطان جيـل نـن سـم همــش بـردر إسـداى

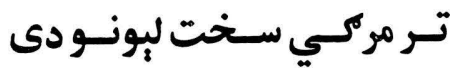

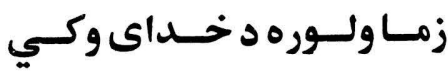
سـيورى راجــور كـهـ د اوربـل

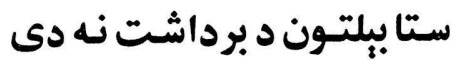

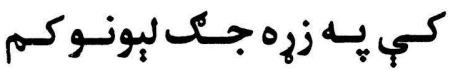

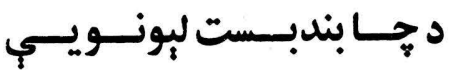

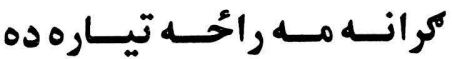
بـل د ورور نـسته ثخـي وكـم

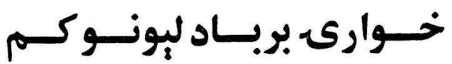

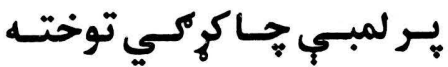

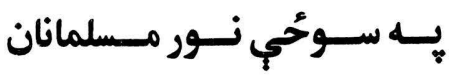

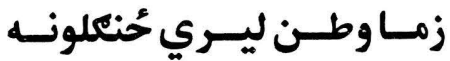

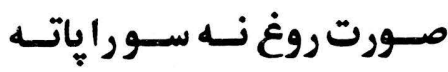
اوبتكي مـ حُحي يـر مـخ بـاران

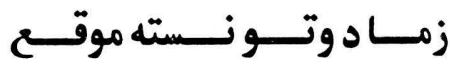

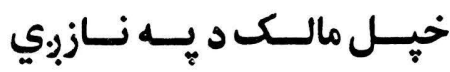
وزكى ترغحَي لله تـاغورحي

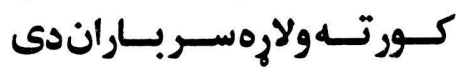

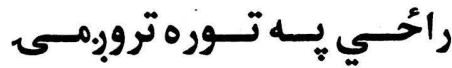

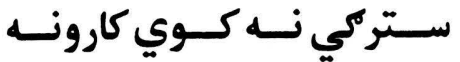

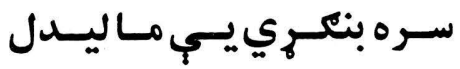
ستا ديــن بــ خـوب كي وكمر

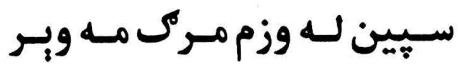
ستا خـولكى سبارم بـه خداى

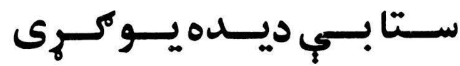

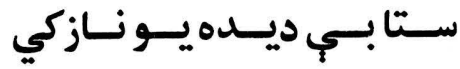
سـتارخســار د بــورى كــل

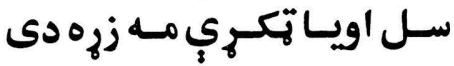

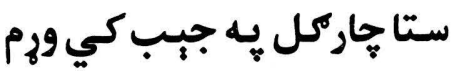

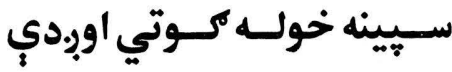
سـتا يـر سـر بانـدي خطبره هده

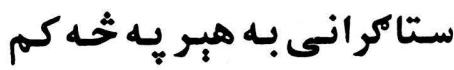

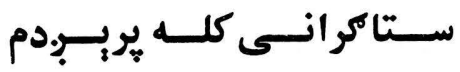

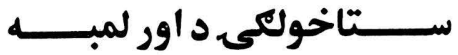

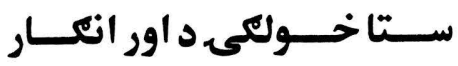
سيني واوري جك يسي غرونه

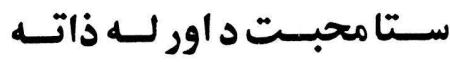

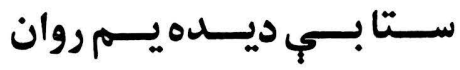

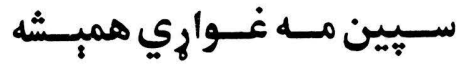

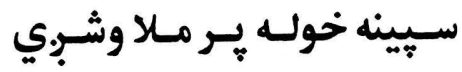

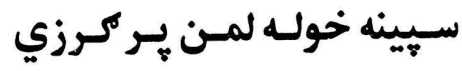

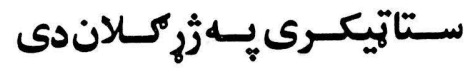

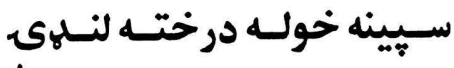


زمــاروزي نـــهـ سـي جــورى

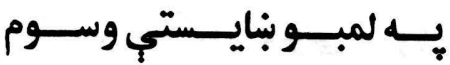

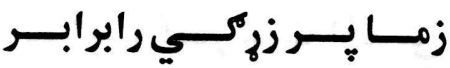

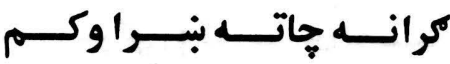

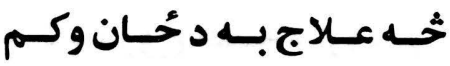

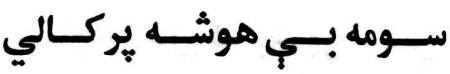
خلكسو :ـــ مـاجـور دى محسـر خـي دابـار نايستي كـور كـئ

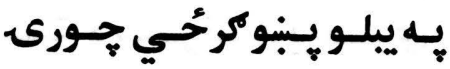

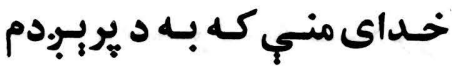
كـه زهوواى نـه تلــم لـه اوبــو

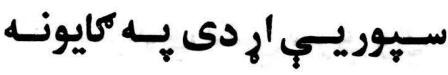

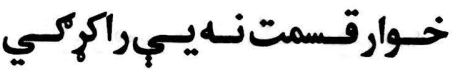
سيور د سـيـن تر كتهوري دى

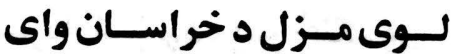
نـنيسي بـ مكركي واهـي ده روزتـي مـهـ د خــاى نـهـي كـي

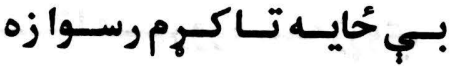
خـوب يـر همخحولـوآرام سـوى بـــه انتظــار كـــي مـــام دي

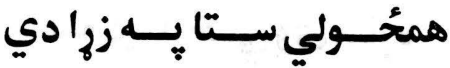

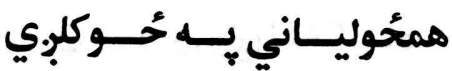
تـه سـوي د تهـول عمــر قيـدي ستا بـر خوله كانهي دي يواته

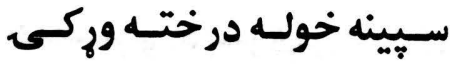
سـتابلتــون زغمـلاى نـه سـم

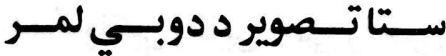
سـتابلتحـون سـتومانه زه كـم سـتابـتــون سـتومانه زه كـم

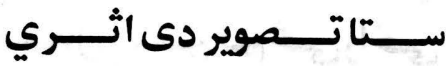

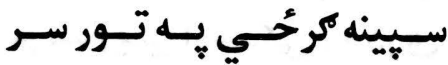

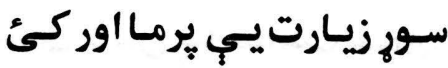

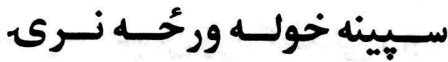
سر به ستا ير حُنكون كنبر.دم

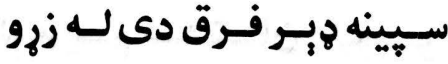
سـان وليـار كنجسى يس ولونه سـتإيـرنـومـهـ سـتركي سـكاني تـك د بـه لـوهي دى ستركي زماواى بنبي دكران سيوبو.مى زمـاو سـتا ضـدي ده سـتا بـه خولـه مـهـ د اوبـه كـي

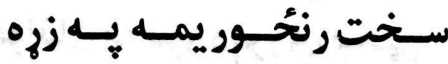

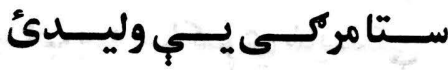
ســا همحَحــولي ليـار خـــاري

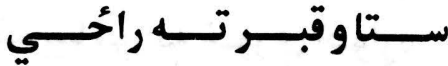

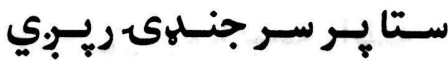

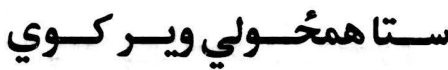

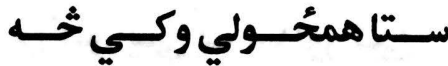


همحٔحسـولي هيــــري زريــــــي

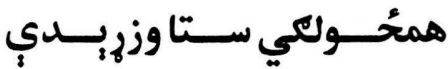
همحُولكي ويايي ثخي راحي

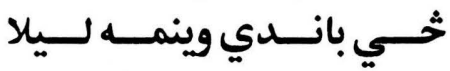

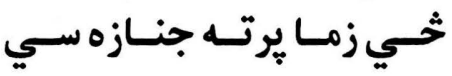

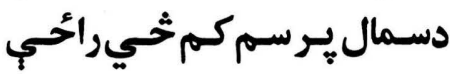
يـر مـخ يـي اوبنـكي نسه دري

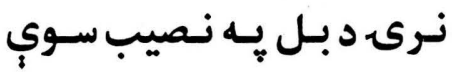

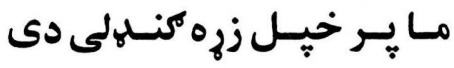

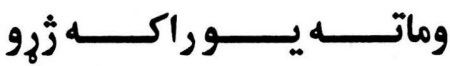

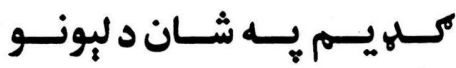
زما د شونلهي غوتي يري ون وي

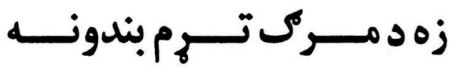

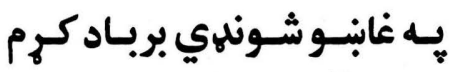

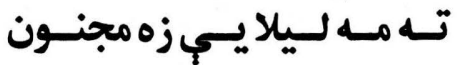

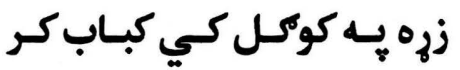

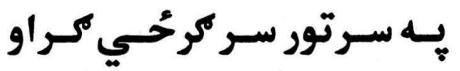
حُوانان بـه نـور هُبروي بنيخي

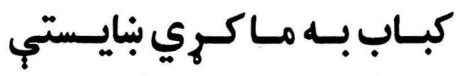
يـه تنـك بـه مـاكـي بنايـستي هنه بيـانـور نه خـوري خـواره

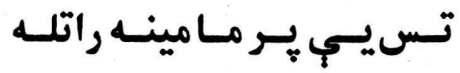

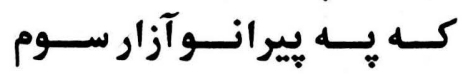
كلى كـوريـي يــ مـا اوركئ

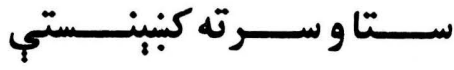
سـتا يـر خـاك راتـولي سـوي

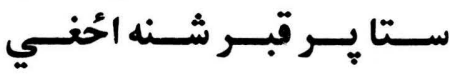

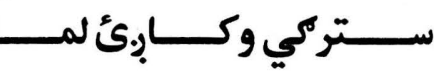
سـتا بـه روح هلتـهـ تـازه سـي

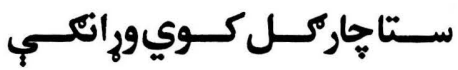

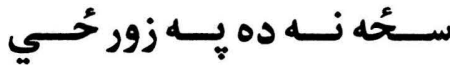
سـول تـكــان سـتاد كــوزدي

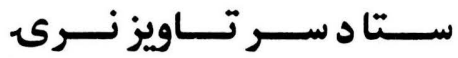

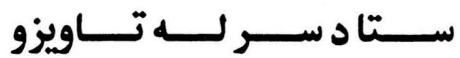

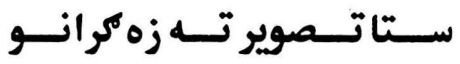
ستا ش شونلهي تكي سري وي

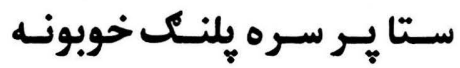

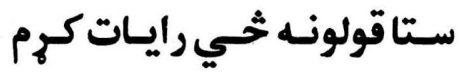

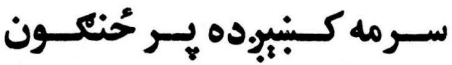
ســـتركي ســــاد اور لمبــــي

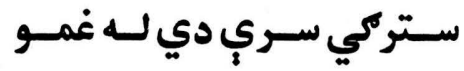

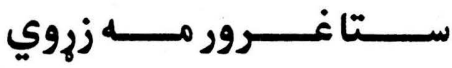
ســــا بِلتــــــون د اور لمبـــــي

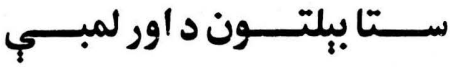
سـتا يـه ديــد خــي وي مـاره

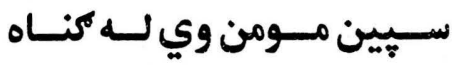

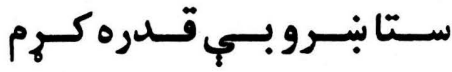
ستا بِلتـون مه مـخ راتور كئ 


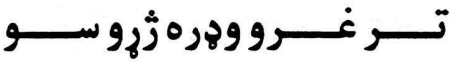

كـه نـرى بيرتـه جـوروه سـوه اوس د ورم زه خوسي خوارى كه ك....بـكاره كي تربـايثّي

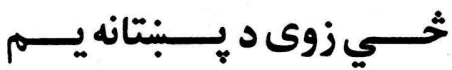
كــان رابنــووه دريـسـي مــرم

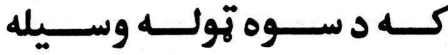

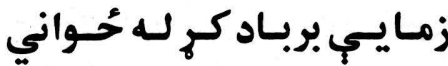

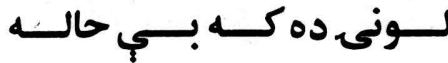

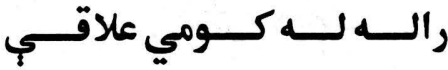

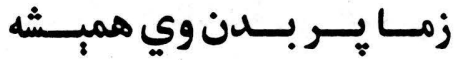

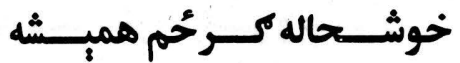
اوبنسكي .بي واكـه لـه مـاحي هـسي مـه نـوم دى دورونـلـي

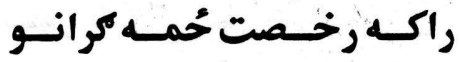

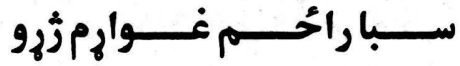
راتــــه اور تهولــــه بــــورى و

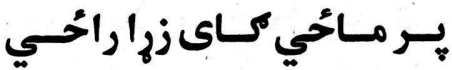
سيورى يـر جـور كه ديككي اوس مسه دود يـر آسـمان كـوره

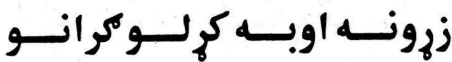

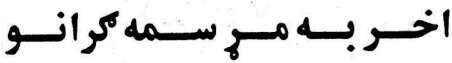

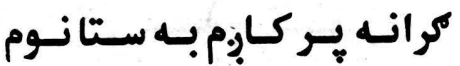

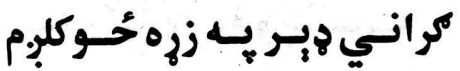

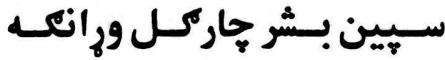

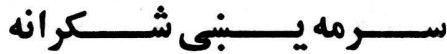

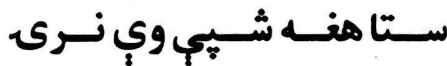

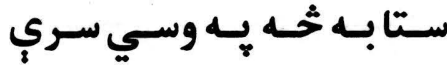

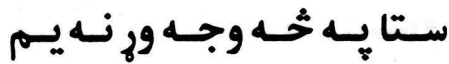

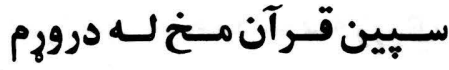
سـري رويبـار دركــه دهوكـه

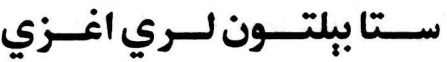

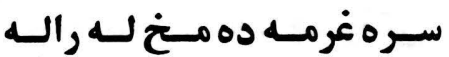
سينه خوله شونهي يـي سري

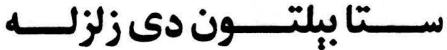

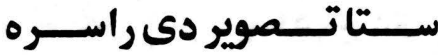

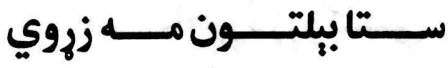

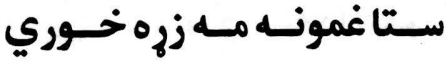

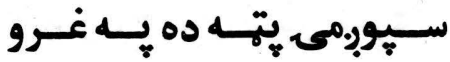

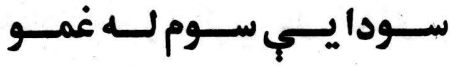

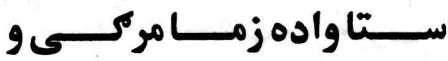
سـتابـتــون كــم سـودائي

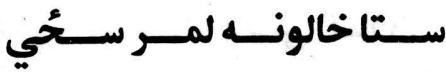
سـتا يــه غــم وسـوم بــي اوره ســتابـتـــــون د نــورو غــــرو

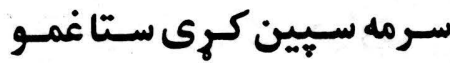

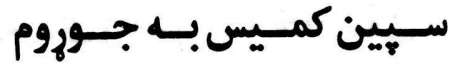

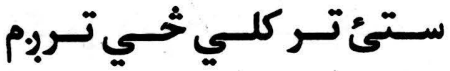




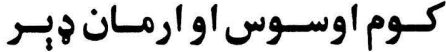

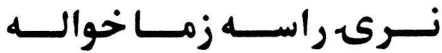

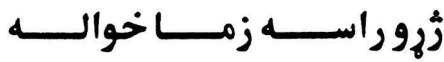

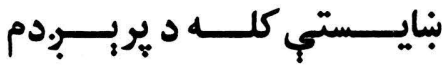

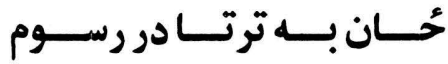

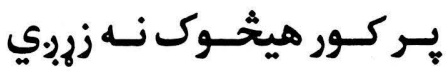

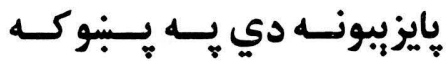

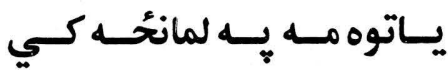

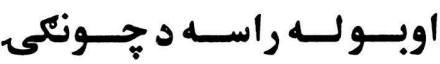

غـــاري كــــوم يــــــــــــــي

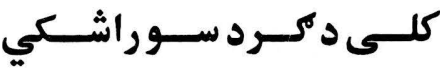

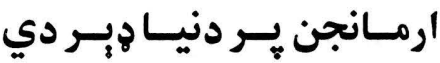

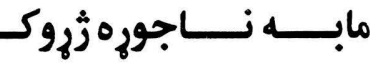

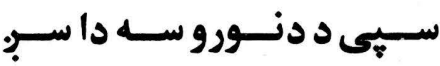

راخبــر د جهـان تـــول كــئ

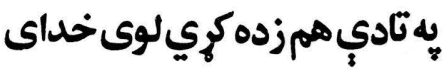

زه شــــم د آســمان ســتوري

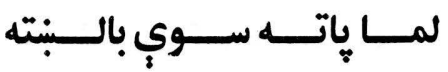

خـــ خراسـك وكـيــــان

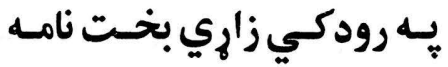

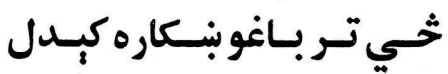

وخت يبي معلوم دى د دراوى

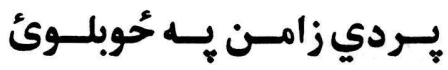

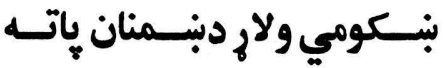

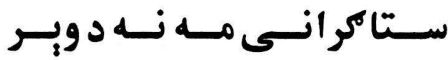

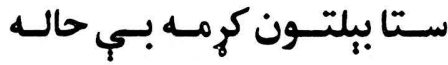

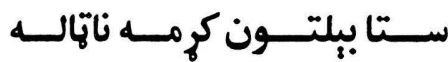

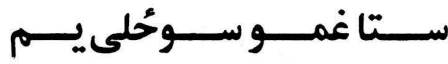

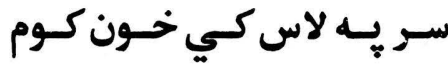

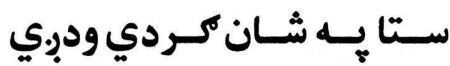

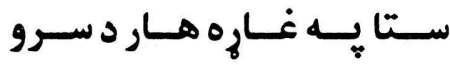

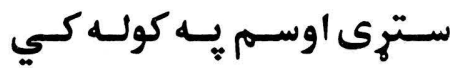

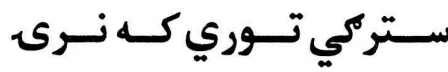

ســتا يــــر نــــوم ديابنـــدي

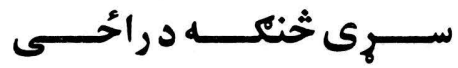

ســتاخحالونه تُبــــر و بـــــــر دي

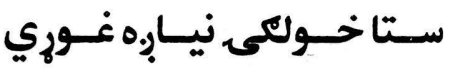

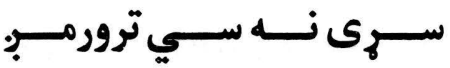

سـور يلـوكي اور دتــوكـرئُ

ستا تر خوله ثحي وحُي كاى

ستا وخوله ته به خوك كوري

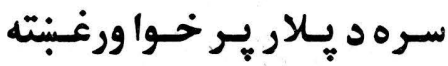

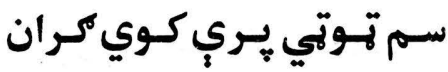

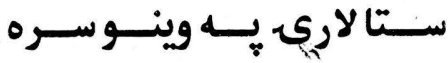

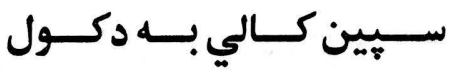

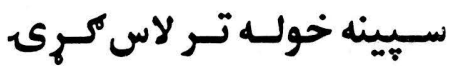

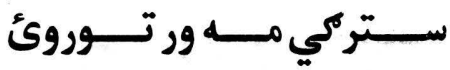

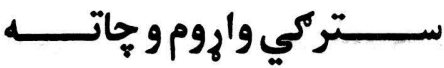


تـو سـوي كنــده شـين خـالى

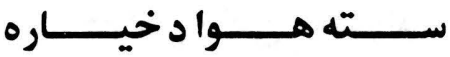

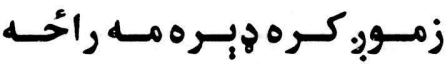

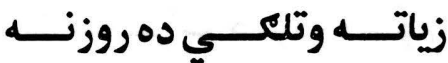

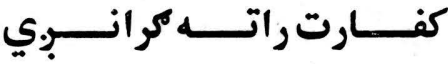

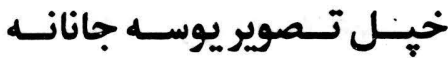

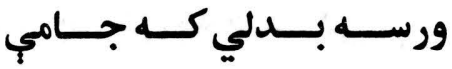

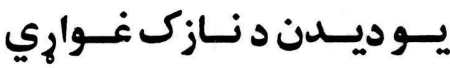

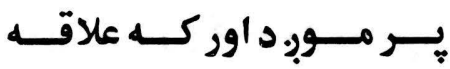

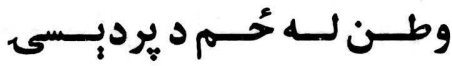

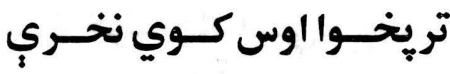

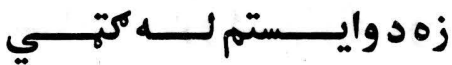

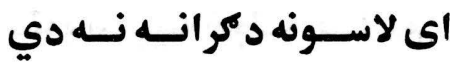

زونــند دسـتاد رضــادركـي

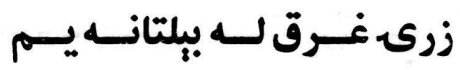

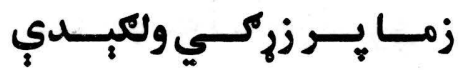

كر انـه د حقق د يرمـا زيـات سو

زونسلد مـهـ تبـاه دى كـي منــي

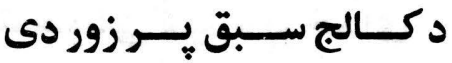

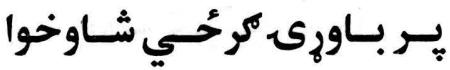

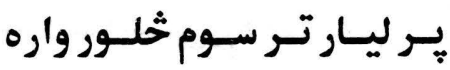

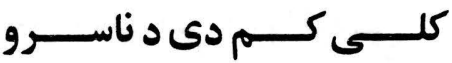

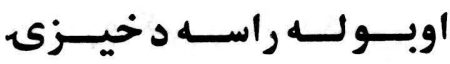

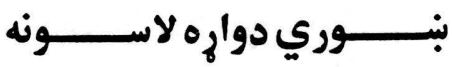

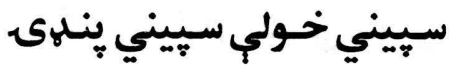

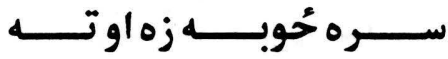

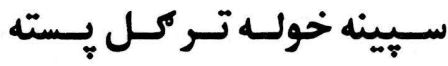

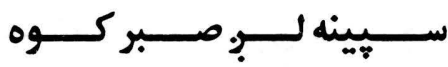

سـتا يـهـ خولـهـ روزه مــاتبري

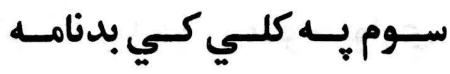

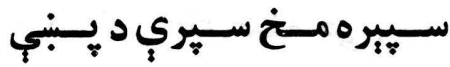

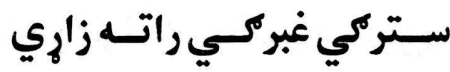

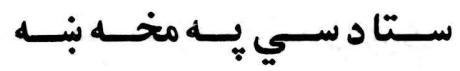

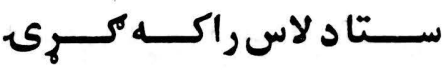

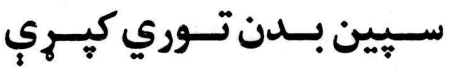

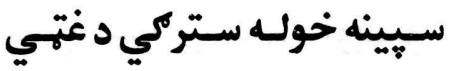

ستا ير تن دي زما ير زرهد دي

سوال كوم د خداى يه در كي

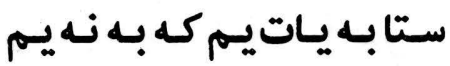

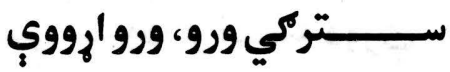

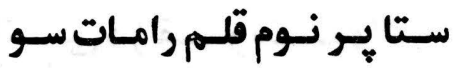

سـتابـتـــون لكــوي خـــولي

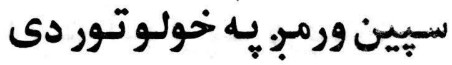

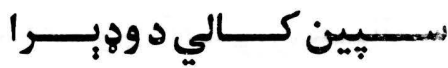

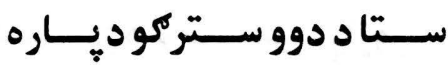

سـيّينه خولـهـ جاركسل دزرو

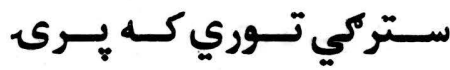

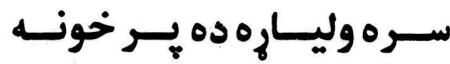


كاكرى غاري

نــازك يركسوال كيـي مبلـيجي

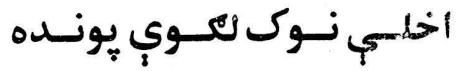

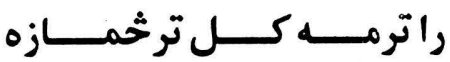

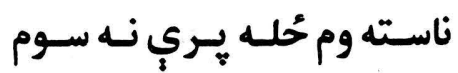

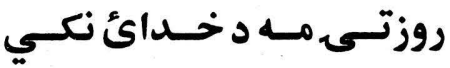

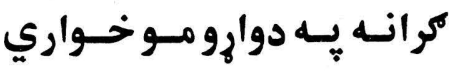
يه كور كي حُاى نسته ثخي زدم

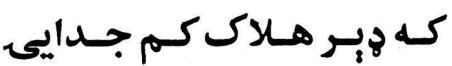

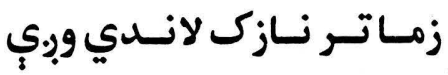
لله مـوبر ولاري د خيـال شـيبي

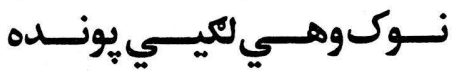

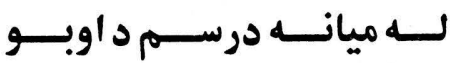

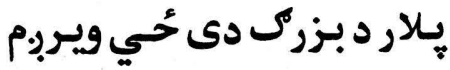

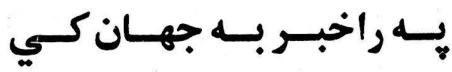
يسر مـرك خنــدا مالـه راحـــي كـــي ســـوداكر نــسته دوري

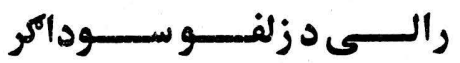
كـه راخبـر سـي جهـان تهولن

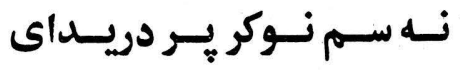

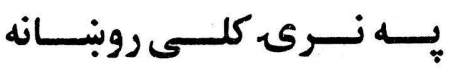

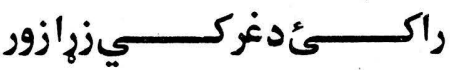
زمـا احسوال د يـر كران ورسي بـهـ جـار كي بوغ دى د مـوري

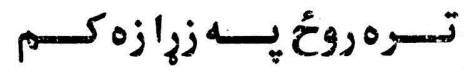

سبيّن كـالي براخسي يـايخّي

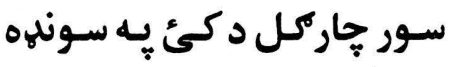

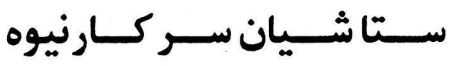

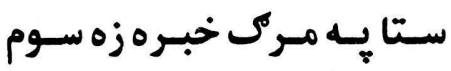

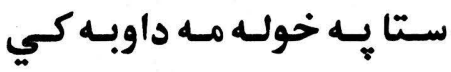

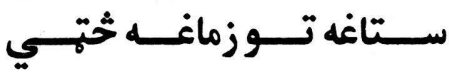
ستا جاركل بـه جيب كي وزئ

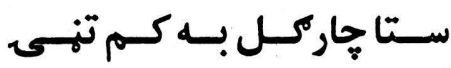

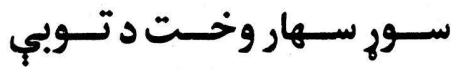

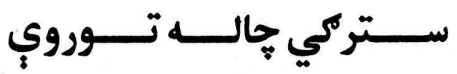

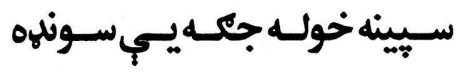

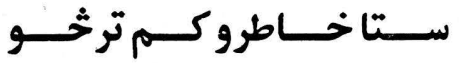

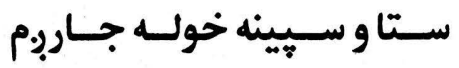

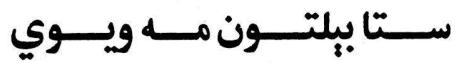

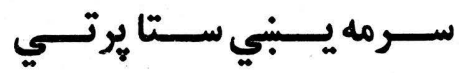

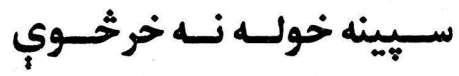

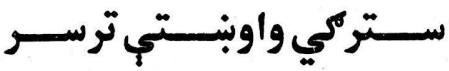
ستا خـولكى بـه خـورم يـهـ زور ستاخـولكى سيارم ير خداى سبينه خولـه شـوبين لـه حُحانهـ

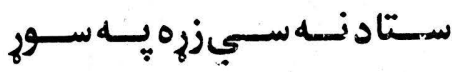
سبين كـالي بسي يـرواترسي

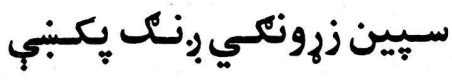
سـتا ديــندن لـه خوبسـهـ وكسم 
فـورتّ سـنهيمن له صسبا حُمِم

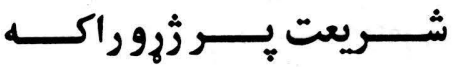

دكـران تـك د منـدوخيل دى

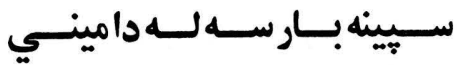
بنــو ور حــق لــه سـبـا بــــايم كي بِيء كي هم نه دى تاوان

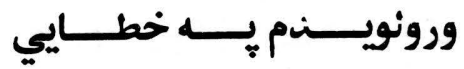

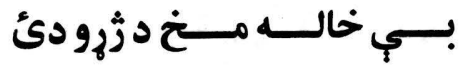
اوس دخلكــو بـــــ ماشـكـ ددى

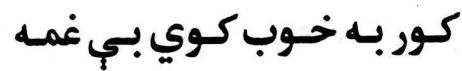
زونـدبـي نـه لولـوزاوال دى

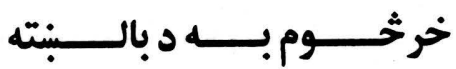

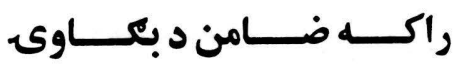
كــورم د كــوز كلـــي مــاينب تــــ اوسـهـ زمــاولــى رويــار وروســتى بغـــور دهبكــاوي

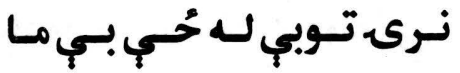
كـي بريـودي كـه د سـيالي ده

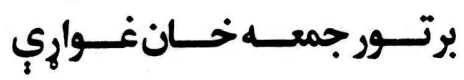
مج

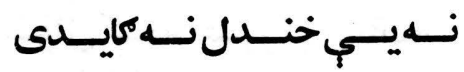

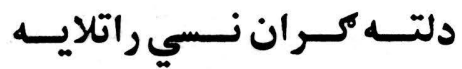

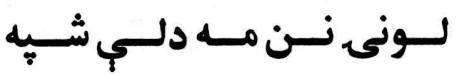
يـوه روحَ الـم لـه دونيـاحــم
ستا خـوكس يـر خداى سيارم

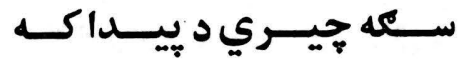
سيّن كالي كر انى يسب هُبر دى

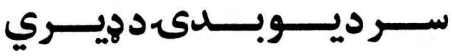
ستا ير خوله دريسم حُين غوارم

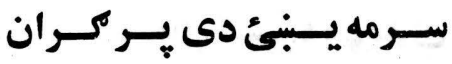
سـتابنتــون كـلهي، كـلهي

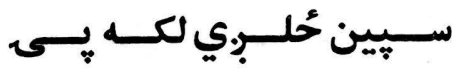
سـتا د خـولي بـر هـاركزك دى سـور تيكــى يـه درختـه كمـه

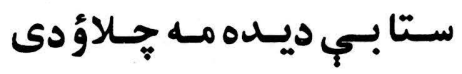
سـتالـه كر انـله نسميب نسته سـور قمسيص كبـلهى، كيـلهى

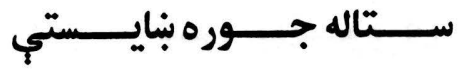
سـتا يـــر خولــه راتــه وليــار

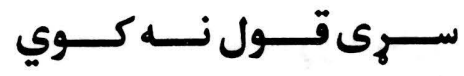

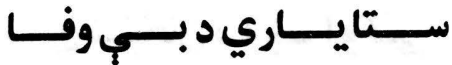

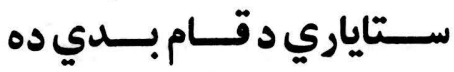

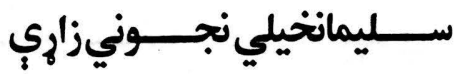

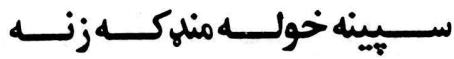

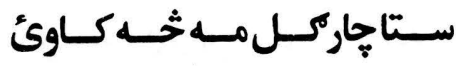

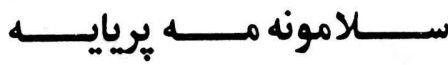
سـتا غـوحي تـر كتّ بـسته ده

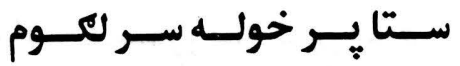


شـلومبى دويــرتريسودى يــامي بــادبــروودى بــوى بــيـراوري

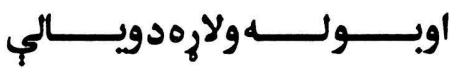

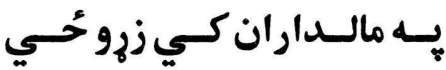
يـه سـورندان مـه وهي كرانه واخـه دسمال كـبنير.ده هيسهيه

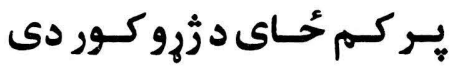

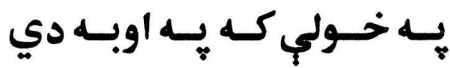
دسمال ير خوركه سي راحيجي

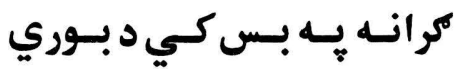

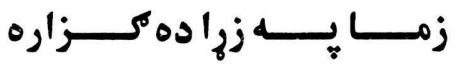
يه تك د ثخوى مري سي راحيب رسك به راواجوي خدائى نور

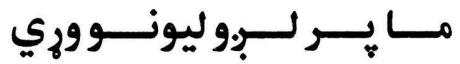

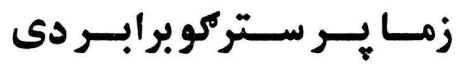

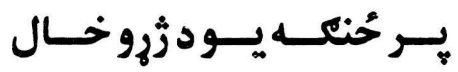
سـري شـــخان بـه بنــراوكـي

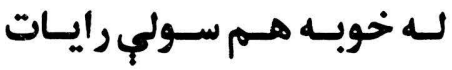
نـرى ليـانـه وسـلي سـيديدي

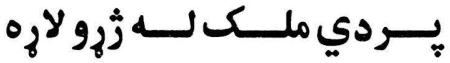

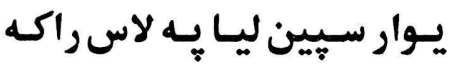

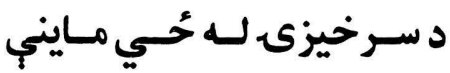
تـر داكرانسى نـه دى زمـازده

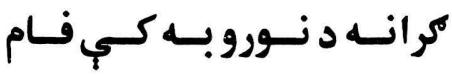

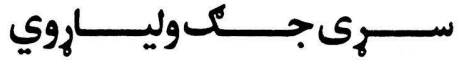

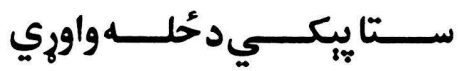

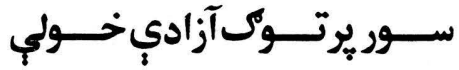

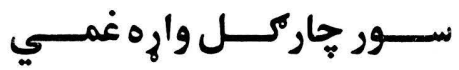
سـتا د راوى دويــالي غــاوه

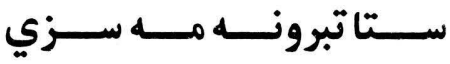
سم خيسور دى سميبي وسور دى سـيـين زرونكسي دلانــده دي ســتا جاركــل كــوي لمبــي

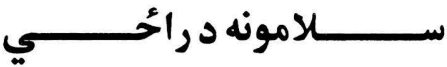

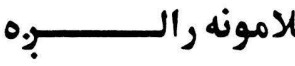

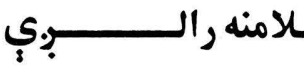

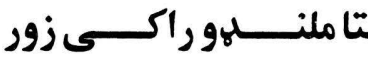

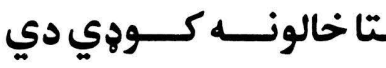
سـتا بـلتــون د دوبسي نمـر دى سـيّينه خولـه آسـماني شــال ساه مه خيزى ستا يه خوله كي

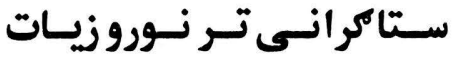
ستركي دوي خيزي كه دري

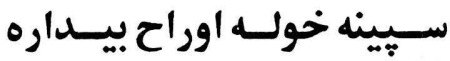

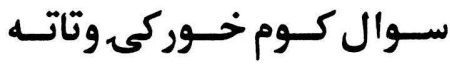
سـور تيكسـرى نـرى يُكـبني

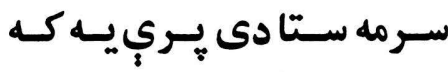
ســـتركي مـــه وهــــهـ مــــام 


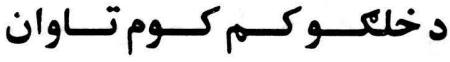

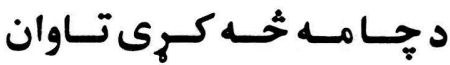
بيــامـــزل د خراســـان واى لـه نــى ترغئحس راغـورحي كلـــى بدايسـسي بــي بـــوري

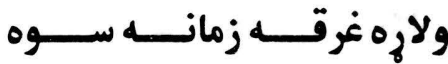

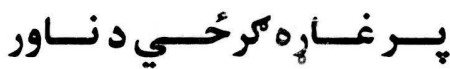

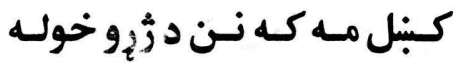

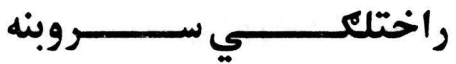
ســـره د راوى لـــه روانـــــي

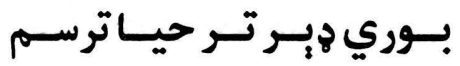
زمـا مجلـس د تربـرو هيــر دى دي

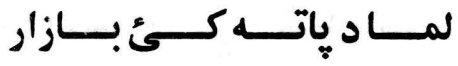

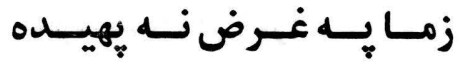

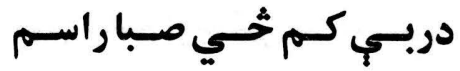

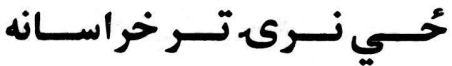

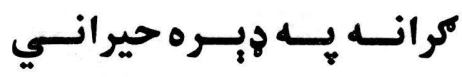

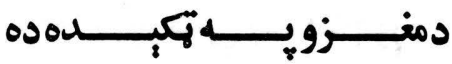

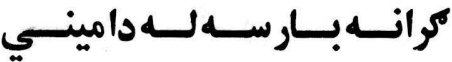

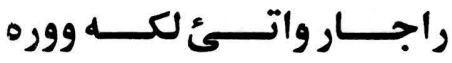

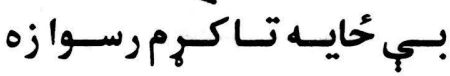
خـوب يـر همزولكـوآرام سـوى

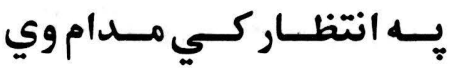

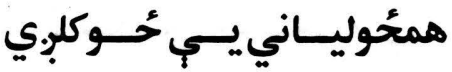

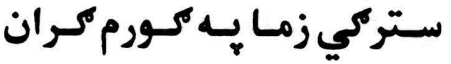

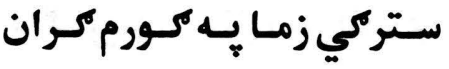
ستركي زماواى يبني دكرانواى ئى

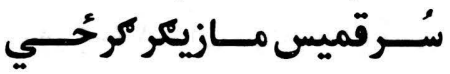

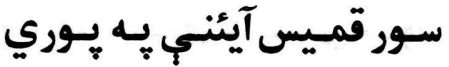

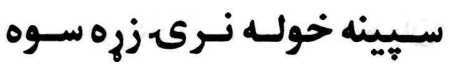
سيّينه خوله سوريجي جاركل

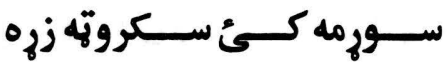
سـبـوبرمى زمـاو سـتا دبنــمنه سـتركي تــوري كسي مـسبري سـره غرمــه ده مـخخ لـه درسـم ستا د خولب محبت مه دهبر سوى

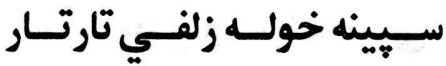

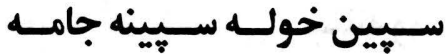
سـتاد لاس وكـوتكي جارسم سـره كرمسي ده كـال لـ كاله

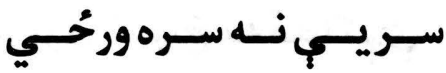

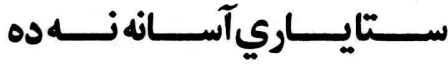

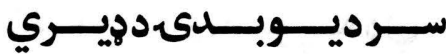

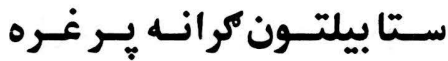
سخت رنحُور سي تـه بـه زيه

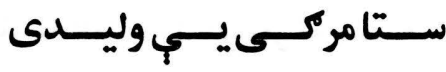

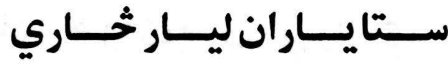

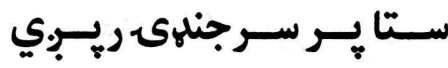


جانــان خـــوب مالـــ راحـــي خلكَوياى لمونحُ يِ روانه دى

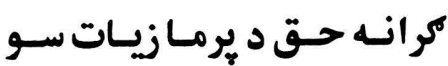

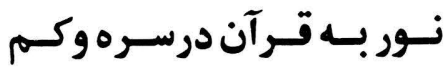

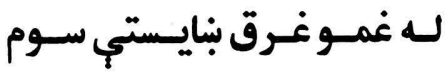

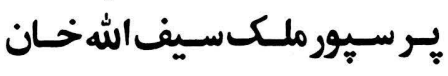

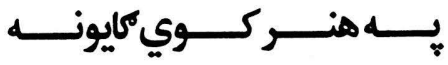

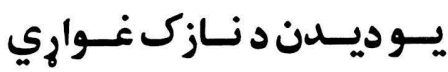

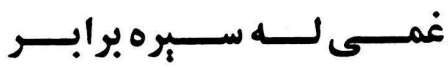
يه يـارى يوهـ دي د تل سري يه يارى يوهـ دي دي كان سري

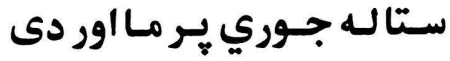

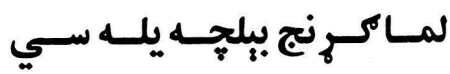
خويـه خنـك كـي يـبنتانه وو

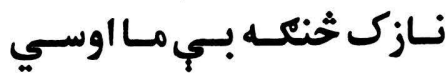
كـلهي ليانـــه سـته دكرانــو تـرورى لمـونحُ مـه قـضاكبري

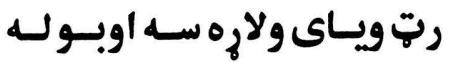

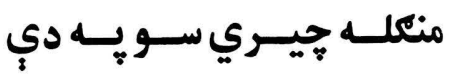

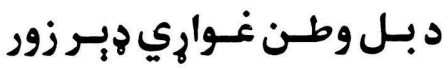

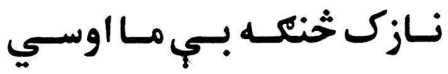

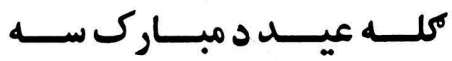
بـاد برهـودى بـوى بـي راوري

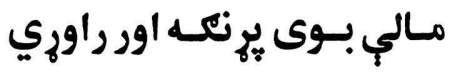

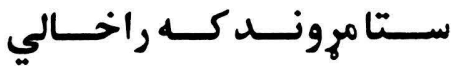

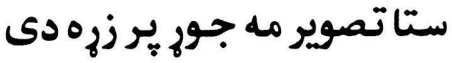

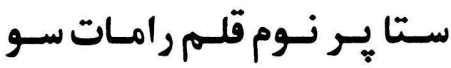

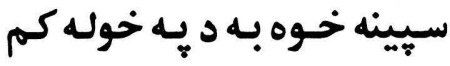

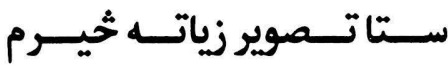

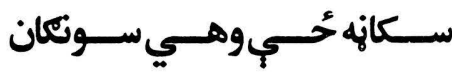

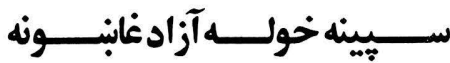

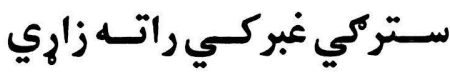

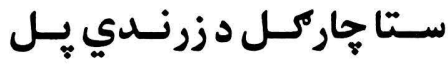

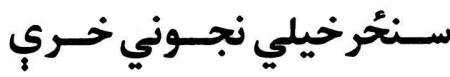
سـنحُحرخيلي نجـــوني خـــــي سين خيسور دي باريبي سور دى سور تيكرى خي رابنـاره سي

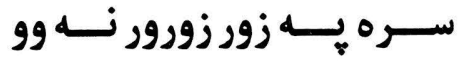
سـوع وهم اوبــكي مـه توسي سور سـاندي كل سوي د سرو

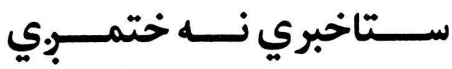
سـرمه خــور سـيـيـم نـاجورة

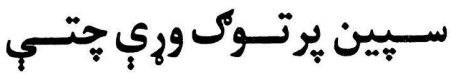

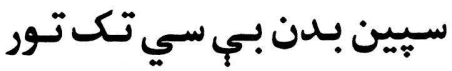

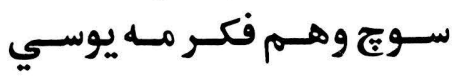

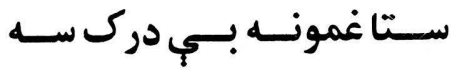

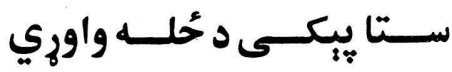

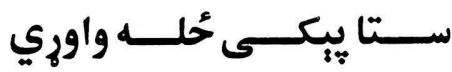


دكر ان كاغــ بـه دسـمال كـم

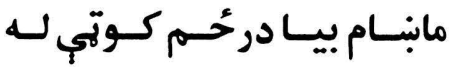
راتــه اور مُحكــه اسـمان سـي

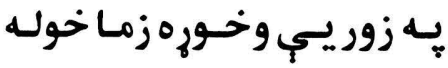

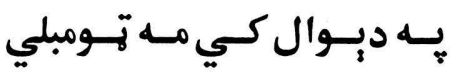
يـر وياله سيّين عبـاشه ناسـت

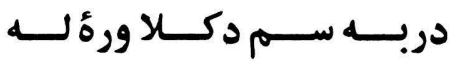

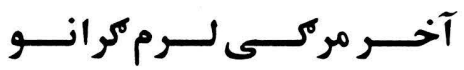

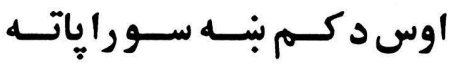

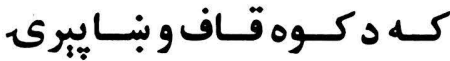

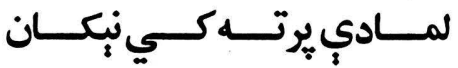

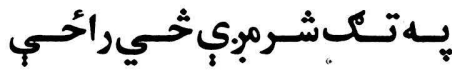
خوب د هير دى يه غوحي كي

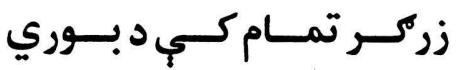

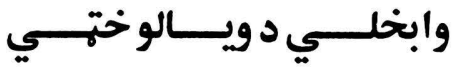

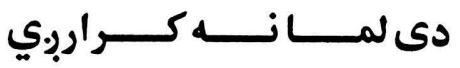
دوب: سـخر غـواري سـتامـور جخــن تهال بــه فر انسسي سـو

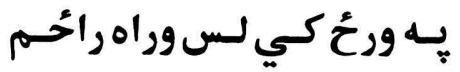

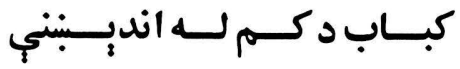

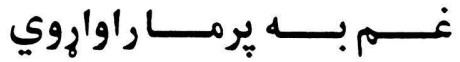
ير منخ يـي سري لمبـي راحَي نـرى د بـل بــه نسبـ سـوي كهـول يـي كـرد بـه رضـاحِي

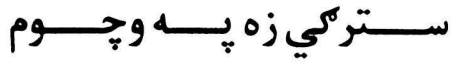

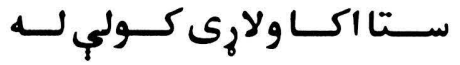
ســتا غمونـــه رابــاران ســـي

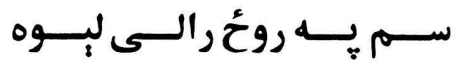

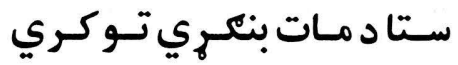
سـور غمــى كـوتكي يـه لاس

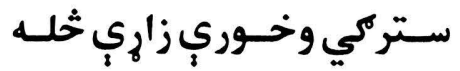
ســـتابلتتون بــــه ورم ترخخــــو سـتا يـر سـر غـم جـور سـو ماتـه سـيـينه خولـه بايسـته نجلــى

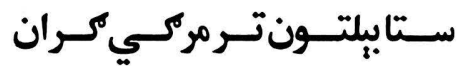

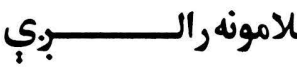

سـيـينه خولـه تنــى د ليكسي سـتا باركـل نــه جــوريسـي

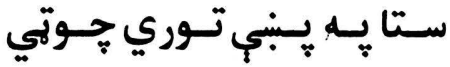

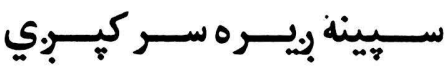

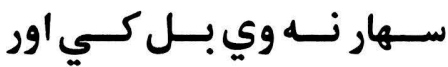

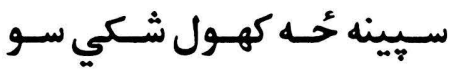

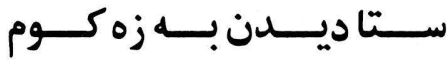

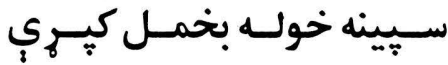

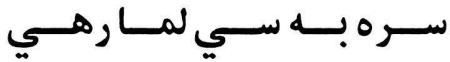

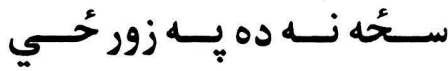
سـول تَكـان سـتاد كـوزدي

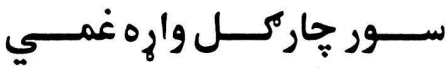




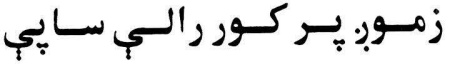

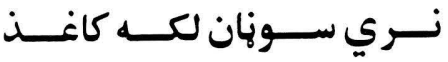
يروت بـر هاكتر يهم دواخهورم

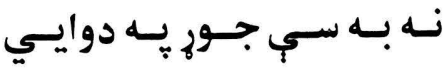

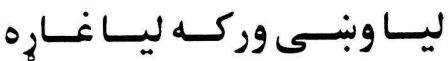
زه ســمرم د آسـمان سـتوري

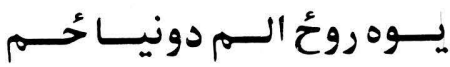

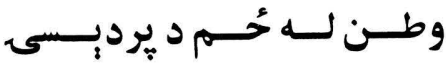

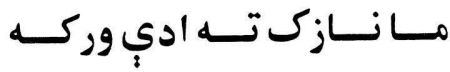
مغـزى مـهـ ويج سـو يــر ديـوال

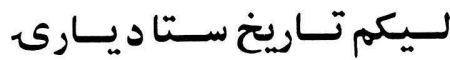

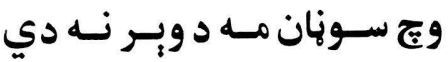

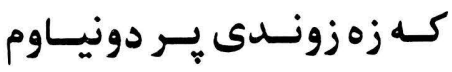

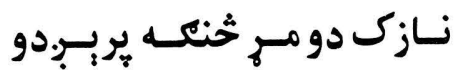

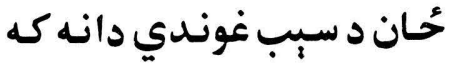

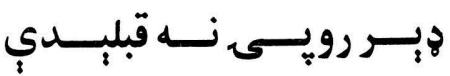

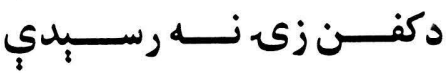
تـــردود كبن كـاني رالـــوربـي

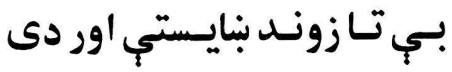
ديـدلـه بــه زمـا راسـي جانـان زه دكر ان ديـد كله يـري ب.دمم نهل بـه سم نـور لـه غمـو خـلاص

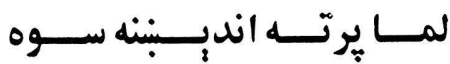

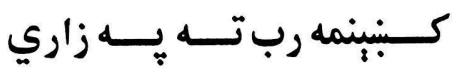

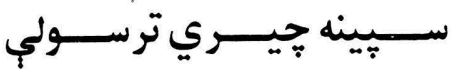

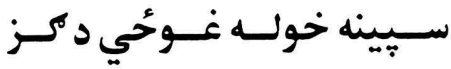

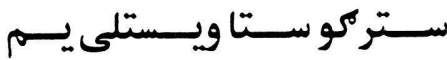

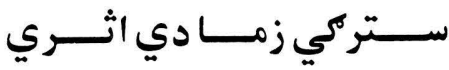

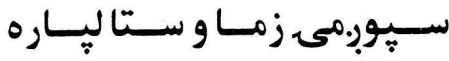
ستا و خوله ته د خلكسك كوري

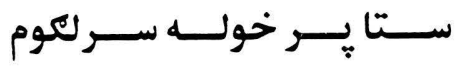

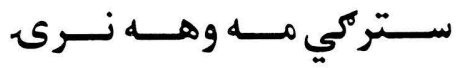

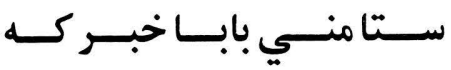

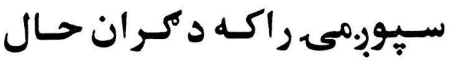

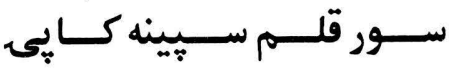

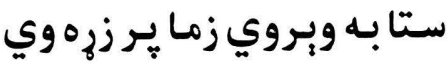

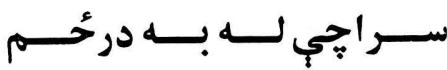

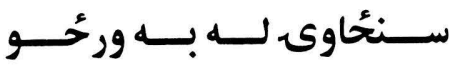
ستركي توري كه خوله سره كه ستا ير خوله مي خحاوري كي لوني

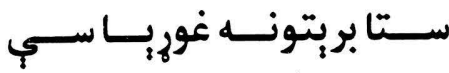

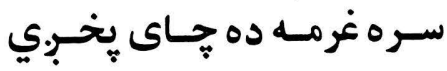

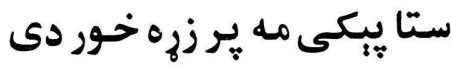

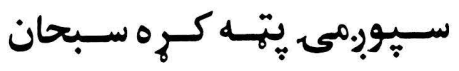

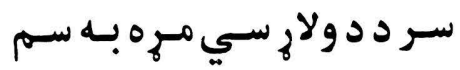

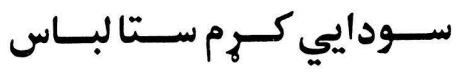
سبين لباس كي رابـكاره سوه

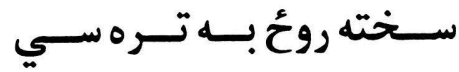




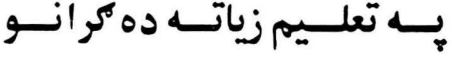

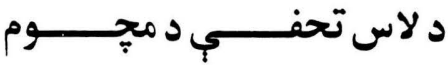
زه غــويى يسـم جــوغ در غــاره

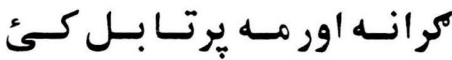

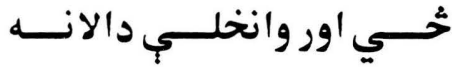

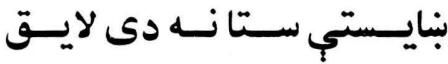
خلكس يـي بـه ديسد نـه مر:بـدل

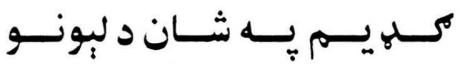

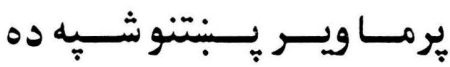
سري زوبس خلك د كنباسبي عجب سرى دى دكر اندوست

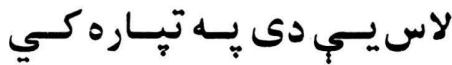

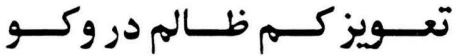
كـورم د شـنب مرغـي كـوردان

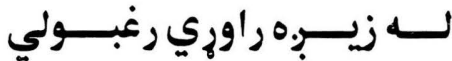

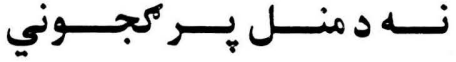

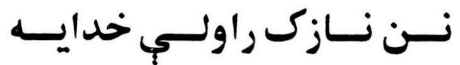

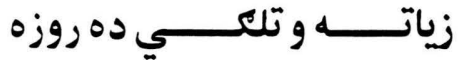
كـر' بـــر بــن كـوم مــاوركئ

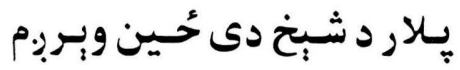
بـهـ دود بسي تـور كي دوكـولجي نـه بـه ميــر نـه بـه بنـارو كـي

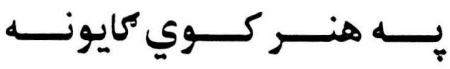
بــه سـوحِي سـيـين مسلمانان

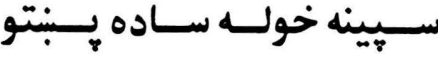

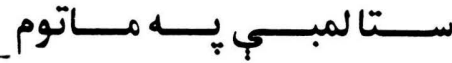

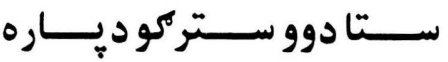
لستا تر بـور دى ما راخيل كئ سـور كميســكي نجلــى رالـه

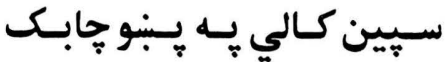

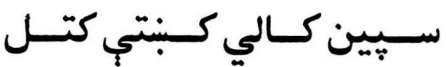

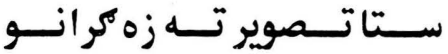

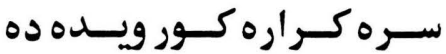
ستا جاركل دى غانبي، غابني

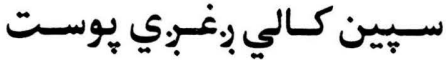
سـره وليساره ده بــه ورهــي سـتايسي صـبر زمـالـه زهزه كـو

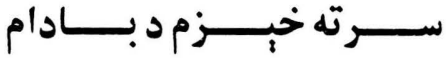
سـري و سـيسني سـولي تهولي سـتا اوبنـان كـركونـه خـوري سـركمي سـوم د بـل لـه كايسه

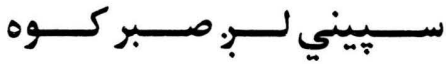
سر مه يري كئ اور بـر بل كَّ

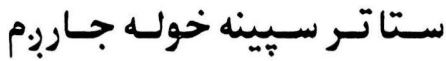

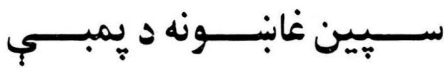
سـيال يـي نسته بـه مــروكي ســـينه خولـه صـدف فابنــونه

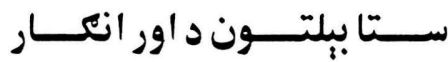




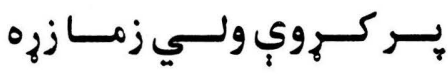

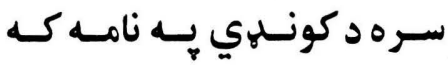

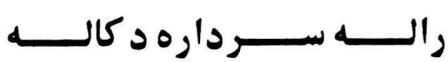

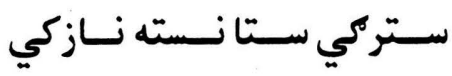

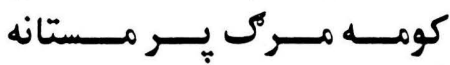

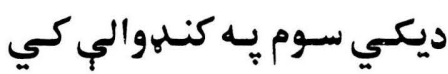
كـل يـهـ حُوز انــو كـي رائسي

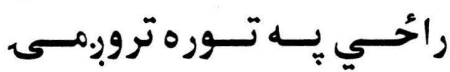
وكــه وس كـــه د زيسـار كــــي

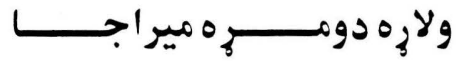

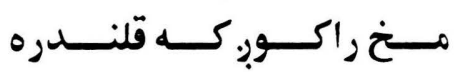
دمسور شـكم بـه بيـدا نـه كـم كه كـار سي هـم نـه دى تـاوان

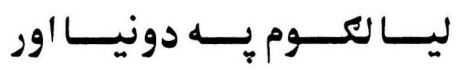
ملكسه خـالي سـوي لـه كر انــو

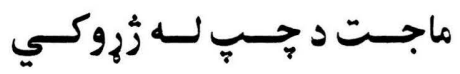

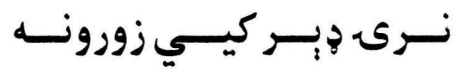

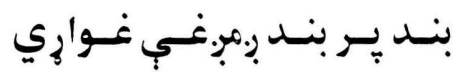

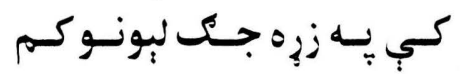

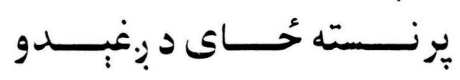

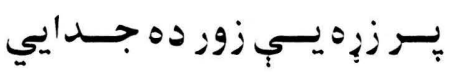
مابـه خـلاص كسي لـه بيلتونسه

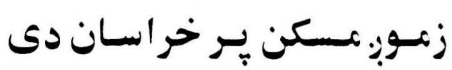

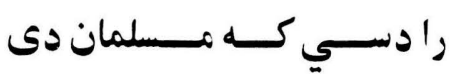

ســــا بـلتــــــون د اور ســـــاره

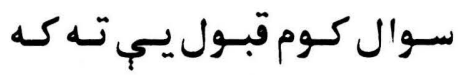

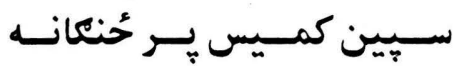

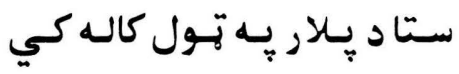

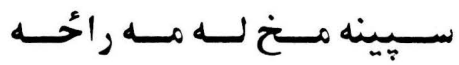

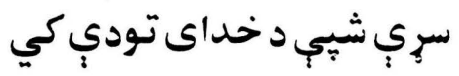

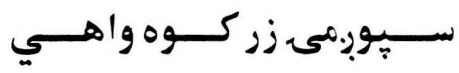

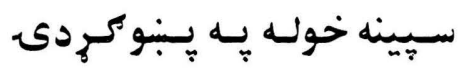

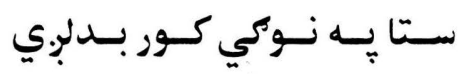

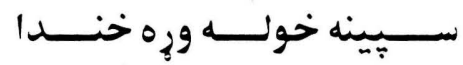

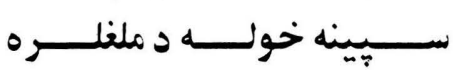

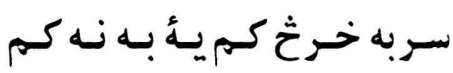

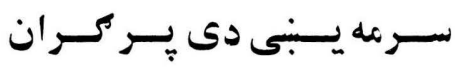

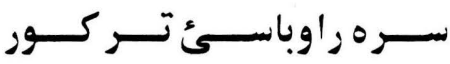

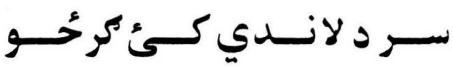

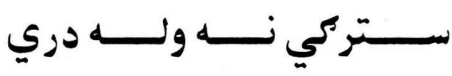
سبين جر ميان دى ولونه ولونه

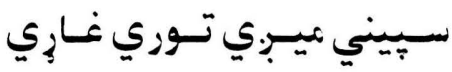

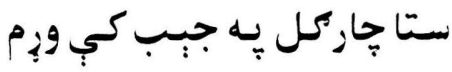

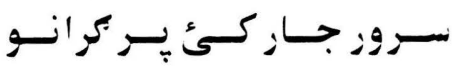

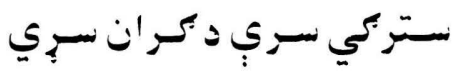

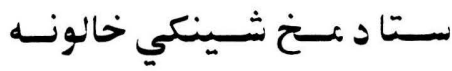

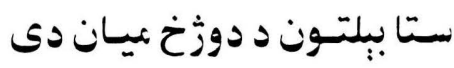

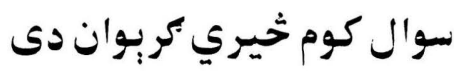


بـهـ زوره غـواري دوكـران ديـد

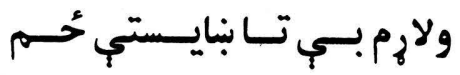

تـردى وطـن غـواري هويـر زور

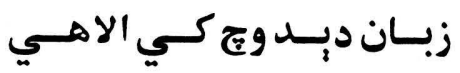
به خود بوهد د حُوانى نه سوم

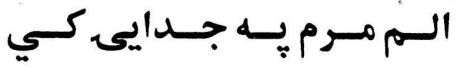
مابـه دربـر غـرق كري سـوجونه

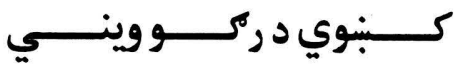

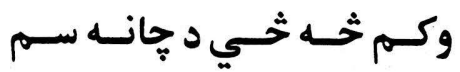
خـوار قسمت نسه يـي راكركـي

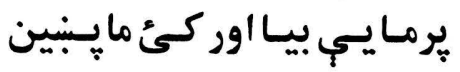
نـن مـه دى مـور بنايسستحي زره

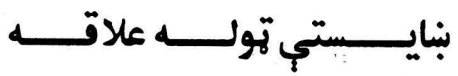

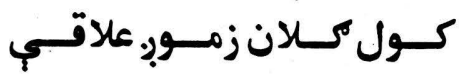

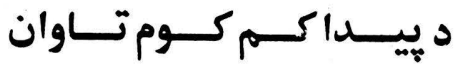

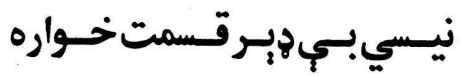

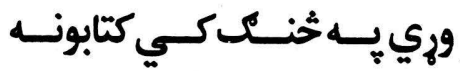
تـرداكر انـى نـه دى زمها زده

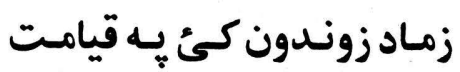
بــر مـرك خنــل مالـه راحَّـي

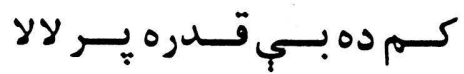

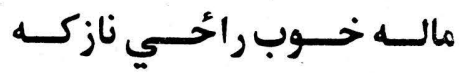
كه هوبر هـلاكى كسم يردبس

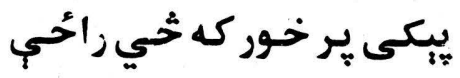

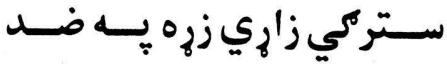

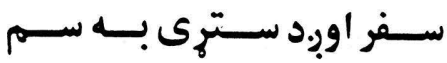
سـيـين بسشر بـي واوري تـور

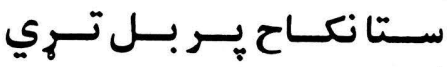
سـتا بــه غــم مبـتاك زه سـوم

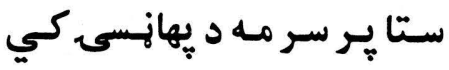
سـتابلتسـون سـي غـاري غرونـه

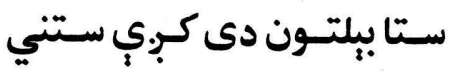
سـتالسه حقـه بـه سـكاره سـم ستا بـه نـوم مـه ستركي وركي سور بـزووان بارخوكـان سيّين

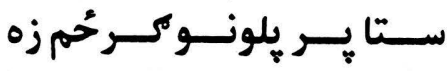

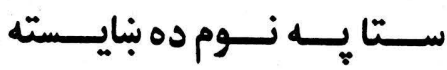

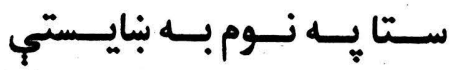
سـتركي زمها اـهـ كـورم كـران

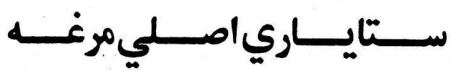

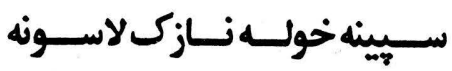

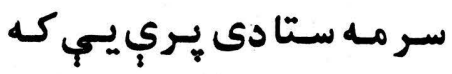

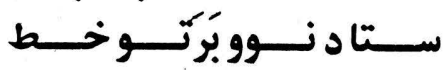
سـر مه كنبــنبود سـتا بــر تــي

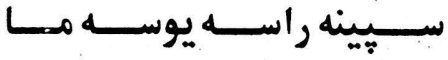

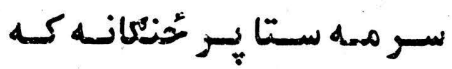

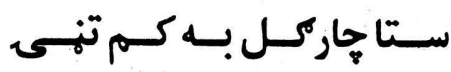
ســا جاركــل كيسـي لمبـــب 
كـــه لمبـوزور ووكسى جــورى

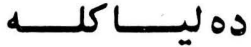
راختك

كران يـه حُوزانـوكي راحِي

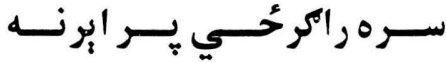

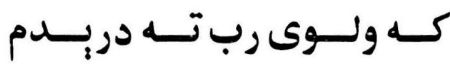

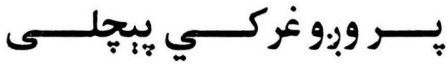

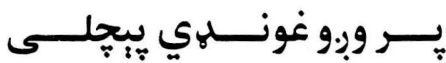

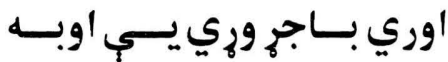

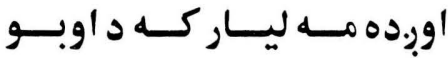
مــاحيكر يــي كـى رابانـدي

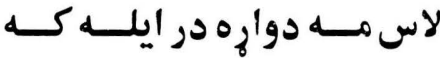

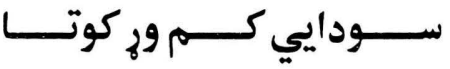

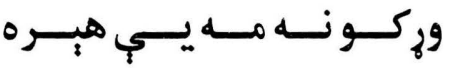
مـخخ لـه مـه هيــره سـوه توبـــه د بـــنامى ليــاري بـــي وزم

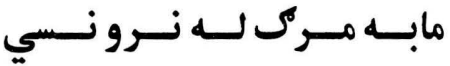

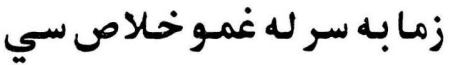

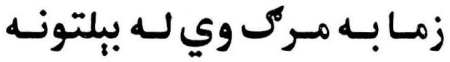
د بِّلتـون اوبنـكي دي راتلـي

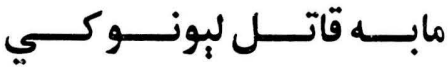

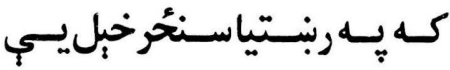

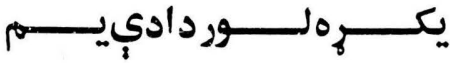

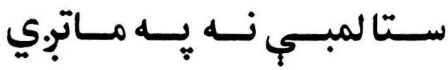

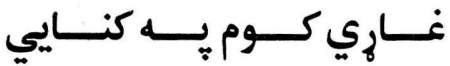

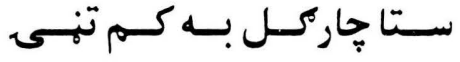

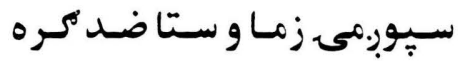

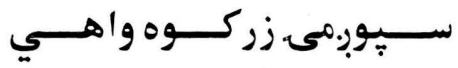

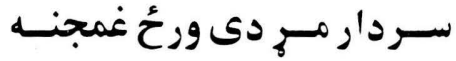

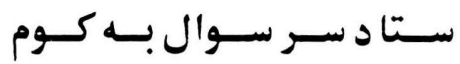

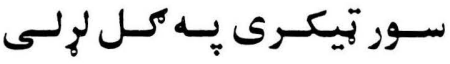

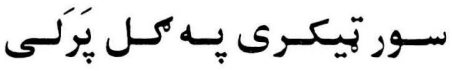

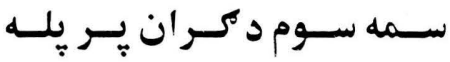

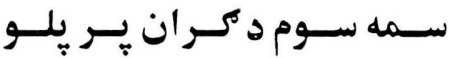
سبـينه خولـه كــر اره خانـدي

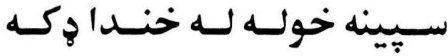

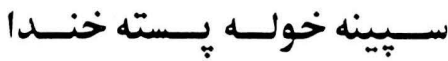

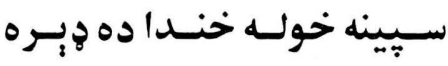

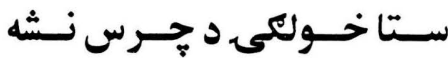

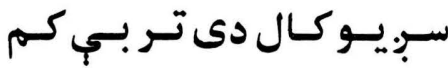
ســينه خولـه وركسي كســي ســوال كــوم مركسى د راسـي

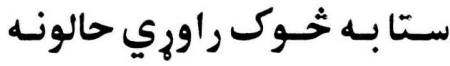
ستا يـر سـيـين مـخ دي يرتي

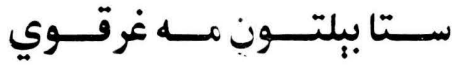

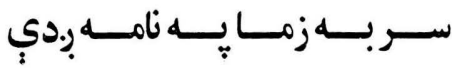

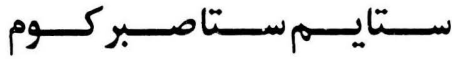

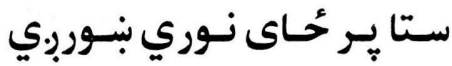
ســتا يـــــــــــوم ده يِابنـــدي 


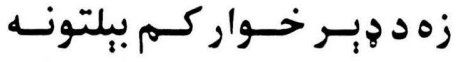

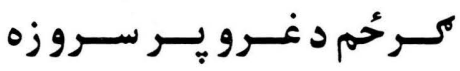

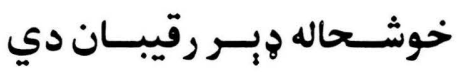

دكران آخري شيب دي بياحي

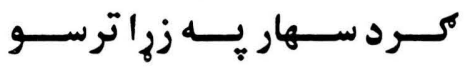

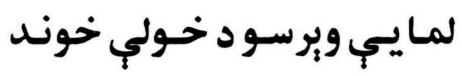

يـري غــوحي د يـهـ نيـاز راورهه

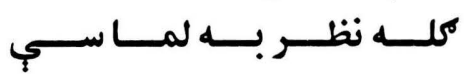

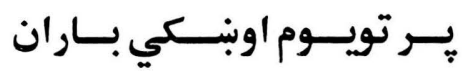

حــــابم د آســـمان ســـتوري

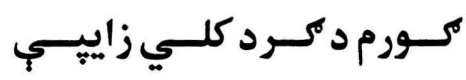

خــوبر د اخلـم كـهـ دروانـهـ دي

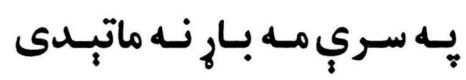

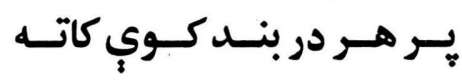

نـور مـه يرهيـز دى لــه خــورو

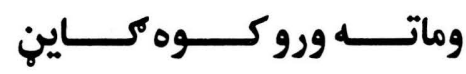

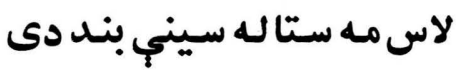

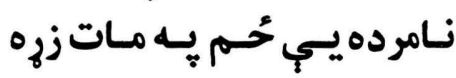

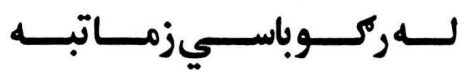

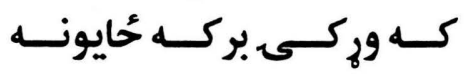

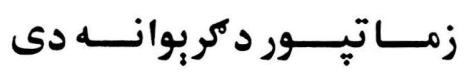

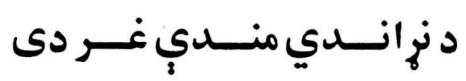

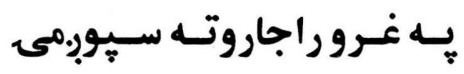

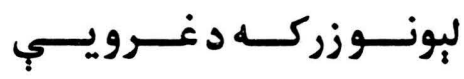

سـتاكريــوان دى زمـا لاسـونه

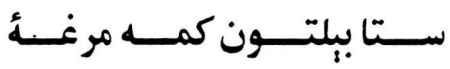

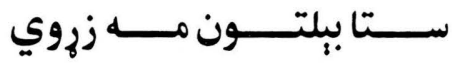

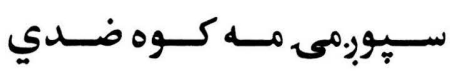

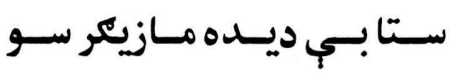

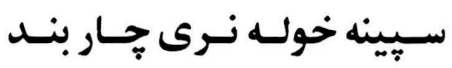

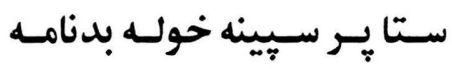

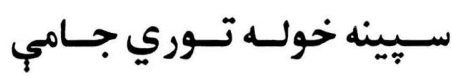

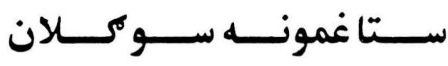

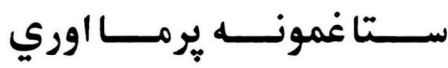

ستا له جـوري سـينيني خـولي

ستا ير تن دي زما يـر زهره دي

سـينه خولـه مـلايـي نـرى

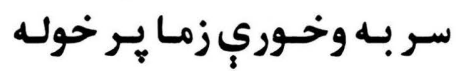

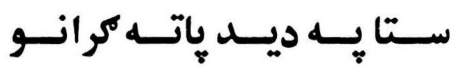

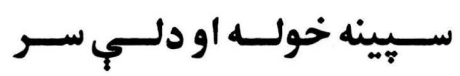

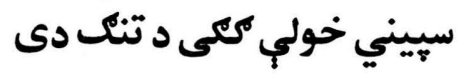

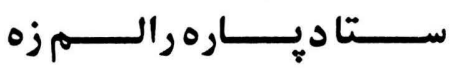

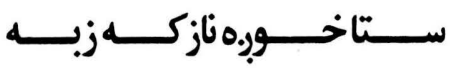

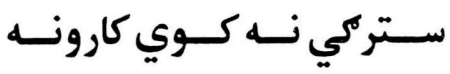

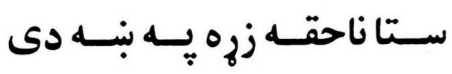

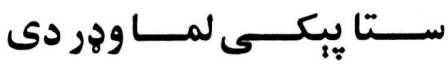

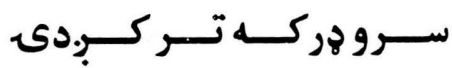

سـري كـردى سـتركي لـرى 
هاكتر وباىجك جور دىترورى

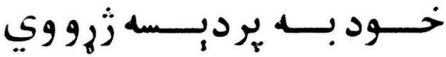
شونهي مه يري كي يه غابنـو

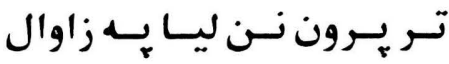

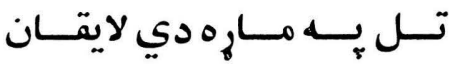

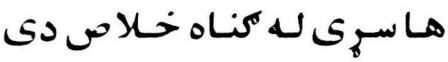

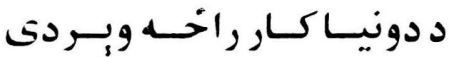
يستّ بسي سـاتم د زئه هيرميـان

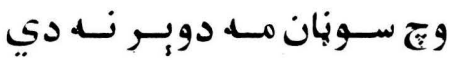

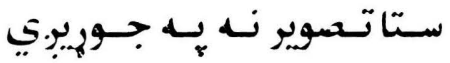
تو سيدو خوندكوي ستا ثنته اوس مل بوى بـ خحي د كمو بوان

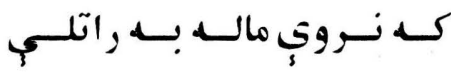

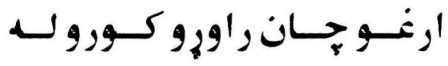
سـري دالان دى لـوتيمي لـوتي

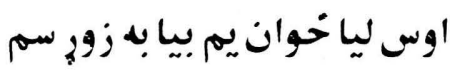

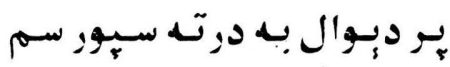

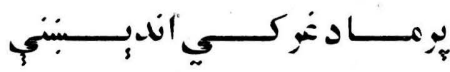

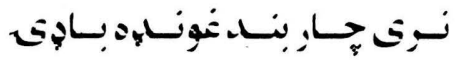

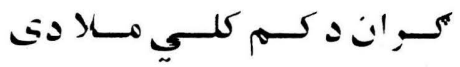

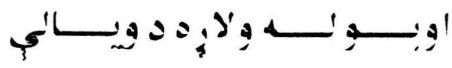
:

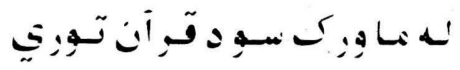

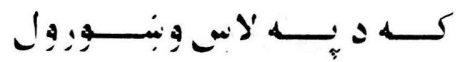

ســين د مـرك وهـي سـكلى

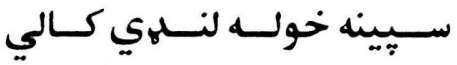

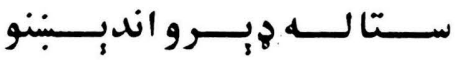
ســتابلتحــــون د خــــوزو بـــار سـتاخــولكى د جنــت ميـان ستا ير تن خحي يبنى لاس دى سي

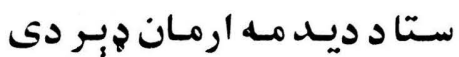

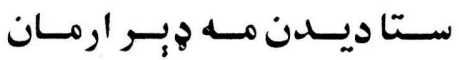
ستابه وبر سي زما ير زيه دي

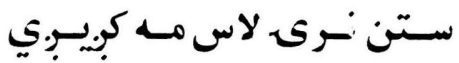

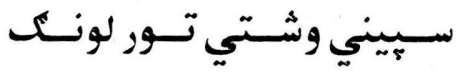
سخن مـ هـوري كسئ يــ خـان

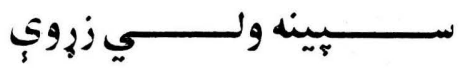

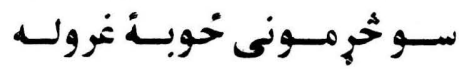

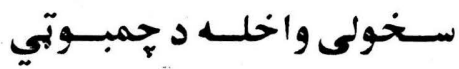

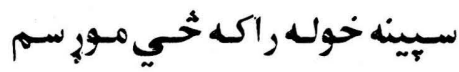

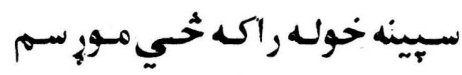

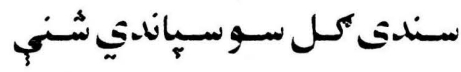

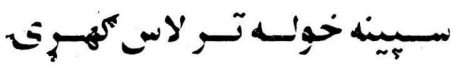

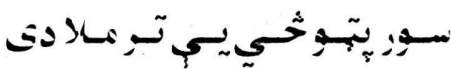

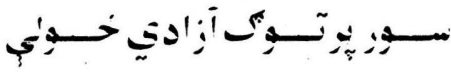

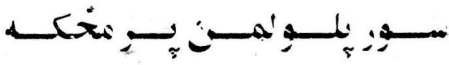

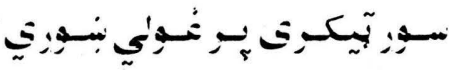

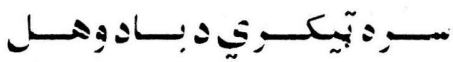




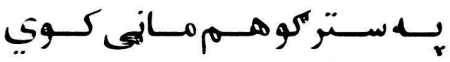

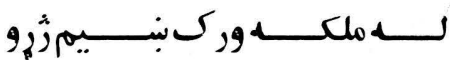

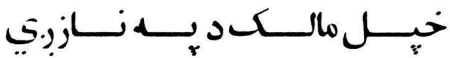

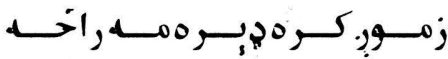

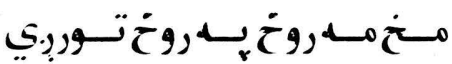

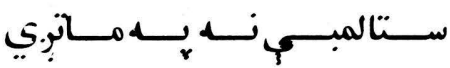
خُخي خوك دنوم واخلهي هو خول

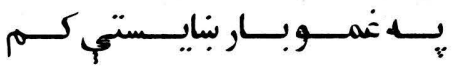

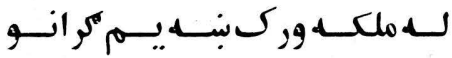

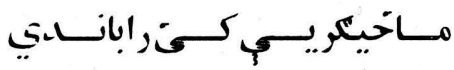

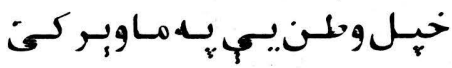

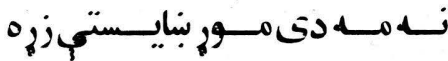

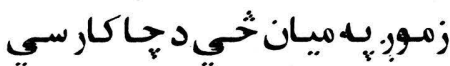

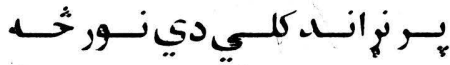

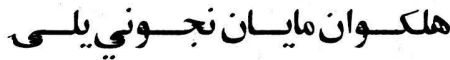

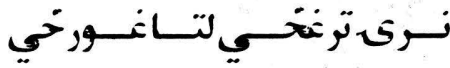

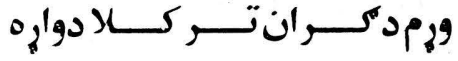

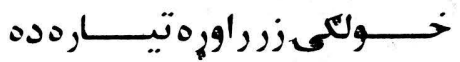

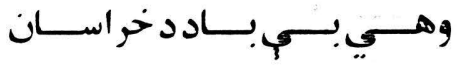

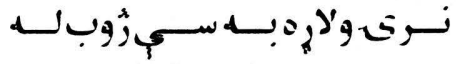

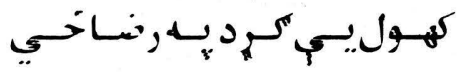

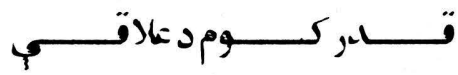

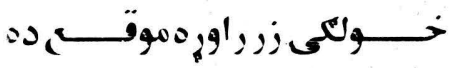

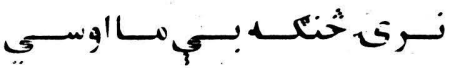

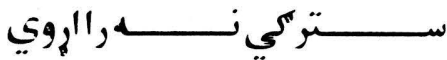

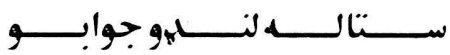

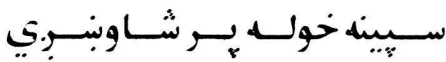

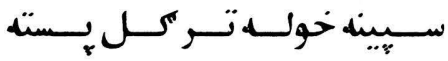

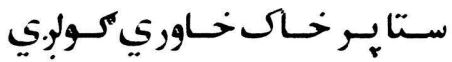

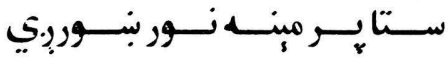

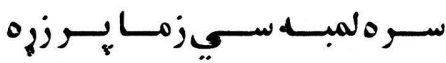

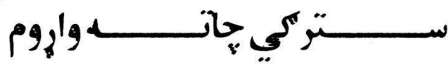

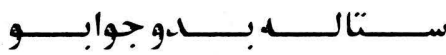

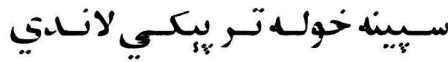

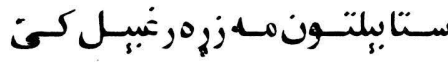

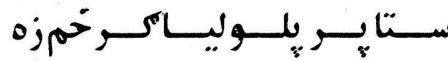

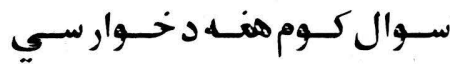

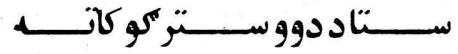

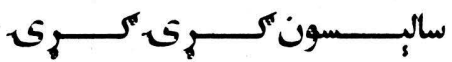

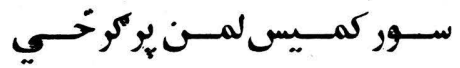

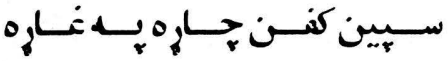

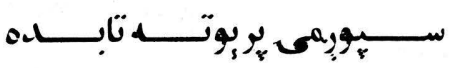

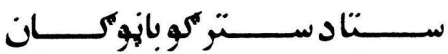

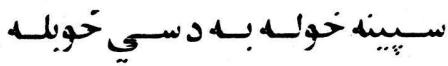

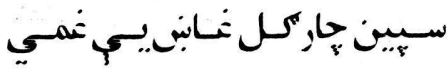

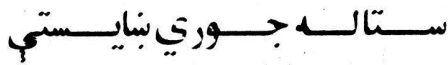

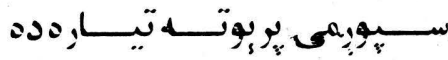

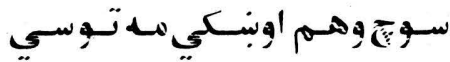


كسه موكسى نــهـــــوراورانـدي

ترمســـادئي

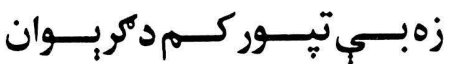

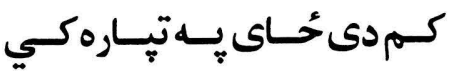

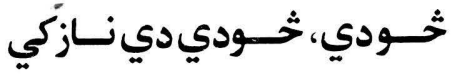

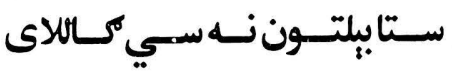

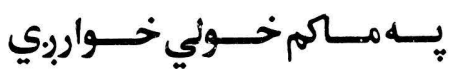

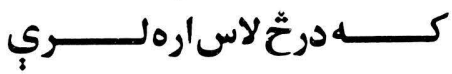

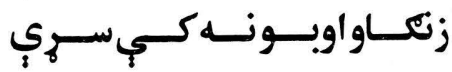

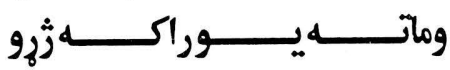

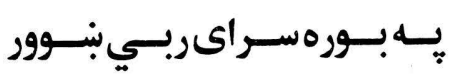

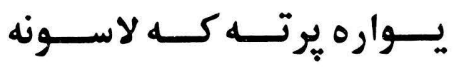

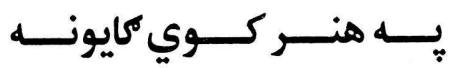

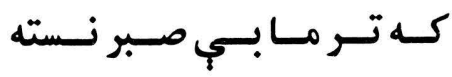

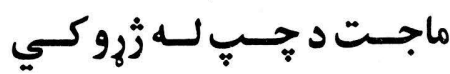

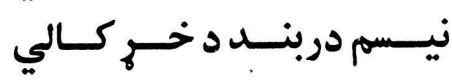

سـتادمسـخ حُوركسـيزمـادي

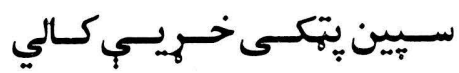

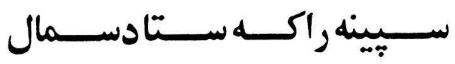

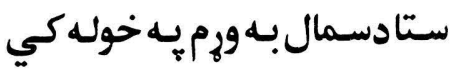

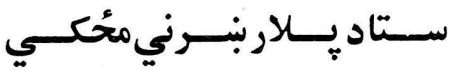

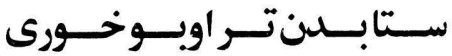

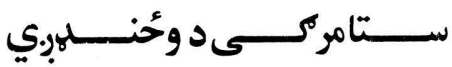

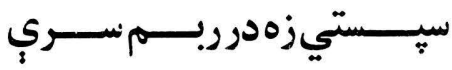

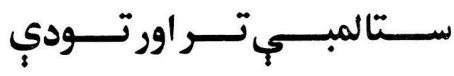

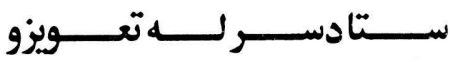

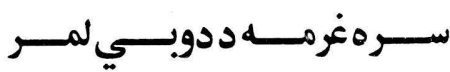

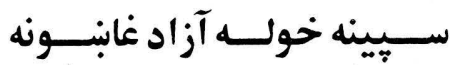

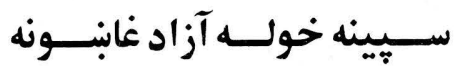

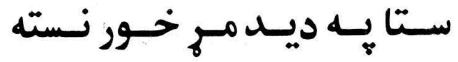

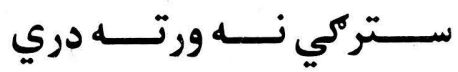

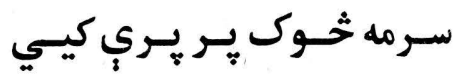

粗。㧗 


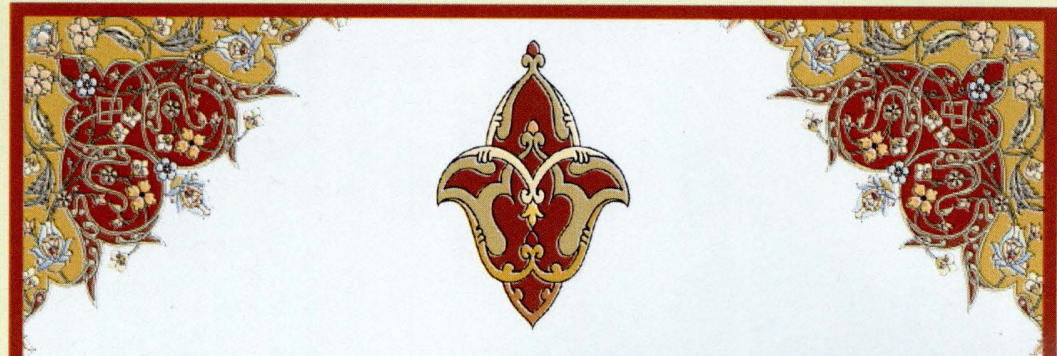

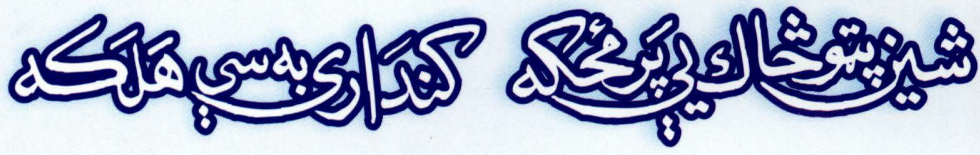

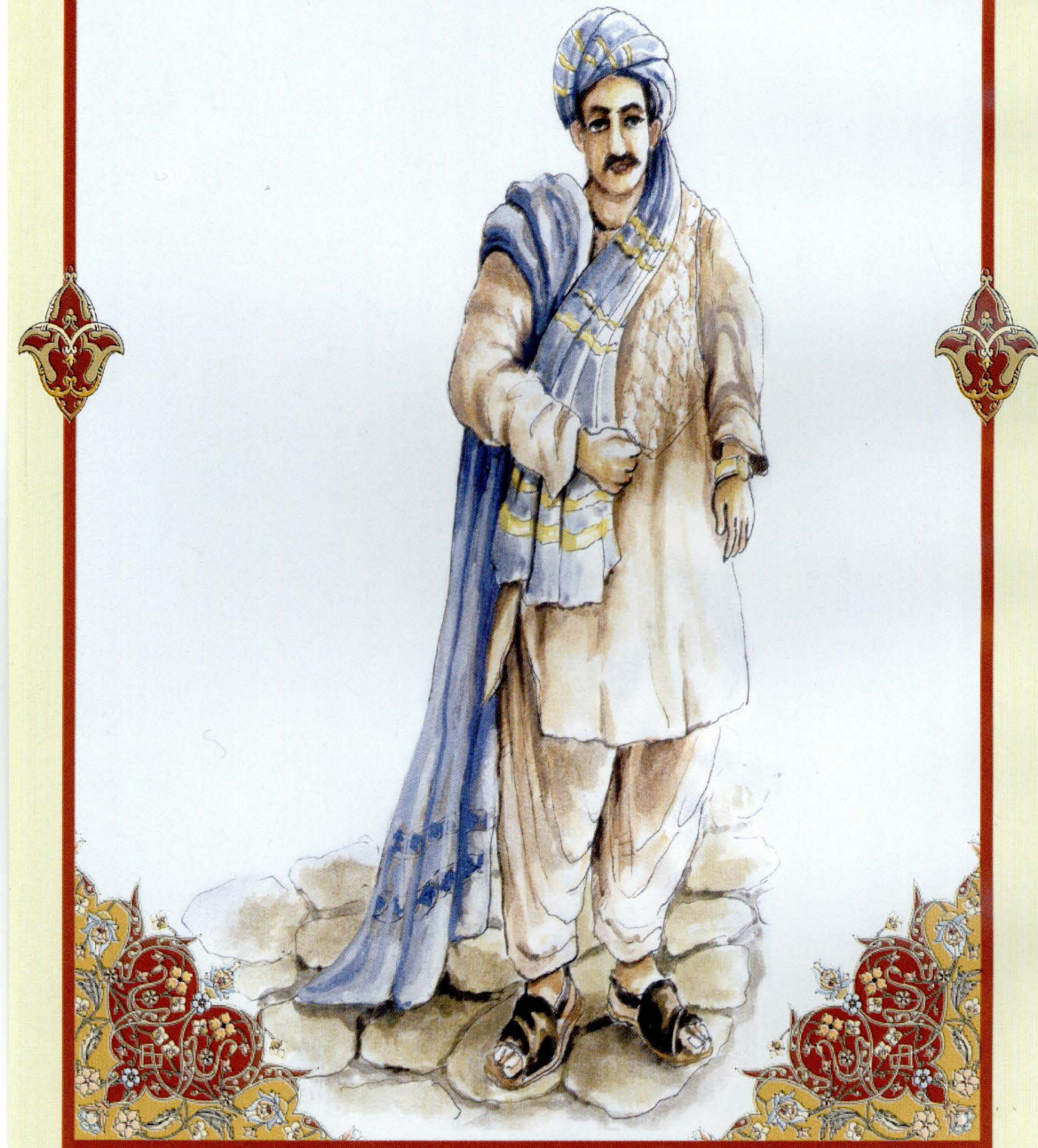




\section{离}

كـهـ بنــده نـــوكي كـلاكـــــي

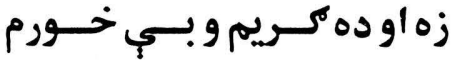
هلكـوان حُحي سـيل بـي وكي وني

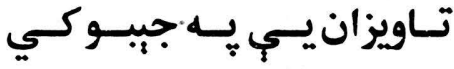
وخـت د اهــار وابـه خلـي اور و بـس تــ خيـزي د غــوخكى

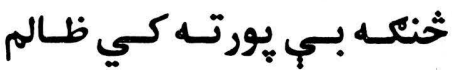

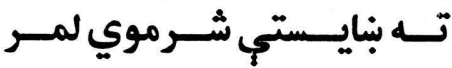
اوخــوري حُحـان د دنيـا روكي

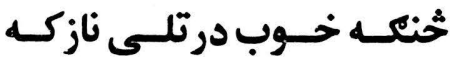
قـام دكـرد غـسـي راواخلـي

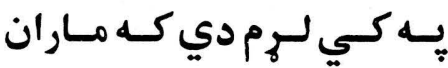

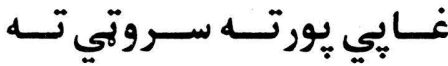

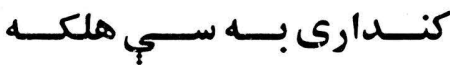

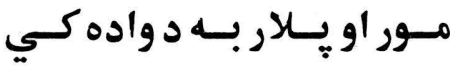

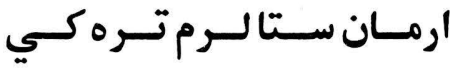

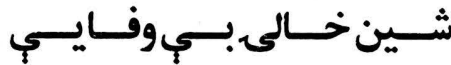

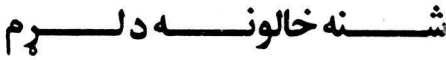

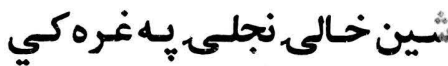
شين خـالى نجونه يـه غروكي

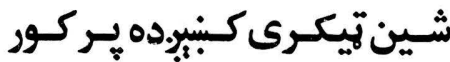

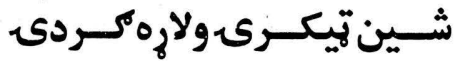

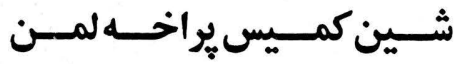

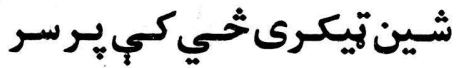

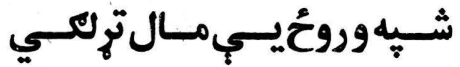

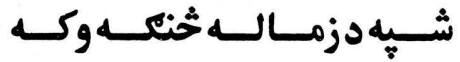

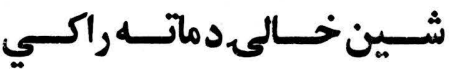

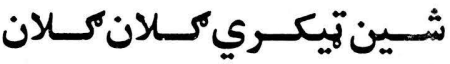

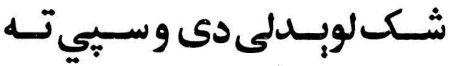

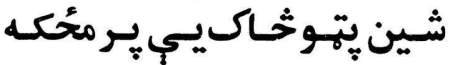

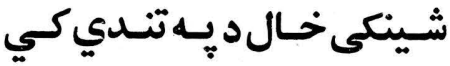
شـينتيكـرىدليكسيكيكي 
مالـــهـ يــــونـــــه دى راغلــــى

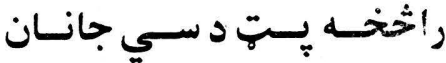

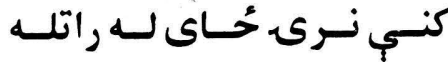
ير ما د مياستو يـه شـان سـوي

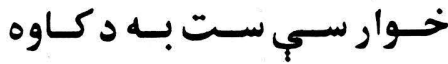
مـاخي ول كـال د سـو دوري يه نيت مه يات سوي د دروزي خداى بـ نوري كي راباندي ير مـوبيسي زور سوه يرديسى كمــيسيــي اور دئ د لـــيلن

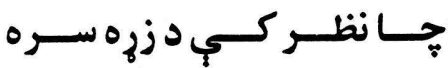

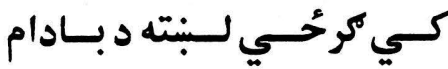

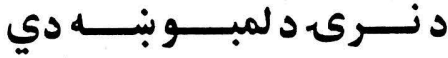

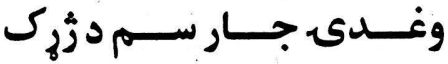

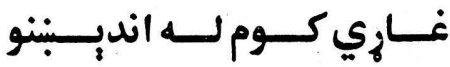

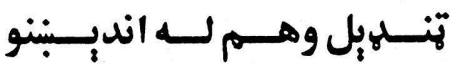

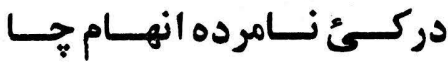
كـه يـه لاس رالـي لـه مـامري

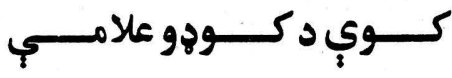

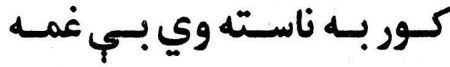

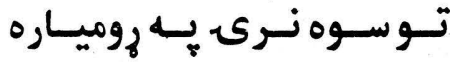

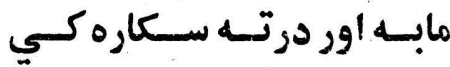
زمــاتكــاو د آسـمان سـتوري

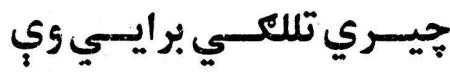

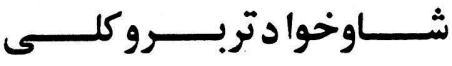

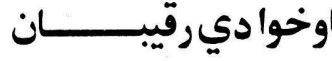

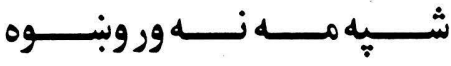

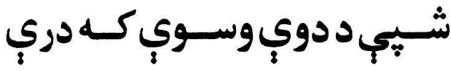

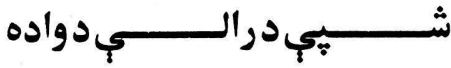

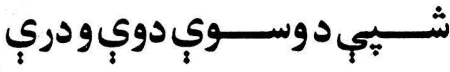

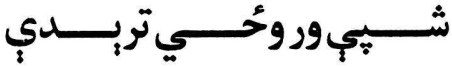

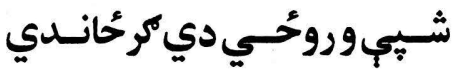

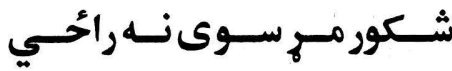

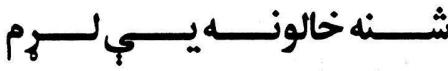

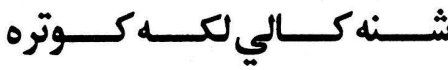

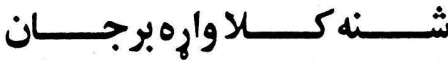
شـنه نـسوار بــه خولـه ترخـهـ دي

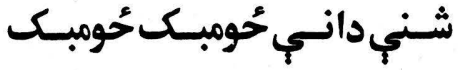

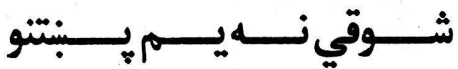

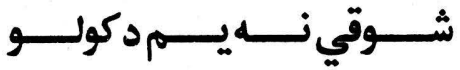

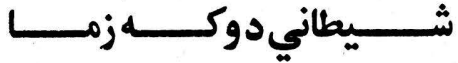

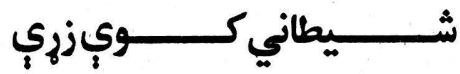
شين تيــرى يــرميـان كـومبي

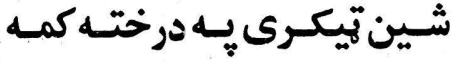

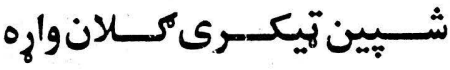

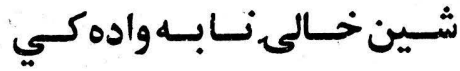

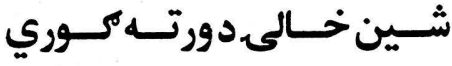

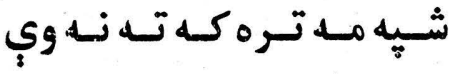


خـوب در تـلاى خنكـه نازكـه

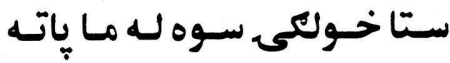

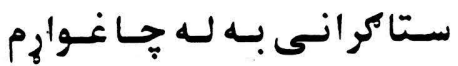
سـتا ديــن لـه خدايسه غـوارم

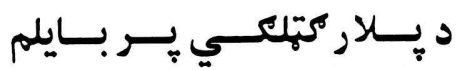

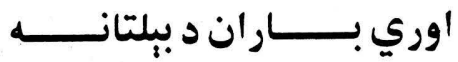
كر مـــي هـــم نــــ دي بــاوالي

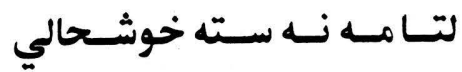

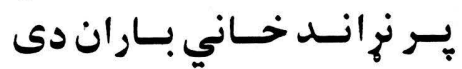

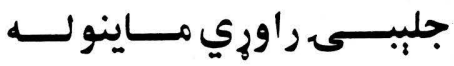

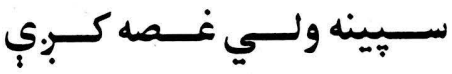
جانـان بـهن نـ كـور تهـ راحُّي

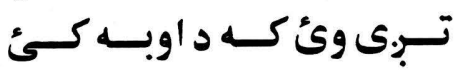
خدي لاس برته كم اسمان دى

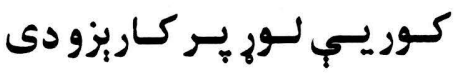

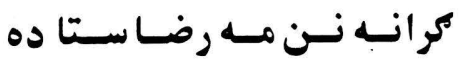

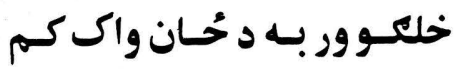
نـرى قـران وكىي بيـا راسـي نـه خـوب راتلــى نـه وه موقه

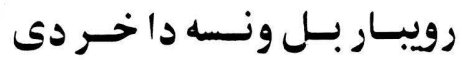

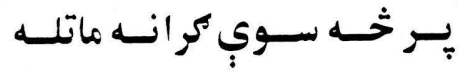

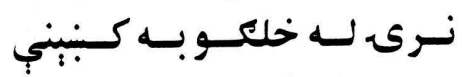

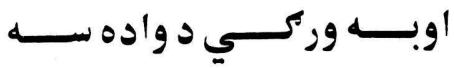

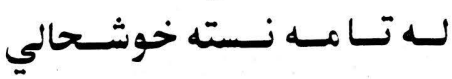

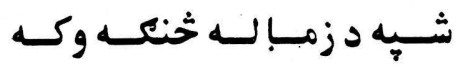

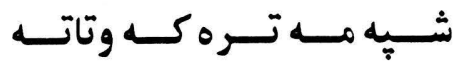

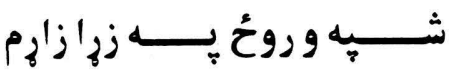

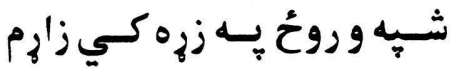

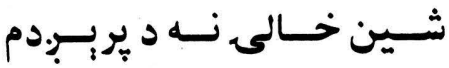

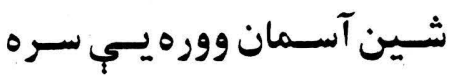
شونحي وخُبي تيكي واوري

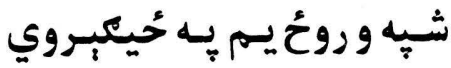
شـاوخوا شــنـكى آسـمان دى

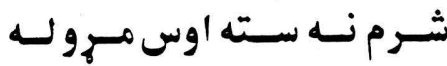

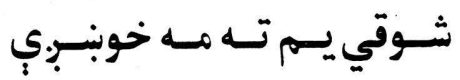

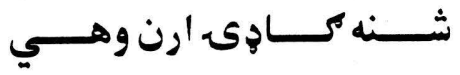

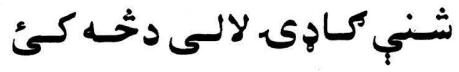

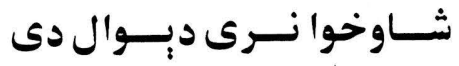

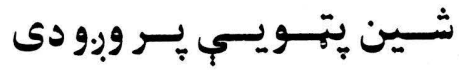

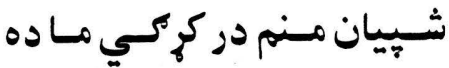
شَيـان منم كه نازي كعاف كم

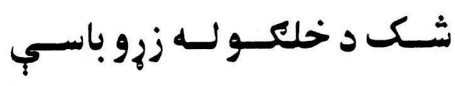

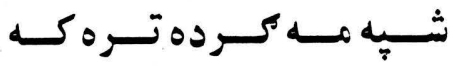

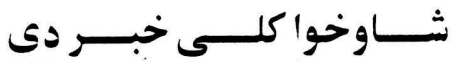

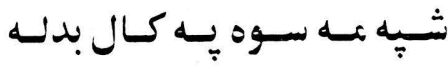

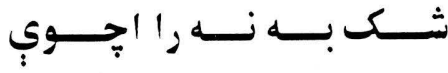
ثـنب خيسترى و جنسل زونسه

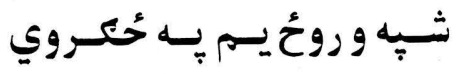


نـــنـن درويـــــتم دى د روزي

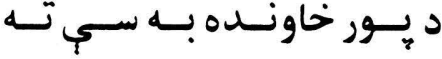

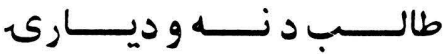

تيكسرى تسس كس دلسي كسوره

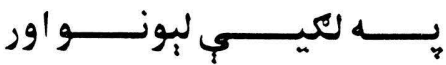

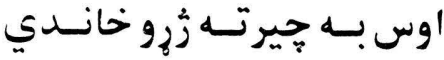

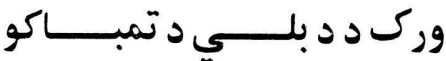
وركسى بـل ديّر مـا اور كسئ

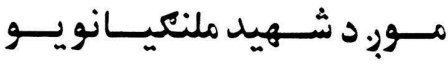

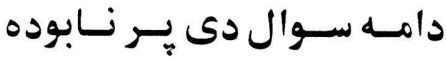

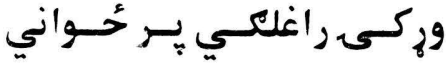
كمــــــــي اور دى د لـــلن ير دى حُـوك بـ د جانان سي

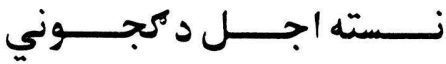

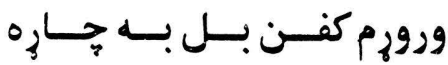
نه خـوب راتلـى نه مـه ليـار وه

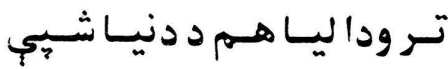
خـوابي نسه وزم يـه لاسـوكي هورى ليار وركه حُمي زوزي كي

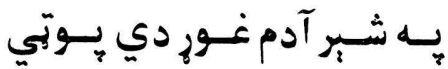

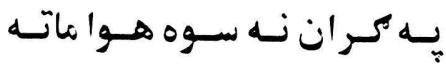
بـل يسي يــر مـخ زلفي مـار ان زمهـادرتـه نيـت دى ديـارى خـواره سـي وسـوم بـي اوره
شـــنخالى كــه خولـه راوري

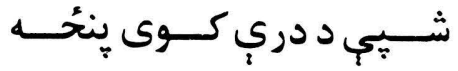

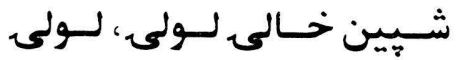

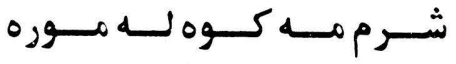

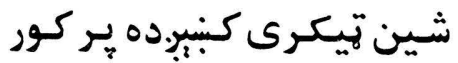
شين تيكـري نسواري يـانكي

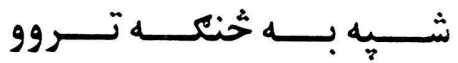
شين كميس د لندى جورئ كئ

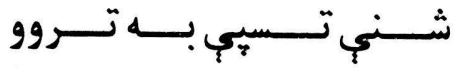
شـيخ بـه نـه باسـي لـه جــوده

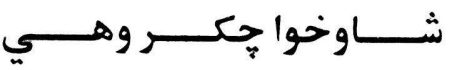

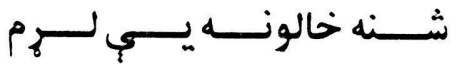

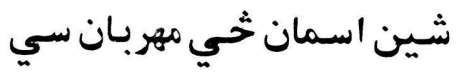

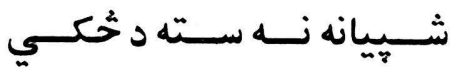

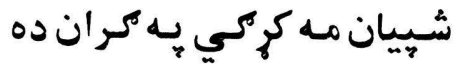

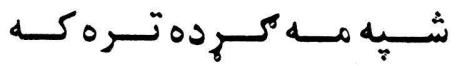

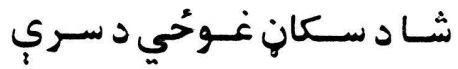

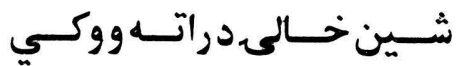
شين كميسيسي دى يه كور كي

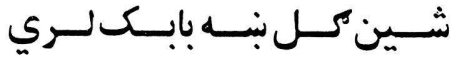

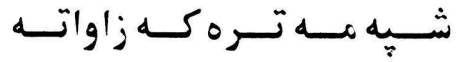

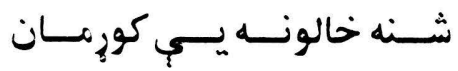

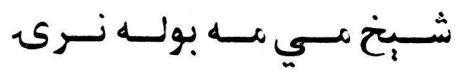

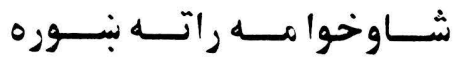


لمـا ورك سـو دو قـرآن تـوري

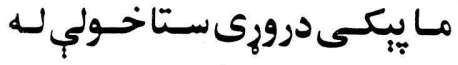

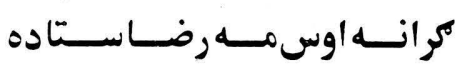

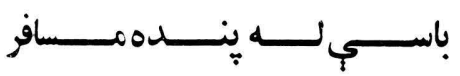

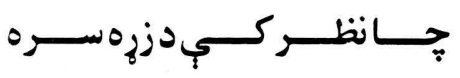

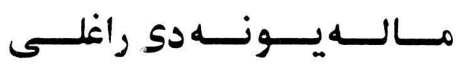

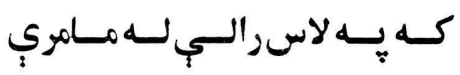

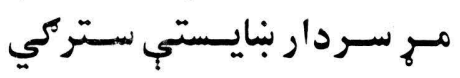

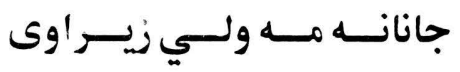

ولاري هجبر خلك د خواران كرل

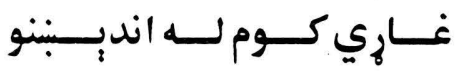

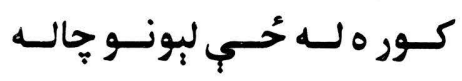

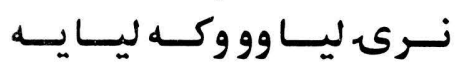

حُــواني نـصيب كـي دمبـاني

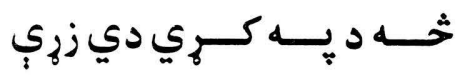

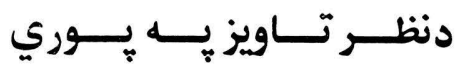

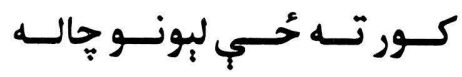

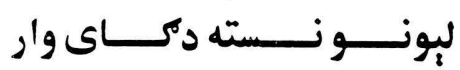

ده يـهـ نجونــوكـي ســـرداره
شين تيكرى كرحي بر غوني

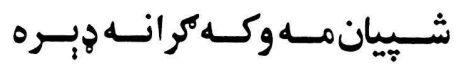

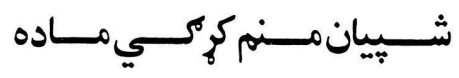

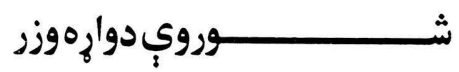

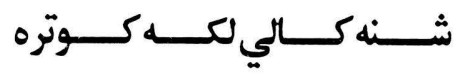

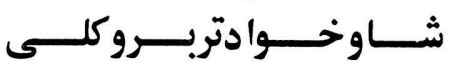

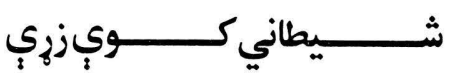

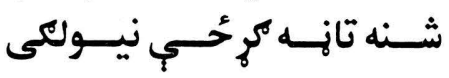

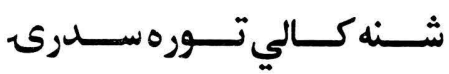

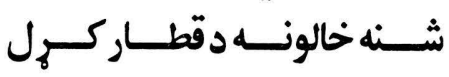

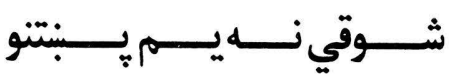

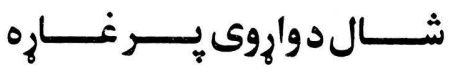

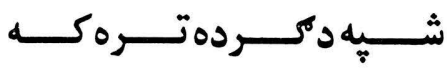

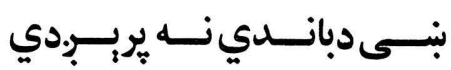

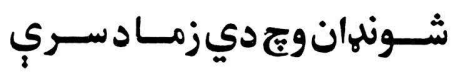

شنه كارئ يـه غـركي نبـوري

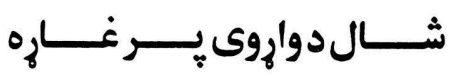

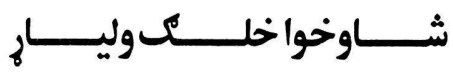

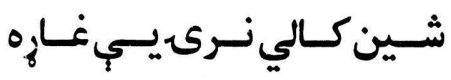

然资 


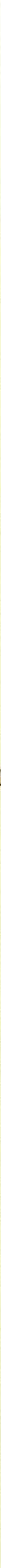




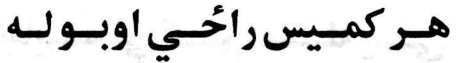

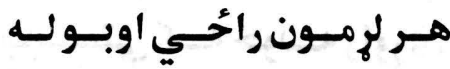

هـر لرمسون راحَـــي اوبـولسه

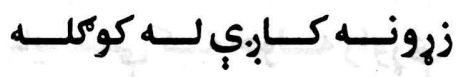

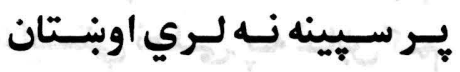

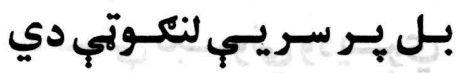

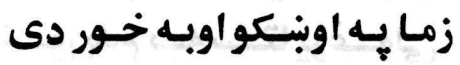

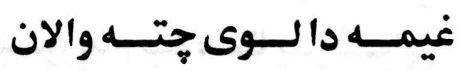
وركي هلكـوان بـي وفـادي

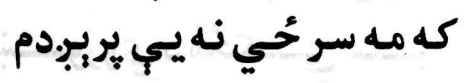

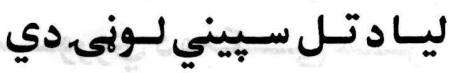

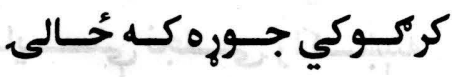

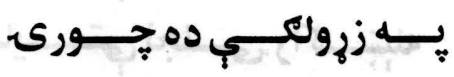

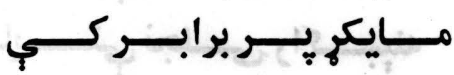

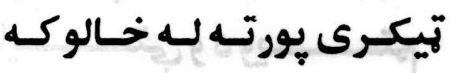

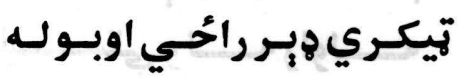

بنايـسته دى و لنـــ بــهــــوره

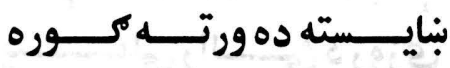
بنايـسته دى و نــــ بــهـ بــوره

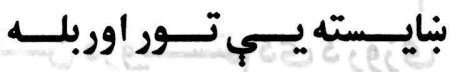

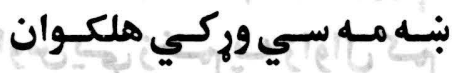
بنه حُوانان بني يبي سيكي دي

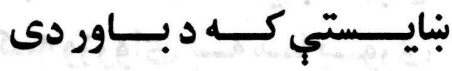
بـــه مـي سـي وزيكي هلكــوان

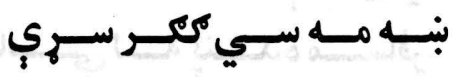

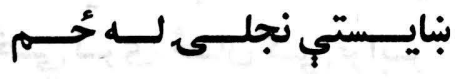

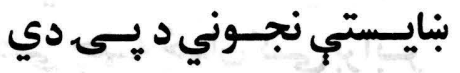
بنـــورر شــنك دى د شـــيلى بنـــوور شـنـك دى د شــــلى

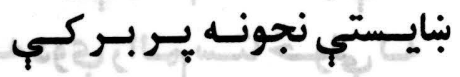

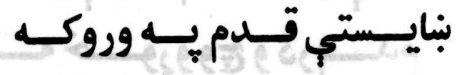

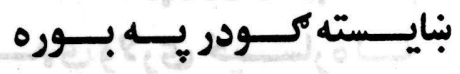


زمـوب. بـه هـم قــر بيـــا سـي

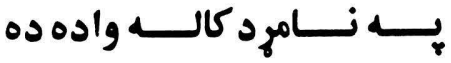
تـر غـم لانـدي د زمـا زرهـ كــ لـوى اختـر لـه مـه ليـار كـوره

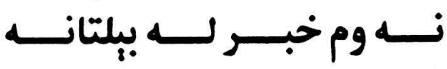
كـم عـلاج بــه د حُــان وكــم

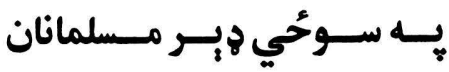

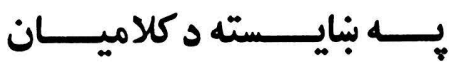

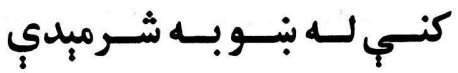

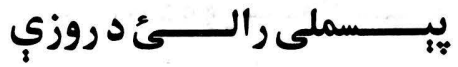

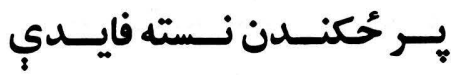

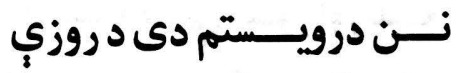

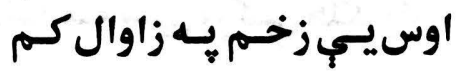

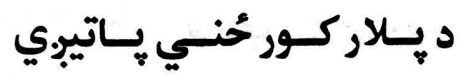

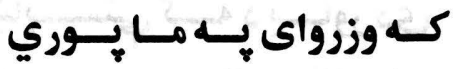
كـه مرغســ واى ادي مــوري

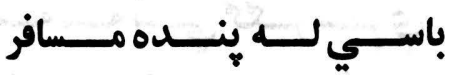

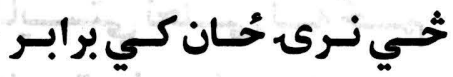

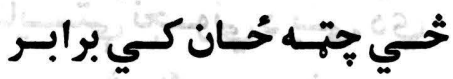
له مرغي رالم سـتاخـولي لـ لـه تـوبي رالهم سـتا خـولي لـ له

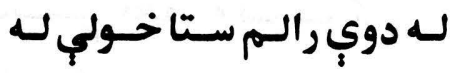

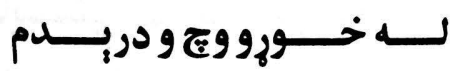

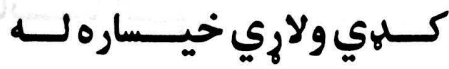

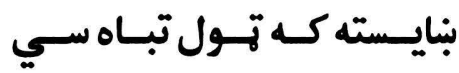

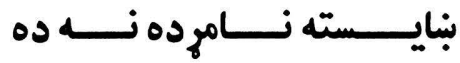

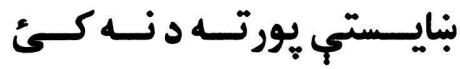

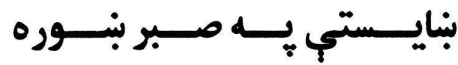

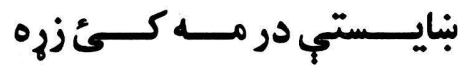

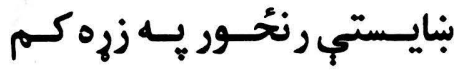

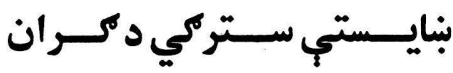

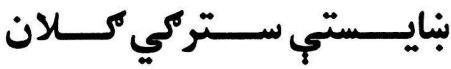

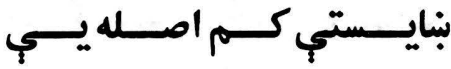

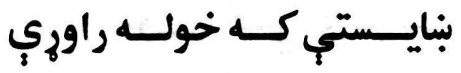

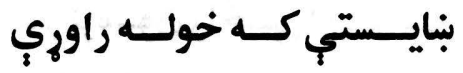

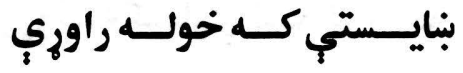

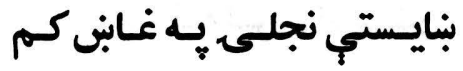

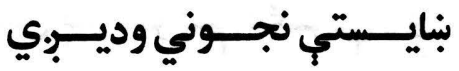

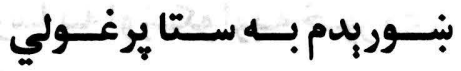

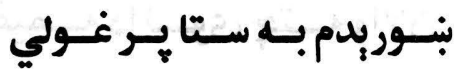
وروي دوارهوزر

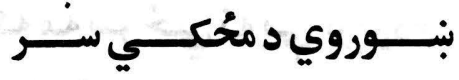

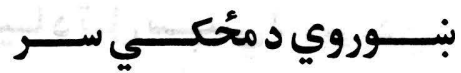

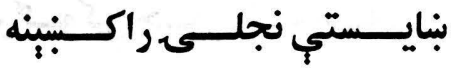

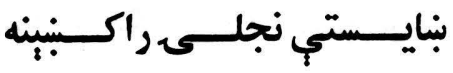

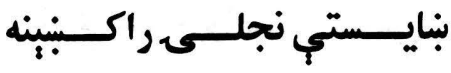

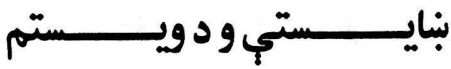

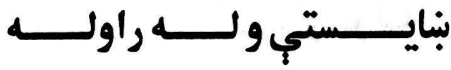


ليـايسي مـوبـ لـه نيمـايي كـه سري له تايسي كبنلى زهره

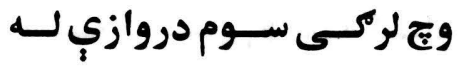

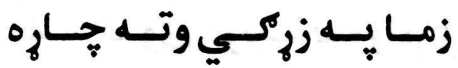

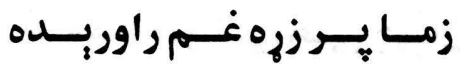

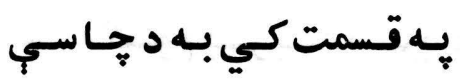

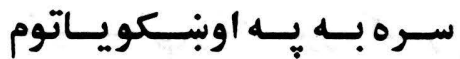

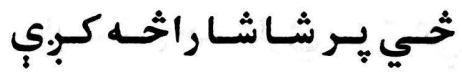

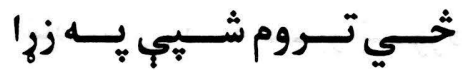

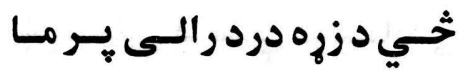
اخــري ديــن لـه بــه راتلـي خـوابي نـه ورم يـه لاسـوكي

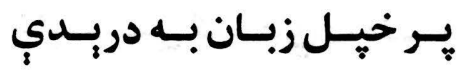

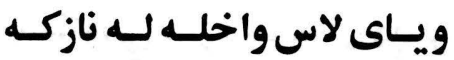

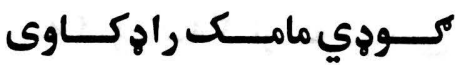
كـبنينه بـوري بخــت بـكمـي

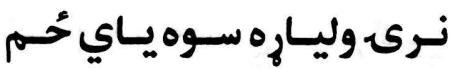

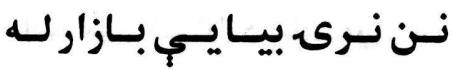

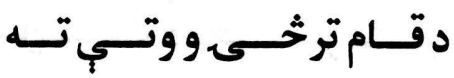

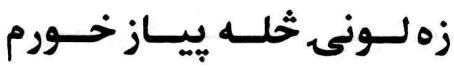

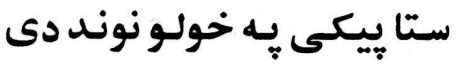

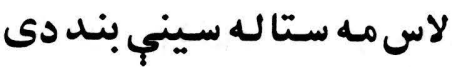

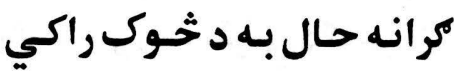
كـ نـوري هـم يــر دونيـا سـته

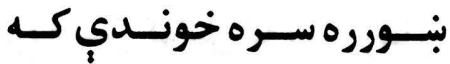

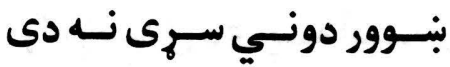

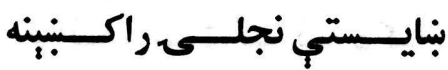

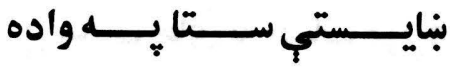

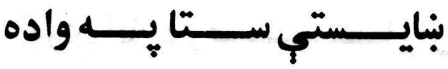

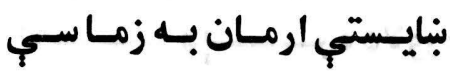

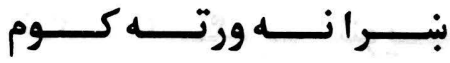

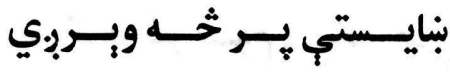

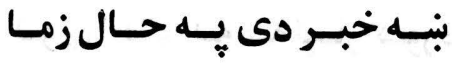

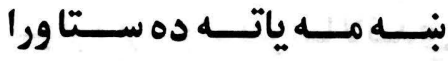

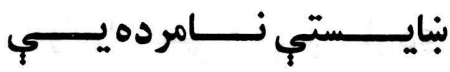

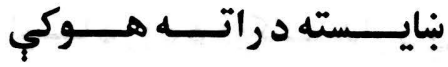

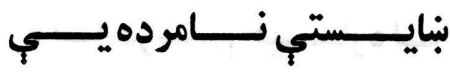

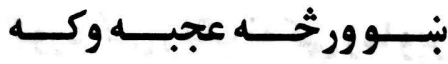

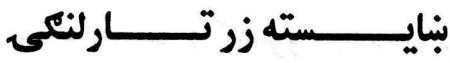
بنايــــتي ســـتركي د بمـــي

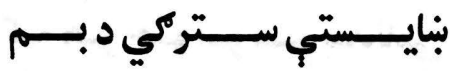

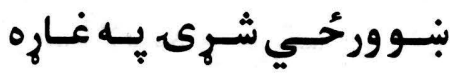

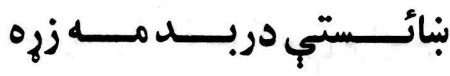
بنــــوور بيــــاز نـــازك غـــــنم

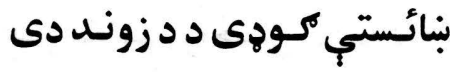

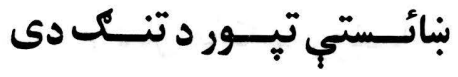
نبكو مي نسته زمورِ يه خواكي

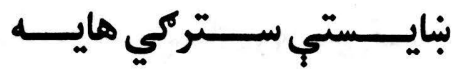


يسه تس كوكل نه سته زما بنـهـ

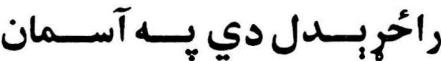

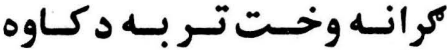

ير سخت حُحاى به حساب غواري

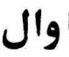
اوري الهّ د رض

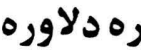

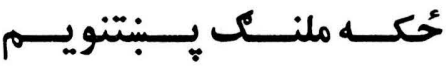

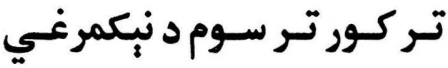
لـوى اختـر لـه مـه ليـار كـوره

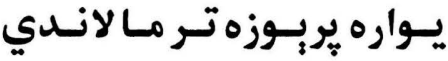

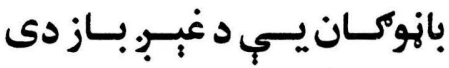
ليـــــــ رود د دوكانــــــار دي

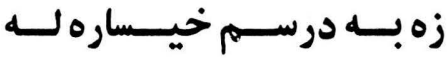
كوره خحي رنك نه كي زماوبر

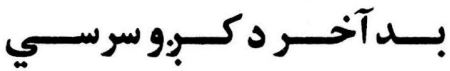

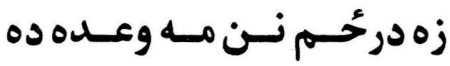

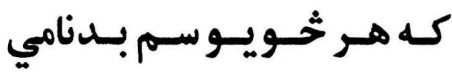

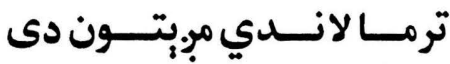

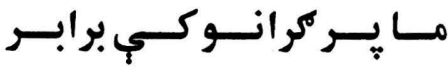

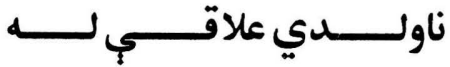

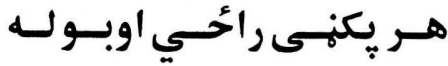

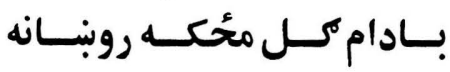

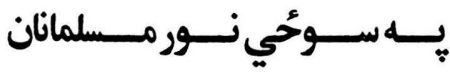

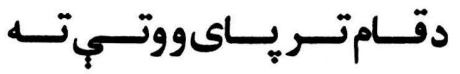

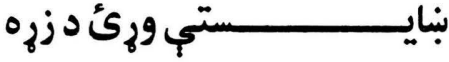

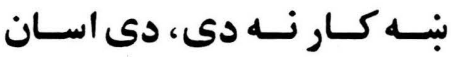
بنــــهـ كرانــــى د نــــهـ كـــاوه

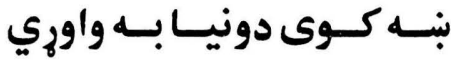

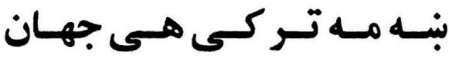

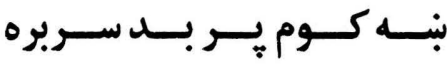

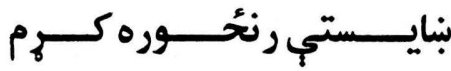
بنايــستب خمــاري ســتركي

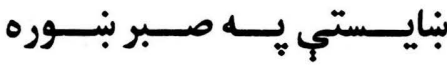

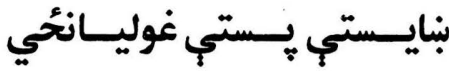

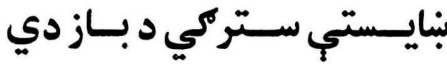
بنايستب سـتركي دمكران دي

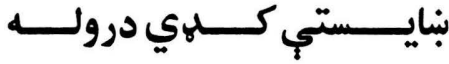

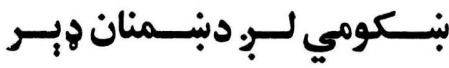

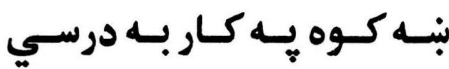

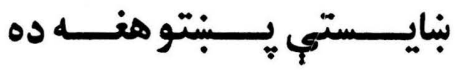

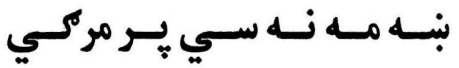

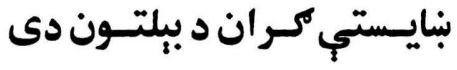

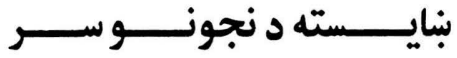

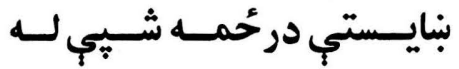

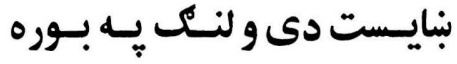
بنـــه موســم دى راسـه كرانــــ

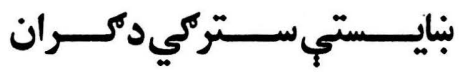

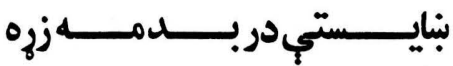




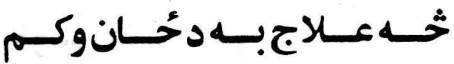

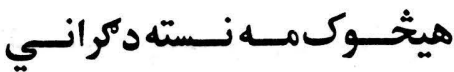

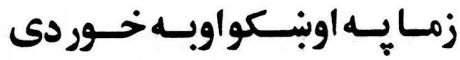

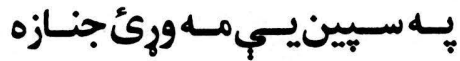

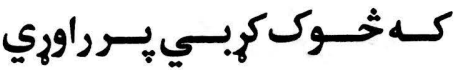

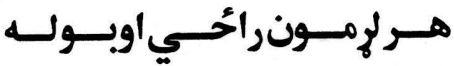

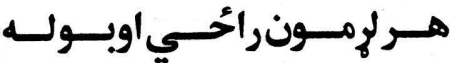

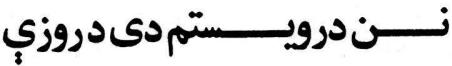

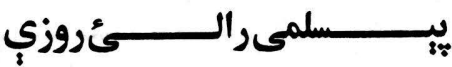

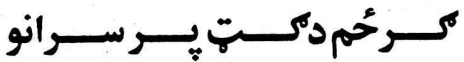

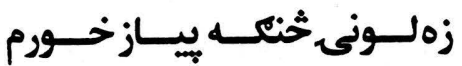

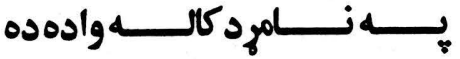

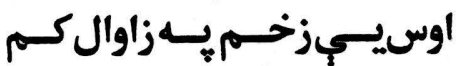

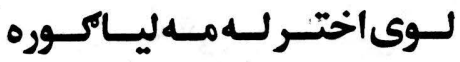

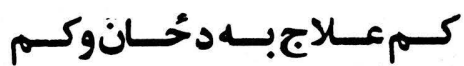

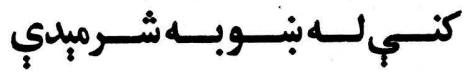

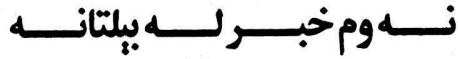

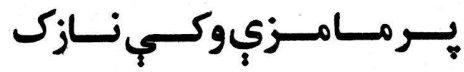
د خــولي خونـد د لمـاويــر سـو

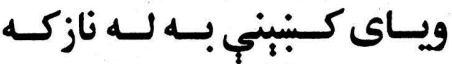

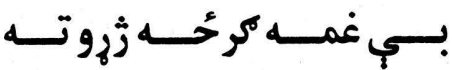
يسر كـل مـه بيـاتـر كسئ مابنـام

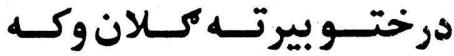

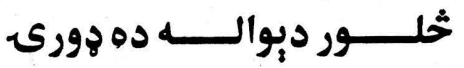

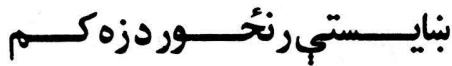

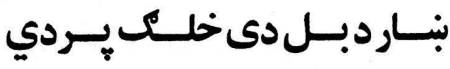

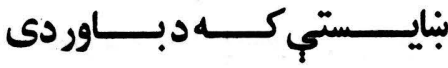

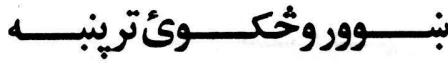

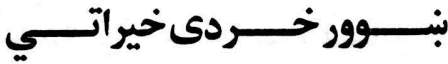

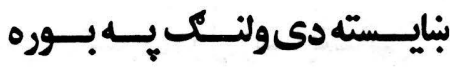

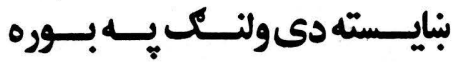

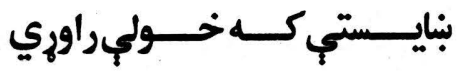

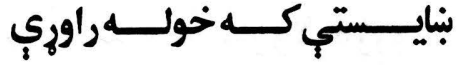

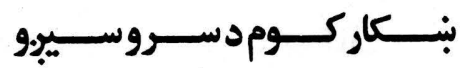

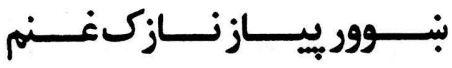

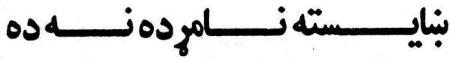

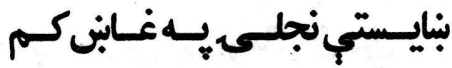

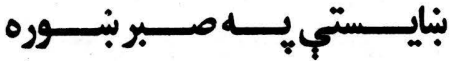

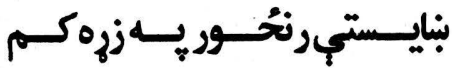

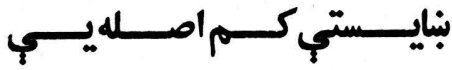

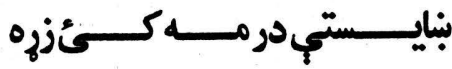

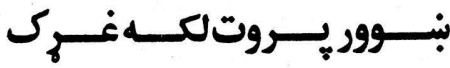
بنـواروز بـه ميـان كي تئر سـو

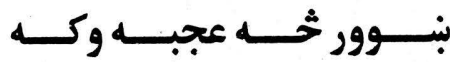

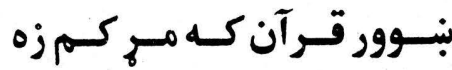

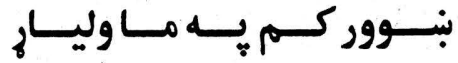

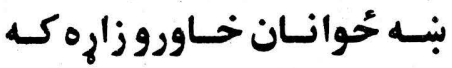

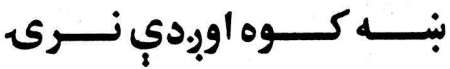


كاكرى غاري

كر انـه حـال بـه دخـوك راكي

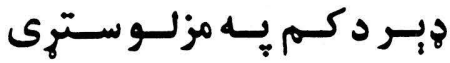

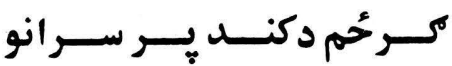

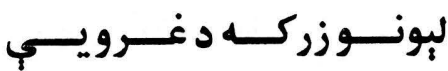

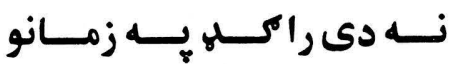

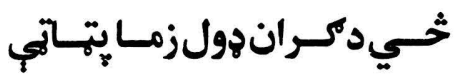

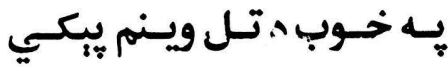
اوس بـ تيـي كوي ستا غاري

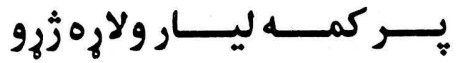

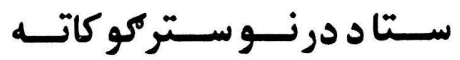
لإِــــونى كــــم دوكانــــــاري كوندي زمور. غيرت بيـا سي سي ربديخخلاصكي برماكران دي يـاكجكـول يــ دونيـار راكي
بنـكومي نسته زموبر بخـوا كي

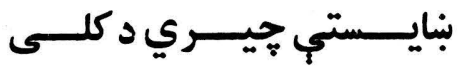

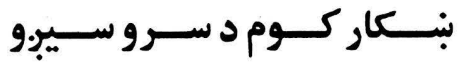

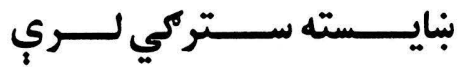

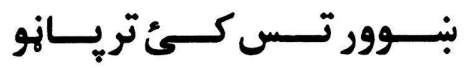

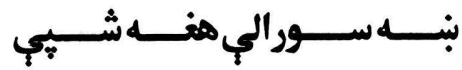

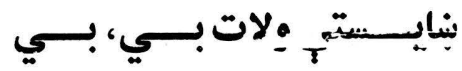

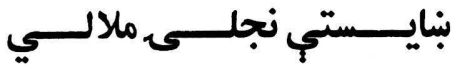

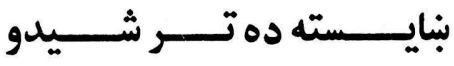

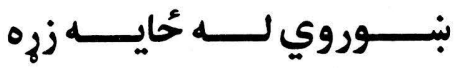
بنايسـتي دي نجــــي دواري بنايســته د تهــول تبـــاه ســي بنايـسته حُحوانــان بنـــيان دي

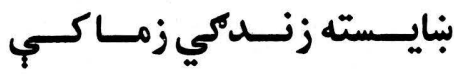




\section{|ص}

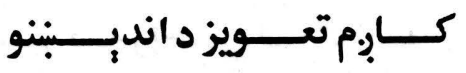

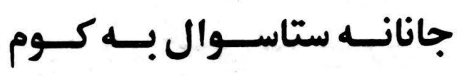
بي قدرى مه كور خراب كئ

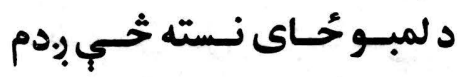
بـر تـاد مـور تـى ده زمـا خوله

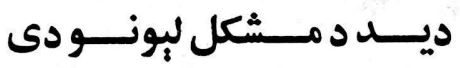

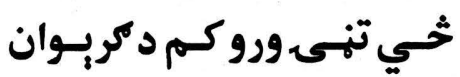

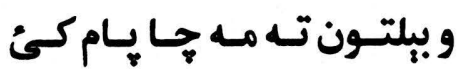

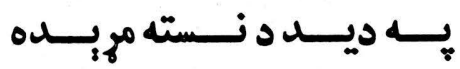

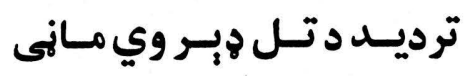
بـهـ كـور كي هإبري دي مـاينب

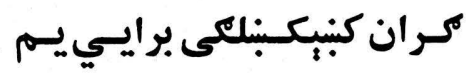
خوبنـــي نـه ســوله زمــامينـهـ

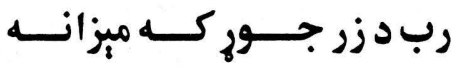

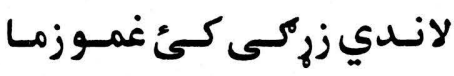

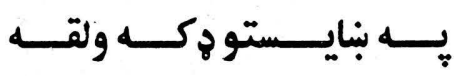

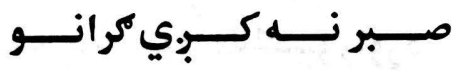

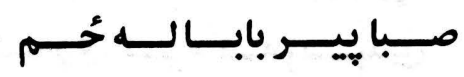
صبر بنهـ دى كـ خـداى راكئ صــبر بنــــه دى و بـــي كـــم

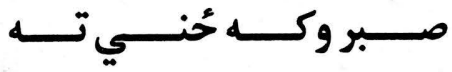

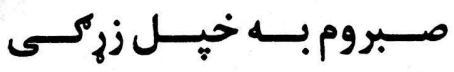

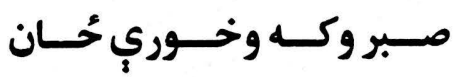
صبر بنه دى خي خداى راكئ

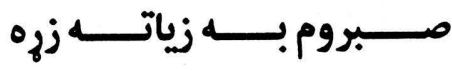

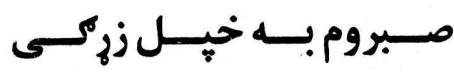

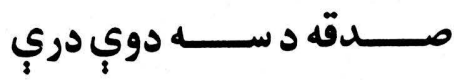
صرت مه خور. سي جوره نه يم

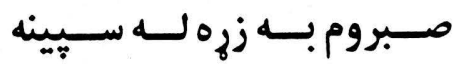

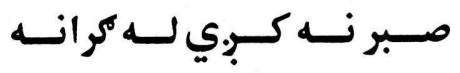

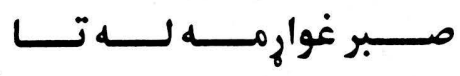

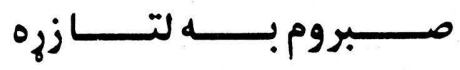


كاكرى غاري

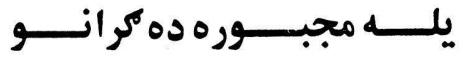

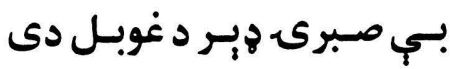

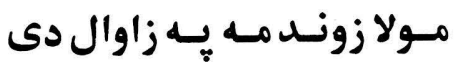

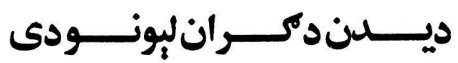

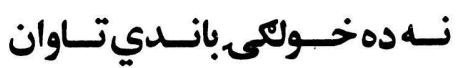

مــولا زونـد مــهـ يـهـ زاوال دى

بـي صـبرى لمهـ جــا بـام كـئ

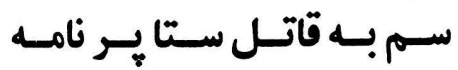

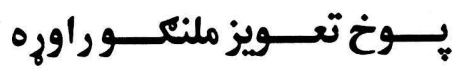

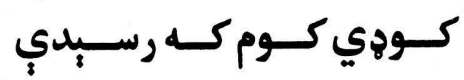

بـي صـبرىمله نوكـان باسـي

بسي صسبرى مسه ريسبني باسـي
صـــبرول كــــــان دي دززو

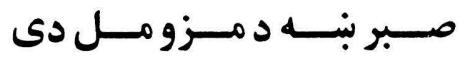

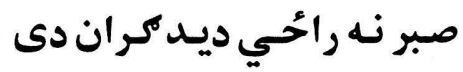

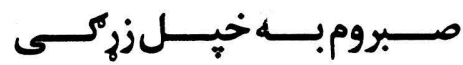

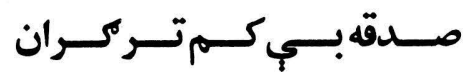

صبر نـه راحُي ديدكر اندي دى

صبر بنه دى خي خداى راكئ

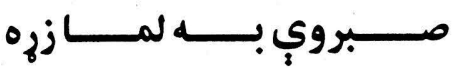

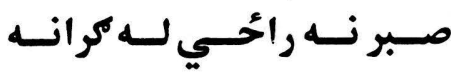

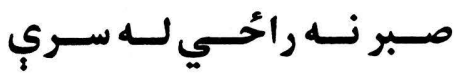

صبر بنـهـ دى مـل بـهـ زمـاسي صبر بنـه دى مـل بـه زمـاسـي

资次 


\section{$\varepsilon$}

رالى خـزان برسـوه غـوخمكى

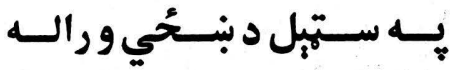

مركى مـهـ تـور لحــد لـه وري

هــم د خاونــد هــم د قريسـب

يسـي زمسوبر بــه بـدنامي دي

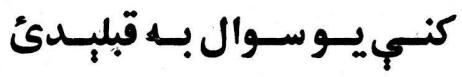

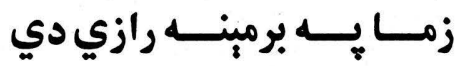

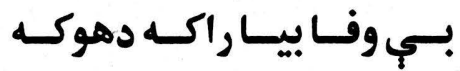

علـــي كــلــــــباز غـــوتى

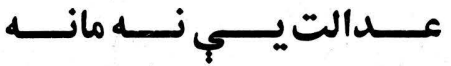

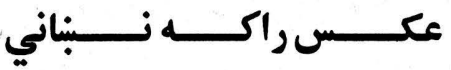

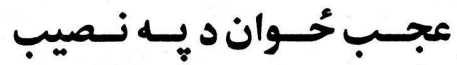

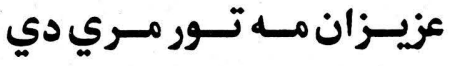

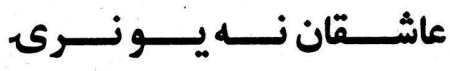

عزيــزان نـــهـ دي مـــري دي

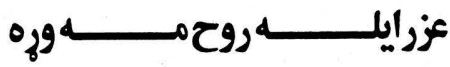

先燐 


\section{(}

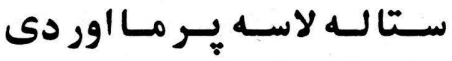
كه خداى ستامور كرهوراخوابنكي

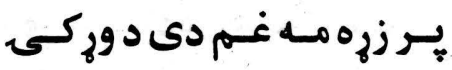

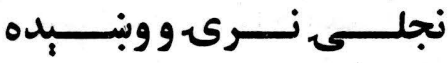
خخي د ارمان نه سي زما خوله

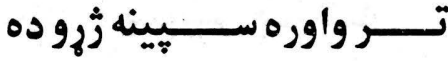
كــــه د خبـــــرو واى يـــــه واده

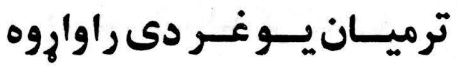

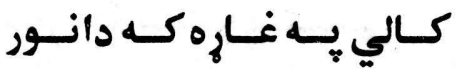

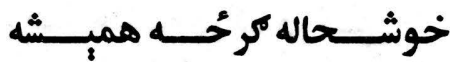

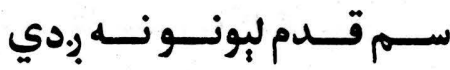
به بحى مه كرد نونف كرى كريوان

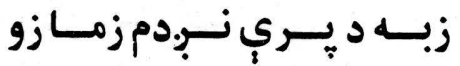
نه سته كرانحي ديديب وكم بـه ديـديسي نـور خلكس مـاره

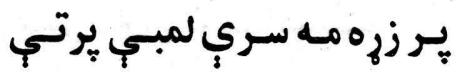

غوخكى بنه دهباديجي سور دى غوامـه يــنـكي ده دوه غابنسكي

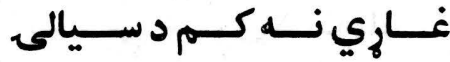

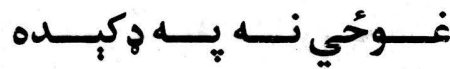

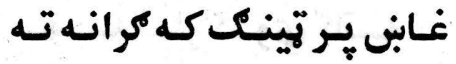

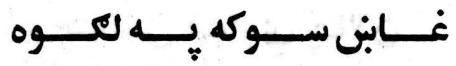

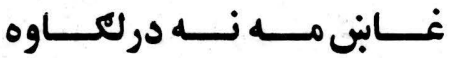

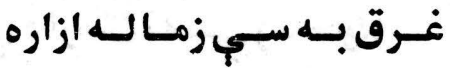

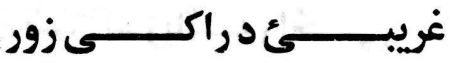

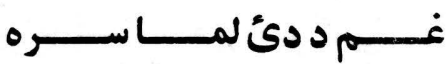

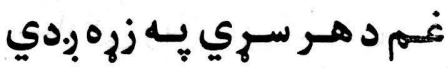
غـوا مـه لـوه بنــاره سـوكـران

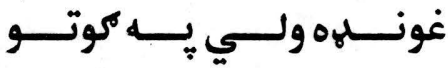

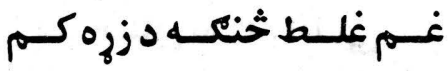

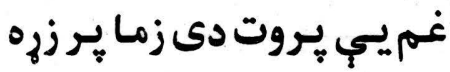

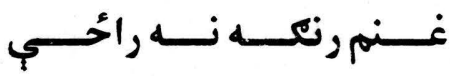


كاكرى غاري

خداى دي د نـوروكي فيشن

كاجسه سـبـان دي د سـري تـي

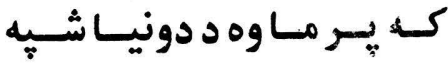

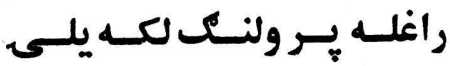

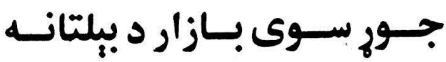

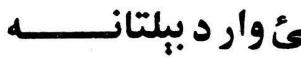

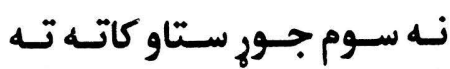

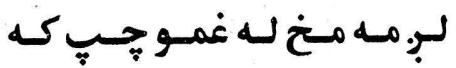

خي دي جـكر وخـوري ماغزه

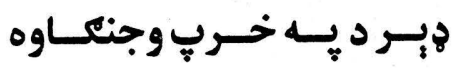

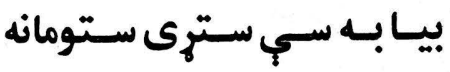

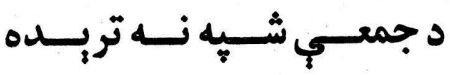

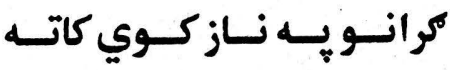

ستاير خولكى غواري جـالان خُمي سار حُاى نـه وي بنــاره خي د ارمان نه سي زما خوله

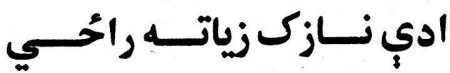
خــي يركستّ مـهـ برابــركي

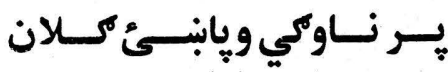

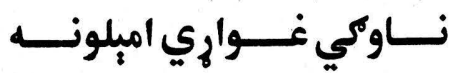
اوس مـه دود يـر آسـمان كـوره

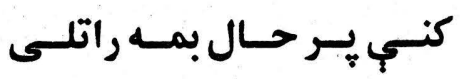

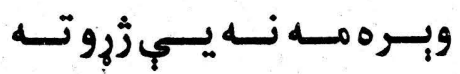

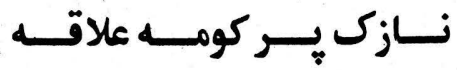

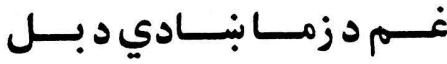

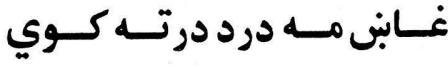

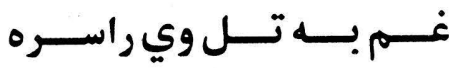

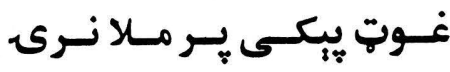

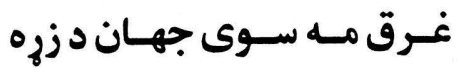

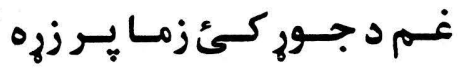

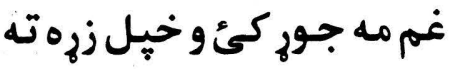
غابن راجك كه خوله مه خئ

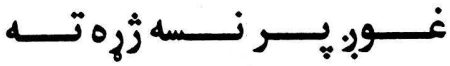

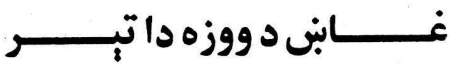

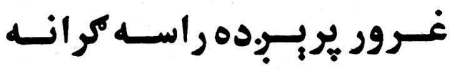

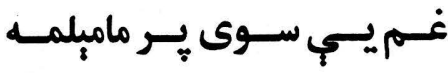
غتهـي سـتركي سـينه خونس

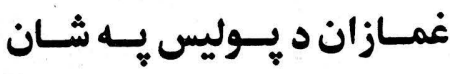

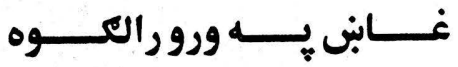
غـابن يـر تينــك كـه كر انـه تـهـ

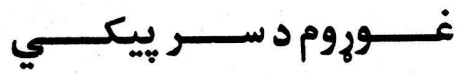
غــم بــه هلتـــه درك دركـــي

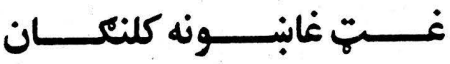

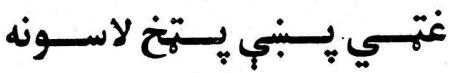
غــــم دوســــوحم بــــي اوره

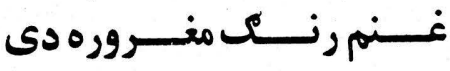

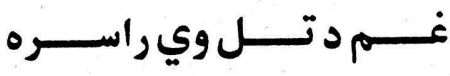

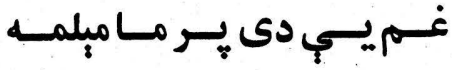


كر انسه بـي تـا هيبر دي حُوانـان

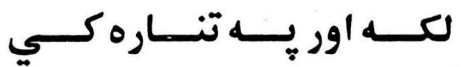
بـ مـوره لـور ده شين خـالى لـي

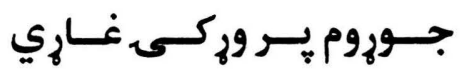
خحي ديد له ولارم سم د مكرانو

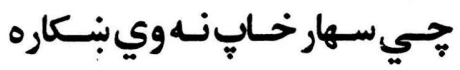

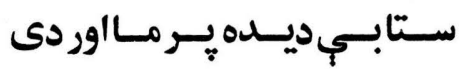

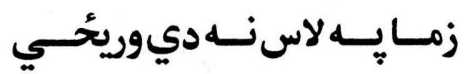

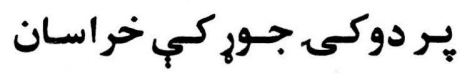

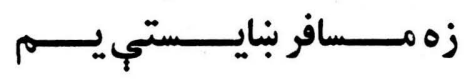

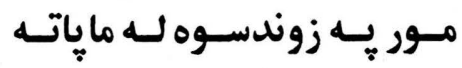

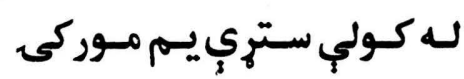

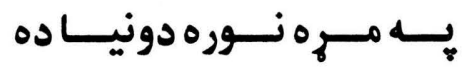

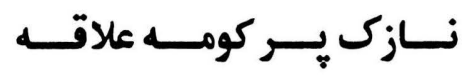
سو نان مه يري كر ل بِ غابنو

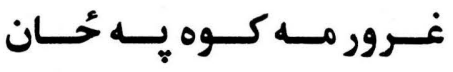
غم د يروت دى زما يه زهرهي يهي

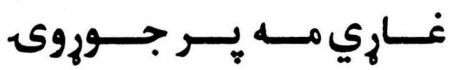
غوبر بِر ونيسي تول دي واوري

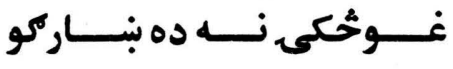

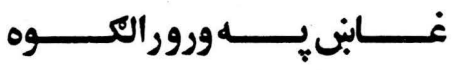
غوخكى بنه دهباتيسي سورئ دوى

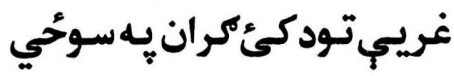
غريـي تـود كئز زما يـر كران

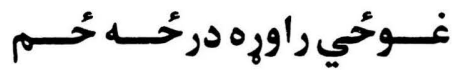

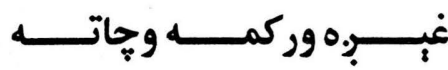

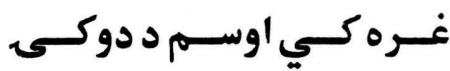

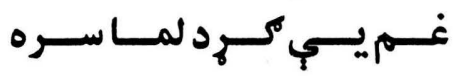

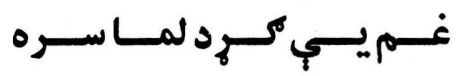

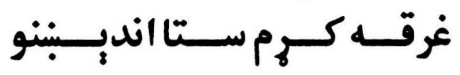
资资 



\section{\$)}

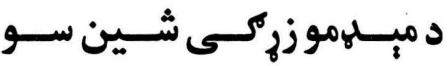

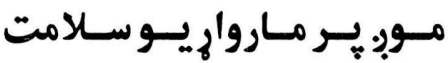

زما به بوخه د خداى سيّين كي

زيـارت كــي كـرحم ســلامت

ثي يه سوع كي مهك ان مل سي
فيض محمل بنـاره ير ينّين سو

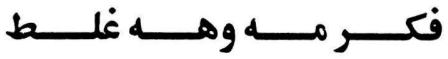

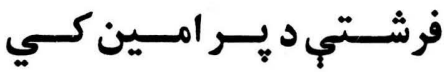

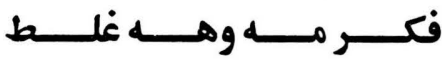

فكـر وم خيـال مـهـبــل سـي

类燐 


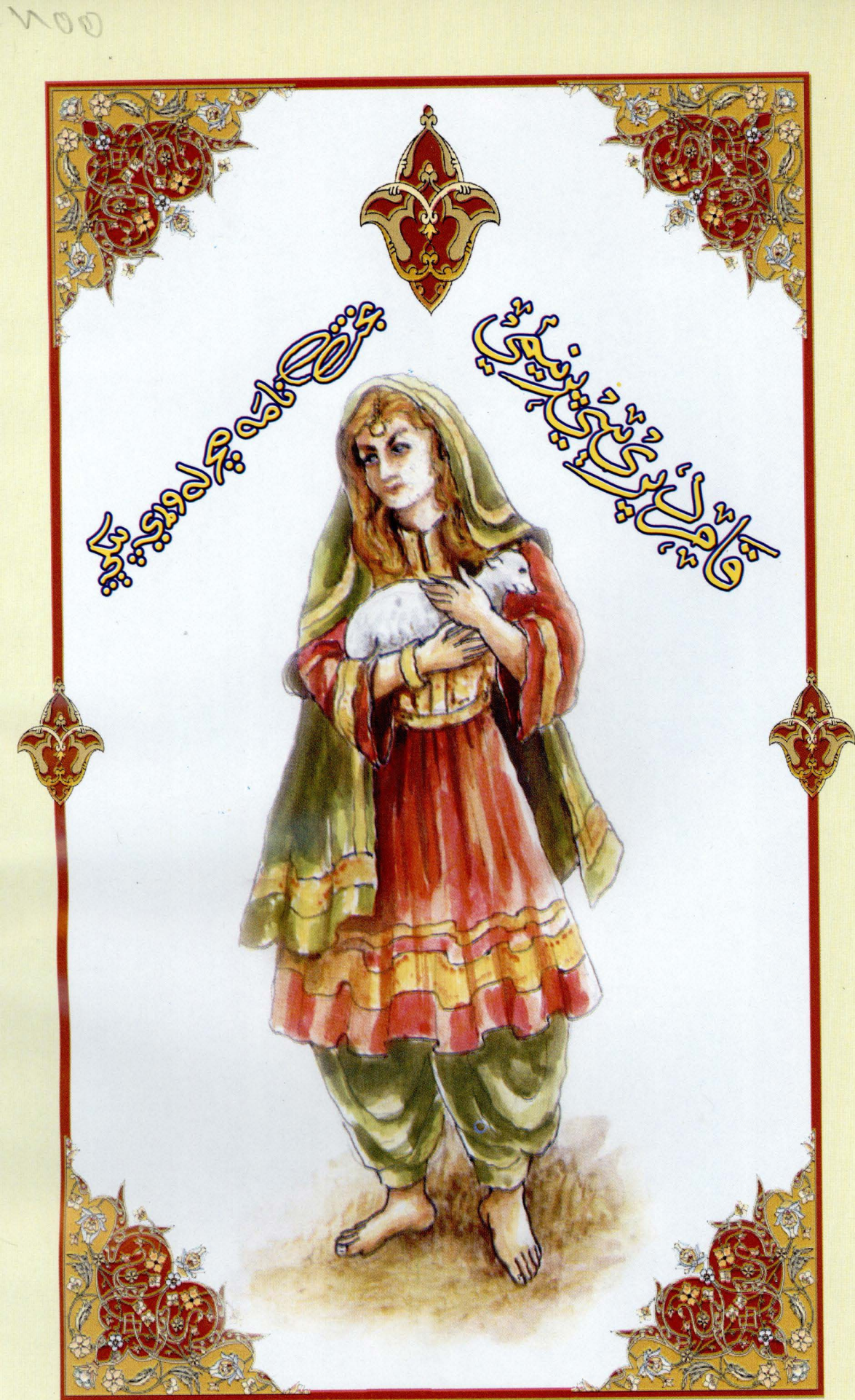




\section{夏苗}

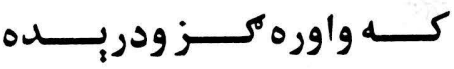

در خـــواروي ســيـن بـــبتـانه دكرانيو كاى دى خحي وكي

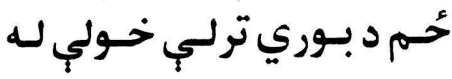

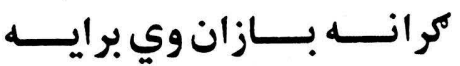

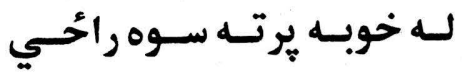
كه سيورِمى دوري خيزي ليا هم ثخي يسـو مـلا سـي ثخلـور نـور

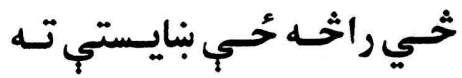
ثخي مه ورك له دونيا نوم سي

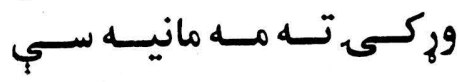

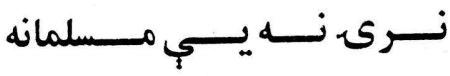

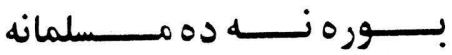

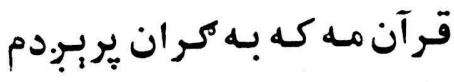

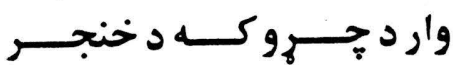

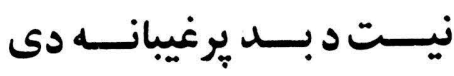

قــــــول مــــــهـ راخــــــواروه

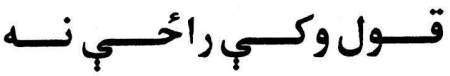
قــول وكـي مـات بــي نكسـي

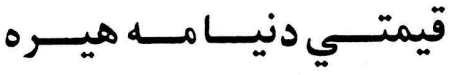

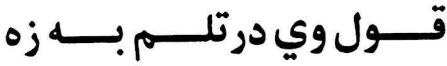

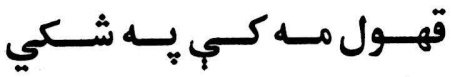

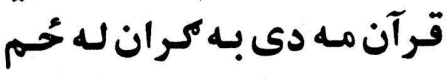

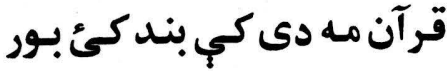
قيامـت جـور سـي زمـا يـر زيره

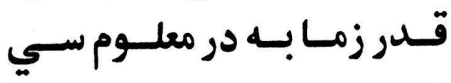
قـول وكسي تـــه ويسـده سـيـي

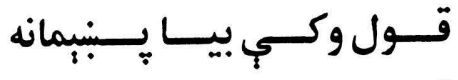

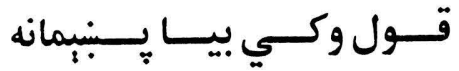
قرآن به واخلم قرآن به كبنبردمد

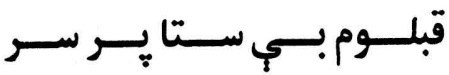
قرآن مه دى كه كر كنده دى يلي 
كاكرى غاري

خهي راخـه حُسي بنايستتي تسه

زوندون جِبر كران سو بي يسياره

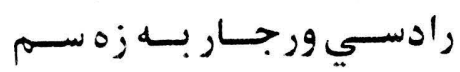

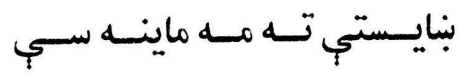

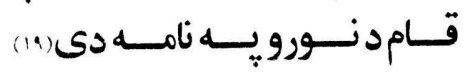

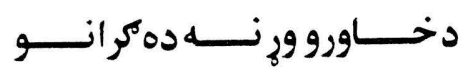

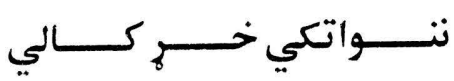

قيانست جـوري سـي زمـا يـر ززه

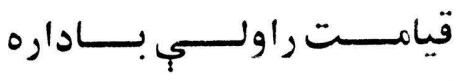
قام يردى دى ورتـلاى نه سم

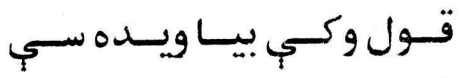

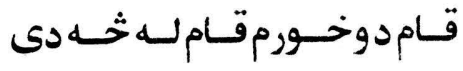

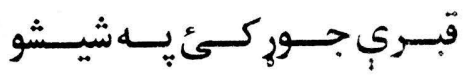
قرآن مه دى بـه حُمم غبركي له

洸潾 

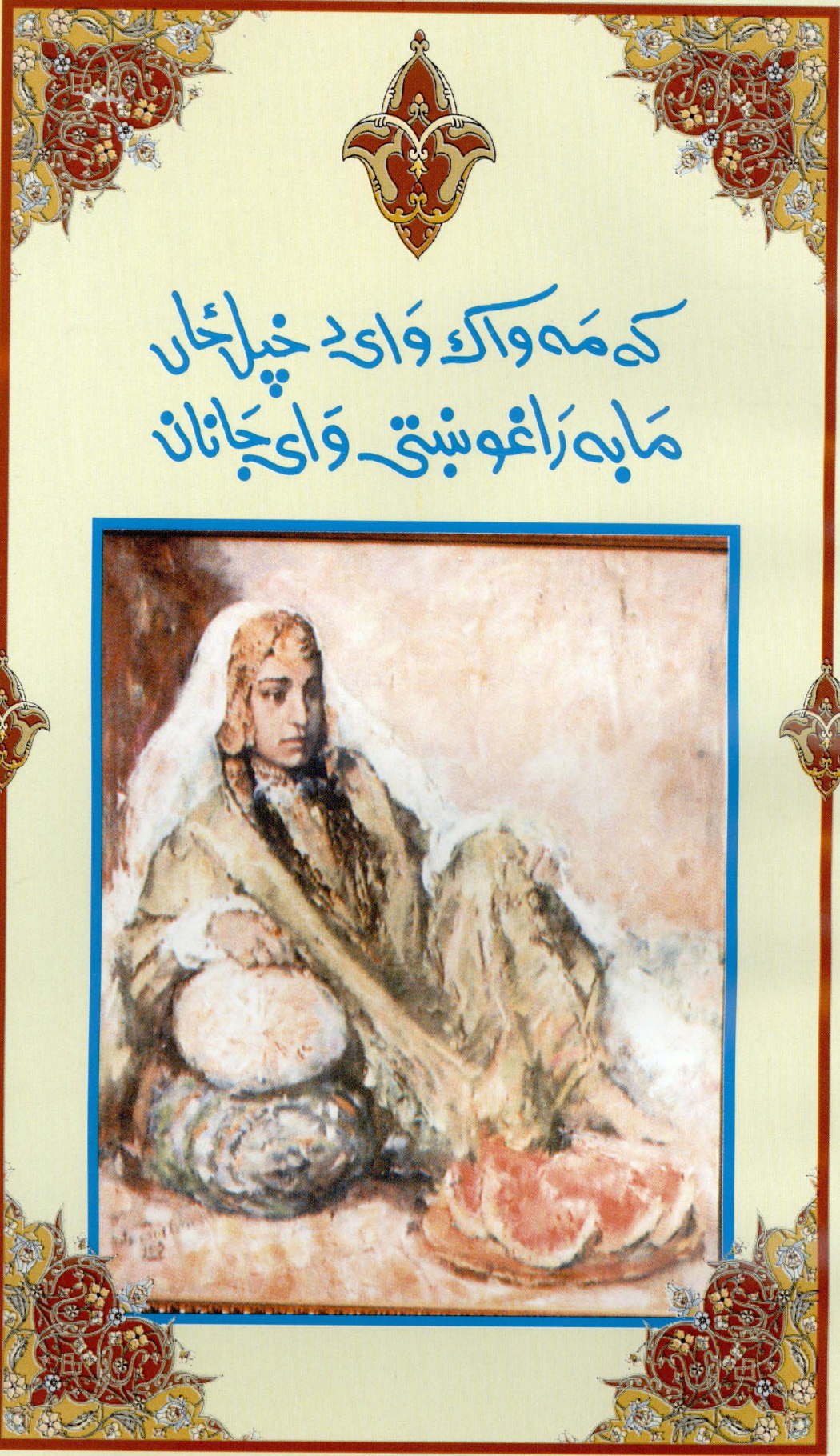


\section{5}

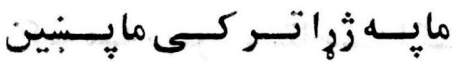

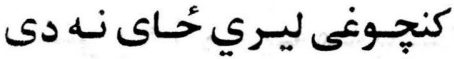

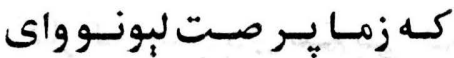

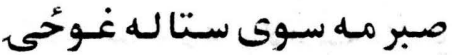

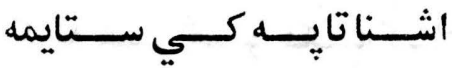

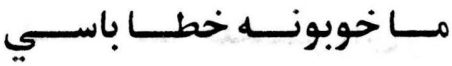

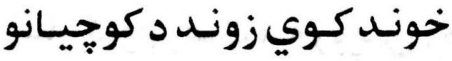

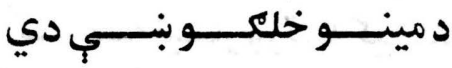

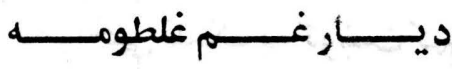
بيرتـهـ راواغونسـده سـتاشــال د سـرت مــه بــوى د كلــوحي خـورى كمزورى دى ستازيره

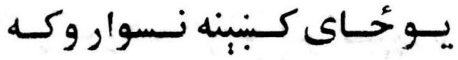

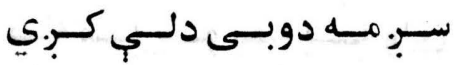

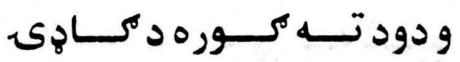
راكركي خـداى نـه ده كـادى

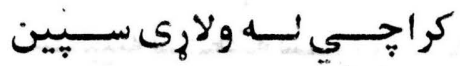

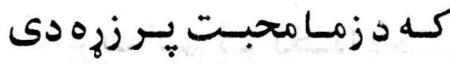

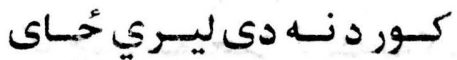

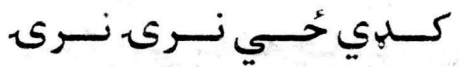

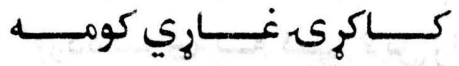
كـهـ راحـــي جانــان د راسـي كـهـ نــصيب سـي د خوارانسـو

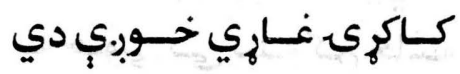

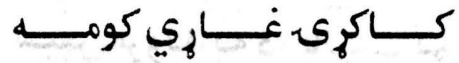

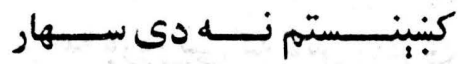

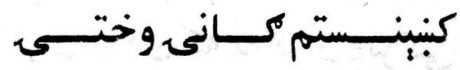

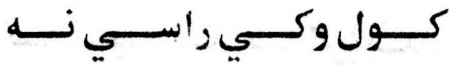

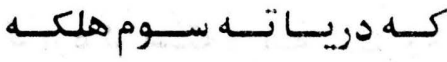

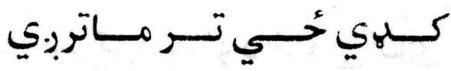

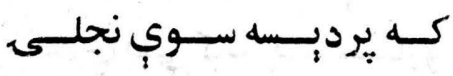
كـــور دليـــــي دى نجلــــى 
كـران سـبق ويسلاى نـه سـي

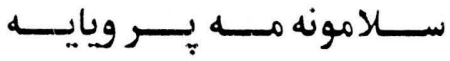

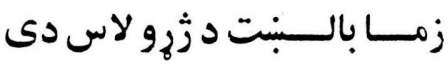

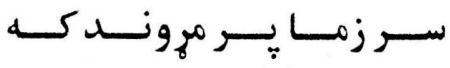

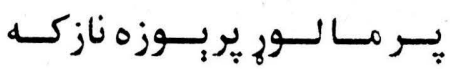

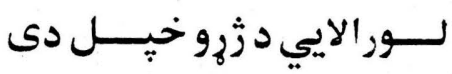

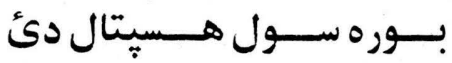

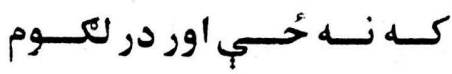

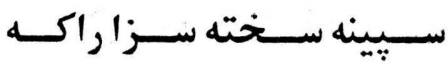

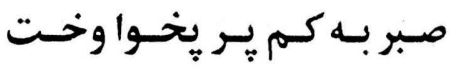
كه جِي سو بخحت ثنـكه به كم

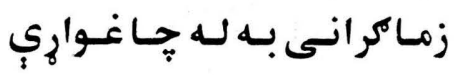

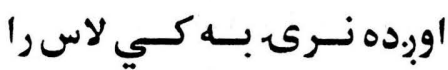

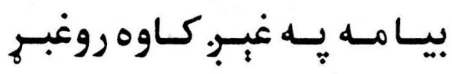

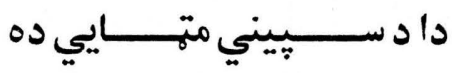
لـه خـولي بـي بيله كـم خاشيه

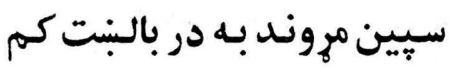
بيا مه ورور يبي كه لاس راوزي

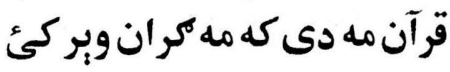

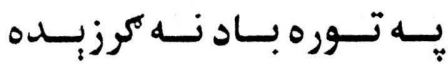

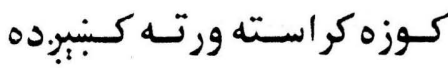
د ستر كو ديـد او د خـولب كتاى

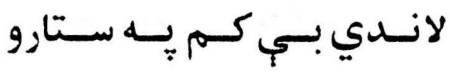

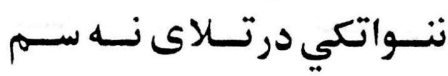

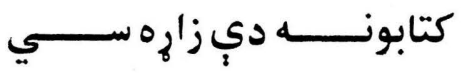

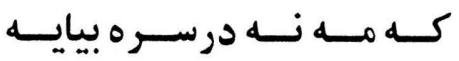
كور. مه كرد دله شيياني خلاص

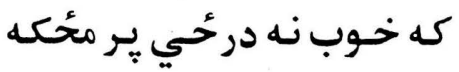
كه خـوب نه درحي يــ مئكس كـه راحـــي وطـن د بــل دى كـهـ رنحـــوور سـوم ورمــه ورئ

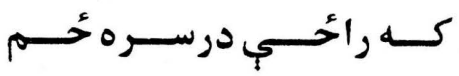

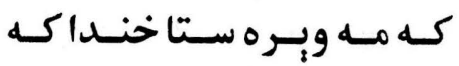

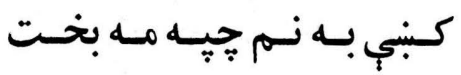
كار كـه جـي دى سـم بسي كمى

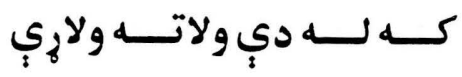

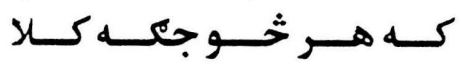

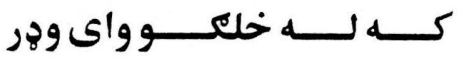
كـار كــوم ريستِ مـه رويسي ده

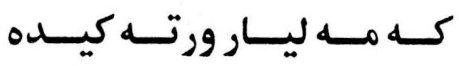
كه راححي تلتك بـه كوبنت كم

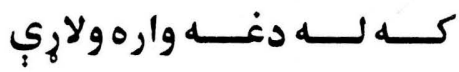
كه مـه غوتهـه يـر مـلا يـري كَئ

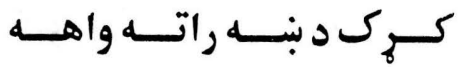

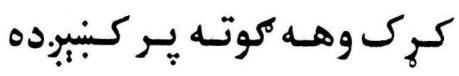

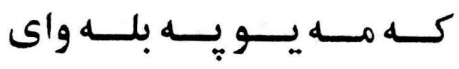

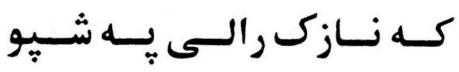

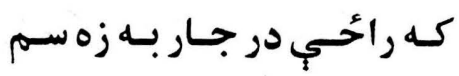


نتسـواتى درتــلاع نـــه ســم ستا حجري لله درتكلاى نه سم صـبر مــه سـوى سـتالـهــوحي

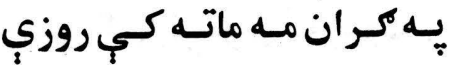

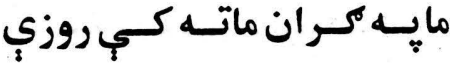

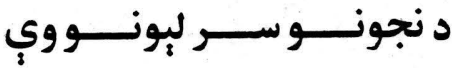

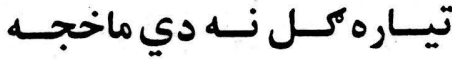

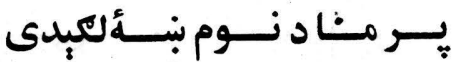

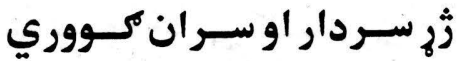
ستا جاركل زما بـه جهبيوو كي سـتا د اوبنـــو بــــــــاران دئ

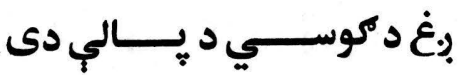

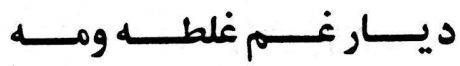
خيل دلبر جـان بـه خـولا كوم

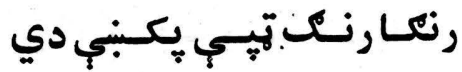

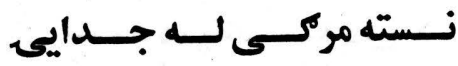

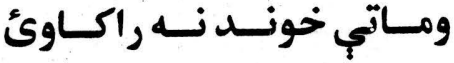

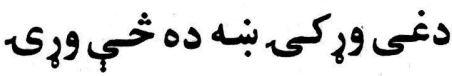
خولـه در ورم باتــه مـانى دئ دوينــي خونـــ دى دكـــي سـترى سـتومان بـه وي كر انـو سـبر. مسله دوبسـى دلـي كيسبري

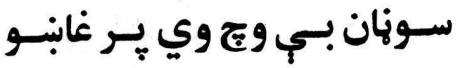

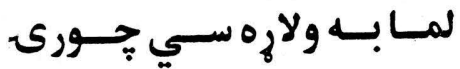

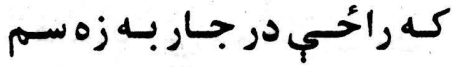

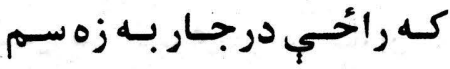

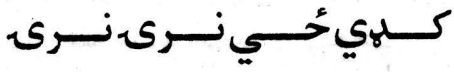

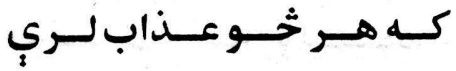

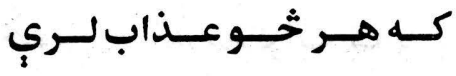
كـله د سـتركي نــه واى شـنـي

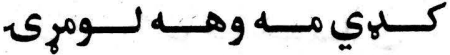

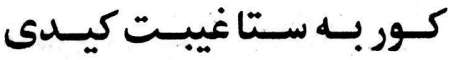

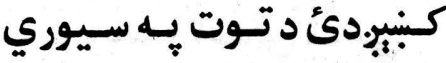

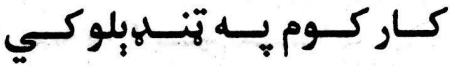
كاغذ رالَئ لونديس ميان دئ كاغنحي موزي يـ كبني دى

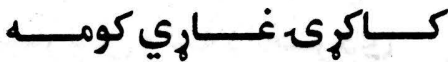

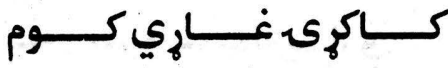
كـاكي غنـاري ليـانبــي دي

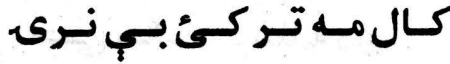

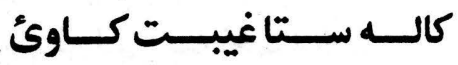

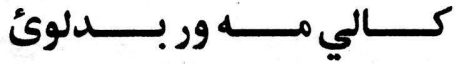
كيـى كاونم خـور تهـــى دئ

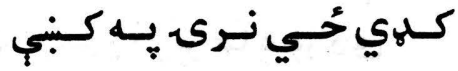
كـلهي خــــي بــر لـوى مزلـو

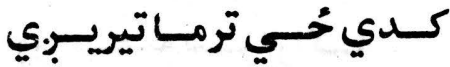

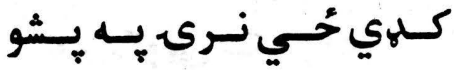

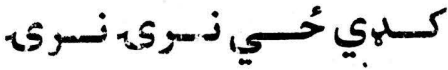


بـه هلمنـد كي مـه جانـان دئ ويـاى يـر سـيوى اوري بـاران

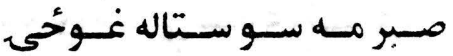

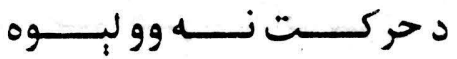
ه خـولب خونسل مـه كر انسه بنه و

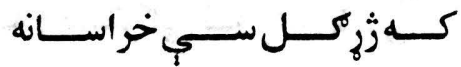

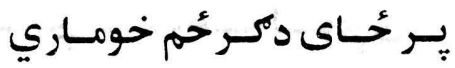
سـتادرواى نـه دهز زمـاويسـره

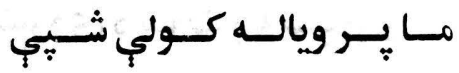
جالــــــه وركـــــــم ســـــلامونه ورك دئ لـه كلـي خومساري

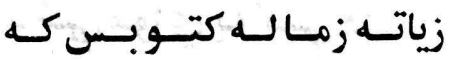

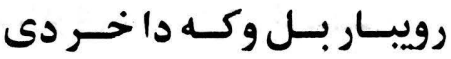
كر انـــه رســـوا ســوله يــاري

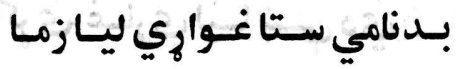
خـي حُحي تــ د مستانه دئ

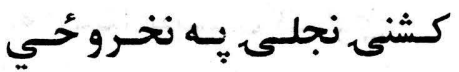
كشنى نجلسى بـه نخــرو

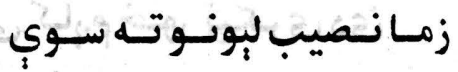
يستّ كر انـى د يـر مـا بـور دئ

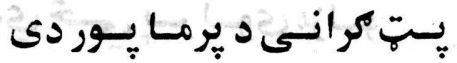

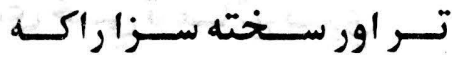
آسمان كوتي كوتي بنكارهي

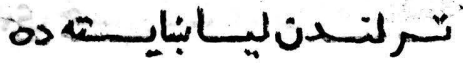

كسي حُحسي نـرى بـاران دى

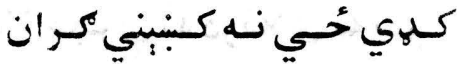

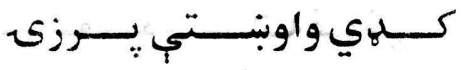
كنب يسي كئ بيلـوتِ بـه خوله

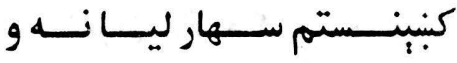

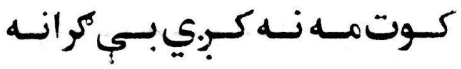

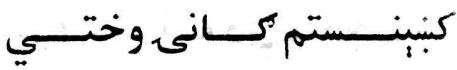

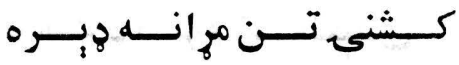

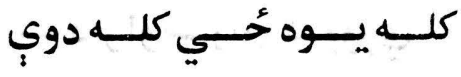

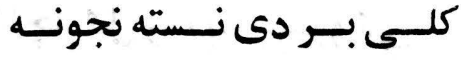

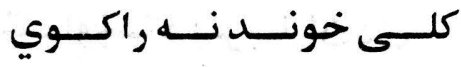
كلى دير دى يـو كي خـوبى كه

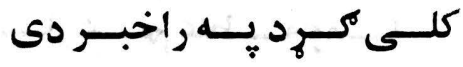

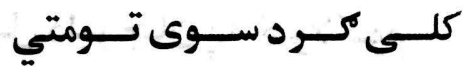

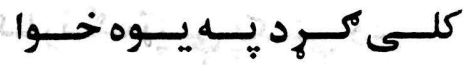

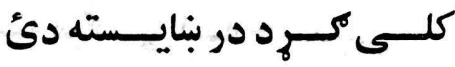

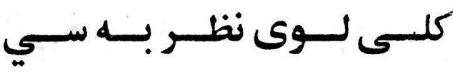

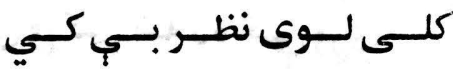
كلى لوى وئ خوبن مله ته سوي

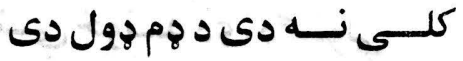
كلهى نه دى زموبر غه دول دى

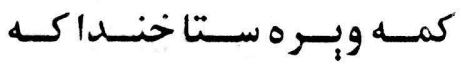
كنجز

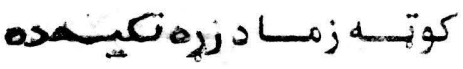




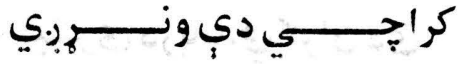

خي دخوك حال نه سيراوزى راكئكي خداي نسه دهنهابيى

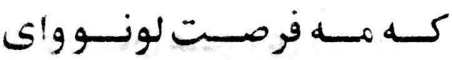
تروزى بـي حاله كم ستالـور

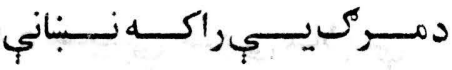
زه ســودايي بنايسـستب كـــم

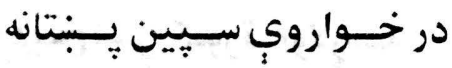
تــر جـــورى نستسته بـي مانسهـ

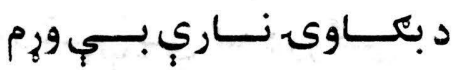

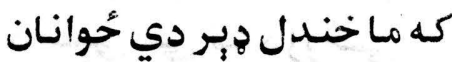
تيـا نصيب مـه د دي خوله ده ده

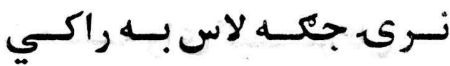

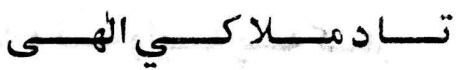
يسه تــور ســر دمرانسو بنــوري زوبــــ د اور واخلــي دانسـور

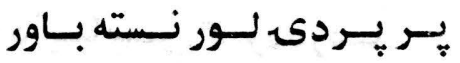

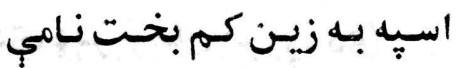
تربسـور مــي مسـه بولسه ترلـي

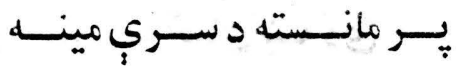

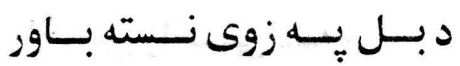

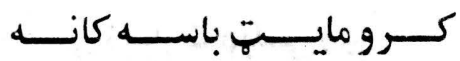

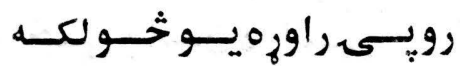

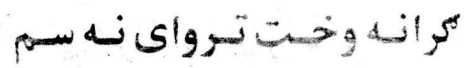

كوتهـه بنسه دم حسال يـهـ كبري

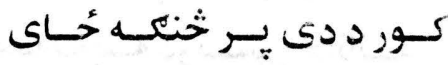

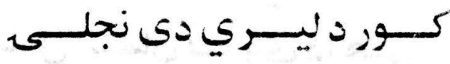

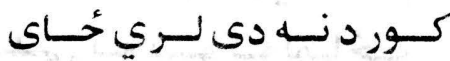

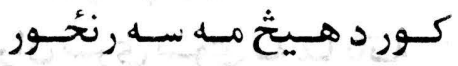

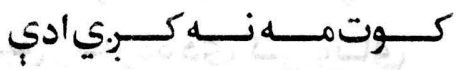

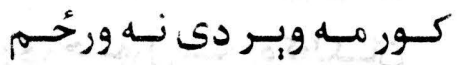

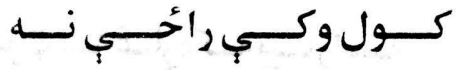
كــول وكـي ســي بــنـبمانه

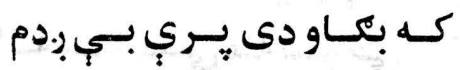
كه بكاو دى خلاص دى كران

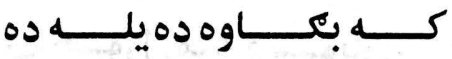

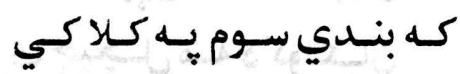

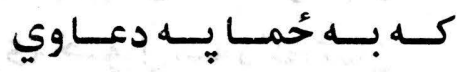

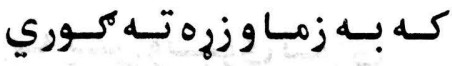

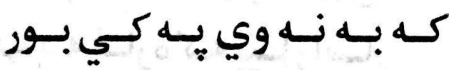

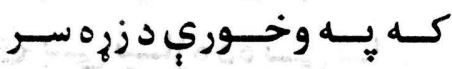

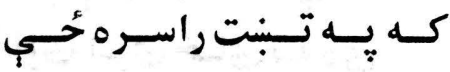

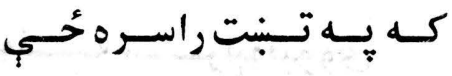

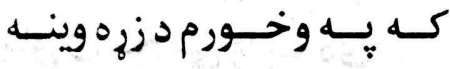

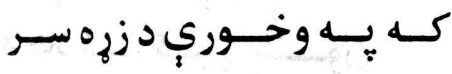

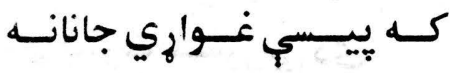

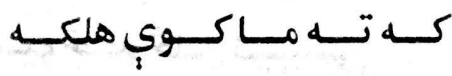

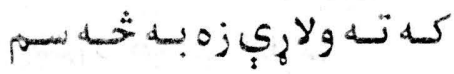


كـور تــه ولاره سـه بــاران دئ

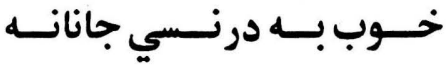

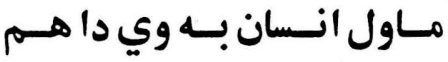

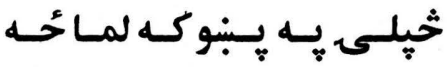

كران سـرى سـوى لـه مـا ياتـه

سـبق زمـا زده دى كـي ويـاى

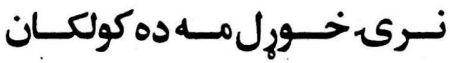

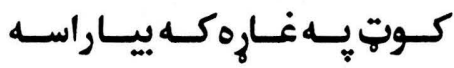

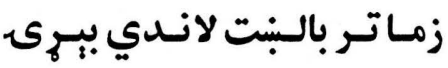

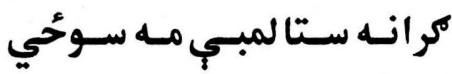

زره مــه سـتا يـه لمبـو سـوحئي

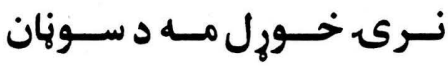

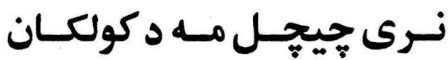
نــرى خـــورل مـــ د كولكــان

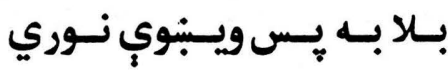

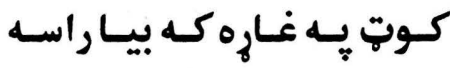

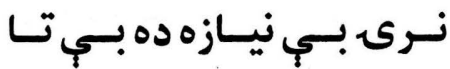
سـنحاوى لـري حُحساى نـه دئ

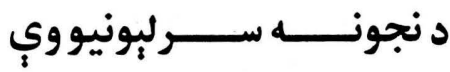
شـنه بـاورى مـخ يـي وابنه دئ

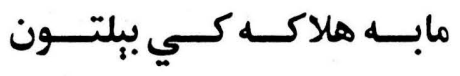
بانــــي يـــرت ســنرزيـى دى

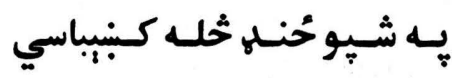
خوله وبنهم برخهـيـي كار سي
كه تيكرى درباندي كران دئ كـه خبــر سـوي زمهـالـه حالـه كـــه خبـــــر واى نــــه ورتلـــم

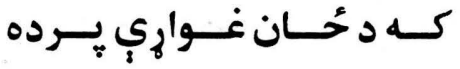

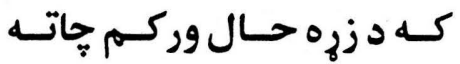
كـه د سـيـيني خـولي مـلايسي

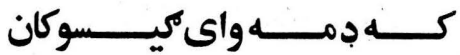

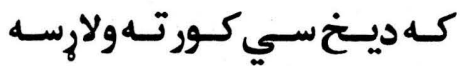

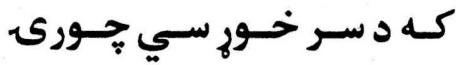

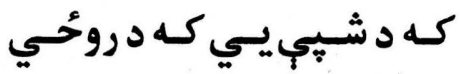

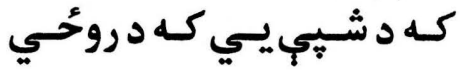
كـــه د مــــه وايـــــه كولكـــــان

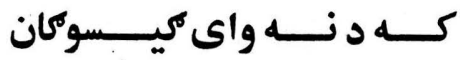

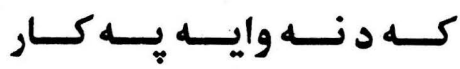
كـــه ديــات وئَ وار د بــــوري كـه ديـخ سـي كـور تـه ولارسهـ

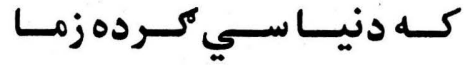
كه دي هير ارمـان يـر زيه دئ كه دي سـتركي مه واى سري

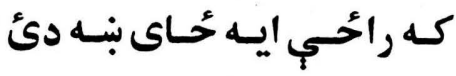

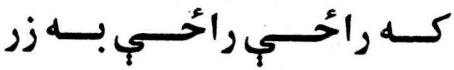
كـه راحسي زيسارت ديلسى دى

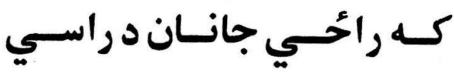
ك راحسـي كرانـودي راسـي 
مـرك مــه قبـل بـــر دنـــا دئ

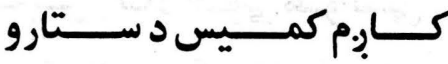

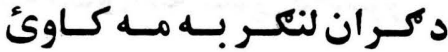

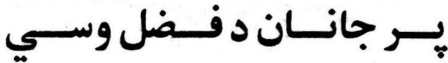

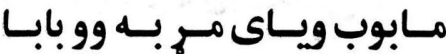
بـوري حج له بـه بيـاولارسم كـلــه درجــور كـم د جـابى

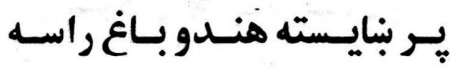

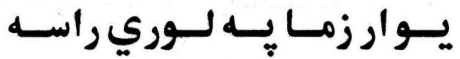

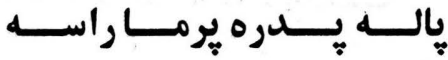

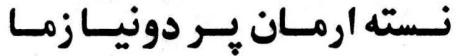

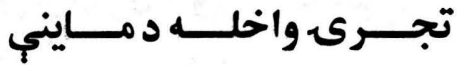

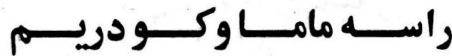

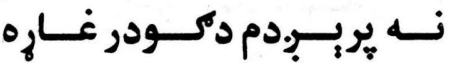

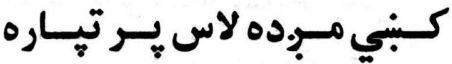
زرى نـــه غـــوارم خلــه راكــــ

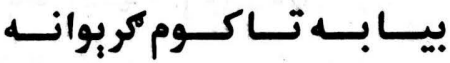
قرآن مه دى كه مه كران هير كئ

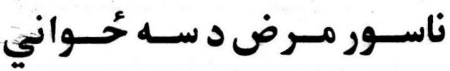

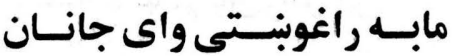

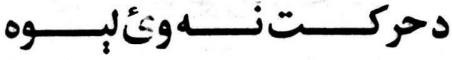

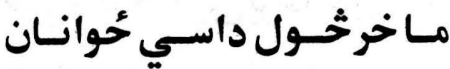

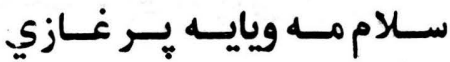
ســام دويــيـي يــــــالبـي

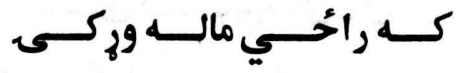

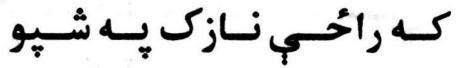

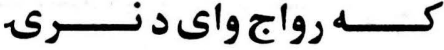
كه زه همه هوم خحه به وسوي

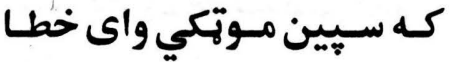

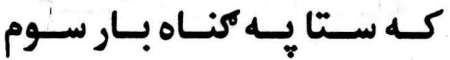

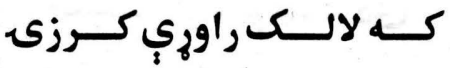

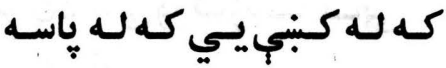

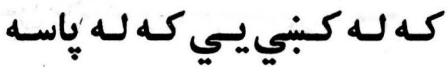
كه لـ كبنبي كي كه لـ ياسيه

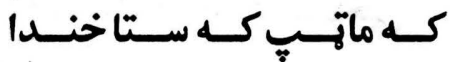

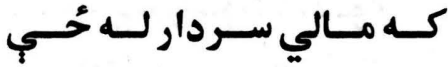

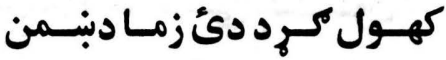
كـه مــه باسـي سـتركي دواره

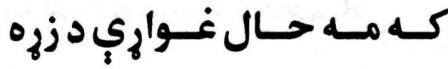
كه مـه سـتاكـوتكي ييـداكس

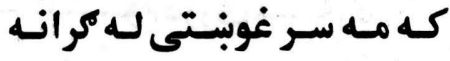
كه مه غوته ير ميان يري كمئ

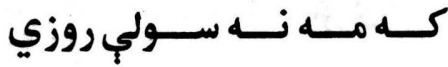

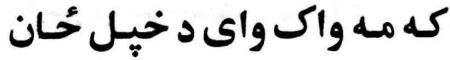

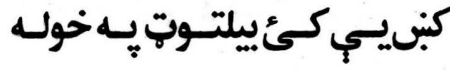

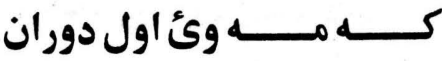

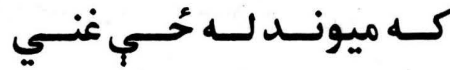

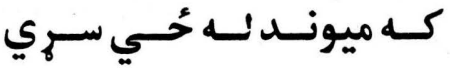




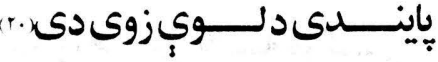

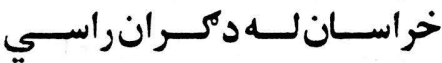

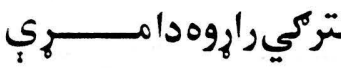

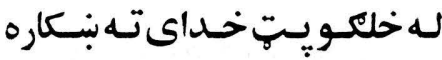

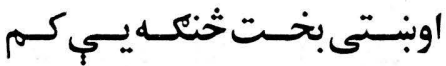

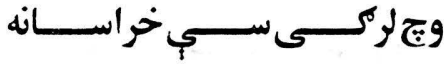

اوس اختيـــار لبونـــــــــــــادى

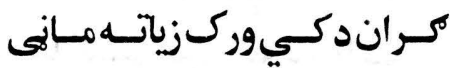

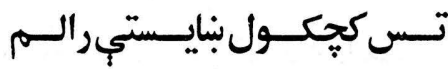

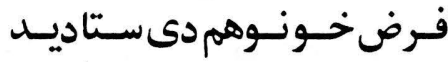

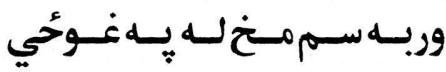

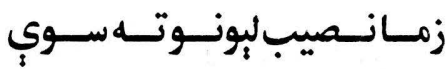

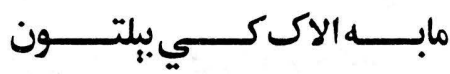

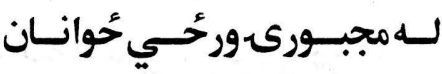

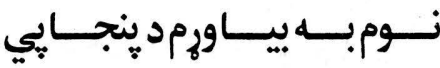

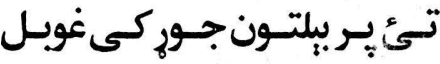

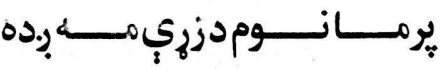

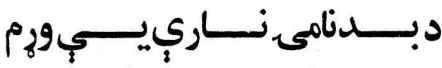

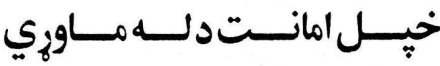

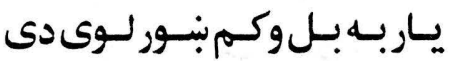

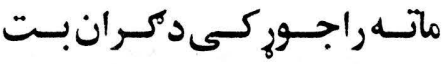

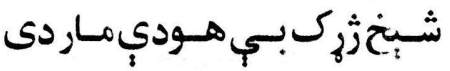
نسرى حسال بـهـ دخـوكسراوري

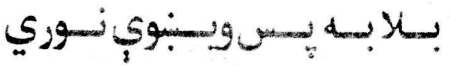

كسه هلـكـدىزرهيسي لـوى

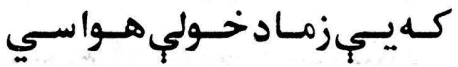

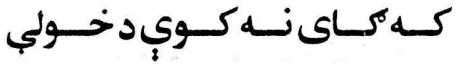

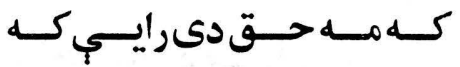

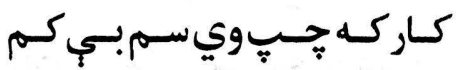

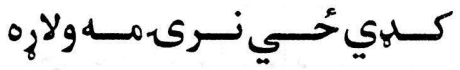

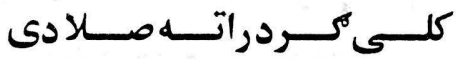

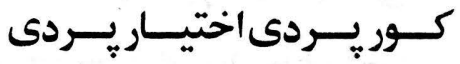

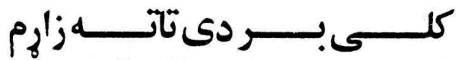

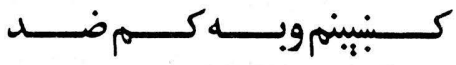

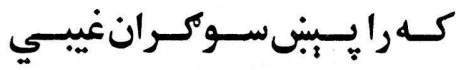
كلى لوى ووئخسوبن مه ته سوي

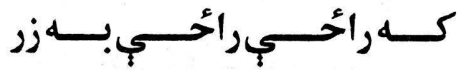

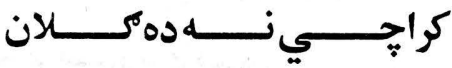

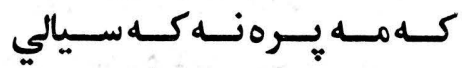

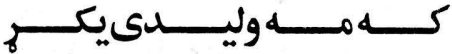

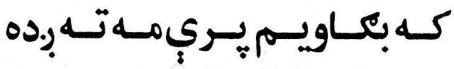

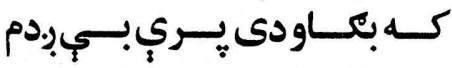

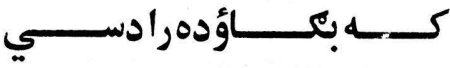

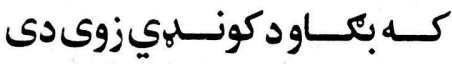

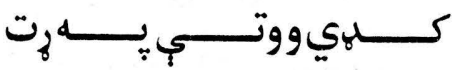
كي خوري سختيبيريوهاردى

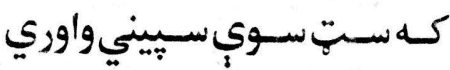

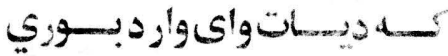


خونـــــوي زونـد د كوجيـانو

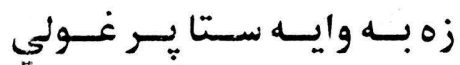

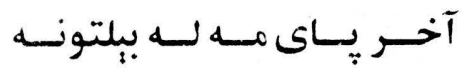
آخــر ديسـدن لـهـ بــه ســي را د لاس كـرى دوكـي كـــران را

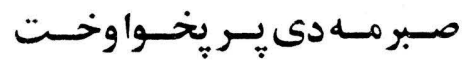

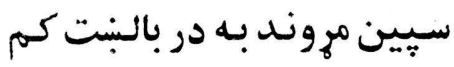

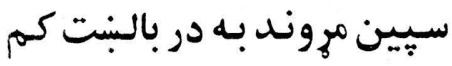

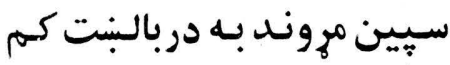

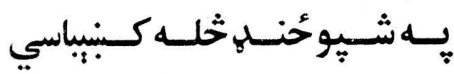

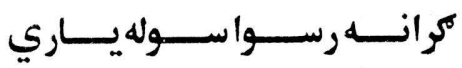

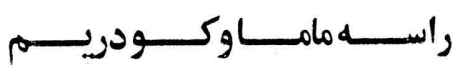

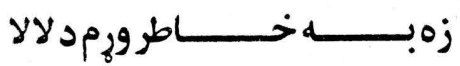

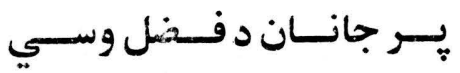

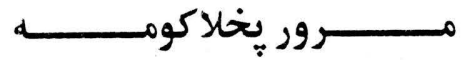

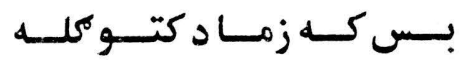

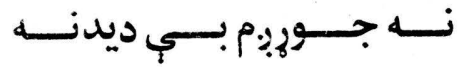

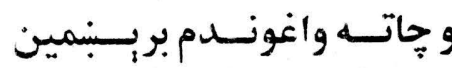

كـــه نـسـبـ سـي د خوار انسـو

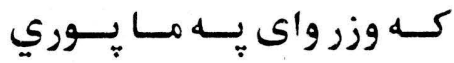

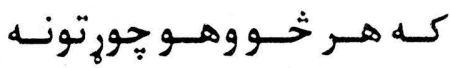

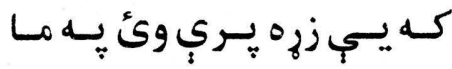

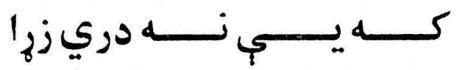

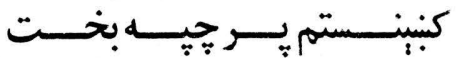

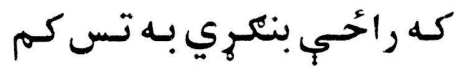

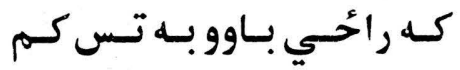
كه راحِي تلتك بـ كوبنت كم

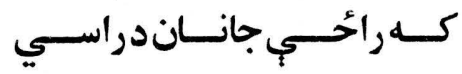

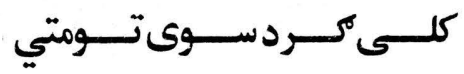

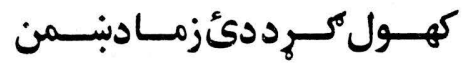

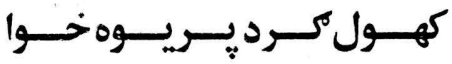

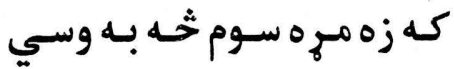

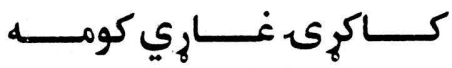

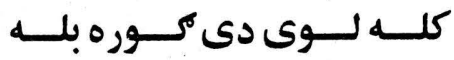

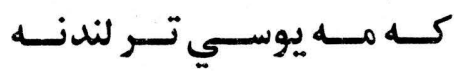
كلـــى بــــر دى نـــته ســـين 


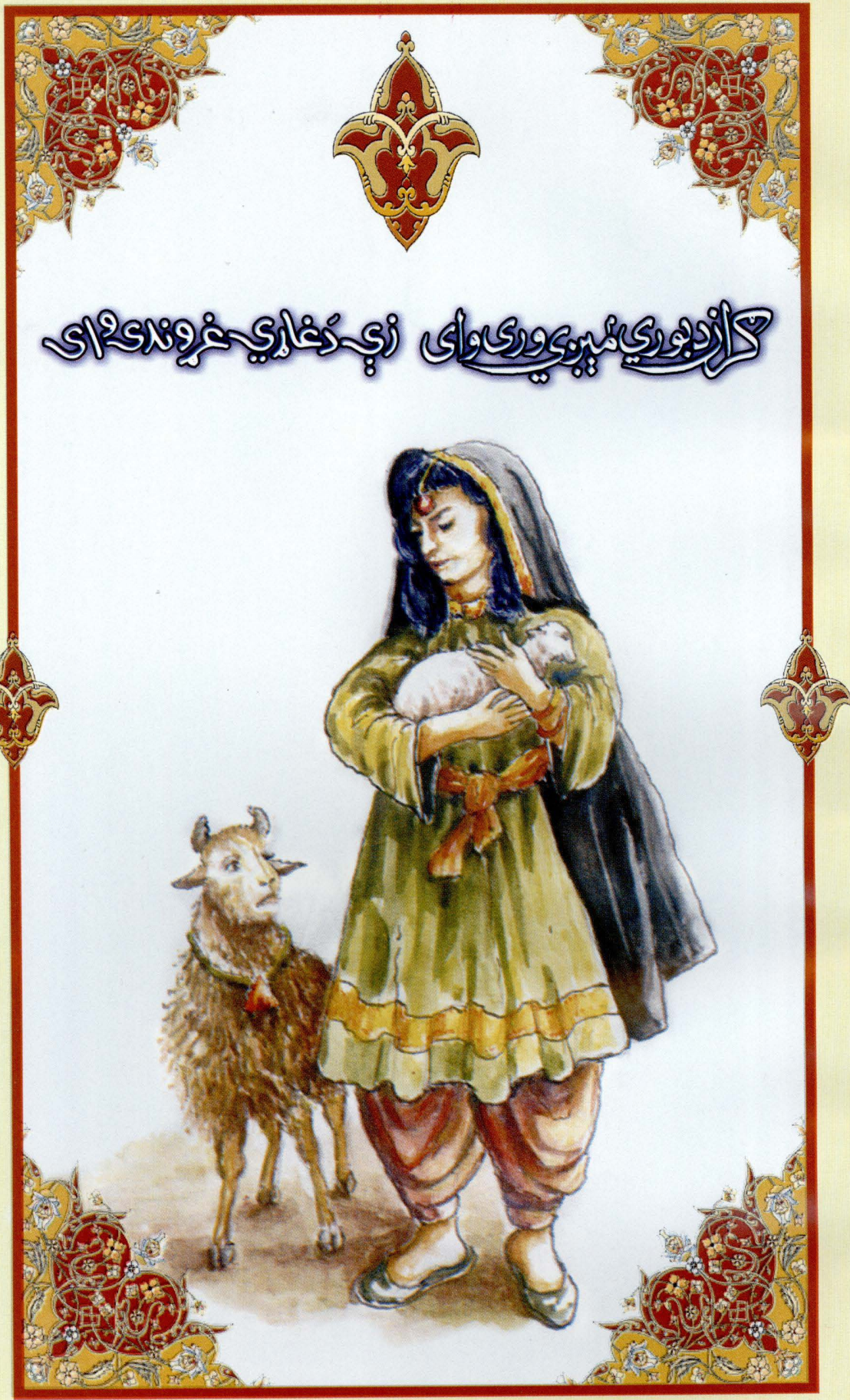




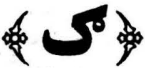

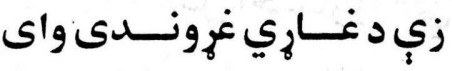
ستا بـكى بـه خولـ نوند دى

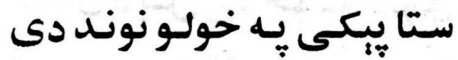

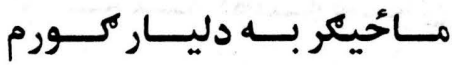
اوس مـــه ريبـــاره ادي ســـوه

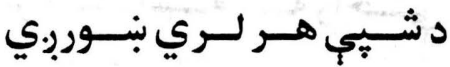

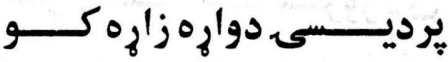

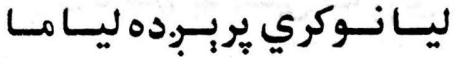

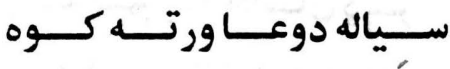

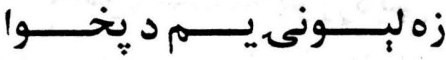

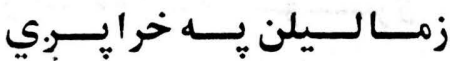

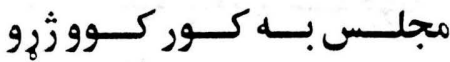

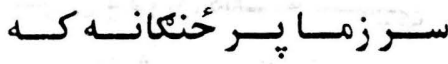

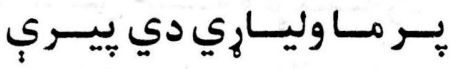
اوس مــه رالــه ترخولـه وينـــ

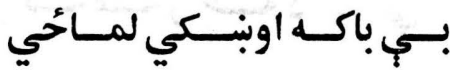

كر ان د بوري مبري ورى واى كودى مل وره كودى دروند دى كودى كنبر.ده كودى دروند دى

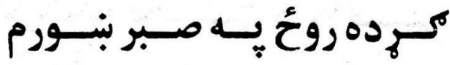

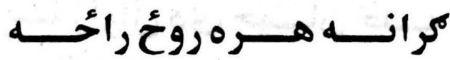

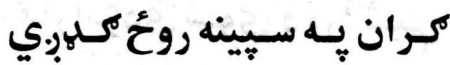

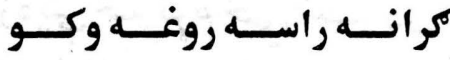

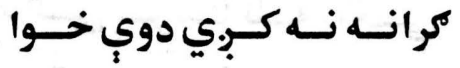

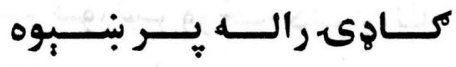

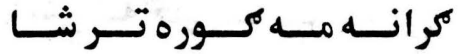

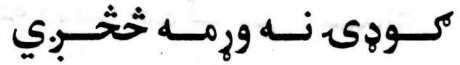

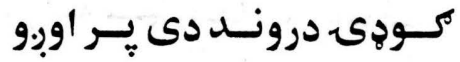

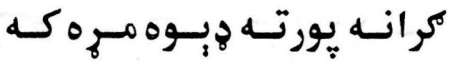

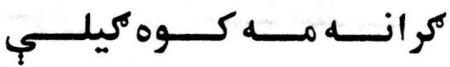

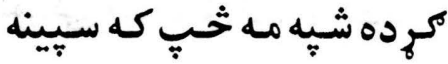

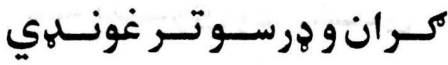




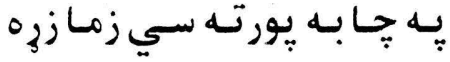
سـهاريسي نـوم نسه زده كيـده كرولكسـيديدي

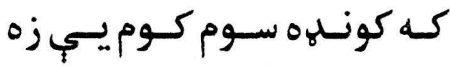

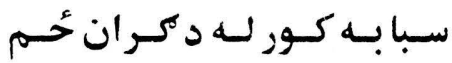

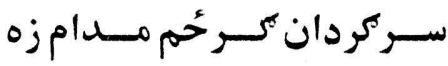

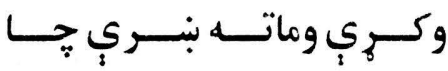

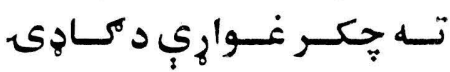

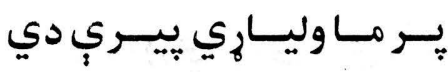

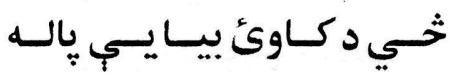

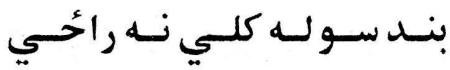

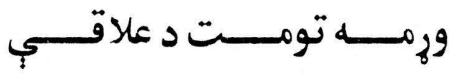

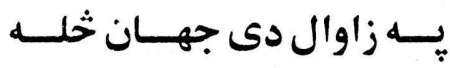

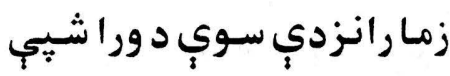
زه يبي خـه كرم خخي اختر دى

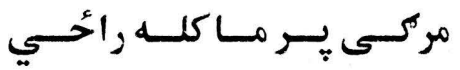

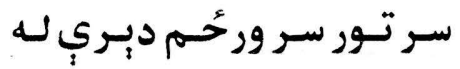
داسي نـه ثخـي مسه وبرتـهـيـي يـه دونيـا خـوك سي رسيباى

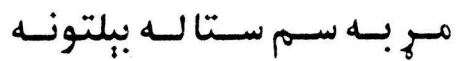

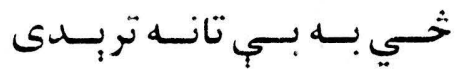

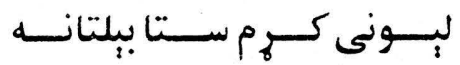
مــوركى تسر كسل تـازه سـاته

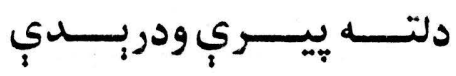

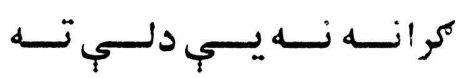

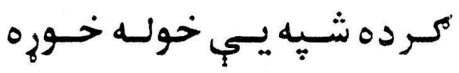

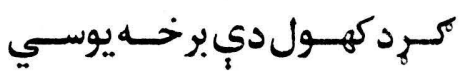

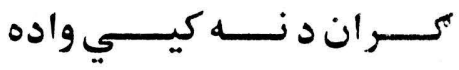

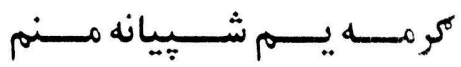

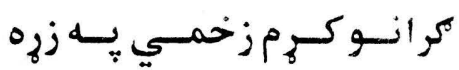

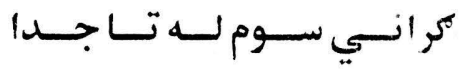

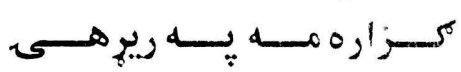

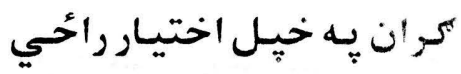

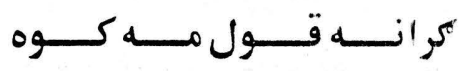

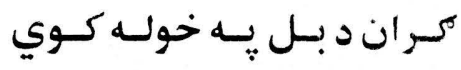

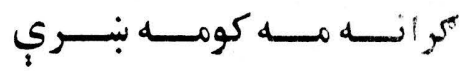

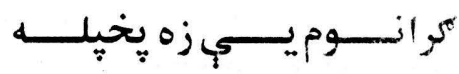

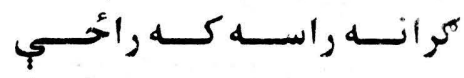

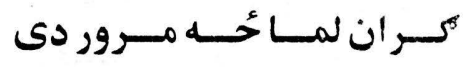

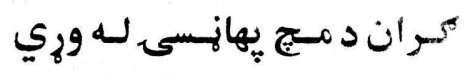

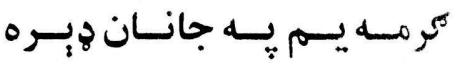

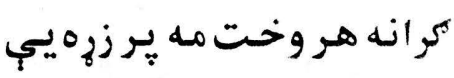

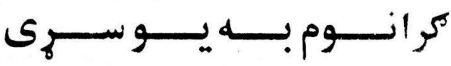

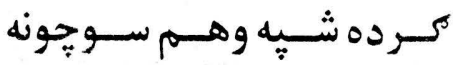

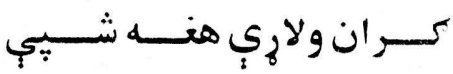

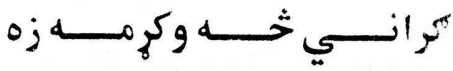

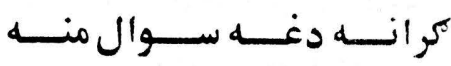

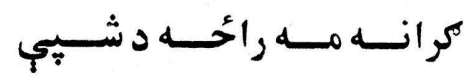


وخت د يسسات دى كـنبيوزي

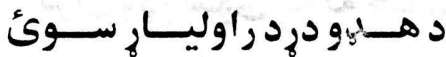

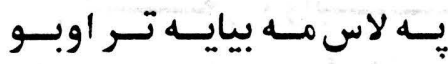
دا دمسـور وود بــلكار حــق دى

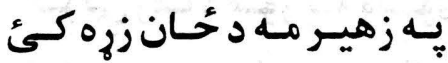

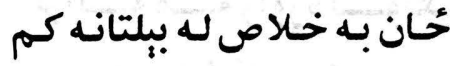
مينــه محبـت بـــهـ سـو رسـوا

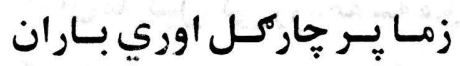
د دوى يـــه ضـل بــهـه وراتلـــي

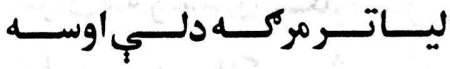

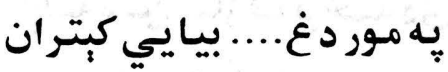

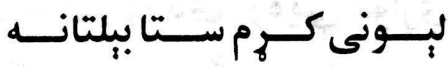

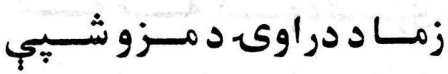

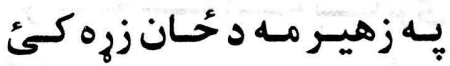
سـورى سـور اور دى رابـــزي بادي شُنب سوكي دي مـاخى سـتاد راوى نـه ده زمهـاء هيـره

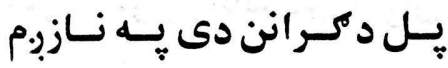

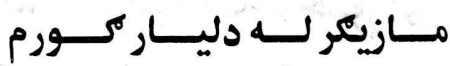

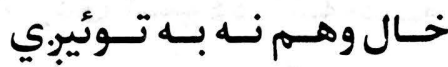
نيـت بـي بـد يــر يـبنتانه وي زماله شيسانيسي هحان خلاص هـرهـي خونـده سوهيـاري بر.بـاده سـوه زمهور.زنسكي

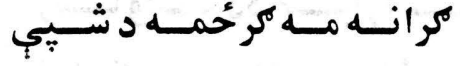

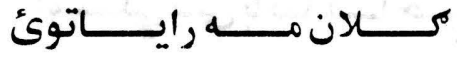
كر انـــه اى ملـــــ دى د غلـــو كوذى كنبر.ده كودى هو كر ان د بل سو خيل مه نه كئ كـران د راسـي ور بسه زوهـ كـم

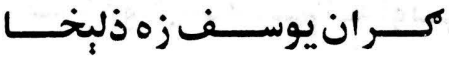

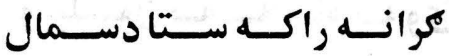

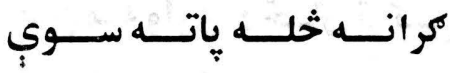

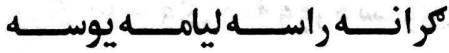

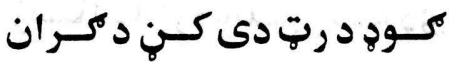

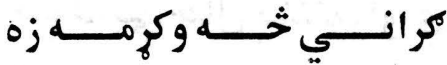

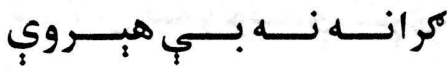
كر ان د بل سوى خيل مه نكى كر ان بـه نمر دى زه يـه سوري

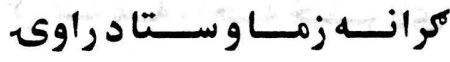

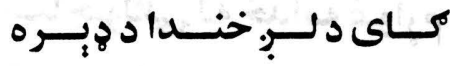

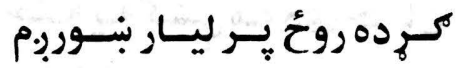

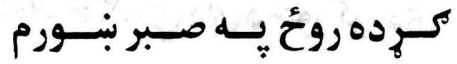
كوتكي نه ورجمكوتكي لوربي كر ان به وي نصيب بـي نه وي كر انخي تلى يورتهيب لاس كئ

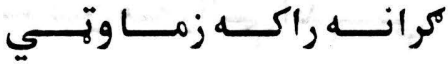

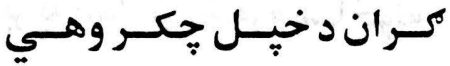




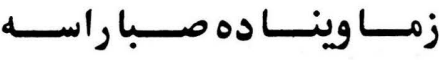

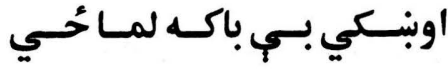

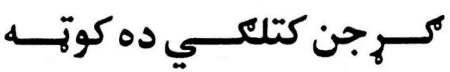

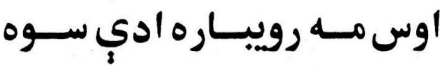

نجونـه نـوري يـهـ واده سـوي

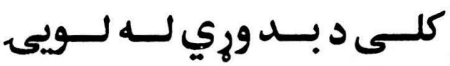

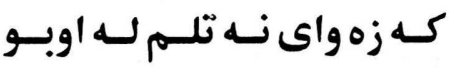

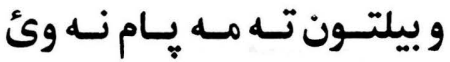

نـن مــه وارى د حُحسان تركسى

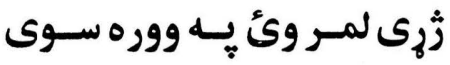

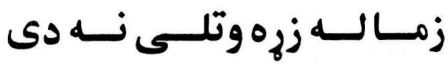

خ خـوك بـ حسال يـبنتنو راوري

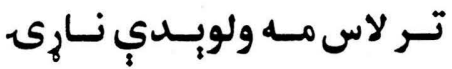

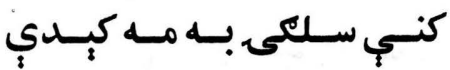

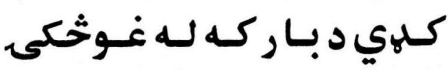

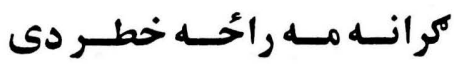

ستاخـوكتى له خدايسه غـوارم

حُكسه يـه كـبني مـه دى جانـان

زماتر خنكس دي دى خدور كور دى

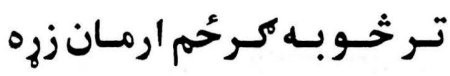

يسه سـره كنجنبن مـه سـو رايـات

مركى د سـيور كسه يـر غوايسه

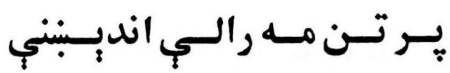

هُبر به تلوار ببي خورم ستاخوله

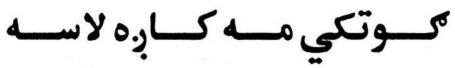

كر ان وهر سوى يه لله خنكلي

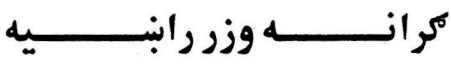

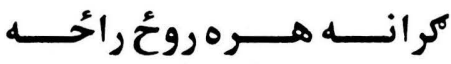

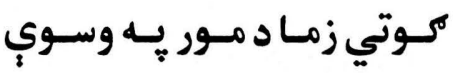

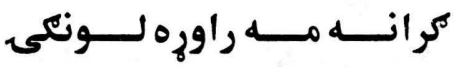
كــران وليــار كـى بنـــو مــرو كران مل كبل كى زيره مه بنه وئ

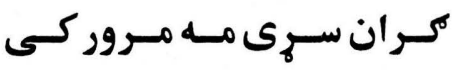

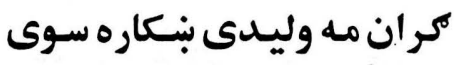

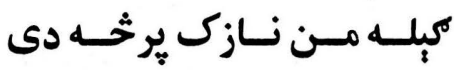

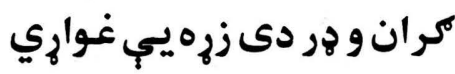

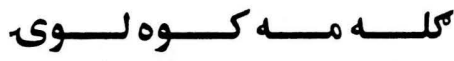

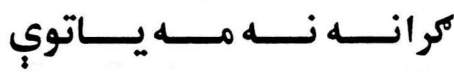

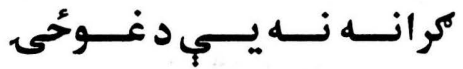
كـرد كهــول يـــه راخبــر دى

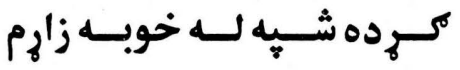

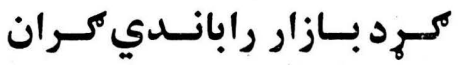

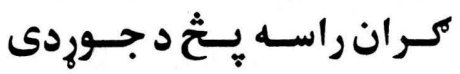
كـونى كــنبر.ده راكــه خولـه

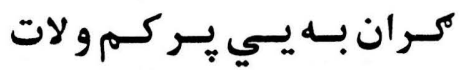

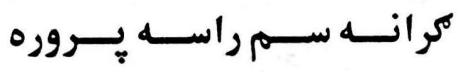

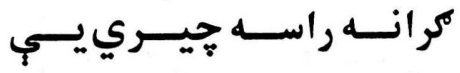

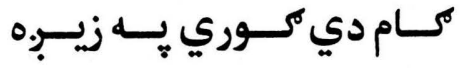




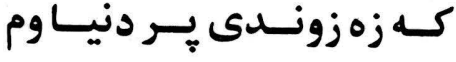

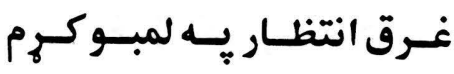

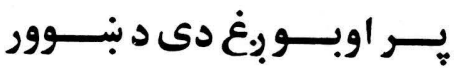

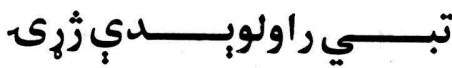

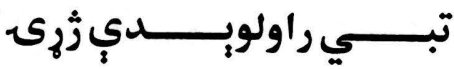

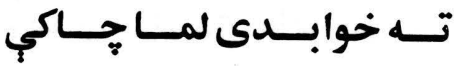

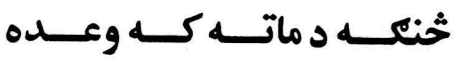

باندي شني سوكي دي ماخى

نجـوني نـوري بــه واده سـوي

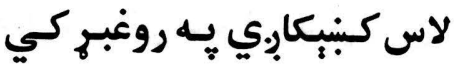

بختــــور د اســـمان ســتوري

سـيـين سـهار ليـا بـه مـاني وئ

خلك الم وياى د دي يـار دى

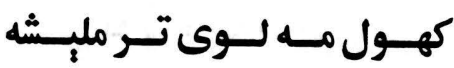

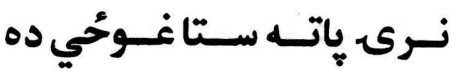

ستا بـكى بـاه خولو نوند دى

ديـلـ دكــران وي لمــاتوسـي

يـو اختــر بـهـ يـر مـادوه سـي

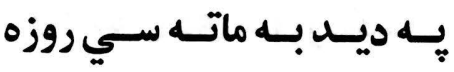

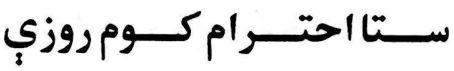

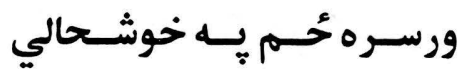

كـه زمـا نسصبـ راكـه دهوكـه

بلتَـون د دوبر زيـات سـوكرانو

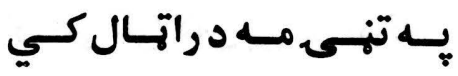

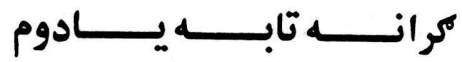

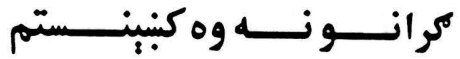

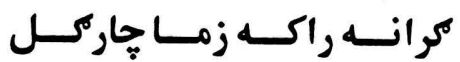

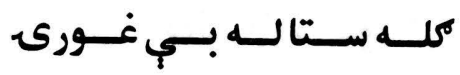

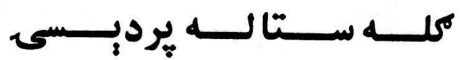

كرانـه راسـه حـال بـه راكـي

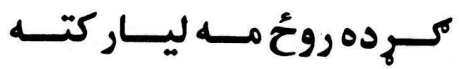

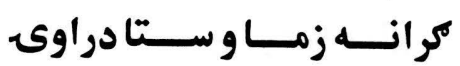

كـوتي زمـاد مــور بـهـ وسـوي

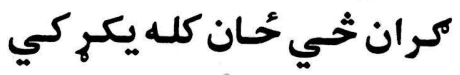

مـرده شـيه كــان ورتهـهـوري

كر ده شيه مه بروت يرتي وئ

كران د راسي زمـا يـه كار دى

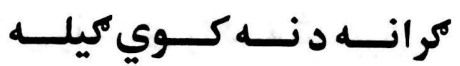

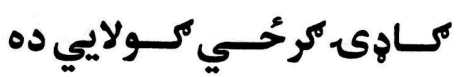

كودى مه وره كوهى ذوروند دى

كرده روعُ مـه لمـر بـر سـر سي

كرانبه راسي وخت به يره سي

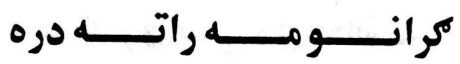

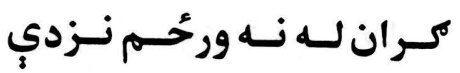

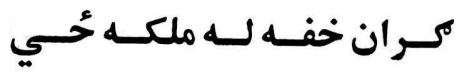

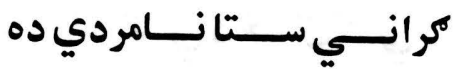

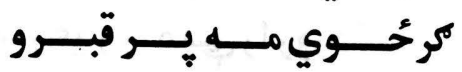

كر ان كه حُي ما د دسمال كي 
نــــى د غـــرو د ســروكــل

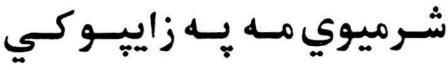

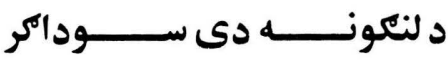

نــــه دى د كونـــهو ســـوداكر

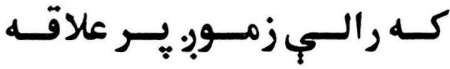

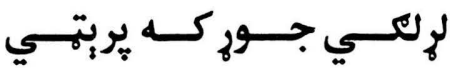

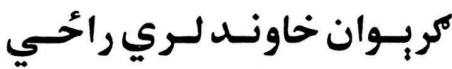

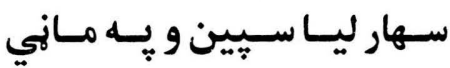

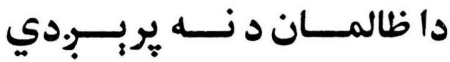

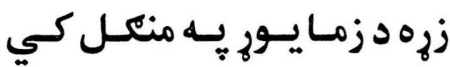

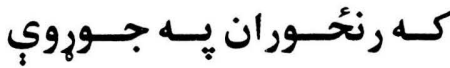

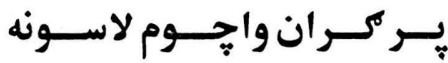

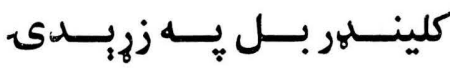

لاس ونــدى راكـــه شـــيرني

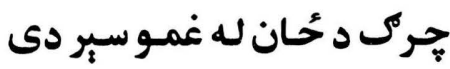

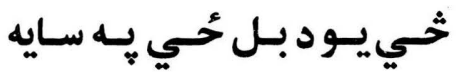

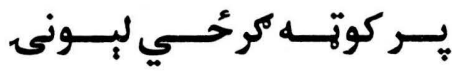

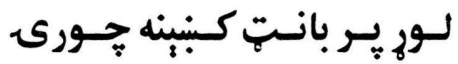

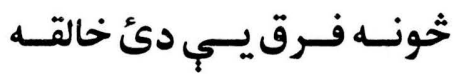

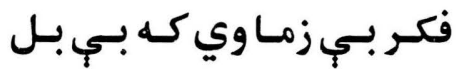

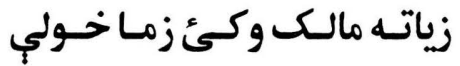

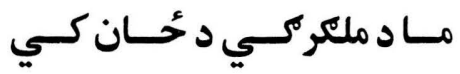

زمـازهيـر زره يـي را روبد كئ

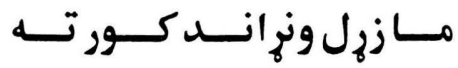

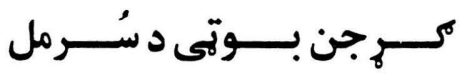

كر ان د خيل خروري بوه

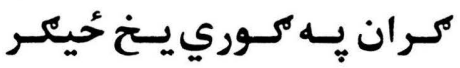

كـران بـه كــوري رون حُيكـر

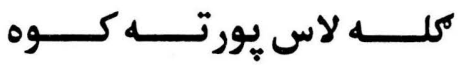

كريـوان تنكك دى تابه خـوري

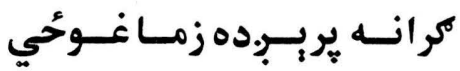

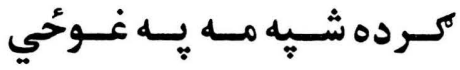

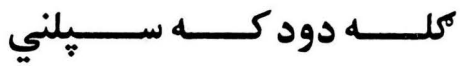

كـل ديـبنى يــه اور بـلـل كـي

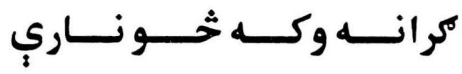

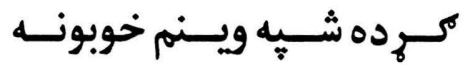

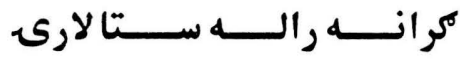

كوتكي نه ورم خلكسي ويني كر انه كبنينه وخت ليا دوبر دى

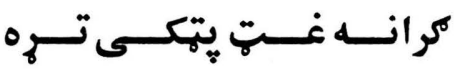

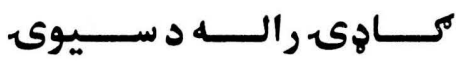

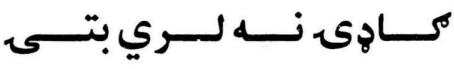
كران آسمان دئ بنـوور مئكـه

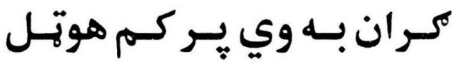

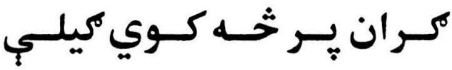
كر ان خـي بـل وطن لـ كُحي كران خي تلى مخيهي را اورودكئ كران خي تلى لاسيب كئ يورته 


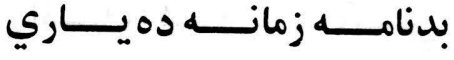
خلك الم وياى د دي يـار دى هاكتر وياى جور به سيتروري قــرآن كـهـ بـل راوري لاسـونه

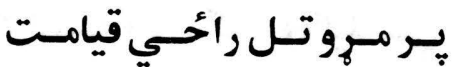

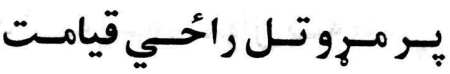
مـاكه خندل هوبر دي حُوانان

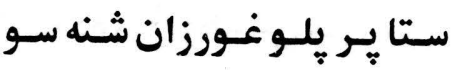

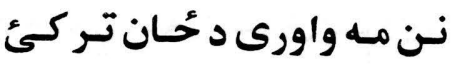

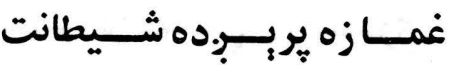
يـهـ لارى مسهـ دراتـال كـي

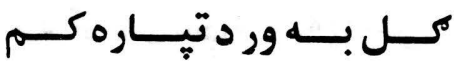
زميي لياد سر كوم باسخواست بيا به د لاس نه وي راخداص

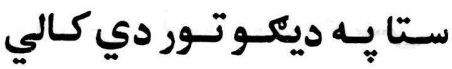

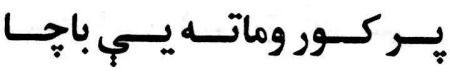

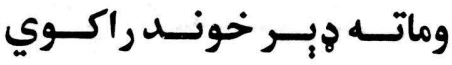
نـوى كريــوان د كسئر رايـري

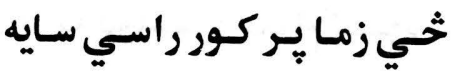
زما خنكلـى بـه در بالبنبت كمر

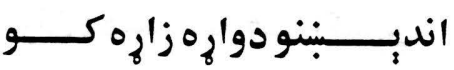

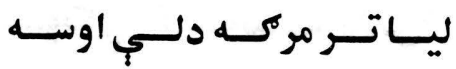

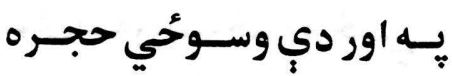

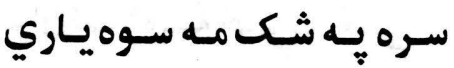

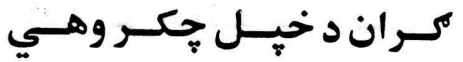
كران د راسي زما يـ كار دى كـران دمـرك سـكلى وهـي

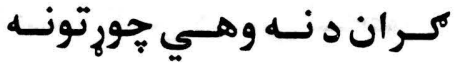

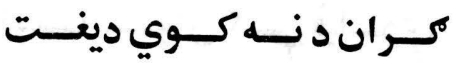

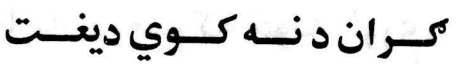
كـران دواخلـي خيـل شـيــان

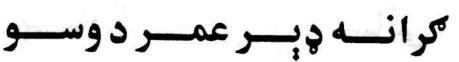
كـران سـرى مــه مـرور كسئ كران قبـول كرى زماوسيت كران كه حُي ما د دسمال كي كي كران كه رالئئزره بـه بنه كمي

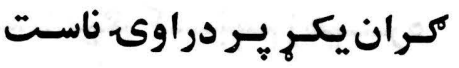

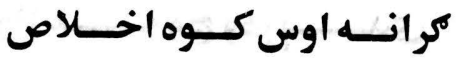

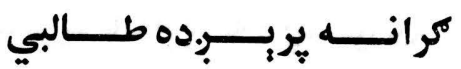

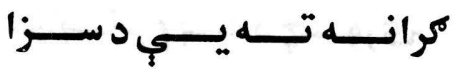

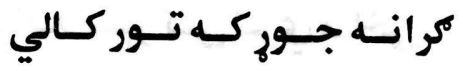

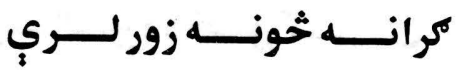

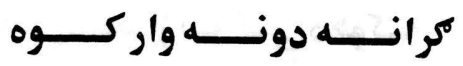

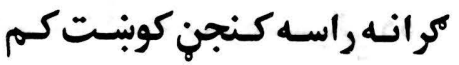

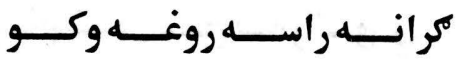

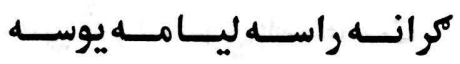

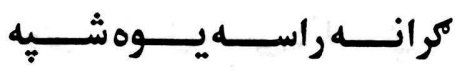

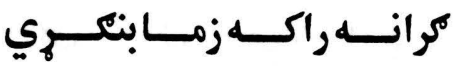


زياتـه بـي خونـد سـوهيـاري غبركسي تنهـ دوكسي رايــري

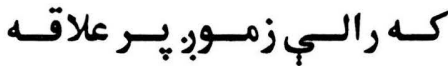

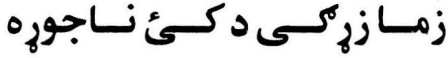
كومـــه ســـوال كـــي قبلـــوي مابنـام درحمم كه خوله راوري

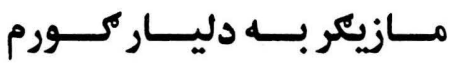

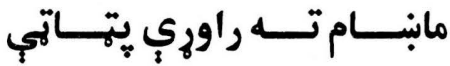

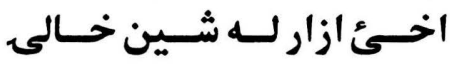

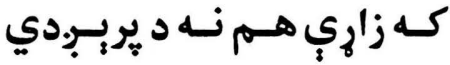
يــايسـو وزمــاد زه خابنـهـ دى

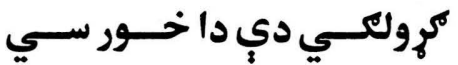

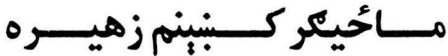

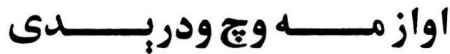

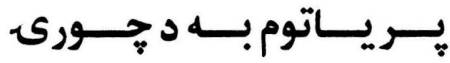

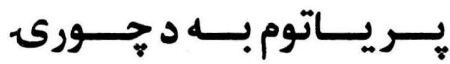

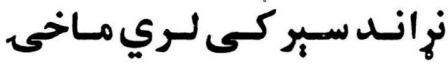
ترمــالــوردودخـــوركـــوردى

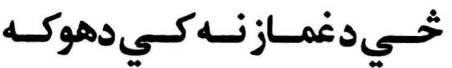

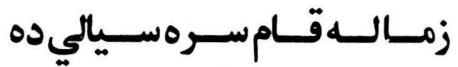

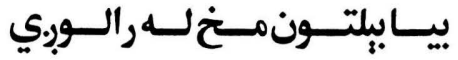
لمايسب خـوك كوي باسخواست

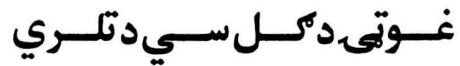

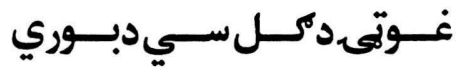

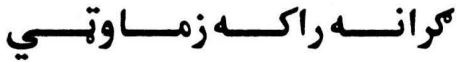

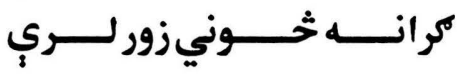

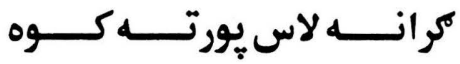

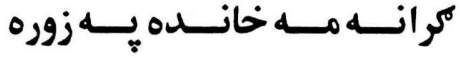

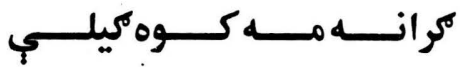

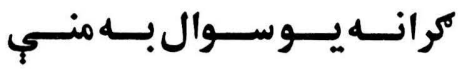

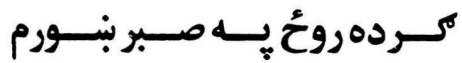

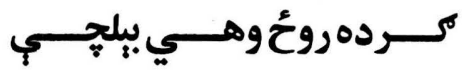

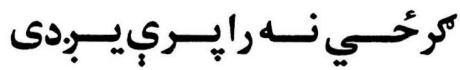

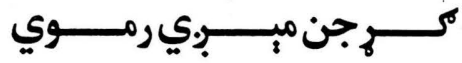

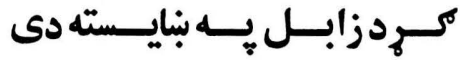
كـــد كهــول دي برخــــيوسـي

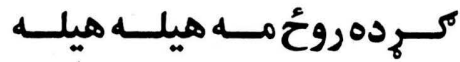

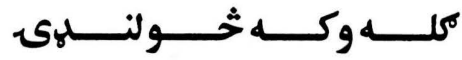
كــوتكي راكـــهـ ســور غمــى

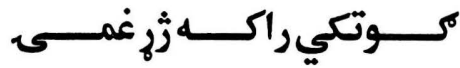

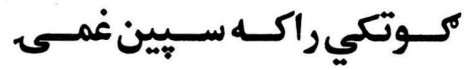

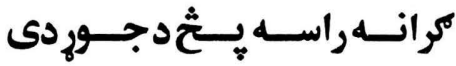

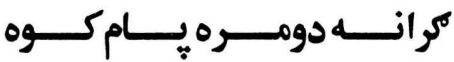

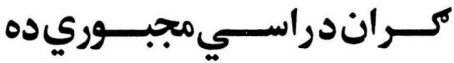

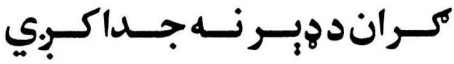

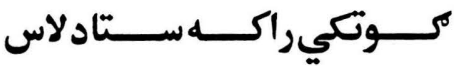

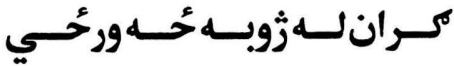

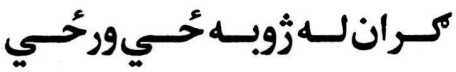




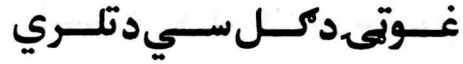

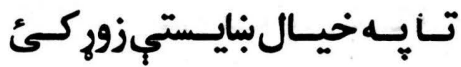

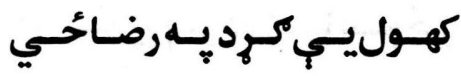

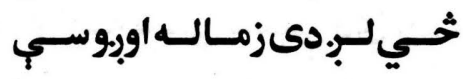

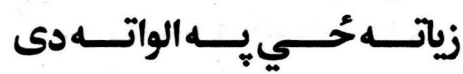

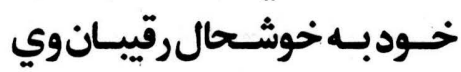

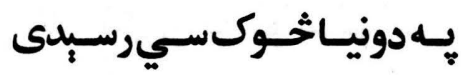

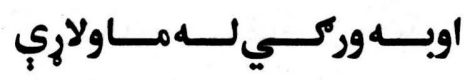

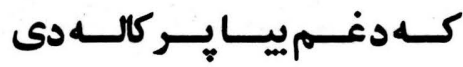

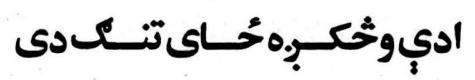

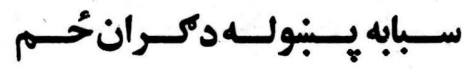

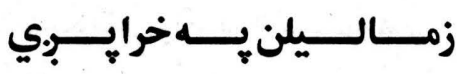

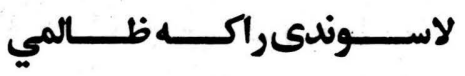

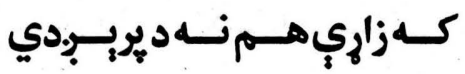

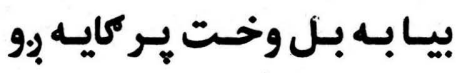

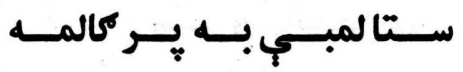

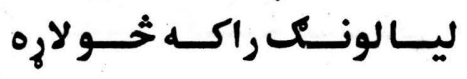

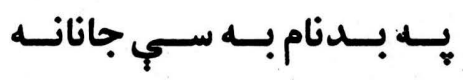

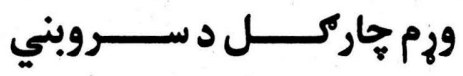
وزم جاركــل زمسـاد شـــريني وهنم خـال خحـي نـهـــاره بري باجسـه د خــان خونــــــاكــوي

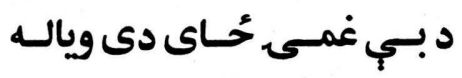

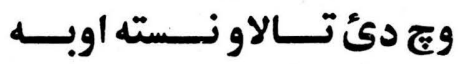

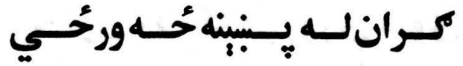

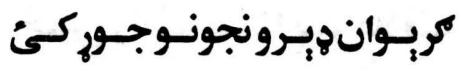

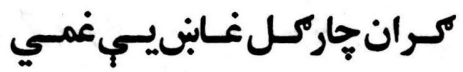
كر انه سمبيجيه خونديوهدسي

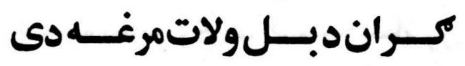

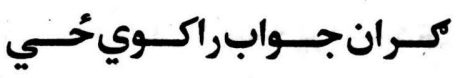

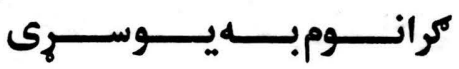

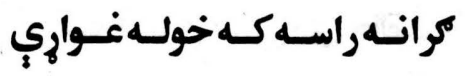

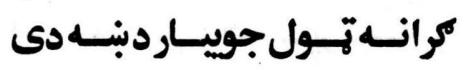

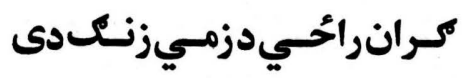

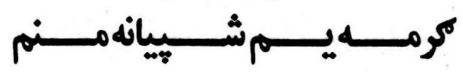

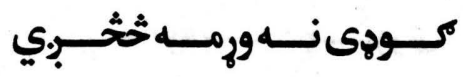

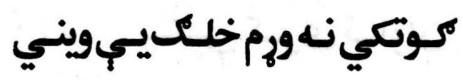

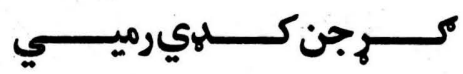

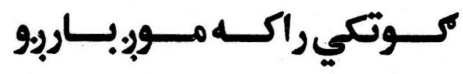

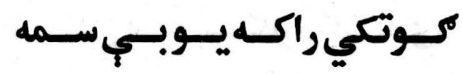

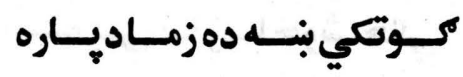

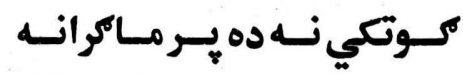
كوتكي نه ورم خلكسيب وويني كوتكي نه ورمخلكسيسيني كـوتكي نـه ورمكـوتكي لـوري

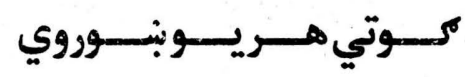

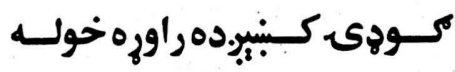

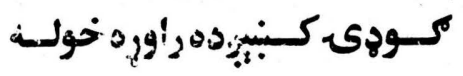


يه لوى رب كه مه روزي سوي

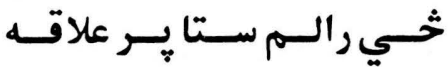

كريسـوان خاونسد لـري راحسي

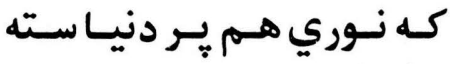

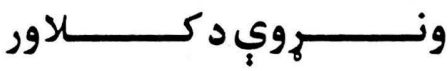

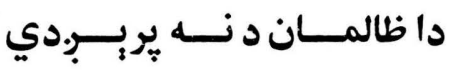

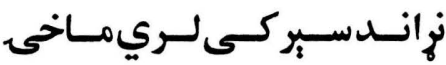

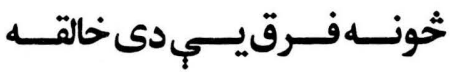

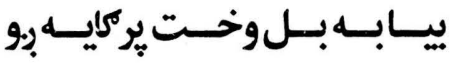

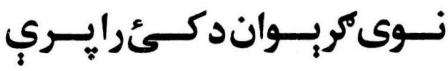

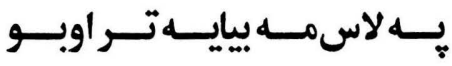

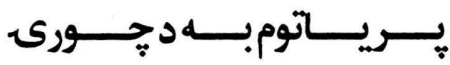

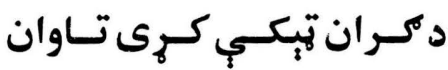

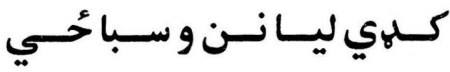

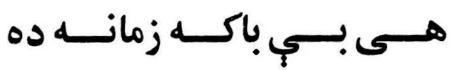

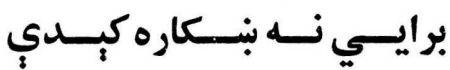

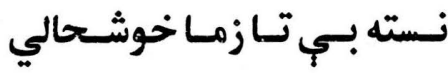

كلــــه ولاريخ بــــازاري ســـوي

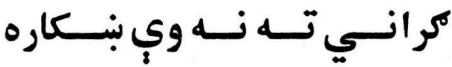

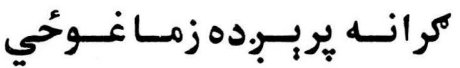

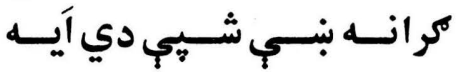

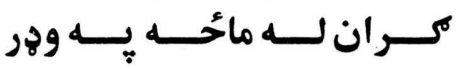

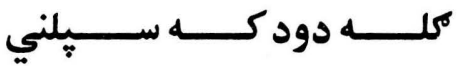

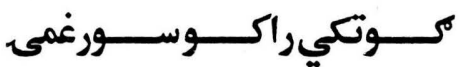

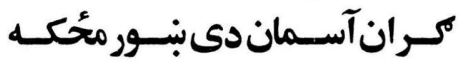

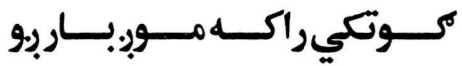

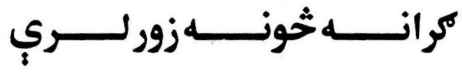

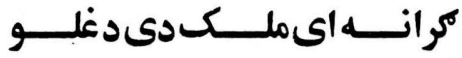

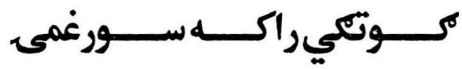

كــوهى كــبـبردى وكسئ كـار

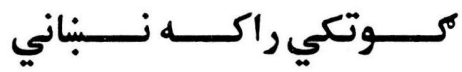

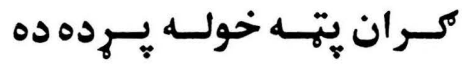

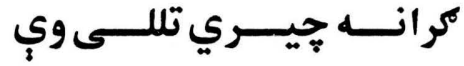

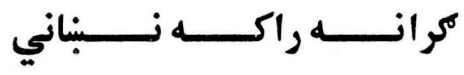

谈燐 


\section{拉}

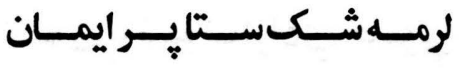

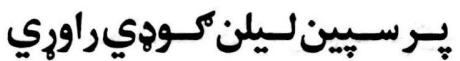

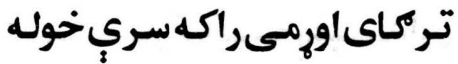

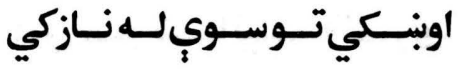

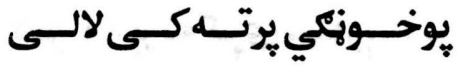

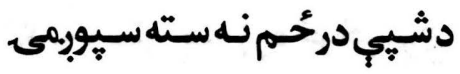

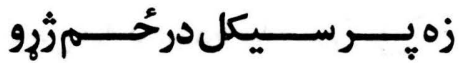

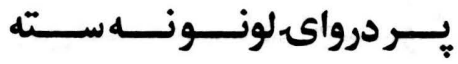

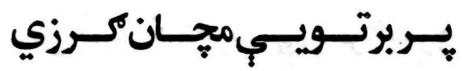

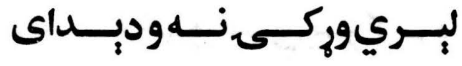

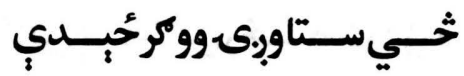

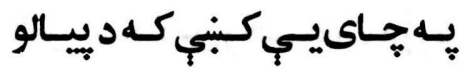

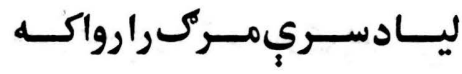

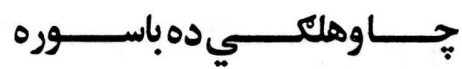
بـه بـبنوبـي خرخي سي نارىى

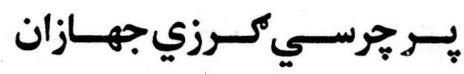

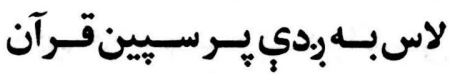

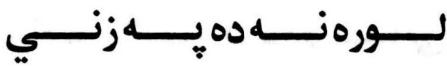

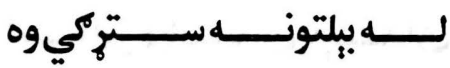
لاسيـيراكئسـتركي

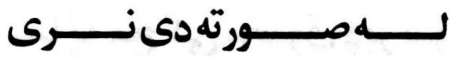

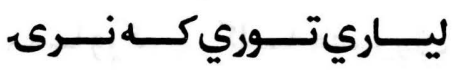

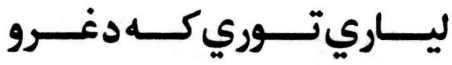
لمـرخيـه دى سـيوريمى نـهـ سـته

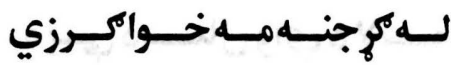

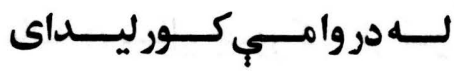

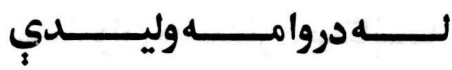

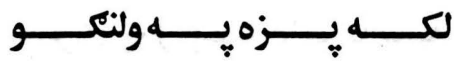

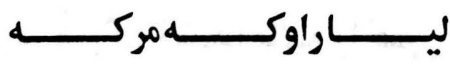

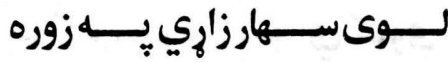

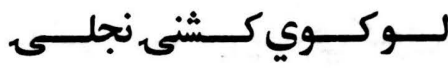

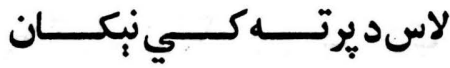




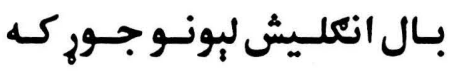
يـردى ليـامـه نـازك تيـر سـو كودى هـ كي ميدان واخلي ظـالمي غـرك د دكرل حُوانـان

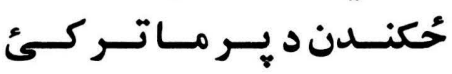

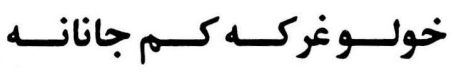

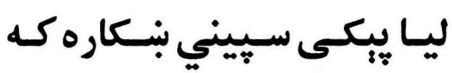

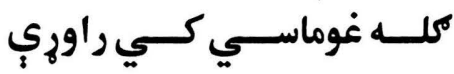

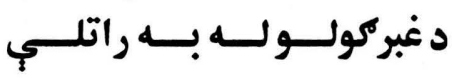

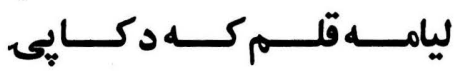

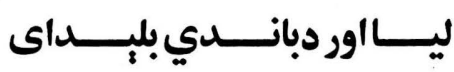

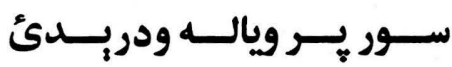

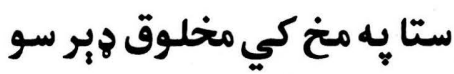

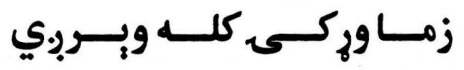

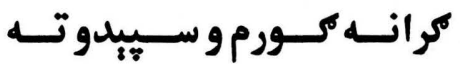

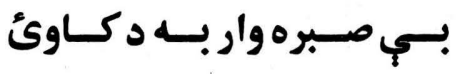
زه يـــي دسـمال واى د لاسـو

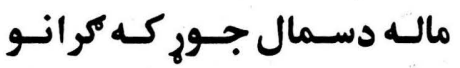

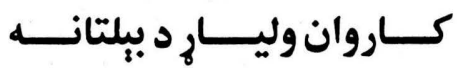

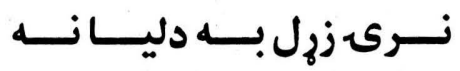

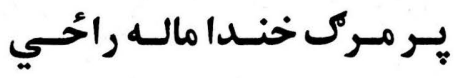

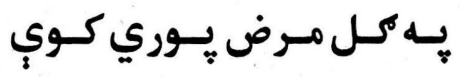
بـهـ كـران مــرض يــوري كـوي

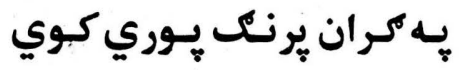

لــه اودنكــه خلاصـهـ مــوركــ لمونحُ مه وكى خواست مه هير سو

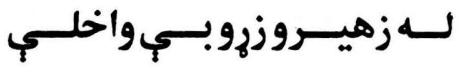

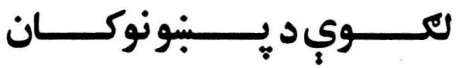

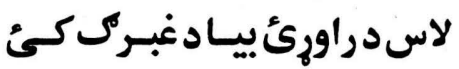

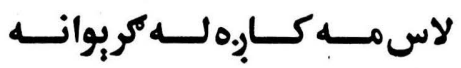

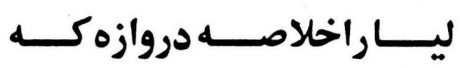

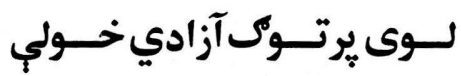

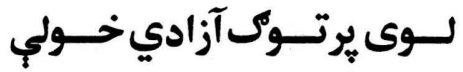

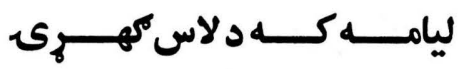

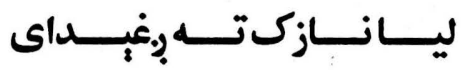

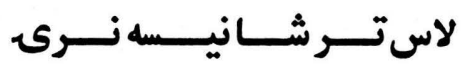
لاس مـه يرته كرى ستاوير سو

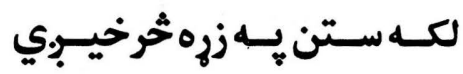

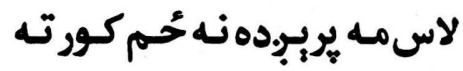

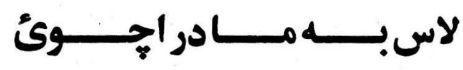

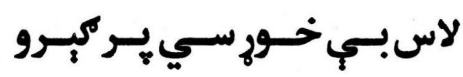

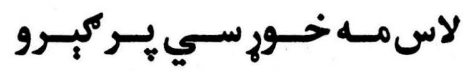

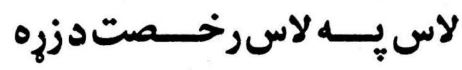

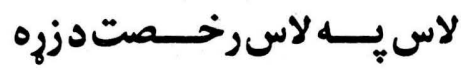

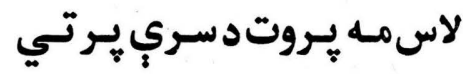

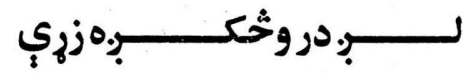

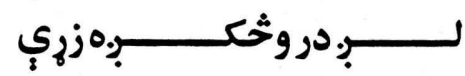

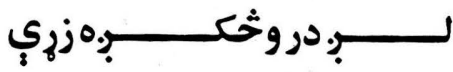


به لاتِيج سري كي دروازي

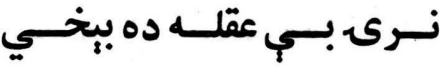
بـر كـور نـاري دي مـاغـواري

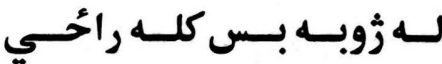

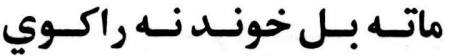
دكــان ســــوكــوي واهـي

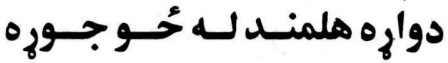

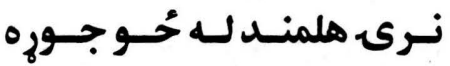
وجــار دي كــرد قريبـان سـي دواده شـــيمي د نـــزدي دئي

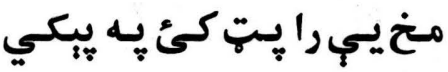

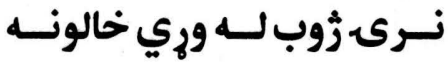
خي تابه زر خلاص كي لونى

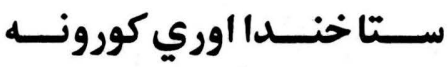

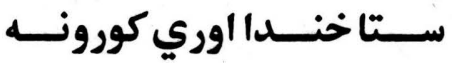

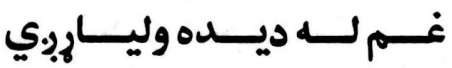

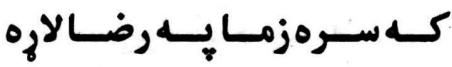

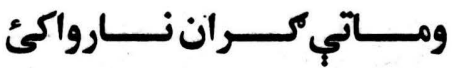
خواره سي غرقدكل حُوانان

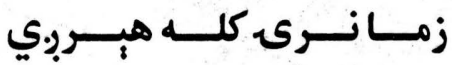

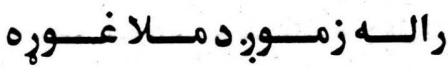

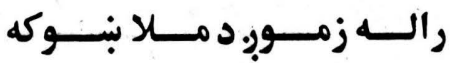

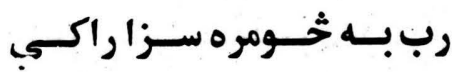

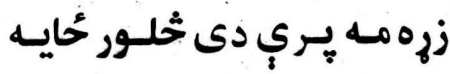

لاسد ســين غرمبــى دشـنـي

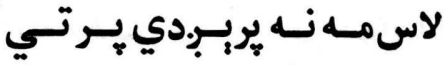

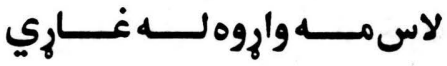

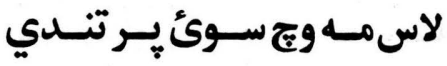

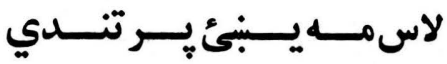
لاسيجي يـروت دى زمايـرتي

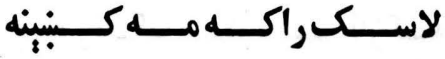

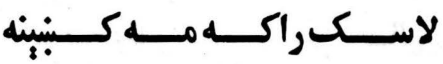

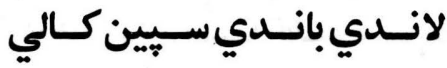

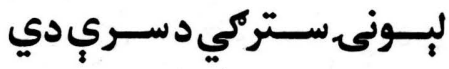

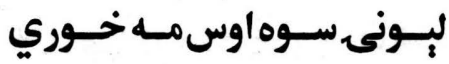

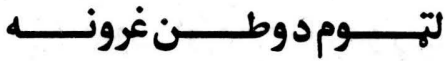

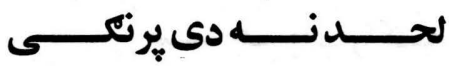

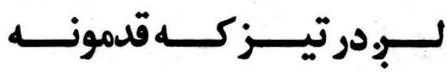

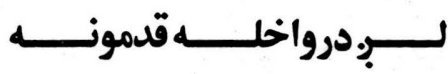

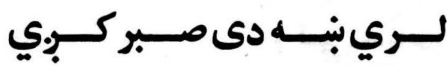
لـوىبـي كـم تـركم خوشـحاله

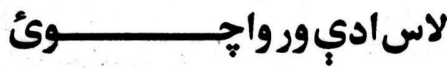

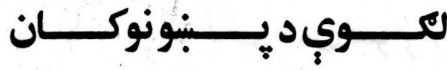

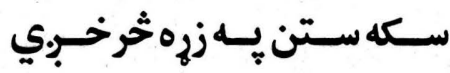

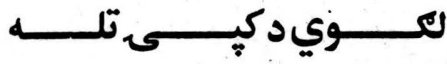

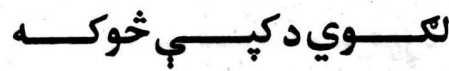
لمـونعُ كـوم سـتركي بــــــــي

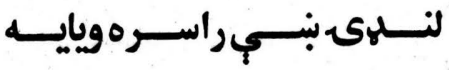


بـل يـهـ زوبكـي د لـوني دئ لـه مجبـورى ورحُــي حُوانـان وسمه ارمان سوه دكران خوله نـى د غـوتِ يـر بنـدو مـات سـهـ

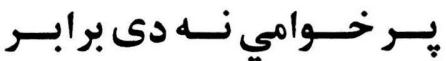

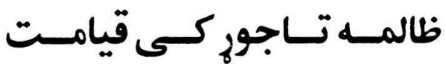

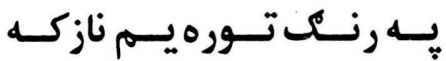
بيـابـه نظـر سي شي شين خـالى بارخوكسان سـتا خلــه ســاره د نــــى ســـتـي لمبــي دي مخ يبي تور سبقيب كران دئ ناري سوي كورمه كيام غواري

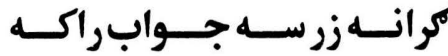
خلك ويايي موتر دئ سركاري حُي نـرى سـتركي كسبنكاربي خـي بنـوور مـر كـم كـي سـاتم

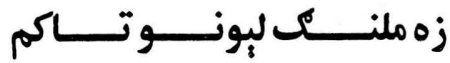

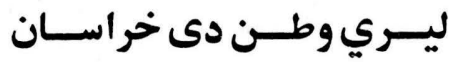
ليا زوندى ظريف خحان غوارم

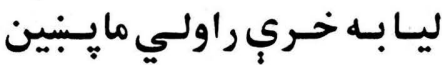

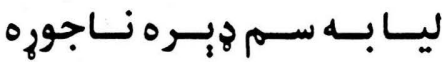

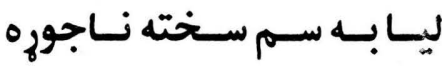

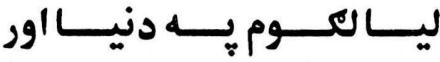

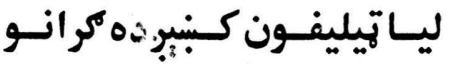

لــوى لنكـــر دميــان سـخي دئ

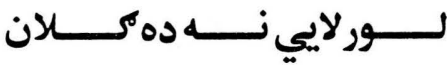

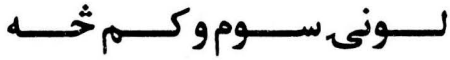

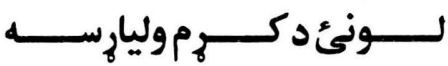

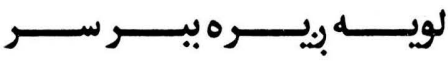

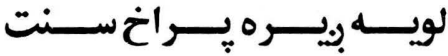

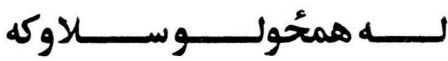

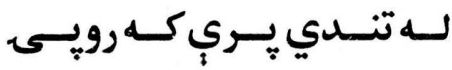

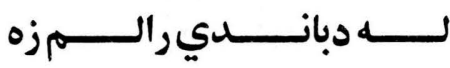

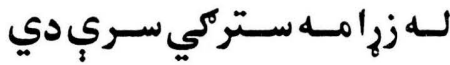

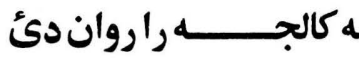
لاسددى كـــهـ زمـالـهـ غــاري

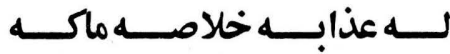

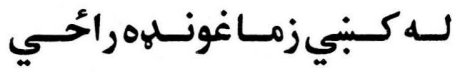

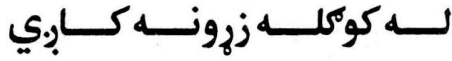

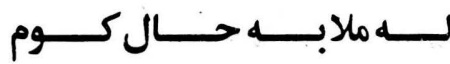

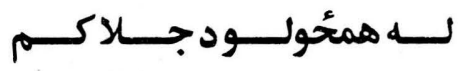

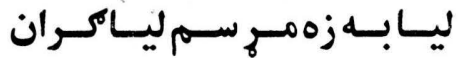

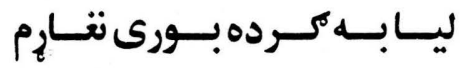

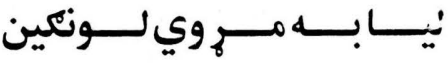
ليـابـه مــره سـم سـتالـه جولـه

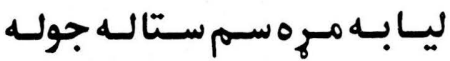

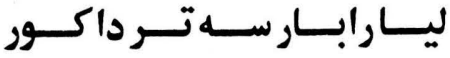

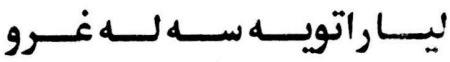




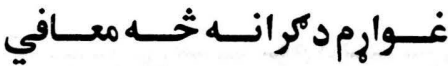

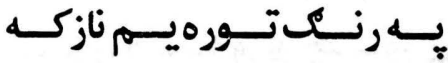

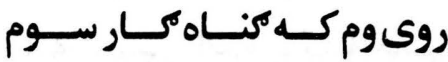

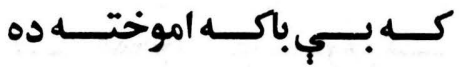

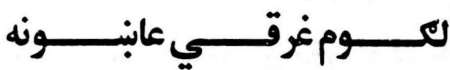

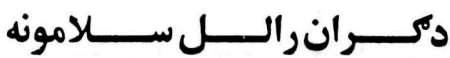

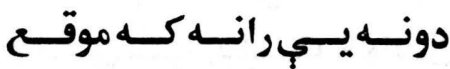
زمابي ديـه دخداى جـور كه

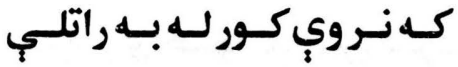

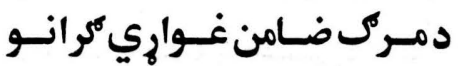

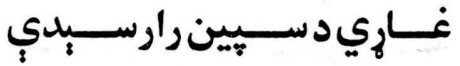

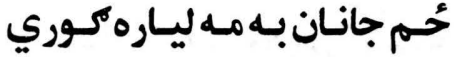
ليـابـه سـور سركي كـوله خـورو

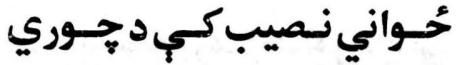

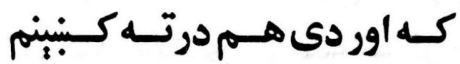

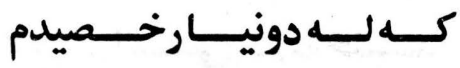

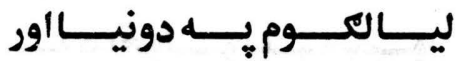

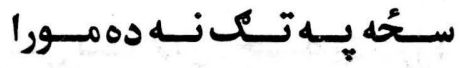

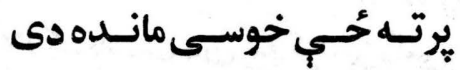

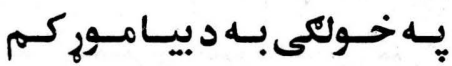

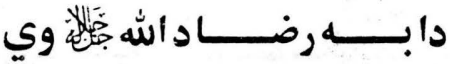

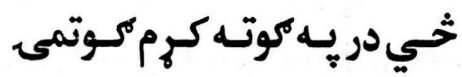

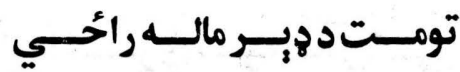

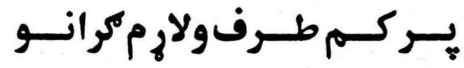

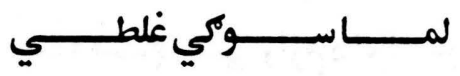

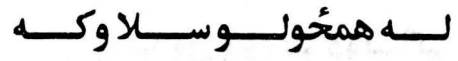

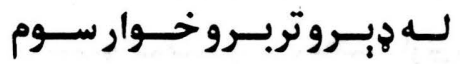

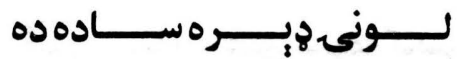

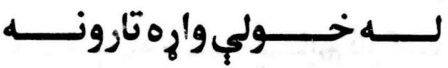

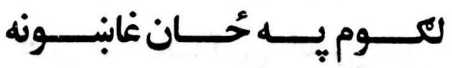

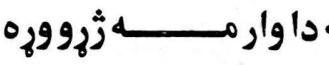
ليــار مـــــــته سـتاوكــور تـــــ

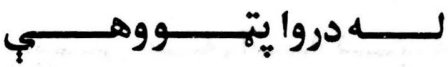

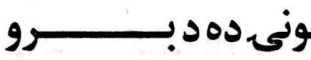

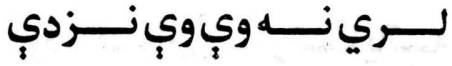
لاسمه سره ستركي مـه تـوري

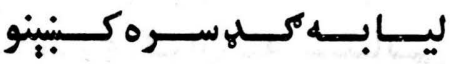

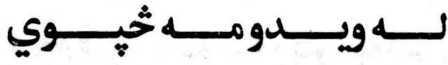

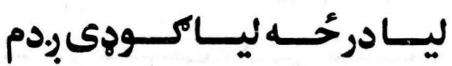

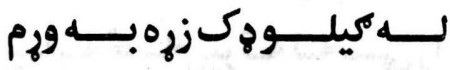

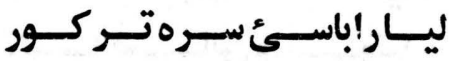

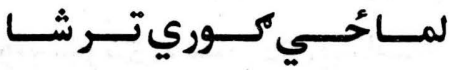

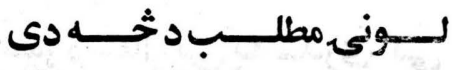

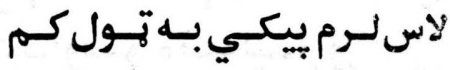

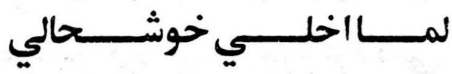

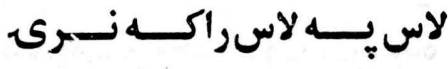

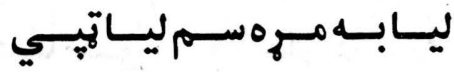

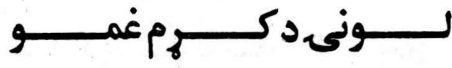




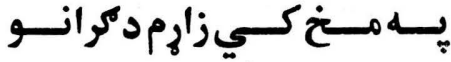

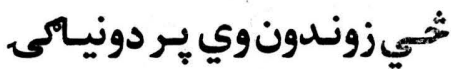

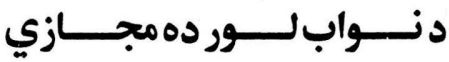

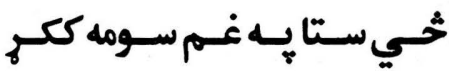

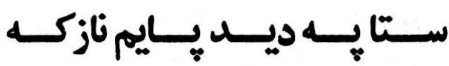

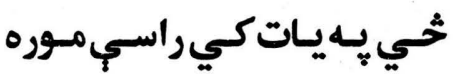
مــوركى تـــــــور غــــدبـولان مـوركى مـه م-ج نـه كره هير بـبنو

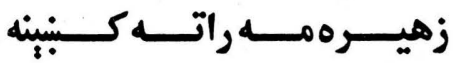

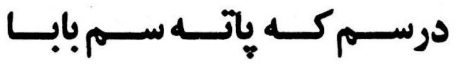

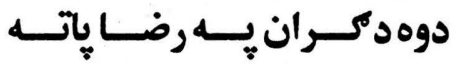

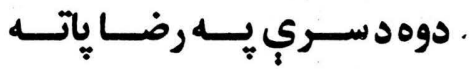

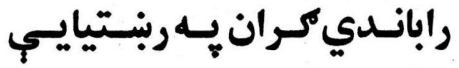

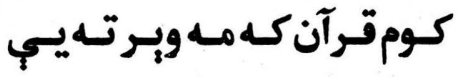

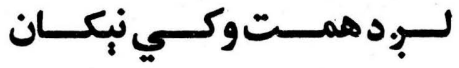

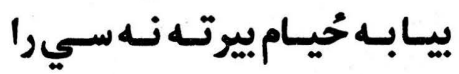

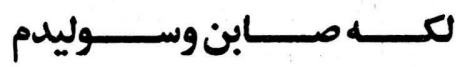

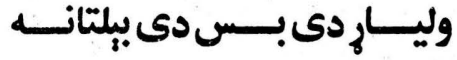
سور دسمال يمب يه سدرى وكي

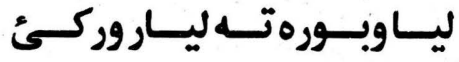

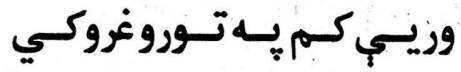

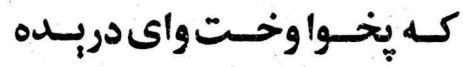

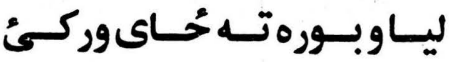

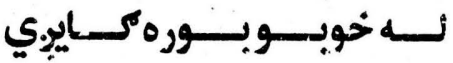

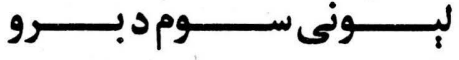

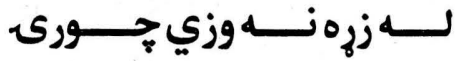

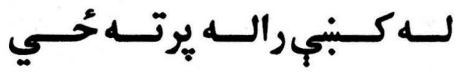

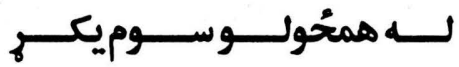

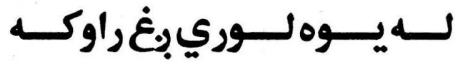
لـهــولب مـهـ سـي خـــواتـوره لانـــي سـول بنايـسته حُوانـان

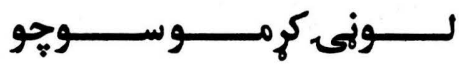

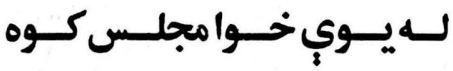

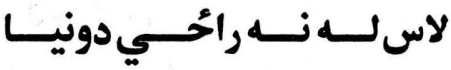

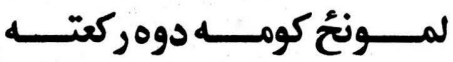

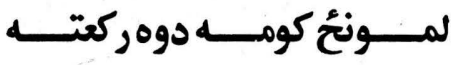

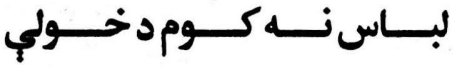

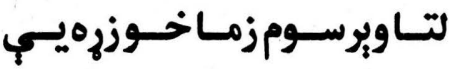

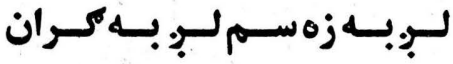

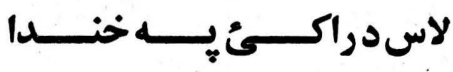

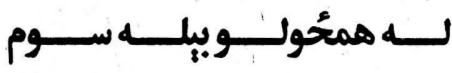

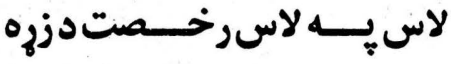

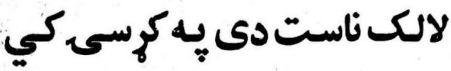

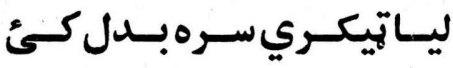
لويسه سـوم يـهـ شـنوبــاغوكي يــي

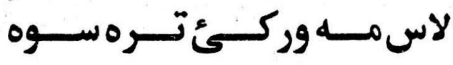

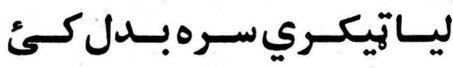

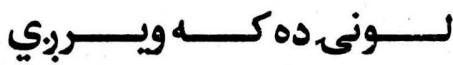




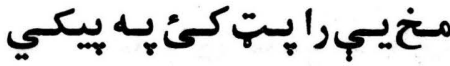

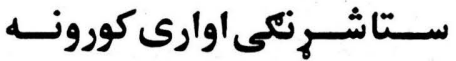

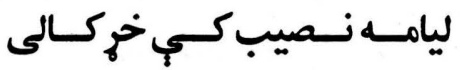

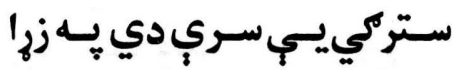

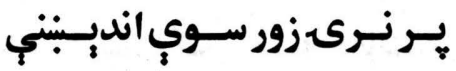

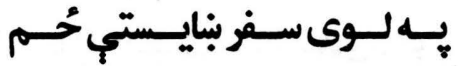

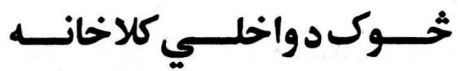

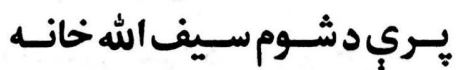

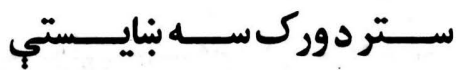

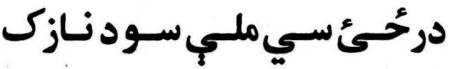

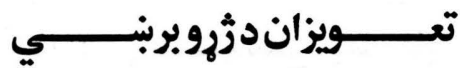

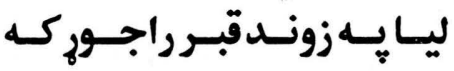

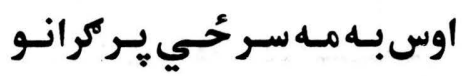

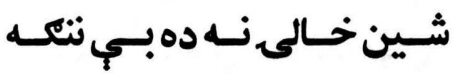

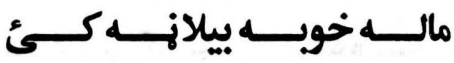

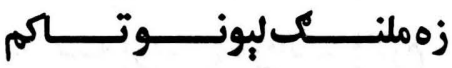

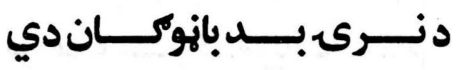

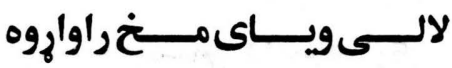

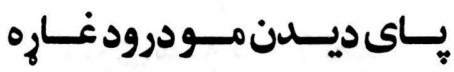

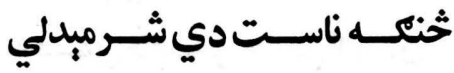

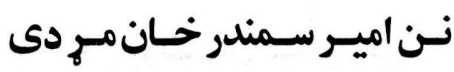

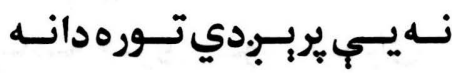

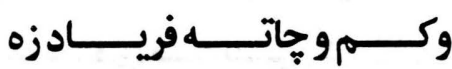

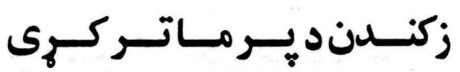

لــونى ســوهاوس مـــــــــوري

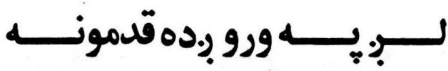

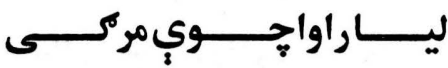

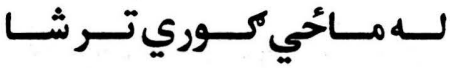

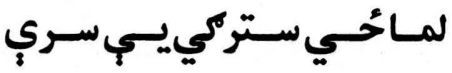

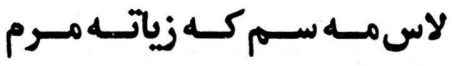

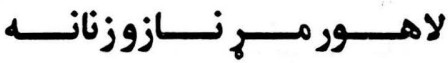

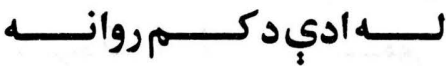

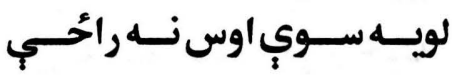

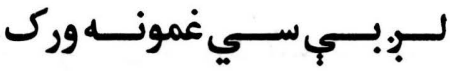

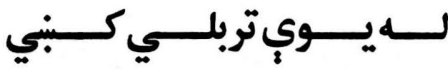

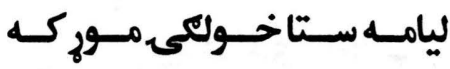

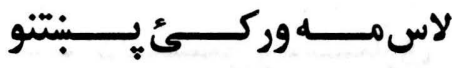

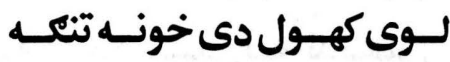

لاس د ويين وئ تينك مه نه كئ

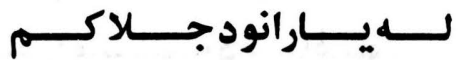

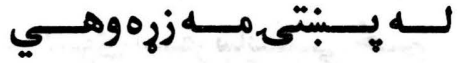

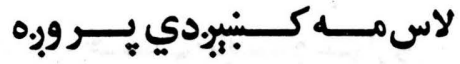

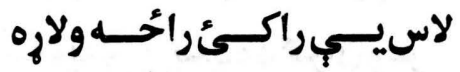

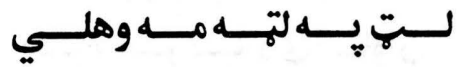

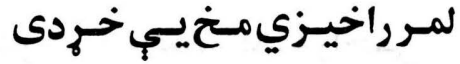

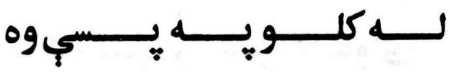

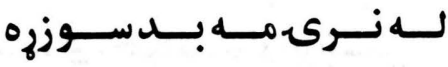

لاسدراورىبيـادغبرك كرى 


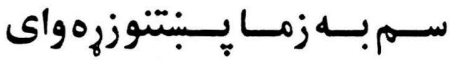
حُـي وكسيكـاى غـواريتـاوان حــاليسـي زر راوزى رويــاره

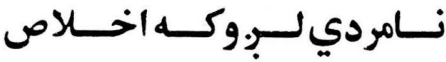

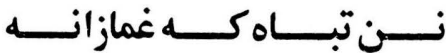

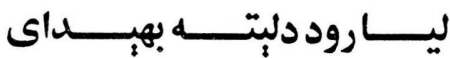

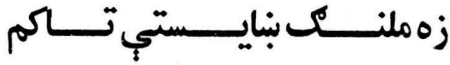

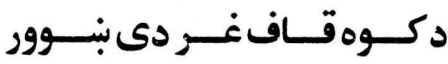
اوس مه عمل سوه دكران خوله

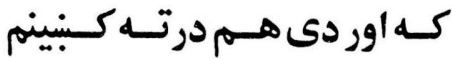

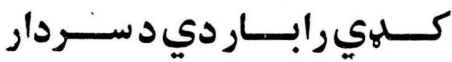

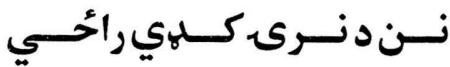

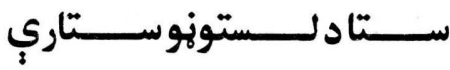

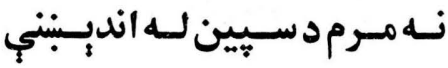

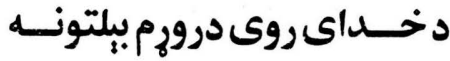

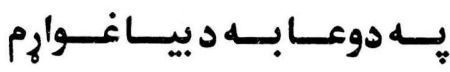

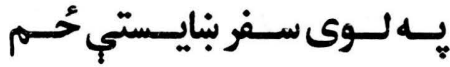

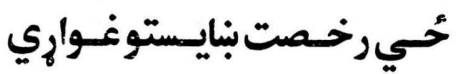

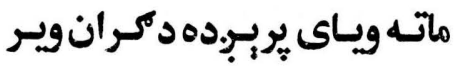

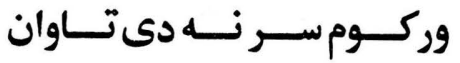

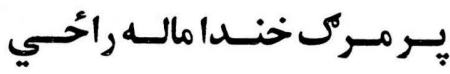

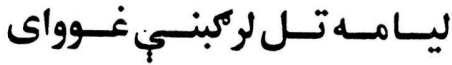

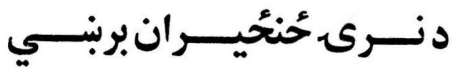

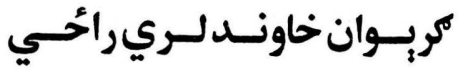

ليساميـيـار واى ليـامي نه واى

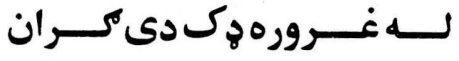

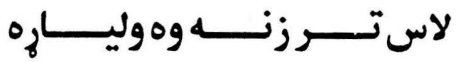

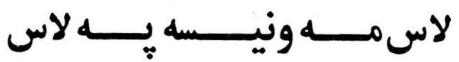

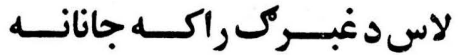

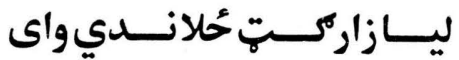

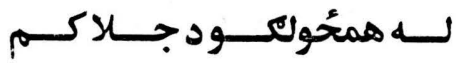

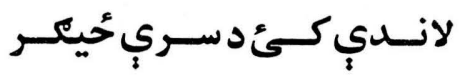

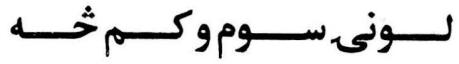

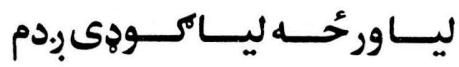
ليــار بـــي نـسمه شـــين ســهار ليـــار بــــهـ نيـــسم د ســــركي

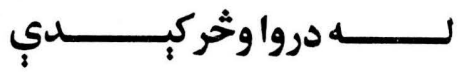

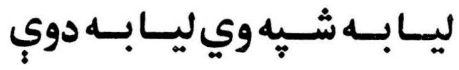

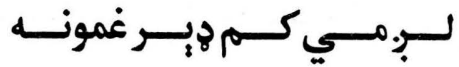

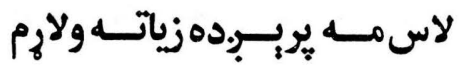

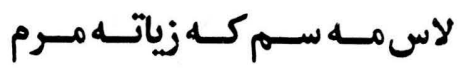

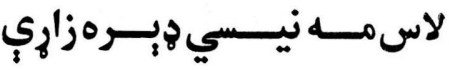

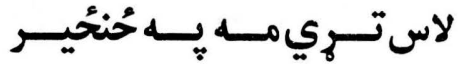

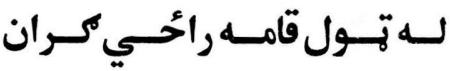
لاسمـه بـروت دى سـتابـــــي

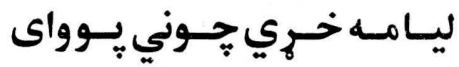

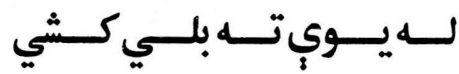

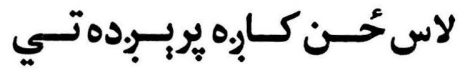


ليـاجرميـان ليـامتـرزى واى

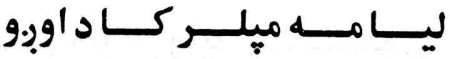

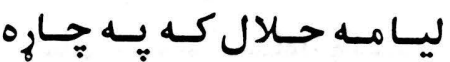
ليا مه واى جوره كبني كنبكي

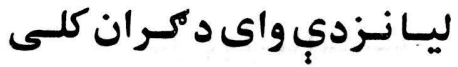

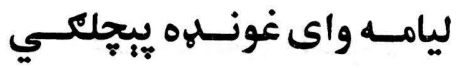

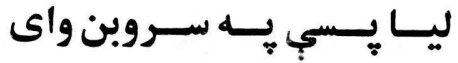

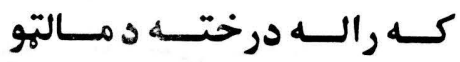
حمما بي ديده د خداى جوري كه حما بي ديده د خداى جوري كه

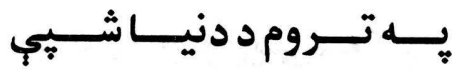

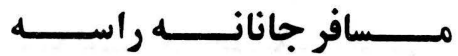

دمـرك تعـويز كلـهـ مـاكــنئ زهيـي هِر كم بـلتي لاسئ

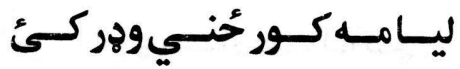
خــداى دجنــت دركـي كرانـو

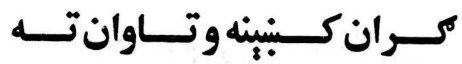

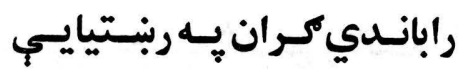

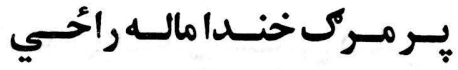

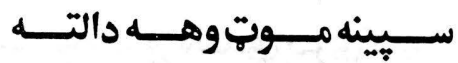

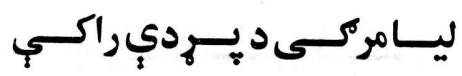

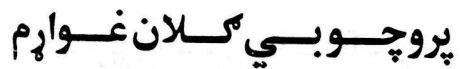

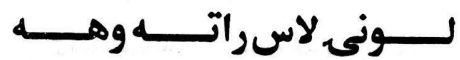

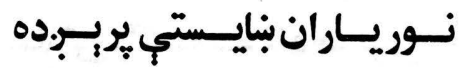

ليـامه كور ير سرهخيزى واى

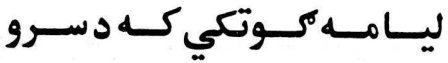

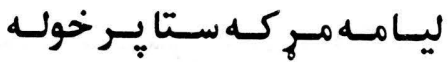

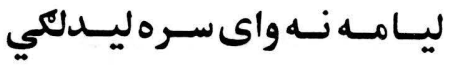

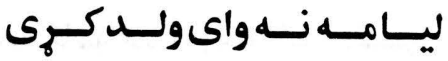

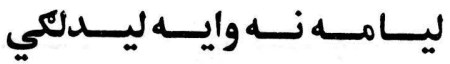

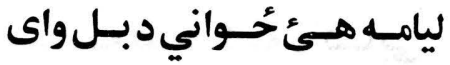

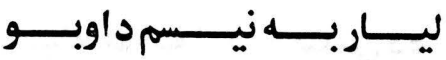

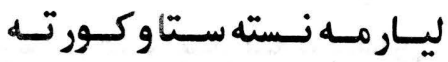

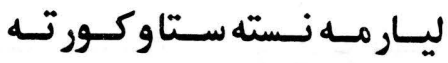

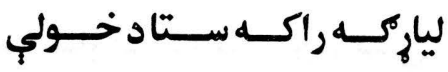

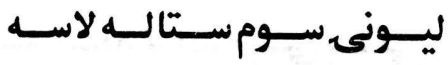

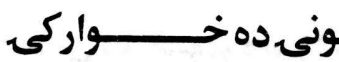

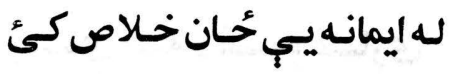

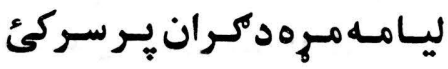

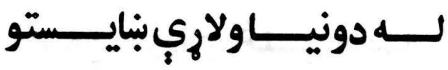

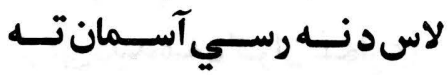

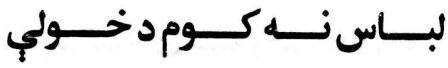

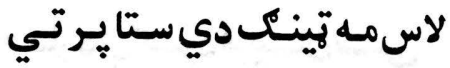

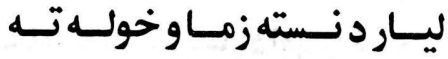

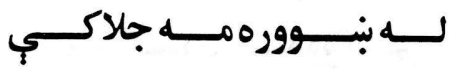

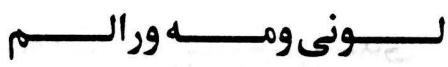

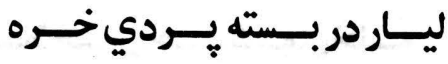

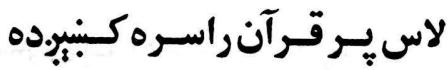




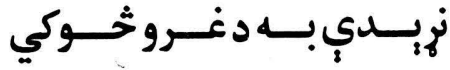

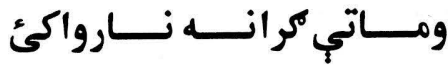

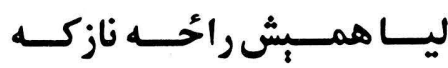
بـل نـصيب لـه خدايـه غـواره

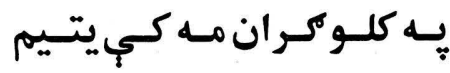

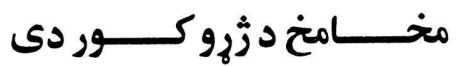

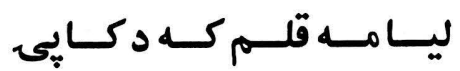
سـينه خولـه لــور د نـامي ده

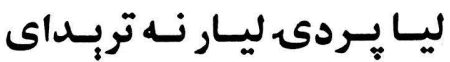

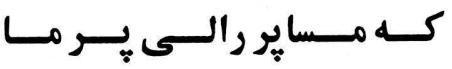

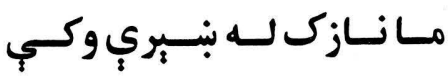

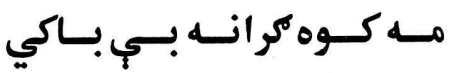
خـداى بـه ثــومره سـزار راكي

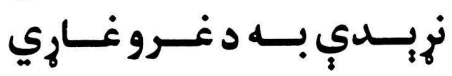

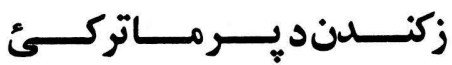

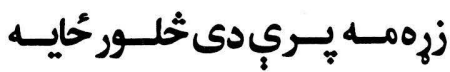

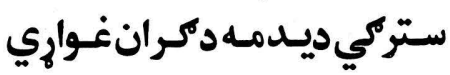

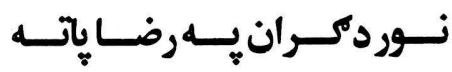
وجــارديكـــردقريــانسـي

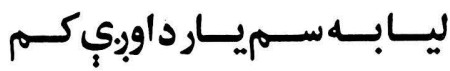

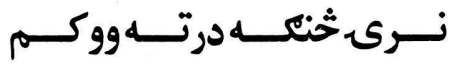

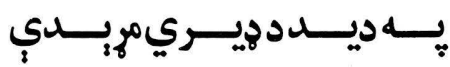

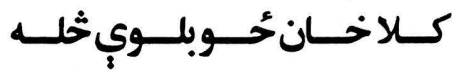

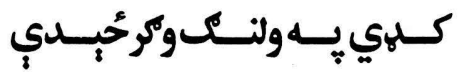

لـوى سـهار دى نــرى هــوكي

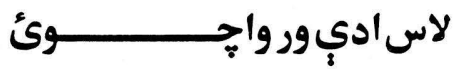

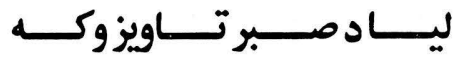

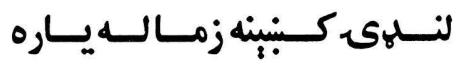

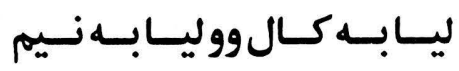

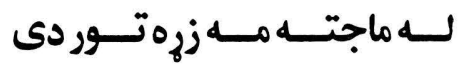

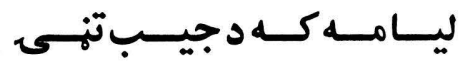

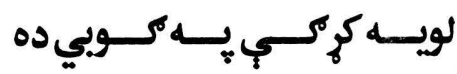

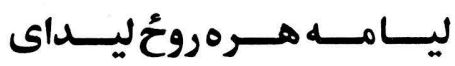

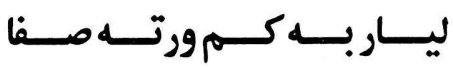

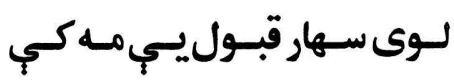

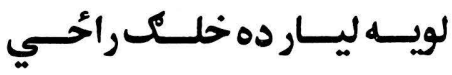

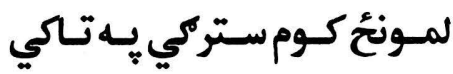
لـــوى ســهار دى نـــرى زاري لاسدراورىييـادغبـركـــئ

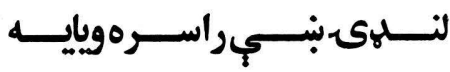

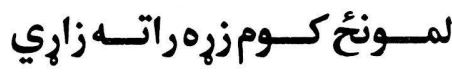

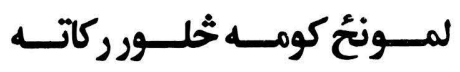

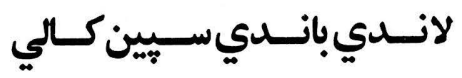

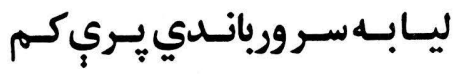

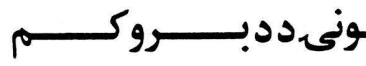

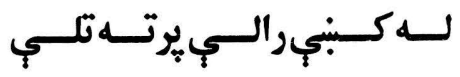

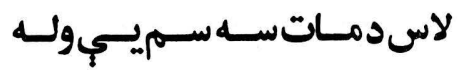

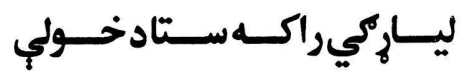




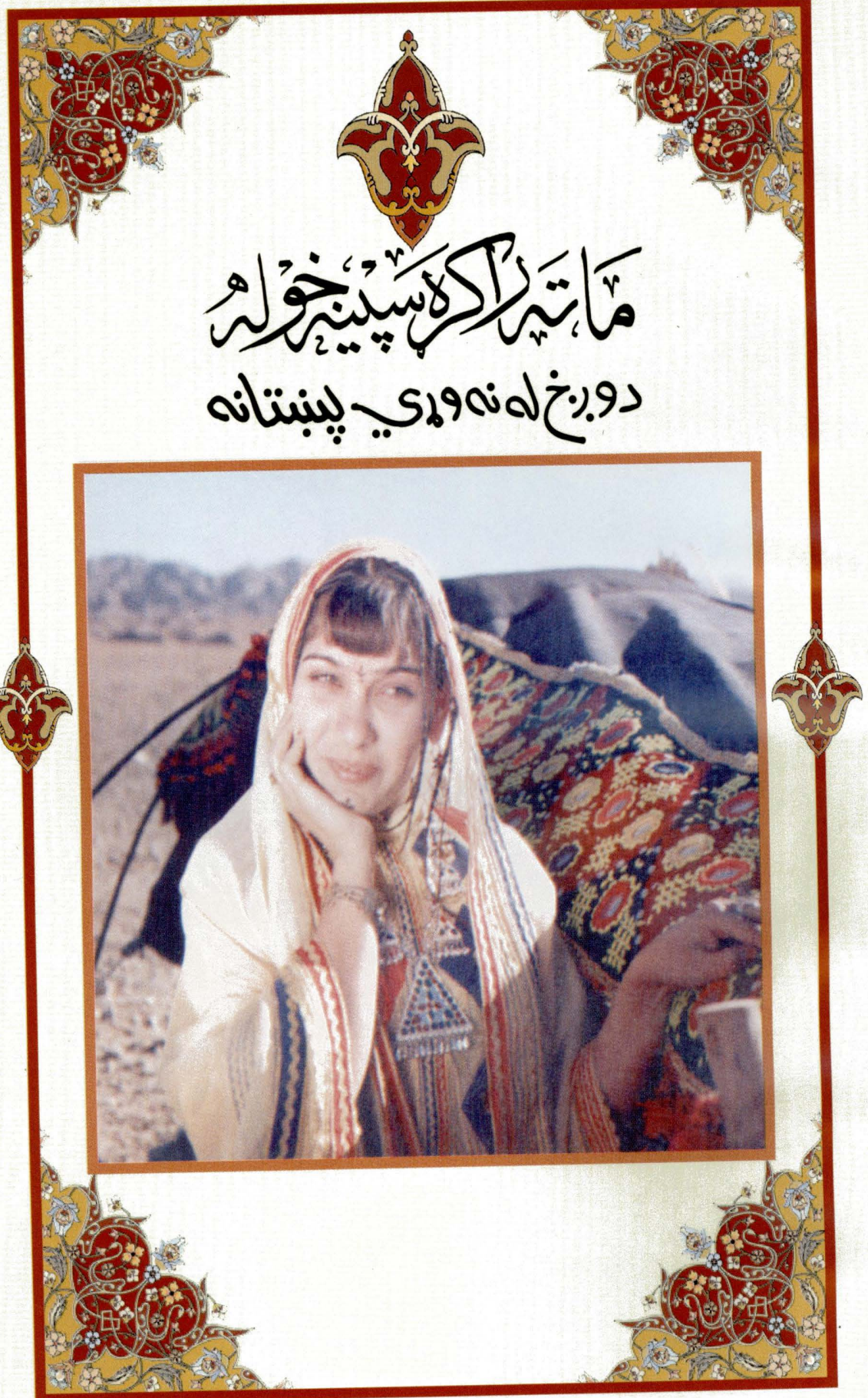




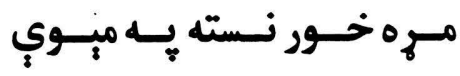

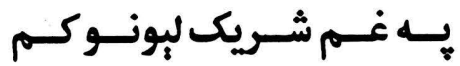
سـيـينه كـومبر سـتا يـه غابنــو

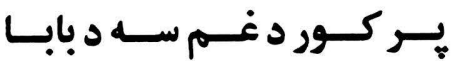
بنـــوو تــــر دركســـــــــــاووت

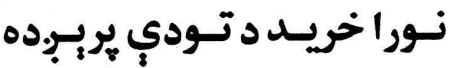

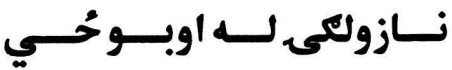

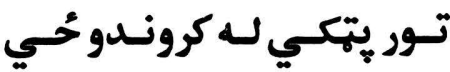
سـور كميـسي لـهـ اوبـوحُحسي توريب تيكرى سيّنيبي كالي

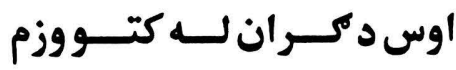
ستا رويبار راته خواست كردى

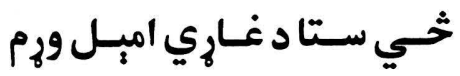

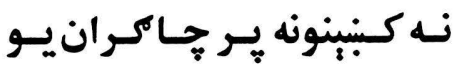
يـه خولـو نونـــــــم د جـــورى

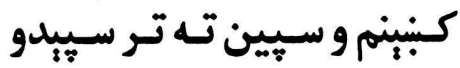

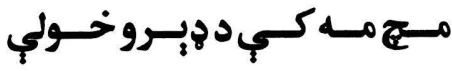

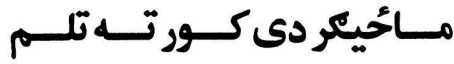

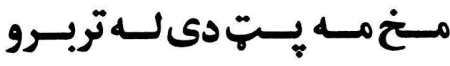

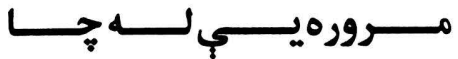

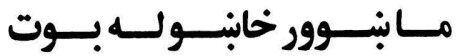
ميـردادواخله سـر يـر كبّب بـده مـاحِيكر دى لمـر لـه نروحُحي مـاحُيكر دى لمــر لـه غروحُحـي

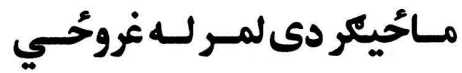

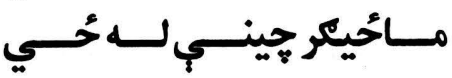

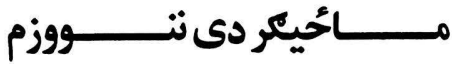

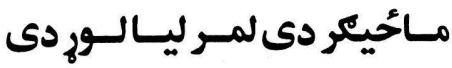

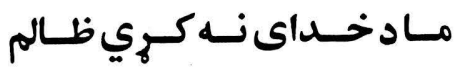

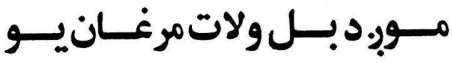

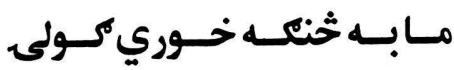

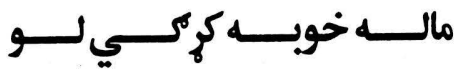




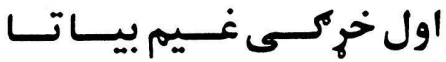

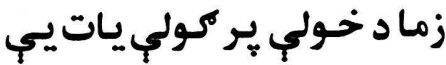

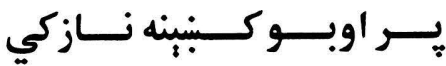

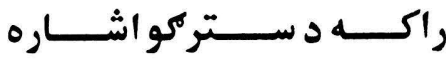

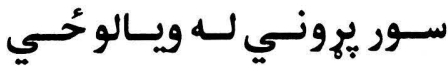
زمــابيـاوس بــورهيـاديبري زهو بــــوره جرمانــــهـ ســـــو

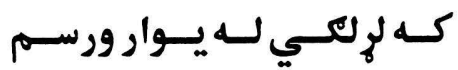
سري يلـوكه لله خـولب يورتهـ سـتا جاركـل د لمبــي وكــي

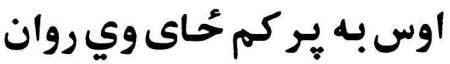
بيلتـون ثُرحوانان يُري باسي

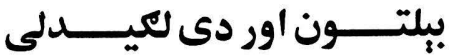
مـازل خــي بـهـ جـايـادكي

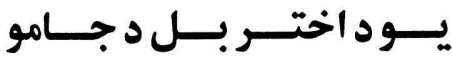

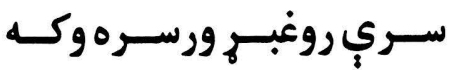

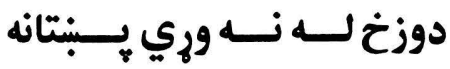

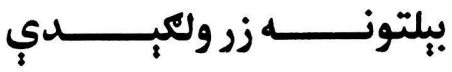

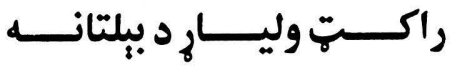

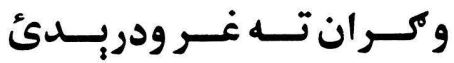
تر سوج مخكي مه لاس دركئ

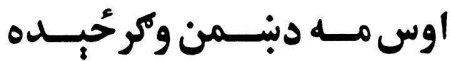
زمــابــندن سـوحي بــي اوره وركى وربه د خولي ميان كي

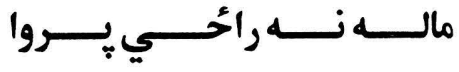

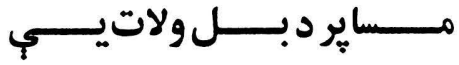

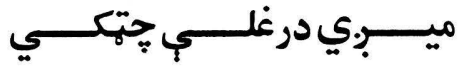

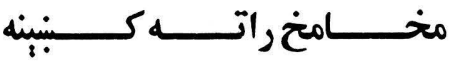

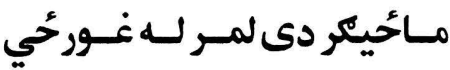

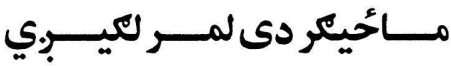
مــاحيكر دى لمــركـورده ســو

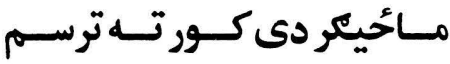

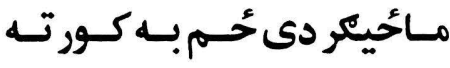

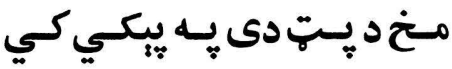

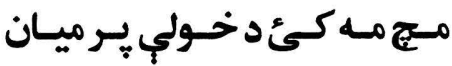
مركى حــق دى غـاري باسـي

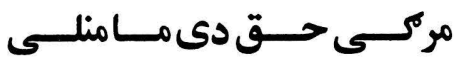

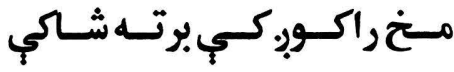

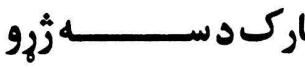

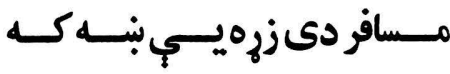

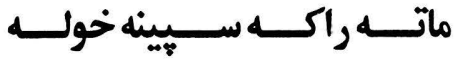
مــاوليـي بـه ليـاخــوشـيبي

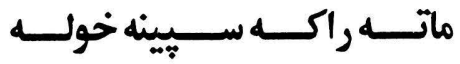

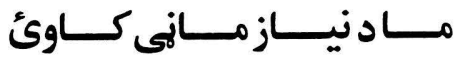

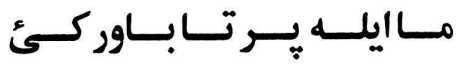
مـــاد ســـتركوتـــــور ســـــاره

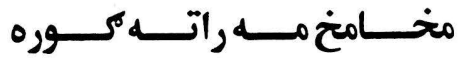

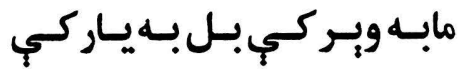


د حكانزوند بـه بـهـ زاوالكي

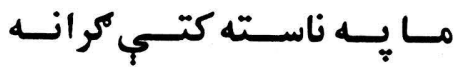
وروسته بـه جـور يـه ارمان خحهـ اوس مسه د كونـلهه كي نبكسان كه ستا يـر در درسي زما سيّى

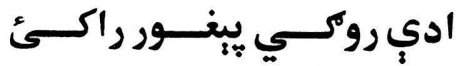
سـور تيكـــى بنايسستي راسـ

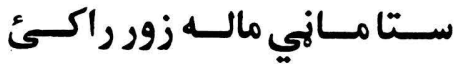

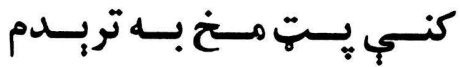

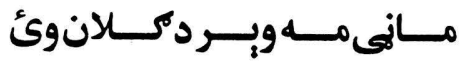
دكران زونل مه بـه زاوال كئ حــواني نسميب كي د جـوري

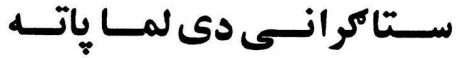

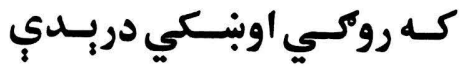

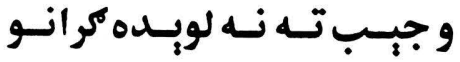

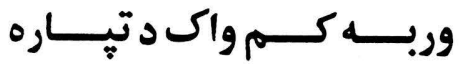
كـه غــواري وربسه كمـه خولـه

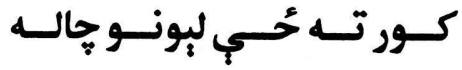

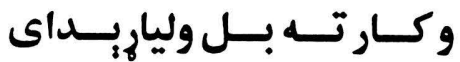

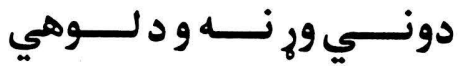

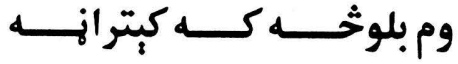
دي بـيـا بـل بـــ دنيـايـار كـئ تسور يسكـي لـهــودروحــي ثخي مـوريسي خـوا بـه بـدوي

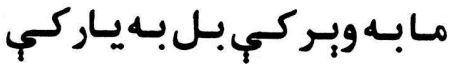

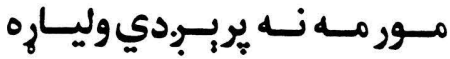

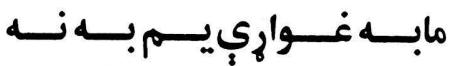

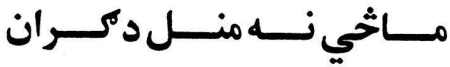

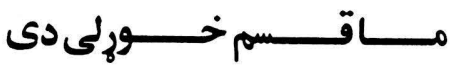

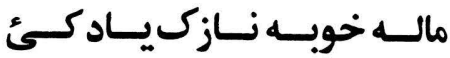

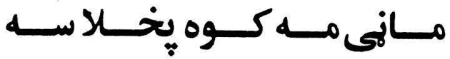

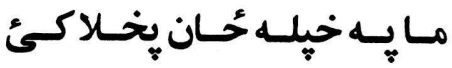

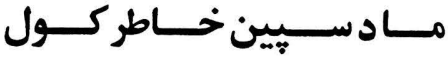

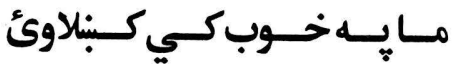

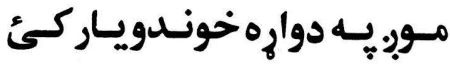

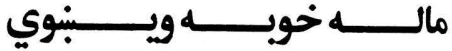

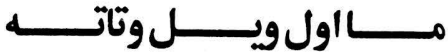

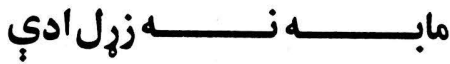

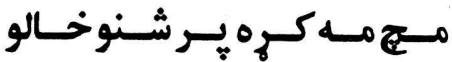

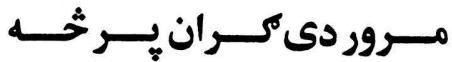

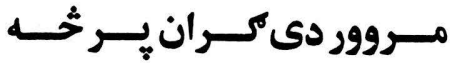

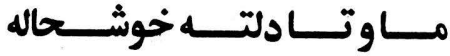

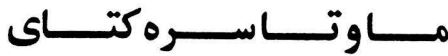

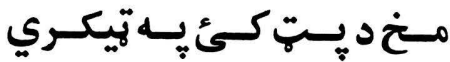

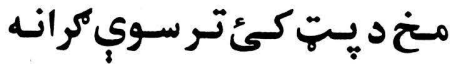

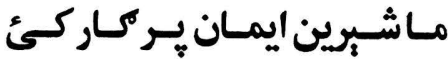
مــاحِيكر دى لمـر لـه غروحَّـي

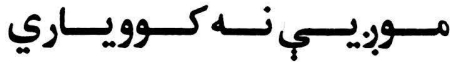


تــــه ملنـــــ د زيــارتو ســوي

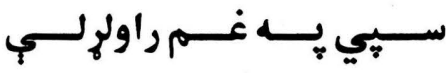
تــــ دبولـو غــورحي صـوفيان

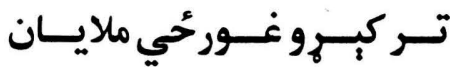

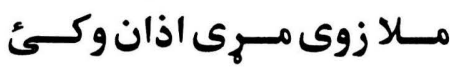

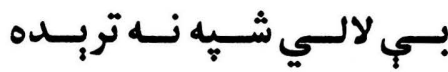

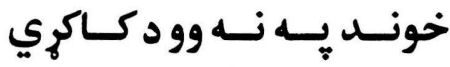
خونسل بــــــي وو دكـاكي كه جـور سو سيّين له بيمارى مر ان له بـه دواري ترلهي حَّو

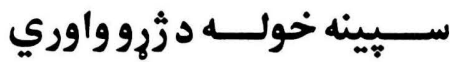

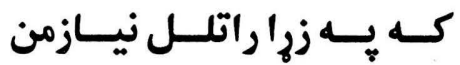

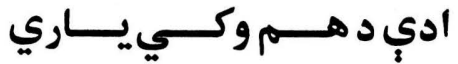

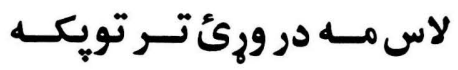

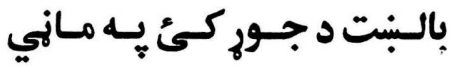

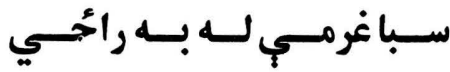
وركسى تـر لانسي كـه جــاره نـن بـه د خونــ نـه وي روزي

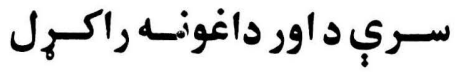
كر ان له حُانه نـواب جـورئ كئ

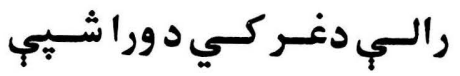
به خوبر مه كئ وخورم بـزوان

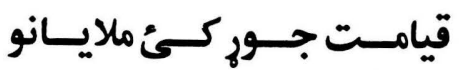

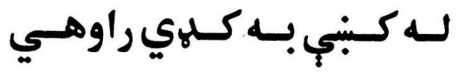

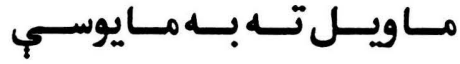

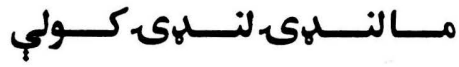

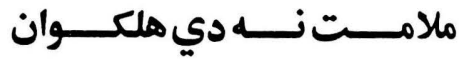

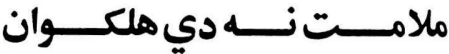

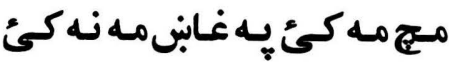

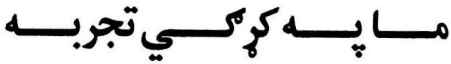

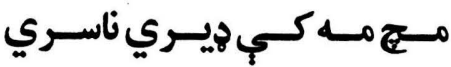

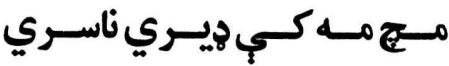

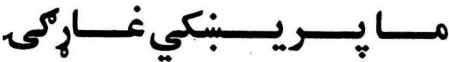

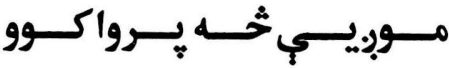
مـا بـه سـبـ كـي كهول غـواري

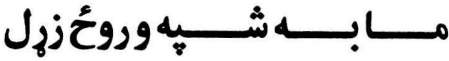

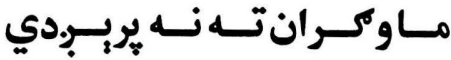

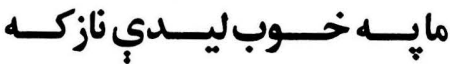

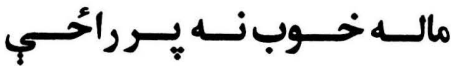

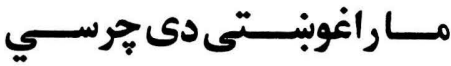

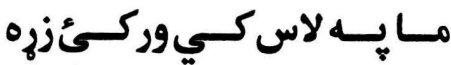

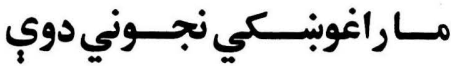

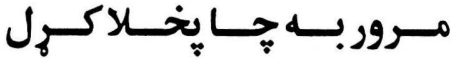
مـاد سـر تيكـــى ورخـوركئ

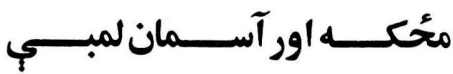

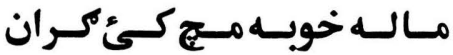

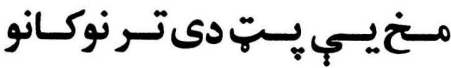

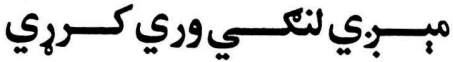




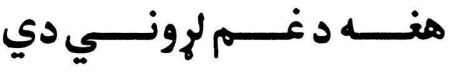

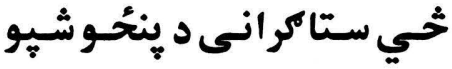

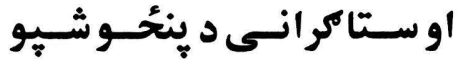

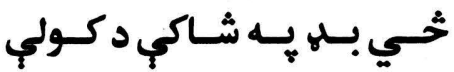

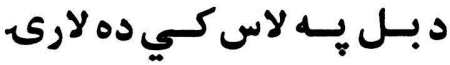

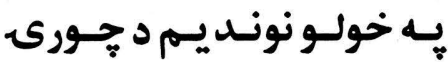

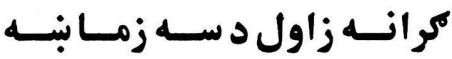

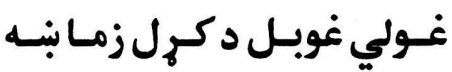

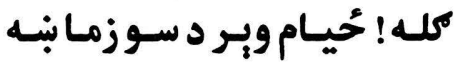
كله ! حُحيـام وبـر د سـوز زمـابنـهـ

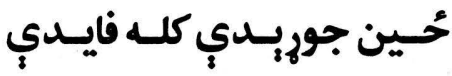

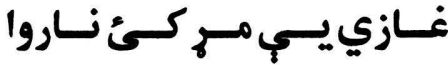

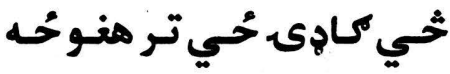

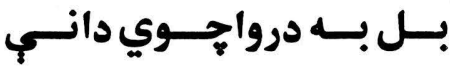

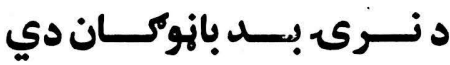

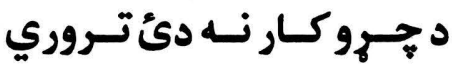
ادي دريـاتي كـه سـتاشـيبي كه جور سوى سيين له ناجورى ادي

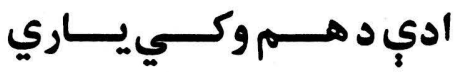

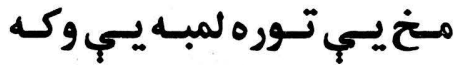
ادي دريـاتي كـه سـتا شـيـي كها بـه دئ مياست رالى لالى

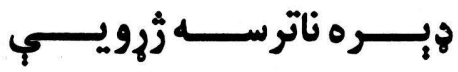

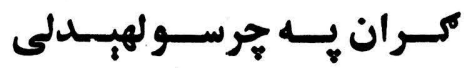

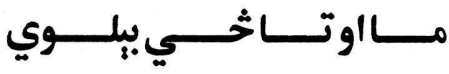

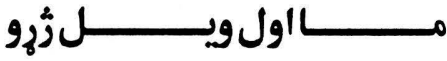

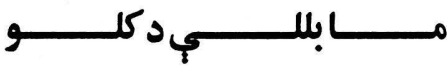

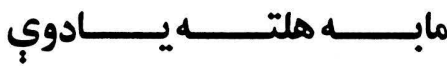

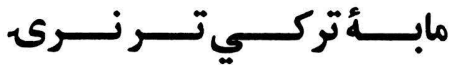

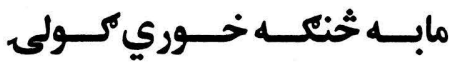

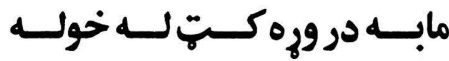

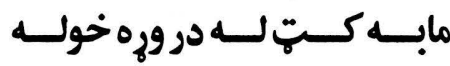

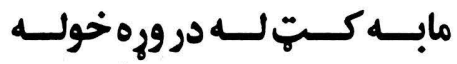

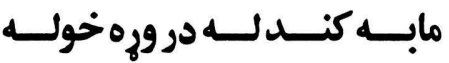
مـاخــوارى يـهـنــــــــبـي

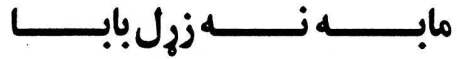

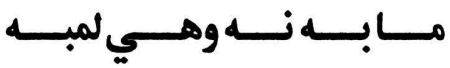

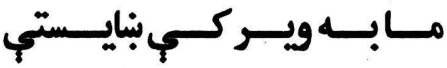

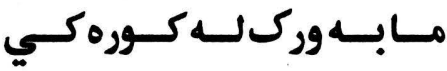

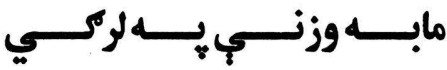

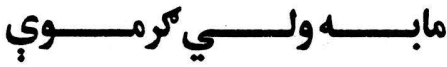

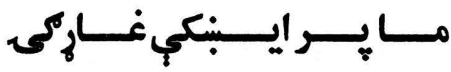

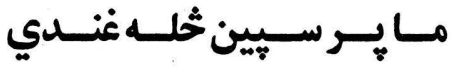

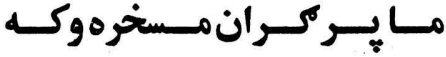

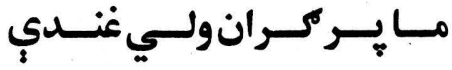

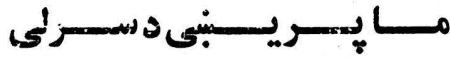

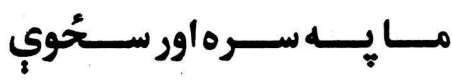

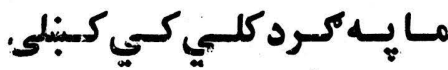




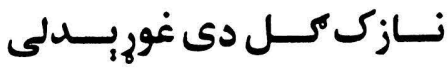

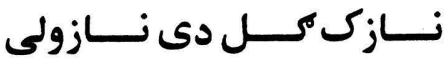

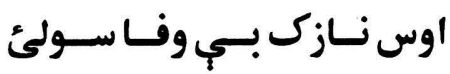

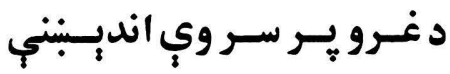

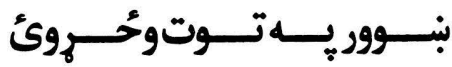

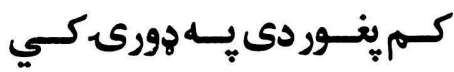

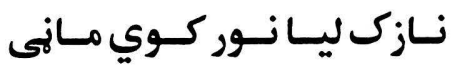

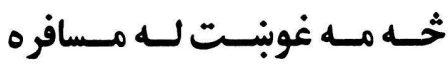
له خوابنـكي مـور نـه جوريـده

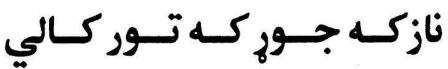

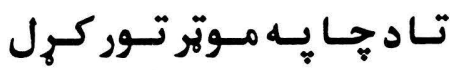

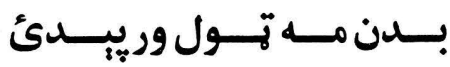
درختي كـل وكي بيـاتوسي

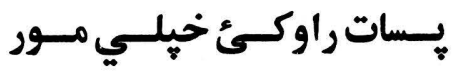

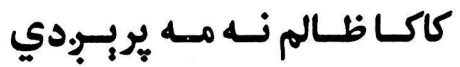

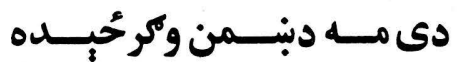

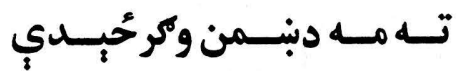

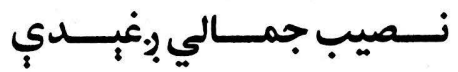
شيـي نزوني سـتا دواده سوي

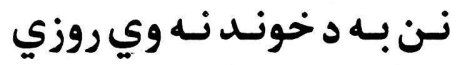

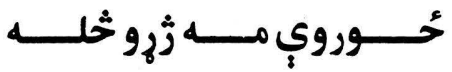
دمسـور و بــار د ســـي روزي

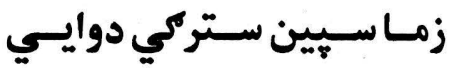

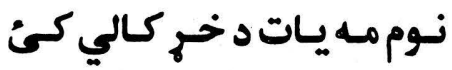

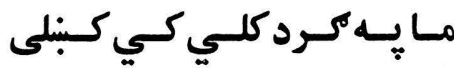

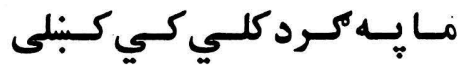

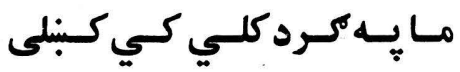

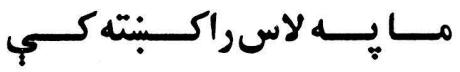

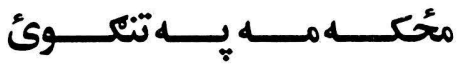

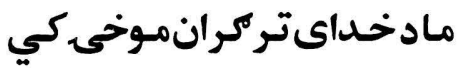

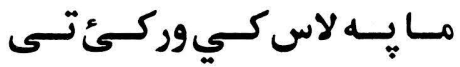

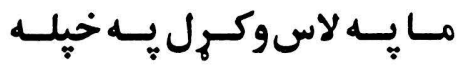

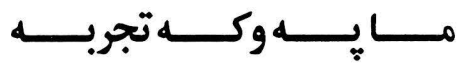

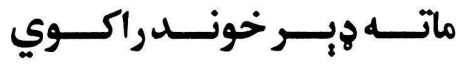

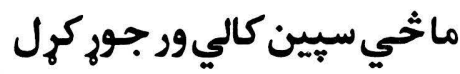

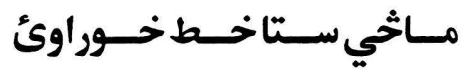

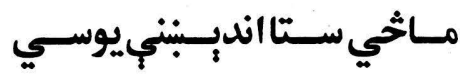

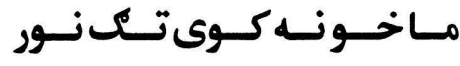

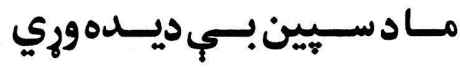

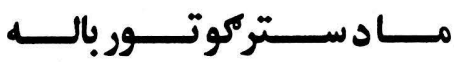
مـــادســتركوتـــور لوســتـي

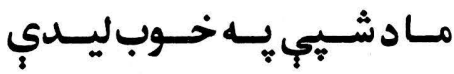

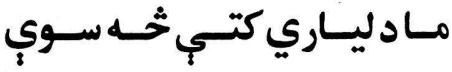

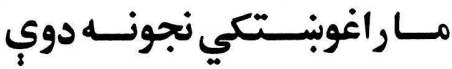

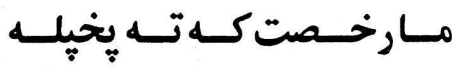

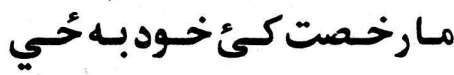

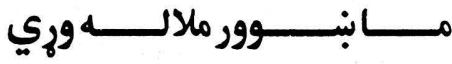

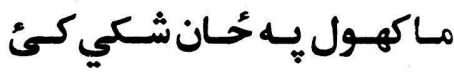


سـر مـــه سـتا بــر ز زكانــه كـهـ

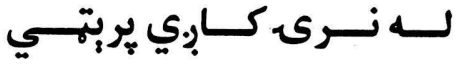
نـز دي سـيـين نـه دئَ راغلـى

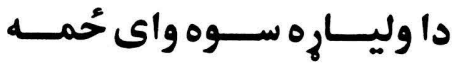

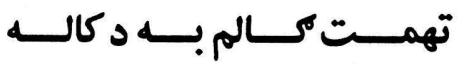
خـــوري ايمــان نــارواكلــى خـوري ايمـان بــي وفـاكلـى

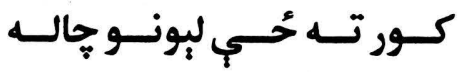

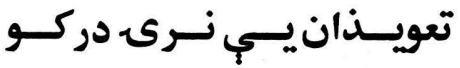

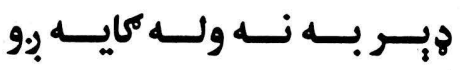

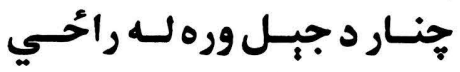

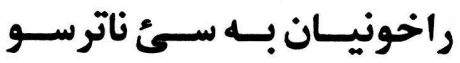

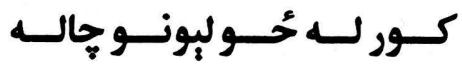

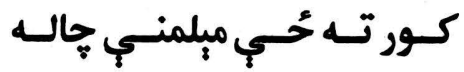
ناست بـ تل كي د لوني واى

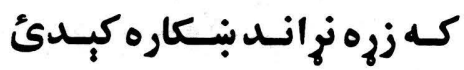
د خيـلـل جانــان ديـــن كــوم يوار تيكرى كه له خولب يورته

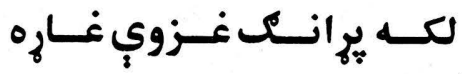

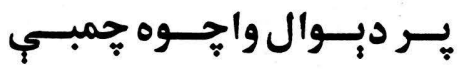

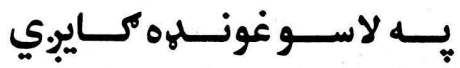
سست ليا وس راته سوالكر دئ

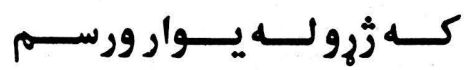

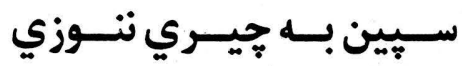

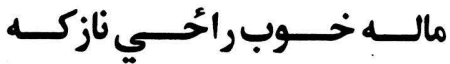

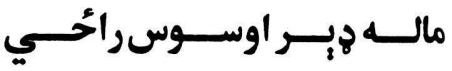

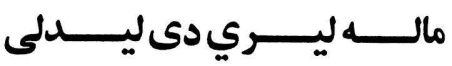

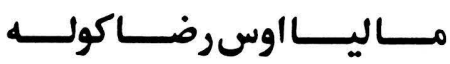

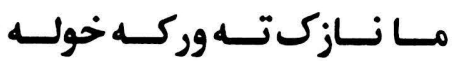

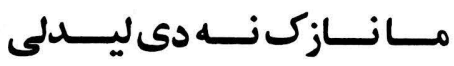

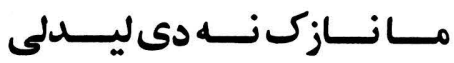

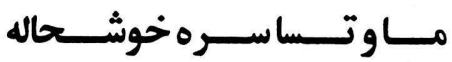

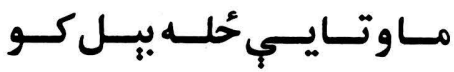

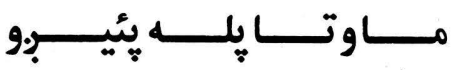

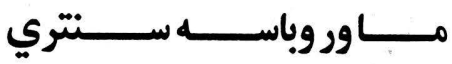

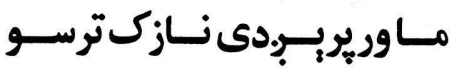

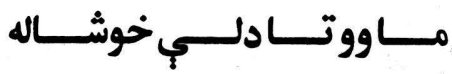

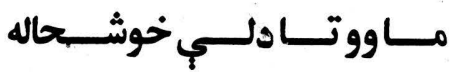

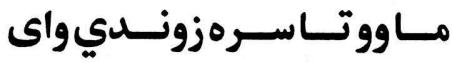

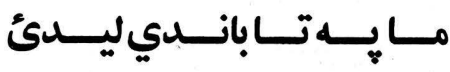

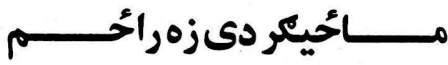

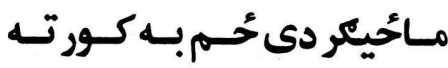

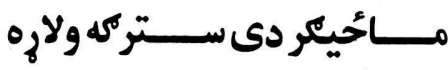

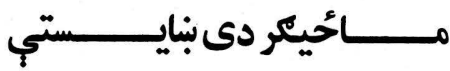

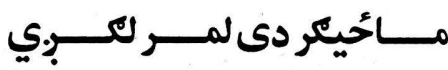

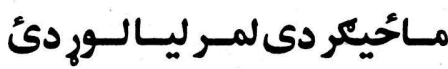

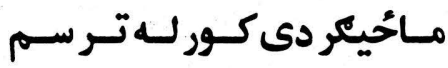

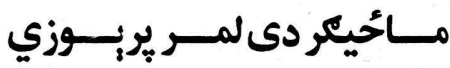


كرانيا اوسراته خواست كر دئ

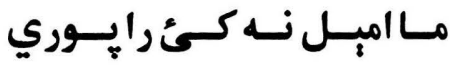
سبين يتجكى له كروندو فئحي

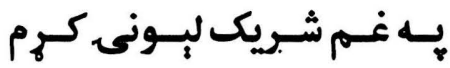

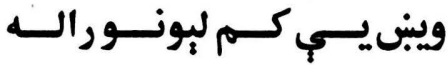

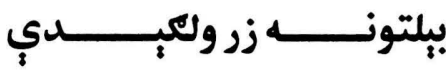

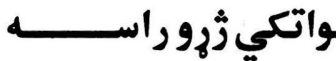

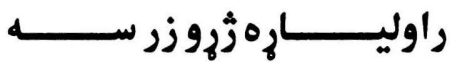

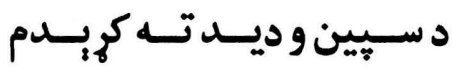

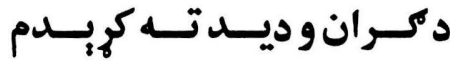

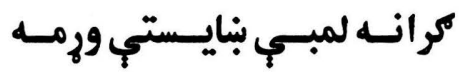

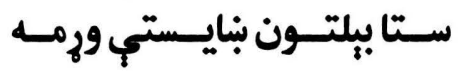
دكـــم ولات بــــه وي جانــان

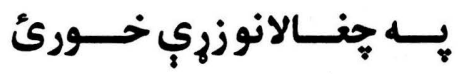
ورالـــم حُـــــاى د كتــــــوري

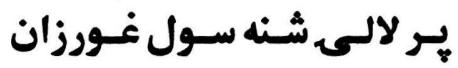

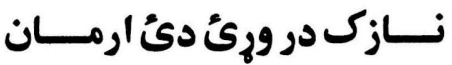

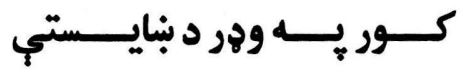

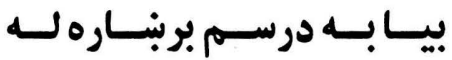

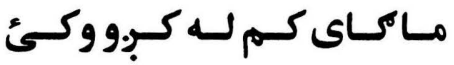
شين تيكرى هيري دي مايني

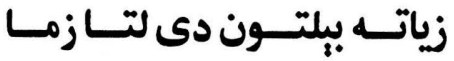

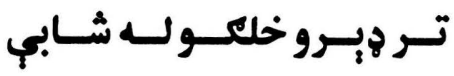
دنـم يـكسى ديـر خــور سـي

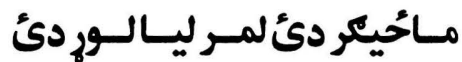

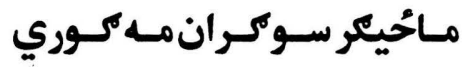

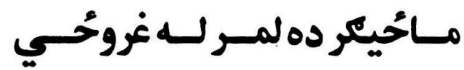

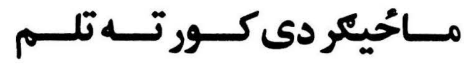

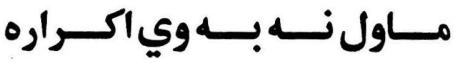

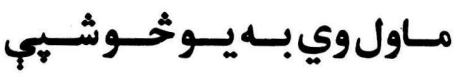

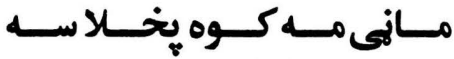

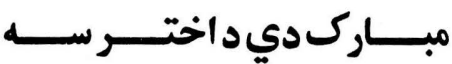

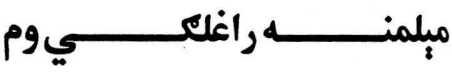

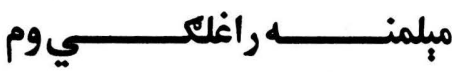

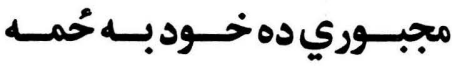

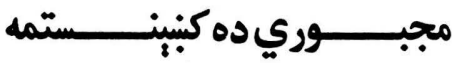

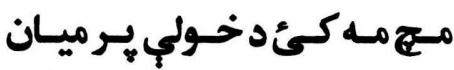

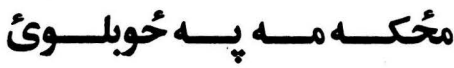

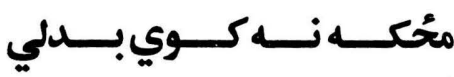

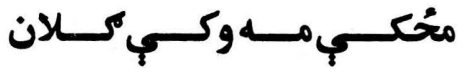

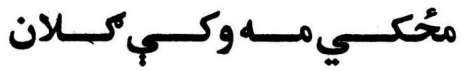

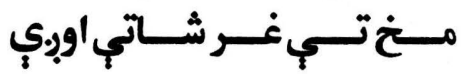

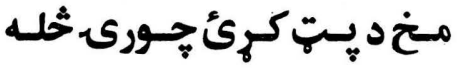

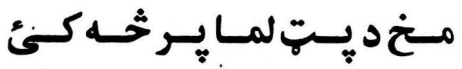

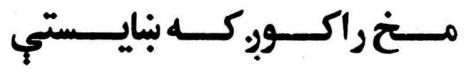

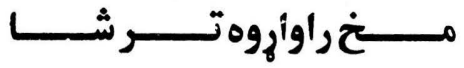

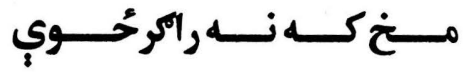

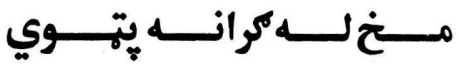


نـاجورهـــوم سـتالـهــــوحَى

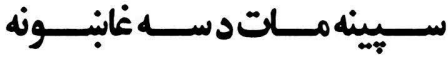

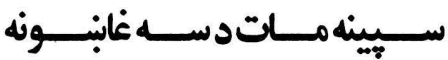

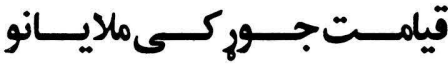

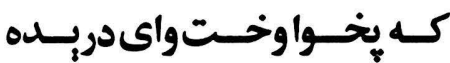

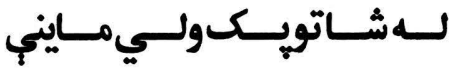

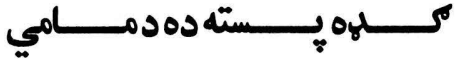

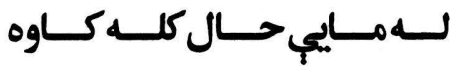

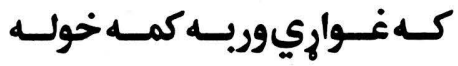

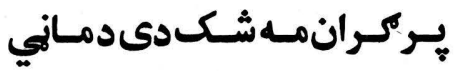

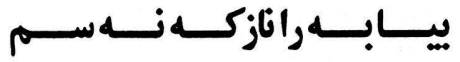

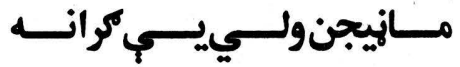

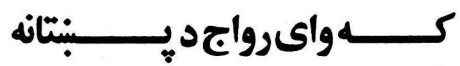

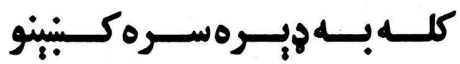

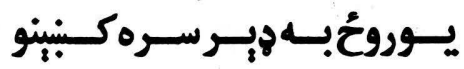

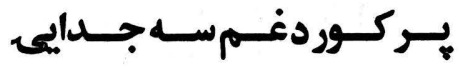

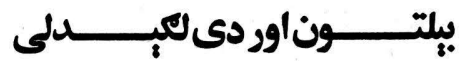

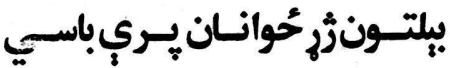

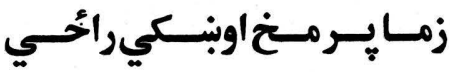

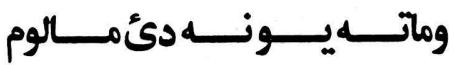

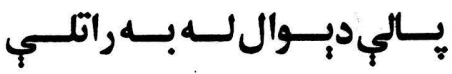

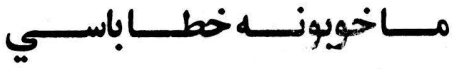

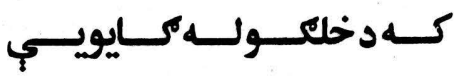

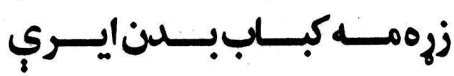

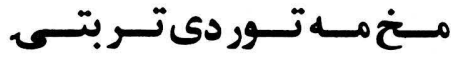

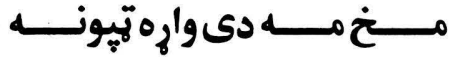

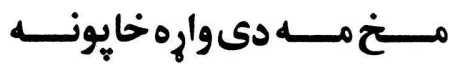

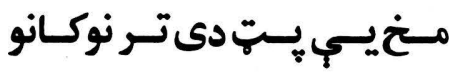

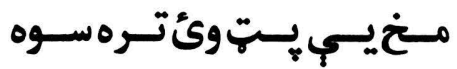

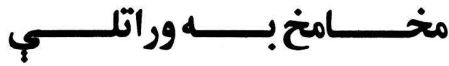

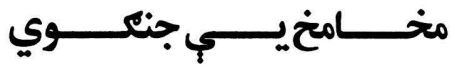

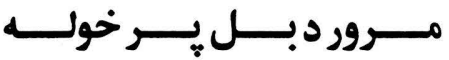

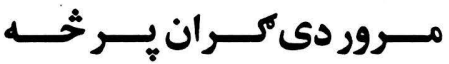

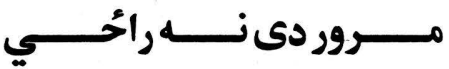

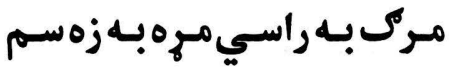

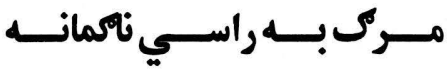

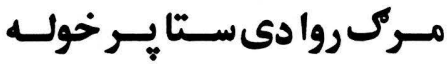

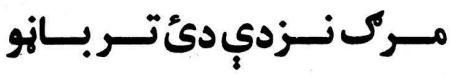

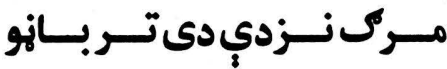

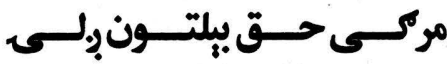

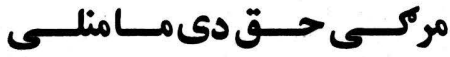
مركـى حسق دىئغــاري باسـي

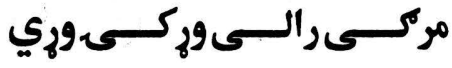

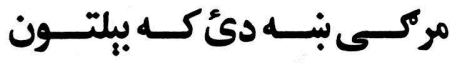

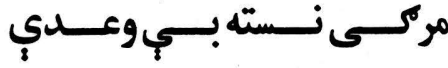

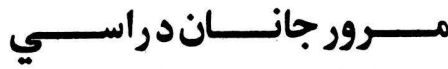
مــرور دخــداى لــــــرويسي مينــــــاوربيلتـــــون لمبـــــي 
كـوتي لـي غوبنــتي ديكـالي

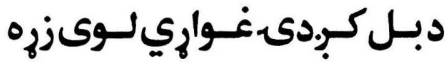

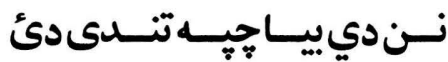

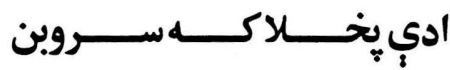

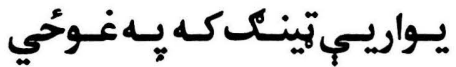

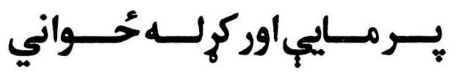

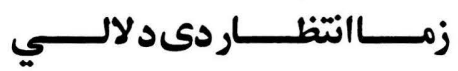

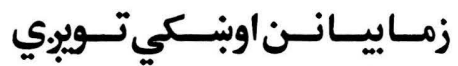

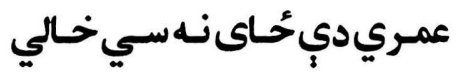

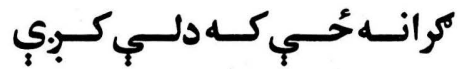

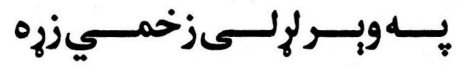

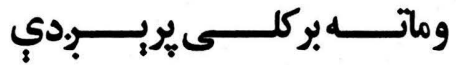

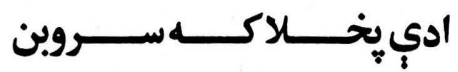

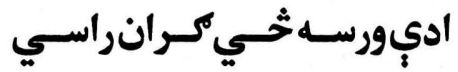
اومـريديخحـاىنهـ سي خـالي

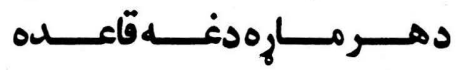
خي خداى مه خلاصكي له كولي

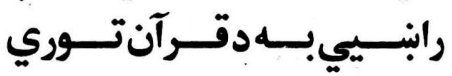

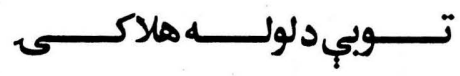

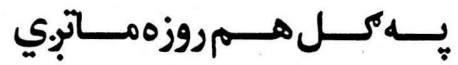

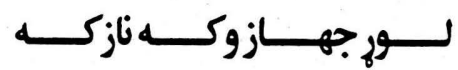
فــتحدبنـــارهغونبــيــوراوري

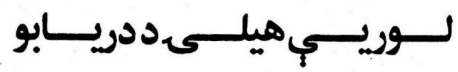

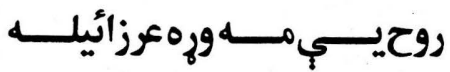

مـــــــروور دى نــــــــراحَــــــي

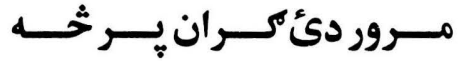

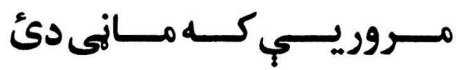

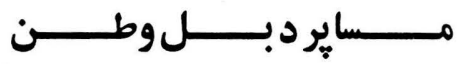

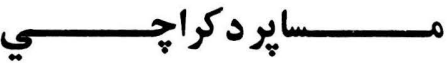

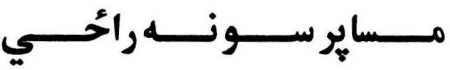

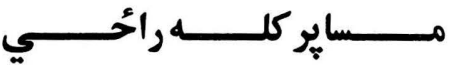

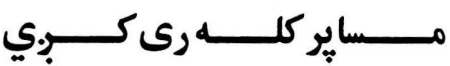

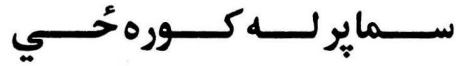

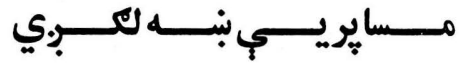

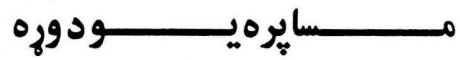

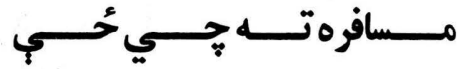

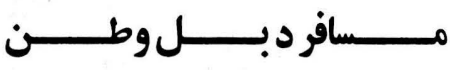

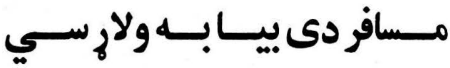

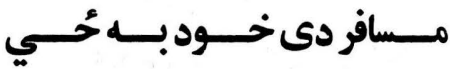

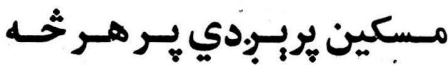

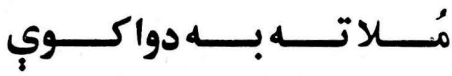

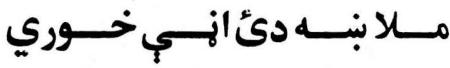

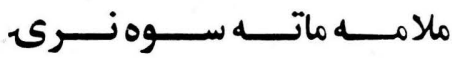

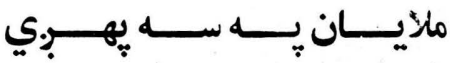

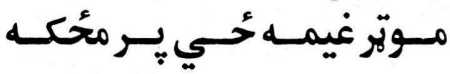

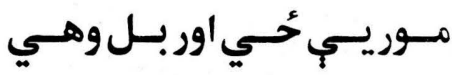

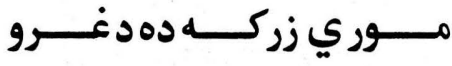

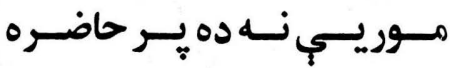


مـازرل ثـــيسه جــايـات كـي

اوسزندى سوي دكران لياري

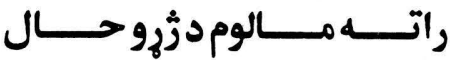

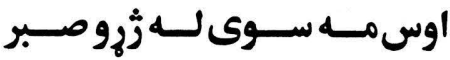

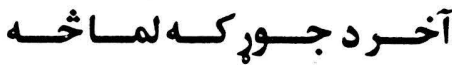

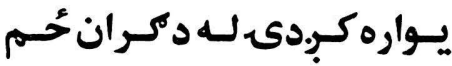
كـه يخــواوخت بيرتـهـراتـلاى

ستركي سـيس دي له مـاواوري

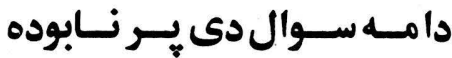

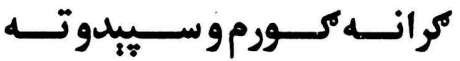

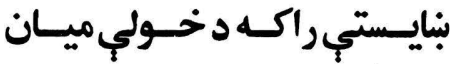

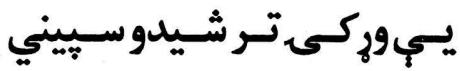

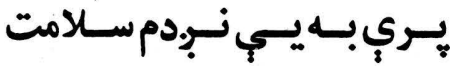

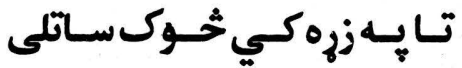
وركس دبسل بـهـ نكساح سـوي

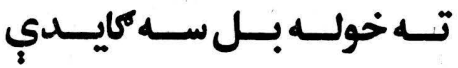

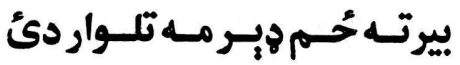

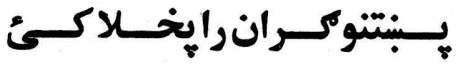

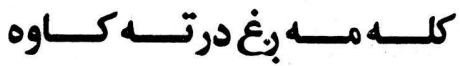
ستاله جـوري يـر مـاكران دي ودوي دزروزغ

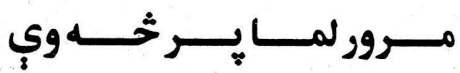

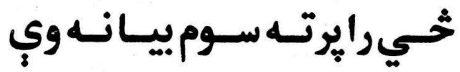
دسري كـور بـه لوبهلهـاركي

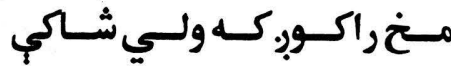

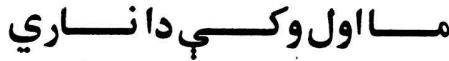

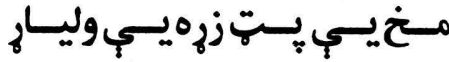

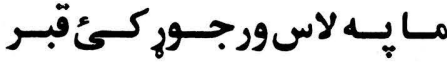

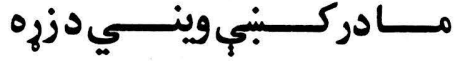

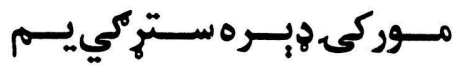

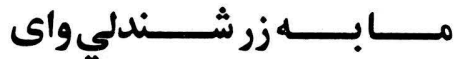

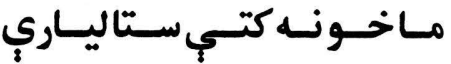

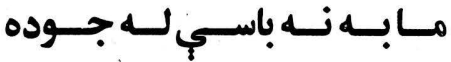

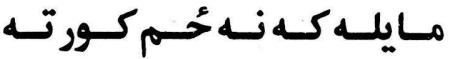

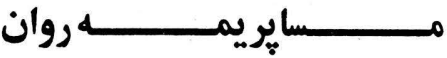
مـخخ ديست كـه خلـك دوينسي

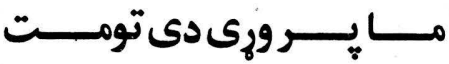

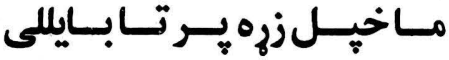

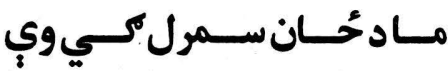

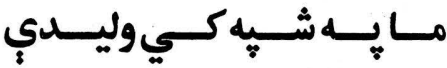

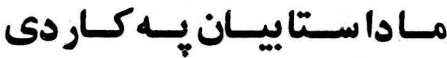

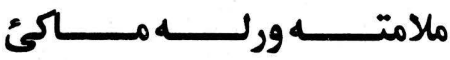

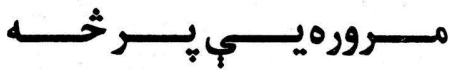

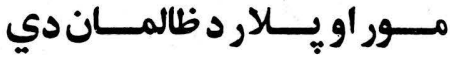
مــور دنستسته بـلكار بــي دوده

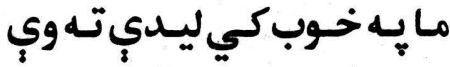

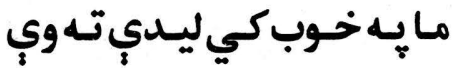

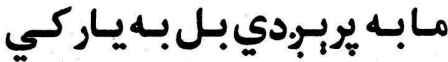


هـهنيـازبـهــوك وركي هودىى

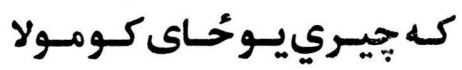

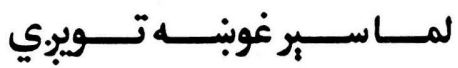

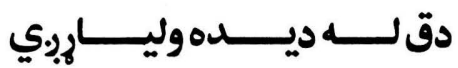

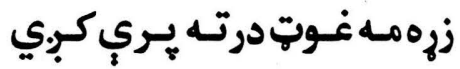

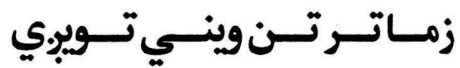

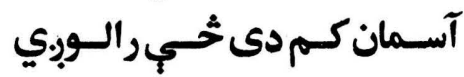

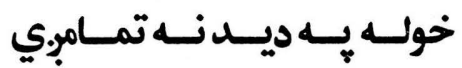

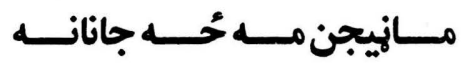

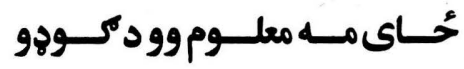

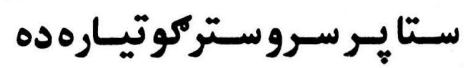

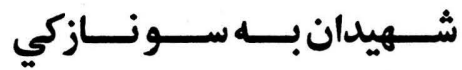

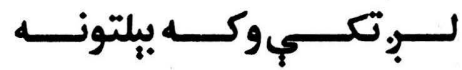

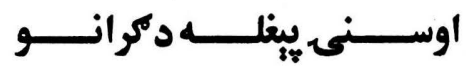

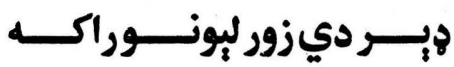

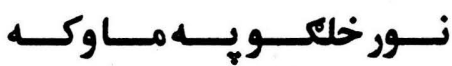

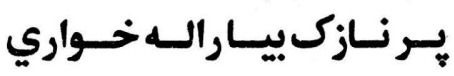

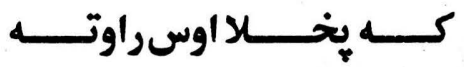

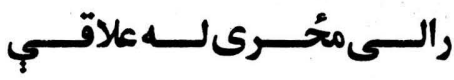

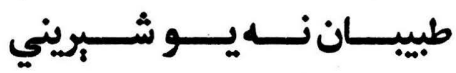

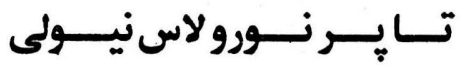

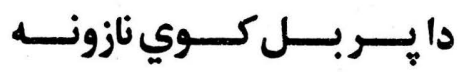

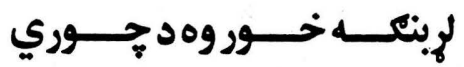

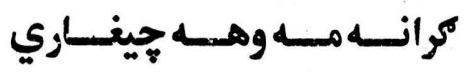

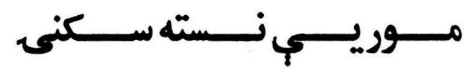

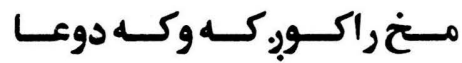

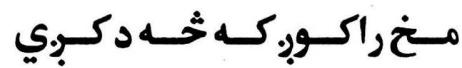

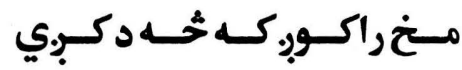

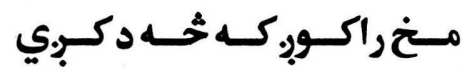

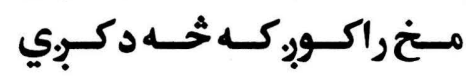

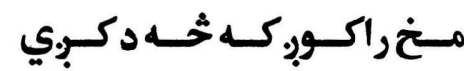

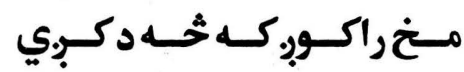

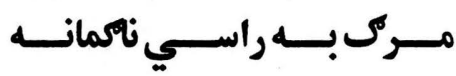

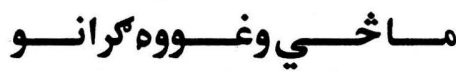

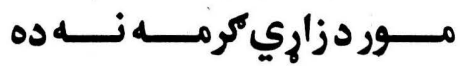

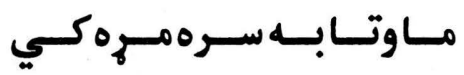

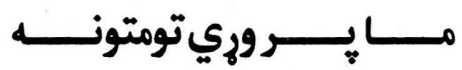

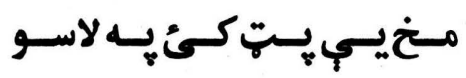

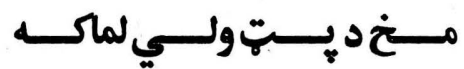

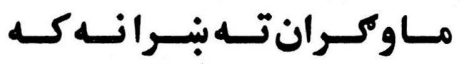

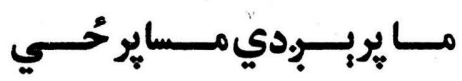

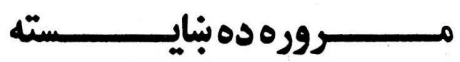

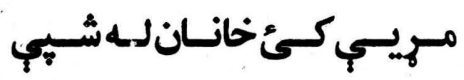

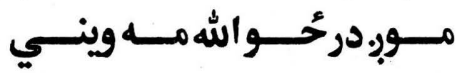

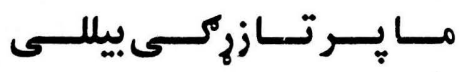

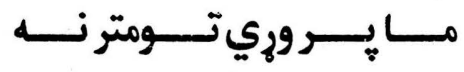

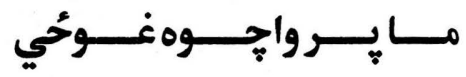
مــور مــه ناسـته وهمـــــــــواري 


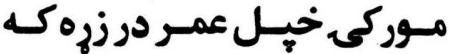

زري غـوني بـانخج :برى كري

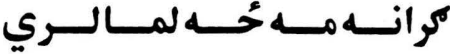

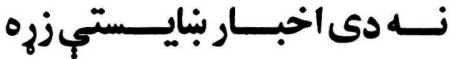
دغــــروشينــشوبي شحنكيـــل

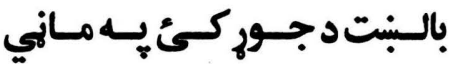
دوارهه وروك سـي شـين خـالى اوسمـهـــم ديكـلانكــــي بوى مـه د برانك د خولـوحَي

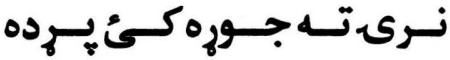

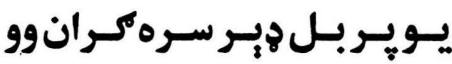

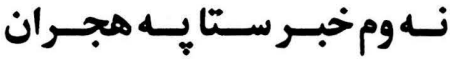

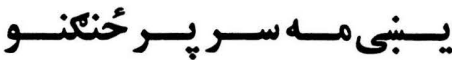

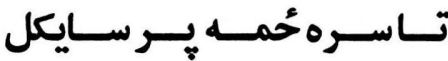

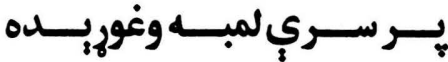

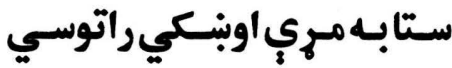

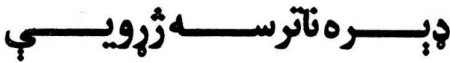

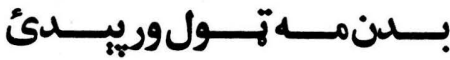
اوسـترى تعلــيم د ســه كرانــو

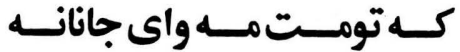

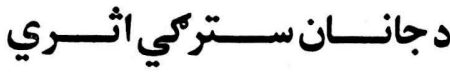

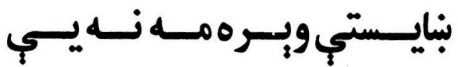

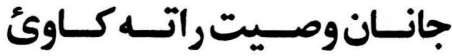
سـتابـه وهبــر ارمسان دزهره سـم

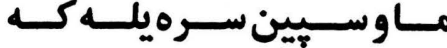
مـاوسـيـن سـره حملـي كري

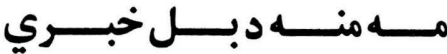

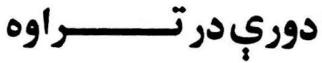

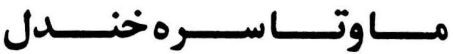

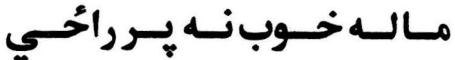

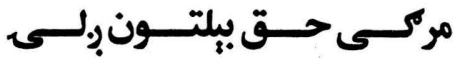
مـاوكــرانتــه ديــــــــي

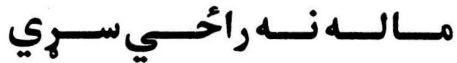

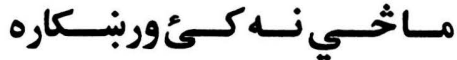

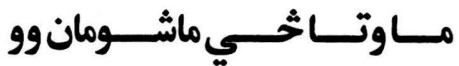

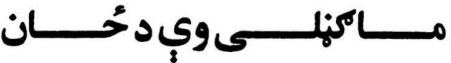

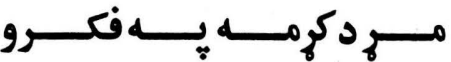

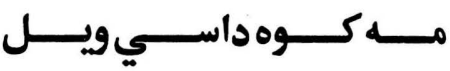

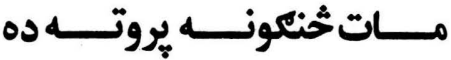
مـرك بـه راسـي مـابـهـيوسـي

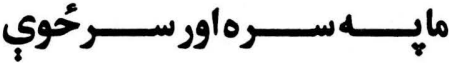

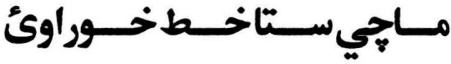

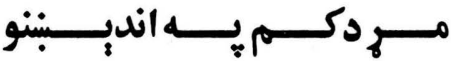

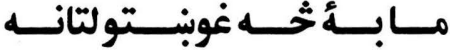

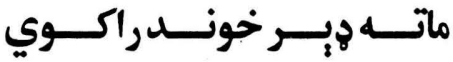

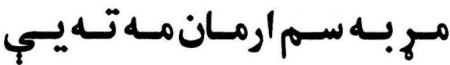

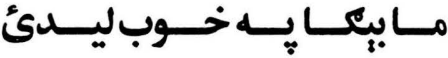
مـرك بـه راسـي مـهـهـهـ زهـم 


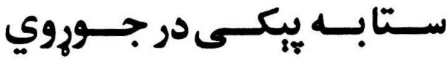

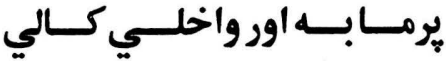

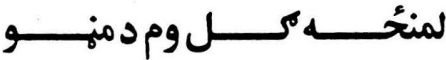
زمهـابـــن ســوحي بــي اوره

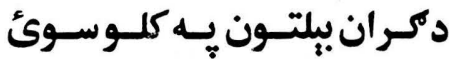

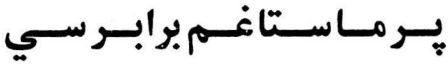

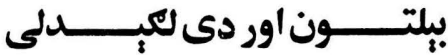

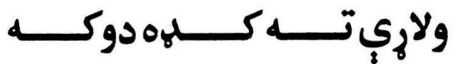

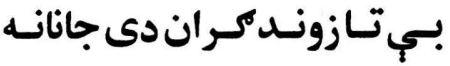

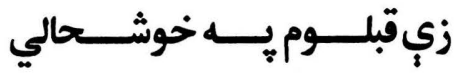

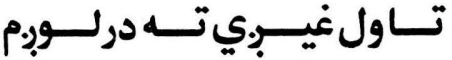

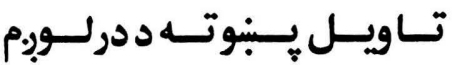

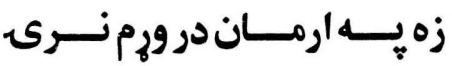

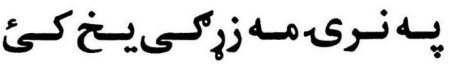

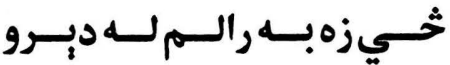

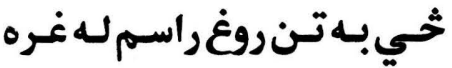

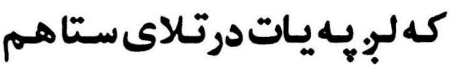

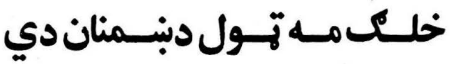

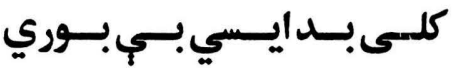

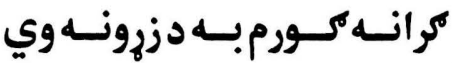

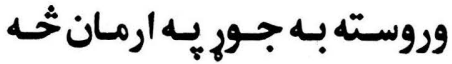

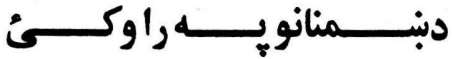

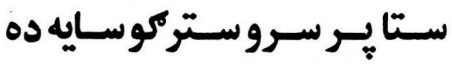

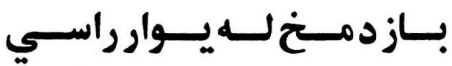

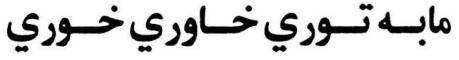

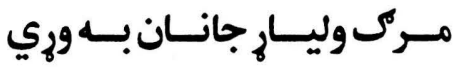

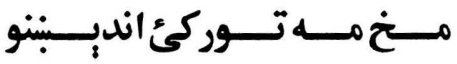

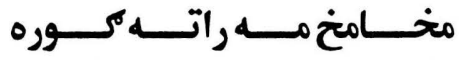

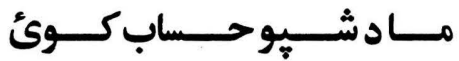

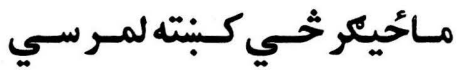
مركسـى حسـق دى مـــورومنلـــى

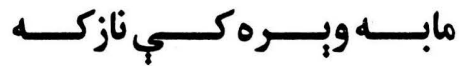

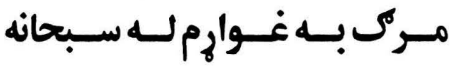

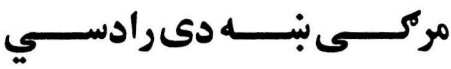

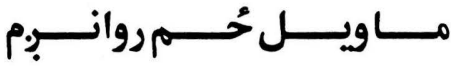

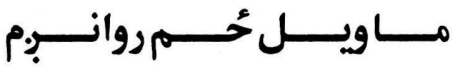

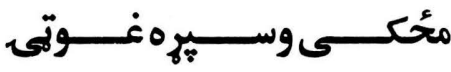

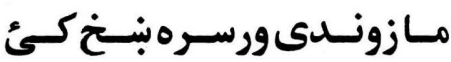

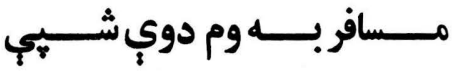

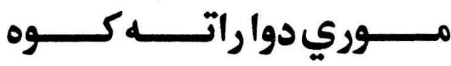

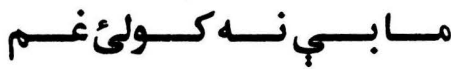

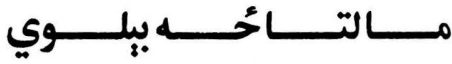

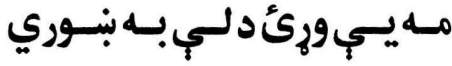

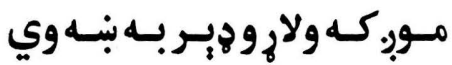

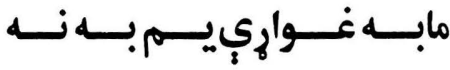

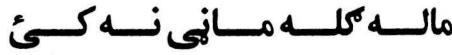

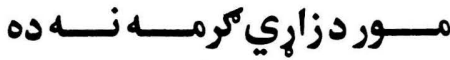

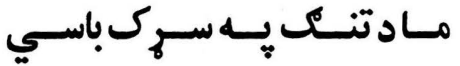




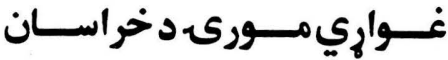

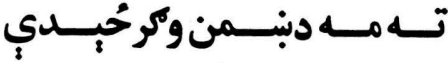

حـقـقرايــلـــــــادي وراري

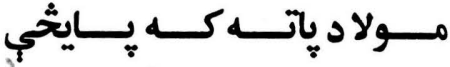

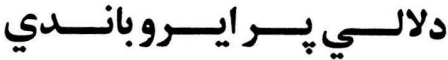
دغـــروشينــشوي دُندكيــــل

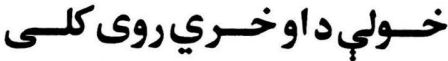

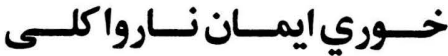
دايـودادوخــي خــداى وكسئ

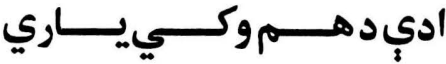

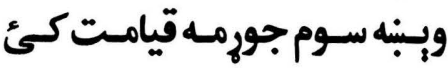

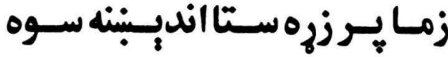

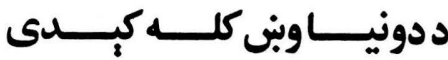

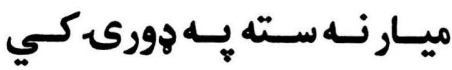

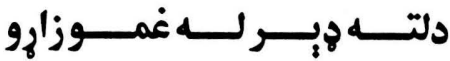

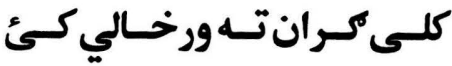

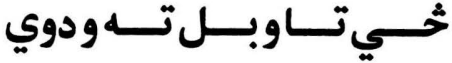

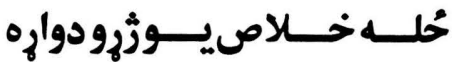
لالـــــــوري كـاهى تركــئ

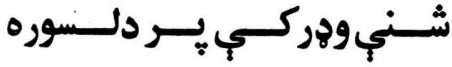

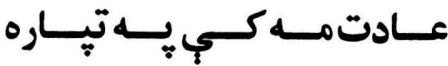

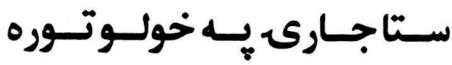

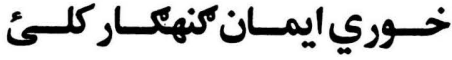

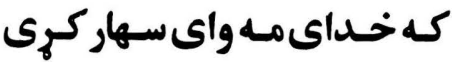

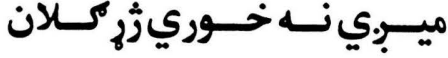

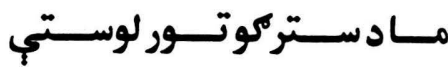

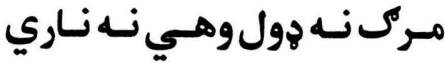

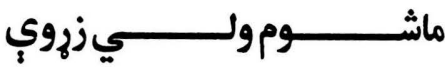

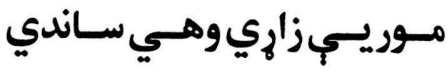

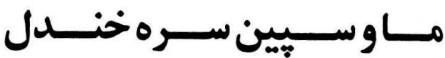

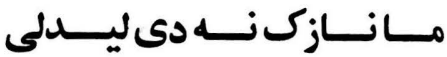
مـــــــــــــــــــــــلى

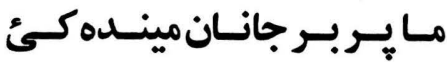

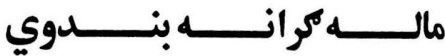
ما به خوبكي كران رخصت كئ مينـه نـه ســوه ســرهلمبـهـ ســوه

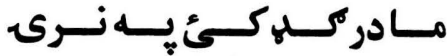
مادخداى تر سيين لومري كي

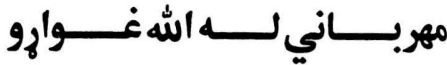

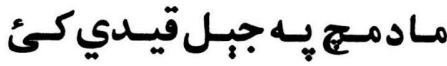

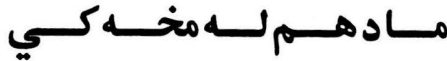

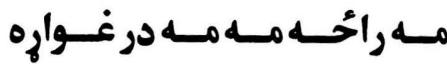

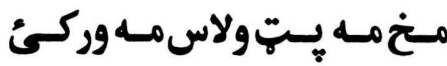

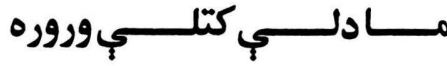

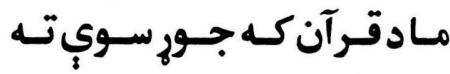

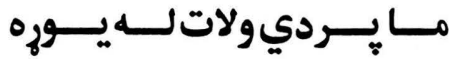

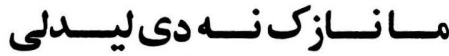
مابـــــهـواى نـــــــــــــــلى 
اديكــــانبـهـ دلــي هوسـي

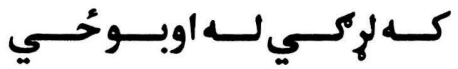

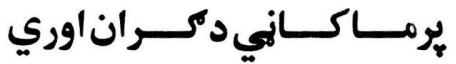

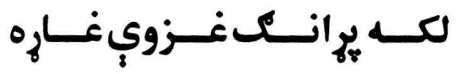

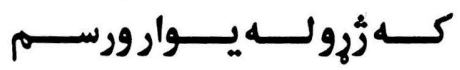

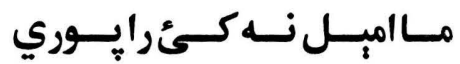

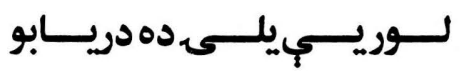

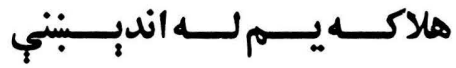

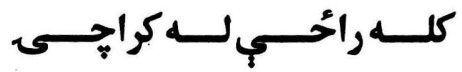

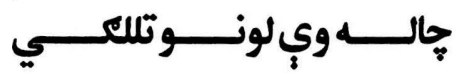
ستي دادوئ ثخي خداى ووكئ

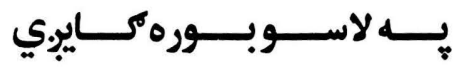
اوسمـهــمـمديكـلانكـــي

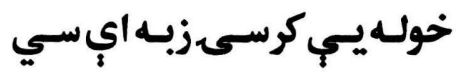

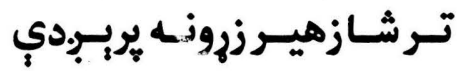

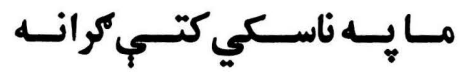

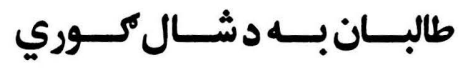

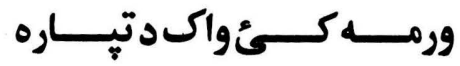

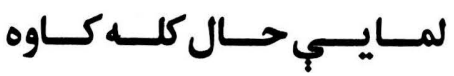

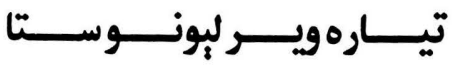

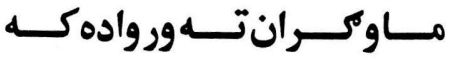

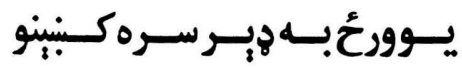

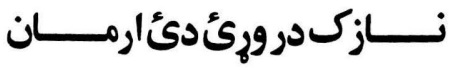
ادي يـهـهـــولاكـهـ سـروبـن

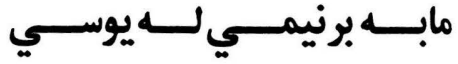

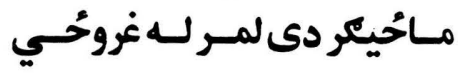

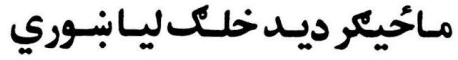

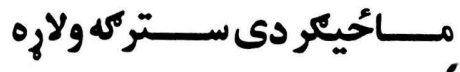

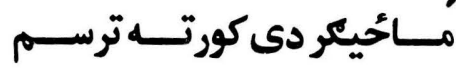
مـاحُيكر دى كـران مـهــــوري

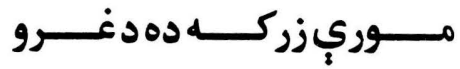

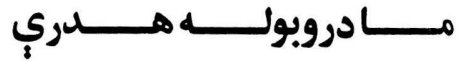

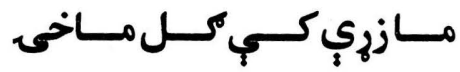

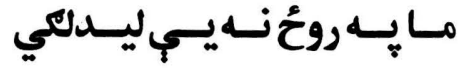

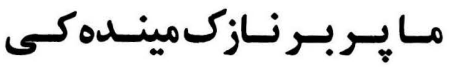

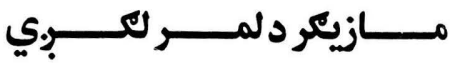

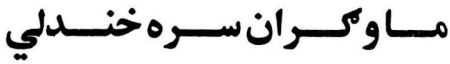

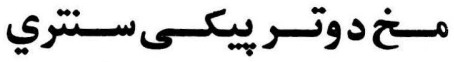

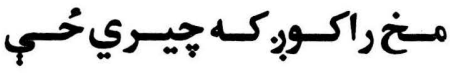

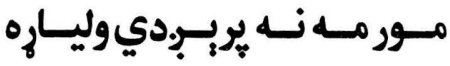

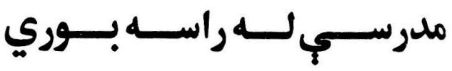

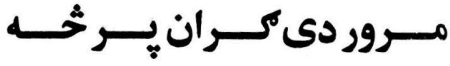

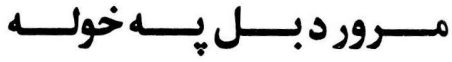

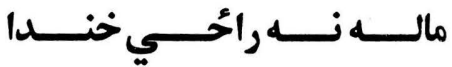

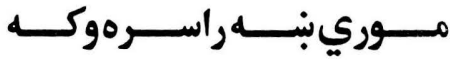

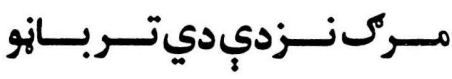

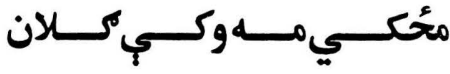

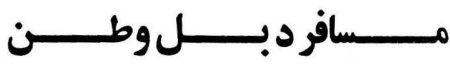




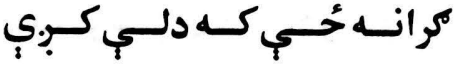
سبر. دهـل درختــي مــاتبري

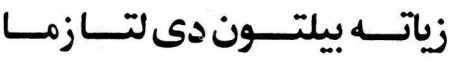

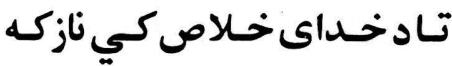

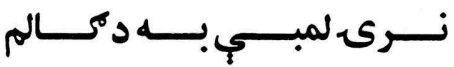

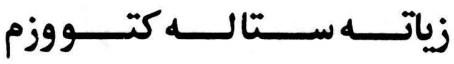

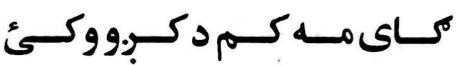

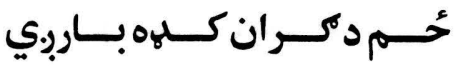

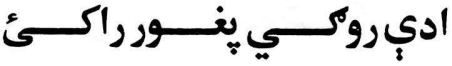

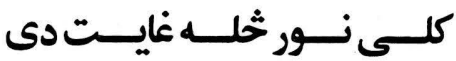

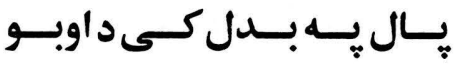

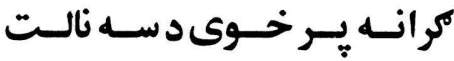

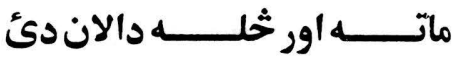

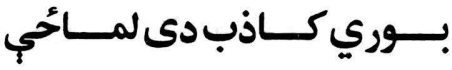

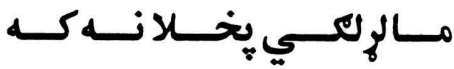

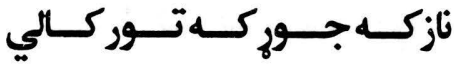

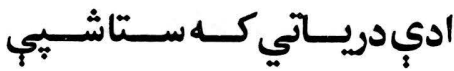

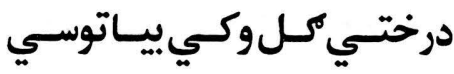
يـــ لاس رخسصت بنايستسي را

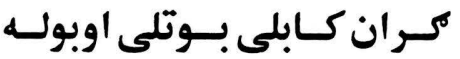

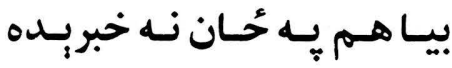
كران سوى بلكي دحُانياركى

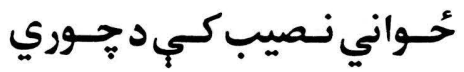

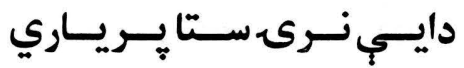

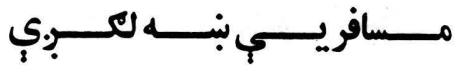

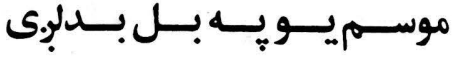
خ راواروه ترش

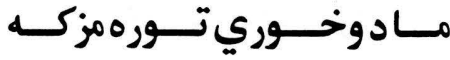

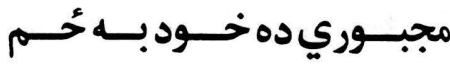

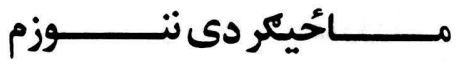

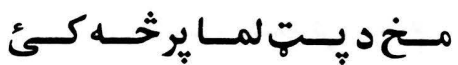

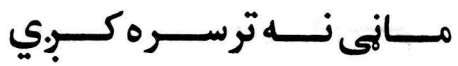

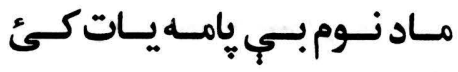

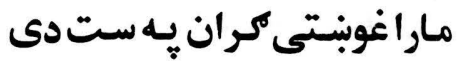
روروندمزئو

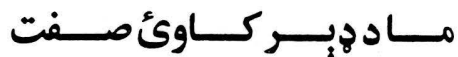

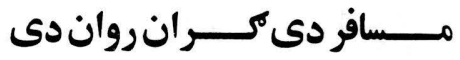

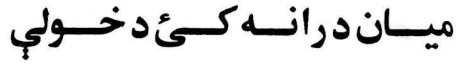

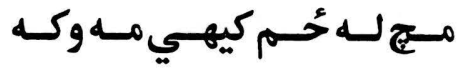

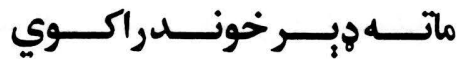

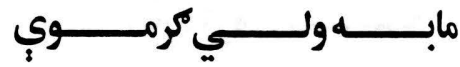

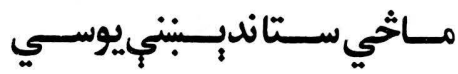

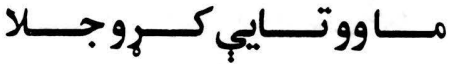

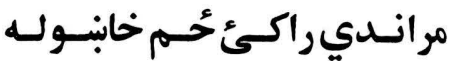

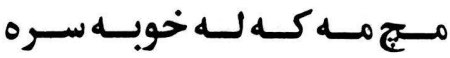

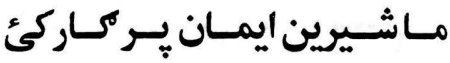

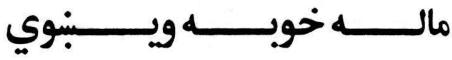
مــرك الــميـــوروحُرائسـي 
وخـت دمكران دميلـوتر سـوى

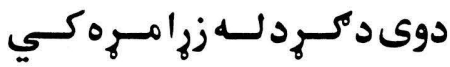

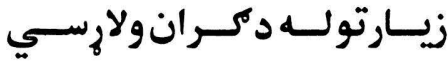

خـي سـتاكر انسى د بينثحـوشـيو

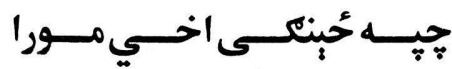

نـنـبـه د خونــدنـهـ وي روزي

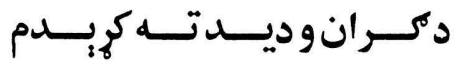

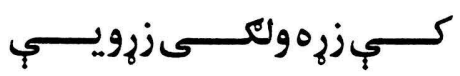

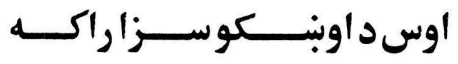

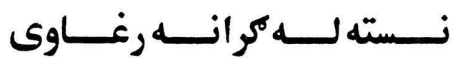

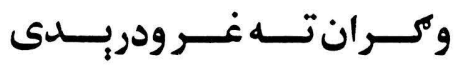

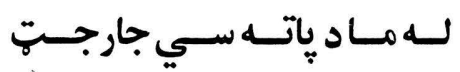

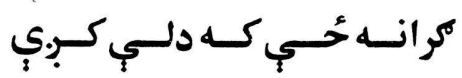
زماجاركـل دتر كران جـار سي

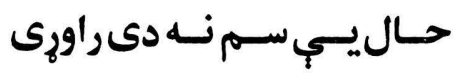

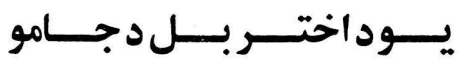

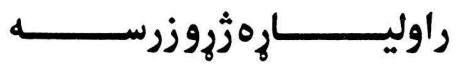
يـردى ملـكـ دى حُـم بنـارهلــ

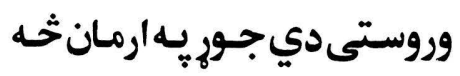

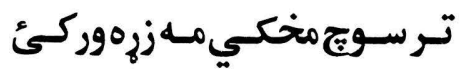

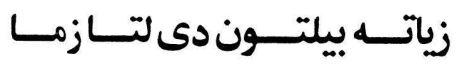

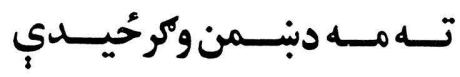

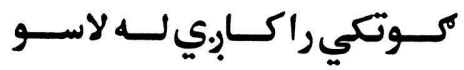

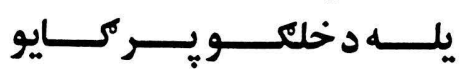

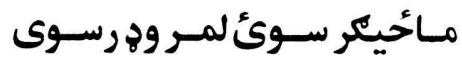

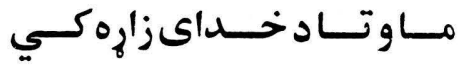

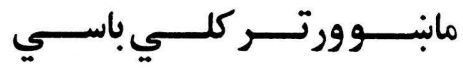

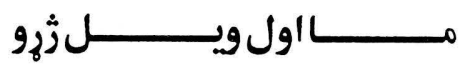

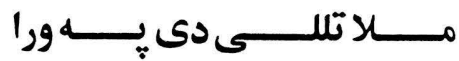

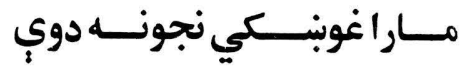

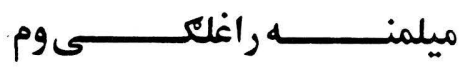

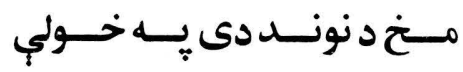

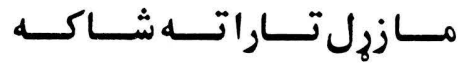

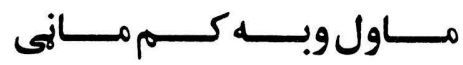

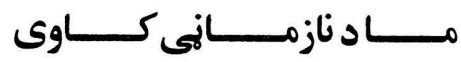

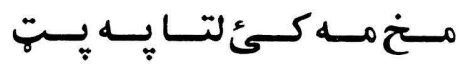

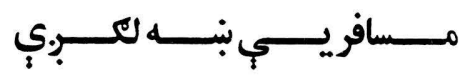

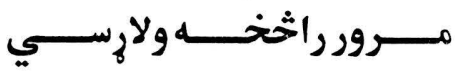

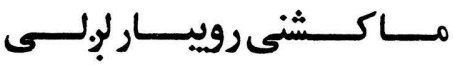

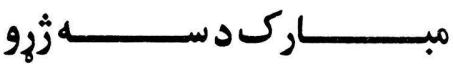

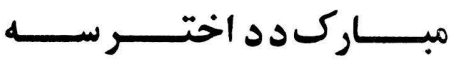

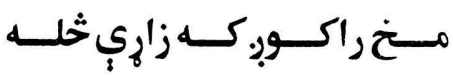

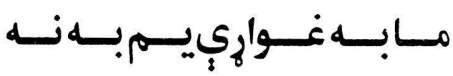

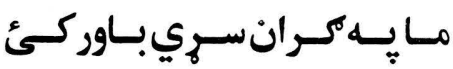

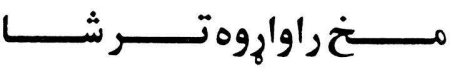

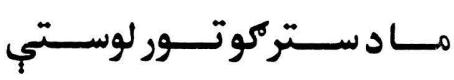

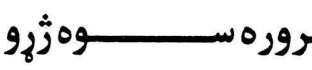

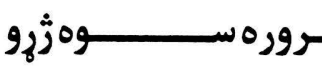




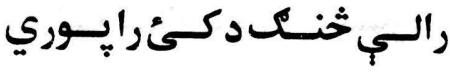

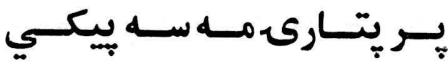

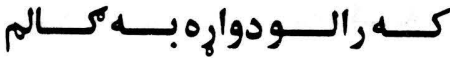

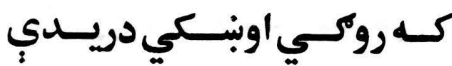
تـابـهـ خيـال لـوتكين جـوركئ

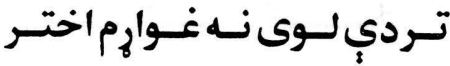

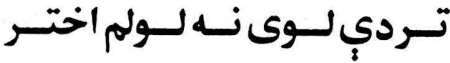

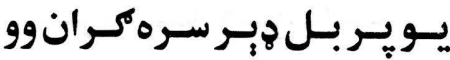

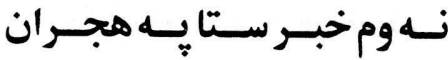

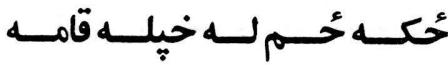
بيـابـهـ اوبــكي دمكرانتوسي درختسيكل وكي بيـاتوسي خـود بــه اوبنــكي يـرتـاتوسي كـوروهوربـه دخـولب ميـان كيجي

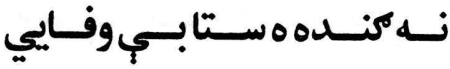

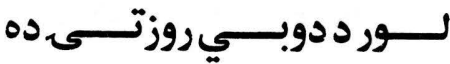

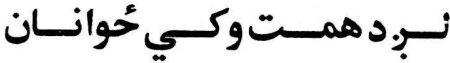

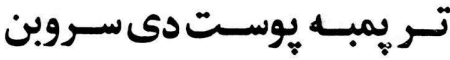

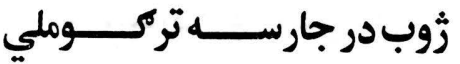

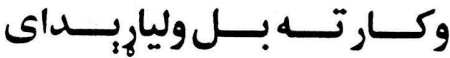

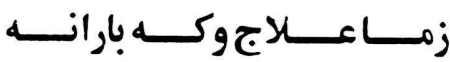

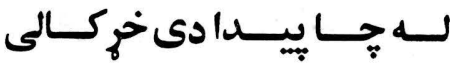
تـكـيـي دزر سـيف اله خـان

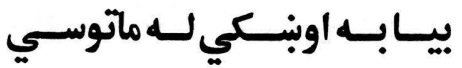

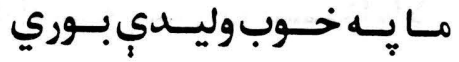

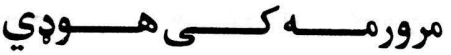

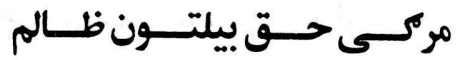

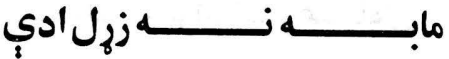

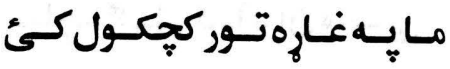

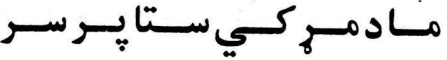

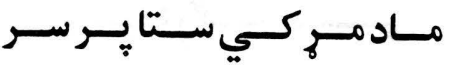

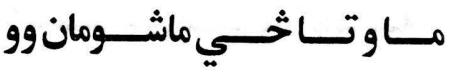

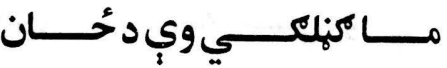

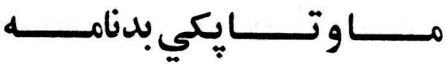
مـرك بـهـ راسـي مـابـهـيوسي

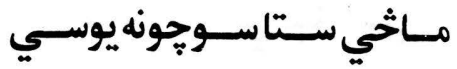

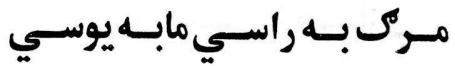

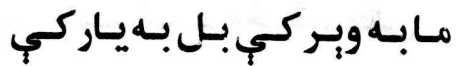
مــابــهـ خــداى نـــهــــــواروي

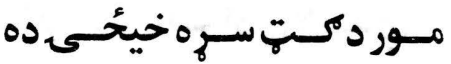

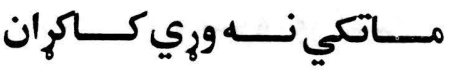

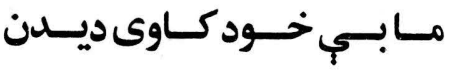

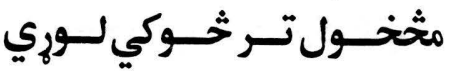

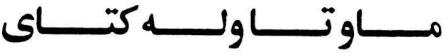

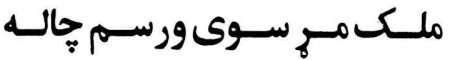
مــوريسي غـوا يـلاريسي غــوني

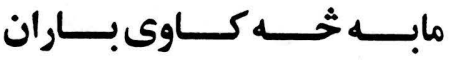

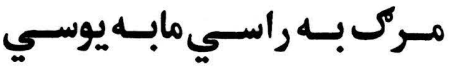




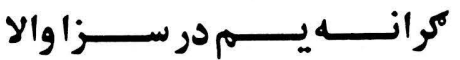

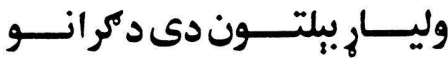

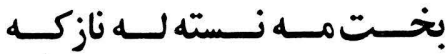

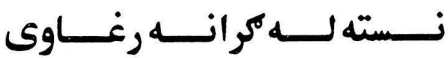

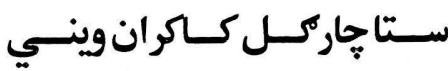

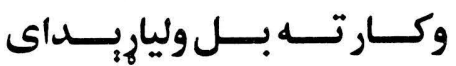

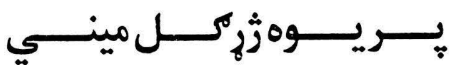

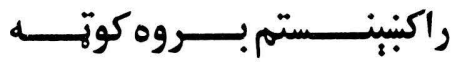

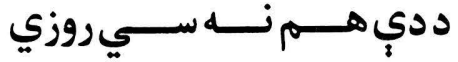

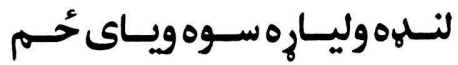

مسشب رتّ مـسه خبـل نـــه دى

خـوب نالم دى ثخي بيـاراسي

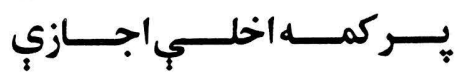

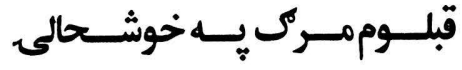

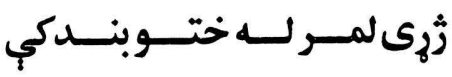

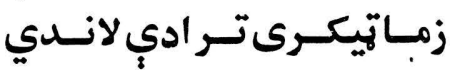

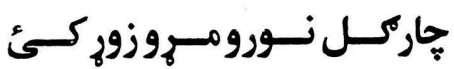

بيـابـه اوبــكي دمكرانتونسي

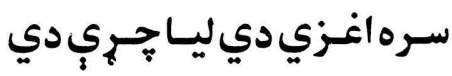

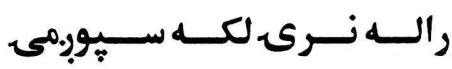

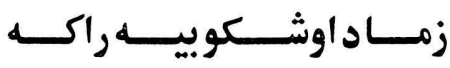

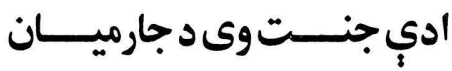

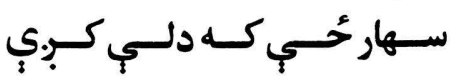

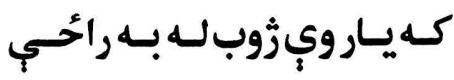

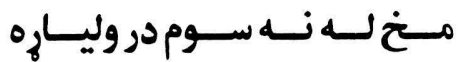

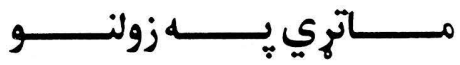

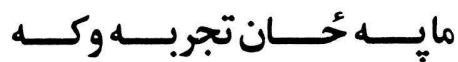

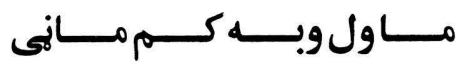

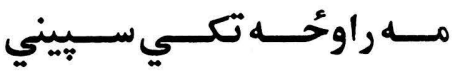

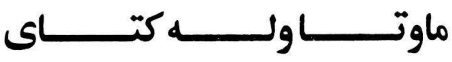

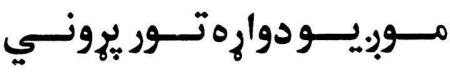

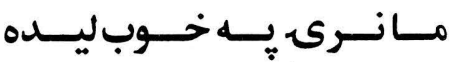

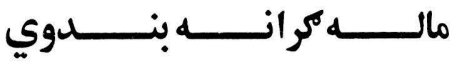

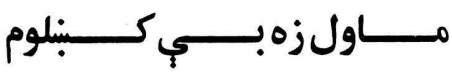

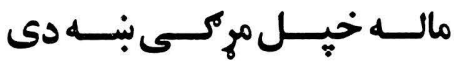

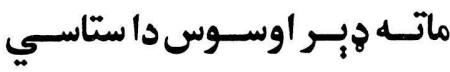

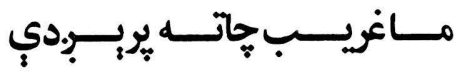

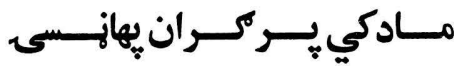

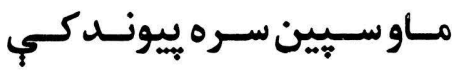

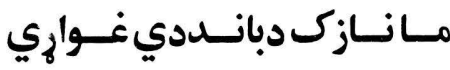

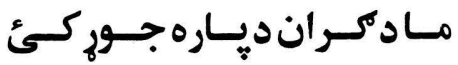
مـرك بــهـ راسـي مابـهـيوسـي

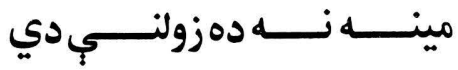

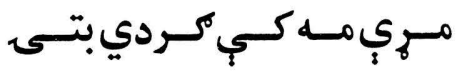

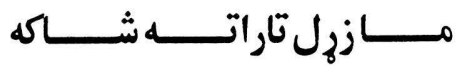

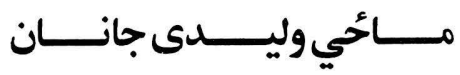

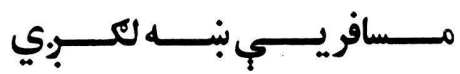

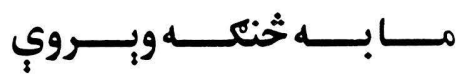




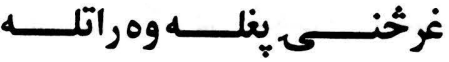

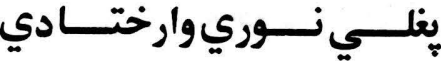

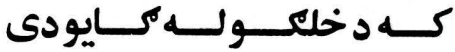

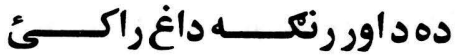

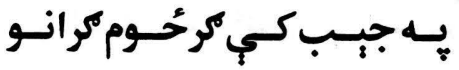

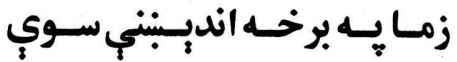

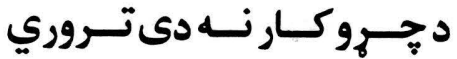

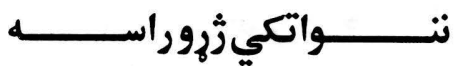

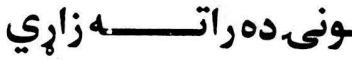

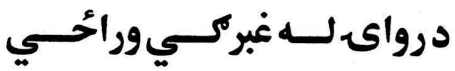

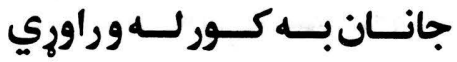

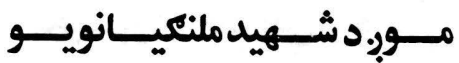

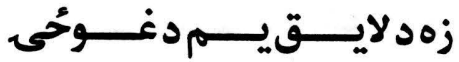

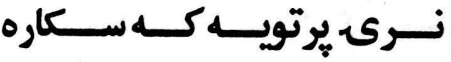

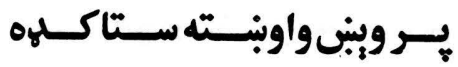

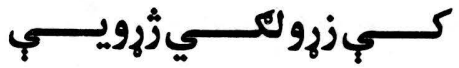

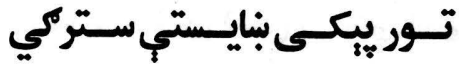

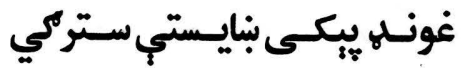

سـور بيكسى بنايستئي سـتركي

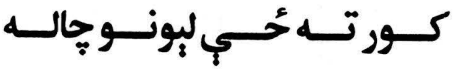

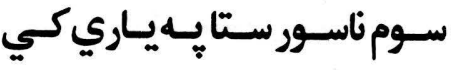

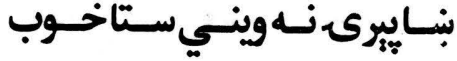

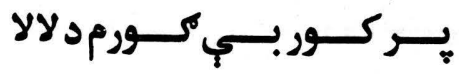

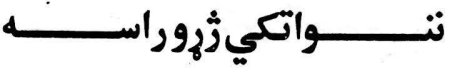

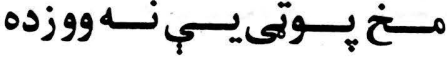

ماتبنكري يه كتّكي ستادي مــرور دخــداىلــــــرودى

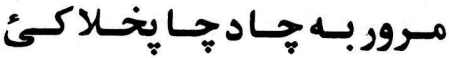

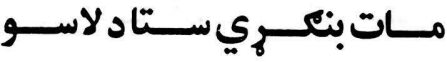
مركى رالى ليـاري دوي سـوي

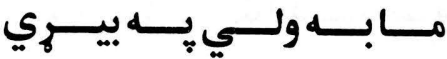

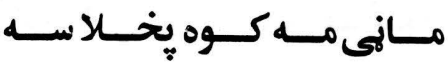

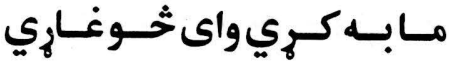

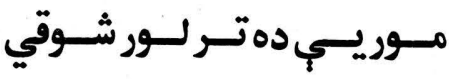

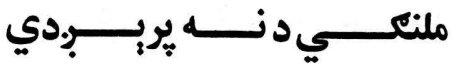

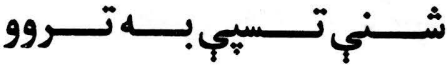

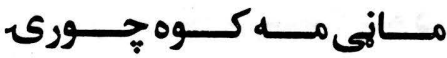

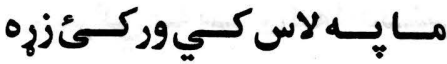

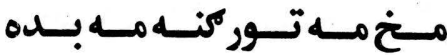

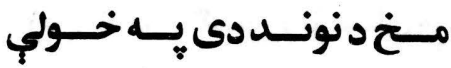

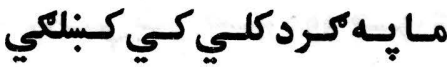
مـابـهــردكلهيكي كـبنكي مـايـهـردكلهيكي كـبنكي

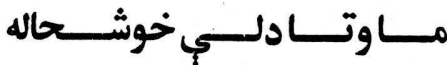

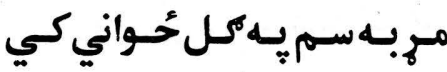

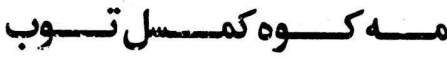

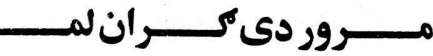

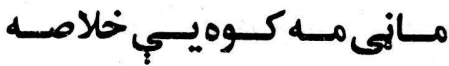


نـن راتـهـ بـروتدى يـر بالـبنت

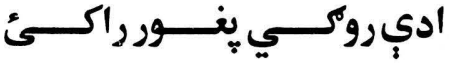

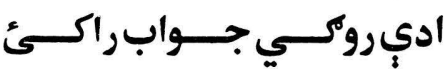

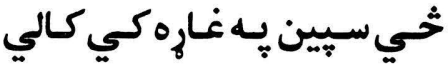

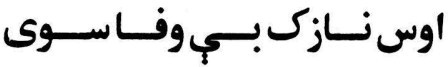

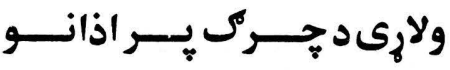

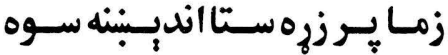

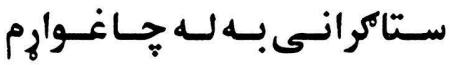

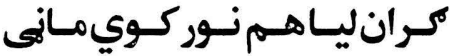

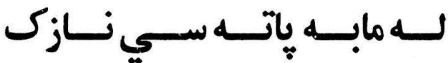

كه وي زونـدى رابـه سي كرانها

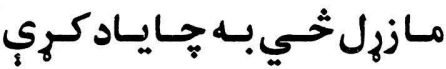

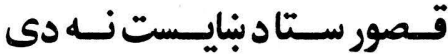

سـتركي مـهـ سـري لـه اندـــبنتي

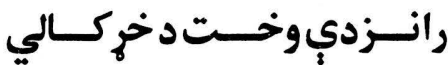

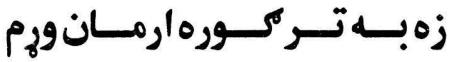

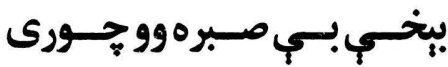

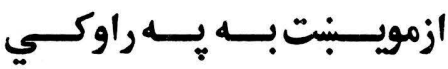

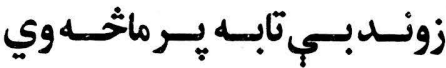

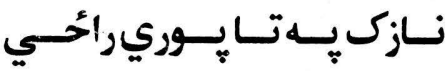

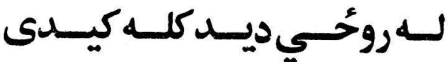

تــور يبكسى يـر سـدو سـمكئ

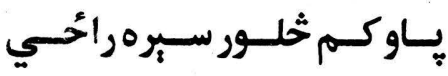

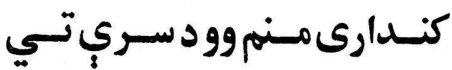

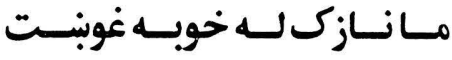

مــانـازكلـه خوبـهــــات كـئ

مـانسازكلـه خوبـهـيـات كئ

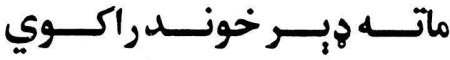

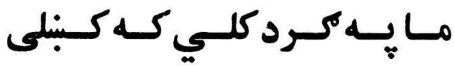

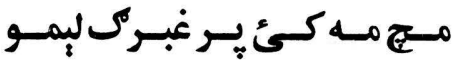

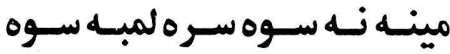

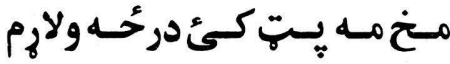

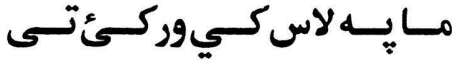

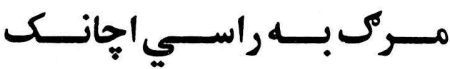

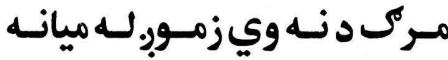

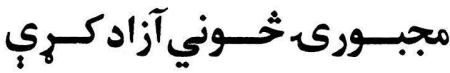

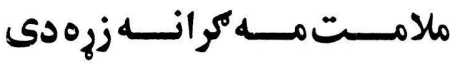

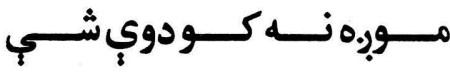

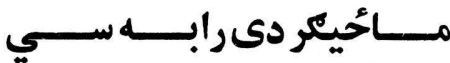

مـرك بــه راسـي ولاربسهـ سـم

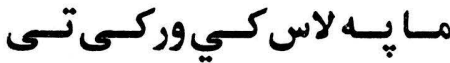

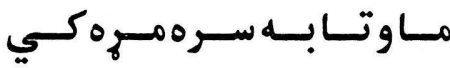

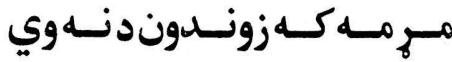

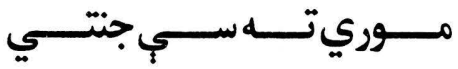

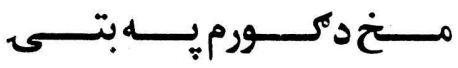

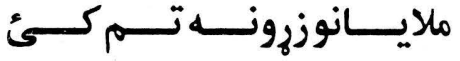

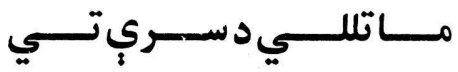

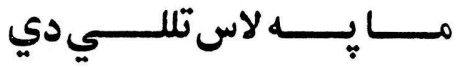


يـوه روحُ بـهــــوربـله دونيـاوري

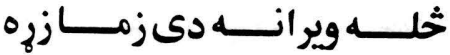

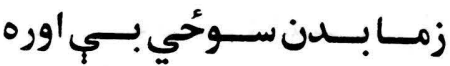

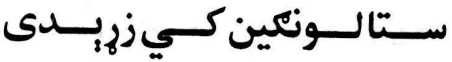
دييوندكبتى دى كي خـوري

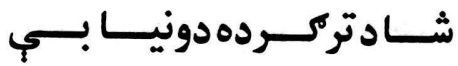

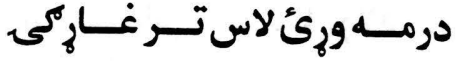

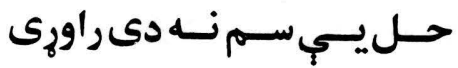

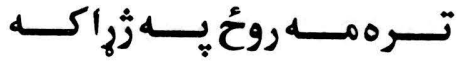

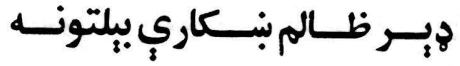

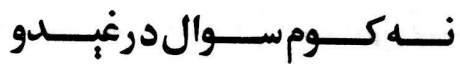

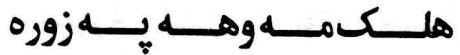

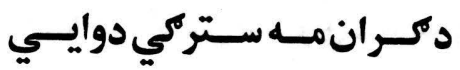
خـال مـه لهم دى كـلانخسوري درختى كل وكسيـيـاتوسي

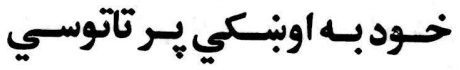

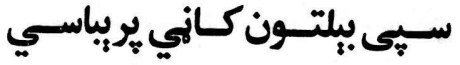

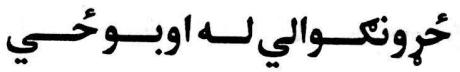
خداى خبر دى خُي كران راسي

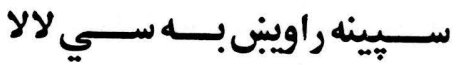

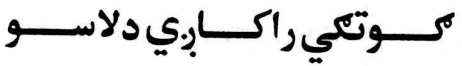

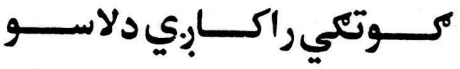
يـركـران معنسوم نـهـ دى كرانسى

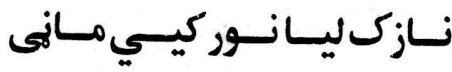

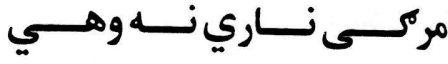

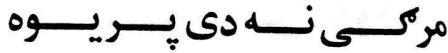

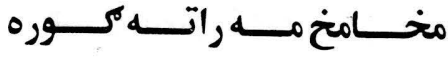

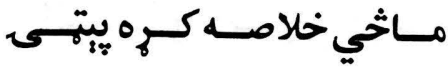

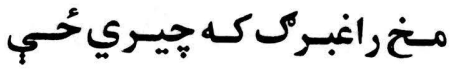

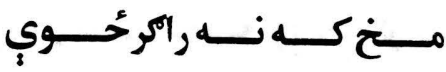

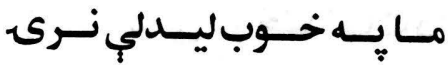

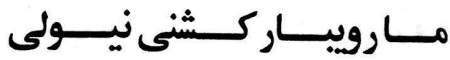

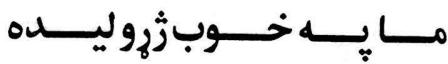

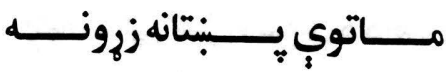

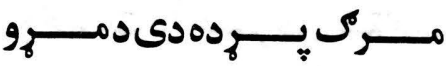

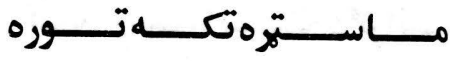

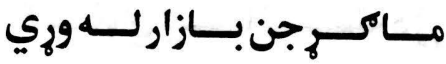

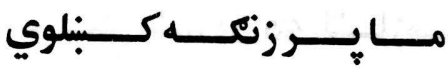
مـاخــي ستاسـوجونه يوسـي مـركبــ راسيـمـابـهيوسي

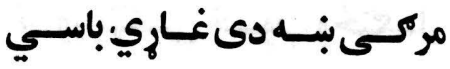

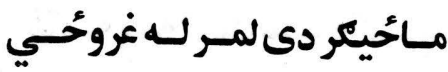

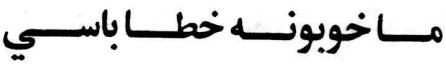

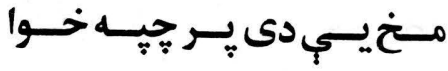
كروروندمزئرو

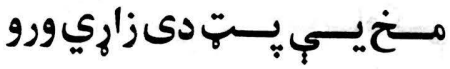

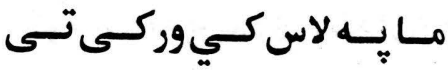

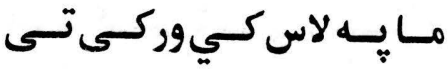




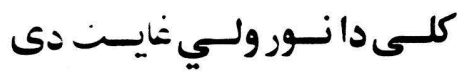

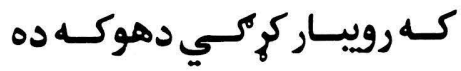

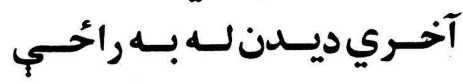

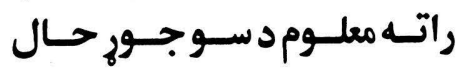
ددونيــاكـاركــوي جـــورى

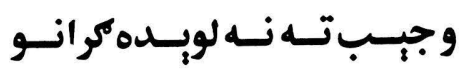

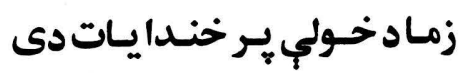

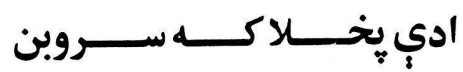

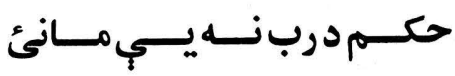
جناسـكي كـل سـوي د دامـان

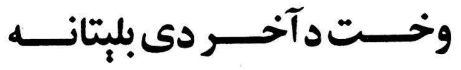

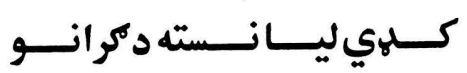

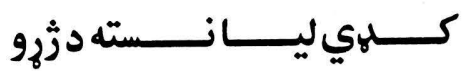

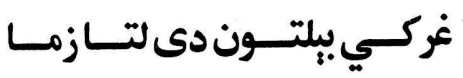

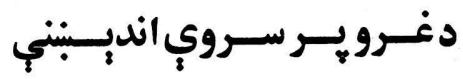

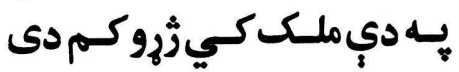

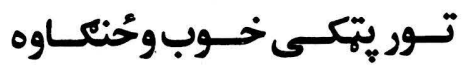

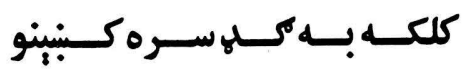

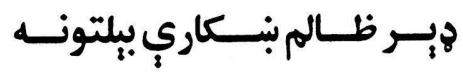
خلك واى ير كران مه وره يّنور

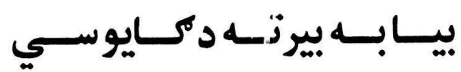

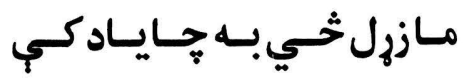
خوكى مه نه يربر.بدي ميندانيو

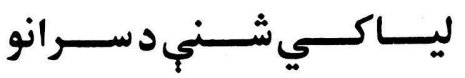

ما راغوبنتى سيّين بـه ست دى

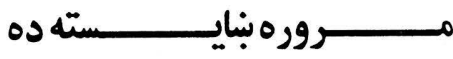

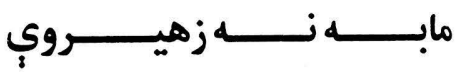

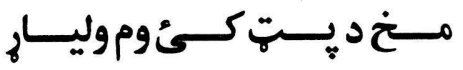

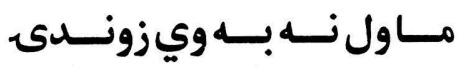

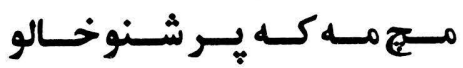

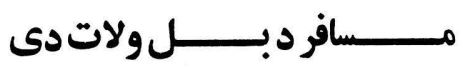

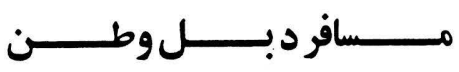

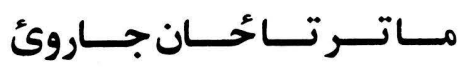

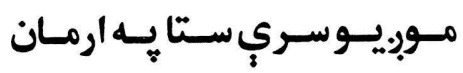

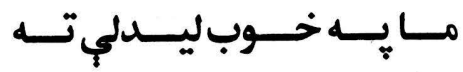

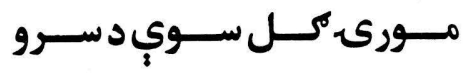

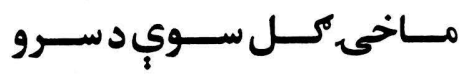

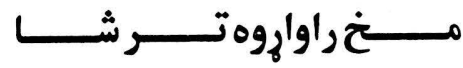

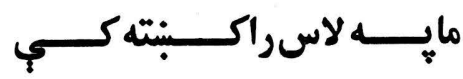

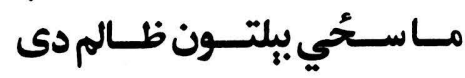

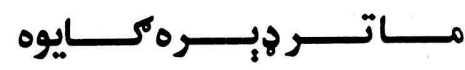

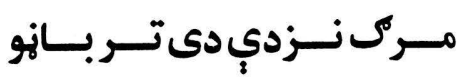

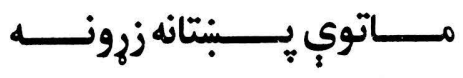

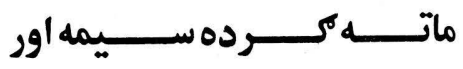
مـري دنسه غوبنــي دي توسيس

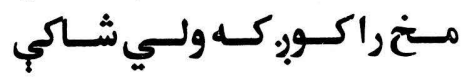

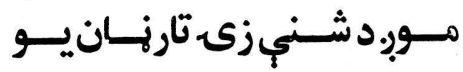

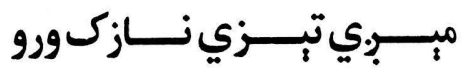


زياتــــهـــــوهكر ســـوملايـــان

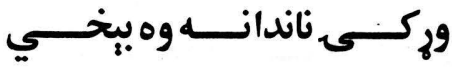

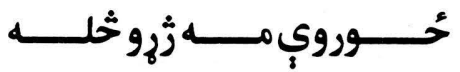

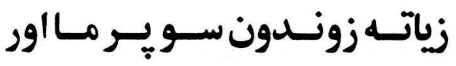

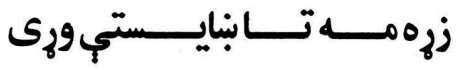

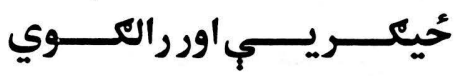

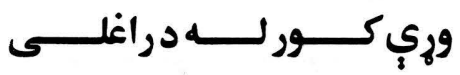

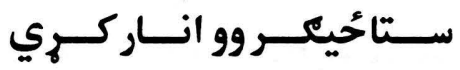

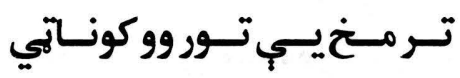

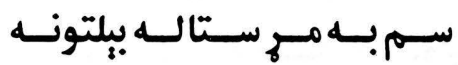

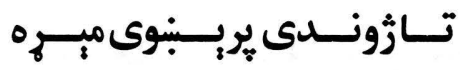

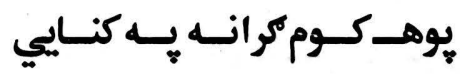

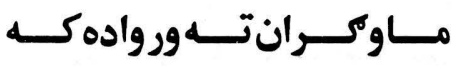

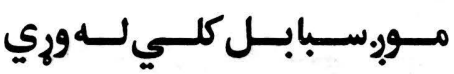

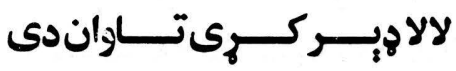

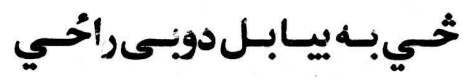

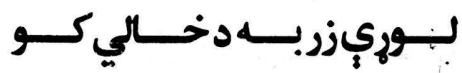

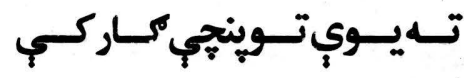

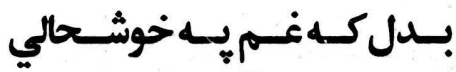

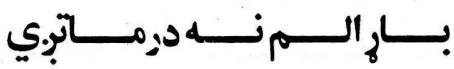

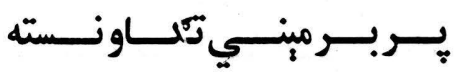

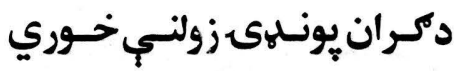

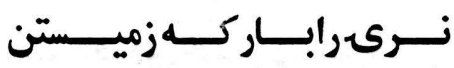

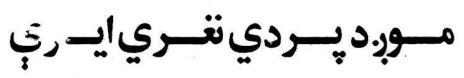

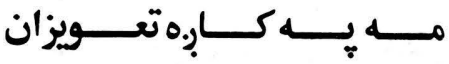

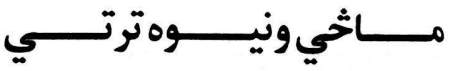

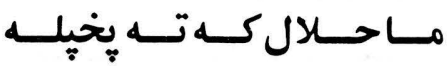

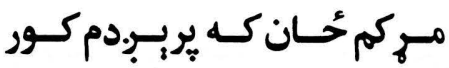

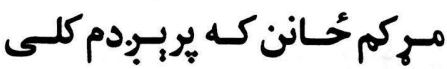

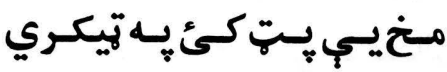

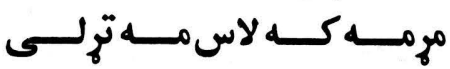

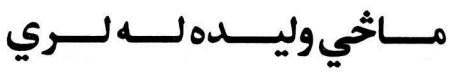

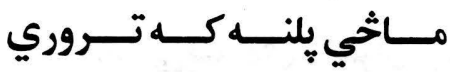

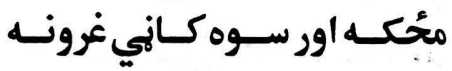

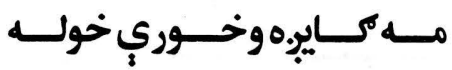

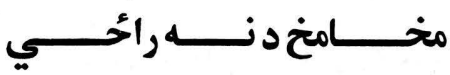

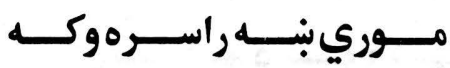

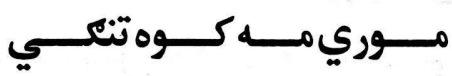

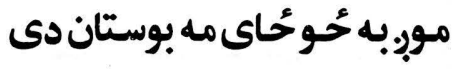

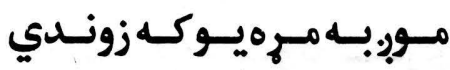

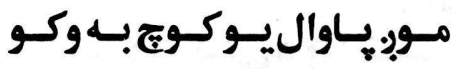

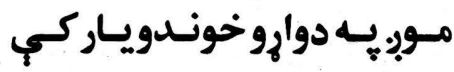

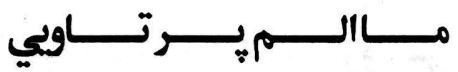

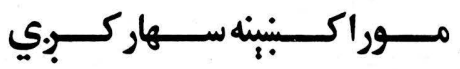

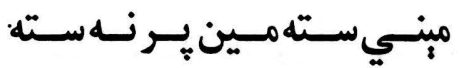

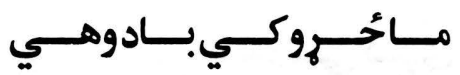

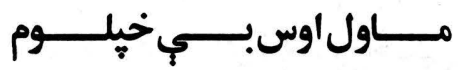

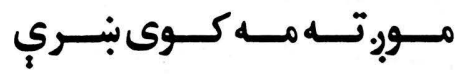




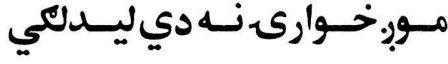

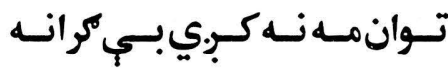

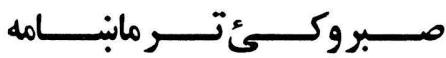

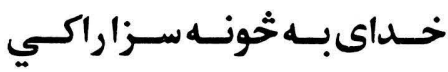

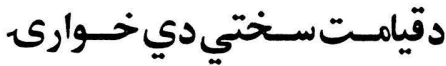

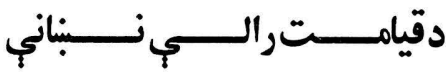

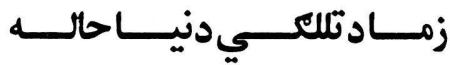

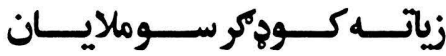

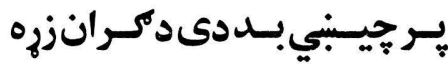

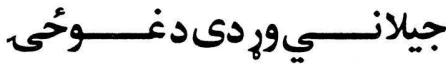

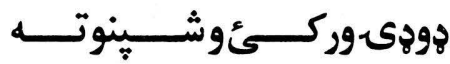
تور تيكرى تره سوي جيري كـاى مــهـ كـم د كـــرو وكـئ

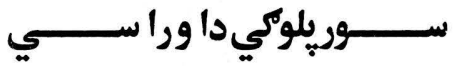

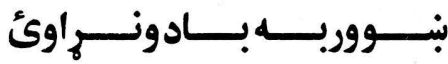

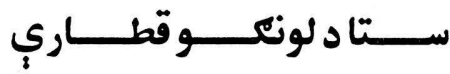
رالـي د غركسـي دوراشــيهي

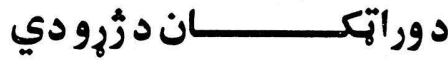

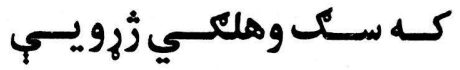

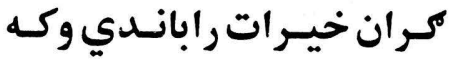

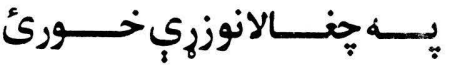

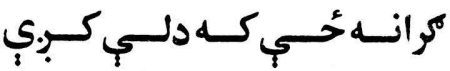
اومـريديخحساىنسه سي بحالي

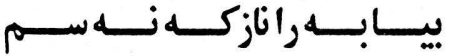

مــوب.دي وخــورود دسر سـتركي

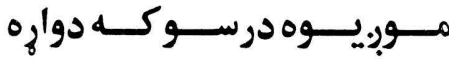

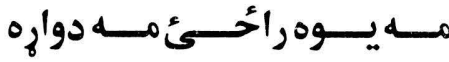

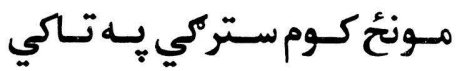

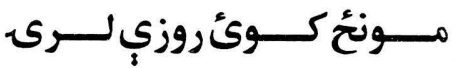

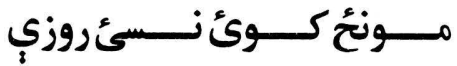

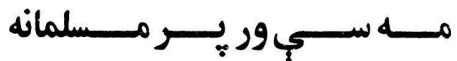

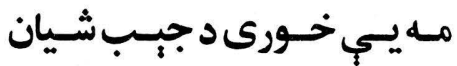

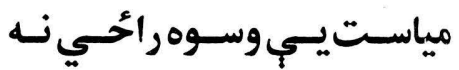

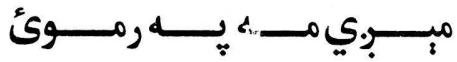

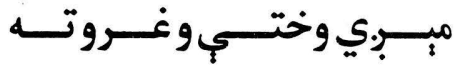

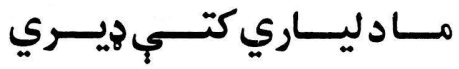

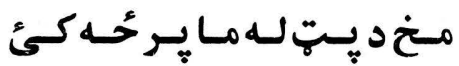

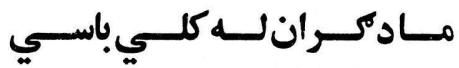

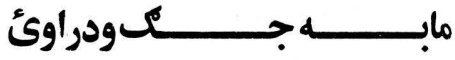

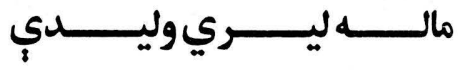

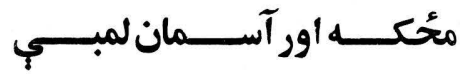

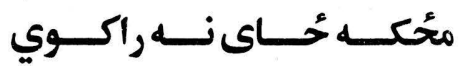

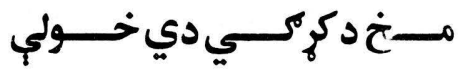

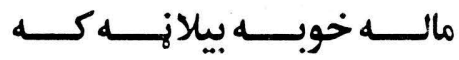

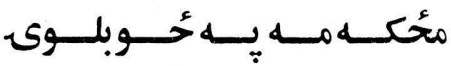

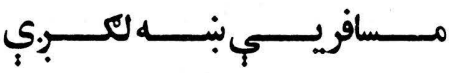

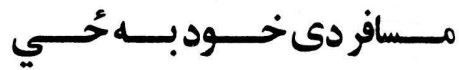

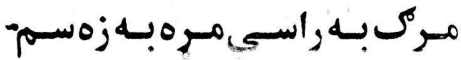


$F \Delta q$

كاكرى غاري

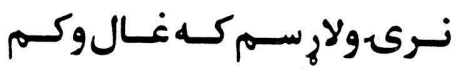

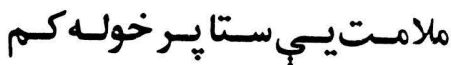

تـر خلييـت لـوى وو سـتازيره

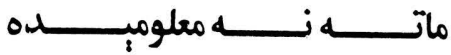

تــــصوير د اخلــــم د غنابنــــــو

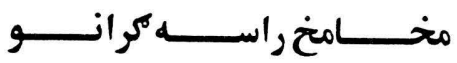

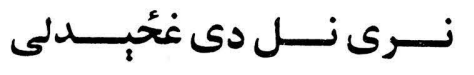

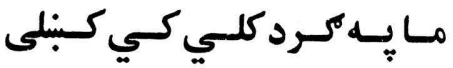

بـلتـون وج كـاني بـري باسـي

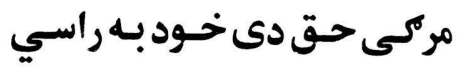

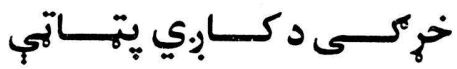

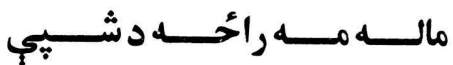

洗洗 
460

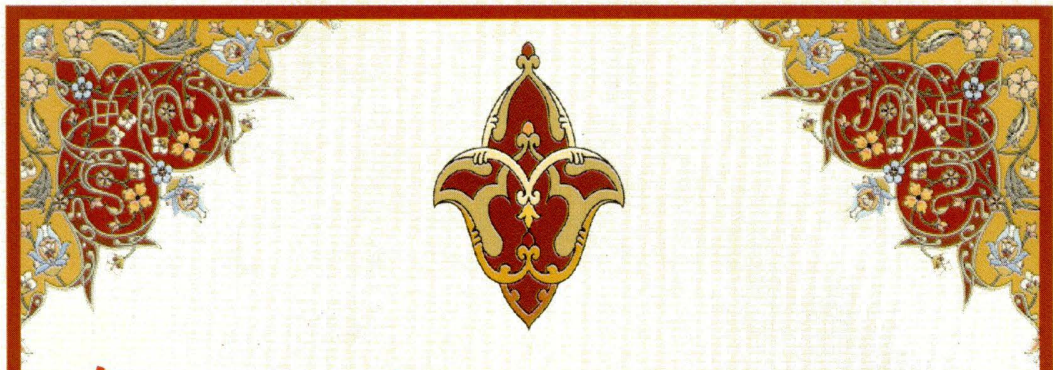

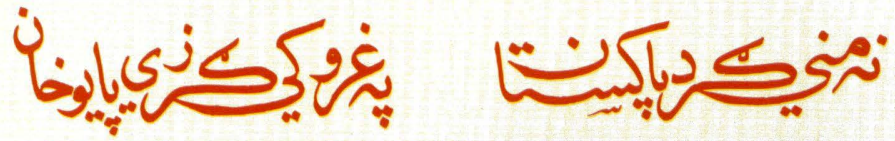

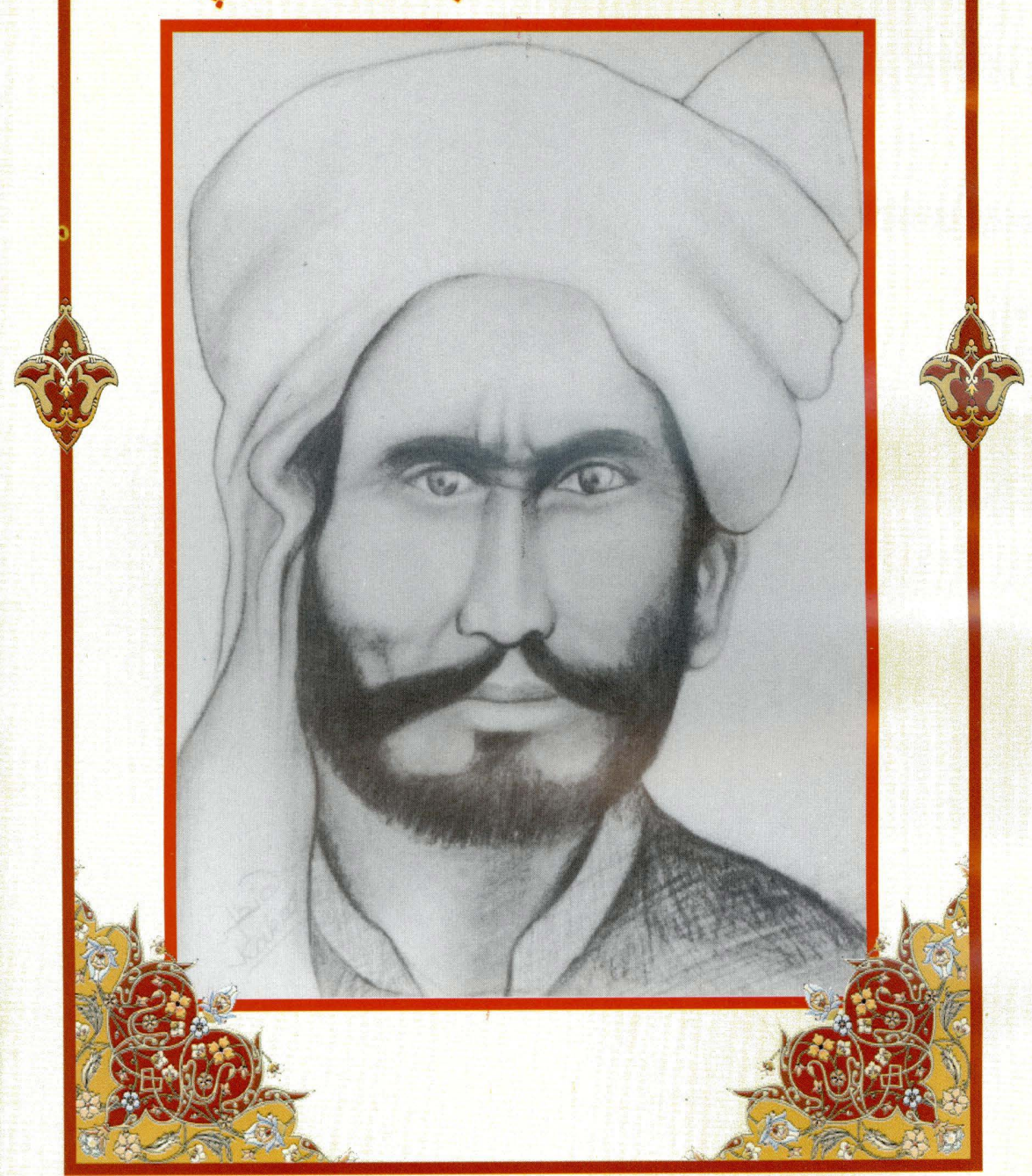




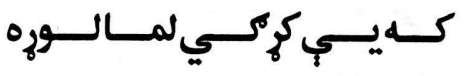

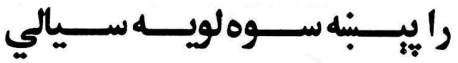

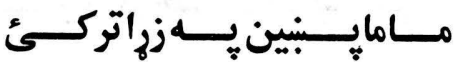

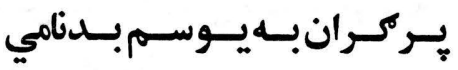

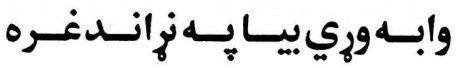

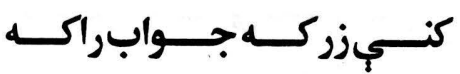

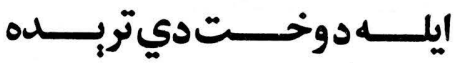

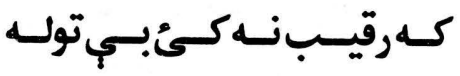

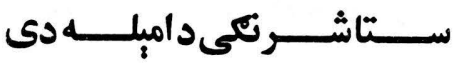

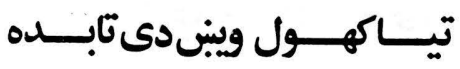

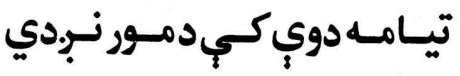

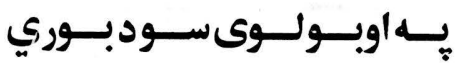

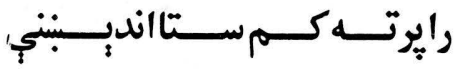

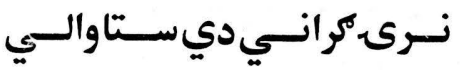

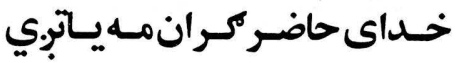

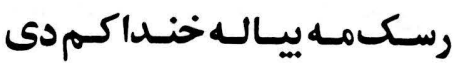

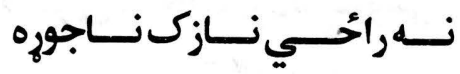

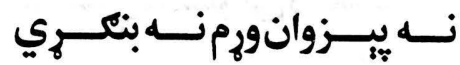

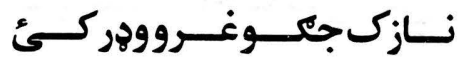

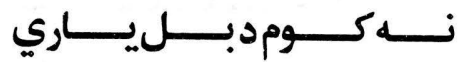

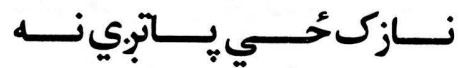

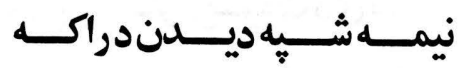

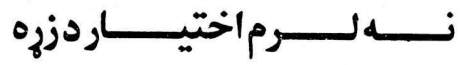

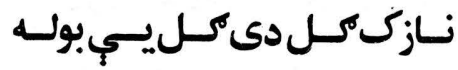

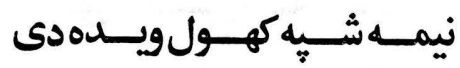

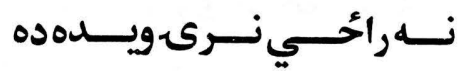

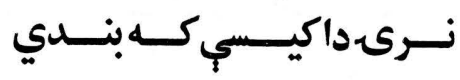

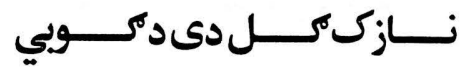

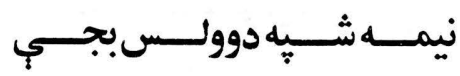

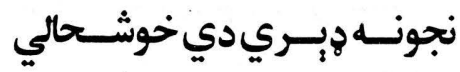

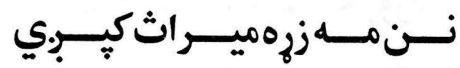

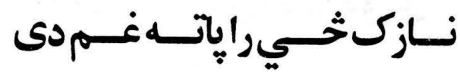


تيـايسهــرجنبنـدوىهـوري

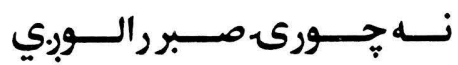

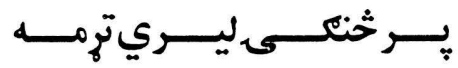

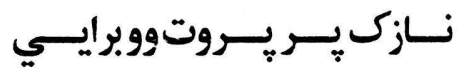

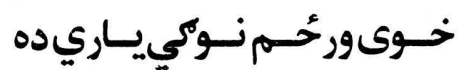

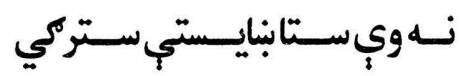

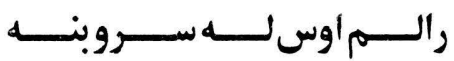

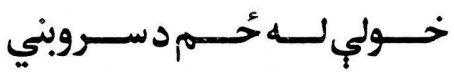

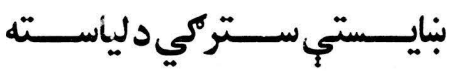

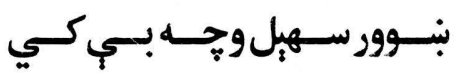

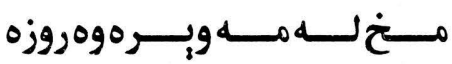

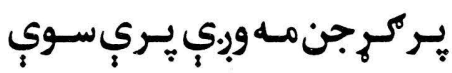

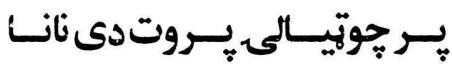

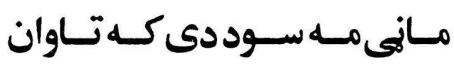

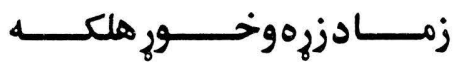

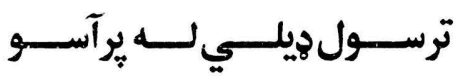

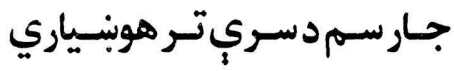

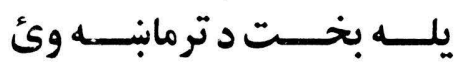

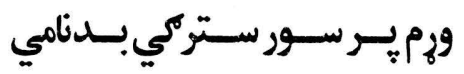

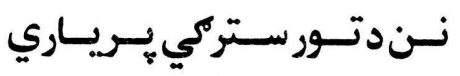

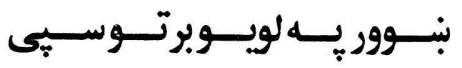

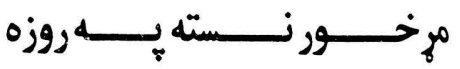

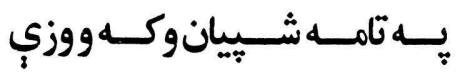
سـره د جاركـل يـهـ رنـاحسي
نـنيـيـهـوديىخـوى ائحي

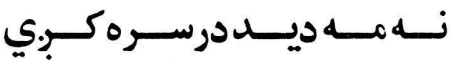

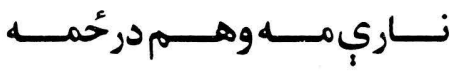

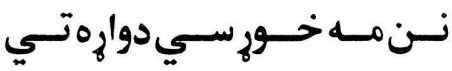

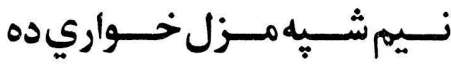

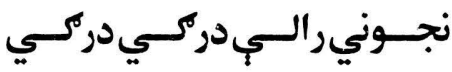

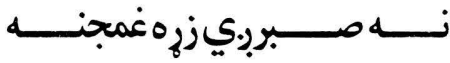

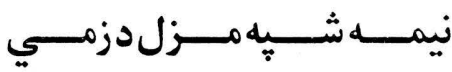

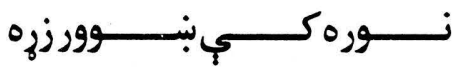

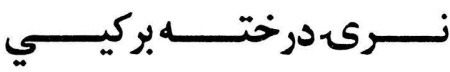

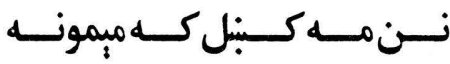
نجوني كئدي سري ووشني سوي

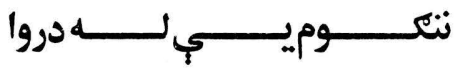

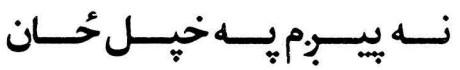

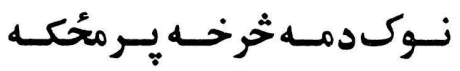

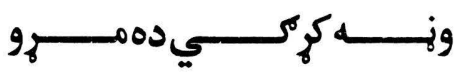

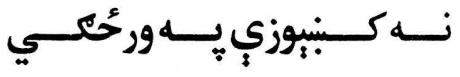
نـاز كـ زمـا وى سـتا لـه خحـه وئ

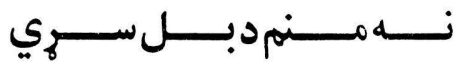

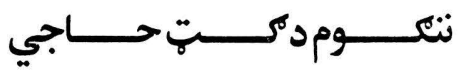

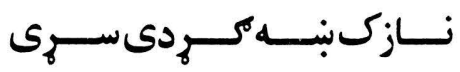

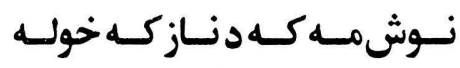

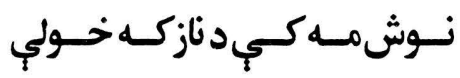

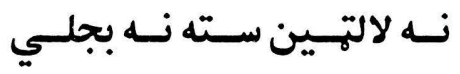




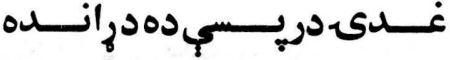

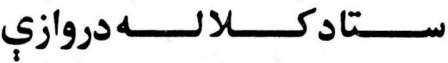

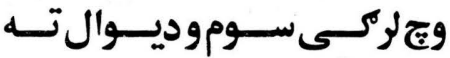
كومدوارهدروازي خلاص

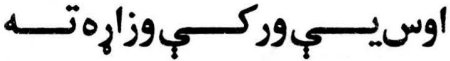
بجي نسواكويـي خولئسري

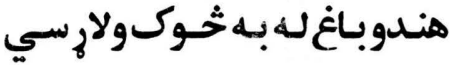

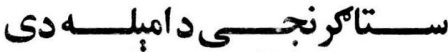

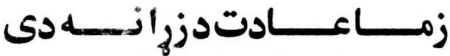

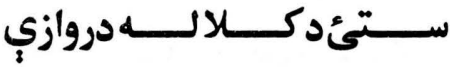

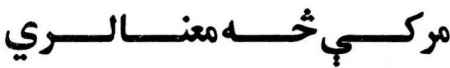

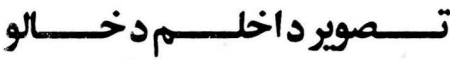

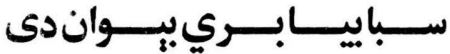

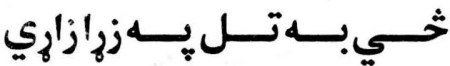

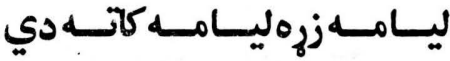

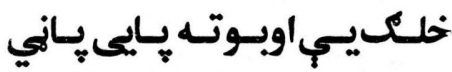

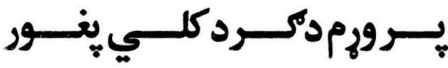

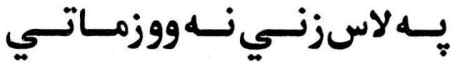

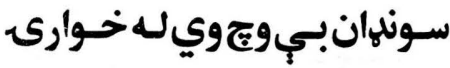

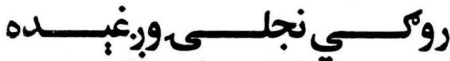

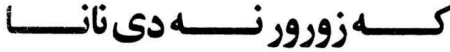

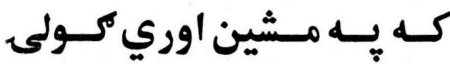
كر انـــه د دوو خونـــويــاري يهله برتـون مسه سـر بـي وسـوي

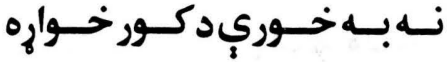

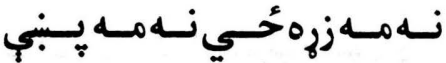

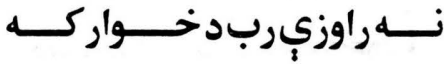

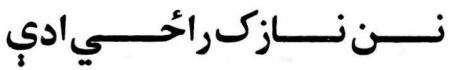

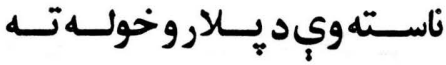

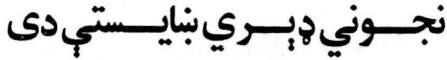

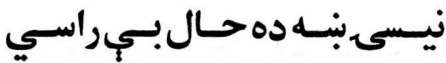

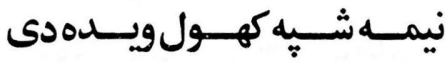

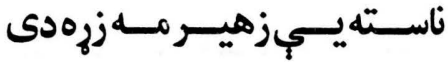

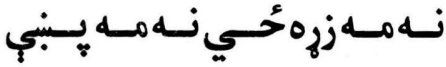

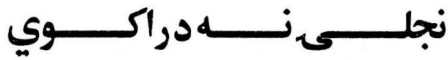

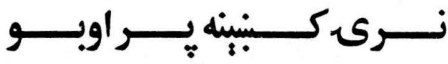

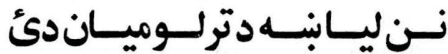

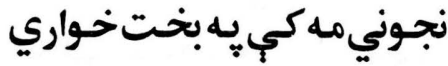

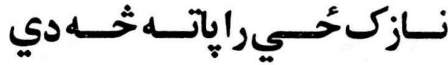

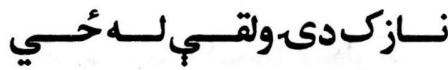

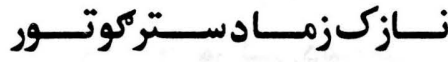

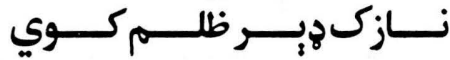

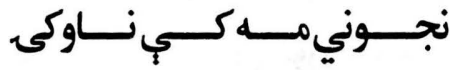

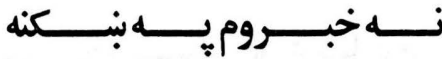

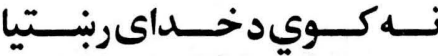

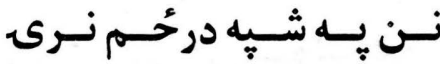

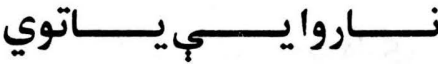

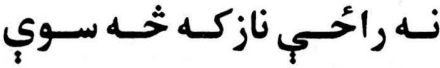


كاكرى غاري

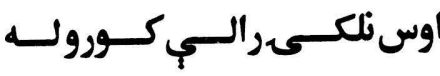

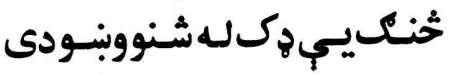

تـر يوستـتينكرمـه ده سـتاخولـ

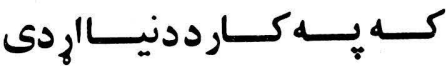

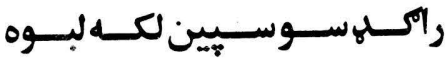

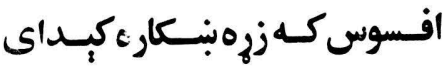

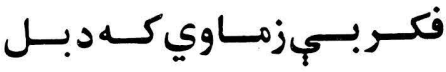

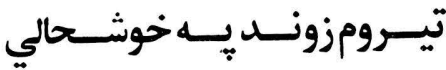

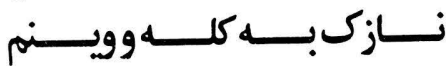

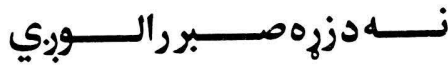

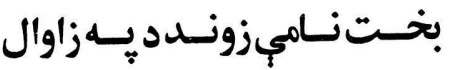

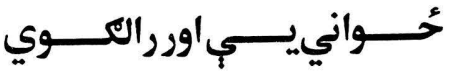

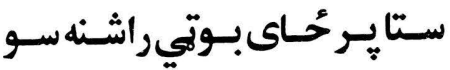

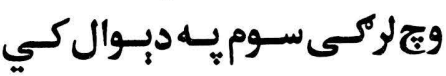

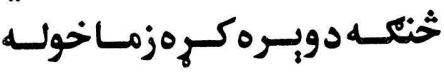

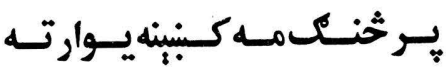

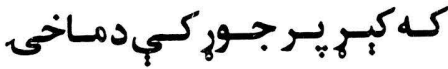

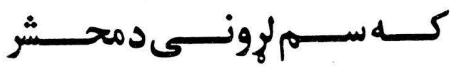

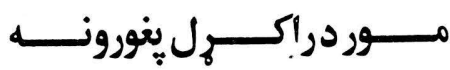

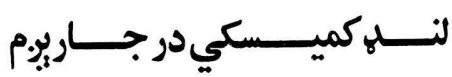

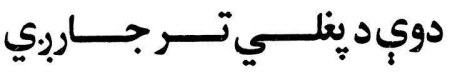
مياست رانيـوكي سوهوليـاكله

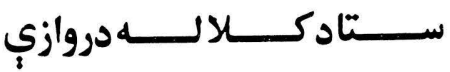
كهلمـهــكـكردمـدعيانسي

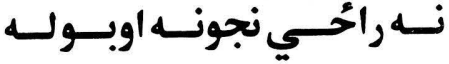

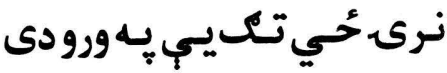

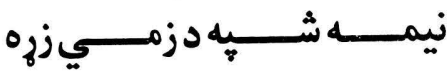

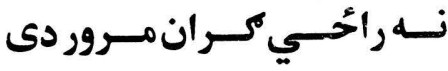

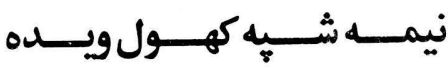

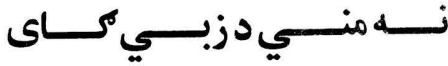

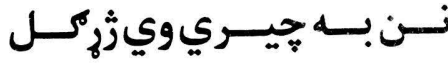

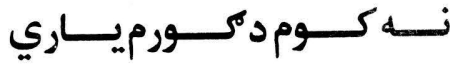

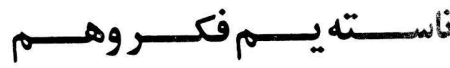

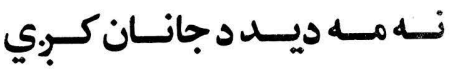

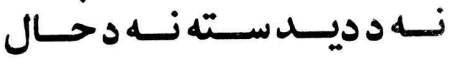

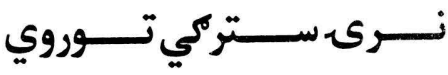

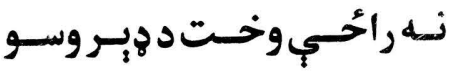
نسه رائحي مـولادي خــــاركي

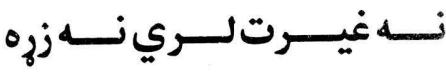

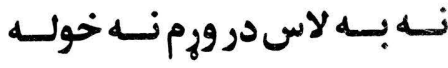

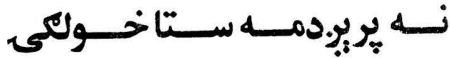

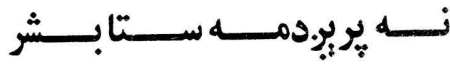

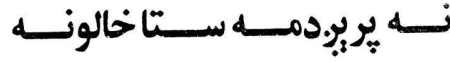

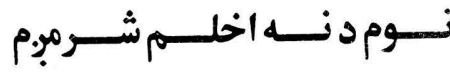

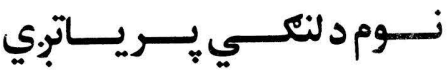

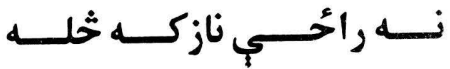

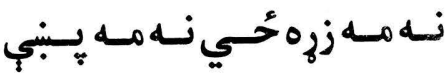

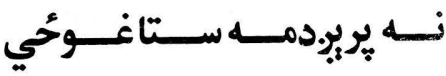




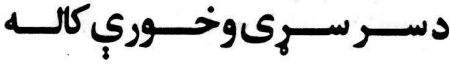

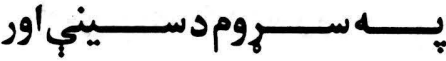

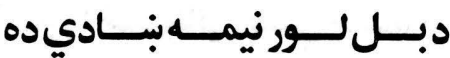

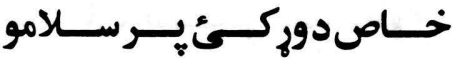

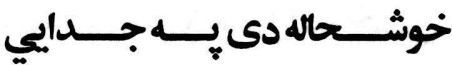

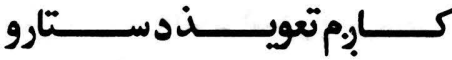

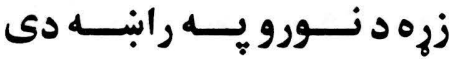

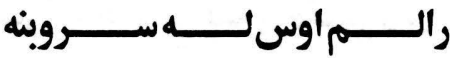

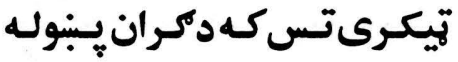

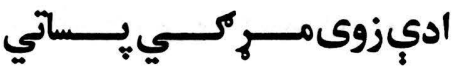

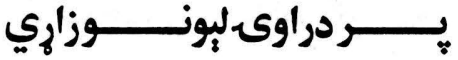
خولـه بـه د بيـــ بـهـ اروا ب.دم لمـادسـيـينوروكسودوسـتان

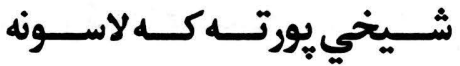

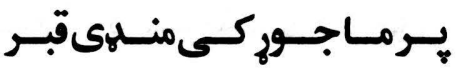

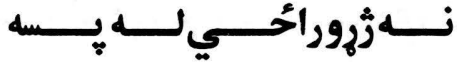

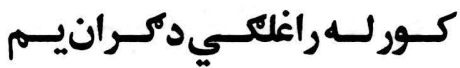

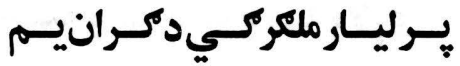

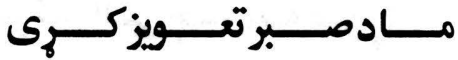

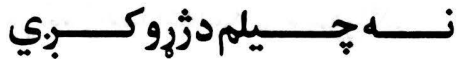

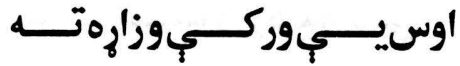

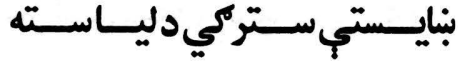

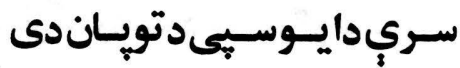
بـوريخـر سـيـىدتويـاندى

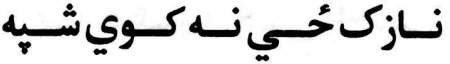
نــازكـ زمــــاد ســـتركوتـــــور

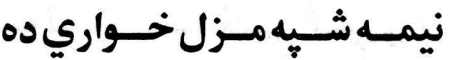

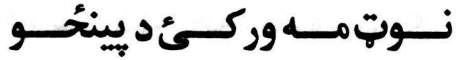

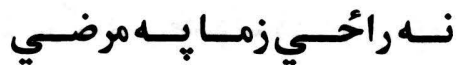

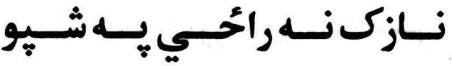
نــه راحُـــي نـازك خفـــه دى

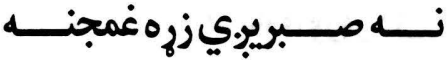

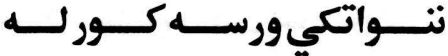

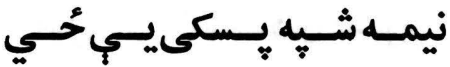

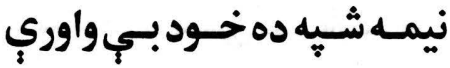

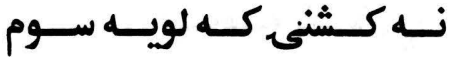

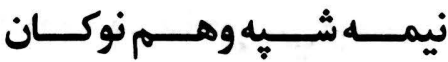

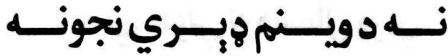

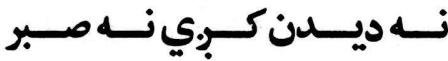

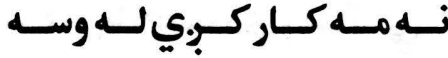

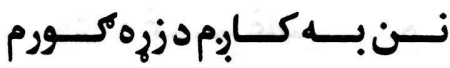

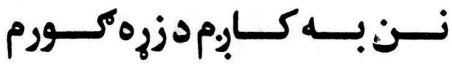

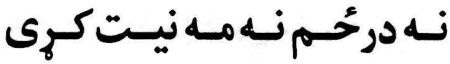

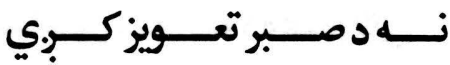

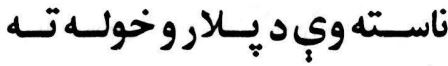

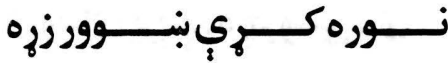

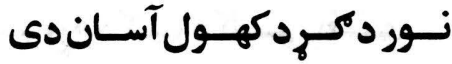
نـور دكـــ كهــول آسـاندى 


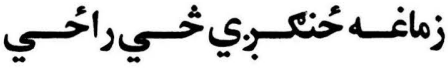

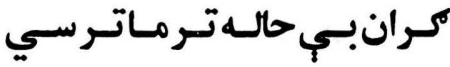

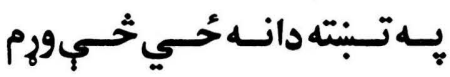

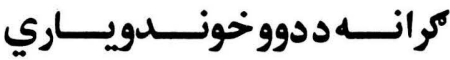

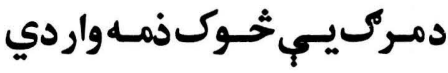

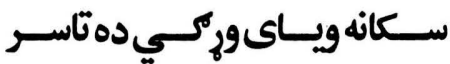

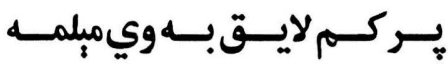

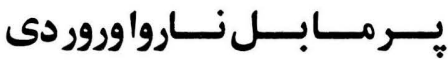
يــرخلكــوعيـددى يـرمـاويـر

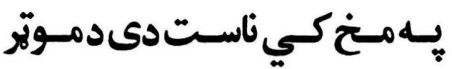

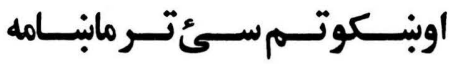

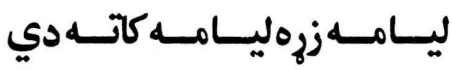

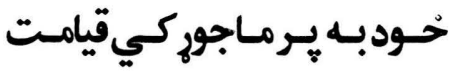
خي خاندي خولبي له دسمال وري

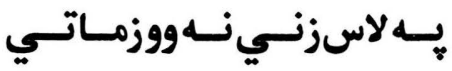

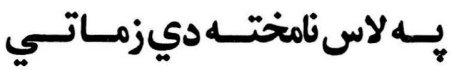

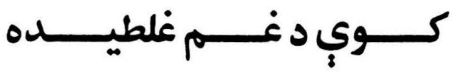
كران مه هيروى يه يات رالى

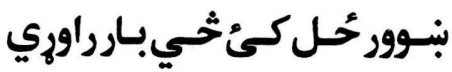

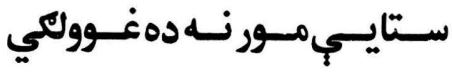

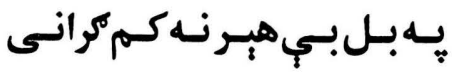

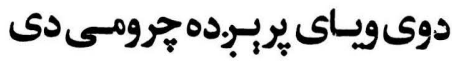

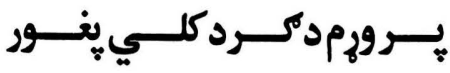

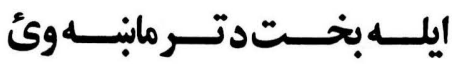

نجــوني مـردي يسه تـكَحسي

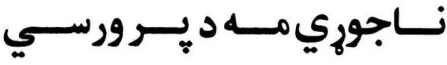

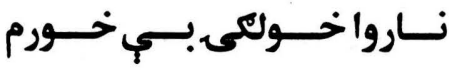

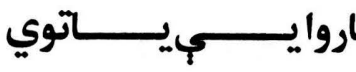

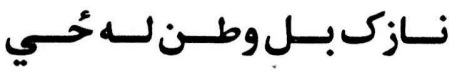

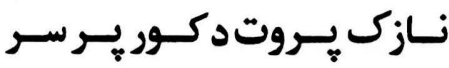

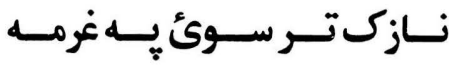

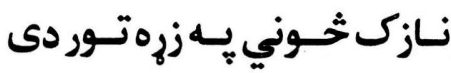

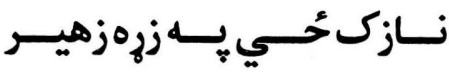

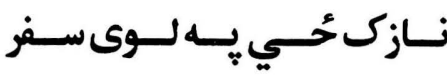

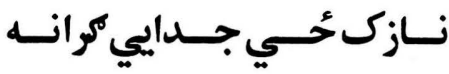

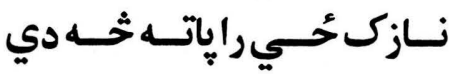

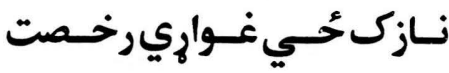

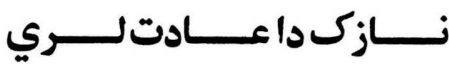

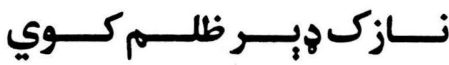

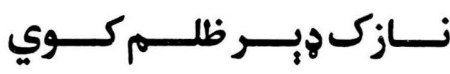

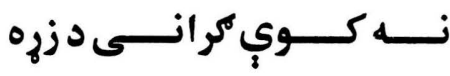
ناسـته ومـهـ ســوج مـهـ ولارى

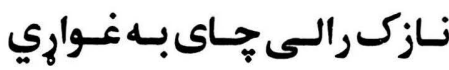

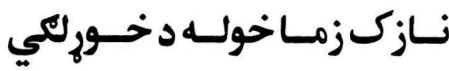

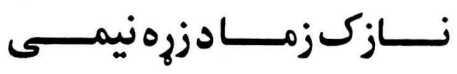

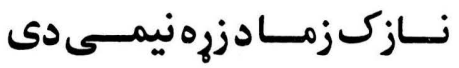

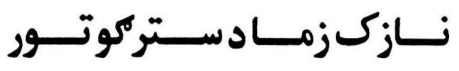

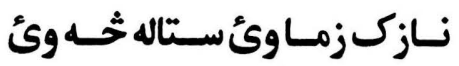




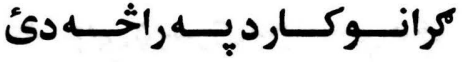

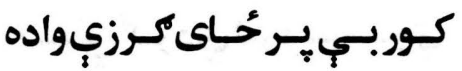

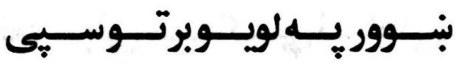

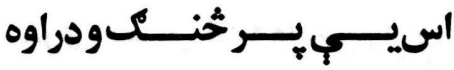

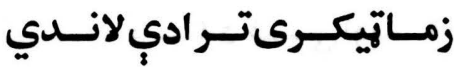

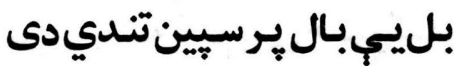

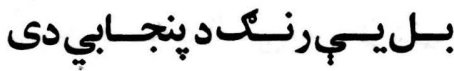

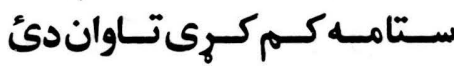

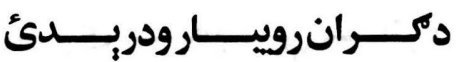

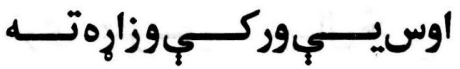

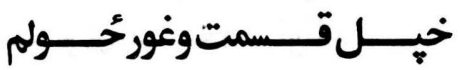

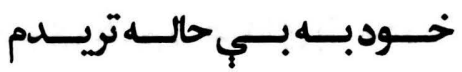

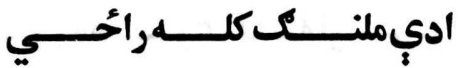

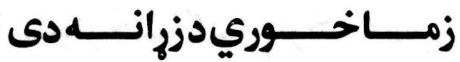

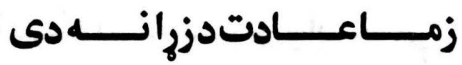

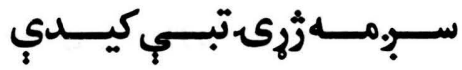

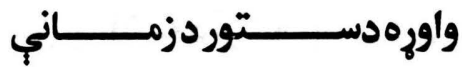

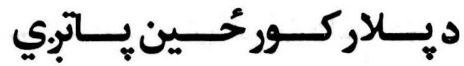

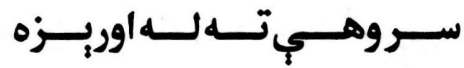

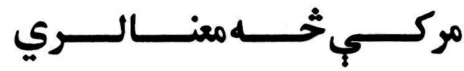

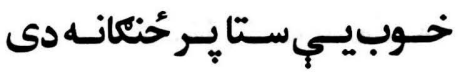

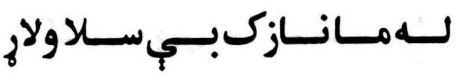

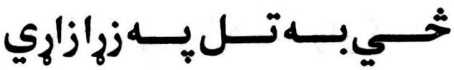

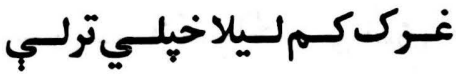

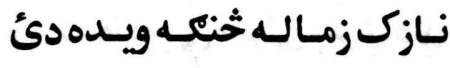

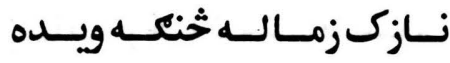

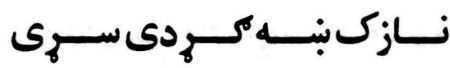

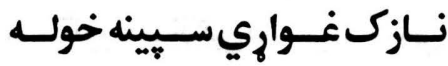

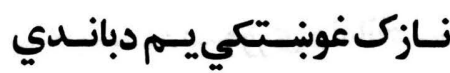

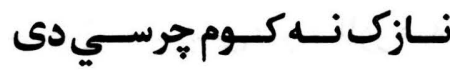

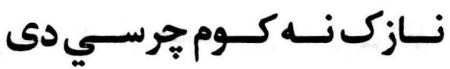

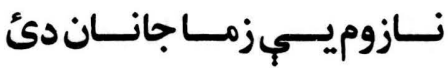

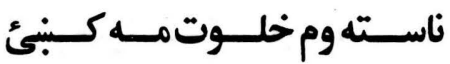

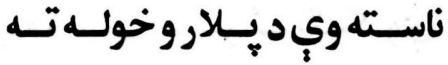

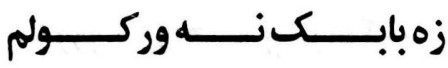

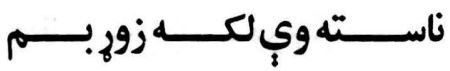

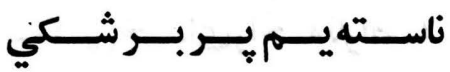

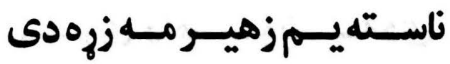

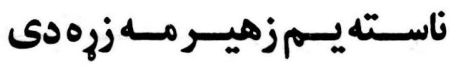

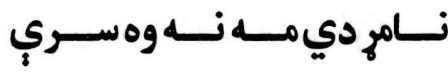

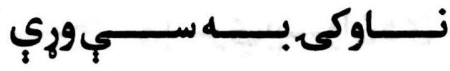

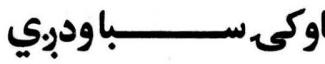

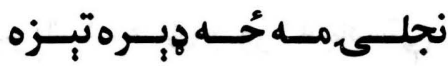

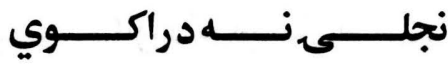

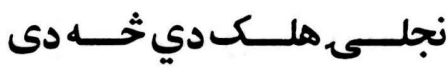

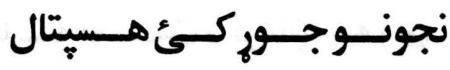
نجونو مه كي يه بخت خـواري

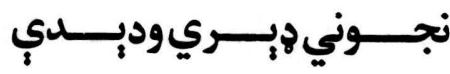


بي نسواكويس خهولي سريدي

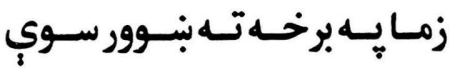

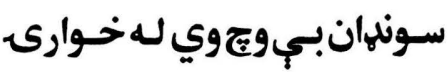
ســتاورابــانكيديدي

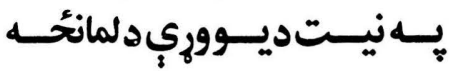

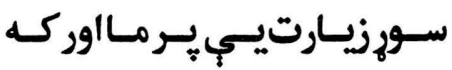

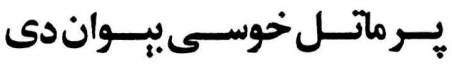

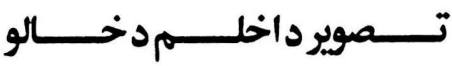

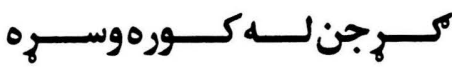

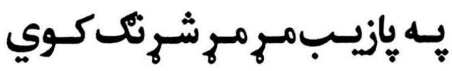

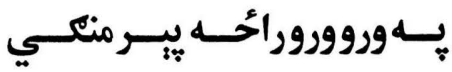

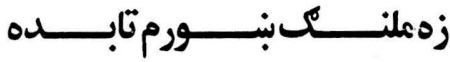

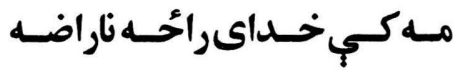

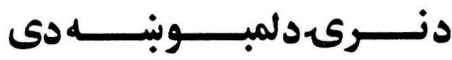

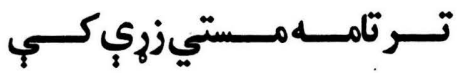

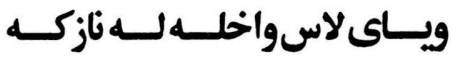

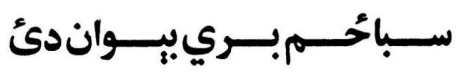

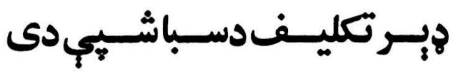
ير يالنكسحاى جـور كه بنايستي

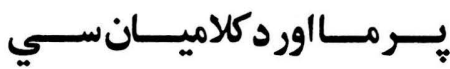

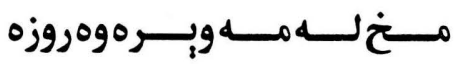

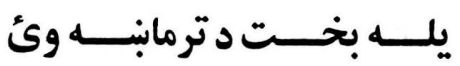
وع لركـى سـوم وديـوال تـــ

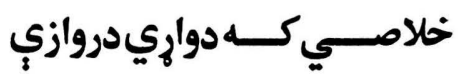

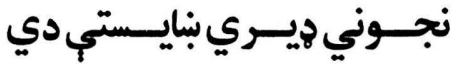

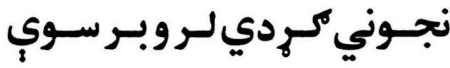

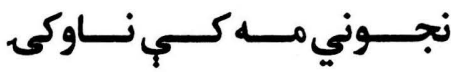

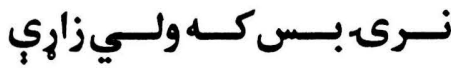

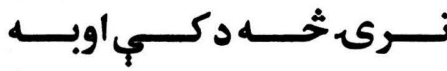

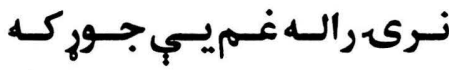

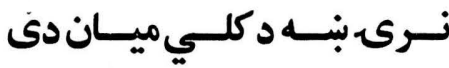

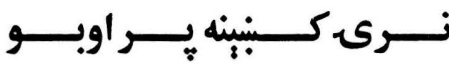

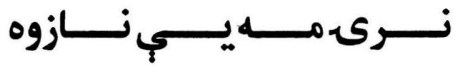
نـرى نجونـه يـه خيــال

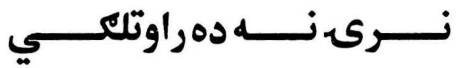
نــرى هـــم دخــداى بنــده

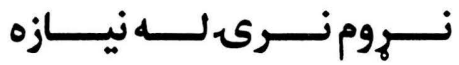

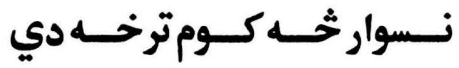

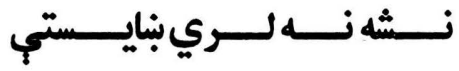

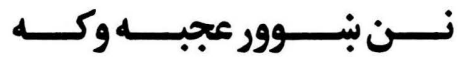

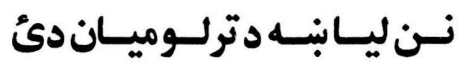

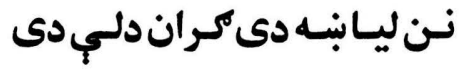

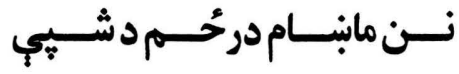

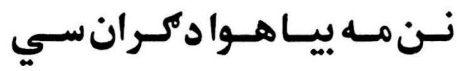

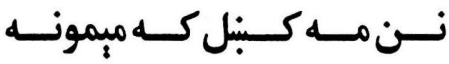
نـازك زمـا وى سـتاله ثـــه وئ

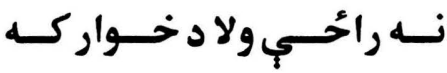

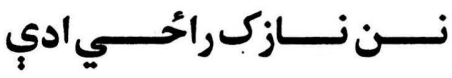




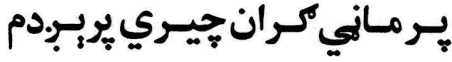

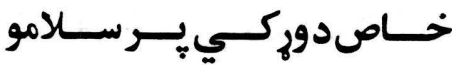

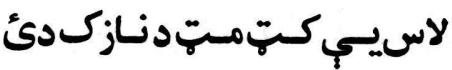

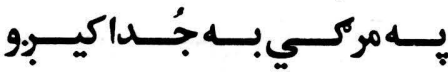

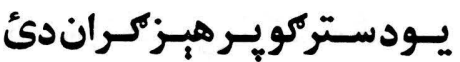

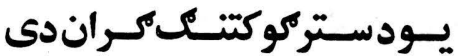

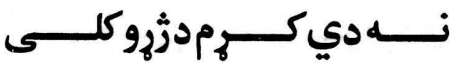

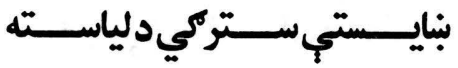
بـوري يـو سـيـى د طوفـان دى سي

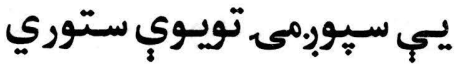

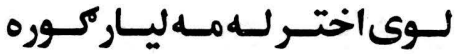

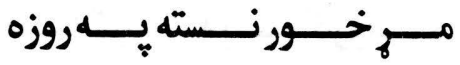

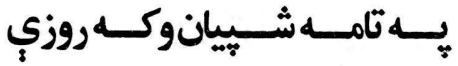

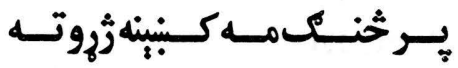

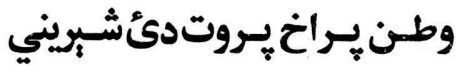

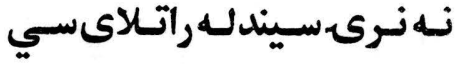

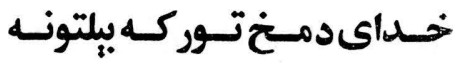

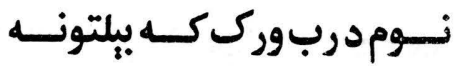

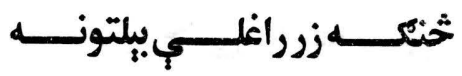
مـانسى مـهـ سـودوى كـاتـاوان

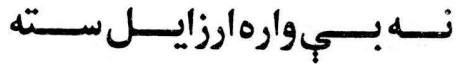

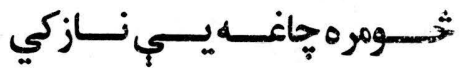

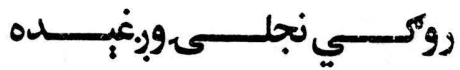

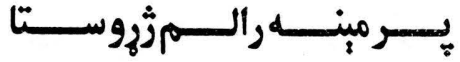

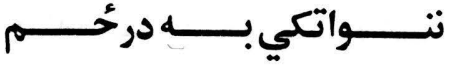

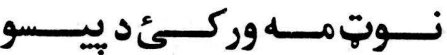

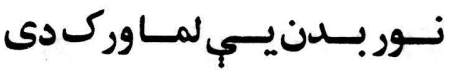

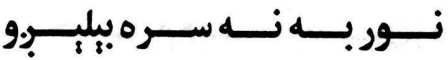

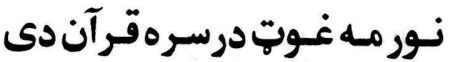

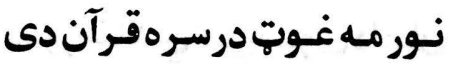

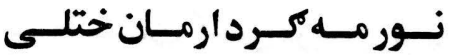

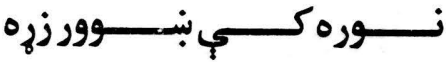

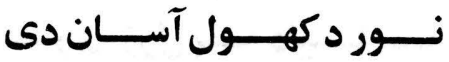
ناسـته يسجي د سـك بـه سـوري

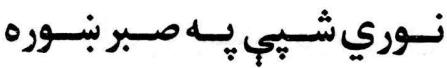

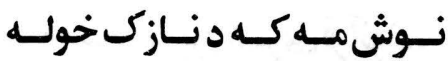

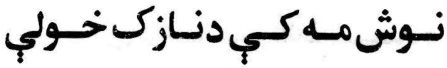

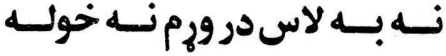

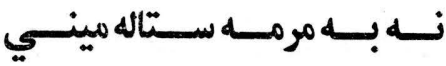
نسه بــرثوبتهنهرو وتساى سـي

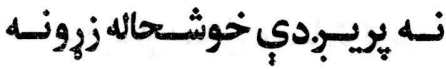

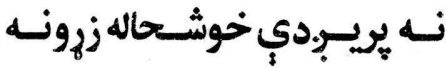

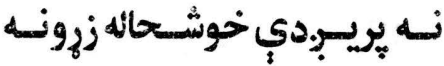

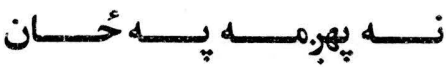

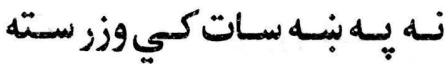

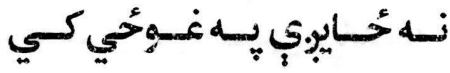

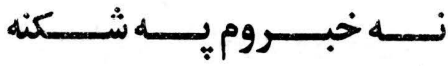

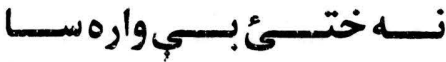


كاكرى غاري

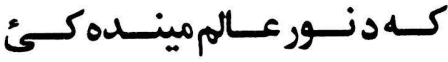

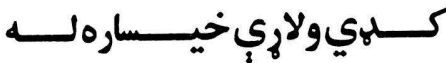

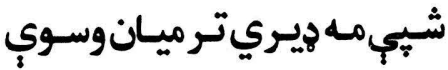

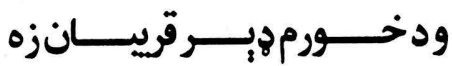

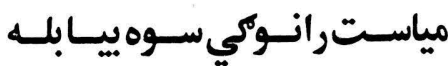

سـور سـانديكـل سـوي دامـانـان

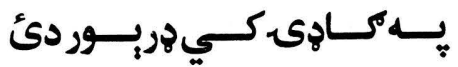

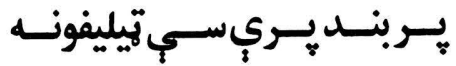

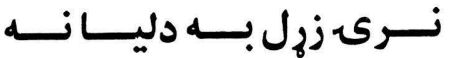

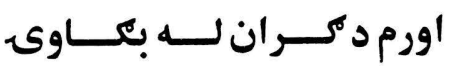

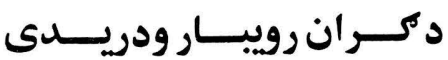

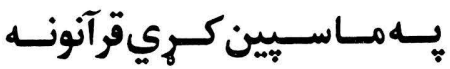

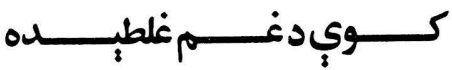

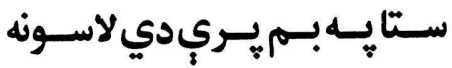

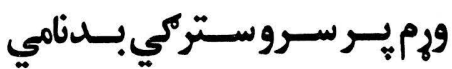

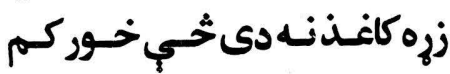

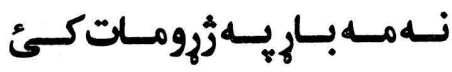

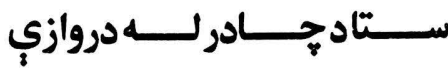

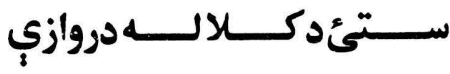

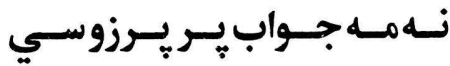

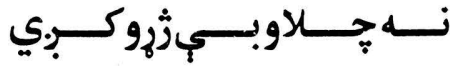

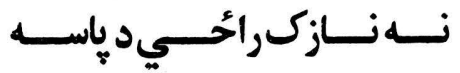

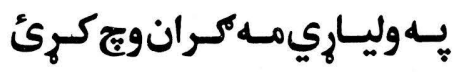

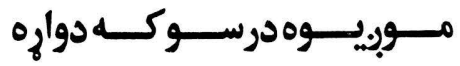

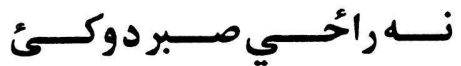

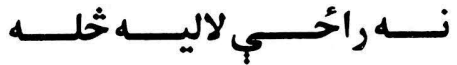

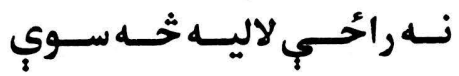

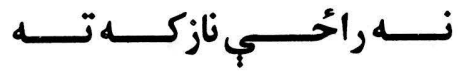

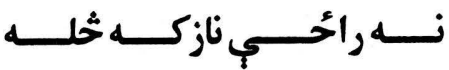

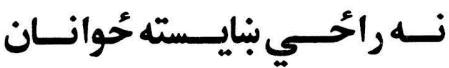

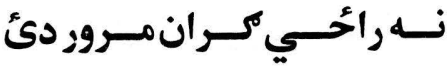

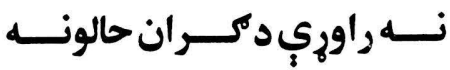

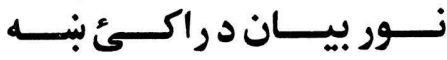

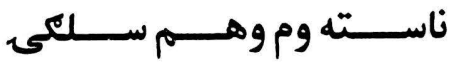

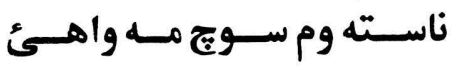

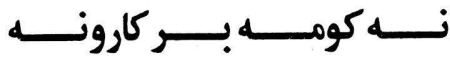

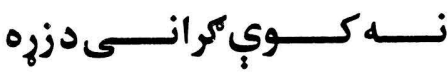

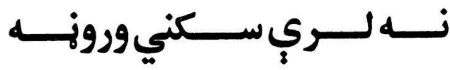

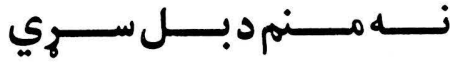
نـه منـي خـي يـه قرآنلـوركم

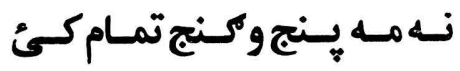

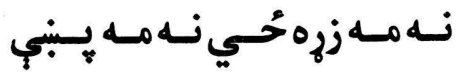

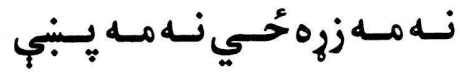

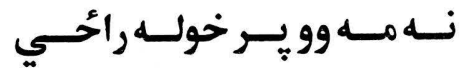

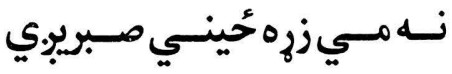

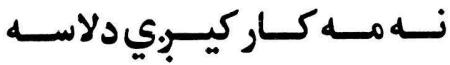

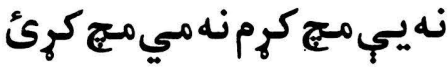

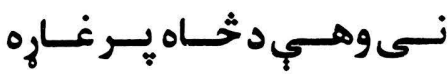




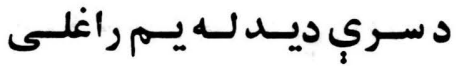

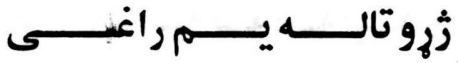

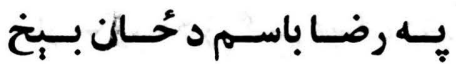
كـمم دي وزر اوس بـــه كيـــه

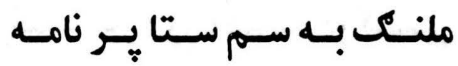

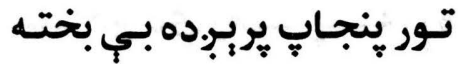

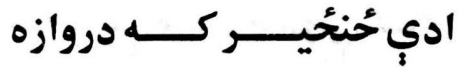
يه درنك يمب تس كم له غؤحى

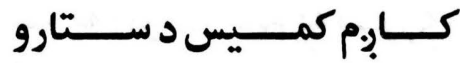
يـــ ليـار ملكركـي دكـرانيـم

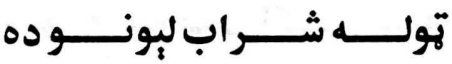
وركى كـلان غـواري زمـازئه

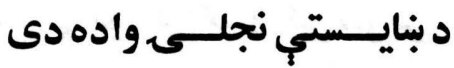

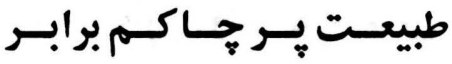

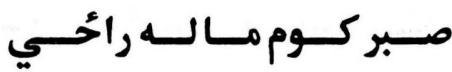

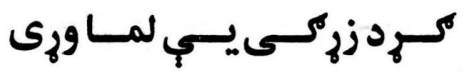

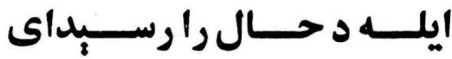

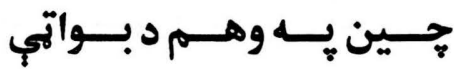

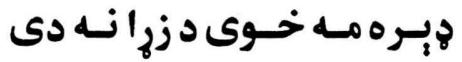
مركى خيـل كـار توسـان ولي زما زهير زهره د حيـام هبر كى

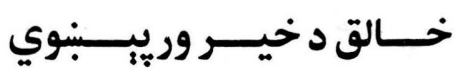

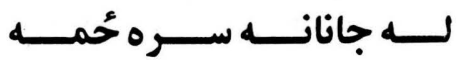
د ديـــن واريسـي سـو خطـــا
نـه مـهـ كـور سـته نـه مـه كلهى نسه مـهـ كـور سـته نـه مـه كلـى

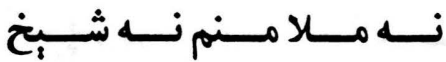
نـوش مسه كـه دوركـي خولـه

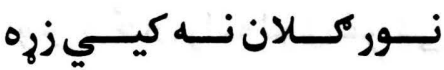
نه هي ستخر سته نه يجي درخته

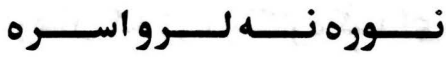

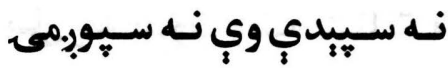

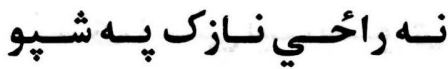

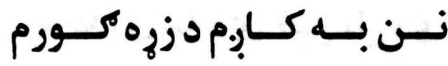

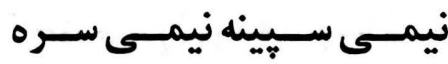

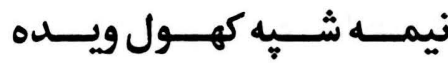
نـن مسـه مــات لـونى زهره دى نـسته ســـيـن وطـن دى بــــ نــه مــه رزقيسـي نــه روزي نـازك ســور يتهكـى تهلـى

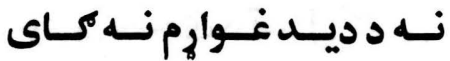
نيست مــه وكَئ سـتاد خـولي ناسـته يمــه دق مــه د زره دى نـه خــوار بريسبردي نـه خـولي

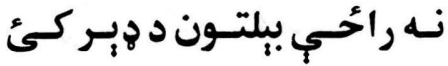

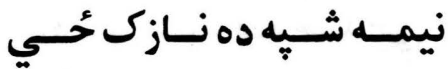

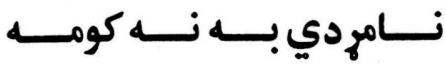

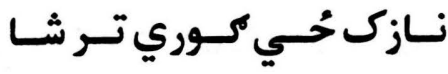


مــوركى ســم مــهـ كـه لاسـونه

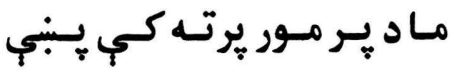
كـه يـر توله دونيـاكـران دي

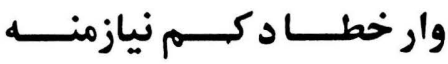
اوس دحُان راته لوى غر كئ خلك دي خوشحال ستا يه واده ارمـان كـه زيره بنــاره كيـداى

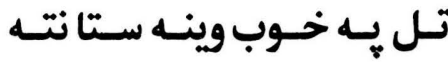

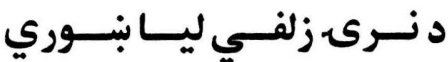
ترما خداى بنه دى ثخي مل دى دى

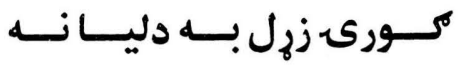
يـر تـاد مـور بــ ده زمـا خوله

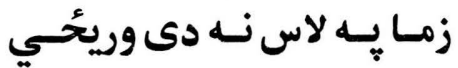

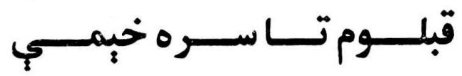
نـه راحُحِي سـتا د وصـال شـيه

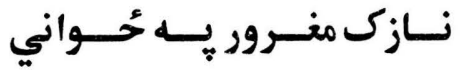
تــومتى ســوي د تـــول كلــي

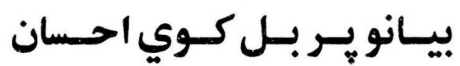

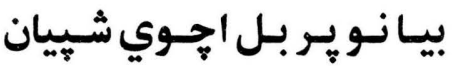

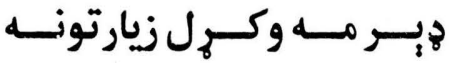

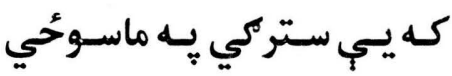
بربـاديسي كـم ميسه جــدايي

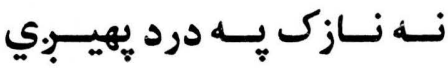
كنـي يــر حـال بمــه راتلـى دردي

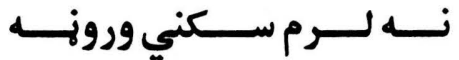

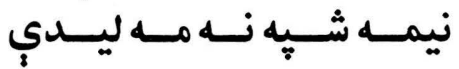

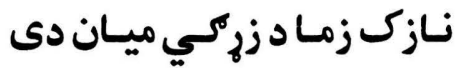

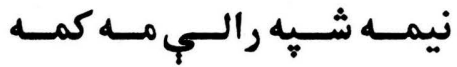

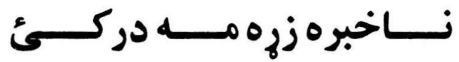

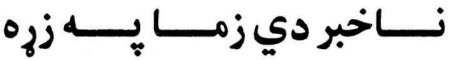
نــه منــي مــه د دخــولي كــاى

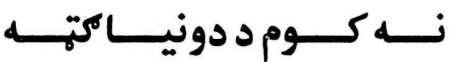
نيم يه لمر دي نيم يه سيوري

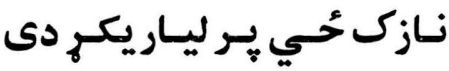

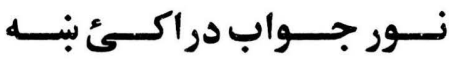

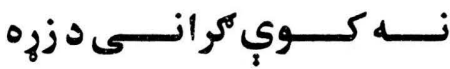
نمريب تودكئكرانكى سوحي

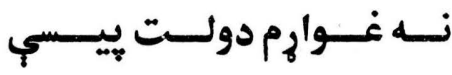

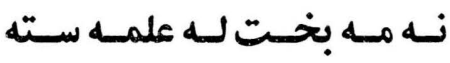

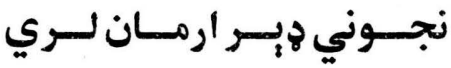

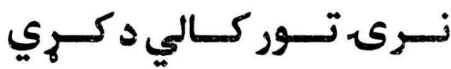

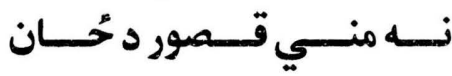

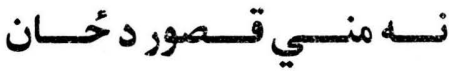

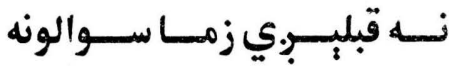
نـه رائسي نسازك لـه روحــي

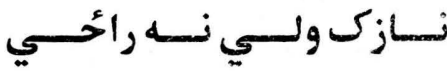

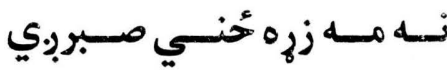

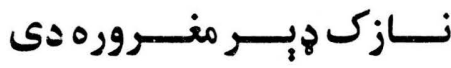




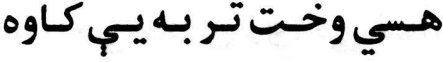

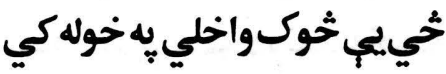

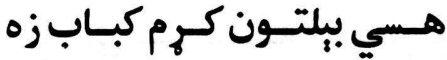

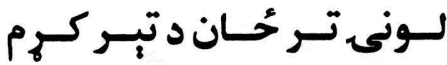

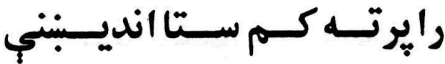

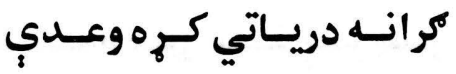

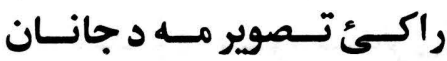

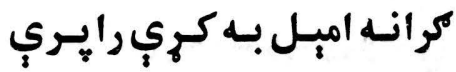

بـي نازكـه زونـدون كـران دى

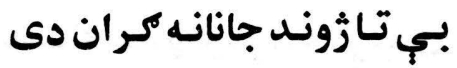

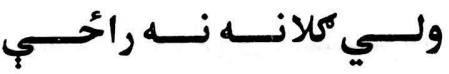

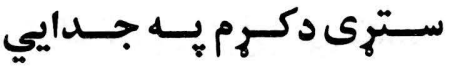

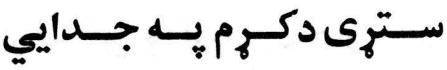

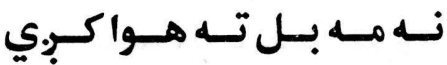

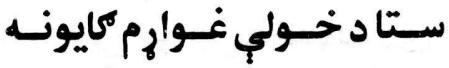

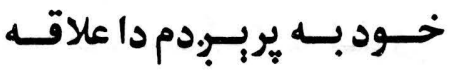

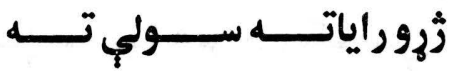

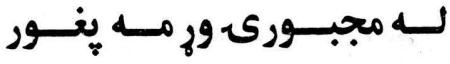

رنحُــور دزرهيسم كـي مينسي

دخيـل كر ان مـه انديبنهن سـوه

يـر كــودر نـه سـته سـتا يبكسي

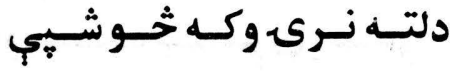

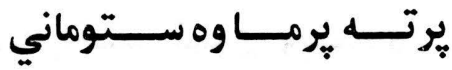

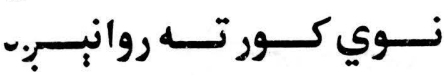

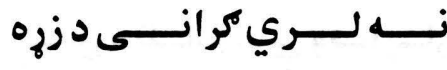

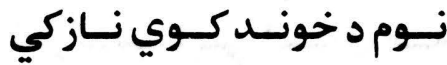

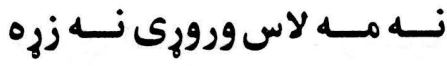

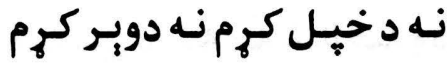

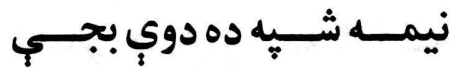

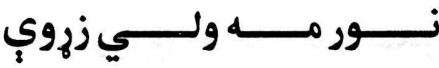

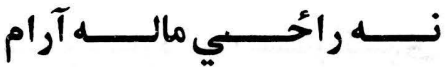

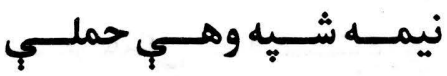

نه راحجي سخت مه كزران دى

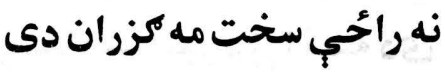

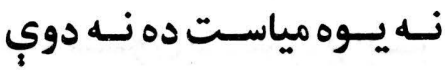

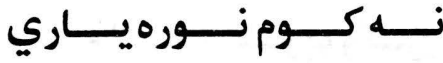

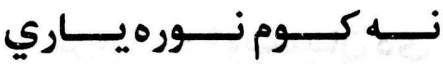

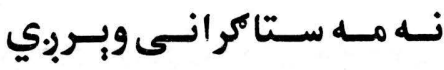

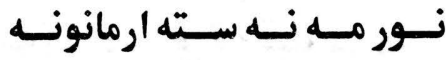

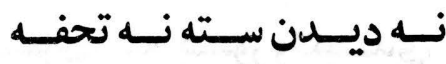

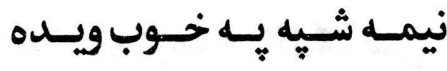
نــه مــه وس سـته نـهله مـهـ زور

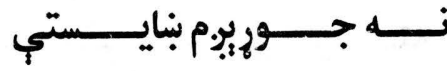

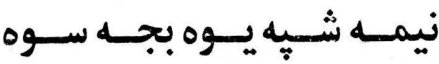

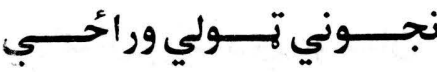
نه مسي حسي تـر محَكي يسبني

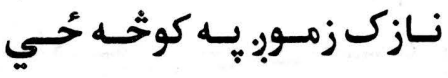

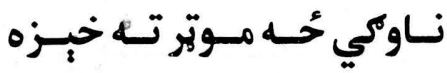


يــــ زهر ظــالم بــي وفـايـار

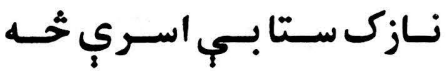

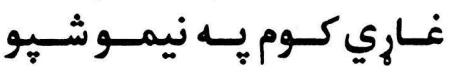

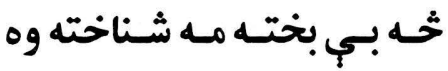

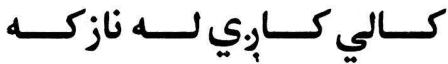

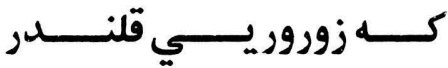
نــهـ وبــوره تــه ليـار كـبـ.ي

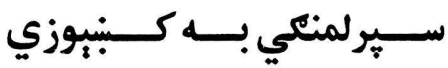
سحر اكى كل سوي دوو واركي

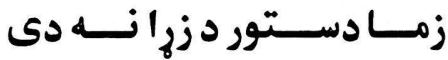

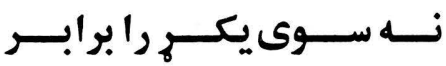
اور مـــ لانــدي ســــوبو وكسئ زماتـر مركه د زوب ميـان دى

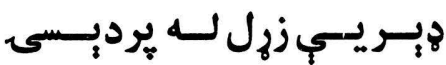

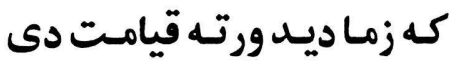

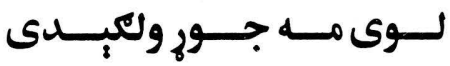

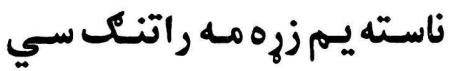

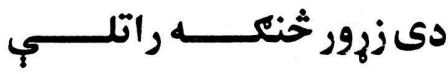

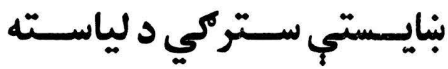
نرى حُانكوى دى ثخي راحي سي لما دكر ان ورك دي دوستان

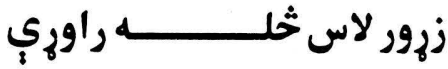
تيــاقهـــول ويبن دى تابــــه وركسى تينــك نــسه وريسهلهي
نه راحي خداى دي كي خوار

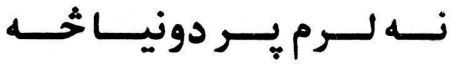

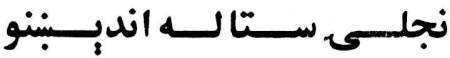

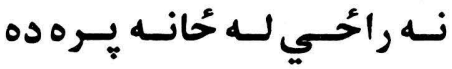

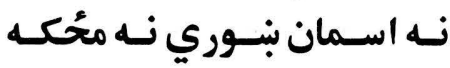

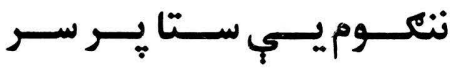

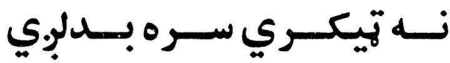
نجونه تل بـه سيوبوريمى وحُّي

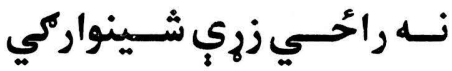
ناسـته يـم ذهيــر مسه زيره دى

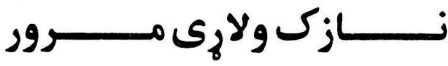
نـازك تلـى رإزغ يــي نكسئ نازك حُي واكي يب د حُان دى

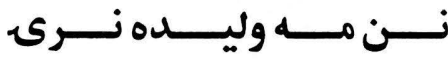
نه راححي كر ان بـ خلوت دئ

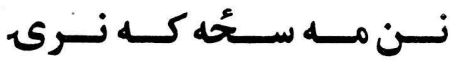

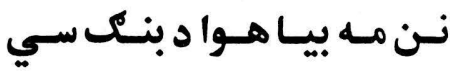

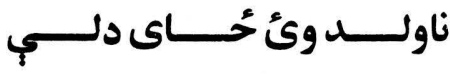

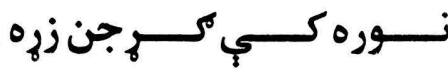

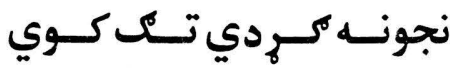

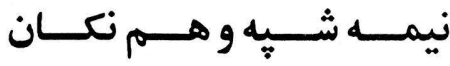

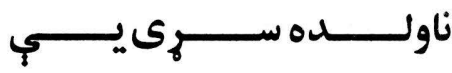

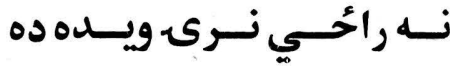

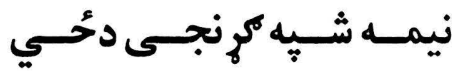




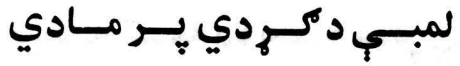

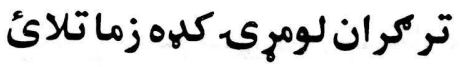

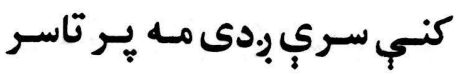
خــــه ناتر ســه مـــ شــاخته دي

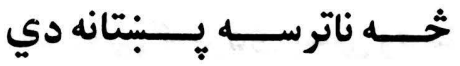

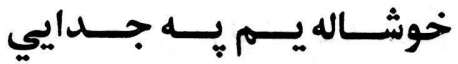
هــري كيلـي ثيــري كريـوان

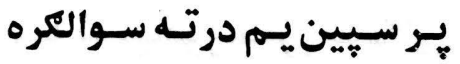

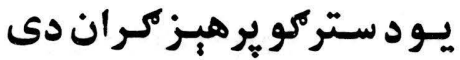

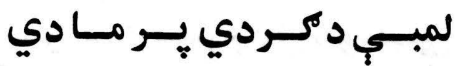

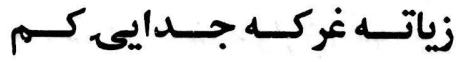
سـتايسيج مسور نـه ده غـولكي

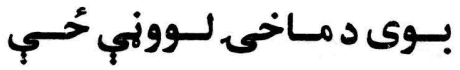
وجار دي كم د سنحُرخيل سي

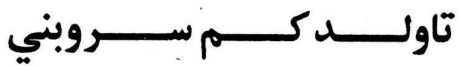

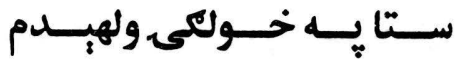
كـله بـــــار د دونيــار دى

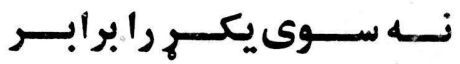

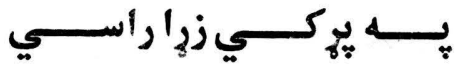
ثر سيّين يسم درته سوال كره بنـــه كهــول دى زرار راسـي زمـار خــصت د ماشـومتـوب و

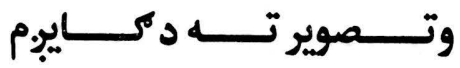

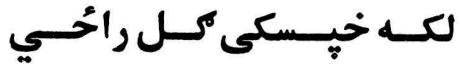

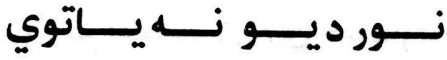

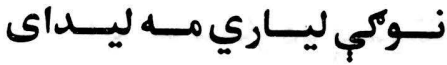

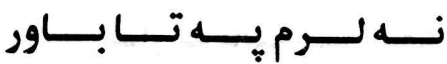

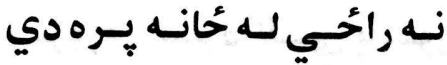

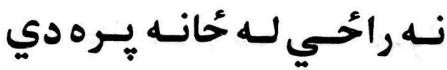

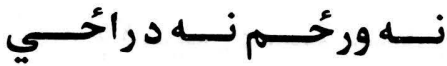

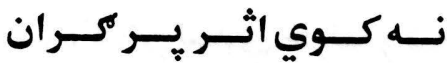

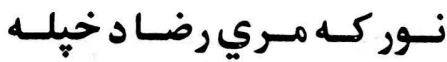
نور مـه غـوت درسره قرآن دى مي

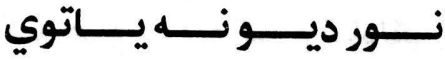

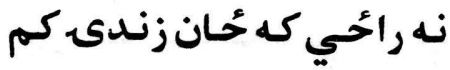
نـازك زمـاخـولكى خـوركسي نجـوني كـــدي خوشـبويسي

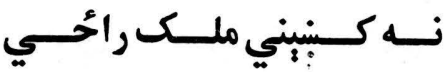

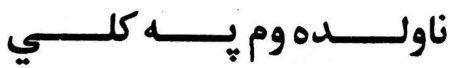

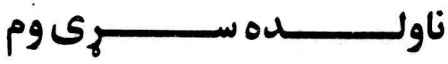

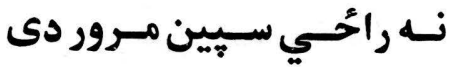

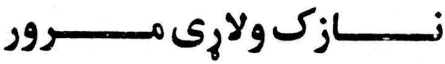
ناسـته يــم هــوا مــه ستاسهي نـور كـه مــري رضـاد خِّلـه ناسـته يــم هـــوا مــه ستاسـي

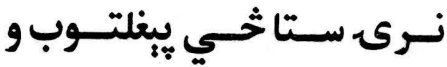
نسور بسه هـم خــومره خــواربون

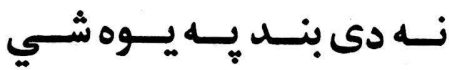


ترســرمه ناسـت دى خمــاري

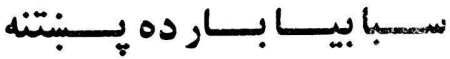

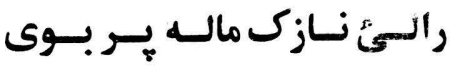

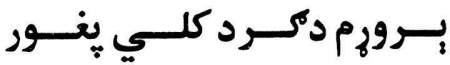

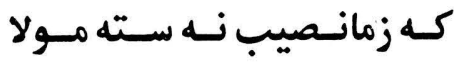

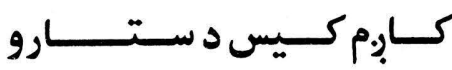
سـره كـالي لنسلهي خولـه وكـــ

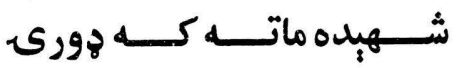

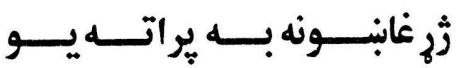

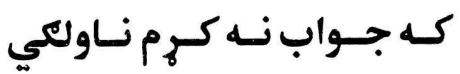
دواره بـه سـتا نسه سـي روزي سـتا يـــ زيسارت ثخوكيــار وم

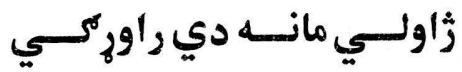
غـواري بـه جـوب كـي متهـي تسر بسنبو مسه وكسبنبه سـراني

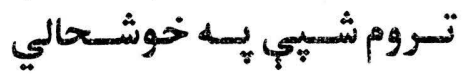

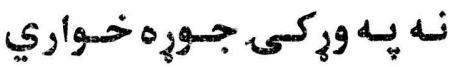

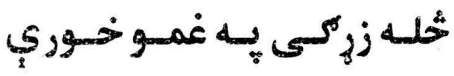
كه مسه حسلال كسئ بـو كئو أنسو

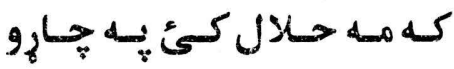

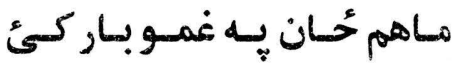

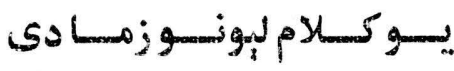

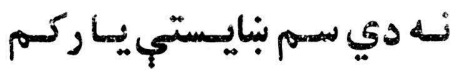

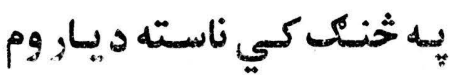

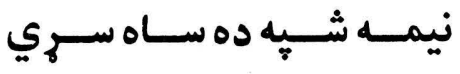

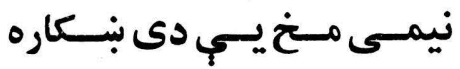

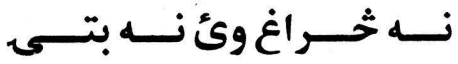

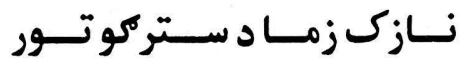

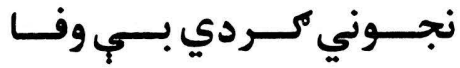

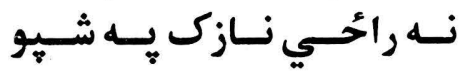

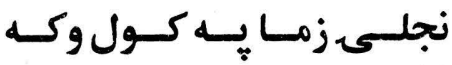

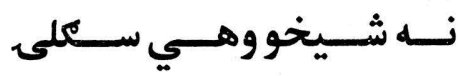

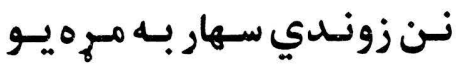

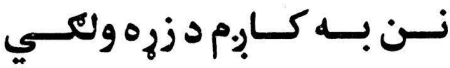
ناست يـر كتّ غـوازي غـوحي

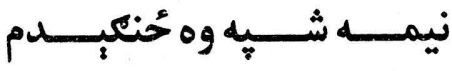

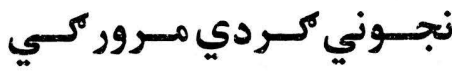

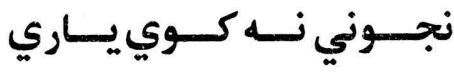

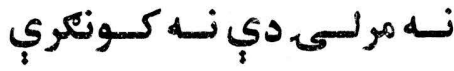

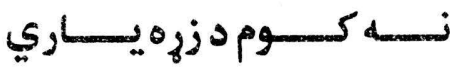

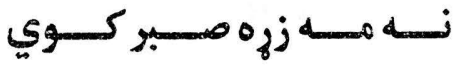

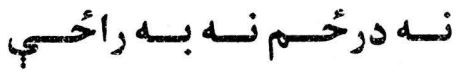

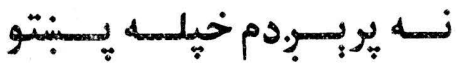

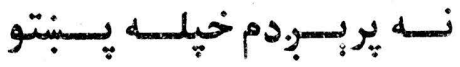
نه رأسي قول يسي خموار كئ

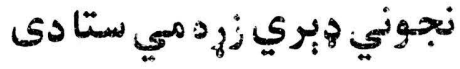
نه دي مت كم نه دي خُوار كم

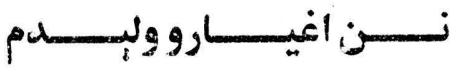


خي وزني مـاستا بـر جارهـل مركى خيـل كارتوسـان ولهي

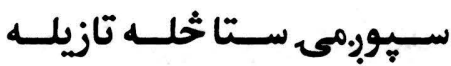
زما خـولكي، د سيـين كالي ده

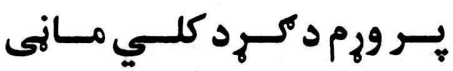

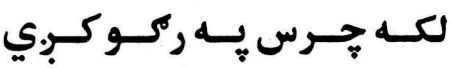

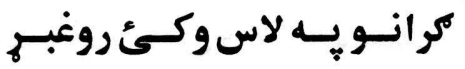

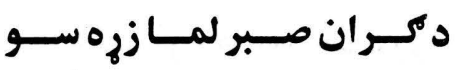

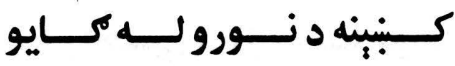

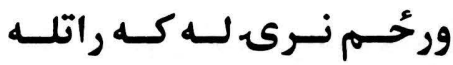

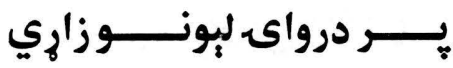

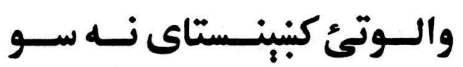
رابه يـات سوي يه لمانحُح كي

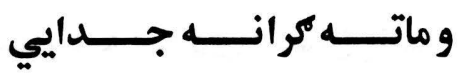

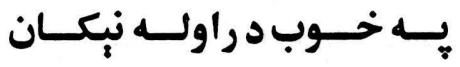
بارخوكـان حُوبنـي زوى مـري

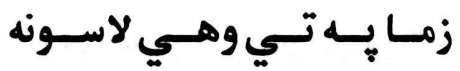

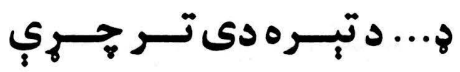

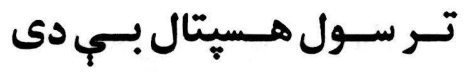

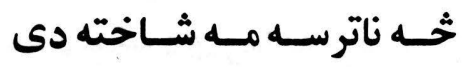

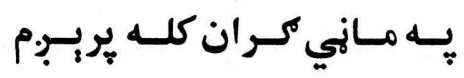

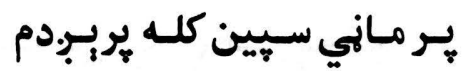

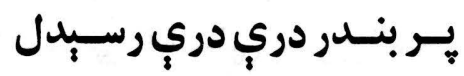
نسـته سـتا بنايسـتـي سـتركي

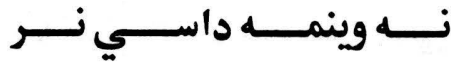

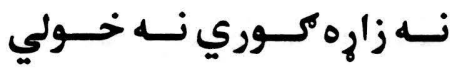

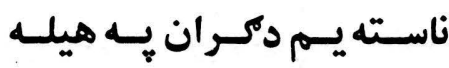

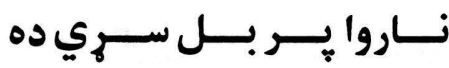

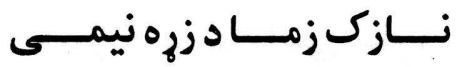

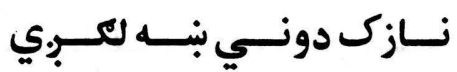

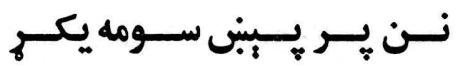

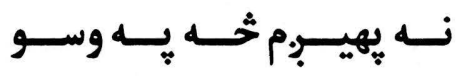

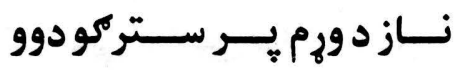

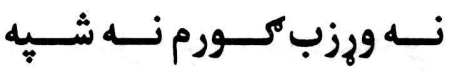
نيمـه شـيه د خــود بـي واوري نـازكى ولارى شـــن مرغـه ســـ

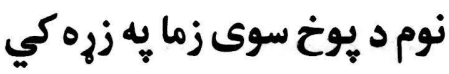

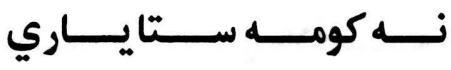

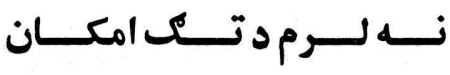

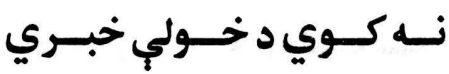

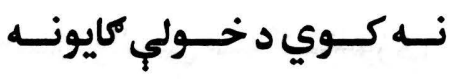
نـازكى...بـهـ كـي رايسري

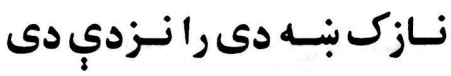

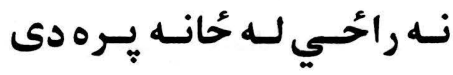

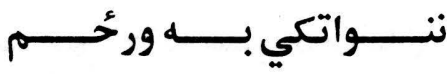

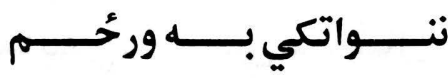

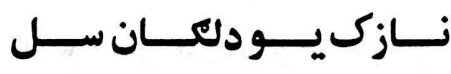
نجـوني رالـي دركسي دركـي 
كـه كلـى هـرد مــدعيان سـي

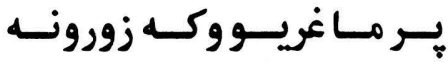

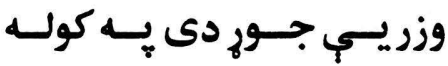

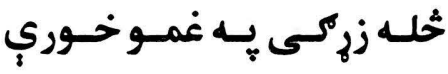
دخيـل قـسمت رالـى تــاوان

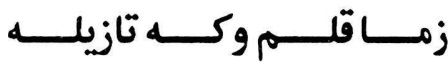

كه ير خُنك ناست واى كر انوستا

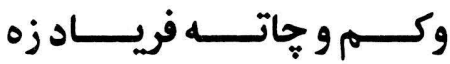

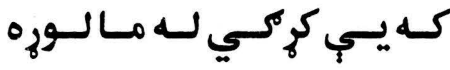

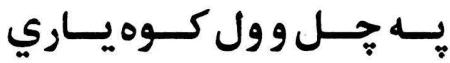

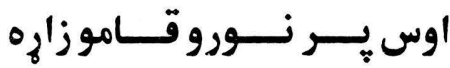

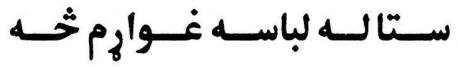

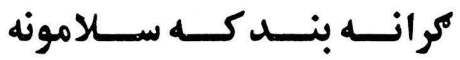

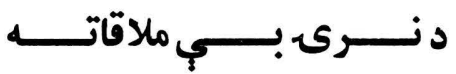
سـيورو.مى هيروتوته تيــاره سـوه

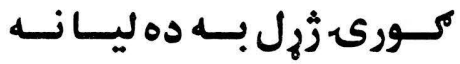

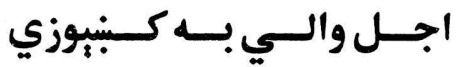

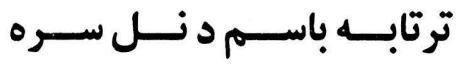
د نـل كارتوس غـواري داسره

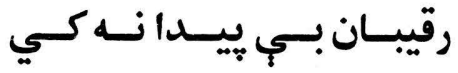

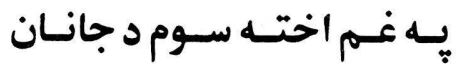
لمـابـه ويــر نـه سـي سـتاشـال

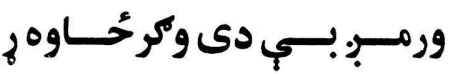

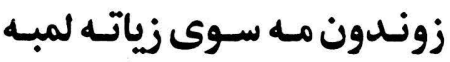

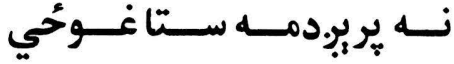

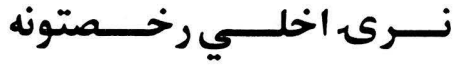

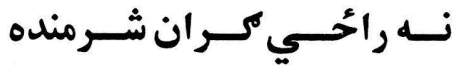

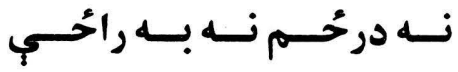

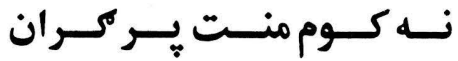

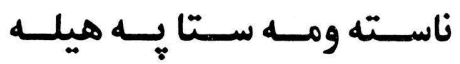
نـــهـ بــــه واى د غــــم ســــودا

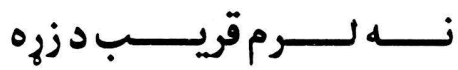

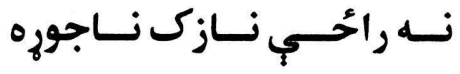

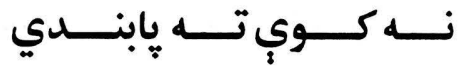
نـه مــه ب.ردي وكـاى تــه غـاره

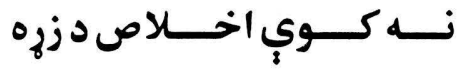

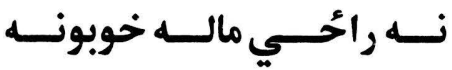

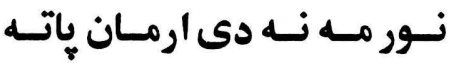

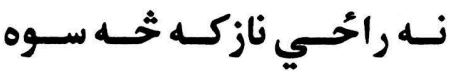

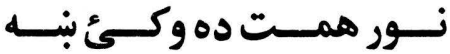
نجـوني تل بـه سـوبـوبهى وزي

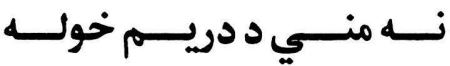

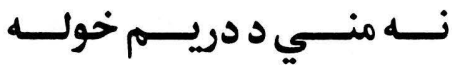
نوم د ليك دى زما يه زره كي

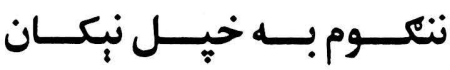
نجـوني دإبري حُي بـ خيهال

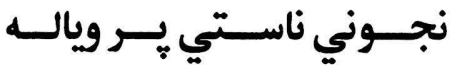

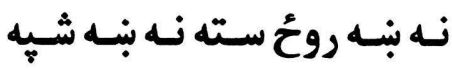


نــــم د دوو ســتركو بنايــــتو

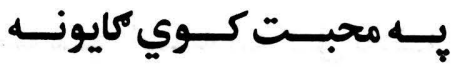
كـهـ بـه جركـ راسـي رقيبـان

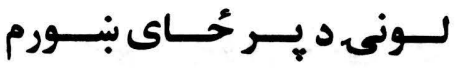

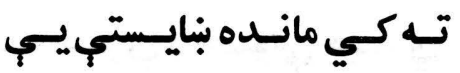

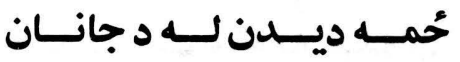
دلتسه هويسر كرحسي بــي كـوره

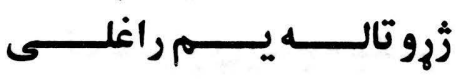

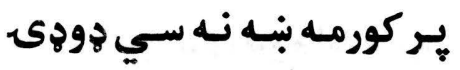

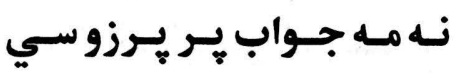

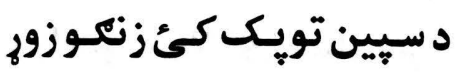

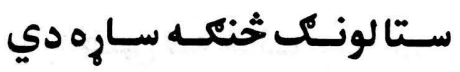
كه مـ خندل هبر دي حُحوانان

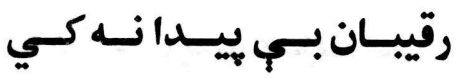

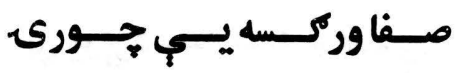

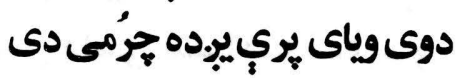

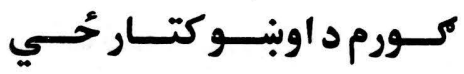
نجـوني كردي ورته ناستكي

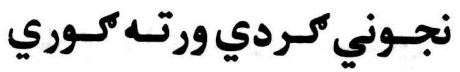

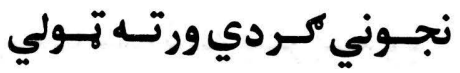

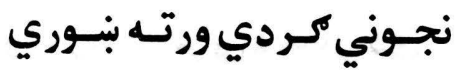

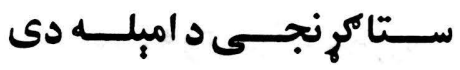

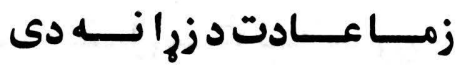

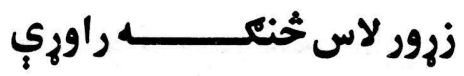

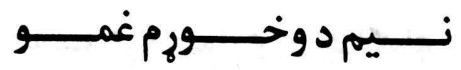
نوري همم سته بنايسته نجونه

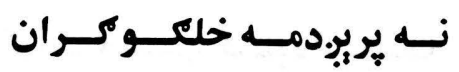

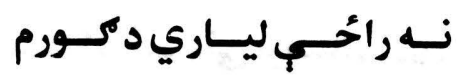

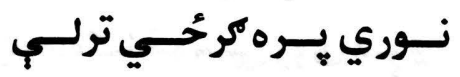

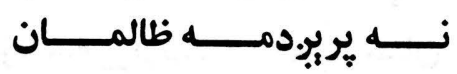

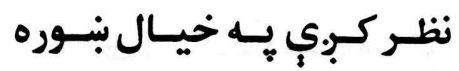

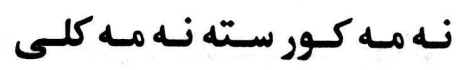

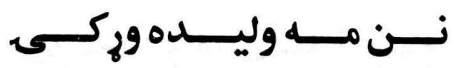

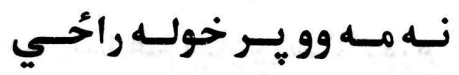

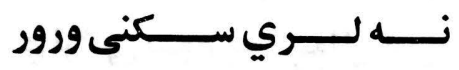
نيمـه شـيه ده خلكـ ويـده دي

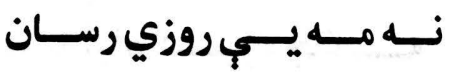
نوم د ليك دى زما يه زره كي

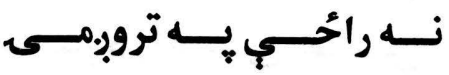

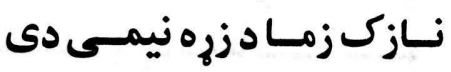

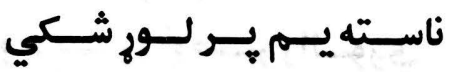
نــازكى نـل دى د جهناســكي

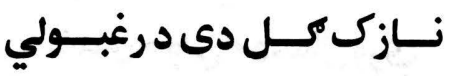

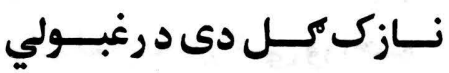

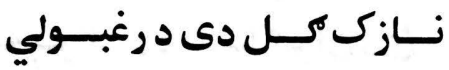

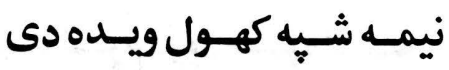

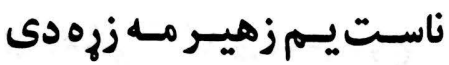

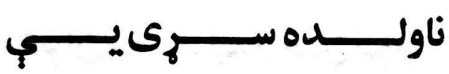


نـه مـه زره غـواري د جــاكـاى

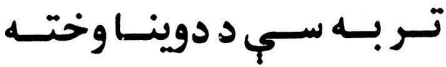

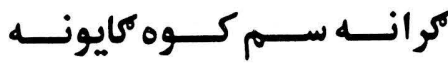

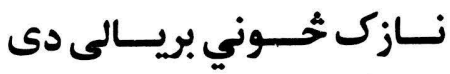

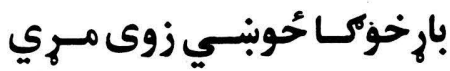

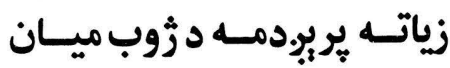

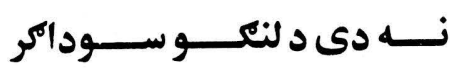

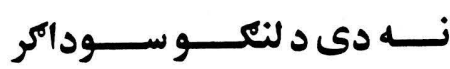

نــــم دى د واوري لــه خابنـــو

اوس ليـا هم ليـاري سـتاكورم

وج لركى سوم يِه ديـوال كي هي

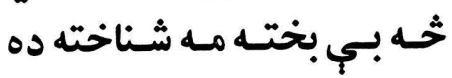

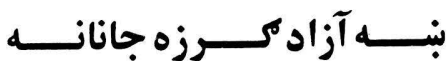

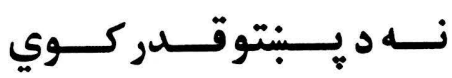

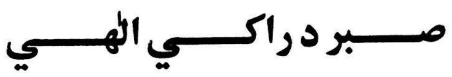

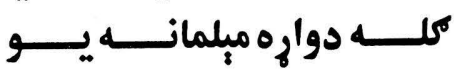

روحُ يـهـ روحُ صـبر رالــوربي

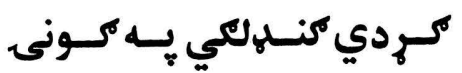

جي خاندي خولي له دسمال وري

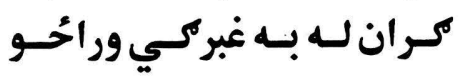

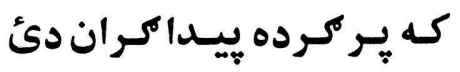

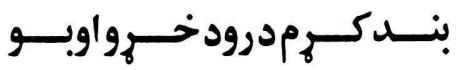

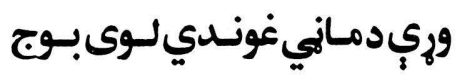

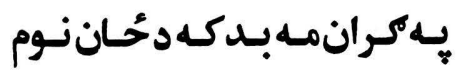

نه مه خواست اخلي لوى خداى

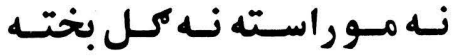

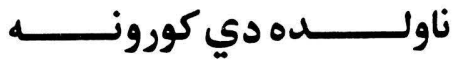

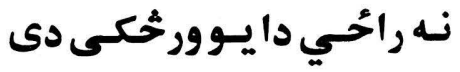

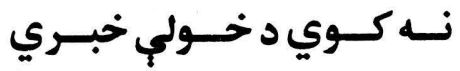
نهل مـه دوست سته نه خيلهوان

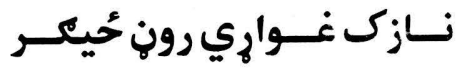

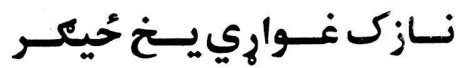
نـازك جــور دى نـيم لـه سـرو نهـ سـته ثــوك يـواحُحي بنــورم نه راحسي مـولادي خـواركي

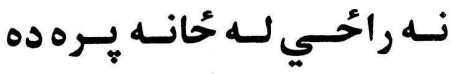

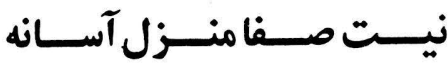

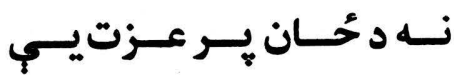

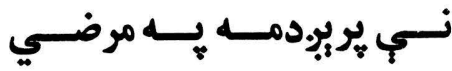

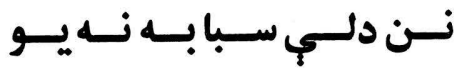

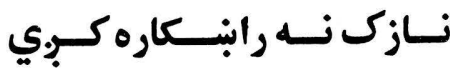

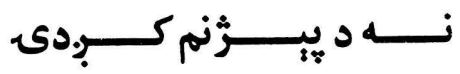

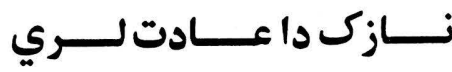

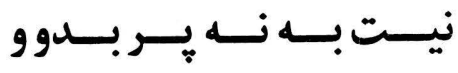
نازك زما د خولب دسمال دئ

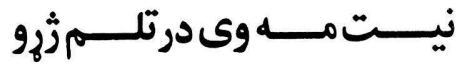

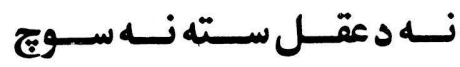

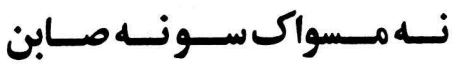


نرى حُانكوى دى ثخي راحي لما دكران ورك دي دوستان

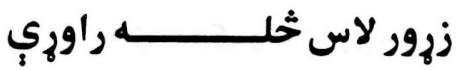

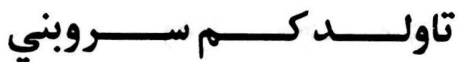

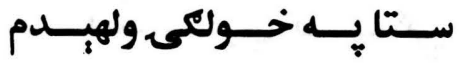

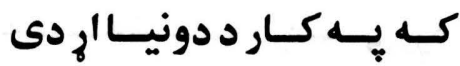

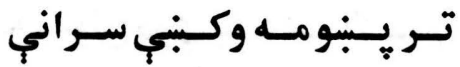

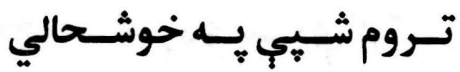

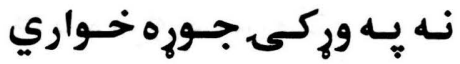

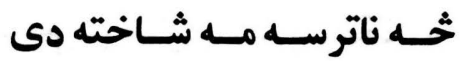

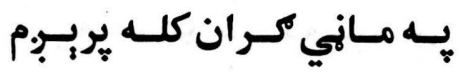

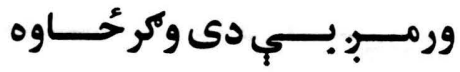

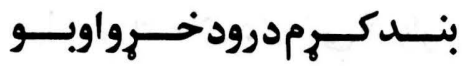

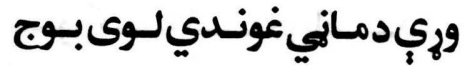

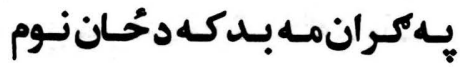

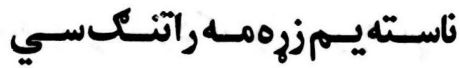

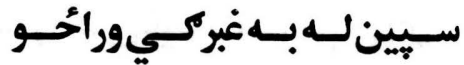

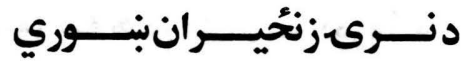

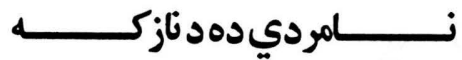

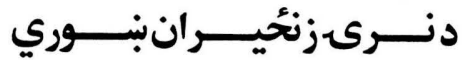

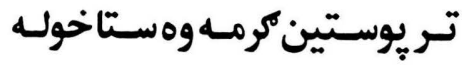

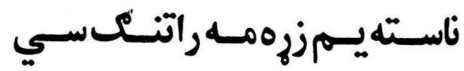

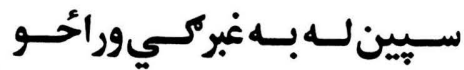

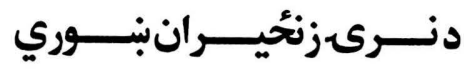

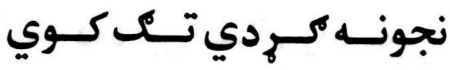

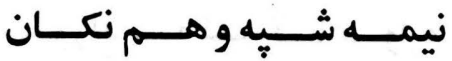

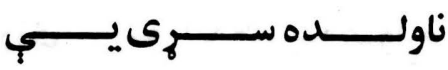

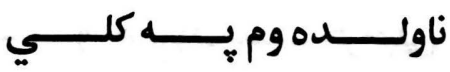

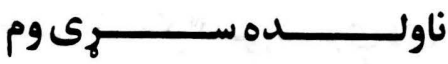

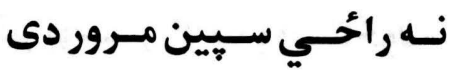

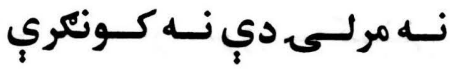

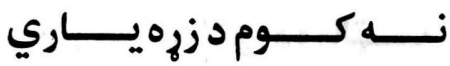

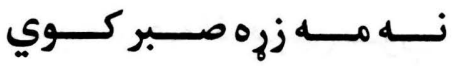

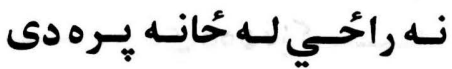

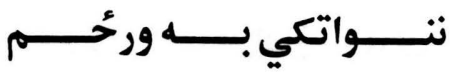

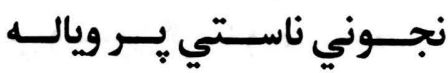

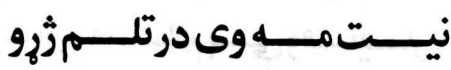

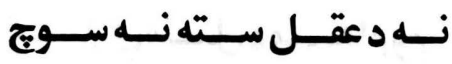

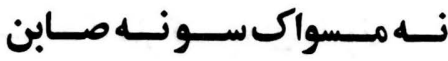

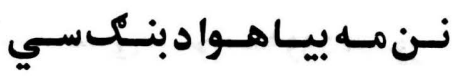

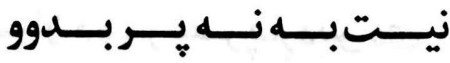
نيم ير لمر حي نيم يه سيوري

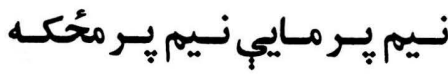
نيم يـه لمر دى نيمي يـه سيوري

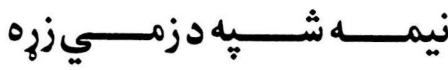

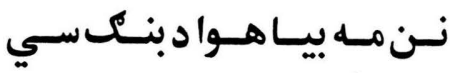

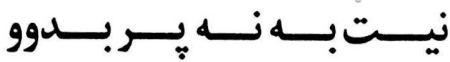
نيم ير لمر حئيميم يه سيوري 


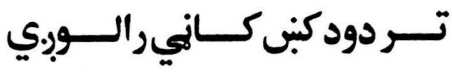

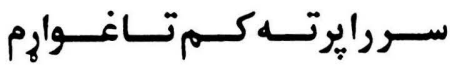

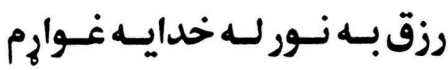

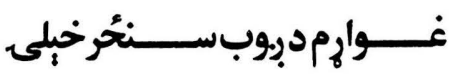

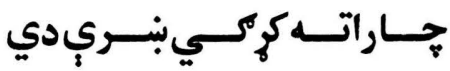

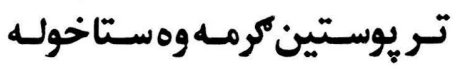

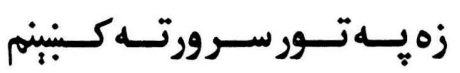

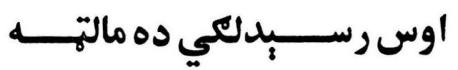

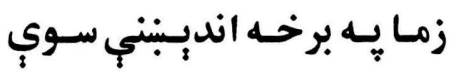

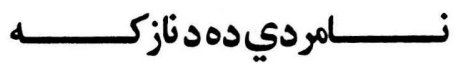

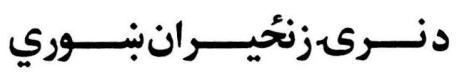

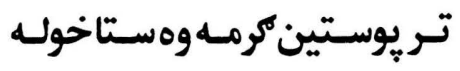

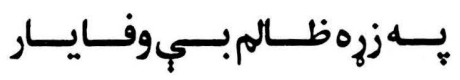

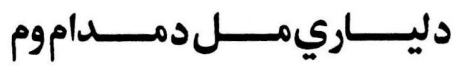

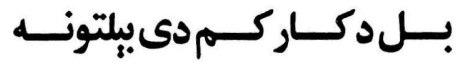

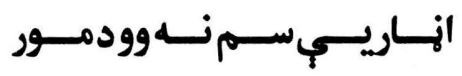

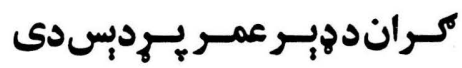

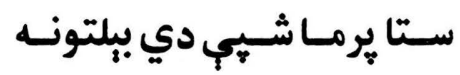

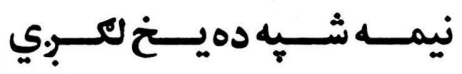

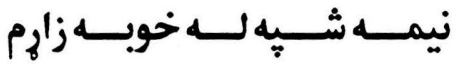
نوم ديوخ سوى زما يهـرزه كي

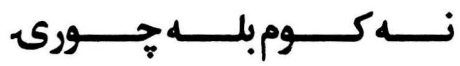

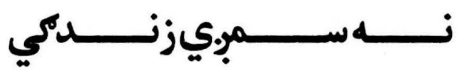

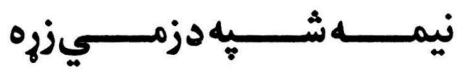

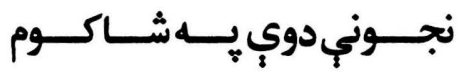

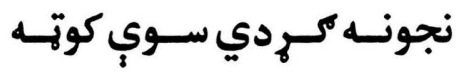
نجونه ولاءي سري وشني سوي

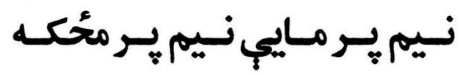

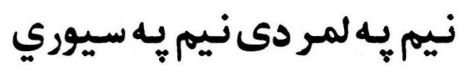

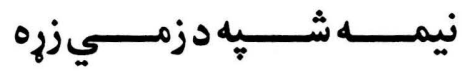

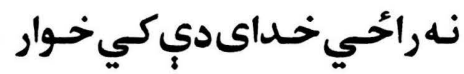

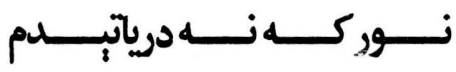

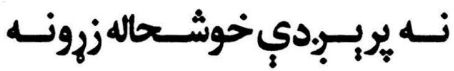

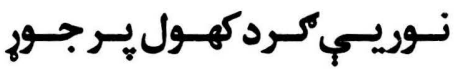

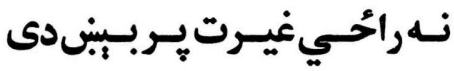

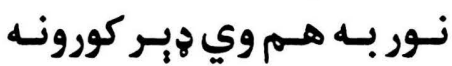

潾 潾 


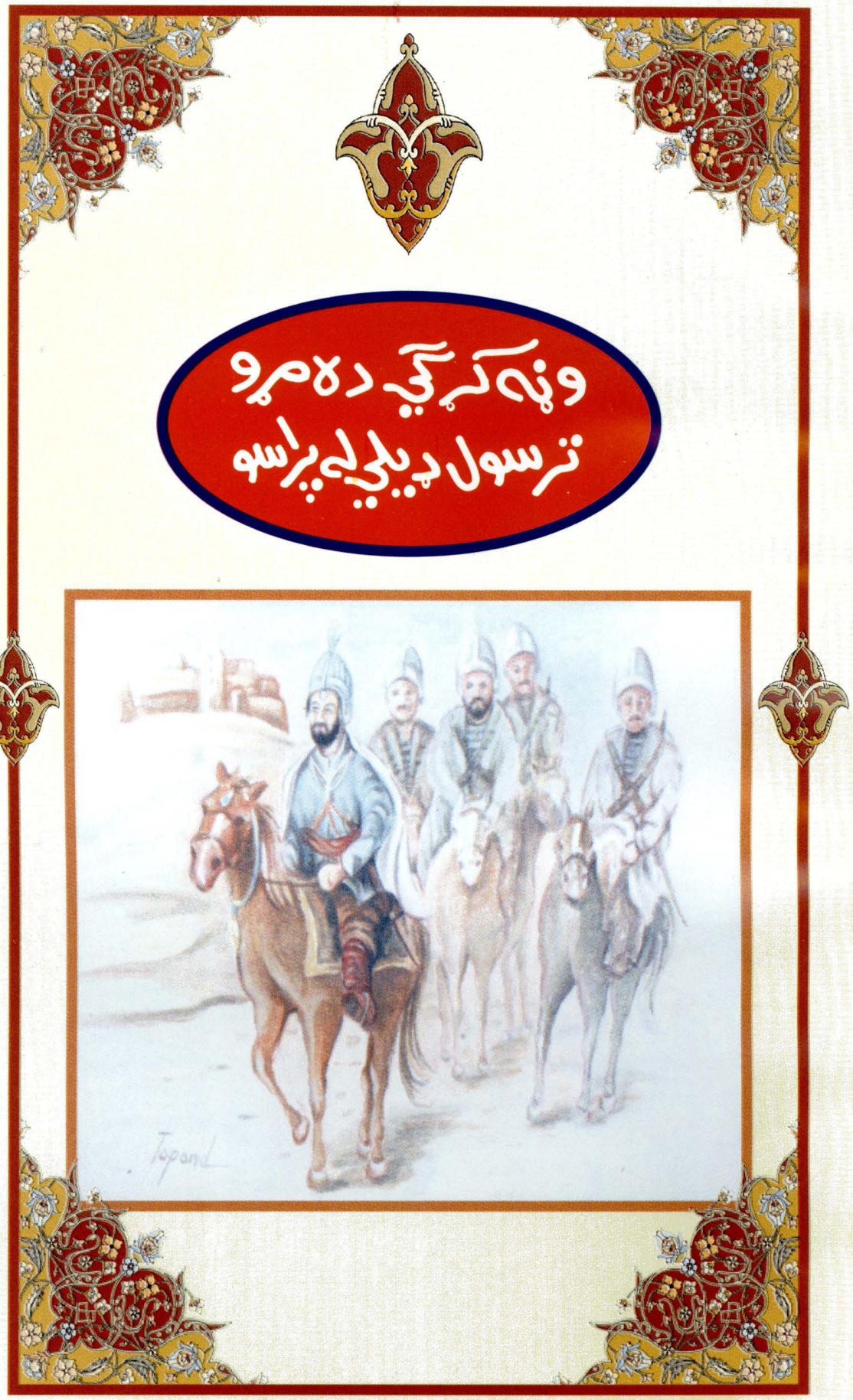




\section{(9)}

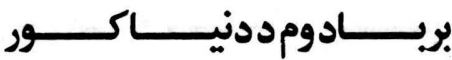

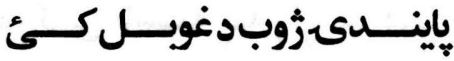
بـورهستركي ولارهتــليـــيـي

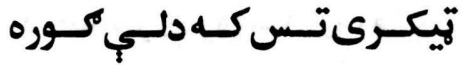

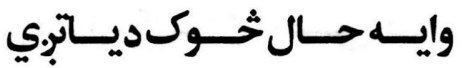

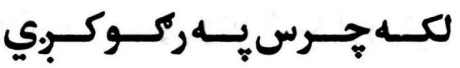

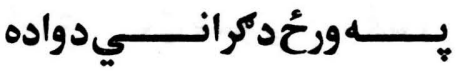

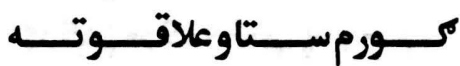

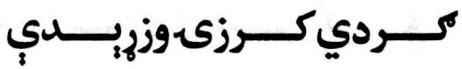

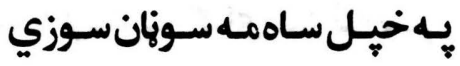

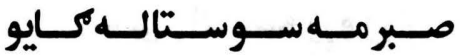
كوره ثخي نوم نه كي زما وبر

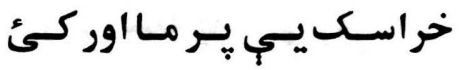

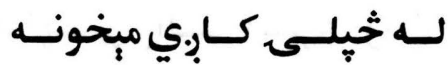
د دووس بخــت يـه هــوا حئي

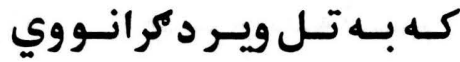

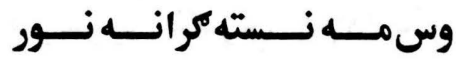

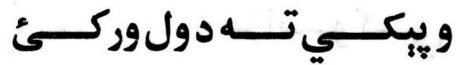

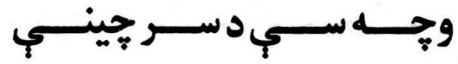

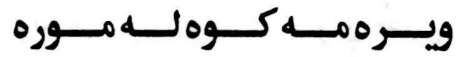

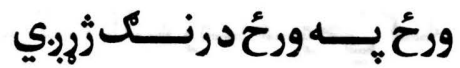

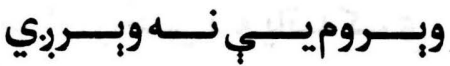

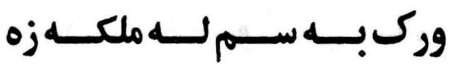

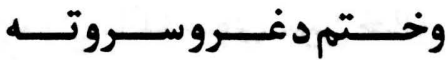
وركـي ســوي لونسكـدانــي

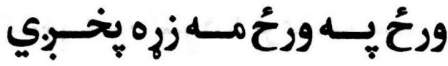

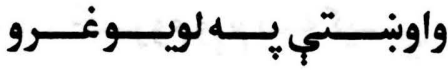

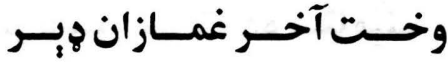
وركسى ثخي يبكس خـور كئ

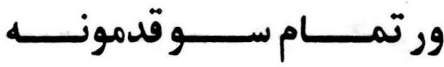
وريــي نــه وه ســا غـــوحي

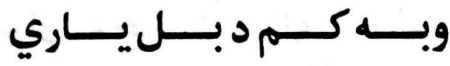




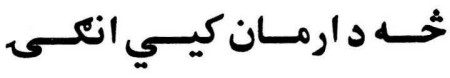

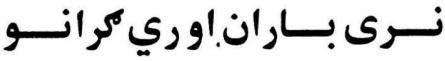

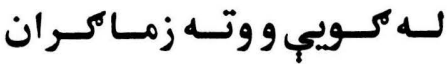
سـوز زيـاتر يسي يـر مـا اور كسئ دخـولي وار نسته ثحي راوري

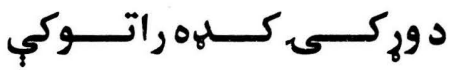
وار خطــاولـي سيسـي سـينيني

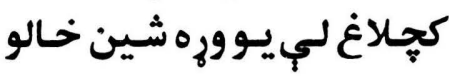

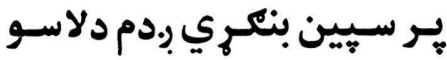

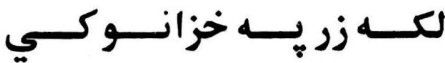
مـوربـهـيـات يــرخراسـانكي اوبــكي رو دونه له سري حُحي

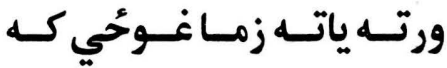

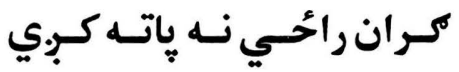

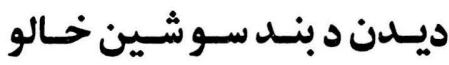
جيري ماتله سوي شين خـالو

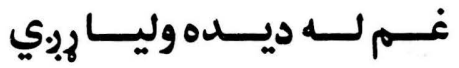

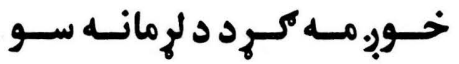

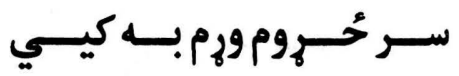
تـر ناسـور سخته ده سـتامينــ

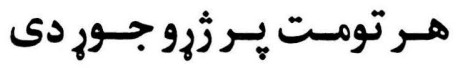

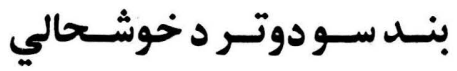
كال مـه كرد تركئ بـي كرانه

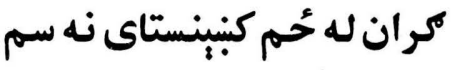

ورايسـي رالـــه وري وركــــ

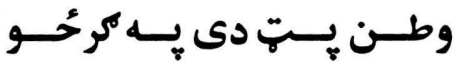

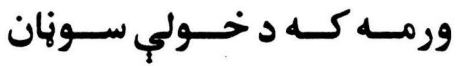

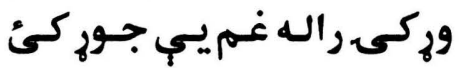

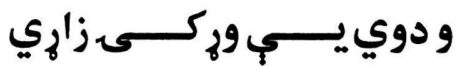

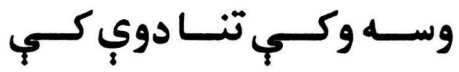

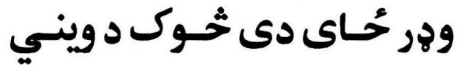

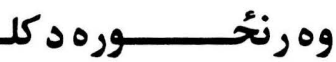

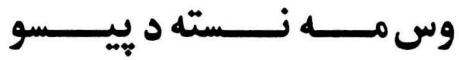
وركى ناسـته بـهـ زابيـوكي

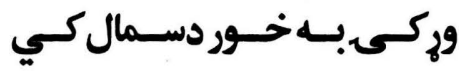

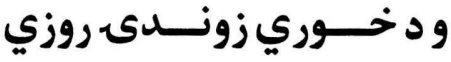

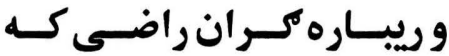
واوري ســـ وي كـــه اوربري

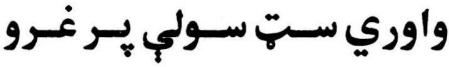

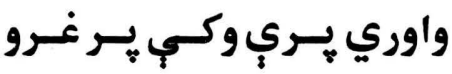

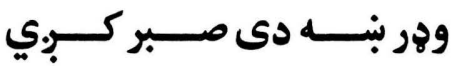

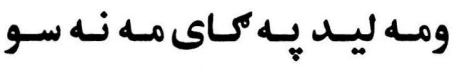

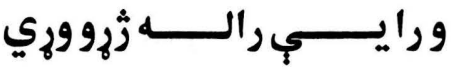

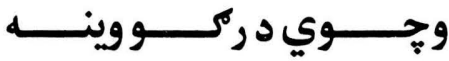
ورور يب نسته يلاريب زوري دى

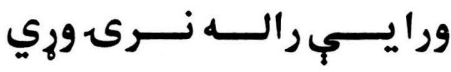

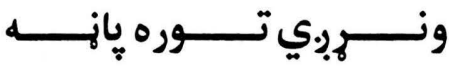

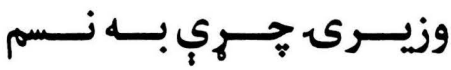




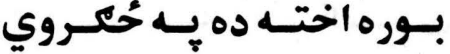
د نـرى حَكــروى سـاره سـته نه وحُي ونغ د سري تر خوله مـا بـه وسـره اور تـه يريـودي

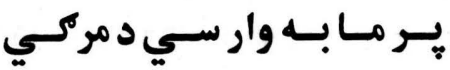

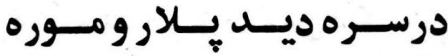
مسوركى بــه وي بـــه انتظــار

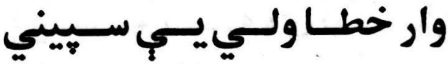
يـر تــا مـسكن كلــه كيـلدى

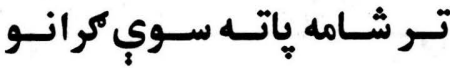

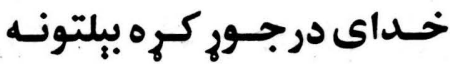
زه ليـا ناسـت وم سـتا دراوى

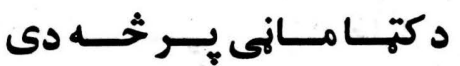
تبر غـرهكي كل سوخـاتولان

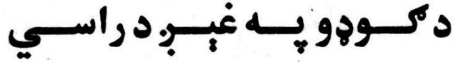

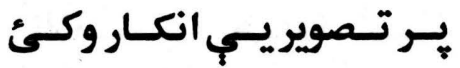

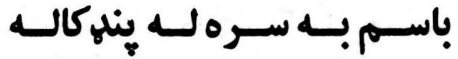

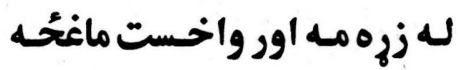
ما نـازك ليـا يـه خـوب نـهـ كئ

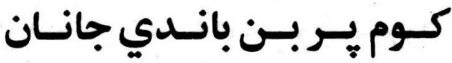
سـتا جاركل مـه بـه جبــوكي

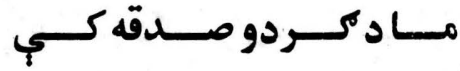
خـور ورى ده بـادبي بـوسي

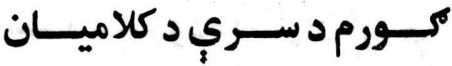

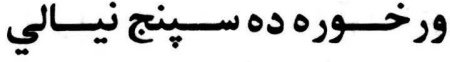
ورته ناست يسم وس مه نه سته

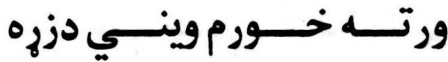

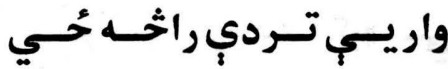

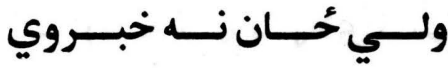

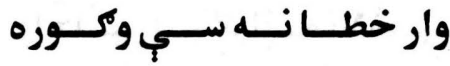
ورتــلاى نـــه ســم زه ناجــــار و هو حُـاى دى ثخـوك دوينـي

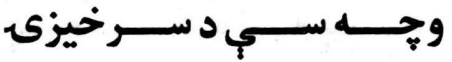

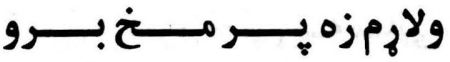

وطـن بــردى نـه سـته نجونسه

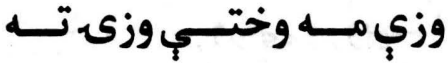
وخــت د نـورو دى زمانـه دى

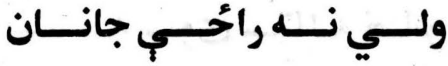
و جــورى تـهله مــه هـوا سـي

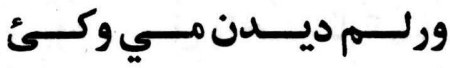

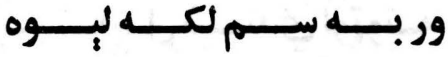
وس مـسه نـله ســته وكسم خـــــ وجــي درختــي صسبر وكـــ

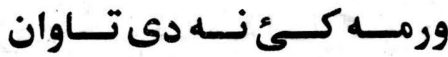

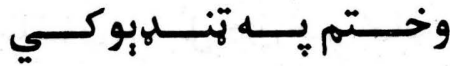
وروزه جوت وي طاقيهي مه كي ورور مبروى دى تينك به اوسي

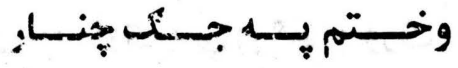




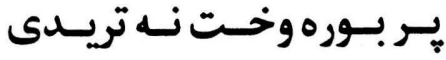

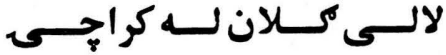

بنائسستي جـــور د غوبــل كـى

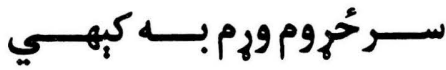

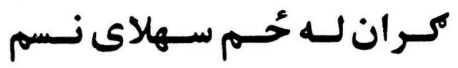

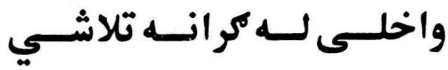

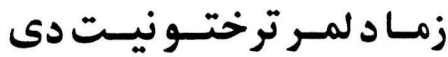

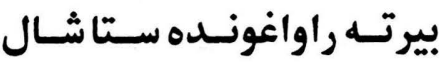

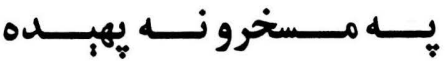

كلـى دكـردحسـي يـهـ مـاني

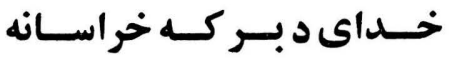

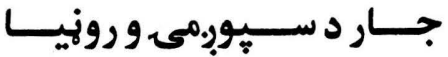

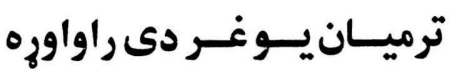

صـبر مـه سـوى سـتالـه خـالو

كبنبنم بـه كران تـه يـه تـور سر

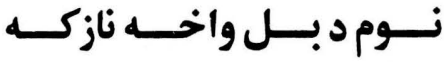

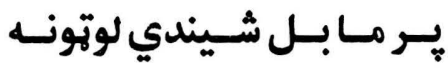

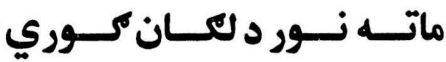

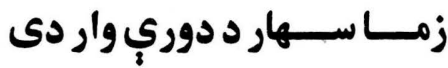

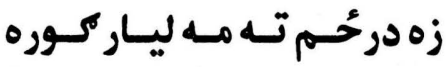

ببلتـون ليـابـل دى ثخيخ كـالم

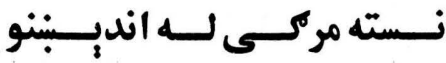

ســروبن غبــرك ســره راحُحي

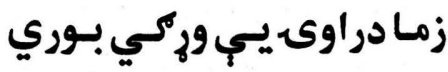

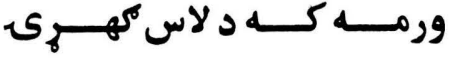

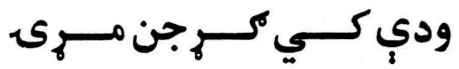

و تهيكـــري تــه د بــاد وركـى ودي

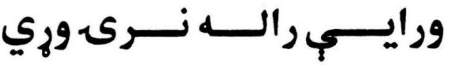

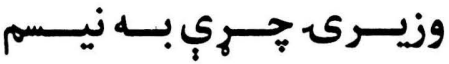

ورك مــه دي د لاس بنكـــــي

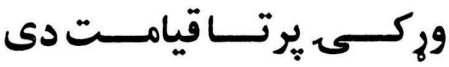

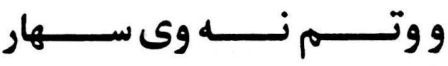

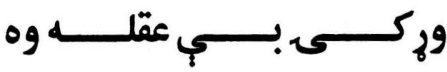

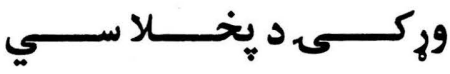

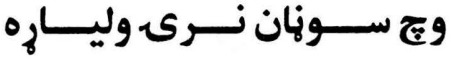

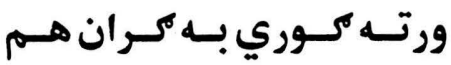

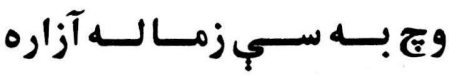

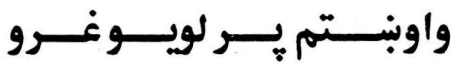

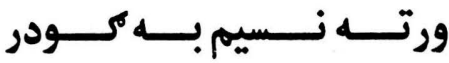

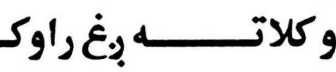

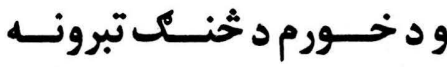

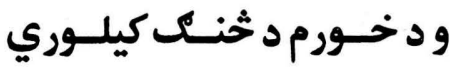

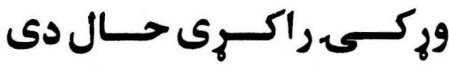

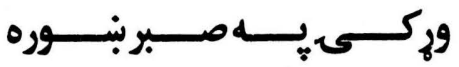

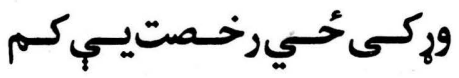

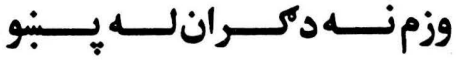

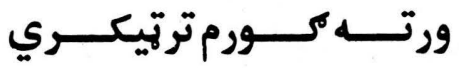

وســـه شــــووده بـــاران اوري 


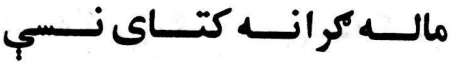

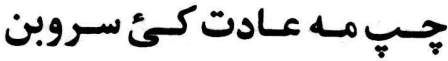
يـر زنهـه يـو دى د سري خـال سـره يـه لاس بيـايسي اوبولـه صـبر كـم دى خـــي رالـوبري ستا بيكى بـه زرتـار جـور دى

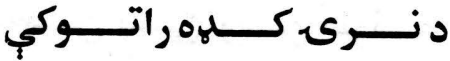

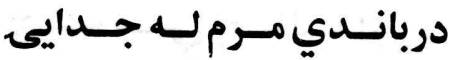

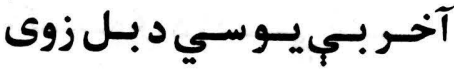

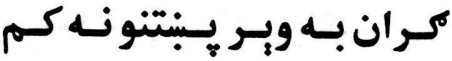
نـامردزونسل بــي وفـاكـم

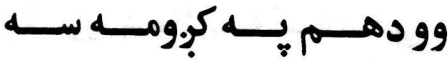

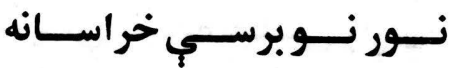

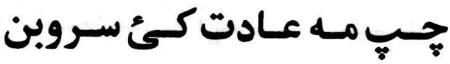

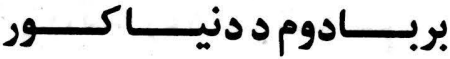

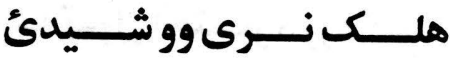
ولـــــور دزارســــــه د باب. تهنــ بركساى و وريسنتو دي

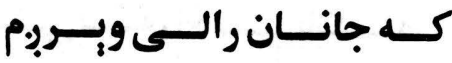

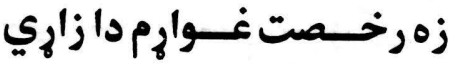
بلــوخمى د بنــــــو ميــان دى

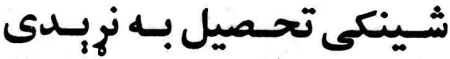
سـى كىي م-ري لله يرونس

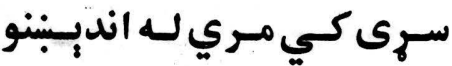

وع وليساريجي وع بـه تـه سـي

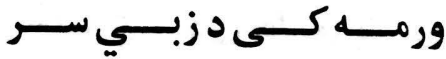

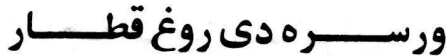

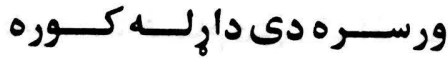

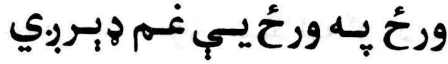

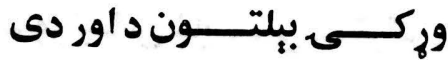

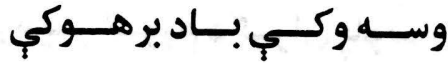

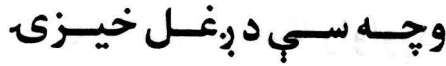
وينسي مـاكــــي بانـلـي تـوى نسور بـه تهول اختيـار دزهر كـم

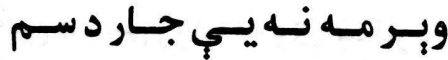

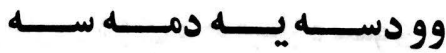

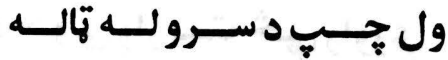

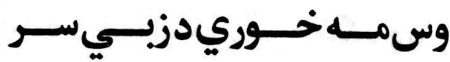

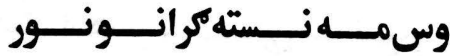

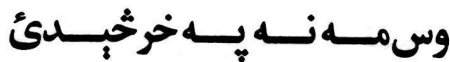
وخت مسه تر سوى سوم.بوها وفــادار خلــــ د نـــــو دي

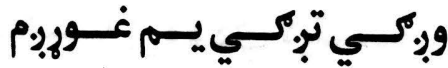
ورتـهـ وع سـوم بـهـه وليـاري

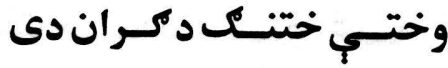
وهور سـوى شــينكى تيكـــى ون

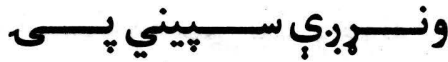

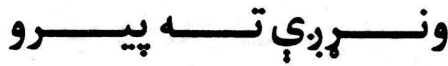




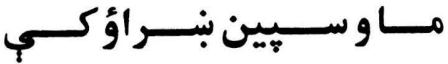

زماغــه غ.... دى خُخلـــور بنـــهـ

زمـاجـواب يـر دنيـاتـران دى

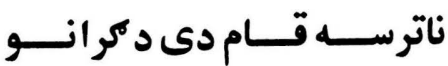

صـبر مــه سـوى سـتالـه كر انــو

تــور لبـاس بنايـستي سـتركي

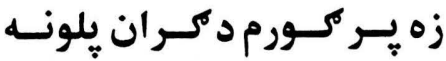

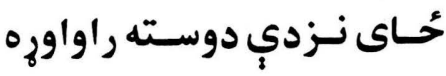

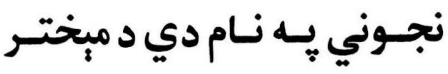

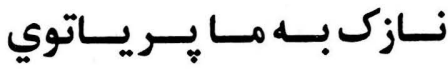

خي د رسم زوب نه وي بنـكاره

ليـاري دوي د خمبــازه سـوي

د خـولب وار نسته ثخي راوري

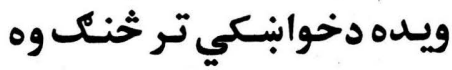

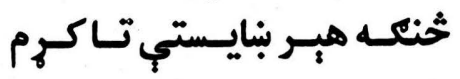

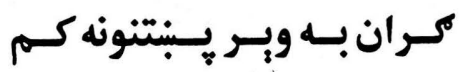

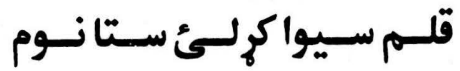

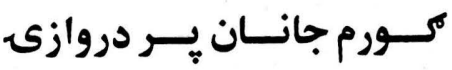

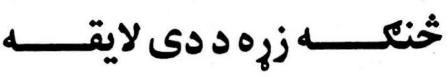

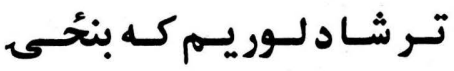

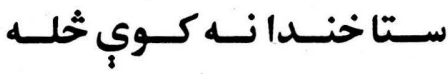

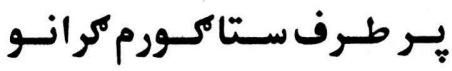

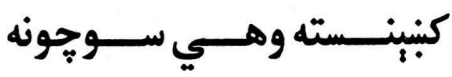

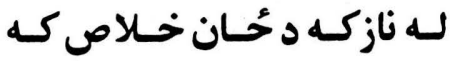

ومــهـي كيـايسي مـهـي كـي

وابسي نخلـي سـتا يـهـ زرنسـده

ووهه سوج خنكه د خيال دى لهي

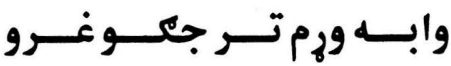

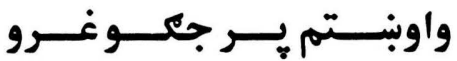

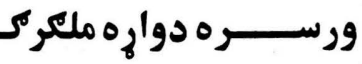

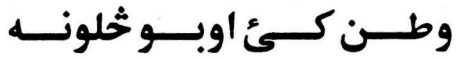

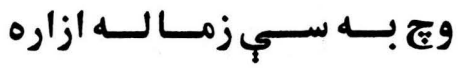

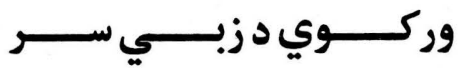

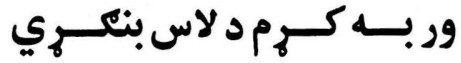

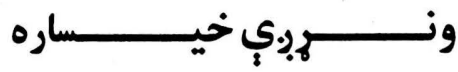

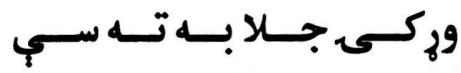

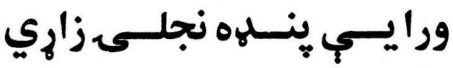

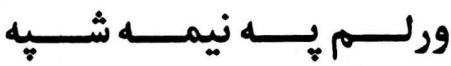

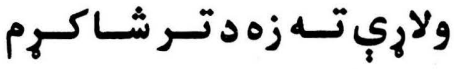

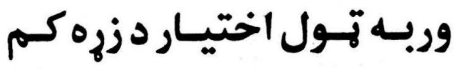

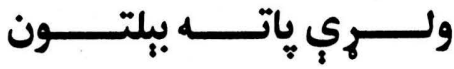

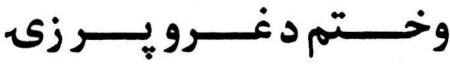

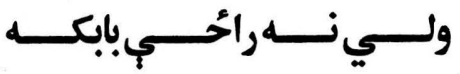

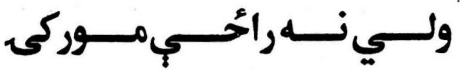

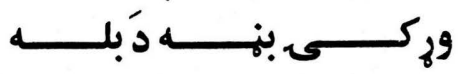

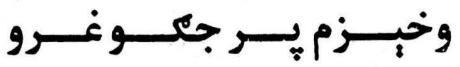

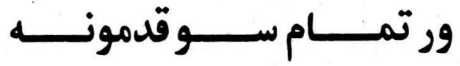

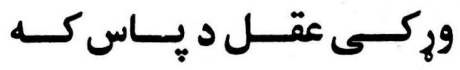




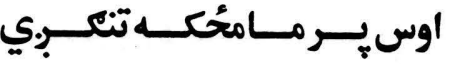

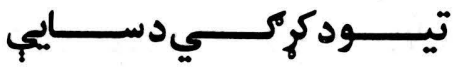

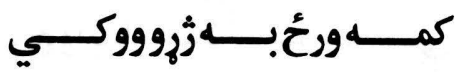

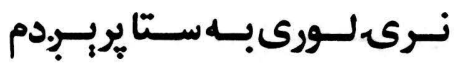

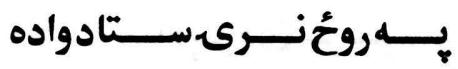

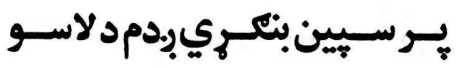

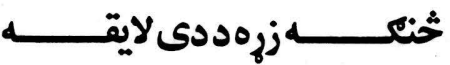

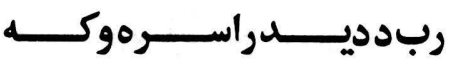

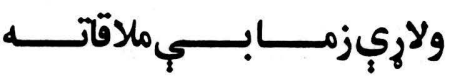

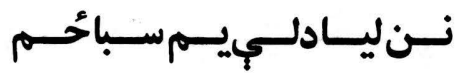

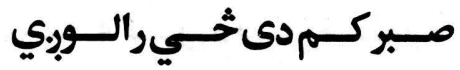

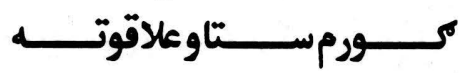

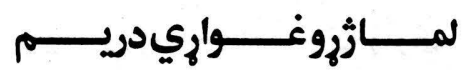

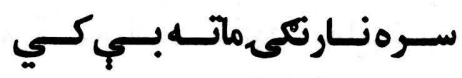

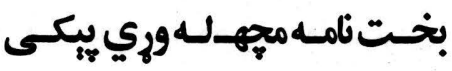

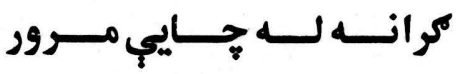

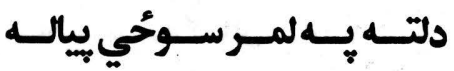

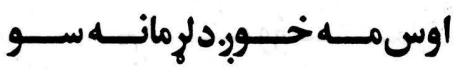

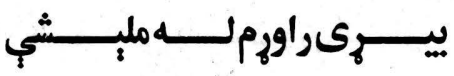

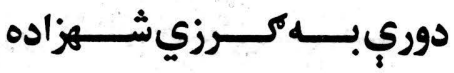

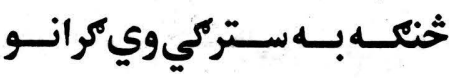

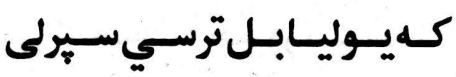

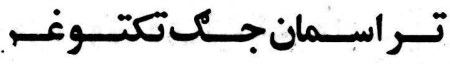

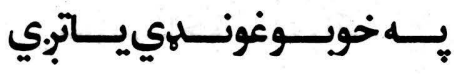

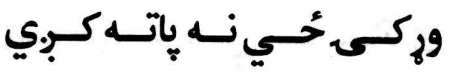

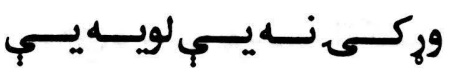

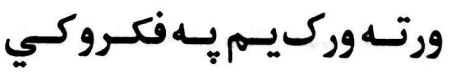

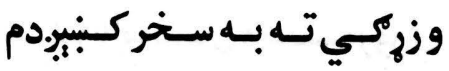

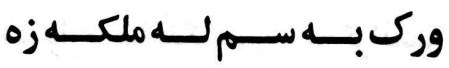

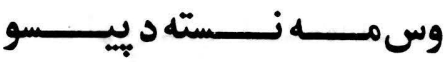

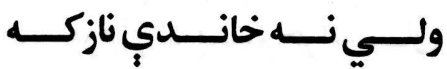

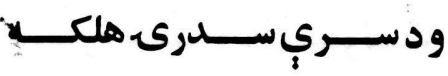

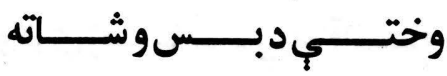

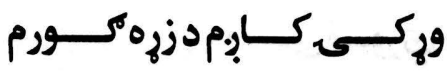

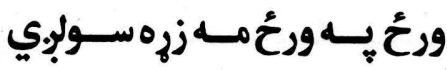

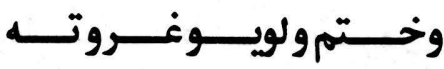

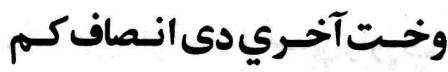

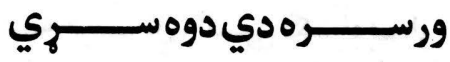

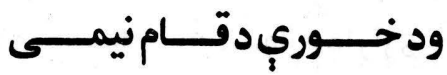

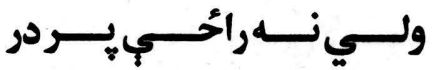

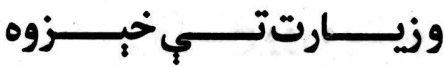

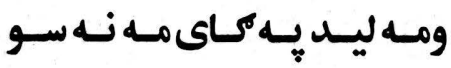

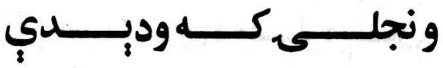

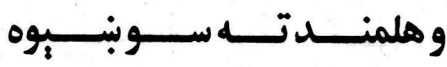

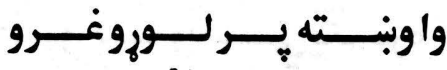

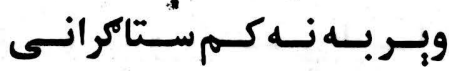

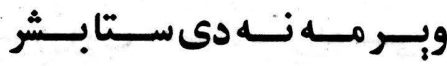

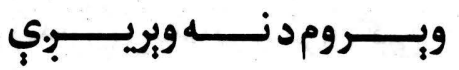




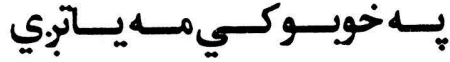

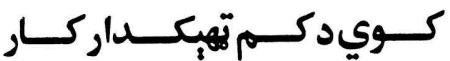

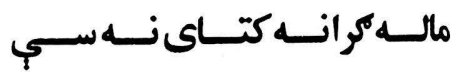

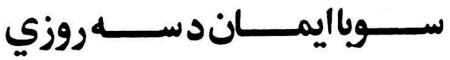

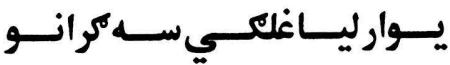

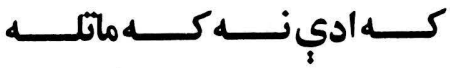

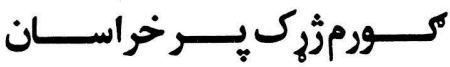

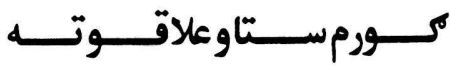

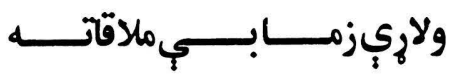

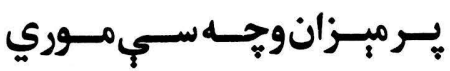

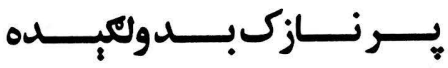

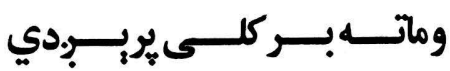

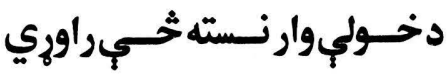

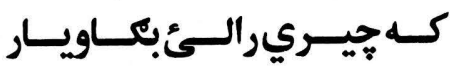

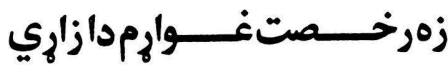

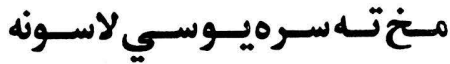

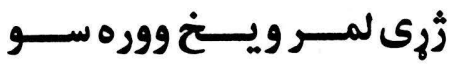
بيرته مه بـتِ كه ستا بهـ شال

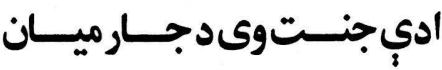

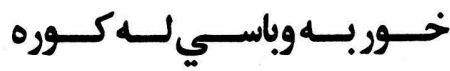

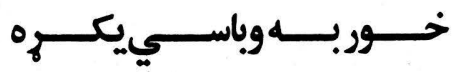

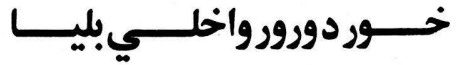
خــوروزي دهبــادبــيـيوسـي

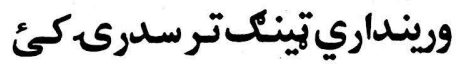

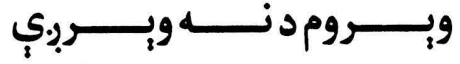

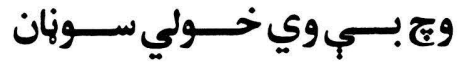
وج وليـار هـلاك بـه تـهـ سـي

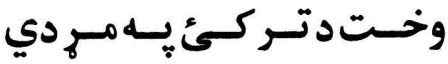

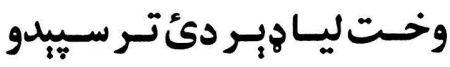

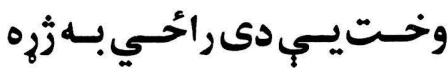

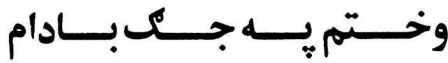

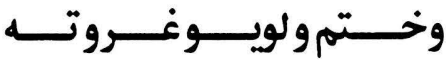

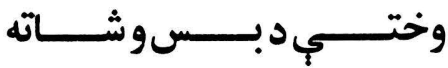

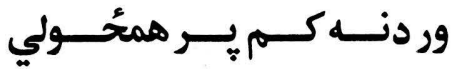

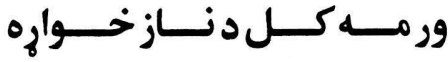

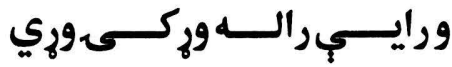

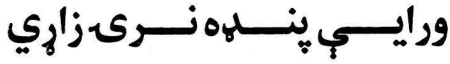

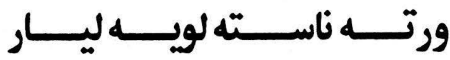

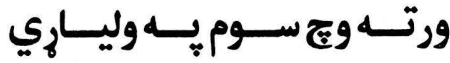

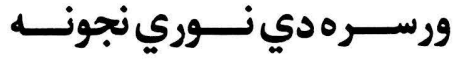

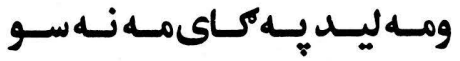

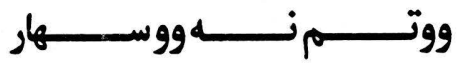

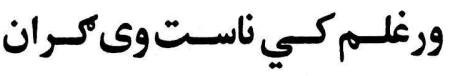

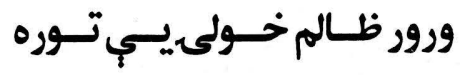

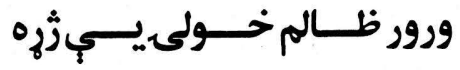

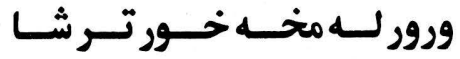
ورور مبروى دى تينك ببه اوسي

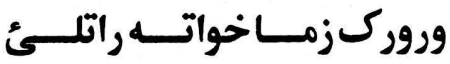




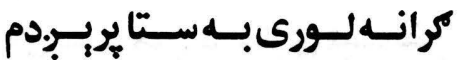

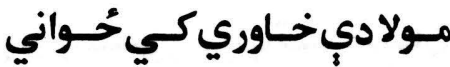

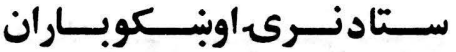
يرراغبرى كُكسكران لاسكئ

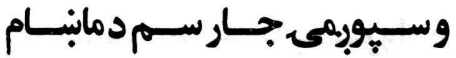

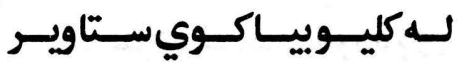

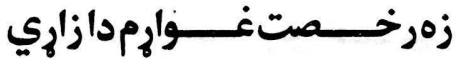

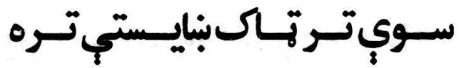

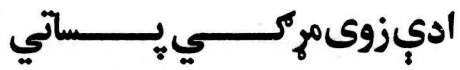

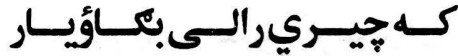

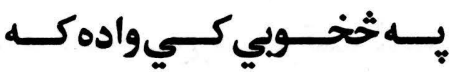

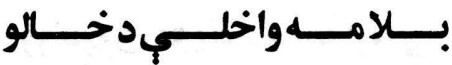

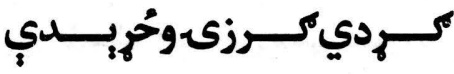

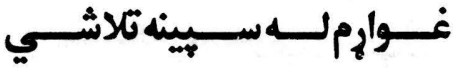

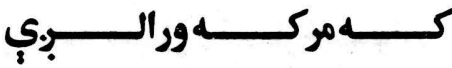

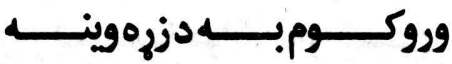

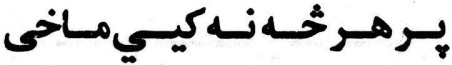

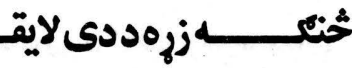

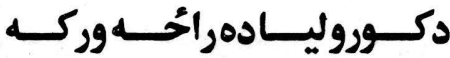

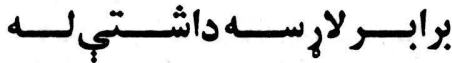
يـو وار ليــا غبركسه سـهـه كرانـو

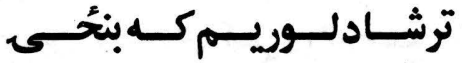

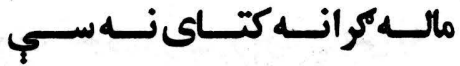

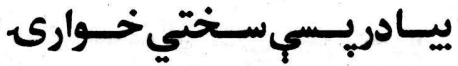

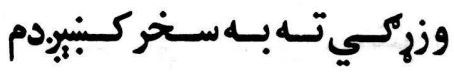

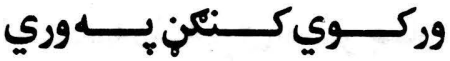

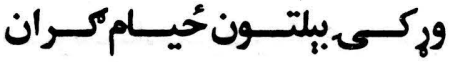

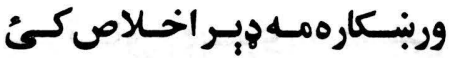

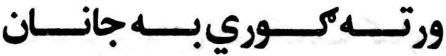

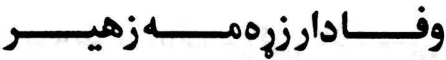

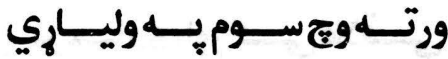

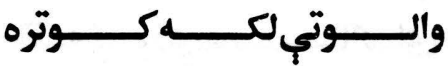

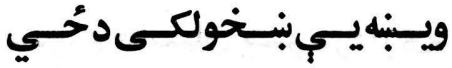

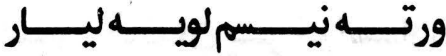

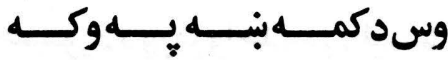

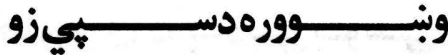

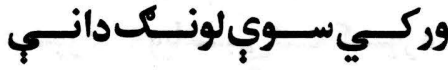

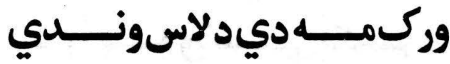

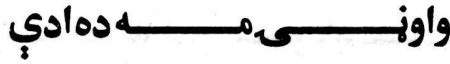

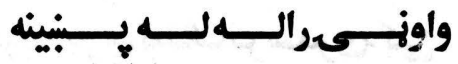

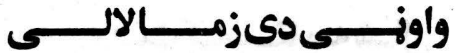

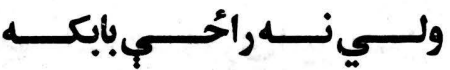

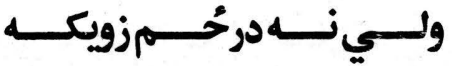

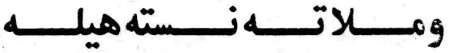

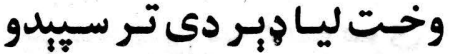

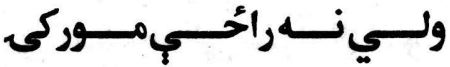

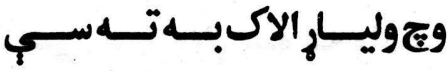

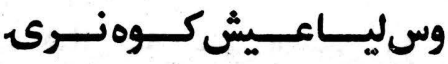




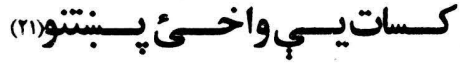

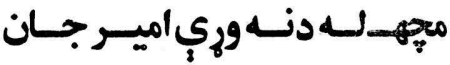

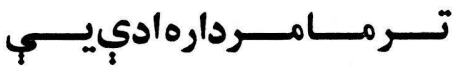

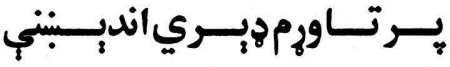

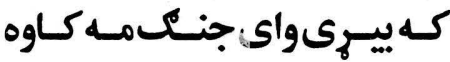

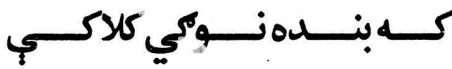

يسـرمسـادياوركسي علاقسيجي

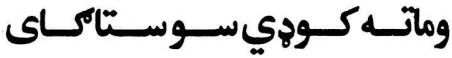

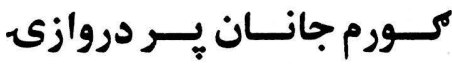

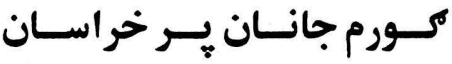

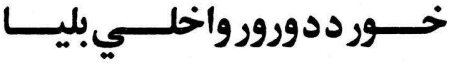
خـوروزى خدهبـاديـيـيـوسيسي

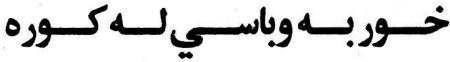

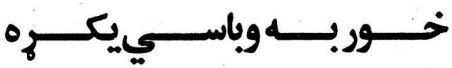

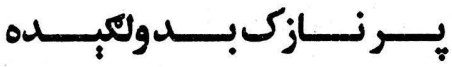
وريندياريتينكترسدرىكئ

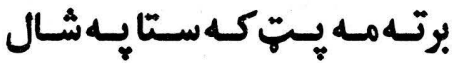

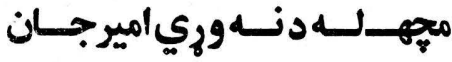

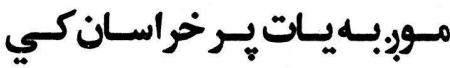

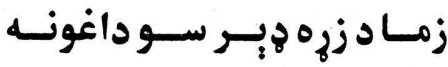

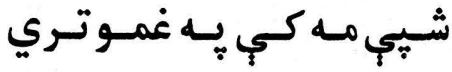
خـي ملكس خـالي سـوله كر انـو درحسئ ثحي ولاج سـويسه واده

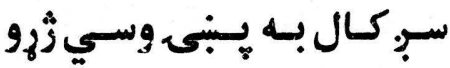

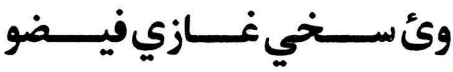

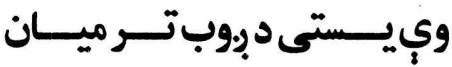

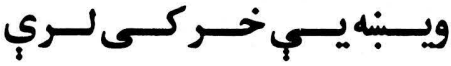

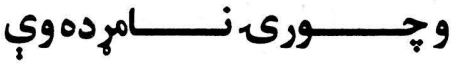

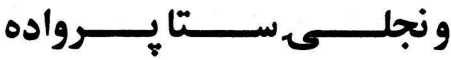

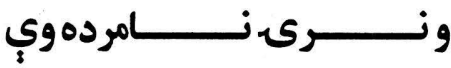

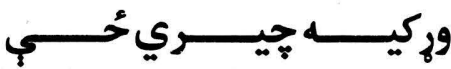

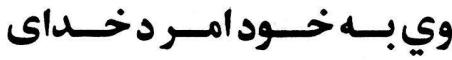

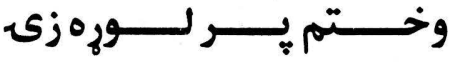

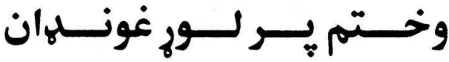

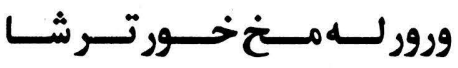
ورور مبروى ودى تينـكبــاوسي

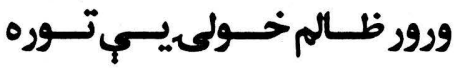

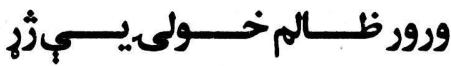

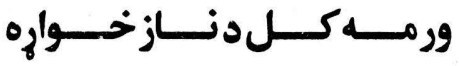

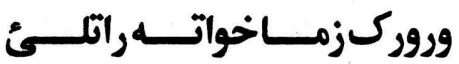

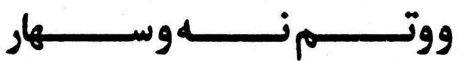

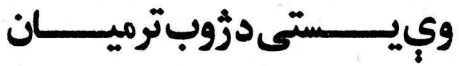
وركى ونسه خسـور دسـمال كـي

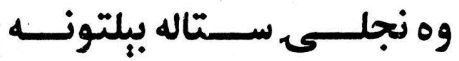
والــوتي ســينينكى كـــوتري

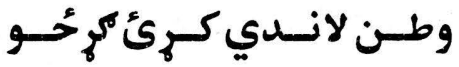

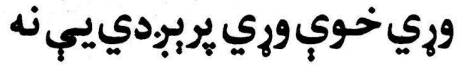

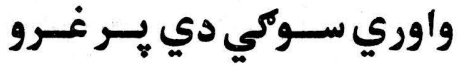




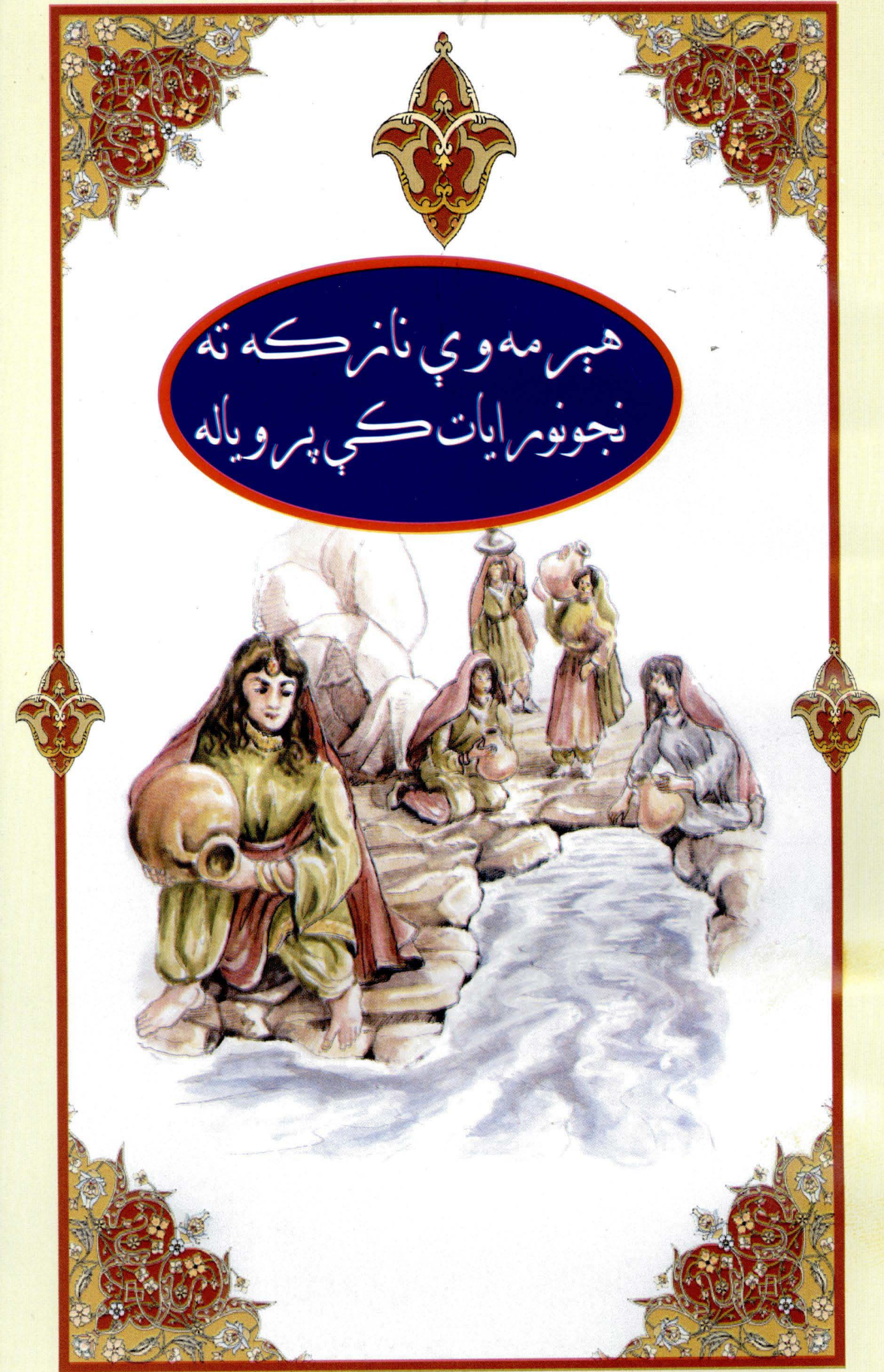


خوارهسي خيلواخله جاركل

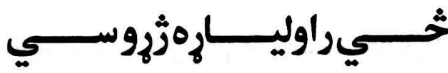

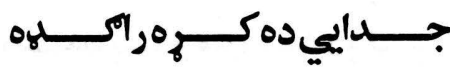

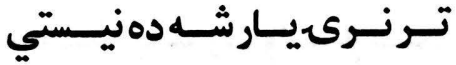

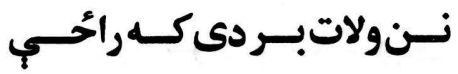

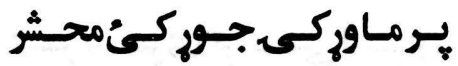

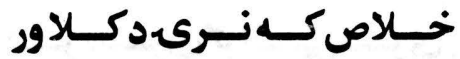

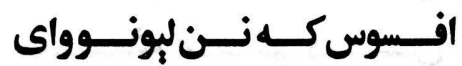

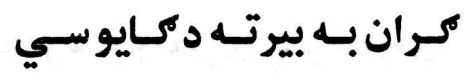
نسته غونلهم خُي وياى كبنبنه

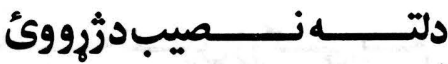

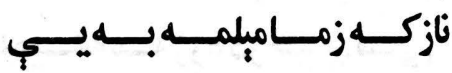

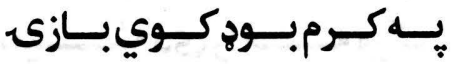

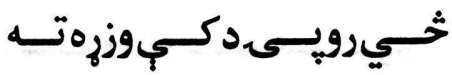

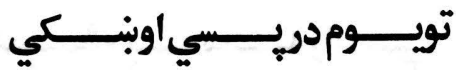

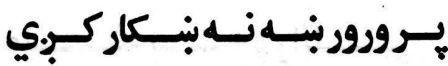

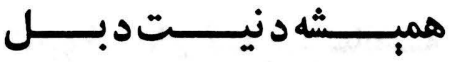

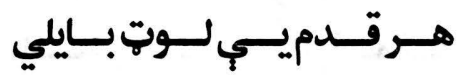

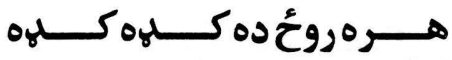

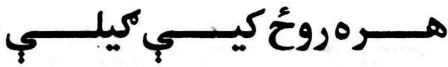

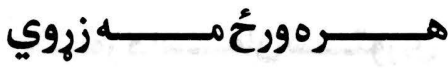

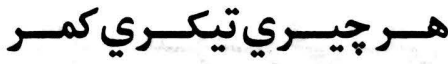

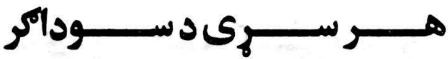

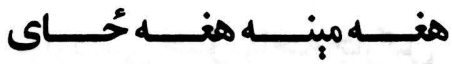
هلم دي يجي غوبنه دي توسي

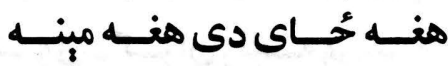

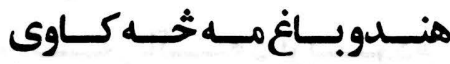

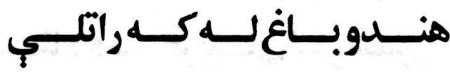

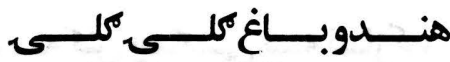

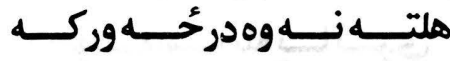

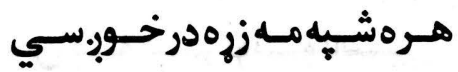
هــرهخــــــــرورورجــــروبي 


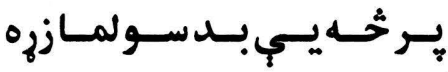

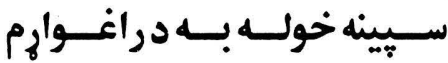

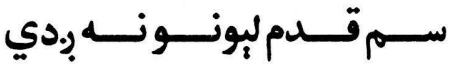

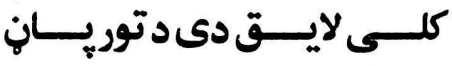

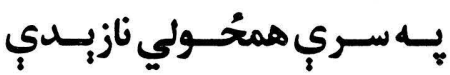

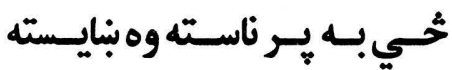
ولـي يــنّمانه ســوي بنايـستي

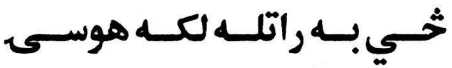

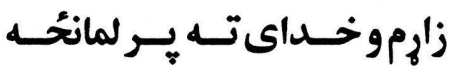

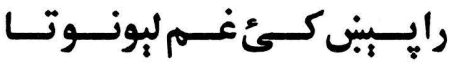

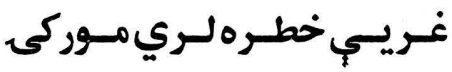

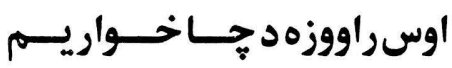
بختــــور دآســـمان ســــتوري

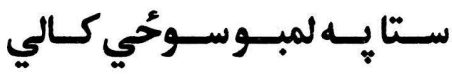

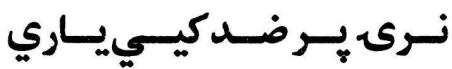
خواره سي خيل واخده جاركل حُيــامـهـ هوتهـل دهد دبـــوري

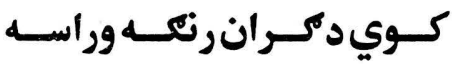

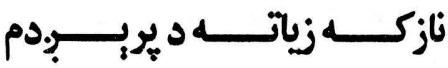

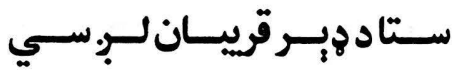

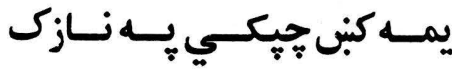

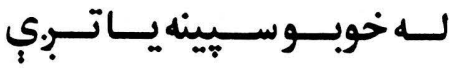

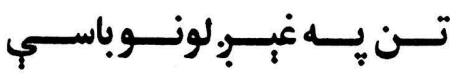
بـهـ سـري همعَــولكي نازيــدي

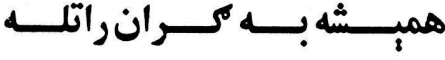

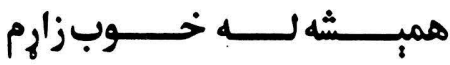

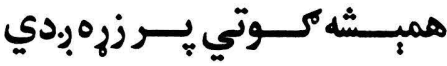

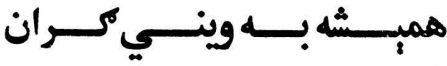

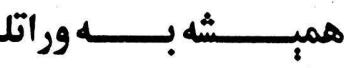

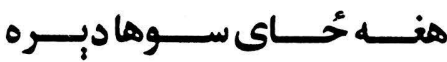

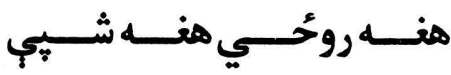
هنـه وخــــيـي خونـدكـاوئ

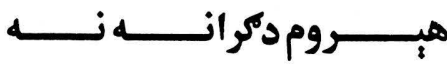

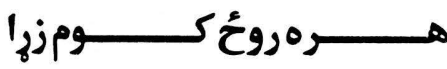

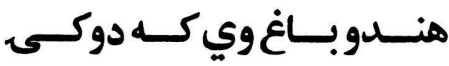

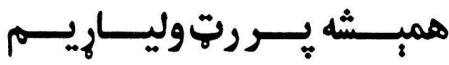

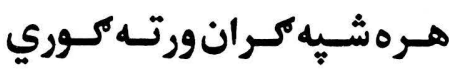

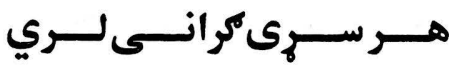

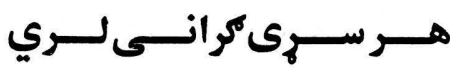

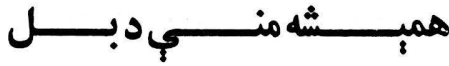

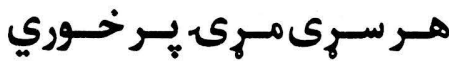

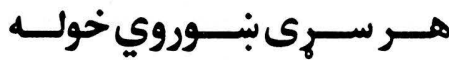

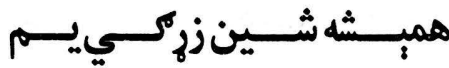

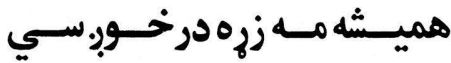

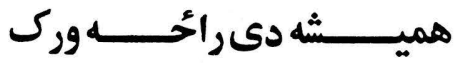

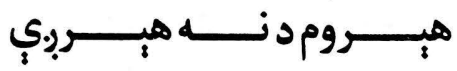

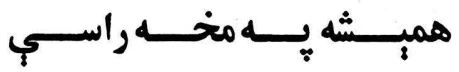

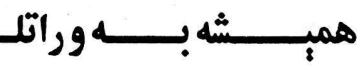




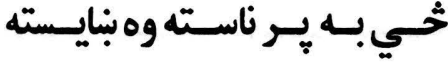

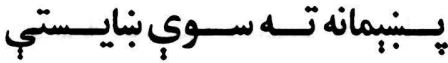

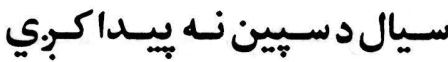

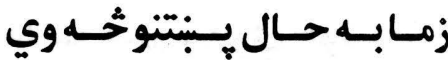
سـتا يـله لمبــوسوكوحي كـالى

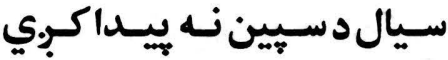

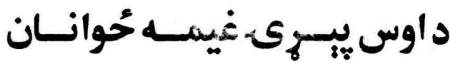
سـتادكـلاب غونـــي حـــواني شـايرى نجــوني.بـي بـيوسـي

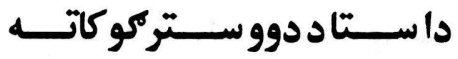
سـتاتسصوير مــن تسهـ رالـوروي اوسيـي ديسـ بــه ملاقـات دى

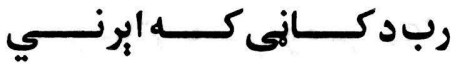

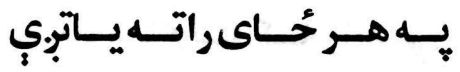

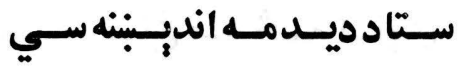

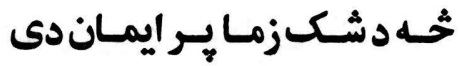

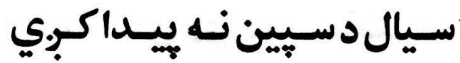

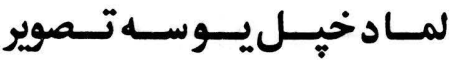
لـري دوي زيسي

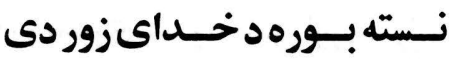

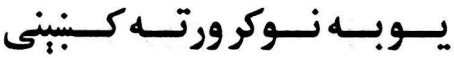

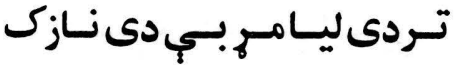

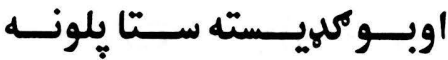

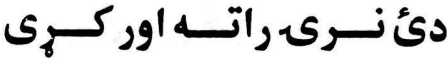

هi

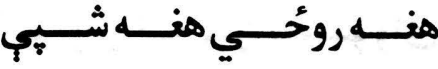

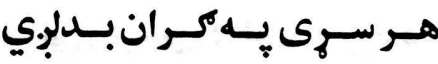

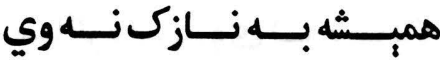

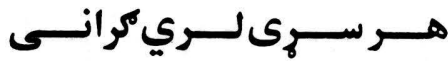

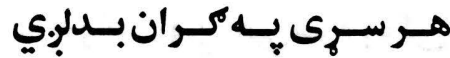

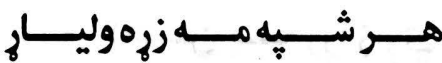

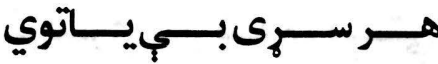

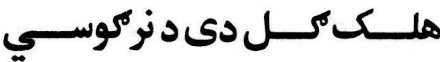

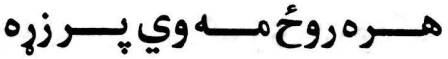

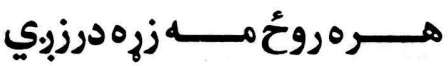
هير مه نه دى سيّين مه يات دىى

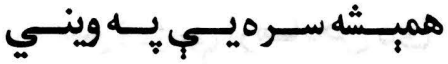

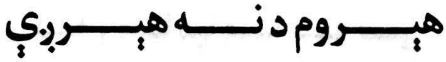

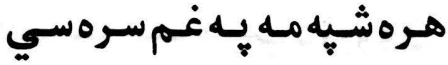

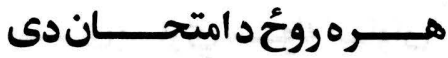

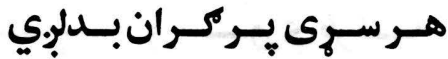

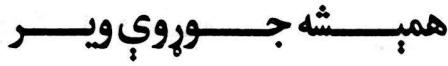

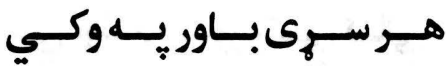

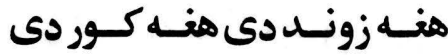

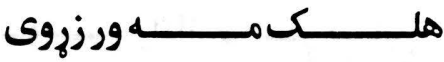

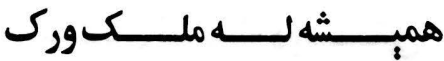

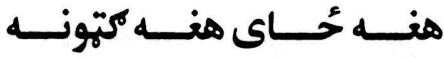
هنـــه كـــور دى هنــــه كلــى 
نسته بـوره ثخـي ويساى كـبنهن

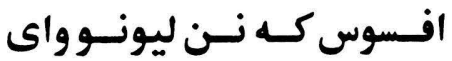

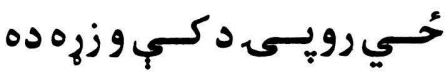

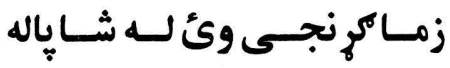

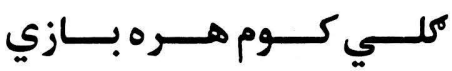
كم به وخت ويخي سره ووكي

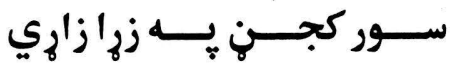

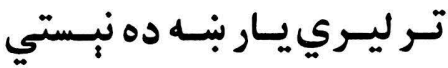

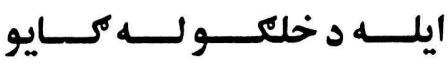
يـه ميـان كي كـرزي د رودك

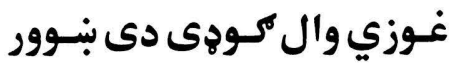

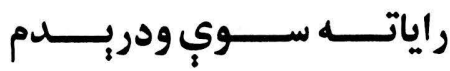
هـر سـرى يسي ارمـانجن دئ

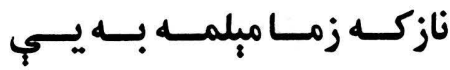

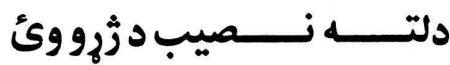
د ســـــــــاري ســوله تــــاوان

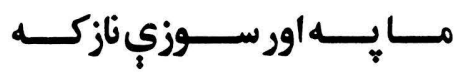

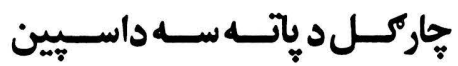

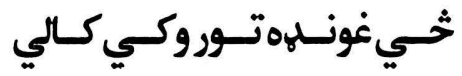

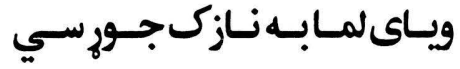

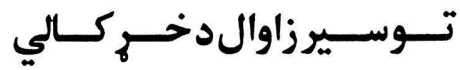

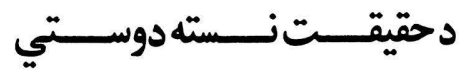

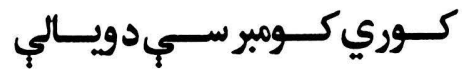
بنسه سـوخـي كـرانوكئوراده

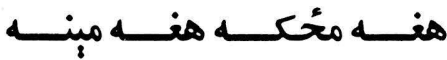

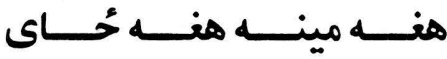

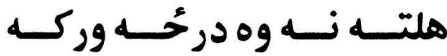

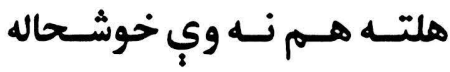

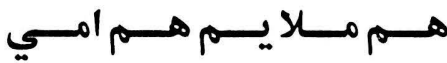

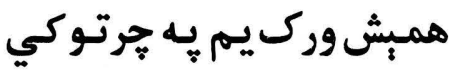

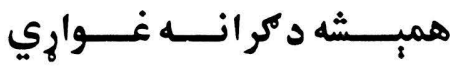

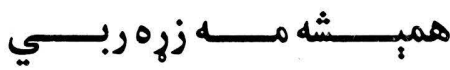

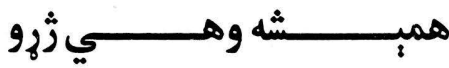

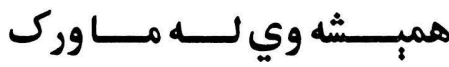

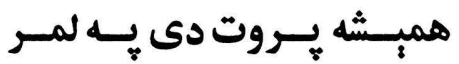

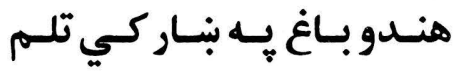

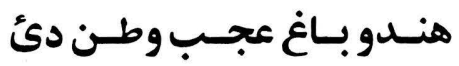

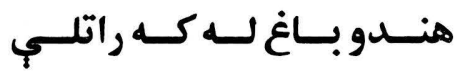

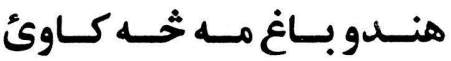

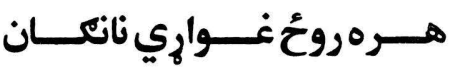

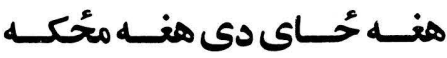

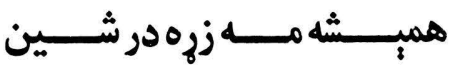

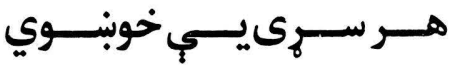

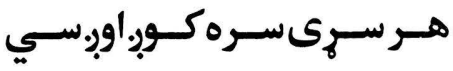

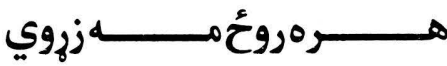

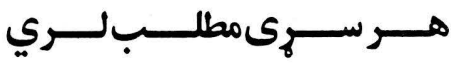

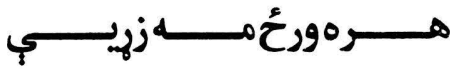
هـره رؤيـي خواسـت كـاوه 


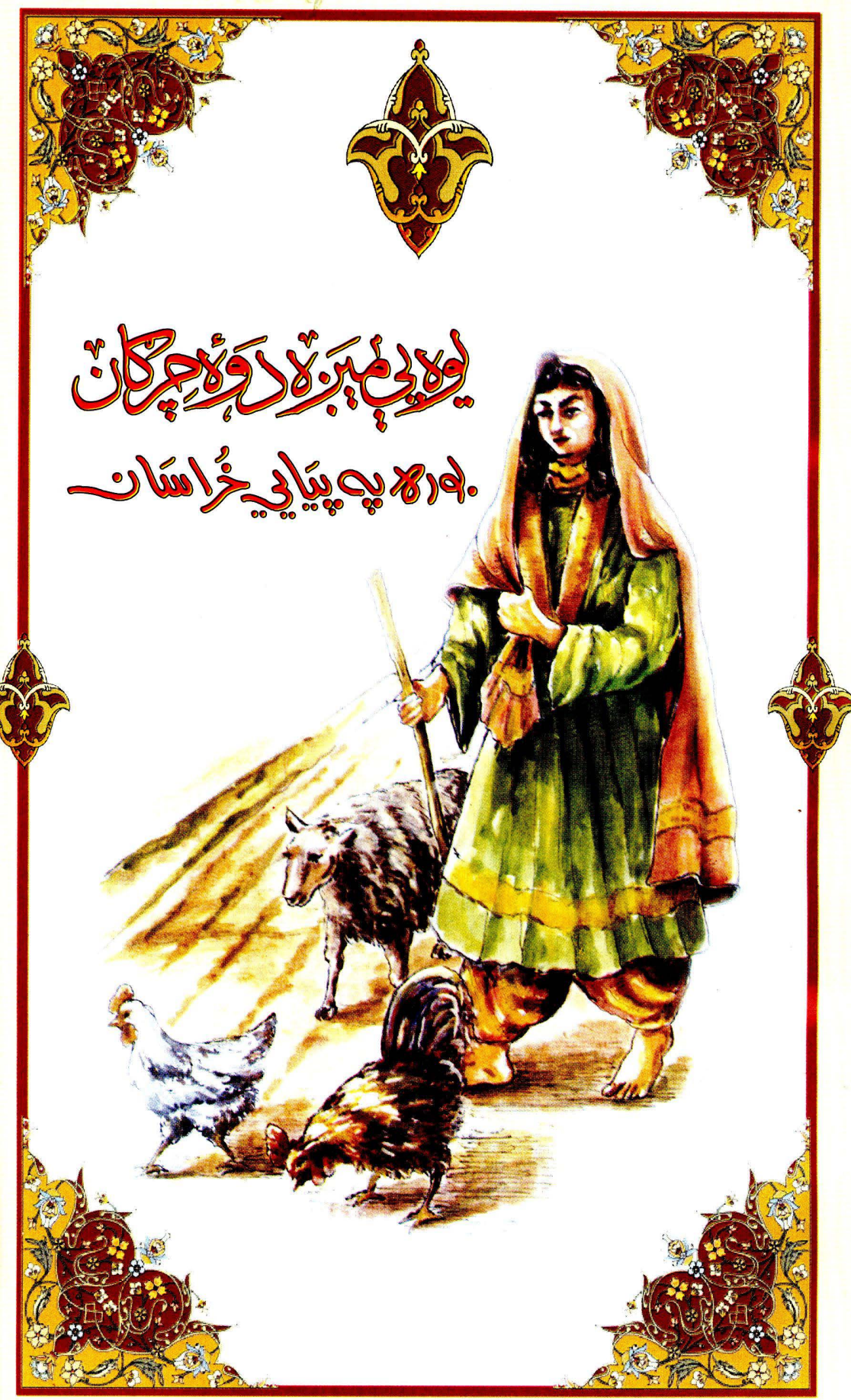




\section{(5)}

بـل مـــهــــودى جلـــولى دى

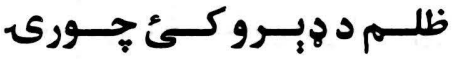

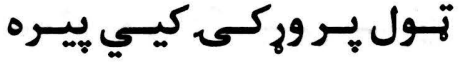

تـولي مـه دود كي يـر دراوى يـ

سـتادسـمال بـه دلبي زروكتم

دا لبــاس خـــومره زور راكـي

اوس شبرجان كبنكي توبه ده

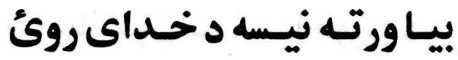

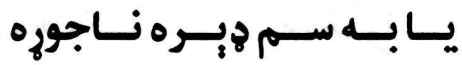

بياد ستا بـلار كي مـا بانـسى

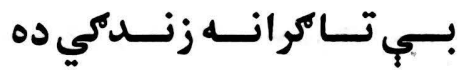

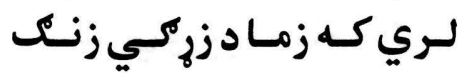

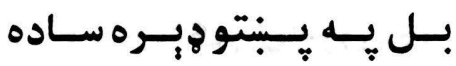

بـل واى مـسكن يـر خر اســان

ما د تور ستركي لمبي خوري بيـا يـه روس كي همسايه واى ليى

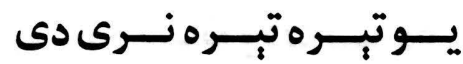

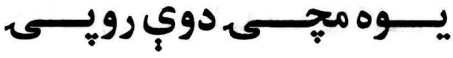

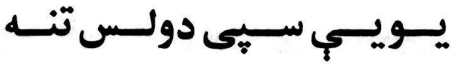

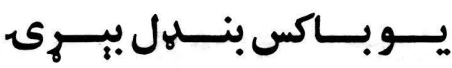

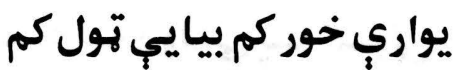

يــواره مختكـي بيرتـهـ شـاكي

يــاري نــه ده ســره لمبــه ده

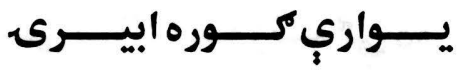

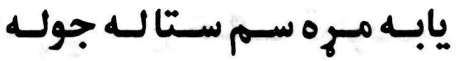

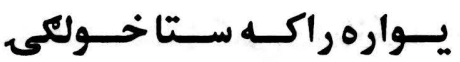

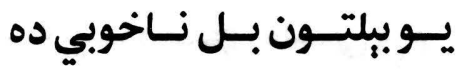

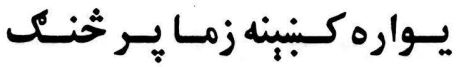

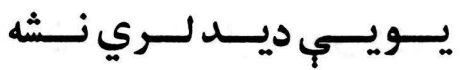

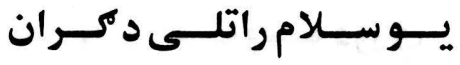

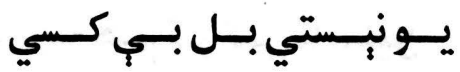
يــوتــصوير دي راســــوراى 
يامــــه قلــــم كــــه د كــــايق كور سيور كى ير ماكر ان دى

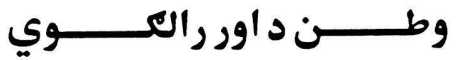
بـل بــه دوبسـى نوانـد راسـي

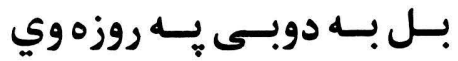

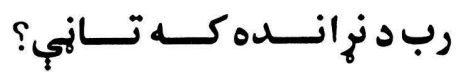
يــراخح وطـن دى د زوب غـاره

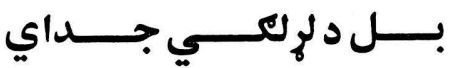

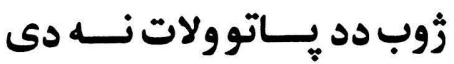

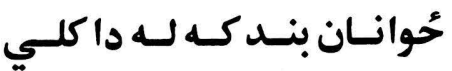

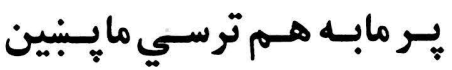

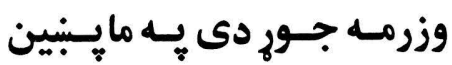

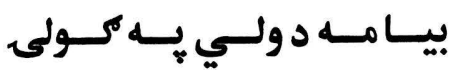
مبرِتـون دى ثخي رامـات سي بـي غونسه ورور دى يـر مابـل

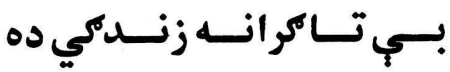

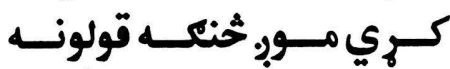
يسه هـر ركست كـي د لمانحُهـ كــه بيـــاد مـــج زولنـــي ورهم

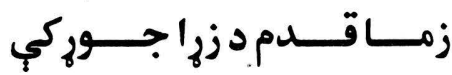
كـران تـر مـاليـا ارمـانجن دى ده

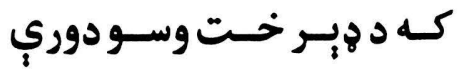

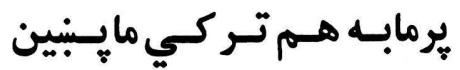

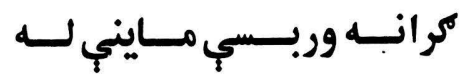

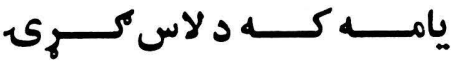

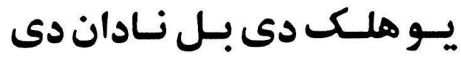

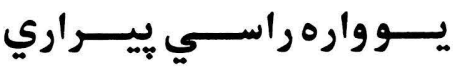

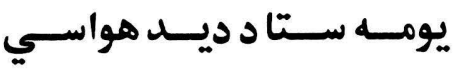
يوبـهـ ســا د خــولي لمبـهـ وي

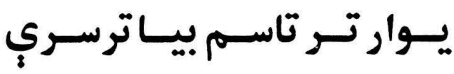

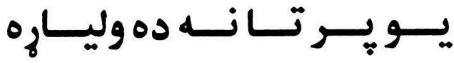

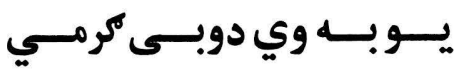

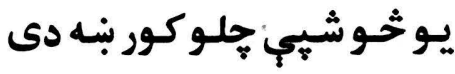

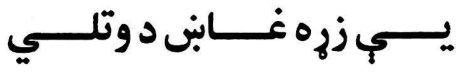

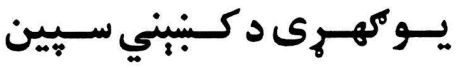

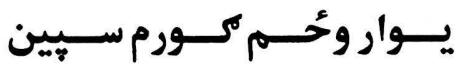

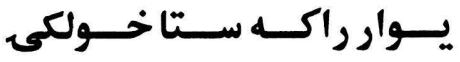
يارمــه يونــه دى ثـــي راسـي

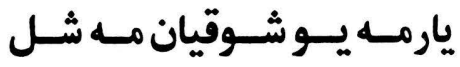

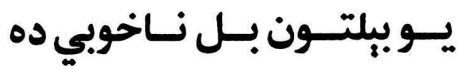

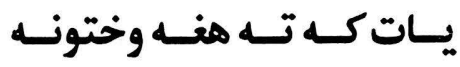

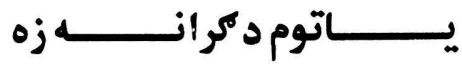

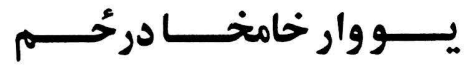
يارمـه مـري ورور مـه نـاجوركي

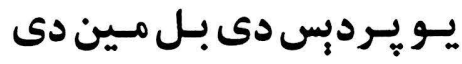

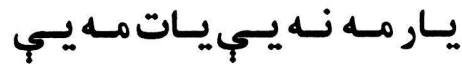
يسـوكـرى د راســي ســينين

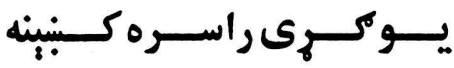




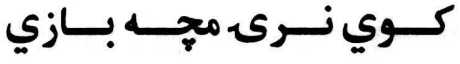

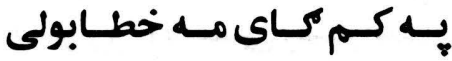

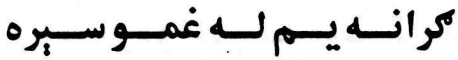
اوس مـه كـإِي لـه سري هـيله

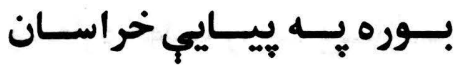

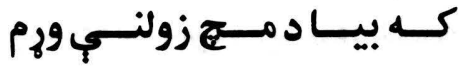

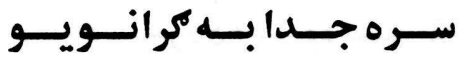
كـم تـاوان بـهـ دمـران وســي

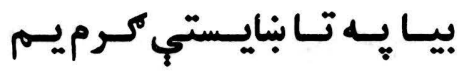

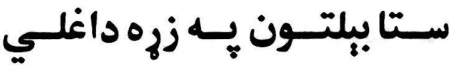
بـــاريـي زمـا يـبنتنوزيرهـئ

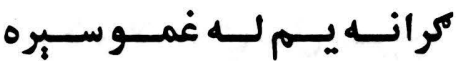
خـي د بـار مـات كـم يـر كـايو بيـاد جــواب راكــي بنايسـته بل بـر سيورِمع راحُّي جانان

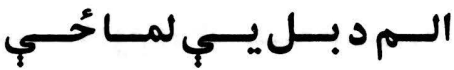
زيـارت دكـرد واخلـي نـور اور

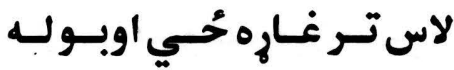
ياتك سيّين يـر دونيـا زماكي وسـوم د سـري يـــه انديــنبنو

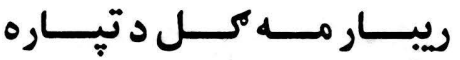
د سيّين حق به هر ما هُبر سي

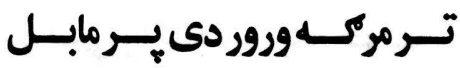

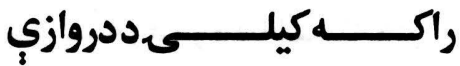

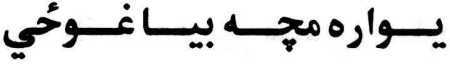

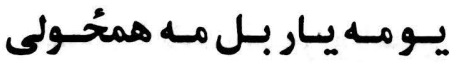

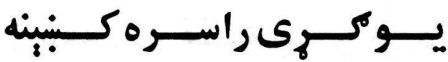
يـويسي وره د.كست حساجي له

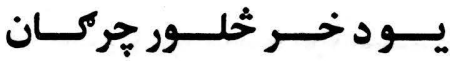

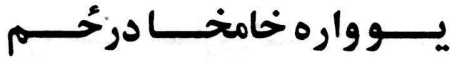

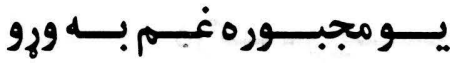
يـوار د راسي زره بي بنه سي

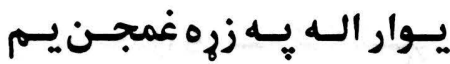
يسـواره راســـه زمسـوروتركلـين يـار دبنـمن سـوى واريبي وكى

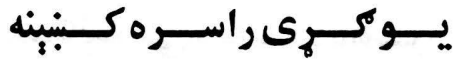

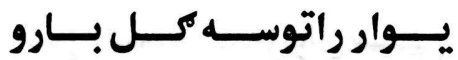

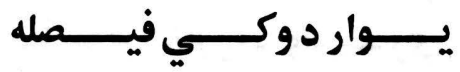

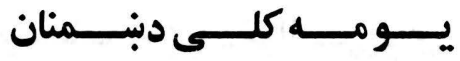

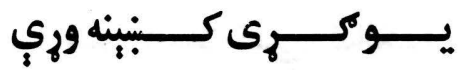

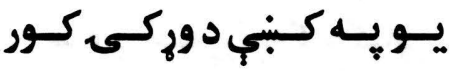

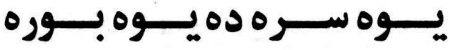

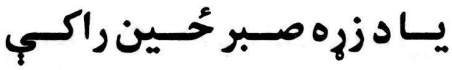

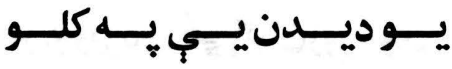

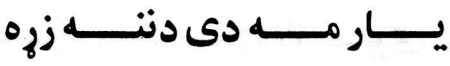
يـونـزل سي بـل د شبي سي سي

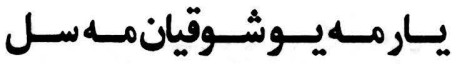

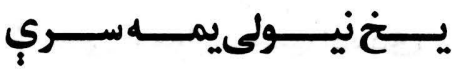




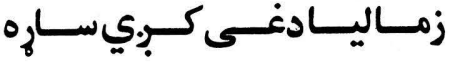

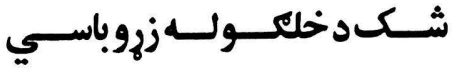

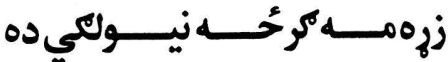

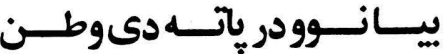

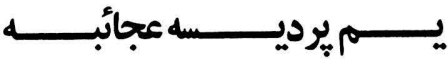

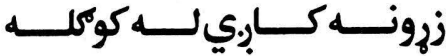

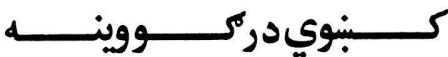

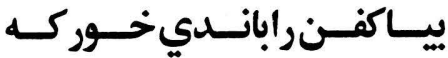

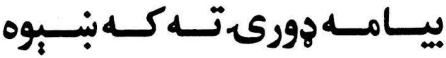

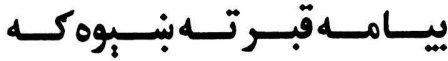

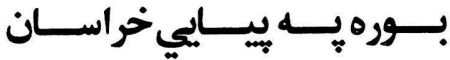

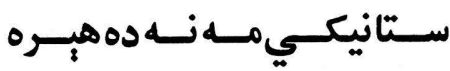

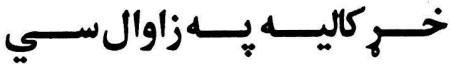

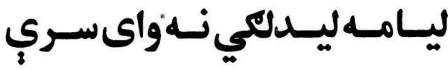

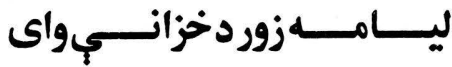

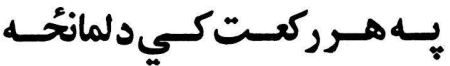

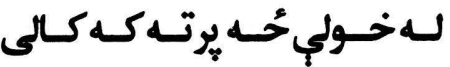

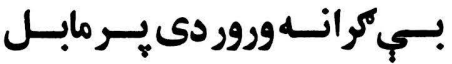
مبريتــوندى ثخـيـي رامـاتسـي اوسبنوور دىخي كرانزورسوى

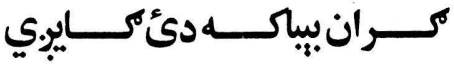

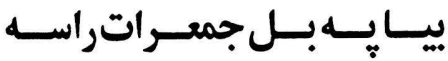

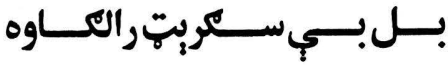

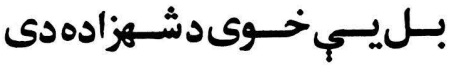

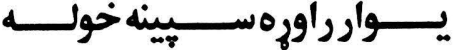

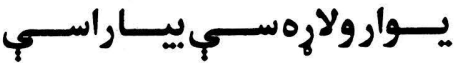

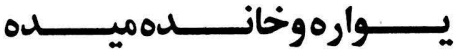

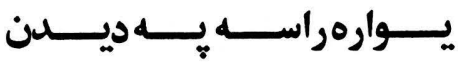

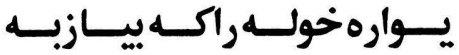

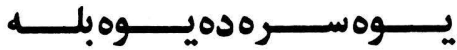

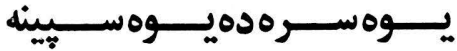

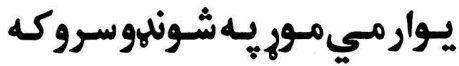

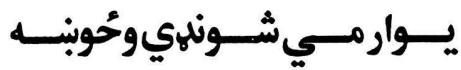

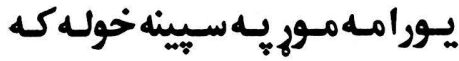

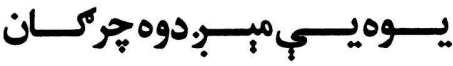

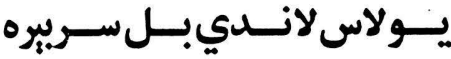

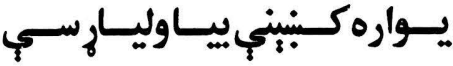

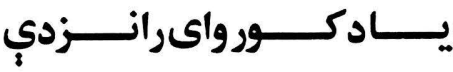

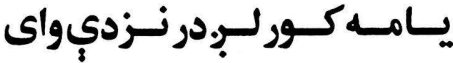

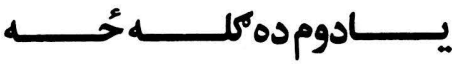

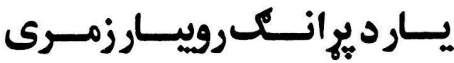

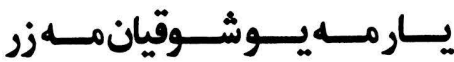

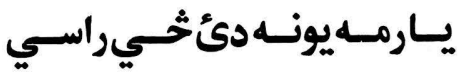

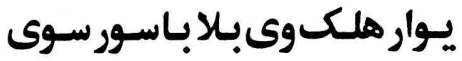

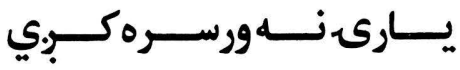

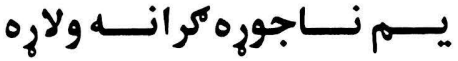

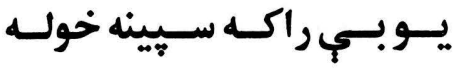

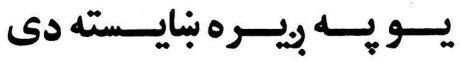




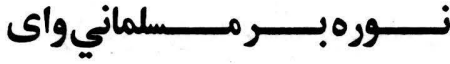

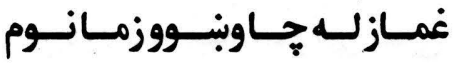
بـلـدبـوى راحَـــينــوراندي

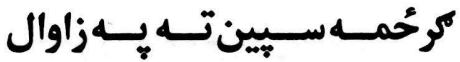

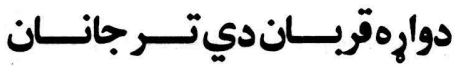

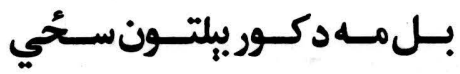

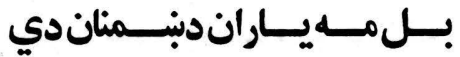

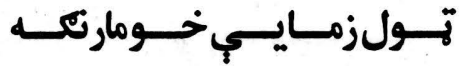

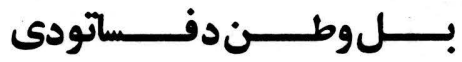

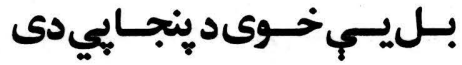

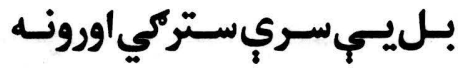

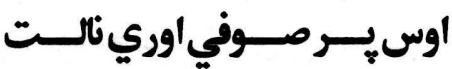

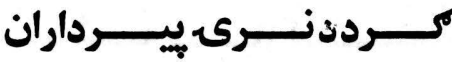

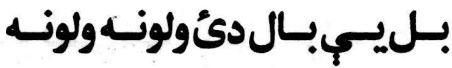

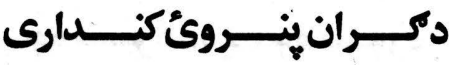

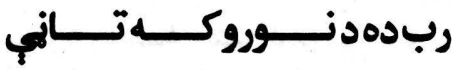

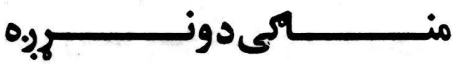

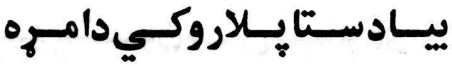

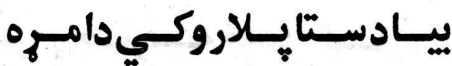

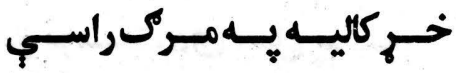

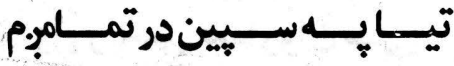

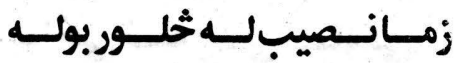

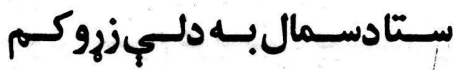

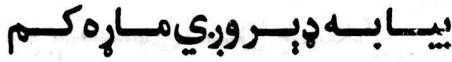

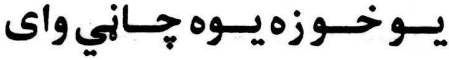
يـو خـواري سـي بـل بـتستون

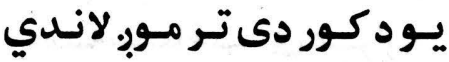

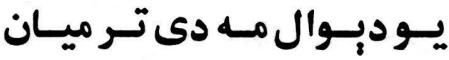

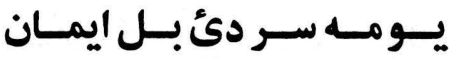

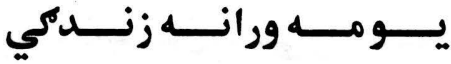

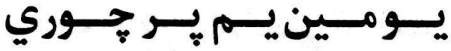

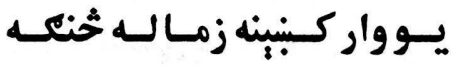
يـو هلـك دى بـل نايوهـ دى يويج بال هر سِيّن تندي دى

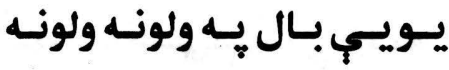

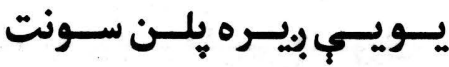
يسويج سـي دوولس كشنيان مسويس سـري سـتركي اور نـه

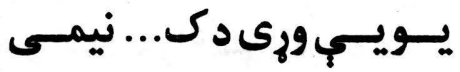

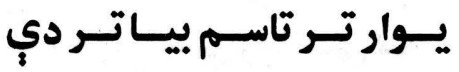

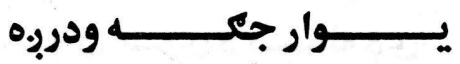

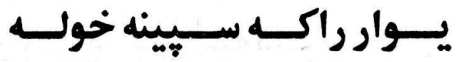

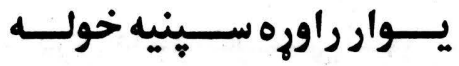

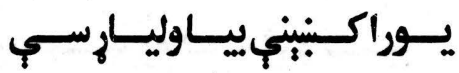

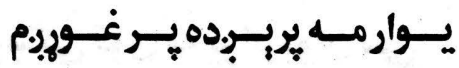

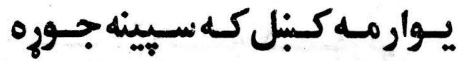

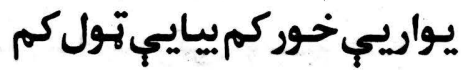

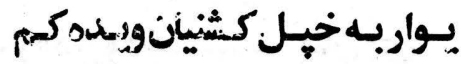




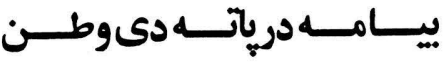

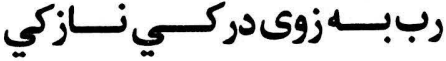

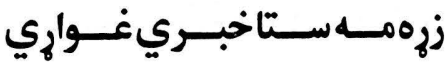

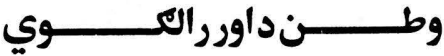

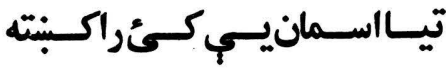

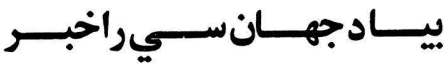

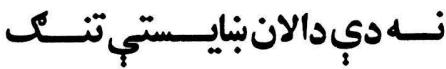

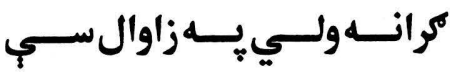

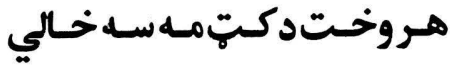

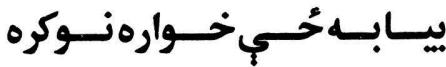

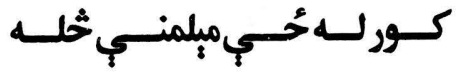

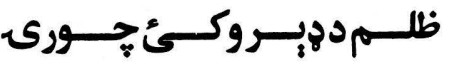

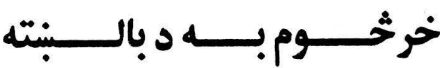

بل يج رون هار كل بنـاره دى بـ

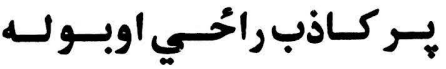

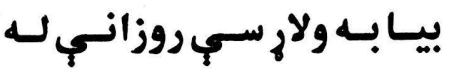

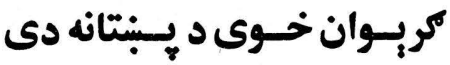

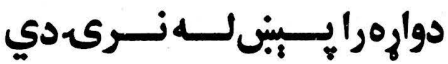

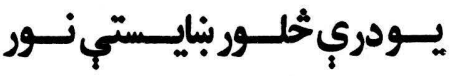

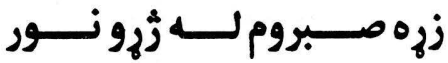
اوبتكي توى مه بر كريوان سي

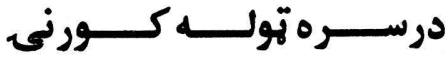

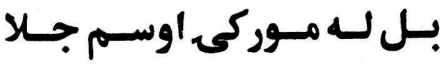

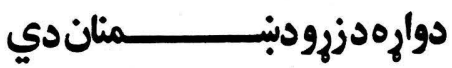

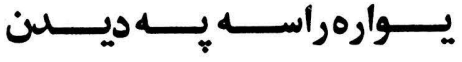

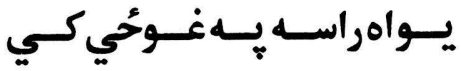

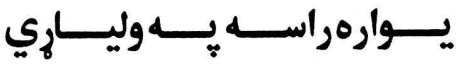

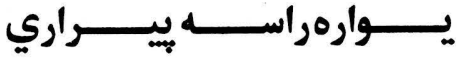

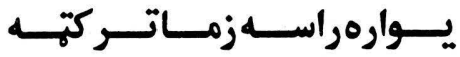

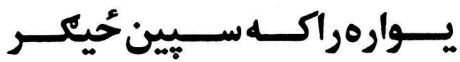

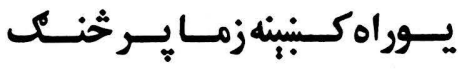

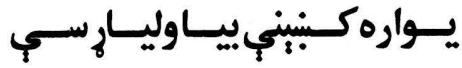

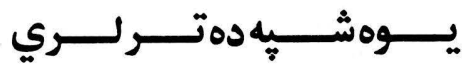

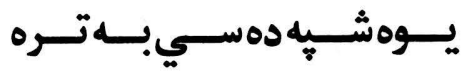

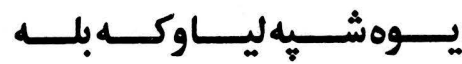

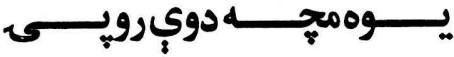

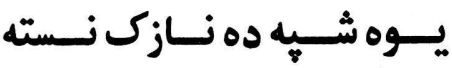

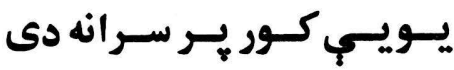

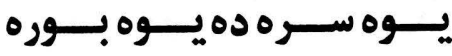

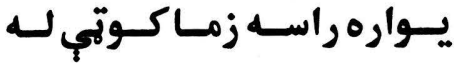

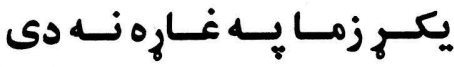

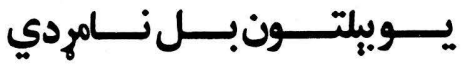

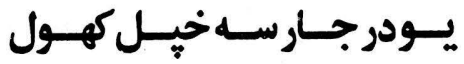

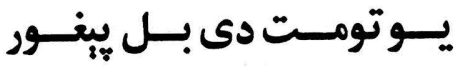
يسو وار راسـي بيــاروان سـي

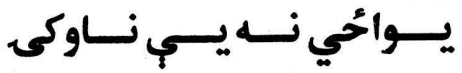

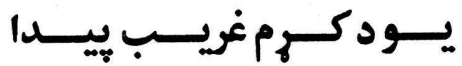

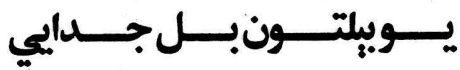




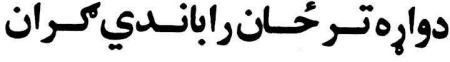

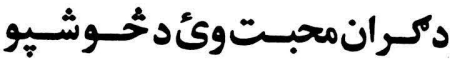

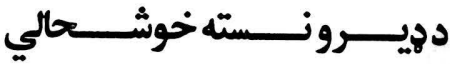

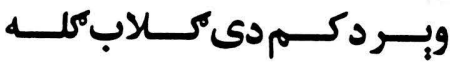

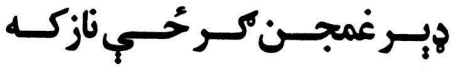

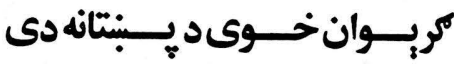

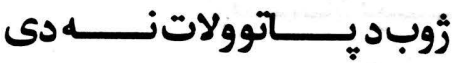

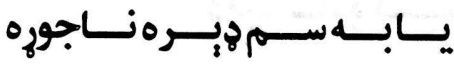

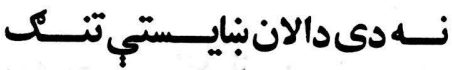

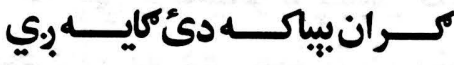

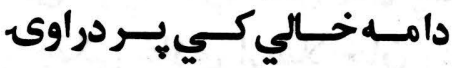

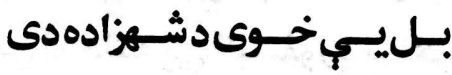

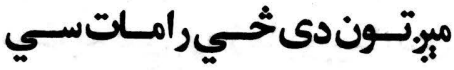

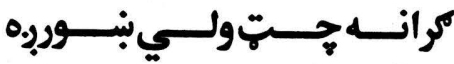

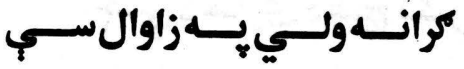

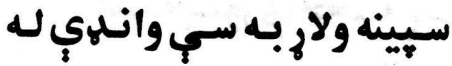
تــر مركسه ورور دى يــر مـابـل سهار كران حُي يه سيبدي كي بياد ستا يلار يري كي زما سر

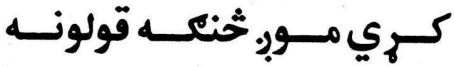

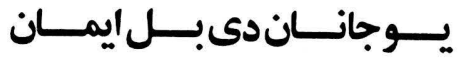

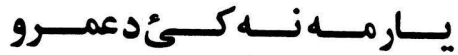

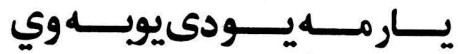

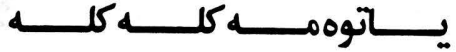

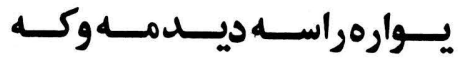

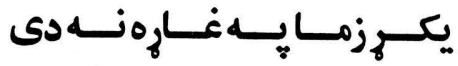

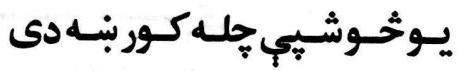

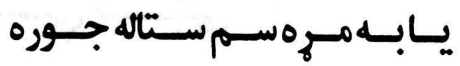

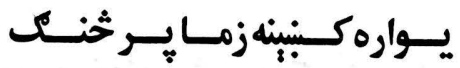

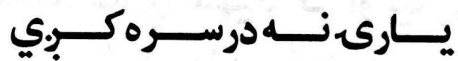

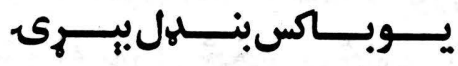

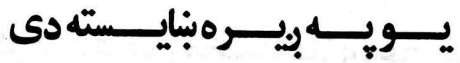

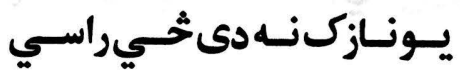

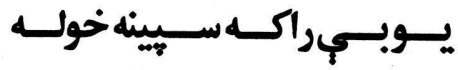

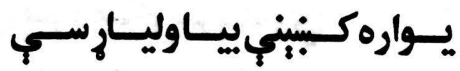

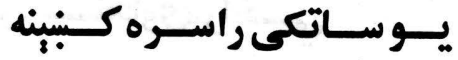

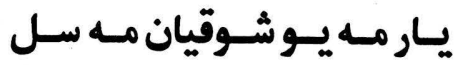
يوه شَه ده خداى دي دويخ

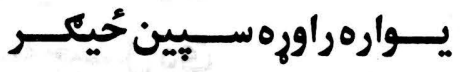

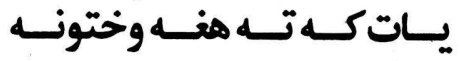




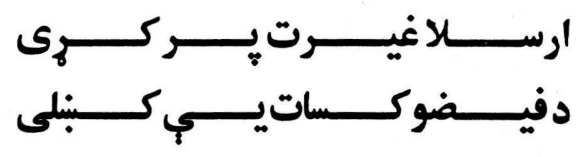

كله جي يرنكيانو د يُبنين فيض محمد غازي شهيد كر او بيا يبي

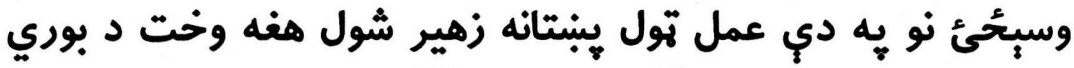

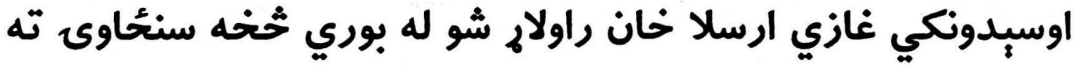

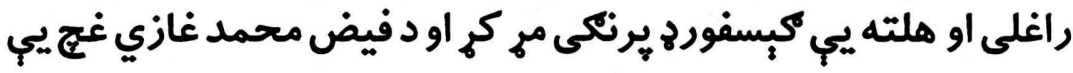

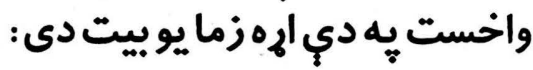

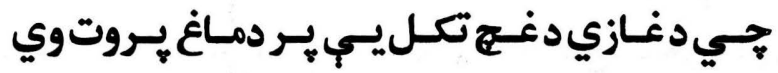

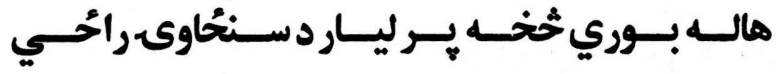

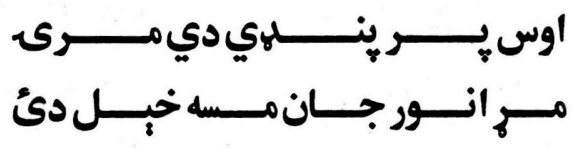

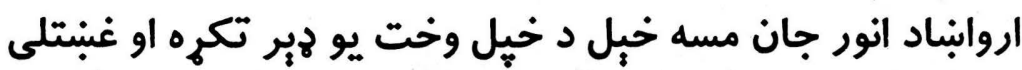

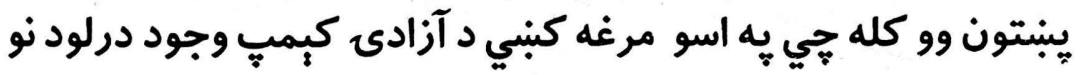

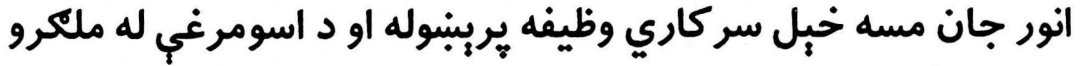
سرهيب هر حول مرسته كوله. 


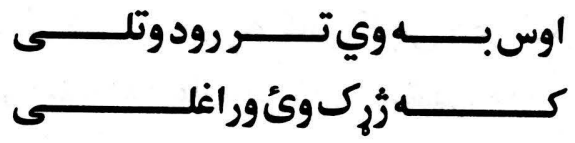

دغه غاره و غازي زرك خان ته منسوب ده. غازي زئ خى خان د خيل وخت يو غنبنلى افغان وو يه خيل رُوند كبني يبي د ينبنتو خاوره و يرنكي ته سكروته كري وهو. :f

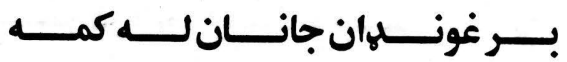

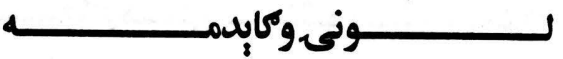

دغه غاره و جانان كاكر ته منسوب ده. كله جي به د سوها:لي

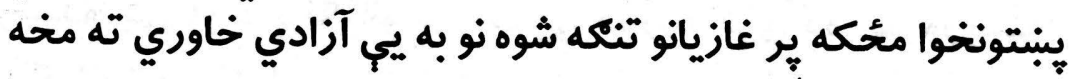

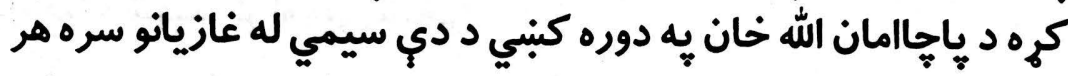

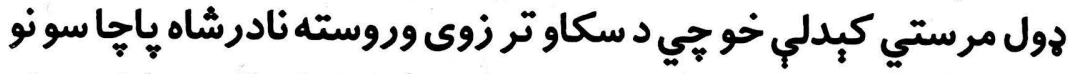
هغه يرنكي مجبوره كرى جي هغو ته به افغانستان كبني حُاى ورنه

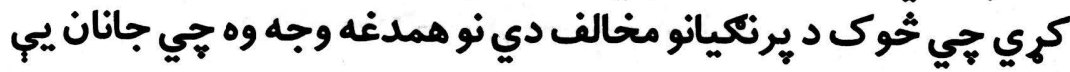

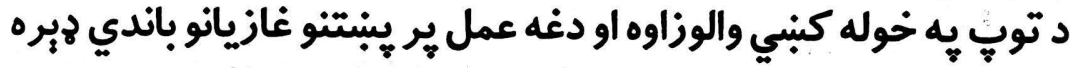

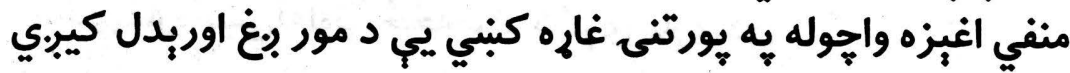

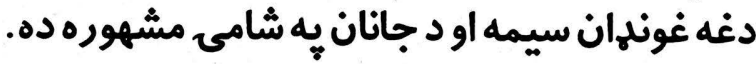

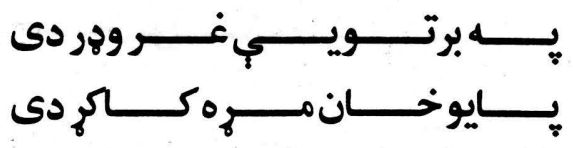

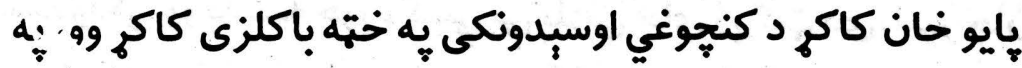
AFA ميلادي كال كبني د باكستان يه ضد افغانستان ته واوبنت إو د 
كاكرى غاري

0.7

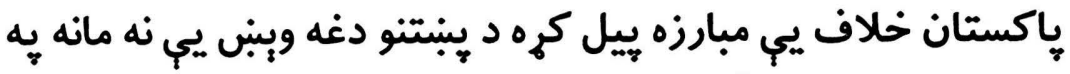

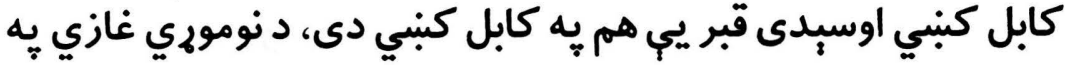

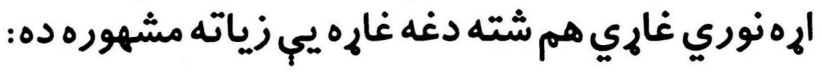
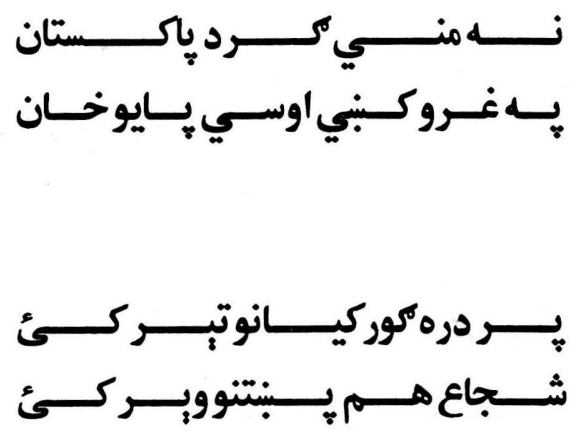

غازي شجاع احمد خبل د توبي كاكرى د ثخاكي نومي كلي

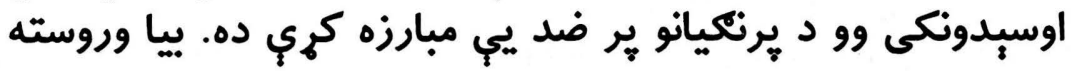
يرنكيانو شهيد كر او ويي سبحئئ. :V

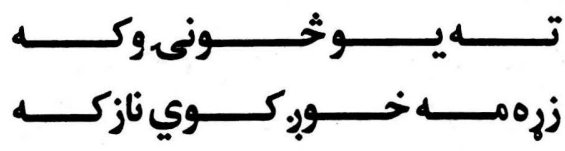

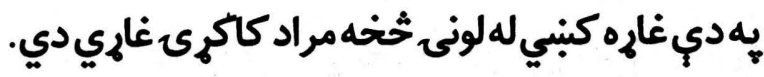
: 1

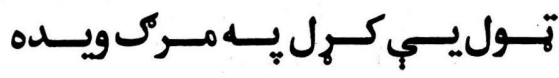

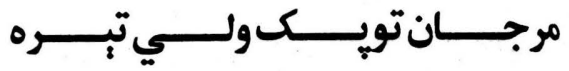

مرجان جي اصل نوم يبي امير جان دى د هندو باغ د شني خوري

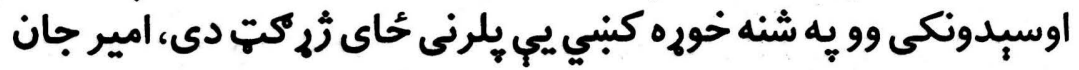

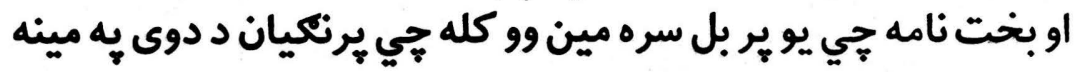


كبي خنه شول نو زموب. دغه ورور او خور د يرنكيانو به ضد مبارزه يّيل كره، د امير جان به إه هُبري غاري او ولسي بدلي اوس هم به ولس كبني ثروندي دي.

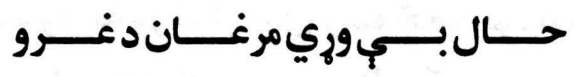

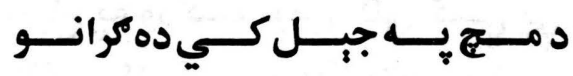

دغه غاره و غازي بخت نامي خور ته منسوب ده، بخت نامه جي د امير ترله وه تر اور.دي مبارزي وروسته يه كال سب 19 اء كنبي يبي د كلا

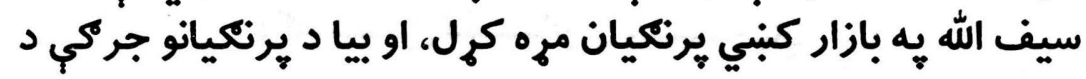

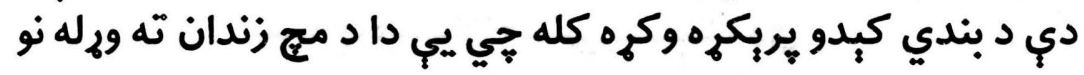

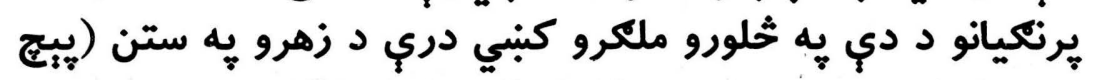
كارى) ورّلي وو، اويوازي هرات خان رُوندى ياته وه. :1.

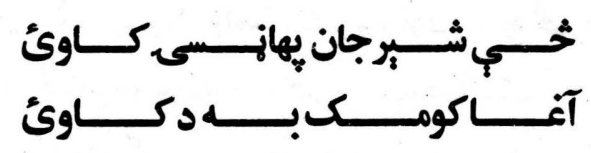

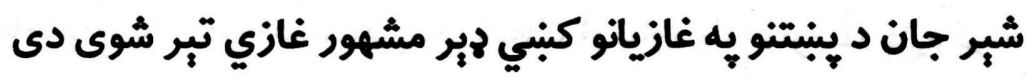

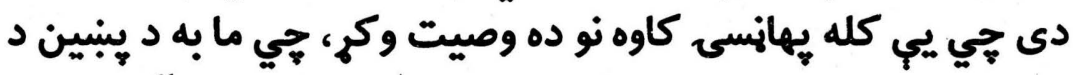

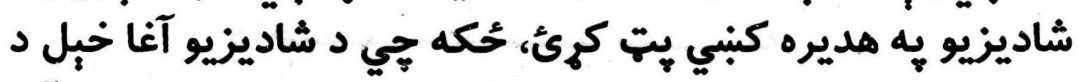

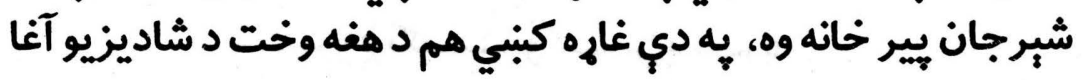
هاحب ته اشار مه دهن.

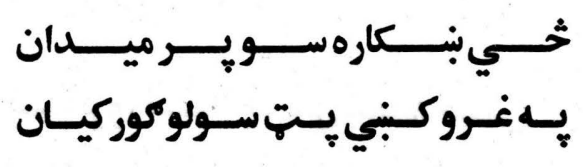

به دي غاره كبني و غازي شجاع ته اشاره ده. 
كاكرى غاري

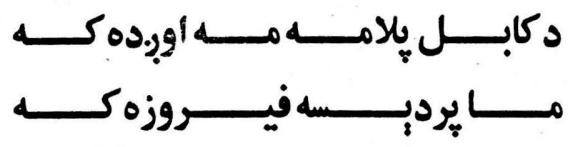

د يايو خان دوه ودونه وو له لومري واده خخخه يوه لور وه جي فيروزه

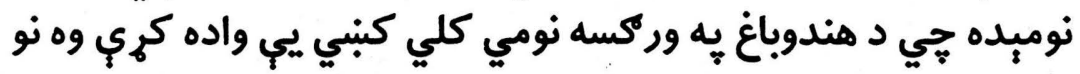

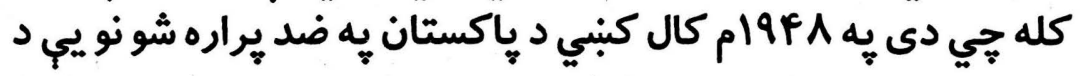

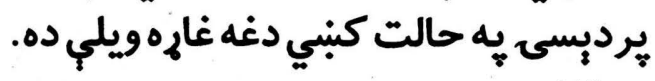
سا:

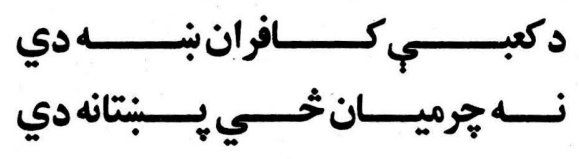

كله جي مري بلوخو د يبنتو نواب صاحب ته لاره نيولي وه او د ده د

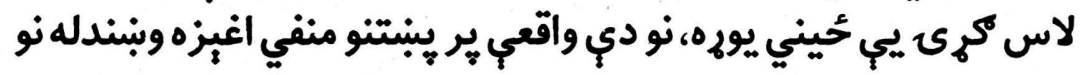

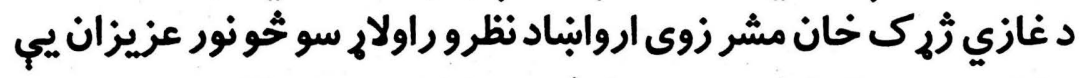

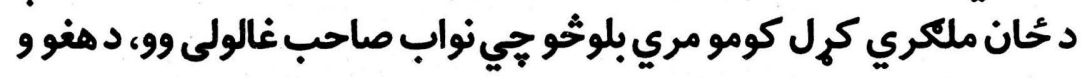

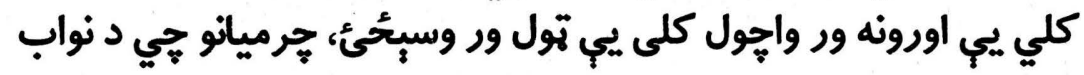

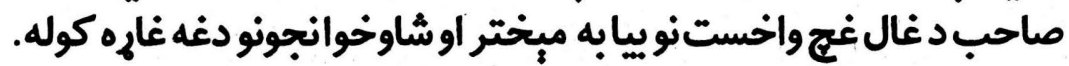
:If

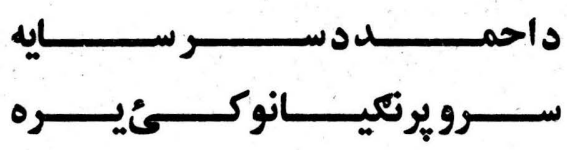

دغه غاره شجاع احمد خبل كاكر ته منسوب ده. :10

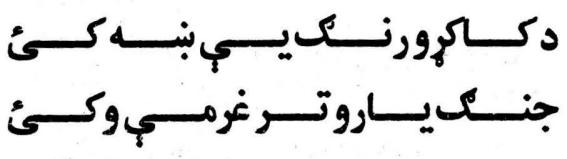




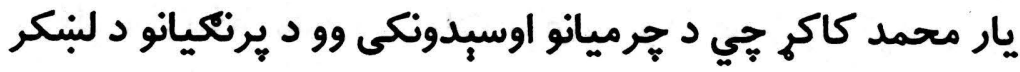

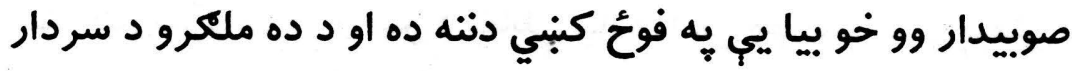

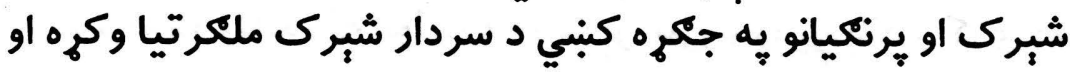

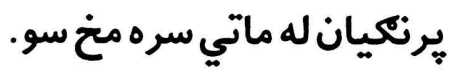

:17

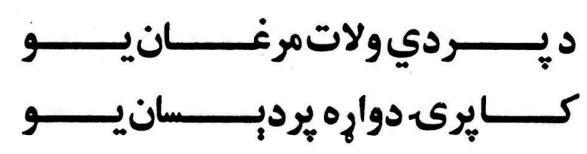

دغه غاره و سردار بنكل خان ته منسوب ده. كايرى يبي د اسيبي نوم

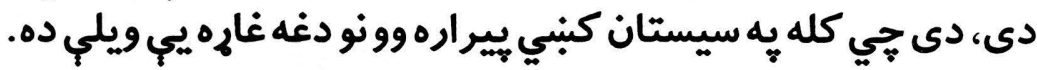
IV

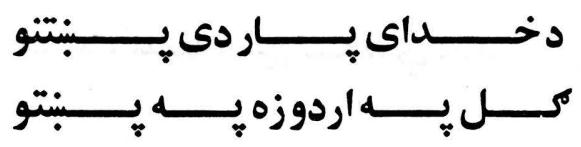

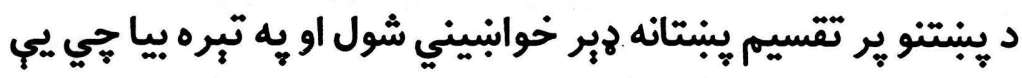

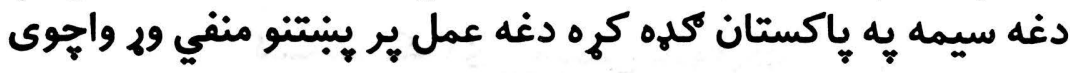

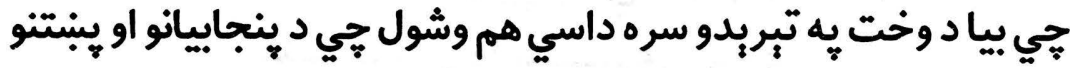

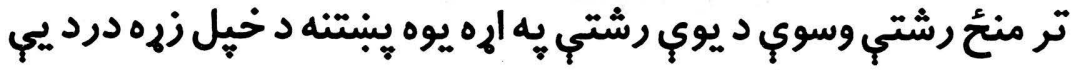
يه دي غإه كبني انحُور كرى دى دئ. :11

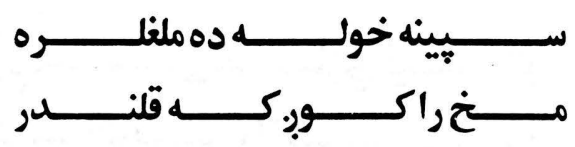

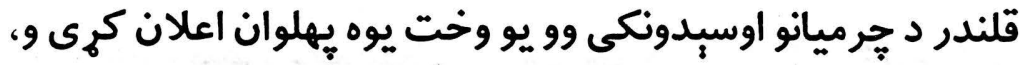

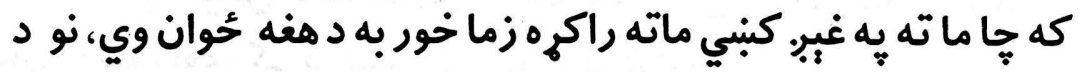

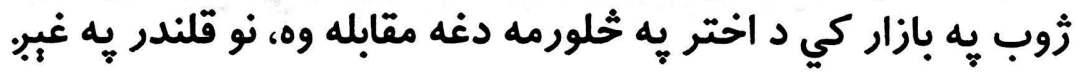


كاكرى ناري

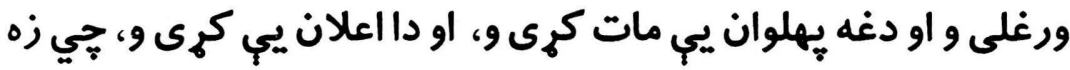

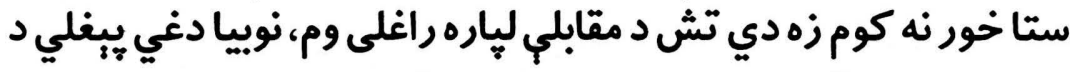

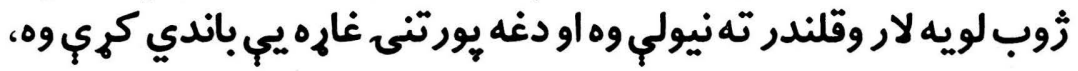

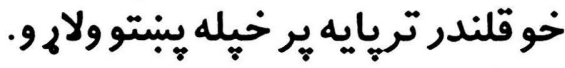
$: 19$

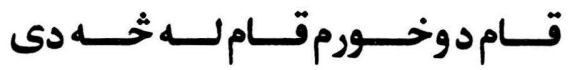

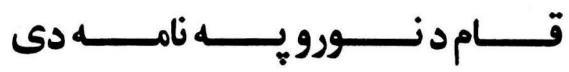

كله جي يبي بخت نامه له سيف الله كلا ثخه مج ته ورله نو هغه وخت

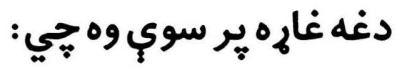

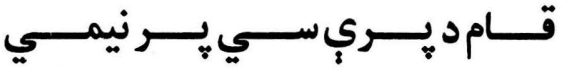

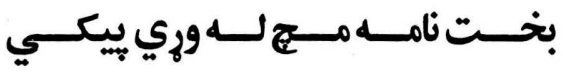

$$
\text { •و بخت نامي بورتنى غاره ورتهويلي وه. }
$$

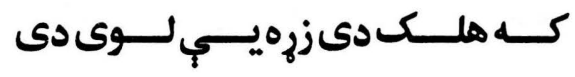

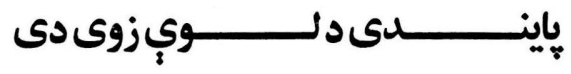

يإيندى درثر خى خان ورور و، دغه غاره هغه ته منسوبه ده. :YI

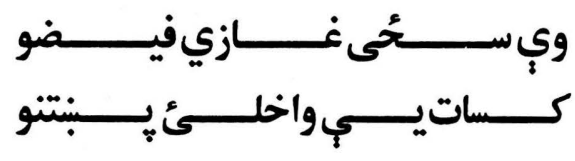

دغه غاره فيض محمدغازي ته منسوبه ده جي بيايبي غازي ارسلا خان يه سنحاوى كي د كيسفو هيه وزّنه كسات واخست. 


\section{ويي يانكه}

إيوزيى، د اوسني زوب يخوانى نوم

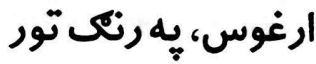

$$
\text { يه رنك توره }
$$

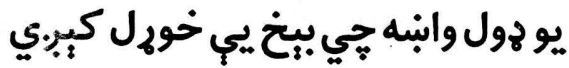

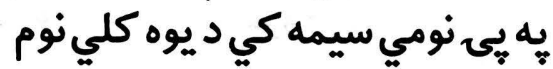

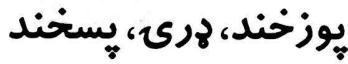
انكى وهونكى، هرى وهونكى د يبنتو اولسي ادب يو منظوم ذرانر

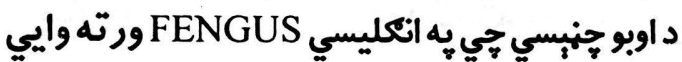
انهار، وضعيت د سيمينوم جتج، غنبتلى حُوان دباسور بنَحُينه يه يُبنين كي د يوه كلينون مينوم خروبن، ميني تنده

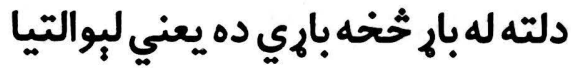

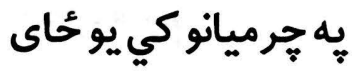

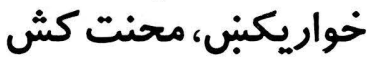

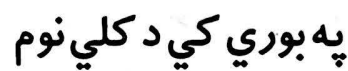
د سنحُاوى او دوكى تر منحُ د حَاى نوم دى دي

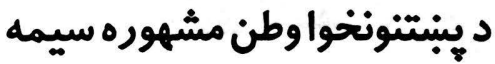

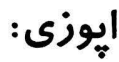

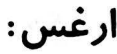

|رغسه: - ارعس:

ارغوج: ارعها

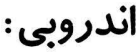

انكه: - (اندوبى

انكيال:

انكى : انيلي

اوبرى :

انار :

ايرنه:

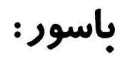

باسوره:

بالاويىى:

بار

باري: باءي

بوسورى

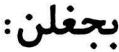

بر نيمى:

بغاوه: بر بيدي"

بورى: 
كاكرى غاري

$$
\begin{aligned}
& \text { يه ينبين كي د يوي وموري سيمينوم } \\
& \text { د ينبتنونخوا وطن مشهور ه دره } \\
& \text { ورهنوته } \\
& \text { غبنتلى } \\
& \text { د كولي بله، د كويلي نيمه كونى }
\end{aligned}
$$

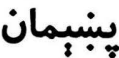

بنَحينه نوم، يو هول تانكه جي بنده وي يعني

$$
\text { نبحَحينه نوم }
$$$$
\text { هرو مرو }
$$

نارينه نوم

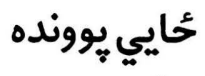

بنَحينه نوم توني

هغه تخته جي مرى يُر مينحي حَيني يُبتانه

$$
\text { باران يو جول جي حُبر نرم وي }
$$$$
\text { وبايوهناجوزي }
$$

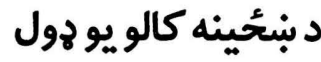

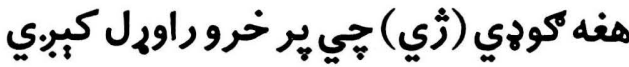

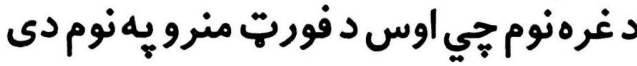
هغه دوره جي يُبتانه يبي د شيطانانو ورابولي

$$
\text { بنبحينه نوم }
$$

$$
\text { عذر، يلمه }
$$

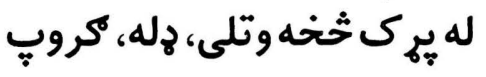

$$
\text { يو حول توره دورهـ }
$$

دلوى كندهار تاريخي سيمه
بوستان:

بولان:

بوىى:

بينبن:

بله:

بكاو :

بكىى:

يردهلري.

ياشى:

ياّله يدره:

يَالِي:

ياوال:

ياوى:

يتارى :

يب ولانكه بولي.

يرخى:

يرنك:

يرإتي:

بلاني:

يوات:

يوخونكي: يوخانه:

$$
\text { بيخّ: }
$$


رواش، يه غره كي كيدونكى تريو بوتى دى ني يبنى :

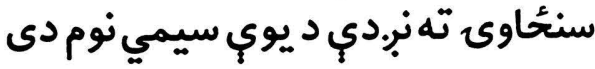
بنحَينه نوم

$$
\begin{aligned}
& \text { بيى: } \\
& \text { يبكى : يجن: }
\end{aligned}
$$

د سيمينوم

د تيو ترميان جور سوي جبب تهو وايي بتر كي

د كوتي شال كوتّ هير نوموئى غر بنحئهينه اونارينه نوم تكتو : تكيه:

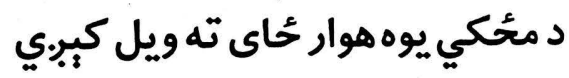
دجيني يوه كوجنى بنه 
كاكرى غاري

$$
\begin{aligned}
& \text { د سيمينوم } \\
& \text { هلك } \\
& \text { نجلى } \\
& \text { دجيني يو هولي } \\
& \text { يو هول خوراكي واببه } \\
& \text { حلنته، يورته كول } \\
& \text { اولاد، غونبي } \\
& \text { كوجنى داغ }
\end{aligned}
$$

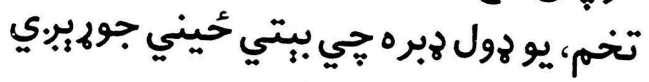

$$
\begin{aligned}
& \text { د سيمي نوم، خنايبيابا } \\
& \text { غاتول، غانتول }
\end{aligned}
$$

دكان

$$
\text { د د سيمينوم }
$$

دي يُخلونجونو و تيو ته كاكر ان خواوايي

$$
\text { نازك }
$$

$$
\text { سهيلى }
$$

$$
\text { نازكي }
$$

ير خبزّى ياوياله د اوبو د جينبنلو حُاى

$$
\text { خود }
$$

$$
\text { خوبن سين نومي }
$$

خيسور، د سيمينوم

$$
\begin{aligned}
& \text { د جيني يو هول } \\
& \text { بلو }
\end{aligned}
$$

جوتبر:

:جورى:

: جورى :

:جونكى :

جيناسكي:

حعلل:

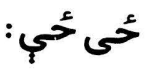

خاتي:

خاكى :

خانى :

خَّتول :

خصت

خسنوب:

خلبيت :

خوا:

خورى:

خوندكى:

خوكي:

خومباهى :

خونه:

خوى:

خورسي:

خيرا:

خيساره:

خيزى : خئ

خاكى: 
$\Delta 10$

كاكرى غاهي

مجّول، مجِّدل

خيّ:

يو هول مينه

يو هول تويك

خخوبي:

حيوان

خمباز0، د يو يواىنوم

خكى :

ثلور بول:

د سمي نوم

خمازه:

خماولنك : خمان

وندر

خنكى : خماون

هغه دوري او باران جي كله سره راسي

د دوو مينو تاكلى حُاى، د واده نيته تاكني ته

خونى :

دراوى :

هم دراوى وايب.

مجبوره، محتاجه

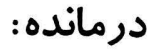

له ورايه

ز

ชذه

دلته

د سيمينوم

ديره غازي خان يا ديره اسماعيل خان

لحد

د سمي نوم

مبدان

يو هول كينه

لار لار، لارونه لارونه

رغستنك

يو هول وابنه دي جي انسانان يبي خوري

$$
\text { د انار دانه }
$$

$$
\begin{aligned}
& \text { دروا: } \\
& \text { دركي دركي: } \\
& \text { دليته : } \\
& \text { دوكى: } \\
& \text { دبري } \\
& \text { : } \\
& \text { هومياره: } \\
& \text { : }
\end{aligned}
$$

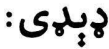

$$
\begin{aligned}
& \text { رسي رسي: } \\
& \text { رغاو: } \\
& \text { رغبولي: } \\
& \text { انكى : }
\end{aligned}
$$

هغه ستركي جي يه تورو كي ثره ليكه لري 
كاكرى غاري

$$
\begin{aligned}
& \text { مانده، رود ملازى، رود جوكيزى } \\
& \text { بي كاره } \\
& \text { كين لاسى } \\
& \text { نارينه نوم } \\
& \text { سني، هُبر } \\
& \text { كنلهو،وت } \\
& \text { د سيمينوم } \\
& \text { بنحَه } \\
& \text { د شيب سور باد }
\end{aligned}
$$$$
\text { رود: }
$$$$
\text { رث: }
$$

ريسا:

ريبنا:

ر

$$
\text { زاركت: }
$$

زاييه:

زاوا:

زر كون، زر كانه، د يوي بِنبتني قبيلي نوم

$$
\text { تاوان (ضرر) }
$$

وري وري هبري، غت فرونل

روب.د

زركون:

زراره:

زني: زران:

زن:

عادت، روربد، اموخته

$$
\text { هبر ساره ته وايي }
$$

زني:

زنتاو:

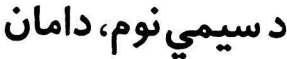

زور:

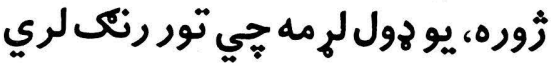

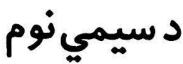

زوركي:

ز زوب:

تبزز، توند

ن إزولى

بنَحِينهنوم

ماروبِنزدي سيمه

د سيمينوم

$$
\text { جارو }
$$

د سيمي نوم، د سيال كاكر د زو كري تاتوبى

$$
\text { ثركند: }
$$

سالِّون: سابو:

سبت:

سخولى:

سرانان: سجون 
DIV كاكرى غاري

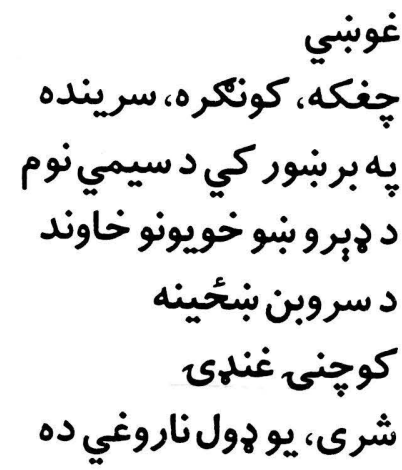

سر.بپ:

سرندى : سرن:

سره خوا:

سروبن:

سروبنه:

سروتهى: سرونه

سرى:

يه غارو كي د مبر.و لياره كار سوي دي

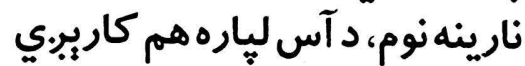

سري : سيرى:

سكان : سكري

د سكان بَحُمنه نوم

سكانه:

بلتى (جارزانو)

سلندى :

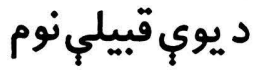

سنرزيى: سنئ

د يوي سيمي نوم

سنحُاوى : سنردي"

د سرينوم

سوبا:

يو هول بونى

سورمل:

هزه

سونلهه:

منحوسه

شونه

يخى، برف

د سيمي نوم، يهوزيرستان كي هم سيوى سته

8.

رضا، قائع

سوى بكني

سون:

سى:

سيوى :

ستّ:

سُع: سع:

يو هول هوسى

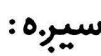

يو هول خونه

هغه حُاى ته جي سيورى لري

ب: بغور 
كاكرى غاري

د هني دري لومرى تنكى

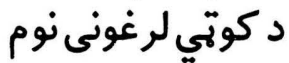

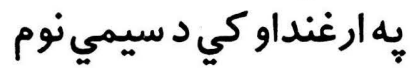
رك، ركونه

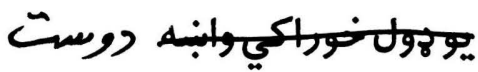
يو هول خواجه د جعفر قبيلي لرغونى نوم يو رول وابنه جي يه ميان كي سييني اوبه لري شلومبي د سيمينوم غرور، مغرور مغروره، بناخه محمد زى ، بناخه سمايل زى، ، زيم يه سريزه كي يبي سينيناوى سوى دى جي جكره، جنك

تنك

غوجبره دعاىنوم

غبر. د سارهزيارت د سيمينوم نازكي غز، يو هول ونه

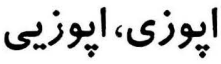
نكاح موجني
شال تنكى: شال كوت : شاله مار : شيلى : شاله شكومى: شكنه: شكون: شلومبي: شونحُى : شارئ نبار كهه : نباخ: بناخه : بناخ: نباخه خيريزى. بنبونو : بنبوور : غال: غايت: غوريزه: غونحُهة : غورنز غوحي: غوخىكى : غوحين غوركي: غُح : عور فورتّ سنهيمن: كاوين: كيى : 


$$
\text { د سيمي نوم }
$$

داني، مشكني، ملغلري

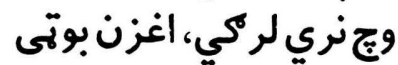
به موسنى خيلو كي د غرهن نوم همسايه توب موسب

كريلين، د يو هول توكر نوم

$$
\text { د سيمي نوم }
$$

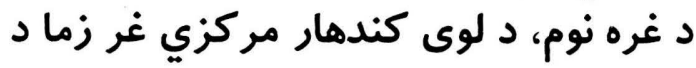

كجلاغ

كرزى

كرغنه :

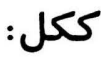

كليورى:

كلبرين:

كمردين:

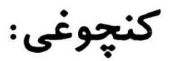
خيرني له مخه د كندهار نوم د كند له غره خخخه اخيستل سوى دى. د افغان وطن يوه كلا جي اوس د دئه سيند يه كند كوبه: ايالت كي دهـ.

د كند غره بـه هره لمن كي كنديل واقع دى او

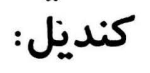

هغه كُاى ته وايي جي اوبه حُني راوزي.

$$
\begin{aligned}
& \text { صبر } \\
& \text { كوڤ: } \\
& \text { كوري كومبر : }
\end{aligned}
$$

د شال كوت لرغوني كوتوالي جي ير حُاى

$$
\text { كوتوالى : }
$$

اوس د كوتوال يهنوم كلى ودان دى.

$$
\text { نارينهنوم }
$$

$$
\text { كر كردار: }
$$


كاكرى غاري

$$
\begin{aligned}
& \text { مجع، خيّ } \\
& \text { كنبل: } \\
& \text { فكر من } \\
& \text { جكيده } \\
& \text { ديوي قبيلي نوم } \\
& \text { د يسو لياره د بوتو خخه جوري سوى شيول } \\
& \text { ضايع } \\
& \text { زغمل } \\
& \text { كهيخ، سهار } \\
& \text { خبره } \\
& \text { كاى، كايونه، خبره، خبري }
\end{aligned}
$$

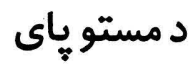

$$
\begin{aligned}
& \text { دنازنوم } \\
& \text { نارينه نوم } \\
& \text { ديوه كلينوم } \\
& \text { جلرِب، باد كولبري } \\
& \text { غونده } \\
& \text { غونده منلهه } \\
& \text { د سيمي نوم، يو هول هبره منيره } \\
& \text { د سيمينوم } \\
& \text { ज) } \\
& \text { يه تيري وروز تكان كي د سيمينوم }
\end{aligned}
$$

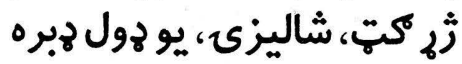

$$
\begin{aligned}
& \text { دخلكو مجموعه } \\
& \text { خيرن، غندلى نومئ مجومونه }
\end{aligned}
$$

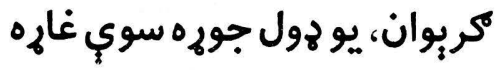

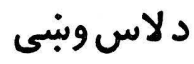

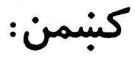

$$
\begin{aligned}
& \text { كن: } \\
& \text { كيتران: } \\
& \text { كير: } \\
& \text { كار : } \\
& \text { كالل : } \\
& \text { كانى : } \\
& \text { كاى: } \\
& \text { كاين: } \\
& \text { : كارئ } \\
& \text { كلان: }
\end{aligned}
$$

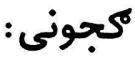

$$
\begin{aligned}
& \text { كوال: } \\
& \text { كولب: } \\
& \text { كوره: } \\
& \text { كورى: } \\
& \text { كوسه: } \\
& \text { كومله: } \\
& \text { كورى : كومل: } \\
& \text { كيزو: } \\
& \text { كت : } \\
& \text { كلئ : } \\
& \text { كر جن: } \\
& \text { ك5كي: } \\
& \text { لاس وندى: }
\end{aligned}
$$


لاستور، د بيى د لونبلو لياره كنهولى لاستور : لاره، انكريزي فوجي مامور لاتَ ورثكى، ول، ولنك ل ل طرز لوون، دِ بِنتنو يوه قبيله كب : كان: لوانه: معتبر لويال: غونسي بوتى : د يوي قبيلي نوم، جمع : لونيان او لوني د سيمي نوم لوني: لي كله : لونه" زهو ونبو ته اور وركولو ته واييي د يوي سيمي نوم

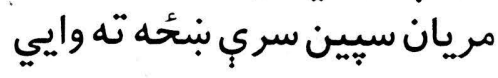
سُحَنه نوم جي نه وي ملامت، جي نه وي خلاص حيني كاكر ان و عام بنحُحو ته مايني وايبي خوابدي، مرورتيا جنسي مستي سُحِنه نوم وابنكى جي له وحغونو جور سوى وي د يوي سيمي نوم نهي نارينهنوم د يوي سيمي نوم منا، يخلنحئى دئي كردى هُبري جي لوبه يه كير. شَحُنهن نوم لباكي: مارويّ: ماسي: ماموره: ماندوره: ماينه: مانور مانزى : مانه متوه: مراده : معوه: مر انده: مستنك : مراه: مشي: مكور: مناكى :

$$
\text { مبتئ: مبراجا: }
$$$$
\text { شَحسنهنه }
$$ 
كاكرى غاري

$$
\text { د د ديوهنوم ديمي نونوم، قبيله }
$$$$
\text { مخخول: }
$$

ميترزى : مئحول

مبختر : مبنر :

ناسر :

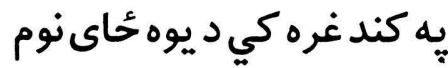

نالت:

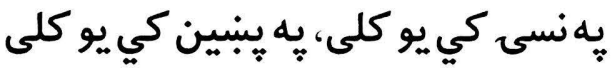

نالى :

نانك :

نانك د ميا عبدالحكيم دي دناز نوم يوني

نانكان:

يو هول غرنىونه جي مبوه كوي

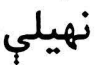

نهيله:

جي نهر وهي يعني نى وهي

نائري: نهيله:

د غرهنوم

نخاس:

د انار ونه

محاوره، آباديدل، ودانـيدل

نر كوسه:

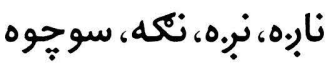

د سيمينوم

نريدلي، كرئيه

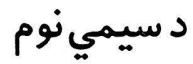

د سيمي نوم، اوس سيبي مسلم باغ بولي

$$
\begin{aligned}
& \text { وارخطا }
\end{aligned}
$$

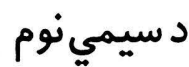

$$
\begin{aligned}
& \text { منحُ مهاله بيراو } \\
& \text { رونيا، رونا } \\
& \text { يه زيرهنرمه، واونى : يه زيرهنرم } \\
& \text { نرينه نوم ترن } \\
& \text { ترتا } \\
& \text { هندوباغ : هرني: } \\
& \text { واردكي: } \\
& \text { والي مرغه : واني" } \\
& \text { وانهه: } \\
& \text { واهي: وانيه: } \\
& \text { واونى : واهي: } \\
& \text { واتهي: } \\
& \text { وتا: }
\end{aligned}
$$$$
\text { نوك خرخ: نيده: }
$$$$
\text { نياب.ه: }
$$$$
\text { نيسى: }
$$$$
\text { نمكهة: }
$$

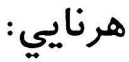




$$
\text { تردئ تهزئ زيارت كي د غرهنه }
$$$$
\text { ودنئ: }
$$$$
\text { ورغركي: }
$$$$
\text { ورحككى: }
$$

ول، مور، لبوزي

كمزوري، ناتوانه

يو هول وابِه، جك جك غورئحدل

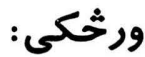

وركسه:

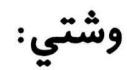

كودر، د لامبلو حُحاى

ولن:

$$
\text { تيريده }
$$

سره درو

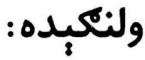

وله درو:

دوريو كندى سرو

gلd

جاره

ولوره:

رينبه

وركه :

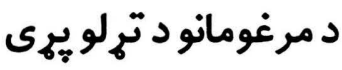

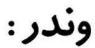

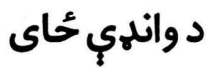

ونهغل:

د كند يه لمن كي د غره يوه برخه

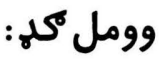

$$
\begin{aligned}
& \text { قابل، لايق } \\
& \text { وريحُي اوباران } \\
& \text { يو والى، اتفاق، اتحاد } \\
& \text { د سيمينوم }
\end{aligned}
$$

:

$: 29$

وز⿻

و

ونى : 


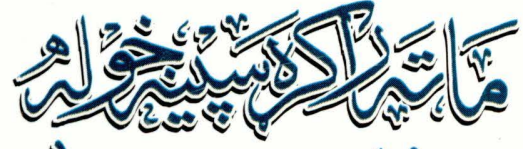

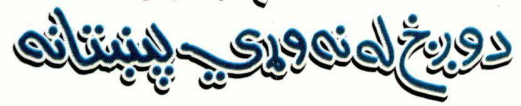
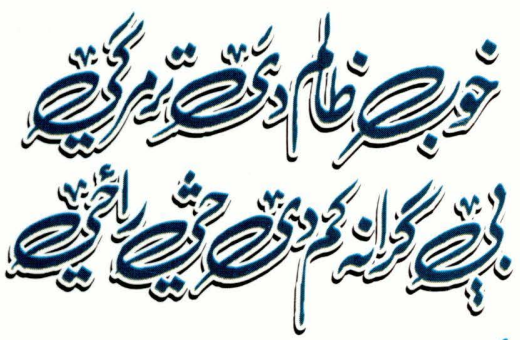

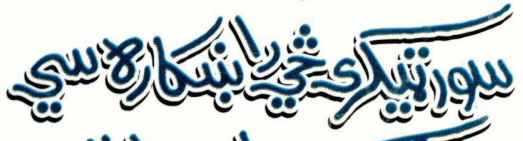

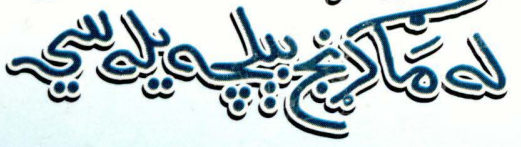

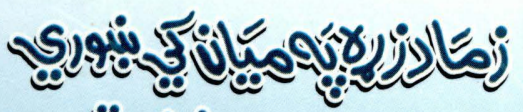

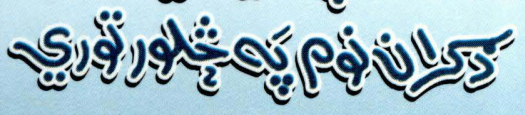

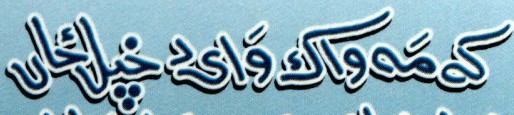
Abs śs 